
Dados Internacionais de Catalogação na Publicação (CIP)

(Câmara Brasileira do Livro, SP, Brasil)

Ciência, tecnologia e inovação [livro eletrônico] : do campo à mesa : volume $2 /$ Anny Kelly Vasconcelos, João Pedro Ferreira, Regiane Ribeiro dos Santos, (org.). -- 1. ed. -- Recife, PE :

Instituto Internacional Despertando Vocações, 2020.

PDF

Vários autores.

ISBN 978-65-88970-00-3

1. Ciências agrárias 2. Embalagens 3. Gestão ambiental 4. Produtos - Desenvolvimento 5. Segurança alimentar 6. Sustentabilidade 7. Tecnologia de alimentos I. Vasconcelos, Anny Kelly. II. Ferreira, João Pedro. III. Santos, Regiane Ribeiro dos.

Índices para catálogo sistemático:

1. Ciências agrárias 630

Cibele Maria Dias - Bibliotecária - CRB-8/9427 


\title{
CIÊNCIA, TECNOLOGIA E INOVAÇÃO: DO CAMPO À MESA
}

\author{
$1^{a}$ Edição \\ Volume 2
}

Recife - PE - Brasil

INSTITUTO INTERNACIONAL DESPERTANDO VOCAÇÕES

2020 


\section{PREFÁCIO}

O Congresso Internacional da Agroindústria - CIAGRO 2020, foi um evento internacional, concebido no âmbito das atividades desenvolvidas no Programa Internacional Despertando Vocações para as Ciências Agrárias (PDVAgro) e realizado pelo Instituto Internacional Despertando Vocações (IIDV).

O CIAGRO 2020 proporcionou a interação entre os participantes e a reflexão e discussão do papel da inovação da ciência e tecnologia, pautada em pesquisas científicas, em todos os segmentos da cadeia produtiva do alimento, envolvendo a alimentação do campo à mesa.

Este e-book volume 2 com 54 capítulos traz uma variedade de artigos alinhados com a área das Ciências Agrárias ao tratar de temas que abordam o desenvolvimento de novos produtos, embalagem e rotulagem de alimentos, gestão ambiental e de resíduos, sustentabilidade na produção de alimentos, tecnologias de alimentos e bebidas, tecnologias emergentes e segurança alimentar.

Por fim, os conteúdos e resultados das pesquisas divulgados contribuem no aumento da disponibilidade de conhecimentos úteis, enriquecendo a formação e atualizando estudantes e profissionais que atuam nos diferentes setores da agroindústria, instigando-os na constante busca de novas tecnologias para a área.

Dr. Regiane Ribeiro dos Santos (Presidência do CIAGRO 2020)

I Congresso Internacional da Agroindústria - CIAGRO 


\section{CONSELHO EDITORIAL}

\section{PRESIDÊNCIA}

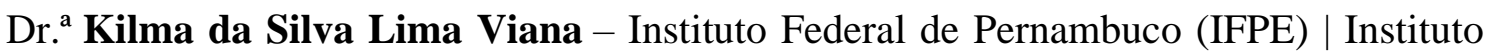
Internacional Despertando Vocações (IIDV)

\section{CONSELHEIROS}

Dr. Airton José Vinholi Júnior - Instituto Federal de Mato Grosso do Sul (IFMS)

Dr. Alexander Patrick Chaves de Sena - Instituto Federal de Pernambuco (IFPE)

Dr. ${ }^{a}$ Ana Patrícia Siqueira Tavares Falcão - Instituto Federal de Pernambuco (IFPE)

Dr. Arquimedes José de Araújo Paschoal - Instituto Federal de Pernambuco (IFPE)

Dr. Dewson Rocha Pereira - Universidade Federal de Pernambuco (UFPE)

Dr. Edísio Raimundo Silva - Instituto Federal de Pernambuco (IFPE)

Dr. ${ }^{a}$ Francisca da Rocha Barros Batista - Instituto Federal do Piauí (IFPI)

Dr. ${ }^{\text {a }}$ Iraneide Pereira da Silva - Instituto Federal de Pernambuco (IFPE)

Dr. Jaime Patrício Leiva Nuñez - Universidad de Playa Ancha (UPLA)

Dr. Jeymesson Raphael Cardoso Vieira - Universidade Federal de Pernambuco (UFPE)

Dr. José Ângelo Peixoto da Costa - Instituto Federal de Pernambuco (IFPE)

Dr. José Ayron Lira dos Anjos - Universidade Federal de Pernambuco (UFPE)

Dr. Jose Cuauhtemoc Ibarra Gamez - Instituto Tecnológico de Sonora, Ciudad Obregón (ITSON)

Dr. ${ }^{a}$ Lastenia Ugalde Meza - Universidad de Playa Ancha (UPLA)

Dr. ${ }^{a}$ Renata Cristine de Sá Pedrosa Dantas - Instituto Federal de Pernambuco (IFPE)

Dr. Roberto Gómez Fernández - Ministério da Educação de Luxemburgo

Dr. ${ }^{a}$ Suzana Pedroza da Silva - Universidade Federal Rural de Pernambuco (UFRPE)

Dr. ${ }^{a}$ Maria Trinidad Pacherrez Velasco - Instituto Federal do Rio Grande do Norte (IFRN)

Dr. Thales Ramon de Queiroz Bezerra - Instituto Federal de Pernambuco (IFPE)

Dr. ${ }^{\text {a }}$ Viviane da Silva Medeiros - Universidade Federal do Rio Grande do Norte (UFRN) Coordenação Executiva

MSc. Erick Viana da Silva- Instituto Federal de Pernambuco (IFPE) | Instituto Internacional Despertando Vocações (IIDV)

\section{COORDENAÇÃO ADMINISTRATIVA}

Esp. Ayrton Matheus da Silva Nascimento - Instituto Internacional Despertando Vocações (IIDV)

Esp. Douglas Salgado da Silva - Instituto Internacional Despertando Vocações (IIDV)

\section{SETOR COMERCIAL/MARKETING}

Cynthia Alice Canuto de Oliveira - Instituto Federal de Pernambuco (IFPE)

Heloisa de Barros Dantas - Universidade Federal de Pernambuco (UFPE)

Kaline Soares da Silva - Instituto Federal de Pernambuco (IFPE) 
Larissa Amanda Pereira da Silva - Instituto Internacional Despertando Vocações (IIDV)

Mariana Almeida Ferreira Lima - Instituto Federal de Pernambuco (IFPE)

Misael Tomaz de Araújo - Universidade Federal Rural de Pernambuco (UFRPE)

\section{COORDENAÇÃO TÉCNICA EDITORIAL}

Vinícius de Barros Monteiro - Instituto Federal de Pernambuco (IFPE)

\section{ASSISTENTES EDITORIAIS}

Anderson Soares da Silva - Instituto Federal de Pernambuco (IFPE)

Carlos Augusto Brandão - Universidade Federal de Pernambuco (UFPE)

Cecília Lima Siqueira - Instituto Federal de Pernambuco (IFPE)

Danielly Francielly dos Santos Silva - Instituto Federal de Pernambuco (IFPE)

Jussara Ricardo da Silva Rodrigues - Instituto Federal de Pernambuco (IFPE)

Karoliny Paula da Silva - Centro Universitário Guararapes (UNIFG)

Palloma Joyce de Aguiar Silva - Instituto Federal de Pernambuco (IFPE) 


\section{Sumário}

\section{Parte 1:Desenvolvimento de novos produtos}

Capítulo 1. Caracterização de cupcakes elaborados com diferentes concentrações de farinha de casca de guavira

Capítulo 2. Desenvolvimento, caracterização e aceitação de brownie de chocolate elaborado com farinha de inhame (Dioscorea sp.) Por secagem convectiva

Capítulo 3. Desenvolvimento de brownie adicionado de bagaço de malte

Capítulo 4. Desenvolvimento e avaliação qualitativa de sorvete simbiótico com soro do leite e extrato de soja

Capítulo 5. Formulações de geleias de rapadura e melado de cana-de-açúcar: caracterização físico-química e sensorial

Capítulo 6. Inclusão de farinha de peixes de diferentes espécies em massa de esfirra aberta

Capítulo 7. Pesquisa de mercado e avaliação sensorial de sorvete de polpa de jaca liofilizada

\section{Parte 2: Embalagem e Rotulagem de alimentos}

Capítulo 8 Comportamento do consumidor frente a diferentes rótulos nutricionais frontais

Capítulo 9 Isoterma de sorção de uva arra $15 \circledR$ desidratada e armazenada em diferentes embalagens

\section{Parte 3: Gestão ambiental e de resíduos, contaminantes e sustentabilidade na produção de alimentos}

Capítulo 10. A importância da agricultura familiar na atualidade

Capítulo 11. Diagnóstico sobre perdas pós-colheita de frutas e hortaliças no CEASA de juazeiro-BA

Capítulo 12. Estudo do aproveitamento de subprodutos agroindustriais: alternativas para os resíduos gerados pelas indústrias de laticínios

Capítulo 13. Influência da temperatura de secagem nas características físico-químicas e nutricionais do bagaço de cerveja

Capítulo 14. Valorization and treatment of oily wastewaters from agro-industries using lipases: an overview

\section{Parte 4: Produção de alimentos}

Capítulo 15. Alternativas sustentáveis para o manejo de fungos e insetos de armazenamento em grãos de milho para a agricultura familiar

Capítulo 16. Caracterização de Escherichia coli isoladas de suabes de frango de corte e de Alphitobius diaperinus em período pré abate

Capítulo 17. Caracterização físico-química do leite, queijo e queijo misto maturado de ovelha crioula

Capítulo 18. Diagnóstico da ambiência aérea de aviários com protótipo de baixo custo

Capítulo 19. Farinhas de resíduos da filetagem de tilápia com sabor 
Capítulo 20. Fortalecimento da pedagogia da alternância na casa familiar rural de São Luís MA: orientações técnicas em avicultura caipira aos educandos

Capítulo 21. Influência do secamento parcial do sistema radicular na qualidade de frutos do maracujá

Capítulo 22. Inovações em proteínas alternativas: uma revisão sobre alimentos plant-based

Capítulo 23. Planta baixa padrão para agroindustrialização do mel no estado do maranhão com vistas à geração de renda para agricultores familiares

Capítulo 24. Qualidade de ovos de galinha submetidos a diferentes condições de armazenamento e tempo de estocagem utilizando imagem térmica em NOVA Andradina/MS

Capítulo 25. Queijo de manteiga produzido com leite de cabra: avaliação bromatológica

Capítulo 26. Secagem em camada de espuma e caracterização físico química da polpa de guavira (Campomanesia adamantium)

Capítulo 27. Variabilidade espacial e temporal da resistência do solo à penetração na região do Vale do Ivinhema/MS

\section{Parte 5: tecnologias de alimentos e bebidas}

Capítulo 28. Consumo de cerveja: descrição dos consumidores na região agreste de Pernambuco

Capítulo 29. Elaboração do licor de romã e canela: qualidade físico-química e microbiológica

Capítulo 30. Estudo da cinética de secagem e caracterização físico- química da polpa de pitanga (Eugenia uniflora).

Capítulo 31. Iogurte probiótico de pitaya com cupuaçu: avaliação físico-química, microbiológica e comportamento reológico

Capítulo 32. Modelagem matemática da liofilização de frutas e avaliação sensorial do produto processado

Capítulo 33. Palma e chia utilizados como substitutos de estabilizantes em sorvete de umbu

Capítulo 34. Perfil dos consumidores de kombucha

Capítulo 35. Perfil sensorial e avaliação física de cookies com farinha mista extrudada de cascas e albedo de maracujá e arroz

Capítulo 36. Uso de revestimento ativo em frutos: uma tecnologia emergente

Capítulo 37. Tecnologias emergentes: uma nova abordagem para reduzir sódio e fosfato em produtos cárneos

\section{Parte 6: Tecnologias emergentes}

Capítulo 38. Encapsulação de óleos essenciais para aplicação em alimentos: uma revisão

Capítulo 39. Estudos prévios para o encapsulamento de compostos usando açaí, whey protein e carragena

Capítulo 40. Extratos de erva mate (Ilex paraguariensis) microencapsulados são parcialmente protegidos contra a perda de atividade antioxidante durante a digestão gastrointestinal

Capítulo 41. Encapsulação de antioxidantes naturais para aplicação em alimentos: uma revisão 
Capítulo 42. Nano-delivery systems of pesticides active agents for agriculture applications - an overview

Capítulo 43. Nanofertilizers: an overview

Capítulo 44. Revestimentos utilizados em nanopartículas magnéticas para imobilização de enzimas: uma revisão

Capítulo 45. Uma perspectiva para otimização do encapsulamento de açaí com whey protein em spray dryer

Capítulo 46. Uso de óleo essencial de pimenta rosa (Schinus terebinthifolius Raddi) incorporado em revestimentos para controle de microrganismos - revisão

\section{Parte 7: Segurança alimentar}

Capítulo 47. A escola como campo de atuação no fortalecimento da alimentação saudável: uma revisão integrativa

Capítulo 48. Aproveitamento do albedo do maracujá na produção de alimentos

Capítulo 49. Análise do perfil dos consumidores de leite condensado, doce de leite e sobremesas lácteas no estado de Pernambuco

Capítulo 50. Aproveitamento integral dos alimentos como instrumento de segurança alimentar e desenvolvimento humano: êxitos e desafios

Capítulo 51. Bactérias ácido lácticas na descontaminação de aflatoxinas em leite bovino: uma revisão

Capítulo 52. Composição centesimal, atividade antioxidante e antimicrobiana de uma planta alimentícia não convencional (PANC) do gênero Amaranthus

Capítulo 53. Do rio à mesa, o consumo de pescados na Amazônia: perfil do consumidor e critérios de compra em Belém (PA)

Capítulo 54. Perfil populacional e conhecimento acerca da fome oculta e biofortificação de alimentos 


\title{
CAPÍTULO 01: CARACTERIZAÇÃO DE CUPCAKES ELABORADOS COM DIFERENTES CONCENTRAÇÕES DE FARINHA DE CASCA DE GUAVIRA
}

\section{CHAPTER 01: CHARACTERIZATION OF CUPCAKES PREPARED WITH GUAVIRA SKIN FLOUR IN DIFFERENT CONCENTRATIONS}

\author{
João Renato de Jesus Junqueira ${ }^{1}$; Mariana Tallita Gomes dos Santos ${ }^{2}$; Danielle Bogo ${ }^{3}$; Ana Cristina
} Araújo Ajalla ${ }^{4}$; Raquel Pires Campos ${ }^{5}$;

\begin{abstract}
Resumo
Cupcakes são produtos de panificação consumidos no Brasil e aceitos por maior parte da população. O objetivo do trabalho foi elaborar a farinha de casca de guavira (FCG), e aplicála na formulação de cupcakes. Na FCG, foram realizadas as análises de umidade $(9,11 \pm 0.81$ $\mathrm{g} / 100 \mathrm{~g})$, cinzas $(2,16 \pm 0.00 \mathrm{~g} / 100 \mathrm{~g})$ e proteínas $(3,54 \pm 0.09 \mathrm{~g} / 100 \mathrm{~g})$. Os cupcakes foram elaborados com diferentes concentrações de FCG (10\% e 15\%) substituindo parcialmente a farinha de trigo. As análises realizadas nos cupcakes foram umidade, cinzas, proteínas, acidez titulável, pH, volume aparente e cor. Os cupcakes com FCG apresentaram maior teor de umidade. Cinzas e proteínas não mostraram diferença significativa $(p<0,05)$ entre as formulações. Acidez titulável apresentou maior teor e $\mathrm{pH}$ menor teor nas formulações com $10 \%$ e $15 \%$ de FCG, quando comparadas com o padrão. O volume aparente diminuiu na presença de FCG e notou-se escurecimento na análise de cor dos cupcakes. De acordo com as análises realizadas, observou-se a viabilidade da substituição parcial de farinha de trigo por FCG na formulação dos cupcakes.
\end{abstract}

Palavras-Chaves: Campomanesia ssp., Cerrado brasileiro, Frutos nativos.

\begin{abstract}
Cupcakes are bakery products consumed in the Brazil and accepted by most of the population. The aim of this work was to obtain guavira skin flour (GSF), and to apply it in the cupcake formulation. For the guavira skin flour, the moisture, ash and protein contents was $9.11 \pm$ $0.81,2.16 \pm 0.00$ and $3.54 \pm 0.09 \mathrm{~g} / 100 \mathrm{~g}$, respectively. The cupcakes were prepared with different concentrations of GSF $(10 \%$ and $15 \%)$ replacing wheat flour. The analyzes performed on the cupcakes were moisture, ash, proteins, titratable acidity, $\mathrm{pH}$, apparent volume and color. Cupcakes prepared with GSF presented higher moisture content. No significant difference $(\mathrm{p}<0.05)$ were observed for the ash and protein contents amid the different formulations. Titratable acidity showed higher content and lower $\mathrm{pH}$ in the formulations with $10 \%$ and $15 \%$ of addition of SGF, in comparison with the standard. The apparent volume decreased in the presence of SGF and color darkening was noted in the cupcakes. According to the performed analyzes, the feasibility of partially replacing wheat flour with SGF in the formulation of cupcakes was observed.
\end{abstract}

Keywords: Campomanesia ssp., Brazilian Savannah, Native fruits.

\footnotetext{
${ }^{1}$ Tecnologia em Alimentos, Universidade Federal de Mato Grosso do Sul, joao.junqueira@ufms.br

2 Tecnologia em Alimentos, Universidade Federal de Mato Grosso do Sul, maritallita95@gmail.com

${ }^{3}$ Tecnologia em Alimentos, Universidade Federal de Mato Grosso do Sul, danielle.bogo@ufms.br

4 Agronomia, Agência de Desenvolvimento Agrário e Extensão Rural de Mato Grosso do Sul, anajallaagraer@gmail.com

${ }^{5}$ Tecnologia em Alimentos, Universidade Federal de Mato Grosso do Sul, raquel.campos@ufms.br
} 


\section{Introdução}

A guavira (Campomanesia ssp.), também conhecida como gabiroba, pertence à família Myrtaceae, sendo um fruto nativo do Cerrado e muito comum no estado de Mato Grosso do Sul. O fruto apresenta reduzida vida útil, com seis dias quando mantido em condições ambiente e sem uso de embalagens adequadas (CAMPOS et al., 2012). A polpa do fruto, de sabor adocicado, pode ser consumida in natura ou em forma de preparações culinárias como geleias e sucos.

Apresenta baixo teor energético, devido à reduzida concentração de macronutrientes, especialmente lipídios $(0,12 \mathrm{~g} / 100 \mathrm{~g})$, e contém bons conteúdos de cálcio, zinco, ferro e fibras (SILVA et al., 2008). Sua polpa e casca são ricas em vitamina C, minerais e compostos bioativos. O bagaço constituído de casca, restos de polpa e sementes da guavira após secagem e pulverização gera a farinha de bagaço de guavira, pode ser utilizado como suplemento alimentar com efeito antitumoral e imunomodulador (ZULIM, 2019).

As farinhas podem ser obtidas de diferentes origens botânicas, embora a farinha de trigo branca seja amplamente utilizada na obtenção de diversos produtos, como bolos, pães e biscoitos. No Brasil, são observados programas de elaboração de alimentos que visam a substituição ou redução da farinha de trigo por outras farinhas obtidas a partir do aproveitamento de partes de plantas e frutos que seriam descartados.

O uso de resíduos de guavira (casca, semente, pedúnculo), provenientes da indústria de polpas congeladas, em adição de até $8 \%$ em barra de cereais foi bem aceito pelas crianças, obtendo-se aceitação sensorial semelhante ao produto padrão e também colabora com a redução de perdas e de efeitos negativos gerados pelo descarte de lixo orgânico no meio ambiente (CAIN et al., 2019).

O desenvolvimento de pesquisas que auxiliem na obtenção de novos produtos com características diferenciadas é uma das necessidades da indústria de alimentos. Os produtos de panificação como bolos e cupcakes são consumidos em todo o mundo, apresentando grande aceitação pela população. De fácil preparo e diversificação de sabores, também possibilitam a substituição total ou parcial de alguns ingredientes, ou adição de componentes que proporcionem melhores características tecnológicas, e forneçam substâncias benéficas ao consumidor (LEBESI; TZIA, 2011).

O melhor aproveitamento dos frutos da guavira associado a criação de novos produtos de panificação pode contribuir com o desenvolvimento da economia do estado de Mato Grosso do Sul e com a sua conservação. Em 2017, este fruto que apresenta importância cultural, foi eleito como símbolo do estado, sendo protagonista de diversos eventos 
gastronômicos, como o "Cata Guavira", em Bonito - MS, que ocorre anualmente e apresenta o apelo para a importância e necessidade do uso sustentável dos frutos nativos, além do Seminário Estadual da Guavira promovido por várias instituições.

Sendo assim, o presente trabalho teve como objetivo avaliar a influência da substituição parcial da farinha de trigo pela farinha de casca de guavira (FCG) em diferentes concentrações (10\% e 15\%) na elaboração de cupcakes, a partir da determinação de propriedades físico-químicas da farinha e dos cupcakes, assim como dos parâmetros de cor e volume aparente dos cupcakes desenvolvidos.

\section{Material e Métodos}

\section{Materiais}

Os frutos de guavira foram coletados no Centro de Pesquisa (Cepaer) da Agência de Desenvolvimento Agrário e Extensão Rural (Agraer), no município de Campo Grande - MS, no mês de novembro de 2019. Na Unidade de Tecnologia em Alimentos (Unital) da Universidade Federal do Mato Grosso do Sul (UFMS), os frutos de guavira foram inicialmente lavados em água corrente. Procedeu-se a separação manual entre a casca e $\mathrm{polpa} / \mathrm{semente}$.

As frações foram congeladas a $-18{ }^{\circ} \mathrm{C}$ para posterior utilização. Para obtenção da farinha da casca da guavira (FCG), as cascas foram descongeladas e em seguida submetidas à secagem em estufa com circulação de ar natural (Lucadema, 82/882, Brasil) a $60{ }^{\circ} \mathrm{C}$, por aproximadamente 48 horas. As cascas desidratadas foram acondicionadas em recipiente de plástico, identificadas e armazenadas, sendo em seguida trituradas em moinho (Tecnal, TE631, Brasil), para obtenção da farinha (Figura 1).

Figura 1. (a) Casca de guavira congelada; (b) Casca de guavira desidratada; (c) Casca de guavira triturada (farinha)

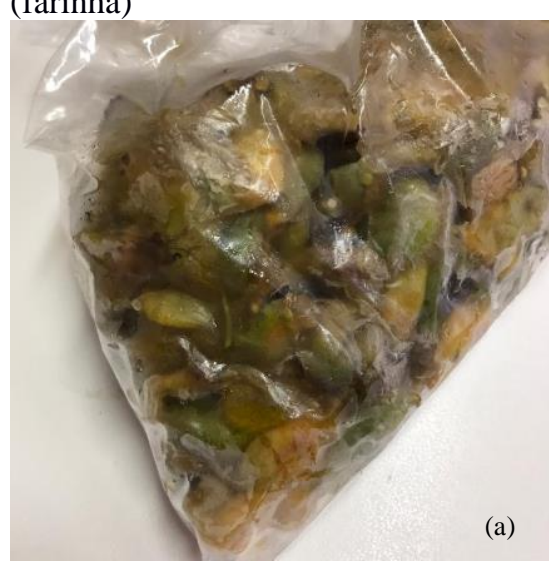

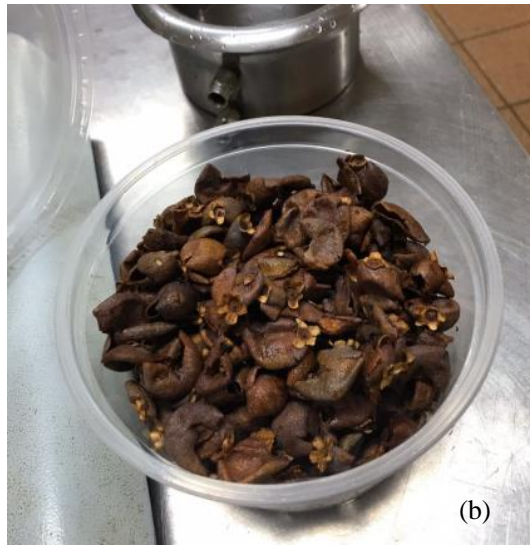

Fonte: Própria (2020).

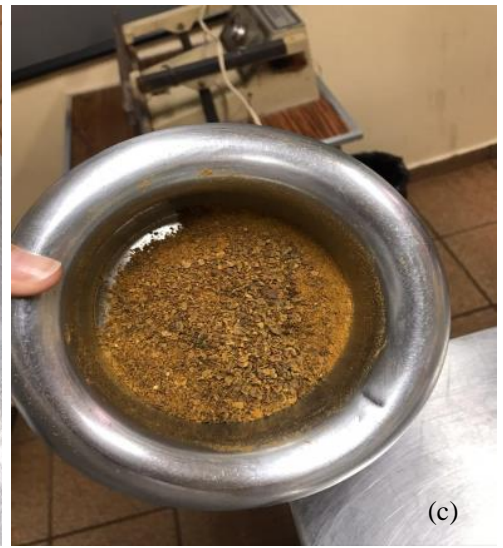


As farinhas de casca de guavira foram identificadas, acondicionadas em recipiente de plástico e armazenadas a temperatura ambiente, por $24 \mathrm{~h}$ até a sua utilização. Os demais ingredientes utilizados na formulação dos cupcakes (farinha de trigo, óleo de soja, açúcar cristal, fermento em pó e ovos) foram adquiridos no comércio local de Campo Grande - MS.

\section{Preparo das formulações}

Foram elaborados três tipos de formulação de cupcakes: Formulação 1 (padrão, sem substituição de farinha de trigo), Formulação 2 (substituição parcial da farinha de trigo pela FCG - 10\%), e Formulação 3 (substituição parcial da farinha de trigo pela FCG - 15\%), conforme apresentado na Tabela 1.

Tabela 1. Formulações dos cupcakes a partir da adição de Farinha de Casca de Guavira (FCG).

\begin{tabular}{cccc}
\hline Ingredientes & Formulação 1 (0\%) & Formulação 2(10\%) & Formulação 3 (15\%) \\
\hline Farinha de trigo & $120 \mathrm{~g}$ & $108 \mathrm{~g}$ & $102 \mathrm{~g}$ \\
Leite & $80 \mathrm{~mL}$ & $80 \mathrm{~mL}$ & $80 \mathrm{~mL}$ \\
Óleo & $40 \mathrm{~mL}$ & $40 \mathrm{~mL}$ & $40 \mathrm{~mL}$ \\
Açúcar & $100 \mathrm{~g}$ & $100 \mathrm{~g}$ & $100 \mathrm{~g}$ \\
Ovos & $44 \mathrm{~g}$ & $44 \mathrm{~g}$ & $44 \mathrm{~g}$ \\
Fermento em pó & $5 \mathrm{~g}$ & $5 \mathrm{~g}$ & $5 \mathrm{~g}$ \\
FCG & - & $12 \mathrm{~g}$ & $18 \mathrm{~g}$ \\
\hline
\end{tabular}

Fonte: Própria (2020).

Na elaboração dos cupcakes, foram adicionados os seguintes ingredientes: farinha de trigo, FCG, óleo de soja, açúcar cristal, leite, fermento em pó e ovos. A preparação da massa dos cupcakes foi realizada manualmente pela mistura contínua das matérias-primas (pesadas em balança analítica), por aproximadamente três minutos, até a obtenção de massa homogênea (Fig. 2). As massas formadas foram dispostas em formas próprias e assadas em forno industrial, na temperatura de $180{ }^{\circ} \mathrm{C}$, de 35 a 40 minutos. Após serem assados, os mesmos foram resfriados, acondicionados em sacos plásticos e armazenados em temperatura ambiente, por $16 \mathrm{~h}$ até a realização das análises.

\section{Caracterização da FCG e dos cupcakes}

A caracterização físico-química da FCG e dos cupcakes foi efetuada no Laboratório de Físico-Química da Unidade de Tecnologia em Alimentos e Saúde Pública (UTASP) da Universidade Federal de Mato Grosso do Sul (UFMS).

A determinação de umidade foi realizada em estufa $\left(105{ }^{\circ} \mathrm{C}\right)$ até peso constante, enquanto a determinação de cinzas foi realizada em mufla $\left(550{ }^{\circ} \mathrm{C}\right)$. Para a análise de proteínas totais, foram avaliados os teores de nitrogênio total, utilizando- se o método 
Kjeldahl empregando como fator de conversão de nitrogênio o valor de 6,25 (IAL, 2008).

Figura 2. Massas dos cupcakes antes do assamento (a) com adição de FCG (b) sem adição de FCG

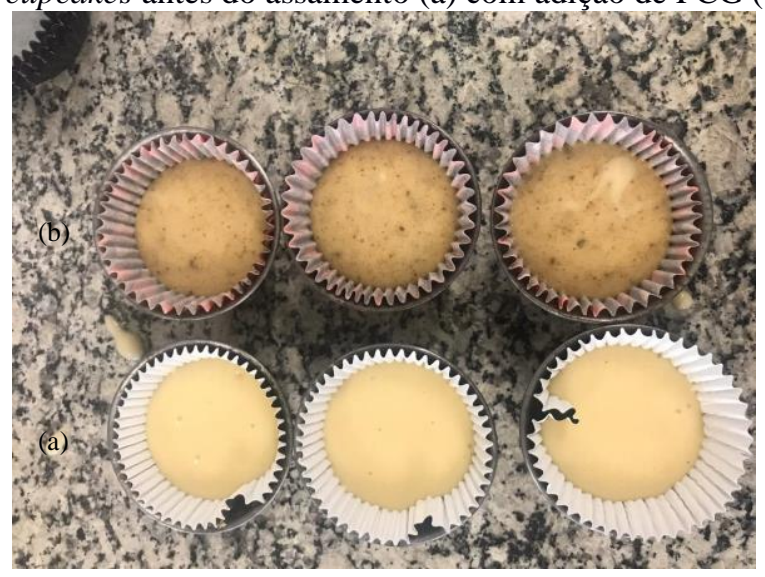

Fonte: Própria (2020).

A composição físico-química das formulações de cupcakes, assim como da FCG foram determinadas segundo metodologia proposta pelo Instituto Adolf Lutz (IAL, 2008), com resultados expressos em g/ $100 \mathrm{~g}$. Todas as análises foram efetuadas em triplicata.

Nas formulações de cupcake, o pH e a acidez titulável, foram avaliados de acordo com as metodologias do Instituto Adolf Lutz (IAL, 2008). O volume aparente dos cupcakes foi determinado pelo deslocamento de sementes de painço, de acordo com método AACC (2000).

A cor da crosta e do miolo dos cupcakes foi determinada empregando colorímetro (Konica Minolta, CM - 2300d, Japão). Os valores de L* (luminosidade, 0 - preto/ 100 branco), $\mathrm{a}^{*}$ (componente vermelho-verde) e $\mathrm{b}^{*}$ (componente amarelo-azul) foram obtidos, sendo a equação 1 utilizada para o cálculo da diferença total de cor $(\Delta \mathrm{E})$.

$$
\Delta E=\sqrt{\left(L^{*}-L_{0}^{*}\right)^{2}+\left(a^{*}-a_{0}^{*}\right)^{2}+\left(b^{*}-b_{0}^{*}\right)^{2}}
$$

O subscrito 0 indica valores obtidos na formulação padrão (sem FCG).

\section{Análises estatísticas}

Os resultados foram analisados utilizando o software Sisvar ${ }^{\circledR}$ (FERREIRA, 2019). Os dados obtidos nas análises físico-químicas e físicas dos cupcakes foram avaliados aplicandose teste de medias (Tukey), com 5\% de nível de significância.

\section{Resultados e Discussão}

\section{Caracterização físico-química da FCG}

As médias e o desvio-padrão dos parâmetros umidade, cinzas e proteínas totais da 
FCG são apresentadas na Tabela 2.

Tabela 2. Composição físico-química da Farinha da casca de Guavira (FCG)

\begin{tabular}{cc}
\hline Componentes & FCG $(\mathrm{g} / 100 \mathrm{~g})$ \\
\hline Umidade & $9,11 \pm 0,81$ \\
Proteínas Totais & $3,54 \pm 0,09$ \\
Cinzas & $2,16 \pm 0,00$ \\
Valores expressos em média \pm desvio padrão. \\
\multicolumn{2}{c}{ Fonte: Própria (2020). }
\end{tabular}

Com base na Tabela 2, observou-se que a FCG obteve teor de umidade igual a 9,11 \pm 0,81 g/ $100 \mathrm{~g}$, abaixo do valor máximo preconizado para farinhas (15 g/ $100 \mathrm{~g}$ ), de acordo com a Resolução RDC n 263 (BRASIL, 2005), o que pode contribuir para manutenção de sua vida útil, bem como retardar o desenvolvimento de microrganismos. Guimarães et al. (2010) obtiveram valor de umidade da farinha da entrecasca da melancia igual a 9,06 g / 100 g, valor próximo ao encontrado em nosso estudo.

O teor de proteínas totais obtido na FCG foi de 3,54 \pm 0,09 g/ $100 \mathrm{~g}$. Cavalcanti et al. (2011) obtiveram o valor de proteínas de 5,57 g/ 100 g para a farinha de juazeiro, valor superior ao encontrado no nosso estudo.

De acordo com a Tabela 2, o teor de cinzas foi igual a 2,16 $\pm 0,00 \mathrm{~g} / 100 \mathrm{~g}$. Campos et al. (2016) encontrou o valor de 2,40 g/ 100 g para cinzas na farinha da casca de pequi, semelhante ao valor reportado para a FCG.

\section{Caracterização físico-química dos cupcakes}

$\mathrm{Na}$ Tabela 3, estão representadas as médias dos componentes físico-químicos analisados das formulações de cupcake.

Tabela 3. Composição físico-química das formulações de cupcakes com diferentes concentrações de Farrinha da Casca de Guavira (FCG) em substituição a farinha de trigo.

\begin{tabular}{cccc}
\hline Componentes & Formulação 1 $(0 \%)$ & Formulação 2 (10\%) & Formulação 3 (15\%) \\
\hline Umidade $(\mathrm{g} / 100 \mathrm{~g})$ & $21,17^{\mathrm{c}} \pm 0,10$ & $22,70^{\mathrm{a}} \pm 0,10$ & $22,00^{\mathrm{b}} \pm 0,01$ \\
Cinzas $(\mathrm{g} / 100 \mathrm{~g})$ & $0,95^{\mathrm{a}} \pm 0,00$ & $0,94^{\mathrm{a}} \pm 0,00$ & $0,99^{\mathrm{a}} \pm 0,10$ \\
Proteínas Totais $(\mathrm{g} / 100 \mathrm{~g})$ & $6,13^{\mathrm{a}} \pm 1,39$ & $6,29^{\mathrm{a}} \pm 0,04$ & $6,20^{\mathrm{a}} \pm 0,39$ \\
Acidez titulável $(\%)$ & $1,13^{\mathrm{b}} \pm 0,05$ & $1,48^{\mathrm{ab}} \pm 0,15$ & $1,82^{\mathrm{a}} \pm 0,27$ \\
pH & $8,80^{\mathrm{a}} \pm 0,05$ & $8,38^{\mathrm{b}} \pm 0,03$ & $8,02^{\mathrm{c}} \pm 0,11$ \\
\hline
\end{tabular}

Letras diferentes na linha indicam diferença significativa pelo teste de Tukey $(\mathrm{p}<0,05)$. Valores expressos em média \pm desvio padrão.

Fonte: Própria (2020).

De acordo com a Tabela 3, observou-se diferença significativa $(\mathrm{p}<0,05)$ nos teores de umidade dos diferentes tratamentos. Maiores teores de umidade foram encontrados nas 
formulações de 10 e $15 \%$ de adição de FCG. A presença de maior teor de fibras na FCG pode ter contribuído para o aumento dos teores de umidade dos cupcakes.

Guimarães et al. (2010) observaram aumento no teor de umidade de bolos adicionados com farinha da entrecasca da melancia. A formulação controle apresentou teor de 25,68 g/ $100 \mathrm{~g}$ e as formulações com adição da farinha apresentaram 30,41 g/ $100 \mathrm{~g}$ e 30,44 g/ $100 \mathrm{~g}$. Estes autores justificaram que a presença de fibras auxilia na retenção de água em sua estrutura durante a etapa de cocção, favorecendo assim um maior teor de umidade final no produto.

Da mesma forma, Andrade et al. (2015), durante a elaboração de bolos com farinha desmucilada de taro, relataram umidade de 23,22 g/ $100 \mathrm{~g}$ a 27,17 g/ $100 \mathrm{~g}$, observando que à medida em que a farinha desmucilada de taro era adicionada, o teor de umidade era aumentado, pois as fibras apresentam propriedade de retenção de água.

Pereira et al. (2010 a) obtiveram teores de umidade de bolos adicionados com flocos de amaranto variando entre 23,9 g/ $100 \mathrm{~g}$ a 28,3 g/ $100 \mathrm{~g}$. Estes autores observaram diferenças significativas para este parâmetro nos diferentes tratamentos (0, 10, 20 e 30\%).

A Agência Nacional de Vigilância Sanitária (Anvisa) recomenda valores máximos de $38 \mathrm{~g} / 100 \mathrm{~g}$ de umidade para produtos de panificação, estando o bolo desenvolvido no presente estudo dentro do recomendado (BRASIL, 2000).

O teor de cinzas representa a quantidade de minerais que contém no produto avaliado. Observando a Tabela 3 , percebe-se que não houve diferença significativa $(p>0,05)$ entre as formulações de cupcakes avaliadas. Moscatto et al. (2004) encontraram valores de cinzas variando entre 1,42 a 1,93 g/ $100 \mathrm{~g}$ em formulações de bolos de chocolate com substituição parcial de farinha de trigo por farinha de yacon e inulina em diferentes concentrações. Pereira et al. (2010a) encontraram valor médio de cinzas igual a 1,99 g/ $100 \mathrm{~g}$ em formulações de bolos de com adição de flocos de amaranto em diferentes concentrações.

Não houve diferença significativa $(p>0,05)$ no teor de proteínas entre as formulações de cupcakes, variando de 6,13 a 6,29 g/ 100 g (Tabela 3). Ou seja, a substituição parcial de farinha de trigo pela FCG não altera o valor protéico nos cupcakes. Marcelino et al. (2018) obtiveram valores 7,8 e 8,52 g/ 100 g quando elaboraram cupcakes com diferentes concentrações de farinha de casca e polpa de baru. Durante a elaboração de bolos com adição de flocos de amaranto em diferentes concentrações, Pereira et al. (2010a) obtiveram valores de proteínas variando entre 5,60 a 6,05 g/ 100 g.

Observando o parâmetro acidez titulável, nota-se que houve diferença significativa $(p<0,05)$ entre as formulações padrão e $15 \%$, entretanto, não houve diferença significativa 
( $p>0,05)$ entre a formulação padrão e $10 \%$, e entre $10 \%$ e $15 \%$. Conclui-se que a maior substituição de FCG levou a um aumento na acidez dos cupcakes.

Moura et al. (2014) obtiveram valor próximo de acidez titulável ao analisarem bolo com farinha de pupunha, 2,47\%, e valores superiores em bolos com adição de farinha de açaí $(4,13 \%)$ e farinha de tucumã $(4,13 \%)$. Silva (2019) obteve valores menores, que ficaram entre $0,05 \%$, e $0,24 \%$ em formulações de bolo com substituição parcial da farinha de trigo pela farinha da massa do xiquexique.

Analisando a Tabela 3, houve diferença significativa $(\mathrm{p}<0,05)$ no $\mathrm{pH}$ entre a formulação padrão e as formulações com substituição por FCG. Observou-se que, ao adicionar a FCG, diminui-se o pH dos cupcakes, o que vem ao encontro do valor aumentado de acidez titulável encontrado nestas formulações. Poletto et al. (2015) obtiveram valor menor, 7,05, ao analisarem bolo de chocolate modificado. Maia et al. (2018) relataram pH 6,65 , ao elaborarem bolo de milho com adição de $5 \%$ de farinha de maracujá.

\section{Análises físicas dos cupcakes}

Os parâmetros de cor para crosta e miolo dos cupcakes estão apresentados na Tabela 4.

De acordo com a Tabela 4, foram observadas diferenças significativas entre os diferentes tratamentos $(\mathrm{p}<0,05)$ entre si para os parâmetros de cor. Conforme maior adição da farinha de casca da guavira, as formulações de cupcake apresentavam redução no parâmetro de luminosidade $\left(\mathrm{L}^{*}\right)$, indicando possível escurecimento tanto da crosta quanto do miolo.

Tabela 4. Composição físico-química das formulações de cupcakes, com diferentes concentrações de Farinha da Casca de Guavira (FCG) em substituição a farinha de trigo.

\begin{tabular}{ccccc}
\hline Crosta & \multicolumn{1}{c}{ Formulação 1 $(0 \%)$} & Formulação 2 (10\%) & Formulação 3 $(15 \%)$ \\
\hline & $\mathrm{L}^{*}$ & $7,05^{\mathrm{a}} \pm 0,15$ & $2,47^{\mathrm{b}} \pm 1,08$ & $1,36^{\mathrm{b}} \pm 0,53$ \\
& $\mathrm{a}^{*}$ & $3,68^{\mathrm{a}} \pm 1,82$ & $1,24^{\mathrm{ab}} \pm 0,38$ & $0,88^{\mathrm{b}} \pm 0,47$ \\
& $\mathrm{~b}^{*}$ & $7,62^{\mathrm{a}} \pm 0,67$ & $2,17^{\mathrm{b}} \pm 0,96$ & $1,14^{\mathrm{b}} \pm 0,64$ \\
\hline Miolo & & & \\
\hline & $\mathrm{L}^{*}$ & $13,23^{\mathrm{a}} \pm 6,38$ & $2,32^{\mathrm{b}} \pm 0,51$ & $3,55^{\mathrm{b}} \pm 0,94$ \\
& $\mathrm{a}^{*}$ & $1,06^{\mathrm{a}} \pm 0,27$ & $0,71^{\mathrm{a}} \pm 0,08$ & $1,19^{\mathrm{a}} \pm 0,34$ \\
& $\mathrm{~b}^{*}$ & $8,81^{\mathrm{b}} \pm 3,13$ & $1,67^{\mathrm{a}} \pm 0,36$ & $2,74^{\mathrm{a}} \pm 0,81$ \\
\hline
\end{tabular}

Letras diferentes na linha indicam diferença significativa pelo teste de Tukey $(\mathrm{p}<0,05)$. Valores expressos em média \pm desvio padrão.

Fonte: Própria (2020).

Padilha et al. (2010) ao obterem valores de 20,91 e 19,79 no parâmetro luminosidade $\left(\mathrm{L}^{*}\right)$, observaram que a adição de farinha de yacon em formulações de bolos de chocolate influenciou em sua caracterização cromática, pois deixou-os mais escuros.

De acordo com Pereira et al. (2010b), o parâmetro luminosidade ( $\left.\mathrm{L}^{*}\right)$ variou de 52,2 a 
56,7 para cor da crosta e de 70,9 a 74,2 para cor do miolo em bolos elaborados com diferentes concentrações de flocos de amaranto.

$\mathrm{Na}$ Tabela 4, observando o parâmetro a* da crosta, percebe-se que houve diferença significativa $(\mathrm{p}<0,05)$ entre as formulações. O padrão se mostrou diferente da formulação com $15 \%$ de FCG, porém, igual à formulação com $10 \%$. O parâmetro a ${ }^{*}$ do miolo, não apresentou diferença significativa ( $>$ >0,05) entre as formulações com adição de FCG e o padrão.

Ao observar o parâmetro $b^{*}$ observou-se que as formulações com substituição parcial da farinha de trigo por FCG, apresentaram diferença significativa (p>0,05) quando comparadas ao padrão. Ao aumentar a concentração de FCG nas formulações, o valor de b* foi reduzido, demonstrando que o bolo obteve menos tons de amarelo. As formulações com substituição de 10 e $15 \%$ de FCG não diferiram entre si. No caso de bolos elaborados com farinha de semente de abóbora, Bitencourt et al. (2014) relataram que apresentaram valores de $b^{*}$ maiores, com 27,83 a 31,18, que aqueles com apenas farinha de trigo, 21,82.

A diferença total de cor $(\Delta \mathrm{E})$ da crosta para a formulação $10 \%$ foi de 7,51 , e para a formulação de $15 \%$ foi de 9,06 . Isso indica que maior substituição de farinha de trigo por FCG levou a um aumento na diferença de cor da crosta com relação à formulação padrão.

De forma semelhante Borges et al. (2013) observaram que ao aumentar a concentração de quinoa na formulação de bolo, houve aumento de $\Delta \mathrm{E}$, indicando escurecimento do mesmo. Andrade et al. (2015) também relataram que ao aumentar a concentração de farinha de taro em bolos, os valores de $\Delta \mathrm{E}$ apresentaram aumento quando comparados ao padrão, mostrando diferença na cor entre as formulações.

A Figura 3 apresenta as diferentes formulações de cupcakes. Visualmente, percebe-se diferenças de coloração entre as formulações após o assamento, o que pode ser comprovado através da Tabela 4.

Na Figura 4 são apresentados os valores de volume aparente obtidos das formulações de cupcakes. Observa-se diferença significativa $(\mathrm{p}<0,05)$ entre os cupcakes com substituição parcial de FCG e o com formulação padrão. Os cupcakes com substituição apresentaram menor volume aparente após cocção e não mostraram diferença significativa $(p>0,05)$ entre si. Ainda assim, as formulações com substituição parcial de farinha de casca de guavira, tiveram um bom desempenho de crescimento.

Ozores et al. (2015) observaram que bolos com adição de 5\% e 10\% de farinha de maracujá obtiveram um aumento significativo no volume específico em relação ao padrão, o que não foi observado com a adição da farinha de casca de guavira. Guimarães et al. (2010) ao estudarem a influência da adição de farinha de entrecasca de melancia na elaboração de 
bolos, observaram que ao adicionar $7 \%$ houve aumento no volume, mas ao adicionar 30\%, houve diminuição. Novos estudos podem ser realizados para verificar a redução do volume aparente nos cupcakes com substituição parcial de FCG.

Figura 3. Cupcakes após o assamento (a) Formulação 1 (0\%), (b) Formulação 2 (10\%), (c) Formulação 3 (15\%)

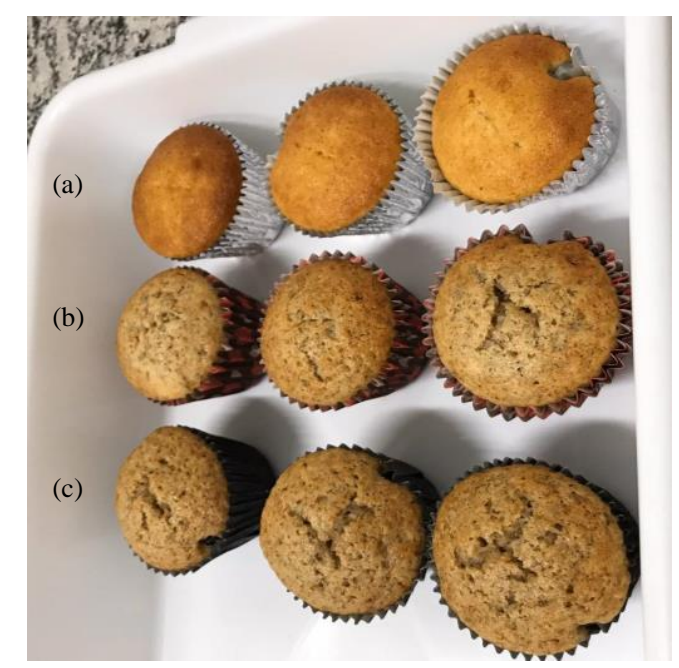

Fonte: Própria (2020).

Figura 4. Valores de volume aparente obtidos das formulações de cupcakes (Médias \pm DP), com diferentes concentrações de Farrinha da Casca de Guavira (FCG) em substituição a farinha de trigo.

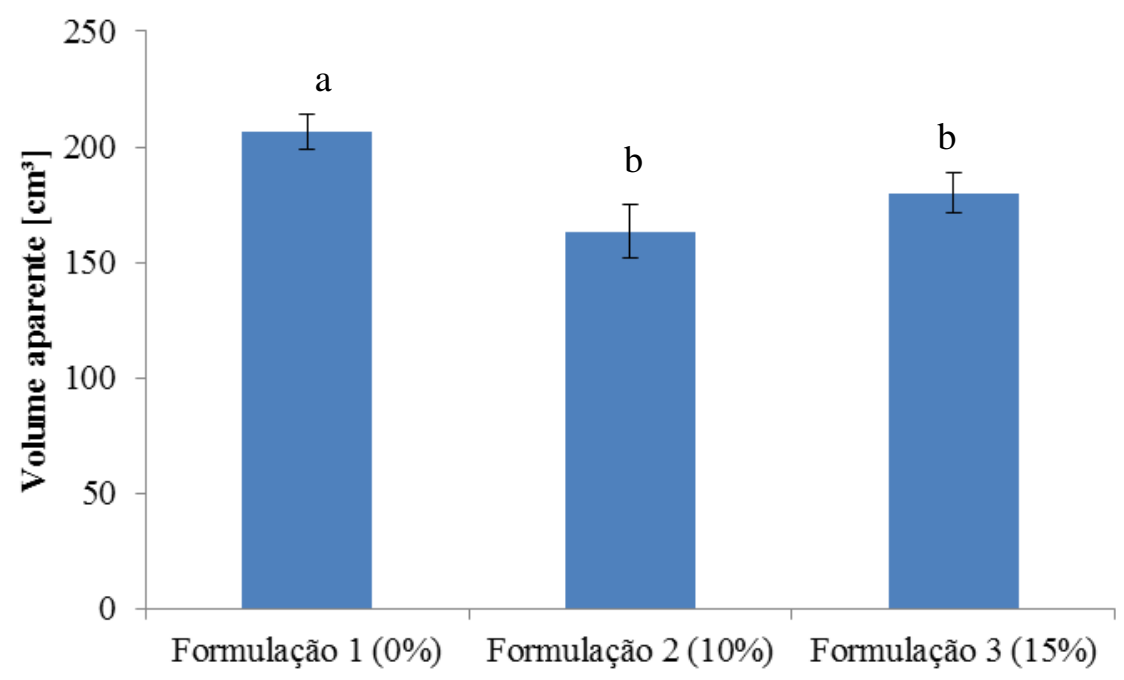

Letras diferentes indicam diferença significativa pelo teste de Tukey $(\mathrm{p}<0,05)$. Valores expressos em média \pm desvio padrão.

Fonte: Própria (2020).

Embora os resultados das análises físicas sejam diferentes do padrão sem adição de FCG, a substituição de farinha de trigo por farinha de casca de guavira apresentou resultados gerais positivos demonstrando a viabilidade do seu uso na elaboração de cupcakes com estes valores de substituição da farinha de trigo. 


\section{Conclusões}

A farinha da casca de guavira (FCG) apresentou baixo teor de umidade, dentro do preconizado para farinhas, com valores de proteínas 3,54 e cinzas de 2,16.

Os cupcakes com substituição de 10 e $15 \%$ de farinha de trigo por FCG apresentaram maior umidade do que a formulação padrão, sem adição de FCG. Os conteúdos de cinzas e proteínas não apresentaram diferença significativa $(\mathrm{p}>0,05)$ entre os cupcakes.

A substituição parcial de farinha de trigo por FCG resultou em maior acidez titulável diminuição do pH em relação ao cupcake padrão.

Conforme o aumento na concentração de FCG maior o escurecimento e menor tonalidade amarelada dos cupcakes, além da diminuição do volume aparente. Conclui-se, pelos resultados obtidos que é viável a substituição de farinha de trigo por farinha de casca de guavira.

\section{Referências}

ANDRADE, L. A.; NAGATA, C. L. P.; ASSUMPÇÃO, G. M. P.; GONÇALVES, G. A. S.; PEREIRA, J. Farinha desmucilada de taro utilizada na elaboração de bolos. Científica, v 43, p. 203-214, 2015

AMERICAN ASSOCIATION OF CEREAL CHEMISTS (AACC). Approved Methods of the AACC. 10. ed. Sant Paul: American Association of Cereal Chemists, 2000.

ASSOCIATION OF OFFICIAL ANALYTICAL CHEMISTS (AOAC). Official Methods of analysis of AOAC International. 19 ed. Washington: AOAC International, 2012.

BITENCOURT, C.; DUTRA, F. L. G.; PINTO, V. Z.; HELBIG, E.; BORGES, L. R. Elaboração de bolos enriquecidos com semente de abóbora: avaliação química, física e sensorial. Boletim Ceppa, v. 32, n. 1, p. 19-32, 2014.

BORGES, J. T. S.; PIROZI, M. R.; VIDIGAL, J. G.; PAULA, C. D.; SILVA, N. A. S. Utilização de farinha mista de trigo e quinoa na elaboração de bolos. Revista Brasileira de Tecnologia Agroindustrial, v. 07, n. 2, p. 1034-1048, 2013.

BRASIL. Ministério de Agricultura, Pecuária e Abastecimento. Instrução normativa $n^{\circ}$ 8, 03 jun. 2005. Regulamento Técnico de Identidade e Qualidade da Farinha de Trigo. Diário Oficial da República Federativa do Brasil, Brasília, DF, Seção 1, n. 105, p. 91.03 junho, 2005 .

CAIN, J. P.; SILVA, A. C. G. da; SOARES, J. M.; SANTOS, M. M. R.; AMARAL, L. A. do; SANTOS, E. F dos; NOVELLO, D. Adição de farinha de resíduos de guavira em barra de cereais: aceitabilidade sensorial e caracterização físico-química. Conexão Ci, Formiga, MG, v. 14 , n. 1, p.18-26. 2019.

CAMPOS, R. P.; HIANE, P. A.; RAMOS, M. I. L.; RAMOS FILHO, M. M.; Macedo, M. L. R. Conservação pós-colheita de guavira (Campomanesia sp.). Revista Brasileira de Fruticultura, Jaboticabal , v. 34, n. 1, p. 41-49, Mar. 2012. 
CAMPOS, R. P. et al. Elaboração e caracterização de farinha da casca de pequi. Agroecologia, v. 11, n. 2, p. 1-12, 2016.

CAVAlCANTI, M. T.; SILVEIRA, D. C.; FLORÊNCIO, I. M.; FEITOSA, V. A.; ELLER, S. C. W. S. Obtenção da farinha do fruto do juazeiro (Ziziphus joazeiro mart.) e caracterização físico-química. Revista Verde de Agroecologia e Desenvolvimento Sustentável, v. 6, p. 220-224, 2011.

FERREIRA, D. F. SISVAR: A Computer Analysis System To Fixed Effects Split Plot Type Designs. Revista Brasileira De Biometria, [S.1.], v. 37, n. 4, p. 529-535, 2019.

GUIMARÃES, R. R.; FREITAS, M. C. J.; SILVA, V. L. M. Bolos simples elaborados com farinha da entrecasca de melancia (Citrullus vulgaris, sobral): avaliação química, física e sensorial. Ciência e Tecnologia de Alimentos, v. 30, n. 2, p. 354-363, 2010.

INSTITUTO ADOLFO LUTZ. Métodos físico-químicos para análise de alimentos. São Paulo: Instituto Adolfo Lutz, 2008. 1020 p.

LEBESI, D. M.; TZIA, C. Effect of the Addition of Different Dietary Fiber and Edible Cereal Bran Sources on the Baking and Sensory Characteristics of Cupcakes. Food and Bioprocess Technology, v. 4, p. 710-722, 2011.

MAIA, S. et al. Farinha de maracujá na elaboração de bolo de milho. Revista Verde de Agroecologia e Desenvolvimento Sustentável, v. 13, n. 3, p. 328-336, 2018.

MARCELINO, G. et al. Caracterização e análise sensorial de cupcakes elaborados com diferentes concentrações de farinha de casca e polpa de baru (Dipteryx alata Vog.). Multitemas, p. 265-281, 2018.

MIRANDA, A. A.; CAIXETA, A. C. A.; FLÁVIO, E. F.; PINHO, L. Desenvolvimento e análise de bolos enriquecidos com farinha da casca do maracujá (Passiflora edulis) como fonte de fibras. Alimentos e Nutrição, v. 24, n. 2, p. 225-232, 2013.

MOSCATTO, J. A.; PRUDÊNCIO, S. H.; HAULY, M. C de O. Farinha de yacon e inulina como ingredientes na formulação de bolo de chocolate. Ciência e Tecnologia de Alimentos, v. 24, n. 4, p. 634-640, 2004.

MOURA, K.; MOURA, S. Desenvolvimento e avaliação das características nutricionais, físico-químicas e sensoriais de bolo com diferentes tipos de farinhas e castanha-dobrasil. Monografia (Bacharelado em Engenharia de Alimentos) - Universidade Federal de Rondônia, Ariquemes, 2014.

OZORES B., et al. Aceitabilidade e características tecnológicas de bolo enriquecido com farinha de maracujá. Revista Ciências da Saúde, v. 16, n. 1, p. 61-69, 2015.

PADILHA, V. M.; ROLIM, P. M.; SALGADO, S. M.; LIVEIRA, A. S.; ANDRADE, S. A. C.; GUERRA, N. B. Perfil sensorial de bolos de chocolate formulados com farinha de yacon (Smallanthus sonchifolius). Ciência e Tecnologia de Alimentos, v. 30, n. 3, p. 735-740, 2010.

PEREIRA, L.; FERNANDES, G. S.; JESUS, J. R.; ALVES, J. S.; PEREIRA, J. Composição 
físico-química de bolos elaborados com amaranto em flocos. XXIV Congresso de Iniciação Científica da Universidade Federal de Lavras, Lavras, 2010a.

PEREIRA, L.; FERNANDES, G. S.; JESUS, J. R.; ALVES, J. S.; PEREIRA, J. Características físicas de bolos elaborados com amaranto em flocos. XXIV Congresso de Iniciação Científica da Universidade Federal de Lavras, Lavras, 2010 b.

POLETTO, B. O.; SANTOS, R. D.; RIBEIRO, E. T. Avaliação físico-química de bolo de chocolate modificado. Revista Científica da Faculdade de Educação e Meio Ambiente, v. 6, n. 2, p. 77-91, 2015.

SILVA, M. R.; LACERDA, D. B. C. L.; SANTOS, G. G.; MARTINS, D. M. DE O. Caracterização química de frutos nativos do Cerrado. Ciência Rural, Santa Maria, v. 38, n. 6, p. 1790-1793, 2008.

SILVA, C. Desenvolvimento, caracterização e análise sensorial de bolo a partir da farinha de xiquexique (Pilosocereus gounellei). XIV Jornada de Iniciação Científica e Inovação Tecnológica, VIII Jornada de Trabalhos de Extensão e VII Jornada de Iniciação a Docência do IF sertão PE. Campus Floresta, Pernambuco, 2019.

ZULIN, N. E. A suplementação com farinha do bagaço do fruto de Campomanesia adamantium promove imunomodulação e redução do crescimento tumoral em ratos Wistar portadores de tumor de Walker 256. Dissertação (mestrado) - Universidade Federal do Paraná, Setor de Ciências Biológicas, Programa de Pós-Graduação em Ciências Fisiológicas. Curitiba, 2019. 


\title{
CAPÍTULO 02: DESENVOLVIMENTO, CARACTERIZAÇÃO E ACEITABILIDADE DE BROWNIE DE CHOCOLATE ELABORADO COM FARINHA DE INHAME (Dioscorea sp.) POR SECAGEM CONVECTIVA
}

\section{CHAPTER 02: DEVELOPMENT, CHARACTERIZATION AND ACCEPTABILITY OF CHOCOLATE BROWNIE MADE WITH INHAME FLOUR (Dioscorea sp.) BY CONVECTIVE DRYING}

\begin{abstract}
Joyce Maria Santino de Oliveira ${ }^{1}$; Luzia Marcia de Melo Silva ${ }^{2}$; Neide Aparecida Ferreira Machado $^{3}$; Julio Augusto Enders de Albuquerque ${ }^{4}$; Francinalva Cordeiro de Sousa ${ }^{5}$
\end{abstract}

\begin{abstract}
Resumo
Este trabalho teve como objetivo estudar o processo de secagem do inhame em estufa, a elaboração de uma farinha para o processamento de brownie e analisar a aceitabilidade do produto. $\mathrm{O}$ inhame in natura foi caracterizado físico-quimicamente e passou pelo processo de secagem convectiva em estufa com circulação forçada de ar em três temperaturas $(50,60$ e $70^{\circ} \mathrm{C}$ ). As farinhas obtidas foram caracterizadas quanto aos parâmetros físico-químicos, tecnológicos e microbiológicos. Foram desenvolvidas cinco formulações de brownies, com diferentes concentrações da farinha de inhame, e submetidos as análises físico-químicas, microbiológicas e sensoriais. Os dados obtidos das caracterizações físico-químicas do inhame in natura, das farinhas de inhame e dos brownies foram submetidos à análise de variância (ANOVA) e as médias foram comparadas pelo teste de Tukey $(\mathrm{p} \leq 0,05)$. Constatou-se que os produtos elaborados estão dentro dos padrões exigidos pela legislação e os resultados da análise sensorial foram satisfatórios para o brownie elaborado com $100 \%$ de farinha de inhame.
\end{abstract}

Palavras-Chaves: Glúten, Massas alimentícias, Processamento de alimentos, Análises físicoquímicas, Análises microbiológicas.

\begin{abstract}
This work aimed to study the drying process of yam in the greenhouse, the preparation of a flour for brownie processing and to analyze the acceptability of the product. The fresh yam was characterized physically and chemically and went through the process of convective drying in an oven with forced air circulation at three temperatures $\left(50,60\right.$ and $\left.70^{\circ} \mathrm{C}\right)$. The flours obtained were characterized in terms of physical-chemical, technological and microbiological parameters. Five brownie formulations were developed, with different concentrations of yam flour, and subjected to physical-chemical, microbiological and sensory analyzes. The data obtained from the physical-chemical characterizations of fresh yams, yam flours and brownies were subjected to analysis of variance (ANOVA) and the means were compared using the Tukey test $(\mathrm{p} \leq 0.05)$. It was found that the products produced are within the standards required by law and the results of the sensory analysis were satisfactory for the brownie made with $100 \%$ yam flour.
\end{abstract}

Keywords: Gluten, Pasta, Food processing, Physical-chemical analysis, Microbiological analysis.

\footnotetext{
${ }^{1}$ Tecnologia de Alimentos, Instituto Federal de Alagoas - IFAL, mariajoyce1.jm@ gmail.com

${ }^{2}$ Tecnologia de Alimentos, Instituto Federal de Alagoas - IFAL, luzia.silva@ifal.edu.br

${ }^{3}$ Tecnologia de Laticínios, Instituto Federal de Alagoas - IFAL, neideferr@gmail.com

${ }^{4}$ Administração, Universidade Federal de Alagoas - UFAL, julioenders@ outlook.com

${ }^{5}$ Tecnologia de Alimentos, Instituto Federal de Pernambuco - IFPE, francinalvacordeiro@barreiros.ifpe.edu.br
} 


\section{Introdução}

A boa alimentação se relaciona ao bem-estar do indivíduo e a satisfação alimentar está inteiramente ligada à qualidade do produto que está sendo ingerido, de acordo com seu aspecto nutricional, sensorial e microbiológico. Cerca de $57 \%$ da população brasileira preferem incluir em suas compras alimentos funcionais, como grãos, raízes e tubérculos, e sua utilização, na maioria das vezes, é realizada como substituição de outros alimentos como garantia de um melhor funcionamento do organismo, manutenção da saúde e na prevenção de alguma intolerância ou alergia alimentar (NIELSEN, 2016).

Ainda, de acordo com a pesquisa realizada pela NIELSEN (2016) 48\% dos brasileiros disseram ter algum tipo de alergia ou intolerância alimentar a um ou mais gêneros alimentícios. Dentre os alimentos que ocasionam as intolerâncias alimentares, destacam-se o trigo, cevada, centeio, aveia etc., que contém glúten e recebe nomes diferentes para cada cereal (ARAÚJO, 2010). O glúten presente no trigo é caracterizado por uma proteína amorfa composta pela mistura de cadeias proteicas longas de gliadina e glutenina, na cevada é a hordeína, no centeio é a secalina e na aveia é a avenina (RODRIGUES et al., 2017, p. 187). Os portadores da Doença Celíaca (DC) não devem consumir produtos alimentícios que contenha glúten em sua composição, visto que, pequenas quantidades da proteína podem desencadear reações causadas pela doença como: diarreia crônica, vômitos, dor abdominal, anemia etc. (SILVA; FURLANETTO, 2010).

A ausência de tolerância ao glúten, identificada como DC, é caracterizada pela produção de anticorpos ao glúten, que agem no intestino delgado, atrofiando-o, em indivíduos predispostos geneticamente, ocasionando a má absorção de nutrientes, vitaminas, sais minerais e água, e o único tratamento para minimizar os efeitos colaterais é uma dieta isenta ao glúten (RODRIGUES et al., 2017, p. 187).

Grande parte dos produtos de amidonarias, que compreendem o setor de farinhas, panificação e massas alimentícias, têm como base de matéria prima a farinha do trigo, que, segundo a Companhia Nacional de Abastecimento (CONAB, 2017) é o cereal mais produzido no mundo. Entretanto, a produção de farinhas a partir de tubérculos, como o inhame (Dioscorea spp.), vem sendo pesquisada como alternativa para elaboração de produtos isentos ao glúten, destinados aos portadores da DC, por ser um alimento de fácil acesso, excelente qualidade nutritiva, energética e de preço acessível (OLIVEIRA et al., 2018; PESSOA et al., 2017).

O inhame (Dioscorea sp.) é uma planta monocotiledônea, herbácea, trepadeira, de clima tropical e subtropical, com grande importância socioeconômica no Nordeste (OLIVEIRA et al., 2018). Em Alagoas, estado em que este trabalho foi desenvolvido, estima-se que existam cerca 
de 2.290 hectares destinados ao cultivo do inhame (Dioscorea sp.), com produtividade média de 12 toneladas por hectare, representando a principal atividade econômica da agricultura familiar da região (LEÃO; CLEMENTINO; BARROS, 2017). O tubérculo é rico em proteína, potássio e cerca de $30 \%$ de sua composição é amido, fonte de energia, sendo parte dele o amido digerido lentamente, que é associado a um melhor controle de diabetes (CHEN et al., 2017; WALTER et al., 2005).

Apesar de suas características, o inhame (Dioscorea sp.) está entre os vegetais subutilizados (PESSOA et al., 2017). O tubérculo é produzido em pequena escala, geralmente, por pequenos agricultores familiares. Sua produção sazonal e problemas no armazenamento são fatores que dificultam seu uso (YASHIKI; TRIBOLI, 2018). Uma alternativa viável é a produção de farinhas a partir do inhame que facilitaria o armazenamento, teria maior disponibilidade de produto, maior vida de prateleira e seria a base para a produção de diversos subprodutos como pães, bolos, brownies etc.

Pelo seu valor nutricional, funcional e pela facilidade de acesso a esse tubérculo na região do Nordeste, o objetivo desta pesquisa foi estudar o processo de secagem do inhame em estufa e a elaboração de uma farinha para processamento de brownie de chocolate.

\section{Material e Métodos}

\section{Obtenção da matéria-prima}

O inhame (Dioscorea sp.) foi adquirido na feira livre local do município de Murici AL. Os tubérculos passaram pelo processo de higienização, que compreende as etapas de limpeza e sanitização, para minimizar a quantidade de microrganismos deterioradores e patogênicos (BRASIL, 2004). Posteriormente, o tubérculo foi descascado, com auxílio de uma faca de aço inoxidável, cortado em tiras de $1 \mathrm{~cm}$ e submetidos à secagem em estufa com circulação forçada de ar (Figura 1). As etapas desta pesquisa foram realizadas no Laboratório de Produtos de Origem Vegetal do Instituto Federal de Alagoas (IFAL) - Campus Murici, Laboratório de Microbiologia do IFAL - Campus Maceió e no Laboratório de Armazenamento e Processamento de Produtos Agrícolas, pertencente à Universidade Federal de Campina Grande (UFCG).

\section{Caracterização físico-química do inhame in natura}

$\mathrm{O}$ inhame in natura foi caracterizado, em triplicata, quanto aos parâmetros físicoquímicos: pH, acidez total titulável, sólidos solúveis totais, teor de água e sólidos totais conforme as Normas Analíticas do Instituto Adolfo Lutz (BRASIL, 2008). 


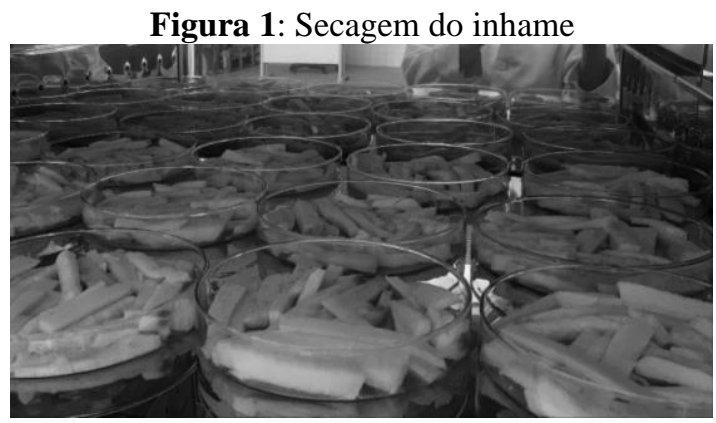

Fonte: Próprio autor

\section{Secagem}

Para a obtenção da farinha de inhame, foram realizados testes preliminares em estufa com circulação forçada de ar em diferentes temperaturas, 50, 60 e $70^{\circ} \mathrm{C}$, por aproximadamente 12 horas. A escolha da temperatura de secagem ideal para realizar os demais experimentos foi baseada na escolha de uma farinha mais fluida, partículas mais aglomeradas e menor teor de água. Verificou-se que a melhor condição de secagem foi a temperatura de $70^{\circ} \mathrm{C}$, que produziu uma farinha com todas as características desejáveis. Após o processo de secagem, a matériaprima desidratada foi acondicionada em dessecador para evitar trocas gasosas com o ambiente, até o momento da desintegração e posterior caracterização físico-química.

\section{Elaboração da farinha de inhame}

Após a secagem, o tubérculo foi desintegrado manualmente, com auxílio de um cadinho e pistilo, obtendo a farinha, sendo posteriormente peneirada, fracionada e acondicionada em embalagens plásticas (Figura 2).

Figura 2: Farinha do inhame

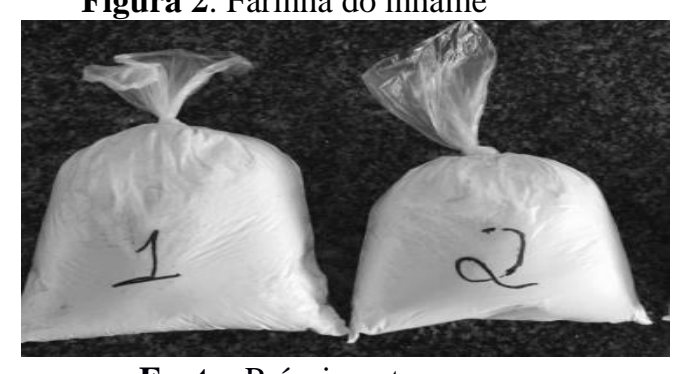

Fonte: Próprio autor

\section{Caracterização físico-química da farinha de inhame}

As farinhas produzidas nas diferentes temperaturas foram caracterizadas quanto aos parâmetros físico-químicos: sólidos solúveis totais, teor de água, sólidos totais, $\mathrm{pH}$, acidez total titulável, e atividade de água, conforme metodologia descrita por Brasil (2008). A amostra que apresentou teor de água favorável dentro dos padrões estabelecidos pela legislação foi escolhida 
para a elaboração dos brownies e caracterizada quanto aos parâmetros tecnológicos e microbiológicos.

\section{Análises tecnológicas da farinha}

Os parâmetros avaliados foram: densidade aparente (SOUZA et al., 2010); densidade compactada (GOULA; ADAMOPOULOS, 2004); fator de Hausner e índice de compressibilidade (YUSOF et al., 2012).

\section{Análises microbiológicas da farinha}

A farinha de inhame foi submetida à análise microbiológica quando aos parâmetros exigidos pela legislação vigente: Coliformes a $35^{\circ}$ e a $45^{\circ} \mathrm{C}$, bactérias aeróbias mesófilas, Salmonella $s p$. bolores e leveduras, de acordo com a metodologia apresentada por Souza, Figueiredo e Santana (2015), os resultados obtidos foram comparados com a legislação que estabelece os Padrões Microbiológicos em Alimentos (BRASIL, 2001).

\section{Processamento dos brownies de inhame}

Foram realizadas cinco formulações de brownie de chocolate, com substituição parcial e total da farinha de trigo pela farinha de inhame. Os ingredientes utilizados no processamento estão descritos na Tabela 1.

Tabela 1: Formulações dos brownies

\begin{tabular}{cccccc}
\hline Ingredientes & F1 & F2 & F3 & F4 & F5 \\
Controle & $25 \%$ & $50 \%$ & $75 \%$ & $100 \%$ \\
\hline Farinha de trigo & $100 \mathrm{~g}$ & $75 \mathrm{~g}$ & $50 \mathrm{~g}$ & $25 \mathrm{~g}$ & $\ldots$ \\
Farinha de inhame & $\ldots$ & $25 \mathrm{~g}$ & $50 \mathrm{~g}$ & $75 \mathrm{~g}$ & $100 \mathrm{~g}$ \\
$\begin{array}{c}\text { Chocolate em barra (75\% cacau), Chocolate em pó } \\
\text { (100\% cacau) e açúcar cristal } \\
\text { Ovos }\end{array}$ & $100 \mathrm{~g}$ & $100 \mathrm{~g}$ & $100 \mathrm{~g}$ & $100 \mathrm{~g}$ & $100 \mathrm{~g}$ \\
& 3 & 3 & 3 & 3 & 3 \\
\hline
\end{tabular}

Fonte: Próprio autor

Os ingredientes para produção dos brownies foram pesados e fracionados em sacos plásticos. Em um recipiente foram adicionados o açúcar, a manteiga, previamente derretida, e os ovos, unindo-os até completa homogeneização. Posteriormente, no mesmo recipiente, adicionou-se a barra de chocolate derretida, a farinha e o cacau em pó.

Utilizou-se uma forma de alumínio quadrada, previamente untada e coberta com papel manteiga, para a acomodação da massa e cozimento em forno pré-aquecido a $180{ }^{\circ} \mathrm{C}$ por 25 
(vinte e cinco) minutos. Após o assamento da massa, os brownies foram cortados, com o auxílio de uma faca, em quadrados de 4x3cm (Figura 3).

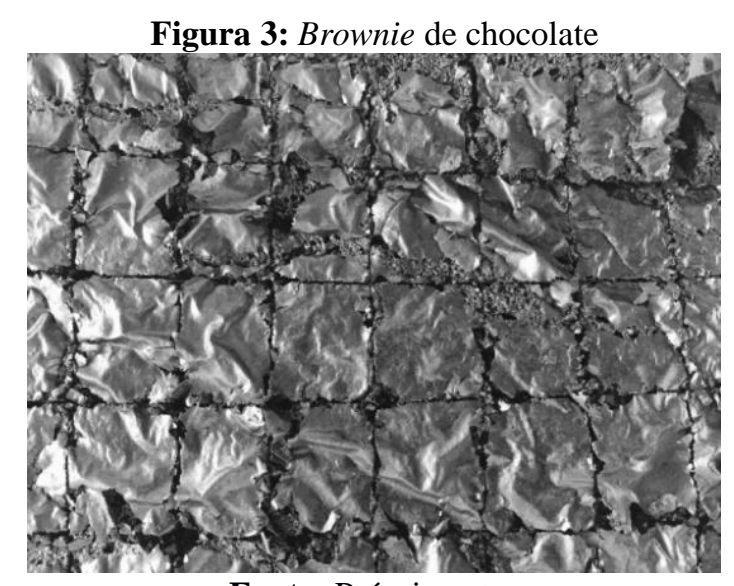

Fonte: Próprio autor

\section{Caracterização físico-química dos brownies}

Os brownies foram caracterizados, em triplicata, quanto aos parâmetros físico-químicos: $\mathrm{pH}$, acidez total titulável, sólidos solúveis totais, teor de água e sólidos totais conforme as Normas Analíticas do Instituto Adolfo Lutz (BRASIL, 2008).

\section{Análise de cor $L^{*}, a^{*}$ e b*}

As análises de cor $\left(\mathrm{L}^{*}, \mathrm{a}^{*} \mathrm{e} \mathrm{b}^{*}\right)$, foram realizadas nas amostras de brownie em espectrofotômetro portátil MiniScan HunterLab XE Plus, modelo 4500 L, equipado com iluminante D65, ângulo de observação de $10^{\circ}$ e calibrado com placa padrão branca $(X=80,5$; $Y=85,3 ; Z=90,0)$, obtendo-se os parâmetros $L^{*}, a^{*}$ e $b^{*}$, em que $L^{*}$ define a luminosidade ( $L^{*}$ $=0-$ preto e $\mathrm{L}^{*}=100-$ branco $)$ e $\mathrm{a}^{*}$ e $\mathrm{b}^{*}$ são responsáveis pela cromaticidade $\left(+\mathrm{a}^{*}\right.$ vermelho $\mathrm{e}-\mathrm{a}^{*}$ verde; $+\mathrm{b}^{*}$ amarelo e $-\mathrm{b}^{*}$ azul).

\section{Análise microbiológica dos brownies}

Os brownies foram submetidos a análises microbiológicas quanto aos parâmetros: Bacillus cereus, Salmonella sp., coliformes a $35^{\circ}$ e a $45^{\circ} \mathrm{C}$, seguindo a metodologia proposta por Silva et al. (2007) e comparados com o estipulado pela legislação (BRASIL, 2001).

\section{Análise sensorial}

O teste sensorial foi aplicado com 55 provadores não treinados, entre eles estudantes e servidores, do Instituto Federal de Alagoas - campus Murici. Foram definidos critérios de participação para a análise sensorial. O provador deveria ter entre 16 e 60 anos de idade, não 
poderia ter alergia ou intolerância aos ingredientes presentes na formulação do produto, preencher seus dados pessoais e assinar o termo de consentimento livre e esclarecido, e, por fim, tinham que ser consumidores de brownie.

A avaliação foi realizada por meio de uma escala hedônica que varia entre "1" a "9" para qualificar os atributos referentes à cor, aparência, odor e sabor, onde "1" refere-se à “desgostei muitíssimo" e "9" significa "gostei muitíssimo". Também foi analisado a intenção de compra, com a escala que varia de " 1 a 5 " onde " 1 " significa "certamente não compraria" e "5" significa "certamente compraria".

\section{Análise estatística}

Os dados experimentais das propriedades físico-químicas e dos testes sensoriais foram submetidos à comparação das médias e desvio padrão. Os resultados da análise estatística dos brownies com diferentes concentrações de farinha de inhame foram submetidos à análise de variância $(\mathrm{p}<0,05)$ ANOVA e ao teste de Tukey, para comparação entre as médias utilizando o Programa ASSISTAT versão 7.7 beta (SILVA; AZEVEDO, 2016).

\section{Resultados e Discussão}

Caracterização físico-química do inhame in natura

O inhame in natura apresentou teor e atividade de água elevado com 69,57\% e 0,98\%, respectivamente. Aquino et al. (2011) analisaram as características físico-químicas do inhame in natura e da farinha de inhame e obtiveram médias de 64,8\% para o teor de água e de $0,92 \%$ para a Aw do inhame in natura. Quanto aos sólidos totais, que é a diferença entre o peso da amostra e o conteúdo de umidade, foi obtido média de 30,4\%.

Na Tabela 2, encontram-se os valores médios e desvio padrão das características físicoquímicas do inhame in natura.

Tabela 2:Caracterização físico-química do inhame in natura

\begin{tabular}{cc}
\hline Parâmetros & Inhame in natura \\
\hline Teor de água (\%) & $69,6 \pm 0,15$ \\
Sólidos totais (\%) & $30,4 \pm 0,15$ \\
pH (potencial hidrogeniônico) & $6,3 \pm 0,3$ \\
Acidez total (\%) & $0,05 \pm 0,2$ \\
Aw (atividade de água) (\%) & $0,98 \pm 0,5$ \\
Sólidos solúveis totais & $0,2 \pm 0,15$ \\
\hline \multicolumn{2}{c}{ pH= potencial hidrogeniônico; Aw = atividade de água } \\
\multicolumn{2}{c}{ Fonte: Próprio autor }
\end{tabular}




\section{Elaboração e caracterização físico-química das farinhas em diferentes temperaturas} (Testes preliminares de secagem)

Com o objetivo de verificar a influência do teor de água na granulometria da farinha, foram realizados testes preliminares para determinação da melhor temperatura de secagem. Foi selecionada a farinha que apresentou menor teor de água e tempo de secagem, além da granulometria observada (Tabela 3 ).

Verifica-se que o teor de água diminuiu consideravelmente após a secagem, quando comparado com o inhame in natura, porém, a temperatura que obteve o melhor resultado com relação ao teor de água e desvio padrão foi a de $70^{\circ} \mathrm{C}$.

A secagem proporcionou um produto com baixo teor de água variando de 8,00\%, para o inhame desidratado a temperatura de $50^{\circ} \mathrm{C}$, a 3,12\%, para o inhame desidratado à $70^{\circ} \mathrm{C}$. Pode-se dizer que as três amostras desidratadas atendem aos padrões exigidos pela ANVISA (2005), a qual determina que o teor de umidade da farinha deve ser de, no máximo, $15 \%$. No trabalho desenvolvido por Miamoto (2008), ao analisar as características da farinha de inhame integral, obteve resultado de 5,37\% para umidade.

Tabela 3: Cinética de secagem

\begin{tabular}{cc}
\hline Amostras & Teor de água \\
\hline Inhame desidratado a $50^{\circ} \mathrm{C}$ & $8,45 \pm 1,6$ \\
Inhame desidratado a $60^{\circ} \mathrm{C}$ & $5,32 \pm 0,15$ \\
Inhame desidratado a $70^{\circ} \mathrm{C}$ & $3,12 \pm 0,13$
\end{tabular}

Fonte: Próprio autor

As farinhas, em diferentes temperaturas, foram caracterizadas quantos aos parâmetros físico-químicos: sólidos totais, sólidos solúveis totais, acidez total titulável e pH (Tabela 4).

Tabela 4: Caracterização físico-química da farinha de inhame em diferentes temperaturas

\begin{tabular}{cllllc}
\hline Amostras & Sólidos totais & Sólidos solúveis & Acidez Total & $\mathrm{pH}$ & SS/AT \\
\hline Farinha de inhame a $50^{\circ} \mathrm{C}$ & $91,55 \pm 1,6$ & $0,20 \pm 0,15$ & $0,15 \pm 0,01$ & $6,3 \pm 0,01$ & $1,33 \pm 0,01$ \\
Farinha de inhame a $60^{\circ} \mathrm{C}$ & $94,68 \pm 0,02$ & $0,19 \pm 0,01$ & $0,29 \pm 0,01$ & $6,3 \pm 0,03$ & $0,65 \pm 0,01$ \\
Farinha de inhame a $70^{\circ} \mathrm{C}$ & $96,88 \pm 0,1$ & $0,20 \pm 0,01$ & $0,56 \pm 0,01$ & $5,4 \pm 0,25$ & $0,36 \pm 0,01$ \\
\hline
\end{tabular}

Fonte: Próprio autor

Com base nos resultados que estão descritos na tabela 4, foi possível observar que o inhame desidratado na temperatura de $70^{\circ} \mathrm{C}$, amostra que apresentou o melhor resultado para o teor de água, obteve o maior valor para o parâmetro de teor de sólidos totais, caracterizado pela diferença entre o peso da amostra e o conteúdo de umidade, com média de 96,88\%. Para o teor 
de sólidos solúveis, não houve diferenças significativas entre as amostras. Os resultados para os parâmetros de acidez, pH e SS/AT (relação entre sólidos solúveis e acidez titulável) foram favoráveis para a amostra desidratada a $70^{\circ} \mathrm{C}$.

$\mathrm{O}$ pH do inhame é encontrado entre 5,5 e 6, caracterizando um tubérculo levemente ácido (UAILA, 2015). Sá et al. (2019) caracterizaram a farinha de inhame e obtiveram valores de 5,6 para o pH e Souza et al. (2012) encontraram valores de 5,5 para a farinha instantânea de fruta pão e acidez no valor abaixo de 3\%, que é o máximo permitido pela Portaria no 554 da Secretaria de Agricultura, do Abastecimento e Reforma Agrária (BRASIL, 1995). Os valores de $\mathrm{pH}$ encontrados nesta pesquisa, para a farinha desidratada à $70^{\circ} \mathrm{C}$, confere maior segurança contra o ataque microbiológico, visto que, a faixa de $\mathrm{pH}$ mais favorável para o crescimento microbiano é entre 6,5 a 7 (FERREIRA; ROBERTO; CAMISA, 2018).

\section{Análise microbiológica da farinha de inhame}

Foi selecionada a farinha que apresentou menor teor de água e melhor granulometria observada. Para a produção da farinha, foi desidratado $1 \mathrm{Kg}$ de inhame em estufa com circulação forçada de ar na temperatura de $70^{\circ} \mathrm{C}$ por $12 \mathrm{~h}$, sendo, posteriormente, caracterizada microbiologicamente e quanto aos parâmetros tecnológicos.

\begin{tabular}{cc} 
Tabela 5: Análise microbiológica da farinha de inhame \\
\hline Parâmetros & Farinha de inhame \\
\hline Coliformes a $35^{\circ} \mathrm{C}(\mathrm{NMP} / \mathrm{g})$ & $<3$ \\
Coliformes a $45^{\circ} \mathrm{C}(\mathrm{NMP} / \mathrm{g})$ & $<3$ \\
Bolores e Leveduras $(\mathrm{UFC} / \mathrm{g})$ & $<3$ \\
Bactérias Aeróbias Mesófilas $(\mathrm{UFC} / \mathrm{g})$ & Ausente \\
Salmonella (UFC/g) &
\end{tabular}

* $\mathrm{NMP} / \mathrm{g}=$ número mais provável por grama; $\mathrm{UFC}=$ unidades formadoras de colônias por grama.

Fonte: Próprio autor

A partir dos dados obtidos foi possível afirmar que a farinha de inhame desidratada a $70^{\circ} \mathrm{C}$ encontra-se dentro dos padrões exigidos pela RDC $\mathrm{n}^{\circ} 12$, de 02 de janeiro de 2001 (BRASIL, 2001).

\section{Análises tecnológicas}

Na Tabela 6, tem-se os valore médios das análises tecnológicas da farinha de inhame desidratada à $70^{\circ} \mathrm{C}$. 
Tabela 6: Análises tecnológicas da farinha de inhame

\begin{tabular}{lc}
\hline Parâmetros & Farinha de inhame a $70^{\circ} \mathrm{C}$ \\
\hline Densidade Aparente & $0,62 \mathrm{~g} / \mathrm{cm}^{3}$ \\
Densidade compactada & $3,14 \mathrm{~g} / \mathrm{cm}^{3}$ \\
Fator de Hausner & 0,20 \\
Índice de compressibilidade & $80,08 \%$ \\
\hline
\end{tabular}

Fonte: Próprio autor

De acordo com a Tabela 6, para o resultado de densidade aparente e densidade compactada, foi obtido a média de $0,62 \mathrm{~g} / \mathrm{cm}^{3}$ e $3,14 \mathrm{~g} / \mathrm{cm}^{3}$, respectivamente. Yashiki e Triboli (2018), estudando a farinha de inhame obtida por atomização, constataram valores de 0,46 $\mathrm{g} / \mathrm{cm}^{3}$ (densidade aparente) e $0,67 \mathrm{~g} / \mathrm{cm}^{3}$ (densidade compactada). Silva et al. (2013) relataram ao pesquisar a farinha de tapioca produzida no estado do Pará, obtiveram valores médio de 0,61 $\mathrm{g} / \mathrm{cm}^{3}$ para densidade aparente.

O Fator de Hausner (FH) apresentou valores médios de 0,20. Segundo Santhalakshmy et al. (2015) o fator de Hausner avalia a coesividade do material, e valores <1,2 são classificados como de baixa coesividade, FH entre 1,2 a 1,4 é de coesividade intermediária e FH >1,4 é considerado de alta coesividade.

O Índice de Carr expressa a capacidade de escoamento e compressão de um sólido (SOUZA, 2017). O índice de Carr (IC) apresentou valor de 80,08\% classificando a farinha com fluidez ruim ou muito ruim, o que a caracteriza como um pó coesivo. Ainda, de acordo com Santhalakshmy et al. (2015), valores de IC>45 são caracterizados como materiais cuja fluidez é muito ruim.

\section{Caracterização físico-química dos brownies de inhame}

Ao analisar os resultados da Tabela 7, observou-se que não houve um comportamento padrão, apresentando oscilações entre os tratamentos, embora não tenha havido diferença estatística entre o controle e as formulações com adição parcial de farinha de inhame. A formulação com $100 \%$ de farinha de inhame foi a que obteve o melhor resultado em relação ao teor de água.

Orsine, Martins e Lima (2016) elaboraram e caracterizaram brownie de chocolate obtido a partir de ingredientes dietéticos, light e não dietéticos e obtiveram os seguintes resultados: 22,68\% para teor de água; 77,32\% para sólidos totais; 6,29 para $\mathrm{pH} ; 41,10^{\circ}$ para sólidos solúveis totais. Souza e Roselino (2019) desenvolveram brownie de chocolate obtido a partir da 
biomassa de banana verde e farinha de arroz, e revelaram o resultado de $18,38 \%$ para o parâmetro de teor de água.

Tabela 7. Análises físico-químicas dos brownies de inhame

\begin{tabular}{|c|c|c|c|c|c|}
\hline \multirow[t]{2}{*}{ Parâmetros } & \multicolumn{5}{|c|}{ Brownies de chocolate com farinha de inhame } \\
\hline & Controle & $25 \%$ & $50 \%$ & $75 \%$ & $100 \%$ \\
\hline Teor de água $(\%)$ & $10,84^{\mathrm{a}} \pm 0,61$ & $11,29^{\mathrm{a}} \pm 0,07$ & $10,50^{\mathrm{a}} \pm 0,05$ & $9,46^{\mathrm{a}} \pm 0,31$ & $6,21^{\mathrm{b}} \pm 0,7$ \\
\hline Sólidos totais $(\%)$ & $89,16^{\mathrm{a}} \pm 0,61$ & $88,71^{\mathrm{a}} \pm 0,07$ & $89,76^{\mathrm{a}} \pm 0,05$ & $90,54^{\mathrm{a}} \pm 0,31$ & $93,72^{\mathrm{b}} \pm 0,17$ \\
\hline $\mathrm{pH}$ & $7,61^{\mathrm{a}} \pm 0,03$ & $7,63^{\mathrm{a}} \pm 0,06$ & $7,47^{\mathrm{a}} \pm 0,09$ & $7,29^{\mathrm{a}} \pm 0,06$ & $7,28^{\mathrm{a}} \pm 0,01$ \\
\hline $\begin{array}{c}\text { Sólidos solúveis } \\
\text { totais }\left({ }^{\circ} \text { Brix }\right)\end{array}$ & $47,57^{\mathrm{b}} \pm 0,15$ & $52,84^{\mathrm{ab}} \pm 2,3$ & $56,92^{\mathrm{a}} \pm 2,6$ & $55,54^{\mathrm{a}} \pm 2,9$ & $58,60^{\mathrm{a}} \pm 0,45$ \\
\hline
\end{tabular}

Fonte: Próprio autor

\section{Análise de cor dos brownies}

A cor da superfície de um produto alimentício é de extrema importância pois está relacionada aos fatores de qualidade detectados pelos órgãos do sentido. A cor, depois do preço do produto, é o atributo mais importante na escolha de um alimento (GAVA; SILVA; FRIAS, 2008, p. 68).

A coordenada $\mathrm{L}^{*}$, referente a luminosidade, varia de 0 (preto) a 100 (branco). Quanto mais próximo de 0 , mais escura é a amostra e quanto mais próximo de 100, mais clara. Observase na Tabela 8 que todas as amostras obtiveram resultados de $L^{*}$ entre 10,03 e 15,79, assim caracterizando que as amostras possuem coloração escura, próprio de um produto elaborado com chocolate.

Padilha et al. (2009) estudaram o uso da farinha de yacon (Smallanthus sonchifolius) na elaboração de bolo de chocolate e avaliaram seu perfil sensorial e cromaticidade. As farinhas, em geral, apresentaram média de 37,85 para o parâmetro L* e foram consideradas escuras, já que apresentaram valores abaixo de $50\left(\mathrm{~L}^{*<50}\right)$.

Para as coordenadas $a^{*}$ e $b^{*}$ foram adquiridos valores positivos de $a+e b+$, respectivamente. Os resultados obtidos nesta análise demonstraram que todas as amostras tiveram coloração similar com valores de +a entre 2,04 a 2,71 e +b entre 1,07 a 1,88.

Tabela 8. Análise de cor dos brownies

\begin{tabular}{cccccc}
\hline Parâmetros & \multicolumn{4}{c}{ Brownie de chocolate com farinha de inhame } \\
\hline & $0 \%$ & $25 \%$ & $50 \%$ & $75 \%$ & $100 \%$ \\
\cline { 2 - 5 } Luminosidade $\left(\mathrm{L}^{*}\right)$ & 15,79 & 13,60 & 14,90 & 14,27 & 13,04 \\
Intensidade do vermelho $\left(+\mathrm{a}^{*}\right)$ & 2,71 & 2,04 & 2,47 & 2,60 & 2,23 \\
Intensidade do amarelo $\left(+\mathrm{b}^{*}\right)$ & 1,88 & 1,20 & 1,07 & 1,74 & 1,44 \\
\hline $\mathrm{L}^{*} 0=$ preto e $\mathrm{L}^{*} 100=$ branco; $+\mathrm{a}^{*}=$ vermelho $-\mathrm{a}^{*}=$ verde; $+\mathrm{b}^{*}=$ amarelo $-\mathrm{b}^{*}=\mathrm{azul}$ \\
Fonte: Próprio autor
\end{tabular}

Machado (2012) desenvolveu bolo de chocolate light a partir da farinha do mesocarpo 
do maracujá e hidrocolóides e obteve valores de $\mathrm{L}^{*}$ menor que 50. Para $\mathrm{a}^{*}$ e $\mathrm{b}^{*}$ foram adquiridos valores positivos, caracterizando amostras com coloração mais escura, provenientes de produtos elaborados com chocolate.

\section{Caracterização microbiológica dos brownies de inhame}

A Agência Nacional de Vigilância Sanitária (ANVISA) na Resolução nº 12, de 02 de janeiro de 2001 (BRASIL, 2001) estabelece os critérios microbiológicos para os alimentos. Observa-se na Tabela 9 os resultados das análises microbiológicas dos brownies.

Tabela 9: Análises microbiológicas dos brownies de inhame

\begin{tabular}{lccccc}
\hline \multicolumn{1}{c}{ Parâmetros } & \multicolumn{5}{c}{ Brownies elaborados com farinha de inhame } \\
\hline \multirow{2}{*}{$\begin{array}{c}\text { Bacillus cereus } \\
\text { Salmonella }\end{array}$} & $<\%$ & $25 \%$ & $50 \%$ & $75 \%$ & $100 \%$ \\
\cline { 2 - 6 } Coliformes a $35^{\circ} \mathrm{C}$ & $<3 \mathrm{NMP} / \mathrm{g}$ & $<3 \mathrm{NMP} / \mathrm{g}$ & $<3 \mathrm{NMP} / \mathrm{g}$ & $<3 \mathrm{NMP} / \mathrm{g}$ & $<3 \mathrm{NMP} / \mathrm{g}$ \\
Coliformes a $45^{\circ} \mathrm{C}$ & $<3 \mathrm{NMP} / \mathrm{g}$ & $<3 \mathrm{NMP} / \mathrm{g}$ & $<3 \mathrm{NMP} / \mathrm{g}$ & $<3 \mathrm{NMP} / \mathrm{g}$ & $<3 \mathrm{NMP} / \mathrm{g}$ \\
\hline
\end{tabular}

A análise de Bacillus Cereus é importante no caso de produtos que sofreram tratamento térmico ou aquecimento. Essa bactéria pode formar esporos resistentes, sobreviver a temperaturas elevadas, se multiplicar e provocar doenças de origem alimentar (GAVA; SILVA; FRIAS, 2008). De acordo com a legislação, no que se refere à Bacillus cereus, o máximo permitido é de $10^{3} \mathrm{UFC} / \mathrm{g}$. Nesta pesquisa foram encontrados valores de $<10 \mathrm{UFC} / \mathrm{g}$ em todas as formulações. Este resultado é semelhante ao trabalho desenvolvido por Orsine, Martins e Lima (2016) que avaliaram microbiologicamente as amostras de brownie de chocolate light e encontraram <10 UFC/g. No estudo feito por Machado et al. (2019) obtiveram valores $<10^{2}$ UFC/g para as amostras de bolo de chocolate, constatando que não houve contaminação microbiológica dos produtos.

A Salmonella é uma bactéria patogênica e tem como habitat o trato intestinal do homem e de animais e são importantes por causarem doenças, principalmente veiculas por alimentos (GAVA; SILVA; FRIAS, 2008). De acordo com a Resolução RDC nº12, de 02 de janeiro de 2001, produtos de confeitaria devem apresentar ausência de Salmonella sp. As amostras avaliadas nesta pesquisa estão dentro dos padrões estabelecidos pela legislação. Ainda, de acordo com Orsine, Martins e Lima (2016) as amostras de brownie avaliadas apresentaram ausência de Salmonella. Resultado semelhante foi obtido por Morais et al., (2017), avaliaram 
microbiologicamente amostras de bolo de abóbora com chocolate e demonstraram ausência da bactéria.

O índice de coliformes expressa as condições higiênicas, não sendo, entretanto, um bom indicativo de contaminação fecal. Os gêneros que pertencem ao grupo "coliformes" são: Escherichia, Enterobacter, Klebsiella e Citrobacter (GAVA; SILVA; FRIAS, 2008). A temperatura ideal de desenvolvimento é à $35^{\circ} \mathrm{C}$. A Resolução ${ }^{\circ} 12$ da ANVISA estabelece como padrão para produtos de confeitaria o máximo de $10^{2} \mathrm{UFC} / \mathrm{g}$ de coliformes. Nesta pesquisa, como demonstrado na Tabela 9, foram encontrados valores $<3 \mathrm{NMP} / \mathrm{g}$.

Quanto aos coliformes à $45^{\circ} \mathrm{C}$, corresponde praticamente à contagem de Escherichia coli e é utilizado como indicador da contaminação fecal. Este grupo, por estar adaptado à temperatura intestinal, é capaz de se desenvolver até $45^{\circ} \mathrm{C}$ (GAVA; SILVA; FRIAS, 2008). A legislação estabelece como padrão microbiológico o máximo de $10^{2} \mathrm{UFC} / \mathrm{g}$ de coliformes à $45^{\circ} \mathrm{C}$. Nesta pesquisa foram encontrados valores de $<3 \mathrm{NMP} / \mathrm{g}$ para todas as amostras de brownie, dessa forma, pode-se afirmar que o produto atende aos padrões microbiológicos.

\section{Análise sensorial dos brownies}

Os resultados da análise sensorial dos brownies de chocolate elaborados com $0 \%, 25 \%$, $50 \%, 75 \%$ e $100 \%$ de farinha de inhame, estão descritos no Gráfico 1.

Gráfico 1: Resultado da análise sensorial para os parâmetros de aparência, cor, odor e sabor.

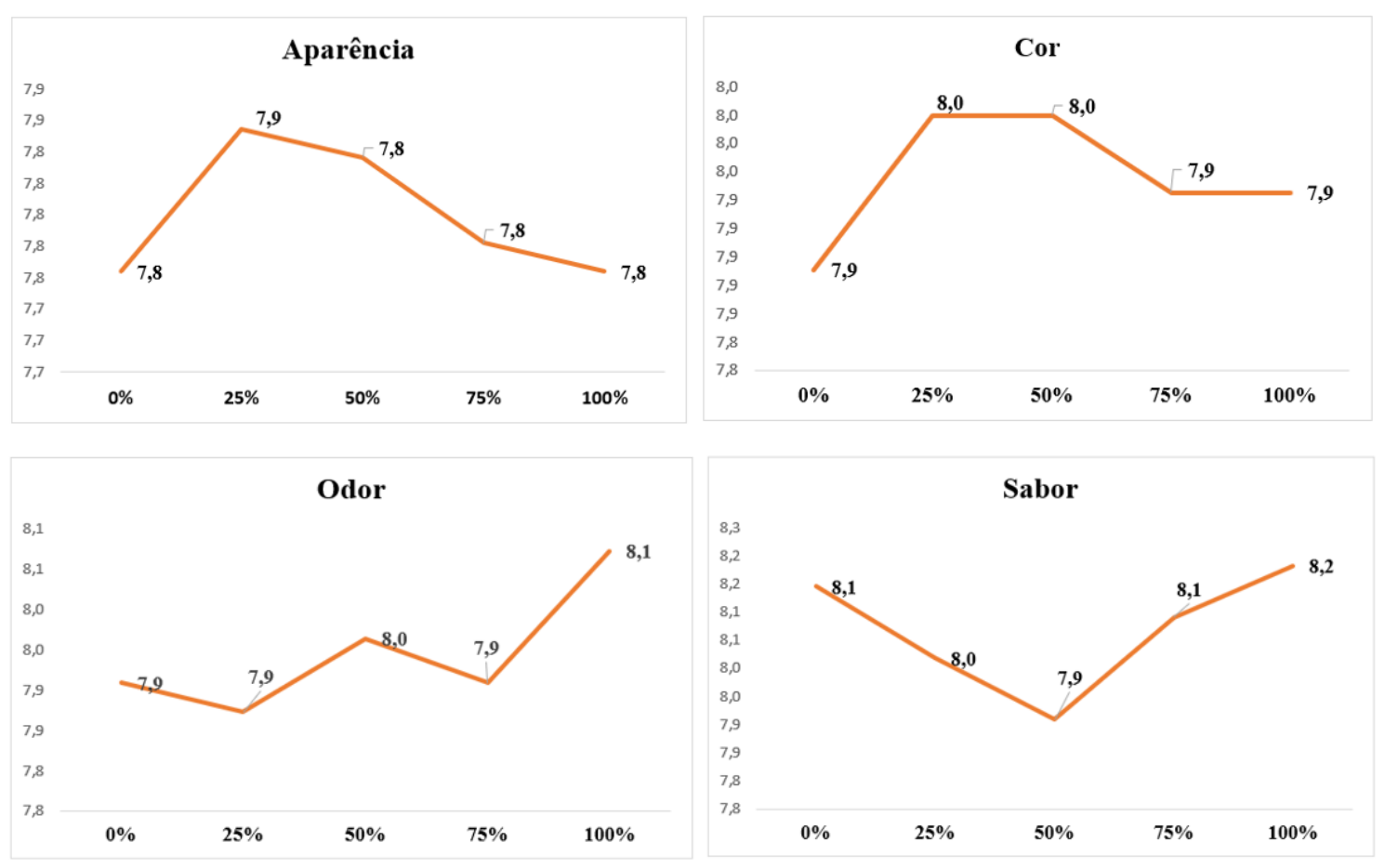

Fonte: Próprio autor 
Observa-se que as notas médias para os atributos do brownie elaborado (aparência, cor, odor e sabor) variaram entre 7,8 a 8,2, cujos termos hedônicos estiveram entre "gostei moderadamente/gostei muito" e "gostei muitíssimo".

De acordo com Gava, Silva e Frias (2008) o atributo "aparência" de um alimento incluem a cor, tamanho, forma, integridade, consistência e defeito de um produto alimentício. Os brownies elaborados com $0 \%$ a $100 \%$ de farinha de inhame obtiveram termos hedônicos entre "gostei moderadamente" e "gostei muito". O brownie elaborado com 100\% de farinha de inhame obteve a mesma média do brownie tradicional (0\%). Pode-se afirmar que no atributo "aparência", o brownie com $100 \%$ de farinha de inhame obteve as mesmas propriedades de qualidade do brownie tradicional. Resultado semelhante foi visto no trabalho feito por Morais et al. (2017), elaboraram um bolo de abóbora com chocolate utilizando $100 \%$ de farinha de arroz e obtiveram valor médio de 8,0 .

De acordo com Cobucci (2010) a característica “cor" é de extrema importância para a escolha de um produto alimentício, pois o primeiro contato do consumidor com o produto é visual. Observa-se que para o parâmetro "cor" foram obtidos valores médios de 7,9 a 8,0. Mais uma vez, o brownie elaborado com $100 \%$ de farinha de inhame obteve média semelhante ao brownie tradicional. Matos et al. (2017) analisaram sensorialmente brownie de chocolate elaborado com farinha de banana verde e demonstraram valores médios de 7,58 e 7,85 para os brownies produzidos com $100 \%$ de farinha de trigo e $100 \%$ de farinha de banana verde, respectivamente.

Odor e sabor são dois fatores de qualidade importantes na escolha de um produto alimentício. De acordo com Gava, Silva e Frias (2008) o sabor é uma resposta integrada às sensações do gosto e do aroma (saboroma) caracterizando o flavor. Para a característica "odor" e "sabor", foi alcançado média entre 7,9 a 8,1 e 7,9 a 8,2, respectivamente. Diferindo dos resultados encontrados nesta pesquisa, Silva et al. (2017) avaliaram sensorialmente brownie elaborado com farinha de berinjela e soro de leite caprino e revelaram valores médios de 5,79 e 6,02, para os atributos odor e sabor, respectivamente.

No que se refere aos resultados da intenção de compra, demonstrados no Gráfico 2, a média obtida foi entre 4 a 5 , cujos termos hedônicos estiveram entre "provavelmente compraria" e "certamente compraria". Entre as amostras de $0 \%$ a $75 \%$ os resultados foram semelhantes, com valores médios de 4,0. O produto que obteve mais escolhas quanto ao termo hedônico de "certamente compraria" foi o brownie produzido com 100\% de farinha de inhame. Ainda, de acordo com Silva et al. (2017) alcançaram média de 3,63 ficando na faixa de "talvez comprasse/ talvez não comprasse". Morais et al. (2017) revelaram média de 4,4 para o bolo de 
abóbora com chocolate a base de farinha de arroz.

Gráfico 2: Intenção de compra

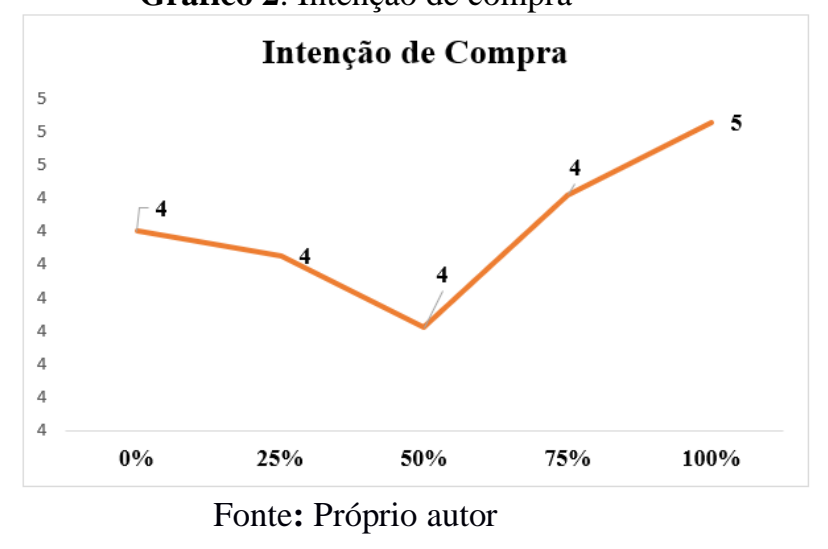

\section{Conclusões}

A utilização do inhame (Dioscorea sp.) para o processamento de farinha apresenta grande potencial para a indústria alimentícia e para os pequenos produtores rurais, tendo em vista, a facilidade de obtenção do tubérculo, características físico-químicas, microbiológicas, organolépticas, tecnológicas e sensoriais. A produção da farinha de inhame, em larga escala, além de contribuir para o crescimento do agronegócio, é uma alternativa viável para a fabricação de massas alimentícias isentas de glúten, destinadas aos indivíduos portadores da Doença Celíaca (DC). Ainda mais, o emprego da farinha de inhame para elaboração de subprodutos proporciona grande índice de aceitabilidade, maior vida de prateleira e evita o surgimento de problemas clínicos para os portadores da DC. Pode-se afirmar que, com base nos dados revelados nesta pesquisa, tanto a farinha de inhame quanto o brownie de chocolate apresentaram excelentes indicativos para o setor alimentício.

\section{Referências}

ANVISA. Agência Nacional de Vigilância Sanitária. Alimentos associados a alergias começam a ser rotulados com advertência ao consumidor. Junho, 2016.

ANVISA. Agência Nacional de Vigilância Sanitária. Resolução - RDC nº . 263, 22 de setembro de 2005. Regulamento técnico para produtos de cereais, amidos, farinhas e farelos.

AQUINO, A. C. M. S; SANTOS, J. C; SILVA G. F. Caracterização físico-química e microbiológica de farinha de inhame durante o armazenamento em diferentes embalagens. Scientia Plena, v.7, n.11, p.1-5, 2011. 
ARAUJO, H. M. C.; ARAUJO, W. M. C.; BOTELHO, R. B. A; ZANDONADI, R. P. Doença celíaca, hábitos e práticas alimentares e qualidade de vida. Rev. Nutr. [online]. 2010, vol.23, n.3, pp.467-474. ISSN 1415-5273. https://doi.org/10.1590/S1415-52732010000300014.

BRASIL. Normas analíticas do Instituto Adolfo Lutz: Métodos químicos e físicos para análises de alimentos. $4^{\text {a }}$ ed. Digital, São Paulo, 2008. 1020 p.

BRASIL. Agência Nacional de Vigilância Sanitária. Resolução - RDC nº 216, de 15 de setembro de 2004. Regulamento técnico de boas práticas para serviços de alimentação. Diário oficial de Brasília, Brasília, 16 de setembro de 2004.

BRASIL, Agência Nacional de Vigilância Sanitária. Resolução-RDC nº 12, de 02 de janeiro de 2001. Regulamento técnico sobre os padrões microbiológicos para alimentos. Diário Oficial de Brasília, Brasília, 02 de janeiro de 2001. Seção 1.

BRASIL. Portaria n. 554, de 30 de agosto de 1995. Norma de identidade, qualidade, apresentação, embalagem, armazenamento e transporte da farinha de mandioca. Diário Oficial da República Federativa do Brasil, Brasília, DF, 01 set. 1995.

BRITO, T. T.; SOARES, L. S.; FURTADO M. C.; CASTRO, A. A.; CARNELOSSI, M. A. G. Composição centesimal de inhame (Dioscorea sp.) in natura e minimamente processado. Scientia Plena, v.7, n.6, 2011.

COBUCCI, R. M. A. (2010). Análise Sensorial: Apostila do Curso. Curso Tecnológico Superior em Gastronomia. Pontifica Universidade Católica de Goiás

CONAB. Companhia Nacional de Abastecimento. A cultura do trigo. 2017. Disponível em: https://www.conab.gov.br/. Acesso em: 25 maio 2020.

CHEN, X.; LI, X.; HUANG, H.; WANG, T.; QU, Z.; MIAO, J.; Gao, W. (2017). Effects of drying processes on starch-related physicochemical properties, bioactive components and antioxidant properties of yam flours. Food Chemistry. p. 224-232.

FERREIRA, P.M.; ROBERTO, B.S.; CAMISA, J. Caracterização e aceitabilidade de barras de 
cereais enriquecidas com colágeno hidrolisado. Revista Virtual de Química, Arapongas, PR, v.10, n.1, p.155-171, mar.2018.

GAVA, A. J.; SILVA, C. A. B.; FRIAS, J. R. G. Aceitabilidade e fatores de qualidade dos alimentos. In: TECNOLOGIA de alimentos princípios e aplicações: princípios e aplicações. São Paulo: Nobel, 2008. cap. 1, p. 68-69. ISBN 978-85-213-1382-3.

GOULA, A. M.; ADAMOPOULOS, K. G. Spray drying of tomato pulp: effect of feed concentration. Drying Technology, New York, v.22, n.10, p.2309-2330, 2004.

LEÃO, F.; CLEMENTINO, G.; BARROS, I. Hortigranjeiros no Estado de Alagoas: Uma análise evolutiva da comercialização dentro do IDERAL/CEASA. Sebrae Alagoas, 2017. p. 173.

MACHADO, N.; MARQUES, R. M. P.; SILVA, S. Z.; BERNARDI, M. D. Pesquisa de consumo sobre produtos de panificação e desenvolvimento, caracterização físico-química e análise sensorial de bolo funcional de chocolate. Fag Journal of Health, [s. l.], ano 2019, v. 1, ed. 1, p. 10-23, 2019.

\section{MACHADO, M. M. Desenvolvimento de formulações de bolos de chocolate light utilizando} farinha do mesocarpo do maracujá e hidrocolóides. Orientador: Francine F. Padilha. 2012. 98 p. Dissertação (Mestrado) - Universidade Tiradentes, Aracaju, 2012.

MATOS, M.; BENINCÁ, S. C.; ZANLOURENSI, C. B.; SCHMITT, V. Análise sensorial e nutricional de brownie com farinha de banana verde. Revista brasileira de obesidade, nutrição e emagrecimento, São Paulo, 2017, v. 11, n. 69, p. 722-730. Disponível em: http://www.rbone.com.br/index.php/rbone/article/view/641. Acesso em: 15 jun. 2020.

MIAMOTO, J. B. M. Obtenção e Caracterização de Biscoito tipo Cookie Elaborado com Farinha de Inhame (Colocasia esculenta L). Orientadora: Joelma Pereira. 2008. 146 f. Dissertação (Mestrado) - Curso de Ciência dos Alimentos, Universidade Federal de Lavras, Minas Gerais, 2008.

MORAIS, J. S.; SASSI, K. K. B.; SOUZA, B. L.; MOREIRA, R. T.; MACIEL, J. F. Desenvolvimento e aceitação de bolo de abóbora com chocolate à base de farinha de 
arroz. Revista Brasileira de Agrotecnologia, Brasil, ano 2017, v. 7, ed. 2, p. 68-72.

NIELSEN, E. O que há na comida e na mente de brasileiro. 2016. Disponível em: https://www.nielsen.com/br/pt/insights/article/2017/o-que-ha-na-comida-e-na-mente-do brasileiro/. Acesso em: 23 maio 2020.

OLIVEIRA, J. M. S.; SOUSA, F. C.; SILVA, L. M. M.; MACHADO, N. A. F. Obtenção da farinha de inhame para processamento de brownie. In: 70 Reunião Anual da SBPC, 2018, Maceió - AL. Anais da 70ª Reunião Anual da Sociedade Brasileira para o Progresso da Ciência, 2018.

ORSINE, J. V. C.; MARTINS, L. F.; LIMA, K. K. B. Caracterização físico-química e microbiológica de brownie de chocolate utilizando-se ingredientes dietéticos, light e não dietéticos. Revista Brasileira de Tecnologia Agroindustrial, Ponta grossa, ano 2016, v. 10, ed. 2, p. 2053-2068.

PADILHA, V. M. et al. Perfil sensorial de bolos de chocolate formulados com farinha de yacon (Smallanthus sonchifolius). Ciênc. Tecnol. Aliment. [conectados]. 2010, vol.30, n.3, pp.735740. ISSN 0101-2061. https://doi.org/10.1590/S0101-20612010000300026 .

PESSOA, T. et al. Características físicas e físico-químicas de palitos de inhame submetidos à desidratação osmótica em solução salina. Holos, n.33, v. 7, 2017.

RODRIGUES, M. A.; FERREIRA, B. S.; SILVA, M. F.; COSTA, M. L. A.; ALMEIDA, A. S.; SANTOS, A. F. A bioquímica dos alimentos e doenças relacionadas. Diversitas Journal, [s.1.], v. 2, n. 2, p. 182-190, 8 ago. 2017. http://dx.doi.org/10.17648/diversitas-journal-v2i2.494.

SÁ, A. R. A. et al. Caracterização físico-química e nutricional de farinhas obtidas de inhame (Dioscorea spp.) e taro (Colocasia esculenta) comercializados em Petrolina-PE. Saúde (Santa Maria), [S.1.], jan. 2019. ISSN 2236-5834. 01 jun. 2020. doi:http://dx.doi.org/10.5902/2236583433647. 
SANTHALAKSHMY, S.; BOSCO, S. J. D.; FRANCIS, S.; SABEENA, M. Effect of inlet temperature on physicochemical properties of spray-dried jamun fruit juice powder. Powder Technology, v.274, n.1, p.37-43, 2015.

SIQUEIRA, M. V. B. M.; Nascimento, W. F.; Silva, L. R. G.; Ferreira, A. B.; Silva, E. F.; Ming, L. C.; Veasy, E. A. (2014) Distribution, management and diversity of yam local varieties in Brazil: a study on Dioscorea alata L. Braz. J. Biol., 74, 52-61.

SILVA, J. Y. P.; SILVA, A. R.; DOMINGOS, L. B. S.; MARTINS, A. C. S.; OLIVEIRA, M. E. G. Avaliação da aceitação sensorial de brownie elaborado com farinha de berinjela e soro de leite caprino. II Congresso brasileiro de ciências da saúde, Campina Grande, 2017, p. 1-9.

SILVA, P. A., et al. Caracterização de farinhas de tapioca produzidas no estado do Pará. Cienc. Rural, Santa Maria, v. 43, n. 1, p. 185-191, 2013.

SILVA, F. A. S.; AZEVEDO, C. A. V. (2016). The Assistat Software Version 7.7 and it use in the analysis of experimental data. Afr. J. Agric. Res. Vol. 11 (39), pp. 3733-3740, 29 September. DOI: 10.5897/AJAR2016.11522.

SILVA, T. S. G.; FURLANETTO, T. W. Diagnóstico de doença celíaca em adultos. Revista da Associação Médica Brasileira, Rio Grande do Sul, Porto Alegre, v. 1, n. 56, p. 122-126, 2010. Disponível em: https://www.scielo.br/pdf/ramb/v56n1/27.pdf. Acesso em: 23 maio 2020.

SILVA, N.; JUNQUEIRA, V. C. A.; SILVEIRA, N. F. A. Manual de métodos de análise microbiológica de alimentos. São Paulo: Varela, 2007. 295p.

SOUZA, M. F.; ROSELINO, M. N. Desenvolvimento, caracterização e aceitação de brownie de cacau potencialmente funcional. Rasbran, São Paulo, ano 2019, n. 2, ed. 10, p. 47-51, 2019. Disponível em: https://rasbran.emnuvens.com.br/rasbran/article/view/1466/263. Acesso em: 8 jun. 2020.

SOUSA, Francinalva Cordeiro de. Compostos bioativos e capacidade antioxidante de cajá e umbu-cajá obtidos por liofilização. Orientadores: Ana Paula Trindade Rocha e Josivanda 
Palmeira Gomes. 2017. 183 f. Tese (Doutorado) - Curso de Engenharia Agrícola, Universidade Federal de Campina Grande, Campina Grande, 2017.

SOUZA, J. R.; FIGUEIREDO, R. M.; SANTANA, C. M. P. Qualidade microbiológica da farinha de mandioca comercializada na região sudoeste da bahia. Revista Brasileira de Produtos Agroindustriais, Campina Grande, v. 2, n. 17, p.117-123, 2015.

SOUZA, D. S. et al. Elaboração de farinha instantânea a partir da polpa de fruta-pão (Artocarpus altilis). Cienc. Rural, Santa Maria, v. 42, n. 6, p.1124-1129, jun. 2012.

SOUZA, R. L. A.; OLIVEIRA, L. S. C.; SILVA, F. L. H.; AMORIM, B. C. Caracterização da poligalacturonase produzida por fermentação semi-sólida utilizando-se resíduo do maracujá como substrato. Revista Brasileira de Engenharia Agrícola e Ambiental, Campina Grande, v.14, n.9, p.987-992, 2010.

UAILA, E. D. Estudo fitoquímico e avaliação do valor nutricional do tubérculo inhame (dioscorea spp.). Orientadores: Amália Uamusse e Victor Sevastianov. 2015. 93f. dissertação (mestrado), Universidade Eduardo Mondlane, Maputo, 2015.

WALTER, M., SILVA, L. P. \& EMANUELLI, T. (2005) Amido resistente: características físico-químicas, propriedades fisiológicas e metodologias de quantificação. Ciência Rural, 35, 974-980.

YASHIKI, L. G.; TRIBOLI, E. P. R. Caracterização de farinha de inhame obtida por atomização. 2018. Disponível em: https://maua.br/files/122017/caracterizacao-farinha-inhameobtida-por-atomizacao-261721.pdf. Acesso em: 25 maio 2020.

YUSOF, Y. A.; SALLEH, F. S. M.; CHIN, N. L.; TALIB, R. A. The drying and tabletting of pitaya powder. Journal of Food Process Engineering, v.35, n.5, p.763-771, 2012. 


\title{
CAPÍTULO 03: DESENVOLVIMENTO DE BROWNIE ADICIONADO DE BAGAÇO DE MALTE
}

\section{CHAPTER 03: DEVELOPMENT OF BROWNIE ADDED MALT BAGASSE}

\author{
Isabella Maciel Costa ${ }^{1}$; Amanda Nayara Abreu Silva ${ }^{2}$; Franciele Marques de Oliveira ${ }^{3}$; Leonara \\ Martins Viana ${ }^{4}$; Kennedy Borges Oliveira ${ }^{5}$
}

\begin{abstract}
Resumo
O brownie é um bolo doce que pode possuir cobertura de chocolate e ser acrescido de manteiga de amendoim, castanha, pedaços de chocolate e outros recheios. O bagaço de malte é o principal subproduto da fabricação de cervejas e por possuir um alto conteúdo de fibras e de resíduos de proteínas, possui potencial de uso em produtos de panificação. O objetivo foi elaborar um brownie adicionado de bagaço de malte e avaliar suas características físico-químicas e sensoriais. Foi elaborada uma formulação com bagaço de malte seco e triturado. Foram realizadas análises de $\mathrm{pH}$, umidade, acidez total titulável, cor, análise sensorial e elaboração da informação nutricional. Os valores $\mathrm{pH}$ e acidez encontrados foram de 5,89 e 1,90\%, caracterizando o produto como de baixa acidez. O teor de umidade foi de 13,2\%, resultado inferior a relatados na literatura. Os resultados da análise sensorial variaram de 7,1 a 8,3 para os atributos indicando que os avaliadores classificaram o brownie entre "gostei moderadamente" e "gostei muito". O valor de intenção de compra foi de 4,15, assinalando que a maioria provavelmente compraria o produto. Desse modo, concluiu-se que é possível elaborar um brownie com bagaço de malte e obter boas características tecnológicas e sensoriais.
\end{abstract}

Palavras-Chaves: Bolo, Fibra de malte, Resíduo, Cerveja.

\begin{abstract}
The brownie is a sweet cake that can have chocolate topping and can be added of peanut butter, chestnut, chocolate pieces and other fillings. The malt bagasse is the main by-product of beer brewing and because it has a high content of fibers and protein residues, it has the potential to be used in bakery products. The objective was to develop a brownie added malt bagasse and evaluate its physical-chemical and sensory characteristics. A formulation with dried and crushed malt bagasse has been developed. Analyses of $\mathrm{pH}$, moisture, total titratable acidity, color, sensory analysis and nutritional information were performed. The $\mathrm{pH}$ and acidity values found were 5.89 and $1.90 \%$, characterizing the product as low acidity. The moisture content was $13.2 \%$, a lower result than reported in the literature. The results of the sensory analysis ranged from 7.1 to 8.3 for the attributes indicating that the evaluators classified the brownie between "liked moderately" and "liked a lot". The purchase intention value was 4.15 , indicating that most of the evaluators would probably buy the product. Therefore, it was concluded that it is develop to prepare a brownie with malt bagasse and obtain good technological and sensory characteristics.
\end{abstract}

Keywords: Cake, Malt fiber, Residue, Beer.

\footnotetext{
${ }^{1}$ Engenharia de Alimentos, Universidade Feral de São João del Rei, bellamaciel@hotmail.com

${ }^{2}$ Engenharia de Alimentos, Universidade Feral de São João del Rei, amandanayara71@gmail.com

${ }^{3}$ Engenharia de Alimentos, Universidade Feral de São João del Rei, francielemarques12@ hotmail.com

${ }^{4}$ Engenharia de Alimentos, Universidade Feral de São João del Rei, leonaravianna@ hotmail.com

${ }^{5}$ Engenharia de Alimentos, Universidade Feral de São João del Rei, k.borges02.kb@gmail.com
} 


\section{Introdução}

As tendências atuais do mercado alimentício estão relacionadas com a conveniência, autenticidade, prazer e saúde (ORSINE; MARTINS; LIMA, 2016). Para os produtos de panificação, os bolos têm cada vez mais destaque no consumo e comercialização no país. Assim, diversas empresas se adaptaram visando diversificar os bolos, texturas, sabores, recheios e produtos semelhantes, como muffins, cupcakes e brownies (SIMON, 2014).

O brownie é um produto de origem americana, classificado como sobremesa, e se caracteriza como um bolo doce, pequeno, que pode possuir uma cobertura de chocolate e ser acrescido em sua parte interna de manteiga de amendoim, castanha, pedaços de chocolate e outros tipos de recheios (COSTA et al., 2015).

A massa do bolo ou de um produto similar é considerada uma emulsão de óleo em água, com uma fase aquosa contendo os ingredientes dissolvidos ou dispersos e com bolhas de ar aprisionadas na fase gordurosa. A incorporação de ar na massa tem influência no volume do bolo, mas para o brownie não se necessita de uma grande incorporação de ar (SIMON, 2014). A utilização de farinhas, ricas em fibras, está sendo usada na elaboração de produtos de panificação e massas alimentícias, ampliando a oferta de produtos com elevado teor de fibra, tanto para os consumidores sadios quanto para aqueles que apresentam algumas doenças crônicas não transmissíveis (QUEIROZ et al., 2016). O conhecimento sobre a importância das fibras alimentares na alimentação devido aos seus efeitos fisiológicos e metabólicos tem levado a um maior interesse do público e, consequentemente, a indústria a desenvolver novos alimentos enriquecidos com fibras (ALMEIDA, 2006).

O aproveitamento de subprodutos agroindustriais tem se mostrado uma grande oportunidade para a indústria de alimentos, visto que atende à demanda de utilização das matérias-primas de forma total, promove agregação de valor perdido e uso sustentável dos resíduos, diminuindo os impactos ambientais que possam causar, além de reduzir custos. Dessa forma, estes resíduos podem ser utilizados como ingredientes para desenvolver um novo produto como alternativa de fonte nutricional (COSTA FILHO et al., 2017; CARVALHO, 2019).

O bagaço ou fibra de malte é o principal subproduto proveniente do processamento inicial da fabricação de cervejas (representa aproximadamente $85 \%$ dos subprodutos totais), sendo gerado de 14 a $20 \mathrm{~kg}$ a cada 100 litros de cerveja produzida, e está disponível em todos os meses do ano, em altas quantidades e a um custo acessível. Ele é composto pela casca da cevada malteada e é resultado do processo de obtenção do mosto, pela fervura do malte moído, que após a filtração, origina este subproduto. Assim, é constituído tanto por restos de casca e 
polpa de malte como dos grãos do adjunto, como milho e trigo (CORDEIRO; EL-AOUAR; GUSMÃO, 2012; PADIA, 2018). A extensa produção anual de cerveja no país, em torno de 8,5 bilhões de litros, fornece uma grande quantidade deste subproduto (MATTOS, 2010).

Esse subproduto é um material lignocelulósico, constituído de 35\% de hemicelulose, $20 \%$ de celulose, $10 \%$ de lignina e 10\% de gorduras (MATTOS, 2010). Ele contém 20 a 30\% de proteínas, 70 a $80 \%$ de fibras, $1,2 \%$ de mono e diácidos fenólicos e é fonte de vitaminas do complexo B, logo, tem um elevado valor nutritivo (HERNÁNDEZ et al., 1999; PADIA, 2018). No entanto, essa composição pode variar de acordo com o tipo de cevada utilizada, as condições de maltagem e mosturação e a quantidade e tipo de adjunto adicionado (SANTOS; DINHAM, 2006). Pelo fato de que o bagaço de malte possui um elevado teor de umidade, valor nutricional e presença de resíduos de açúcares fermentescíveis, ele é susceptível à contaminação por microorganismos, principalmente por bolores, e deve ser retirado da cervejaria o mais rápido possível. Sendo assim, deve-se utilizar técnicas de conservação como a secagem, o congelamento e a adição de conservantes para aumentar sua vida de prateleira (PADIA, 2018).

Devido ao fato de apresentar um alto conteúdo de compostos orgânicos e de alto valor nutricional, o bagaço de malte precisa passar por um tratamento antes de ser descartado para evitar danos ambientais. Sendo assim, o seu aproveitamento em outros processos ou produtos é extremamente vantajoso, pois obtém-se maior valor agregado devido ao uso para fins mais nobres e apresenta-se como uma alternativa economicamente viável para destinação dos resíduos (CARVALHO, 2019).

Também pelo fato do bagaço de malte possuir um alto conteúdo de fibras e de resíduos de proteínas e açúcares, ele se torna um subproduto com potencial de uso em produtos de panificação, como bolos, biscoitos e pães de forma, em que a adição de fibras oferece efeitos benéficos, do ponto de vista nutricional e funcional, ao consumidor (CORDEIRO; ELAOUAR; GUSMÃO, 2012). Dessa forma, ao utilizar esse subproduto no ramo de panificação, espera-se uma maior valorização do resíduo, aumentando seu valor agregado e trazendo benefícios à indústria alimentícia (MATTOS, 2010).

Nesse sentido, o objetivo deste trabalho foi desenvolver uma formulação de brownie com apelo nutricional diferenciado pela adição de bagaço de malte, um subproduto industrial rico em fibras, de modo a aproveitá-lo na fabricação de um alimento. Além disso, objetivouse avaliar seu teor de umidade, $\mathrm{pH}$, acidez, cor e suas características sensoriais.

\section{Material e Métodos}

Elaboração e teste de formulação do brownie 
Todos os ingredientes utilizados foram adquiridos no comércio local da cidade de Sete Lagoas - Minas Gerais e estavam dentro da data de validade. O bagaço de malte foi doado por uma cervejaria artesanal da cidade para a condução do experimento e estava congelado no momento da recepção. O bagaço foi previamente seco em estufa com circulação de ar a 40 ${ }^{\circ} \mathrm{C} / 48$ horas e, em seguida, triturado e peneirado para utilização nas formulações.

Foram desenvolvidas duas formulações para teste (Tabela 1): uma sem adição de cerveja comercial (F1) e outra com a presença desta bebida $(\mathrm{F} 2)$.

Tabela 1. Formulações dos brownies com adição de bagaço de malte.

\begin{tabular}{lcc}
\hline \multicolumn{1}{c}{ Ingrediente } & F1 (\%) & F2 (\%) \\
\hline Chocolate meio amargo bem picado & 12,1 & 10,4 \\
Margarina sem sal & 17,5 & 15,1 \\
Bagaço de malte & 5,4 & 4,6 \\
Cerveja comercial Pilsen teor alcoólico 4,6\% vol. & 0 & 13,9 \\
Ovos & 13,5 & 11,6 \\
Açúcar & 33,7 & 29,0 \\
Farinha de trigo sem fermento & 10,8 & 9,3 \\
Sal & 0,5 & 0,5 \\
Cacau em pó & 2,4 & 2,1 \\
Chocolate meio amargo em pedaços finos (ralado) & 4,0 & 3,5 \\
\hline F1 - formulação de brownie sem cerveja comercial Pilsen e F2 - formulação de brownie contendo cerveja \\
comercial Pilsen. & &
\end{tabular}

Para a produção do brownie, o preparo foi baseado no método descrito por Queiroz et al. (2016) com algumas adaptações. Em primeiro lugar, derreteu-se o chocolate meio amargo bem picado juntamente com a margarina em banho-maria e reservou-se. Os ovos foram batidos até ficarem volumosos. Em seguida, adicionou-se açúcar, farinha de trigo sem fermento, sal, cacau em pó, chocolate meio amargo ralado, bagaço de malte e adicionou-se o preparo reservado. $\mathrm{O}$ bagaço de malte foi previamente seco em estufa a $40{ }^{\circ} \mathrm{C}$ com circulação de ar por 48 horas e, em seguida, triturado em mixer e peneirado. Na formulação F2, procedeu-se da mesma forma adicionando ao final a cerveja. Posteriormente, colocou-se cada mistura em uma assadeira untada com óleo e polvilhada com cacau em pó e assou-se a $180^{\circ} \mathrm{C}$ por 40 minutos. Antes de desenformar, deixou-se resfriar por 1 hora.

\section{Análises físico-químicas}

Foram realizadas análises de $\mathrm{pH}$, umidade e acidez total titulável conforme metodologias descritas pelo Instituto Adolfo Lutz (2008), em triplicata.

Para a avaliação da cor, também realizada em triplicata, utilizou-se um colorímetro portátil 
(Minolta Chroma meter CR-210), calibrado previamente e no sistema de cor CIELAB, em que os valores de L* (luminosidade/brilho) variam do preto ao branco ( 0 a 100), os valores do croma $a^{*}$ variam do verde $\left(-a^{*}\right)$ ao vermelho $\left(+a^{*}\right)$ e os valores do croma $b^{*}$ variam do azul $\left(-b^{*}\right)$ ao amarelo $\left(+b^{*}\right)$.

\section{Análise sensorial e pesquisa de mercado}

O teste foi desenvolvido no Laboratório de Análise Sensorial do Departamento de Engenharia de Alimentos (DEALI) da Universidade Federal de São João del Rei, campus Sete Lagoas (UFSJ-CSL). Os materiais necessários para preparação das amostras foram obtidos em comércio local da cidade de Sete Lagoas.

Para a análise sensorial, utilizou-se o teste de aceitação e de intenção de compra. A análise foi conduzida em cabines individuais utilizando luz branca e a melhor formulação foi analisada por 68 avaliadores não treinados, com idade acima de 18 anos e vinculados à UFSJCSL (estudantes, técnicos e professores). Antes da análise, todos os avaliadores assinaram o Termo de Consentimento Livre e Esclarecido (TCLE). A amostra foi identificada com três números aleatórios, servida em pratos descartáveis numa bandeja contendo um copo descartável com água e uma ficha de avaliação. Na ficha, foram analisados os atributos de cor, aroma, sabor, textura e impressão global por meio de uma escala hedônica estruturada de 9 pontos com as opções variando de "desgostei extremamente" (1) a "gostei extremamente" (9).

Para o teste de intenção de compra, foi utilizada uma escala estruturada de 1 a 5 com as opções variando de "certamente não compraria" (1) a "certamente compraria" (5). Após a análise sensorial, foi aplicada uma pesquisa de mercado abordando a frequência de consumo de brownie e de produtos adicionados de fibra, se o avaliador já havia consumido algum produto contendo subproduto da produção de cerveja, se era consumidor de cerveja, se consumia cerveja artesanal, se a adição de fibras influencia no momento da compra e sugestões de melhoria (Figura 1).

O grau de aceitação foi quantificado de acordo com a média das respostas e o índice de aceitabilidade foi calculado de acordo com a Equação 1 (SILVA et al., 2017):

$$
\mathrm{IA}(\%)=\mathrm{A} \times 100 / \mathrm{B}
$$

(Equação 1)

Onde:

$\mathrm{A}=$ nota média obtida para $\mathrm{o}$ atributo;

$\mathrm{B}=$ nota máxima dada ao atributo. 
Figura 1. Pesquisa de mercado aplicada após a realização da análise sensorial.

1. Com que frequência você costuma consumir brownie?

( ) Nunca ( ) Quase nunca ( ) As vezes ( ) Quase sempre ( ) Sempre

2. Você já consumiu algum produto contendo subproduto da produção de cerveja (malte)?

$$
\text { ( ) Sim ( ) Não }
$$

3. Você é consumidor de cerveja?

$$
\text { ( ) } \operatorname{Sim} \text { ( ) Não }
$$

Se sim, você tem o costume de consumir cerveja artesanal?

$$
\text { ( ) } \operatorname{Sim} \text { ( ) Não }
$$

4. Com que frequência você costuma consumir produtos adicionados de fibras?

( ) Nunca ( ) Quase nunca ( ) As vezes ( ) Quase sempre ( ) Sempre

5. A adição de fibras no produto influencia no momento de compra?

$$
\text { ( ) } \operatorname{Sim} \text { ( ) Não }
$$

6. O que você acha que poderia melhorar no produto?

Fonte: Própria (2020).

\section{Informação Nutricional}

Para elaboração da tabela nutricional do brownie, seguiu-se os passos descritos no Manual de Rotulagem Nutricional Obrigatória - Manual de Orientação às Indústrias de Alimentos da Agência Nacional de Vigilância Sanitária (ANVISA, 2005) com o auxílio de uma planilha do Excel para realizar os cálculos. A porção foi definida de acordo com a $\operatorname{RDC~}{ }^{\circ} 359$, de 23 de dezembro de 2003 (BRASIL, 2003).

\section{Resultados e Discussão}

\section{Teste de formulação}

As características sensoriais do produto obtido com a formulação F1 (sem adição de cerveja) não foram as esperadas, uma vez que houve um crescimento inicial exagerado da massa no forno seguido de redução do volume (murchamento). Além disso, o produto ficou ressecado, ou seja, não apresentou a consistência fofa esperada para o brownie. Já a formulação F2 (com adição de cerveja) apresentou crescimento e consistência característicos de brownie e, portanto, foi a formulação selecionada para as análises físico-químicas e sensoriais. 


\section{Análises físico-químicas}

Os resultados de $\mathrm{pH}$, acidez total titulável, umidade e cor podem ser observados na Tabela 2.

Tabela 2. pH, acidez total titulável, umidade e cor das amostras de brownie.

\begin{tabular}{ccc}
\hline Parâmetro & Resultado \\
\hline $\mathrm{pH}$ & & $5,89 \pm 0,03$ \\
Acidez total titulável $(\%)$ & $1,90 \pm 0,03$ \\
Umidade $(\%)$ & & $13,2 \pm 0,25$ \\
& $\mathrm{~L}^{*}$ & $30,51 \pm 1,23$ \\
Cor & $\mathrm{a}^{*}$ & $7,90 \pm 0,19$ \\
& $\mathrm{~b}^{*}$ & $11,01 \pm 0,15$
\end{tabular}

Fonte: Própria (2020).

Conforme o valor de $\mathrm{pH}$, os alimentos podem ser divididos em: alimentos de baixa acidez $(\mathrm{pH}>4,5)$, alimentos ácidos ( $\mathrm{pH}$ entre 4,0 e 4,5) e alimentos muito ácidos $(\mathrm{pH}<4,0)$. Dessa forma, percebe-se que o produto desenvolvido é classificado como de baixa acidez, pois o valor de $\mathrm{pH}$ encontrado foi de 5,89. Esta faixa favorece o crescimento de diversas bactérias, bolores e leveduras, pois encontra-se no seu ponto ótimo de crescimento. Este $\mathrm{pH}$ em torno da neutralidade torna o meio propício para micro-organismos, sejam eles patogênicos ou deteriorantes (FRANCO; LANDGRAF, 1996; MOURA; MOURA, 2014). Sendo assim, técnicas para aumentar a vida útil do produto deveriam ser utilizadas. Um bom método de armazenamento e embalagem é fundamental para garantir maior vida de prateleira a um produto. As embalagens multicamadas/laminadas se caracterizam como uma boa barreira à umidade, gases, aromas e à luz e poderiam ser uma boa alternativa para acondicionamento do produto elaborado. Além disso, a adição de um agente conservante poderia ser considerada.

No estudo de Orsine, Martins e Lima (2016) foram elaboradas duas formulações de brownie de chocolate com ingredientes dietéticos, light e não dietéticos e estas continham propionato de sódio e sorbato. Eles encontraram valores de pH de 6,29 e 7,34 para as duas formulações desenvolvidas, que são resultados superiores aos obtidos neste trabalho, mas que também se encontram em uma faixa que favorece o crescimento de micro-organismos.

O pH é um valor que expressa o ácido dissociado, já a acidez titulável expressa a quantidade do ácido presente. A determinação da acidez total em alimentos é bastante importante tendo em vista que através dela, pode-se obter dados valiosos na apreciação do processamento e do estado de conservação dos alimentos, além disso, pode-se afirmar que há uma relação inversamente proporcional entre estes parâmetros, pois quanto menor o $\mathrm{pH}$, maior 
a acidez encontrada (MOURA et al., 2014). Dessa forma, foi possível confirmar a relação pH e acidez, visto que o valor de acidez encontrado foi baixo o que corrobora o $\mathrm{pH}$ mais elevado.

No presente estudo, o brownie apresentou um teor de umidade de 13,2\%, o que representa um baixo teor. A Resolução CNNPA n¹2 de 1978 (BRASIL, 1978) determina um valor máximo de $15 \%$ de umidade para produtos à base de cereais. Dessa forma, o brownie elaborado atende ao estabelecido nessa legislação.

Orsine, Martins e Lima (2016) encontraram valores de 22,68\% e 24,95\% em suas formulações, que são superiores aos obtidos neste trabalho. Simon (2014) ao avaliar as características físico-químicas de brownie com farinha de arroz e trigo sarraceno obteve um teor de umidade de 23\%. Já Queiroz et al. (2016) ao avaliar três formulações de brownies produzidos a partir de farinha de coco e farinha de arroz, encontrou teores de umidade que variaram de $16,53 \%$ a $22,98 \%$.

Na formulação do brownie estudado, utilizou-se maior concentração de farinha de trigo em relação ao bagaço de malte. Panzarini et al. (2014) encontraram maiores teores de umidade em formulações de bolo elaboradas com maior porcentagem do bagaço, portanto, com mais fibra alimentar. Isso se justifica pela propriedade das fibras de reterem e manterem água em sua estrutura durante o processo de cocção, ou seja, há uma elevação na umidade de produtos à medida que o teor de fibras é aumentado. Além disso, o tempo de forneamento também pode influenciar no teor de umidade, visto que quanto maior o tempo de forneamento, maior a evaporação de água e, consequentemente, menor o teor de umidade.

Em relação aos parâmetros de cromaticidade $\left(a^{*}\right.$ e $\left.b^{*}\right)$, foi possível observar que a amostra se apresentou nas regiões vermelha e amarelo já que a leitura do colorímetro demonstrou valores positivos para estas coordenadas. Panzarini et al. (2014) menciona em seu trabalho que a combinação dos cromos positivos $a^{*}$ e $b^{*}$ resulta da cor marrom, coloração característica de produtos desenvolvidos com chocolate e seus derivados. Quanto ao parâmetro de luminosidade $\left(\mathrm{L}^{*}\right)$, as amostras foram consideradas escuras, já que na escala de 0 a 100 apresentaram valores abaixo de $50\left(\mathrm{~L}^{*}<50\right)$. Ademais, outros fatores podem ter afetado a coloração dos brownies, como a presença de açúcares e ovos, assim como o calor, que acelera reações de caramelização e de Maillard, levando ao escurecimento progressivo da crosta e do miolo (PANZARINI et al., 2014).

A coloração dos alimentos representa um dos atributos mais importantes observados pelos consumidores podendo intervir na decisão de compra, bem como representa o indicador de pigmentos durante o escurecimento não enzimático e o processo de caramelização (SCHMIELE et al., 2011). Logo, para os brownies, o consumidor espera uma coloração marrom 
escuro, pois é feita uma associação com a presença do chocolate. Na Figura 2, é possível observar a coloração obtida no brownie elaborado.

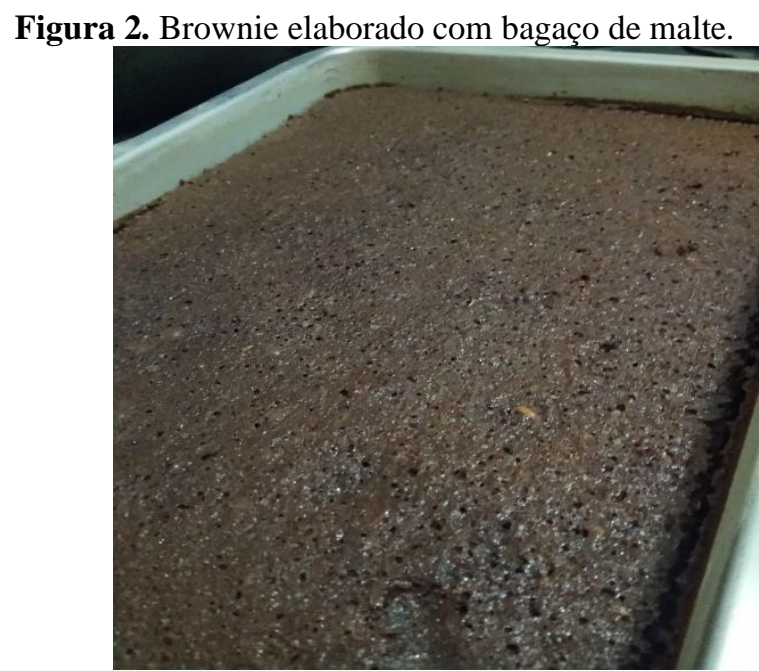

Fonte: Própria (2020)

\section{Análise sensorial}

Os resultados da média de aceitação sensorial para cada parâmetro e o índice de aceitabilidade (IA) estão descritos na Tabela 3.

Tabela 3. Média das notas de aceitação sensorial para cada atributo e índice de aceitabilidade das amostras de brownie com fibra de malte.

\begin{tabular}{lcc}
\hline \multicolumn{1}{c}{ Atributo } & Média de aceitação & Índice de aceitabilidade (\%) \\
\hline Impressão global & 7,9 & 87,6 \\
Sabor & 8 & 100 \\
Textura & 7,1 & 78,6 \\
Aroma & 7,9 & 88,2 \\
Cor & 8,3 & 92,8 \\
\hline \multicolumn{3}{c}{}
\end{tabular}

Pôde-se observar que a amostra apresentou resultados que variaram de 7,1 a 8,3 para os atributos avaliados indicando que os provadores classificaram o brownie entre "gostei moderadamente" e "gostei muito". Dentre os atributos, o que obteve uma menor média de aceitação $(7,1)$ foi a textura.

A textura foi um dos pontos mais citados para melhoria na pesquisa de mercado, uma vez que as fibras estavam ligeiramente aparentes. Isso provavelmente se deve ao fato de que o processo de refinamento do bagaço de malte foi artesanal (trituração em mixer e em peneira comercial) e a percepção sensorial das fibras ficou mais evidente. Contudo, considerando-se um processamento industrial, em que o bagaço passaria por etapas refinadas de trituração e 
peneiramento ou ainda poderia ser transformado em farinha, a percepção sensorial das fibras poderia ser diminuída e haver uma aceitação ainda maior.

Com relação à intenção de compra, o valor médio encontrado foi de 4,15 o que indica que a maioria dos provadores provavelmente comprariam o produto. Dessa forma, este poderia ser um bom nicho de mercado para se investir. Além da facilidade de preparo e da boa aceitação, o brownie é um tipo de inovação gourmet que tem sido a causa de sucesso de vários negócios, principalmente as confeitarias e, logo, uma ótima atividade para empreender (KALIL, 2020; LISBOA, 2020; SANTIAGO, 2020; SEBRAE, 2020).

Para que o IA indique boa aceitação, os atributos sensoriais devem apresentar um valor igual ou maior a 70\% (DUTCOSKY, 2011). Desse modo, pôde-se perceber que a amostra obteve valores de IA superiores a $70 \%$ para todos os atributos, sendo assim um resultado satisfatório. $\mathrm{O}$ atributo que apresentou maior IA foi o sabor, enquanto o de menor foi a textura. No trabalho de Mattos (2010), foi elaborado um pão adicionado de $30 \%$ de fibras a partir do bagaço de malte e na análise sensorial, os valores médios para os atributos mostraram boa aceitação, ficando entre 7,2 e 8 e os índices de aceitabilidade para todos os atributos foram superiores a 70\%, que são resultados semelhantes aos encontrados no presente estudo. Panzarini et al. (2014) encontraram em suas duas formulações de bolo de mel enriquecido com fibras do bagaço de malte índices de aceitabilidade acima de $80 \%$ para todos os atributos. Dalmolin et al. (2019), por sua vez, ao elaborar uma formulação de brownie funcional sem glúten e sem lactose encontraram para os atributos valores médios variando de 5,94 a 6,54 e índices de aceitabilidade superiores a $80 \%$.

As Figuras 3 e 4 apresentam a frequência com que os provadores consomem brownie e fibras.

Figura 3. Frequência de consumo de brownie pelos participantes.

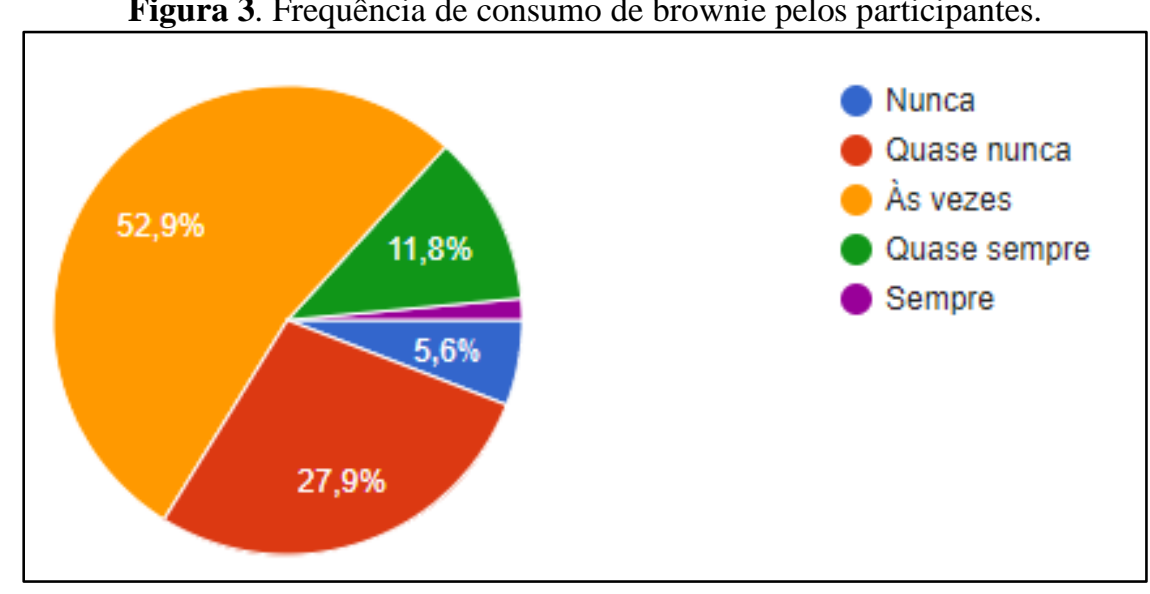

Fonte: Própria (2020). 
Figura 4. Frequência com que os provadores costumam consumir produtos adicionados de fibras.

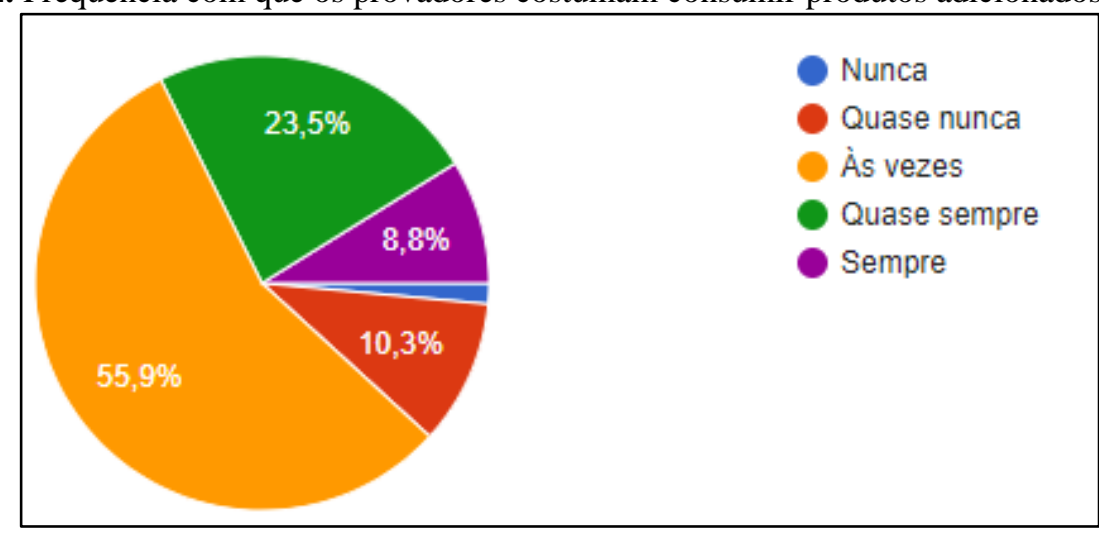

Fonte: Própria (2020).

Foi possível observar um comportamento semelhante de frequência de consumo de brownie e de fibras pelos participantes. Em sua maioria, tanto o consumo de brownie como de fibras é feito ocasionalmente pelos provadores $(52,9 \%$ e 55,9\%, respectivamente, disseram consumir "as vezes"). Isso provavelmente se deve ao fato de que tanto o brownie quanto os produtos adicionados de fibra possuem um valor agregado e, com isso, possuem preços mais elevados, o que limita o consumo ao poder de compra do cliente.

Ainda com relação à pesquisa de mercado, 66,2\% já consumiram alimentos adicionados de um subproduto da fabricação de cerveja, sendo ainda que a maioria desses, são consumidores de cervejas artesanais $(61,8 \%$ dos provadores são consumidores de cerveja e desses, $55,8 \%$ costumam consumir cerveja artesanal). Isso indica que provavelmente as pessoas que consomem cerveja artesanal têm maior interesse em alimentos que sejam fabricados com subprodutos do processo fermentativo e poderiam ser o público-alvo para direcionamento de ações de marketing.

Por fim, a maioria dos participantes apontou a adição de fibras como influenciadora na intenção de compra $(66,2 \%)$ indicando que o produto desenvolvido pode ter um potencial no mercado. Atualmente, como os consumidores se preocupam mais com a saúde, a difusão de conhecimentos sobre informações nutricionais tem crescido e, assim, as preferências dos clientes tem se modificado. Dessa forma, uma determinada característica nutricional que é importante para o consumidor pode ser decisiva no momento de uma escolha entre marcas (BERNARDON; PERIN; SAMPAIO, 2008).

\section{Informação Nutricional}

A informação nutricional do brownie elaborado pode ser observada no Quadro 1:

Foram coletadas informações nutricionais de dois brownies de chocolate de marcas comerciais conhecidas (A e B) que continham ingredientes base semelhantes aos utilizados 
neste trabalho (Quadro 2) com a finalidade de comparação.

Quadro 1. Informação nutricional do brownie elaborado com bagaço de malte.

\begin{tabular}{|c|c|c|}
\hline \multicolumn{3}{|c|}{ Informação Nutricional } \\
\hline \multicolumn{3}{|c|}{ Porção 40 g (1 unidade) } \\
\hline \multicolumn{2}{|c|}{ Quantidade por porção } & $\% \mathrm{VD}(*)$ \\
\hline Valor energético & $125 \mathrm{kcal}=524 \mathrm{~kJ}$ & 6 \\
\hline Carboidratos & $17 \mathrm{~g}$ & 6 \\
\hline Proteínas & $1,7 \mathrm{~g}$ & 2 \\
\hline Gorduras totais & $5,5 \mathrm{~g}$ & 10 \\
\hline Gorduras saturadas & $1,9 \mathrm{~g}$ & 9 \\
\hline Gorduras trans & $0 \mathrm{~g}$ & $* *$ \\
\hline Fibra alimentar & $1,5 \mathrm{~g}$ & 6 \\
\hline Sódio & $48 \mathrm{mg}$ & 2 \\
\hline \multicolumn{3}{|c|}{$\begin{array}{l}\text { (*) \% Valores diários com base em uma dieta de } 2000 \mathrm{kcal} \text { ou } 8400 \mathrm{~kJ} \text {. Seus valores diários } \\
\text { podem ser maiores ou menores dependendo de suas necessidades energéticas. } \\
(* *) \text { VD não estabelecido. }\end{array}$} \\
\hline
\end{tabular}

Fonte: Própria (2020).

Quadro 2. Informação nutricional de dois brownies de chocolate das marcas comerciais A e B.

\begin{tabular}{|c|c|c|c|c|}
\hline \multicolumn{5}{|c|}{ Informação Nutricional } \\
\hline \multicolumn{5}{|c|}{ Porção 40 g } \\
\hline & \multicolumn{2}{|l|}{ Marca A } & \multicolumn{2}{|l|}{ Marca B } \\
\hline & Quantidade por porção & $\% \mathrm{VD}(*)$ & Quantidade por porção & $\% \mathrm{VD}(*)$ \\
\hline Valor energético & $163 \mathrm{kcal}=681 \mathrm{~kJ}$ & 8 & $179 \mathrm{kcal}=752 \mathrm{~kJ}$ & 9 \\
\hline Carboidratos & $21 \mathrm{~g}$ & 7 & $20 \mathrm{~g}$ & 7 \\
\hline Proteínas & $2,1 \mathrm{~g}$ & 3 & $2,1 \mathrm{~g}$ & 3 \\
\hline Gorduras totais & $7,1 \mathrm{~g}$ & 13 & $10 \mathrm{~g}$ & 18 \\
\hline Gorduras saturadas & $2,7 \mathrm{~g}$ & 12 & $5,7 \mathrm{~g}$ & 26 \\
\hline Gorduras trans & $1,2 \mathrm{~g}$ & $* *$ & $0 \mathrm{~g}$ & $* *$ \\
\hline Fibra alimentar & $1,0 \mathrm{~g}$ & 4 & $0,8 \mathrm{~g}$ & 3 \\
\hline Sódio & $168 \mathrm{mg}$ & 7 & $14 \mathrm{~g}$ & 1 \\
\hline
\end{tabular}

Fonte: Própria (2020).

Confrontando as informações apresentadas no Quadro 1 com o Quadro 2, pode-se observar que o brownie desenvolvido neste trabalho apresenta menores valores de carboidratos, proteínas, gorduras totais, gorduras saturadas e valor energético quando comparado às duas marcas comerciais A e B. Tanto o produto da marca B quanto o brownie adicionado de fibra 
de malte não contém gorduras trans. Com relação ao teor de sódio, a formulação desenvolvida possui um menor teor que a marca $\mathrm{A}$, porém maior que a marca B. Por fim, considerando o valor de fibras, o brownie desenvolvido apresenta um maior teor que as duas marcas comerciais, o que provavelmente se deve à presença do bagaço de malte.

\section{Conclusões}

Concluiu-se que é possível elaborar um brownie adicionado de bagaço de malte e obter boas características tecnológicas e sensoriais. O brownie desenvolvido demonstrou baixa acidez, coloração marrom, umidade baixa e apresentou uma boa aceitação sensorial e intenção de compra. Contudo, se o processo de refinamento do bagaço de malte fosse mais minucioso, poderia se alcançar uma maior aceitação do produto com uma textura mais agradável. Assim, a formulação poderia ser aperfeiçoada para se tornar um produto com aceitação ainda maior.

\section{Referências}

ALMEIDA, E. L. Efeito da adição de fibra alimentar sobre a qualidade de pão pré-assado congelado. 2006, 328 f. Dissertação (Mestrado em Tecnologia de Alimentos) - Universidade Estadual de Campinas, Campinas, 2006.

ANVISA. Manual de Orientação às Indústrias de Alimentos. $2^{\circ}$ versão, Brasília: Ministério da Saúde, Agência Nacional de Vigilância Sanitária/Universidade de Brasília, 2005.

BERNARDON, R.; PERIN, M. G.; SAMPAIO, C. H. Influência das Informações Nutricionais na Intenção de Compra do Consumidor de Alimentos. In: XXXII Encontro da ANPAD, 2008, Rio de Janeiro. Anais do XXXII Encontro da ANPAD, 2008.

BRASIL. Comissão Nacional de Normas e Padrões para Alimentos (CNNPA). Aprova Normas Técnicas Especiais, do Estado de São Paulo, revistas pela CNNPA, relativas a alimentos (e bebidas), para efeito em todo território brasileiro. Resolução CNNPA no 12, de 1978. Diário Oficial da União, Brasília, 24 de julho de 1978.

BRASIL. Ministério da Saúde. Aprova o Regulamento Técnico de Porções de Alimentos Embalados para Fins de Rotulagem Nutricional. Resolução RDC ${ }^{\circ}$ 359, de 23 de dezembro de 2003. Diário Oficial da União. Brasília, 26 de dezembro de 2003.

CARVALHO, J. M. A cerveja e a viabilidade tecnológica e nutricional do aproveitamento do resíduo de seu processamento: revisão. 2019. $33 \mathrm{f}$. Trabalho de conclusão de curso de Graduação apresentado ao curso de Engenharia de Alimentos - Universidade Federal de Lavras. Lavras, 2019.

CORDEIRO, L. G.; EL-AOUAR, A. A.; GUSMÃO, R. P. Caracterização do bagaço de malte oriundo de cervejarias. Revista Verde, Mossoró - RN, v. 7, n. 3, p. 20-22, 2012.

COSTA, B. P.; LOURENCO, L. B. V.; Silva, I.D.; Miranda, K. W. E.; ZAMBELLI, R. A.; SOUSA, C.R.V. Perfil sensorial de brownie funcional com farinha de banana verde, enriquecida de nozes e sementes de chia. In: Anais do Simpósio Latino Americano de Ciências 
de Alimentos, 2015, Campinas. Anais eletrônicos do Simpósio Latino Americano de Ciências de Alimentos, 2015.

COSTA FILHO, D. V.; SILVA, A. J.; SILVA, P. A. P.; SOUSA, F. C. Aproveitamento de resíduos agroindustriais na elaboração de subprodutos. In: II Congresso Internacional das Ciências Agrárias - COINTER - PDVAgro, 2017. Anais do Congresso Internacional das Ciências Agrárias - COINTER - PDVAgro, 2017.

DALMOLIN, C., IENSEN, G., RIBEIRO, J., LOPES, M., \& BASSO, C. Análise sensorial de um brownie sem glúten e sem lactose. Disciplinarum Scientia, Série: Ciências da Saúde, Santa Maria, v. 20, n. 2, p. 295-303, 2019.

DUTCOSKY, S. D. Análise sensorial de alimentos. 3. ed. Curitiba: Champagnat, 2011.

FRANCO, B. D. G. M.; LANDGRAF, M. Microbiologia dos alimentos. São Paulo: Atheneu, 1996.

HERNÁNDEZ, A.; RODRÍGUEZ, J. L.; LOPEZ, B.; ZERQUERA, O. Caracterización química e functional del afrech de malta. Alimentaria, n. 302, p. 105-107, 1999.

INSTITUTO ADOLFO LUTZ - IAL. Normas analíticas do Instituto Adolfo Lutz. 2.ed. São Paulo, v. 4, formato digital, 2008.

KALIL, M. Brownies e cookies têm se mostrado excelente negócio para jovens empreendedores da Capital. Disponível em: https://gauchazh.clicrbs.com.br/donna/noticia/2015/11/brownies-e-cookies-tem-se-mostradoexcelente-negocio-para-jovens-empreendedores-da-capital-cjplhzrpz003bh9cn0uco0535.html. Acesso em: 25 maio 2020.

LISBOA, A. P. Doceira apresenta excelência na gestão e nos brownies. Disponível em: https://www.correiobraziliense.com.br/app/noticia/eu-estudante/trabalho-e-

formacao/2017/09/17/interna-trabalhoeformacao-2019,626708/doceira-apresenta-excelenciana-gestao-e-nos-brownies.shtml. Acesso em: 25 maio 2020.

MATTOS, C. Desenvolvimento de um pão fonte de fibras a partir do bagaço de malte. 2010. 40 f. Monografia (Graduação em Engenharia de Alimentos) - Universidade Federal do Rio Grande do Sul, Porto Alegre, 2010.

MOURA, K. L. A.; MOURA, S. I. A. Desenvolvimento e avaliação das características nutricionais, físico-químicas e sensoriais de bolo com diferentes tipos de farinhas e Castanha-do-Brasil (Bertholletia excelsa HBK). 2014. 65 f. Monografia (Bacharelado em Engenharia de Alimentos) - Fundação Universidade Federal de Rondônia, Ariquemes, 2014.

ORSINE, J. V. C.; MARTINS, L. F.; LIMA, K., K., B. Caracterização físico-química e microbiológica de brownie de chocolate utilizando-se ingredientes dietéticos, light e não dietéticos. Revista Brasileira de Tecnologia Agroindustrial, v. 10, n. 2, p. 2053-2068, 2016. PADIA, M. L. B. Cookie funcional com bagaço de malte uma nova proposta quando comparado ao industrializado. 2018. 61 f. Monografia (Bacharelado em Nutrição) Universidade Regional do Noroeste do Estado do Rio Grande do Sul - Unijuí, Ijuí, 2018.

PANZARINI, N. H.; RABBERS, A.; DA TRINDADE, J. L. F., DE MATOS, E. A. S. A., CANTERI, M. H. G., \& BITTENCOURT, J. V. M. Elaboração de bolo de mel enriquecido 
com fibras do bagaço da indústria cervejeira. Revista Brasileira de Tecnologia Agroindustrial, v. 8, n. 1, p. 1154-1164, 2014.

QUEIROZ, M. P.; COSTA A., C., S.; CARVAlHO C., U., S.; CAVAlCANTI, M., S., J.; SOARES, K., B. Avaliação das características físico-químicas de brownies produzidos a partir de farinha de coco e farinha de arroz. In: ONE, G. M. C.; CARVALHO, A. G. C. Nutrição e Saúde: conhecimento, integração e tecnologia 1. João Pessoa: Impressos Adilson, 2016, p. 98-110.

SANTIAGO, B. A expansão do brownie. Disponível em: https://www.argosjr.com/expansaodo-brownie/. Acesso em: 25 maio 2020.

SANTOS, J. I.; DINHAM, R. O essencial em cervejas e destilados. São Paulo: Senac, 2006. $135 \mathrm{p}$.

SEBRAE. Empresários apostam no brownie como oportunidade de negócio. Disponível em: https://www.sebrae.com.br/sites/PortalSebrae/ufs/se/noticias/empresarios-apostam-nobrownie-como-oportunidade-de-

negocio,3b4a2586d3e02510VgnVCM1000004c00210aRCRD. Acesso em: 25 maio 2020.

SCHMIELE, M.; DA SILVA, L. H., DA COSTA, P. F. P., RODRIGUES, R. D. S.; CHANG, Y. K. Influência da adição de farinha integral de aveia, flocos de aveia e isolado proteico de soja na qualidade tecnológica de bolo inglês. Boletim do Centro de Pesquisa de Processamento de Alimentos, v. 29, n. 1, p. 71-82, 2011.

SILVA, J. Y. P.; SILVA, A. R.; DOMINGOS, L. B. S.; MARTINS, A. C. S.; OLIVEIRA, M. E. G. Avaliação da aceitação sensorial de brownie elaborado com farinha de berinjela (Solanum melongena L.) e soro de leite caprino. In: II Congresso Brasileiro de Ciências da Saúde, 2017, Campina Grande. Anais do II Congresso Brasileiro de Ciências da Saúde, 2017.

SIMON, A. Elaboração de brownie sem glúten com a utilização de farinha de arroz e trigo sarraceno. 2014. $71 \mathrm{f}$. Trabalho de conclusão de curso de Graduação apresentado ao curso de Engenharia de Alimentos - Universidade Federal do Rio Grande do Sul. Porto Alegre, 2014. 


\title{
CAPÍTULO 04: DESENVOLVIMENTO E AVALIAÇÃO QUALITATIVA DE SORVETE SIMBIÓTICO COM SORO DO LEITE E EXTRATO DE SOJA
}

\author{
CHAPTER 04: DEVELOPMENT AND QUALITATIVE EVALUATION OF \\ SYMBOTIC ICE CREAM WITH MILK SERUM AND SOY EXTRACT
}

\author{
Layane Rosa da Silva ${ }^{1}$; Antonio Alef Pereira de Oliveira ${ }^{2}$; Aliou Toro Lafia ${ }^{3}$; José Douglas \\ Bernardino Domingos ${ }^{4}$; Fabiana Augusta Santiago Beltrão ${ }^{5}$
}

\begin{abstract}
Resumo
O consumidor entende que alimentação saudável envolve a escolha de alimentos que, ao mesmo tempo, são capazes de fornecer os nutrientes necessários ao organismo e minimizar o risco de doenças. Portanto o objetivo desse estudo foi desenvolver um sorvete simbiótico com soro do leite e extrato de soja, e realizar a caracterização físico-química. Assim, com o objetivo de atender as expectativas dos consumidores em consumir um alimento funcional e nutritivo. $\mathrm{O}$ sorvete desenvolvido e analisado foi adicionado uma concentração de $10 \%$ de soro do leite e $10 \%, 15 \%$ e $20 \%$ de extrato de soja. As análises físico-químicas realizadas seguiram a metodologia proposta pelo Instituto Adolfo Lutz, a saber: determinação de sólidos solúveis totais, lactose, determinação da acidez com resultados expressos em g de ácido lático por cento, e determinação de gordura por Soxhlet. Os resultados mostraram valores diferentes para os diferentes tratamentos com exceção do teor de sólidos solúveis ( ${ }^{\circ}$ Brix), que correspondem a $1,20 \mathrm{em}$ todos os tratamentos. Com relação aos resultados de gordura a formulação 3, corresponde ao maior percentual com 52,33\%. Os alimentos adicionados de microrganismos probióticos estão sendo cada vez mais consumidos, principalmente devido aos efeitos benéficos atribuídos a esses microrganismos. Pesquisas já feitas, informam que a administração de ingredientes probióticos e prebióticos na alimentação resultam em efeitos benéficos à saúde do consumidor. O sorvete, é uma opção promissora para o desenvolvimento do produto funcional proposto. Os resultados deste trabalho podem contribuir para o desenvolvimento de novos produtos para a indústria alimentícia.
\end{abstract}

Palavras-Chaves: Sorvete, Simbiótico, Funcional, Probiótico, Prebiótico.

\begin{abstract}
The consumer understands that healthy eating involves choosing foods that, at the same time, are capable of providing the necessary nutrients to the body and minimizing the risk of diseases. Therefore, the objective of this study was to develop a symbiotic ice cream with whey and soy extract, and perform the physical-chemical characterization. Thus, in order to meet the expectations of consumers in consuming a functional and nutritious food. The developed and analyzed ice cream was added with a concentration of $10 \%$ whey and $10 \%, 15 \%$ and $20 \%$ soy extract. The physical-chemical analyzes carried out followed the methodology proposed by the Adolfo Lutz Institute, namely: determination of total soluble solids, lactose, determination of acidity with results expressed in $\mathrm{g}$ of lactic acid percent, and determination of fat by Soxhlet. The results showed different values for the different treatments with the exception of the content of soluble solids ( ${ }^{\circ}$ Brix), which correspond to 1.20 in all treatments. Regarding the fat results, formulation 3 , corresponds to the highest percentage with 52, 33\%. Foods added with probiotic

\footnotetext{
${ }^{1}$ Bacharelado em Agroindústria, Universidade Federal da Paraíba/UFPB, layanerossa@ gmail.com

${ }^{2}$ Bacharelado em Agroindústria, Universidade Federal da Paraíba/UFPB, aleffjoe@ gmail.com

${ }^{3}$ Mestrando em Tecnologia Agroalimentar, Universidade Federal da Paraíba/UFPB, zime1990@ gmail.com

${ }^{4}$ Bacharelado Nutrição e Dietética, Universidade Federal de Campina Grande/UFCG, douglas94nc@gmail.com

${ }^{5}$ Doutora em Biotecnologia, Universidade Federal da Paraíba/UFPB, fabs.15@ hotmail.com
} 
microorganisms are being increasingly consumed, mainly due to the beneficial effects attributed to these microorganisms. Research already done, inform that the administration of probiotic and prebiotic ingredients in the food results in beneficial effects to the consumer's health. Ice cream is a promising option for the development of the proposed functional product. The results of this work can contribute to the development of new products for the food industry.

Keywords: Ice cream, Symbiotic, Functional, Probiotic, Prebiotic.

\section{Introdução}

Os alimentos que estão sendo adicionados de microrganismos probióticos cada vez mais vem sendo amplamente consumidos, principalmente devido aos efeitos benéficos atribuídos a esses microrganismos, como: atividade antimicrobiana, estimulação do sistema imune, regulação intestinal, melhoria da digestão da lactose e atividade anticarcinogênica e antimutagênica. No entanto, é importante ressaltar que esses efeitos dependem do tipo de cepa probiótica administrada (BAŞYIĞIT; KULEAŞAN; KARAHAN, 2006; CRUZ et al., 2009).

Probióticos são definidos atualmente como micro-organismos vivos que, quando administrados em quantidades adequadas, conferem um benefício à saúde do hospedeiro (HILL et al., 2014). Os principais probióticos estudados e utilizados são as bactérias que pertencem aos gêneros Lactobacillus e Bifidobacterium (O'FLAHERTY; KLAENHAMMER, 2010; ROSS et al., 2010; RAMASAMY et al., 2012; SHARMA; DEVI, 2014).

Os efeito benéficos dos probióticos são amplamente dependentes da sua capacidade de atingir o seu local de ação apropriado, geralmente o intestino distal, em estado viável e em populações suficientes (KENT; DOHERTY, 2014). Pesquisas envolvendo prebióticos estão sendo direcionadas no sentido de identificar aspectos de saúde associados à sua utilização, o que inclui a redução da diarreia, a modulação da resposta imune e o incremento na biodisponibilidade mineral (RASTALL; GIBSON, 2015).

O consumidor entende que alimentação saudável envolve a escolha de alimentos que, ao mesmo tempo, são capazes de fornecer os nutrientes necessários ao organismo e minimizar o risco de doenças como hipertensão, diabetes, osteoporose, doenças cardiovasculares, entre outras. Durante os últimos 60 anos, alimentos com atributos de saúde tornaram-se cada vez mais importantes e os estudos indicam que os consumidores dão igual peso para atributos de saúde e sensoriais no momento da escolha dos produtos alimentícios (CODRON et al., 2005).

A demanda por alimentos que fornecem benefícios à saúde de forma a reduzir o risco do aparecimento de doenças e que supram as necessidades nutricionais do organismo é cada vez mais evidente. A incorporação de microrganismos probióticos e ingredientes prebióticos aos alimentos pode agregar valor aos produtos e oferecer os benefícios dos alimentos funcionais 
se incluídos diariamente na dieta. O sorvete é uma excelente fonte de energia e, apesar de conter açucares e gorduras, é geralmente considerado um alimento nutritivo, uma vez que contém leite e frutas em sua formulação (GOFF; HARTEL, 2013).

A Agência Nacional de Vigilância Sanitária (ANVISA) determina normas e procedimentos para registrar os alimentos funcionais no Brasil. Para lançar um produto no mercado com um registro de um alimento com alegação de propriedades funcionais de saúde, esta deve seguir a legislação do Ministério da Saúde e apresentar um relatório técnico- científico com muitas informações que comprovam os seus benefícios e a garantia de segurança para seu consumo.

Alimento funcional é aquele que além de atender à necessidade nutricional básica do consumidor, quando consumido, resulta em efeitos metabólicos e/ou fisiológicos benéficos à saúde (ROBERFROID, 2000). Para que este tipo de alimento exerça seus efeitos benéficos para a saúde, a ingestão deve ocorrer diariamente (PANDIYAN et al., 2012).

A crescente preocupação com a saúde e o interesse no bem estar físico são as principais razões para o aumento do consumo de alimentos que garantem benefícios à saúde. Nos últimos anos, o alimento não é visto apenas como um veículo de nutrientes essenciais para assegurar o crescimento e o bom desenvolvimento do organismo, mas como uma via para melhorar o bem estar e a saúde (HASLER; BROWN, 2009).

A indústria láctea é amplamente favorecida para o desenvolvimento de alimentos funcionais do tipo probióticos, prebióticos e simbióticos, uma vez que esses ingredientes se adaptam bem às bases lácteas e essas por sua vez, são largamente aceitas pelo mercado consumidor (ALVES et al., 2013; CRUZ et al., 2009).

O sorvete, alimento de alto valor nutricional, é uma opção promissora para o desenvolvimento de produto funcional, pois sabe-se que a incorporação de microrganismos probióticos e inulina nesta matriz não afeta a qualidade global do produto, e, além de ser amplamente consumido por várias faixas etárias, corresponde às expectativas da procura por produtos saudáveis e saborosos ao paladar (SOUZA et al., 2010).

Assim como os probióticos, a administração de ingredientes prebióticos na alimentação, como a inulina, pode resultar em efeitos benéficos à saúde, como mudanças positivas significativas na microbiota intestinal humana (BRUZZESE et al., 2006; RAMIREZ-FARIAS et al., 2009), uma vez que esses ingredientes não são hidrolisados e nem absorvidos no trato gastrintestinal superior humano. Assim, são capazes de estimular seletivamente a multiplicação de bactérias benéficas no cólon (MATTILA-SANDHOLM et al., 2002), têm potencial para reprimir patógenos e limitar a virulência dos mesmos por imunoestimulação, promovendo 
resistência à colonização por microrganismos patogênicos, melhorando assim, a imunidade de quem consome essas substâncias (HAULY; MOSCATTO, 2002; SAAD, 2006).

O leite e seus derivados têm sido testados como alimentos funcionais e tem despertado grande interesse por parte da indústria de laticínios, com destaque para o soro obtido como um subproduto da produção de queijo, que vem sendo apontado como alimento funcional com vários benefícios à saúde (TAVARES; MALCATA, 2016). Na indústria de laticínios, o soro, que é gerado após o processo de coagulação da caseína, é um subproduto descartado na maioria das vezes. Para reduzir os danos ambientais causados pelo descarte deste material, muitas indústrias têm desenvolvido produtos baseados na utilização do soro de leite (BALDISSERA et al., 2011).

Em virtude do desejo por alternativas vegetarianas e da intolerância a produtos lácteos, a demanda mundial por produtos não derivados do leite está crescendo (FARNWORTH et al., 2007; PRADO et al., 2008; RIVERA-ESPINOZA; GALLARDO-NAVARRO, 2010). Nesse contexto, a soja aparece como um substituto ideal para o consumo, com características nutricionais intrínsecas favoráveis à saúde do consumidor. Na composição da soja encontramse em majoritário nutrientes como proteínas, lipídios e carboidratos. A soja também é importante fonte de outros compostos, tais como fibras, oligossacarídeos (rafinose e estaquiose), vitaminas e minerais, como o cálcio (ROSSI et al., 2011).

Portanto o objetivo deste trabalho foi desenvolver um sorvete simbiótico com soro do leite e extrato de soja em diferentes proporções para assim verificar a influência desses ingredientes na viabilidade dos probióticos e em suas características físico-químicas. A proporção utilizada para produção foi de $10 \%$ de soro do leite e extrato de soja acrescentado na formulação do sorvete natural.

\section{Material e Métodos}

As análises físico-químicas foram realizadas no Laboratório de Análises Físicoquímicas de Alimentos do CCHSA UFPB Campus III. Para análise físico-química foram determinados soídos solúveis totais usando um refratômetro ABBE, gordura (SOXHLET), lactose (LANE-EYNON) e acidez (titulação) segundo Instituto Adolfo Lutz (IAL, 2008).

Para determinação do teor de sólidos solúveis totais - SST, foi utilizado um Becker de $100 \mathrm{~mL}$ e bastão de vidro e refratômetro de ABBE (Figura 1). O procedimento aconteceu da seguinte forma: foram pesados $5.0088 \mathrm{~g}$ da amostra, depois o refratômetro foi aferido com água destilada colocando algumas gotas no prisma e logo a seguir feita a leitura, zerando o refratômetro. Depois de secar o prisma com algodão e acrescentar um pouco da amostra foi 
feita a leitura novamente, realizando 4 repetições, até padronizar, por Instituto Adolfo Lutz (IAL, 2008).

Para determinação de gordura pelo método de Soxhlet - foi utilizado um extrator de Soxhlet de $125 \mathrm{~mL}$, balão de Soxhlet de $125 \mathrm{~mL}$, balão de Soxhlet, condensador de refluxo, bateria de aquecimento, estufa a $105^{\circ} \mathrm{C}$, balança analítica, dessecador, pinça metálica, cartucho de Soxhlet, éter de petróleo. O procedimento aconteceu da seguinte forma: balão de Soxhlet foi previamente aquecido em estufa a $105{ }^{\circ} \mathrm{C}$ por 1 (uma) hora, e esfriado em dessecador durante 30 minutos e então pesado em balança analítica. Foram pesadas aproximadamente $5 \mathrm{~g}$ da amostra em uma balança analítica diretamente no cartucho de Soxhlet. O cartucho foi colocado com a amostra no extrator de Soxhlet. Depois o balão de Soxhlet foi acoplado ao extrator e adicionados $80 \mathrm{~mL}$ (balões de $125 \mathrm{~mL}$ ) éter de petróleo, e logo a seguir, levado o conjunto para a bateria de aquecimento onde foi acoplado ao condensador de refluxo. A água de refrigeração e a bateria de aquecimento foram ligadas e procedida a extração dos lipídeos por aproximadamente 6 (seis) horas. Após as 6 (seis) horas, houve a recuperação do solvente hexano, e o balão de Soxhlet foi levado com os lipídeos para uma estufa a $105^{\circ} \mathrm{C}$ durante 2 (duas) horas. Passadas as 2 (duas) horas, o balão de Soxhlet foi retirado da estufa e colocado em um dessecador durante 30 minutos. Após os 30 minutos, o balão de Soxhlet foi retirado do dessecador e pesado em uma balança analítica, por Instituto Adolfo Lutz (IAL, 2008).

Figura 1. Refratômetro utilizado para realização da análise físico-química dos sorvetes

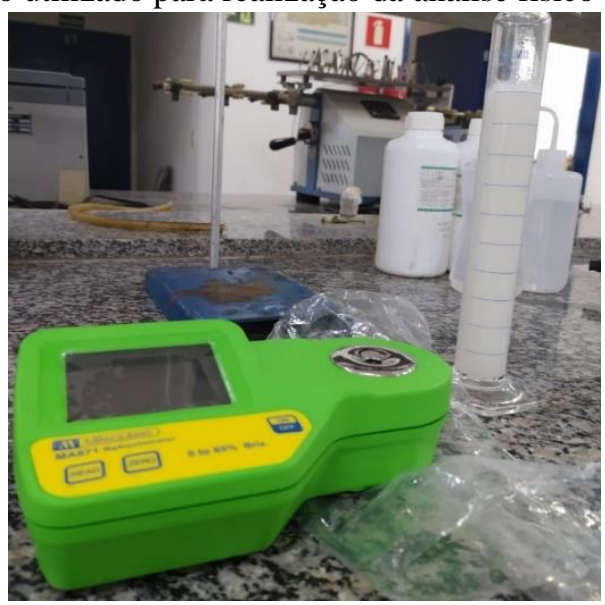

Fonte: Própria (2020).

Para determinação de glicídios redutores em lactose - aconteceu da seguinte forma: com auxílio de uma pipeta volumétrica foram transferidos $10 \mathrm{~mL}$ da amostra de sorvete simbiótico para balões volumétricos de $250 \mathrm{~mL}$, adicionados em cada balão $10 \mathrm{~mL}$ de água, 
$5 \mathrm{~mL}$ da solução de sulfato de zinco a $30 \%$ e $5 \mathrm{~mL}$ da solução de ferrocianeto de potássio a 15\%, após cada adição houve homogeneização. Depois ficou a sedimentar durante 5 minutos, o volume foi completado com água e o balão agitado para homogeneizar. Após homogeneização a amostra foi filtrada de forma límpida, em um frasco de Erlenmeyer de 300 $\mathrm{mL}$. Para um balão de fundo chato de $300 \mathrm{~mL}$, foram transferidos $10 \mathrm{~mL}$ de cada uma das soluções de Fehling nomeadas acima (Figura 2) e adicionados $40 \mathrm{~mL}$ de água. O balão foi aquecido até a ebulição em chapa aquecedora. O filtrado foi transferido para uma bureta de 25 mL e adicionado, às gotas, sobre a solução do balão em ebulição, agitando sempre, utilizando uma garra, até que esta solução mudasse de coloração azul à incolor (no fundo do balão ficou um resíduo vermelho-tijolo), por Instituto Adolfo Lutz (IAL, 2008).

Figura 2. Análise físico-química realizada, solução de Fehling

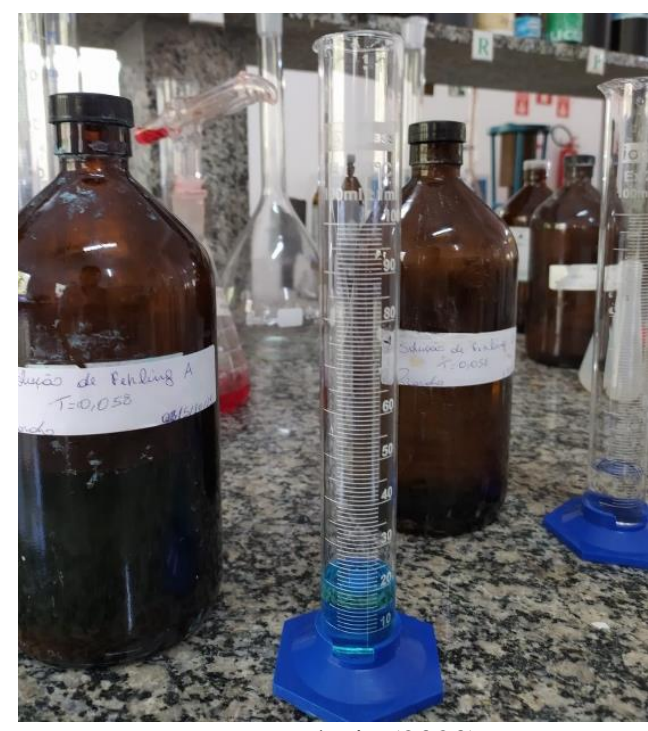

Fonte: Própria (2020).

Para determinação de acidez - aconteceu da seguinte forma: foram pesados em um Erlenmeyer de $250 \mathrm{~mL}$, aproximadamente $5 \mathrm{~g}$ da amostra, conforme, com auxílio de uma balança analítica e adicionados em cada Erlenmeyer $50 \mathrm{~mL}$ de água destilada com o auxílio de uma proveta. Os Erlenmeyer foram agitados para uma perfeita homogeneização e acrescentados 3 a 5 gotas do indicador fenolftaleína a $1 \%$. As amostras foram tituladas com uma solução de $\mathrm{NaOH}$ a $0,1 \mathrm{~N}$ previamente padronizada até a viragem da solução do incolor para a cor róseo claro, por Instituto Adolfo Lutz (IAL, 2008).

O soro de leite, microrganismos probiótico e extrato de soja foram adquiridos do Laboratório Pesquisa e Desenvolvimento de Produtos Laticínios (PDLAT/UFPB) da Universidade Federal da Paraíba Campus III, Bananeiras-PB (UFPB III). Foram elaboradas três formulações de sorvetes com $10 \%, 15 \%$ e $20 \%$ de extratos soja. 
As análises físico-químicas foram realizadas no Laboratório de Análises Físicoquímicas de Alimentos do CCHSA UFPB Campus III. Para análise físico-química foram determinados soídos solúveis totais usando um refratômetro ABBE, gordura (SOXHLET), lactose (LANE-EYNON) e acidez (titulação) segundo Instituto Adolfo Lutz (IAL, 2008).

\section{Resultados e Discussão}

Os resultados das análises físico-químicas, encontram-se na Tabela 1. Os resultados mostraram valores diferentes para os diferentes tratamentos com exceção do teor de sólidos solúveis ( ${ }^{\circ}$ Brix), que correspondem a 1,20 em todos os tratamentos.

Em sorvetes formulados com leite, teores de sólidos solúveis podem variar (SOUSA, 2013). Outro ponto importante que deve-se levar em conta é que o produto em análise não foi adicionado de nenhuma fruta, e isto pode ter influenciado também em um teor de sólidos solúveis tão baixo.

Romano (2012), analisando o teor de sólidos solúveis em iogurte simbiótico obteve um percentual de até 1,94 , o mesmo relata que não houve diferença significativa entre as demais formulações.

Tabela 1. Resultado da análise físico-química dos sorvetes

\begin{tabular}{cccc}
\hline & \multicolumn{3}{c}{ Amostras } \\
\cline { 2 - 4 } Componentes & $\mathrm{T} 1$ & $\mathrm{~T} 2$ & $\mathrm{~T} 3$ \\
\hline ' $\mathrm{Brix}$ & 1,20 & 1,20 & 1,20 \\
Gordura $(\%)$ & 40,03 & 42,72 & 52,33 \\
Lactose (\%) & 0,0055 & 0,0063 & 0,0068 \\
Acidez (\%) & 1,78 & 1,19 & 1,22 \\
\hline & T1 com $10 \%, \mathrm{~T} 2$ com $15 \%$ e T3 com $20 \%$ de extrato de soja.
\end{tabular}

Com relação aos resultados de gordura, as amostras diferiram entre si, podemos observar que a formulação 3, corresponde ao maior percentual de gordura 52, 33\%, e as demais formulações 1 e 2 os valores respectivamente são de 40,03\% e 42,72\% apresenta-se com menor quantidade de gordura. Essa diferença entre os valores em cada formulação, se dá pela quantidade de extrato adicionado. Onde por ser um extrato tem teor reduzido de gordura, além de ser uma grande fonte de proteínas, e vitaminas do complexo B (SILVA, 2008).

Foram encontrados resultados inferiores ao do presente trabalho, Bertolo (2014) ao avaliar sorvete à base de soja com adição de yacon, onde relata que o percentual de gordura encontrado foi de $12,29 \%$. 
Oliveira (2019), relatou teores de proteína divergentes em suas formulações de $2,95 \%$ e de 3,96\%, entretanto não houve diferença significativa no teor de proteínas, logo segue a linha de outros sorvetes a base de fruta.

O percentual de lactose foi um dos mais baixos encontrado, onde respectivamente foi obtido 0,0055 para tratamento $1 ; 0,0063$ para tratamento 2 e 0,0068 para o tratamento 3 ou seja a quantidade de açúcar neste sorvete é muito pequena quando comparada com outros autores.

Guedes, em sua pesquisa concluiu que, em sorvetes com baixo teor de lactose, ou com adição parcial de polpa de fruta tem boa aceitação, onde as mesmas correspondem a 35\% da intenção de compra.

Além disso com a baixa quantidade de lactose no produto, aumenta-se o interesse de consumidores por esta classe de alimentos. (MIGUEL, 2009).

A acidez variou entre $1,78 \%$ e 1,22\% o baixo valor já era esperado devido a composição do produto. A produção de ácido láctico, acetaldeído e diacetil pela fermentação láctica, modificam as características sensoriais de produtos à base de extrato de soja (FERNÁNDEZ, 2015).

Resultados superiores aos encontrados no presente trabalho foram reportados por Fernández (2015), que estudou o desenvolvimento de sorvetes probióticos à base de extrato solúvel de soja é obteve resultados de pH entre 4,37 e 4,72.

Miguel (2009), desenvolveu sorvete simbiótico à base de extrato aquoso de soja e de yacon onde constatou que na formulação de sorvete desenvolvido com 100\% de extrato de soja o pH estabelecido foi de 6.2.

\section{Conclusões}

O soro do leite pode ser uma opção barata para cultivos probióticos, e a fermentação do extrato hidrossolúvel de soja por bactérias láticas e probióticas promove as características sensoriais da bebida e confere benefícios fisiológicos ao organismo. Sendo assim, os microrganismos probióticos na formulação do sorvete simbiótico demostram que o sorvete pode ser um alimento funcional.

O sorvete simbiótico com soro do leite e extrato de soja, é uma boa alternativa para quem procura uma alimentação mais saudável. Os resultados deste trabalho podem contribuir para o desenvolvimento de novos produtos para a indústria alimentícia.

\section{Referências}

AHMAD, N.; LI, L.; YANG, X.-Q.; NING, Z.-X.; RANDHAWA, M.A. Improvements in the 
flavour of soy cheese. Food Technology and Biotechnology, v.46, n.3, p.252-261, 2008.

ANEKELLA, K.; ORSAT, V. Optimization of microencapsulation of probiotics in raspberry juice by spray drying. LWT - Food Science and Technology, v.50, n.1, p.17-24, 2013.

AGÊNCIA NACIONAL DE VIGILÂNCIA SANITÁRIA. Resolução RDC n.266, de 22 de setembro de 2005. Aprova o regulamento técnico para gelados comestíveis e preparados para geladoscomestíveis.Disponívelem:http://portal.anvisa.gov.br/wps/wcm/connect/f5d552004a9 bdc469832dc4600696f00/Resolucao_RDC_n_266_de_22_de_setembro_de_2005.pdf?MOD= AJPERES. Acesso em: 10 mai. 2020.

AGÊNCIA NACIONAL DE VIGILÂNCIA SANITÁRIA. Alimentos. Alimentos com alegações de propriedades funcionais e ou de saúde, novos alimentos/ingredientes, substâncias bioativas e probióticos. Brasília, 2008. Disponível em: http://www.anvisa.gov.br/alimentos/comissoes/tecno_lista_alega.htm. Acesso em: 16 mai. 2020.

ALVES, L.L. et al. Cream cheese as a symbiotic food carrier using Bifidobacterium animalis Bb-12 and Lactobacillus acidophilus La-5 and inulin. International Journal of Dairy Technology, v. 66, n. 1, p. 63-69, feb. 2013.

BALDISSERA, A.C.N.; DELLA BETTA, F.; PENNA, A.L.B.; LINDNER, J.D.D. Alimentos funcionais: uma nova fronteira para o desenvolvimento de bebidas proteicas à base de soro de leite. Semina: Ciências Agrárias, v.32, p.1497-1512, 2011.

BERTOLO, A.P. Sorvete a base de soja com enriquecimento nutricional pela adição de batata yacon. Orientado: Ernesto Quast 2014. 85 f. Trabalho de Conclusão de Curso (Bacharel em Engenharia de Alimentos) - Universidade Federal da Fronteira Sul, Laranjeiras do Sul.

BAŞYIĞIT, G.; KULEAŞAN, H.; KARAHAN, A.G. Viability of human-derived probiotic lactobacilli in ice cream produced with sucrose and aspartame. Journal of Industrial Microbiology \& Biotechnology, v. 33, n. 9, p. 796-800, sep., 2006.

BEDANI, R.; ROSSI, E.A.; SAAD, S.M.I. Impact of inulin and okara on Lactobacillus acidophilus La-5 and Bifidobacterium animalis Bb-12 viability in a fermented soy product and probiotic survival under in vitro simulated gastrointestinal conditions. Food Microbiology, v.34, n.2, p.382-389, 2013.

BEHRENS, J.H.; SILVA, M.A.A.P. Atitude do consumidor em relação à soja e produtos derivados. Ciência e Tecnologia de Alimentos, v.24, n.3, p.431-439, 2004.

BRUZZESE, E. et al. Impact of prebiotics on human health. Digestive and Liver Disease, v. 38, n. 2, p. 283-287, dec., 2006. 
CODRON, J.-M.; GRUNERT, K.; GIRAUD-HERAUD, E.; SOLER, L.-G.; REGMI, A. Retail sector responses to changing consumer preferences. In: REGMI, A.; GEHLHAR, M., eds. New directions in global food markets. Washington: United States. Departament of Agriculture, 2005.cap.3, p.32-46. (Agriculture Information Bulletin, n.794).

\section{COMPANHIANACIONALDEABASTECIMENTO.AcompanhamentodasafraBrasileira:g}

rãos - safra 2014/2015 - Quarto Levantamento: Janeiro/2015. Brasília: CONAB,2015.90p.Disponívelemhttp://www.conab.gov.br/OlalaCMS/uploads/arquivos/15_0 1_09_09_00_21_boletim_graos_j aneiro_2015.pdf. Acesso em: 13 mai. 2020.

FARNWORTH, E.R.; MAINVILLE, I.; DESJARDINS, M.-P.; GARDNER, N.; FLISS, I.; CHAMPAGNE, C. Growth of probiotic bacteria and bifidobacteria in a soy yogurt formulation. International Journal of Food Microbiology, v.116, n.1, p.174-181, 2007.

FOOKS, L.J.; FULLER, R.; GIBSON, G.R. Prebiotics, probiotics and human gut microbiology. International Dairy Journal, v.9, n.1, p.53-61, 1999.

FERNÁNDEZ, L.C. Desenvolvimento de sorvetes probióticos a base de extrato solúvel de soja. Orientador: Ismael Maciel de Mancilha. 2015. 89 f. Dissertação (Mestrado em Microbiologia Aplicada) - Universidade de São Paulo, Lorena.

GEISER, M. The wonders of whey protein. NSCA's Performance Training Journal, v.2, n.5, p.13-15, 2003.

GUEDES, S.M.; BEZERRA, J, J.M.V.; TEIXEIRA, A.M.; RIGO, M. Avaliação sensorial e físico-química de sorvete com baixo teor de lactose e adição de polpa de abacaxi (Ananas comosus L. Merril). Revista Unicentro, v.14, n.1, p.01-08, Guarapuava, 2018.

GIBSON, G.R. Fibre and effects on probiotics (the prebiotic concept). Clinical Nutrition Supplements, v. 1, p. 25-31, 2004.

GIBSON, G.R.; ROBERT, H.M.; VAN LOO, J.V.; RASTALL, R.A.; ROBERFROID, M.B. Dietary modulation of the human colonic microbiota: updating the concept of prebiotics. Nutrition Research Reviews, v.17, n.2, p.259-275, 2004.

HAMILTON-MILLER, J.M.T. Probiotics and prebiotics in the elderly. Postgraduate Medical Journal, v.80, n.946, p.447-451, 2004.

HASLER, C.M.; BROWN, A.C.; AMERICAN DIETETIC ASSOCIATION. Position of the American Dietetic Association: functional foods. Journal of the American Dietetic Association, v.109, n.4, p.735-746, 2009. 
HAULY, M.C. de O.; MOSCATTO, J.A. Inulina e oligofrutoses: uma revisão sobre propriedades funcionais, efeito prebiótico e importância na indústria de alimentos. Semina: Ciências Exatas e Tecnológicas, Londrina, v. 23, n. 1, p. 105-118, dez., 2002.

HEENAN, C.N.; ADAMS, M.C.; HOSKEN, R.W.; FLEET, G.H. Survival and sensory acceptability of probiotic microorganisms in a nonfermented frozen vegetarian dessert. LWT - Food Science and Technology, v.37, n.4, p.461-466, 2004.

HOMAYOUNI, A. et al. Effect of microencapsulation and resistant starch on the probiotic survival and sensory properties of synbiotic ice cream. Food Chemistry, v. 111, n. 1, p. 50-55, nov., 2008.

HOMAYOUNI, A. et al. Growth and survival of some probiotic strains in simulated ice cream conditions. Journal of Applied Sciences, v. 8, n. 2, p. 379-382, 2008.

HOMAYOUNI, A. et al. Factors influencing probiotic survival in ice cream: a review. International Journal of Dairy Science, v. 7, n. 1, p. 1-10, jan./mar., 2012.

INSTITUTO ADOLFO LUTZ. Métodos físico-químicos para análise de alimentos. $4^{\mathrm{a}}$ ed., $1^{a}$ ed. Digital, São Paulo, 2008. 1020p.

INSTITUTO ADOLFO LUTZ. Normas Analíticas do Instituto Adolfo Lutz. v. 1: Métodos químicos e físicos para análise de alimentos, 3. ed. São Paulo: IMESP, 1985, p. 206.

INSTITUTO ADOLFO LUTZ. Métodos físico-químicos para análise de alimentos. $4^{\mathrm{a}}$ ed., $1^{a}$ ed. Digital, São Paulo, 2008. 1020p.

INSTITUTO ADOLFO LUTZ. Métodos físico-químicos para análise de alimentos. $4^{\mathrm{a}}$ ed., $1^{\mathrm{a}}$ ed. Digital, São Paulo, 2008. 1020p.

KENT, R.M.; DOHERTY, S.B. Probiotic bacteria in infant formula and follow-up formula: microencapsulation using milk and pea proteins to improve microbiological quality. Food Research International, v.64, p.567-576, 2014. [Review].

KOMATSU, T.R.; BURITI, F.C.A.; SAAD, S.M.I. Inovação, persistência e criatividade superando barreiras no desenvolvimento de alimentos probióticos. Revista Brasileira de Ciências Farmacêuticas, v. 44, n. 3, p. 329-347, jul./set., 2008.

KUMAR, V.; RANI, A.; SOLANKI, S.; HUSSAIN, S.M. Influence of growing environment on the biochemical composition and physical characteristics of soybean seed. Journal of Food Composition and Analysis, v.19, n.2/3, p.188-195, 2006. 
LIONG, M.-T.; EASA, A.M.; LIM, P.-T.; KANG, J.-Y. Survival, growth characteristic and bioactive potential of Lactobacillus acidophilus in soy-based cream cheese. Journal of the Science of Food and Agriculture, v.89, n.8, p.1382-1391, 2009.

LIU, D.-M.; LI, L.; YANG, X.-Q.; LIANG, S.-Z.; WANG, J.-S.Survivability of Lactobacillus rhamnosus during the preparation of soy cheese. Food Technology and Biotechnology, v.44, n.3, p.417-422, 2006.

MARSHALL, R.T. Frozen Desserts In: MARTH, E. H.; STEELE, J. L. Applied Dairy Microbiology. 2rd. New York: Marcel Dekker, 2001. cap. 4. p. 93-125.

MIGUEL, D.P. Desenvolvimento de sorvete de "iogurte" simbiótico à base de extrato aquoso de soja e de yacon (Smallanthus sonchifolius) fermentado com Lactobacillus acidophilus CRL 1014. 118f. 2009. Tese (Doutorado em Alimentos e Nutrição) - Universidade Estadual "Júlio de Mesquita Filho", Araraquara.

MARTINEZ, R.C.; BEDANI, R. SAAD, S.M. Scientific evidence for health effects attributed to the consumption of probiotics and prebiotics: an update for current perspectives and future challenges. British Journal of Nutrition, v.15, 2015.

MATTILA-SANDHOLM, T. et al. Technological challenges for future probiotic foods. International Dairy Journal, v. 12, n. 2, p. 173-182, feb./mar., 2002.

MONTAGNER, G.E.; STORCK, C.R. Sorvete com extrato hidrossolúvel de arroz: análise físico-química e sensorial. Ciência e Tecnologia de Alimentos, v.15, Santa Maria, 2020.

NOUSIA, F.G.; ANDROULAKIS, P.I.; FLETOURIS, D.J. Survival of Lactobacillus acidophilus LMGP-21381 in probiotic ice cream and its influence on sensory acceptability. International Journal of Dairy Technology, v. 63, n. 1, p. 1-7, feb., 2011.

OLIVEIRA, B.C. Desenvolvimento e caracterização de sorvete enriquecido com licopeno. Orientadora: Maria Josiane Sereia. 2019. 56 f. Trabalho de Conclusão de Curso (Engenheiro de Alimentos) - Universidade Tecnológica Federal do Paraná, Campo Mourão.

PANDIYAN, C. et al. Effect of incorporation of inulin on the survivability of Lactobacillus acidophilus in synbiotic ice cream. International Food Research Journal, v. 19, n. 4, p. 1729$1732,2012$.

PINTOR, A.; SEVERIANO-PÉREZ, P.; TOTOSAUS, A. Optimization of fat-reduced ice cream formulation employing inulin as fat replacer via response surface methodology. Food Science and Technology International, v. 00, n. 0, p. 1-12, 2013.

ROBERFROID, M. B. Prebiotics and probiotics: are they functional foods?. The American Journal of Clinical Nutrition, v. 71, n. 1, p. 1682-1687, 2000. 
ROMANO, C. C. Influência da inulina nas características químicas, sensoriais e sobrevivência do L. acidofilus em frozen yogurt simbiótico com teor reduzido de lactose. 2012. 32 f. Trabalho de Conclusão de Curso (Tecnologia de Alimentos) - Universidade Tecnológica do Paraná, Campo Mourão.

ROBERFROID, M.B. General introduction: prebiotics in nutrition. In: GIBSON, G.R.; ROBERFROID, M.B., ed. Handbook of prebiotics. Boca Raton: CRC, 2008a. p.1- 11.

ROSSI, E.A.; CAVALLINI, D.C.U.; MANZONI, M.S.J.; ROSSI, P.R. Produtos probióticos e prebióticos à base de soja. In: SAAD, S.M.I.; CRUZ, A.G.; FARIA, J.A.F., eds. Probióticos e prebióticos em alimentos: fundamentos e aplicações tecnológicas. São Paulo: Varela, 2011. cap.22, p.541-563.

SAAD, S.M.I. Probióticos e prebióticos: o estado da arte. Revista Brasileira de Ciências Farmacêuticas, v. 42, n. 1, p. 1-16, jan./mar., 2006.

SÁNCHEZ, B.; REYES-GAVILÁN, C.G.; MARGOLLES, A.; GUEIMONDE, M. Probiotic fermented milks: present and future. International Journal of Dairy Technology, v.62, n.4, p.472-483, 2009.

SOUZA, J. C. B. et al. Sorvete: composição, processamento e viabilidade da adição de probiótico. Brazilian Journal of Food and Nutrition, v. 21, n. 1, p. 155-165, jan./mar., 2010.

SOUSA, G. L. Desenvolvimento de sorvete simbiótico de graviola (Annona muricara L.) com teor reduzido de gordura e avaliação da resistência gastrointestinal dos probióticos in vitro. 2013. $154 \mathrm{f}$. Tese (Doutorado em Tecnologia de Alimentos) - Universidade de São Paulo, São Paulo.

GOFF, H.D.; HARTEL, R.W. Ice Cream. New York: Springer US, 2013. 462p.

SOUZA, J. C. B. et al. Sorvete: composição, processamento e viabilidade da adição de probiótico. Brazilian Journal of Food and Nutrition, v. 21, n. 1, p. 155-165, jan./mar., 2010.

SILVA, D.T. Extrato de soja: características, métodos de obtenção e compostos benéficos a saúde humana. Orientador: Valdecir Carlos Ferri. 2008. 34 f. Trabalho de Conclusão de Curso (Bacharelado em Química) - Universidade Federal de Pelotas, Pelotas, 2008.

SU, P.; HENRIKSSON, A.; MITCHELL, H. Prebiotics enhance survival and prolong the retention period of specific probiotic inocula in an in vivo murine model. Journal of Applied Microbiology, v.103, n.6, p.2392-2400, 2007.

TAVARES, T.; MALCATA, F.X. Whey and Whey Powders: Protein Concentrates and Fractions. In: CABALLERO, B.; FINGLAS, P.M.; TOLDRÁ, F., eds. Encyclopedia of Food and Health. Oxford: Academic Press, 2016. 
TRIPATHI, M.K.; GIRI, S.K. Probiotic functional foods: survival of probiotics during processing and storage. Journal of Functional Foods, v.9, p.225-241, 2014.

USDEC. Reference manual for US whey and lactose products. Arlington, VA: US Dairy ExportCouncil.2006.

Disponívelem:http://usdec.files.cmsplus.com/PDFs/2008ReferenceManuals/Whey_Lactose_R eference_Manual_Complete2_Opti mized.pdf. Acesso em: 03 jun. 2020.

VARGAS, L. A.; OLSON, D. W.; ARYANA, K. J. Whey protein isolate improves acid and bile tolerances of Streptococcus thermophilus ST-M5 and Lactobacillus delbrueckii ssp. bulgaricus LB-12. Journal of Dairy Science, v.98, n.4, p.2215-2221, 2015.

VIEIRA, A.F.; ROCHA, A.P.T.; SANTOS, D.C.; MORAIS, H.M.B.R.; ALMEIDA, R.D.; SILVA, S.N. Aceitabilidade e caracterização física e físico-química de doce tipo doce de leite produzido com extrato hidrossolúvel de soja. Revista Principia, n.42, João Pessoa, 2018.

WEI, Q.-K.; CHEN, T.-R.; CHEN, J.-T. Using of Lactobacillus and Bifidobacterium to product the isoflavone aglycones in fermented soymilk. International Journal of Food Microbiology, v.117, n.1, p.120-124, 2007. 


\title{
CAPÍTULO 05: FORMULAÇÕES DE GELEIAS DE RAPADURA E MELADO DE CANA-DE-AÇÚCAR: CARACTERIZAÇÃO FÍSICO-QUÍMICA E SENSORIAL
}

\section{CHAPTER 05: FORMULATIONS OF RAPADURA JAMES AND SUGAR CANE HONEY: PHYSICAL-CHEMICAL AND SENSORIAL CHARACTERIZATION}

\author{
Erika de Sousa Dias ${ }^{1}$; Emanuel Neto Alves de Oliveira ${ }^{2}$; Wisla Kívia de Araújo Soares ${ }^{3}$; Bruno \\ Fonsêca Feitosa ${ }^{4}$; Edilayane da Nóbrega Santos ${ }^{5}$
}

\begin{abstract}
Resumo
O beneficiamento da cana-de-açúcar através dos seus derivados possui alta aceitabilidade comercial, podendo serem utilizados na elaboração de novos produtos com apelo regional. Assim, objetivou-se desenvolver formulações de geleias de rapadura e melado de cana-deaçúcar, bem como analisar as características físico-químicas e sensoriais. As geleias foram desenvolvidas através de testes preliminares, sendo avaliados os parâmetros físico-químicos, aceitação sensorial de atributos, Índice de Aceitabilidade e intenção de compra. Os resultados foram analisados através de Análise de Variância, em Delineamento Inteiramente Casualizado, sendo as médias comparadas pelo teste de Tukey, a nível de 5\% de significância. O teor de água da geleia de rapadura $(30,49 \%)$ foi inferior ao da geleia de melado $(38,61 \%)$. A geleia de melado foi caracterizada com pH ácido $(3,51)$ e maior sensação de doçura. Ambos os produtos estão menos susceptíveis a multiplicação de microrganismos, devido aos baixos valores de atividade de água. Houveram diferenças significativas entre as geleias nos atributos sensoriais aparência, consistência, espalhabilidade e impressão global. Infere-se que as formulações foram validadas, evidenciando produtos inovadores e com expressivo apelo regional. Ambas as formulações foram bem aceitas sensorialmente, com índice de aceitabilidade acima de $70 \%$ em todos os atributos, destacando-se a geleia de melado de cana-de-açúcar.
\end{abstract}

Palavras-Chaves: Aceitabilidade, Novos produtos, Saccharum officinarum.

\begin{abstract}

\footnotetext{
1 Técnica em Alimentos, IFRN, erika_souza9@ hotmail.com

${ }^{2}$ Docente da área de Tecnologia de Alimentos, IFRN, emanuel.oliveira16@gmail.com

${ }^{3}$ Engenharia de Alimentos, CCTA/UFCG, wisla-kivia@ hotmail.com

${ }^{4}$ Engenharia de Alimentos, CCTA/UFCG, brunofonsecafeitosa@live.com

${ }^{5}$ Engenharia de Alimentos, CCTA/UFCG, layane.nobrega@hotmail.com
}

The processing of sugarcane through its derivatives has a high commercial acceptability and can be used in the development of new products with regional appeal. Thus, the objective was to develop formulations of rapadura jellies and sugarcane molasses, as well as to analyze the physical-chemical and sensory characteristics. The jellies were developed through preliminary tests, being evaluated the physical-chemical parameters, sensory acceptance of attributes, Acceptability Index and purchase intention. The results were analyzed using Analysis of Variance, in a Completely Randomized Design, and the means were compared by the Tukey test, at the level of $5 \%$ of significance. The water content of rapadura jelly (30.49\%) was lower than that of molasses jelly (38.61\%). The molasses jelly was characterized with an acidic $\mathrm{pH}$ (3.51) and a greater sensation of sweetness. Both products are less susceptible to the multiplication of microorganisms, due to the low values of water activity. There were significant differences between the jellies in the sensory attributes of appearance, consistency, spreadability and overall impression. It is inferred that the formulations were validated, showing innovative products and expressive regional appeal. Both formulations were well accepted sensorially, with an acceptability index above $70 \%$ in all attributes, especially sugar cane 
DIAS, E. S. et al.

molasses jelly.

Keywords: Acceptability, New products, Saccharum officinarum.

\section{Introdução}

A produção de cana-de-açúcar (Saccharum officinarum) no Brasil iniciou a partir do período colonial, sendo trazida pelos colonizadores, que impulsionaram a formação dos primeiros engenhos no país. O clima ofereceu condições favoráveis para o desenvolvimento da planta, além de terem sido comercializadas as primeiras mudas (DELGADO et al., 2016; SANTOS; BORÉM, 2016). Na safra de 2018/19, a produção de cana-de-açúcar no Brasil atingiu 620,44 milhões de toneladas (CONAB, 2019), destacando-se a importância para o agronegócio, principalmente, na região Nordeste (DÍAZ; QUINONEZ, 2017).

Através do beneficiamento da cana-de-açúcar, obtém-se o melado e a rapadura, que são produtos com alta aceitabilidade comercial e de fácil produção (SEBRAE, 2014). Comumente, tornaram-se fontes de geração de renda e empregos para o homem do campo, sendo fabricados artesanalmente em engenhos (DELGADO et al., 2016), com matéria-prima não fermentada, isenta de matéria terrosa, parasitos, detritos animais e vegetais. Esses produtos devem ser isentos de qualquer adição de essências, corantes naturais ou artificiais, conservadores e edulcorantes (BRASIL, 1978).

A rapadura é obtida a partir da concentração do caldo-de-cana quente, caracterizada por ser de massa dura, cor âmbar castanha, aroma e sabor específicos (AZEVÊDO et al., 2015; DÍAZ; QUINONEZ, 2017; JERONIMO, 2018). O fácil acesso e alto valor nutricional da rapadura elevam o consumo majoritariamente no sertão nordestino (BATISTA et al, 2019), posto que o desenvolvimento de novas apresentações é uma estratégia para promover esse consumo (AZEVÊDO et al. 2015). De acordo com a Tabela Brasileira de Composição de Alimentos (TACO), para cada $100 \mathrm{~g}$ de rapadura há $368 \mathrm{Kcal}$ de valor energético, 0,67 g de proteínas, $90 \mathrm{~g}$ de carboidratos, 0,63 g de lipídeos e não apresenta fibra alimentar e colesterol (TACO, 2020).

O melado é obtido a partir do caldo-de-cana ou até mesmo da rapadura, através de processos tecnológicos, que diferem pelo tempo de cozimento. Trata-se do primeiro produto a ser formado, passando aproximadamente 3 horas sob aquecimento (RADDATTZ et al, 2015). De acordo com a TACO, para cada $100 \mathrm{~g}$ de rapadura há $306 \mathrm{Kcal}$ de valor energético, 76,6 g de carboidratos e não apresenta proteínas, lipídeos, fibra alimentar e colesterol (TACO, 2020). Assim como os demais derivados da cana-de-açúcar, a rapadura e o melado são comumente 
utilizados como adoçante, consumidos in natura (VICENTINI-POLETTE, 2019) ou podem ser submetidos a processos tecnológicos para a produção de doces e geleias.

A Agência Nacional de Vigilância Sanitária (ANVISA) define geleia de fruta como "o produto obtido pela cocção, de frutas, inteiras ou em pedaços, polpa ou suco de frutas, com açúcar e água e concentrado até consistência gelatinosa" (BRASIL, 1978; 2005). Tendo em vista a elaboração de novos produtos com o apelo regional, objetivou-se com esta pesquisa desenvolver formulações de geleias de rapadura e melado de cana-de-açúcar, bem como analisar as características físico-químicas e sensoriais.

\section{Material e Métodos}

A pesquisa foi desenvolvida no Instituto Federal de Educação, Ciência e Tecnologia do Rio Grande do Norte, campus Pau dos Ferros, localizado no Alto Oeste Potiguar, Rio Grande do Norte, Brasil. As matérias-primas foram adquiridas no comércio local da cidade de Pau dos Ferros-RN.

Através de testes preliminares, as geleias foram elaboradas no Laboratório da Unidade Industrial Escola do referido campus, conforme as formulações apresentadas na Tabela 1.

Tabela 1. Formulações das geleias de rapadura e melado de cana-de-açúcar

\begin{tabular}{ccccc}
\hline & \multicolumn{4}{c}{ Formulações } \\
\cline { 2 - 5 } Ingredientes & \multicolumn{2}{c}{ Geleia de rapadura } & \multicolumn{2}{c}{ Geleia de melado } \\
\cline { 2 - 5 } & $\mathrm{g}$ & 30,5 & $\mathrm{~g}$ & $\%$ \\
\hline Rapadura & 2500 & - & 2500 & 30,5 \\
Melado & - & 48,8 & 4000 & 48,8 \\
Água & 4000 & 12,2 & 1000 & 12,2 \\
Sacarose & 1000 & 8,5 & 70 & 8,5 \\
\hline Pectina de ATM* & 70 & & & - \\
\hline
\end{tabular}

*ATM - Alto Teor de Metoxilação.

Fonte: Própria (2020).

Inicialmente, a rapadura foi submetida ao processo de raspagem com facas de aço inoxidável para facilitar a posterior homogeneização com os demais ingredientes. A pectina de Alto Teor de Metoxilação (ATM) e a sacarose foram misturados em panela de aço inoxidável e, respectivamente para cada formulação, acrescentou-se a rapadura ou o melado de cana-deaçúcar e os demais ingredientes manualmente.

As misturas foram submetidas ao aquecimento até atingirem teores de sólidos solúveis totais mínimos de $65^{\circ}$ Brix para a geleia de rapadura e de $55^{\circ}$ Brix para a geleia de melado de cana-de-açúcar. Então, o aquecimento foi interrompido e as geleias, ainda quentes, foram envasadas em potes de vidro de $200 \mathrm{~mL}$ com tampas metálicas, sendo posteriormente invertidos 
por 5 segundos, a fim de promover o tratamento térmico da tampa e evitar o desenvolvimento de microrganismos. Em seguida, as geleias foram resfriadas, através de imersão em água a temperatura ambiente, e armazenadas em prateleiras nessa mesma condição de temperatura.

As análises físico-químicas foram realizadas no Laboratório de Análise Físico-Química de Alimentos do referido campus. As geleias foram analisadas, em triplicata, quanto aos parâmetros:

- Teor de água (\%) e sólidos totais (\%): Secagem em estufa, a $105^{\circ} \mathrm{C} / 24 \mathrm{~h}$, segundo normas do Instituto Adolfo Lutz (IAL, 2008);

- Cinzas (\%): Incineração em forno mufla, a $550^{\circ} \mathrm{C} / 6 \mathrm{~h}$, segundo normas do Instituto Adolfo Lutz (IAL, 2008);

- $\quad$ pH: Método potenciométrico, através de pHmetro digital, calibrado com soluções tampão pH 4,0 e 7,0, segundo normas do Instituto Adolfo Lutz (IAL, 2008);

- Acidez total titulável (\%): Método titulometria, com neutralização dos ácidos, utilizando solução de Hidróxido de Sódio $(\mathrm{NaOH})$ a $0,1 \mathrm{~N}$ e indicador fenolftaleína a $1 \%$, segundo normas do Instituto Adolfo Lutz (IAL, 2008);

- Sólidos solúveis totais ( ${ }^{\circ}$ Brix): Determinada em refratômetro manual, segundo normas do Instituto Adolfo Lutz (IAL, 2008);

- Ratio: Calculado pela razão entre os sólidos solúveis totais e acidez total titulável;

- Açúcares totais e redutores (\%): Método de Lane-Eynon com solução de Fehling A e B, segundo normas do Instituto Adolfo Lutz (IAL, 2008);

- Açúcares não redutores (\%): Foi determinado pela diferença entre os açúcares totais e redutores, segundo normas do Instituto Adolfo Lutz (IAL, 2008);

- Atividade de água: Determinada em equipamento digital de bancada, segundo normas do Instituto Adolfo Lutz (IAL, 2008);

As análises sensoriais foram realizadas no Laboratório de Análise Sensorial de Alimentos do referido campus. Procedeu-se com 56 provadores não treinados, sendo aplicado teste de aceitação com base na metodologia descrita por Dutcosky (2013). Os provadores receberam uma amostra de cada formulação, um copo com água para a limpeza do palato e bolacha tipo água e sal para testar a espalhabilidade das geleias.

Para o teste de aceitação sensorial dos atributos cor, aparência, aroma, sabor, doçura, consistência, espalhabilidade e impressão global foi utilizada uma escala hedônica estruturada de 9 pontos: 1 - desgostei muitíssimo, 2 - desgostei muito, 3 - desgostei moderadamente, 4 desgostei ligeiramente, 5 - não gostei/ nem desgostei, 6 - gostei ligeiramente, 7 - gostei moderadamente, 8 - gostei muito e 9 - gostei muitíssimo (DUTCOSKY, 2013). 
Com os dados obtidos dos atributos sensoriais foi calculado o Índice de Aceitabilidade para cada atributo (Equação 1), de acordo com Gularte (2009).

$$
I A(\%)=\frac{M}{N} * 100
$$

Em que:

M - média do somatório dos resultados dos provadores;

$\mathrm{N}$ - número de pontos utilizados na escala de avaliação.

Também avaliada a intenção de compra das geleias, utilizando uma escala estruturada de 5 pontos: 1 - certamente não compraria, 2 - possivelmente não compraria, 3 - talvez compraria/ talvez não compraria, 4 - possivelmente compraria e 5 - certamente compraria (DUTCOSKY, 2013).

A pesquisa foi realizada em Delineamento Inteiramente Casualizado (DIC). Os resultados obtidos foram analisados com o auxílio do software Assistat versão 7.7 beta (SILVA; AZEVEDO, 2016), através de Análise de Variância (ANOVA). As médias foram comparadas pelo teste de Tukey, a nível de 5\% de significância $(\mathrm{p}<0,05)$.

\section{Resultados e Discussão}

$\mathrm{Na}$ Tabela 2 estão apresentados os resultados obtidos nas análises físico-químicas das geleias de rapadura e melado de cana-de-açúcar. Houveram diferenças significativas $(\mathrm{p}<0,05)$ entre as geleias para todos os parâmetros físico-químicos analisados.

Tabela 2. Resultados das análises físico-químicas das geleias de rapadura e melado de cana-de-açúcar

\begin{tabular}{ccc}
\hline Parâmetros & \multicolumn{2}{c}{ Formulações } \\
\cline { 2 - 3 } & Geleia de rapadura & Geleia de melado \\
\hline Teor de água (\%) & $30,49^{\mathrm{b}} \pm 0,15$ & $38,61^{\mathrm{a}} \pm 0,27$ \\
Sólidos totais (\%) & $69,51^{\mathrm{a}} \pm 0,15$ & $61,39^{\mathrm{b}} \pm 0,27$ \\
Cinzas (\%) & $0,77^{\mathrm{a}} \pm 0,03$ & $0,16^{\mathrm{b}} \pm 0,02$ \\
pH & $5,56^{\mathrm{a}} \pm 0,05$ & $3,51^{\mathrm{b}} \pm 0,12$ \\
Acidez total titulável $(\%)$ & $0,24^{\mathrm{a}} \pm 0,02$ & $0,16^{\mathrm{b}} \pm 0,02$ \\
Sólidos solúveis totais ( ${ }^{\circ}$ Brix) & $67,00^{\mathrm{a}} \pm 0,00$ & $58,00^{\mathrm{b}} \pm 0,00$ \\
Ratio & $246,73^{\mathrm{b}} \pm 17,05$ & $417,87^{\mathrm{a}} \pm 15,11$ \\
Açúcares totais $(\%)$ & $92,79^{\mathrm{a}} \pm 1,40$ & $87,08^{\mathrm{b}} \pm 1,25$ \\
Açúcares redutores $(\%)$ & $12,51^{\mathrm{b}} \pm 0,40$ & $63,23^{\mathrm{a}} \pm 0,24$ \\
Açúcares não redutores $(\%)$ & $76,26^{\mathrm{a}} \pm 1,23$ & $22,66^{\mathrm{b}} \pm 0,70$ \\
Atividade de água & $0,77^{\mathrm{b}} \pm 0,00$ & $0,82^{\mathrm{a}} \pm 0,00$
\end{tabular}

Médias seguidas na linha pela mesma letra não diferem significativamente entre si pelo teste de Tukey a 5\% de significância.

Fonte: Própria (2020). 
O teor de água da geleia de rapadura $(30,49 \%)$ foi inferior ao da geleia de melado $(38,61 \%)$, possivelmente devido a rapadura ser um alimento sólido e seco, com menos umidade em sua composição. Também observou-se na geleia de rapadura um maior teor de sólidos totais e cinzas.

Semelhante aos resultados desta pesquisa, Garcia et al. (2017) obtiveram teor de água de $35,31 \%$, ao avaliarem a geleia de buriti. Oliveira et al. (2018) obtiveram uma variação de 38,43 a $42,42 \%$ de teor de umidade, ao avaliarem as amostras convencionais de geleias de umbu-cajá.

Maia et al. (2014) obtiveram teor de cinzas de 0,36\%, ao avaliarem a geleia de tamarindo, estando inferior ao teor da geleia de rapadura e superior ao teor da geleia de melado, porque a rapadura é concentrada durante o processamento, tornando-se mais seca e com maior teor de sólidos.

Quanto ao parâmetro $\mathrm{pH}$, a geleia de melado apresentou o menor valor médio de 3,51, caracterizado com pH ácido, quando comparado com a geleia de rapadura $(5,56)$. A geleia de melado também apresentou valor de acidez total titulável inferior em relação a geleia de rapadura.

Observou-se que o resultados obtidos para a geleia de melado aproximou-se ao valor encontrado por Caetano et al. (2012), na produção de geleia de acerola a partir da polpa, com pH 3,48. Gomes et al. (2013), na produção de geleia de maracujá e cenoura, obtiveram um valor de acidez total titulável de $0,77 \%$, provavelmente devido a composição química do maracujá.

O teores de sólidos solúveis totais obtidos para os produtos foram de $67^{\circ}$ Brix (geleia de rapadura) e $58^{\circ}$ Brix (geleia de melado). Vale ressaltar que a legislação preconiza o mínimo de 62 e $65^{\circ}$ Brix para a geleia comum e extra, respectivamente, quando a geleia são elaboradas com vegetais (BRASIL, 1978; 2005). Oliveira et al. (2019), ao elaborarem geleias de achachairu adoçadas com açúcar cristal e mascavo, obtiveram os teores de 65,71 e $67,40{ }^{\circ}$ Brix, respectivamente.

A geleia de melado apresentou um valor médio de Ratio de 417,87, indicando o produto com maior sensação de doçura. Segundo Castro et al. (2015), a relação entre sólidos solúveis totais e acidez total titulável está relacionada a doçura. Oliveira et al. (2016), ao elaborarem e avaliarem a geleia de laranja e de laranja com hortelã, obtiveram média geral de Ratio de 157,73 .

A geleia de rapadura apresentou uma média para o teor de açúcares totais e não redutores de 92,79 e 76,26\%, respectivamente, estando superiores aos teores da geleia de melado. 
Segundo Azevêdo et al. (2015), a composição da rapadura possui predominantemente sacarose, um tipo de açúcar não redutor.

No entanto, no que diz respeito aos teores de açúcares redutores, observou-se resultados maiores na geleia de melado (63,23\%). É possível justificar esse fato, segundo Emídio (2016), devido ao melado de cana-de-açúcar apresentar na sua composição um valor igual ou superior a $30 \%$ de glicose, visando impedir a recristalização da sacarose.

A geleia de melado apresentou um maior valor de atividade de água em relação a geleia de rapadura. Porém, ambos os produtos estão menos susceptíveis a multiplicação de microrganismos, devido aos baixos valores de atividade de água obtidos. Conforme Barros et al. (2019), a atividade de água é proporcional a susceptibilidade do desenvolvimento de microrganismos. Teles et al. (2017) desenvolveram uma geleia comum de graviola com pimenta, utilizando $0,5 \%$ de pectina, e obtiveram o valor de 0,81 , estando semelhante a geleia de melado da presente pesquisa.

Na Tabela 3 e Figura 1 estão apresentados, respectivamente, os resultados obtidos nas análises de aceitação sensorial e Índice de Aceitabilidade (IA) para cada atributo das geleias de rapadura e melado de cana-de-açúcar. Houveram diferenças significativas $(p<0,05)$ entre as geleias nos atributos sensoriais de aparência, consistência, espalhabilidade e impressão global.

Tabela 3. Resultados das análises sensoriais das geleias de rapadura e melado de cana-de-açúcar

\begin{tabular}{ccc}
\hline Atributos & \multicolumn{3}{c}{ Formulações } \\
\cline { 2 - 3 } & Geleia de rapadura & Geleia de melado \\
\hline Cor & $7,98^{\mathrm{a}} \pm 0,84$ & $8,27^{\mathrm{a}} \pm 0,84$ \\
Aparência & $7,75^{\mathrm{b}} \pm 0,92$ & $8,21^{\mathrm{a}} \pm 0,97$ \\
Aroma & $7,38^{\mathrm{a}} \pm 1,33$ & $7,77^{\mathrm{a}} \pm 1,22$ \\
Sabor & $7,75^{\mathrm{a}} \pm 1,28$ & $7,88^{\mathrm{a}} \pm 1,25$ \\
Doçura & $7,61^{\mathrm{a}} \pm 1,15$ & $7,71^{\mathrm{a}} \pm 1,22$ \\
Consistência & $6,91^{\mathrm{b}} \pm 1,12$ & $7,88^{\mathrm{a}} \pm 1,10$ \\
Espalhabilidade & $7,39^{\mathrm{b}} \pm 1,33$ & $7,93^{\mathrm{a}} \pm 1,22$ \\
Impressão Global & $7,68^{\mathrm{b}} \pm 1,18$ & $8,07^{\mathrm{a}} \pm 0,99$ \\
\hline
\end{tabular}

Médias seguidas na linha pela mesma letra não diferem significativamente entre si pelo teste de Tukey a 5\% de significância.

Fonte: Própria (2020).

$\mathrm{O}$ atributo cor não apresentou diferença significativa entre as geleias $(\mathrm{p}<0,05)$, com notas médias que variaram entre os termos hedônicos "gostei moderadamente" e "gostei muitíssimo". Os IA obtidos foram de 88,69 e 91,87\% para as geleias de rapadura e melado, respectivamente. Oliveira et al. (2015), ao analisarem sensorialmente as geleias convencionais de umbu-cajá, obtiveram nota média de 7,53, que foram menores do que as notas obtidas pelas geleias do presente estudo. 
Figura 1. Índices de Aceitabilidade (IA) das geleias de rapadura e melado de cana-de-açúcar.

Cor

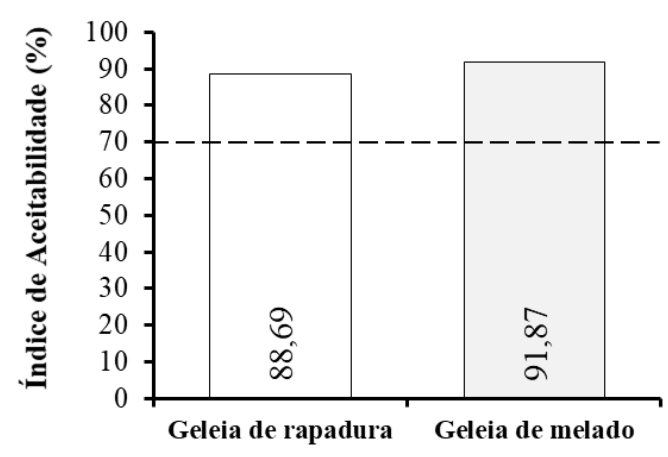

Aroma

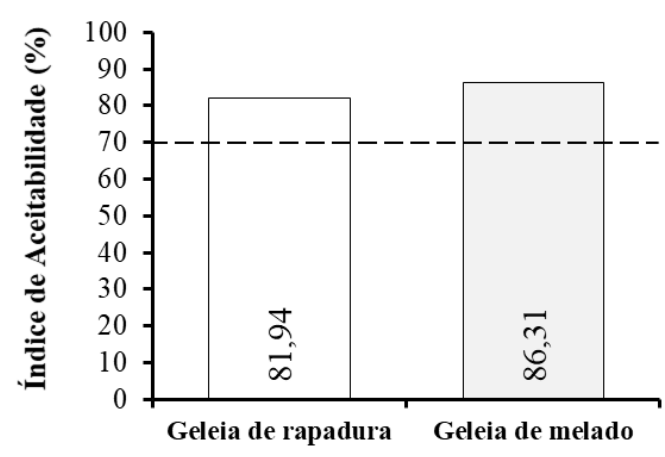

Doçura
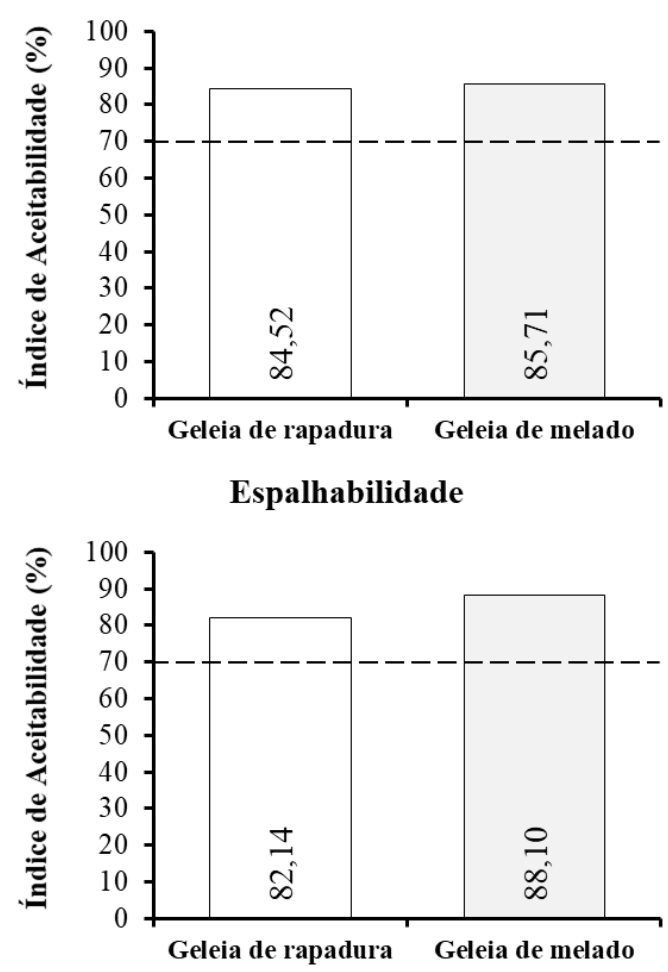

Aparência

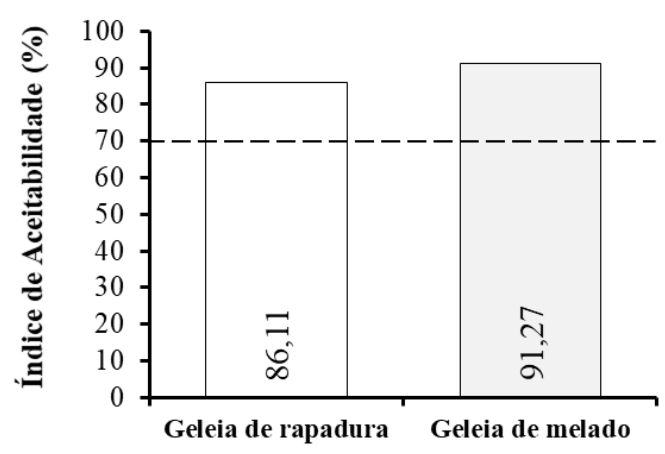

Sabor

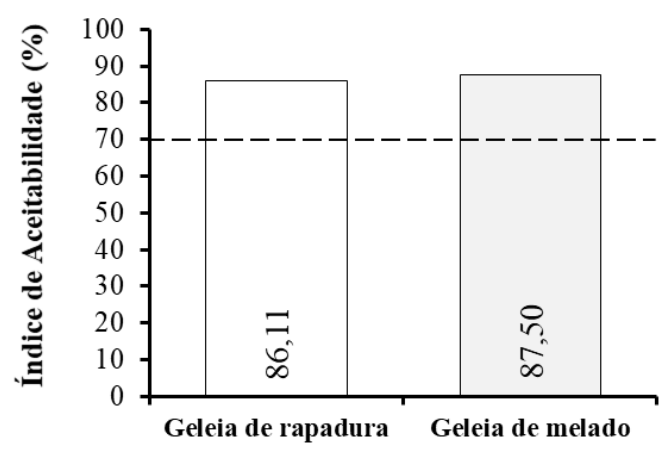

Consistência
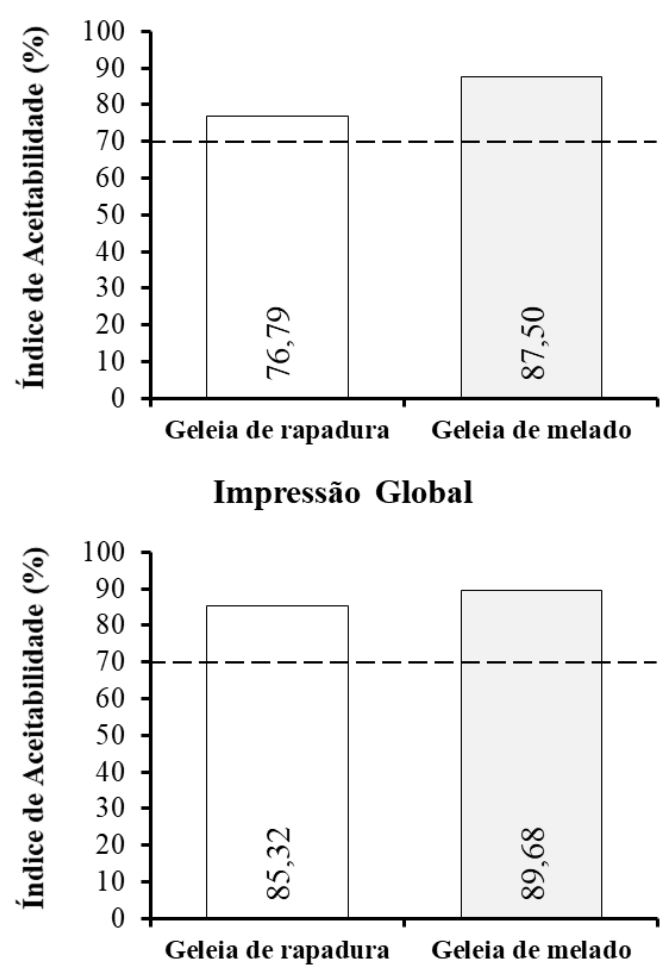

Fonte: Própria (2020). 
Nos atributos aparência e impressão global as notas foram superiores para a geleia de melado, posto que variaram entre os termos hedônicos "gostei moderadamente" e "gostei muitíssimo". Os IA obtidos foram de 91,27\% para aparência e 89,68\% para impressão global, ambos da geleia de melado. Rybka et al. (2018), ao analisarem a geleia de manga adicionada de fibras, obtiveram IA médio de 77,17\% para a impressão global, estando menor do que os resultados das geleias na presente pesquisa.

As geleias no atributo aroma não apresentaram diferenças significativas entre si $(\mathrm{p}<0,05)$, com notas médias que variaram entre os termos hedônicos "gostei moderadamente" e "gostei muito". Os IA obtidos foram de 81,94 e 86,31\% para as geleias de rapadura e melado, respectivamente.

Os atributos sabor e doçura não apresentaram diferenças significativas entre as geleias $(\mathrm{p}<0,05)$, com notas médias que variaram entre os termos hedônicos "gostei moderadamente" e "gostei muito". Os IA variaram entre 84,52 e 87,50\% nas geleias de rapadura e melado, respectivamente. Nesses atributos as matérias-primas utilizadas nas formulações das geleias não interferiram na aceitação sensorial pelos provadores. Vieira et al. (2017), ao avaliarem a geleia mista de casca de abacaxi e polpa de pêssego, obtiveram média de 8,40 no atributo sabor.

O atributo consistência está fortemente ligado ao teor de sólidos solúveis totais (BARRETO et al., 2015). Quanto aos atributos consistência e espalhabilidade, não houveram diferença significativas entre as geleias $(\mathrm{p}<0,05)$. As notas médias variaram entre os termos hedônicos "gostei ligeiramente" e "gostei muito". Os IA variaram entre 76,79 e 88,10\% nas geleias de rapadura e melado.

Souza et al. (2016) produziram geleias de tamarindo com pectina e obtiveram notas médias entre 8,00 e 8,28 para a consistência. As geleias da presente pesquisa foram elaboradas a partir de derivados do caldo de cana-de-açúcar, que conservam todos os nutrientes presentes nessa matéria-prima (SOARES, 2017), mas que não contém quantidade substancial de pectina. Guilherme et al. (2012), ao analisarem geleia de tamarillo, obtiveram nota média de 6,6 para o atributo espalhabilidade.

Na Figura 2 estão apresentados os resultados do Índice de Aceitabilidade Geral das geleias de rapadura e melado de cana-de-açúcar.

Verifica-se que a Aceitabilidade Geral das geleias desenvolvidas na presente pesquisa foram superiores a 70\%. Segundo Gularte (2009), um produto deve apresentar o percentual mínimo de $70 \%$ no IA para ser cogitado ao lançamento no mercado. Os valores demostraram boa aceitabilidade sensorial das geleias, independente da matéria-prima usada. 
Figura 2. Aceitabilidade Geral das geleias de rapadura e melado de cana-de-açúcar.

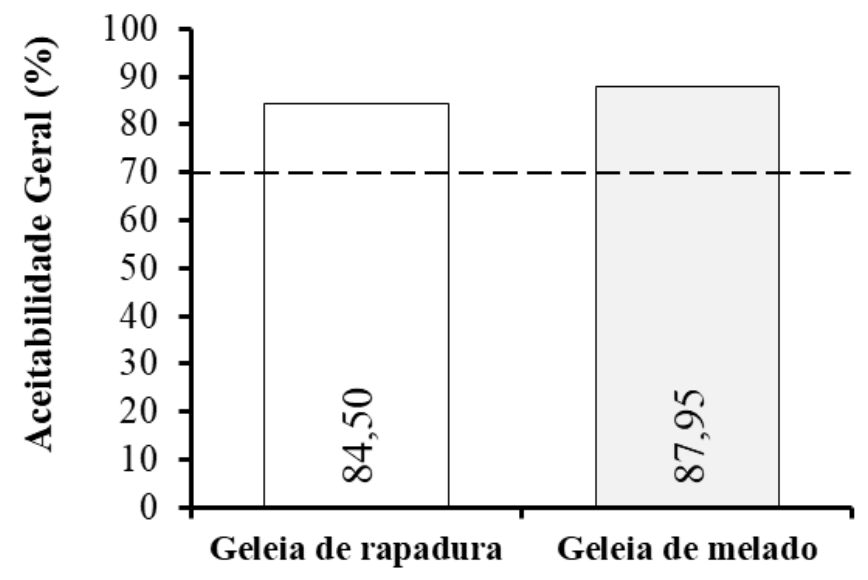

Fonte: Própria (2020).

Porém, a geleia de melado apresentou um resultado superior, com 87,95\%. Oliveira Neto et al. (2016), ao elaborarem e avaliarem geleias enriquecidas com farinha do resíduo agroindustrial de abacaxi, obtiveram uma variação na Aceitabilidade Geral entre 69,83 e $77,18 \%$, estando menores aos resultados obtidos na presente pesquisa.

Na Figura 3 estão apresentados os resultados da intenção de compra das geleias de rapadura e melado de cana-de-açúcar.

Figura 3. Intenção de compra das geleias de rapadura e melado de cana-de-açúcar.

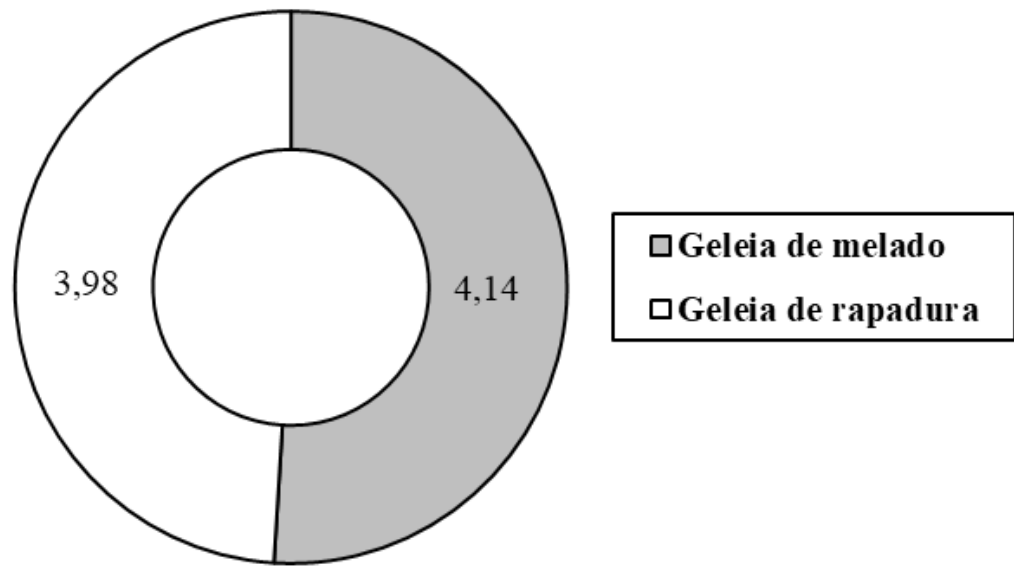

Fonte: Própria (2020).

$\mathrm{Na}$ intenção de compra das geleias, observou-se que a geleia de melado obteve nota média superior a geleia de rapadura, com 4,14 e 3,98, respectivamente. As notas obtidas correspondem aos termos hedônicos entre "talvez compraria/ talvez não compraria" e “certamente compraria", corroborando com os resultados apresentados na Figura 2.

Feitosa et al. (2017), ao aproveitarem a casca de banana na elaboração de quatro geleias com especiarias, obtiveram intenção de compra correspondente aos termos hedônicos "talvez 
compraria/ talvez não compraria" e "provavelmente compraria" para as geleias padrão, com cravo, canela e gengibre.

\section{Conclusões}

As formulações para a elaboração de geleias de rapadura e melado de cana-de-açúcar foram validadas, evidenciando produtos inovadores e com expressivo apelo regional. A geleia de rapadura apresentou características de pH pouco ácido e elevada concentração de sólidos, enquanto a geleia de melado demonstrou maior sensação de doçura.

Ambas as formulações foram bem aceitas sensorialmente, com índice de aceitabilidade acima de $70 \%$ em todos os atributos. A geleia de melado destacou-se com notas superiores nos atributos aparência, consistência, espalhabilidade e impressão global, provavelmente devido ser mais úmida. Porém, ainda são necessárias análises complementares para avaliar a estabilidade durante ao armazenamento.

\section{Referências}

AZEVÊDO, L. P. M.; NASCIMENTO, H. M. A.; MOREIRA, R. T.; PEREIRA, E. M. Elaboração e caracterização de doce de coco adicionado de diferentes concentrações de rapadura. Revista Verde de Agroecologia e Desenvolvimento Sustentável, v. 10. p.30-34, 2015. Disponível em: 〈https://doi.org/10.18378/rvads.v10i3.3585>.

BARRETO, P. P. A. F. A. P.; BETTANI, S. R.; BORGES, M. T. M. R.; BERNARDI, M. R. V. Avaliação físico-química e sensorial de diferentes melados. Revista de Agricultura, v. 90. p. 217-228, 2015. Disponível em: 〈https://doi.org/10.37856/bja.v90i3.66〉.

BARROS, S. L.; SILVA, W. P; FIGUEIRÊDO, R. M. F; ARAÚJO, T. J; SANTOS, N. C; GOMES, J. P. Efeito da adição de diferentes tipos de açúcar sobre a qualidade físico-química de geleias elaboradas com abacaxi e canela. Principia, v. 45. p. 150-157, 2019. Disponível em: <https://doi.org/10.18265/1517-03062015v1n45p150-157>.

BATISTA, E. M.; BARCElOS, S. C.; SILVA, E. F.; SÁ, D. M. A. T.; CAVALCANTE, A. B. D. Características físico-químicas e composição centesimal de rapaduras tradicionais. Higiene Alimentar, v. 3. p. 1314-1318, 2019. Disponível em: <http://www.higienista.com.br/wpcontent/uploads/Anais-Higienistas-2019_VERS\%C3\%83O-ATUALIZADA-FINAL.pdf>.

BRASIL. Agência Nacional de Vigilância Sanitária. Resolução - CNNPA no 12, de 1978. Normas Técnicas Especiais: padrões de identidade e qualidade para os alimentos (e bebidas). Diário Oficial [da] República Federativa do Brasil. São Paulo, 1978.

BRASIL. Agência Nacional de Vigilância Sanitária. Resolução RDC n 272, de 22 de setembro de 2005. Regulamento técnico para produtos de vegetais, produtos de frutas e cogumelos comestíveis. Diário Oficial [da] República Federativa do Brasil, Brasília, 2005.

CAETANO, P. K.; DAIUTO, É. R.; VIEITES, R. L. Caracterização físico-química e sensorial de geleia elaborada com polpa e suco de acerola. Brazilian Journal of Food Technology, 
Campinas, v. 15. p. 191-197, 2012. Disponível em: <https://doi.org/10.1590/S1981$\underline{67232012005000011>\text {. }}$

CASTRO, T. M. N.; ZAMBONI, P. V.; DOVADONI, S.; CUNHA NETO, A.; RODRIGUES, L. J. Parâmetros de qualidade de polpas de frutas congeladas. Revista do Instituto Adolfo Lutz, São Paulo, p. 426-436, 2015. Disponível em: <http://www.ial.sp.gov.br/resources/insituto-adolfolutz/publicacoes/rial/10/rial74_4_completa/artigos-separados/1677.pdf $>$.

CONAB. Companhia Nacional de Abastecimento. Acompanhamento da safra brasileira de cana-de-açúcar. Observatório agrícola. Brasília: Conab, 2019. ISSN 2318-7921.

DELGADO, L. C.; BORGES, G. N.; VAlENTINI, C. M. A.; FARIA, R. A. P. G. Aspectos culturais e ambientais no processo de produção de rapadura na comunidade de Bonsucesso em Várzea Grande-MT. Biodiversidade, v. 15, n. 2, p. 21-39, 2016. Disponível em: <http://periodicoscientificos.ufmt.br/ojs/index.php/biodiversidade/article/view/3958/2753 >.

DÍAZ, M. M. O.; QUIÑÓNEZ, L. V. C. R. Evaluation of the social-environmental impacts associated with the production of panela in Santander (Colombia). Corpoica Ciencia $\mathbf{y}$ Tecnología Agropecuaria, v. 18, n. 2, p. 379-396, 2017. Disponível em: <https://doi.org/10.21930/rcta.vol18_num2_art:637>.

DUTCOSKY, S. D. Análise sensorial de alimentos. $4^{\mathrm{a}}$ ed. Curitiba: Champagnat, 2013. 531p.

EMÍDIO, J. E. Hidrólise enzimática na fabricação de melado de cana-de-açúcar. 2016. 67f. Dissertação (Mestrado em Agroecologia e Desenvolvimento Rural) - Universidade Federal de São Carlos, Araras, 2016.

FEITOSA, B. F.; DIAS, A. L.; OLIVEIRA, E. N. A.; ROCHA, É. M. F. F. Aproveitamento da casca de banana na elaboração de geleia com especiarias. IN: II Congresso Internacional da Diversidade do Semiárido, Anais... Campina Grande, 2017.

GARCIA, L. G. C.; GUIMARÃES, W. F.; RODOVAlHO, E. C.; PERES, N. R. A. A.; BECKER, F. S.; DAMIANI, C. Geleia de buriti (Mauritia flexuosa): agregação de valor aos frutos do cerrado brasileiro. Brazilian Journal Of Food Technology, p. 1-5. 2017. Disponível em: 〈https://doi.org/10.1590/1981-6723.4316>.

GOMES, R. B.; SANTOS, M. B.; CARDOSO, R. L.; TAVARES, J. T. Q.; CUNHA, D. S. Elaboração e avaliação físico-químico e sensorial de geleia de maracujá com cenoura. Enciclopédia Biosfera, v. 9, p. 2765-2770, 2013. Disponível em: $<$ https://www.conhecer.org.br/enciclop/2013a/agrarias/ELABORACAO\%20E\%20AVALIAC AO.pdf $>$.

GUILHERME, P. R.; PESSATTO, C. C.; ZAIKA, W. R.; QUAST, E.; QUAST, L. B.; ORMENESE, R. C. S. C.; RAUPP, D. S. Desenvolvimento de geleia de tamarillo contendo polpa integral. Brazilian Journal of Food Technology, v. 1 p. 141-149, 2012. Disponível em: <http://dx.doi.org/10.1590/S1981-67232012005000007>.

GULARTE, M. A. Análise sensorial. Universitária da Universidade Federal de Pelotas, 2009. 
IAL. Instituto Adolfo Lutz. Métodos físico-químicos para análise de alimentos. $4^{\mathrm{a}}$ ed., $1^{\mathrm{a}} \mathrm{ed}$. Digital, São Paulo, 2008. 1020p.

JERONIMO, E. M. Produção de açúcar mascavo, rapadura e melado no âmbito da agricultura familiar e sua importância na alimentação humana. Ciência Alimentando o Brasil. São Paulo, p. 111-120, 2018. Disponível em: < $\underline{\text { https://agbbauru.org.br/publicacoes/Alimentando2ed/pdf/Alimentando2ed-07.pdf }>\text {. }}$

MAIA, J. D.; TRAVÁLIA, B. M; ANDRADE, T. A; SILVA, G. K. C.; ANDRADE, J.K. S.; JÚNIOR, A. M. O.; MOREIRA, J. J. S. Desenvolvimento, avaliação físico-química, microbiológica e sensorial de geleia de tamarindo. Revista Gestão, Inovação e Tecnologias, v. 4. p. 632-641, 2014.

OLIVEIRA, E. N. A.; FEITOSA, B. F.; SOUZA, R. L. A. Tecnologia e processamento de frutas: doces, geleias e compotas. 1 ed. Natal: Editora IFRN, 2018. 316p. ISBN: 978-8594137-48-7.

$<$ https://memoria.ifrn.edu.br/bitstream/handle/1044/1664/Tec.\%20e\%20Proc.\%20de\%20Frut as\%20-\%20E-Book.pdf? sequence $=1 \&$ isAllowed $=\mathrm{y}>$.

OLIVEIRA, E. N. A; SANTOS, D. C; ROCHA, A. P. T; GOMES, J. P.; FEITOSA, R. M.; FEITOSA, B. F. Composição nutricional de geleias de umbu-cajá durante estocagem em temperatura ambiente. Brazilian of Journal of Food Technology, v. 21, e2018033, 2018. Disponível em: 〈https://doi.org/10.1590/1981-6723.3318>.

OLIVEIRA, E. N. A; SANTOS, D. C; ROCHA, A. P. T; GOMES, J. P. Perfil microbiológico e sensorial de geleias convencionais de umbú-caja. Comunicata Scientiae, v. 6. p.250-254, 2015. Disponível em: 〈https://dialnet.unirioja.es/servlet/articulo?codigo=6294664>.

OLIVEIRA, M. M. T.; BRAGA, T. R.; PINHEIRO, G. K.; SILVA, L. R.; VIEIRA, C. B.; TORRES, L. B. V. Parâmetros físico-químicos, avaliação microbiológica e sensorial de geleias de laranja orgânica com adição de hortelã. Revista de la Facultad de Agronomía, v. 115. p. 29-34, 2016.

Disponível em: $<$ http://sedici.unlp.edu.ar/bitstream/handle/10915/54166/Documento_completo.pdfPDFA.pdf?sequence $=1 \&$ isAllowed $=\mathrm{y}>$.

OLIVEIRA, K. D. C.; SILVA, S. S; LOSS, R. A; GUEDES, S. F. Análise sensorial e físicoquímica de geleia de achachairu (Garcinia humillis (Vahl) C. D. Adam). Segurança Alimentar e Nutricional, v. 26. p. 1-10, 2019. Disponível em: <https://doi.org/10.20396/san.v26i0.8653566>.

OLIVEIRA NETO, J. O.; FEITOSA, B. F.; GERMANO, A. M. L. O.; FREITAS, P. V. C.; ROCHA, É. M. F. F.; OLIVEIRA, E. N. A. Geleias enriquecidas com farinha do resíduo agroindustrial de abacaxi: elaboração e caracterização. IN: II ENCONTRO NACIONAL DA AGROINDUSTRIA, Anais... Bananeiras, p. 901-905, 2016.

RADDATTZ, C.; ROSSATO, M. V.; PICCININ, Y. Apuração dos custos de produção e do resultado em uma agroindústria. IN: XXII CONGRESSO BRASILEIRO DE CUSTOS, Anais... Foz do Iguaçu, PR, Brasil, 2015. 
RYBKA, A. C. P; LIMA, A. S; CASTRO, C. D. P. C. Geleia de manga "Tommy Atkins" adicionada de fibras - Aceitação sensorial. IN: CONGRESSO BRASILEIRO DE CIÊNCIA E TECNOLOGIA DE ALIMENTOS, Anais... v. 26. p. 1-8, 2018.

SANTOS, F; BORÉM, A. Cana-de-açúcar: do plantio à colheita. Viçosa, MG: Universidade Federal de Viçosa, 2013. 257p. ISBN 978-85-914438-0-2.

SEBRAE. Produtos derivados da cana-de-açúcar, 2014. Disponível em: $<$ https://respostas.sebrae.com.br/produtos-derivados-da-cana-de-acucar/>. Acesso em: 28 jul. 2020.

SILVA, F. A. Z.; AZEVEDO, C. A. V. The assistat software version 7.7 and its use in the analysis of experimental data. African Journal of Agricultural Research, v. 11, n. 3, p. 37333740, 2016. Disponível em: 〈https://doi.org/10.5897/AJAR2016.11522〉.

SOARES, E. A. Avaliação físico-química e sensorial de caldo de cana-de-açúcar. 2017. 49f. Dissertação (Mestrado em Agroecologia e Desenvolvimento Rural) - Universidade Federal de São Carlos, Araras, 2017.

SOUZA, F. G.; BARBOSA, F. F.; RODRIGUES, F. M. Avaliação de geleia de tamarindo sem pectina e com pectina proveniente do albedo do maracujá amarelo. Journal of Bioenergy And Food Science, v. 3. p. 78-88, 2016. Disponível em: 〈https://doi.org/10.18067/jbfs.v3i2.52〉.

TACO. Tabela Brasileira de Composição de Alimentos. TBCA - 7.1, 2020. Disponível em: <http://www.tbca.net.br/index.html>. Acesso em: 28 jul. 2020.

TELES, A. C. M.; PINTO, E. G.; SANTOS, J. R.; OLIVEIRA, C. F. D.; SOARES, D. S. B. Desenvolvimento e caracterização físico-química de geleia comum e extra de graviola com pimenta. Revista de Agricultura Neotropical, v. 4. p. 72-77, 2017. Disponível em: <https://doi.org/10.32404/rean.v4i1.1341>.

VIEIRA, E. C. S.; SILVA, E. P.; AMORIM, C. C. M.; SOUSA, G. M.; BECKER, F. S.; DMIANI, C. Aceitabilidade e características físico-químicas de geleia mista de casca de abacaxi e polpa de pêssego. Científica, v. 45. p. 115-122, 2017. Disponível em: <http://dx.doi.org/10.15361/1984-5529.2017v45n2p115-122>.

VICENTINI-POLETTE, C. M. Caracterização físico-química e sensorial de melados comerciais de cana-de-açúcar. 2019. 58 f. Dissertação (Mestrado em Agroecologia e Desenvolvimento Rural) - Universidade Federal de São Carlos, 2019. 


\title{
CAPÍTULO 06: INCLUSÃO DE FARINHA DE PEIXES DE DIFERENTES ESPÉCIES EM MASSA DE ESFIRRA ABERTA
}

\section{CHAPTER 06: INCLUSION OF FISH FLOUR OF DIFFERENT SPECIES IN OPEN SPHERE PASTA}

\author{
Melina Franco Coradini ${ }^{1}$; Natalia Cavicchioli²; Ana Paula Sartório Chambo ${ }^{3}$; Graciela Lucca \\ Braccini $^{4}$; Maria Luiza Rodrigues de Souza ${ }^{5}$
}

\section{Resumo}

O objetivo foi elaborar esfirra aberta com a inclusão de farinha de peixe de diferentes espécies, para avaliar a composição química, microbiológica e sensorial. Para farinha de peixe, foram utilizadas carcaças de tilápia do Nilo, salmão, atum e sardinha. As carcaças de salmão, atum e sardinha foram submetidas ao cozimento. As carcaças de tilápia foram submetidas à salmouragem com extrato de alecrim defumados. Posteriormente todas as matérias primas foram prensadas, moídas, desidratadas, moídas novamente e embaladas a vácuo. Foram elaboradas quatro massas de esfirra com inclusão de $10 \%$ de farinha aromatizada de peixe (Tratamento1= controle - tilápia - FT; tratamento 2= Tilápia+Salmão FTS; tratamento 3= tilápia+atum - FTA; tratamento 4= tilápia+sardinha - FTSA). A mistura foi de $80 \%$ farinha de tilápia e $10 \%$ da farinha das demais espécies. A inclusão de farinhas de espécies marinhas (atum, salmão e sardinha) na de tilápia aromatizada não apresentaram diferença no teor de umidade e cinzas, mas proporcionou um enriquecimento proteico e aumento no valor calórico das esfirras aberta prontas para consumo, e os teores de carboidratos foram reduzidos. As esfirras abertas prontas com a inclusão de FT e FTS foram melhores aceitas pelos provadores com maior intenção de compra destes produtos em relação aos demais.

Palavras-Chaves: Oreochromis niloticus, Resíduos de beneficiamento, Sardinella brasiliensis, Salmo salar, Tunnus spp.

\begin{abstract}
The objective of this work was to elaborate open spheric with the inclusion of fish meal of different species, to evaluate the chemical, microbiological and sensory composition. For fishmeal, carcasses of Nile tilapia (Oreochromis niloticus), salmon (Salmo salar), tuna (Tunnus spp) and sardines (Sardinella brasiliensis) were used. The carcasses of salmon, tuna and sardines were subjected to cooking. Tilapia carcasses were subjected to brining with smoked rosemary extract. Subsequently, all raw materials were pressed, ground, dehydrated, ground again and vacuum-packed. Four spherical doughs were prepared with the inclusion of $10 \%$ flavored fish meal $($ Treatment $1=$ control - tilapia - FT; treatment $2=$ Tilapia + Salmon FTS; treatment 3 = tilapia + tuna - FTA; treatment $4=$ tilapia + sardines - FTSA). The mixture was $80 \%$ tilapia flour and $10 \%$ flour from the other species. The inclusion of flours of marine species (tuna, salmon and sardines) in the flavored tilapia did not show any difference in the moisture and ash content, but it provided a protein enrichment and an increase in the caloric value of the ready-to-eat open spheres, and the carbohydrate contents. have been reduced. The open spheres ready with the inclusion of FT and FTS were better accepted by

\footnotetext{
${ }^{1}$ Pós-graduação em Zootecnia, Universidade Estadual de Maringá, melinacoradini@ gmail.com

${ }^{2}$ Graduação em Zootecnia, Universidade Estadual de Maringá, natalia.cavicchioli@ hotmail.com

${ }^{3}$ Pós-graduação em Zootecnia, Universidade Estadual de Maringá, ana.chambo@ hotmail.com

4 Professora, Centro Universitário de Maringá, grabraccini@gmail.com

${ }^{5}$ Professora, Universidade Estadual de Maringá, mlrsouza.uem@gmail.com
} 
the tasters with greater intention to purchase these products in relation to the others. And they would buy the spheres if they were available on the market.

Keywords: Oreochromis niloticus, Processing residues, Sardinella brasiliensis, Salmo salar, Tunnus spp.

\section{Introdução}

Cerca de 70\% da superfície do planeta é constituído por água, disso, apenas 2,5\% são de água doce, e o restante é de água salgada (VALE, 2012). O Brasil possui 12\% da reserva de água doce do mundo (FAO, 2012), apresentando assim, um grande potencial de produção para o pescado.

O pescado é um alimento rico nutricionalmente, devido à sua excelente fonte proteica, considerando uma variação entre as espécies de peixes de 15 a 25\%. Além disso, ele é uma fonte de minerais, principalmente cálcio, fósforo e ferro (OLIVEIRA et al., 2002) e vitaminas A, D e do complexo B, em especial a B12 (VILA NOVA et al., 2005). Apresenta também, todos os aminoácidos essenciais, com elevado teor em lisina, aminoácido iniciador do processo digestivo. A digestibilidade é alta, acima de 95\%, conforme a espécie (SOARES; GONÇALVES, 2012). O valor biológico é próximo de 100, determinado pela alta absorção dos aminoácidos essenciais e com o processamento e congelamento a qualidade proteica do pescado é mantida (OETTERER et al., 1983).

Com uma maior divulgação das qualidades e a importância nutricional do pescado, o consumo no país vem aumentando e pode-se dizer que a maioria da população brasileira está consumindo a quantidade mínima recomendada por ano, que é cerca de $14 \mathrm{~kg}$. Mas, segundo o Ministério da Agricultura, dados que são, ainda, abaixo da média mundial, que é de $20 \mathrm{~kg}$, mas acima dos $12 \mathrm{~kg}$ recomendados pela Organização das Nações Unidas para Alimentação e a Agricultura (FAO). Segundo o Ministério da Pesca, em 2009, o Brasil consumia apenas $9 \mathrm{~kg}$ por ano (FAO, 2014). Apesar do grande mercado consumidor, o Brasil apresenta um dos menores índices de consumo per capita de pescado do mundo (GODOY et al., 2010).

Durante o processamento do pescado, cerca de $50 \%$ da sua carcaça é descartada na filetagem e no enlatamento. Essa grande quantidade de partes não aproveitadas geram novas possibilidades para aumentar o aproveitamento, armazenamento e destino desses resíduos. A transformação de partes como cabeça, cauda, carcaça em farinhas, com a finalidade de aproveitar esses resíduos da indústria, geram um coproduto com valor nutricional ainda elevado e que pode ser utilizado para enriquecer produtos nutricionalmente inferiores, os 
tornando mais nutritivos, com o aumento do teor proteico e fonte de ácidos graxos essenciais (BORGHESI et al., 2013).

Os resíduos da industrialização do pescado podem ser dirigidos para vários tipos de aproveitamento e divididos em 4 categorias: alimentos para consumo humano, ração para animais, fertilizantes ou produtos químicos. A maioria se destina a produção de farinha, para consumo animal (ARRUDA; OETTERER, 2004).

Segundo Godoy et al. (2012) a farinha a partir de carcaças de tilápia apresenta 32,51\% de proteína bruta, $19,725 \%$ de lipídeos e $26,22 \%$ de cinzas, e ela pode ser incluída em diversos produtos doces e salgados, e pode ser obtida de peixes de diversas espécies, geralmente os produtos que apresentam essa inclusão de farinha são bem aceitos quando apresentado para avaliação sensorial.

A esfirra aberta é um produto de grande aceitação pela população, pois seu consumo tem aumentado nas diferentes faixas etárias, podendo ser observado pelo número de esfirrarias nas cidades, em especial nos grandes centros. No entanto, a sua massa se baseia em farinha de trigo, ou seja, alto teor de carboidratos. Todavia, isso pode ser mudado através da inclusão de proteína de origem animal, em especial de peixes na massa, sendo facilitado na forma em pó. Assim, devido ao elevado valor nutricional do peixe, além de incentivar indiretamente o consumo do pescado e o aproveitamento dos resíduos de filetagem; desde que se utilizando boa logística dentro da unidade de processamento quanto à higiene-sanitária e temperatura de conservação destes resíduos, torna-se uma forma muito interessante de uso.

Assim, o objetivo deste trabalho foi elaborar e avaliar a esfirra aberta com inclusão de farinha aromatizada de tilápia e diferentes espécies de peixes, quanto aos aspectos nutricionais, microbiológicos e sensoriais.

\section{Material e Métodos}

\section{Obtenção das carcaças e elaboração das farinhas de peixes de diferentes espécies}

Foram utilizadas carcaças de tilápia do Nilo (Oreochromis niloticus), oriundas da Smart Fish (Rolândia/PR), carcaças de salmão (Salmo salar) obtidas da empresa Taiyo de Maringá, atum (Tunnus spp) e sardinha (Sardinella brasiliensis) provenientes da empresa Gomes da Costa (Itajaí/SC). As carcaças foram transportadas em caixas isotérmicas e armazenadas em freezer $\left(-18^{\circ} \mathrm{C}\right)$ até o momento da elaboração das farinhas. A estocagem, elaboração das farinhas e esfirras foram realizadas no Laboratório de Tecnologia de Pescado na Fazenda Experimental de Iguatemi (FEI), que pertence a Universidade Estadual de Maringá, localizada no Distrito de Iguatemi (Maringá-PR, Brasil). 
Para a elaboração das farinhas, todas as carcaças foram descongeladas, sendo que para as carcaças de tilápia do Nilo e salmão foram retiradas às nadadeiras e a cabeça. Da sardinha e do atum foram utilizadas as extremidades caudais dos peixes sem remoção da carne. Após o preparo das matérias primas, com exceção da tilápia, estas foram lavadas, pesadas, sanitizadas (proxitane $1512 ® 0,1 \mathrm{mg} / \mathrm{kg}$ ) e submetidas ao cozimento em panela de pressão com antioxidante (BHT 0,5 mg/kg) por 60 minutos. Depois foram prensadas (prensa hidráulica com capacidade de 10 toneladas) e moídas em moedor de carne. Foram obtidas massas e estas foram desidratadas em estufa com circulação de ar forçado com temperatura de $60^{\circ} \mathrm{C}$, por 24h. Com o produto desidratado o mesmo foi moído em moinho tipo faca (Willye - modelo TE-650) e embalado a vácuo.

Para a farinha aromatizada de tilápia as carcaças foram imersas em salmoura a $20 \%$ ( $2: 1$ - volume da salmoura/peso) com extrato de alecrim natural, utilizado $0,1 \%$ sobre peso das carcaças e batido em liquidificador com $100 \mathrm{ml}$ de água. As carcaças foram drenadas e submetidas à secagem por 30 minutos a $50^{\circ} \mathrm{C}$. Em seguida, as carcaças foram defumadas com adição de fumaça sendo utilizada para isso a serragem de eucalipto rosa (Eucalyptus globulus), a temperatura foi mantida entre $60-70^{\circ} \mathrm{C}$ com o auxílio de gás de cozinha. Após as carcaças serem defumadas, prensadas, moídas e desidratadas e novamente moídas em moinho tipo faca, conforme procedimento descrito anteriormente para as demais espécies de peixe. As farinhas de todas as espécies foram congeladas $\left(-18^{\circ} \mathrm{C}\right)$ até o momento da preparação das misturas (mix) e o preparo das massas de esfirras.

\section{Elaboração das esfirras aberta com a inclusão das farinhas de peixes de diferentes espécies}

Para elaboração das misturas foi utilizado a farinha de tilápia, que foi aromatizada pelo extrato de alecrim e fumaça no processo de defumação. Nos demais tratamentos foram utilizados $80 \%$ de farinha aromatizada, acrescido das inclusões das farinhas referentes às demais espécies de peixes, em um total de $20 \%$ para cada mistura. Portanto, foram elaborados quatro tratamentos (Tratamento 1 - 100\% farinha aromatizada de tilápia - FT; Tratamento 2 $80 \%$ de farinha aromatizada de tilápia+ 20\% de farinha de salmão - FTS; Tratamento 3 - 80\% de farinha aromatizada de tilápia+ 20\% de farinha de atum - FTA; Tratamento 4 - $80 \%$ de farinha aromatizada de tilápia+20\% de farinha de sardinha - FTSA).

Para a elaboração da massa foram adicionados a farinha de trigo comum, $10 \%$ de farinha de peixe (conforme o tratamento) sobre o peso da farinha de trigo, o fermento biológico seco, açúcar, sal, água e o óleo em um recipiente. Após a homogeneização dos 
ingredientes, a massa ficou em descanso por 50 minutos para crescimento. A mesma foi aberta em espessura de $1 \mathrm{~cm}$ com rolo de macarrão e foram cortados círculos com cerca de $8 \mathrm{~cm}$ de diâmetro. Essa massa foi pré-assada em forno convencional á $200^{\circ} \mathrm{C}$ por 10 minutos. Depois foi adicionado o recheio composto pela carne moída, tomate, cebola, suco de limão, cheiro verde e azeite de oliva, e adicionado na superfície do produto (molho de cobertura) conforme indicado na Tabela 1, da massa pré-assada e processada.

Tabela 1. Quantidades dos ingredientes utilizados para elaboração da massa de esfirra aberta com a inclusão de diferentes farinhas de peixe de diferentes espécies e o molho.

\begin{tabular}{lc}
\hline \multicolumn{1}{c}{ Ingrediente } & Quantidade \\
\hline Massa & $(\mathrm{g})$ \\
\hline Farinha de trigo & 400 \\
Farinha de peixe de diferentes espécies (10\%) & 40 \\
Fermento & 5 \\
Açúcar & 20 \\
Sal & 10 \\
Água & 200 \\
Óleo & 15 \\
\hline Molho & \\
\hline Carne bovina moída & 400 \\
Tomate & 300 \\
Cebola & 175 \\
Suco de limão & 40 \\
Cheiro verde & 10 \\
Azeite de Oliva & 15 \\
\hline
\end{tabular}

As esfirras abertas já em temperatura ambiente foram embaladas de acordo com seus respectivos tratamentos e congeladas $\left(-18^{\circ} \mathrm{C}\right)$ para realização das análises de composição centesimal. Para a análise microbiológica, as amostras foram refrigeradas $\left(5\right.$ a $\left.7^{\circ} \mathrm{C}\right)$ até o momento da análise e para sensorial foram imediatamente preparadas, cortadas, embaladas, identificadas e acondicionadas em refrigeração para análise em 24 horas.

\section{Análise microbiológica das farinhas e das esfirras aberta pronta (com molho)}

A análise microbiológica das farinhas e das esfirras aberta pronta (com molho) foram realizadas no laboratório do Departamento de Análises Clínicas no laboratório de Microbiologia e Microscopia de Alimentos da Universidade Estadual de Maringá-UEM.

As amostras foram analisadas para o número mais provável (NMP) de Coliformes a $35^{\circ} \mathrm{C}$ e $45^{\circ} \mathrm{C}$, contagem de Staphylococcus, coagulase positiva em unidade formadora de colônia (UFC)/grama e de Salmonella spp, de acordo com a APHA (1992). O protocolo microbiológico seguiu os padrões recomendados pela Resolução RDC nº 12 , de 2 de janeiro de 2001, da Agência Nacional de Vigilância Sanitária (BRASIL, 2001). 


\section{Análises de composição centesimal e valor calórico}

Essas análises foram realizadas no Laboratório de Alimentos e Nutrição Animal (LANA) da Universidade Estadual de Maringá/UEM. Foram analisadas amostras das farinhas referentes a cada tratamento, das massas assada da esfirra aberta e das esfirras aberta prontas (com molho). Todas as análises da composição centesimal foram realizadas em triplicata, utilizando-se 6 amostras por tratamentos, sendo a esfirra a unidade experimental. Para a determinação de cinzas e umidade foi utilizada a metodologia da AOAC (2005). Os teores de proteína bruta foram avaliados pelo método de semi-micro Kjeldahl (SILVA; QUEIROZ, 2002). Para a extração dos lipídios totais utilizou-se o método Bligh e Dyer (1959). Os teores de carboidratos foram estimados utilizando-se uma fórmula matemática que considera a soma dos valores de umidade, proteína, lipídeos e cinzas substituídos de 100\% (BRASIL, 2003).

O valor calórico total foi obtido pela soma da multiplicação dos valores das médias de proteínas, lipídios e carboidratos multiplicados pelos fatores $4,9,4$, respectivamente (SOUCI et al., 2003).

\section{Análise sensorial das esfirras aberta prontas}

Os produtos prontos foram cortados em sub amostras $( \pm 25 \mathrm{~g})$, embaladas em papel alumínio, etiquetados com 3 números aleatórios por tratamento e oferecido para 80 provadores não treinados para realização da análise sensorial.

A análise sensorial foi realizada em cabines individuais pintadas de branco e sob luz branca, para equivaler à luz do dia. Foi fornecida uma amostra de cada tratamento da esfirra aberta (correspondente a cada tratamento) para os 80 provadores não treinados que avaliaram os atributos sensoriais de aroma, cor, sabor, textura, impressão geral e a intenção de compra.

Além das amostras codificadas os provadores também receberam uma ficha para a análise sensorial e um copo de água mineral à temperatura ambiente para avaliação das amostras. Nessa ficha foi avaliado os atributos sensoriais do produto, através da escala hedônica de 9 pontos, tendo como escores variando de 9 (gostei muitíssimo) até 1 (desgostei muitíssimo) (STONE; SIDEL, 1993; DUTCOWSKY, 2011) para avaliação dos atributos sensoriais e, outra para avaliar a intenção de compra utilizando-se a escala de 5 pontos, na qual 5 representava a nota máxima "certamente compraria" e 1 representava a nota mínima "certamente não compraria", empregando os procedimentos segundo Meilgaard et al. (1991) e Damásio e Silva (1996). 
Foi avaliado o Índice de Aceitação (AI) das esfirras utilizando a equação: IA= Ax100/B, onde $\mathrm{A}=$ nota máxima do produto e $\mathrm{B}=$ nota mínima da escala, indicada por Dutcosky (2011).

O projeto com a inclusão de farinhas de peixes de água doce e marinho em produtos alimentícios foi aprovado pelo comitê de ética da Universidade Estadual de Maringá, cujo número do CAAE é 14219213.1.0000.0104.

\section{Delineamento experimental}

Para avaliar os efeitos dos níveis de inclusão das farinhas de peixes de diferentes espécies, nas esfirras abertas utilizou-se o sistema computacional SAS (PROC GENMOD), para análise dos resultados da sensorial, considerando-se a distribuição das variáveis como sendo gama com função de ligação inversa. Considerados os efeitos de tratamento e degustadores (80 repetições), por meio de teste de médias e o comportamento das notas dos degustadores em função da inclusão da farinha de peixe nas esfirras aberta.

A análise da composição centesimal de cada tratamento com três repetições da esfirra aberta pronta, bem como apenas sua massa, foi submetida à análise de variância com nível de $5 \%$ de probabilidade (SAS, 2000). Para a análise microbiológica não foi realizada à análise estatística, apenas para verificar a qualidade do produto.

Não foi realizada análise estatística para a composição química das farinhas utilizadas, sendo apenas para caracterização do produtos.

\section{Resultados e Discussão \\ Análises microbiológicas}

As análises microbiológicas estavam dentro dos padrões microbiológicos estabelecidos pela RDC n⿳012, da Agência Nacional de Vigilância Sanitária do Ministério da Saúde (BRASIL, 2001). Segundo Padrão NRC nº12 ANVISA (BRASIL, 2001) Coliformes $45^{\circ} \mathrm{C}$ até $10^{2}$, Staphylococcus até $10^{3}$, Salmonella à $25 \mathrm{~g}$ deve ser ausente.

Os resultados das análises das farinhas, massas e das esfirras aberta pronta para coliformes a $35^{\circ} \mathrm{C}$ e $45^{\circ} \mathrm{C}$ foi de $<3 \mathrm{NMP} / \mathrm{g}$, Staphylococcus spp coagulase positiva foi < $1 \times 10^{2}$ e ausência de Salmonella $s p$ em $25 \mathrm{~g}$ de amostra, estando assim, tanto as farinhas, massa e esfirra pronta aptos para o consumo humano. Qualquer contaminação na farinha ou massa no processamento poderia ter sido detectada. Mostrando que independente do processo utilizado na produção das esfirras houve um adequado controle higiênico-sanitário, por não ter ocorrido contaminação nas farinhas ou própria esfirra aberta pronta. 


\section{Análise composição química das farinhas, das massas pré-assada e das esfirras aberta prontas para consumo}

O valor nutritivo do alimento pode ser indicado através da sua análise de composição química, essa indica os valores de proteína bruta, umidade, lipídios, cinzas, carboidratos e o valor calórico. Resultados das análises de composição química das farinhas, da esfirra pronta quanto da massa da esfirra são observados nas Tabelas 2, 3 e 4.

Tabela 2. Composição química das farinhas de diferentes espécies de peixes utilizadas na inclusão na massa de esfirra aberta.

\begin{tabular}{lcccccc}
\hline Farinhas & $\begin{array}{c}\text { Umidade } \\
(\%)\end{array}$ & $\begin{array}{c}\text { Proteína } \\
\text { Bruta }(\%)\end{array}$ & $\begin{array}{c}\text { Lipídios } \\
(\%)\end{array}$ & $\begin{array}{c}\text { Cinzas } \\
(\%)\end{array}$ & $\begin{array}{c}\text { Carboidratos } \\
(\%)\end{array}$ & $\begin{array}{c}\text { Valor Calórico } \\
(\mathrm{kcal} / 100 \mathrm{~g})\end{array}$ \\
\hline FT & 9,49 & 48,92 & 10,64 & 30,06 & 0,89 & 294,97 \\
FTS & 9,15 & 48,45 & 10,86 & 30,36 & 1,18 & 296,26 \\
FTA & 8,99 & 51,98 & 10,10 & 27,55 & 1,38 & 304,34 \\
FTSA & 9,38 & 49,13 & 9,80 & 30,80 & 0,89 & 288,28
\end{tabular}

Valores médios de triplicata de cada amostra *FT=farinha de tilápia, FTS=farinha de tilápia+Salmão, FTA=farinha de tilápia+Atum, FTSA=farinha de tilápia +Sardinha.

O teor de umidade das farinhas variou de $8,99 \%$ a $9,49 \%$, estando com o teor dentro do que se recomenta para farinhas de peixe que é de até $12 \%$, de acordo com o Regulamento da Inspeção Industrial e Sanitária de Produtos de Origem Animal (RIISPOA, 1997). As farinhas de peixes apresentaram 48,45\% a 51,98\% de proteina. A farinha com inclusão de atum $(51,98 \%)$ e sardinha $(49,13 \%)$ apresentaram maiores teores de proteina em função da origem da matéria prima utilizada (extremidade caudal do peixe), pois nestas duas continham maior quantidade de carne, comparada as de tilápia e salmão.

O teor de lipídeos totais variou de $9,80 \%$ a $10,86 \%$ e cinzas de $27,55 \%$ a 30,80\% nas diferentes farinhas analisadas. Os maiores teores de cinzas devem-se ao tipo de matéria prima utilizada, pois nestes estava incluído uma maior quantidade de espinhaço (coluna vertebral, espinhas e/ou costelas), apenas os resíduos de atum a quantidade de carne era elevado comparados aos demais resíduos utilizados para elaboração das farinhas.

O teor de carboidrato foi baixo para todas as farinhas $(0,89$ a $1,38 \%)$, mas o valor calórico das farinhas variou de 288,28 a 304,34 kcal/100g. Sendo o mix com atum o mais calórico (Tabela 2).

Souza et al. (2017) elaboraram e caracterizaram farinhas de resíduos do beneficiamento da tilápia, atum, salmão e sardinha para utilizar em produtos alimentícios. Usaram a mesma metodologia descrita neste experimento, e os autores relataram que a farinha de atum apresentou maior teor de proteina $(83,28 \%)$ e menor teor de matéria mineral $(5,31 \%)$. Já, a farinha de salmão apresentou maior teor de lipídeos $(18,81 \%)$ e a de sardinha o menor 
$(3,98 \%)$. A farinha de tilápia apresentou maior matéria mineral (37,66\%), dos quais 9,37\% de cálcio $6,08 \%$ de fósforo. Observou-se maior teor de ferro nas farinhas de sardinha e atum (121,95 e 106,38 mg kg-1). Apesar do teor proteico de atum ser elevado neste experimento, foi muito inferior ao relatado por Souza et al. (2017). Mas, não esquecendo que neste experimento das esfirras foi a mistura da farinha de tilápia aromatizada (90\%) e 10\% de atum, sendo ainda a maior proporção a presença da farinha de tilápia, por isso menor valor proteico.

Para a massa pré-assada da esfirra houve diferença significativa para todos os nutrientes e valor calórico (Tabela 3). As diferenças encontradas no teor de umidade nas massas pré-assadas das esfirras podem estar relacionadas ao conteúdo de lipídeos observado nas massas das esfirras com a inclusão de farinha de peixes das diferentes espécies, pois a umidade tem uma relação inversamente proporcional com a quantidade de gordura (Minozzo, 2010). Também, a umidade deve-se ao tempo de exposição dentro do forno, no momento de pré-assar, por maior que tenha sido o controle, ainda outros fatores acabaram influenciando nessa umidade, pois existiu a dificuldade de colocar todas as esfirras referentes aos tratamentos juntos no mesmo momento para assar, além da não uniformidade no tamanho e espessura dessas massas de esfirras. São fatores que contribuem na variação da umidade das esfirras e consequentemente nos demais nutrientes.

Tabela 3. Composição química da massa pré-assada da esfirra aberta com inclusão de farinha de peixe de diferentes espécies.

\begin{tabular}{lcccccc}
\hline Tratamentos & $\begin{array}{c}\text { Umidade } \\
(\%)\end{array}$ & $\begin{array}{c}\text { Proteína } \\
(\%)\end{array}$ & $\begin{array}{c}\text { Lipídeos } \\
(\%)\end{array}$ & $\begin{array}{c}\text { Cinzas } \\
(\%)\end{array}$ & $\begin{array}{c}\text { Carboidratos } \\
(\%)\end{array}$ & $\begin{array}{c}\text { Valor Calórico } \\
(\mathrm{kcal} / 100 \mathrm{~g})\end{array}$ \\
\hline FT & $23,69 \pm 0,44^{\mathrm{a}}$ & $13,07 \pm 0,55^{\mathrm{a}}$ & $2,43 \pm 0,65^{\mathrm{b}}$ & $4,94 \pm 0,30^{\mathrm{a}}$ & $55,86 \pm 0,65^{\mathrm{b}}$ & $297,67 \pm 6,15^{\mathrm{b}}$ \\
FTS & $23,47 \pm 0,22^{\mathrm{b}}$ & $12,00 \pm 0,52^{\mathrm{b}}$ & $2,53 \pm 0,55^{\mathrm{b}}$ & $4,20 \pm 0,44^{\mathrm{b}}$ & $57,80 \pm 1,29^{\mathrm{a}}$ & $301,95 \pm 1,87^{\mathrm{b}}$ \\
FTA & $23,4 \pm 0,16^{\mathrm{b}}$ & $12,56 \pm 0,04^{\mathrm{ab}}$ & $2,99 \pm 0,09^{\mathrm{b}}$ & $4,52 \pm 0,12^{\mathrm{ab}}$ & $56,52 \pm 0,01^{\mathrm{b}}$ & $303,24 \pm 0,58^{\mathrm{b}}$ \\
FTSA & $23,44 \pm 0,19^{\mathrm{b}}$ & $12,42 \pm 0,10^{\mathrm{ab}}$ & $4,37 \pm 1,29^{\mathrm{a}}$ & $4,91 \pm 0,27^{\mathrm{a}}$ & $55,86 \pm 0,65^{\mathrm{b}}$ & $312,43 \pm 8,61^{\mathrm{a}}$ \\
\hline C.V. $(\%)$ & 0,31 & 1,57 & 10,57 & 2,37 & 0,53 & 0,52 \\
\hline Valor de p & $<0,0001$ & 0,0240 & 0,0120 & 0,0070 & 0,0080 & 0,0030 \\
\hline
\end{tabular}

Médias na mesma coluna seguidas de letras distintas diferem entre si pelo teste de Tukey $(\mathrm{P}<0,05)$; Valores expressos em Média \pm Desvio Padrão. C. V. = Coeficiente de Variação. *FT=farinha de tilápia, FTS=farinha de tilápia+Salmão, FTA=farinha de tilápia+Atum, FTSA=farinha de tilápia +Sardinha.

A proteína bruta das massas de esfirras com inclusão de farinha aromatizada de tilápia $(13,07 \%)$, foi significativamente superior em relação a tilápia com salmão (12\%), não diferindo dos demais (Tabela 3). Tudo indica que no perfil de aminoácidos das farinhas elaboradas neste experimento apresentem resultados semelhantes aos relatados por Souza et al. (2017). Os autores afirmaram que o ácido glutâmico apareceu em maior proporção em todas as farinhas, seguido pela lisina, leucina, glicina e ácido aspártico. 
Os teores de lipídios da massa das esfirras com inclusão de farinha de sardinha $(4,37 \%)$ foi significativamente superior às demais esfirras. As cinzas nas massas das esfirras foram significativamente superiores ao FT $(4,94 \%)$ e FTSA $(4,91 \%)$, comparado as FTS $(4,20 \%)$. As esfirras com inclusão de FTS $(57,80 \%)$ apresentaram $(\mathrm{P}<0,05)$ superior teor de carboidratos comparado aos demais tratamentos, cujo valor médio foi de 56,08\% (Tabela 3). A inclusão do FTSA aumentou significativamente o valor calórico nas massas das esfirras (Tabela 3).

De acordo com Souza et al. (2017) as farinhas de salmão (53,71 g kg-1), sardinha (47,46 g kg-1) e atum (36,98 g kg-1) apresentaram as maiores quantidades de ácidos graxos da série n-3. Portanto, a inclusão da farinha de tilápia aromatizada com as de espécies marinhas (salmão, atum e sardinha) na esfirra aberta estudadas neste trabalho pode estar proporcionando uma qualidade superior de lipídeos em relação às que apenas tem a farinha de tilápia. Independente da espécie de peixe, Souza et al. (2017) afirmaram que as farinhas apresentam alto valor biológico e nutricional, sendo boa fonte de cálcio, fósforo e ferro. Baseado nestas informações tudo indica que as massas das esfirras também agregaram maior valor nutricional, em função dos aminoácidos presentes nas farinhas de peixes, assim como os ácidos graxos e minerais.

Na Tabela 4 consta a análise de composição química das esfirras aberta prontas para consumo. Não houve diferença para umidade e cinzas, cujas médias foram 23,36\% e 4,44\%, respectivamente. A esfirra pronta que apresentou o maior teor proteico $(\mathrm{P}<0,05)$ foi com inclusão de farinha aromatizada de tilápia com atum (FTA), com (20,72\%) e a esfirra com menor teor $(15,72 \%)$ foi a com a inclusão de apenas farinha aromatizada de tilápia (FT). As esfirras com farinha aromatizada com salmão apresentaram maiores teores de lipídeos e valor calórico quando comparada as esfirras com inclusão de apenas a farinha aromatizada de tilápia (FT). Isto ocorreu em função dos teores elevados de gordura presente nos resíduos de beneficiamento das espécies de peixes marinhos utilizados neste experimento (salmão, atum e sardinha), que consequentemente contribuiu no cálculo do valor calórico dessas esfirras. Também deve ser levado em consideração que nestas esfirras foram utilizadas o molho de cobertura e nesta consta o teor de azeite de oliva (Tabela 1) utilizado no molho e da carne bovina. Outra consideração refere-se à distribuição do molho sobre a massa pré-assada, que dificilmente fica uma distribuição homogênea entre as unidades de cada tratamento e mesmo entre os tratamentos. A inclusão da farinha de espécies de peixes marinhas (salmão, atum e sardinha) nas esfirras que receberam a farinha aromatizada de tilápia influenciou significativamente nos teores de carboidratos, cujos teores foram significativamente 
inferiores, ou seja, para FTS $(50,61 \%)$, FTA $(47,69 \%)$ e FTSA $(50,24 \%)$ comparadas as esfirras apenas com inclusão de farinha aromatizado de tilápia $(53,18 \%)$.

Tabela 4. Composição centesimal de esfirra aberta pronta com inclusão de farinha de diferentes espécies de peixes.

\begin{tabular}{lcccccc}
\hline Tratamentos & $\begin{array}{c}\text { Umidade } \\
(\%)\end{array}$ & $\begin{array}{c}\text { Proteína } \\
\text { Bruta }(\%)\end{array}$ & $\begin{array}{c}\text { Lipídios } \\
(\%)\end{array}$ & $\begin{array}{c}\text { Cinzas } \\
(\%)\end{array}$ & $\begin{array}{c}\text { Carboidratos } \\
(\%)\end{array}$ & $\begin{array}{c}\text { Valor Calórico } \\
(\mathrm{kcal} / 100 \mathrm{~g})\end{array}$ \\
\hline FT & $23,75 \pm 0,34^{\mathrm{a}}$ & $15,72 \pm 2,32^{\mathrm{c}}$ & $2,77 \pm 0,98^{\mathrm{b}}$ & $4,58 \pm 0,21^{\mathrm{a}}$ & $53,18 \pm 2,75^{\mathrm{a}}$ & $300,54 \pm 7,07^{\mathrm{b}}$ \\
FTS & $22,97 \pm 0,44^{\mathrm{a}}$ & $17,63 \pm 0,41^{\mathrm{b}}$ & $4,48 \pm 0,73^{\mathrm{a}}$ & $4,30 \pm 0,07^{\mathrm{a}}$ & $50,61 \pm 0,18^{\mathrm{b}}$ & $313,33 \pm 5.72^{\mathrm{a}}$ \\
FTA & $23,37 \pm 0,04^{\mathrm{a}}$ & $20,72 \pm 2,68^{\mathrm{a}}$ & $4,12 \pm 0,37^{\mathrm{a}}$ & $4,14 \pm 0,23^{\mathrm{a}}$ & $47,69 \pm 2,74^{\mathrm{c}}$ & $310,79 \pm 3,18^{\mathrm{ab}}$ \\
FTSA & $23,62 \pm 0,21^{\mathrm{a}}$ & $18,07 \pm 0,03^{\mathrm{b}}$ & $3,61 \pm 0,14^{\mathrm{a}}$ & $4,45 \pm 0,08^{\mathrm{a}}$ & $50,24 \pm 0,19^{\mathrm{b}}$ & $305,79 \pm 1,82^{\mathrm{ab}}$ \\
\hline C.V. $(\%)$ & 0,94 & 0,63 & 11,18 & 4,19 & 0,72 & 0,92 \\
\hline Valor de p. & 0,0770 & $<0,0001$ & 0,0490 & 0,2370 & $<0,0001$ & $<0,0370$ \\
\hline
\end{tabular}

Médias na mesma coluna seguidas de letras distintas diferem entre si pelo teste de Tukey $(\mathrm{P}<0,05)$; Valores expressos em Média \pm Desvio Padrão. C. V. = Coeficiente de Variação. *FT=farinha de tilápia, FTS=farinha de tilápia+Salmão, FTA=farinha de tilápia+Atum, FTSA=farinha de tilápia +Sardinha.

Campelo et al. (2017) avaliaram a inclusão de diferentes níveis ( $0 \%, 5 \%, 10 \%, 15 \%$ e $20 \%$ ) de farinha de atum na massa de pizza. Eles relataram que com o aumento do percentual de inclusão de farinha de atum resultou em elevação nos teores de proteína bruta $(10,89$ a $18,94 \%)$, de lipídeos totais $(4,63$ a 5,89\%) e de cinzas $(2,54$ a 3,54\%) nas massas, sem influenciar no teor de umidade e no valor calórico. Deveria ter sido elaborada esfirra sem a inclusão de farinha na massa, pois assim possibilitaria saber o incremento proteico que ocorreu com a inclusão das diferentes farinhas de peixes. Dessa forma, observa-se que a farinha de tilápia por ser menos proteica e gordurosa (menor teor de lipídeos) também proporcionou menor teor proteico e de lipídeos nas massas de esfirra.

Os teores de proteína bruta obtidos neste experimento foram inferiores aos relatados por Centenaro et al. (2007) que desenvolveram pães com inclusão de polpa lavada úmida e seca de cabrinha (Prionotus punctatus), obtendo aumento no conteúdo proteico de 31 e $45 \%$ para pães com inclusão de 3 e $5 \%$ de polpa lavada seca, e aumento de $48 \%$ no conteúdo proteico para pães com inclusão de $50 \%$ de polpa lavada úmida. Estes autores utilizaram inclusões de 3 e 5\% de carne mecanicamente separada (apenas a carne sem espinhas) e desidratada. O teor de proteína do produto elaborado foi muito superior aos obtidos neste trabalho, pois neste, para obtenção das farinhas foram utilizados a carne e espinhas.

Também, pães com inclusão de hidrolisado proteico do peixe cabrinha (Prionotus punctatus) apresentaram um aumento de 5,3\% no conteúdo proteico, quando comparado com pães padrão, que foi $11,5 \%$ e 7,8\%, respectivamente (SALAS-MELLADO et al., 2007). Portanto, haveria necessidade de incluir o tratamento testemunha para saber o quanto houve de incremento proteico com a inclusão da farinha de peixe. Mas, independente disso pode-se 
observar que a medida que houve a inclusão das demais espécies de peixes na farinha de tilápia houve um acréscimo no teor de proteína das esfirras aberta prontas, refletindo dessa forma a presença dos teores proteicos das espécies incluídas na mistura.

\section{Análise Sensorial das esfirras aberta prontas}

Os atributos cor e textura não apresentaram diferenças em relação aos diferentes tratamentos, apresentando notas médias de 7,02 e 6,81, respectivamente, o que corresponde na escala hedônica a gostei moderadamente (7) e gostei ligeiramente (6), mostrando assim, que em relação a esses aspectos houve boa aceitação dos provadores ao produto elaborado.

Já para os atributos sabor, aroma e impressão global, houve diferenças significativas, sendo que as esfirras com inclusão de farinha aromatizada de tilápia (FT- tratamento 1), a inclusão desta mesmo com salmão (FTS- tratamento 2), apresentam significativamente as melhores notas respectivamente para aroma $(7,20$ e 7,44) e sabor $(7,26$ e 7,52). A intenção de compra da esfirra com FTS apresentou melhor resultado, não diferindo das esfirras com FT, respectivamente (Tabela 5). Para a impressão global dos produtos, sendo os tratamentos 1 e 2 (FT e FTS) foram as que apresentaram as melhores notas 7,42 e 7,36, respectivamente. $\mathrm{O}$ tratamento 2 também foi o que obteve a melhor nota no teste de intenção de compra 4,02, indicando que os consumidores possivelmente comprariam o produto, comprovando que a esfirra com a inclusão da farinha de tilápia aromatizada com salmão (FTS), foi a que obteve melhor aceitação entre os provadores.

Avaliando diferentes níveis de farinha de atum em massa de pizza, Campelo et al. (2017), relataram que a medida que houve elevação dos níveis de inclusão na massa afetou a cor. As notas foram inferiores para as massas com 15 a $20 \%$ de farinha de atum, com pontuações de 5,68 e 5,08, respectivamente (nem gostaram / nem não gostaram) pela classificação da escala hedônica de 9 pontos de Dutcosky (2012). Neste experimento a inclusão da farinha de tilápia com atum não influenciou na cor da massa de esfirra, ou melhor, as farinhas de espécie marinhas (10\%) misturada com 90\% de farinha de tilápia não interferiu na cor das massas. Se comparado as notas dos provadores da massa de pizza com as da massa de esfirra aberta, avaliando no mesmo nível de inclusão da farinha para os dois, as notas foram 6,19 e 6,84, respectivamente.

Segundo Goes et al. (2017) a inclusão de diferentes níveis de farinha de tilápia no macarrão não afetou a cor e sabor, cujas notas variaram de 6,35 a 7,0 para estes dois atributos. Estas notas foram inferiores as obtidas para esfirra aberta com a farinha de tilápia (Tabela 5). 
Tabela 5. Resultados da análise sensorial de esfirras aberta com inclusão de farinha de peixe de diferentes espécies.

\begin{tabular}{ccccccc} 
Tratamentos & Cor & Aroma & Textura & Sabor & $\begin{array}{c}\text { Impressão } \\
\text { Global }\end{array}$ & $\begin{array}{c}\text { Intenção de } \\
\text { Compra }\end{array}$ \\
\hline CP-T & $7,14 \pm 0,12^{\mathrm{a}}$ & $7,20 \pm 0,19^{\mathrm{a}}$ & $7,00 \pm 0,19$ & $7,26 \pm 0,57^{\mathrm{a}}$ & $7,42 \pm 0,66^{\mathrm{a}}$ & $3,66 \pm 0,24^{\mathrm{ab}}$ \\
CP-TS & $7,22 \pm \mathrm{a} 0,20^{\mathrm{a}}$ & $7,44 \pm 0,43^{\mathrm{a}}$ & $7,08 \pm 0,27$ & $7,52 \pm 0,83^{\mathrm{a}}$ & $7,36 \pm 0,60^{\mathrm{a}}$ & $4,02 \pm 0,60^{\mathrm{a}}$ \\
CP-TA & $6,84 \pm 0,18^{\mathrm{a}}$ & $6,66 \pm 0,35^{\mathrm{b}}$ & $6,80 \pm 0,01$ & $6,10 \pm 0,59^{\mathrm{b}}$ & $6,42 \pm 0,34^{\mathrm{b}}$ & $3,10 \pm 0,32^{\mathrm{bc}}$ \\
CP-TSR & $6,88 \pm 0,14^{\mathrm{a}}$ & $6,74 \pm 0,27^{\mathrm{b}}$ & $6,36 \pm 0,45$ & $6,88 \pm 0,19^{\mathrm{b}}$ & $5,90 \pm 0,86^{\mathrm{b}}$ & $2,88 \pm 0,54^{\mathrm{c}}$ \\
\hline C.V. $(\%)$ & 21,65 & 23,04 & 24,13 & 25,71 & 23,91 & 33,98 \\
\hline Valor de p & 0,5130 & 0,0490 & 0,1270 & $<0,0001$ & $<0,0001$ & $<0,0001$ \\
\hline
\end{tabular}

Médias na mesma coluna seguidas de letras distintas diferem entre si pelo teste de Tukey $(\mathrm{P}<0,05)$; Valores expressos em Média \pm Desvio Padrão. C. V. = Coeficiente de Variação. *FT=farinha de tilápia, FTS=farinha de tilápia+Salmão, FTA=farinha de tilápia+Atum, FTSA=farinha de tilápia +Sardinha.

Gaio et al. (2014) elaboraram pão de milho com diferentes concentrações de farinha de carcaça de tilápia do Nilo. Segundo os autores a formulação com $50 \%$ de farinha de tilápia apresentou 25,8 \% de intenção de compra, sendo o maior índice de aceitabilidade para o pão de milho sem adição de farinha de carcaça de tilápia (33,33\%). Os autores relataram que o índice de aceitabilidade (IA) foi $82,44 \% ; 77,6 \% ; 74 \%$ e $75,06 \%$, respectivamente para as formulações F0\% (sem adição), F10\% (10\% de adição), F15\% (15\% de adição) e F20\% (20\% de adição) de farinha de carcaça de tilápia. Pode se considerar um alimento de acordo com suas propriedades sensoriais aceito ao se obter um índice de aceitabilidade de no mínimo $\geq$ $70 \%$ (BISPO et al., 2004).

Campelo et al. (2017) recomendaram a adição de 5 a $20 \%$ de farinha de atum à massa de pizza, por ser eficaz na melhoria do valor nutricional e no perfil de ácido graxos e não interferiu nos atributos de aroma, sabor, impressão global e intenção de compra das pizzas. Porém, neste experimento das esfirras aberta, o sabor, aroma, impressão global e intenção de compra de certa forma foram afetados pelas caracteristicas organolepticas da inclusão da farinha de tilápia com atum e da farinha de tilápia com sardinha nas esfirras, cujo sabor, aroma e cor ficaram forte quando comparado as esfirras com farinha de tilápia e salmão ou somente farinha aromatizada de tilápia.

\section{Conclusões}

Quanto à análise microbiológica, as farinhas das diferentes espécies de peixes, a massa pré-assada e a esfirra aberta pronta se apresentaram dentro dos padrões de consumo exigidos pela legislação vigente, portanto estavam aptas para o consumo humano.

A farinha aromatizada de tilápia com atum e com sardinha apresentaram maiores teores de proteínas. As farinhas apresentaram baixo teor de carboidratos, a farinha de tilápia com atum apresentou maior valor calórico e menor teor de cinzas, isto ocorreu em função do 
tipo de matéria prima utilizada na elaboração da farinha de atum, por apresentar mais carne do que o espinhaço do peixe.

As esfirras prontas para consumo não apresentaram diferença no teor de umidade $\mathrm{e}$ cinzas. Porém, com inclusão de tilápia aromatizada e demais farinhas (salmão, atum e sardinha) aumentou o teor proteico das esfirras prontas, assim como o valor calórico, mas reduziu os teores de carboidratos nessas esfirras.

O produto foi bem aceito pelos provadores e a preferência foi pela esfirra aberta com inclusão da farinha aromatizada de tilápia (100\%) (FT) e as esfirras com inclusão da farinha aromatizada de tilápia (90\%) com salmão (10\%) (CP-TS), indicando que comprariam caso estas estivessem disponíveis no mercado.

\section{Referências}

AOAC, Association Methods of Analysis of AOAC International, 2005.

APHA. Compendium of methods for the microbiological examination of foods. 3. ed. Washington, DC, p.1219, 1992.

ARRUDA, L. F. Aproveitamento do resíduo do beneficimaneto de Tilápia do Nilo para obtenção de silagem e óleo como subprodutos. Piracicaba, 2004.

BISPO, E. S.; SANTANA, L. R. R.; CARVALHO, R. D. S.; LEITE, C. C.; LIMA, M. A. C. Processamento, estabilidade e aceitabilidade de marinado de vongole (anomalocardia brasiliana). Ciência e Tecnologia de Alimentos, Campinas, v 3, p. 353-356, 2004.

BLIGH, E.G.; DYER, W.J.; Can. J. Biochem. Physiol. 1959.

BORGHESI, R.; HISANO, H.; SUCASAS, L. F. A.; LIMA, L. K. F.; MARÍLIA OETTERER, M. Influencia da nutrição sobre a qualidade do pescado: especial referência aos ácidos graxos-Corumbá : Embrapa Pantanal; Dourados : Embrapa Agropecuária Oeste, p. 21, 2013.

BRASIL. Agência Nacional de Vigilância Sanitária. Resolução - RDC no 12 (D.O.U de D.O.U de 02/01/2001). Padrão Microbiológico para Alimentos, 2001.

CARDOSO, A. A.; CORADINI, M. F.; SOUZA, M. L. R.; CHAMBO, A. P. S.; Panqueca sem glúten com a inclusão dos níveis de concentrado proteico de peixe, análise, composição química e microbiológica. ANAIS do VI Simpósio de Gestão do Agronegócio e VI Mostra de trabalhos científicos, 2015.

CENTENARO G. S. Enriquecimento de pão com proteínas de pescado. Ciência e Tecnologia de Alimentos. V 27 Campinas July/Sept. 2007.

DAMÁSIO, M. H.; SILVA, M. A. A. P. Curso de treinamento em análise sensorial. Apostila. Campinas: Fundação Tropical de Tecnologia "André Tosello", 1996.

DUTCOSKY, S., D. Análise sensorial de alimentos. 4. ed. Curitiba: Champagnat, p. 531, 
2011.

GAIO, C.; SCOPEL, T. Elaboração de pão de milho com diferentes concentrações de farinha de carcaça de tilápia do nilo (Oreochromis niloticus). Medianeira, 2014.

GODOY, L. C.; FRANCO, M. L. R. S.; FRANCO, N. P.; SILVA, A. F.; ASSIS, M. F.; SOUZAI, N. E.; MATSUSHITA, M.; VISENTAINER, J. V. Análise sensorial de caldos e canjas elaborados com farinha de carcaças de peixe defumadas: aplicação na merenda escolar. Campinas: Ciência e Tecnologia de Alimentos, p. 86-89, 2010.

GODOY, L. C.; FRANCO, M. L. R. S.; FRANCO, N. P.; SILVA, A. F.; ASSIS, M. F.; SOUZAI, N. E.; MATSUSHITA, M.; VISENTAINER, J. V.

HUSS, H.H. Garantia da qualidade dos produtos de pesca. 334. ed. Roma: Fao, p. 176, 1997.

IBRAHIM, S. M.; Evaluation of Production and Quality of Salt-Biscuits Supplemented with Fish Protein Concentrate. World Journal of Dairy \& Food Sciences. v 4, p. 28-31, 2009.

KUBTIZA, F. Aproveitamento dos subprodutos do processamento de pescados. Panorama da Aquiicultura, v 16, p. 23-29, 2006.

MEDEIROS, P. R. M. S. Composição química e avaliação sensorial de biscoitos elaborados com polpa de pequi desidratada. Goiânia, p. 72, 2009.

MEILGAARD, M.; CIVILE, G.V.; CARR, B.T. Sensory evaluation techniques. 2. ed.MPA. Ministério da Pesca e Aquicultura. Boletim estatístico da pesca e aquicultura: Brasil 2010. Brasília, 2013.

MINOZZO, M. G.; WASZCZYNSKYJ, N.; BEIRÃO, L.H. Características físico-químicas do patê de tilápia do nilo (Oreochromis niloticus), comparado a produtos similares comerciais. Alim. Nutr., Araraquara, v 15, p. 101-105, 2004.

NEUTZLING, I. Água: bem público universal. : Editora unisinos, p. 143, 2004.

OETTERER, M. Tecnologias emergentes para processamento do pescado produzido em piscicultura. In: Cyrino, J. E.P. et al. Tópicos especiais em Piscicultura de água doce tropical intensiva. São Paulo: TecArt, p. 481-500, 2004.

FURLAN, E.; GALVÃO, J.; MACIEL, E.; MATTHIENSEN, A.; OETTERER, M. Qualidade e processamento do pescado. Rio De Janeiro: Elsevier Editora Ltda, 2014.

OLIVEIRA, M. V. M.; SANCHEZ, L. M. B.; JÚNIOR, F. M. V.; PÉREZ, J. R. O.; PIRES, C. C.; HAYGERT, I. M. P.; FRIZZO, A.; LANA, R. P. Avaliação das Farinhas de Peixe e Pena, no Confinamento de Bezerros Leiteiros Desmamados, Através de Dietas Calculadas em Termos de Proteína Bruta ou de Proteína Metabolizável, R. Bras. Zootec, v 31, p. 1571-1581, 2002.

OLIVEIRA, M. V. M.; SANCHEZ, L. M. B.; JÚNIOR, F. M. V.; PÉREZ, J. R. O.; PIRES, C. C.; HAYGERT, I. M. P.; FRIZZO, A.; LANA, R. P.

PETENUCI, M. E.; STEVANATO, F. B.; MORAIS, D. R.; SANTOS, L. P.; SOUZA, N. 
E.;VISENTAINER, J. V. 2010. Composição e estabilidade lipídica da farinha de espinhaço de tilápia. Ciência e agrotecnologia, v 34, p. 1279-1284, 1993.

RIISPOA - Regulamento da Inspeção Industrial e Sanitária de Produtos de Origem animal. Ministério da Agricultura, Pecuária e Abastecimento. Seção II- Derivado do Pescado, Artigo 466, 1997.

ROCHA, J. B. S.; SILVEIRA, C. S.; LEDO, C. A. S.; BARRETO - MAGISTRA, N. S. E. Composição e estabilidade de farinha de tilápia ( ) produzida artesanalmente para o consumo humano. 4. ed. Cruz Das Almas: Magistra, p. 215-220, 2011.

SALAS-MELlADO, M.; HERNÁNDEZ, C. P.; MORAES, K. S.; ZAVAREZE, E. R. Produção de hidrolisado de cabrinha (Prionotus punctatus) e o efeito na composição química e características tecnológicas de pão. R. Bras. Agrociência, Pelotas, v 13, p. 349-353, 2007.

SAS user'sguide: Statistics. Statistical Analysis System Institute Inc, Cary, NC. 2005. Silva, D.J.; Queiroz, A.C. Análise De Alimentos: Métodos Químicos e Biológicos.

SIMOES, D. R. S.; QUEIROZ, M. I.; VOLPATO, G.; ZEPKA, L. Q. Desodorização de base protéica de pescado (BPP) com ácido fosfórico. Ciência e Tecnologia de Alimentos, v 24, p. 23-26, 2004.

SOARES, K. M. P; GONÇALVES, A A. Qualidade e segurança do pescado. 71. ed. São Paulo: Rev. Inst. Adolfo Lutz (Impr.), 2012.

SOUCI, S.W.; FACHMAN, H.; KRAUT, E. Foods composition and nutrition tables, St.ed Stuttgart: Medpharm Scientific Publishers, p. 1188, 2000.

Souza, M. L. R. Industrialização, comercialização e perspectivas. In: ZIMMERMANN, S.; RIBEIRO, R. P; MARQUES, H.L.M.; VARGAS, L. (Org.). Fundamentos da Moderna Aqüicultura. 1 ed. Canoas: ULBRA, p. 149-189, 2001.

STONE, H.; SIDEL, J. L. Sensory Evaluation Practices, 2 ed. San Diego: Academic Victorino, Célia Jurema Aito. Planeta água morrendo de sede: uma visão analítica na metodologia do uso e abuso dos recursos hídricos. Porto Alegre: EDIPUCRS, 2007.

Vale S.A, Brasil, 2012.

VIEIRA, V.I.; FRANCO, M.L.R.S.; MIKCHA, J.M.G.; GASPARINO, E. Elaboração de pão de mel com diferentes níveis de inclusão de farinha de peixe: análise de composição centesimal, microbiológica e sensorial. In.:XXII Encontro Anual de Iniciação Científica. Anais ... Maringá, 2013.

VILA NOVA, C. M. V. M.; GODOY, H.T.; ALDRIGUE, M. L. Composição química, teor de colesterol e caracterização dos lipídios totais de tilápia (Oreochromis niloticus) e pargo (Lutjanus purpureus). Ciência e Tecnologia de Alimentos. v 25, p. 430-436, 2005. 


\title{
CAPÍTULO 07: PESQUISA DE MERCADO E AVALIAÇÃO SENSORIAL DE SORVETE DE POLPA DE JACA LIOFILIZADA
}

\section{CHAPTER 07: MARKET RESEARCH AND SENSORY EVALUATION OF LYOPHILIZED JACK FRUIT PULP ICE CREAM}

Guilherme Miiller Pereira ${ }^{1}$; Henry Charles Albert David Naidoo Terroso de Mendonça Brandão ${ }^{2}$; William Arthur Philip Louis Naidoo Terroso de Mendonça Brandão ${ }^{3}$ Saraspathy Naidoo Terroso Gama de Mendonça ${ }^{4}$

\begin{abstract}
Resumo
A produção de jaca no Brasil, ocorre nos meses de janeiro a abril, necessitando de tecnologias que preservem o fruto para consumo. A utilização do método de liofilização, conhecido como processo de secagem, oferece produtos de elevada qualidade. Este estudo almejou desenvolver um sorvete com a polpa de jaca liofilizada e avaliar a sua qualidade microbiológica, e sensorial, após a aplicação de uma pesquisa de mercado, abrangendo 120 participantes. Observou-se que $38,3 \%$ dos entrevistados consomem leite uma vez ao dia, 5,8\% tem o hábito de consumir leite mais de três vezes ao dia e $15 \%$ não tem o hábito de consumo. Quanto ao consumo de frutas frescas, notou-se que somente $22,5 \%$ consomem três vezes ao dia. Notou-se que o consumidor de frutas desidratadas ainda é restrito, pois $65,8 \%$ dos entrevistados afirmaram não ter o hábito de consumir frutas desidratadas, sendo um ponto positivo e motivador para a elaboração de gelados comestíveis com adição da polpa de jaca liofilizada. Observou-se que a formulação F2 (7,40\% de polpa de jaca liofilizada), apresentou intensidade para o sabor e aroma, cor, cremosidade, e doçura na "medida certa", indicando que esta quantidade de polpa de jaca liofilizada adicionada no sorvete, atendeu às expectativas dos consumidores.
\end{abstract}

Palavras-Chaves: Fruta, Secagem, Gelado comestível.

\begin{abstract}
Jackfruit production in Brazil takes place from January to April, requiring technologies that preserve the fruit for consumption. The use of the freeze-drying method, known as the drying process, offers high quality products. This study aimed to develop an ice cream with lyophilized jackfruit pulp and to evaluate its microbiological and sensory quality, after the application of a market research, covering 120 participants. It was observed that $38.3 \%$ of the interviewees consume milk once a day, $5.8 \%$ have the habit of consuming milk more than three times a day and $15 \%$ do not have the habit of consuming it. As for the consumption of fresh fruits, it was noted that only $22.5 \%$ consume three times a day. It was noted that the consumer of dehydrated fruits is still restricted, as $65.8 \%$ of the interviewees stated that they did not have the habit of consuming dehydrated fruits, being a positive and motivating point for the production of edible ice creams with the addition of lyophilized jackfruit pulp. It was observed that the formulation F2 (7.40\% of lyophilized jackfruit pulp), presented intensity for the flavor and aroma, color, creaminess and sweetness in the "right measure", indicating that this amount of lyophilized jackfruit pulp added in the ice cream, met consumer expectations
\end{abstract}

Keywords: Fruit, Drying, Edible ice cream.

\footnotetext{
${ }^{1}$ Engenharia de Alimentos, Universidade Tecnológica Federal do Paraná-MD, guilhermemiiller@ hotmail.com

${ }^{2}$ Licenciatura em Química, Universidade Tecnológica Federal do Paraná-MD, henrybrandao@utfpr.edu.br

${ }^{3}$ Engenharia de Alimentos, Universidade Tecnológica Federal do Paraná-MD, terroso@utfpr.edu.br

${ }^{4}$ Pós-Graduação em Tecnologias Computacionais para o Agronegócio, Universidade Tecnológica Federal do Paraná-MD, naidoo@utfpr.edu.br
} 


\section{Introdução}

A jaca possui uma casca com uma coloração amarelada, onde os frutículos possuem sabor doce e odor forte e característico, reconhecível a longa distância, sendo estes os principais atributos favoráveis ao seu consumo (MITRA; MAITY, 2002). É uma fruta rica em cálcio, fósforo e ferro e vitaminas do complexo B, principalmente as vitaminas B2 (Riboflavina), B5 (Niacina) e fibras, sendo indicada às pessoas com problemas intestinais (CRANE; BALERDI; CAMPBELL, 2002; SOUZA et al, 2009).

Devido a sua composição nutricional relevante, a polpa de jaca pode ser utilizada no desenvolvimento de produtos, como por exemplo o sorvete. Segundo a Resolução RDC no 266 de 2005, o sorvete é definido como um gelado comestível, sendo esse um produto alimentício obtido a partir de uma emulsão de gorduras e proteínas, com ou sem adição de outros ingredientes e substâncias, ou de uma mistura de água, açúcares e outros ingredientes e substâncias que tenham sido submetidas ao congelamento, em condições tais, que garantam a conservação do produto no estado congelado ou parcialmente congelado, durante a armazenagem, o transporte e a entrega ao consumo (BRASIL, 2005).

Considerada uma fruta sazonal, a jaca (Artocarpus heterophyllus, Lam) é produzida e comercializada na região Nordeste, e seu consumo ocorre, quase na sua totalidade, sob a forma in natura. A sua produção ocorre nos meses de janeiro a abril, a razão pela qual, nos meses restantes necessita-se de tecnologias que preservem ou transformem o fruto fresco para posterior consumo (DUARTE et al., 2012).

A técnica de secagem de frutas é empregada para melhorar a estabilidade através da diminuição da atividade de água, onde são utilizadas várias técnicas de preservação como: secagem solar, secagem convectiva, micro-ondas, desidratação osmótica, "spray-drying" liofilização e leito fluidizado (MARQUES; SILVEIRA; FREIRE, 2006).

A utilização do método de liofilização, que é conhecido como o processo de secagem, oferece produtos de elevada qualidade. Devido à ausência de água líquida e às baixas temperaturas requeridas no processo, o encolhimento e a migração de sólidos solúveis no interior do material são minimizados. A estrutura porosa do material seco facilita a rápida reidratação, e a retenção de componentes aromáticos voláteis (RATTI, 2001; GEORGE; DATTA, 2002).

No intuito de se identificar o comportamento e expectativas de consumo de frutas, e a aceitabilidade de produtos elaborados com a sua polpa, um instrumento eficaz na obtenção de dados, pode ser a pesquisa de mercado e a aplicação da análise sensorial pode fornecer subsídios para o desenvolvimentos de produtos alimentícios. 
Tanto o marketing como o estudo do comportamento do consumidor, têm se tornado fatores decisivos para o sucesso das empresas, pois a decisão e a satisfação, são influenciados por fatores culturais, sociais, pessoais e psicológicos, que precisam ser bem conhecidos e observados pelas organizações, sendo importante que os clientes estejam encantados pelas empresas que podem satisfazer suas necessidades, uma vez que esse encantamento é decisivo para a realização da compra, bem como para sua fidelização e atração de novos consumidores (QUIRINO, 2018).

O comportamento do consumidor engloba o estudo do fato de que existe uma forte influência dos ambientes sociais e também da cultura quanto ao hábito de compra (SCHIFFMAN; KANUK, 2000).

Através de uma análise minuciosa do comportamento do consumidor, é possível planejar as melhores estratégias de lançamento de um produto, agregar serviços, inovar, posicionar-se, buscar mercados, ou a melhor forma de condução da divulgação de um produto ou serviço (OLIVEIRA, 2016).

A pesquisa de mercado é uma ferramenta estratégica de negócios, que o marketing executa e conduz para atender o mercado quanto às intenções de produtos bem como às motivações e hábitos de compra dos consumidores, estratégias de concorrência e as tendências do ambiente como produtos, marcas, lugares, figuras públicas, consumidores e empresas (LARIOS-GÓMEZ et al., 2017).

No domínio sobre a preferência humana, a distinção ocorre entre os alimentos aceitos pelas suas propriedades sensoriais e aqueles ingeridos pelo benefício proporcionado (ROZIN, 1996). Segundo o Instituto Adolfo Lutz (2008), a análise sensorial é realizada em função das respostas transmitidas pelos seres humanos em relação ás sensações provenientes de reações de certos estímulos. Isto gera a interpretação das propriedades intrínsecas dos produtos ao serem analisados. Nesta relação os estímulos são medidos por processos físicos e químicos e as sensações por efeitos psicológicos, onde são utilizados os sentidos da visão, olfato, audição, tato e gosto.

A análise sensorial é importante para avaliar a aceitabilidade de um novo produto disponível no mercado bem como a qualidade do mesmo (TEIXEIRA, 2009).

Este estudo almejou observar o comportamento de consumo sobre frutas, leite e o estado nutricional dos participantes envolvidos nesta pesquisa, e avaliar a aceitabilidade de formulações de sorvete elaborado com polpa de jaca liofilizada. 


\section{Material e Métodos}

As jacas, adquiridas no comércio local do município de Medianeira-Pr, foram submetidas a um processo de higienização com hipoclorito de sódio a $2 \%$ por 15 minutos (BRASIL, 2013), para posterior eliminação de contaminantes, e em seguida foram descascadas, separando-se a semente da polpa, seguida da etapa de congelamento a $-18{ }^{\circ} \mathrm{C}$ em Freezer (modeloTensão (V), marca Consul). As polpas de jaca foram submetidas ao processo de liofilização em um equipamento (modelo Freezone 6, marca Labconco), a uma pressão de 1 mbar e temperatura de $60^{\circ} \mathrm{C}$ por 72 horas.

Todo o processo de produção do sorvete foi realizado no laboratório de Laticínios da Universidade Tecnológica Federal do Paraná - UTFPR Câmpus Medianeira. Para o estudo foram elaboradas três formulações de gelado comestível, com diferentes concentrações de polpa de jaca liofilizada (PJL): Tratamento 01 uma formulação controle ou padrão (sorvete de creme com adição de soro de leite em pó), sem adição de polpa de jaca liofilizada; Tratamento 02: foi elaborada uma formulação (sorvete de creme com adição de soro de leite em pó), adicionando-se 7,40\% de polpa de jaca liofilizada; Tratamento 03: foi elaborada uma formulação (sorvete de creme com adição de soro de leite em pó) adicionando-se 19,35\% de polpa de jaca liofilizada.

A calda do sorvete padrão foi composta por leite UHT, soro de leite em pó, açúcar refinado, creme de leite, emulsificante, estabilizante e saborizante de creme. Para que fosse possível garantir a qualidade do produto elaborado, as formulações foram pasteurizadas a $63^{\circ} \mathrm{C}$ por 30 minutos, conforme exigência da legislação para gelados comestíveis (MAPA,2003), e submetidas às análises microbiológicas realizadas no Laboratório de Microbiologia da UTFPR, Câmpus, Medianeira-PR, conforme legislação vigente.

Desta forma, foram realizadas as análises microbiológicas no produto final/sorvete de jaca, estabelecidas pela Resolução RDC nº 12 de 02 de janeiro de 2001 da Agência Nacional de Vigilância Sanitária (BRASIL, 2001) em sorvete, como: Staphylococcus coagulase positiva, Salmonella $s p$ e Coliformes $45^{\circ} \mathrm{C}$. Foi realizada a análise de coliformes a $35^{\circ} \mathrm{C}$ mesmo não havendo limite na legislação vigente. As metodologias empregadas para as análises microbiológicas seguiram a Instrução Normativa $n^{\circ} 62$ de 26 de agosto de 2003, sendo estas realizadas em triplicata (BRASIL, 2003).

A análise sensorial, de todas as formulações de sorvete de jaca elaboradas, foi realizada no laboratório de Análise Sensorial (LB-24) da UTFPR Campus Medianeira, mediante a colaboração de 120 avaliadores não treinados, constituídos por funcionários públicos, funcionários terceirizados, alunos dos cursos de Tecnologia de Alimentos da UTFPR, 
Tecnologia Ambiental, Desenvolvimento de Sistemas, Engenharia de Alimentos, Engenharia Elétrica, PROFOP, Engenharia de Produção, e foi aplicada a Escala do Ideal (Just About RightJAR), para medir a intensidade desejada dos atributos no sorvete, pelos consumidores e a sua intenção de compra (DUTCOSKY, 2013). Realizou-se uma pesquisa de mercado sobre o consumo de frutas, leite, frutas desidratadas, e dados como sexo, peso, altura e idade.

Submeteu-se o projeto ao Comitê de Ética em Pesquisa com Seres Humanos, que foi aprovado sob o parecer de número 1.675.812, para o seu desenvolvimento, conforme previsto na Resolução 466/2012 do Ministério da Saúde.

\section{Resultados e Discussão}

A pesquisa de mercado abrangeu a aplicação de um questionário, abordando-se a opinião de 120 avaliadores, sendo 40,84\% homens e 59,17\% mulheres, na categoria de estudantes, professores e funcionários da Universidade Tecnológica Federal do Paraná, UTFPR câmpus Medianeira, e na faixa etária de 18-59 anos. Abordaram-se questões sobre o índice de massa corporal (IMC), hábitos de consumo de leite, frutas in natura e desidratadas, como informações necessárias para o desenvolvimento de formulações de sorvete adicionado de polpa de jaca liofilizada.

A Tabela 1 apresenta os dados relacionados ao IMC (Índice de Massa Corpórea), obtido a partir da relação massa corporal e estatura $\left(\mathrm{kg} / \mathrm{estatura}^{2}\right)$ ou Índice de Quetelet $\left(\mathrm{kg} / \mathrm{m}^{2}\right)$, que se baseia em padrões internacionais desenvolvidos para pessoas adultas, e propostos pela Organização Mundial de Saúde (WHO, 2000), que subsidiaram a análise nesta pesquisa.

Tabela 1. Classificação de peso pelo índice de massa corporal (IMC).

\begin{tabular}{ccc}
\hline Classificação & $\mathrm{IMC}\left(\mathrm{Kg} / \mathrm{m}^{2}\right)$ & Risco de Comorbidades \\
\hline Baixo Peso & $<18,5$ & Baixo \\
Peso Normal & $18,5-24,9$ & Médio \\
Sobre Peso & $\geq 25$ & - \\
Pré-obeso & 25,0 a 29,9 & Aumentado \\
Obeso I & 30,0 a 34,9 & Moderado \\
Obeso II & 35,0 a 39,9 & Grave \\
Obeso III & $\geq 40,0$ & Muito grave \\
\hline \multicolumn{2}{c}{ Fonte: WHO (2000). }
\end{tabular}

A Figura 1 aponta os dados relacionados ao IMC (Índice de Massa Corpórea), obtido a partir da relação massa corporal e estatura $\left(\mathrm{kg} /\right.$ estatura $\left.^{2}\right)$ ou Índice de Quetelet $\left(\mathrm{kg} / \mathrm{m}^{2}\right)$. Foram realizados 120 registros para se classificar o IMC dos participantes, segundo a classificação da Organização Mundial de Saúde (WHO, 2000). 
Os resultados encontrados (Figura 1), indicam que 19,17\% dos entrevistados encontram-se dentro do limite de normalidade de peso, $25 \%$ apresentam-se com peso abaixo do desejável e 26,7\% apresentam-se acima do peso normal, na faixa do sobrepeso. Tem-se identificado que $15,9 \%$, encontram-se na faixa de pré-obeso, e 13,23\% dos entrevistados estão distribuídos nas faixas de obesidade grau I, II e III o que sugere uma intervenção nutricional neste grupo. De acordo com Carvalho et al., (2001), é provável que para o controle da obesidade e para se evitar as enfermidades associadas, seja necessário não só controlar a ingestão energética, mas também, a composição dos alimentos ingeridos no sentido de se obter uma alimentação mais saudável.

Figura 1. IMC (Índice de Massa Corpórea) dos avaliadores.

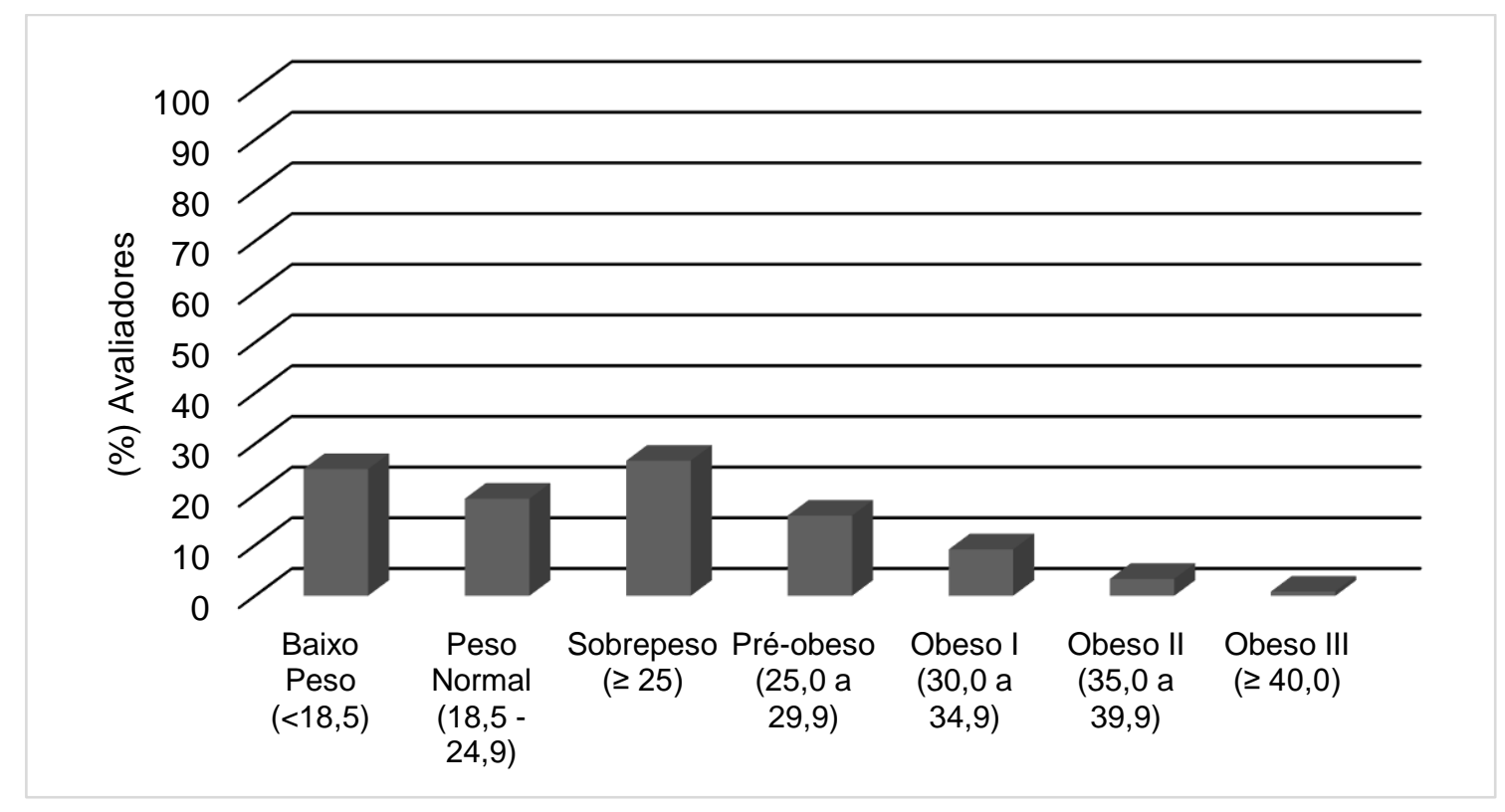

Fonte: Própria (2016).

Na Figura 2, verificou-se que dos 120 avaliadores, 38,3\% consomem leite uma vez ao dia, 22,5\% consomem duas vezes, 18,3\% consomem três vezes ao dia, 5,8\% tem o hábito de consumir leite mais de três vezes ao dia e $15,1 \%$ não tem o hábito de consumir leite.

Os principais objetivos de uma alimentação saudável e equilibrada são a promoção da saúde e a prevenção de doenças, pois o leite de vaca contém vários nutrientes, podendo se destacar as proteínas, carboidratos, lipídios, vitaminas e minerais. Na adolescência o leite fornece condições para o rápido crescimento com ótima constituição muscular, óssea e endócrina, onde, a ingestão adequada de cálcio é fundamental, pois $95 \%$ da quantidade total de cálcio dos ossos depositam-se entre os 18 e 22 anos. E nas mulheres, mais de $51 \%$ do pico de massa óssea é acumulado durante a puberdade (JACKMAN et al., 1997; PHILIPPI, 2011). 
Figura 2. Frequência de consumo de leite.

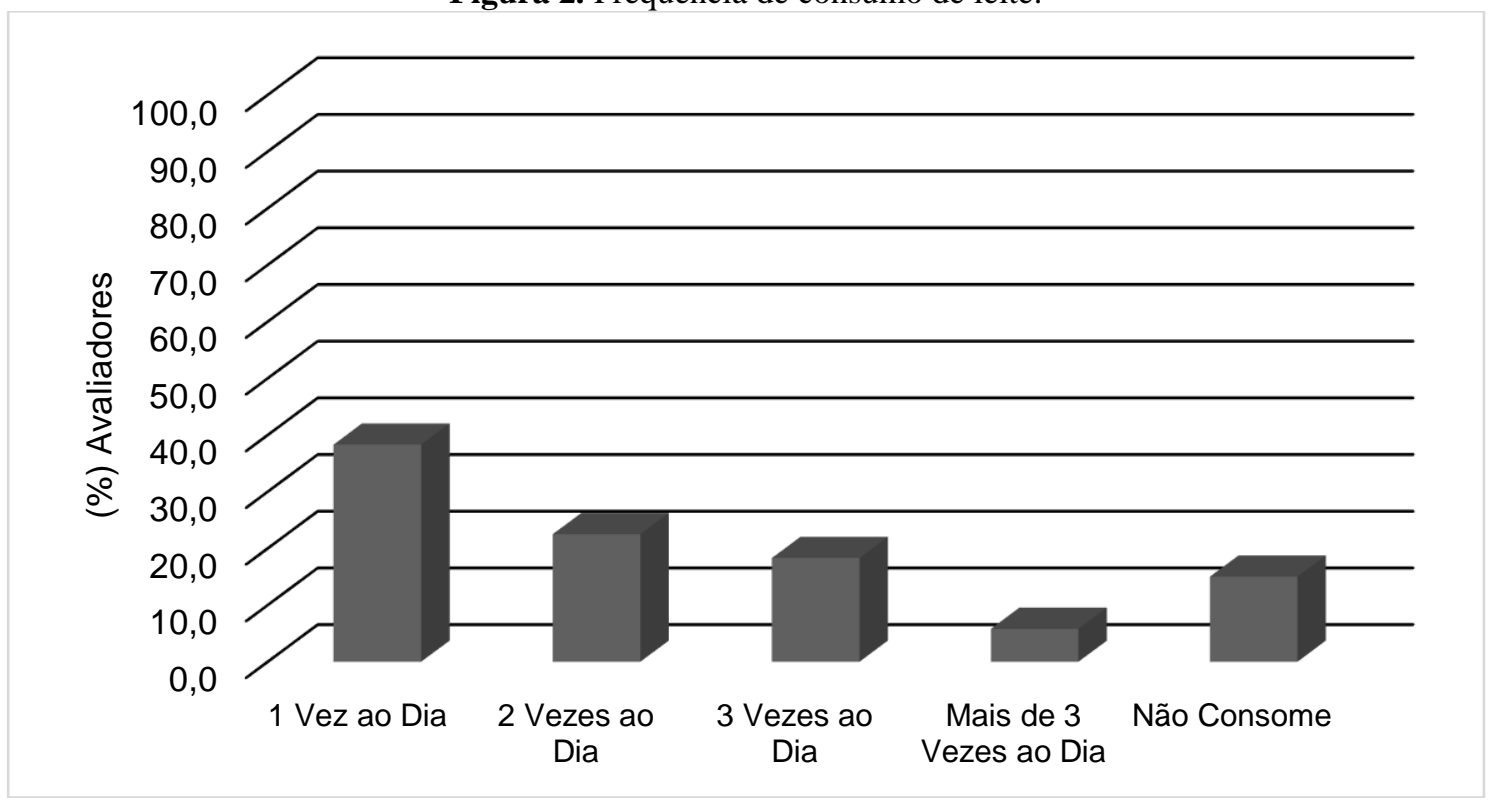

Fonte: Própria (2016).

A Figura 3 mostra dados inerentes a frequência de consumo de fruta in natura, onde apenas $1,7 \%$ dos entrevistados disseram não consumir frutas. Pelo menos $30 \%$ consomem uma vez ao dia, 37,5\% duas vezes ao dia, e $22,5 \%$ consomem três vezes ao dia, e $8,3 \%$ consomem acima de três vezes ao dia. Observando-se a Figura 3, notou-se que um total de 98,3\% dos avaliadores consome frutas diariamente, porém 67,5\% ingerem abaixo da recomendação do Guia Alimentar Brasileiro do Ministério da Saúde, de no mínimo três porções por dia (BRASIL,2005).

Segundo dados da Organização Mundial da Saúde (2010), define, para a população, metas de ingestão de frutas seja diariamente, pela extrema importância do benefício da ingestão de nutrientes como vitaminas, água, minerais, fibras, etc. Recomenda o consumo de, pelo menos, $400 \mathrm{~g}$ de frutas e verduras diariamente, sendo de três a cinco porções de frutas com cores variadas para garantir uma fonte de nutrientes mais completa e a prevenção de doenças cardiovasculares, câncer, diabetes e obesidade. O relatório afirma que há evidências convincentes de que as frutas diminuem o risco de obesidade e doenças cardiovasculares, e que as mesmas, provavelmente, diminuem o risco de diabetes.

O principal motivo pelos quais os entrevistados consomem frutas in natura é atribuído ao valor nutritivo e aos efeitos terapêuticos, como os benefícios a saúde.

Analisando a Figura 4, percebe-se que o consumidor de frutas desidratadas ainda é restrito, pois $65,8 \%$ dos entrevistados e avaliadores, afirmaram não ter o hábito de consumir frutas desidratadas e $34,8 \%$ alegaram consumir frutas desidratadas, sendo este um ponto 
positivo na elaboração de gelados comestíveis com adição da polpa de jaca liofilizada enriquecendo o produto final.

Figura 3. Frequência de consumo de frutas in natura pelos avaliadores.

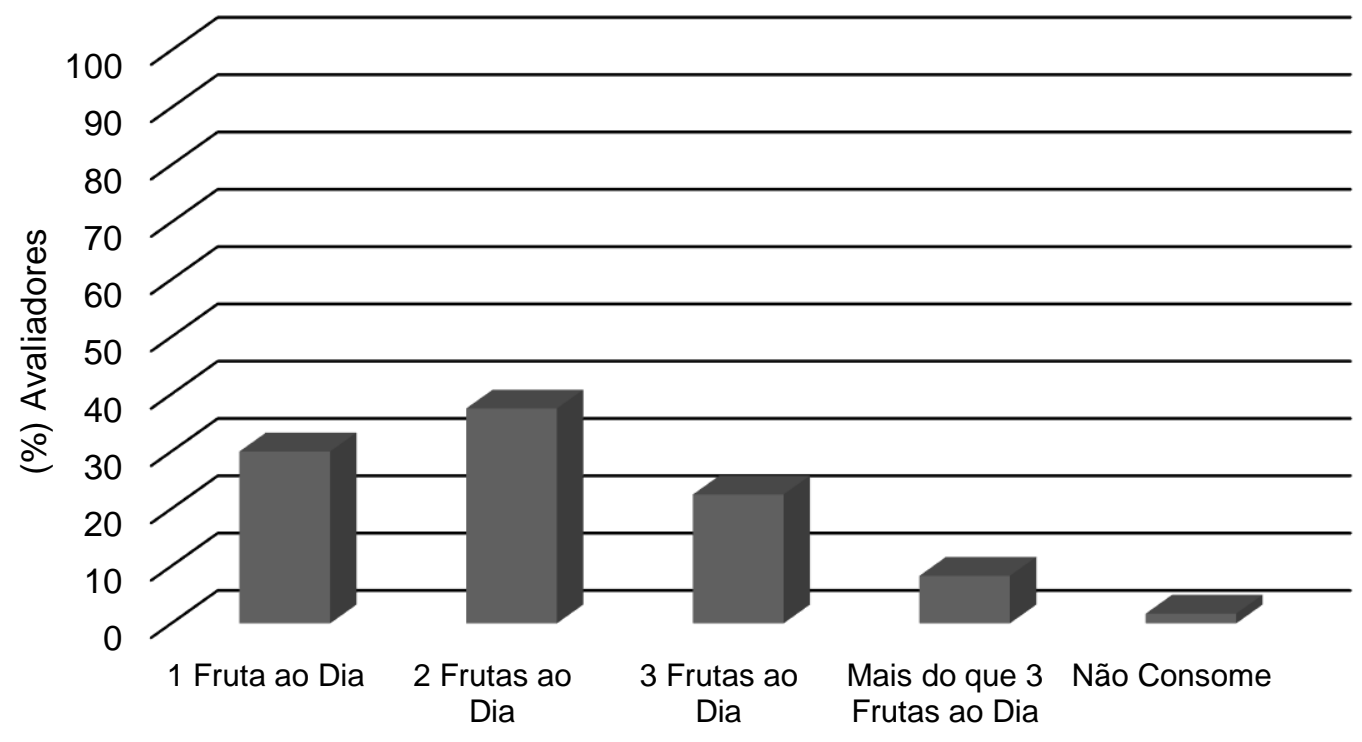

Fonte: Própria (2016).

Figura 4. Frequência de consumo de frutas desidratadas.

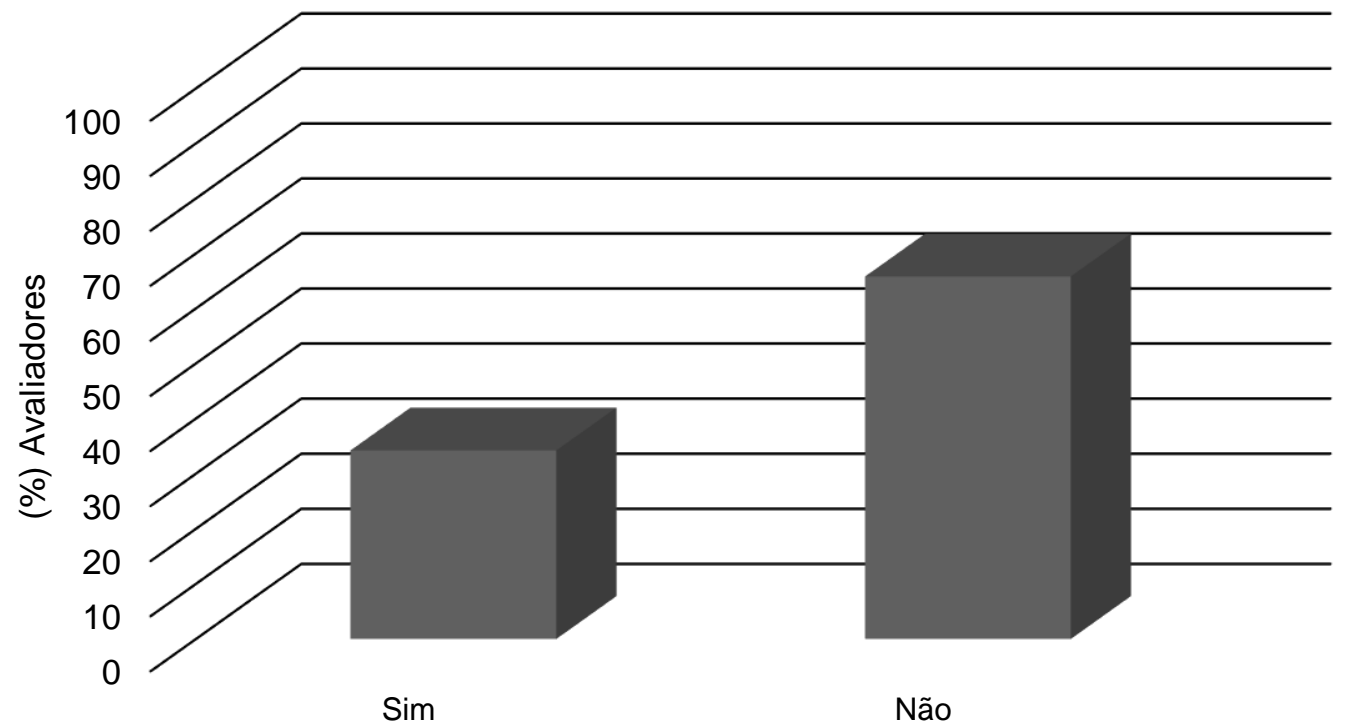

Fonte: Própria (2016).

Segundo a Agência Nacional de Vigilância Sanitária (ANVISA, 2005), a fruta desidratada, é o produto obtido pela perda parcial da água da polpa da fruta in natura, por processos tecnológicos adequados que possibilitem a manutenção de no máximo $25 \%$ de 
umidade (g/100 g), mas as frutas desidratadas atingem o nível de 10 a 15\%, de umidade para que não haja atividade dos microrganismos presentes nos alimentos, evitando-se assim a perda da qualidade. As frutas secas, ao contrário das frutas in natura, representam uma fonte mais concentrada de nutrientes, fibras e compostos bioativos.

Segundo Matos (2007), as vantagens da desidratação das frutas estão na possibilidade de seu consumo anterior ao período de safra, preservação de excedentes de colheita, aumento de sua vida útil, agregação de valor ao produto, além de reduzir custos com transporte, embalagem e requerer menor área para armazenamento, fonte de energia.

Segundo a Resolução RDC nº 12, de 02 de janeiro de 2001(BRASIL, 2001), as análises microbiológicas foram conduzidas para avaliar a qualidade dos gelados comestíveis para verificar a existência de micro-organismos e para obtenção de informações sobre as condições de higiene durante a produção e a qualidade da polpa de jaca liofilizada, utilizada na elaboração do gelado comestível, assim, garantindo a segurança do alimento oferecido aos consumidores na análise sensorial. As análises microbiológicas do sorvete foram realizadas em triplicata, garantindo a inocuidade do alimento, aos avaliadores na análise sensorial. A Tabela 2 mostra os resultados das análises microbiológicas realizadas após a elaboração dos gelados comestíveis adicionados de polpa de jaca liofilizada.

Tabela 2. Avaliação microbiológica das distintas formulações de sorvete.

\begin{tabular}{ccccc}
\hline **Amostra & $\begin{array}{c}\text { Coliformes } \\
35^{\circ} \mathrm{C}\end{array}$ & Coliformes $45^{\circ} \mathrm{C}$ & $\begin{array}{c}\text { Staphylococcus } \\
\text { coagulase positiva }\end{array}$ & Salmonella sp/25g \\
\hline F1 & $<3,0 \mathrm{NMP} / \mathrm{g}$ & $<3,0 \mathrm{NMP} / \mathrm{g}$ & $<10^{2} \mathrm{UFC} / \mathrm{g}$ & Ausência em $25 \mathrm{~g}$ \\
$\mathrm{~F} 2$ & $<3,0 \mathrm{NMP} / \mathrm{g}$ & $<3,0 \mathrm{NMP} / \mathrm{g}$ & $<10^{2} \mathrm{UFC} / \mathrm{g}$ & Ausência em $25 \mathrm{~g}$ \\
$\mathrm{~F} 3$ & $<3,0 \mathrm{NMP} / \mathrm{g}$ & $<3,0 \mathrm{NMP} / \mathrm{g}$ & $<10^{2} \mathrm{UFC} / \mathrm{g}$ & Ausência em $25 \mathrm{~g}$ \\
*Limites & ------ & $5,0 \times 10 \mathrm{~g}$ & $5,0 \times 10^{2} \mathrm{~g}$ & Ausência em $25 \mathrm{~g}$
\end{tabular}

*Resolução RDC No 12, de 02 de janeiro de 2001. UFC- Unidade Formadoras de Colônia, NMP- Número Mais Provável. **F1- 0\% Polpa de Jaca Liofilizada, F2- 25\% Polpa Jaca Liofilizada e F3- 75\% Polpa Jaca Liofilizada. Fonte: Brasil (2001).

As amostras de gelado comestíveis contendo diferentes concentrações de jaca liofilizada, foram avaliados em relação aos atributos doçura, consistência cremosa, cor, aroma de jaca e sabor de jaca em escala do ideal, conforme as Figuras 5 e 6.

Nos atributos doçura e consistência cremosa, as formulações F1, F2 e F3 obtiveram uma aceitação satisfatória pelos avaliadores, caracterizando as amostras como "medida certa", para os dois atributos analisados na Figura 5. Sendo mais aceita pelos avaliadores nos dois requisitos acima, a formulação F1 em relação ao atributo doçura apresentou-se na categoria "medida certa" com $74,2 \%$ de aprovação, e consistência cremosa na "medida certa" com $67,5 \%$ de 
aceitação pelos avaliadores. Esta formulação considerada como padrão, não continha polpa de jaca liofilizada (PJL).

Figura 5. Dados sobre a intensidade de atributos pela Escala do Ideal.

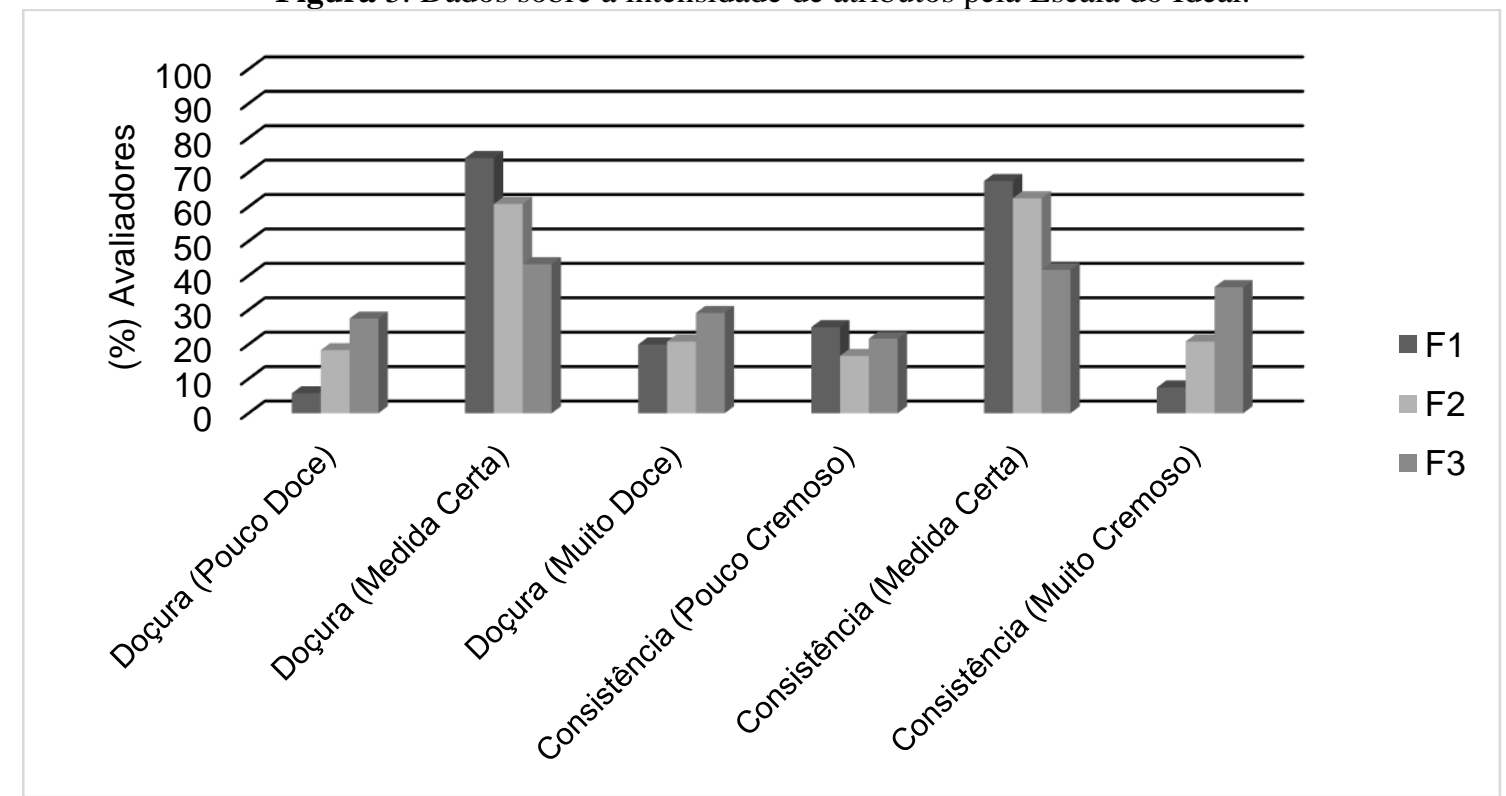

*F1- 0\% Polpa de Jaca Liofilizada (PJL), F2- 7,40\% Polpa Jaca Liofilizada (PJL) e F3- 19,35\% Polpa Jaca Liofilizada (PJL).

Fonte: Própria (2016).

No entanto, as formulações com adição de polpa de jaca liofilizada obtiveram resultados satisfatórios, sendo o mais preferido a formulação F2 (7,40\% de polpa de jaca liofilizada), quanto à doçura, onde $60,84 \%$ apontaram esta formulação como "medida certa", e no atributo cremosidade como "medida certa" com $62,5 \%$ da aprovação dos avaliadores como observado na Figura 5.

A doçura é o gosto mais importante para o ser humano, dentre os gostos básicos identificados como doce, amargo, ácido, salgado e umami, e corresponde a um importante papel na preferência alimentar, entendendo-se que os compostos doces induzem à respostas hedônicas positivas consideradas inatas, até mesmo em recém-nascidos (SALMINEN e HALLIKAINEN, 1990).

Observa-se na Figura 6, os dados sobre intensidade dos atributos cor, aroma de jaca e sabor de jaca respectivamente:

Notou-se que as formulações F1 (padrão, 0\% PJL) e F2 (7,40\% PJL) aproximaram-se quanto a intensidade da cor na" medida certa", sendo de $89 \%$ e $87,5 \%$, respectivamente, indicando uma aceitação satisfatória, e a formulação F3 apresentou 70\% quanto à intensidade 
da cor na "medida certa", indicando que a proporção de 19,35\% de polpa de jaca liofilizada, apresentou uma aceitação satisfatória no produto final.

Figura 6. Dados da intensidade dos atributos pela Escala do Ideal.

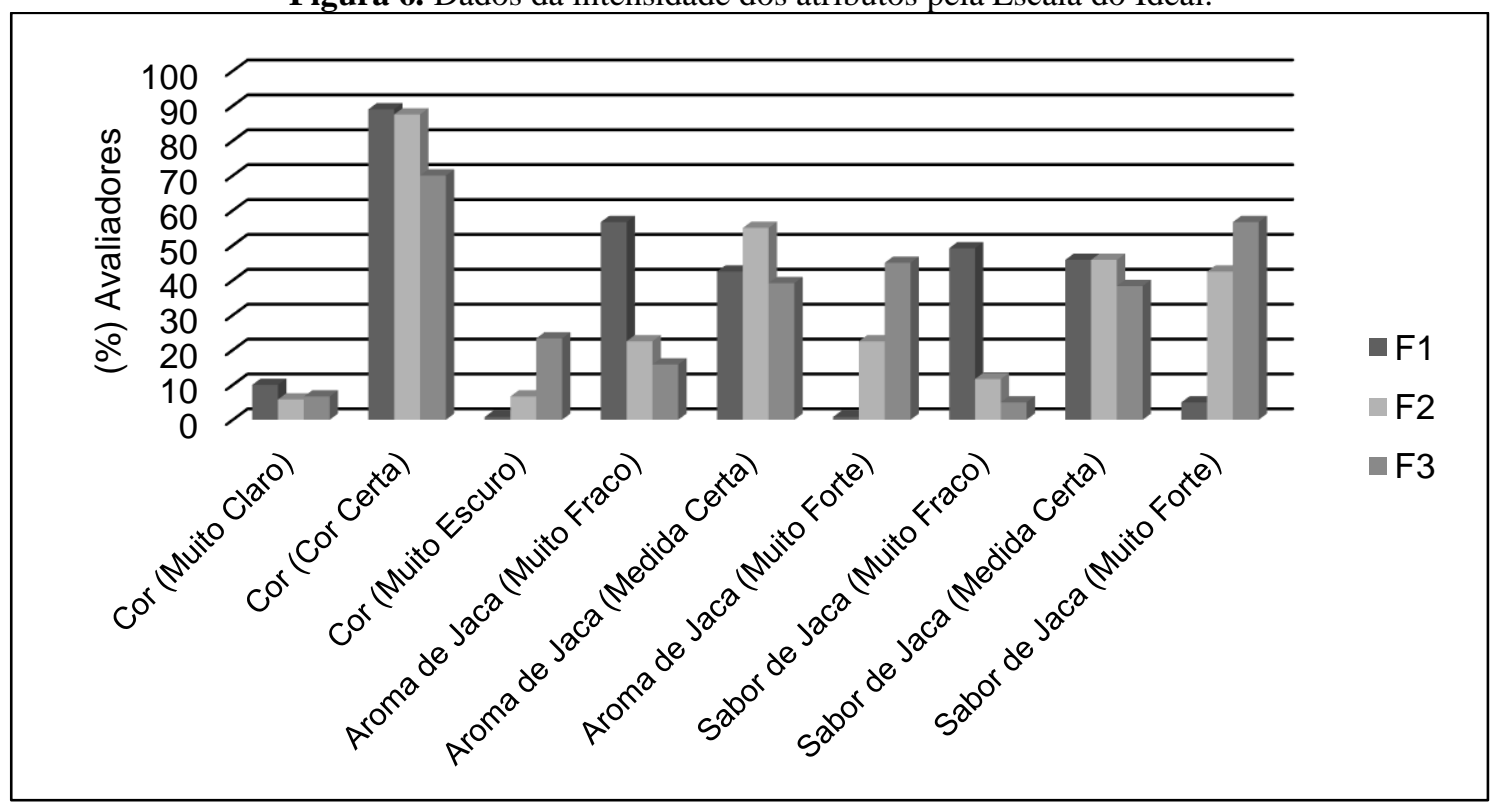

*F1- 0\% Polpa de Jaca Liofilizada (PJL), F2- 7,40\% Polpa Jaca Liofilizada (PJL) e F3- 19,35\% Polpa Jaca Liofilizada (PJL).

Fonte: Própria (2016).

Observou-se que a formulação F2 apresentou intensidade para o sabor e aroma na "medida certa", indicando que o acréscimo de 7,40\% de polpa de jaca liofilizada, atendeu às expectativas dos consumidores para estes atributos. A formulação F3 com 19,35\% de polpa de jaca liofilizada apresentou-se na intensidade “ muito forte", indicando que a proporção de 19,35\% de polpa de jaca liofilizada não foi bem aceita para estes atributos.

$\mathrm{Na}$ avaliação sensorial, mediante a Escala do Ideal, os avaliadores registram suas respostas para cada amostra, indicando o quão ideal (medida certa), as amostram se situam, considerando-se o atributo analisado. O método afetivo, denominado Escala-do-Ideal (Justabout-right scale ou JAR), é o mais utilizado para se medir a quantidade ideal de um determinado componente a ser adicionado num alimento ou bebida para provocar a melhor aceitação e preferência de um grupo de avaliadores (VICKERS, 1988).

A Figura 7, ilustra a intenção de compra para as formulações de sorvete sabor jaca em diferentes concentrações.

Notou-se que os consumidores através do Teste de Intenção de compra (Figura7), em que o sorvete adicionado de 7,40\% de polpa de jaca liofilizada (F2), obteve percentual satisfatório de intenção de compra, quanto às categorias "certamente compraria" e "possivelmente compraria" correspondendo a $66,66 \%$ das respostas, e não desconsiderando a 
aceitabilidade da formulação com 19,35\% de polpa de jaca liofilizada (F3), que obteve um percentual de intenção de compra, nas classificações "certamente compraria" e "possivelmente compraria", correspondendo a um total de 55,84\% da intenção de compra do produto.

Figura 7. Intenção de compra para as formulações de sorvete sabor jaca.

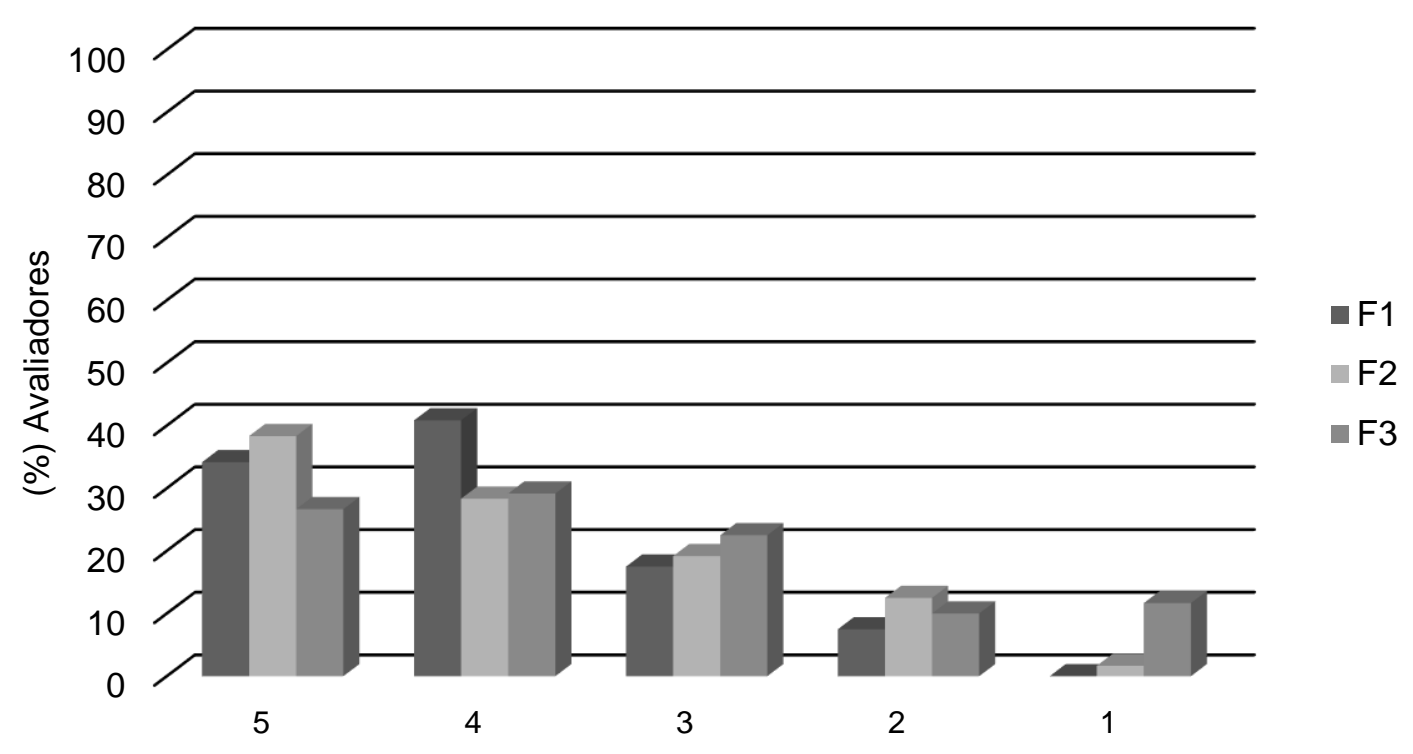

*F1- 0\% Polpa de Jaca Liofilizada, F2- 7,40\% Polpa de Jaca Liofilizada e F3- 19,35\% Polpa de Jaca Liofilizada. **Escala de categorias: (5) Certamente Compraria, (4) Possivelmente Compraria, (3) Talvez Comprasse/Talvez não Comprasse, (2) Possivelmente não Compraria, (1) Certamente não Compraria.

Fonte: Própria (2016).

O sorvete padrão (F1) obteve $34,17 \%$ de respostas para a categoria "certamente compraria"; e para o critério "possivelmente compraria" obteve 40,83\%. Quanto ao critério “talvez comprasse/talvez não comprasse", o sorvete padrão (F1) obteve 17,50\%, os sorvetes adicionados de 7,40\% e 19,35\% de jaca liofilizada (F2 e F3), obtiveram respectivamente $19,17 \%$ e $22,50 \%$ das respostas. Os critérios "provavelmente não comprariam" e "certamente não comprariam" obtiveram percentuais baixos para as três formulações analisadas.

O menor percentual da intenção de compra para a categoria "certamente não compraria", foi de 11,67\% para sorvete de polpa de jaca liofilizada nas formulações F3 e F2, e "possivelmente não compraria" de 12,5\% para a formulação F1. Este comportamento dos avaliadores indica que as duas formulações contendo polpa de jaca liofilizada apresentaram uma satisfatória intenção de compra.

\section{Conclusões}

Os resultados microbiológicos das formulações de gelados comestíveis, apresentaramse de acordo com os padrões vigentes na legislação brasileira, garantindo-se a sua inocuidade 
para o consumo durante a avaliação sensorial.

A amostra de sorvete F2 (7,40\% PJL) avaliada sensorialmente quantos aos atributos de doçura e cremosidade, sabor, aroma e cor, apresentou avaliação de "na medida certa" ( ideal), o que denota uma aceitação satisfatória perante os consumidores, embora a amostra padrão F1(sem adição de polpa de jaca) tenha também sido bem avaliada.

Denota-se que, considerando-se o comportamento dos consumidores em relação a sua percepção dos atributos sensoriais no teste de Escala do Ideal, a formulação contendo 7,40\% de polpa de jaca liofilizada obteve melhor aceitação, podendo ser produzida no futuro e inserida no mercado de gelados comestíveis, como uma alternativa saudável aos consumidores, tendo em vista que esta fruta apresenta propriedades nutritivas relevantes, quanto aos teores de vitaminas, minerais e fibras.

Quanto à intenção de compra, observou-se que as formulações adicionadas de polpa de jaca liofilizada obtiveram uma satisfatória aceitação.

Faz-se necessário uma maior divulgação sobre a elaboração de gelados comestíveis com adição de polpa de jaca liofilizada, para que haja um consumo desta fruta através do seu processamento, o que agrega valor ao produto final, permitindo a sua disponibilidade em épocas adversas a sua sazonalidade.

\section{Referências}

BRASIL. Resolução RDC N. ${ }^{\circ}$ 12, de 02 de janeiro de 2001. Dispõe sobre os princípios gerais para o estabelecimento de critérios e padrões microbiológicos para alimentos. Agência Nacional de Vigilância Sanitária (ANVISA). Diário Oficial da União, Brasília, DF, 10 jan. 2001. Seção 1N n.80-E, p.1-9.

BRASIL. Ministério da Saúde. Resolução RDC n. 266, de 22 de setembro de 2005. Regulamento técnico para gelados comestíveis e preparados para gelados comestíveis. Diário Oficial da República Federativa do Brasil, Brasília, 23 set. 2005. Seção 1, p.370.

BRASIL. Agência Nacional de Vigilância Sanitária/MS. Resolução RDC n. 272 de 22 de set 2005. Aprova o Regulamento Técnico para Produtos de Vegetais, Produtos de Frutas e Cogumelos Comestíveis. Diário Oficial da República Federativa do Brasil, Brasília, 23.set.2005. Seção 1, n.184, p.374-375.

BRASIL. Ministério da Agricultura, Pecuária e Abastecimento (MAPA). Instrução Normativa $\mathrm{N}^{\circ}$ 62, de 26 de agosto de 2003, D.O.U 18/09/2003. Oficializa os Métodos Analíticos Oficiais para Análises Microbiológicas para Controle de Produtos de Origem Animal e Água. Diário Oficial da República Federativa do Brasil, Brasília, 18.set. 2003. Seção 1, n.181 p. 14.

BRASIL Ministério da Saúde. Secretaria de Atenção à Saúde. Coordenação Geral da Política de Alimentação e Nutrição. Guia alimentar para a população Brasileira: promovendo a 
alimentação saudável. Brasília: Ministério da Saúde, 2005. pg. 236, (Série A. Normas e Manuais Técnicos).

BRASIL. Secretaria de Estado da Saúde de São Paulo. Centro de Vigilância Sanitária. Portaria CVS-5, de 9 de abril de 2013. Diário Oficial. Poder Executivo. Estado de São Paulo. Seção I.p.32-34, 2013.

CARVALHO, C. M. R. G de.; NOGUEIRA, A. M. T.; TELES, J. B. M.; PAZ, S. M. R da.; SOUSA, R. M. L. de. Consumo Alimentar de Adolescentes Matriculados em um Colégio Particular de Teresina, Piauí, Brasil. Revista de Nutrição, v.14, n.2, p.85-93, 2001.

CRANE, J.H., BALERDI, C.F. CAMPBELL, R.J. The Jackfruit (Artocarpus heterophyllus, Lam.) in Florida. Fact sheet HS 882. Horticultural Sciences Department, Florida Cooperative Extension Service. Institute of Food and Agricultural Sciences. Gainesville: University of Florida, 2002. 12p.

DUARTE Martins, Maria Elita e outros. Desidratação osmótica de fatias de jaca. Revista Ciência Agronômica, Fortaleza, v. 43, p. 478-483, 2012.

DUTCOSKY, S.D. Análise sensorial de alimentos. Curitiba: Champagnt, 2013.

GEORGE, J.P.; DATTA, A.K. Development and validation of heat and mass transfer models for freeze-drying of vegetable slices. Journal of Food Engineering, v.52, n.1, p. 89-93, 2002.

INSTITUTO ADOLFO LUTZ (SÃO PAULO). Métodos físico-químicos para análise de alimentos/coordenadores Odair Zenebon, Neus Sadocco Pascuet e Paulo Tiglea. 4. ed. São Paulo: Instituto Adolfo Lutz, 2008.p.1020.versão eletrônica.

JACKMAN, L.A.; MILLANE, S.S.; MARTIN, B.R.; MADEIRA, O.B.; PEACOCK, M.; WEAVER, C M. Calcium retention in relation to calcium intake and postmenarcheal age in adolescent females. American Journal of Clinical Nutrition, v. 66, p. 327-333, 1997.

LARIOS-GÓMEZ, E.; RAMÍREZ, J.M.; Rodríguez, E.S. Pesquisa de mercado em marketing, análise comparativa com o método científico da epistemologia das ciências de gestão. Revista de Administração da UNIMEP, v.15, n.4, p. 179-204, 2017.

MATOS, E.H.S.F, Desidratação de frutas e legumes. Dossiê Técnico. Sistema Brasileiro de Respostas Técnicas. Brasília: UnB, 2007.21p.

MITRA, S.K.; MAITY, C.S. A summary of the genetic resources of jackfruit (Artocarpus heterophyllus, Lam.) in west bengal, india. Acta Horticulturae, v.27.n.575 p.269-271 2002.

MARQUES, L.G., SILVEIRA, A. M., FREIRE, J. T. Freeze-drying characteristics of tropical fruits, Drying Technology, v. 24, n.1-7, pp. 457- 463, 2006.

OLIVEIRA, F. G. B. Comportamento do Consumidor: Os Fatores de Influência. Revista Científica Multidisciplinar Núcleo do Conhecimento, v. 9, n.1, p 613-630, 2016.

ORGANIZAÇÃO MUNDIAL DA SAÚDE. Organização para a Alimentação e Agricultura das Nações Unidas. Relatório de peritos sobre Dieta, Nutrição e Prevenção de Doenças 
Crônicas. Genebra: Organização Mundial da Saúde/Alimentação e Agricultura da Organização das Nações Unidas; 2010. WHO Technical Report Series 916.

PHILIPPI, S. T. Nutrição e técnica dietética. São Paulo: Manole, 2011.

QUIRINO, G. M. R. Marketing para o mercado de eventos: o comportamento do consumidor. Revista Científica Multidisciplinar Núcleo do Conhecimento, v. 07, n.3, p, 38-52, 2018.

RATTI, C. Hot air and freeze-drying of high-value foods: a review. Journal of Food Engineering, v.49, n.4, p. 311-319, 2001.

ROZIN, P. Towards a Psychology of Food Choice. Bruxelles: Institut Danone, 1996.

SALMINEN, S.; HALIKAINEN, A. Sweeteners. In: Food Additives. BRANEN, A.L.; DAVIDSON, P.M.; SALMINEN, S.(Ed.). New York: Marcel Dekker, Inc, 1990, pp. 297- 327.

SCHIFFMAN, L.G.; KANUK, L. L. Comportamento do consumidor. 6. ed. Rio de Janeiro: Editora LTC, 2000. 476 p.

SOUZA SANT'ANNA, Tatiana e outros. Desidratação osmótica de frutículos de jaca (Artocarpus heterophyllus, Lam.): aplicação de modelos matemáticos. Acta Scientiarum. Technology, v.31, n.2, p.225-230, 2009.

TEIXEIRA, L.V. Análise sensorial na indústria de alimentos. Revista do Instituto de Laticínios "Cândido Tostes, v.64, n.366, p.12-21, 2009.

VICKERS, Z. Sensory specific satiety in lemonale a just right scale for sweeteness. Journal of Sensory Studies., v.3, n.1, p.1-8, 1988.

WORLD HEALTH ORGANIZATION. Obesity: preventing and managing the global epidemic. Report of a World Health Organization Consultation. Geneva: World Health Organization, 2000. p. 256. WHO Obesity Technical Report Series, n. 284. 


\title{
CAPÍTULO 8: COMPORTAMENTO DO CONSUMIDOR FRENTE A DIFERENTES RÓTULOS NUTRICIONAIS FRONTAIS
}

\section{CHAPTER 08: CONSUMER BEHAVIOR IN FRONT OF DIFFERENT FRONTAL NUTRITIONAL LABELS}

Handressa Dark Soares de Oliveira ${ }^{1}$; Deborah Gonçalves Carrijo ${ }^{2}$; Mariana Carvalho Oliveira ${ }^{3}$; Vania Carvalho ${ }^{4}$.

\begin{abstract}
Resumo
Considerando que a rotulagem nutricional de alimentos em vigor atualmente no Brasil é considerada muito confusa por parte de grande parte da população brasileira, faz-se necessário um estudo de desenvolvimento de diferentes rótulos nutricionais. Os rótulos têm como objetivo mostrar as informações necessárias para o consumidor sobre os constituintes, evitando futuras complicações. No entanto, algumas pessoas possuem dificuldade para a leitura do mesmo. O objetivo deste trabalho foi desenvolver 4 tipos de rótulos nutricionais frontais (com a fonte maior, estilo semáforo, ordem decrescente, somente com o valor diário) comparando com o rótulo comercial, avaliando o comportamento do consumidor em relação as informações nutricionais e assim melhorar a promoção á saúde da população brasileira. Os resultados obtidos foram que o rótulo que possuía maior fonte obteve maior aceitação em relação ao rótulo comercial, além disso, alguns julgadores disseram que não obtinha muitos conhecimentos sobre o valor diário recomendado, dificultando a leitura do rótulo.
\end{abstract}

Palavras-Chaves: Rotulagem, Semafórico, Percepção, Compreensão.

\begin{abstract}
The fact that the nutritional labeling of foods currently in force in Brazil is considered to be very confusing on the part of the great part of the brazilian population, makes it necessary to study the development of different nutricional labels. The labels aim to show the necessary information to the consumer about the components, avoiding future complications. However, some people find it difficult to read the same. The objective of this work was to develop 4 types of frontal nutritional labels (with a larger font, semantic style, decreasing order, only with the daily value) comparing with the comercial label, evaluating the consumer behavior in relation to nutritional information and, thus, improve the health promotion of the health promotion of the brazilian population. The results obtained were those that were labeled and those that had the greatest source of the use reported on comercial labels, in addition, some judges judged that they did not obtain much knowledge about the recommended daily value, making it difficult to read the label.
\end{abstract}

Keywords: Labeling, Traffic Light, Perception, Undertanding.

\footnotetext{
${ }^{1}$ Estudante de Graduação: Tecnologia em alimentos, Instituto Federal Goiano Campus Morrinhos, handressadark@outlook.com.br

${ }^{2}$ Estudante de Graduação: Tecnologia em alimentos, Instituto Federal Goiano Campus Morrinhos, deborahcarrijo@gmail.com.br

${ }^{3}$ Estudante de Graduação: Tecnologia em alimentos, Instituto Federal Goiano Campus Morrinhos, marianacoliveira@hotmail.com.com.br

${ }^{4}$ Professora: Tecnologia em alimentos, Instituto Federal Goiano Campus Morrinhos, vania.carvalho@figoiano.edu.br
} 


\section{Introdução}

De acordo com os estudos do Ministério da Saúde que constatou que mais da metade da população brasileira $(55,78 \%)$ está com excesso de peso e 19,8\% está obesa, associado ao crescente consumo de alimentos industrializados, que têm sido considerados um dos fatores que contribuem para o aumento na prevalência de obesidade e doenças crônica (BRASIL, 2018; WORLD HEALTH ORGANIZATION, 2003), observa-se a necessidade de maior atenção quanto ao entendimento e compreensão das informações nutricionais contidas nos produtos.

Independente da origem do produto, a Resolução RDC n. 360, de 23 de dezembro de 2003 determina que a rotulagem nutricional seja obrigatória em alimentos produzidos e embalados na ausência do cliente (BRASIL, 2003) e com isso garante que os rótulos sejam o principal elo entre o consumidor e o produto (MARINS; JACOB; PERES, 2008). A rotulagem nutricional dos alimentos permite ao consumidor o acesso ás informações nutricionais e os parâmetros indicativos de qualidade e segurança do seu consumo. Ao mesmo tempo, o acesso a essa informação atende as exigências da legislação e impulsiona investimento, por parte da indústria, na melhoria do perfil nutricional dos produtos cuja composição declarada pode influenciar o consumidor quanto á sua aquisição (FERREIRA; LANFER-MARQUEZ, 2007).

As informações sobre os alimentos muitas vezes aparecem dispersas pela a embalagem, como as peças desconexas. No Brasil, a assim chamada informação nutricional aparece como tabela, separada da lista de ingredientes, por sua vez separada de outros elementos informativos, como o símbolo para transgênico, as alegações de sem glúten, sem lactose, sem adição de açúcares, diet ou light, entre outros (OLIVEIRA; BOCCHINI, 2015).

A rotulagem nutricional de alimentos em vigor atualmente no Brasil é considerada muito confusa por parte de grande parte da população brasileira, e com isso faz-se necessário um estudo de desenvolvimento de diferentes rótulos nutricionais para facilitar a identificação dos principais macronutrientes presentes nos alimentos que podem causar efeitos maléficos ao organismo. A utilização de rótulos frontais pode ser uma alternativa para informar de forma mais clara os consumidores sobre os macros e micronutrientes contidos nos alimentos que podem causar malefícios/benefícios no corpo humano, fazendo com que a população brasileira possa ter uma alimentação mais balanceada saudável, garantindo a eficácia da Lei Orgânica de Segurança Alimentar e Nutricional (BRASIL, 2006).

A rotulagem nutricional de alimentos permite ao consumidor o acesso ás informações nutricionais e aos parâmetros indicativos de qualidade e segurança do seu consumo. Ao mesmo tempo, o acesso a essa informação atende ás exigências da legislação e impulsiona investimento, por parte da indústria, na melhoria do perfil nutricional dos produtos cuja 
composição declarada pode influenciar o consumidor quanto á sua aquisição (LOBANCO et al, 2009).

A agência Nacional de vigilância Sanitária (ANVISA) na resolução - RDC n. 259, de 20 de setembro de 2002, regulamentada a rotulagem de alimentos, tornando obrigatório: a denominação de venda do produto, listas dos ingredientes, o conteúdo líquido, identificação de origem e do lote, o prazo de validade e a instrução sobre o preparo e uso do alimento, quando necessário (BRASIL, 2002). A maioria dos estudos sobre rótulos dos alimentos se refere ao uso de uma informação nutricional que relata uma concentração mais detalhada de nutrientes do produto (quantidade de calorias, tamanho da porção, conteúdo de macro e micronutrientes e ingestão diária recomendada). E, outros tipos de rótulos usados para transmitir aos consumidores informações referente à saúde e alegações nutricionais são pouco estudados (CAVALIERE; MARCHI; BANTERLE, 2016).

A atenção à nutricão, incluindo a leitura da informação nutricional, pode ser uma forma eficaz de melhorar o comportamento alimentar e a prevenção de doenças crônicas relacionadas à obesidade (POST et al., 2010). O uso das informações nutriocionais nos rótulos dos alimentos estão associados à ingestão de gordura, consumo de dietas ricas em vitamina $\mathrm{C}$, ingestão de ferro e menor consmo de açúcar (GRAHAM; HEIDRICK; HODGIN, 2015).

Assim, o objetivo deste trabalho é desenvolver diferentes tipos de rótulos nutricionais frontais e avaliar a compreensão do consumidor em relação às informações nutricionais frontais e assim melhorar a promoção á saúde da população brasileira.

\section{Material e Métodos}

\section{Material}

Foram avaliados os rótulos nutricionais presentes em néctares de abacaxi. A partir do rótulo existente no mercado deste produto, foram desenvolvidos 4 tipos diferentes de rótulos nutricionais frontais.

\section{Métodos}

\section{Desenvolvimento dos rótulos}

As artes dos rótulos nutricionais frontais foram desenvolvidas no laboratório de informática do Instituto Federal Goiano - Campus Morrinhos, e atendendo as principais dificuldades encontradas pelos consumidores brasileiros para compreensão das informações nutricionais. Os tipos desenvolvidos foram:

1) Rótulo Nutricional Frontal em ordem decrescente de importância: este rótulo levou em 
conta os macro e micronutrientes que podem causar benefícios ao consumidor, sendo colocados em primeiro lugar na tabela nutricional seguidos dos que menor importância (ou que podem causar malefícios aos consumidores) em ordem decrescente;

2) Rótulo Nutricional Frontal estilo semáforo: este tipo de rótulo fornece cores nos macros e micronutrientes presentes, onde a cor vermelha indica macro ou micronutriente que pode causar malefício ao consumidor, a cor amarela indica macro ou micronutriente que deve ser consumido com atenção, e a cor verde indica o macro ou micronutriente que pode causar benefício ao consumidor;

3) Rótulo Nutricional Frontal com a letra maior: este tipo de rótulo irá fornecer as mesmas informações que a informação nutricional encontrada nos comércios, exceto o tamanho da fonte que será maior;

4) Rótulo Nutricional Frontal estilo Valor Diário: este tipo de rótulo fornece apenas o valor diário na informação nutricional (VD*).

Após o desenvolvimento das artes de cada rótulo nutricional frontal os mesmos foram encaminhados a uma gráfica da cidade de Morrinhos-GO para impressão. Ao todo foram confeccionadas 5 unidades de cada rótulo totalizando 20 unidades.

\section{Avaliação da compreensão e percepção do consumidor}

Antes de responder qualquer questionamento, foi entregue aos participantes o TCLE (Termo de Compromisso Livre e Esclarecido) para que fosse lido, compreendido e assinado. Após o consentimento do julgador em participar da pesquisa foi entregue o questionário socioeconômico e o de intenção de compra. A análise sensorial foi submetida ao Comitê de Ética em Pesquisa com aprovação de número do parecer 3.440.063.

Foram recrutados 100 julgadores voluntários para responderem os questionários socioeconômicos. Após a avaliação do questionário socioeconômico, foram realizadas as apresentações de cada rótulo aos consumidores e a avaliação da intenção de compra dos julgadores (Figura 1).

Em seguida, foi realizada a avaliação da compreensão e percepção das informações nutricionais contidas no produto (Figura 2). Estas análises foram realizadas no Instituto Federal Goiano campus Morrinhos e em mais dois supermercados da cidade. 
Figura 1 - Ficha de avaliação para intenção de compra dos produtos com nutricional frontal.

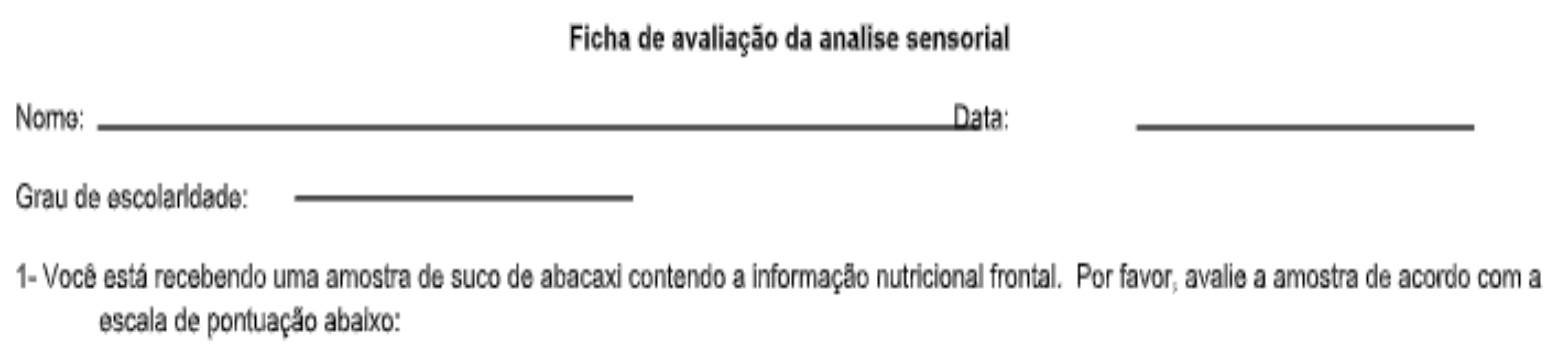

Amostra $n^{\circ}$

2-Assinale, para esta amostra, qual seria sua aceitação de compra:

( ) Eu certamente compraria essa amostra

( ) Eu possivelmente comprarla essa amostra

( ) Tonho duvidas se compraria essa amostra

( ) Eu possivelmente näo compraria essa amostra

( ) Eu certamente não compraria essa amostra

\section{Análise Estatística}

Com os dados fornecidos pelos julgadores foram realizadas análises estatísticas com a construção de gráficos circulares, sendo as suas áreas diretamente proporcionais às frequências correspondentes, utilizando o programa Excel 2016. Ou seja, a amplitude do ângulo ao centro de cada setor circular é diretamente proporcional à frequência que representa. Os dados de compreensão e percepção dos quatro rótulos nutricionais frontais foram expressados pela média e desvio padrão dos 100 resultados obtidos. Foi utilizado ainda um rótulo nutricional comercial com a finalidade de comparação com os demais rótulos frontais. Foi realizada a comparação estatística entre os 5 rótulos por meio do Teste de Tukey com nível de significância de 95\%, utilizando o software Statistica 7.0. 
Figura 2 - Ficha sensorial para avaliação da compreensão e percepção dos rótulos nutricionais frontais.

\section{Ficha de avaliaçăo da analise sensorial}

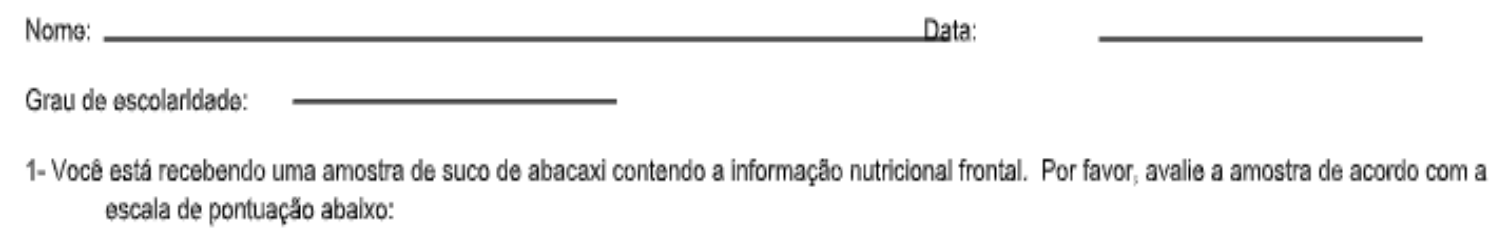

Amostra $n^{\circ}$

9- Gostei extremamente
8- Gostei muitíssimo
7- Gostei moderadamente
6- Gostei levemente
5- Não gostei nem desgostei
4- Desgostei levemente
3- Desgostei moderadamente
2- Desgostei multissimo
1-Desgostei extromamente

\begin{tabular}{|l|l|}
\hline item & Nota \\
\hline Compreensẵo & \\
\hline Percepção & \\
\hline
\end{tabular}

\section{Resultados e Discussão}

Os dados obtidos na pesquisa indicam um público formado majoritariamente por mulheres. Estes resultados concordam com os achados por Martins (2004) e por Machado et al. (2014), que realizaram estudos em Niterói/RJ e Mato Grosso (MT), respectivamente, nos quais a maioria dos frequentadores de supermercados eram do sexo feminino. Os resultados apresentaram que predominantemente $52 \%$ dos julgadores leem os rótulos nutricionais (Gráfico 01); isto deve ao fato dos consumidores estarem cada vez mais interessados por uma melhor qualidade de vida e preocupados com o que estão consumindo.

Gráfico 01: Porcentagem de julgadores que possuem o hábito ao ler informações nutricionais.

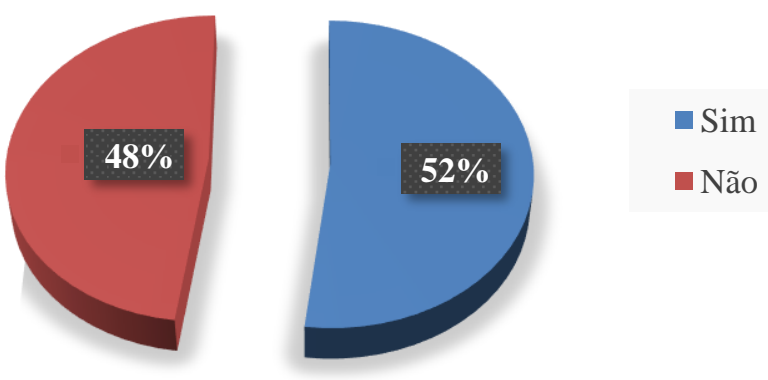

[113] 
Como é possível observar no Gráfico 1, houve uma pequena diferença na quantidade de provadores que alegaram ter o hábito de ler rótulos nutricionais para aqueles que alegaram não ler, este resultado opõe-se ao estudo realizado por Marzarotto e Alves (2017), onde 69,6\% dos entrevistados alegaram ter o hábito de ler rótulos. O estudo realizado por Fernandes, Machado e Vieira (2010) conclui que o consumidor que não possui o hábito de leitura, devese pelo rótulo conter letras de tamanho irregular, linguagem técnica e abreviações. Por isso, a grande necessidade que novas pesquisas na área de rotulagem, para desenvolver rótulos com a nomenclatura mais acessível e melhor entendimento.

De acordo, Marins e Jacob (2014) que avaliaram o hábito de leitura dos rótulos dos produtos alimentícios, sendo que, 61\% dos consumidores possuíam o hábito de ler (considerando os sexos, as mulheres eram 64,1\%). Indicando que, apesar das mulheres nas últimas décadas estarem atuando e conquistando cada vez mais o mercado de trabalho, as tarefas domésticas como as compras de casa e alimentação familiar ainda são, na sua maioria, trabalhos tradicionalmente femininos.

Mermelstein (1993) relata a necessidade de incentivar o hábito de leitura dos rótulos, usando de forma a educar os consumidores. Porém, Levy e Fein (1998) aponta que os consumidores que habitualmente consultam os rótulos são capazes de entender facilmente, estabelecendo comparações entre os produtos. O estudo de Souza et al. (2011) retrata as motivações para não consultar a declaração nutricional apontando que $36 \%$ dos entrevistados alegaram falta de interesse e/ou falta de hábito; 30,7\% não tinham tempo; $5 \%$ não faziam dieta alimentar; 3,9\% relataram não confiar na declaração nutricional e 3\% responderam que o rótulo era ilegível. Um estudo realizado por Marins et al. (2008) com 400 julgadores/ consumidores sobre o hábito de leitura e entendimento das informações da rotulagem dos produtos alimentícios identificou que as principais dificuldades na compreensão da rotulagem são: uso da linguagem técnica, utilização de siglas e abreviações e poucas informações sobre os componentes alimentares potencialmente alérgicos ou de pouca legibilidade. Isto indica que a maioria dos consumidores não tem interesse ou não compreende os rótulos, podendo ser explicado pelo fato de ser pouco ensinado e incentivado no Brasil o uso da leitura básica para rótulos alimentícios.

O resultado encontrado para o presente estudo apresenta-se como um ponto negativo, uma vez que, segundo Carvalho (2006), a rotulagem nutricional é muito importante quando se trata de escolhas alimentares saudáveis, pois é no rótulo do alimento que são fornecidas aos consumidores as informações necessárias para comparação e esclarecimento, e para que ele possa decidir pela compra do produto. Entretanto, no estudo realizado por Casemiro e Linde 
(2006), foram identificados que nos usuários e não-usuários afirmaram encontrar a informação nutricional nos alimentos que compram, mostrando que apesar de alguns consumidores não utilizarem, estes apresentam o conhecimento de que estas estão presentes nos alimentos.

A rotulagem nutricional é como qualquer outra fonte de informação, sendo parte de um processo educativo, devendo ser trabalhada de modo a servir como instrumento para a educação em saúde (SOUZA, et al. 2005). Os consumidores de alimentos não demostram interesse por essas informações, pois desconhecem os benefícios que elas trazem. As ações educativas deveriam ser criadas para orientar a população sobre a leitura dos rótulos e as informações nutricionais, assim tornando o consumidor mais consciente no momento da aquisição dos alimentos (DIAZ, 2006). Consequentemente, os consumidores com o conhecimento adquirido iriam ficam mais atentos ao tipo de alimento que consomem evitando futuros problemas.

Para os provadores que alegaram ter o hábito de leitura, foi avaliada a frequência em que essa leitura ocorre, os resultados estão apresentados no Gráfico 2.

De acordo com os resultados observados $79 \%$ dos julgadores que tem o hábito de ler as informações nutricionais o fazem pelo menos uma vez por semana. Após isto, os julgadores foram submetidos ao questionário em relação à intenção de compra de cada julgador em relação à apresentação dos rótulos nutricionais frontais; que estão apresentados nos Gráficos 3, 4, 56 e 7 abaixo. Para a avaliação da intenção de compra foi entregue uma ficha sensorial contendo as notas que variavam de 5 (certamente compraria) a 1 (certamente não compraria).

Gráfico 2. Frequência de leitura de informações nutricionais pelos provadores.

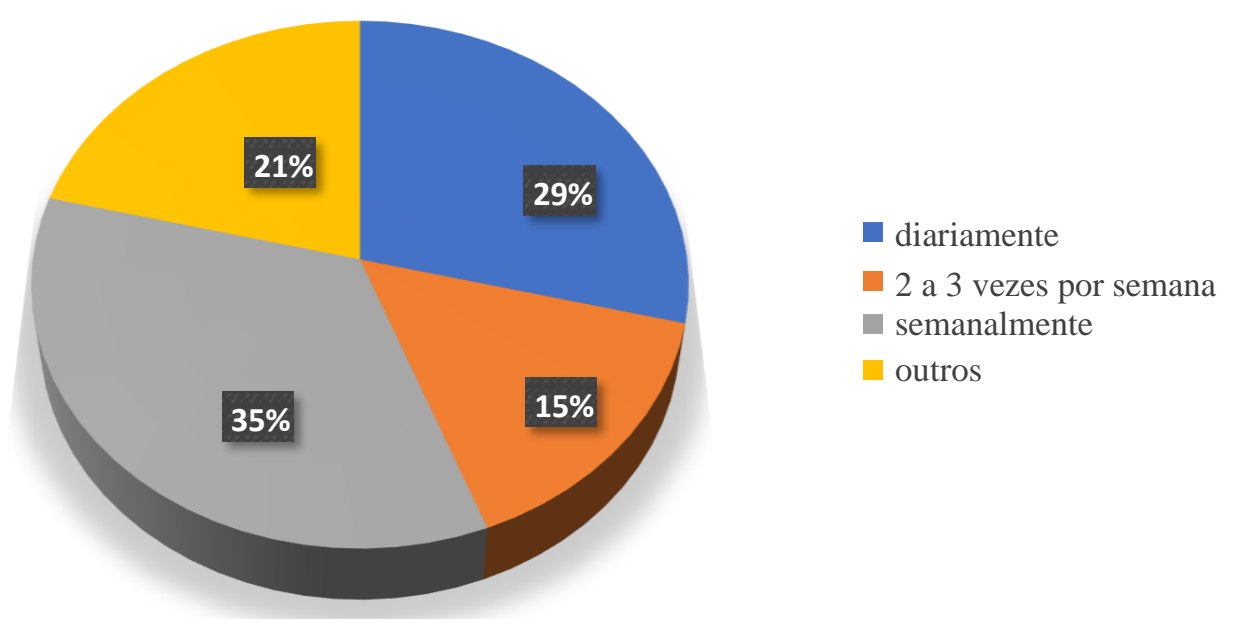


Gráfico 03: Rótulo Nutricional Frontal em ordem decrescente de importância.

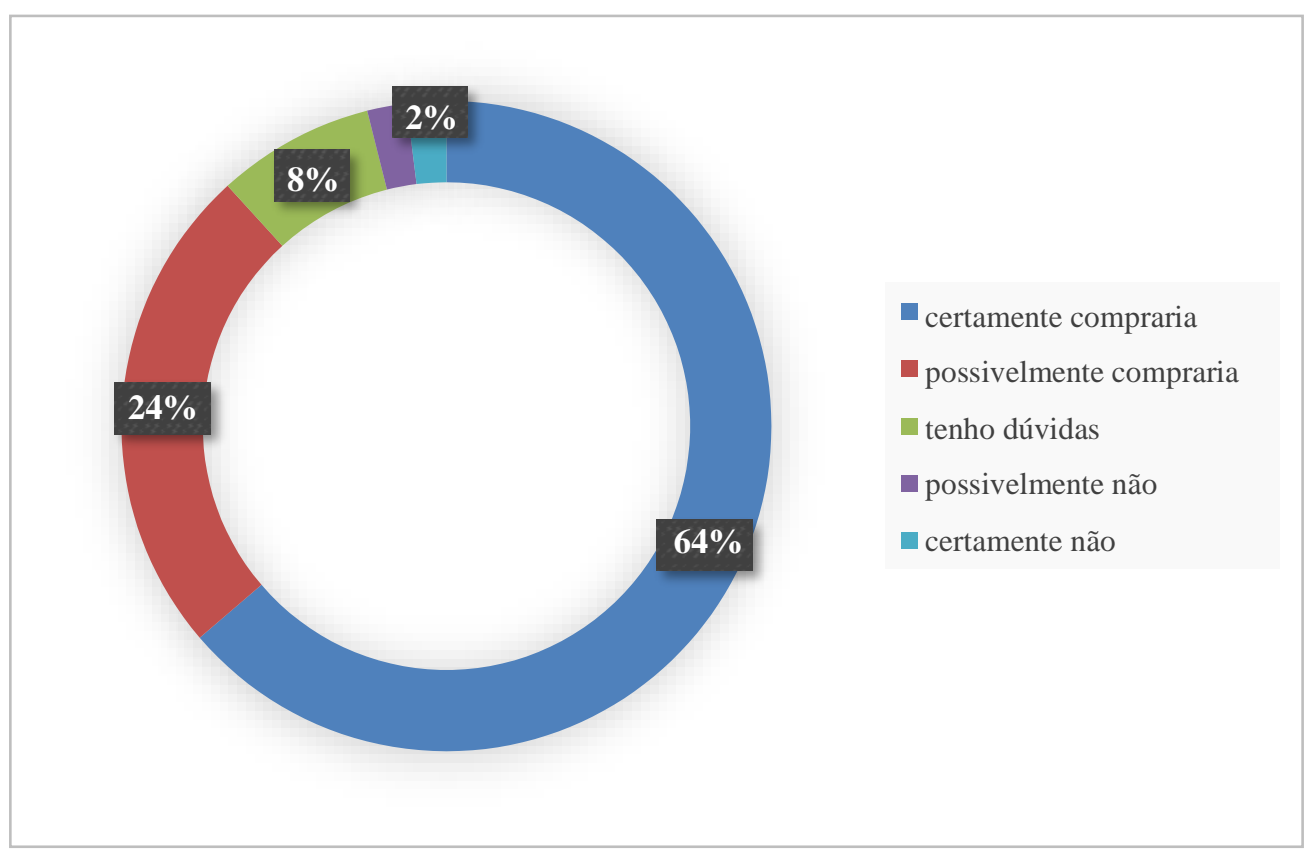

Gráfico 04: Rótulo Nutricional Frontal estilo semáforo.

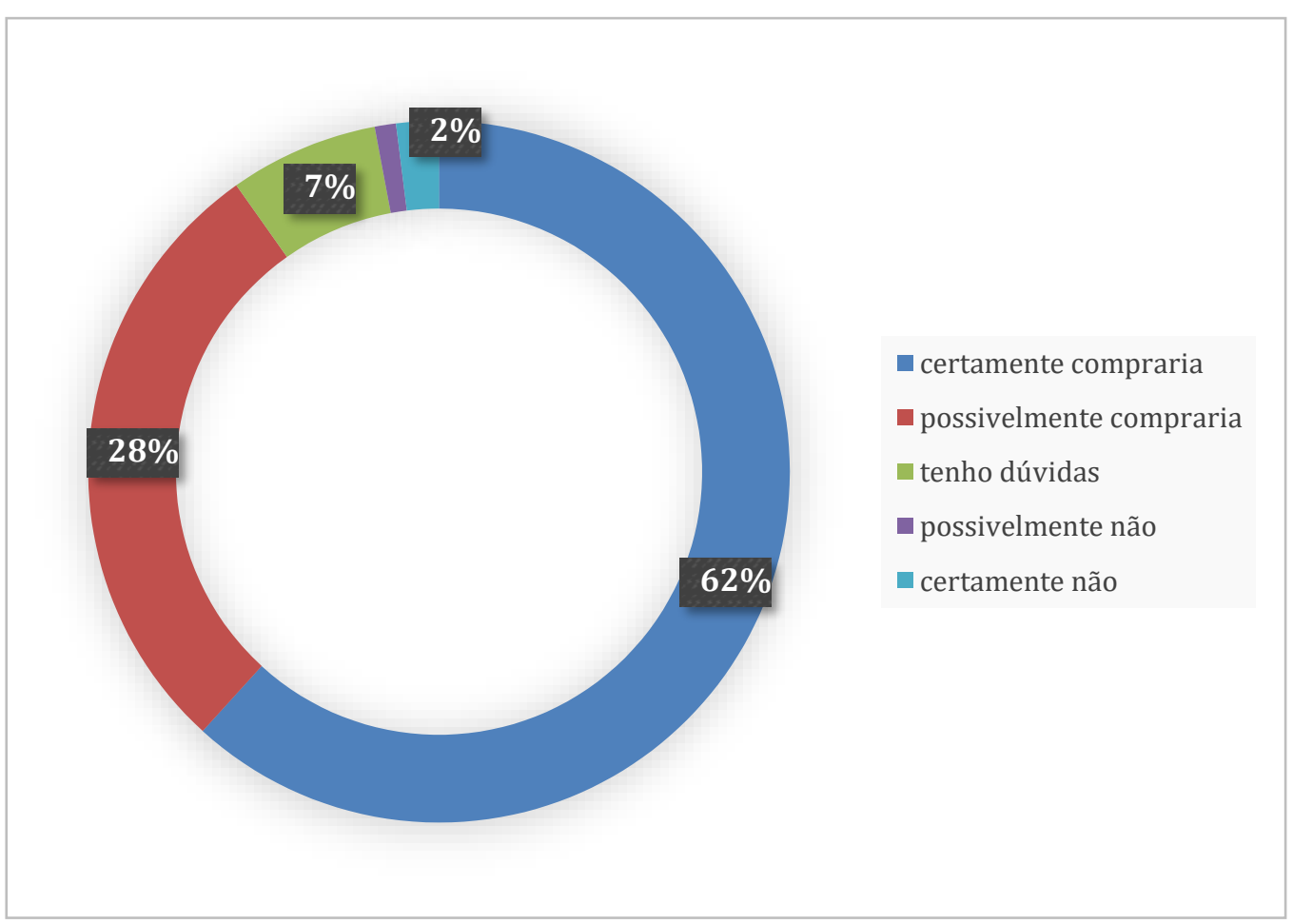


Gráfico 05: Rótulo Nutricional Comercial.

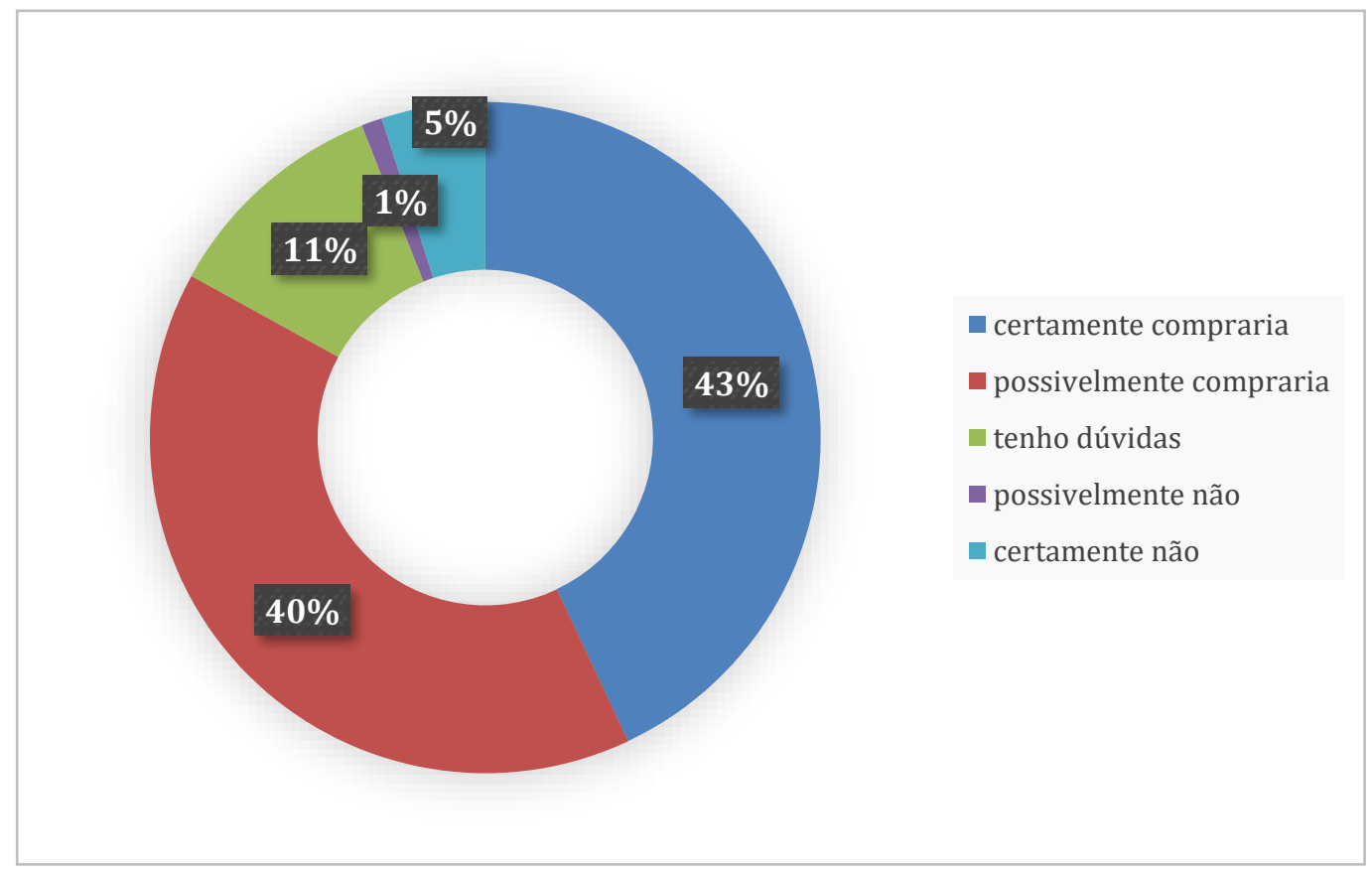

Gráfico 06: Rótulo Nutricional Frontal com maior fonte.

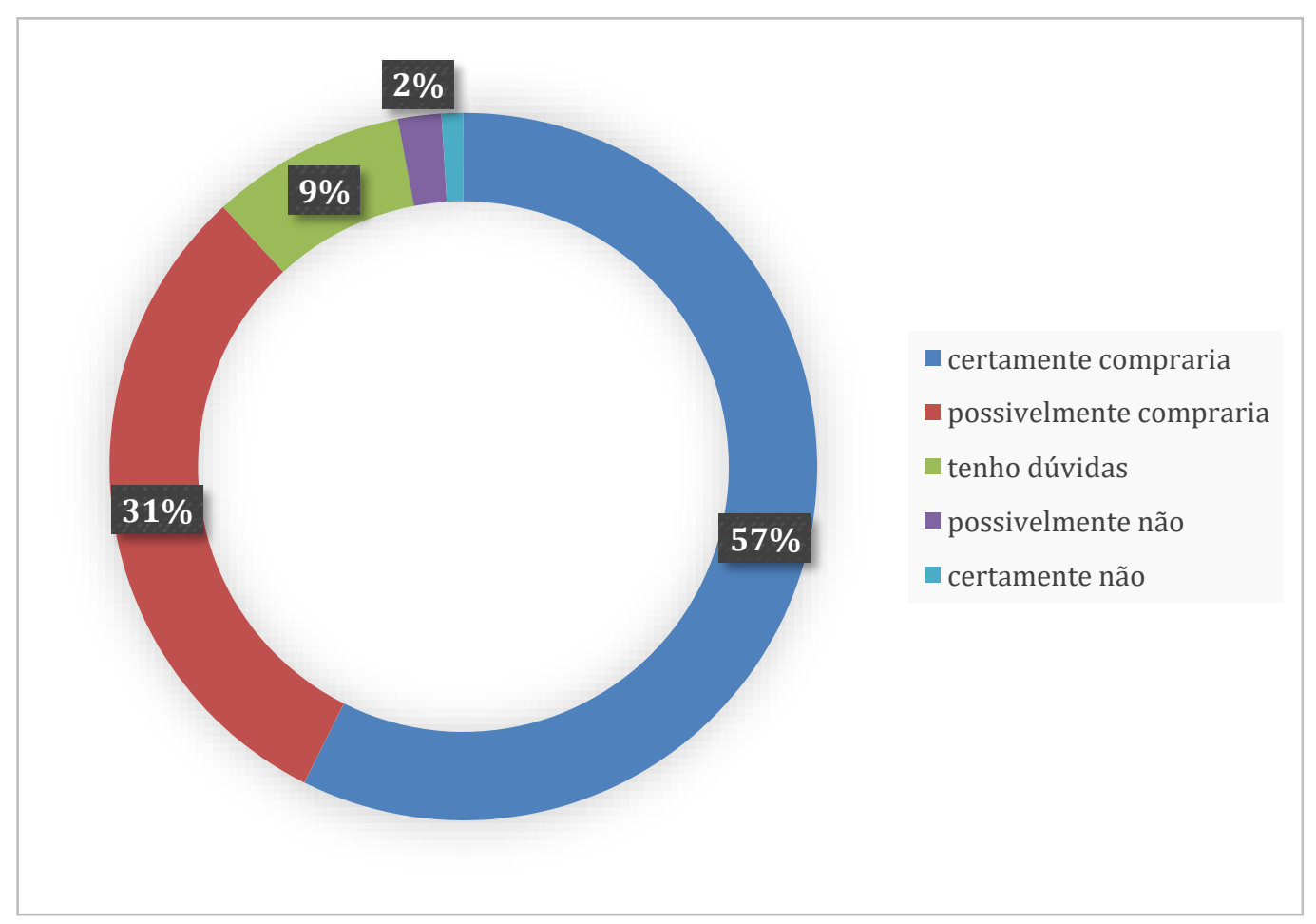

[117]

CIÊNCIA, TECNOLOGIA E INOVAÇÃO: DO CAMPO À MESA. RECIFE: EDITORA IIDV, 2020 
Gráfico 07: Rótulo Nutricional Frontal com valor diário recomendado.

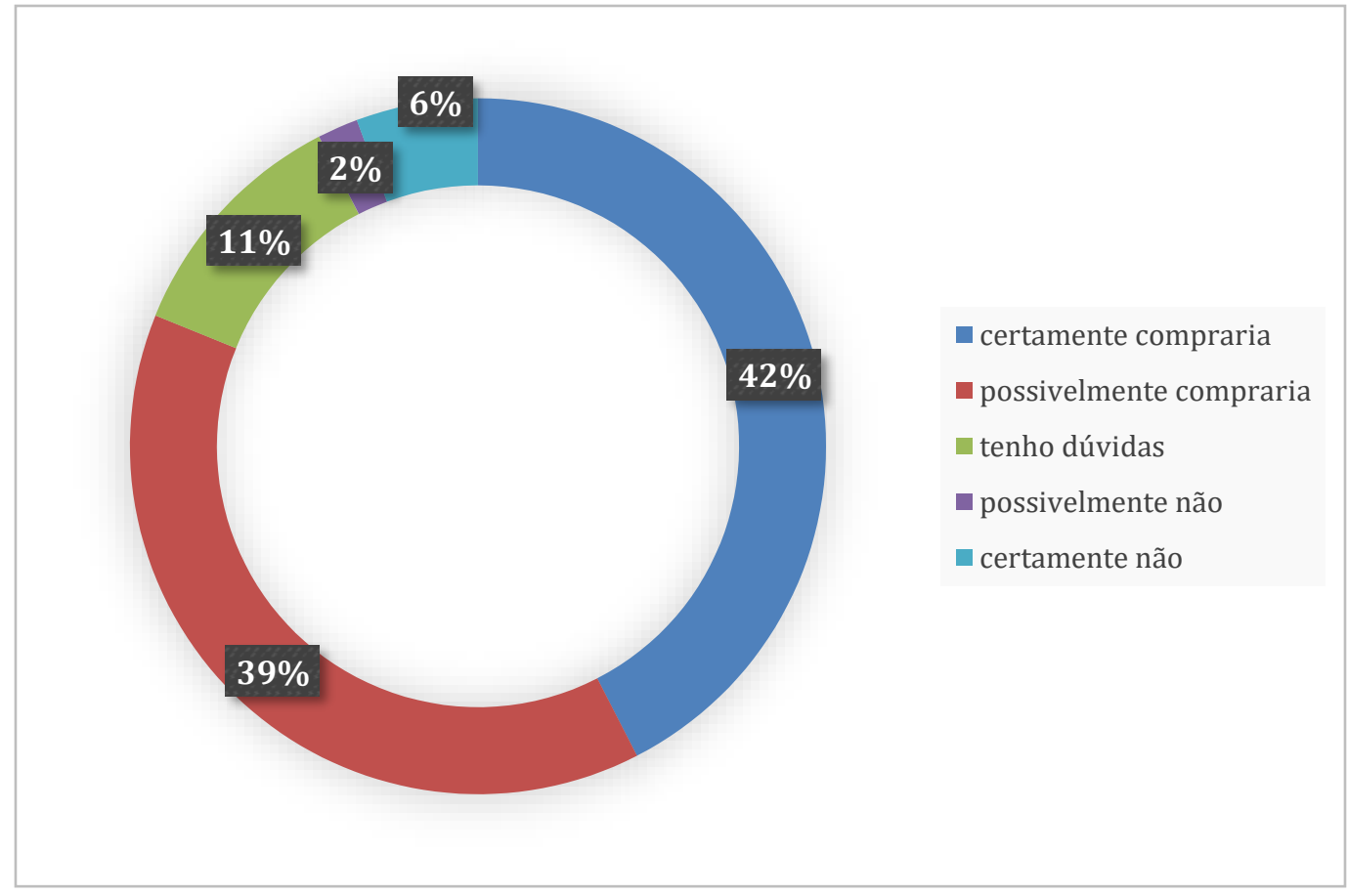

Pelos dados apresentados verificou-se que os julgadores avaliados indicaram a amostra que apresenta o rótulo nutricional frontal desenvolvido com a maior fonte com maior intenção de compra (57\%); isto se deve ao fato das informações nutricionais contidas nos rótulos nutricionais de alimentos muitas vezes não são utilizadas pelos consumidores, pois acham de difícil entendimento devido a linguagem utilizada e o tamanho das letras (YOSHIZAWA et al. 2003). O segundo rótulo nutricional avaliado com maior aceitação foi do rótulo nutricional comercial (43\%) seguido do rótulo que apresentava apenas VD (42\%).

Apesar da grande maioria dos julgadores (79\%) terem o hábito de ler as informações nutricionais pelo menos uma vez na semana, observou-se que havia falta de informação sobre o significado de algumas informações. O valor diário recomendado foi uma dessas informações que poucos julgadores sabiam identificar. Por este motivo, a intenção de compra avaliada para o rótulo nutricional frontal que apresentava apenas o VD teve uma menor intenção de compra em relação ao rótulo nutricional comercial. De acordo com Marins e Jacob (2015) onde os mesmos avaliaram a compreensão sobre o significado da unidade usada para definir o percentual de valor diário (\%VD), apenas $15,5 \%$ souberam dizer o significado para o símbolo \%VD. O não entendimento deste item pode comprometer toda a percepção do consumidor, transformando este importante instrumento de informação nutricional em um instrumento figurativo e sem aplicação para a obtenção de bons resultados.

Além disso, foram avaliados os critérios de compreensão e percepção entre os 
julgadores (Tabela 01).

Tabela 01. Dados de compreensão e percepção dos julgadores.

\begin{tabular}{ccc}
\hline Rótulos & Compreensão & Percepção \\
\hline Comercial & $6,6 \pm 2,1^{\mathrm{c}}$ & $6,6 \pm 2,1^{\mathrm{c}}$ \\
Semáforo & $8,3 \pm 1,1^{\mathrm{a}}$ & $8,1 \pm 1,3^{\mathrm{a}}$ \\
Decrescente & $7,8 \pm 1,3^{\mathrm{a}, \mathrm{b}}$ & $7,8 \pm 1,5^{\mathrm{a}, \mathrm{b}}$ \\
Valor Diário & $7,3 \pm 1,8^{\mathrm{b}}$ & $7,2 \pm 1,9^{\mathrm{b}, \mathrm{c}}$ \\
Letra Maior & $8,1 \pm 1,1^{\mathrm{a}}$ & $7,9 \pm 1,4^{\mathrm{a}}$ \\
\hline
\end{tabular}

Letras iguais na mesma coluna indicam diferença significativa pelo Teste de Tukey $(\mathrm{p}<0,05) .(\mathrm{n}=100)$

$\mathrm{Na}$ perspectiva de pesquisa analítica, salienta-se que os conceitos e compreensão e percepção são diferentes. A compreensão segue os parâmetros de entendimento do indivíduo por meio da capacidade de racionalidade humana, enquanto a percepção pode ser compreendida como o processo pelo qual um indivíduo seleciona, organiza e interpreta estímulos visando um quadro significativo e coerente do mundo, sendo que o estímulo é uma unidade de dados para um dos sentidos - marca, propaganda, por exemplo. Os indivíduos selecionam os estímulos, organizam-nos de acordo com princípios psicológicos e os interpretam levando em conta suas necessidades, suas expectativas e suas experiências (SCHIFFMAN, KANUK, 2000).

Podemos observar pelos resultados que o rótulo semáforo obteve maiores resultados em relação à compreensão. Entretanto, não difere estatisticamente $(\mathrm{p}<0,05)$ dos rótulos frontais que possuem a Letra Maior e que apresentam os ingredientes de forma decrescente de importância. Já em percepção, os rótulos semafórico e que possui letra maior que apresentaram maior percepção dos julgadores. Dessa forma, os dados apresentaram que o rótulo comercial foi o que apresentou menor compreensão e percepção de acordo com a avaliação de 100 julgadores. Sendo assim, há a necessidade de interferir nos rótulos dos produtos brasileiros para que os consumidores possam ter mais interesse em ler as informações contidas nos produtos bem como melhorar a capacidade de compreensão e percepção da rotulagem nutricional.

\section{Conclusões}

Com isso, é possível perceber que o rótulo nutricional frontal que apresenta uma fonte maior teve maior aceitação em comparação ao rótulo comercial; alguns julgadores citaram principalmente o tamanho da fonte como um problema para aqueles que teriam grau de deficiência visual, e havia falta de compreensão por meio da tabela apresentada nos rótulos comerciais. A falta de informação sobre o valor diário recomendado fez com que os julgadores preferissem o rótulo comercial, mesmo alegando sentirem dificuldade em ler o rótulo. Como o rótulo comercial foi considerado o de menor compreensão e percepção, conclui-se que a 
rotulagem nutricional brasileira deve ser revista para incentivar a leitura dos consumidores e facilitar a comunicação entre indústrias e consumidor final.

Portanto, se faz necessário mais trabalhos que avaliem o comportamento dos consumidores frente a rotulagem nutricional, com o intuito de priorizar a saúde do consumidor.

\section{Referências}

BRASIL. Ministério da saúde. Agência Nacional de Vigilância Sanitária. Resolução RDC ANVISA/MS no 259, de 20 de setembro de 2002. Regulamento Técnico Para Rotulagem de Alimentos embalados. Disponível em: http://www.anvisa.gov.br/resol/2002/259_rdc.htm. Acesso em: 06/08/2020.

BRASIL. Ministério da Saúde (2018). Disponível em: https://www.saude.gov.br/noticias/agencia-saude/46485-mais-da-metade-dos-brasileiros-estaacima-do-peso. Acesso em 10 agosto 2020.

BRASIL. Decreto $\mathbf{n}^{\circ}$ 11.346, de 15 de setembro de 2006. Cria o Sistema Nacional de Segurança Alimentar e Nutricional - Sisan com vistas em assegurar o direito humano á alimentação adquada, e dá outras providências. Diário Oficial da República Federativa do Brasil, Brasília, DF, V. 143, N. 179, 18 set. 2006. p. 1.

BRASIL. Resolução da Diretoria Colegiada da Agência Nacional de Vigilância Sanitária. Resolução n. 360. Aprova regulamento técnico sobre rotulagem nutricional de alimentos embalados, tornando obrigatória a rotulagem nutricional. Diário Oficial [da] União, Brasília, DF, 23 dez. 2003.

CAPORALE, G.; MONTELEONE, E. Influence about manufacturing processo $\mathrm{n}$ beer acceptability. Food Quality and Preference, v.15, n.3, p.271-278,2004.

CARVALHO, J. L. V.; DIAS, P. D. F.; OLIVEIRA, A. T.; AMORIM, E. Orientação para rotulagem de alimentos. São Paulo: ABIMA/EMBRAPA, 2006.

CASSEMIRO, I, A.; COLAUTO, N. B.; LINDE, G. A. rotulagem nutricional: quem lê e por quê? Arquivo Ciências da Saúde Unipar, Umuarama, v.10, n.1, p.9-16, jan/abr., 2006. Disponível em: http://resvistas.unipar.br/saude/article/view/136/112. Acesso em 06/08/2020.

CAVALIERE, A.; MARCHI, E.D.; BANTERLE, A. Does consumer health-orientation affect 
use of nutritionfacts panel and claims? An empirical analysis in Italy. Food Quality and Preference, v. 54, p. 110-116, 2016.

DIAZ, A. M. L. Validação de um instrumento de avaliação do comportamento do consumidor adulto com sobrepeso/obesidade frente ás informações nutricionais dos rótulos de alimentos (Monografia), Brasília: Curso de Especialização em Qualidade de Alimentos da Universidade de Alimentos; 2006.

FELIPE, M. R.; MEZADRI, T.; CALIL, J. Rotulagem de alimentos: o comportamento do consumidor usuários de supermercados do balneário Camboriú/SC. Higiene Alimentar, São Paulo, v. 17, n. 111, p. 49-57, 2003.

FERNANDES, L. B.; MACHADO, S.; VIEIRA, D. A. P. Avaliação qualitativa do hábito de leitura e entendimento dos rótulos de alimentos do município de Inhumas - GO. In: IV seminário de iniciação científica do instituto federal de educação, ciência, e tecnologia de goiás/ ifg. Anais... Inhumas - GO, set., 2010.

FERREIRA, A. B.; LANFER- MARQUEZ, U. M. Legislação brasileira frente á rotulagem nutricional de alimentos. Revista de nutrição, vol.,20. n.1, pp.83-93,2007.

GRAHAM, D.J.; HEIDRICK, C.; HODGIN, K. Nutrition label viewing during a food-selection task: front-of-package labels vc nutrition faction labels. Journal of Academy of Nutriction and Dietetics, 115:1636-46, 2015.

LEVY AS, FEIN SB. Consumer's ability to perform tasks using nutrition labels. Journal of Nutritional Education. 1998; $30 \quad$ (4): 210-7. http://dx.doi.org/10.1016/S00223182(98)70321-8.

LOBANCO, C. M.; VEDOVATO, G. M.; CANO, C. B.; BASTOS, D. H. M. Fidedignidade de rótulos de alimentos comercializados no município de São Paulo, SP. Revista Saúde Pública. 2009;43(3):499-505.

MACHADO, W. R. C.; LEUNG, R.; LEITE, M. A. G. Percepção do consumidor sobre rotulagem de produtos lácteos industrializados. Revista de Engenharia e Tecnologia. 2014; v. 6, n. 2: 140-150. 
MARINS, B.R.; JACOB, S.C.; PERES, F. Avaliação qualitativa do hábito de leitura e entendimento: recepção das informações de produtos alimentícios. Ciência e Tecnologia de Alimentos, vol. 28(3), p. 579-585,2008.

MARINS, B.R; JACOB, S.C. Evaluation of the habit of reading and understanding the label for consumers Niteroi, RJ. Revista Visa em Debate, vol. 3, n. 3, p. 122-129, 2015.

MARINS, B. R.; JACOB, S. C. Avaliação do hábito de leitura e da compreensão da rotulagem por consumidores de Niterói, RJ. Rio de janeiro: visa em debate, 2014. 8p.

MARTINS, B. R. Análise do hábito de leitura e entendimento/recepção das informações contidas em rótulos de produtos alimentícios embalados, pela população adulta frequentadora de supermercados, no Município de Niterói/ RJ. 2004. 149f. Dissertação (Mestrado em Vigilância Sanitária de Produtos) - Fundação Instituto Oswaldo Cruz, Niterói, 2004.

MARZAROTTO, B.; ALVES, M. K. Leitura de rótulos de alimentos por frequentadores de um estabelecimento comercial. Flores da Cunha, RS. Revista Ciência\&Saúde. 2017;10(2):102108.

MERMELSTEIN NH. A new era in food labeling. Food Technology, 1993;47 (2): 81-6.

OLIVEIRA, L. L.; BOCCHINI, M.A. Legibilidade visual para informação nutricional em rótulos de alimentos. In: C. G. Spinillo; L. M. Fadel; V. T. Souto; T.B.P. Silva\& R. J. Camara (Eds). Anais [Poster] of the 7th Information Design International Conference CIDI 2015 [Blucher Design Proceedings, num.2, vol.2]. São Paulo: Blucher, 2015. ISSN 2318-6968.

POST, R.E.; MAINOUS, A.G.; DIAZ, V.A.; MATHESON, A.M.; EVERETT, C.J. Use of nutrition facts label in chronic disease management: results from the national health and nutrition examination survey. Journal of Academy of Nutriction and Dietetics, 110:628-42, 2010.

SCHIFFMAN, L. G.; KANUK, L. L. Comportamento do Consumidor. 6. ed. Rio de Janeiro: LCT, 2000. 475 p.

SOUZA, S. M. F. C. et al. Utilização da informação nutricional de rótulos por consumidores de 
Natal, Brasil. Revista Panamericana Salud Pública, v.29, n.5 p. 337- 43, 2005. Disponível em: http://www.scielosp.org/pdf/rpsp/v29n5/a06v29n5.pdf. Acesso em: 06/08/2020.

SOUZA SM, LIMA KC, MIRANDA HF, CAVALCANTI FI. Utilização da informação nutricional de rótulos por consumidores de natal, Brasil. Revista Panamerica de Salud Publica,2011; 29(5): 337-43.

WORLD HEALTH ORGANIZACION. Diet, nutricion and the preventionof chronic diseases: Report of a joint WHO/FAO7 Expert Consultation. Geneva; 2003. (WHO Technical Repoort Series, 916).

YOSHIZAWA, N. et al. Rotulagem de alimentos como veículo de informação aoconsumidor: adequações e irregularidades. Boletim do Centro Pesquisa e Processamento de Alimentos. 2003; 21 (1): 169-80. 


\title{
CAPÍTULO 09: ISOTERMA DE SORÇÃO DE UVA ARRA 15® DESIDRATADA E ARMAZENADA EM DIFERENTES EMBALAGENS
}

\section{CHAPTER 09: GRAPE SORRERM ISOTHERM ARRA 15® DEHYDRATED AND STORED IN DIFFERENT PACKAGES}

\author{
Joselane Nascimento da Silva ${ }^{1}$; Iasmim Pereira Oliveira ${ }^{2}$; Nailton Macedo de Albuquerque \\ Junior $^{3}$; Aurianna Barros Coelho ${ }^{4}$; Silvana Belém de Oliveira Vilar ${ }^{5}$
}

\section{Resumo}

O Brasil é o $3^{\circ}$ maior produtor de frutas no mundo, sendo que a cada ano vem se destacando na variedade de vegetais produzidos. Como exemplo, temos a inserção de novas variedades de uvas dentre elas a Arra $15^{\prime}($, na região do Vale do São Francisco. No entanto, devido a elevada exportação dessa fruta, uma boa parte considerada imprópria é descartada, por não apresentar o padrão necessário. Dessa forma, a busca por tecnologias adequadas para reduzir essas perdas é de extrema importância, como por exemplo, a elaboração de uvas-passas atrelado ao uso de embalagens eficientes. Sendo assim, este trabalho objetivou comparar o comportamento de uvas passas de 'Arra $15^{\prime}(\mathbb{}$ ' armazenadas em duas distintas embalagens por 30 dias. As uvas in natura foram pré-tratadas com $\mathrm{NaOH}$ a $1 \%$, secas em Air fryer e armazenadas em bandejas de poliestireno (PS) com auxílio do filme de cloreto de polivinila (PVC) e em Polietileno de baixa densidade (PEBD). Após as análises, concluiu-se que a embalagem de PEBD apresentou maior estabilidade de isoterma de sorção, além da composição centesimal da fruta não ter sido alterada de forma significativa após processamento.

Palavras-Chaves: Conservação, Isoterma, Redução de perdas, Secagem, Tecnologia.

\begin{abstract}
Given the diversity of fruits in Brazil, the country is the 3rd largest producer and increases its cultivation each year, as the insertion of new varieties of grapes (Arra $15^{\prime} \circledR$ ) in the region of the São Francisco Valley, because they present good characteristics not only for consumption but also for processing. However, due to the high export of this fruit, a good part considered improper is discarded, for not presenting the necessary pattern. Therefore, the search for adequate technologies to reduce these losses is of extreme importance, such as the elaboration of raisins linked to the use of efficient packages. Therefore, this work aimed to produce 'Arra $15^{\prime} \AA$ raisins evaluating loss of mass, isotherm of sorption and physical-chemical composition of this agricultural product. To carry out the work, Airfryer drying was used along with pretreatment with $1 \% \mathrm{NaOH}$, and later stored in packages of Ps+PVC and LDPE for 30 days. After the analyses, it was concluded that the LDPE package showed greater stability of sorption isotherm and that the centesimal composition of the fruit was not significantly altered after processing.
\end{abstract}

Keywords: Conservation, Isotherm, Loss reduction, Drying, Technology.

\footnotetext{
${ }^{1}$ Graduada em Tecnologia em Alimentos, Instituto Federal do Sertão Pernambucano, joselanens13@hotmail.com

${ }^{2}$ Graduada em Tecnologia em Alimentos, Instituto Federal do Sertão Pernambucano, mimuefs@gmail.com

${ }^{3}$ Graduado em Tecnologia em Alimentos, Instituto Federal do Sertão Pernambucano, junior.nailton@ gmail.com

${ }^{4}$ Mestre em Horticultura, Professora Instituto Federal do Sertão Pernambucano, aurianna.coelho@ifsertao-pe.edu.br

${ }_{5}^{5}$ Doutora em Tecnologia em Alimentos, Professora do Instituto Federal do Sertão Pernambucano, silvana.belem@ifsertaope.edu.br
} 


\section{Introdução}

Numa escala mundial, o Brasil se encontra em $3^{\circ}$ lugar no ranking de produção de frutas, por apresentar uma grande diversidade tanto de frutas frescas como processadas (ALAMAR et al., 2016), com aproximadamente 45 milhões de toneladas por ano, dos quais $65 \%$ são vendidos no mercado interno e 35\% no mercado externo (EMBRAPA, 2019). Dados da ABRAFRUTAS (2020), mostram que a produção de frutas atingiu um nível de crescimento de $16 \%$ nas exportações de frutas no ano de 2019, onde 980.000 toneladas foram exportadas, em comparação com 848.000 toneladas em 2018. O principal é a exportação de manga com aumento de $30 \%$ nas exportações, $27 \%$ de melão, $19 \%$ de uvas e $10 \%$ de limões.

Devido à variedade de frutas, na região no Submédio do Vale do São Francisco, é evidente que vêm sendo introduzidas diversa cultivares de uvas, principalmente do tipo sem sementes, devido à preferência dos consumidores de diversos mercados, apontada a partir da década de 1990, bem como aos melhores preços adquiridos no mercado externo (LEÃO et al., 2011), o qual é o destino de uma fração importante da uva cultivada nesta região.

A partir dessas novas cultivares inseridas na produção frutífera do Vale do São Francisco, pode-se encontrar a variedade Arra $15^{\prime}\left({ }^{\circledR}\right.$. A produção em geral busca a designação de métodos de cultivo adequados para as circunstâncias regionais, assim como novos para acrescentar características, aperfeiçoar a qualidade da uva para o consumo in natura e determinar o ponto de colheita adequado à comercialização, visto que é uma variedade que apresenta propriedades como abundantes bagas, sem sementes e atraentes, com uma tonalidade de casca verde-clara e brilhante, em cachos de dimensão média a grande (KARNIEL; GIUMARRA, 2011).

Mello (2016) relatou que do cultivo de uva do país, 52,12\% neste ano foi usada para processamento, principalmente na forma de vinho, suco de frutas e derivados, e o restante para consumo fresco. Os dados de VITIBRASIL (2016), confirmam que o volume de processamento dessa forma seca de frutas ainda é muito baixo. Em 2015 dados mostram que o Brasil importou da Argentina, Estados Unidos, Chile, Emirados Árabes Unidos e Irã e outros países produtores de uva, um total de cerca de 24,8 toneladas de uvas - passas, o gasto total é de cerca de 40,6 milhões de dólares. O principal motivo da importação é que o país possui a menor área de plantio de trepadeiras sem sementes (mais adequadas para as passas), resultando em suprimento insuficiente desse tipo de uvas desidratadas.

A relevância da ciência e tecnologia de alimentos está no desenvolvimento de tecnologias e processos que possam diminuir perdas, principalmente para aumentar o suprimento de alimentos e garantir sua durabilidade a extenso prazo em termos de qualidade 
SILVA, J. N. et al.

(NESPOLO, 2015; GAVA, 2008).

A produção de uva- passas é um método alternativo para reduzir as importações e reduzir as perdas pós-colheita. Segundo Costa et al. (2015), o uso de bagas excedentes e de alta qualidade para a produção de uva - passas, pode diminuir os rendimentos e é uma opção de mercado para os produtores de uvas de mesa.

De acordo com Feiden et al. (2015), a secagem ou desidratação é uma tecnologia de conservação que reduz a umidade em frutas ou vegetais e minimiza a possibilidade de degradação microbiana, transformação enzimática e oxidação sem perder cor, aroma, sabor e textura. Para obter uvas - passas, a fruta passa por um processo de secagem ou desidratação.

A secagem possivelmente é um dos métodos mais antigos de preservação de alimentos pós-colheita empregados pelo homem. Este processo baseia-se na retirada de água de um material, com transferência de calor e massa, ou seja, conserva o material restringindo a umidade presente, sendo uma tecnologia de baixo custo que geralmente leva a poucas alterações sensoriais e nutritivas (ONWUDE et al, 2016).

A secagem é um processo amplamente utilizado na indústria de alimentos, pois proporciona o desenvolvimento de novos produtos com elevada vida útil (MACIEL et al., 2017). A conservação pelo processo de secagem está relacionada ao fato dos microrganismos, das enzimas e de todo o mecanismo metabólico necessitarem de água para realizar suas atividades (MARTINAZZO et al.,2007).

Dentre os processos de secagem existentes na literatura têm-se a secagem pelo air fryer, o qual se obtém produtos sem comprometer suas características organolépticas, além de ser uma técnica alternativa e prática para estimar a matéria seca de alimentos volumosos utilizados em confinamentos.

Esse equipamento dispõe de um ventilador interno, combinando altas taxas de convecção e transferência de calor por radiação, com isso o ar quente circula através do conjunto do motor do ventilador para cavidade do equipamento, onde o ar quente é dirigido de uma maneira em que um fluxo de gás turbulento colide, diretamente, com alimento proporcionando a secagem acelerada do produto alimentício. $\mathrm{O}$ ar também é distribuído uniformemente e as alterações na qualidade do produto são minimizadas devido à sua cavidade cilíndrica (TERUEL, 2015).

A capacidade dos alimentos de absorverem umidade, ou seja, a sua higroscopicidade, que está relacionada à sua estabilidade física, química e microbiológica, é indispensável para avaliar o comportamento higroscópico através das Isotermas de sorção (Cavalcante et al., 2018), a qual segundo Martins et al., (2015) representa a relação entre a atividade de água e 
SILVA, J. N. et al.

umidade de um alimento, a uma temperatura constante.

Através do processamento de alimentos, novos produtos podem ser desenvolvidos com alto valor agregado e praticidade. Além disso, o processo de secagem é uma tecnologia de preservação mais usada no mundo por garantir uma maior shelf-life e reduzir o teor de umidade e a atividade da água nos alimentos para impedir o desenvolvimento microbiológico (SANTOS et al., 2015).

A vida útil corresponde ao período em que o alimento é armazenado sob certas condições que podem reter suas propriedades sensoriais, microbianas e físico-químicas. A estabilidade desses produtos é afetada pelos seguintes fatores: processo de preservação, atividade de umidade, material de embalagem e natureza dos alimentos (CORRÊA et al., 2015).

A embalagem desempenha um papel fundamental no armazenamento, transporte e manutenção da qualidade dos alimentos durante sua vida útil. O plástico é tradicionalmente usado como embalagem, devido às boas propriedades mecânicas, baixo custo e baixa permeabilidade ao vapor de água e alta compatibilidade com diferentes alimentos (GARAVAND et al., 2017; HONG et al., 2017).

Atrelado ao processo de secagem, a utilização de embalagens são de extrema relevância devido melhorar o manuseio, armazenamento e transporte, bem como garantir a preservação das características nutricionais e microbiológicas do produto. Dessa forma para garantir a sanidade e qualidade dos frutos, a escolha do tipo de material utilizado na embalagem é de extrema importância (LORENZI et al., 2014).

Diante disto, a crescente preocupação com desperdício de frutas em relação às questões ambientais, e a importância do reaproveitamento destas com tecnologias avançadas, baseadas nos impactos causados pela desidratação e uso de embalagens eficientes na conservação dos produtos, o presente estudo visou elaborar uva-passa (Arra $15^{\prime}($ ) analisando a composição físico-química e avaliando a isoterma de sorção dela à partir do armazenamento em diferentes embalagens.

\section{Material e Métodos}

\section{Matéria-prima}

Para realização do presente trabalho foram utilizadas uvas de variedade Arra $15^{\prime}{ }^{\circledR}$ doadas pela Fazenda Esperança, localizada no Projeto Senador Nilo Coelho, Núcleo 4, Petrolina-PE. Os frutos maduros e considerados como de "descartes" pela fazenda foram imediatamente transportados para o Laboratório Experimental de Alimentos (LEA) do Instituto 
SILVA, J. N. et al.

Federal de Educação, Ciência e Tecnologia do Sertão Pernambucano (IF Sertão-PE), onde foram selecionados e higienizados em solução clorada.

\section{Caracterização Físico-química}

Após a higienização, foram retiradas amostras das uvas para a caracterização in natura e após 30 dias de armazenamento, sendo avaliadas quanto ao teor umidade, $\mathrm{pH}$, sólidos solúveis, acidez total titulável e cor, conforme metodologias descritas em IAL (2008).

\section{Secagem}

Primeiramente as uvas foram pesadas em balança analítica, logo após foi realizada a pesagem e o tratamento químico com hidróxido de sódio à $1 \%$ por 30 segundos, em fervura, e assim colocadas no secador Air Fryer.

\section{Armazenamento}

Após a secagem das amostras, estas foram armazenadas em embalagens de polietileno de baixa densidade (PEBD) e em bandejas de poliestireno (PS) com auxílio do filme de cloreto de polivinila (PVC).

\section{Isoterma de Sorção}

As isotermas de sorção foram realizadas de acordo com a metodologia descrita por Coelho e Azevedo (2013), para avaliar a embalagem mais adequada para o armazenamento de uvas passas. As uvas-passas colocadas nas embalagens de PEBD e PS+PVC foram pesadas, e em seguida transferidas para os frascos de vidro contendo soluções salinas saturadas.

\section{Análise estatística}

Os resultados das análises foram avaliados pela análise descritiva, teste shapiro-wilk para normalidade, seguido de teste ANOVA, utilizando-se o programa Biostat 5.0.

\section{Resultados e Discussão}

Os valores obtidos a partir da triplicata das análises centesimais das uvas in natura, antes do processo de secagem e pré-tratamento com $\mathrm{NaOH}$, estão destacados na Tabela 01 .

O teor de umidade encontrado na uva in natura é aceitável, pois é uma fruta com uma grande quantidade de água, entretanto é importante observar que fatores como região, 
SILVA, J. N. et al.

maturidade, características do solo, clima e época de colheita também interferem nas propriedades físicas e químicas da fruta. (MORZELLE et al., 2015).

Tabela 1. Caracterização físico-química in natura da uva Arra 15’`®.

\begin{tabular}{|c|c|c|}
\hline \multicolumn{2}{|c|}{ Análise } & Resultados \\
\hline \multicolumn{2}{|c|}{ Umidade $(\%)$} & $79,27 \pm 0,02$ \\
\hline \multicolumn{2}{|c|}{$\mathrm{pH}$} & $3,5 \pm 0,01$ \\
\hline \multicolumn{2}{|c|}{${ }^{\circ}$ Brix } & $19,3 \pm 0,36$ \\
\hline \multicolumn{2}{|c|}{ Acidez Titulável } & $7,9 \pm 0,04$ \\
\hline & $\mathrm{L}^{*}$ & $43,6 \pm 1,34$ \\
\hline \multirow[t]{2}{*}{ Cor } & $a^{*}$ & $-5,01 \pm 0,15$ \\
\hline & $\mathrm{b}^{*}$ & $42,8 \pm 3,59$ \\
\hline
\end{tabular}

Fonte: Própria (2020).

$\mathrm{O} \mathrm{pH}$ dos alimentos é uma característica que depende de vários fatores, entre eles, o estado de preservação e condições das matérias-primas utilizadas, com isso o pH encontrado para a uva in natura é ótimo do ponto de vista microbiológico.

Segundo Brasil (2018) uvas destinadas ao processamento devem-se ter no mínimo $14^{\circ}$ Brix, assim a Arra $15^{\prime}{ }^{\circledR}$ utilizada encontra-se acima do valor estabelecido, estando adequada para o processo.

Em relação a acidez titulável, o valor encontrado é significativo, comparando com outras variedades, tendo em vista que a produção de ácidos orgânicos está ligado com a região e ao clima durante o crescimento e amadurecimento das uvas (ZERAVIK et al., 2016).

A cor é um importante atributo de qualidade de frutas frescas e processadas, pois ela está muito relacionada à aceitação dos alimentos pelo consumidor, sendo o aspecto visual o principal fator decisivo na escolha de um produto (RIBEIRO et al., 2012), com isso a coloração do produto ao final do processo deve ser semelhante a cor natural.

As determinações físico-químicas ( ${ }^{\circ} \mathrm{Brix}, \mathrm{pH}$, acidez e cor) foram realizadas após 30 dias, para cada embalagem específica, comparando assim os resultados entre elas.

Os dados amostrais foram tratados estatisticamente, analisando a normalidade pelo teste de Shapiro-wilk com nível de significância de $\mathrm{p}<0,05$. Seguido da análise descritiva quantitativa e teste ANOVA. Os resultados obtidos estão descritos abaixo na Tabela 2. 
SILVA, J. N. et al.

Tabela 2. Análise estatística das propriedades físico-químicas das uvas-passas nas embalagens de Ps+PVC e PEBD, após 30 dias de armazenamento.

\begin{tabular}{cccccc}
\hline \multirow{2}{*}{ Análise } & \multicolumn{2}{c}{$\mathrm{X}$} & \multicolumn{2}{c}{$\mathrm{CV}(\%)$} & \multirow{2}{*}{ Valor de P } \\
\cline { 2 - 5 } & Ps+PVC & PEBD & Ps+PVC & PEBD & \\
\hline Brix & $55 \mathrm{a} \pm 0,0$ & $53,3 \mathrm{a} \pm 1,1$ & - & 2,17 & \\
$\mathrm{pH}$ & $3,0 \mathrm{a} \pm 0,0$ & $3,0 \mathrm{a} \pm 0,0$ & - & 0,0 & $4 \%$ \\
Acidez & $2,0 \mathrm{a} \pm 0,0$ & $2,0 \mathrm{a} \pm 0,0$ & - & 0,0 & \\
Umidade & $78,6 \mathrm{a} \pm 8,6$ & $77,9 \mathrm{~b} \pm 2,2$ & 11 & 2,8 & \\
\hline
\end{tabular}

Fonte: Própria (2020).

Comparando as duas embalagens utilizadas, pode-se observar que os valores de ${ }^{\circ} \mathrm{Brix}$ não apresentaram diferença significativa entre elas, mostrando valores médios confiáveis por apresentarem desvio padrão e coeficiente de variação reduzidos (não ultrapassando 10\%). Ainda, segundo o teste de Shapiro-Wilk a dispersão dos valores foi normal. O pré-tratamento com $\mathrm{NaOH}$ não influenciou significativamente no teor de sólidos solúveis, tendo em vista que o processo de secagem concentrou mais esses compostos.

Sabe-se que o potencial hidrogeniônico é um dos parâmetros mais importantes de avaliação dos alimentos, uma vez que indica se os produtos estão seguros em relação ao crescimento de microrganismos. Notou-se que não houve diferenças significativas deste parâmetro, bem como o pré-tratamento com $\mathrm{NaOH}$ não alterou significativamente os valores de $\mathrm{pH}$ durante o período de armazenamento. Em comparação com a literatura, foram encontrados valores semelhantes entre 3,5 e 4,5 no estudo feito por Costa (2015), o qual realizou a desidratação de uvas 'Itália' pré-tratadas com a mesma substância.

A uva na sua forma in natura possui uma acidez elevada, tal propriedade permaneceu na uva-passa, sendo que o teor de acidez pode apontar o estado de conservação de um alimento, estando relacionada a presença de ácidos orgânicos encontrados naturalmente em frutas e vegetais como os ácidos málico, cítrico e tartárico, sendo esse último predominante na uva (RIBEIRO et al., 2016). Durante o período de armazenamento pôde-se observar que não houve uma mudança significativa das suas quantidades nas uvas-passas, tanto na Ps+PVC como na PEBD, mostrando que as embalagens utilizadas e o pré-tratamento, não alteraram a acidez do produto.

A umidade é um dos principais parâmetros, relacionados à qualidade da uva-passa, uma vez que a sua quantidade influencia diretamente na concentração de nutrientes e fito químicos bioativos (DOYMAZ, 2006). A umidade final apresentou que houve uma perda de água após o 
SILVA, J. N. et al.

processo de secagem em ambas embalagens, sendo que a embalagem PEBD uma melhor redução deste parâmetro.

Os valores da análise de cor a partir dos parâmetros $L^{*}, a^{*}$ e b* das uvas armazenadas após o processo de secagem e pré-tratamento com $\mathrm{NaOH}$, estão destacados na Tabela 3.

Tabela 3. Variação da cor das uvas em cada embalagem ao decorrer do tempo.

\begin{tabular}{cccccccc}
\hline \multirow{2}{*}{$\begin{array}{c}\text { Período de } \\
\text { armazenamento }\end{array}$} & \multicolumn{3}{c}{ Ps + PVC*$^{*}$} & \multicolumn{3}{c}{ PEBD* } & \multicolumn{2}{c}{ Valor de P } \\
\cline { 2 - 7 } & $\mathrm{L}^{*}$ & $\mathrm{a}^{*}$ & $\mathrm{~b}^{*}$ & $\mathrm{~L}^{*}$ & $\mathrm{a}^{*}$ & $\mathrm{~b}^{*}$ & \\
\hline 30 dias & $17,8 \mathrm{a}$ & $3,0 \mathrm{a}$ & $2,5 \mathrm{a}$ & $17,2 \mathrm{a}$ & $2,6 \mathrm{a}$ & $1,9 \mathrm{a}$ & \\
\hline
\end{tabular}

Valores obtidos através da respectiva análise em triplicata.

Fonte: Própria (2020).

Os valores de Luminosidade não apresentaram diferença significativa entre as embalagens e tratamento utilizados, assim como as coordenadas $\mathrm{a}^{*} \mathrm{e} \mathrm{b}^{*}$, mostrando que os dois métodos tiveram efeitos similares, em relação a mudança de cor, no produto ao final de 30 dias de armazenamento.

A partir do diagrama de cores (Figura 1) junto com valores obtidos na análise por calorimetria, é possível diagnosticar a cor final do produto nas duas embalagens.

Figura 1. Diagrama de cor.

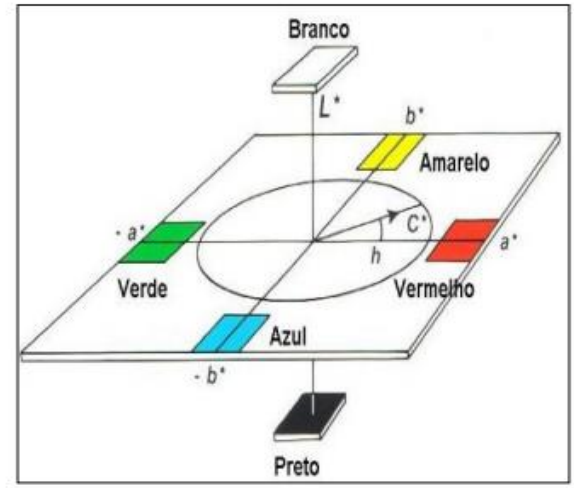

Fonte: Hunter Lab (2019).

Após avaliação de dados, e comparação no diagrama pôde-se verificar a coloração da uva passa (Figura 2). De acordo com os resultados obtidos, durante o armazenamento houve a intensificação do escurecimento da uva passa, porém sem um efeito significativo no parâmetro $L^{*}$ em relação ao processo de secagem e pré-tratamento empregado. Quanto aos valores encontrados para a coordenada $a^{*}$ que indica a cor para tons de vermelho e verde e para 
coordenada $b^{*}$ que reflete a mudança de tons entre o amarelo e azul, esta foi influenciada pelo tempo de armazenamento em ambas embalagens.

Figura 2. Determinação da cor das uvas passas.

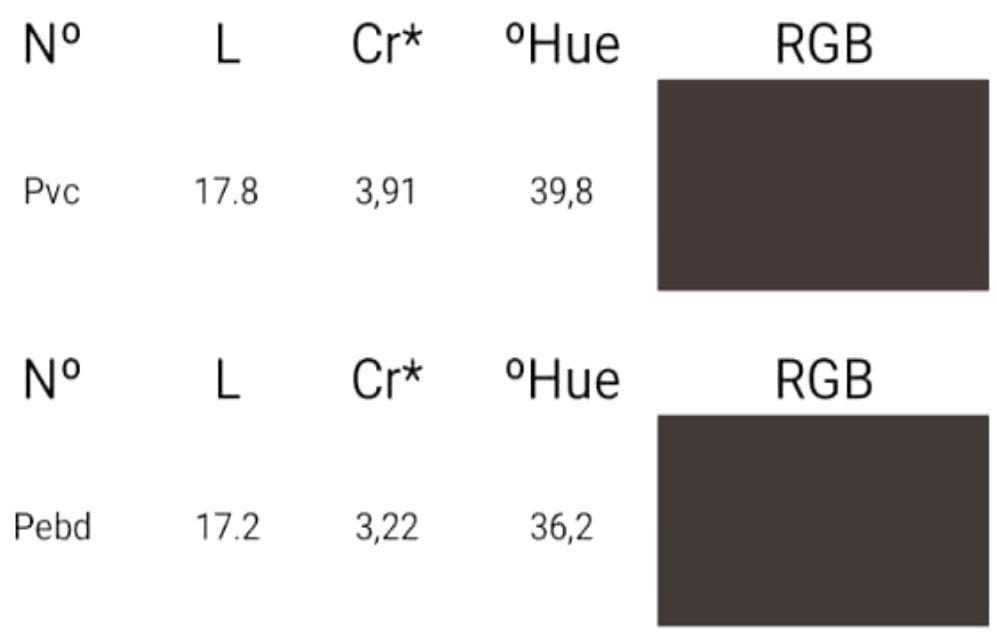

Fonte: Aplicativo Análise de cor (Research Lab Tools).

Os resultados referentes às variações de peso de Isoterma das uvas-passas nas embalagens Ps+PVC e PEBD estão representadas abaixo nas Figuras 3 e 4.

A partir dos valores obtidos em ambas embalagens, (Figuras 3 e 4) pôde-se verificar que houve perda de massa na maioria dos frascos, pré-tratadas quimicamente na air fryer, na temperatura utilizada, influenciando consequentemente na diminuição da umidade, indicando assim a seguridade do produto quanto ao crescimento microbiano, além de reações oxidativas, shelf-life e qualidade final.

Figura 3. Variação do peso de isoterma das Uvas-passas, em Ps + PVC, no início e fim de armazenamento.

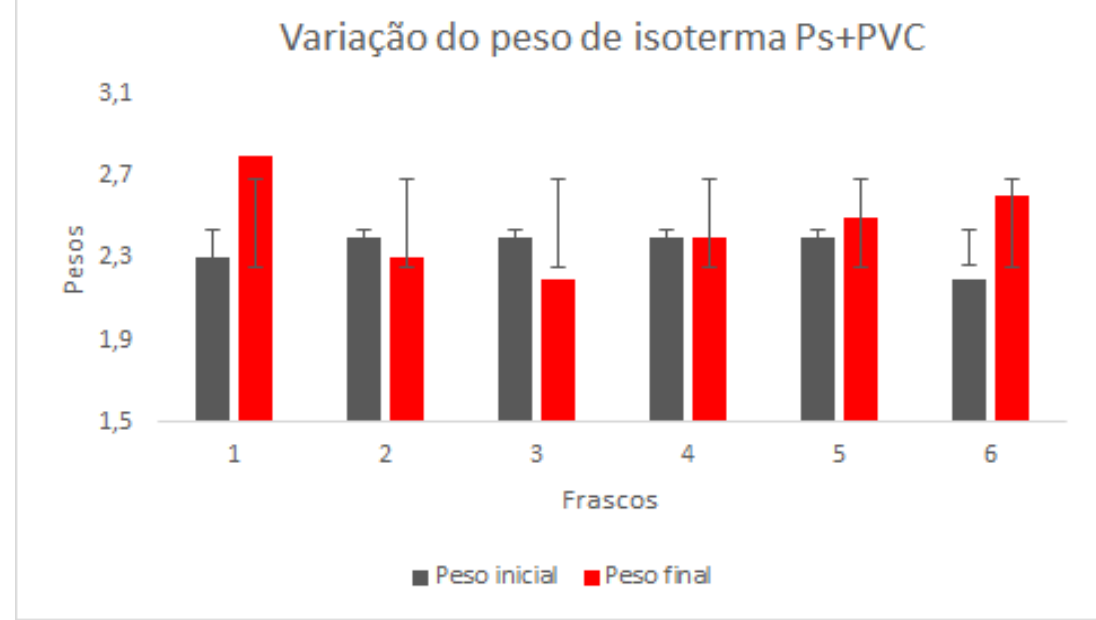

Fonte: Própria (2020).

[132] 
SILVA, J. N. et al.

Figura 4. Variação do peso de isoterma das Uvas-passas, em PEBD, no início e fim de armazenamento.

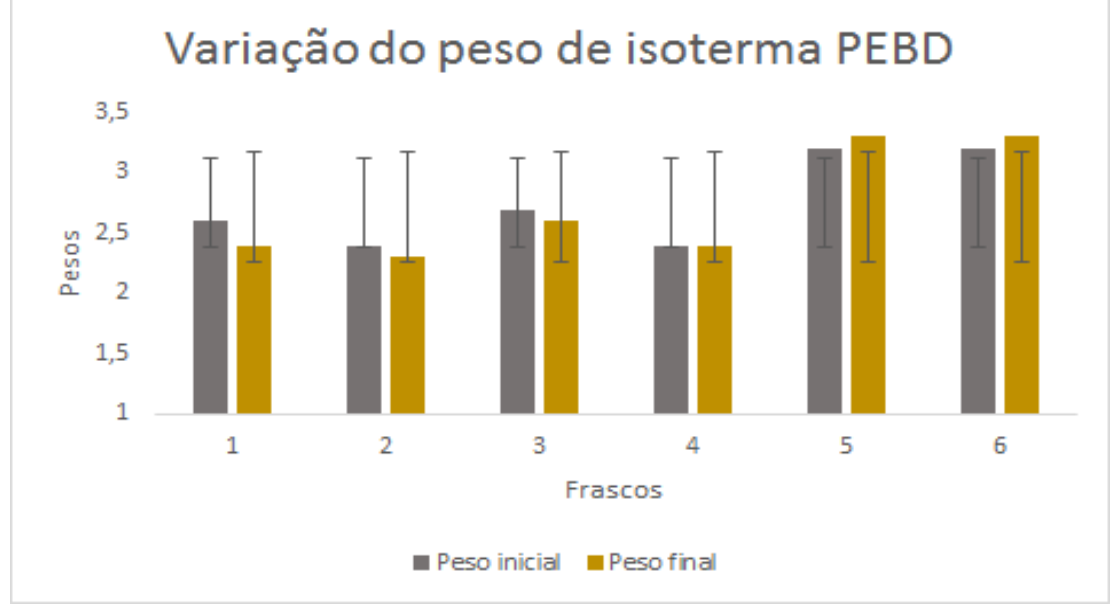

Fonte: Própria (2020).

Os resultados referentes a Isoterma de sorção das uvas-passas nas embalagens Ps+PVC e PEBD está representada abaixo na Figura 5.

Figura 5. Valores da isoterma de sorção das uvas-passas nas duas embalagens utilizadas.

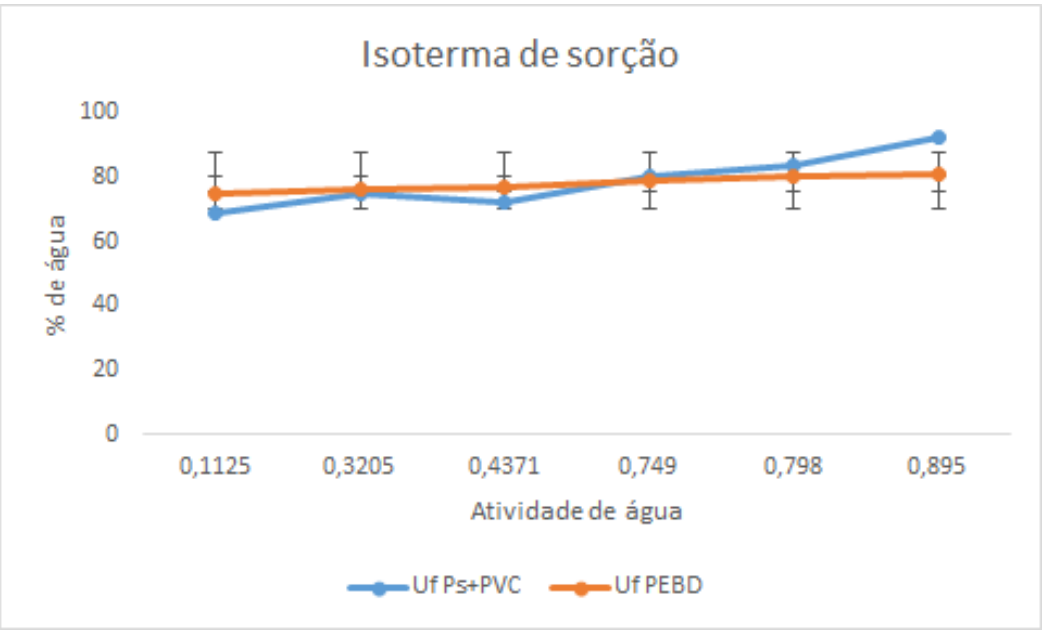

Fonte: Própria (2020).

Após trinta dias de estabilização as isotermas foram adquiridas, observou-se que o processo de secagem reduziu a umidade inicial $(79,27 \%)$ para $24 \%$ posteriormente, influenciando na quantidade de água no produto, evitando que haja crescimento de microrganismos e promovendo uma maior concentração de nutrientes e compostos. De acordo com Wang (2016) vários pré-tratamentos, incluindo tratamentos químicos, físicos e de branqueamento, têm sido realizados para remover a camada de cera dos frutos antes do processo de secagem. Todos os resultados indicaram que a taxa de secagem aumenta e o tempo de secagem diminui, para que as uvas atinjam a umidade segura necessária para o armazenamento. 
SILVA, J. N. et al.

Dessa forma, o pré-tratamento com o $\mathrm{NaOH}$ utilizado, influenciou em um período de secagem menor, devido a temperatura aplicada, proporcionando uma umidade constante em menor tempo.

A partir da estatística realizada, as embalagens utilizadas apresentaram diferenças significativas do teor de umidade nas uvas-passas, com isso observou-se que a embalagem de PEBD demonstrou um menor índice de adsorção de água e consequentemente um maior de dessorção, resultando em dados mais constantes (Figura 5).

\section{Conclusões}

A partir da análise físico-química na uva (Arra $\left.15^{\prime}{ }^{\circledR}\right)$ in natura, conclui-se que a fruta, possui propriedades suficientes para o processo de fabricação de uvas-passas, além disso a utilização do refugo diminui o descarte e consequentemente o desperdício, obtendo-se assim um produto com valor agregado.

Ao final do armazenamento, averiguou-se que a composição centesimal, exceto a umidade, não foi alterada de forma significativa, após a secagem, continuando a ter propriedades suficientes para a elaboração de uvas-passas.

A utilização do pré-tratamento com $\mathrm{NaOH}$ foi satisfatória, quanto a velocidade de secagem, além de não modificar, significativamente, as propriedades físico-químicas.

Entre as embalagens utilizadas, a de PEBD foi a que apresentou resultados mais satisfatórios em relação às isotermas de sorção.

Aconselha-se a utilização de outros pré-tratamentos e de maiores tempos de armazenagem, bem como o uso de outras técnicas de secagem, uma vez que a uva Arra $15^{\prime}($ é uma variedade nova na região do Submédio do Vale do São Francisco e apresenta boas propriedades para a formulação de novos subprodutos.

\section{Referências}

ABRAFRUTAS - Associação Brasileira dos Produtores Exportadores de Frutas e Derivados. Dados estatísticos do setor: Estatísticas das exportações de frutas em 2019.

ALAMAR, P. D.; CARAMÊS, E. T. S.; POPPI, R. J.; PALLONE, J. A. L. Quality evaluation of frozen guava and yellow passion fruit pulps by NIR spectroscopy and chemometrics. Food Research International, v. 85, n. 7, p. 209-214, 2016. 
ARAÚJO, R. D. F.; VILAR, S. B. O.; BARROS, E. R. Kinetics of Drying and PhysicalChemical Quality of Peach cv. Hubimel. Journal of Agricultural Science, 11(16), 223-232. 2019.

CAVAlCANTE, C. E. B.; ROdRIGUES, S.; AFOnSO, M. R. A.; COSTA, J. M. C. Comportamento Higroscópico da Polpa de Graviola em Pó Obtida Por Secagem em Spray Dryer, Brazilian Journal of Food Technology, Vol 21, 2018.

COSTA, J. D. S.; FIGUEIREDO NETO, A.; NUNES, S. M.; RYBKA, A. C. P.; BIASOTO, A. C. T.; FREITAS, S. T. Caracterização física e físico-química de uva Itália desidratada. Revista Iberoamericana de Tecnología Postcosecha, v. 16, n. 2, p. 273-280, 2015.

COSTA, J. D. S.; FIGUEIREDO NETO, A.; NUNES, S. M.; RYBKA, A. C. P.; BIASOTO, A. C. T.; FREITAS, S. T. Caracterização física e físico-química de uva Itália desidratada. Revista Iberoamericana de Tecnología Postcosecha, v. 16, n. 2, p. 273-280, 2015.

EMPRAPA. Ciência que transforma: Resultados e impactos positivos da pesquisa agropecuária na economia, no meio ambiente e na mesa do brasileiro. 2019. Disponível em: $<$ https://www.embrapa.br/grandes-contribuicoes-para-a-agricultura-brasileira/frutas-ehortalicas>. Acesso em 03/08/2020.

FEIDEN, A.; FEIDEN, A.; GALVANI, F.; CAMPOLIN, A. Desidratação de frutas utilizando secador solar. Corumbá: Embrapa Pantanal, 2015. 5 p. (Comunicado Técnico 98). Disponível em: 〈https://www.infoteca.cnptia.embrapa.br/infoteca/bitstream/doc/1037117/1/COT98.pdf $>$.

FEIDEN, A.; FEIDEN, A.; GALVANI, F.; CAMPOLIN, A. Desidratação de frutas utilizando secador solar. Corumbá: Embrapa Pantanal, 2015. 5 p. (Comunicado Técnico 98). Disponível em: 〈https://www.infoteca.cnptia.embrapa.br/infoteca/bitstream/doc/1037117/1/COT98.pdf $>$.

GARAVAND, F.; ROUHI, M.; RAZAVI, S. H.; CACCIOTTI, I.; MOHAMMADI, R. Improving the integrity of natural biopolymer films used in food packaging by crosslinking approach: A review. International Journal of Biological Macromolecules, v. 104, p. 687-707, 2017. 
GAVA, A. J; FRIAS, J. R.G; SILVA, C.A.B. Tecnologia de alimentos: princípios e aplicações. São Paulo: Nobel, 2008.

HONG, J.; CHEN, Y.; WANG, M.; YE, L.; QI, C.; YUAN, H.; ZHENG, T.; LI, X. Intensification of municipal solid waste disposal in China. Renewable and and Sustainable Energy, v. 69, p. 168-176, 2017.

KARNIEL, E. S.; GIUMARRA, E. S. Grape Plant Named “Arrafifteen”e. US Pat. 2011/0219502 P1, 8 set, 2011. 4p.

LEÃO, P. C. de S.; BRANDAO, E. O.; GONCALVES, N. P. da S. Caracterização agronômica e molecular do clone Itália Muscat no Submédio do Vale do São Francisco.

LOPES, R.L.T. Dossiê técnico: conservação de alimentos. Fundação tecnológica de Minas Gerais, CETEC, 2007.

MARTINAZZO, A. P.; CORRÊA, P. C.; RESENDE, O.; MELO, E. C. Análise e descrição matemática da cinética de secagem de folhas de capim limão. Revista Brasileira de Engenharia Agrícola e Ambiental, v. 11, n.3, p.301- 306, 2007.

MARTINS, M. G.; MARTINS, D. E. G.; PENA, R. S. Drying Kinetics and Hygroscopic Behavior of Pirarucu (Arapaima Gigas) Fillet with Different Salt Contents, LWT - Food Science and Technology, Vol 62, p. 144-151. 2015.

MORZELLE, M. C., BACHIEGA, P., SOUZA, E. C., VILAS BOAS, E. V. B., LAMOUNIER, M. L. Caracterização química e física de frutos de curriola, gabiroba e murici provenientes do cerrado brasileiro. Revista Brasileira de Fruticultura, 37, 96- 103. 2015.

NESPOLO, C. R. et al. Práticas em tecnologia de alimentos. Porto Alegre: Artmed. Produced by Deep Fat Frying and Air Frying. Journal of Food Science. Vol. 80, Nr. Revista Brasileira de Fruticultura, Jaboticabal, v. 33, n. 1, p. 297-302, mar. 2015.

SANTOS, N. C.; BARROS, S. L.; MONTEIRO, S. S.; SILVA, S. N.; RIBEIRO, V. H. A.; SILVA, V. M. A.; GOMES, J. P.; SANTIAGO, A. M.; LUIZ, M. R.; VIEIRA, D. M.; 
RIBEIRO, T. P.; LIMA, M. A. C.; ALVES, R. E. Maturação e Qualidade de Uvas para Suco em Condições Tropicais, nos Primeiros Ciclos de Produção. 2015.

TERUEL, M. de. R. et al. A Comparative Study of the Characteristics of French Fries, 2015. VITIBRASIL. Dados da vitivinicultura. Brasília: Embrapa, 2016. Disponível em: $<$ http://vitibrasil.cnpuv.embrapa.br/index.php?sopcao=sopt_05\&opcao=opt_05>.

WANG, J., MUJUMDAR, A. S., MU, W., FENG, J., ZHANG, X., ZHANG, Q., FANG, X., GAO, Z., AND XIAO, H. Grape Drying: Current Status and Future Trends. In MORATA, A.; LOIRA, I. Grape and Wine Biotechnology, In Tech Open; 2016.

ZERAVIK, J.; FOHLEROVA, Z.; MILOVANOVIC, M.; KUBESA, O.; ZEISBERGEROVA, M.; LACINA, K.; PETROVIC, A.; GLATZ, Z.; SKLADAL, P. Various instrumental approaches for determination of organic acids in wines. Food Chemitry, v. 194, p. 432-440, 2016. 


\title{
CAPÍTULO 10: A IMPORTÂNCIA DA AGRICULTURA FAMILIAR NA ATUALIDADE
}

\section{CHAPTER 10: THE CURRENT IMPORTANCE OF FAMILY AGRICULTURE}

\author{
Maria Madalena Bertolini ${ }^{1}$; Pedro Luiz Paula Filho ${ }^{2}$; Saraspathy Naidoo Terroso Gama de Mendonça ${ }^{3}$
}

\begin{abstract}
Resumo
Nos anos sessenta, o Brasil estimulou a mecanização sem limites, ofertando linhas de crédito, apoiando a agricultura de grande extensão. A agricultura de subsistência, foi negligenciada em favor da produção de exportação. Com a preocupação mundial em torno da preservação da biodiversidade e evitar-se o prejuízo aos recursos naturais, várias instituições têm demostrado interesse em fortalecer a agricultura familiar, como forma de sustentabilidade ambiental, segurança e soberania alimentar. Este estudo bibliográfico almeja apontar a importância da agricultura familiar e seus gargalos, e motivar a reflexão sobre a priorização de políticas públicas. A Assembleia Geral das Organizações das Nações Unidas destaca a Década da Agricultura Familiar de 2018 a 2029, chamando atenção a esta categoria de produtores, desamparados e responsáveis por $80 \%$ dos alimentos produzidos no mundo. Observa-se que os setores públicos precisam priorizar e elaborar políticas públicas quanto à linhas de crédito para modernizar e fortalecer os pequenos produtores, viabilizar assistência técnica, acesso às tecnologias e incentivo às mulheres e aos jovens, para melhorar o seu nível de estudo, apoiando-os na permanência no campo. Sem dúvida, a agricultura familiar é a atividade de produção essencial para alimentar a população mundial, bem como propiciar às futuras gerações, um meio ambiente preservado.
\end{abstract}

Palavras-Chave: Desenvolvimento, Alimentação, Biodiversidade, Agricultores.

\begin{abstract}
In the sixties, Brazil stimulated mechanization without limits, offering credit lines, supporting large-scale agriculture. Subsistence agriculture was neglected in favor of export production. With the worldwide concern around the preservation of biodiversity and the avoidance of damage to natural resources, several institutions have shown interest in strengthening family farming, as a way of environmental sustainability, security and food sovereignty. This bibliographic study aims to point out the importance of family farming and its bottlenecks, and to motivate reflection on the prioritization of public policies. The General Assembly of United Nations Organizations highlights the Decade of Family Farming from 2018 to 2029, drawing attention to this category of producers, destitute and responsible for $80 \%$ of the food produced in the world. It is observed that the public sectors need to prioritize and elaborate public policies regarding lines of credit to modernize and strengthen small producers, provide technical assistance, access to technologies and encourage women and young people to improve their level of study, supporting them while staying in the field. Undoubtedly, family farming is the essential production activity to feed the world population, as well as to provide future generations with a preserved environment.
\end{abstract}

Keywords: Development, Food, Biodiversity, Farmers.

\footnotetext{
${ }^{1}$ Programa de Pós Graduação em Tecnologias Computacionais para o Agronegócio, Universidade Tecnológica Federal do Paraná-MD, madalenabertolini@hotmail.com

${ }^{2}$ Programa de Pós Graduação em Tecnologias Computacionais para o Agronegócio, Universidade Tecnológica Federal do Paraná-MD, pedrol@utfpr.edu.br

${ }^{3}$ Programa de Pós Graduação em Tecnologias Computacionais para o Agronegócio, Universidade Tecnológica Federal do Paraná-MD, naidoo@ufpr.edu.br
} 


\section{Introdução}

A agricultura familiar é de grande importância social e econômica, responsável pelo abastecimento de alimentos no Brasil e no mundo. Esta importante parcela de trabalhadores rurais foram excluídos das políticas de desenvolvimento elaboradas para a produção das grandes propriedades, e sofrem com a demanda da competividade e desafios da globalização (DOS SANTOS; MITJA, 2016). Outro dilema é a crescente dependência e uso das tecnologias na agricultura, fato que impõe um fardo às pequenas propriedades, por falta de recursos e de assistência técnica. Ressalta-se que os agricultores apresentam baixa escolaridade, o que dificulta o uso das Tecnologias de Informação-TIs (DEPOINTI, 2014).

Nações Unidas- ONU, lançou de 2019 a 2028 um programa intitulado como a Década das Nações Unidas para a Agricultura Familiar, com o objetivo de impulsionar a elaboração de políticas públicas que promovam o desenvolvimento permitindo a sustentabilidade e a preservação do meio ambiente (DA SILVA, 2019). Neste sentido o Comitê Gestor da ONU, aprovou o Plano de Ação Global da Década, para que posteriormente cada país elabore o seu Plano. Desta forma, oportuniza discussões sobre a realidade, as necessidades e a importância da agricultura familiar, que tanto contribui para a alimentação no mundo (FRATARI; DA SILVA, 2019).

Um aspecto fundamental da agricultura familiar é a produção de alimentos saudáveis, utilizando práticas que não agridem o meio ambiente e a biodiversidade e a saúde, aumentando a produtividade, de modo a alimentar quase 10 bilhões de habitantes no mundo até 2050. A agricultura familiar é essencial para se alcançar a segurança alimentar no mundo.

O Brasil tem se destacado com as políticas de incentivo ao pequeno produtor com a criação do Programa Nacional de Fortalecimento da Agricultura familiar - PRONAF, e o Governo Federal criou a Lei nº11.947/2009, a qual obriga a aquisição de produtos através do Programa Nacional de Alimentação Escolar -PNAE, e o Programa e o Programa de Aquisição de Alimentos - PAA. Estes contribuem para a segurança alimentar saudável e sustentável, atendendo às necessidades nutricionais desse público (BRASIL,2016; BEVILAQUA, 2016).

Outo aspecto necessário para melhorar a sustentabilidade, tanto para os agricultores, quanto para a sociedade em geral, é a educação, que implementa a capacidade de desenvolver a conscientização, em especial das futuras gerações, que são as crianças (REIS; LIMA; DESIDERIO, 2018).

Neste sentido, os agricultores necessitam de uma atenção especial, para que permaneçam no campo, com políticas públicas, e educação que desperte a sensibilidade e 
responsabilidade ambiental, promovendo a qualidade de vida (REIS; LIMA; DESIDERIO, 2018).

Este estudo bibliográfico pressupõe uma reflexão sobre as estratégias necessárias à implementação da Agricultura familiar no Brasil, de forma sustentável, produzindo alimentos necessários, de qualidade e, combinando produtividade, com reordenamento econômico e social, educacional, além de se evitar, da melhor forma possível, a agressão ao meio ambiente.

\section{Desenvolvimento}

\subsection{Desenvolvimento da Agricultura no Brasil}

O Brasil a partir da década de sessenta, iniciou um processo de modernização da agricultura, incentivada pelos países desenvolvidos, e para isso estimulava a mecanização, utilização de adubos químicos, sementes hibridas selecionadas para melhor produtividade, uso do agrotóxico para a prevenção de pragas e ervas daninhas, e ainda melhorou as linhas de créditos, com o intuito de aumentar a produção agrícola, para o mercado externo, tendo como foco as grandes propriedades rurais(NAVOLAR; RIGNON; PHILIPPI, 2009; FROTA; OLIVEIRA; COSTA, 2017).

A agricultura de subsistência, ficou fora do desenvolvimento, sem políticas que amparassem essa parcela fundamental de trabalhadores. $O$ pequeno produtor rural, da agricultura de subsistência passou a ser visto como inferior, e ultrapassado, devido às tecnologias utilizadas pela agricultura de grande extensão. Desta maneira, perderam espaço no cenário da produção, fazendo com que muitos agricultores abandonassem a atividade no campo, em busca de melhores oportunidades de trabalho na cidade, causando o êxodo rural, e sobretudo originando mais desigualdade social (VIEIRA; IZA; KORZ; FISCHER,2018).

Recentemente, os olhares da sociedade voltaram-se para a agricultura de pequenas propriedades, levantando muitos aspectos relevantes e necessários para que possam assegurar a sustentabilidade e fixação do trabalhador no campo. Os agricultores lutam para sobreviver e tornar estas propriedades economicamente sustentáveis nesse mercado globalizado, com economia agressiva e falta de oportunidades, libertando-se do êxodo rural. Estas propriedades produzem alimentos para o consumo da população, saudáveis e com benefícios ao meio ambiente, tendo em vista que causam menor impacto ambiental.

\subsection{Reconhecimento da Agricultura Familiar}

Na década de 90, o poder público reconheceu a importância do papel do pequeno produtor, com o decreto Lei $\mathrm{n}^{\circ} 1.946$, no ano de 1995, com a criação do Programa Nacional 
de Agricultura Familiar (PRONAF). Este programa fornece recursos para o pequeno produtor investir na propriedade, para o desenvolvimento do agronegócio, com as menores taxas de juros do mercado. O agricultor pode utilizar os recursos que são exclusivamente para essa categoria em compra de sementes, equipamentos, maquinários ou fazer melhorias na infraestrutura da propriedade (BRASIL, 2016; BEVILAQUA, 2016).

Agricultura familiar teve o marco legal ao ser definida e reconhecida legalmente pela Lei 11. 326/2006 (BRASIL,2006), como a atividade desenvolvida pelos agricultores na área rural e que possuem propriedade de até quatro módulos fiscais, o que representa 72 hectares para o município de Serranópolis do Iguaçu-PR, e na qual utilizam mão de obra do próprio núcleo familiar, bem como a maior parte da renda ser proveniente da produção rural (BRASIL, 2006). Essa agricultura de subsistência é responsável por mais de $70 \%$ da alimentação produzida no Brasil (LIMA; SILVA; IWATA, 2019) e de igual importância para a alimentação no âmbito mundial, e a mesma é realizada em menor extensão e se destaca como a base econômica de $90 \%$ dos pequenos municípios de até vinte mil habitantes.

O debate sobre a relevância da agricultura familiar, na produção de alimentos e desenvolvimento da economia sustentável, tem conseguido apoio de diversos setores da sociedade (BEZERRA; SCHLINDWEIN, 2017). Esta forma de cultivo, utiliza maquinário em menor escala, sendo assim, com menor impacto ambiental, e desperdício de recursos naturais. Contudo, ao se desenvolver, implementa também a agricultura sustentável, que atende às necessidades de produção de alimentos, e preserva a biodiversidade, utilizando a terra com o menor prejuízo possível.

\subsection{Agriculturas Sustentáveis}

Desenvolvimento sustentável foi usado pela Organização das Nações Unidas (ONU), no estudo sobre mudanças climáticas, devido à problemática ambiental, com o intuito de corrigir os riscos e estimular o desenvolvimento com menor impacto ao meio ambiente e de finalidade preventiva. Este estudo foi utilizado para se referir a atividade agrícola desenvolvida em harmonia e cuidados com os recursos naturais. Esse equilíbrio é essencial para a permanência da vida humana neste planeta com saúde, qualidade e dignidade (BEVILAQUA, 2016).

Tudo está sendo globalizando, porém esta valorização da sustentabilidade é urgente para que seja essencial aos valores mundiais, a fim de se resgatar os recursos ambientais para nossos filhos, netos e gerações futuras.

A agricultura sustentável precisa atender às necessidades básicas dos seres humanos 
(água, alimentos, combustíveis, roupas, proteção), a fim de ter, abrigo, dignidade e liberdade, nas gerações existentes e para as futuras (AMARAL; ARAÚJO, 2015). Esta perspectiva precisa ter um novo foco, nas relações humanas, ligada à solidariedade, cooperação, colocando também mulheres, como protagonistas neste processo de mudanças (VIEIRA; IZA; KORZ; FISCHER, 2018).

Com habilidade feminina, as mulheres agricultoras abraçam os desafios, como por exemplo, de algo novo como a sustentabilidade, e vem colocando em ação os ensinamentos e conhecimentos transmitidos de geração à geração, diversificando a produção da propriedade, colocando em foco a sua manutenção com a produção de alimentos, fortalecendo a sua autonomia e empoderamento. Esta sustentabilidade permeia os aspectos social, ambiental e econômico. O empreendedorismo feminino vem ao encontro de uma qualidade de vida da família e o viver em harmonia com o meio ambiente (VIEIRA; IZA; KORZ; FISCHER, 2018).

A agricultura sustentável aparece como foco à agricultura familiar, trazendo uma pressão da sociedade, por produção que conserve os recursos naturais, forneça alimentos saudáveis e de qualidade nutricional, entretanto que não ameace o meio ambiente, a saúde, o desenvolvimento tecnológico, a segurança alimentar, garantindo os direitos básicos do ser humano (BEVILAQUA, 2016).

A sociedade depara-se diante de um grande desafio de resgatar a viabilidade da agricultura familiar, melhorando a produção, sem ignorar as tecnologias, protegendo os recursos naturais. Neste sentido, é necessário se evitar o empobrecimento do solo, cuidar da biodiversidade, conservar a qualidade da água, do ar e garantindo a viabilidade da propriedade, com qualidade de vida dos trabalhadores, tornando-a atrativa às novas gerações, principalmente fixando os jovens no campo, preservando a cultura local que resguarda a natureza e o desenvolvimento da comunidade, evitando o temível êxodo rural (BEVILAQUA, 2016).

Inegavelmente que a agricultura familiar precisa ser fortalecida e ampliada com o apoio de políticas públicas, que afirmam o comprometimento com a sustentabilidade no âmbito socioeconômico e ambiental. Esta modalidade agrícola, é responsável em gerar mão de obra e alimentos saudáveis aos agricultores e responsável pela segurança alimentar do país, entretanto, necessita de se tornar o foco das atenções da sociedade.

Para enfrentar este cenário de desvalorização em que se encontra a agricultura familiar, a Organização das Nações Unidas- ONU, lançou de 2019 a 2028 um programa intitulado como "Década das Nações Unidas para a Agricultura Familiar", com o objetivo de 
impulsionar a elaboração de políticas públicas, que promovam o desenvolvimento permitindo a sustentabilidade e a preservação do meio ambiente (DA SILVA, 2019).

Desta forma, oportuniza discussões sobre a realidade, as necessidades e a importância da agricultura familiar, que tanto contribui para a alimentação no mundo (FRATARI; DA SILVA, 2019).

Convém ressaltar que a sustentabilidade exige ações imediatas e urgentes e de forma coletiva, sendo mister o uso da ferramenta poderosa para conscientização, que é a educação. Os professores são formadores de opinião, neste sentido, de grande importância para a construção de uma consciência direcionada para a sustentabilidade ambiental. Este trabalho precisa ser organizado nas redes de ensino, em todas as etapas de escolaridade, sendo de suma importância que se inicie o mais cedo possível, envolvendo as crianças na formação de opinião a respeito do cuidado com a preservação e conservação dos recursos naturais (REIS; LIMA; DESIDERIO,2018). Desta forma, as políticas educacionais devem evidenciar a sensibilização para uma consciência planetária, onde todos terão a oportunidade de aprender valores, comportamentos e modos éticos de vida, necessários para um futuro sustentável, em especial às futuras gerações de agricultores familiares.

\subsection{Discussão}

\subsubsection{Sustentabilidade e qualidade de vida}

O estudo e o uso da palavra sustentabilidade tem gerado inúmeras pesquisas e discussões, tanto no meio acadêmico, quanto na sociedade de modo geral, no Brasil e principalmente entre as nações de maior desenvolvimento, classificadas como de primeiro mundo.

A palavra sustentabilidade, deriva do verbo sustentar que vem do latim, sustentare, que significa conservar, amparar, defender, manter (BEVILAQUA,2016).

Esse termo refere-se aos cuidados com um mundo não visto por partes, e sim como um ambiente ecológico na totalidade, onde acontecem as relações sociais, a produção, o desenvolvimento tecnológico a todo vapor. Neste sentido, há a necessidade de se analisar o significado da palavra num sentido mais amplo contudo, sem omitir o que afeta o ser humano, como por exemplo a saúde, lazer, trabalho educação, política, economia, fatores aliados aos recursos naturais.

As agressões ao meio ambiente realizados em qualquer lugar do mundo proporcionam consequências em âmbito global. Obviamente, que para haver mudança, faz-se necessário alterar o enfoque de prosperidade econômica, para um desenvolvimento que preserve ao 
máximo os recursos ambientais, o desenvolvimento sustentável, a ética nas ações humanas em relação à natureza (BEVILAQUA, 2016).

Neste sentido, a sustentabilidade precisa estar baseada nas relações sociais de trabalho e produção, econômica e ambiental.

Certamente que ao trazer como foco esse assunto, é necessário apresentar outra temática que é a produção de alimentos, necessária para a sobrevivência da humanidade. Como alimentar quase oito milhões de pessoas, tendo com o eixo principal o respeito com o meio ambiente, e ser economicamente viável, é um dilema a ser contextualizado.

Sem dúvida, os atores sociais principais neste cenário são os pequenos produtores rurais, ou seja, os representantes da agricultura familiar. Evidentemente que há a necessidade de aumentar a produção de alimentos, para promover a segurança alimentar, porém com o foco mantendo na preservação dos recursos naturais, respeitando-se o meio ambiente, através do cultivo e produção de forma ética e responsável, no que tange o ecossistema.

\subsubsection{A Contribuição da Agricultura Familiar para a Sustentabilidade}

A agricultura familiar é uma atividade capaz de aumentar a produção de alimentos, e ser economicamente viável, com práticas responsáveis com o meio ambiente, tendo mercado crescente aos produtos saudáveis e frescos, fornecidos diretamente dos produtores. Esta prática incorpora os fatores econômicos, sociais e ambientais, por ser desenvolvida pelo núcleo familiar, e considera a terra como um bem comum dos membros, utilizada para atender as suas necessidades, valorizando a diversidade, utilizando a policultura, distribuindo com equilíbrio os espaços, gerando qualidade de vida (RIBEIRO, 2017).

Vale ressaltar que ao se desenvolver e fortalecer a agricultura familiar, estar-se-á fortalecendo a sustentabilidade do meio ambiente, os agricultores, e a sociedade local, regional e do país (RIBEIRO, 2017).

Dada à importância desta atividade de produção, para a segurança alimentar e sustentabilidade dos recursos naturais, torna-se urgente um envolvimento dos diversos setores da sociedade e como principal foco, o poder público, viabilizando ações voltadas às pequenas propriedades rurais, para se evitar o abandono do campo, causando o êxodo rural e maiores problemas sociais na área urbana. Verifica-se que a falta de estímulo à continuidade familiar/sucessão, pode causar esvaziamento do campo, devido aos jovens, filhos de agricultores, almejarem novas perspectivas nos grandes centros (POTRICH; GRZYBOVSKI; TOEBE, 2016).

Neste cenário em que a mulher vem participando de todos os aspectos da sociedade, e 
buscando seu empoderamento e seu espaço como protagonista, há necessidade de reconhecer e valorizar seu trabalho e sua vida, a fim de lhe proporcionar autonomia, autoestima no direcionamento de mudanças, onde prevaleça a qualidade de vida e a sustentabilidade na produção. Estas mudanças na vida de quem sempre foi submissa, ocorrerão a partir do conhecimento, e reconhecimento de sua importância na efetivação de novos paradigmas de produção (VIEIRA; IZA; KORZ; FISCHER, 2018). Nota-se que as mulheres despontam com algo novo, rompendo os padrões vigentes, e se destacando como empreendedoras rurais, valorizando os saberes compartilhados através de gerações, promovendo mudanças, confrontando com a produção convencional (VIEIRA; IZA; KORZ; FISCHER,2018), melhorando sua independência e contribuindo para uma nova forma de produzir, utilizando sensibilidade e criatividade feminina.

Sem dúvida que a Organização das Nações Unidas - ONU oportuniza a sociedade, analisar, pesquisar e apoiar a agricultura familiar reconhecendo sua importância, declarando a Década da Agricultura Familiar de 2019 a 2028. Espera-se que os líderes mundiais adotem políticas de apoio a estes trabalhadores do campo, que norteiem um novo sistema de alimentação e desenvolvimento rural sustentável. Neste sentido, urge que o objetivo não seja somente a produção, mas que sejam contemplados os aspectos socioeconômicos, bem como a sustentabilidade dos recursos naturais (SILVA, 2019).

\subsubsection{Políticas Públicas para a Agricultura Familiar}

O Brasil destaca-se na formulação de políticas públicas, para o incentivo e fortalecimento da agricultura familiar, para o desenvolvimento rural, aumentando a produtividade de maneira sustentável, e que reflita na melhoria da qualidade de vida dos produtores, do meio ambiente e o fornecimento de produtos saudáveis aos consumidores. Para tanto são necessários investimentos, a abertura de financiamentos, acesso às novas tecnologias, bem como a implementação do conhecimento, e por conseguinte a aprendizagem por meio de suporte técnico, para melhorar a gestão e ampliar os mercados para a comercialização dos produtos (BOJANIC, 2017).

O Governo Federal criou o Programa Nacional de Fortalecimento da Agricultura Familiar (PRONAF), como incentivo às linhas de crédito para proporcionar financiamentos aos pequenos agricultores. Concebe-se que este Programa está contribuindo para o aumento da produtividade, e melhorar a renda das famílias (BEVILAQUA, 2016).

Outros programas que tem se tornado referência são o Programa de Aquisição de Alimentos (PAA), e o Programa Nacional de Alimentação Escolar (PNAE), onde 
obrigatoriamente $30 \%$ dos recursos repassados pelo Fundo Nacional de Desenvolvimento da Educação (FNDE), devem ser aplicados na aquisição de gêneros alimentícios provenientes da agricultura familiar. Com estes programas, o governo garante mercado estável para os produtores, em seu próprio município e região, contribuindo para a economia local. Estes programas têm se destacado e apontados como exemplos a outros países (RIBEIRO; PEREIRA, 2015; BRASIL, 2016).

A Lei $n^{\circ} 11.947 / 2009$, que obriga a compra dos produtos da agricultura familiar, representa um ato de pioneirismo e de avanço, para ofertar aos estudantes no mínimo uma alimentação diária de qualidade, e a contrapartida governamental vem a subsidiar a aquisição dos gêneros para aplicação na área de ensino. O programa contribui para o aumento da renda dos produtores locais, melhorando a qualidade de vida de suas famílias, evitando-se o êxodo rural, promovendo o desenvolvimento socioeconômico do município.

Esta política de estímulo, tem impacto positivo na alimentação das crianças e adolescentes da rede pública, destacando-se que para uma parcela considerável de alunos, esta é a refeição mais importante do dia (RIBEIRO; PEREIRA, 2015; BRASIL, 2016). Estes alimentos são mais saudáveis, naturais, frescos, diversificados, e contribuem para uma alimentação equilibrada. Ressalta-se que a alimentação escolar tem importante papel no crescimento e no rendimento escolar (LIMA; SILVA, 2016). Um aluno bem nutrido apresenta um potencial intelectual melhor ((RIBEIRO; PEREIRA, 2015). Estas escolas da rede pública, atendem alunos mais vulneráveis na questão econômica, e que apresentam necessidades nutricionais (BRASIL, 2006). Com os neurônios bem nutridos, aumenta a capacidade cerebral, melhorando as funções cognitivas como a atenção, memorização, concentração, e o raciocínio, fatores imprescindíveis para uma aprendizagem melhor (RIBEIRO; SILVA, 2013). A Lei ${ }^{\circ} 11.947 / 2009$ permitiu aos alunos das escolas públicas aumentar o rendimento escolar, e ter expectativa de uma vida melhor, e poder usufruir de uma alimentação saudável, atendendo aos preceito da segurança alimentar, sustentável(RIBEIRO; PEREIRA, 2015).

Para a organização de uma sociedade responsável ambientalmente, a nível nacional e mundialmente, o caminho é a ênfase na educação dos cidadãos. Ressalta-se que a educação é prioridade, na efetivação de uma proposta socialmente e economicamente correta, em relação ao meio ambiente. Os conceitos de busca e luta por uma sociedade responsável vão sendo inseridos, e transformando e rompendo os antigos paradigmas de desenvolvimento (REIS; LIMA; DESIDERIO, 2018). 


\section{Considerações Finais}

Quando se reflete sobre o desenvolvimento sustentável, precisa-se lembrar que sua extensão ultrapassa os cuidados com o meio ambiente, pois. abrange ainda as relações sociais, políticas, culturais e econômicas, no dia a dia das pessoas, bem como com as gerações futuras. O homem possui as necessidades básicas de sobrevivência, para tanto produz com seu trabalho e consome bens, entretanto, nem sempre se preocupa com o equilíbrio do ecossistema. Uma das necessidades básicas e essenciais é a produção de alimentos, sendo também uma preocupação mundial, onde uma parcela da sociedade não possui a alimentação necessária.

Durante muito o poder público se preocupou em ofertar linhas de crédito para agricultura de grande extensão. Estas políticas econômicas iniciaram uma revolução, em que o meio ambiente não era considerado, devido ao exagero na obtenção do lucro, com a produção para exportação. As pequenas propriedades rurais esquecidas, e sem apoio, ou políticas de incentivo, com o passar do tempo devido o abandono, tornaram-se inviáveis. Com esse descaso, muitas famílias venderam suas propriedades para alcançarem melhores condições nas cidades, ocasionado com esta mudança drástica, um problema nas áreas urbanas.

Aos poucos, a atenção voltou-se para a agricultura familiar, que além de ser a responsável pela produção da maior parte dos alimentos, também contribui para a conservação do meio ambiente. Neste sentido, o Brasil criou algumas políticas de apoio, como por exemplo a Lei 11.947/2009, que representa um ato de pioneirismo e de avanço, para ofertar aos estudantes no mínimo uma alimentação diária de qualidade, e a contrapartida governamental, vem a subsidiar a aquisição dos gêneros para aplicação na área de ensino, o que obriga os municípios a investirem na aquisição de gêneros alimentícios da agricultura familiar.

A obrigatoriedade da aquisição de alimentos da agricultura familiar local, possibilitou às crianças e adolescentes da Educação Básica das escolas públicas, uma alimentação equilibrada, respeitando-se as necessidades nutricionais desta faixa etária, promovendo a sua segurança alimentar, ou seja uma alimentação sustentável, para que possam ter um adequado desenvolvimento físico, fisiológico e intelectual.

O diferencial dos alimentos é o fato de possuírem o valor nutricional necessário e fundamental ao bom desempenho na aprendizagem, pois aumenta a capacidade cerebral, melhorando a atenção, memorização, concentração e o raciocínio, imprescindíveis para a aprendizagem. Esta lei permitiu aos alunos das escolas públicas aprimorarem o seu 
rendimento escolar e terem uma expectativa de futuro promissor e valorizarem a agricultura familiar, conhecendo e respeitando o nobre trabalho dos pequenos produtores e seus familiares.

Com a mudança de paradigmas no conceito de qualidade de vida e sustentabilidade, a sociedade voltou-se para o foco na preservação ambiental. E surge o grande questionamento, de como se deve preservar os recursos naturais, com a eminente falta de alimento no mundo. Sem dúvida, os estudos e análises das autoridades e cientistas, demonstraram que a agricultura familiar é essencial para a produção de alimentos saudáveis e necessários para a segurança alimentar mundial, com práticas educacionais e conscientes, que preservam o meio ambiente e a biodiversidade.

Neste sentido com a necessidade global de se aumentar a produção de alimentos, de uma forma que cause o menor prejuízo ao meio ambiente e erradicar a fome, a ONU vê a necessidade de despertar a atenção e o foco das autoridades internacionais, nacionais, locais, bem como da sociedade, para a importância da agricultura familiar no enfrentamento desta problemática eminente.

Ao se oficializar o Programa 2019 A 2028 o decênio da agricultura familiar, motivada pela iniciativa da ONU, coloca-se uma perspectiva de elaboração de políticas públicas, a fim de se alcançar os objetivos direcionados para o aumento da produção de alimentos, suficientes e acessíveis para toda população mundial, garantindo a segurança nutricional, e cumprindo os objetivos da ODS da agenda 2030. Além disso, estas ações fortalecem a economia local, e promovem a justiça social no campo, que por muito tempo ficou negligenciada, de forma que o foco central seja a preservação sustentável dos recursos naturais, e consequentemente a vida humana, promovendo desta maneira a educação ambiental e a conscientização do homem para a execução de práticas adequadas.

Desta forma, é imprescindível que o poder público, além de criar políticas de fortalecimento e mercado seguro para a comercialização dos produtos, precisa se preocupar com a educação, dos agricultores e seus familiares, voltada para a responsabilidade ambiental. Tornando-os cidadãos, conscientes de suas ações, despertando a sensibilidade ecológica, para um desenvolvimento sustentável, tendo a visão de humanidade e não somente lucratividade.

De acordo com este cenário, há a necessidade de estabelecer conceitos inovadores, hábitos novos, diferentes perspectivas, o bem estar e qualidade de vida, levando em conta o desenvolvimento econômico sustentável, bem como a implementação do respeito pelos recursos naturais, com a visão de que são essenciais à sobrevivência da humanidade sob o ponto de vista físico, fisiológico, econômico e psicossocial. 
A Década se fundamentou em uma visão de um mundo onde todos tivessem a oportunidade de se beneficiar da educação e de aprender valores, comportamentos e modos de vida exigidos para um futuro sustentável visando uma transformação positiva das sociedades a nível local, regional e global. As suas dimensões perpassaram por questões de natureza educativa, ambiental, social, econômica e política que fossem capazes de promover melhorias e tornar os diferentes sujeitos participativos nos processos de escolhas e tomadas de decisões.

Enfatiza-se que o Brasil participa do grupo de países associados, composto pela Rússia, Índia, China e África do Sul, denominado de BRICS, no qual, todos são classificados como emergentes pela ONU, e realizam programas de desenvolvimento da agricultura familiar em seu território. O Brasil participa deste grupo, junto com os demais, os quais realizam comércio entre si, e por consequência, há o fortalecendo do superávit da balança comercial, para a expansão da agricultura familiar, tornando-a indispensável para a segurança alimentar sustentável e econômica destes países, o que incide sobre a sua soberania.

Há o entendimento de que a agricultura familiar é essencial para o desenvolvimento renovável da área rural. Portanto, os investimentos que o Governo Federal já realiza, necessitam ser ampliados, para fortalecer cada vez mais a atividade agrícola de suma importância para o Brasil, enquanto um país emergente, melhorando a qualidade de vida de seus diversos atores sociais que compõem a sociedade.

\section{Referências}

AMARALA Adriana Queiroz do; ARAÚJO, Elvira Aparecida Simões de. Agricultura Familiar de Sustentabilidade: uma Análise da Produção Científica da Embrapa. Universidade de Taubaté e Faculdade Pitágoras de Imperatriz. São Paulo e Maranhão. Publicado na Rev. Cienc. Gerenc., v. 19, n. 29, p. 47-50, 2015. Disponível em: file://C:/Users/User/Downloads/2986-Texto\%20do\%20artigo-11397-1-10-

20150827\%20(1).pdf. Acesso em: 28/07/20.

AZEVEDO, E; RIGON, S. A. Sistema alimentar com base no conceito de sustentabilidade. In: TADDEI, J. A.; LANG, R. M. F.; SILVA, G. L.; TOLONI, M. H. A. Nutrição em saúde pública. São Paulo: Rubio, 2010. p. 543-560.

BRASIL. Fundo Nacional de Desenvolvimento da Educação (FNDE). Conselho Deliberativo. Resolução FNDE CD no 032, de 10 de agosto de 2006. Estabelece as normas para a execução do Programa Nacional de Alimentação Escolar (Pnae). 2006. Disponível em: http://www.fnde.gov.br>. Acesso em 21 de maio de 2020.

BRASIL. Presidência da República. Casa Civil. Lei n 11.947, de 16 de junho de 2009 dispõe sobre o atendimento da alimentação escolar e do Programa Dinheiro Direto na Escola aos alunos da educação básica. Disponível em: 
http://www.planalto.gov.br/ccivil_03/_Ato2007-2010/2009/Lei/L11947.htm >. Acesso em 12 de maio de 2020.

BRASIL. Ministério da Educação. Fundo Nacional de Desenvolvimento da Educação FNDE. Aquisição de produtos da agricultura familiar para a alimentação escolar. 2. ed. Brasília: FNDE, 2016. Disponível em: https://www.fnde.gov.br/programas/pnae/pnae-areagestores/pnae-manuais-cartilhas/item/8595-manual-de-aquisi\%C3\%A7\%C3\%A3o-deprodutos-da-agricultura-familiar-para-a-alimenta\%C3\%A7\%C3\%A3o-escolar. Acesso em: 12 de maio de 2020.

BEVILAQUA, Karen Affonso. Pensando Além Da Produção: Uma Análise Da Agricultura Familiar Como Ferramenta De Consolidação Da Sustentabilidade Pluridimensional E Da Segurança Alimentar. Universidade Estadual Paulista Júlio de Mesquita Filho, $\quad$ Franca, 2016. Disponível em: repositorio.unesp.br/bitstream/handle/11449/148615/bevilaqua_ka_me_fran.pdf?sequence=3. Acesso em: 29/07/20.

BEZERRA, Gleicy Jardi; SCHLINDWEIN, Madalena Maria. Agricultura familiar como geração de renda e desenvolvimento local: uma análise para Dourados, MS, Brasil. Revista une analyse à Dourados, MS, Brésil Agricultura familiar, Dourados, MS, Brasil. DOI: http://dx.doi.org/10.20435/1984-042X-2016-v.18-n.1(01). Disponível em: www.scielo.br/pdf/inter/v18n1/1518-7012-inter-18-01-0003.pdf. Acesso em: 27/07/20.

BOJANIC, Alan. Iniciativa regional da FAO aponta agricultura familiar como promotora do desenvolvimento rural sustentável e a agenda 2030. Publicado em 13/10/2017, Organização Das Nações Unidas. FAO. Disponível em: fao.org/brasil/noticias/detail-events/pt/c/1043666/. Acesso em 26/07/20.

CRUZ, Fernanda. Década da agricultura familiar pode mudar o futuro global. Asa Brasil, 31/09/19. Disponível em: https://agroecologia.org.br/2019/05/31/decada-daagriculturafamiliar-pode-mudar-o-futuro-global/. Acesso em 20/06/20.

DOS SANTOS, A.M.; MITJA, D.; Agricultura familiar e desenvolvimento local: os desafios para a sustentabilidade econômico-ecológica na comunidade de Palmares II, Parauapebas. PA .Interações, 2016, Campo Grande, v. 13, n. 1, 2016. Disponível em: /centrodeestudoseassessoria.org.br/comeca-oficialmente-a-decada-da-agricultura-familiardas-nacoes-unidas/. Acesso em 12/06/20.

ELIAS, Lilian de Pellegrini; BELIK, Walter; ODERICH, Edmundo Hoppe. A construção de um sistema alimentar sustentável e a agricultura familiar. IX Seminário Internacional sobre Desenvolvimento Regional, Processos, Política e Transações Territoriais, Santa Cruz do Sul, Rio Grande do Sul, 2019. Disponível em: file://C:/Users/User/Downloads/194061192617324-1-PB.pdf. Acesso: 15/06/20.

ENNIS, Rocío; NIETO, Daniela Patricia; SFICH, Vivian Mariel. Hacia un modelo productivo alternativo al hegemónico: el casode los productores hortícolas del Partido La Plata. XXI Jornadas de Geografía de la UNLP, 9 a 11 de outubro de 2019, Ensenada, Argentina.Disponívelem:http://www.memoria.fahce.unlp.edu.ar/trab_eventos/ev.13539/ev.13 539.pdf. Acesso em: 12/06/20. 
FANTELI, Dreisse Gabbi; FERREIRA, Aline Guterres; TONETTO, Cristiane Maria; BELING Helena Maria. A agricultura familiar e suas estratégias de sobrevivência. Dissertação de Mestrado - Universidade Federal de Santa Maria, Estado do Rio Grande do Sul, Santa Maria, 2019. Disponível em: /www2.faccat.br/portal/sites/default/files/fantineli_ferreira_godoy_beling.pdf. Acesso em $12 / 06 / 20$.

LIMA, Antônia Francisca; SILVA, Edvânia Gomes de Assis; IWATA, Bruna de Freitas. Agriculturas e agricultura familiar no Brasil: uma revisão de literatura. Revista Retratos de Assentamentos, v. 22, $\mathrm{n}^{\mathrm{o}} .1$, p.50-68, 2019, ISSN: 1516-8182, doi: i: $10.25059 / 2527-$ 2594/retratosdeassentamentos/2019.v22i1.332. https://www.researchgate.net/publication/334268386_Agriculturas_e_agricultura_familiar_no _Brasil_uma_revisao_de_literatura. Acesso em 15/06/20.

MARIAN, Marcia Gilmara; IZA, Oscar Benigno; KORZ, Camila; FISCHER, Jocimar. Agricultura sustentável: favorecendo ambientes saudáveis e o empoderamento feminino. Publicado em Rev. Ed. Popular, Uberlândia, v. 18, n. 2, p. 4-25, maio/ago. 2019, DOI: https://doi.org/10.14393/REP-v18n22019-46405.

Disponível

em: file://C:/Users/User/Desktop/agricultura $\% 20 \mathrm{e} \% 20 \mathrm{o} \% 20 \mathrm{empreendedorismo} \% 20 \mathrm{feminino.pdf}$. Acesso em: 28/07/20.

NAVOLAR, T. S.; RIGON, S. A.; PHILIPPI, J. M. S. Diálogo entre agroecologia e promoção da saúde. Revista Brasileira em Promoção da Saúde, Fortaleza, v. 23, n. 1, p. 6979, jan./mar. 2010. Doi: 10.5020/18061230.2010.p69.

ORGANIZAÇÃO DAS NAÇÕES UNIDAS. ONU. Agricultura Familiar e Sustentabilidade. DA SILVA, Jose Grazino, Estado de São Paulo, 14/06/19. Disponível em: https://nacoesunidas.org/artigo-agricultura-familiar-e-sustentabilidade/ . Acesso em 14/06/20

ORGANIZAÇÃO DAS NACÕES UNIDAS. ONU. Agricultores familiares são essenciais para subsistência global, diz oficial da ONU. Publicado em 29 de maio de 2019. Disponível em: https://nacoesunidas.org/agricultores-familiares-sao-essenciais-para-subsistencia-globaldizoficial-da-onu/. Acesso em: 25/05/20.

ORGANIZAÇÃO DAS NAÇÕES UNIDAS. ONU. Década da Agricultura Familiar: Carta aberta de Julio Berdegue, representante regional da FAO. FAO, Publicado em 27 de agosto 2019. Disponível em: http://www.fao.org/brasil/noticias/detailevents/pt/c/1206221/. Acesso em: 11/06/20.

ORGANIZAÇÃO DAS NAÇÕES UNIDAS. ONU. Agricultores familiares são essenciais para subsistência global. Publicado em 29/05/2019, atualizado em 14/11/2019. Disponível em: https://nacoesunidas.org/agricultores-familiares-sao-essenciais-para-subsistencia-globaldiz-oficial-da-onu/. Acesso em: 26/07/20.

PILLADO-ALBARRÁN,Karla Violeta; RAMÍREZ-HERNÁNDEZ, Javier Jesús; AVITIARODRÍGUEZ Jessica Alejandra. Acesso à comida: um contraste de visões. Ano 5, Número 9, janeiro a junho de 2020. Revista CoPaLa. Pp 101-124. ISSN: 2500-8870. Disponível em: http://www.revistacopala.com/DOI: 10.35600.25008870.2020.9.00161. Acesso em: 11/06/20. 
POTRICH, Rafaele; GRZYBOVSK, Denize; TOEBE, Carlisa Smoktunowicz. Sustentabilidade nas pequenas propriedades rurais: um estudo exploratório sobre a percepção do agricultor. Publicado em v. 25 n. 1: Estudos Sociedade e Agricultura, fevereiro a maio de 2017, DOI: https://doi.org/10.36920/esa-v25n1-9. Disponível em file:///C:/Users/User/Downloads/826-Texto\%20do\%20artigo-2538-1-1020170424\%20(1).pdf. Acesso 28/07/20.

RIBEIRO, Mariana Emidio Oliveira. Alternativas De Adoção De Práticas No Âmbito Do Desenvolvimento Sustentável Em Propriedades Rurais Familiares. Universidade do Vale do Taquari - UNIVATES. Lajeado, Rio Grande do Sul, dezembro de 2017. Disponível: /www.univates.br/bdu/bitstream/10737/2144/1/2018MarianaEmidioOliveiraRibeiro.pdf.

Acesso: 29/07/20.

RIBEIRO, A. C. L. A.; PEREIRA, D.D. Alimentação Escolar E Sua Contribuição Para Uma Educação De Qualidade. In: VII Fórum Internacional de Pedagogia, 4, 2015, Campina Grande. Anais...Campina Grande: Editora Realize, 2015, p.1-12.

SILVA, F. R. F. Gênero, agroecologia e economia solidária: estudo de caso do grupo de mulheres do Acampamento Recanto da Natureza em Laranjeiras do Sul-PR. DMA, Curitiba, v. 39, p. 115-132, 2016. Doi: doi.org/10.5380/dma.v39i0.45697. Acesso: https://revistas.ufpr.br/made/article/view/45697. Acesso em 28/07/20.

SILVA, José Graziano. Agricultura familiar e sustentabilidade. Publicado em 14/06/2019 Atualizado em 14/06/2019, Organização Das Nações Unidas. FAO. Disponível em: nacoesunidas.org/artigo-agricultura-familiar-e-sustentabilidade. Acesso em 29/07/20.

REIS, Marlene Barbosa de Freitas; LIMA, Daniela da Costa Britto Pereira; DESIDERIO, Mônica. Desenvolvimento, educação e sustentabilidade: questões emergentes e desafiadoras. Publicado em Rev. Eletrônica Mestr. Educ. Ambient.Rio Grande, v. 35, n. 3, p. 4-22, set./dez.2018.E-ISSN 1517-1256. Disponível em: /Users/User/Downloads/7855-248451-PB.pdf. Acesso em 30/07/20. 


\title{
CAPÍTULO 11: DIAGNÓSTICO SOBRE PERDAS PÓS-COLHEITA DE FRUTAS E HORTALIÇAS NO CEASA DE JUAZEIRO-BA
}

\section{CHAPTER 11: DIAGNOSIS OF POST-HARVEST LOSSES OF FRUITS AND VEGETABLES IN CEASA DE JUAZEIRO-BA}

\author{
Iasmim Pereira Oliveira ${ }^{1}$; Kathianny Neris de Castro $^{2}$; Julianna Cantalino dos Santos ${ }^{3}$; \\ Silvana Bélem de Oliveira Villar ${ }^{4}$
}

\begin{abstract}
Resumo
O Brasil possui uma grande extensão territorial, com solos férteis que favorecem a alta produção de alimentos, porém vem enfrentando muitas dificuldades em relação ao grande desperdício desses produtos, desde a lavoura até o consumidor. Com isso, as empresas utilizam hortifrutigranjeiros denominados Sistemas Nacionais de Centrais de Abastecimento (CEASA) para realizar a distribuição. É no Vale do São Francisco, na cidade de Juazeiro-BA que está localizada uma das maiores CEASAS do país, responsável por receber muitos alimentos de diversas regiões e distribuir ao consumidor. Assim, o presente projeto teve como objetivo, analisar e identificar as causas dos desperdícios, como também informar aos comerciantes práticas pós-colheita e os possíveis impactos relacionados ao grande amontoado de resíduos gerados. Para a concretização da pesquisa, baseou-se no método hipotético-dedutivo, promovendo uma busca de dados, formulando questionários e panfletos para ação. Como resultado, observou-se a falta de discernimento técnico e consciência pessoal, dos comerciantes e das pessoas no geral, pois a não obrigatoriedade, ocasionava o desinteresse sobre o tema. A vista disso, conclui-se que a realização de projetos como este, geram um despertar e fazem com que a comunidade possa enxergar alguns problemas e atitudes, que de certa forma já se tornaram comuns e involuntários.
\end{abstract}

Palavras-Chaves: Desperdício, Mercado do produtor, Resíduos.

\begin{abstract}
Brazil has a large territorial extension, with fertile soils that favor high food production, but it has been facing many difficulties in relation to the great waste of these products, from the farming to the consumer. As a result, companies use horticultural products called National Supply Center Systems (CEASA) to carry out distribution. One of the largest CEASAS in the country is located in the São Francisco Valley, in the city of Juazeiro-BA, which is responsible for receiving many foods from various regions and distributing them to consumers. Thus, this project aimed to analyze and identify the causes of waste, as well as to inform traders about post-harvest practices and the possible impacts related to the large pile of waste generated. The research was based on the hypothetical-deductive method, promoting a search for data, formulating questionnaires and pamphlets for action. As a result, it was observed the lack of technical discernment and personal conscience, of the merchants and people in general, since the non-binding, caused the disinterest on the subject. In view of this, it was concluded that the realization of projects such as this one generates an awakening and makes the community see some problems and attitudes, which in a certain way have already become common and involuntary.
\end{abstract}

\footnotetext{
${ }^{1}$ Tecnologia em alimentos, IF sertão-PE, mimuefs@gmail.com

2 Tecnologia em alimentos, IF sertão-PE, kathiannyneres@gmail.com

${ }^{3}$ Mestre, Professora do IF Sertão Pernambucano, juliana.cantalino@ifsertao-pe.edu.br

${ }^{4}$ Doutora, Professora do IF Sertão Pernambucano, silvana.belem@ifsertao-pe.edu.br
} 
Keywords: Waste, Producer market, Residue.

\section{Introdução}

O Vale do São Francisco possui uma alta capacidade produtiva de frutas se destacando em campo nacional, principalmente nas cidades de Juazeiro-BA e Petrolina-PE. Isto só se torna possível devido a utilização do mecanismo de irrigação e ao clima diferenciado. Com o apoio de órgãos públicos como a Companhia de Desenvolvimento dos Vales do São Francisco e do Parnaíba (Codevasf), Universidade Federal do Vale do São Francisco (Univasf) e da Empresa Brasileira de Pesquisa e Agropecuária (Embrapa-Semiárido) acabou se tornando um polo de desenvolvimento tecnológico da fruticultura irrigada (RICARDO et al. 2016).

O município de Juazeiro possui um PIB per capta de R $\$ 16.687,70$ (IBGE/2017) mas, por outro lado o município tem um IDH-M: 0,677 médio (PNUD/2010). A cidade ocupa o quarto lugar no ranking de comercialização de hortigranjeiros, se tornando essencial para o fortalecimento do mercado interno e externo (CONAB, 2019).

De acordo com o Decreto Federal $n^{\circ} 70.502 / 1972$ que regulamenta a lei $n^{\circ} 5727$ de 04.11.1971 a respeito do Sistema Nacional de Centrais de Abastecimento (CEASA). As CEASAS são empresas estatais ou de capital misto (público, privado), destinadas a aprimorar a comercialização e distribuição de produtos hortifrutigranjeiros.

Em Juazeiro se encontra um dos maiores CEASAS do Brasil - o Mercado do Produtor -, esse centro de abastecimento foi inaugurado em julho de 1984, mas só apenas em fevereiro de 1986 que foi iniciado o funcionamento administrativo. É o quarto maior do Norte/Nordeste em volume e comercialização do país. O mercado possui 1.300 comerciantes, 1.350 boxes e 250 ambulantes, em média 10 mil pessoas frequentam o local e por dia circula 200 a 250 caminhões (PREFEITURA DE JUAZEIRO, 2020).

Neste local o lixo produzido chega a aproximadamente 19 toneladas $\backslash$ dia onde $65 \%$ dele é composto por alimentos (Autarquia Municipal de Abastecimento), o que pode ser considerada uma quantia muito elevada para um país como o Brasil onde o índice de fome chega a 54\% (Instituto Brasileiro de Geografia e Estatística - IBGE 2015), e no município de juazeiro, 9,7 \% da população vivem abaixo da linha da pobreza (IBGE 2010).

Segundo dados da Organização das Nações Unidas (ONU, 2012), o Brasil é um dos maiores produtores de alimentos do mundo, mas enfrenta dificuldades em relação ao desperdício durante as etapas da cadeia produtiva. Com relação ao total dos desperdícios, estes já são percebidos na colheita do produto, que paira em torno de $10 \%$, prosseguindo nas 
etapas de transporte e industrialização, somando 50\%. Além dessas etapas, as perdas se estendem também para a comercialização (30\%) e, ainda 10\%, que são desperdiçados durante o seu preparo. (ONU, 2012) Para essa Organização, o Brasil desperdiça aproximadamente $64 \%$ da produção de alimentos gerada anualmente, o que incide diretamente na quantidade e na qualidade dos produtos.

As perdas pós-colheita podem ser definidas como aquelas que ocorrem após a colheita em virtude da falta de comercialização ou do consumo do produto em tempo hábil; ou seja, é um dano resultante à cultura, ocorridos após a sua colheita, acumulada desde o local da produção, somando-se aos deterioração ocorrida durante o transporte, armazenamento, processamento e /ou comercialização do produto vendável (CHITARRA; CHITARRA, 2005).

O manuseio pós-colheita envolve uma série de etapas, que vão desde a escolha do ponto ótimo de maturidade hortícola para a colheita, passando pela adoção de embalagens e métodos de resfriamento rápido adequados, até a tecnologias que permitam significativa agregação de valor como é o caso do processamento mínimo (CAMARGO, 2016).

Em conformidade com a Organização das Nações Unidas (ONU) para a Agricultura e Alimentação (FAO) apud Chitarra e Chitarra (2005), as causas primárias de perdas são: a) perdas biológicas, ocasionadas pelo consumo do vegetal por roedores, pássaros, entre outros animais que causam o desaparecimento do alimento; b) microbiológicas, devido a danos por fungos e bactérias; c) químicas, pelas reações químicas provocadas pelos constituintes do alimento, causando modificações na coloração, sabor, textura, valor nutritivo e, ainda, contaminação acidental por substâncias químicas; d) reações bioquímicas, mediadas por enzimas, gerando amolecimento ou descoloração; e) mecânicas, devido ao manuseio inadequado, como, cortes, abrasões, amassamentos, quedas; f) físicas, pelos extremos de calor ou frio; g) fisiológicas, que são alterações de caráter não parasitário que afetam as hortaliças, alterando seu metabolismo (respiração e transpiração) durante a maturação e senescência, acelerando as reações de deterioração; e h) psicológicas, devido à rejeição do consumidor pelo tipo de produto, tabu religioso ou intolerância alimentar culminando na redução do consumo.

As causas secundárias de perdas estão relacionadas à intervenção humana, como manuseio ou uso de tecnologias inadequadas ou insuficientes que levam às causas primárias de perdas, isto é, condições inadequadas de colheita, embalagem e manuseio incorreto; e falta de contentores adequados para o transporte e manuseio no carregamento e descarga. Além disso, o armazenamento, usualmente inadequado para proteger o produto, transporte (veículos e rodovias) inadequados; deficiência ou falta da cadeia de frio no transporte ou armazenamento; 
sistemas de comercialização tradicionais e deficientes; falta de legislação e ausência de padrões legais de qualidade para classificação ou sua não utilização; são fatores que causam rejeição de frutas e hortaliças (CHITARRA; CHITARRA, 2005).

Nesse sentido, o presente trabalho teve como objetivo identificar e qualificar as formas de desperdício que acontece através do mapeamento técnico, como também sensibilizar e conscientizar as pessoas que fazem parte do comercio local, para tentar minimizar este desperdício.

\section{Material e Métodos}

Como base metodológica utilizou-se o método hipotético-dedutivo, que de acordo com Karl Popper (1975), este método procura uma solução, mediante tentativas de erradicar os erros. (GIL, 1999) Com isso, desempenhou-se uma busca de dados, sobre o tema, local e material comercializado, dentro do ambiente que possibilitou uma contextualização e compreensão do assunto. Para um conhecimento no local (CEASA), foram realizadas visitas ao local de estudo.

Logo, houve a elaboração de um questionário (Figura 1) sobre práticas de pós-colheita, e a respeito do nível de conhecimento da população em relação ao desperdício no local, levando em consideração o que foi observado e estudado na etapa anterior. Essa inquirição foi aplicada tendo como formato uma entrevista pessoal, efetuados em horários pré-definidos, com o propósito de identificar as condições dos produtos e o nível de informação das pessoas.

Com conformidade no conhecimento de Bardin (2011), abordou-se uma análise de dados qualitativos, dispondo ao entrevistador um questionário que possibilite a fácil compreensão do ponto de vista, perspectiva e entendimento do entrevistado.

Após o questionamento realizou-se a tabulação e verificação dos dados, com o objetivo de fazer um levantamento dos principais fatores que geram desperdício e apontar técnicas ou possibilidades de redução percentual relacionado ao desperdício dos alimentos comercializados no local.

Para abordagem quantitativa utilizou-se a estatística descritiva com o auxílio do programa Excel, que possibilita a elaboração de gráficos e demonstrações de percentuais, médias, entre outros.

Na identificação de possíveis falhas nos processos pós-colheita (manuseio, embalagem, acondicionamento nos transportes), realizou-se visitas de campo e observou algumas fazendas, bem como, aplicou questionários específicos para os proprietários (Figura 2), obtendo uma tabulação dos dados 
Figura 1. Questionário mercado produtor sobre perdas de frutas e hortaliças na pós colheita em geral.

1- Qual atividade você exerce no mercado do produtor?

$\begin{array}{llll}\text { a) Transportador } & \text { b) Comerciante } & \text { c) Comprador local d) Agente e) Outros }\end{array}$

2- Qual a importância do CEASA na sua vida?

a) Extrema importância b) Importante c) Pouco importante d) Indiferente

3- Você sabe que no Brasil $40 \%$ das frutas e hortaliças são desperdiçadas antes de chegar à mesa do consumidor?

$\begin{array}{lll}\text { a) } & \text { Sim Não } & \text { c) Já escutei algo sobre }\end{array}$

4- Você sabia que há um grande desperdício de alimentos neste local?

$\begin{array}{lll}\text { a) } & \text { Sim Não } & \text { c) Imagino }\end{array}$

5- Este desperdício te preocupa de alguma forma?

a) Muito b) Moderadamente c) Pouco d) Não me importa

6- Você tem ou teve algum conhecimento sobre frutas e hortaliças para trabalhar aqui?
a) Muito conhecimento
b) Muito
c) Pouco
d) Não tenho

7- Você acha importantes as formações das pessoas que trabalham com frutas e hortaliças?

$\begin{array}{lll}\text { a) } \quad \operatorname{Sim} & \text { b) Não } & \text { c) Indiferente }\end{array}$

8- $\quad$ Teria interesse em aprender como manusear frutas e hortaliças para diminuir as perdas dos seus produtos?

$\begin{array}{lll}\text { a) } \quad \operatorname{Sim} & \text { b) Não } & \text { c) Indiferente }\end{array}$

Fonte: Própria (2018).

Figura 2. Questionário sobre as técnicas pós-colheita realizado nas fazendas visitadas.

\begin{tabular}{|ll|}
\hline $1-$ & Qual atividade você exerce neste local? \\
$2-$ & Qual sua formação? \\
$3-$ & Em que período é feita a colheita? \\
$4-$ & Que tipo de colheita é realizada? \\
$5-$ & Em que etapas da cadeia produtiva as perdas pós-colheita são mais problemáticas? \\
$6-$ & Qual a estimativa de desperdício em relação a cultivar? \\
$7-$ & O que é feito com o refugolresíduos? \\
$8-$ & Quais os impactos financeiros gerados por essa perda? \\
$9-$ & Você sabia que a fome no Brasil e no mundo, estão diretamente ligadas a essa perda e a má \\
distribuição? & $\quad$ Você concorda que boas técnicas de pós-colheita podem minimizar esse desperdício? \\
$10-$ & $\quad$ que é feito na fazenda para minimizar esse desperdício? \\
$11-$ &
\end{tabular}

Fonte: Própria (2018). 
Com os resultados dos questionários e visitas, elaborou-se panfletos informativos, o qual foi distribuído no local em conjunto intercorreu a realização de palestras informais em pequenos grupos, com o objetivo de sensibilizar as pessoas. Além disso, efetuou-se uma confecção de cartazes para serem fixados de forma aleatória dentro do mercado como instrumento de conscientização. Ademais, realizou-se métodos de análise documental e observação, completando a pesquisa.

\section{Resultados e Discussão}

Foi realizada uma conversa informal com a direção Geral do CEASA Juazeiro-Ba e visita ao centro de abastecimento, buscando identificar o ponto de vista da direção sobre o desperdício, assim como perceber as dificuldades que a Associaçãolgestão tem em relação ao tema. Nesse primeiro momento foi percebida a falta de um programa de beneficiamento dos vegetais nos estádios mais avançados de maturação, bem como ausência de parcerias para sua realização, além da dificuldade de conscientização da população que transita naquele comércio. Segundo a gestão do local, lá são produzidos aproximadamente 19 toneladas de resíduos por mês, onde $69 \%$ é constituído de alimentos. Ele relatou que os resíduos do local não são recolhidos de forma seletiva e seu destino é o aterro sanitário da cidade.

Salienta-se que estes resíduos poderiam ser reutilizados/trabalhados em forma de adubo orgânico, ao invés de ser meramente descartado em aterros sanitários. Burkot (2015) menciona que todo o material proveniente das centrais de abastecimento pode ser aproveitado ou reutilizado de diferentes formas, de acordo com seu grau de maturação.

Uma prática adotada pela gestão é a adaptação de espaços para o despejo dos resíduos, havendo a possibilidade de serem coletados pelos agentes de limpeza do estabelecimento e direcionados ao destino final. Além disso, os comerciantes que não organizam seus resíduos, são multados e notificados. Porém, ainda há muitos resíduos jogados pelo chão.

Dentro do CEASA encontram-se diversos boxes comerciais, que vão de pequenos a grandes produtores, e existe a venda de outros itens que não são frutas ไhortaliças. Para realizar atividades dentro do local é necessário um cadastramento oficial da empresa, o qual se faz necessário uma certificação da Agência Nacional de Vigilância Sanitária (ANVISA) e um alvará de funcionamento, já nos casos de pequenos produtores, o cadastro é feito com CPF e comprovante de residência.

No Mercado não existe espaços definidos para cada classe de alimento, assim como não possui uma separação entre varejo, atacado e caminhões, para aqueles que não possuem o boxe. 
Segundo o diretor do local, há um programa de mudança de espaço físico do CEASA para outra área maior e mais adequada, já que o local atual $(8,4$ ha) não suporta a população.

Para a Associação Brasileira das Empresas de Refeições Coletivas - ABERC (2018) as centrais de abastecimento devem possibilitar as condições que garantam a proteção dos alimentos e redução ao mínimo das perdas.

O CEASA funciona de segunda à sábado, a partir das 03h da manhã, exceto na segunda cujo horário de abertura é as 00h, pois no domingo não funciona.

A corporação não tem a rastreabilidade dos produtos comercializados, pois recebem alimentos de diversos locais e estados; fator esse que está diretamente ligado ao desperdício. Desta maneira, Soares (2014) revela que a falta de planos de ações logísticos eficazes aliados às más condições das estradas fazem com que $30 \%$ da safra colhida seja desperdiçada do campo ao consumidor.

Seguindo os métodos do estudo, após a aplicação dos questionários, pôde-se observar que a maioria das pessoas que frequentam e utilizam o local eram sequencialmente: $45.5 \%$ comerciantes, seguidos de $32.75 \%$ transportadores, e $24 \%$ compradoreslatravessadores, os quais classificam o CEASA como sua grande fonte de renda (Figura 3).

Figura 3. Conhecimento das pessoas relacionado ao desperdício e a importância que isso significava para elas.

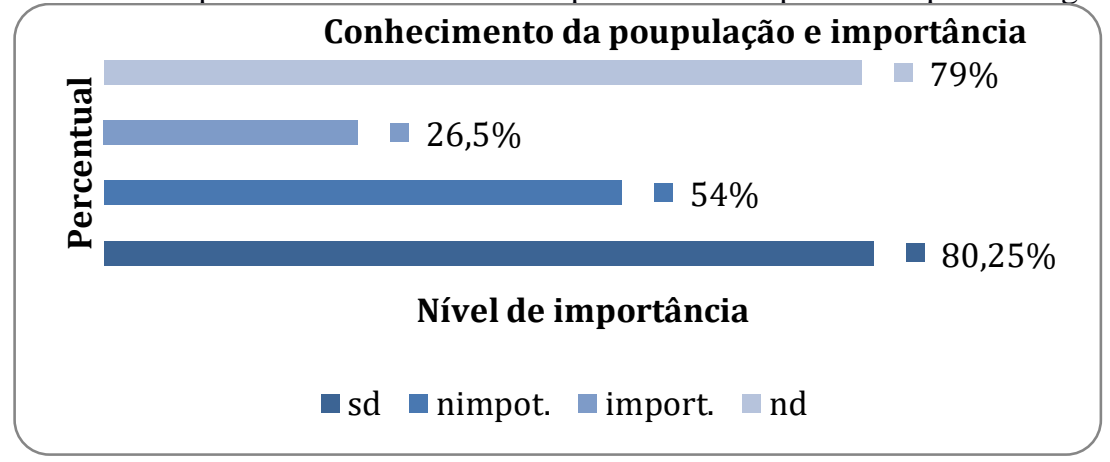

Leg. - nd: não sabia do desperdício; sd: sabia do desperdício; import: se importava com o desperdício; nimport: não se importava com o desperdício.

Fonte: Própria. (2018).

Constatou-se que a população tem conhecimento do desperdício produzido e ao mesmo tempo demonstraram não se importar com as consequências que este amontoado pode causar. Ademais, observou-se que, aproximadamente 93\%, não possuía conhecimentos específicos sobre técnicas pós-colheita como: manusear, transportar e armazenar estes alimentos, e também mostraram uma falta de interesse em adquirir essa compreensão, já que este conhecimento não 
é exigido para se trabalhar no local, o que influencia diretamente na alta produção de resíduos alimentares.

Percebeu-se que mesmo sendo multados, quando a fiscalização acontecia, a maioria dos indivíduos não separavam seus resíduos, apenas eram jogados pelo chão, obtendo como resultado um aumento no resíduo gerado, devido ao aumento de problemas com pragas urbanas. Convém salientar, entretanto, que uma pequena parte o recolhe os resíduos e o destina à animais como refeição (Figura 4).

Figura 4. Resultado da análise sobre o destino dos resíduos gerados.

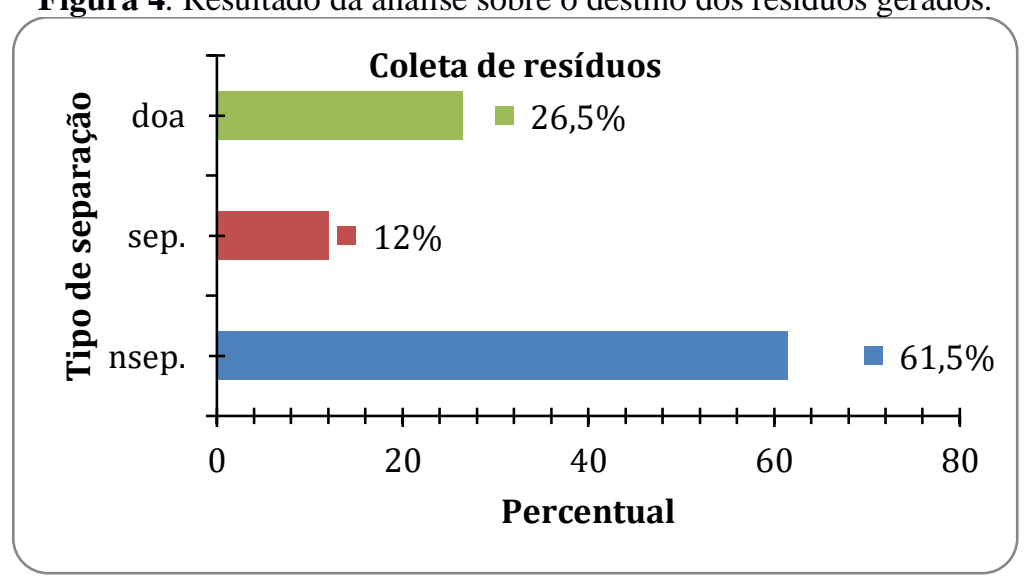

Leg. 2 - doa: doação; sep.: separa seus resíduos; nsep: não separa seus resíduos. Fonte: Própria (2018).

Pôde-se observar que o principal fator do desperdício ou geração de resíduos na CEASA Juazeiro são os produtos machucados e consequentemente deteriorados em partes. Esta situação pode ser explicada, muito provavelmente, pelo fato de quase metade dos produtos comercializados na central serem oriundos de outros estados e sendo assim, são submetidos ao transporte rodoviário. Para Silva e Bazoli (2017) o transporte é um fator que gera grandes índices com perdas de alimentos. Apenas $4 \%$ dos entrevistados declararam que receberam algum tipo de orientação sobre técnicas pós colheita, enquanto $81 \%$ relatou não ter recebido nenhuma orientação e $15 \%$ se mostraram indiferentes em relação ao assunto. Estes resultados influenciam diretamente na contribuição de formação de resíduos no local, uma vez que quanto menor o nível de conhecimento na área, maiores são as chances do alimento se tornar não aceitável comercialmente na central

Segundo Southerton e Yates (2015), o desperdício de alimentos só pode ser plenamente compreendido quando abordado dentro do conjunto mais amplo de processos socioculturais que afetam a alimentação contemporânea. 
Assim, a partir dos dados obtidos, foram elaborados folders (Figura 5) para servir como instrumento de sensibilização e disseminação de conhecimento. Distribuídos no local juntamente com uma palestra informal à partir de pequenos grupos, pois o CEASA não disponibilizava um espaço físico para realização de uma palestra formal. Com isso, foram concedidos 400 panfletos e estima-se um alcance de aproximadamente 800 pessoas.

Figura 5. Folder informativo com técnicas pós-colheita.
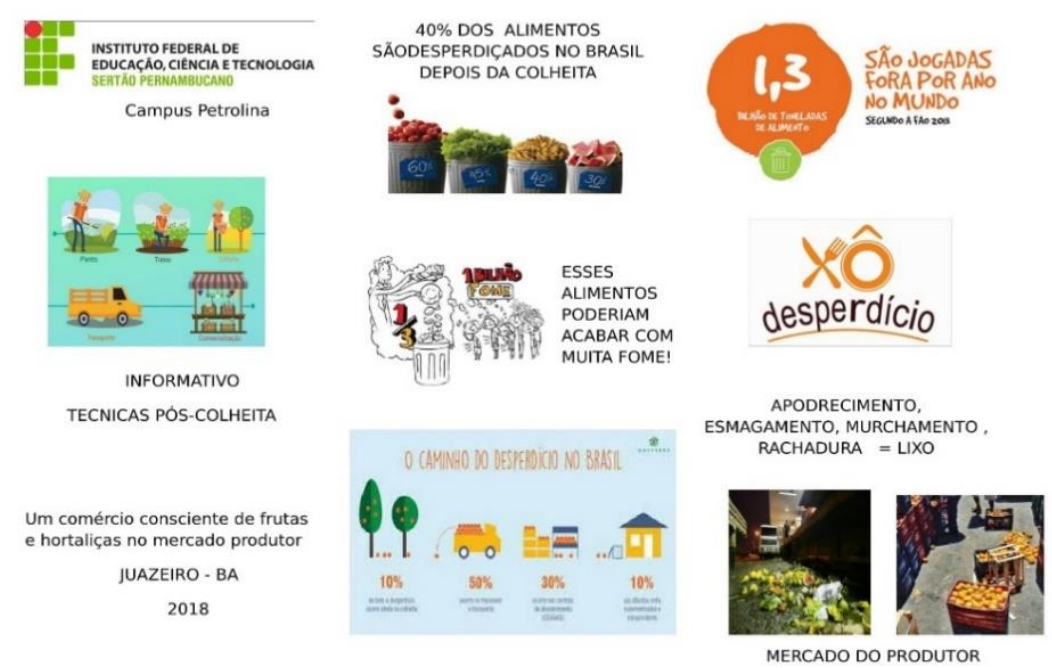

Fonte: Própria (2018).

Direcionando o estudo à algumas fazendas produtoras visitadas no vale do São Francisco, também foi realizada a aplicação de um questionário específico sobre técnicas póscolheita nas propriedades, com o objetivo de identificar alguma relação com o aumento de resíduos no CEASA (Figura 6).

De acordo com os resultados, constatou-se que praticamente todas as propriedades visitadas possuíam profissionais capacitados que tinham conhecimentos sobre pós-colheita e os colocavam em pratica. Como também, disponibilizavam para seus funcionários cursos e treinamento sobre o tema, a fim de minimizar as perdas no local.

Além disso, pôde-se identificar que há pouca produção de resíduos e de refugos nas propriedades, pois encaminhavam para algum tipo de reutilização em indústrias. Chegando à conclusão que o desperdício nas fazendas visitadas pode ser considerado não significativo.

Houve a realização de uma análise comparativa entre as fazendas e o CEASA, pois apesar das empresas se tratarem de caráter distintos, a diretoria da Agência Municipal do Meio Ambiente (AMA) também tem condições de se organizar como entidade, que presta serviços ao município, e juntamente com parcerias, realizar atividades em prol da diminuição dos resíduos alimentares. Segundo estudos similares na CEASA de Serra IRS, os autores mostram 
que esse tipo de trabalho pode ser realizado em qualquer outra central. (DALEGRAVE et. al., 2017).

Figura 6. Avalição de técnicas pós-colheita utilizadas nas fazendas e a relação de profissionais capacitados.

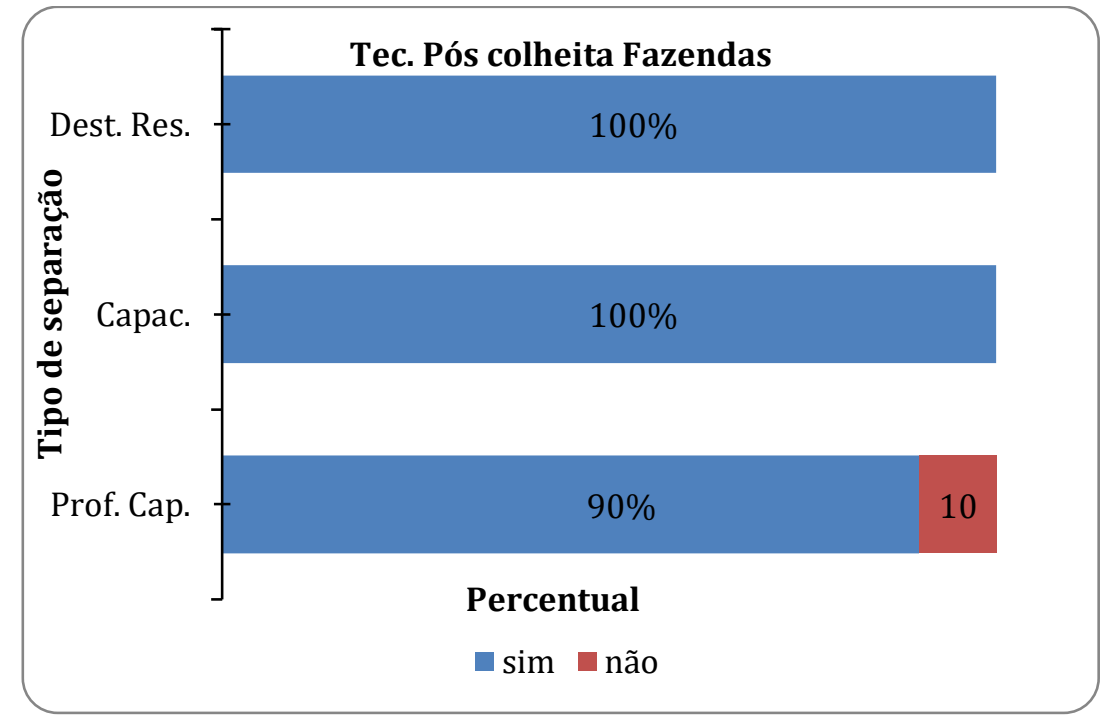

Leg.3 - prof.cap.: Presença de um profissional capacitado; capac: ofereciam cursos e palestras de capacitação; dest.res.: destinavam seus resíduos para indústria.

Fonte: Própria (2018).

Além das atividades realizadas, foram aplicados cartazes (Figura 7) com o intuito de sensibilizar e estimular o pensamento crítico, sobre a situação atual de desperdício, como também conscientizar a população em relação ao tema. Foram confeccionados cartazes de tamanhos médios, que tivesse uma fácil visualização e entendimento a uma curta distância, com a finalidade de chamar a atenção de quem passasse por perto. Eles foram espalhados uniformemente por todo o espaço físico da entidade tendo como proposito um alcance máximo de visualizações. Nesta última fase do projeto, pôde-se perceber uma atenção maior à realização das atividades pelas pessoas no local, pois as pessoas se manifestavam apoiando o trabalho, mostrando resultados positivos ao projeto. Com isso, foi realizada uma última visita ao local, após um mês de aplicação dos cartazes e estes ainda se encontravam aderidos as paredes.

$\mathrm{Na}$ busca pela conscientização da população este estudo levou ao público aspectos sociais, culturais e econômicos através da execução de atividades e disseminação de conhecimento, proporcionando um despertar e senso crítico sobre o assunto abordado.

Cunha et. al. (2019) avaliaram a necessidade da articulação social, governamental e dos gestores da instituição, uma vez que programas desenvolvidos nas centrais de abastecimento possuem expressiva relevância em termos de ganhos sociais. 
Figura 7. Cartaz utilizado com o objetivo de promover a sensibilização das pessoas sobre o desperdício de alimentos.

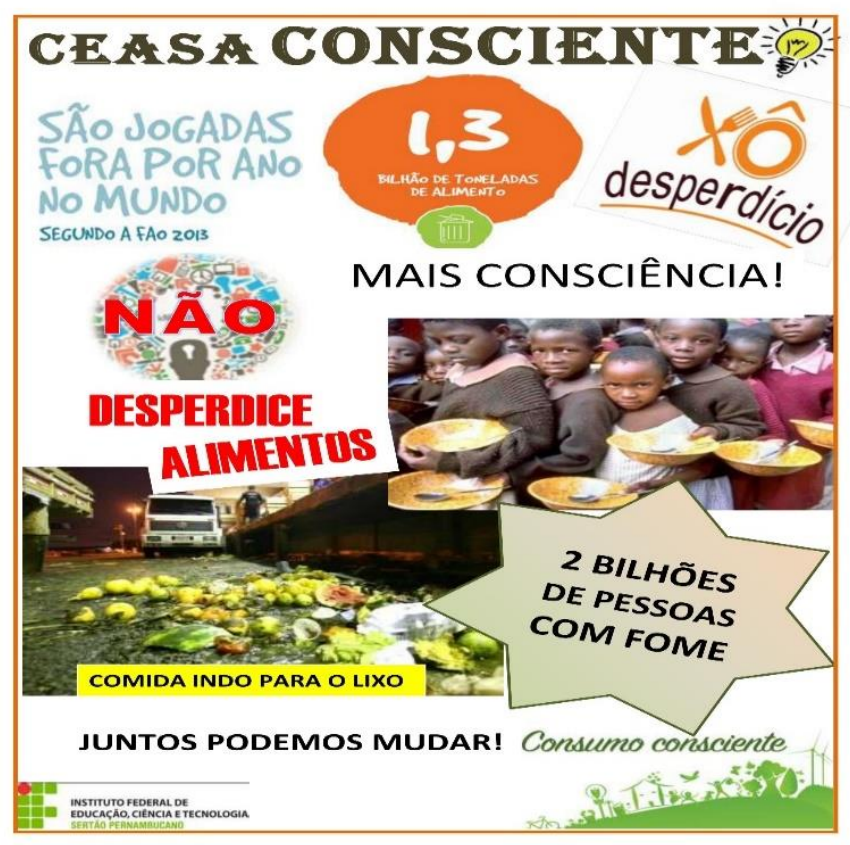

Fonte: Própria (2018).

Foi possível identificar que, os maiores fatores geradores dos resíduos na central são a falta de conhecimento técnico e consciência pessoal. Mas que em contra partida atividades como a realização de projetos como este, geram um despertar e fazem com que a comunidade possa, enxergar alguns problemas e atitudes, que de certa forma já se tornaram comuns e involuntários.

Recomenda-se que para estudos futuros, tente-se realizar a aplicação da coleta seletiva no local e um programa de destino ou beneficiamento dos resíduos, formando parcerias com empresas e a prefeitura, que além de identificar os meios causadores da expansão desses resíduos, estes possam ser reutilizados e não descartados como lixo.

\section{Conclusões}

A falta de conhecimento técnico e conscientização populacional sobre boas práticas de manipulação pós-colheita de vegetais pode ser o principal motivo gerador do desperdício alimentar no CEASA de Juazeiro-BA.

Necessita-se a realização de mais trabalhos que busquem a sensibilização sobre a perda de alimentos e os impactos gerados dessa ação.

Vale salientar, desta forma, que trabalhos de extensão e conscientização são essenciais para a democratização do acesso a informação. 
Recomenda-se para trabalhos futuros realização de metodologias de maior impacto para resultados mais positivos. Além de parcerias entre empresas de beneficiamento para destinação dos resíduos gerados.

\section{Referências}

ABERC. (2018) ASSOCIAÇÃO BRASILEIRA DAS EMPRESAS DE REFEIÇÕES COLETIVAS. Unidade de Alimentação e Nutrição condições estruturais: edifícios e instalações. In: - Manual prático de elaboração e serviço de refeições para coletividade. Disponivel em: https://aberc.com.br/.

BARDIN L. L'Analyse de contenu. Editora: Presses Universitaires de France, 1977. Análise de conteúdo. SP: Edições 70, 2011

BURKOT, C. R. \& AHRENS, R. B. (2015). Avaliação de Aproveitamento dos resíduos agrícolas para a produção de briquetes ecológicos. Revista Brasileira de Tecnologia Agroindustrial, 9(2), 1860-1874.

CAMARGO, LEANDRO NEVES. Manual pós-colheita da fruticultura brasileira. Londrina: Eduel, 2016. Disponível em: http://www.eduel.com.br.

CENCI, S. A; SOARES, A. G.; FREIRE JUNIOR, M. Manual de perdas pós-colheita em frutos e hortaliças. Rio de Janeiro: EMBRAPA-CTAA, 1997. 29p. (EMBRAPA-CTAA. Documentos, 27).

CENCI, S A. Boas Práticas de Pós-colheita de Frutas e Hortaliças. Brasília: Embrapa $\begin{array}{lllll}\text { Informação } & \text { Tecnológica } & \text { p. } & \text { 67-80, } & \text { Disponível }\end{array}$ em:http://www.ceasa.gov.br/dados/publicacao/pub09.pdf. Acesso em: 24 julho 2020.

CONAB- Companhia Nacional de Abastecimento. Juazeiro/BA integra parceria para prover dados sobre frutas e hortaliças ao Prohort. Juazeiro-Ba, 2019. Disponível em:https://www.conab.gov.br/ultimas-noticias/2989-juazeiro-ba-integra-parceria-para-proverdados-sobre-frutas-e-hortalicas-ao-prohort. Acesso em: 18 julho 2020. 
CUNHA, JOSÉ TAVARES \& JOÃO BATISTA M. R. NETO. Sistema de Gestão integrados: qualidade, meio ambiente, responsabilidade social, segurança e saúde no trabalho. Editora: SENAC. São Paulo, 2019.

CHITARRA, M. I. F.; CHITARRA, A. B. Pós-colheita de frutas e hortaliças: Fisiologia e manejo. 2. Ed. rev. e ampl. Lavras: UFLA, 2005. 785 p.

DALEGRAVE. Josué. et. Al. O desperdício de alimentos: um estudo de caso na CEASA Serra RS. Disponível em: http://ojs.fsg.br/index.php/pesquisaextensao/article/view/1751/1426. Acesso em: 27 julho 2020.

EMBRAPA. Manual de perdas pós-colheita em frutos e hortaliças p.06-22, 1997. Disponível em: http://poscolheita.cnpdia.embrapa.br/documents/36843/1212205/colheita_e_beneficiamento_ de_frutas_e_horalicas/efb05ffb-595e-4ec9-acfb-2375ca43e017. Acesso em: 06 julho 2020.

GIL, Antônio Carlos. Métodos e técnicas de pesquisa social. São Paulo: Atlas, 1999.

GUSTAVSSON, J. et al. Global food losses and food waste: extent, causes and prevention. Food and agriculture organization of the United Nations - FAO. 2011.

IBGE- Instituto Brasileiro de Geografia e Estatística. Cidades e Estados. Disponível em: https://www.ibge.gov.br/cidades-e-estados/ba/juazeiro.html. Acesso: 10 junho 2020.

JUAZEIRO, Portal. Mercado do produtor de Juazeiro. Disponível em: https://www6.juazeiro.ba.gov.br/negocios/. Acesso em: 08 julho 2020.

ORGANIZAÇÃO DAS NAÇÕES UNIDAS PARA AGRICULTURA E ALIMENTAÇÃO. FAO no Brasil 2017. Disponível em: http://www.fao.org/brasil/pt/. Acesso em: 28 julho 2020.

ORGANIZAÇÃO DAS NAÇÕES UNIDAS - ONU. FAO discute produção mundial de alimentos. FAO notícias 2012. Disponível em: https://nacoesunidas.org/ . Acesso em: 25 julho. 2020. 
PLANALTO- Presidência da República Casa Civil. DECRETO No 70.502, DE 11 DE MAIO DE 1972. Disponível em:http://www.planalto.gov.br/ccivil_03/decreto/19701979/D70502.htm. Acesso em: 22 julho 2020.

RICARDO, Francisco Duarte. et al. Análise do Agronegócio. Mercado agroexportador de fruticultura irrigada. Universidade Federal do Vale do São Francisco. Petrolina-PE. p. 35-37, 2016.

ROESCH, Sylvia Maria Azevedo. Projetos de Estágio e de Pesquisa em Administração. $3^{\text {a }}$. Ed. Ed. Atlas, 2005. São Paulo.

SILVA, M. M.; BAZOLI, T. N. Operações e Logística. São Paulo. Pearson Prentice Hall, 2017.

SOARES, Antônio Gomes. Desperdício de Alimentos no Brasil: um desafio político e social a ser vencido. Embrapa $\quad$ Disponível http://atividaderural.com.br/artigos/508fc56454d19.pdf. Acesso em: 28 julho. 2020.

SOUTHERTON, D.; YATES, L. Exploring food waste through the lens of social practice theories: some reflections on eating as a compound practice. In: EKSTROM, K. M. (Ed.). Waste management and sustainable consumption. London: Routledge, 2015. p. 133-149. 


\title{
CAPÍTULO 12: ESTUDO DO APROVEITAMENTO DE SUBPRODUTOS AGROINDUSTRIAIS: ALTERNATIVAS PARA OS RESÍDUOS GERADOS PELAS INDÚSTRIAS DE LATICÍNIOS
}

\section{CHAPTER 12: STUDY OF THE APPROVAL OF AGRO-INDUSTRIAL BY- PRODUCTS: ALTERNATIVES FOR WASTE GENERATED BY THE DAIRY INDUSTRIES}

\author{
Débora Karina Ferreira de Lira ${ }^{1}$; Gerla Castello Branco Chinelate ${ }^{2}$
}

\begin{abstract}
Resumo
$\mathrm{Na}$ indústria de laticínios existem subprodutos com propriedades funcionais provenientes do processo de fabricação de alguns alimentos, como exemplos o soro de leite, oriundo da produção de queijos, também conhecido como soro de queijo e o leitelho, obtido do processo de produção da manteiga. Eles possuem elevado teor nutricional em sua composição e é sugerido no enriquecimento ou desenvolvimento de novos produtos. Apesar dos seus benefícios, ao serem descartados de forma inadequada, eles são considerados altamente poluentes devido sua alta carga orgânica. Em virtude disso, o presente artigo aborda o tema da utilização do soro de leite e leitelho na elaboração de produtos alimentícios, como também identificar as tecnologias possíveis para utilizá-los como ingredientes. A metodologia utilizada consistiu em uma revisão bibliográfica com levantamento de informações sobre o tema por meio de artigos e dissertações nacionais. Nesta revisão observou-se que diversos trabalhos estão sendo realizados, comprovando a eficiência desses subprodutos em alimentos, mas que ainda assim, comparado ao volume gerado e a quantidade de opções de fabricação, o aproveitamento e valorização no âmbito comercial ainda é baixo. Por essa razão será apresentada o uso desses subprodutos em diversos tipos de alimentos, contribuindo para uma maior valorização comercial.
\end{abstract}

Palavras-Chave: Aproveitamento, subprodutos, soro de leite, leitelho.

\begin{abstract}
In the dairy industry there are by-products with functional properties from the manufacturing process of some foods, such as whey, derived from cheese production, also known as cheese whey and buttermilk, obtained from the butter production process. They have a high nutritional content in their composition and are suggested in the enrichment or development of new products. Despite their benefits, when improperly disposed of, they are considered highly polluting due to their high organic load. As a result, this article addresses the issue of using whey and buttermilk in the preparation of food products, as well as identifying possible technologies for using them as ingredients. The methodology used consisted of a bibliographic review with gathering information on the theme through articles and national dissertations. In this review it was observed that several works are being carried out, proving the efficiency of these by-products in food, but that, still, compared to the volume generated and the quantity of manufacturing options, the use and valorization in the commercial scope is still low. For this reason, the use of these by-products in different types of food will be presented, contributing to a greater commercial valorization.
\end{abstract}

Keywords: Utilization, by-products, whey, buttermilk.

\footnotetext{
${ }^{1}$ Engenharia de Alimentos, Universidade Federal do Agreste de Pernambuco, deborakarina.ufrpe@gmail.com

${ }^{2}$ Doutora, Professora do curso de Engenharia de Alimentos da Universidade Federal do Agreste de

Pernambuco, gerla.chinelate@ufape.edu.br
} 


\section{Introdução}

O Brasil ocupa no mundo a terceira posição de maior produtor de leite e é responsável pela produção de diversos produtos lácteos (EMBRAPA, 2019). Diante desse cenário e a crescente preocupação com o desenvolvimento de produtos sustentáveis, as indústrias alimentícias estão cada vez mais pressionadas a reduzirem os resíduos produzidos durante o processamento de seus insumos, principalmente as indústrias de laticínios (DELGADO, 2007). Desse modo, a destinação do que se tornaria resíduo industrial, para fabricação de alimentos inovadores, se apresenta como uma excelente alternativa para o seu não descarte.

De acordo com Kubota et al. (2012), a indústria de alimentos se encontra em constante busca pela inovação, com eficiência em seus processos produtivos e na geração de resultados em seus produtos finais, levando sempre em consideração a alta competitividade e concorrência junto aos consumidores mais bem informados e exigentes. Em razão disso, o mercado de alimentos e bebidas tem expandido a tentativa de satisfazer o consumidor no lançamento de produtos.

No que se refere ao setor lácteo, a implementação de inovações também faz parte do seu cenário industrial principalmente por dois motivos: primeiro, o leite é uma matéria-prima bastante perecível e precisa de buscas por maior qualidade e durabilidade em seus produtos, e segundo, a preocupação emergente com o desenvolvimento sustentável de produtos, devido aos seus efluentes agroindustriais (DELGADO; BARIN-CRUZ, 2007). O que se refere ao último, Vourch et al. (2008) ressalta que os efluentes líquidos constituem a principal fonte de poluição dessa indústria em razão da alta carga orgânica dos resíduos do leite e produtos derivados do leite.

O leite é a matéria-prima de origem animal básica na alimentação humana, constituída por uma série de componentes, como: água, lipídeos, carboidratos, proteínas e nutrientes. Ele é utilizado na produção de muitos alimentos como: bebida láctea, leite fermentado, coalhada, queijos, leite em pó, manteiga, creme de leite, requeijão, iogurte, doce de leite, leite pasteurizado, ricota, etc. (CRUZ et al., 2015).

É importante salientar que durante o processamento desses produtos, quantidades consideráveis de subprodutos são gerados. Por exemplo, a produção de queijo resulta em produção adicional de soro; produção de manteiga resulta em leitelho adicional; produção deóleo de manteiga resulta em soro cremoso adicional; etc. (BANASZEWSKA et al., 2014). Neste trabalho, serão destacados dois subprodutos que possuem grande potencial comercial e capacidade de poluição severa, caso descartado de forma incorreta: o soro de leite e o leitelho. 
O soro de leite é classificado pelo Regulamento de Inspeção Industrial e Sanitária de Produtos de Origem Animal - RIISPOA, no Art. 400 do decreto nº 9.013 (BRASIL, 2017) como o produto líquido de caráter lácteo extraído da coagulação do leite no processamento de queijos, de caseína e de produtos similares. Ele possui cerca da metade dos nutrientes originais do leite sendo abundante em componentes tais como: proteínas do soro, vitaminas hidrossolúveis, sais minerais e lactose (SMITHERS, 2008).

As proteínas presentes no soro do leite oferecem muitos benefícios para o homem, como: reparação celular, construção e reparação de músculos e ossos, dão energia ao corpo, além de outros benefícios que estão ligados a processos metabólicos, como atividade imunoestimulante, proteção ao sistema cardiovascular e atividade antimicrobiana e antiviral (SGARBIERI, 2005; HARAGUCHI et al., 2006).

No entanto, como resíduo, proporciona malefícios ao meio ambiente e à sociedade. Ao ser descartado, se torna um dos efluentes líquidos que mais contribuem para a alta carga poluidora das indústrias de laticínios. Dez litros de soro descartado incorretamente equivalem à poluição causada por cinco habitantes (MOREIRA; SILVA; ANTUNES, 2000), além de ser cem vezes mais poluente que o esgoto doméstico (SILVA, 2011). De acordo com Rosenthal (2016), o aproveitamento desse subproduto teve um aumento com a chegada de instalações de unidades industriais de concentração e secagem no Brasil, mas ainda assim, o volume descartado ou subutilizado ainda é elevado.

Outro subproduto a ser discutido neste trabalho é o leitelho, o qual é classificado também pelo RIISPOA no Art. 404 (BRASIL, 2017), como o produto lácteo liberado durante o batimento do creme pasteurizado para a produção de manteiga. Assim como o soro de leite, o aproveitamento total do leitelho ainda é um grande desafio para as indústrias brasileiras. Já no mercado internacional, ele é um produto bastante popular e consumido como um tipo de bebida láctea ou um tipo de leite fermentado, também chamado de fermented buttermilk, frequentemente consumido com cereais ou como substituto do leite fresco (ANTUNES et al., 2012).

O leitelho contém a maior parte da proteína encontrada no leite, além de possuir vitaminas, minerais e propriedades funcionais devido a presença de fosfolipídios, que por sua vez são provenientes das membranas fragmentadas dos glóbulos de gordura do leite interrompidas durante a agitação. A sua presença influencia na redução do colesterol no sangue, inibição e impedimento do desenvolvimento de bactérias que se aderem as paredes do trato gastrointestinal (FONG; NORRIS; MACGIBBON, 2007; NOH; KOO, 2004). Em virtude dessas características, ele se apresenta como uma boa alternativa para formulações de 
novos produtos alimentícios, pois possui várias propriedades benéficas a saúde do consumidor.

Em resumo, os subprodutos discutidos contêm uma parte consideravelmente grande de nutrientes na sua composição. No entanto, por causa da elevada demanda biológica de oxigênio não devem ser misturados aos demais efluentes da indústria. Pelo contrário, devem ser captados e conduzidos separadamente, de modo a propiciar o seu aproveitamento na fabricação de outros produtos lácteos ou para utilização direta na alimentação de animais (SILVA, 2011).

Ao serem submetidos a tecnologias, produtos são gerados com alto teor de nutrientes e alimentos são enriquecidos pela possibilidade de utilizar os subprodutos como ingredientes, dando-lhes propriedades nutritivas, ou seja, potencial de fabricar alimentos funcionais que de acordo com Vidal et al. (2012) são aqueles que fornecem benefícios adicionais na alimentação do consumidor, os quais produzem efeitos fisiológicos ou metabólicos por meio do desempenho de algum nutriente, na manutenção das funções do organismo humano.

Diante do exposto, o presente artigo aborda vários estudos sobre alternativas de aproveitamento, afim de evitar impactos negativos ao meio ambiente e aproveitar os nutrientes presentes nas composições desses subprodutos.

\section{Desenvolvimento}

Este trabalho foi desenvolvido com base em artigos e dissertações nas diversas áreas de Ciência e Tecnologia de Alimentos que abordavam alternativas de aproveitamento do soro de leite e leitelho na elaboração de produtos, além de identificar as tecnologias de tratamento existentes para utilizá-los como ingredientes na formulação de alimentos.

\subsection{Discussão}

\subsubsection{Utilização do soro do leite}

A princípio, grande parte do soro de leite gerado no Brasil, provem de pequenas e médias queijarias, o que torna o investimento em tecnologia necessária para o beneficiamento do subproduto mais difícil (ALVES, 2014). No entanto, estudos sobre o problema de aproveitamento do soro já vem sendo realizado há alguns anos. Machado (2001) chega a comentar que é possível ter ações conjuntas que solucionem definitivamente esse problema, sendo elas: a adoção de programas para melhoria da qualidade nas indústrias e a implementação de unidades estratégicas bem localizadas para facilitar o encaminhamento do 
subproduto para uma unidade de processamento.

Durante a fabricação de queijos o soro representa $90 \%$ do volume do leite, pois para produzir $1 \mathrm{~kg}$ de queijo são necessários $10 \mathrm{~L}$ de leite, o que gera $9 \mathrm{~L}$ de soro (LEITE; BARROZO; RIBEIRO, 2012). A utilização desse soro ainda não é significativa no Brasil, uma vez que apenas cerca de $15 \%$ do soro de leite líquido é empregado como matéria-prima no setor tecnológico alimentício (ROHFLES, 2014). Este percentual é empregado na fabricação de algumas bebidas e alimentos.

Como bebidas podem ser encontradas processadas de diversas maneiras como UHT, pasteurizadas, bebidas lácteas fermentadas semelhantes ao iogurte, bebidas lácteas não fermentadas, soft-drinks, carbonatadas e em diversos sabores (LIMA; MADUREIRA; PENNA, 2002). Dentre elas, a produção de bebida láctea é uma das principais opções de aproveitamento do soro de leite no Brasil (SANTOS, 2008).

O Regulamento Técnico de Identidade e Qualidade de Bebidas Lácteas (BRASIL, 2005) define a bebida láctea como o produto resultante da mistura do leite e soro de leite, fermentadas ou não, adicionadas ou não de outros ingredientes. PESCUMA et al. (2010) comentam que essas bebidas com a presença do soro possuem muitos benefícios para o consumidor devido a ação de bactérias láticas na fermentação do soro, as quais realizam intensa atividade metabólica sobre os carboidratos, lipídeos, proteínas e peptídeos alergênicos que nele estão presentes. Promovendo assim, contribuições na digestibilidade, preservação, melhoria da textura e perfil sensorial do alimento.

Siqueira, Machado e Stamford (2013) realizaram um levantamento bibliográfico sobre bebidas lácteas a base de soro com adição de frutas e ressaltaram que essa combinação tem melhorado as características de aromas e sabor desse tipo de bebida, além de estimular o interesse em alcançar o consumidor devido as recomendações nutricionais do consumo de frutas e hortaliças. Estudos sobre a elaboração de bebidas lácteas com adição do soro e polpas de frutas: abacaxi (BRANDÃO et al., 2006); graviola (MATOS, 2009); umbu (SANTOS et al., 2006); manga (SANTOS et al., 2008); açaí (ZOELLNER et al., 2009); acerola (CRUZ et al., 2009); morango (CALDEIRA et al., 2010), (OLIVEIRA et al., 2006); pêssego (KEMPKA et al., 2008) e uva (KREUTZ; LEHN; SOUZA, 2012).

O soro do leite é também bastante utilizado na formulação de alimentos funcionais. Dentre os mais variados tipos de produtos funcionais, o soro do leite é encontrado comercialmente em barras de cereais, biscoitos, massas prebióticas, bebidas antioxidantes, chocolates probióticos, entre outros (BADISSERA et al., 2011). Segundo Alves (2014) 
durante a fabricação desses alimentos, o soro é utilizado na forma líquida ou em pó (obtidos através do uso de tecnologias de separação por membrana, evaporação à vácuo e secagem por atomização), possibilitando também a produção dos concentrados e isolados proteicos do soro.

Silva, (2011) fez a elaboração de um leite condensado a partir do soro de leite em pó, denominada pela autora de "mistura láctea", com intuito de substituir o leite condensado utilizado em sobremesas. As análises demonstraram que esse produto a base de soro de leite apresentou valores semelhantes ao tradicional, o que pode ser considerada uma ótima alternativa para sobremesas.

Também na área de sobremesas, Vettorello et al. (2017) fizeram uso do soro de leite para elaborar diferentes formulações de sorvete, substituindo o leite UHT por soro de leite em pó. Após a obtenção do produto final foram realizadas as seguintes análises: físicoquímicas de proteína, gordura e sólidos totais. Os resultados de todas as análises foram favoráveis ao desenvolvimento desse produto, com bom índice de aceitação sensorial.

Bedendo et al. (2019) discorreram sobre a substituição de leite em pó por concentrado proteico de soro de leite (WPC - WheyProteinConcentrate) e açúcar cristal por mascavo para elaboração de bolo sem glúten. A substituição dos ingredientes não influenciou a estrutura física do bolo e obtiveram uma boa aceitabilidade das amostras oferecidas, sendo assim, uma boa alternativa a ser introduzida numa alimentação mais saudável.

Soares et al. (2018) também fizeram a elaboração de bolos, só que sem adição de açúcar e com adição da proteína do soro de leite como substituto do trigo, avaliando o efeito das diferentes proporções da proteína do soro e manteiga. Os resultados de análises físicoquímicas e sensoriais do produto final apresentaram o teor maior de proteínas e menor teor de carboidratos totais, atingindo o objetivo do trabalho e sendo apropriados para o consumo por aqueles que possuem restrições de sacarose.

Arrais (2015) apresentou mais uma alternativa para o uso do soro, utilizando-o na fabricação de uma ricota funcional. De acordo com Pinto (2010), a ricota é constituída quase somente de proteínas do soro, sendo a albumina a principal e de globulina obtida através do soro de queijo. O trabalho citado elaborou uma ricota com a adição de soro e/ou inulina e/ou cultura probiótica com várias formulações e obteve resultados tecnologicamente viáveis para a reprodução desse produto.

Soares (2011) desenvolveu um iogurte probiótico aproveitando o soro de queijo de coalho fazendo avaliações de diferentes processos de pasteurização e concentração de leite em pó. Em todas as formulações não ocorreu a contaminação por bactérias deteriorantes e a 
contagem de bactérias lácteas foi de valor adequado, demonstrando que esse produto é uma alternativa viável para agregar valor ao subproduto.

Terra (2009) desenvolveu uma mortadela substituindo a água que seria empregada na sua elaboração por três proporções diferentes de soro de leite líquido. Essa substituição não exerceu influência significativa nas características sensoriais, pH, coloração, estabilidade da emulsão e líquido liberado após tratamento térmico das mortadelas. Logo, o soro pode ser empregado na fabricação de mortadelas e enriquecer esse produto com suas propriedades nutritivas.

Carvalho et al. (2015), desenvolveram uma formulação de pão de queijo fazendo a substituição parcial ou total do leite por diferentes concentrações de soro de leite. Por meio de avaliações de análises sensoriais do produto final, foi possível concluir que o pão de queijo enriquecido com soro de leite não obteve diferença significativa em relação ao produto padrão, além de ter uma boa aceitação dos consumidores. Fabricação de outros pães com o uso do soro: pão francês (SILVA et al., 2011) e pão de forma (ARAÚJO; ARAÚJO; SAMPAIO, 2011; CALDAS, 2007; NETO, 2007; RODRIGUES, 2008).

Lima e Rocha (2016) elaboraram formulações de doce de leite com diferentes concentrações de soro, com objetivo de estudar a viabilidade econômica da produção desse produto. Foram realizados cálculos de investimentos físicos e financeiros e obtiveram resultados que indicaram que a formulação com maior porcentagem de soro se mostrou mais lucrativa, se apresentando assim, como um produto com excelente potencial e viabilidade econômica para ser fabricado.

Fernandes et al. (2015) utilizaram o soro de leite para obtenção de filmes biodegradáveis a partir do concentrado proteico de soro irradiado, visando avaliar a sua eficiência como embalagem para maçã. Foram produzidos e avaliados os filmes com o concentrado proteico sem tratamento e outros submetidos por irradiação gama. A partir dos resultados, foi possível concluir que o produto irradiado apresentou aplicabilidade para ser utilizado em embalagens alternativas com intuito em preservar a cor e retardar o escurecimento da maçã após o corte.

\subsubsection{Utilização do leitelho}

A quantidade de leitelho gerado por dia no Brasil ainda não é divulgada precisamente. Essa realidade é provavelmente devido ao déficit no controle do registro de produção, o qual é feito basicamente nas grandes unidades beneficiadoras e por ser comum misturar-se o leitelho com soro advindo da fabricação de queijos. De forma geral, sabe-se que a produção 
deleitelho é em grande volume, pois para cada $\mathrm{Kg}$ de manteiga produzida, tem-se um valor similar ao do leitelho (CAVALARI, 2017).

A maioria dos trabalhos existentes sobre a utilização do leitelho é relacionado a bebidas lácteas. Assim como o soro de leite, existem também bebidas funcionais com características nutritivas produzidos a base de leitelho.

Hiroki et al. (2013) utilizaram o leitelho para elaborar quatro formulações de leite fermentado probiótico com baixo teor de lactose adicionado de culturas probióticas e $30 \%$ de leitelho. O leite fermentado é defino por Carneiro (2012) como o leite inoculado com culturas iniciadoras de microrganismos ácido-láticos, que convertem parte da lactose do leite em ácido lático por meio da fermentação, nome genérico dado aos produtos como: iogurte, leite cultivado, leite acidófilo, kefir, kumys e coalhada. O produto citado fez uso das propriedades funcionais do leitelho para classificá-lo como probiótico e obtiveram ótimos resultados.

Pfrimer (2018) elaborou uma bebida láctea fermentada e saborizada com polpa de cagaita com sete formulações de diferentes concentrações de leite, mistura soro/leitelho e polpa de cagaita. Foram avaliadas as suas características físico-químicas, microbiológicas e aceitação sensorial, as quais apresentaram resultados dentro do padrão estabelecido pela legislação e altas notas na análise sensorial e intenção de compra.

Ribeiro (2012) também utilizou o leitelho para produção de uma bebida láctea fermentada, só que em vez de introduzir uma mistura de soro/leitelho, fez uma substituição parcial e total do soro de leite por leitelho. Após as análises, foi possível concluir que essa substituição não interferiu no processo de fermentação e nas populações dos microrganismos adicionados, além de proporcionar um aumento na viscosidade e na quantidade de minerais do produto final.

Cavalari (2017) desenvolveu uma bebida láctea fermentada com adição de iogurte natural e leitelho. Foram realizadas análises sensoriais de teste de aceitação, intenção de compra e escala do ideal para doçura e textura. Em relação ao teste de aceitação e intenção de compra, obtiveram ótimas notas pelos provadores, já o ideal para doçura e textura, ficaram entre ligeiramente menor que o ideal e ideal. Ainda assim, não descarta a possibilidade do leitelho ser uma ótima opção para o uso em bebidas compostas.

Teixeira (2013) desenvolveu uma bebida simbiótica substituindo o soro lácteo por leitelho em diferentes concentrações com a adição de leite integral, açúcar, inulina, frutooligossacarídeo e culturas láticas probióticas. O produto obteve boa aceitação em relação as propriedades organolépticas e impressão global dos consumidores, favorecendo a fabricação dessa bebida e a chance de sucesso para o mercado de alimentos funcionais. 
Outro tipo de bebida estudada e desenvolvida, foi o kefir, definida por Dias (2016) como um leite fermentado produzido artesanalmente a partir da fermentação do leite pelos grãos de kefir que contêm uma população estável de micro-organismos, resultando em um produto de propriedade ácida e de levemente alcoólico. Monteiro e Gomes (2018) avaliaram o efeito da substituição de leite por leitelho na produção de kefir com dois tratamentos distintos e obtiveram resultados de uma aceitação sensorial similar ao do produto produzido com leite.

Em informações citadas anteriormente, vimos que o leitelho é rico em fosfolipídios, componente que apresenta funções nutricionais e efeitos benéficos para a saúde do consumidor. O leitelho na forma fluida possui uma concentração de fosfolipídios totais de sete a nove vezes maior do que no leite fluido desnatado (CHRISTIE; NOBLE; DAVIES, 1987). Posto isso, o seu aproveitamento como substituto do leite fluido desnatado seria uma opção interessante para formulação de alimentos funcionais. A exemplo disso, Assumpção (2013) desenvolveu uma ricota com adição do leitelho em substituição ao leite desnatado e os resultados mostraramque não houve diferença significativa quanto aos aspectos sensoriais e ao rendimento esperado, apresentando-se como uma das alternativas de utilização para evitar o seu descarte.

O uso de tecnologias favorece um aumento na diversidade de produtos, uma vez que é possível elaborar ingredientes e adicioná-los na formulação de alimentos. A título de exemplo, Costa (2008) desenvolveu um ingrediente lácteo enriquecido em fosfolipídios do leitelho a partir da associação de duas tecnologias de fracionamento: a ultrafiltração e a extração com fluido supercrítico (EFS). A partir dos resultados obtidos do ingrediente lácteo, pôde-se concluir que é possível fabricar leitelho em pó através dessas tecnologias e utilizá-lo como ingrediente especialmente em alimentos de baixo $\mathrm{pH}$.

Juliano et al. (2014) fabricaram uma sobremesa láctea utilizando como base proporções de leitelho: leite com e sem a presença de emulsificante, denominada de "sobremesa láctea tipo frozen yogurt" com características funcionais. Frozen yogurt é uma sobremesa fermentada e congelada similar ao valor nutricional do iogurte com o sabor refrescante do sorvete e que possui baixo teor de gordura e lactose (GOFF, 2011). No trabalho citado, todas as formulações independente da proporção leitelho: leite apresentaram maior rendimento e dureza com a presença de emulsificante, mostrando um retorno positivo no fabrico deste produto.

Outra sobremesa a ser destacada é o sorvete, bastante requerida no cenário mundial por agradar todo e qualquer tipo de público. A aplicabilidade do leitelho em sorvetes se 
apresenta como uma alternativa para aqueles que pretendem consumir sobremesas com menos teor de gordura. Walus (2014) elaborou um sorvete com adição de leitelho e substituição parcial de gordura e os resultados das análises físico-químicas mostraram que esse procedimento não teve influência direta no comportamento e nas características físicas de sorvete. Logo, pôde-se concluir que é possível o uso do leitelho em substituição parcial da gordura do sorvete.

Além disso, pode-se fazer também o uso do leitelho no desenvolvimento de alimentos na panificação, no entanto, essa área de estudo é pouco explorada. Nesse âmbito, Gonzalez et al. (2009) realizaram um estudo sobre o adição do leitelho na formulação de pães. Após a obtenção do produto, foi realizada uma avaliação sensorial por meio do teste de escala hedônica e os resultados das amostras apesentaram que não houve diferença significativa ao nível de 1\% comparados aos pães sem o leitelho, além de obter aceitabilidade dos avaliadores. Em vista disso, a fabricação de pães com adição de leitelho se apresenta viável devido a permanência das características físicas de pão e sabor a gosto dos consumidores.

\section{Considerações Finais}

A partir da revisão bibliográfica, conclui-se que o soro de leite e o leitelho podem dar origem a uma série de produtos, sendo utilizado tanto na forma fluida quanto em pó (por meio da aplicação de tecnologias), enriquecendo o valor nutricional dos alimentos e auxiliando na redução dos impactos ambientais.

Também foi notório que esses subprodutos tem sido tema de muitos trabalhos científicos ao longo dos anos, no entanto, existem mais estudos a respeito da utilização do soro de leite comparado aos estudos realizados sobre o uso do leitelho. Isto deve ser resultado da maiorquantidade de produtos disponíveis a base de soro de leite no mercado. $\mathrm{O}$ soro proveniente da fabricação de queijo corresponde a um volume expressivo na indústria alimentícia brasileira, logo existe soro lácteo em abundância comparado ao leitelho e por isso mais preocupação com o seu descarte inadequado e aproveitamento. Atualmente, a produção e o consumo de manteiga está em crescimento, o que retornaria em mais subproduto e maior possibilidade de ser mais explorado comercial e academicamente.

Além disso, outro ponto verificado com a revisão bibliográfica foi a praticidade dos dois subprodutos abordados. Além de possuírem baixo custo para as indústrias, já que são resultantes de processos de fabricação, eles podem ser utilizados de forma fluida em diversos produtos sem a necessidade do uso de tecnologias, sendo um bom aspecto para as indústrias de pequeno e médio porte. 
Finalmente, ficou evidente a necessidade de uma mudança de tratamento no que se refere ao desuso do soro de leite e do leitelho durante a fabricação de produtos, ou seja, observálos como potenciais fontes de lucro e não como resíduos. Para isso é preciso uma organização industrial que possibilite o encaminhamento dos mesmos para serem processados, dessa forma é possível aproveitar as suas propriedades nutritivas e desenvolver ações tecnológicas vinculadas à industrialização, podendo introduzi-los em diversos alimentos comerciais.

\section{Referências}

ALVES, M. P.; MOREIRA, R. de O.; JÚNIOR, P. H. R.; MARTINS, M. C. F.; PERRONE, Í.

T.; CARVALHO, A. F. Soro de leite: tecnologias para o processamento de coprodutos. Revista do Instituto Laticínios Cândido Tostes, Juiz de Fora, v. 69, n. 3, p. 212-226, maio/jun. 2014.

ANTUNES, A. E. C.; LISERRE, A. M.; FARIA, E. V.; YOSUYANAGI, K.; LERAYER, A. L. S. Buttermilk probiótico. Alim. Nutr., Araraquara, v. 23, n. 4, p. 619-629, out./dez. 2012.

ARAÚJo, N. G; ARAÚJO, P. M. A. G; SAMPAIO, S. B. Elaboração de Pão de Forma Enriquecido com Soro de Queijo. Disponível em: $<$ https://cienciadoleite.com.br/noticia/292 5/elaboracao-de-pao-de-forma-enriquecido-comsoro-de-queijo>. Acesso em: 03 jul. 2020.

ARRAIS, Bárbara C. D. Desenvolvimento de ricota funcional: avaliação das características físico-químicas e microbiológicas do produto. Dissertação de Mestrado. Londrina, $2015 . \quad$ Disponível em: http://repositorio.pgsskroton.com.br/bitstream/123456789/719/1/DESEN VOLVIMENTO\%20DE\%20RICOTA\%20FUNCIONAL.pdf>. Acesso em: 23 jun. 2020.

ASSUMPÇÃO, Giovana M.P.; PAULA, Alcimara A. A. De. Utilização do leitelho na fabricação da ricota em substituição ao leite desnatado. Disponível em: <https://www. fatecourinhos.edu.br/retec/index.php/retec/article/view/38/96>. Acesso em: 27 jun. 2020.

BADISSERA, A. C.; BETTA, F. D.; PENNA, A. L. B.; LINDNER, J. de D. Alimentos funcionais: uma nova fronteira para o desenvolvimento de bebidas protéicas a base de soro de leite. Semina: Ciências Agrárias, Londrina, v. 32, n. 4, p. 1497-1512, out./dez. 2011.

BANASZEWSKA, A.; CRUIJSSEN, F.G.; CLAASSEN, G. D. H.; VAN DER VORST, J.G.A.J. Effect and key factors of byproducts valorization: The case of dairy industry. Journal of dairy science, v. 97, n.4, p. 1893-1908, 2014.

BEDENDO, Anandra et al. Substituição de leite em pó por concentrado proteico de soro de leite (WPC - WheyProteinConcentrate) para elaboração de bolo sem glúten. Braz. J. of Develop, Curitiba, v. 5, n. 7, p. 8062-8073 jul. 2019.

BRANDÃO, W.A.P.L.N.T.M. et al. Bebida fermentada probiótica de soro de leite. Higiene Alimentar, v.20, n.143, p.56-59, 2006.

BRASIL. Ministério da Agricultura. Regulamento Técnico de Identidade e Qualidade para 
Bebidas Lácteas. Instrução normativa $n^{\circ} 16$ de 23 de agosto de 2005. Diário Oficial da União da República Federativa do Brasil, Brasília, seção 1, p. 7, 2005.

BRASIL. Regulamento de Inspeção Industrial e Sanitária de Produtos de Origem Animal (RIISPOA). Decreto $\mathbf{n}^{\mathbf{0}}$ 9.013, 29 de março de 2017. Disponível em: <http://www3. servicos.ms.gov.br/iagro_ged/pdf/2511_GED.pdf>. Acesso em: 23 jun. 2020.

CALDEIRA, Luciana A. et al. Desenvolvimento de bebida láctea sabor morango utilizando diferentes níveis de iogurte e soro lácteo obtidos com leite de búfala. Ciência Rural, $\quad$ v.40, n.10, p.2193-2198, $2010 . \quad$ Disponível em: $<$ http://www.scielo.br/scielo.php?script=sci_ar $\quad$ ttext\&pid=S010384782010001000023\&lng=en\&nrm=iso>. Acesso em: 27 jun. 2020.

CALDAS, M.C.S. Aproveitamento de soro de leite na elaboração de pão de forma. Dissertação de Mestrado. UFPB João Pessoa, 2007.

CARNEIRO, C. da S.; CUNHA; F. L.; CARVALHO, R. de; CARRIJO, K. de F.; BORGES, A.; CORTEZ, M.A.S. Leites fermentados: histórico, composição, características físico químicas, tecnologia de processamento e defeitos. PUBVET, Londrina, V. 6, N. 27, Ed. 214, Art. 1424, 2012.

CARVALHO, G. S. de; SILVA, L. M. da; COELHO, K. O.; BUENO, C. P.; NEVES, R. B. S.

Aproveitamento do soro para a produção de pães de queijo. Disponível em: <https://www.anais.ueg.br/index.php/cepe/article/view/5413/3210>. Acesso em: 24 de jun. 2020.

CAVALARI, Izabel C. da S. Elaboração de bebida fermentada com utilização de leitelho. Trabalho de conclusão de curso (Técnico em alimentos integrado ao ensino médio) - Instituto Federal de São Paulo -Campus Barretos, 2017.

COSTA, Marcela de R. Obtenção de ingrediente lácteo enriquecido em lipídeos polares a partir de leitelho de soro. Dissertação de Doutorado. UNICAMP, Campinas, SP, 2008. Disponível em: http://repositorio.unicamp.br/jspui/handle/REPOSIP/255201. Acesso em: 04 jun. 2020.

CHRISTIE, W. W.; NOBLE, R C.; DAVIES, G. Phospholipids in milk and dairy products. Journal of the Society of Dairy Technology, v. 40, p. 10-12, 1987.

CRUZ, A. G.; SANT'ANA, A. S.; MACCHIONE, M. M.; TEIXEIRA, Â. M. \& SCHMIDT, F.L. Milk drink using whey butter cheese (queijo manteiga) and acerola juice as a potential source of vitamin C. Food Bioprocess Technology, v.2, n.4, p.368-373 2009. Disponível em:

<http://www.springerlink.com/content/4822tp722q3j865j/fulltext.pdf >. Acesso em: 06 jul. 2020.

CRUZ, A.G.; ZACARCHENCO, P.B.; OLIVEIRA, C.A.F.; CORASSIN, C.H. Química, Bioquímica, Analise Sensorial e Nutrição no Processamento de Leite e Derivados. Coleção Lácteos. Rio de Janeiro: Elsevier, 2015.

DELGADO, N. A. A inovação sob a perspectiva do desenvolvimento sustentável: os casos 
de uma cooperativa de laticínios brasileira e de outra francesa. Porto Alegre, 2007. Dissertação (Mestrado em Administração). Programa de pós-graduação em Administração, Universidade Federal do Rio Grande do Sul.

DELGADO, N. A.; BARIN-CRUZ, L. As Inovações no Setor de Laticínios: o Caso do Grupo Cooperativo Francês 3A. In: Encontro da Associação Nacional de Pós Graduação e Pesquisa em Administração, 2007, Rio de Janeiro. XXXI EnANPAD, 2007.

DIAS, P. A. et al. Propriedades antimicrobianas do Kefir. Arq. Inst. Biol., v.83, 1-5, e0762013, 2016.

EMBRAPA. Anuário Leite 2019. Disponível em: < https://ainfo.cnptia.embrapa.br/digital/b itstream/item/198698/1/Anuario-LEITE-2019.pdf>. Acesso em: 23 jun. 2020.

FERNANDES, A. P. S.; COSTA, J. B.; SOARES, D. S. B; MOURA, C. J.; SOUZA, A. R. G. Aplicação de filmes biodegradáveis produzidos a partir de concentrado proteico de soro de leite irradiado. Pesq. Agropec. Trop., Goiânia, v. 45, n. 2, p. 192-199, abr./jun. 2015.

FONG, B.Y.; NORRIS, C.S.; MACGIBBON, A.K.H. Protein and lipid composition of bovine milk-fat-globule membrane. International Dairy Journal, v.17, n.4, p.275-288, 2007. GONZALEZ, S. L. Elaboração de pães com adição de soro de manteiga. Ambiência Revista do Setor de Ciências Agrárias e Ambientais V. 5 N. 3 Set./Dez. 2009.

GOFF, H. D. Ice cream and frozen desserts: product types. In: Encyclopedia of dairy sciences, $2^{\circ}$ ed. Academic Press, London, U K, v.2 p.893-912, 2011.

HARAGUCHI F.K.; ABREU W.C.; PAULA H. Proteínas do soro do leite: composição, propriedades nutricionais, aplicações no esporte e benefícios para a saúde humana. Revista Brasileira de Nutrição, 19(4):479-488, jul./ago., Campinas, 2006.

HIROKI, Ana P. et al. Elaboração de leite fermentado probiótico com baixo teor de lactose e adição de leitelho. Disponível em:

<https://proceedings.science/slaca/slac a2013/trabalhos/elaboracao-de-leite-fermentadoprobiotico-com-baixo-teor-de-lactose-eadi cao-de-leitelho?lang=pt-br>. Acesso em: 23 jun. 2020.

JULIANO, R. S. et al. Desenvolvimento de sobremesa láctea tipo frozen yogurt com características funcionais. Florianópolis, 2014. Disponível em: $<$ http://pdf.blucher.com.br.s31.amazonaws.com/chemicalengineeringproceedings/cobeq2014/0412-25631-159563. pdf >. Acesso em: 24 jun. 2020.

KEMPKA, Aniela P. et al. Formulação de bebida láctea fermentada sabor pêssego utilizando substratos alternativos e cultura probiótica. Ciência e Tecnologia de Alimentos, Supl.28, p.170-177, 2008. Disponível em: <http://www.scielo.br/pdf/cta/v28s0/27.pdf>. Acesso em: 28 jun. 2020.

KREUTZ, D.H.; LEHN, D.N.; SOUZA, C.F. V. de. Efeito da adição de soro de queijo sobre as características sensoriais de bebidas lácteas fermentadas sabor uva. Disponível em: < http://www.univates.br/revistas/index.php/destaques/article/view/246/0> . Acesso em: 04 jul. 2020. 
KUBOTA, Flávio I. Teoria da solução inventiva de problemas integrada à produção mais limpa. Dissertação de Mestrado. Santa Maria, 2012.Disponível em: < https://repositorio.ufsm.br/bitstream/handle/1/8222/KUBOTA\%2C\%20FLAVIO\%20ISSA O. pdf? sequence=1\&isAllowed=y>. Acesso em: 03 de jul. 2020.

LEITE, M.T.; BARROZO, M.A.D.S.; RIBEIRO, E.J. Canonical analysis technique as an approach to determine optimal conditions for lactic acid production by lactobacillus helveticus ATCC 15009. International Journal of Chemical Engineering, v. 2012, p. 1-9. Disponível em: < https://www.hindawi.com/journals/ijce/2012/303874/>. Acesso em: 25 jun. 2020.

LIMA, F. R. S. \& ROCHA, L. de O. Aproveitamento do soro de leite proveniente da produção do queijo do Serro para fabricação de doce de leite: Viabilidade econômica. Rev. Inst. Laticínios Cândido Tostes, Juiz de Fora, v. 71, n. 2, p. 83-93, abr/jun, 2016.

LIMA, S. M. C. G.; MADUREIRA, F. C. P.; PENNA, A. L. B. Bebidas lácteas - nutritivas e refrescantes. Milkbizz Tecnologia Temático, v. 1, n. 3, p. 4-11, 2002.

MACHADO, Rosângela M. G.; SILVA, Patrícia, C. Da; FREIRE, Valdir H. Controle ambiental em indústrias de laticínios. Disponível em: $<\mathrm{http}: / / \mathrm{www}$. signuseditora.com.b r/ba/pdf/07/07\%20-\%20Gestao.pdf >. Acesso em: 26 jun. 2020.

MATOS, R.A. Desenvolvimento e mapa de preferência externo de bebida láctea à base de soro e polpa de graviola (Annona muricata). 2009. 79f. Dissertação (Mestrado em Engenharia de processos de Alimentos) - Curso de Pós-graduação em Engenharia de Alimentos, Universidade Estadual do Sudoeste da Bahia, BA.

MONTEIRO, Paulo S.; GOMES, Paôla da S. Produção de kefir como uma alternativa para a utilização de leitelho. Rev. Inst. Laticínios Cândido Tostes, Juiz de Fora, v. 73, n. 3, p. 162- 171, jul/set, 2018.

MOREIRA, A.; SILVA, A.; ANTUNES, M. (2000) Soro de leite: de resíduo a alimento. Alimentos e Nutrição, v. 4, p. 32-35.

NETO, B.A de M. Aproveitamento de soro de leite de cabra na elaboração de pão de forma. Dissertação de Mestrado. UFPB João Pessoa, 2007. Disponível em: http://livros01.livrosgratis.com.br/cp045882.pdf. Acesso em: 01 jun. 2020.

NOH, S.K. \& KOO, S.L. Milk sphingomyelin is more effective than egg sphingomyelin in inhibiting intestinal absorption of cholesterol and fat in rats. Journal of Nutrition, v.134, p.2611-2616, 2004.

OLIVEIRA, Gleyciane I.C. et al. Alimentação e suplementação de ferro em uma população de lactentes carentes. Revista de Pediatria, v.28, n.1, p.18-25, 2006. Disponível em:

<http://www.pediatriasaopaulo.usp.br/upload/pdf/1153.pdf〉. Acesso em: 26 Jul. 2020.

PESCUMA, Micaela et al. Functional fermented whey-based beverage using lactic acid 
bacteria. International. Journal of Food Microbiology, v.141, p.73-81, 2010.

PFRIMER, Renata $T$. Desenvolvimento e avaliação de bebida láctea fermentada acrescida de leitelho e saborizada com polpa de cagaita. Disponível em: < https://repos itorio.bc.ufg.br/tede/handle/tede/8290>. Acesso em: 26 jun. 2020.

PINTO, Graciele F. de S. Determinação de Triptofano em Queijo Ricota. Trabalho de Conclusão de Curso - Fundação Educacional do Município de Assis - FEMA -- Assis, 2010. Disponível em: < https://cepein.femanet.com.br/BDigital/arqTccs/0711290945.pdf>. Acesso em: 11 jul. 2020.

RIBEIRO, Priscila Costa. Utilização do leitelho para produção de bebida láctea probiótica. 2012. 42 f. Dissertação (Mestrado em Ciência e Tecnologia do Leite) - Centro de Ciências Biológicas e da Saúde, Universidade Norte do Paraná, Londrina, 2012.

RODRIGUES, Andréia P. et al. Elaboração de sorvete sabor chocolate com teor de gordura reduzido utilizando soro de leite em pó. Vetor, Rio Grande, 16(1/2): 55-62, 2006.

RODRIGUES, Fabiola F. G. Elaboração de pão de forma com adição de concentrado protéico de Soro de leite. Dissertação de Mestrado. UFPB João Pessoa, 2008. Disponível em: http://livros01.livrosgratis.com.br/cp066973.pdf. Acesso em: 29 jun. 2020.

ROHFLES, Ana Lúcia B. et. al. Aproveitamento de agroindústrias do setor queijeiro para desenvolvimento de produtos alimentícios e redução de impacto ambiental. TECNOLÓGICA, Santa Cruz do Sul, v.18, n.1, p. 13-18, jan./jun. 2014.

ROSENTHAL, Amauri. Aproveitamento de soro de leite de pequenas queijarias. In: EMBRAPA. Disponível em: < https://www.embrapa.br/busca-de-projetos/-/projeto/20 7283/aproveitamento-de-soro-de-leite-de-

pequenasqueijarias\#: :text=0\%20aproveitamento $\%$

20do\%20soro\%20de,soro\%20ou\%20de\%20seus\%20subprodutos.>. Acesso em: 27 jun. 2020 .

SANTOS, Calila T. et al. Elaboração e caracterização de uma bebida láctea fermentada com polpa de umbu (Spondias tuberosa sp.). Revista Brasileira de Produtos Agroindustriais, v.8, n.2, p.111-116, 2006. Disponível em: <http://www.deag.ufcg.edu.br/rbpa//rev 82/Art823.pdf>. Acesso em: 08 jul. 2020.

SANTOS, Calila T. et al. Influência da concentração de soro na aceitação sensorial de bebida láctea fermentada com polpa de manga. Alimentos e Nutrição, v.19, n.1, p.55-60, 2008. Disponível em: <http://serv-bib.fcfar.unesp.br/seer/index.php/alimentos/article/view File/199/204>. Acesso em: 29 jun. 2020.

SGARBIERI, Valdemiro C., Revisão: Propriedades estruturais e físico-químicas das proteínas do leite. Brazilian Journal of Food Technology, v.8, n.1, p. 43-56, jan./mar., 2005. SILVA, Cláudia V. Da. Desenvolvimento de uma mistura láctea a base de soro de leite em substituição ao leite condensado para emprego na produção de sobremesas industriais. Disponível em: $<\mathrm{https}$ ://repositorio.ufmg.br/bitstream/1843/BUBDAHSN27/1/desenvolvime nto_de_uma_mistura_1_ctea_a_base_de_soro_de_leite_em substitui_o_ao_leite_condensa do_para_emprego_na_produ 1.pdf $>$. Acesso em: 3 jul. 
2020.

SILVA, Carlos A. et al. Utilização de soro de leite na elaboração de pães: estudo da qualidade sensorial. Revista Brasileira de Produtos Agroindustriais, Campina Grande, v.13, n.Especial, p.355-362, 2011.

SILVA, Danilo J. P. da. Resíduos na indústria de laticínios. Disponível em: < https://www2.cead.ufv.br/sgal/files/apoio/saibaMais/saibaMais2.pdf >. Acesso em: 31 jul. 2020.

SIQUEIRA, Amanda de M. O.; MACHADO, Erilane de C. L. and STAMFORD, Tânia L. M. Bebidas lácteas com soro de queijo e frutas. Cienc. Rural [online]. 2013, vol. 43, n9, pp. 1693-1700. ISSN 0103-8478.

SOARES, D. S. et al. Aproveitamento de soro de queijo para a produção de iogurte probiótico. Arq. Bras. Med. Vet. Zootec. vol.63 no.4 Belo Horizonte Agos. 2011.

SOARES, Jéssica P. et al. Efeito da adição de proteína do soro do leite como substituto do trigo na formulação de bolos sem adição de açúcar. Braz. J. Food Technol. vol.21. Campinas 2018 Epub Nov 13, 2017.

SOUZA, Simone L.Q. de. Gestão ambiental na indústria de laticínios: aplicação da produção mais limpa. Disponível em: <https://pdfs.semanticscholar.org/a8cf/91a79d689 959198a8d6a1a4d4779a7dcdf09.pdf>. Acesso em: 26 jun. 2020.

VETTORELlO, G.; DALCORSO. A. B.; BETTI, J.; KEMERICH. G. T.; OLIVEIRA, E. C. Elaboração de sorvete com adição de soro de queijo em pó. Revista Destaques Acadêmicos, Lajeado, v. 9, n. 4, 2017.

VIDAL, A. M.; DIAS, D. O.; MARTINS, E. S. M.; OLIVEIRA, R. S.; NASCIMENTO, R. M.

S.; CORREIA, M. das G. da S. A ingestão de alimentos funcionais e a sua contribuição para a diminuição da incidência de doenças. Cadernos de Graduação - Ciências Biológicas e da Saúde. Aracaju v. 1, n.15, p. 43-52, out. 2012.

VOURCH M.; BALANNEC, B.; CHAUFER, B.; DORANGE, G. Treatment of dairy industry wastewater by reverse osmosis for water reuse. Desalination, v. 219, p. 190-202, 2008.

TEIXEIRA, Stella M. B. Utilização do leitelho no desenvolvimento de bebida simbiótica. Disponível <http://repositorio.ufla.br/jspui/bitstream/1/4562/1/TESE_Utiliza\%c3\%a7\%c3

$\%$ a3o\%20de\%20leitelho\%20no\%20desenvolvimento... pdf $>$. Acesso em: 28 jun. 2020.

TERRA, Nelcindo N.et al. Emprego de soro de leite líquido na elaboração de mortadela. Disponível em: <https://www.scielo.br/scielo.php?pid=S0103-84782009000300038\&scrip t=sci_arttext $>$. Acesso em: 01 jul. 2020.

SMITHERS, GW. Whey and whey proteins: from "gutter to gold". International Dairy Journal. 2008;18:695-704. Disponível em: <https://www.sciencedirect.com/science/article/ab s/pii/S0958694608000344. Acesso em: 
09 jul. 2020.

WALUS, Cláudia. Sorvete com adição de leitelho e substituição parcial de gordura. 2014. Trabalho de Conclusão de (Curso Tecnologia em Alimentos) - Universidade Tecnológica Federal do Paraná. Ponta Grossa, 2014. Disponível em: <http://repositorio.roca.utfp r.edu.br/jspui/bitstream/1/8056/1/PG_COALM_2014_2_22.pdf >. Acesso em: 09 jul. 2020.

ZOELLNER, S.S. et al. Whey beverage with açai pulp as a food carrier of probiotic bacteria. Australian Journal of Dairy Technology, v.64, n.2, p.165-169, 2009. Disponível em: <http://cat.inist.fr/?aModele=afficheN\&cpsidt=22157872>. Acesso em: 03 jul. 2020. 


\title{
CAPÍTULO 13: INFLUÊNCIA DA TEMPERATURA DE SECAGEM NAS CARACTERÍSTICAS FÍSICO-QUÍMICAS E NUTRICIONAIS DO BAGAÇO DE CERVEJA
}

\section{CHAPTER 13: INFLUENCE OF DRYING TEMPERATURE ON PHYSICAL- CHEMICAL AND NUTRITIONAL CHARACTERISTICS OF BREWERY BAGACE}

\author{
Lisangela Bagatini ${ }^{1}$, Gabriela Diersmann Azevedo ${ }^{2}$, Voltaire Sant'Anna ${ }^{3}$
}

\section{Resumo}

O bagaço de malte, considerado o maior resíduo sólido cervejeiro é conhecido por conter ricos componentes que permanecem inexplorados durante o processamento. Tendo em vista seu alto teor de umidade, este estudo avaliou os efeitos da secagem sobre características tecnológicas e nutricionais importantes para a indústria alimentícia. Avaliou-se a influência do processo de secagem por convecção natural, entre 60 e $100{ }^{\circ} \mathrm{C}$, na concentração de polifenóis totais, flavonóis, ésteres tartáricos, compostos com atividade antioxidante, $\mathrm{pH}$, cor e capacidade de retenção de água e óleo do bagaço de malte proveniente do processo de produção da cerveja Pilsen. Amostras liofilizadas foram usadas para comparação. Amostras secas à $60{ }^{\circ} \mathrm{C}$ e $80^{\circ} \mathrm{C}$ apresentaram maior concentração de polifenóis totais, flavonóis, ácidos fenólicos e compostos com capacidade de eliminar radicais livres. $\mathrm{O}$ pH encontrado variou entre 5,0 e 5,6. Nenhuma das temperaturas empregadas impactaram em alteração significativa no parâmetro de cor em relação às amostras liofilizadas. A capacidade de retenção de água do bagaço de malte seco foi maior que a de óleo. Os resultados indicam que sua secagem a $80^{\circ} \mathrm{C}$ é a melhor alternativa por manter características funcionais do resíduo e apresentar maior eficiência do processo em termos de tempo.

Palavras-Chaves: Bagaço de malte, Secagem, Valorização de resíduos, Sustentabilidade, Polifenóis.

\begin{abstract}
Brewery spent grain, considered the largest solid beer residue, is known to contain rich components that remain untapped during processing. In view of its high moisture content, this study evaluated the effects of drying on technological and nutritional characteristics important for the food industry. The influence of the drying process by natural convection, between 60 and $100{ }^{\circ} \mathrm{C}$, on the concentration of total polyphenols, flavonols, tartaric esters, compounds with antioxidant activity, $\mathrm{pH}$, color and water and oil retention capacity of malt bagasse was evaluated. from the lager production process. Freeze-dried samples were used for comparison. Dry samples at $60{ }^{\circ} \mathrm{C}$ and $80{ }^{\circ} \mathrm{C}$ showed a higher concentration of total polyphenols, flavonols, phenolic acids and compounds capable of eliminating free radicals. The $\mathrm{pH}$ found varied between 5.0 and 5.6. None of the temperatures employed impacted a significant change in the color parameter in relation to lyophilized samples. The water holding capacity of dry malt bagasse was greater than that of oil. The results indicate that drying at $80{ }^{\circ} \mathrm{C}$ is the best alternative for maintaining functional characteristics of the residue and presenting greater efficiency of the process in terms of time.

\footnotetext{
${ }^{1}$ Mestrado Profissional em Ambiente e Sustentabilidade, Universidade Estadual do Rio Grande do Sul, nutricao@educteutonia.com.br

${ }^{2}$ Bacharelado em Ciência e Tecnologia de Alimentos, Universidade Estadual do Rio Grande do Sul, gabidiersmann@hotmail.com

${ }^{3}$ Mestrado Profissional em Ambiente e Sustentabilidade, Universidade Estadual do Rio Grande do Sul, voltairesantanna@uergs.edu.br
} 
Keywords: Brewery spent grain, Drying, Waste recovery, Sustainability, Polyphenols.

\section{Introdução}

Responsável por gerar grande quantidade de resíduos, a atividade industrial de alimentos e bebidas é causa de preocupação, considerando que o destino incorreto destes subprodutos é um dos responsáveis pelas agressões ao ambiente. Para enfrentar este problema, diminuir sua geração seria o caminho mais racional, entretanto, o aumento da população global a uma velocidade exponencial e perdas que ocorrem nas diversas etapas da cadeia produtiva, demandam a implementação concomitante de práticas de redução e reutilização (MUSSATO, 2009; LYNCH et al., 2016).

Neste contexto, o bagaço de malte, considerado o maior resíduo sólido cervejeiro (MUSSATTO et al., 2006; XIROS; KRISTHAKOPOULOS, 2012) e formado no início do processo de produção de cerveja é conhecido por conter quantidades significativas de ricos componentes que permanecem inexplorados durante o processamento. Apesar de estar disponível em grandes volumes, seu destino usual tem sido a venda para elaboração de ração animal ou a própria doação para o mesmo fim. Consegue-se ter a dimensão do impacto ambiental que este setor pode provocar considerando que cada hectolitro (100 litros) de cerveja produzida gera entre 14 e $20 \mathrm{~kg}$ de bagaço, visto como sobras de processamento sem serventia ou valor econômico, e cujo montante pode chegar a $85 \%$ do total de resíduos gerados (MUSSATO et al., 2006; XIROS; KRISTHAKOPOULOS, 2012; LYNCH et al., 2016). Neste aspecto, a desidratação tem se apresentado como um caminho para melhorar a estabilidade microbiológica e bioquímica de resíduos da indústria alimentícia, permitindo estudos de viabilidade para ser utilizado como ingrediente nutricional para humanos.

O bagaço de cerveja tem se mostrado como importante fonte de polifenóis e fibras (MUSSATO et al., 2006; LYNCH et al., 2016), além de apresentar potencial de ser utilizado como ingrediente funcional na indústria de alimentos (SAURA-CALIXTO, 2011). Tendo em vista que o bagaço de malte proveniente da produção de cerveja apresenta alto teor de umidade levando o resíduo a um curto prazo de validade (MUSSATO et al., 2006; VALISH et al., 2011), este estudo tem o objetivo de avaliar os efeitos da secagem por convecção natural, na faixa de temperatura de 60 a $100^{\circ} \mathrm{C}$, sobre a cor, $\mathrm{pH}$, concentração de polifenóis totais, flavonóis, ésteres tartáricos, compostos com atividade antioxidante e capacidade de retenção de água e óleo, utilizando amostras liofilizadas como técnica de controle. Considerando que o malte tipo Pilsen é o mais utilizado, optou-se por estudar os efeitos da secagem exclusivamente sobre este que é o maior resíduo da indústria cervejeira. 


\section{Material e Métodos}

As matérias-primas utilizadas para a obtenção do bagaço de malte foram adquiridas em empresa local especializada em cervejas artesanais (Porto Alegre, RS, Brasil).

\section{Processo de produção do bagaço de malte}

Para o melhor controle da obtenção do bagaço de malte, os resíduos foram obtidos em laboratório, através do processo de brassagem de $2,3 \mathrm{Kg}$ de cevada malteada acrescidos de $7 \mathrm{~L}$ de água mineral. Tal mistura foi mantida a $42-45^{\circ} \mathrm{C}$ por $15 \mathrm{~min}, 52-55^{\circ} \mathrm{C}$ por $20 \mathrm{~min}$ e $62-65$ ${ }^{\circ} \mathrm{C}$ por mais $15 \mathrm{~min}$, sendo aquecida até atingir $80^{\circ} \mathrm{C}$ por $5 \mathrm{~min}$. Depois, procedeu-se a lavagem do produto com água corrente por $20 \mathrm{~min}$. Adicionou-se mais $8 \mathrm{~L}$ de água mineral à $80^{\circ} \mathrm{C}$ e repetiu-se a lavagem por $20 \mathrm{~min}$. $\mathrm{O}$ mosto foi filtrado. $\mathrm{O}$ resíduo inicial apresentou umidade inicial em torno de $72 \%( \pm 0,0063)$.

\section{Experimentos de secagem}

Imediatamente após sua obtenção, o bagaço de malte úmido foi submetido aos procedimentos de secagem, quando seu conteúdo foi dividido em duas amostras colocadas em estufa de ar estático (Solab SL100, São Paulo, Brasil). As amostras úmidas foram dispostas em camada única, em bandejas de metal de 12,5 cm de largura, 19,7 cm de comprimento e $1 \mathrm{~cm}$ de altura, em equipamento previamente aquecido. Cada amostra, separadamente, foi exposta às temperaturas de $60^{\circ} \mathrm{C}, 80^{\circ} \mathrm{C}$ e $100^{\circ} \mathrm{C}$. Mensurou-se a perda de massa a cada 30 min até atingir peso constante. Em seguida procedeu-se a moagem das amostras secas em processador industrial. O moedor foi higienizado com álcool $70 \%$ e deixado para secar naturalmente antes do preparo da amostra. Após este procedimento, as amostras foram peneiradas em malhas de 5 mm de abertura e transferidas para embalagens estéreis de polietileno escuro, dentro de uma capela laminar de fluxo. Amostras liofilizadas (Liotop L101, São Paulo, Brasil) foram utilizadas como controle. O teor de umidade das amostras, antes e após o experimento de secagem, foi determinado pelo método padrão AOAC ( 2001).

\section{Análise do pH}

Para determinar o $\mathrm{pH}$ das amostras, $1 \mathrm{~g}$ do resíduo seco foi diluído em 7,5 $\mathrm{mL}$ de água destilada fervida e resfriada por $1 \mathrm{~h}$, agitando suavemente a cada $15 \mathrm{~min}$. O sistema foi filtrado em papel Whatman $n^{\circ} 1$ e o extrato aquoso foi submetido à análise em pHmetro (Universal, modelo MT-610, São Paulo, Brasil), conforme AOAC (1990). 


\section{Análise de cor}

Os parâmetros CIELAB foram determinados usando iluminação difusa D-65 de um colorímetro Minolta Chroma CR-400 (Konica Minolta). O instrumento foi calibrado com uma placa branca padrão. Os parâmetros medidos foram $L^{*}$ (luminosidade), $a^{*}$ (vermelhidão) e $b^{*}$ (amarelo). São coordenadas cromáticas demonstradas por um diagrama de cores, cujos parâmetros foram definidos pela Comissão Internacional de Iluminação (CIE) e chamado de espaço CIELab.

\section{Análise de polifenóis}

Os extratos foram preparados misturando-se $1 \mathrm{~g}$ de matéria seca em pó do bagaço de malte em $50 \mathrm{~mL}$ de solução de etanol $50 \%$ (v:v), mantendo o sistema a $60{ }^{\circ} \mathrm{C}$ por 30 min para posterior análise (SANT’ANNA, 2013). Em seguida, os extratos foram filtrados em papel filtro Whatman $\mathrm{n}^{\circ} 1$. As extrações foram realizadas em duplicata.

A concentração de polifenóis totais foi determinada pelo método de Folin-Ciocalteau descrito por Singleton e Rossi (1965), onde alíquotas de $40 \mu \mathrm{L}$ dos extratos foram misturados com 3,2 mL de água destilada e $200 \mu \mathrm{L}$ de solução de carbonato de sódio $20 \%$ (m/v). Após 15 min no escuro, foram adicionados $600 \mathrm{~mL}$ de solução do reagente de Folin-Ciocalteau e o sistema mantido à temperatura ambiente no escuro por $90 \mathrm{~min}$. A absorbância foi medida a 765 nm (SINGLETON; ROSSI, 1965) pelo espectrofotômetro UV-1600 (Pró-Análise, Brasil). Para quantificação foi empregada uma curva padrão com solução de ácido gálico nas seguintes concentrações: 200, 300, 500, 600, 700, 800, 900, 1000 mg/L. Foi calculado um coeficiente de correlação $\left(\mathrm{R}^{2}\right)$, resultando $\mathrm{R}^{2}=0,9902$. O teor de polifenóis totais foi expresso em $\mathrm{mg}$ equivalente de Ácido Gálico (EAG)/100g de bagaço seco. O reagente Folin-Ciocalteau e o ácido gálico foram obtidos na Vetec Química Fina (Duque de Caxias, Brasil). Os produtos químicos restantes foram comprados da Neon (Suzano, Brasil).

A concentração de flavonóis totais foi determinada usando o método descrito por Mazza e colaboradores (1999). Amostras de $250 \mu \mathrm{L}$ de extrato foram misturados com $250 \mu \mathrm{L}$ de $\mathrm{HCl}$ $0,1 \%$ em etanol $95 \%$ e $4,5 \mathrm{~mL}$ de $\mathrm{HCl}$ a $2 \%$. A mistura foi submetida a um agitador mecânico e colocada em repouso no escuro por $15 \mathrm{~min}$. Posteriormente foi realizada a leitura no espectro e comparada a uma amostra de água destilada. A absorbância a $360 \mathrm{~nm}$ foi então mensurada. Para quantificação foi empregada uma curva padrão com solução de epicatequina nas concentrações entre 10 e $200 \mathrm{mg} / \mathrm{L}$. Foi calculado um coeficiente de correlação $\left(\mathrm{R}^{2}\right)$, resultando 
$\mathrm{R}^{2}=0,9976$. O teor de flavonóis foi expresso em mg equivalente de epicatequina (EE)/100g de bagaço seco.

A concentração de ácidos fenólicos foi determinada usando o método descrito por Mazza e colaboradores (1999). Amostras de $250 \mu \mathrm{L}$ de extrato foram misturados com $250 \mu \mathrm{L}$ de $\mathrm{HCl}$ 0,1\% em etanol 95\%. Depois, $4,5 \mathrm{~mL}$ de $\mathrm{HCl}$ a $2 \%$. A mistura foi submetida a um agitador mecânico e colocada em repouso no escuro por 15 min. Posteriormente realizou-se a leitura no espectro e comparou-se a uma amostra de água destilada. A absorbância a $320 \mathrm{~nm}$ foi então mensurada. Para quantificação foi empregada uma curva padrão com solução de ácido caféico nas concentrações entre 10 e 200 mg/L. Foi calculado um coeficiente de correlação $\left(\mathrm{R}^{2}\right)$, resultando $\mathrm{R}^{2}=0,9936$. O teor de ácidos fenólicos foi expresso em mg equivalente de ácido caféico (ACE)/100g de bagaço seco.

\section{Atividade antioxidante}

A atividade antioxidante do bagaço seco foi avaliada pelos métodos de sequestro do radical DPPH (1,1-difenil-2-picrilhidrazil) e eliminação do radical ABTS (ácido 3etilbenzotiazolina-6-sulfônico) gerado durante o ensaio. A capacidade de sequestrar o radical DPPH, segundo método descrito por Brand-Williams et al. (1995), se dá pela mistura de alíquotas do extrato das amostras solução de DPPH (Sigma Aldrich, EUA) em metanol. Após agitação, os tubos foram deixados em repouso ao abrigo da luz por aproximadamente 15 a 20 min e a absorbância foi medida a $515 \mathrm{~nm}$. A determinação da atividade de eliminação do radical ABTS, conforme Re et al. (1999), envolve a geração do cromóforo do radical ABTS por oxidação do ABTS com persulfato de potássio (Neon (Suzano, Brasil)). O radical catiônico $\operatorname{ABTS}^{\bullet+}$ (Sigma Aldrich, EUA) foi produzido por reação da solução de $7 \mathrm{mmol} / \mathrm{L}$ ABTS com $140 \mathrm{mmol} / \mathrm{L}$ de persulfato de potássio, a qual permaneceu no escuro por 16h, à temperatura ambiente antes do uso. Para o ensaio, a solução foi diluída com etanol até uma absorbância de 0,7 a $734 \mathrm{~nm}$. Uma alíquota de $30 \mu \mathrm{L}$ de extrato foi misturada com $1 \mathrm{~mL}$ da solução e, uma leitura de absorbância $(734 \mathrm{~nm})$ foi realizada após 6 minutos. Água destilada, em vez de amostra, foi usada para comparação. A capacidade de sequestrar o radical foi expressa em percentual, calculada em relação ao controle (sem antioxidante). Os resultados foram expressos como: atividade de eliminação $(\%)=\left[1-\left(\mathrm{A} / \mathrm{A}_{0}\right)\right] \times 100$, onde $\mathrm{A}$ é a absorbância do teste, e $\mathrm{A}_{0}$ é a absorbância do controle. 


\section{Capacidade de retenção de água e de óleo}

A capacidade de retenção de água das amostras de bagaço de malte seco foi analisada pela manutenção de $0,5 \mathrm{~g}$ da mistura em $10 \mathrm{~mL}$ de água destilada por 16 horas de acordo com Rosell et al. (2009), com modificações. O sistema foi então centrifugado à temperatura ambiente e rotação de $140 \mathrm{~g}$ e a parte líquida pesada. A capacidade de retenção de água foi calculada pela a diferença de líquido adicionado e não absorvido, descontando-se a umidade inicial do material.

A capacidade de absorção de óleo foi analisada pela manutenção da mesma massa de amostra mantida em contato com $50 \mathrm{~mL}$ de azeite de oliva extra virgem por 24 horas. Os sistemas foram centrifugados a $140 \mathrm{~g}$ e diferença e a fração não absorvida foram pesadas em balança analítica, conforme Rosell et al. (2009).

\section{Análise estatística}

As experiências foram conduzidas em triplicata e as médias de dois experimentos independentes foram calculadas. Os valores obtidos foram comparados por Análise de Variância (ANOVA), pelo software Excel 2013 e tratadas pelo teste de Tukey, pelo Statistica 10.0. As diferenças foram consideradas estatisticamente significativas quando $p<0,05$.

\section{Resultados e Discussão}

\section{Polifenóis totais, flavonóis, ésteres tartáricos e atividade antioxidante}

Extratos de malte e cevada caracterizam-se pelo alto teor de flavonóis e ácidos fenólicos, os quais lhe conferem potente atividade antioxidante (BARBOSA-PEREIRA et al., 2014).

$\mathrm{O}$ efeito das diferentes temperaturas de secagem sobre a concentração de compostos bioativos e a atividade antioxidante do bagaço de malte seco encontrados neste estudo estão demonstrados na Tabela 1.

Entre as amostras secas em diferentes temperaturas, àquelas submetidas à $60{ }^{\circ} \mathrm{C}$ apresentaram maior concentração de polifenóis totais, flavonóis, ácidos fenólicos e compostos com capacidade de eliminar radicais ABTS(ácido 3-etilbenzotiazolina-6-sulfônico) ao final do processo. Em comparação com as amostras liofilizadas, àquelas expostas a procedimentos de secagem a 60 e $80{ }^{\circ} \mathrm{C}$ apresentaram quantidades semelhantes $(p>0,05)$ de polifenóis totais e flavonóis após o processo, resultado semelhante encontrado por Hii e colaboradores (2009), em amostras secas de cacau. Contudo, a $100{ }^{\circ} \mathrm{C}$, o bagaço seco apresentou quantidades significativamente $(p<0,05)$ menores destas substâncias. Altas temperaturas podem impactar a 
degradação de vários compostos, incluindo polifenóis (LARRAURI et al.,1997; WANG; XU, 2007).

Tabela 1. Influência de diferentes temperaturas de secagem sobre a concentração de polifenóis totais, flavonóis, ésteres tartáricos e compostos com atividade antioxidante no bagaço de Malte

\begin{tabular}{lcccc}
\hline & $100^{\circ} \mathrm{C}$ & $80^{\circ} \mathrm{C}$ & $60^{\circ} \mathrm{C}$ & Liofilizado \\
\hline $\begin{array}{l}\text { Polifenóis totais } \\
(\mathrm{mg} \text { GAE/100g) }\end{array}$ & $7601,402 \pm 759,75^{\mathrm{b}}$ & $11944,962 \pm 834,67^{\mathrm{a}}$ & $12210,499 \pm 1500,18^{\mathrm{a}}$ & $9515,595 \pm 1528,01^{\mathrm{a}}$ \\
$\begin{array}{l}\text { Flavonóis } \\
(\mathrm{mg} \mathrm{EE} / 100 \mathrm{~g})\end{array}$ & $2620,742 \pm 260,30^{\mathrm{b}}$ & $3395,449 \pm 241,19^{\mathrm{a}}$ & $3604,209 \pm 327,89^{\mathrm{a}}$ & $3618,775 \pm 397,71^{\mathrm{a}}$ \\
$\begin{array}{l}\text { Ésteres tartáricos } \\
(\mathrm{mg} \text { CA/100g) }\end{array}$ & $1440,029 \pm 226,55^{\mathrm{b}}$ & $1423,463 \pm 234,33^{\mathrm{b}}$ & $1538,401 \pm 139,80^{\mathrm{b}}$ & $3601,620 \pm 157,90^{\mathrm{a}}$ \\
DPPH (\%) & $6,036 \pm 0,019^{\mathrm{c}}$ & $10,905 \pm 1,549^{\mathrm{b}}$ & $10,603 \pm 0,931^{\mathrm{b}}$ & $16,183 \pm 1,853^{\mathrm{a}}$ \\
ABTS (\%) & $48,075 \pm 0,53^{\mathrm{b}}$ & $50,625 \pm 0,39^{\mathrm{b}}$ & $60,225 \pm 3,85^{\mathrm{a}}$ & $68,875 \pm 0,39^{\mathrm{a}}$ \\
\hline
\end{tabular}

$\overline{\mathrm{a}, \mathrm{b}, \mathrm{c}}$ letras diferentes na mesma linha indicam diferença significativa $(p<0,05)$.

Fonte: Autora (2019).

Barbosa-Pereira e colaboradores (2014), comprovaram em sua pesquisa que extratos brutos de compostos fenólicos com alta atividade antioxidante pode ser obtida a partir dos resíduos de cervejarias, e que podem ser usados como fonte barata de compostos. Moreira e colaboradores (2013), observaram que os bagaços de maltes pilsen, melano, melano 80 e cararé, apresentaram maiores quantidades de compostos fenólicos quando comparados ao chocolate e ao bagaço preto $(19,5 \pm 0,6$ e 16,2 \pm 0,6 $\mathrm{mg}$ GAE /g db para os tipos claro e escuro, respectivamente). Samaras e colaboradores (2005), descobriram que a catequina e o ácido ferúlico eram os compostos fenólicos mais abundantes nos maltes mortos e torrados, e que os ácidos ferúlicos eram altamente sensíveis à degradação durante o tratamento de assados.

Os resultados referentes a quantidade de ácidos fenólicos encontrados nas amostras de BM secas a 60,80 e $100{ }^{\circ} \mathrm{C}$ apresentaram comportamento semelhante entre si $(p>0,05)$, porém antagônico às amostras liofilizadas, ou seja, em qualquer uma das três temperaturas de secagem houve perda maior de ésteres tartáricos em comparação às amostras que passaram por liofilização. Hii e colaboradores (2009), da mesma forma, demonstraram em seu estudo, não haver diferença significativa no conteúdo fenólico para amostras secas a 60 e $80^{\circ} \mathrm{C}$.

A capacidade de eliminação do radical ABTS (ácido 3-etilbenzotiazolina-6-sulfônico) analisada no bagaço de malte seco a $60{ }^{\circ} \mathrm{C}$ demonstrou semelhança $(p>0,05)$ ao resultado encontrado na amostra liofilizada. Contudo, resultados diferentes foram constatados ao desidratar as amostras à 80 e $100{ }^{\circ} \mathrm{C}$. Após serem submetidas a estas temperaturas, verificouse perda significativa $(p<0,05)$ da capacidade das amostras de bagaço de malte de eliminar o radical ABTS (ácido 3-etilbenzotiazolina-6-sulfônico). 
A capacidade de sequestrar o radical DPPH (1,1-difenil-2-picrilhidrazil), analisada no bagaço de malte seco a $60{ }^{\circ} \mathrm{C}$ demonstrou semelhança $(p>0,05)$ ao resultado encontrado na amostra seca a $80{ }^{\circ} \mathrm{C}$. Contudo, resultados diferentes foram constatados ao desidratar as amostras à $100{ }^{\circ} \mathrm{C}$, cujos resultados após o procedimento, demonstraram perda significativa $(p<0,05)$ de tal capacidade. Sant'Anna (2013) ao analisarem efeitos da secagem sobre o bagaço de uva Vitis labrusca $c v$. "Isabel" demonstraram que compostos fenólicos totais e compostos com capacidade de eliminação de radicais DPPH permaneceram estáveis, embora compostos com capacidade de eliminação de radicais ABTS mostraram-se suscetíveis a degradação.

pH

$\mathrm{O}$ efeito da secagem sobre o $\mathrm{pH}$ do resíduo seco está representado na Figura 1. Os resultados mostram que o bagaço de cerveja seco apresenta $\mathrm{pH}$ ácido entre 5,0 e 5,6, o que pode ser importante para sua estabilidade microbiológica durante o período de armazenamento. Larsson e Sanderberg (1995) observaram valores semelhantes de $\mathrm{pH}$ para aveias malteadas, indicando maior estabilidade microbiana devido ao $\mathrm{pH}$ ácido das amostras. A secagem do resíduo à 60 e $80^{\circ} \mathrm{C}$ não impactou em alteração significativa $(p>0,05)$ do $\mathrm{pH}$ das amostras em comparação àquelas liofilizadas.

Figura 1. Efeito dos tratamento de secagem sobre o $\mathrm{pH}$ de bagaço de cerveja

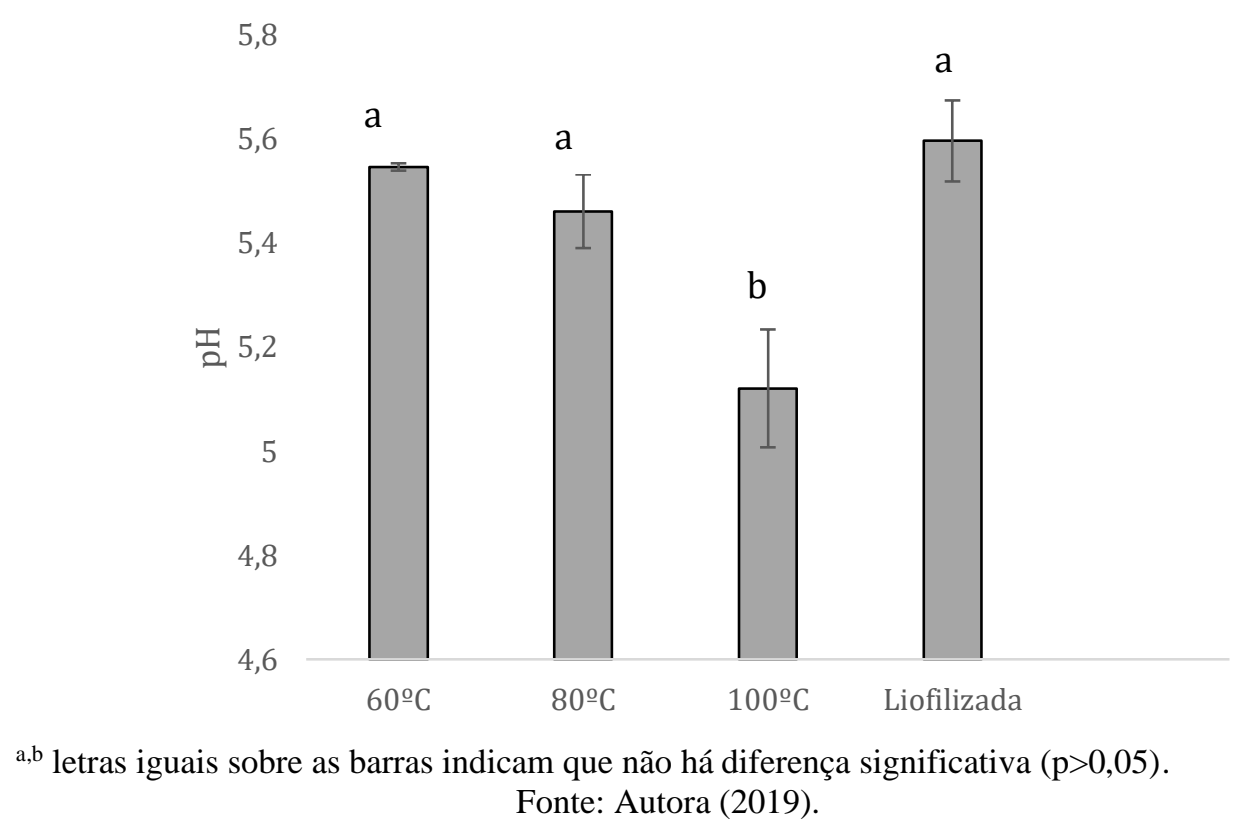

$\mathrm{Na}$ utilização de temperatura de $100{ }^{\circ} \mathrm{C}$ para a secagem, obervou-se redução significativa $(p<0,05)$ nesta propriedade. A redução do $\mathrm{pH}$ pode estar relacionada à hidrólise de 
lipídeos, produzindo ácidos graxos ou hidrólise protéica, produzindo aminoácidos ou produtos intermediários com maior acidez (MIRANDA; EL-DASH, 2002).

\section{Análise de cor}

Os resultados da análise de cores, de acordo com a metodologia CIELAB, estão demonstrados na Tabela 2.

Tabela 2. Análise de cor do bagaço de cerveja seco em diversas temperaturas e liofilizado

\begin{tabular}{|c|c|c|c|}
\hline & $L^{*}$ & $a^{*}$ & $b^{*}$ \\
\hline Liofilizado & $40,18 \pm 0,98^{\mathrm{a}}$ & $5,63 \pm 0,02^{\mathrm{a}}$ & $18,46 \pm 0,38^{\mathrm{a}}$ \\
\hline $100^{\circ} \mathrm{C}$ & $42,02 \pm 0,94^{\mathrm{a}}$ & $4,86 \pm 0,10^{\mathrm{a}}$ & $19,52 \pm 0,28^{\mathrm{a}}$ \\
\hline $80^{\circ} \mathrm{C}$ & $42,72 \pm 0,05^{\mathrm{a}}$ & $5,05 \pm 0,24^{\mathrm{a}}$ & $20,04 \pm 0,05^{\mathrm{a}}$ \\
\hline $60^{\circ} \mathrm{C}$ & $40,22 \pm 1,02^{\mathrm{a}}$ & $4,92 \pm 0,11^{\mathrm{a}}$ & $18,67 \pm 0,47^{\mathrm{a}}$ \\
\hline
\end{tabular}

Os resultados mostram que não houve diferença significativa $(p>0,05)$ para o parâmetro $L^{*}$, indicando que as amostras apresentam grau de coloração escura semelhante. Resultados semelhantes foram encontrados sobre o impacto da secagem em forno de ar estático para os parâmetros $a^{*}$ e $b^{*}$, em que as temperaturas empregadas não impactaram em alteração significativa $(p>0,05)$ no parâmetro de cor em relação às amostras liofilizadas, demonstrando ser uma forma mais econômica de desidratar o bagaço de malte sem alterar sua cor característica.

O fato do grau de coloração das amostras não apresentar diferença significativa em nenhum dos parâmetros avaliados pode estar ligado ao efeito que o tratamento térmico tem durante a formação das cores dos maltes, sendo os escuros obtidos pela utilização de tostadores a temperaturas acima de $200{ }^{\circ} \mathrm{C}$. Para obtenção de maltes claros, utilizam-se temperaturas amenas durante o processo de secagem dos grãos germinados, como as utilizadas neste experimento, com o objetivo de remover umidade e conservar enzimas que atuam de forma imprescindível na conversão do amido em açúcares solúveis responsáveis, entre outras características, pela cor (LI et al., 2014). Larrauri e colaboradores (1998), avaliaram a influência de temperaturas entre 60 e $140^{\circ} \mathrm{C}$ na degradação da cor após secagem de bagaço de uva e concluíram que a intensidade da cor vermelha não diminuiu com o tratamento entre 60 e $100{ }^{\circ} \mathrm{C}$, porém o mesmo não ocorreu com a luminosidade em relação à amostra liofilizada. 


\section{Capacidade retenção de água e óleo}

Os resultados para a capacidade de absorção de água e óleo estão representados na Figura 2. As amostras de bagaço de malte liofilizadas apresentaram capacidade significativamente superior $(p<0,05)$ de retenção de água quando comparadas à secagem com equipamentos convencionais. Santana e Oliveira (2005) observaram resultados semelhantes em sua pesquisa com subproduto do maracujá em pó. Ainda em relação a análise da capacidade absorção de água, Collar e colaboradores (2007) e Ferreira e colaboradores (2013), também observaram que fibra comercial de maçã, bambu, aveia e farinhas de vegetais apresentaram capacidade de retenção de água com valores semelhantes aos encontrados para o resíduo de cerveja no presente trabalho. A Figura 2 mostra ainda que a capacidade de absorção de água pelo bagaço de malte seco em estufa de ar estático, também foi maior que a de óleo. Este mesmo resultado foi constatado por Huige (1994) em sua pesquisa com farinha de bagaço de malte. Além de apresentar alto teor de fibras alimentares, o estudo demonstrou que o subproduto tem grande capacidade de absorção de água e reduzida habilidade de absorção de gordura. Isso possivelmente se deve ao fato do resíduo ser rico em monossacarídeos e polissacarídeos e seus derivados.

Figura 2. Efeito da secagem sobre a capacidade de absorção de água (barras pretas) e óleo (barras cinzas) de bagaço de malte

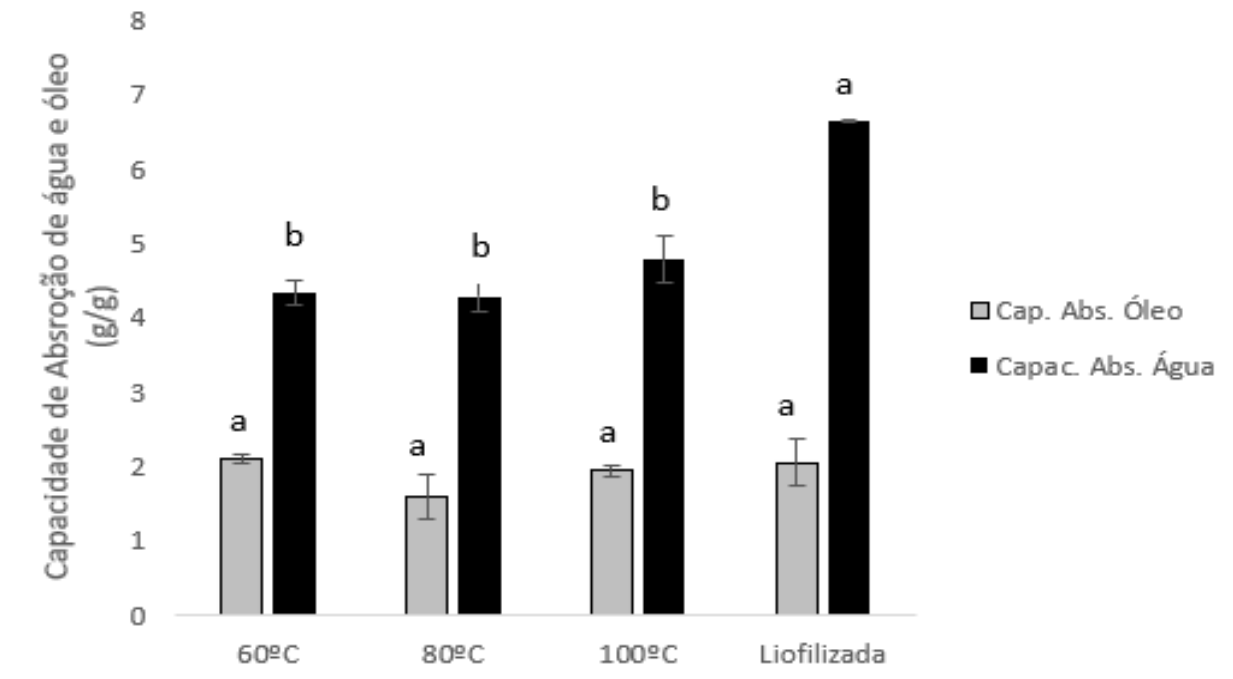

${ }^{\mathrm{a}, \mathrm{b}}$ letras diferentes sobre barras da mesma cor indicam diferença significativa $(\mathrm{p}<0,05)$ Fonte: Autora (2019).

Sabe-se que o grão de cevada tem um nível de beta-glucanos que é muito maior do que o encontrado em outros grãos (NEWMAN et al., 1989; MCINTOSH et al., 1991). Os betaglucanos, segundo Cavallero et al. (2002), são uma espécie de fibra alimentar solúvel que, uma vez na presença de água, avoluma-se para formar soluções viscosas. 
Em relação ao efeito dos diferentes tratamentos de secagem sobre a propriedade de absorção de água do bagaço de malte, observou-se diferença significativa $(p<0,05)$ entre todos eles e a técnica de liofilização, a qual demonstrou maior parâmetro. Santana e Oliveira (2005), da mesma forma, observaram que o subproduto liofilizado do maracujá em pó apresentou maior índice de absorção de água nas amostras liofilizadas do que as submetidas à secagem por ar quente.

Em relação à capacidade de absorção de óleo, observa-se que não houve diferença significativa $(p>0,05)$ para os diferentes tratamentos testados. Ferreira e colaboradores (2013), observaram valores semelhantes de capacidade de absorção de óleo para farinhas de frutas e vegetais em seu estudo.

\section{Conclusões}

O maior resíduo sólido cervejeiro demonstra, através deste estudo, ter qualificação para ser uma fonte promissora de antioxidantes naturais, podendo ser uma alternativa para substituir os antioxidantes sintéticos atualmente usados na indústria de alimentos. Além disso, demonstra capacidade de manter outras qualidades físico-químicas que lhe habilitam como opção econômica, por ser facilmente obtido através de procedimentos comuns de secagem.

Os resultados do presente estudo indicam que a utilização de temperaturas de secagem na faixa de $60^{\circ} \mathrm{C}-80^{\circ} \mathrm{C}$ não impactam na concentração de diferentes classes de polifenóis e compostos com diferentes atividades antioxidantes extraíveis da matriz alimentar. Nessa faixa de temperatura, os resultados mostram que a técnica de liofilização não implica em melhor eficiência. Mesmo comportamento é observado em relação à cor e pH e capacidade de absorção de óleo. A utilização de temperaturas de $100{ }^{\circ} \mathrm{C}$, contudo, implica em redução de compostos bioativos. Devido ao menor tempo de processamento, os resultados do presente trabalho indicam a utilização de temperaturas de secagem de até $80^{\circ} \mathrm{C}$, apesar de mais estudos de eficiência de processo serem necessários.

\section{Referências}

ASSOCIATION OF OFFICIAL ANALYTICAL CHEMISTS. Official methods of analysis of the Association of the Analytical Chemistry. 15. ed. Arlington, 1990. ASSOCIATION OF OFFICIAL ANALYTICAL CHEMISTS. Official methods of analysis of the Association of the Analytical Chemistry. 17. ed. Arlington, 2001. 
BARBOSA-PEREIRA, L.; BILBAO, A.; VILCHES, P.; ANGULO, I.; LLUIS, J.; FITÉ, B.; PASEIRO-LOSADA, P.; CRUZ, J.M. Phenolic profile and antioxidant properties of a crude extract obtained from a brewery waste stream. Food Research International, v. 51, n. 2, p. 663-669, 2014.

BRAND-WILLIAMS, W.; CUVELIER, M.; BERSET, C. Use of a free radical method to evaluate antioxidant activity. LWT-Food Science and Technology, v. 28, p. 25-30, 1995.

CAVAllERO, A.; EMPILlI, S.; BRIGHENTI, F.; STANCA, A. M. High (1-3,1-4)-b-glucan barley fractions in bread making and their effects on human glycemic response. Journal of Cereal Science, v.36, p.59-66, 2002.

COLLAR, C.; SANTOS, E.; ROSELL, C.M. Assessment of the rheological profile of fibreenriched bread doughs by response surface methodology. Journal of Food Engineering, v.78, n.3, p. 820-826, 2007.

DOBRZANSKI, J; DIAS, L.F; AYALA, L.A.C. Característica e utilização do bagaço de cerveja em panificação. Anais da IV Semana de Tecnologia em Alimentos, 4, 2008, Ponta Grossa. Paraná: UTFPR. v.2, n.7, 2008.

FERREIRA, M. S. L.; SANTOS, M. C. P.; MORO, T. M. A.; BASTO, G. J.; ANDRADE, R. M. S.; GONÇALVES, É. C. B. A. Formulation and characterization of functional foods based on fruit and vegetable residue flour. Journal of Food Science and Technology, v.52, n.2, p.822-830, 2013.

HII, C. L.; LAW, C. L.; CLOKE, M.; SUZANNAH, S. Thin layer drying kinetics of cocoa and dried product quality. Biosystem Engineering, v.102, p.153-161, 2009.

HUIGE, N.J. Brewery by-products and effluents. In: Hardwick, W.A. (Ed.). Handbook of Brewing. New York: Marcel Dekker, 1994, p. 501-550.

LARRAURI, J. A.; RUPÉREZ, P.; BORROTO, B.; SAURA-CALIXTO, F. Effect of drying temperature on the stability of polyphenols and antioxidant activity of red grape pomace peels. Journal of Agricultural and Food Chemistry, v.45, p.1390-1393, 1997. 
LARSSON, M.; SANDERBERG, A.S. Malting of oats in a pilot-process. Effects of heat treatment storage and soaking conditions on phytate reduction. Journal of Cereal Science, v.21, p.87-95, 1995.

LI, X.; JIN, Z.; GAO, F.; LU, J.; CAI, G.; DONG, J.; YU, J.; YANG, M. Comparative Proteomic Analysis of Dan'er Malts Produced from Distinct Malting Processes by TwoDimensional Fluorescence Difference in Gel Electrophoresis (2D-DIGE). Journal of Agricultural and Food Chemistry, v.62, n.38, p.9310-9316, 2014.

LYNCH, K. M.; STEFFEN, E.J.; ARENDT, E. K. Brewers' spent grain: a review with an emphasis on food and health Inst. Brew. Journal of the Institute of Brewing, v.122, p 553$568,2016$.

MAZZA, G.; FUKUMOTO, L.; DELAQUIS, P.; GIRARD, B.; EWERT, B. Anthocyanins, phenolics, and color of Cabernet Franc, Merlot, and Pinot Noir wines from British Columbia. Journal of Agricultural and Food Chemistry, v.47, n.10, p.4009-4017, 1999.

MCINTOSH, G. H.; WHYTE, J.; MCARTHUR, R.; NESTEL, P. J. Barley and wheat foods: influence on plasma cholesterol concentrations in hypercholesterolemic men. American Journal of Clinical Nutrition, v.53, n.5, p.1205-1209, 1991.

MIRANDA, M. Z. de; EL-DASH, A. Farinha integral de trigo germinado: Características nutricionais e estabilidade ao armazenamento. Ciência e Tecnologia de Alimentos, v.22, n.3, p.216-223, 2002.

MOREIRA, M. M., MORAIS, S., CARVALHO, D. O., BARROS, A. A., DELERUE-MATOS, C., GUIDO, L. F. Brewer's spent grain from different types of malt: Evaluation of the antioxidant activity and identification of the major phenolic compounds. Food Research International, v.54, p.382-388, 2013.

MUSSATTO, S. I., DRAGONE, G., ROBERTO, I. C. Brewer's spent grain: generation, characteristics and potential applications. Journal of Cereal Science, v.43, p.1-14, 2006. 
MUSSATTO, S. I. Biotechnological potential of brewing industry by-products. In: Singh nee' Nigam, P., Pandey, A. (eds.) Biotechnology for Agro-Industrial Residues Utilisation, p. 314-326. Netherlands: Springer Science+Business Media BV, 2009.

NEWMAN, R. K.; LEWIS, S. E.; NEWMAN, C. W.; BOIK, R. J.; RAMAGE, R. T. Hypochoesterolemic effect of barley foods on healthy men. Nutritional Reports International, v.39, p.749-760, 1989.

OliveirA FILHO, J. F. Extração de Corante Natural a Partir do Resíduo da Uva. Orientadora: Sousa, Magna Angélica dos Santos Bezerra. 2017. 45f. Trabalho de Conclusão de Curso (Graduação em Engenharia Química) - Departamento de Engenharia Química, Universidade Federal do Rio Grande do Norte, Natal, 2017.

RE, R.; PELLEGRINI, N.; PROTEGGENTE, A.; PANALA, A.; YANG, M.; RICE-EVANS, C. Antioxidant activity applying an improved ABTS radical cation decolorization assay. Free Radical Biology and Medicine, v.26, p.1231-1237, 1999.

ROSELL, C. M.; SANTOS, E.; COLLAR, C. Physico-chemical properties of commercial fibres from different sources: A comparative approach. Food Research International, v.42, p.176-184, 2009.

SAMARAS, T. S.; CAMBURN, P. A.; CHANDRA, S.; GORDON, M. H.; AMES, J. M. Antioxidant Properties of Kilned and Roasted Malts. Journal of Agricultural and Food Chemistry, v.53, p.8068-8074, 2005.

SANT'ANNA, V. Concentração de suco de uva por osmose direta e estudo tecnológico para o aproveitamento do bagaço. Orientadora: Tessaro, Isabel Cristina. 2013. 177f. Tese de Doutorado (Programa de Pós-Graduação em Engenharia Química) - Departamento de Engenharia Química, Universidade Federal do Rio Grande do Sul, Porto Alegre, 2013.

SANTANA, A. F.; OLIVEIRA, L. F. Aproveitamento da casca de melancia (Curcubita citrullus, shrad) na produção artesanal de doces alternativos. Alimentos e Nutrição Araraquara, v.6, n.4, p.363-368, 2005. 
BAGATINI, L.; AZEVEDO, G. D.; SANT’ANNA, V.

SAURA-CALIXTO, F. Dietary Fiber as a Carrier of Dietary Antioxidants: An Essential Physiological Function. Journal of Agricultural and Food Chemistry, v.59, p 43-49, 2011.

SINGLETON, V. L; ROSSI, J. A. Colorimetry of total phenolics with phosphomolybdicphosphotungstic acid reagents. American Journal of Enology and Viticulture, v.20, p.144$158,1965$.

VASHISHT, T.; SINGH, R. K.; PEGG, R. B. Effects of drying on the phenolics content and antioxidant activity of muscadine pomace. LWT - Food Science and Technology, v.44, p.1649-1657, 2011.

XIROS, C.; CHRISTAKOPOULOS, P. Biotechnological Potential of Brewers Spent Grain and its Recent Applications. Waste and Biomass Valorization, v.3, n.2, p.213-232, 2012.

WANG, W.-D.; XU, S.-Y. Degradation kinetics of anthocyanins in blackberry juice and concentrate. Journal of Food Engineering, v.82, n.3, p.271-275, 2007. 


\title{
CHAPTER 14: VALORIZATION AND TREATMENT OF OILY WASTEWATERS FROM AGRO-INDUSTRIES USING LIPASES: AN OVERVIEW
}

\author{
Jéssica Mulinari ${ }^{1}$; Afonso Henrique da Silva Júnior ${ }^{2}$; Carlos Rafael Silva de Oliveira ${ }^{3}$; Francisco \\ Wilson Reichert Júnior ${ }^{4}$
}

\begin{abstract}
Oily wastewater from agro-industries can cause severe environmental and public health damages if unproperly treated. The conventional methods have several limitations for the treatment of oily wastewaters since the oil fraction can cause pipe clogging and biomass washout during the biological step. Based on this, the use of lipases can increase the oil removal efficiency of the treatments, minimizing operational problems, and improving the performance of the biological process. Lipases can also be used for the valorization of the oily wastewaters, transforming these waste streams into valuable compounds, such as biodiesel, lubricants, antioxidant agents, etc. The use of wastes for the production of value-added compounds follows the circular economy approach, minimizing the generation of residues and potential environmental liabilities. Thus, this study aims to give a general overview of the main topics related to the treatment and valorization of oily wastewaters using lipases. The main characteristics of oily wastewaters from agro-industries are addressed, as well as the most used conventional techniques for their treatment. Some relevant information about the enzyme lipase is also discussed to give the reader a background about how these enzymes can be applied for the treatment and transformation of oily wastes.
\end{abstract}

Keywords: Oily wastewater, Liquid effluent, Enzyme, Waste, Reuse.

\section{Introduction}

From agricultural production to consumption, a great amount of food is wasted. When uncorrected managed, these wastes can cause severe environmental and public health damages. With the growing population, food production will need to be intensified and, consequently, the amount of food waste will also increase. Therefore, it is necessary to develop new technological solutions to reduce food waste by avoiding its production, reusing, recycling or treating it in a more sustainable way.

Among food wastes, oily wastewaters can be a very dangerous environmental liability when unproperly treated or irresponsibly disposed of. The presence of oil in the wastewater can increase the treatment cost due to the need for more chemicals or operational problems such as pipe clogging, as well as decrease the treatment efficiency by inhibiting the growth and some

\footnotetext{
${ }^{1}$ Environmental and Sanitary Engineer (Federal University of Fronteira Sul - UFFS), Master in Chemical Engineering (Federal University of Santa Catarina - UFSC), PhD student in Chemical Engineering (UFSC), jessicamulinari15@gmail.com

${ }^{2}$ Agro-industrial Engineer (Federal University of Rio Grande - FURG), Master student in Chemical Engineering (UFSC), afonso.ufsc@gmail.com

${ }^{3}$ Textile Engineer (State University of Maringá - UEM), Master in Chemical Engineering (UFSC), PhD student in Chemical Engineering (UFSC), carlos.oliveira@ posgrad.ufsc.br

${ }^{4}$ Agronomist (UFFS), Master in Environmental Science and Technology (UFFS), PhD student in Plant Genetic Resources (UFSC), chicowrj@gmail.com
} 
metabolic pathways of essential microorganisms. On the other hand, the lipid-rich wastewaters from food industries have great potential to be used in the production of several value-added products. The valorization of wastes follows the circular economy approach being adopted in several industries, according to which wastes can be transformed from possible environmental contaminants into potential revenue streams. However, conventional transformation techniques generally require chemicals or chemical catalysts with substantial energy consumption, and the reactions have limited specificity, resulting in the formation of byproducts, especially when using complex medias such as oily wastewaters. To turn the processes more environmentally friendly, the use of enzymes has demonstrated to be a great alternative. In the case of oily wastewaters, lipases can be used to degrade and modify the oil fraction through hydrolysis, esterification, and transesterification reactions.

Therefore, this study aims to review the main aspects related to the treatment and valorization of oily wastewater from agro-industries using lipases. The main features of oily wastewater are addressed as well as the conventional techniques most used for its treatment. Some relevant information about lipases is discussed and the use of these enzymes for the treatment and valorization of oily wastewaters, focusing on agro-industrial wastewaters, is highlighted. The objective is to show the several possibilities of biocatalysis using lipases for the transformation of oily wastewaters into less pollutant streams and/or value-added products. For this, the past 10-years of research work was accessed and reviewed from five databases (Scopus, Web of Science, Springer, Taylor and Francis, and Science Direct) using the portal of journals from Coordenação de Aperfeiçoamento de Pessoal de Nível Superior (CAPES).

\section{Oily wastewater from food industry}

Agro-industries produce a huge amount of wastewater with high lipid content originated from animal (dairy and meat industries) or vegetable sources (sunflower, soybean, corn canola, coconut, olive oil industries and else). These lipids are composed of oils, greases, fats, or longchain fatty acids that increase the complexity and costs of the wastewater treatment (BELDEAN-GALEA et al., 2013). Fats, oils and greases are predominantly composed of triacylglycerol, which are esters formed of glycerol and three fatty acids. In addition to triacylglycerol, several minor components are also present such as mono and diglycerides (important as emulsifiers), free fatty acids, tocopherol (an important antioxidant), sterols and vitamins from soluble fats (GRILO et al., 2014). Table 1 shows the fat, oil and grease contents of some industrial wastewaters. 
Besides a high content of lipids, wastewaters from agro-industrial food processing, such as edible oil industries, generally have high chemical oxygen demand (COD), biological oxygen demand (BOD), total suspended solids (TSS), total dissolved solids (TDS), phosphates and sulfates (AHMAD et al., 2020; ASLAN et al., 2009; NWEKE; NWABANNE; IGBOKWE, 2014). However, the composition and the characteristics of oily wastewater vary between different industries and also between different batches in the same industry (AHMAD et al., 2020; NWEKE; NWABANNE; IGBOKWE, 2014). Thus, a proper characterization of the wastewater is necessary to determine which treatments and/or reuse/valorization processes are more adequate and feasible. If the wastewater treatment fails in removing fats, oils and greases from the effluent, these compounds can cause severe environmental damages, as well as public health issues and agricultural production losses, as summarized in Figure 1.

Table 1. Oil and grease composition of different agro-industrial wastewaters.

\begin{tabular}{ccc}
\hline Source & Fat, oil and grease $(\mathrm{mg} / \mathrm{L})$ & Reference \\
\hline Sea food processing & $250-5,000$ & (KLAUCANS; SAMS, 2018) \\
Meat processing & $100-2,000$ & (KLAUCANS; SAMS, 2018) \\
Poultry slaughterhouse & 1,200 & (DAMASCENO et al., 2018) \\
Dairy industry & 350 & (KURUP; ADHIKARI; ZISU, 2019) \\
Vegetable oil industry & 54 & (SHARGHI; SHORGASHTI; BONAKDARPOUR, 2016) \\
Vegetable oil industry & $413-667$ & (MA et al., 2015) \\
Palm oil mill & 4,000 & (SINGH et al., 2010) \\
Palm oil mill & 3,580 & (IWUAGWU; UGWUANYI, 2014) \\
Sunflower oil industry & $533-760$ & (ASLAN et al., 2009) \\
Sunflower oil refinery & 74 & (GHASEMIAN; SHARGHI; DAVARPANAH, 2017) \\
Soya oil refinery & 1550 & (RAJKUMAR; MUTHUKUMAR; SIVAKUMAR, 2010) \\
Corn oil industry & $308-499$ & (ASLAN et al., 2009)
\end{tabular}

Source: Authors.

When discharged into the sewer system, the oil can cause great damages to the city infrastructure, such as the clogging of pipes and channels, and increase the costs of the treatment since more chemicals are needed (WALLACE et al., 2017). The clogging can result in increased pressure in the pipeline and consequent leakage of the sewage into the soil. These leakages can reach the groundwater or cause sewage reflux to the surface.

Once the oil passes through the sewer system and enters the sewage treatment plants, it can cause an overloading of the process, decreasing the treatment's efficiency. The oil can also cause blockages in the plant infrastructure. These issues increase the costs of operation and maintenance of the treatment system (WALLACE et al., 2017). It is estimated that fats, oils and greases correspond to $25 \%$ of the sewage treatment cost (EUROPEAN BIOMASS INDUSTRY ASSOCIATION, 2015). Besides, high concentrations of oil in the wastewater can negatively 
affect the performance of microorganisms in degrading it as well as other organic compounds. Thus, a slower degradation rate can lead to oil discharge with the treated effluent directly to water bodies (WALLACE et al., 2017).

Figure 1. Main effects of the incorrect disposal of oily wastewater in the sewage system, water bodies and soil.

EFFECTS OF OILY WASTEWATER INCORRECT DISPOSAL

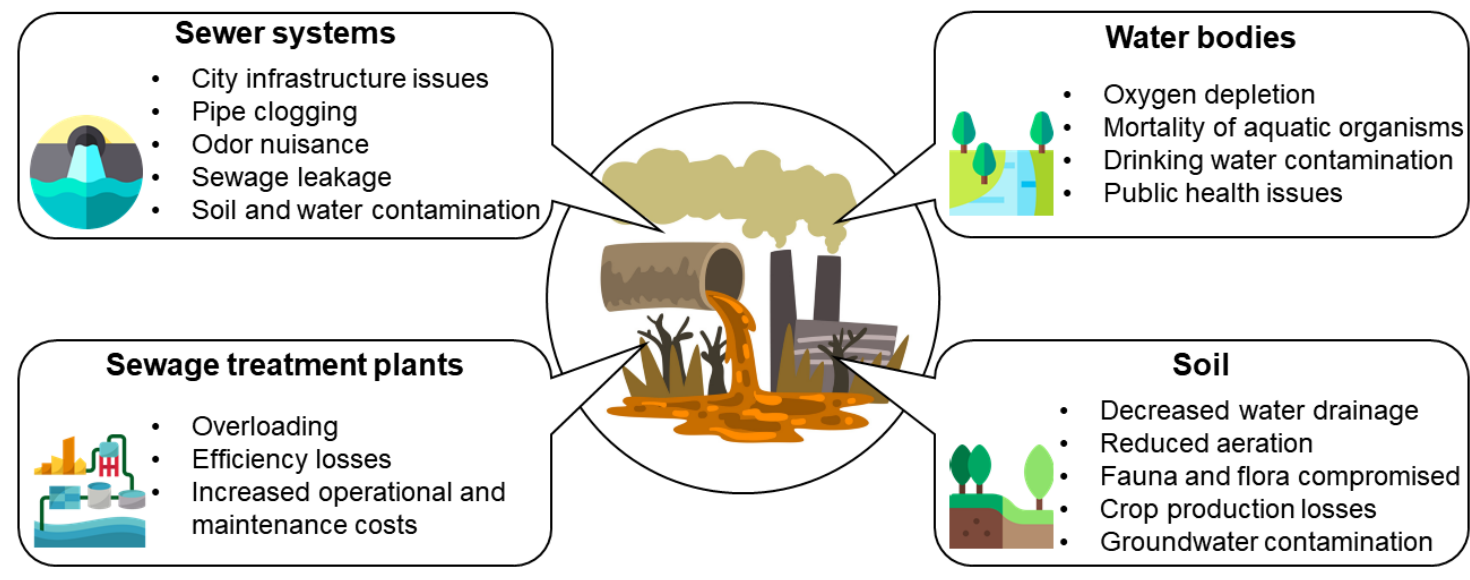

Source: Authors.

When discharged in water bodies, the oil can end up forming a thin film on the water surface, preventing the entry of sunlight and gaseous exchanges. Thus, the aeration process is compromised and, due to oxygen depletion, the aerobic organisms are affected (FINGAS, 2015). Once in the soil, the oil changes the soil's physical properties by clogging the pores, which promotes the soil waterproofing, decreasing water drainage and aeration (SANTOS; MARANHO, 2018). Thus, all fauna and flora present in the soil are compromised, which can affect crop production. Besides, depending on the physical-chemical characteristics of the soil, the relief and the climate, the oil can penetrate the soil and/or runoff, reaching the groundwater and the surface water bodies close to the discharge point (YANXUN et al., 2011).

The importance of proper management and treatment of the oily wastewaters generated in agro-industries is unquestionable not only to comply with environmental regulations and standards but also to avoid environmental and public health issues. The next topic approaches some conventional techniques used for the treatment of oily wastewaters.

\section{Conventional treatments of oily food waste}

Different conventional techniques are used for the treatment of oily wastewater, including physical (such as gravity settling and flotation), chemical (such as flocculation and coagulation), and biological processes (aerobic and anaerobic digestion) (LOUHICHI et al., 
2019). In typical wastewater treatment plants, a combination of treatments is applied, generally, a physical-chemical process followed by biological degradation. The appropriate technology is usually dictated by the characteristics of the compounds present in the wastewater. The degree of dispersion and the stability of the oil droplets are the most important factors. These characteristics are ruled by the diameter of the droplets: free oil (>150 $\mu \mathrm{m})$, dispersed oil (20$150 \mu \mathrm{m})$, emulsified oil $(<20 \mu \mathrm{m})$ and soluble oil $(<5 \mu \mathrm{m})$ (PINTOR et al., 2016).

Physical methods are mainly used for the separation of the oil fraction from the wastewater. Free, dispersed, and some emulsified oil can be removed by these methods. The most used physical techniques in agro-industrial wastewater treatment are gravity settling and flotation. In the gravity settling process, the wastewater is kept in a tank with no intervention until the oil phase rises to the surface (LONG, 1995). It is a simple, low cost and easy to maintain method. However, depending on the wastewater characteristics, large retention times are necessary to reach a good oil removal. To accelerate the process, flotation can be used. Flotation is based on the preferential adherence of the oil phase into bubbles of a gas (generally air) that permeates the suspension, being carried to the surface because of its lower density (YU; HAN; HE, 2017). The oil removal efficiency by flotation is influenced mainly by $\mathrm{pH}$, gas flow rate, bubble size, bubble rising velocity, and bubble formation frequency (PAINMANAKUL et al., 2010). Although this method generates low volumes of sludge, it presents high energy consumption for the generation of the bubbles and high maintenance costs (YU; HAN; HE, 2017). In both methods, once in the surface, the concentrated oil fraction can be mechanically skimmed off or allowed to overflow from the settler/flotation tank (LONG, 1995).

The main chemical conventional methods used in agro-industrial wastewater treatment plants are flocculation and coagulation. These methods are mostly used for the removal of free, dispersed, and mainly for coarse emulsified oil. First, the coagulation process causes the destabilization of the oil droplets, breaking the emulsion through the addition of appropriate chemicals that promote the attraction between the oil droplets (TANSEL; SEVIMOGLU, 2006). Generally, saline solutions with high ionic strength (such as aluminum and ferric salts) or polymers are used. Then, the destabilized oil droplets are induced to coalesce and flocculation occurs, forming large agglomerates that can be easily separated by flotation or gravity settling (KHOUNI et al., 2020). However, high consumption of chemicals and high sludge generation are the major drawbacks of these methods (MA et al., 2015).

Chemical methods have limitations in removing fine emulsified oil and soluble oil. Thus, in conventional treatment processes, physical-chemical methods are followed by biological methods. Biological methods consist of the use of microbial metabolisms to 
transform complex and potentially toxic pollutants into harmless substances (YU; HAN; HE, 2017). Biological processes are classified according to oxygen demand into aerobic and anaerobic treatments that can be used alone or in combination (AHMAD et al., 2020). Aerobic treatments require the presence of oxygen and can remove a great fraction of the organic content of the oily wastewaters. They can be applied at room temperature $\left(25-35^{\circ} \mathrm{C}\right)$ but require adequate aeration and $\mathrm{pH}$ adjustment for an efficient performance (GUNAY; KARADAG, 2015). Thus, high energy requirements for aeration is a disadvantage of the method, as well as possible bulking sludge and excessive biomass growth (TIMMERMANS; VAN HAUTE, 1984; VIDAL et al., 2000). Furthermore, the presence of a high concentration of oil in the wastewater can have a detrimental impact on oxygen transfer efficiency, compromising the aerobic process effectiveness, and the low activity associated with the excessive quantity of oil delays sedimentation which can cause biomass loss through the reactor's outflow (CAMMAROTA; FREIRE, 2006; CHAO; YANG, 1981).

To reduce the costs with aeration and the sludge formation, anaerobic processes can be an alternative to treat oily wastewaters. Anaerobic processes occur in the absence of oxygen (so no aeration is needed) and present high retention time and slow microbial growth when compared to aerobic processes (OHIMAIN; IZAH, 2017). Normally, the degradation of organic pollutants by anaerobic digestion consists of four steps: hydrolysis, acidogenesis, acetogenesis, and methanogenesis (AHMED et al., 2015). If the biodegradation is complete, the end products are methane and carbon dioxide. As methane is one of the end products of anaerobic digestion, anaerobic treatments can be applied in combination with biogas production, a biofuel that can be used by the industry itself (AHMED et al., 2015; KALAT; YÜCEER, 2017). In general, when compared to aerobic digestion, anaerobic systems have shown higher removal efficiencies, lower cost, and lower sludge production, besides enabling the conversion of waste to useful products (AHMAD et al., 2020; DOULA et al., 2017). However, anaerobic processes generally require longer retention times and larger surface areas due to slow startup (ALHAJI et al., 2016; STRONACH; RUDD; LESTER, 1986). The Up-flow Anaerobic Sludge Blanket (UASB) is the most popular anaerobic digestor applied for the treatment of wastewater with high organic load (GUNAY; KARADAG, 2015). UASB reactors are considered a low-cost and efficient high-rate anaerobic treatment system, which is due to the retention of high concentrations of biomass, the upward flow of the wastewater (no agitation needed), the ability to resist to low concentrations of oxygen without compromise the microbial metabolic activities, and the possibility of producing biogas (CHIPASA; MĘDRZYCKA, 2006; LETTINGA, 1995; STRONACH; RUDD; LESTER, 1986). Although UASB reactors have 
shown great performances in the treatment of high organic load wastewaters, some problems were reported when treating lipid-rich wastewater, such as flotation of the biomass granules due to fat, oil and/or grease adsorption (CHIPASA; MĘDRZYCKA, 2006; RINZEMA; ALPHENAAR; LETTINGA, 2007) and inhibitory effects of the long-chain fatty acids on the anaerobic microorganisms (KOSTER; CRAMER, 1987; LALMAN; BAGLEY, 2001; NING et al., 2018). These problems can be solved by applying a pre-treatment of the wastewater to remove free and suspended lipids and by using lipid-tolerant microorganisms (DAMASCENO et al., 2018; DEL NERY et al., 2007).

Generally, a physical-chemical method is followed by a biological method for the treatment of wastewater with high lipids load. The goal of the physical-chemical method is to remove coarse lipids that would compromise the biological process. However, the physicalchemical techniques only remove the lipid fraction and the generated sludge must be properly treated and disposed of, which represent a huge cost for the industry, in addition to often being an environmental liability. Based on this, the development of new techniques able to degrade even coarse lipids is fundamental to make the wastewater treatment cheaper and more environmentally friendly by minimizing sludge production. Moreover, the lipids that pass to the biological treatment can inhibit the metabolism of the microorganisms, increase the retention time needed to adequate biodegradation, and cause biomass flotation leading to biomass washout. Thus, a pre-treatment able to degrade the triacylglycerols to less complex molecules could decrease retention time and avoid failure of the biological process. Based on this, the treatment of oily wastewater using enzymes, mainly lipases, is an environmentally friendly alternative that can be used before or in combination with the biological treatment. Enzymes can be used to degrade the lipids and/or convert them into valuable products. The next section will elucidate the many possibilities regarding lipases and their use in the treatment and/or valorization of oily wastewaters.

\section{Lipases}

Lipases (triacylglycerol acyl hydrolases, E.C. 3.1.1.3) are enzymes that have the natural ability to act at an organic-aqueous interface catalyzing the total or partial hydrolysis of carboxylate ester bonds of triacylglycerol to diacylglycerol, monoacylglycerol, glycerol and free fatty acids in an aqueous medium (Figure 2a). The hydrolysis of triacylglycerols occurs by sequential cleavage of the acyl groups in the glyceride, in such a way that, in a given instant, the reaction mixture can contain triglycerides, diacylglycerols, monoacylglycerols, glycerol and fatty acids simultaneously. Since the equilibrium between the forward and reverse reactions is 
controlled by the water activity, i.e. water concentration in the reaction media, under waterrestrict conditions, the reverse reaction (esterification) can occur (Figure 2b) (BORRELLI; TRONO, 2015). Different transesterification reactions can also occur at low water content, such as exchange of groups between two esters (Figure 2c), between an ester and an alcohol (alcoholysis, Figure 2d), an ester and an acid (acidolysis, Figure 2e), and an ester and an amine (aminolysis, Figure 2f) (BORRELLI; TRONO, 2015).

Figure 2. Reactions catalyzed by lipases.
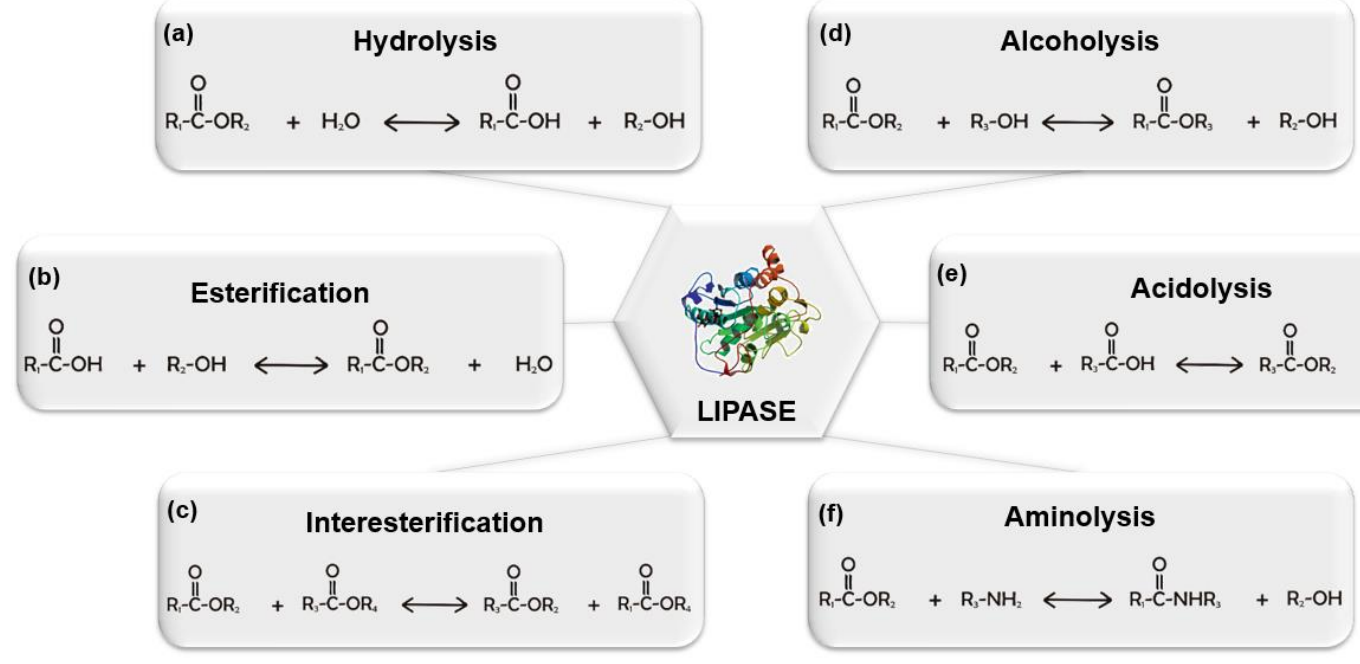

Source: Authors.

Lipases have a great affinity with a wide range of substrates, high stability to temperature, $\mathrm{pH}$, and organic solvents, and can be chemoselective, regioselective and enantioselective (BARROS; FLEURI; MACEDO, 2010; GOLUNSKI et al., 2016). Due to these features and the ability to catalyze hydrolysis and synthesis reactions, lipases have been used in several applications in the pharmaceutical, food, chemical and cosmetic industries, in the formulation of detergents and the production of biodiesel (ALMEIDA et al., 2019; BOROWIECKI; DRANKA, 2019; ĆOROVIĆ et al., 2020; JAHANGIRI et al., 2018; MURILLO et al., 2019; PHUKON et al., 2020).

Lipases can be produced from microorganisms (bacteria or fungi), plants (mainly from seeds and latex), and animals (pancreatic, hepatic or gastric lipases). Microbial lipases are the most used ones due to the easier extraction process that allows large-scale production (COSTA et al., 2017; JOSHI; SHARMA; KUILA, 2019). Fungi are the most used microorganisms to lipase production since the lipases produced by them are extracellular in nature and then can be easily extracted from the fermentation media, reducing the production costs (MEHTA; BODH; 
GUPTA, 2017). The fermentation process can be conducted in two ways, by solid-state fermentation or by submerged fermentation. Solid-state fermentation consists of a fermentation process on solid substrates in the absence or almost absence of water, while submerged fermentation takes place in a liquid medium containing soluble nutrients (CASTILHO et al., 2000). Submerged fermentation is widely used due to the easier control of operational parameters such as temperature and $\mathrm{pH}$, and for having higher homogeneity than solid-state fermentation, which makes nutrient transfer more efficient (COLLA et al., 2016). However, submerged fermentation can have limited oxygen transfer if the agitation is not adequate, which is worsened in the case of fungi due to the filamentous morphology of hyphae in liquid media (COLLA et al., 2016). Solid-state fermentation, in turn, can have lower costs due to less water and energy demand (no agitation needed). In both cases, lipase-producing fungi can be grown in synthetic media or in natural media, such as agro-industrial residues, which besides being a substrate for the growth of the microorganisms, are also a source of carbon and nitrogen (RAVINDRAN et al., 2018). The use of waste for the production of lipases as well as other bioproducts has several advantages such as the reduction of process costs, the valorization of low value-added materials, and the reduction of environmental pollution. Table 2 shows some examples of lipases produced by submerged or solid-state fermentation using different microorganisms grown in agro-industrial residues.

Table 2. Microbial lipases produced through fermentation using agro-industrial residues as substrate.

\begin{tabular}{|c|c|c|c|c|}
\hline Substrate & Microorganism & Fermentation & Lipase yield & Reference \\
\hline Cottonseed oil cake & Cryptococcus sp. & Solid-state & $753 \mathrm{U} / \mathrm{g}^{*}$ & $\begin{array}{l}\text { (THIRUNAVUKARASU et al. } \\
\text { 2016) }\end{array}$ \\
\hline Canola cake & Aspergillus niger & Solid-state & $837 \mathrm{U} / \mathrm{g}$ & (TREICHEL et al., 2016) \\
\hline Sugarcane bagasse & $\begin{array}{l}\text { Rhizomucor sp. and } \\
\text { Penicillium sp. }\end{array}$ & Solid-state & $\begin{array}{l}0.58 \mathrm{U} / \mathrm{g} \text { and } \\
0.47 \mathrm{U} / \mathrm{g}\end{array}$ & (PINOTTI et al., 2017) \\
\hline Castor seed cake & $\begin{array}{l}\text { Aspergillus oryzae and } \\
\text { Aspergillus japonicas }\end{array}$ & Solid-state & $\begin{array}{l}25 \mathrm{U} / \mathrm{g} \text { and } \\
19 \mathrm{U} / \mathrm{g}\end{array}$ & (JAIN; NAIK, 2018) \\
\hline Soapstock & Candida rugosa & Submerged & $7,400 \mathrm{U} / \mathrm{L}^{* *}$ & $\begin{array}{l}\text { (ABDELMOEZ; MOSTAFA; } \\
\text { MUSTAFA, 2013) }\end{array}$ \\
\hline $\begin{array}{l}\text { Palm oil mill } \\
\text { wastewater }\end{array}$ & Bacillus niacini & Submerged & $31,000 \mathrm{U} / \mathrm{L}$ & (OYEDELE et al., 2019) \\
\hline Mango seed and peel & Yarrowia lipolytica & Submerged & $3,500 \mathrm{U} / \mathrm{L}$ & $\begin{array}{c}\text { (PEREIRA; FONTES- } \\
\text { SANT'ANA; AMARAL, 2019) }\end{array}$ \\
\hline
\end{tabular}

*Units of enzymatic activity per gram of solid substrate; ${ }^{* *}$ Units of enzymatic activity per liter of submerged media. Source: Authors.

Lipases produced by different microorganisms in diverse conditions can have distinct characteristics in terms of selectivity, activity, specificity, stability, and structure. Normally, the lipase structure is formed by an $\alpha-\beta$ hydrolase fold and a catalytic triad composed of the amino 
acids serine, histidine and aspartic acid or glutamic acid (MULINARI; OLIVEIRA; HOTZA, In press). It has four substrate-binding sites: three pockets and an oxyanion hole. The pockets hold the fatty acids of the substrate at sn-1, sn-2 and sn-3 positions. In most lipases, the active site is protected by an amphiphilic $\alpha$-helix peptide sequence lid (KAPOOR; GUPTA, 2012). When in contact with a hydrophobic surface, the hydrophobic residues of the lid are exposed, opening the lid and turning the catalytic triad accessible to the substrate, which enhances the catalytic activity of the lipase (GUPTA; BHATTACHARYA; MURTHY, 2013). This phenomenon is called interfacial activation. However, lipases from different origins and production conditions can have distinct characteristics, such as two lids (MARAITE et al., 2013; YAACOB et al., 2016) or no lid (ADLERCREUTZ, 2013; MARTINELLE; HOLMQUIST; HULT, 1995).

Lipases with different features can be produced focusing on the application of the enzyme. Regarding the use of lipases in the treatment of oily wastewater, hydrolytic lipases are the most interesting ones since they can transform the triacylglycerols in less complex molecules, facilitating the degradation by biological processes. Besides treatment, some components of the oily wastewaters can be transformed into value-added products (such as biodiesel, surfactants, and lubricants) using lipases as catalysts. In this case, lipases with higher esterification/transesterification activity are more interesting. Based on this, the next topic approaches the use of lipases for the treatment and valorization of oily wastewaters, mainly from agro-industries.

\section{Lipases in the treatment and valorization of oily wastewaters}

While some lipases can hydrolyze only specific triacylglycerols others can catalyze the hydrolysis of triacylglycerols that contain different fatty acids in their composition, which can be of great interest for the treatment of wastewaters with a high content of lipids (BARROS; FLEURI; MACEDO, 2010; MACRAE; HAMMOND, 1985). The use of lipases reduces the organic matter concentration (in terms of COD), the color and the amount of suspended solids and lipids in the wastewater, which improves the operating conditions of the biological treatment and unclogs oil films in connection pipes, increasing the lifespan of the equipment (MENDES et al., 2005). Furthermore, the specificity of the lipase allows the control of the released products, avoiding the generation of toxic subproducts. The moderate operational conditions required by lipases and the need to add no chemicals can reduce the costs related to energy consumption and equipment (MENDES et al., 2005). 
The treatment of oily wastewater using lipases aims to hydrolyze the triacylglycerols of the oil into free fatty acids and glycerol. The lipases can be used as a pretreatment before biological treatment or in combination with the biological process. In both cases, several studies showed that the use of lipases improved the performance of the biological treatment, mainly in terms of COD reduction and biogas production, in the treatment of wastewaters from the poultry industry (AFFES et al., 2017; VALLADÃO et al., 2011) and dairy industry (ADULKAR; RATHOD, 2015; MENDES; CASTRO, 2005; ROSA et al., 2009), for example. Table 3 shows some examples of studies using lipases for the hydrolysis of oily wastewaters.

Table 3. Examples of oily wastewaters treated with lipases.

\begin{tabular}{|c|c|c|c|c|}
\hline $\begin{array}{c}\text { Oily } \\
\text { wastewater }\end{array}$ & Lipase & Process conditions & Main results & Reference \\
\hline $\begin{array}{l}\text { Dairy } \\
\text { wastewater }\end{array}$ & $\begin{array}{l}\text { Porcine pancreatic } \\
\text { lipase }\end{array}$ & $\begin{array}{l}\text { Enzyme concentration of } \\
0.3 \% \quad(\mathrm{w} / \mathrm{v}) ; \quad \mathrm{pH} \quad 8 ; \\
200 \mathrm{rpm} ; 37^{\circ} \mathrm{C} ; 24 \mathrm{~h}\end{array}$ & $38 \mathrm{mM}$ of FFA & $\begin{array}{l}\text { (MENDES; } \\
\text { CASTRO, 2005) }\end{array}$ \\
\hline $\begin{array}{l}\text { Swine meat } \\
\text { industry } \\
\text { wastewater }\end{array}$ & $\begin{array}{l}\text { Penicillium } \\
\text { restrictum lipase }\end{array}$ & $\begin{array}{l}\text { Enzyme concentration of } \\
5 \%(\mathrm{w} / \mathrm{v}) ; 45^{\circ} \mathrm{C} ; 10 \mathrm{~g} / \mathrm{L} \\
\text { of oil and grease; } \mathrm{pH} 6 \text {; } \\
100 \mathrm{rpm} ; 24 \mathrm{~h}\end{array}$ & $\begin{array}{l}100 \mu \mathrm{mol} / \mathrm{mL} \text { of } \\
\text { FFA }\end{array}$ & (RIGO et al., 2008) \\
\hline $\begin{array}{l}\text { Waste } \\
\text { cooking oil } \\
(\text { WCO })\end{array}$ & $\begin{array}{l}\text { Aspergillus niger } \\
\text { lipase }\end{array}$ & $\begin{array}{lr}\text { Ultrasound-assisted } \\
\text { hydrolysis; } \quad 45{ }^{\circ} \mathrm{C} \text {; } \\
\text { oil:water ratio } \quad \text { of } \\
1: 3(\mathrm{v}: \mathrm{v}) ; & \text { enzyme } \\
\text { concentration } & \text { of } \\
15 \%(\mathrm{v} / \mathrm{v}) ; & 12 \mathrm{~h} ; 170 \mathrm{rpm}\end{array}$ & $63 \mu \mathrm{mol} / \mathrm{mL}$ of FFA & $\begin{array}{l}\text { (MULINARI et al., } \\
\text { 2017) }\end{array}$ \\
\hline $\begin{array}{l}\text { Leather } \\
\text { industry } \\
\text { wastewater }\end{array}$ & $\begin{array}{l}\text { Bacillus cereus } \\
\text { lipase } \\
\text { inmobilized } \\
\text { activated carbon }\end{array}$ & $\begin{array}{l}\text { Packed bed reactor; } \\
60 \text { min; } \mathrm{pH} 10 ; 40{ }^{\circ} \mathrm{C}\end{array}$ & $\begin{array}{l}99 \% \text { of fat } \\
\text { degradation }\end{array}$ & $\begin{array}{l}\text { (POUNSAMY } \\
\text { al., 2019) }\end{array}$ \\
\hline $\begin{array}{l}\text { Pet food } \\
\text { industry } \\
\text { wastewater }\end{array}$ & $\begin{array}{l}\text { Candida rugosa } \\
\text { lipase immobilized } \\
\text { in hybrid sol- } \\
\text { gel/calcium alginate } \\
\text { beads }\end{array}$ & $\begin{array}{l}\text { Enzymatic hydrolysis } \\
\text { followed by anaerobic } \\
\text { biodegradation; } 5 \%(\mathrm{v} / \mathrm{v}) \\
\text { of wastewater; } 0.04 \mathrm{~g} \\
\text { beads/g oil; } \mathrm{pH} 6.8 ; \\
150 \mathrm{rpm} ; 37^{\circ} \mathrm{C} ; 30 \mathrm{~min}\end{array}$ & $\begin{array}{l}\text { Enhanced COD and } \\
\text { grease removal; } \\
\text { higher biogas } \\
\text { production; no foam } \\
\text { production }\end{array}$ & $\begin{array}{l}\text { (JEGANATHAN; } \\
\text { NAKHLA; BASSI, } \\
2007)\end{array}$ \\
\hline $\begin{array}{l}\text { Fish- } \\
\text { processing } \\
\text { plant } \\
\text { wastewater }\end{array}$ & $\begin{array}{l}\text { Penicillium } \\
\text { simplicissimum } \\
\text { lipase }\end{array}$ & $\begin{array}{l}\text { Enzymatic hydrolysis } \\
\text { followed by anaerobic } \\
\text { biodegradation; } \\
1,500 \mathrm{mg} / \mathrm{L} \text { of oil and } \\
\text { grease; } 8 \mathrm{~h} ; 30{ }^{\circ} \mathrm{C} \text {; } \\
150 \mathrm{rpm} \text {; pH } 5\end{array}$ & $\begin{array}{l}\text { Enhanced COD } \\
\text { reduction from } 80 \text { to } \\
91 \%\end{array}$ & $\begin{array}{l}\text { (ALEXANDRE et } \\
\text { al., 2011) }\end{array}$ \\
\hline $\begin{array}{l}\text { Desiccated } \\
\text { coconut } \\
\text { processing } \\
\text { plant } \\
\text { wastewater }\end{array}$ & $\begin{array}{l}\text { Porcine pancreatic } \\
\text { lipase }\end{array}$ & $\begin{array}{l}\text { Enzymatic hydrolysis } \\
\text { followed by anaerobic } \\
\text { biodegradation; } 37{ }^{\circ} \mathrm{C} \text {; } \\
100 \mathrm{rpm} ; 24 \mathrm{~h} \text {; enzyme } \\
\text { concentration } \\
0.1 \%(\mathrm{v} / \mathrm{v})\end{array}$ & $\begin{array}{l}\text { Higher initial biogas } \\
\text { production rate ( } 25 \\
\text { mL/day) and higher } \\
\text { daily production } \\
\text { during first } 10 \text { days. }\end{array}$ & $\begin{array}{l}\text { (SAMARASIRI; } \\
\text { RATHNASIRI; } \\
\text { FERNANDO; } \\
\text { 2019) }\end{array}$ \\
\hline
\end{tabular}


However, before thinking about the treatment of oily wastewater, the reuse and valorization of its components must be taken into account. Agro-industrial waste (including oily wastewaters) contains several valuable compounds that can be recovered, reused, transformed, and utilized in a variety of applications (AHMAD et al., 2020). The biotransformation of the oily wastewaters can generate commercially important products such as biofuels, surfactants, lubricants, organic acids, glycerol, among others (AHMAD et al., 2020; ANDLER; GODDARD, 2018). Table 4 shows some examples of value-added products produced from oily wastewaters by lipase-catalyzed processes.

Table 4. Valorization of oily wastewater through lipase-catalyzed processes aiming for the production of valueadded products.

\begin{tabular}{|c|c|c|c|c|}
\hline $\begin{array}{c}\text { Oily } \\
\text { wastewater }\end{array}$ & Lipase & Catalyzed reaction & Main results & Reference \\
\hline $\begin{array}{l}\text { Waste } \\
\text { cooking oil } \\
(\text { WCO) }\end{array}$ & $\begin{array}{l}\text { Candida rugosa } \\
\text { lipase } \\
\text { immobilized in } \\
\text { polyethersulphone } \\
\text { hollow fiber } \\
\text { membrane }\end{array}$ & $\begin{array}{l}\text { Submerged membrane } \\
\text { reactor; } 80 \mathrm{kPa} ; \mathrm{pH} 7 \\
35^{\circ} \mathrm{C} ; \text { aqueous phase } \\
\text { flow rate of } 0.06 \mathrm{~m} / \mathrm{s} \text {; } \\
\text { organic phase stirring of } \\
89 \mathrm{rad} / \mathrm{s} ; 27 \mathrm{~min} \text {. }\end{array}$ & $250 \mathrm{mmol} / \mathrm{L} . \mathrm{h}$ of FFA & $\begin{array}{l}\text { (CHAKRABORTY; } \\
\text { DRIOLI; GIORNO, } \\
2012 \text { ) }\end{array}$ \\
\hline $\begin{array}{l}\text { Olive mill } \\
\text { wastewater } \\
(\text { OMW) }\end{array}$ & Novozyme 435 & $\begin{array}{l}\text { Esterification of tyrosol } \\
\text { and hydroxytyrosol } \\
\text { extracted from OMW } \\
\text { with butyric, decanoic, } \\
\text { lauric, and palmitic acids; } \\
\text { OMW:fatty acid } 1: 8 \\
(\mathrm{~m} / \mathrm{m}) ; 45{ }^{\circ} \mathrm{C} ; 200 \mathrm{rpm} ; \\
72 \mathrm{~h} .\end{array}$ & 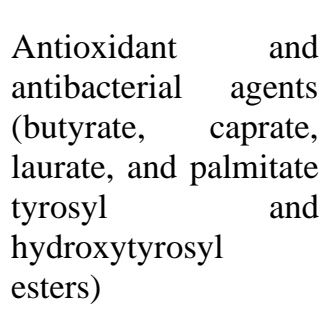 & (AISSA et al., 2017) \\
\hline $\begin{array}{l}\text { Recovered } \\
\text { coconut oil } \\
(\mathrm{RCO})\end{array}$ & $\begin{array}{l}\text { Thermomyces } \\
\text { lanuginosa lipase }\end{array}$ & $\begin{array}{l}\text { Modification of maize } \\
\text { and cassava starches by } \\
\text { enzymatic esterification } \\
\text { with RCO fatty acids. }\end{array}$ & $\begin{array}{l}\text { Thermoplastic } \\
\text { starches (which can } \\
\text { be used in plastic and } \\
\text { pharmaceutical } \\
\text { industries) }\end{array}$ & $\begin{array}{l}\text { (RAJAN; PRASAD; } \\
\text { ABRAHAM, 2006) }\end{array}$ \\
\hline $\begin{array}{l}\text { Waste } \\
\text { cooking oil } \\
(\text { WCO })\end{array}$ & $\begin{array}{l}\text { Immobilized } \\
\text { lipases Lipozyme } \\
\text { TL IM and } \\
\text { Novozym } 435\end{array}$ & $\begin{array}{l}\text { Continuous esterification } \\
\text { in ultrasound-assisted } \\
\text { system. }\end{array}$ & $\begin{array}{l}79 \% \text { conversion of } \\
\text { WCO hydrolysates in } \\
\text { ethyl esters after } \\
9 \text { min }\end{array}$ & $\begin{array}{l}\text { (ZENEVICZ et al., } \\
2017)\end{array}$ \\
\hline $\begin{array}{l}\text { Palm oil mill } \\
\text { effluent } \\
\text { (POME) }\end{array}$ & Candida sp. lipase & $\begin{array}{l}\text { Enzymatic hydrolysis (40 } \\
{ }^{\circ} \mathrm{C}, \mathrm{pH} 7,650 \mathrm{rpm}, 20 \\
\mathrm{U} / \mathrm{mL} \text { of enzyme, } 50 \% \\
(\mathrm{v} / \mathrm{v}) \text { of POME) followed } \\
\text { by non-catalytic } \\
\text { esterification }\left(75^{\circ} \mathrm{C}, 950\right. \\
\text { rpm, alcohol to fatty acid } \\
\text { ratio of } 3: 1) .\end{array}$ & $\begin{array}{l}\text { Bio-lubricant; } \\
\text { hydrolysis rate of } 0.16 \\
\mathrm{mg} / \mathrm{s} . \mathrm{L} \text {; esterification } \\
\text { rate of } 0.0018 \mathrm{mg} / \mathrm{s} . \mathrm{L}\end{array}$ & $\begin{array}{l}\text { (SYAIMA et al., } \\
2015)\end{array}$ \\
\hline $\begin{array}{l}\text { Waste frying } \\
\text { palm oil }\end{array}$ & $\begin{array}{l}\text { Candida } \\
\text { antarctica lipase }\end{array}$ & $\begin{array}{l}16.6 \% \quad(\mathrm{w} / \mathrm{w}) \\
\text { content; } 5.5 \% \quad(\mathrm{w} / \mathrm{w}) \\
\text { lipase load; } 30{ }^{\circ} \mathrm{C} ; 22 \mathrm{~h} .\end{array}$ & $\begin{array}{l}\text { Biodiesel yield of } \\
95 \%\end{array}$ & $\begin{array}{l}\text { (GUO; SUN; LIU, } \\
\text { 2020) }\end{array}$ \\
\hline
\end{tabular}


The enzymatic production of biodiesel from oily wastewater using lipases is the most broadly studied, since the use of commercial vegetable oils makes biodiesel more expensive than conventional diesel (ALPTEKIN; CANAKCI; SANLI, 2014). The use of edible oils for biodiesel production can also cause an increase in vegetable oil prices and represent a competition with food production, inflating the debate food versus energy since more crops would be needed specifically for biofuel (ALPTEKIN; CANAKCI; SANLI, 2014; ZHANG et al., 2010). For biodiesel production, lipases catalyze esterification and transesterification reactions to produce specific esters from fatty acids. The use of lipases prevents soap formation during transesterification, reducing the generation of byproducts and avoiding operational problems (ANDLER; GODDARD, 2018). Furthermore, lipases require more moderate processing conditions than chemical catalysts and can act in solvent-free mediums, improving the process sustainability (ANDLER; GODDARD, 2018)

However, the high cost of commercial lipases is a limiting factor for the use of the enzyme in wastewater treatment, which demonstrates the importance of developing lipase production techniques through highly efficient microorganisms using low-cost substrates as agro-industrial residues. Besides, for the use of enzymes to become competitive, their reuse is necessary and, although good conversions are reported in the literature, the vast majority of the studies use the enzyme in its free form (NIELSEN; BRASK; FJERBAEK, 2008). Therefore, when thinking about reuse and retention of enzyme activity, the immobilization technique appears like an excellent alternative. In addition to facilitating the reuse of the enzyme, immobilization on solid supports can improve catalytic, thermal, and chemical stability, enable continuous operations, and significantly reduce operating costs (RAMANI et al., 2010). However, there are few commercially available immobilized lipases, such as Novozym 435 (immobilized on acrylic resin) and Lipozyme TL IM (immobilized on silica gel carriers), but the small size of the support is still a challenge for the industry in terms of the enzyme recovery at the end of the process.

The cost of the immobilized lipases, mainly the support material costs, is the main limitation for lipase use in environmental applications such as wastewater treatment and valorization (MOHAMAD et al., 2015). Thus, a rational design focused on the application of the enzyme is essential to develop a robust biocatalyst that can be successfully used at the industrial scale. This design must carefully choose the best lipase source, enzyme production conditions, support material, and immobilization procedure to obtain a highly active lipase with great stability over the aimed application. Furthermore, the biocatalysts must increase the 
environmental sustainability of the industrial processes and, at the same time, they must be economically viable so that they can compete on an equal footing with conventional processes.

\section{Final Considerations}

The use of lipases for the treatment and valorization of oily wastewaters from agroindustries has proven to be a great alternative to improve the environmental sustainability of food production. The use of lipases can enhance the quality of the treated wastewater, minimize operational issues such as pipe clogging and foam formation, and facilitate some already established procedures such as biological treatments. Though, before thinking about the treatment of the oily wastewaters, their valorization should be considered since this lipid-rich waste can be used as a renewable resource for the production of several value-added products. In this case, lipases can catalyze several important synthesis reactions, such as hydrolysis, esterification, and transesterification. However, there are still some limitations to the broader use of lipases in environmental processes, such as the reusability of the biocatalysts and the economic feasibility, which demonstrates that more studies should be performed to turn the enzymatic processes more attractive to the industries. Based on this, the use of lipases for the treatment and valorization of oily wastewater is a very active research topic, with several possibilities to be explored and improved aiming its application at the industrial level.

\section{References}

ABDELMOEZ, W.; MOSTAFA, N. A.; MUSTAFA, A. Utilization of oleochemical industry residues as substrates for lipase production for enzymatic sunflower oil hydrolysis. Journal of Cleaner Production, v. 59, p. 290-297, 15 nov. 2013.

ADLERCREUTZ, P. Immobilisation and application of lipases in organic media. Chemical Society Reviews, v. 42, n. 15, p. 6406-6436, 2013.

ADULKAR, T. V.; RATHOD, V. K. Pre-treatment of high fat content dairy wastewater using different commercial lipases. Desalination and Water Treatment, v. 53, n. 9, p. 2450-2455, 2013.

AFFES, M. et al. Effect of bacterial lipase on anaerobic co-digestion of slaughterhouse wastewater and grease in batch condition and continuous fixed-bed reactor. Lipids in Health and Disease, v. 16, n. 195, 2017.

AHMAD, T. et al. Utilization of wastewater from edible oil industry, turning waste into valuable products: a review. Trends in Food Science \& Technology, v. 99, p. 21-33, 2020.

AHMED, Y. et al. Production of biogas and performance evaluation of existing treatment processes in palm oil mill effluent (POME). Renewable and Sustainable Energy Reviews, v. 42, p. 1260-1278, 2015. 
AISSA, I. et al. Valorization of antioxidants extracted from olive mill wastewater. Biotechnology and Applied Biochemistry, v. 64, n. 4, p. 579-589, 2017.

ALEXANDRE, V. M. F. et al. Performance of anaerobic bioreactor treating fish-processing plant wastewater pre-hydrolyzed with a solid enzyme pool. Renewable Energy, v. 36, n. 12, p. 3439-3444, 2011.

ALHAJI, M. H. et al. Photocatalytic treatment technology for palm oil mill effluent (POME): a review. Process Safety and Environmental Protection, v. 102, p. 673-686, 2016.

ALMEIDA, J. M. et al. Biochemical characterization and application of a new lipase and its cognate foldase obtained from a metagenomic library derived from fat-contaminated soil. International Journal of Biological Macromolecules, v. 137, p. 442-454, 2019.

ALPTEKIN, E.; CANAKCI, M.; SANLI, H. Biodiesel production from vegetable oil and waste animal fats in a pilot plant. Waste Management, v. 34, n. 11, p. 2146-2154, 2014.

ANDLER, S. M.; GODDARD, J. M. Transforming food waste: how immobilized enzymes can valorize waste streams into revenue streams. npj Science of Food, v. 2, n. 19, 2018.

ASLAN, S. et al. Characterization and biological treatability of edible oil wastewaters. Polish Journal of Environmental Studies, v. 18, p. 533-538, 2009.

BARROS, M.; FLEURI, L. F.; MACEDO, G. A. Seed lipases: sources, applications and properties: a review. Brazilian Journal of Chemical Engineering, v. 27, p. 15-29, 2010.

BELDEAN-GALEA, M. S. et al. Characterization of the fate of lipids in wastewater treatment using a comprehensive GC $\times$ GC/qMS and statistical approach. Analytical Methods, v. 5, n. 9, p. 2315-2323, 2013.

BOROWIECKI, P.; DRANKA, M. A facile lipase-catalyzed KR approach toward enantiomerically enriched homopropargyl alcohols. Bioorganic Chemistry, v. 93, p. 102754, 2019.

BORRELLI, G. M.; TRONO, D. Recombinant lipases and phospholipases and their use as biocatalysts for industrial applications. International Journal of Molecular Sciences, v. 16, n. 9, p. 20774-20840, 2015.

CAMMAROTA, M. C.; FREIRE, D. M. G. A review on hydrolytic enzymes in the treatment of wastewater with high oil and grease content. Bioresource Technology, v. 97, n. 17, p. 2195-2210, 2006.

CASTILHO, L. R. et al. Economic analysis of lipase production by Penicillium restrictum in solid-state and submerged fermentations. Biochemical Engineering Journal, v. 4, n. 3, p. 239-247, 2000.

CHAKRABORTY, S.; DRIOLI, E.; GIORNO, L. Development of a two separate phase submerged biocatalytic membrane reactor for the production of fatty acids and glycerol from residual vegetable oil streams. Biomass and Bioenergy, v. 46, p. 574-583, 2012.

CHAO, A. C.; YANG, W. Biological treatment of wool scouring wastewater. Journal (Water Pollution Control Federation), v. 53, p. 311-317, 1981. 
CHIPASA, K. B.; MĘDRZYCKA, K. Behavior of lipids in biological wastewater treatment processes. Journal of Industrial Microbiology and Biotechnology, v. 33, n. 8, p. 635-645, 2006.

COLLA, L. M. et al. Surface response methodology for the optimization of lipase production under submerged fermentation by filamentous fungi. Brazilian Journal of Microbiology, v. 47, n. 2, p. 461-467, 2016.

ĆOROVIĆ, M. et al. Enzymatically derived oil-based L-ascorbyl esters: synthesis, antioxidant properties and controlled release from cosmetic formulations. Sustainable Chemistry and Pharmacy, v. 15, p. 100231, 2020.

COSTA, T. M. et al. Lipase production by Aspergillus niger grown in different agroindustrial wastes by solid-state fermentation. Brazilian Journal of Chemical Engineering, v. 34, n. 2, p. 419-427, 2017.

DAMASCENO, F. R. C. et al. Treatment of wastewater with high fat content employing an enzyme pool and biosurfactant: technical and economic feasibility. Brazilian Journal of Chemical Engineering, v. 35, n. 2, p. 531-542, 2018.

DEL NERY, V. et al. Long-term operating performance of a poultry slaughterhouse wastewater treatment plant. Resources, Conservation and Recycling, v. 50, p. 102-114, 2007.

DOULA, M. K. et al. Olive mill waste: recent advances for the sustainable development of olive oil industry. In: Olive Mill Waste. Elsevier, 2017. p. 29-56.

EUROPEAN BIOMASS INDUSTRY ASSOCIATION. Transformation of used cooking oil into biodiesel: from waste to resource, 2015. Available at <https://www.eubren.com/UCO_to_Biodiesel_2030_01.pdf>. Accessed in Jun. 15, 2020.

FINGAS, M. Vegetable oil spills: oil properties and behavior. In: FINGAS, M. (Ed.).

Handbook of oil spill science and technology. Hoboken, NJ: John Wiley \& Sons, Inc, 2015. p. 79-91.

GHASEMIAN, P.; SHARGHI, E. A.; DAVARPANAH, L. The influence of short values of hydraulic and sludge retention time on performance of a membrane bioreactor treating sunflower oil refinery wastewater. International Journal of Engineering, v. 30, n. 10, 2017.

GOLUNSKI, S. M. et al. Interference of salts used on aqueous two-phase systems on the quantification of total proteins. International Journal of Biological Macromolecules, v. 83, p. 30-33, 2016.

GRILO, E. C. et al. Alpha-tocopherol and gamma-tocopherol concentration in vegetable oils. Food Science and Technology, v. 34, n. 2, p. 379-385, 2014.

GUNAY, A.; KARADAG, D. Recent developments in the anaerobic digestion of olive mill effluents. Process Biochemistry, v. 50, n. 11, p. 1893-1903, 2015.

GUO, J.; SUN, S.; LIU, J. Conversion of waste frying palm oil into biodiesel using free lipase A from Candida antarctica as a novel catalyst. Fuel, v. 267, p. 117323, 2020. 
GUPTA, S.; BHATTACHARYA, A.; MURTHY, C. N. Tune to immobilize lipases on polymer membranes: techniques, factors and prospects. Biocatalysis and Agricultural Biotechnology, v. 2, n. 3, p. 171-190, 2013.

IWUAGWU, J. O.; UGWUANYI, J. O. Treatment and valorization of palm oil mill effluent through production of food grade yeast biomass. Journal of Waste Management, v. 2014, 2014.

JAHANGIRI, A. et al. Hydrophilization of bixin by lipase-catalyzed transesterification with sorbitol. Food Chemistry, v. 268, p. 203-209, 2018.

JAIN, R.; NAIK, S. N. Adding value to the oil cake as a waste from oil processing industry: production of lipase in solid state fermentation. Biocatalysis and Agricultural Biotechnology, v. 15, p. 181-184, 2018.

JEGANATHAN, J.; NAKHLA, G.; BASSI, A. Hydrolytic pretreatment of oily wastewater by immobilized lipase. Journal of Hazardous Materials, v. 145, n. 1, p. 127-135, 2007.

JOSHI, R.; SHARMA, R.; KUILA, A. Lipase production from Fusarium incarnatum KU377454 and its immobilization using $\mathrm{Fe}_{3} \mathrm{O}_{4}$ NPs for application in waste cooking oil degradation. Bioresource Technology Reports, v. 5, p. 134-140, 2019.

KALAT, D. G.; YÜCEER, A. Anaerobic mesophilic and thermophilic treatability of vegetable oil refining wastewater. Process Safety and Environmental Protection, v. 109, p. $151-157,2017$.

KAPOOR, M.; GUPTA, M. N. Lipase promiscuity and its biochemical applications. Process Biochemistry, v. 47, n. 4, p. 555-569, 2012.

KHOUNI, I. et al. Efficiency of a coagulation/flocculation-membrane filtration hybrid process for the treatment of vegetable oil refinery wastewater for safe reuse and recovery. Process Safety and Environmental Protection, v. 135, p. 323-341, 2020.

KLAUCANS, E.; SAMS, K. Problems with fat, oil, and grease (fog) in food industry wastewaters and recovered FOG recycling methods using anaerobic co-digestion: a short review. Key Engineering Materials, v. 762, p. 61-68, 2018.

KOSTER, I. W.; CRAMER, A. Inhibition of methanogenesis from acetate in granular sludge by long-chain fatty acids. Applied and Environmental Microbiology, v. 53, n. 2, p. 403409, 1987.

KURUP, G. G.; ADHIKARI, B.; ZISU, B. Recovery of proteins and lipids from dairy wastewater using food grade sodium lignosulphonate. Water Resources and Industry, v. 22, p. $100114,2019$.

LALMAN, J. A.; BAGLEY, D. M. Anaerobic degradation and methanogenic inhibitory effects of oleic and stearic acids. Water Research, v. 35, n. 12, p. 2975-2983, 2001.

LETTINGA, G. Anaerobic digestion and wastewater treatment systems. Antonie van Leeuwenhoek, v. 67, n. 1, p. 3-28, 1995. 
LONG, R. B. Separation Processes in Waste Minimization. New York: Marcel Dekker, Inc., 1995.

LOUHICHI, G. et al. Process optimization via response surface methodology in the physicochemical treatment of vegetable oil refinery wastewater. Environmental Science and Pollution Research, v. 26, n. 19, p. 18993-19011, 2019.

MA, Z. et al. Submerged membrane bioreactor for vegetable oil wastewater treatment. Chemical Engineering \& Technology, v. 38, n. 1, p. 101-109, 2015.

MACRAE, A. R.; HAMMOND, R. C. Present and future applications of lipases. Biotechnology and Genetic Engineering Reviews, v. 3, n. 1, p. 193-218, 1985.

MARAITE, A. et al. Lipase from Pseudomonas stutzeri: purification, homology modelling and rational explanation of the substrate binding mode. Journal of Molecular Catalysis B: Enzymatic, v. 87, p. 88-98, 2013.

MARTINELLE, M.; HOLMQUIST, M.; HULT, K. On the interfacial activation of Candida antarctica lipase A and B as compared with Humicola lanuginosa lipase. Biochimica et Biophysica Acta (BBA) - Lipids and Lipid Metabolism, v. 1258, n. 3, p. 272-276, 1995.

MEHTA, A.; BODH, U.; GUPTA, R. Fungal lipases: a review. Journal of Biotech Research, v. 8, p. 58-77, 2017.

MENDES, A. A. et al. Aplicação de lipases no tratamento de águas residuárias com elevados teores de lipídeos. Química Nova, v. 28, n. 2, p. 296-305, 2005.

MENDES, A. A.; CASTRO, H. F. DE. Effect on the enzymatic hydrolysis of lipids from dairy wastewater by replacing Gum Arabic emulsifier for sodium chloride. Brazilian Archives of Biology and Technology, v. 48, p. 135-142, 2005.

MOHAMAD, N. R. et al. An overview of technologies for immobilization of enzymes and surface analysis techniques for immobilized enzymes. Biotechnology \& Biotechnological Equipment, v. 29, n. 2, p. 205-220, 2015.

MULINARI, J. et al. Ultrasound-assisted hydrolysis of waste cooking oil catalyzed by homemade lipases. Ultrasonics Sonochemistry, v. 35, p. 313-318, 2017.

MULINARI, J.; OLIVEIRA, J. V.; HOTZA, D. Lipase immobilization on ceramic supports: an overview on techniques and materials. Biotechnology Advances, p. 107581, In press.

MURILLO, G. et al. Scaled-up biodiesel synthesis from Chinese Tallow Kernel oil catalyzed by Burkholderia cepacia lipase through ultrasonic assisted technology: a non-edible and alternative source of bio energy. Ultrasonics Sonochemistry, v. 58, p. 104658, 2019.

NIELSEN, P. M.; BRASK, J.; FJERBAEK, L. Enzymatic biodiesel production: technical and economical considerations. European Journal of Lipid Science and Technology, v. 110, n. 8, p. 692-700, 2008.

NING, Z. et al. Anaerobic digestion of lipid-rich swine slaughterhouse waste: methane production performance, long-chain fatty acids profile and predominant microorganisms. Bioresource Technology, v. 269, p. 426-433, 2018. 
NWEKE, C. N.; NWABANNE, J. T.; IGBOKWE, P. K. Kinetics of batch anaerobic digestion of vegetable oil wastewater. Open Journal of Water Pollution and Treatment, v. 1-10, 2014.

OHIMAIN, E. I.; IZAH, S. C. A review of biogas production from palm oil mill effluents using different configurations of bioreactors. Renewable and Sustainable Energy Reviews, v. 70, p. 242-253, 2017.

OYEDELE, S. A. et al. Enhanced lipolytic activity potential of mutant Bacillus niacini EMB5 grown on palm oil mill effluent (POME) and biochemical characterization of purified lipase. Biocatalysis and Agricultural Biotechnology, v. 18, p. 101017, 2019.

PAINMANAKUL, P. et al. Effect of bubble hydrodynamic and chemical dosage on treatment of oily wastewater by Induced Air Flotation (IAF) process. Chemical Engineering Research and Design, v. 88, n. 5, p. 693-702, 2010.

PEREIRA, A. S.; FONTES-SANT'ANA, G. C.; AMARAL, P. F. F. Mango agro-industrial wastes for lipase production from Yarrowia lipolytica and the potential of the fermented solid as a biocatalyst. Food and Bioproducts Processing, v. 115, p. 68-77, 2019.

PHUKON, L. C. et al. Production and characterisation of lipase for application in detergent industry from a novel Pseudomonas helmanticensis HS6. Bioresource Technology, v. 309, p. $123352,2020$.

PINOTTI, L. M. et al. Production of lipolytic enzymes using agro-industrial residues. Chemical Engineering Transactions, v. 56, p. 1897-1902, 2017.

PINTOR, A. M. A. et al. Oil and grease removal from wastewaters: sorption treatment as an alternative to state-of-the-art technologies: a critical review. Chemical Engineering Journal, v. 297, p. 229-255, 2016.

POUNSAMY, M. et al. Removal of fat components in high TDS leather wastewater by saline-tolerant lipase-assisted nanoporous-activated carbon. Applied biochemistry and biotechnology, v. 187, n. 2, p. 474-492, 2019.

RAJAN, A.; PRASAD, V. S.; ABRAHAM, T. E. Enzymatic esterification of starch using recovered coconut oil. International Journal of Biological Macromolecules, v. 39, n. 4, p. $265-272,2006$.

RAJKUMAR, K.; MUTHUKUMAR, M.; SIVAKUMAR, R. Novel approach for the treatment and recycle of wastewater from soya edible oil refinery industry: an economic perspective. Resources, Conservation and Recycling, v. 54, n. 10, p. 752-758, 2010.

RAMANI, K. et al. Immobilisation of Pseudomonas gessardii acidic lipase derived from beef tallow onto mesoporous activated carbon and its application on hydrolysis of olive oil.

Process Biochemistry, v. 45, n. 6, p. 986-992, 2010.

RAVINDRAN, R. et al. A review on bioconversion of agro-industrial wastes to industrially important enzymes. Bioengineering, v. 5, n. 4, p. 93, 2018. 
RIGO, E. et al. Comparison of two lipases in the hydrolysis of oil and grease in wastewater of the swine meat industry. Industrial \& Engineering Chemistry Research, v. 47, n. 6, p. 1760-1765, 2008.

RINZEMA, A.; ALPHENAAR, A.; LETTINGA, G. The effect of lauric acid shock loads on the biological and physical performance of granular sludge in UASB reactors digesting acetate. Journal of Chemical Technology \& Biotechnology, v. 46, n. 4, p. 257-266, 2007.

ROSA, D. R. et al. Performance and molecular evaluation of an anaerobic system with suspended biomass for treating wastewater with high fat content after enzymatic hydrolysis. Bioresource Technology, v. 100, n. 24, p. 6170-6176, 2009.

SAMARASIRI, B. K. T.; RATHNASIRI, P. G.; FERNANDO, D. Development of an enzymatic hydrolysis pretreatment strategy to improve batch anaerobic digestion of wastewater generated in desiccated coconut processing plants. In: Moratuwa Engineering Research Conference (MERCon), 2019, Moratuwa, Sri Lanka. Anais..., p. 314-129, 2019.

SANTOS, J. J.; MARANHO, L. T. Rhizospheric microorganisms as a solution for the recovery of soils contaminated by petroleum: a review. Journal of Environmental Management, v. 210, p. 104-113, 2018.

SINGH, R. P. et al. Composting of waste from palm oil mill: a sustainable waste management practice. Reviews in Environmental Science and Bio/Technology, v. 9, n. 4, p. 331-344, 2010.

STRONACH, S. M.; RUDD, T.; LESTER, J. N. Anaerobic digestion processes in industrial wastewater treatment. Berlin, Heidelberg: Springer Berlin Heidelberg, 1986.

SYAIMA, M. T. S. et al. The synthesis of bio-lubricant based oil by hydrolysis and noncatalytic of palm oil mill effluent (POME) using lipase. Renewable and Sustainable Energy Reviews, v. 44, p. 669-675, 2015.

TANSEL, B.; SEVIMOGLU, O. Coalescence and size distribution characteristics of oil droplets attached on flocs after coagulation. Water, Air, and Soil Pollution, v. 169, n. 1, p. 293-302, 2006.

THIRUNAVUKARASU, K. et al. Degradation of poly(butylene succinate) and poly(butylene succinate-co-butylene adipate) by a lipase from yeast Cryptococcus sp. grown on agroindustrial residues. International Biodeterioration \& Biodegradation, v. 110, p. 99-107, 2016.

TIMMERMANS, P.; VAN HAUTE, A. Influence of the type of organisms on the biomass hold-up in a fluidized-bed reactor. Applied Microbiology and Biotechnology, v. 19, n. 1, p. 36-43, 1984.

TREICHEL, H. et al. Lipase production from a newly isolated Aspergillus niger by solid state fermentation using canola cake as substrate. Current Biotechnology, v. 5, n. 4, p. 295-300, 2016.

VALLADÃO, A. B. G. et al. Profiles of fatty acids and triacylglycerols and their influence on the anaerobic biodegradability of effluents from poultry slaughterhouse. Bioresource Technology, v. 102, n. 14, p. 7043-7050, 2011. 
VIDAL, G. et al. Influence of the content in fats and proteins on the anaerobic biodegradability of dairy wastewaters. Bioresource Technology, v. 74, n. 3, p. 231-239, 2000 .

WALLACE, T. et al. International evolution of fat, oil and grease (FOG) waste management: a review. Journal of Environmental Management, v. 187, p. 424-435, 2017.

YAACOB, N. et al. Toluene promotes lid 2 interfacial activation of cold active solvent tolerant lipase from Pseudomonas fluorescens strain AMS8. Journal of Molecular Graphics and Modelling, v. 68, p. 224-235, 2016.

YANXUN, S. et al. Analysis of the groundwater and soil pollution by oil leakage. Procedia Environmental Sciences, v. 11, p. 939-944, 2011.

YU, L.; HAN, M.; HE, F. A review of treating oily wastewater. Arabian Journal of Chemistry, v. 10, p. S1913-S1922, 2017.

ZENEVICZ, M. C. P. et al. A two-step enzymatic strategy to produce ethyl esters using frying oil as substrate. Industrial Crops and Products, v. 108, p. 52-55, 2017.

ZHANG, Z. et al. Food versus fuel: what do prices tell us? Energy Policy, v. 38, n. 1, p. 445$451,2010$. 


\title{
CAPÍTULO 15: ALTERNATIVAS SUSTENTÁVEIS PARA O MANEJO DE FUNGOS E INSETOS DE ARMAZENAMENTO EM GRÃOS DE MILHO PARA A AGRICULTURA FAMILIAR
}

\author{
CHAPTER 15: SUSTAINABLE ALTERNATIVES FOR THE MANAGEMENT OF \\ STORAGE INSECTS AND FUNGI IN MAIZE GRAINS FOR FAMILY \\ AGRICULTURE
}

\author{
Gisele Silva Oliveira ${ }^{1}$; Oziana Ferreira da Silva Oliveira ${ }^{2}$
}

\section{Resumo}

O milho é um grão de grande valor econômico e social para a agricultura familiar por sua diversidade de usos, podendo ser empregado na alimentação humana e animal. $O$ armazenamento é uma estratégia adotada pelos produtores para garantir sua disponibilidade ao longo das épocas de escassez. Promover a sanidade desse material muitas vezes é um fator limitante devido as condições precárias de armazenamento, o surgimento de fungos e insetos que danificam a massa de grãos diminui a qualidade do produto. A partir disso, buscou-se através de uma revisão de literatura estratégias que visem o controle de fungos e insetos de armazenamento baseados em produtos de origem vegetal e de fácil disponibilidade para o agricultor. Há um grande potencial no uso de extratos, óleos e pós de origem vegetal para o combate de fungos e insetos de armazenamento, visto que muitos dos materiais podem ser encontrados na propriedade rural ou serem adquiridos por um baixo custo, sendo viável para o uso em condições de armazenamento e atuando de diversas formas sobre os problemas fitossanitários. Ainda são necessárias ações de assistência técnica e extensão rural para divulgar essas práticas, além de pesquisas a respeito do potencial de espécies vegetais locais.

Palavras-Chave: Micotoxinas, Perda econômica, Produtos botânicos.

\begin{abstract}
Corn is a grain of great economic and social value for family agriculture due to its diversity of uses and can be used in human and animal food. Storage is a strategy adopted by producers to ensure its availability during times of scarcity. Promoting the health of this material is often a limiting factor due to the precarious storage conditions, the appearance of fungi and insects that damage the grain mass decreases the quality of the product. From this, strategies were sought through a literature review aimed at controlling fungi and storage insects based on products of plant origin and easily available to the farmer. There is great potential in the use of extracts, oils and powders of plant origin to combat fungi and storage insects, since many of the materials can be found on the rural property or can be purchased at low cost, being viable for use in storage conditions and acting in various ways on phytosanitary problems. Technical assistance and rural extension actions are still needed to publicize these practices, in addition to research on the potential of local plant species.
\end{abstract}

Keywords: Mycotoxins, Economic loss, Botanical products

\footnotetext{
${ }^{1}$ Bacharelado em agronomia, Instituto Federal de Pernambuco, Liveirag@gmail.com

${ }^{2}$ Licenciada em Ciências Biológicas, Universidade Federal de Pernambuco, Ozianaferreira1 @ hotmail.com
} 


\section{Introdução}

O milho (Zea mays L.) é um dos grãos mais importantes produzidos no Brasil, alcançando cerca de 100,04 milhões de toneladas de grãos produzidos no país, sendo o estado do Mato Grosso o maior produtor nacional (CONAB, 2020).

Além de ser uma importante commodity brasileira, o milho ganha destaque na agricultura familiar e em populações de baixa renda, representando um importante recurso econômico e nutricional, uma vez que ele pode ser comercializado, garantindo renda ao produtor, ou até mesmo utilizado como fonte energética na alimentação humana e animal (CRUZ et al., 2011; PIMENTEL et al., 2011).

Os grãos são colhidos quando atingem a maturidade fisiológica e devem ser secos e conservados de maneira adequada a fim de evitar perdas na qualidade do produto, o armazenamento de grãos e sementes é uma estratégia antiga do produtor para garantir recursos alimentares ou econômicos e fonte de propagação de espécies em épocas de escassez ou fora da época de cultivo, entretanto o baixo uso e até mesmo a falta de acesso a tecnologias por parte desses agricultores levam a perda do material armazenado pelo ataque de roedores, insetospraga e fungos de armazenamento que reduzem a higiene dos grãos e podem produzir micotoxinas prejudiciais à saúde humana e animal (SANTOS, 2006; CRUZ et al., 2011; HAGSTRUM; PHILLIPS, 2017; SENAR, 2018).

Os grãos armazenados estão sujeitos a fatores que podem causar sua rápida degradação, fatores externos, como a temperatura e a umidade, influenciam diretamente na qualidade do produto a longo prazo, os ambientes onde não é possível realizar o controle dessas condições tornam-se propícios ao ataque de pragas (BERGAMASCHI; MATZENAUER, 2014; SENAR, 2018). Teores de umidade acima de $13 \%$ tornam os grãos mais susceptíveis ao desenvolvimento de fungos fitopatogênicos que, ao longo de sua colonização, provocam o aquecimento da massa de grãos, alterando seu aroma e sabor, enquanto que temperaturas entre 25 e $34{ }^{\circ} \mathrm{C}$ podem favorecer o estabelecimento de insetos-praga (CASELA; FERREIRA; PINTO, 2006; SENAR, 2018; ANDRADE et al., 2020).

As infestações de fungos muitas vezes iniciam em campo, fungos do gênero Fusarium spp. possuem a característica de alterar o sabor provocando o "grão ardido", tornando-se um problema para o consumo pela presença de micotoxinas como fumonisinas, zearalenona, vomitoxinas, entre outras, que podem causar danos à saúde (CASELA; FERREIRA; PINTO, 2006; JIMENEZ-GARCIA et al., 2018). O gênero Aspergillus representa um dos diversos gêneros de fungos patogênicos que causam perdas na pré e pós-colheita de grãos de milho, com aproximadamente 200 espécies que produzem metabólitos secundários que, além de causar a 
degradação do material armazenado e perda econômica, podem provocar intoxicações ou ser letal para humanos e animais, não só através do consumo, mas também a exposição aos esporos pode causar danos ao agricultor que está diariamente nas instalações de armazenamento de grãos, podendo causar doenças pulmonares, insuficiência hepática e levar à morte (ELIAS et al., 2015; SCAZZOCCHIO, 2019). O gênero Colletotrichum é um dos mais comuns associados a problemas de pós-colheita, causando a doença conhecida por antracnose, que se caracteriza como o apodrecimento do tecido vegetal e pode causar perdas de até $100 \%$ da produção em condições de armazenamento (DEAN et al., 2012)

Um outro fator a ser mencionado é a presença de insetos-praga, o Sitophilus zeamais Motsch., Sitotroga cerearella Olivier e Prostephanus truncatus Horn são os insetos de maior relevância para o milho em condições de armazenamento, causando percas pelo consumo do grão, reduzindo o seu peso, provocando a diminuição do valor econômico do produto pela presença de ovos e excrementos dos insetos e redução do valor nutricional, além de diminuir a capacidade de germinação das sementes e causar o aquecimento dos grãos, os insetos podem ainda ser disseminadores de esporos de fungos e o dano causado no grão pode servir de entrada para microrganismos fitopatogênicos por aumentarem a susceptibilidade do milho a agentes externos (SANTOS, 2006; ELIAS et al., 2015; LORINI, 2015).

Medidas para atenuar os prejuízos causados por essas pragas devem ser tomadas desde o campo, o controle com químicos sintéticos é o mais difundido, mas apresenta pontos negativos como o seu alto custo e a presença de resíduos nos alimentos e no ambiente, sendo um risco tanto para a saúde humana quanto para o agroecossistema, porém é fundamental práticas como a colheita no estádio de desenvolvimento correto, a limpeza, secagem e seleção dos grãos sadios a fim de evitar infestações oriundas do campo, além disso, outras estratégias podem ser tomadas, os recipientes e/ou embalagens utilizadas para armazenar devem ser uma aliada na hora de guardar tais produtos, sacos hermeticamente fechados com umidade de $18 \%$ são capazes de reduzir a população de S. zeamais durante 180 dias pelo aumento da concentração de dióxido de carbono na embalagem, levando os gorgulhos à morte, mas em contrapartida favorecem o aparecimento de fungos que produzem micotoxinas, o uso de variedades resistentes ao ataque de pragas e doenças que possuem características físicas como a dureza e densidade ou químicas como conteúdo de proteína bruta e teor de amilose podem tornar os grãos mais resistentes ao ataque e estabelecimento de fungos e diminuir o consumo dos insetos e consequentemente diminuir a velocidade de infestação, o controle biológico com espécies como Heterorhabditis bacteriophora, Steinernema carpocapsae e S. feltiae mostra-se promissor ao reduzir algumas populações de insetos-praga, mas ainda está longe da realidade 
do agricultor (LIKHAYO et al., 2018; MBATA; IVEY; SHAPIRO-ILAN, 2018; SENAR, 2018; NGOM et al., 2020).

Para o controle de pragas de produtos armazenados, as técnicas foram aprimoradas ao longo dos anos e também passada por diversas gerações os conhecimentos obtidos, a troca e o comércio de mercadorias favoreceu a disseminação de doenças e pragas agrícolas, com isso, o uso de cinzas e carvão vegetal, pó de giz e utilização de plantas tóxicas foram algumas das técnicas utilizadas na antiguidade para reduzir a perda de produtos armazenados (HAGSTRUM; PHILLIPS, 2017).

Dessa forma, o manejo de pragas de grãos armazenados pode ser realizado de diversas outras maneiras, a utilização de produtos alternativos à base de vegetais para a conservação de sementes e grãos pode reunir diversos mecanismos de ação e reduzir os níveis de infestação de insetos e fungos, agregando mais uma forma de combate contra os problemas nos grãos (HIKAL; BAESHEN; SAID-AL AHL, 2017; RIBEIRO; VENDRAMIM, 2019). Produtos botânicos são uma alternativa aos químicos sintéticos pela acessibilidade e baixo custo de produção, sendo uma tecnologia viável para agricultores com poucos recursos financeiros (MIDEGA et al., 2016; OKEREKE; GODWIN-EGEIN; MORDI, 2017; MACHINGURA, 2019).

A partir disso, buscou-se investigar através de uma revisão da literatura estratégias de controle sustentável e de baixo custo que apresentam evidencias científicas a respeito de sua eficiência contra os principais fungos e insetos-praga relacionados ao armazenamento do milho.

A pesquisa trata-se de uma revisão da literatura de caráter qualitativa. Foram selecionados trabalhos científicos entre os anos de 2016 a 2020 nas plataformas Science Direct, Portal de periódicos CAPES e Google Acadêmico nos idiomas português e inglês com a ajuda dos descritores: Zea mays, armazenamento e produtos botânicos. Os trabalhos científicos encontrados foram submetidos a avaliação de título e resumo, e os que se enquadraram no tema principal foram selecionados. Após essa triagem, os estudos foram analisados buscando extrair as informações desejadas para a construção deste trabalho.

\section{Desenvolvimento}

O controle dos problemas fitossanitários em armazenamentos de grãos de milho pode ser realizado com a utilização de extratos, óleos e pós derivados de espécies vegetais, sejam folhas, raízes, frutos, ramos ou sementes que muitas vezes são encontradas na propriedade rural do agricultor ou são materiais possíveis de serem adquiridos por um baixo custo, esses produtos atuam como deterrente alimentar ou de oviposição, repelente, como regulador de crescimento 
ou inibindo a progênie dos insetos, nos fungos, cessa o crescimento, impede o estabelecimento da colônia ou retarda seu crescimento, entre outros fatores que garantem sucesso na sua utilização (TOFEL et al., 2016; HAGSTRUM; PHILLIPS, 2017; AGALE et al., 2020).

\subsection{Extratos}

O extrato de folhas de Corchorus olitorius L. impediu completamente o crescimento das colônias fúngicas de Fusarium sp. e Aspergillus sp. (AKWAJI; UMANA; OKON, 2016). Em ensaios in vitro os extratos aquosos de Gongronema latifolium Benth. e Vernonia amygdalina Delile reduziram consideravelmente o crescimento de A. niger, extrato das sementes de Moringa oleífera Lam. apresentou eficácia de 95,5\% no controle de fungos de armazenamento e não comprometeu a qualidade de germinação das sementes, já o extrato de Piper nigrum L. inibiu o desenvolvimento de fungos em sementes de milho estocadas e não prejudicou a germinação (FONTE, 2016; OKEREKE; GODWIN-EGEIN; MORDI, 2017; SILVA, 2018).

O extrato etanólico de folhas de Chromolaena odorata L. em S. zeamais reduziu a progênie, porém não apresentou efeito repelente sobre os adultos (JNR; ABUGRI; AFUN, 2016). Extratos de espécies da família Annonaceae mostram-se promissores no controle do $S$. zeamais por causar mortalidade e reduzir drasticamente a progênie (RIBEIRO, 2016). Extratos aquosos de folhas de Pterocarpus santalinoides causou mortalidade e diminuição da emergência de adultos de $S$. zeamais, aumentando a mortalidade a medida que os insetos foram expostos a doses e períodos de tempo maiores, em consequência, os danos por perfuração e a perca de peso diminuíram (NKECHI et al., 2018). O extrato de folhas de Eucalyptus sp. foi capaz de controlar a população de $S$. zeamais por 3 meses em condições de armazenamento (TANKA, 2018). O extrato de Hyptis suaveolens L. causou repelência de insetos de S. zeamais, além disso, foi capaz de diminuir a emergência e causar mortalidade (GARIBA, 2018).

O extrato preparado com a casca de Citrus sinensis L. foi capaz de controlar as infestações de $S$. cerealella sem afetar a qualidade de germinação das sementes do milho, garantindo a qualidade fisiológica e diminuindo a perca de peso das sementes (CARVALHO et al., 2017).

Em P. truncatus os extratos de Lantana camara L., M. oleifera, C. sinensis e Hyptis suaveolens L. reduziu a sobrevivência dos insetos quando os extratos foram aplicados na fase de ovo e também houve redução na emergência de adultos, porém $H$. suaveolens obteve maior atividade repelente sobre os insetos, esses extratos formam capazes de diminuir os danos durante o período de armazenamento (GARIBA, 2018). 


\section{2 Óleos}

O óleo essencial de Curcuma longa L. apresentou efeito antifúngico e antiaflatoxigênica em A. flavus (HU et al., 2017). Os óleos essenciais de Cinnamomum sp. e Cymbopogon sp. foram eficazes no controle de Aspergillus sp. (MORAES, 2018). O óleo de Zingiber officinale Rosc. foi capaz de inibir o crescimento e a produção de aflotoxinas de $A$. flavus, sendo uma alternativa aos controles sintéticos (NERILO et al., 2020).

Óleo essencial do rizoma de Cochlospermum panchonii Hook ao ser avaliado em sementes de milho conseguiu reduzir o crescimento micelial de $C$. graminicola e não afetou o vigor germinativo das sementes (OUATTARA, et al., 2018). O óleo essencial de Cymbopogon winterianus Jowitt inibiu o crescimento de C. gloeosporioides e C. falcatum por diminuir a germinação dos esporos dos fungos (BALENDRES; CUEVA, 2019). O oléo essencial de Caryocar brasiliense Cambess mostrou-se eficaz no controle de Colletotrichum sp. (LIMA, 2019).

O óleo de Lippia graveolens Kunth. apresentou compostos que podem causar toxicidade fumigante contra $S$. zeamais e inibiu o crescimento de $F$. verticillioides demonstrando sua capacidade protetora (PESCHIUTTA et al., 2016). O óleo essencial de Eucalyptus camaldulensis Dehnh. inibiu completamente o crescimento de F. oxysporum, F. solani, F. verticillioides, $F$. proliferatum, e $F$. subglutinans, sendo sua eficácia uma importante ferramenta para a substituição de químicos sintético (GAKUUBI; MAINA; WAGACHA, 2017). O oléo essencial de Cananga odorata inibiu o crescimento fúngico de $F$. graminearum e reduziu a produção de micotoxinas por ele produzido (KALAGATUR et al., 2018). O óleo essencial de Cymbopogon martinii diminuiu o crescimento micelial de $F$. verticillioides reduzindo também o número de sementes de milho infectadas pelo fungo (ALVES et al., 2019). Os óleos essenciais de Cinnamomum zeylanicum, folhas de C. martinii, Citrus aurantium L. $e$ Mentha viridi L. demonstraram ser eficazes na redução da quantidade de zearalenona produzida por Fusarium spp., além de dificultar o crescimento do fungo (PERCZAK et al., 2020).

Os óleos essenciais de Syzygium aromaticum L. e Mentha pulegium L. possuem capacidade antifúngica em condições de armazenamento (BENTO, 2016) O óleo das folhas de Lippia multiflora Moldenk em A. flavus impediu o crescimento fúngico, porém também impediu a germinação das sementes de milho (MOHAMED et al., 2020).

O óleo de Ocimum kilimandscharicum Guerke foi capaz de reduzir os danos causados por S. zeamais (SM et al., 2018). O óleo extraído das sementes de Azadirachta indica A. Juss, apesar de não causar mortalidade direta dos adultos de $S$. zeamais, é capaz de causar efeitos subletais, ele inibe a alimentação deste inseto, o que pode ter levado a morte por desnutrição, 
atua como regulador de crescimento, podendo causar mortalidade em estágios imaturos e afeta a progênie e assim, diminui a infestação ao longo das gerações, chegando a eliminação da progênie em alguns casos, além disso, o óleo de $A$. indica consegue manter suas propriedades inseticidas por mais tempo quando comparado a óleos de Cymbopogon winterianus Jowitt, Cinnamomum verum L. e Eucalyptus globulus L. (TOFEL et al., 2016; TOFEl et al., 2017; MINKS, 2019). Em S. zeamais o óleo das folhas de Croton rudolphianus Müll. Arg. causou mortalidade dos insetos adultos por ingestão, quando utilizado no substrato alimentar, e também morte por contato ao ser aplicado diretamente nos insetos, além de apresentar efeito atrativo aos insetos (RIBEIRO et al., 2019). O óleo de L. camara causou repelência de S. zeamais (AYALEW, 2020).

Quando utilizado os óleos de Artemisia khorassanica Podl. e Artemisia sieberi Bess em S. cerealella, além de causar mortalidade, em baixas concentrações eles provocaram efeitos subletais, como o aumento do tempo de desenvolvimento dos ovos e diminuição da fase adulta e da fecundidade do inseto-praga (NASERI et al., 2017). O óleo essencial das raízes de Carlina acaulis L. causou mortalidade superior a $97 \%$ em indivíduos de P. truncatus quando expostos por 3 dias (KAVALLIERATOS et al., 2020).

\subsection{Pós}

O pó das folhas de Plectranthus glandulosus Hook foi capaz de causar mortalidade em S. zeamais e sua eficiência continuou alta mesmo quando as folhas foram submetidas a secagem ao sol, indicando que os componentes que causam a mortalidade dos insetos não são perdidos quando o material vegetal é exposto a radiação solar (TOFEl et al., 2017). A terra de diatomácea é uma outra alternativa no controle de $S$. zeamais, apesar de não ser de origem vegetal, é um pó inerte que tem efeito abrasivo que ao entrar em contato com a epicutícula do inseto rompe a camada de cera protetora e induz a perda de água do corpo do inseto, causando morte por dessecação e, por isso, pode ser utilizada em conjunto com produtos botânicos para garantir a eliminação dos problemas (RIBEIRO; LOVATTO; VENDRAMIM, 2018).

O Pó de Eucalyptus citriodora Hook foi capaz de repelir S. zeamais, diminuindo a oviposição na massa de grãos (MACHINGURA, 2019). Os pós de Nicotiana tabacum L., Coffea arábica L. e Baccharis trimera Less. foram capazes de reduzir a alimentação larval de $S$. zeamais, além de diminuir a quantidade e o peso de insetos adultos emergidos, causando um menor consumo de grãos (WENNECK et al., 2020). O pó de folhas de $L$. camara apresentou atividade repelente contra S. zeamais (AYALEW, 2020). 
Em S. cereallela o pó de folhas A. indica de foi capaz de controlar a praga em condições de armazenamento (VERMA et al., 2016). O pó de Aloe marlothii mostrou ser eficaz no controle de P. truncatus, garantindo a sanidade dos grãos estocados (MUCHIRIRI, 2018). Os pós foliares de Chromolaena odorata, Tithonia diversifolia Hemsl., Theobroma cacao L., A. indica, Citrus sinensis L. quando utilizados junto ao pó de própolis mostraram eficácia no controle de $P$. truncatus em milho armazenado (OSIPITAN et al., 2018). O Pó de E. citriodora foi capaz de repelir P. truncates (MACHINGURA, 2019).

\subsection{Discussão}

Os extratos, óleos e pós obtidos de espécies vegetais é uma ferramenta importante na manutenção da sanidade no ambiente de armazenamento, pois possuem diversos compostos que atuam de diferentes formas, tanto no controle do crescimento fúngico, na germinação de esporos e na produção de micotoxinas, como na mortalidade e fisiologia do inseto, variando de acordo com a espécie vegetal utilizada (HIKAL; BAESHEN; SAID-AL AHL, 2017; HU et al., 2017; AGALE et al., 2020).

A repelência é uma característica relevante, visto que evita que os insetos-praga se estabeleçam no milho, evitando assim a perda pelo ataque da praga, alguns fungos como o $F$. verticillioides, que causa a podridão do milho, é um fungo de armazenamento que quando há a interação fungo-grão emite compostos orgânicos voláteis que tornam o grão menos atrativo para o S. zeamais e, dessa forma, reduz o dano pelo inseto, causando um efeito protetor aos grãos de milho, porém aumenta o dano pelo fungo (USSEGLIO et al., 2017; MACHINGURA, 2019).

Produtos alternativos à base de vegetais que apresentam atividade atrativa e inseticida podem ser utilizados como iscas tóxicas, uma vez que quando misturados ao substrato alimentar tornam-se mais atrativos que o substrato sozinho, dessa forma, mesmo quando o controle não apresenta $100 \%$ de eficácia, ele ainda pode ser utilizado alinhado a outras práticas de manejo para garantir a sanidade do milho armazenado (BENTO, 2016; HIKAL; BAESHEN; SAIDAL AHL, 2017; RIBEIRO et al., 2019).

A utilização dos pós é uma ferramenta interessante, uma vez que cria uma barreira física entre o grão e o fungo e/ou inseto, dificultando o estabelecimento, além disso, em insetos podem causar asfixia por obstruir os espiráculos e traqueias, já os óleos essenciais apesar de serem ferramentas mais seguras em relação aos inseticidas químicos, apresentam limitações como o sabor residual que alguns óleos podem deixar nos grãos, utilizar doses menores pode melhorar 
o gosto, mas ao mesmo tempo diminui a capacidade fungicida e inseticida (TOFEL et al., 2016; HAGSTRUM; PHILLIPS, 2017; HIKAL; BAESHEN; SAID-AL AHL, 2017).

Outros fatores que podem ser limitantes à utilização de produtos vegetais é em relação a sua ação ao longo do tempo, algumas propriedades que garantem a capacidade fungicida e inseticida de extratos, óleos e pós podem se degradar facilmente com a temperatura, exposição à luz e umidade, causando um decréscimo na sua eficiência à medida que aumenta o tempo acondicionado, por outro lado, a alta volatilidade dos óleos pode ser um ponto positivo ao ser utilizada na fumigação de insetos, uma vez que apresentam baixo risco para o produtor ao manusear o produto, outro ponto importante é que muitos desses óleos utilizados apresentam diversos compostos com ação fungicida que inibem a produção de micotoxinas, podendo atuar tanto no inseto quanto no fungo (TOFEL et al., 2016; NASERI et al., 2017; KALAGATUR et al., 2018).

Os produtos de origem vegetal mostram-se promissores no controle de fungos e insetos de armazenamento, a utilização deles alinhada a boas práticas de colheita e pós-colheita pode garantir uma vida útil maior e com melhor qualidade para os grãos e sementes de milho (MIDEGA et al., 2016; AGALE et al., 2020).

Ainda assim é importante a realização de avaliações quanto a durabilidade em condições reais de armazenamento para garantir uma maior vida útil desses produtos, a fitotoxidez no milho é outro parâmetro a ser analisado, pois mesmo possuindo atividade fungicida ou inseticida, alguns produtos podem diminuir a qualidade da semente e do grão armazenado, ainda é necessário a investigação de seus efeitos em organismos não-pragas (SOUJANYA et al., 2016; TOFEL et al., 2016; MORAES, 2018).

\section{Considerações Finais}

A partir do levantamento bibliográfico efetuado, esta revisão fornece um panorama a respeito de algumas espécies vegetais e suas formas de uso que podem ser empregadas no controle de fungos e insetos-praga no armazenamento do milho realizado na agricultura familiar, podendo ser aplicadas na forma de extratos, óleos ou pós. Os óleos vegetais se destacam como estratégias promissoras no combate de diversas espécies de fungos e insetos.

A alta degradabilidade ao longo do tempo é um fator interessante a medida que não gera resíduos para o meio ambiente, mas pode ser um fator limitante devido ao seu curto prazo de proteção, dessa forma, esses produtos podem ser empregados alinhados a outras práticas de conservação dos grãos e sementes que iniciam desde a colheita, seleção do material a ser 
guardado e do recipiente a ser utilizado, assim o agricultor poderá contar com mais uma tática de proteção para a sua produção.

São necessárias mais pesquisas a respeito do potencial de espécies locais para a proteção de grãos, assim como da associação de diferentes produtos vegetais e também o seu efeito em inimigos-naturais.

Por fim, é fundamental ações de assistência técnica e extensão rural que visem difundir esses conhecimentos, visto que são estratégias sustentáveis e de baixo custo para os agricultores familiares.

\section{Referências}

AGALE, S. V. et al. Chapter-3 Botanicals Methods of Plant Disease Control. Current Research and Innovations in Plant Pathology, p. 29, 2020.

AKWAJI, P. I.; UMANA, E. J.; OKON, E. I. Phytochemical and Antifungal Activity of Leaf Extracts of Corchorus olitorius and Gongronema latifolium on Fungi Associated with PostHarvest Deterioration of Maize (Zea mays) Seeds in Oban Community, Nigeria. World Scientific News, v. 53, n. 3, p. 157-177, 2016.

ALVES, F. et al. Control of Fusarium verticillioides using Palmarosa essential oil (Cymbopogon martinii). Int. J. Curr. Microbiol. App. Sci, v. 8, n. 5, p. 484-494, 2019.

ANDRADE, J. G. et al. Diagnóstico das técnicas de produção e armazenamento de sementes crioulas em assentamentos rurais de Aparecida, Paraíba, Brasil. Research, Society and Development, v. 9, n. 5, p. e130953147, 2020.

AYALEW, A. A. Insecticidal activity of Lantana camara extract oil on controlling maize grain weevils. Toxicology Research and Application, v. 4, p. 1-10, 2020.

BALENDRES, M. A. O.; CUEVA, F. M. D. Growth-inhibiting activity of citronella essential oil to multiple fungal plant pathogens. bioRxiv, p. 860718, 2019.

BENTO, M. G. R. Avaliação da atividade fungicida de óleos essenciais e suas substâncias ativas no controlo de fungos de armazenamento. 2016. $121 \mathrm{f}$. Dissertação (Mestrado em Engenharia Agronómica, especialização em Proteção de Plantas) - Instituto Superior de Agronomia da Universidade de Lisboa, Lisboa, 2016.

BERGAMASCHI, H.; MATZENAUER, R. O milho e o clima. Porto Alegre: Emater/RSAscar, 2014. 84 p.

CARVALHO, R. L. L. et al. Controle alternativo de Sitotroga cerealella em sementes de milho armazenadas. Biodiversidade, v. 16, n. 1, 2017.

CASELA, C. R.; FERREIRA, A. S.; PINTO, N. F. J. A. Doenças na Cultura do Milho. Sete Lagoas - MG: Embrapa, 2006, 14 p. (Circular técnica, 83). 
CONAB, Companhia Nacional de Abastecimento. Acompanhamento de safra brasileiro grãos: Quinto levantamento, fevereiro 2020 - safra 2019/20. Brasília: Companhia Nacional de Abastecimento. 2020. Disponível em: https://www.conab.gov.br/index.php/infoagro/safras/graos. Acesso em: 03 jul. 2020.

CRUZ, J. C. et al. Produção de milho na agricultura familiar. Sete Lagoas - MG: Embrapa, 2011, 42 p. (Circular técnica, 159).

DEAN, R. et al. The Top 10 fungal pathogens in molecular plant pathology. Molecular plant pathology, v. 13, n. 4, p. 414-430, 2012.

ELIAS, M. C. et al. Tecnologias de pré-armazenamento, armazenamento e conservação de grãos. Material didático. Universidade Federal de Pelotas. Pelotas, RS, 2015.

FONTE, R. N. Uso de extratos vegetais e terra diatomácea associados ao condicionamento fisiológico no tratamento e armazenamento de sementes de milho (Zea mays L.). 2016. 102 f. Tese (Doutorado em Fitotecnia) - Universidade Federal Rural Do Rio De Janeiro, Seropédica, RJ, 2016.

GAKUUBI, M. M.; MAINA, A. W.; WAGACHA, J. M. Antifungal activity of essential oil of Eucalyptus camaldulensis dehnh. against selected Fusarium spp. International journal of microbiology, v. 2017, 2017.

GARIBA, Y. S. Assessment of Four Plant Extracts as Maize Seed Storage Protectants against Sitophilus Zeamais and Prostephanus Truncatus in Ghana. 2018. Tese de Doutorado. University of Ghana.

HAGSTRUM, D. W.; PHILLIPS, T. W. Evolution of Stored-Product Entomology: Protecting the World Food Supply. Annual Review of Entomology, p. 379-397, 2017.

HIKAL, W. M.; BAESHEN, R. S.; SAID-AL AHL, H. A. H. Botanical insecticide as simple extractives for pest control. Cogent Biology, v. 3, p. 1-16, 2017.

HU, Y. et al. Mechanisms of antifungal and anti-aflatoxigenic properties of essential oil derived from turmeric (Curcuma longa L.) on Aspergillus flavus. Food chemistry, v. 220, p. 1-8, 2017.

JIMENEZ-GARCIA, S. N. et al. Fusarium Mycotoxins and Metabolites that Modulate Their Production. Fusarium - Plant Diseases, Pathogen Diversity, Genetic Diversity, Resistance and Molecular Markers, 2018. DOI: 10.5772/intechopen.72874. Disponível em: https://www.intechopen.com/books/fusarium-plant-diseases-pathogen-diversity-geneticdiversity-resistance-and-molecular-markers/fusarium-mycotoxins-and-metabolites-thatmodulate-their-production. Acesso em: 29 jul. 2020.

JNR, I. Y.; ABUGRI, A. D.; AFUN, J. V. K. Efficacy of ethanolic leaf extract of Chromolaena odurata in controlling Sitophilus zeamais in stored maize. Journal of Experimental Agriculture International, p. 1-10, 2016.

KALAGATUR, N. K. et al. Discrete and combined effects of Ylang-Ylang (Cananga odorata) essential oil and gamma irradiation on growth and mycotoxins production by Fusarium graminearum in maize. Food Control, v. 94, p. 276-283, 2018. 
KAVALLIERATOS, N. G. et al. Effectiveness of eight essential oils against two key storedproduct beetles, Prostephanus truncatus (Horn) and Trogoderma granarium Everts. Food and Chemical Toxicology, v. 139, p. 1-13, 2020.

LIKHAYO, P. et al. Maize grain stored in hermetic bags: Effect of moisture and pest infestation on grain quality. Journal of Food Quality, p. 1-9, 2018.

LIMA, J. C. L. Manejo fitossanitário da cultura do milho (Zea mays L.) utilizando defensivos naturais. 2019. $56 \mathrm{f}$. Trabalho de conclusão (Bacharelado em Engenharia de Biossistemas) - Universidade Federal de Campina Grande, Sumé, 2019.

LORINI, I. Perdas anuais em grãos armazenados chegam a $10 \%$ da produção nacional. Visão agrícola, v. 13, p. 127-129, 2015.

MACHINGURA, J. Assessment of grain protection through the incorporation of Eucalyptus citriodora leaves in grain/insecticide admixtures in Zimbabwe. Journal of Horticulture and Postharvest Research, v. 2, p. 49-60, 2019.

MBATA, G. N.; IVEY, C; SHAPIRO-ILAN, D. The potential for using entomopathogenic nematodes and fungi in the management of the maize weevil, Sitophilus zeamais (Motschulsky) (Coleoptera: Curculionidae). Biological Control, v. 125, p. 39-43, 2018.

MIDEGA, C. A. O. et al. Managing storage pests of maize: Farmers' knowledge, perceptions and practices in western Kenya. Crop Protection, v. 90, p. 142-149, 2016.

MINKS, F. Ação de óleos essenciais na persistência da mortalidade do gorgulho e sobre atributos de qualidade fisiológica de sementes de milho. 2019. $34 \mathrm{f}$. Trabalho de conclusão (Bacharelado em agronomia) - Universidade Federal da Fronteira Sul, Cerro Largo - RS, 2019.

MOHAMED, C. et al. Use of bioactive chitosan and Lippia multiflora essential oil as coatings for maize and sorghum seeds protection. EurAsian Journal of BioSciences, v. 14, n. 1, p. 27 34, 2020.

MORAES, S. P. C. B. Controle com óleos essenciais dos fungos Aspergillus sp. e Sclerotinia sclerotiorum no tratamento de sementes de feijão durante o armazenamento. 2018. $81 \mathrm{f}$. Dissertação (Mestrado em Produção Vegetal) - Universidade Federal do Espírito Santo, Alegre, 2018.

MUCHIRIRI, B. Efficacy of Aloe Marlothii Formulations in Controlling Larger Grain Borer (Prostephanus Truncatus) in Different Maize (Zea Mays) Varieties. 2018. Tese de Doutorado. BUSE.

NASERI, B. et al. Fumigant toxicity and sublethal effects of Artemisia khorassanica and Artemisia sieberi on Sitotroga cerealella (Lepidoptera: Gelechiidae). Journal of Insect Science, v. 15, n. 5, p. 1-7, 2017.

NERILO, S. B. et al. Antifungal activity and inhibition of aflatoxins production by Zingiber officinale Roscoe essential oil against Aspergillus flavus in stored maize grains. Ciência Rural, v. 50, n. 6, 2020. 
NGOM, D. et al. Varietal susceptibility of maize to larger grain borer, Prostephanus truncatus (Horn) (Coleoptera; Bostrichidae), based on grain physicochemical parameters. PLoS ONE, v. 15, n. $4, \quad 2020.40$ Disponível https://journals.plos.org/plosone/article?id=10.1371/journal.pone.0232164. Acesso em: 17 jul. 2020.

NKECHI, E. F. et al. Effects of aqueous and oil leaf extracts of Pterocarpus santalinoides on the maize weevil, Sitophilus zeamais pest of stored maize grains. African Journal of Agricultural Research, v. 13, n. 13, p. 617-626, 2018.

OKEREKE, V.; GODWIN-EGEIN, M.; MORDI, C. In vitro evaluation of leaf extracts on the growth of Aspergillus niger infecting maize grains. Azarian Journal of Agriculture, v. 4, n. 1, p. 12-17, 2017.

OSIPITAN, A. A. et al. Evaluation of bee propolis and some plant products in the management of Larger Grain Borer, Prostephanus truncatus (Coleoptera: Bostrichidae) in stored maize. International Journal of Agriculture and Biosciences, v. 7, n. 3, p. 135-138, 2018.

OUATTARA, S. et al. Antifungal activity of Cochlospermum panchonii hook rhizomes essential oil on eight phytopathogenic fungi. Research Journal of Life Sciences, Bioinformatics, Pharmaceutical and Chemical Sciences, v. 4, n. 4, p. 626-636, 2018.

PERCZAK, A. et al. The Inhibitory Potential of Selected Essential Oils on Fusarium spp. Growth and Mycotoxins Biosynthesis in Maize Seeds. Pathogens, v. 9, n. 1, p. 23, 2020.

PESCHIUTTA, M. L. et al. Effectiveness of Mexican oregano essential oil from the Dominican Republic (Lippia graveolens) against maize pests (Sitophilus zeamais and Fusarium verticillioides). AGRISCIENTIA, v. 33, n. 2, p. 89-97, 2016.

PIMENTEL, M. A. G. et al. Recomendações de boas práticas de armazenamento de milho em espiga para agricultura familiar. Embrapa Milho e Sorgo-Circular Técnica (INFOTECAE), 2011.

RIBEIRO, I. A. T. A. et al. Chemical characterization and insecticidal effect against Sitophilus zeamais (maize weevil) of essential oil from Croton rudolphianus leaves. Crop Protection, v. 129, p. 1-7, 2019.

RIBEIRO, L. P. et al. Searching for promising sources of grain protectors in extracts from Neotropical Annonaceae. Boletín Latinoamericano y del Caribe de Plantas Medicinales y Aromáticas, v. 15, n. 4, p. 215-232, 2016.

RIBEIRO, L. P.; LOVATTO, M.; VENDRAMIM, J. D. Avaliação da eficácia de duas formulações comerciais de terra de diatomácea no controle do gorgulho-do-milho com base em parâmetros toxicológicos. Agropecuária Catarinense, Florianópolis, v. 31, n. 1, p. 56-60, 2018. Disponível em: http://publicacoes.epagri.sc.gov.br/index.php/RAC/article/view/111. Acesso em: 22 jan. 2020.

RIBEIRO, L. P.; VENDRAMIM, J. D. Associação de extratos vegetais e terra de diatomácea no controle do gorgulho-do-milho Sitophilus zeamais MOTS. (Coleoptera: Curculionidae). 
Revista Brasileira de Agropecuária Sustentável, v. 9, n. 1, p. 9-16, 2019. Disponível em: https://periodicos.ufv.br/rbas/article/view/7966. Acesso em: 21 jan. 2020.

SANTOS, J. P. Controle de Pragas Durante o Armazenamento de Milho. Sete Lagoas MG: Embrapa, 2006, 20 p. (Circular técnica, 84).

SCAZZOCCHIO, C. Aspergillus: A Multifaceted Genus. Encyclopedia of Microbiology, p. 262-292, 2019.

SENAR, Serviço Nacional de Aprendizagem Rural. Grãos: armazenamento de milho, soja, feijão e café. Brasília: Senar, 2018. 100 p. (Coleção SENAR 216). Disponível em: https://www.cnabrasil.org.br/assets/arquivos/216-ARMAZENAMNTOS-GR\%C3\%83OS.pdf. Acesso em: 10 jun. 2020.

SILVA, M. I. P. Avaliação do extrato vegetal de moringa no controle de fungos em sementes de milho. 2018. $38 \mathrm{f}$. Trabalho de conclusão (Bacharelado em Engenharia agrícola e ambiental) - Universidade Federal de Mato Grosso, Rondonópolis, 2018.

SM, K. et al. Bioefficacy of Selected Plant Extracts against Sitophilus zeamais on Post-Harvest Management of Zea mays. The Journal of Phytopharmacology, v. 7, n. 4, p. 384-391, 2018. Disponível em: http://www.phytopharmajournal.com/Vol7_Issue4_06.pdf. Acesso em: 03 jun. 2020.

SOUJANYA, P. L. et al. Potentiality of botanical agents for the management of post harvest insects of maize: a review. Journal of Food Science and Technology, v. 53, p. 2169-2184, 2016.

TANKA, V. D. Effect of Temperature On, And the Efficacy of Eucalyptus Leaf Extracts Against Sitophilus Zeamais Motschulsky (Coleoptera: Curculionidae) in Stored Maize. 2018. Tese de Doutorado. University of Ghana.

TOFEL, K. H. et al. Degradation of azadirachtin A on treated maize and cowpea and the persistence of Azadirachta indica seed oil on Callosobruchus maculatus and Sitophilus zeamais. Journal of Stored Products Research, v. 69, p. 207-212, 2016.

TOFEL, K. H. et al. Insecticidal products from Azadirachta indica and Plectranthus glandulosus growing in Cameroon for the protection of stored cowpea and maize against their major insect pests. Industrial Crops \& Products, v. 110, p. 58-64, 2017.

USSEGLIO, V. L. et al. Volatile organic compounds from the interaction between Fusarium verticillioides and maize kernels as a natural repellents of Sitophilus zeamais. Journal of Stored Products Research, v. 73, p. 109-114, 2017.

VERMA, R. K. et al. Studies on the biology and evaluation of different plant-based powders as grain protectant against Sitotroga cerealella (Olivier) on maize grains. Research on Crops, v. 17, n. 4, p. 740-744, 2016.

WENNECK, G. S. et al. Deterrência à alimentação e à oviposição de Sitophilus zeamais Motschulsky (Coleoptera: Curculionidae) pelo uso pós vegetais em milho armazenado. Colloquium Agrariae, v. 16, n. 2, p. 50-59, 2020. Disponível em: https://revistas.unoeste.br/index.php/ca/article/view/3062. Acesso em: 23 jun. 2020. 


\title{
CAPÍTULO 16: CARACTERIZAÇÃO DE Escherichia coli ISOLADAS DE SUABES DE FRANGO DE CORTE E DE Alphitobius diaperinus EM PERÍODO PRE ABATE
}

\section{CHAPTER 16. CHARACTERIZATION OF Escherichia coli ISOLATED FROM CHICKEN SWABS AND Alphitobius diaperinus IN PRE-SLAUGHTER PERIOD}

\author{
Maísa Fabiana Menck Costa ${ }^{1}$, Ana Angelita Sampaio Baptista ${ }^{2}$, Larissa Justino ${ }^{3}$; Beatriz Queiroz dos \\ Santos $^{4}$, Renata Katsuko Takayama Kobayashi ${ }^{5}$
}

\begin{abstract}
Resumo
A avicultura é uma potência econômica para o Brasil. A utilização de antibióticos na produção animal pode levar a uma maior pressão de seleção sobre os microrganismos e consequentemente selecionar micro-organismos resistentes. Escherichia coli é apontada como um importante bioindicador de resistência aos antimicrobianos. O objetivo deste estudo foi determinar o perfil fenotípico de resistência aos antimicrobianos de Escherichia coli presentes na microbiota intestinal de aves no final do ciclo produtivo. Foram colhidos suabes de cloaca de frangos de corte (60 aves) e Alphitobios diaperinus. As amostras foram semeadas em Ágar MacConkey suplementado ou não com ciprofloxacina, e de cada meio foi selecionada uma amostra de Escherichia coli. O teste de sensibilidade aos antimicrobianos e a detecção fenotípica de betalactamases de espectro estendido (ESBL) foram realizados de acordo com CLSI e BrCast. Foram analisados 20 isolados de E. coli de suabes cloacais e quatro de Alphitobious diaperinus, os quais apresentaram elevada resistência a Sulfametoxazol + trimetoprim e ampicilina, e 100\% dos isolados em Ágar MacConkey suplementado com ciprofloxacina foram multirresistentes. É possível concluir que existe um alto perfil de resistência em isolados de Escherichia coli da microbiota intestinal de frangos de corte no período pré-abate e de Alphitobius diaperinus e que este pode atuar como veiculador e manter estes micro-organismos no ambiente.
\end{abstract}

Palavras-Chaves: Escherichia coli, Frango de corte, Resistência antimicrobianos, Ciprofloxacina.

\begin{abstract}
Poultry farming is an economic power for Brazil. The use of antibiotics in animal production can lead to greater selection pressure on microorganisms and consequently select resistant microorganisms. Escherichia coli is identified as an important bioindicator of resistance to antimicrobials. The aim of this study was to determine the phenotypic resistance profile to Escherichia coli antimicrobials present in the intestinal microbiota of birds at the end of the production cycle. Swabs from broilers (60 birds) and Alphitobios diaperinus were collected. The samples were seeded on MacConkey agar supplemented or not with ciprofloxacin, and a sample of Escherichia coli was selected from each medium. The sensitivity test to antimicrobials and the phenotypic detection of extended-spectrum beta-lactamases (ESBL) were performed according to CLSI and BrCast. Twenty $E$. coli isolates from cloacal swabs and four Alphitobious diaperinus were analyzed, which showed high resistance to Sulfametoxazol + trimethoprim and ampicillin, and 100\% of the isolates on MacConkey Agar supplemented with ciprofloxacin were multidrug-resistant. It is possible to conclude that there is a high

\footnotetext{
${ }^{1}$ Mestranda em Microbiologia, CCB/UEL, maisafabi@ hotmail.com

${ }^{2}$ Docente em Medicina aviária, CCA/HV/UEL, anaangelita@uel.br

${ }^{3}$ Mestranda em Medicina Veterinária, FMVZ/UNESP, larissajustino7@ hotmail.com

${ }^{4}$ Pós graduanda em Medicina aviária, DMVP/UEL, beatriz.queiroz@uel.br

${ }^{5}$ Pós Doutorado pelo Institut Armand-Frappier, Professor Associado UEL, kobayashirkt@uel.br
} 
resistance profile in isolates of Escherichia coli from the intestinal microbiota of broilers in the pre-slaughter period and of Alphitobius diaperinus and that it can act as a carrier and maintain these microorganisms in the environments.

Keywords: Escherichia coli, Broiler, Antimicrobial resistance, Ciprofloxacin.

\section{Introdução}

O Brasil está entre os três maiores produtores de carne de frango do mundo, com a produção de aproximadamente 13 mil toneladas, atualmente é o principal país exportador, sendo o Paraná o estado brasileiro que lidera a produção e exportação (ABPA, 2019; IBGE, 2017).

O consumo per capita brasileiro da carne de frango é $42 \mathrm{~kg} / \mathrm{ano}$ (ABPA, 2018; OECD/FAO, 2019), sendo uma das proteínas de maior consumo, se enquadra como um veículo de alto risco na disseminação de patógenos zoonóticos e reservatório de resistência a antibióticos (OECD/FAO, 2019; NEU, 1992; WITTE, 1998). Uma vez que um ambiente apresente resistência, esta pode chegar a outros locais e outros países (CDC, 2019).

Em 2006 a União Europeia proibiu o uso de antimicrobianos como promotores de crescimento, desde então medidas alternativas vem sendo buscadas, o frango de corte demanda da utilização de antimicrobianos de três formas, como promotores de crescimento, como preventivos e como terapêutico. Porem independentemente da forma, e da espécie que utilize, a utilização de antimicrobianos leva a uma maior pressão de seleção e consequentemente a um maior número de microrganismos resistentes (CYOIA et al., 2019; THANNER; DRISSNER; WALSH, 2016; VAN IMMERSEEL et al., 2016).

A resistência a antimicrobianos é definida como a capacidade que um organismo adquire de poder sobreviver a um fármaco com ação bactericida ou bacteriostática. Pode ocorrer pela pressão de seleção, ou seja, os microrganismos sensíveis morrem e os organismos resistentes sobrevivem podendo aumentar sua população, por mutações pontuais no cromossomo, ou por disseminação de genes que conferem resistência (CDC, 2019).

A disseminação de genes por meio da transferência de material genético pode ocorrer por conjugação, por transdução ou por transformação. A conjugação é definida pela habilidade que alguns microrganismos possuem de transferência de material genético (plasmídeos) por pili sexuais, a transdução ocorre com o auxílio de bacteriófagos e a transformação ocorre pela absorção de DNA presente no ambiente (GIGUÈRE et al., 2010).

Escherichia coli pode ser considerada um bioindicador de resistência aos antimicrobianos, uma vez que existem muitos estudos desse microrganismo e uma importante correlação desta espécie microbiana entre humanos e animais (SEO, SHIM e LEE, 2019; 
OIKARAINEN et al., 2019; PESCIAROLI et al., 2020; THEOBALD et al., 2019; JOHNSON et al., 2012; PITOUT, 2012; MELLATA, 2013).

Escherichia coli é um bacilo anaeróbico facultativo, Gram negativo não formador de esporos, que pode apresentar flagelos peritríquios, pertence a ordem Enterobacteriales e família Enterobacteriaceae (FU et al., 2013; WILLIAMS et al., 2010).

Trata-se de um microrganismo que pode ser comensal e estar presente no trato gastrintestinal da grande maioria dos animais, dentre esses os humanos e as aves, porém também pode apresentar-se como um microrganismo patogênico, levando a enfermidades no trato gastrointestinal de humanos (ex.: O157:H7), ou no sistema urinário (ex.: J96) e em aves, levar a um quadro de colibacilose (BIDÊ; BANARCORSI; BINGEN, 2012; KAPER; KATARO; MOBLEY, 2004).

Os Alphitobius diaperinus (Cascudinhos) são insetos encontrados em aviários, e colaboram com a permanência de microrganismos patogênicos ou comensais em galpões de frangos de corte e pela permanência de microrganismos resistentes no ambiente avícola, quando não for realizado um processo de fermentação e eliminação dos insetos adequadamente (DAVIES; WRAY, 1995; CHERNAKI-LEFFER et al., 2002; VITTORI et al., 2007).

A resistência a antimicrobianos é um relevante tema na atualidade, de acordo com O’Neil (2016) estima-se que em 2050 haverá aproximadamente 10 milhões de mortes ano devido à resistência aos antimicrobianos. Mediante a situação atual com uma pandemia e altas taxas de mortalidade, fatores que afetam a vida são e serão importantes pontos de atenção e cuidado (WHO, 2020). Nos EUA os dados apontam que em 2018 ao menos 2,8 milhões de pessoas foram infectadas por microrganismos resistentes e mais de 35 mil mortes/ ano (CDC, 2019).

Dentre os antimicrobianos utilizados tanto na medicina humana quanto na medicina veterinária está a ciprofloxacina. Trata-se de uma quinolona, com espectro de ação contra a maioria dos bacilos Gram negativos, que em humanos pode ser utilizada para o tratamento contra infecções causadas por Escherichia coli, Proteus mirabilis e Pseudomonas aeruginosa (KUPCZIK et al., 2009).

A presença de microrganismo na microbiota de aves no período pré abate, é um dado importante pois pode representar a contaminação presente nas linhas de abate, com conteúdo intestinal (MELLATA, 2013).

O objetivo do presente estudo foi determinar o perfil de resistência fenotípico de Escherichia coli isoladas de frango de corte e de Alphitobius diaperinus no final do ciclo produtivo. 


\section{Material e Métodos}

\section{Colheita de Material}

As colheitas foram realizadas em duas granjas de frango de corte do norte do Paraná, sempre respeitando um período máximo de três dias anteriores ao abate. Em cada granja foram coletados de forma aleatória suabes cloacais de 30 aves. Estes foram armazenados em meio de transporte Cary-Blair e mantidos refrigerados até serem encaminhados ao Laboratório de Medicina Aviária para processamento.

Também foram coletados aleatoriamente ao longo de toda a extensão de cada galpão aproximadamente 50 Alphitobius diaperinus em potes de coleta estéreis e mantidos refrigerados até o processamento.

\section{Isolamento de Escherichia coli}

Os suabes (30) de cada granja foram agrupados em cinco pools, e incubados em água peptonada tamponada (Accumedia), por $18-20$ horas a $37^{\circ} \mathrm{C}$. Os cascudinhos foram colocados em solução salina estéril por 10 minutos, na proporção de 1:10, seguidos de imersão em álcool $70^{\circ} \mathrm{C}$ por $10 \mathrm{~min}$, retirado o excesso de umidade em papéis estéreis e então macerados em cadinhos com o auxílio de pistilos, ambos estéreis e incubados em água peptonada tamponada (Accumedia), na proporção de 1:10, por $18-20$ horas a $37^{\circ} \mathrm{C}$.

Posterior as amostras foram plaqueados em ágar MacConkey (Acumedia) sem adição de antimicrobianos (MC1) e em ágar MacConkey suplementado com ciprofloxacina $8 \mu \mathrm{g} / \mathrm{mL}$ (MC 2) (CLSI, 2019). De cada placa foi selecionada uma colônia que apresentava morfologia característica da espécie, que foram submetidas a seis testes de triagem bioquímica Ágar tríplice açúcar (TSI), Ágar indol sulfeto motilidade (SIM), Citrato, Urease, Celobiose, Lisina e Sorbitol, os dois isolados foram armazenados a $-20^{\circ} \mathrm{C}$ até o momento do uso, Tabela 1.

\section{Identificação de Escherichia coli}

Os isolados lactose positiva em ágar MC 1 e $\mathrm{MC}$ 2, foram submetidos a triagem bioquímica e identificados como E. coli quando: Ágar tríplice açúcar (TSI) - com base e bisel ácidos, produção negativa para Sulfeto de Hidrogênio (H2S) e resultado variável para a

produção de gás; Ágar indol sulfeto motilidade (SIM) - com produção de indol positiva, motilidade variável e negativo para a produção de H2S; Citrato, Urease e Celobiose - negativos assim como Lisina e Sorbitol- positivos. 


\section{Teste fenotípico de resistência a antimicrobianos}

O teste fenotípico de resistência foi realizado por aproximação de discos, conforme descrito pelo CLSI (2019) e BrCast (2019). Os antimicrobianos utilizados foram: Amoxacilinaácido Clavulânico (AMC - $20 / 10 \mu \mathrm{g}$ ), Aztreonam (ATM - 30 $\mu \mathrm{g}$ ), Cefotaxima (CTX - $30 \mu \mathrm{g}$ ),

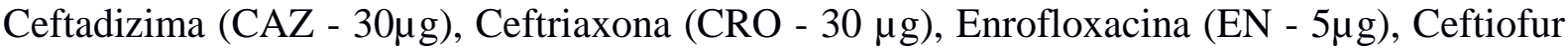

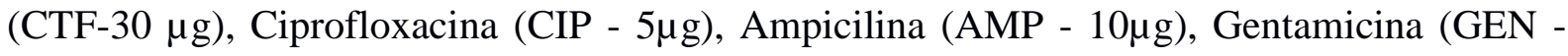

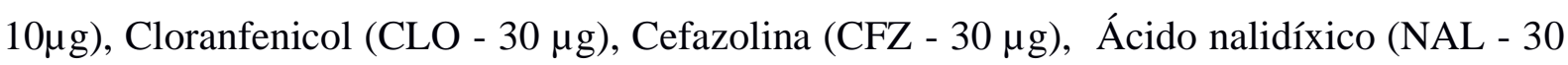

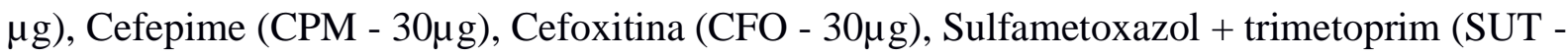
1,25/23,75 $\mu \mathrm{g}$ ), Imipenem (IMP - $10 \mu \mathrm{g}$ ), Tetraciclina (TET - $30 \mu \mathrm{g}$ ), Fosfomicina (FOS - 200 $\mu \mathrm{g})$. A cepa de Escherichia coli ATCC 25922 foi utilizada como controle padrão para o teste de antibiograma. Foram considerados isolados multirresistentes a drogas (MDR), os que apresentaram resistência a três ou mais classes de antimicrobianos (MAGIORAKOS et al., 2012).

Tabela 1. Apresentação do número de isolados com relação a sua origem.

\begin{tabular}{|c|c|c|c|}
\hline \multicolumn{2}{|c|}{ Meio de Cultura/ Origem Isolado } & $\begin{array}{c}\text { Ágar MacConkey } \\
\text { (Número de isolados) }\end{array}$ & $\begin{array}{l}\text { Ágar MacConkey CP } \\
\text { (Número de isolados) }\end{array}$ \\
\hline \multirow{6}{*}{ 莺 } & Suabe 1 & 1 & 1 \\
\hline & Suabe 2 & 1 & 1 \\
\hline & Suabe 3 & 1 & 1 \\
\hline & Suabe 4 & 1 & 1 \\
\hline & Suabe 5 & 1 & 1 \\
\hline & Alphitobius diaperinus & 1 & 1 \\
\hline \multirow{7}{*}{$\frac{\sim}{\stackrel{\widetilde{\sigma}}{\Xi}}$} & Suabe 1 & 1 & 1 \\
\hline & Suabe 2 & 1 & 1 \\
\hline & Suabe 3 & 1 & 1 \\
\hline & Suabe 4 & 1 & 1 \\
\hline & Suabe 5 & 1 & 1 \\
\hline & Alphitobius diaperinus & 1 & 1 \\
\hline & Total & 12 & 12 \\
\hline
\end{tabular}

*Ágar MacConkey 1 = sem suplementação com antimicrobianos; Ágar MacConkey 2= MacConkey suplementado com ciprofloxacina.

Fonte: Própria (2020).

\section{Teste fenotípico da produção de $\beta$-lactamase de espectro expandido}

A avaliação da produção de $\beta$-lactamase de espectro expandido (ESBL), foi realizada de acordo com o descrito pelo CLSI (2018) e BrCast (2017), com 20 mm de distância halo halo, entre os discos de amoxacilina- ácido clavulânico (AMC - 20 / $10 \mu \mathrm{g}$ ), um monobactâmco aztreonam (ATM - 30 $\mu \mathrm{g}$ ) e as cefalosporinas cefotaxima (CTX - $30 \mu \mathrm{g}$ ), ceftadizima (CAZ $30 \mu \mathrm{g})$ e ceftriaxona (CRO - $30 \mu \mathrm{g}$ ). A formação de um halo fantasma, ou distorção dos halos 
de cefalosporina ou monobactâmico quando em contato com a difusão do ácido clavulânico no meio de cultura demonstram a produção de ESBL.

\section{Resultados e Discussão}

Foram isolados ao total 24 Escherichia coli, sendo destas 12 a partir do Ágar MacConckey suplementado com ciprofloxacina e 12 sem a suplementação de antimicrobiano no meio de cultura, sendo 20 isolados de suabes cloacais e quatro isolados de Alphitobius diaperinus.

Tanto em MC1 quanto em MC2 foi observado crescimento microbiano e isolamento de Escherichia coli. Yassin et al. (2017) observaram que mais de 55\% dos seus isolados de origem avícola apresentaram resistência a ciprofloxacina sem necessidade de pré-seleção com antimicrobianos. Giufrè et al. (2012) utilizaram 101 cepas de Escherichia coli, destas 33 resistentes a ciprofloxacina, com o objetivo de comparar isolados de humanos e isolados de aves com relação ao genótipo, se eram compartilhados ou não. Em ambos os trabalhos observaram uma alta prevalência de resistência a ciprofloxacina, porém nenhum utilizou uma seleção prévia.

\section{Teste fenotípico de resistência a antimicrobianos}

Nos 10 isolados de suabe cloacal de ágar MacConkey sem suplementação com ciprofloxacina foi possível observar que o 50\% (5/10) apresentaram perfil de resistência ampicilina, seguidos para ciprofloxacina, ácido nalidíxico e sulfametoxazol + trimetoprim com $20 \%(2 / 10)$ e fosfomicina, cefazolina, gentamicina, enrofloxacina e cefotaxima com $10 \%(1 / 10)$ de resistência, Figura 1.

Dos 10 isolados de suabe cloacal proveniente do ágar MacConkey (8ug Cipro) observou-se $100 \%$ (10/10) de resistência ao ácido nalidíxico, pois trata-se da mesma classe antimicrobiana do agente de pré seleção, também apresentou 100\% (10/10) de resistência a enrofloxacina uma fluorquinolona, seguidos pela ampicilina e sulfametoxazol + trimetoprim, ambos com 70\% (7/10) de resistência, tetraciclina $60 \%$ (6/10), cefazolina e cefotaxima 50\% (5/10), Figura 2.

Foi possível observar que não houve diferença significativa no perfil de resistência a antimicrobianos nos isolados com seleção ou sem previa seleção com ciprofloxacina, sendo a Sulfametoxazol + trimetoprim e a ampicilina os antimicrobianos com maior resistência. Todavia houve diferença na quantidade de isolados com um maior perfil de sensibilidade frente aos antimicrobianos. 
Figura 1. Apresentação do perfil de sensibilidade dos isolados de Escherichia coli isolada de frangos de corte e Alphitobius diaperinus no período pré abate.

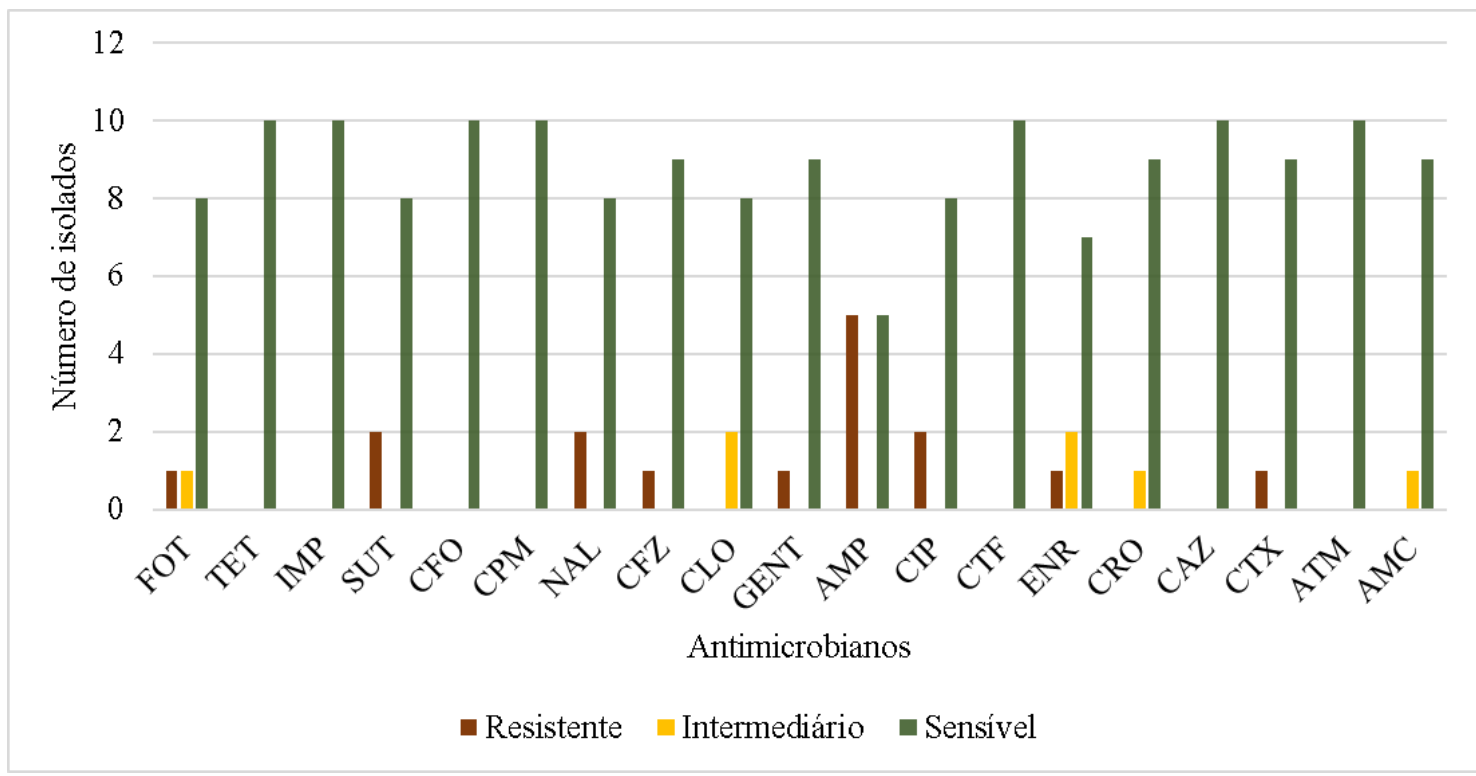

*Amoxacilina - ácido Clavulânico (AMC), Aztreonam (ATM), Cefotaxima (CTX), Ceftadizima (CAZ), Ceftriaxona (CRO), Enrofloxacina (EN), ceftiofur (CTF), Ciprofloxacina (CIP), Ampicilina (AMP), Gentamicina (GEN), Cloranfenicol (CLO), cefazolina (CFZ), Ácido nalidíxico (NAL), Cefepime (CPM), Cefoxitina (CFO), Sulfametoxazol + trimetoprim (SUT), Imipenem (IMP), Tetraciclina (TET), Fosfomicina (FOS).

Fonte: Própria (2020).

Figura 2. Perfil de sensibilidade de E.coli proveniente de suabe cloacal de frangos de corte com isolamento, utilizando MacConkey (8ug/mL cipro).

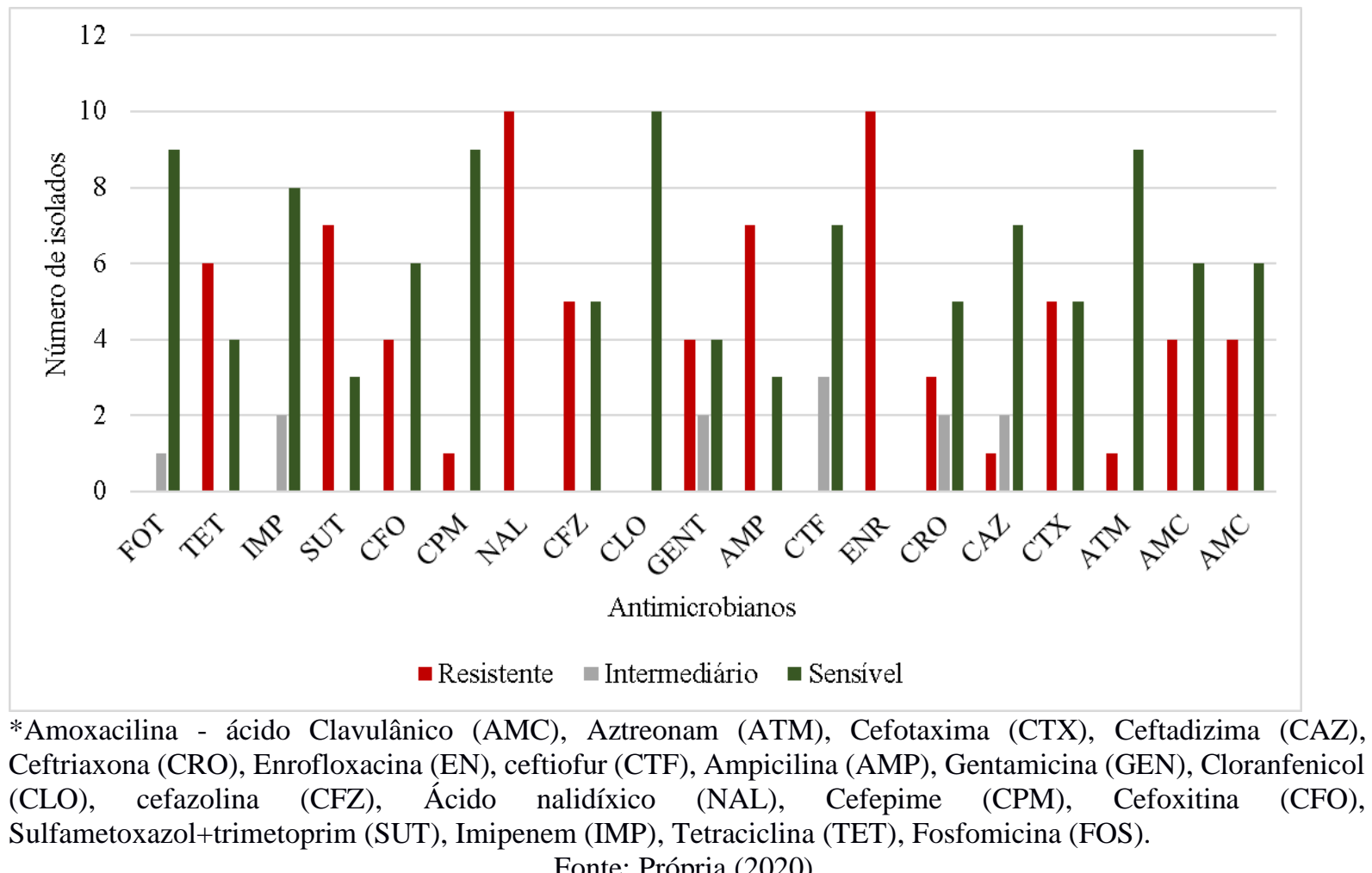
Fonte: Própria (2020).

Foi detectado 100\% (10/10) de perfil MDR em E. coli proveniente de suabe de cloaca 
de frangos com previa seleção (MC 8ug/mL) enquanto 30\% (3/10) dos isolados foram MDR quando não foi feito uso de pré seleção com antimicrobianos.

Aslantaş (2020), na Turquia, encontrou alta resistência ao ácido nalidíxico (92,9\%), ciprofloxacina (76\%), sulfametoxazol-trimetoprim $(78,6 \%)$ e tetraciclina $(73,4 \%)$ em E. coli isolada de frangos de corte Seo, Shim e Lee (2019) trabalharam com 591 isolados de E. coli, e 65 foram resistentes a cefalosporinas de terceira geração, destes 78,5\% apresentaram MDR e $27,7 \%$ foram ESBL positivos.

Foram isoladas quatros cepas de E. coli de Alphitobius diaperinus. Estes insetos podem permanecer na cama do aviário mesmo após a fermentação e podem ficar alojados na nas instalações, fissuras de pisos concretados, alimentando-se de matéria orgânica, fezes e aves mortas, colaborando com a permanência de microrganismos resistentes no ambiente.

E. coli $(\mathrm{n}=2)$ isolada em ágar MacConkey 1, originária de cascudinhos, apresentaram $100 \%(2 / 2)$ de resistência frente a tetraciclina e ácido nalidíxico, seguidos por $50 \%$ (1/2) a fosfomicina, ciprofloxacina e enrofloxacina. A maior sensibilidade foi observada à imipenem, sulfazotrim, cefoxitina, cefepime, cefazolina, cloranfenicol, gentamicina, ampicilina, ceftiofur, cefotaxima, ceftriaxona, aztreonam, ceftazidima e amoxacilina - ácido clavulânico, Tabela 2.

Já E. coli $(\mathrm{n}=2)$ isolada em MacConkey 2, foi observado 100\% (2/2) de resistência a enrofloxacina e ácido nalidíxico, seguidos pela fosfomicina, tetraciclina, cefoxitina, cefepime, cefazolina, gentamicina, ampicilina, ceftriaxona, cefotaxima, amoxacilina- ácido clavulânico, com 50\% (1/2) de resistência. E 100\% (2/2) de sensibilidade a imipenem, sulfazotrim, cloranfenicol, ceftazidima, aztreonam.

Dos isolados de Alphitobius diaperinus somente um de origem sem previa seleção com ciprofloxacina não foi MDR, todos os outros apresentaram-se multirresistentes a drogas.

E pode-se observar que os antimicrobianos com maior resistência foram a tetraciclina, a enrofloxacina, ácido nalidíxico e a fosfomicina, quando comparando-se os meios. Resistência a importantes antimicrobianos foi encontrada em cascudinhos, o que demonstra a necessidade do controle e de medidas de controle para esse coleóptero (JAPP; BICHO; SILVA, 2010).

\section{Teste fenotípico $\beta$-lactamase de espectro expandido}

Com relação a produção de $\beta$-lactamase de espectro expandido, nenhum dos isolados oriundos MC apresentou a enzima. Enquanto dos isolados em MC-CP 50\% (5/10) apresentaram a enzima produtora de ESBL, Tabela 3. 
Tabela 2. Perfil de suscetibilidade a antimicrobianos de E. coli isoladas de Alphitobius diaperinus em ágar MacConkey (MC) e Ágar MacConkey suplementado com Ciprofloxacina (8ug/mL) (MC-CP).

\begin{tabular}{|c|c|c|c|c|c|c|c|}
\hline \multirow{2}{*}{\multicolumn{2}{|c|}{ Meio para seleção/ Antimicrobianos }} & \multicolumn{2}{|c|}{ Resistente } & \multicolumn{2}{|c|}{ Intermediário } & \multicolumn{2}{|c|}{ Sensível } \\
\hline & & MC & $\mathrm{CP}$ & MC & $\mathbf{C P}$ & MC & $\mathbf{C P}$ \\
\hline \multirow{19}{*}{ 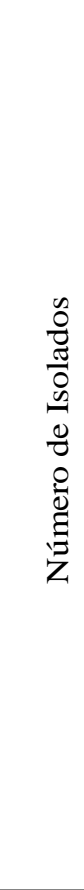 } & FOT & 1 & 1 & 0 & 0 & 1 & 1 \\
\hline & TET & 2 & 1 & 0 & 0 & 0 & 1 \\
\hline & IMP & 0 & 0 & 0 & 0 & 2 & 2 \\
\hline & SUT & 0 & 0 & 0 & 0 & 2 & 2 \\
\hline & $\mathrm{CFO}$ & 0 & 1 & 0 & 0 & 2 & 1 \\
\hline & CPM & 0 & 1 & 0 & 0 & 2 & 1 \\
\hline & NAL & 2 & 2 & 0 & 0 & 0 & 0 \\
\hline & CFZ & 0 & 1 & 0 & 0 & 2 & 1 \\
\hline & CLO & 0 & 0 & 0 & 0 & 2 & 2 \\
\hline & GENT & 0 & 1 & 0 & 0 & 2 & 1 \\
\hline & AMP & 0 & 1 & 0 & 0 & 2 & 1 \\
\hline & CIP & 1 & 2 & 0 & 0 & 1 & 0 \\
\hline & CTF & 0 & 0 & 0 & 1 & 2 & 1 \\
\hline & ENR & 1 & 2 & 1 & 0 & 0 & 0 \\
\hline & CRO & 0 & 1 & 0 & 0 & 2 & 1 \\
\hline & CAZ & 0 & 0 & 0 & 0 & 2 & 2 \\
\hline & CTX & 0 & 1 & 0 & 0 & 2 & 1 \\
\hline & ATM & 0 & 0 & 0 & 0 & 2 & 2 \\
\hline & $\mathrm{AMC}$ & 0 & 1 & 0 & 0 & 2 & 1 \\
\hline
\end{tabular}

*Amoxacilina - ácido Clavulânico (AMC), Aztreonam (ATM), Cefotaxima (CTX), Ceftadizima (CAZ), Ceftriaxona (CRO), Enrofloxacina (EN), ceftiofur (CTF), Ciprofloxacina (CIP), Ampicilina (AMP), Gentamicina (GEN), Cloranfenicol (CLO), cefazolina (CFZ), Ácido nalidíxico (NAL), Cefepime (CPM), Cefoxitina (CFO), Sulfametoxazol+trimetoprim (SUT), Imipenem (IMP), Tetraciclina (TET), Fosfomicina (FOS). **MC $=$ ágar MacConkey sem a suplementação com antimicrobianos; $\mathrm{CP}=$ ágar MacConkey acrescido de ciprofloxacina.

Fonte: Própria (2020).

Tabela 3. Número de E. coli isoladas de suabe cloacal de frangos de corte utilizando ágar MacConkey e MacConkey + CIPRO (8ug/mL) quanto a produção da enzima ESBL.

Meios de cultura/ESBL

ESBL Positivo

ESBL Negativo

\begin{tabular}{lcc}
\hline MacConkey & 0 & 10 \\
MacConkey + Ciprofloxacina $(8 \mathrm{ug} / \mathrm{mL})$ & 5 & 5 \\
\hline
\end{tabular}

*ESBL- $\beta$-lactamase de espectro expandido.

Fonte: Própria (2020).

É importante destacar que a ciprofloxacina pertence a classe das quinolonas, enquanto para a avaliação fenotípica de ESBL, são necessários cefalosporinas de $3^{\circ}, 4^{\circ}$ ou $5^{\circ}$ geração e/ ou um monobactâmico.

Estudo realizado por Matsumura et al. (2015) utilizando E. coli isolada de hospitais do Japão, demonstrou correlação entre ciprofloxacina e ESBL, sendo 396 amostras resistentes a 
ciprofloxacina de 1079 isolados de Escherichia coli produtores de ESBL, indicando que 37\% das amostras ESBL positivo eram resistentes a ciprofloxacina.

Falgenhauer et al., (2019) obtiveram 140 amostras fecais de frangos de corte de oito granjas na África, dos quais 41 (29\%) foram ESBL positivos. E eles observaram que existe uma grande diferença na prevalência de ESBL, que pode variar entre 0 a $85 \%$.

Aslantaş (2020) coletou 430 amostras de suabe cloacal de frangos de corte e destas 154 $(35,8 \%)$ foram positivas para E. coli produtora de ESBL / pAmpC.

Awoh et al. (2020) coletaram 111 amostras de fezes de aves, de 52 núcleos distintos. Destas foram isoladas 22 isolados E. coli, aproximadamente $31 \%$ foram ESBL positivos, Nigéria.

Os dados corroboram com os encontrados, nenhum dos isolados de E. coli sem previa seleção apresentaram ESBL positivo, com relação a correlação de resistência a ciprofloxacina e ESBL, com uma previa seleção $50 \%$ dos isolados foram ESBL positivo. Somente dois isolados de MC apresentaram resistência a ciprofloxacina.

\section{Conclusões}

Conclui-se que existe um alto percentual Escherichia coli isoladas da microbiota intestinal de frangos de corte no período pré abate, resistente a sulfametoxazol + trimetoprim, enrofloxacina e a ampicilina, independentemente do tipo de meio de cultura empregado. Os isolados de Escherichia coli, de Alphitobius diaperinus, apresentam alto perfil de resistência, principalmente a tetraciclina, enrofloxacina e fosfomicina. Comparando ambos os meios de cultura utilizados, os isolados em meio Macconkey suplementado com ciprofloxacina apresentaram perfil de resistência a um número maior de antimicrobianos, assim como um maior número de isolados multirresistentes a drogas e produtores de $\beta$-lactamase de espectro estendido.

\section{Referências}

ABPA. Relatório Anual. ABPA- Associação Brasileira de Proteína Animal. 2019.

ASLANTAŞ, Ö.. High occurrence of CMY-2-type beta-lactamase-producing Escherichia coli among broiler flocks in Turkey. Tropical Animal Health and Production, v. 52(4), p. 16811689, 2020.

AWORH, M. K., KWAGA, J., OKOLOCHA, E., HARDEN, L., HULL, D., HENDRIKSEN, R. S., \& THAKUR, S..Extended-spectrum B-lactamase-producing Escherichia coli among humans, chickens and poultry environments in Abuja, Nigeria. One Health Outlook, v. 2(1), p. 8. 2020. 
BIDÊ, P., BONARCORSI, S., \& BINGEN, E. [Virulence factors and pathophysiology of extraintestinal pathogenic Escherichia coli]. Archives De Pediatrie: Organe Officiel De La Societe Francaise De Pediatrie, v. 19(3), p. 80-92, 2012.

BrCAST. Brazilian Committee on Antimicrobial Susceptibility Testing (BrCAST). Versão 6.0, 2017.

CDC. Center for Disease Control and Prevention. Antibiotic/ Antimicrobial Resistance (AR/ AMR). U.s. Department of Health \& Human Services. Disponivel em: < https://www.cdc.gov/drugresistance/index.html >, Acesso em: Junho, 2020.

CHERNAKI-LEFFER, A. M., BIESDORF, S. M., ALMEIDA, L. M., LEFFER, E. V. B., \& VIGNE, F.. Isolamento de enterobactérias em Alphitobius diaperinus e na cama de aviários no oeste do estado do Paraná, Brasil. Brazilian Journal of Poultry Science, v. 4(3), p. 243-247, 2002.

CLSI. Clinical and Laboratory Standards Institute (CLSI). Performance Standards for Antimicrobial Susceptibility Testing. 28th ed. CLSI supplement M100, Wayne, Pennsylvania 19087 USA, 2018.

CLSI. Clinical and Laboratory Standards Institute. Suggested Grouping of US-FDA Approved Antimicrobial Agents That Should Be Considered for Routine Testing and Reporting on Nonfastidious Organisms by Clinical Laboratories. 29ed. CLSI guideline M100-S29. Wayne, PA: Clinical and Laboratory Institute, 2019.

CYOIA, P. S., KOGA, V. L., NISHIO, E. K., HOULE, S., DOZOIS, C. M., DE BRITO, K., DE BRITO, B. G., NAKAZATO, G., \& KOBAYASHI, R.. Distribution of ExPEC Virulence Factors, blaCTX-M, fosA3, and mcr-1 in Escherichia coli Isolated From Commercialized Chicken Carcasses. Frontiers in microbiology, v. 9, p. 3254, 2019.

DAVIES, R.h. \& WRAY, C.. Contribution of the lesser mealworm beetle (Alphitobius diaperinus) to carriage of Salmonella Enteritidis in poultry. The Veterinary Record, v. 137(16), p. 407-408, 1995.

FALGENHAUER, L., IMIRZALIOGLU, C., OPPONG, K., AKENTEN, C. W., HOGAN, B., KRUMKAMP, R., POPPERT, S., LEVERMANN, V., SCHWENGERS, O., SARPONG, N., OWUSU-DABO, E., MAY, J., \& EIBACH, D.. Detection and Characterization of ESBLProducing Escherichia coli From Humans and Poultry in Ghana. Frontiers in Microbiology, v. 9, p. 33582019.

FU, Y., DEIORIO-HAGGAR, K., ANTHONY, J., \& MEYER, M. M.. Most RNAs regulating ribosomal protein biosynthesis in Escherichia coli are narrowly distributed to Gammaproteobacteria. Nucleic Acids Research, v. 41(6), p. 3491-3503, 2013.

GIGUÈRE, S.; PRESCOTT, J. F.; BAGGOT, J. D.; WALKER, R. D.; DOWLING, P. M.. Terapia Antimicrobiana em Medicina Veterinária. 4 ed, São Paulo:Ed. Roca, 2010. 683p

IBGE.

CensoAgro, 2017. https://censoagro2017.ibge.gov.br/templates/censo_agro/resultadosagro/pecuaria.html. 
JAPP, A. K., BICHO, C. DE L., \& SILVA, A. V. F. DA.. Importância e medidas de controle para Alphitobius diaperinus em aviários. Ciência Rural, v. 40(7), p. 1668-1673, 2010.

JOHNSON, T. J., LOGUE, C. M., JOHNSON, J. R., KUSKOWSKI, M. A., SHERWOOD, J. S., BARNES, H. J., DEBROY, C., WANNEMUEHLER, Y. M., OBATA-YASUOKA, M., SPANJAARD, L., \& NOLAN, L. K.. Associations between multidrug resistance, plasmid content, and virulence potential among extraintestinal pathogenic and comensal Escherichia coli from humans and poultry. Foodborne Pathogens and Disease, v. 9(1), p. 37-46, 2012.

KAPER, J. B., NATARO, J. P., \& MOBLEY, H. L. T.. Pathogenic Escherichia coli. Nature Reviews Microbiology, v. 2(2), n. 123-140, 2004.

KUPCZIK, F.; VIALLE, L.R.G.; NOBRE L.O.; VIEIRA, L.A.; FERNANDES, A.E.. Influência da ciprofloxacina na consolidação óssea de fraturas de fêmur em ratos. Acta Ortopédica Brasileira. v.17(4), p. 228-231, 2009.

MAGIORAKOS, A. P., SRINIVASAN, A., CAREY, R. B., CARMELI, Y., FALAGAS, M. E., GISKE, C. G., HARBARTH, S., HINDLER, J. F., KAHLMETER, G., OLSSONLILJEQUIST, B., PATERSON, D. L., RICE, L. B., STELLING, J., STRUELENS, M. J., VATOPOULOS, A., WEBER, J. T., \& MONNET, D. L.. Multidrug-resistant, extensively drugresistant and pandrug-resistant bacteria: an international expert proposal for interim standard definitions for acquired resistance. Clinical microbiology and infection: the official publication of the European Society of Clinical Microbiology and Infectious Diseases, v.18(3), p.268-281, 2012.

MATSUMURA, Y., JOHNSON, J. R., YAMAMOTO, M., NAGAO, M., TANAKA, M., TAKAKURA, S., ICHIYAMA, S., KYOTO-SHIGA CLINICAL MICROBIOLOGY STUDY GROUP, \& KYOTO-SHIGA CLINICAL MICROBIOLOGY STUDY GROUP.. CTX-M-27and CTX-M-14-producing, ciprofloxacin-resistant Escherichia coli of the H30 subclonal group within ST131 drive a Japanese regional ESBL epidemic. Journal of Antimicrobial Chemotherapy, v. 70(6), p. 1639-1649, 2015.

MELLATA, M.. Human and avian extraintestinal pathogenic Escherichia coli: infections, zoonotic risks, and antibiotic resistance trends. Foodborne Pathogens and Disease, v. 10(11), p. $916-932,2013$.

NEU HC.. The crisis in antibiotic resistance. Science, v.257, p.1064-1073, 1992.

OECD/FAO, OECD-FAO Agricultural Outlook 2019-2028, OECD Publishing, Paris, 2019. https://doi.org/10.1787/agr_outlook-2019-en.

OIKARAINEN, P. E., POHJOLA, L. K., PIETOLA, E. S., \& HEIKINHEIMO, A.. Direct vertical transmission of ESBL/pAmpC-producing Escherichia coli limited in poultry production pyramid. Veterinary Microbiology, v. 231, p. 100-106, 2019.

O'NEILL.. Antimicrobial Resistance: Tackling a Crisis for the Health and Wealth of Nations. Review on Antimicrobial Resistance, 2014. Acessado em 20.08.2019. http://amrreview.org/sites/default/files/AMR\%20Review\%20Paper\%20-

20Tackling $\% 20 \mathrm{a} \% 20$ crisis $\% 20$ for $\% 20$ the $\% 20$ health $\% 20$ and $\% 20$ wealth $\% 20$ of $\% 20$ nations_1. pdf. 
PESCIAROLI, M., MAGISTRALI, C. F., FILIPPINI, G., EPIFANIO, E. M., LOVITO, C., MARCHI, L., MARESCA, C., MASSACCI, F. R., ORSINI, S., SCOCCIA, E., TOFANI, S., \& PEZZOTTI, G.. Antibiotic-resistant commensal Escherichia coli are less frequently isolated from poultry raised using non-conventional management systems than from conventional broiler. International Journal of Food Microbiology, v. 314, p. 108391, 2020.

PITOUT, J. D. D.. Extraintestinal pathogenic Escherichia coli: a combination of virulence with antibiotic resistance. Frontiers in Microbiology, v. 3, n. 9, pp. 1-7, 2012.

SEO, K. W., SHIM, J. B., \& LEE, Y. J.. Emergence of CMY-2-Producing Escherichia coli in Korean Layer Parent Stock. Microbial Drug Resistance (Larchmont, N.Y.), v. 25(3), p. 462468, 2019.

THANNER, S.; DRISSNER, D.; WALSH F.. Antimicrobial Resistance in Agriculture. MBio, American Society for Microbiology. v. 7(2), 2016.

THEOBALD, S., ETTER, E. M. C., GERBER, D., \& ABOLNIK, C.. Antimicrobial Resistance Trends in Escherichia coli in South African Poultry: 2009-2015. Foodborne Pathogens and Disease, v.16(9), p. 652-660, 2019.

VAN IMMERSEEL, F., LYHS U., PEDERSEN K., PRESCOTT J.F.. Recent breakthroughs have unveiled the many knowledge gaps in Clostridium perfringens associated necrotic enteritis in chickens: the first International Conference on Necrotic Enteritis in Poultry. Avian Pathology, v. 45, n. 3, p.269-270, 2016.

VITTORI, J., SCHOCKEN-ITURRINO, R. P., TROVÓ, K. P., RIBEIRO, C. A. M., BARBOSA, G. G., DE SOUZA, L. M., \& PIGATTO, C. P. ([s.d.]).. Alphitobius diaperinus como veiculador de Clostridium perfringens em granjas avícolas do interior paulista - Brasil.

Ciência Rural. v. 37(3), 2007.

WILLIAMS, K. P., GILLESPIE, J. J., SOBRAL, B. W. S., NORDBERG, E. K., SNYDER, E. E., SHALLOM, J. M., \& DICKERMAN, A. W. .Phylogeny of Gammaproteobacteria. Journal of Bacteriology, v. 192(9), p. 2305-2314, 2019.

WITTE W.. Medical consequences of antibiotic use in agriculture. Science, v. 279, p. 996-997. 1998.

WHO, Boletim da Organização Mundial da Saúde 2020; 98: 442-442A. doi: http://dx.doi.org/10.2471/BLT.20.268573. Disponível em

https://www.who.int/bulletin/volumes/98/7/20-268573/en/ > Acesso em : Agosto, 2020.

YASSIN, A. K., GONG, J., KELLY, P., LU, G., GUARDABASSI, L., WEI, L., HAN, X., QIU, H., PRICE, S., CHENG, D., \& WANG, C.. Antimicrobial resistance in clinical Escherichia coli isolates from poultry and livestock, China. PLoS ONE, v.12(9), p. 1-8, 2017. 


\title{
CAPÍTULO 17: CARACTERIZACAO FÍSICO-QUÍMICA DO LEITE, QUEIJO E QUEIJO MISTO MATURADO DE OVELHA CRIOULA
}

\section{CHAPTER 17: PHYSICOCHEMICAL CHARACTERIZATION OF MILK AND MATURE CHEESE FROM CRIOULA SHEEP}

\author{
Shara Vargas Roque ${ }^{1}$; Diogo Maus ${ }^{2}$
}

\begin{abstract}
Resumo
A produção do leite ovino tem aumentado, sendo a região sul responsável por $20,3 \%$ do total produzido no Brasil. No Rio Grande do Sul, a fronteira oeste tem destaque na criação de ovelhas Crioulas, que associada a produção de leite, se apresenta como uma alternativa sustentável de baixo investimento e de fácil implementação pela agricultura familiar, trazendo alternativas de renda para as pequenas e médias propriedades rurais. Dessa forma, o objetivo do trabalho foi a produção de queijo maturado a partir do leite de ovelhas Crioulas e de leite misto (mistura de leite de ovelha Crioula com leite bovino). Foram realizadas 2 formulações de queijos, sendo a primeira somente com leite de ovelhas Crioulas e outro com leite misto (50\% leite de ovelha: $50 \%$ leite bovino). Os queijos foram submetidos a caracterização físico-química e de textura. O queijo produzido com leite de ovelha Crioula apresentou maior teor de proteína e menor teor de gordura em relação ao queijo produzido a partir do leite misto. A textura dos queijos produzidos com leite de ovelha Crioula apresentou maiores valores de dureza, mastigabilidade e coesividade.
\end{abstract}

Palavras-Chaves: Ovelha Crioula, Leite, Queijo, Textura.

\begin{abstract}
Sheep milk production has increased, with the southern region accounting for $20.3 \%$ of the total produced in Brazil. Rio Grande do Sul, the western border is highlighted in the creation of Creole sheep, which associated with milk production, presents itself is a sustainable alternative, with low investment and easy implementation by family farming, bringing income alternatives to small and medium-sized rural properties. Thus, the aim of the work was the production of matured cheese from the milk of Crioula sheep and mixed milk (mixture of Crioula sheep milk and bovine milk). Two cheese formulations were produced, the first with only Crioula sheep milk and the other with mixed milk (50\% sheep milk: $50 \%$ bovine milk). Both cheeses were submitted to physical-chemical and texture characterization. The cheese produced from Crioula sheep milk had a higher protein and lower fat content in relation to cheese produced from mixed milk. Greater values of hardness, chewiness and cohesiveness were found in the texture of cheeses made from Crioula sheep milk.
\end{abstract}

Keywords: Crioula sheep, Milk, Cheese, Texture.

\footnotetext{
1 Discente de Curso de Tecnologia em Agroindústria, Instituto Federal Farroupilha - Campus Alegrete, sharavargasroque@gmail.com

2 Professor Doutor em Tecnologia de Alimentos, Instituto Federal Farroupilha - Campus Alegrete, diogo.maus@gmail.com
} 


\section{Introdução}

A Ovelha Crioula é considerada uma raça local com origem nos rebanhos introduzidos pelos jesuítas no Rio Grande do Sul durante o século XVII e do cruzamento com outras raças importadas a partir da colonização portuguesa. A raça Crioula está classificada como rara e conserva traços dos ovinos primitivos e em 1982 começou a ser preservada pela Embrapa Pecuária Sul, em Bagé-RS, sendo identificadas quatro variedades dessa raça: a Fronteira (localizada ao sul do estado do Rio Grande do Sul), a Serrana ou Crioula Preta (localizada no nordeste gaúcho e planalto catarinense), a Crioula Zebura ou Ovelha de Presépio (localizada no sul do Paraná) e a Crioula Comum ou Ovelha Ordinária (localizada acima do Paraná) (ARCOR, 2019).

A raça de ovinos Crioulos é rústica, adapta-se a diferentes condições de climática, de solo e vegetação, possuindo resistência a endoparasitas e problemas podais. A ovelha Crioula representa uma enorme importância social para os pequenos produtores rurais contribuindo para a manutenção do homem no campo (ARCOR, 2019).

A produção de leite ovino vem crescendo no Brasil, tendo sido incluída no censo agropecuário de 2017. Nesse ano foi registrado a produção de $1.652 .000 \mathrm{~L}$, sendo a região sul responsável por 20.3\% do total produzido de leite de ovelha (MAGALHÃES; LUCENA, 2019). No Rio Grande do Sul, a fronteira oeste tem destaque na criação de ovelhas Crioulas, que associada a produção de leite, se apresenta como uma alternativa sustentável de baixo investimento e de fácil implementação pela agricultura familiar, trazendo alternativas de renda para as pequenas e médias propriedades rurais.

O leite ovino apresenta maiores teores de gordura, proteínas e minerais, principalmente o cálcio, em relação aos leites de vaca ou cabra (PELLEGRINI, 2012), especialmente esse leite apresenta alto teor de proteína (5,2\%) e gordura (7,9\%) (WLASTRA, 2006), o que resulta em um alto rendimento na fabricação de queijos (aproximadamente 25\%). Praticamente toda a produção de leite de ovelha está direcionada a produção de derivados lácteos. A coloração do leite de ovelha é intensamente branca e homogênea, o que o difere do leite de vaca, pois essa característica está associada à ausência de $\beta$-caroteno, pigmento precursor do retinol (vitamina A) (PENNA, 2011).

O queijo maturado de leite de ovelha é considerado de sabor forte e marcante, principalmente devido a presença de ácidos graxos de cadeia curta e média (WLASTRA, 2006), que podem ser liberados durante a lipólise. Uma alternativa para suavizar o sabor e o aroma marcantes desse tipo de queijo é a mistura do leite de ovelha com leite de vaca. Essa mistura permite maior dispersão dos ácidos graxos de cadeia curta, equilibrando o sabor e a textura do 
queijo durante o processo de maturação. Além disso, a mistura do leite ovino e bovino é uma alternativa para as propriedades rurais em períodos sazonais, com baixa produção de leite de ovino, permitindo a padronização da produção de queijos durante todo o ano.

$\mathrm{Na}$ maturação de queijos ocorrem uma série de processos bioquímicos (glicólise, proteólise e lipólise) e microbiológicos que caracterizarão o flavor e a textura característicos de cada variedade de queijo (McSWEENEY, 2004; PERRY, 2004). A textura é um parâmetro fundamental para a avaliação dos queijos, sendo citado por Childs e Drake (2009) como o segundo fator mais importante na aceitabilidade de queijos com reduzido teor de gordura.

A textura foi definida por Bourne (1978) como o conjunto de características físicas que surgem a partir dos elementos estruturais dos alimentos, são detectados pela sensação do toque e está relacionado com a deformação, desintegração e com o fluxo dos alimentos submetidos a uma força e são medidos objetivamente por funções de massa, tempo e distâncias. A textura dos alimentos pode ser avaliada, além da avaliação sensorial, por métodos instrumentais.

O principal teste instrumental utilizado para a determinação da textura é a Análise Instrumental do Perfil de Textura (TPA). O teste simula a ação de compressão e corte dos dentes durante a mastigação, consistindo em aplicações sucessivas de forças (deformantes) ao corpo de prova, e a partir disso é possível gerar uma curva força x tempo, do qual podem ser extraídos os parâmetros de textura como a dureza, mastigabilidade, elasticidade e coesividade (BOURNE, 2002).

A mudança da textura dos queijos é devido, principalmente, à hidrólise da micela de caseína durante proteólise, pela mudança do pH (migração e a solubilização de fosfato de cálcio coloidal), mudanças na mobilidade da água associada as caseínas, à perda de umidade e a difusão do sal (McSWEENEY, 2004).

A atividade proteolítica em queijos é principalmente determinada pelo tipo e níveispresentes de coalho residual na massa do queijo, enzimas nativas do leite (como a plasmina), proteinases e peptidases do fermento lático e, ou microbiota natural do leite, proteinases exógenas ou peptidases adicionadas ao leite para acelerar a maturação, pela relação sal na umidade, pela temperatura de maturação e mudanças no pH durante a maturação (FOX, 1993; McSWEENEY, 2004). Os peptídeos, produtos da ação do coagulante, são sem gosto ou amargos e não contribuem diretamente ao sabor e aroma típicos dos queijos, entretanto sua produção, principalmente nas primeiras semanas de maturação, é essencial para suavizar a textura borrachenta e elástica do queijo. 
Não existem trabalhos sobre a produção de queijo a partir do leite de ovelha Crioula, dessa forma o objetivo do trabalho foi a elaboração, caracterização e determinação da textura de queijos maturados produzidos a partir do leite de ovelha Crioula e leite misto (50\% leite de ovelha Crioula:50\% leite bovino).

\section{Material e Métodos}

O leite de ovelhas Crioulas foi obtido no setor de ovinocultura do Instituto Federal Farroupilha-campus Alegrete. As ovelhas foram alimentadas com a pastagem típica do bioma pampa. O leite integral bovino da raça Jersey foi obtido no setor de bovinocultura de leite do campus. Foram realizados 2 tratamentos para a produção dos queijos, sendo o primeiro somente com leite de ovelha Crioula e o segundo uma mistura (1:1) de leite de ovelha Crioula e leite bovino.

O processamento e maturação do queijo ocorreu no setor de Agroindústria do campus. Para o processamento, o leite foi aquecido a $35^{\circ} \mathrm{C}$ e adicionado de cultura láctica composta por Lactococcus lactis ssp. lactis, Lactococcus lactis ssp. cremoris, Lactococcus lactis ssp. lactis biovar. diacetylactis, e Leuconostoc (Sacco Brasil ${ }^{\circledR}$, Campinas, SP, Brasil), cloreto de cálcio (200 mg/Kg) e coagulante Ha La 1175 (Chr. Hansen ${ }^{\circledR}$, Valinhos, SP, Brasil) em quantidade suficiente para coagulação do leite em 35 minutos. O coágulo foi cortado em cubos de 1,0 cm de aresta seguido de agitação lenta e progressiva por 15 minutos. O cozimento da massa foi realizado de forma indireta com aquecimento da massa gradativamente até atingir a temperatura final de $42{ }^{\circ} \mathrm{C}$. Após o cozimento, foi realizada a dessoragem, enformagem da massa e prensagem (15 psi/15 min, 20 psi/15 min, 35 psi/30 min e 45 psi/80 min). Ao saírem da prensa, os queijos foram mantidos em salmoura $(20 \%)$ a $5{ }^{\circ} \mathrm{C}$ por 12 horas. Ao final, os queijos foram mantidos a $12{ }^{\circ} \mathrm{C}$ por 48 horas, embalados à vácuo em sacos termoencolhíveis e armazenados a $12{ }^{\circ} \mathrm{C}$ em incubadora BOD (MA 415; Marconi Equipamentos para Laboratórios Ltda, Piracicaba, SP, Brasil.) durante 90 dias.

Para as análises, os queijos foram escolhidos aleatoriamente, e em seguida, foram retiradas e desprezadas fatias de aproximadamente $0,5 \mathrm{~cm}$ das laterais e das partes superior e inferior. Para as análises de composição, a parte central da peça foi cortada em cubos e triturada em multiprocessador até obtenção de partículas de 2 a $3 \mathrm{~mm}$ que foram homogeneizadas manualmente. Este material obtido foi acondicionado em frascos de vidro e mantido sob refrigeração a $12{ }^{\circ} \mathrm{C}$, durante um período de 1 a 2 horas até o momento das análises. A composição e textura dos queijos foram avaliadas após os 90 dias de maturação.

Todas as análises de composição foram realizadas em triplicata. $\mathrm{O}$ pH foi determinado 
por método potenciométrico, em potenciômetro DM22 (Digimed, São Paulo, SP - Brasil), com introdução direta do eletrodo nas amostras (AOAC, 2006). O teor de extrato seco total e o teor de cinzas foi determinado gravimetricamente (AOAC, 2006). O teor de gordura, pelo método de Gerber (AOAC, 2006). O nitrogênio total (NT) foi determinado pelo método de Kjeldahl (AOAC, 2006). Para a obtenção da porcentagem de proteína total, multiplicou-se a porcentagem obtida de nitrogênio total pelo fator de conversão 6,38.

Para a análise de textura, os queijos foram amostrados com auxílio de uma sonda em formas cilíndricas de 2,0 cm de diâmetro por 3,0 cm de altura. A textura foi avaliada pela análise do perfil de textura (TPA), utilizando em texturômetro TA-XT2 Texture Analyzer (Stable Micro Systems Ltd., Godalming, Surrey, UK) operado pelo software Texture Expert. O experimento foi realizado em sala com temperatura ambiente $\left(25^{\circ} \mathrm{C}\right)$. O teste utilizado foi o de dupla compressão, com cilindro acrílico de $2,5 \mathrm{~cm}$ de diâmetro e uma deformação atribuída à amostra de 20\%. A distância percorrida pelo cilindro até a amostra foi de $10 \mathrm{~mm}$ com uma velocidade de 2 mm.s-1. Submeteu-se a amostra a duas compressões simulando a ação da $1^{\mathrm{a}} \mathrm{e}$ $2^{a}$ mordidas. Com a deformação da amostra, pelo software do equipamento, uma curva de força - compressão foi traçada. A partir dessa curva obtiveram-se os parâmetros primários: dureza, elasticidade e coesividade; e secundário: mastigabilidade, que compõem características mecânicas dos queijos (FOX et al., 2000). A análise de textura foi realizada em quintuplicata.

Os dois tratamentos do queijo foram produzidos no mesmo dia a partir da mesma batelada de leite bovino e de leite de ovelha Crioula. Os dados da composição e textura dos queijos foram avaliados por Análise de Variância (ANOVA) e teste de Tukey para comparação das médias em nível de significância de 5\%, em software Statistica (StatSoft Inc., Tulsa, OK).

\section{Resultados e Discussão}

A Tabela 1 apresenta os valores para a composição físico-química do leite de ovelha Crioula e do leite misto (ovelha e bovino) utilizados para a produção dos queijos maturados.

Os leites apresentaram variação significativa $(p \leq 0,05)$ de composição em relação ao teor de gordura, proteína e extrato seco total. O leite de ovelha Crioula apresentou baixo teor de gordura $(1,8 \%)$ e alto teor proteico $(7,15 \%)$. O leite misto, no qual foram misturadas proporções iguais de leite de ovelha crioula e leite bovino, apresentou maior teor de gordura $(2,5 \%)$ e menor teor proteico $(4,92)$. Os valores de $\mathrm{pH}$ e cinzas não diferiram significativamente entre as amostras de leite.

O leite de ovelha crioula apresentou valores de gordura menores que os esperados para esse tipo de leite, que é em média 7,8\%, enquanto que o teor proteico está acima da média para 
leites de ovelhas $(5,2 \%)$ (WALSTRA, 2006). A literatura apresenta os teores médios da composição do leite de ovelha, porém não foram encontrados estudos com a composição específica para a raça Crioula.

Tabela 1. Composição físico-química do leite de ovelha Crioula e do leite misto (ovelha e vaca).

\begin{tabular}{ccc}
\hline Análises & $\begin{array}{c}\text { Leite Ovelha } \\
\text { Crioula* }\end{array}$ & $\begin{array}{c}\text { Leite Misto (Ovelha e } \\
\text { Vaca) } *\end{array}$ \\
\hline Extrato Seco Total (\%) & $11,84^{\mathrm{b}}$ & $12,54^{\mathrm{a}}$ \\
Gordura (\%) & $1,8^{\mathrm{b}}$ & $2,5^{\mathrm{a}}$ \\
Proteína (\%) & $7,15^{\mathrm{a}}$ & $4,92^{\mathrm{b}}$ \\
Cinzas (\%) & $0,85^{\mathrm{a}}$ & $0,86^{\mathrm{a}}$ \\
pH & $6,80^{\mathrm{a}}$ & $6,80^{\mathrm{a}}$ \\
\hline
\end{tabular}

Médias com letras iguais, na mesma linha, não diferem significativamente entre si $(\mathrm{p}>0,05)$. Fonte: Própria (2020)

Os valores encontrados para a composição físico-química dos queijos maturados produzidos a partir de leite de ovelha Crioula e leite misto são apresentados na Tabela 2.

Tabela 2. Composição físico-química dos queijos maturados de leite de ovelha Crioula e do leite misto.

\begin{tabular}{ccc}
\hline Análises & $\begin{array}{c}\text { Queijo Leite Ovelha } \\
\text { Crioula }\end{array}$ & Queijo Leite Misto \\
\hline Extrato Seco Total (\%) & $53,11^{\mathrm{b}}$ & $58,54^{\mathrm{a}}$ \\
Umidade (\%) & $45.89^{\mathrm{a}}$ & $41.46^{\mathrm{b}}$ \\
Gordura (\%) & $12,0^{\mathrm{b}}$ & $18,0^{\mathrm{a}}$ \\
Extrato Seco Desengordurado (\%) & $41,11^{\mathrm{a}}$ & $40,54^{\mathrm{a}}$ \\
Gordura no Extrato Seco (\%) & $22,60^{\mathrm{b}}$ & $30.75^{\mathrm{a}}$ \\
Proteína (\%) & $30,71^{\mathrm{a}}$ & $28,96^{\mathrm{b}}$ \\
Cinzas (\%) & $5,78^{\mathrm{b}}$ & $6,68^{\mathrm{a}}$ \\
$\mathrm{pH}$ & $5,80^{\mathrm{a}}$ & $5,70^{\mathrm{a}}$ \\
\hline Médias com letras iguais, na mesma linha, não diferem significativamente entre si $(\mathrm{p}>0,05)$.
\end{tabular}
Fonte: Própria (2020)

Seguindo a tendência da composição do leite, os queijos produzidos somente com leite de ovelha crioula apresentaram alto valor proteico e baixo teor de gordura. O extrato seco total do queijo produzido com leite de ovelha Crioula foi menor em relação ao queijo produzido com leite misto, esse fato pode ser atribuído ao baixo teor de gordura encontrado do leite de ovelha crioula.

Em relação a umidade e gordura no extrato seco, os queijos produzidos com leite de ovelha Crioula e leite misto podem ser classificados como queijos de média umidade e semigordos, de acordo com o Regulamento Técnico de Identidade e Qualidade de Queijos (BRASIL, 1996).

Estudos que determinaram a composição de queijos produzidos a partir de leite de ovelha com o mesmo tempo de maturação, encontraram valores maiores para o teor de gordura 
(CODA, et al., 2006; FALLICO, et al., 2006; FREITAS; MALCATA, 2000). Não foram encontrados, para fins de comparação, estudos sobre queijo produzidos a partir de leite de ovelha Crioula. Queijos de ovelha normalmente apresentam valores superiores a $40 \%$ de gordura no extrato seco. No caso do queijo de leite de ovelha Crioula esse teor não ultrapassou $30 \%$, o que pode ser atribuído ao baixo teor de gordura inicial do leite.

O queijo de leite de ovelha Crioula apresentou $\mathrm{pH}$ final de 5,8 e o queijos produzido a partir de leite misto apresentou pH final de 5,7. Não houve diferença significativa de pH entre os tratamentos, estando os valores dentro da faixa esperada para queijos com 90 dias de maturação. O desenvolvimento do $\mathrm{pH}$ é dependente da cultura láctea, que produz ácido láctico e enzimas, preservando e propiciando o processo de maturação dos queijos (WALSTRA, 2006).

O perfil de maturação dos queijos é dependente do coalho residual e das enzimas da cultura láctea utilizada durante o processamento dos queijos. Para a produção dos queijos maturados foi utilizada uma cultura aromatizante, que além da produção de ácido láctico, promove o desenvolvimento do sabor, aroma e textura do queijo.

Para avaliar a textura dos queijos maturados de leite de ovelha Crioula e leite misto foi utilizada a análise de perfil de textura (Tabela 3).

$\underline{\text { Tabela 3. Perfil de textura (TPA) dos queijos de leite de ovelha Crioula e leite misto. }}$

\begin{tabular}{ccc}
\hline Parâmetros & $\begin{array}{c}\text { Queijo Leite } \\
\text { Ovelha Crioula }\end{array}$ & $\begin{array}{c}\text { Queijo Leite } \\
\text { Misto }\end{array}$ \\
\hline Dureza (N) & $436,61^{\mathrm{a}}$ & $373,37^{\mathrm{b}}$ \\
Mastigabilidade (N) & $142,64^{\mathrm{a}}$ & $51,75^{\mathrm{b}}$ \\
Coesividade * & $0,33^{\mathrm{a}}$ & $0,14^{\mathrm{b}}$ \\
Elasticidade $^{*}$ & $0,99^{\mathrm{a}}$ & $0,99^{\mathrm{a}}$ \\
\hline
\end{tabular}

N-Newton *adimensional.

Fonte: Própria (2020)

Os queijos apresentaram diferenças significativas $(p \leq 0,05)$ para os parâmetros de dureza, mastigabilidade e coesividade. A elasticidade não apresentou diferença significativa $(p \geq 0,05)$ entre os tratamentos.

O queijo produzido com leite de ovelha Crioula apesentou maior dureza, mastigabilidade e coesividade que o queijo produzido com leite misto. Esses valores podem ser explicados pelo maior teor proteico e menor teor de gordura do queijo produzido com leite de ovelha quando comparado ao queijo produzido a partir do leite misto. Durante o processamento de queijos, a gordura fica retida fisicamente na rede proteica formada durante a coagulação do leite. Essa retenção da gordura favorece a maciez, sendo que quanto maior o teor de gordura menores serão os valores de dureza, mastigabilidade e coesividade do queijo (FOX, 2000). 
A dureza é definida como a força requerida para comprimir um alimento entre os molares, para se obter uma deformação. Mastigabilidade é a energia necessária para mastigar um alimento sólido até o ponto de ser engolido (SZCZESNIAK, 1963; FOX et al., 2000). Dessa forma, os resultados de dureza e mastigabilidade demonstram que o queijo produzido a partir do leite misto exige uma força menor para atingir a deformação (menos firme) e menos energia é necessária para mastigá-los até estarem prontos para serem deglutidos, corroborando com os resultados obtidos de teor de gordura nos queijos (Tabela 2).

A coesividade é definida como a extensão que o queijo pode ser deformado até que haja ruptura. O menor teor de gordura no queijo produzido com leite de ovelha Crioula em relação ao queijo produzido com leite misto, permitiu a formação de uma rede proteica mais coesa, resultando em uma estrutura mais compacta, com maior quantidade de água imobilizada e consequentemente mais resistente a mordida.

Por sua vez, a elasticidade é a taxa pela qual um material deformado volta à sua condição original, após ser removida a força deformante. Portanto, a elasticidade está diretamente relacionada a rede proteica formada durante o processo de coagulação, e que sofre modificações durante a proteólise. Apesar dos queijos diferirem significativamente em relação ao teor de proteína (Tabela 2$)$, essa diferença não afetou significativamente $(p \geq 0,05)$ a elasticidade dos queijos.

Portanto, nesse estudo, podemos afirmar que os queijos produzidos com leite misto, ovino e bovino, apresentaram maior maciez e relação aos queijos de leite de ovelha Crioula. Esse resultado deve ser complementado com a análise sensorial, objetivando a confirmação dos resultados instrumentais pelos consumidores.

\section{Conclusões}

Os queijos produzidos a partir de leite de ovelhas Crioulas e leite misto, ovino e bovino, foram classificados como queijos de baixa umidade e semigordos, sendo que o queijo de leite misto apresentou maior maciez em relação ao queijo produzido somente com leite de ovelha Crioula. A produção de ambos os queijos são alternativas viáveis para agregar renda às propriedades criadoras de ovelhas Crioulas.

\section{Referências}

AOAC - Association of Official Analytical Chemists. Official methods of analysis of AOAC International. Washington, 2006. 
ARCO. Padrões raciais. Disponível em:

<http://www.arcoovinos.com.br/index.asp?pag=padroes.asp\#>. Acesso em: 23 dez. 2019.

BOURNE, M. C. Texture profile analysis. Food Technol., v. 32, n. 7, p. 62-66, 72, 1978.

BOURNE, M. Food Texture and Viscosity: Concept and Measurement. 2nd ed. San Diego: Academic Press, 2002.415p.

BRASIL. Ministério da Agricultura, Pecuária e Abastecimento. Regulamento Técnico de Identidade e Qualidade de Queijos. Brasília, 2006

CHILDS, J. L., DRAKE, M. Consumer perception of fat reduction in cheese. J. Sens. Stud. 24, 902-921. 2009.

CODA R., BRECHANY E., DE ANGELIS M., DE CANDIA S., DI CAGNO R. \& GOBBETTI M. Comparison of the Compositional, Microbiological, Biochemical, and Volatile Profile Characteristics of Nine Italian Ewes' Milk Cheeses. Journal of Dairy Science. 89: 4126-4143, 2006.

FALLICO V., TUMINELLO L., PEDILIGGIERI C., HORNE J., CARPINO S., LICITRA G. Proteolysis and Microstructure of Piacentinu Ennese Cheese Made Using Different Farm Technologies. Journal of Dairy Science. 89: 37-48, 2006.

FOX P.F. Cheese: An Overview. In: Fox P.F. (eds) Cheese: Chemistry, Physics and Microbiology. Springer, Boston, MA, 1993.

FOX; McSWEENEY, P. L. H. Dairy chemistry and biochemistry. London: Blackie Academic \& Professional, 1998. 478 p.

FOX, P. F.; GUINEE, T. P.; COGAN, T. M. et al. Fundamentals of Cheese Science. Gaithersburg, Maryland: Aspen Publishers. 2000. 587p.

FREITAS C. \& MALCATA F.X. Microbiology and Biochemistry of Cheeses with Appélation d'Origine Protegeé and Manufactured in the Iberian Peninsula from Ovine and Caprine Milks. Journal of Dairy Science. 83: 584-602, 2000.

KRAMER \& SZCZENIAK, A. S. Texture measurements of foods. Boston: D. Reidel. Publishing Company, 1973. 175 p.

MAGALHAES, K. A.; LUCENA, C. C. de. Características e evolução da ovinocultura a partir dos dados defi nitivos do Censo Agropecuário de 2017. Sobral: Embrapa Caprinos e Ovinos, 2019.

MCSWEENEY, P.L.H.; FOX P.F.; LUCEY J.A.; JORDAN K.N.; COGAN T.M. Contribution of the indigenous microflora to the maturation of Cheddar cheese. Int. Dairy J. 1993; 3: 613634 
PELLEGRINI L., G.; CASSANEGO, D. B; GUSSO, A. P.; MATTANNA, P.; SILVA, S. V. Características físico-químicas de leite bovino, caprino e ovino. Synergismus scyentifica UTFPR, Pato Branco, 07, 2012.

PENNA, C. F. A. M. Produção e parâmetros de qualidade de leite e queijos de ovelhas Lacaune, Santa Inês e mestiças submetidas a dietas elaboradas com soja ou linhaça. Universidade Federal de Minas Gerais. 2011, 154 p.

PERRY, Katia S. P.. Queijos: aspectos químicos, bioquímicos e microbiológicos. Química. Nova, São Paulo, v. 27, n. 2, p. 293-300, 2004.

SZCZESNIAK, A. S. Classification of textural characteristics. J. Food Sci. V. 28, n. 4, p. 385389, 1963.

WALSTRA, P.; JENNESS, R. Dairy chemistry and physics. Nova York: John Wiley e Sons, 2006 . 


\title{
CAPÍTULO 18. DIAGNÓSTICO DA AMBIÊNCIA AÉREA DE AVIÁRIOS COM PROTÓTIPO DE BAIXO CUSTO
}

\section{CHAPTER 18. AERIAL ENVIRONMENT DIAGNOSIS OF THE POULTRY HOUSE WITH LOW COST PROTOTYPE}

\author{
Leandro Augusto de Carvalho' ${ }^{1}$ Jorge Otta Junior ${ }^{2}$; Augusto Vaghetti Luchese ${ }^{3}$, Laercio Mantovani \\ Frare $^{4}$; Pedro Luiz de Paula Filho ${ }^{5}$
}

\section{Resumo}

A ambiência aérea de aviários é um assunto que vem sendo abordado em pesquisas voltadas, tanto para o bem-estar animal, quanto para a saúde dos trabalhadores da atividade avícola. A razão motivando o desenvolvimento dessa pesquisa foi a carência de equipamentos de baixo custo, que possibilitem o diagnóstico das condições aéreas dos aviários. Para tanto, foi construído um protótipo que permitiu realizar análises em quatro dias amostrais da produção de frango de corte e apresentado um relatório resumido dos aspectos ambientais de amônia, dióxido de carbono, temperatura e umidade relativa do ar, com base em coletas contínuas realizadas durante o ciclo produtivo. Diante disso, observou-se que o aviário experimental obteve resultados dentro dos padrões ideais para criação de frango de corte, bem como das condições de trabalho salubre.

Palavras-Chaves: Avicultura, Amônia, Dióxido de carbono, Aviário.

\begin{abstract}
The air environment of poultry is a subject that has been addressed in research focused on both animal welfare and the health of poultry workers. The reason that motivated the development of this research was the lack of low cost equipments that allow the diagnosis of the aviary air condition. To this end, a prototype was built that made it possible to carry out analyzes on four sampling days of the production of broiler chicken and presented a summary report of the environmental aspects of ammonia, carbon dioxide, temperature and relative humidity, based on continuous collections carried out during the productive cycle. Therefore, it was observed that the experimental poultry house obtained results within the ideal standards for broiler rearing, as well as healthy working conditions.
\end{abstract}

Keywords: Aviculture, Ammonia, Carbon dioxide, Poultry house.

\footnotetext{
${ }^{1}$ Programa de Pós Graduação Tecnologias Computacionais para o Agronegócio, UTFPR Campus Medianeira, leandrocarvalho@utfpr.edu.br

${ }^{2}$ Programa de Pós Graduação Tecnologias Computacionais para o Agronegócio, UTFPR Campus Medianeira, jorgejunior@utfpr.edu.br

${ }^{3}$ Programa de Pós Graduação Tecnologias Computacionais para o Agronegócio, UTFPR Campus Medianeira, aluchese@utfpr.edu.br

${ }^{4}$ Programa de Pós Graduação Tecnologias Computacionais para o Agronegócio, UTFPR Campus Medianeira, laercio@utfpr.edu.br

${ }^{5}$ Programa de Pós Graduação Tecnologias Computacionais para o Agronegócio, UTFPR Campus Medianeira, pedrol@utfpr.edu.br
} 


\section{Introdução}

A avicultura é considerada uma importante atividade para a economia e desenvolvimento do agronegócio do país. De acordo com o Departamento de Agricultura dos Estados Unidos (USDA), o Brasil é o segundo maior produtor mundial de carne de frango, atrás apenas dos Estados Unidos (FRANCO, 2017).

Esse cenário se deve principalmente aos constantes ganhos de produtividade, sobretudo, através da melhoria dos índices de conversão alimentar, dos ganhos nutricionais, da pesquisa em genética, da maior automação dos aviários e de um melhor manejo (SOUSA; OSAKI, 2005).

A atividade avícola tem se destacado no campo da produção animal por ser um ciclo produtivo de curta duração, com bons retornos financeiros, exigência de pequenas áreas para implantação de granjas, entre outros motivos. Das espécies mais exploradas, destaca-se o frango, mas existe também a produção de codornas, patos, marrecos, perus, avestruzes, entre outros. A principal atividade é a produção de carne e ovos, conhecida como exploração de ave de corte e ave de postura, respectivamente (LOPES, 2011).

A cadeia produtiva de frango de corte é constituída por várias etapas interligadas entre si, que compreendem desde a produção das matrizes até o processamento e comercialização da carne industrializada. $\mathrm{O}$ aviário é um elo da cadeia produtiva e corresponde a uma etapa de produção onde se dá o crescimento e a engorda dos pintainhos, que ali chegam com algumas horas depois de nascidos, e ficam até a época de abate, aos 43 dias aproximadamente (ARAÚJO et al. 2008).

Durante esse período, as condições de alojamento devem garantir a proteção das aves, fornecendo conforto térmico com níveis apropriados de ventilação, umidade, temperatura, abrigo contra precipitação, insolação direta e segurança contra animais predadores. Um animal está em bom estado de bem-estar se estiver saudável, confortável, bem nutrido, seguro, for capaz de expressar seu comportamento inato, e se não estiver sofrendo com estados desagradáveis, tais como dor, medo e angústia (OIE, 2019).

Além disso, essas unidades devem apresentar condições de trabalho em conformidade com as normativas vigentes, preservando a saúde dos trabalhadores. Atividades de até 48 horas por semana em ambientes com concentração de 20 ppm (partes por milhão) de amônia são considerados de grau médio de insalubridade (BRASIL,1978). Portanto, para garantir as condições ideais de bem-estar animal e de segurança no trabalho, alguns fatores devem ser observados referente à ambiência aérea dos aviários. 
A concentração dos gases nos galpões está diretamente relacionada com fatores como temperatura, umidade relativa do ar, material e idade da cama aviária, tipo de ventilação, duração do ciclo de frangos e densidade de criação entre outros (OVIEDO-RONDON, 2008; OLIVEIRA; MONTEIRO, 2013).

A cama do aviário possui como principais funções reduzir o impacto e atrito da ave com o piso, absorver a umidade do galpão e diluir a matéria fecal. Geralmente são utilizados materiais como maravalha ou serragem de madeira, por ter alta disponibilidade, baixo custo e ser absorvente. É na cama do aviário onde ocorre a decomposição microbiana do nitrogênio dos dejetos dos frangos, que passa a emitir o gás amônia para o ar (ARAÚJO, 2013).

O nível de amônia ideal para criação de frango de corte deve ser inferior à 10 ppm. Taxas de concentração acima de 10 ppm podem danificar a superfície do pulmão, aumentar a suscetibilidade à doenças respiratórias, e reduzir a taxa de crescimento (ROSS, 2018; COBB, 2008). Além da amônia, existem outros contaminantes do ar como poeira, excesso de vapor de água e gases como dióxido de carbono e monóxido de carbono, igualmente prejudiciais quando em níveis elevados.

Os fatores térmicos como temperatura do ar, umidade, radiação térmica e movimentação do ar afetam mais diretamente a ave, pois comprometem sua função vital mais importante: a manutenção da própria homeotermia (TINOCO, 2001). Dessa forma, alguns equipamentos básicos para a criação das aves são requeridos como exaustores, nebulizadores e aquecedores.

Muitos dos equipamentos utilizados nos aviários são automatizados por meio de sensoriamento e programação pré-definida. Por exemplo, para acionamento dos sistemas de ventilação e aquecimento são utilizados sensores de temperatura e umidade conectados a uma unidade central. Da mesma forma, o sistema de reabastecimento da linha de comedouro é acionado por sensores nos pratos dos comedouros. Também são empregados temporizadores que controlam a iluminação.

Com relação ao monitoramento dos níveis de gases, existem equipamentos para medição e controle de gases, de uso geral que podem ser aplicados na avicultura, além de alguns sensores específicos para avicultura que podem ser interligados às centrais de automação dos aviários. O inconveniente destes sensores está relacionado ao alto investimento, o que inviabiliza este controle à pequenos produtores. Com intuito de suprir esta lacuna, o objetivo principal desse estudo consiste no desenvolvimento de um protótipo de baixo custo, capaz de fornecer ao avicultor, o diagnóstico da ambiência aérea dos aviários, fornecendo informações de temperatura, umidade, concentração de amônia e de dióxido de carbono. 


\section{Material e Métodos}

O protótipo utilizado nesse estudo, responsável por detectar as concentrações de amônia, dióxido de carbono, temperatura e umidade, foi construído utilizando placa de prototipagem e sensores de baixo custo. Os sensores de amônia modelo MQ-135, de dióxido de carbono, MG-811, e, de temperatura e umidade do ar, BME280, possuem preços acessíveis e são encontrados em lojas especializadas.

De maneira geral, o funcionamento do sistema consiste em 3 etapas: coleta dos dados pelos sensores, envio das informações utilizando a rede sem fio para um servidor de dados, e processamento desses dados para exibição em forma de gráficos e análise estatística. A Figura 1 ilustra os componentes necessários e interação entre eles.

Figura 1. Diagrama dos componentes do sistema

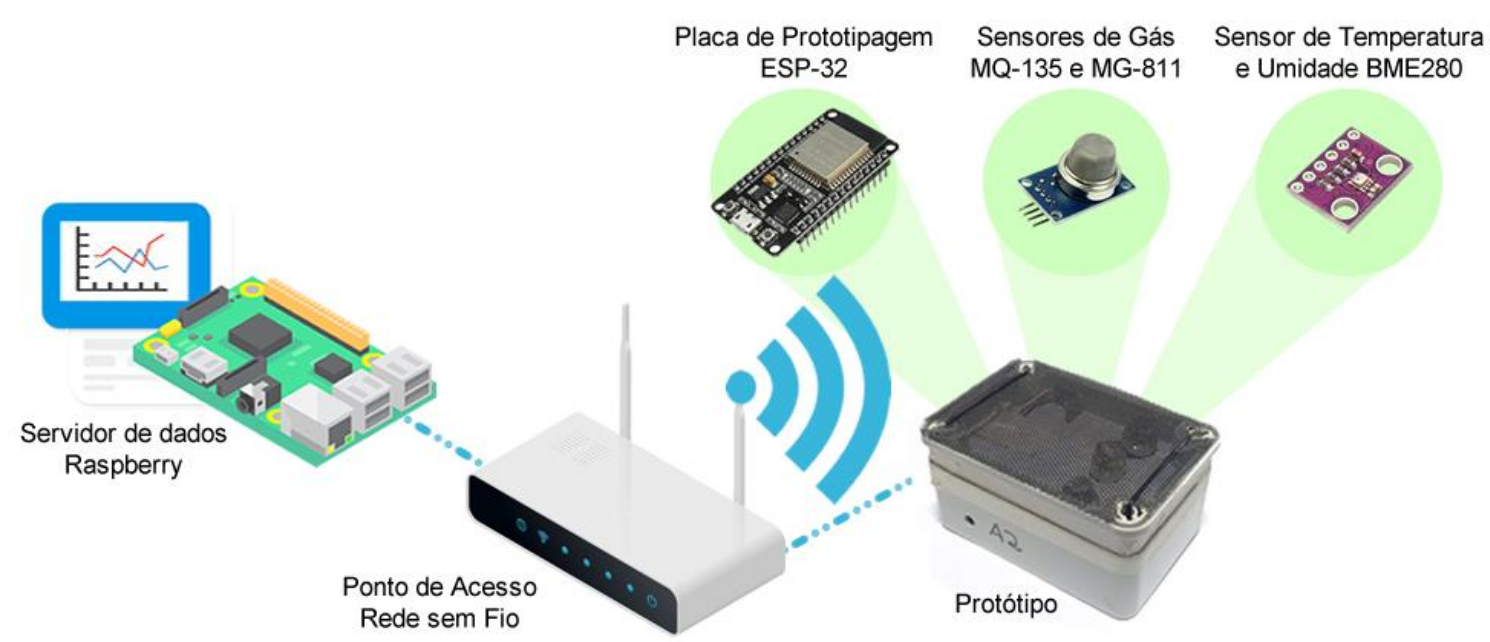

Fonte: Própria (2020).

Esses sensores são conectados nas portas de entrada e saída de sinal da placa de prototipagem ESP32, permitindo a leitura dos valores pelo software que é executado pelo microprocessador da placa. A placa de prototipagem ESP32 possui 34 portas programáveis, conexão com rede sem fio e Bluetooth, além de permitir o desenvolvimento de software utilizando esses e outros recursos disponíveis pela placa. Além da coleta, a placa de prototipagem realiza o tratamento dos dados dos módulos sensores, conexão na rede sem fio e encaminhamento dos dados para o servidor.

Para a função de servidor de armazenamento dos dados, foi utilizado um computador de placa única, Raspberry PI 3 modelo B. Esse computador também possui um valor acessível, assim como os demais componentes, além de outros recursos como a possibilidade de instalação de sistema operacional e serviços. 
Para desenvolver o relatório de diagnóstico da ambiência aérea dos aviários, foi preciso integrar um sistema informatizado de painéis de monitoramento chamado ThingsBoard. Esse sistema permite realizar a comunicação entre o servidor e o protótipo, além de fornecer recursos gráficos para exibição dos dados.

Todos os componentes do protótipo, placa de prototipagem e sensores, foram acondicionados em uma caixa de montagem, com tela perfurada permitindo a exposição dos sensores, mas protegendo os componentes contra ações externas, conforme apresentado na Figura 2.

Figura 2. Protótipo montado com a tela de proteção.

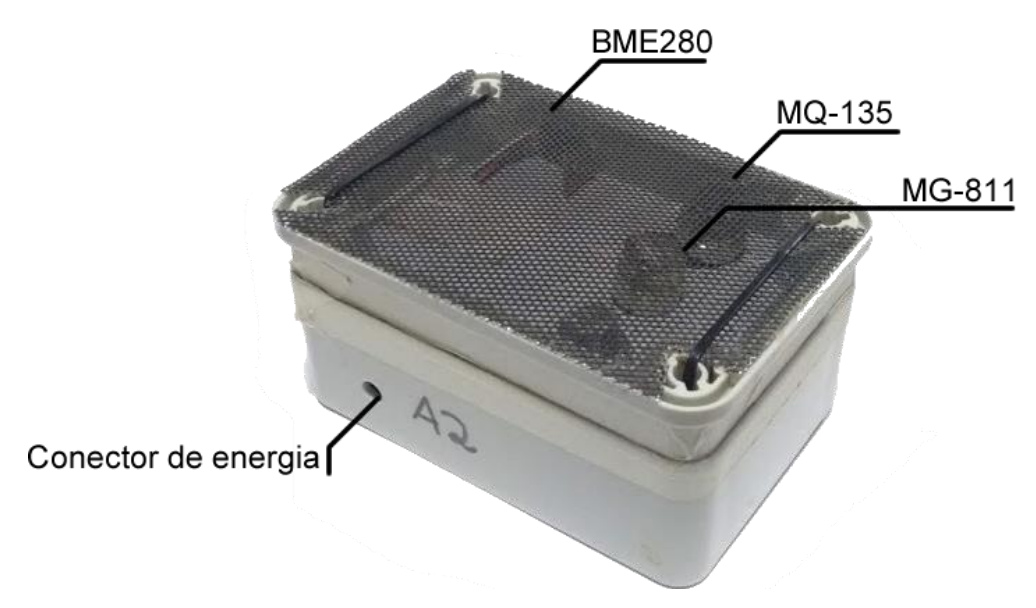

Fonte: Própria (2020).

A Tabela 1 apresenta os custos aproximados dos materiais utilizados para confecção do protótipo. Todos esses valores estão em Reais $(\mathrm{R} \$)$ e foram baseados na data da compra em Abril de 2018.

Tabela 1. Custos aproximados dos materiais do protótipo

\begin{tabular}{ll}
\hline Material & Valor $(\mathrm{R} \$)$ \\
\hline Placa de desenvolvimento ESP-32 & 57,04 \\
Sensor de gás amônia MQ-135 & 25,76 \\
Sensor de gás dióxido de carbono MG-811 & 109,87 \\
Sensor de temperatura e umidade BME-280 & 41,40 \\
Caixa para montagem & 29,90 \\
Total & $\mathrm{R} \$ 263,97$ \\
\hline
\end{tabular}
Fonte: Própria (2020).

O custo aproximado para aquisição dos materiais para produção de um protótipo foi de R\$263,97. Ainda houve o investimento no servidor de monitoramento (Raspberry), acrescendo $\mathrm{R} \$ 277,84$ ao valor total da solução. Sendo assim, pode-se afirmar que para realizar esse estudo foram despendidos $\mathrm{R} \$ 541,81$ para aquisição de materiais e equipamentos. 
As coletas foram realizadas em granja comercial de frango de corte localizada no município de Cascavel - PR, no distrito de Sede Alvorada, na Mesorregião Oeste Paranaense, latitude $24^{\circ} 49^{\prime} 36^{\prime \prime} \mathrm{S}$ e longitude $53^{\circ} 40^{\prime} 17^{\prime \prime} \mathrm{O}$, no $6^{\circ}, 8^{\circ}, 9^{\circ}$ e $12^{\circ}$ dia de alojamento dos frangos, entre os dias 02 e 08 de abril de 2019.

As condições meteorológicas características de Cascavel - PR em abril são temperaturas máximas entre $26{ }^{\circ} \mathrm{C}$ a $23{ }^{\circ} \mathrm{C}$, raramente caindo abaixo de $18{ }^{\circ} \mathrm{C}$ ou ultrapassando $30{ }^{\circ} \mathrm{C}$. As temperaturas mínimas em torno de $15{ }^{\circ} \mathrm{C}$ a $12{ }^{\circ} \mathrm{C}$, raramente caindo abaixo de $7{ }^{\circ} \mathrm{C}$ ou ultrapassando $18{ }^{\circ} \mathrm{C}$. A probabilidade de um dia com precipitação ao longo de abril decresce gradualmente, começando o mês com 38\% e terminando com 36\% (WEATHERSPARK, 2020).

As coletas foram realizadas em aviário com área de $1.200 \mathrm{~m}^{2}$, com pé-direito de 2,2 metros e pilares de concreto a cada 3 metros, com tesouras de madeiras e cobertura de telhas de barro. O sistema de ventilação era do tipo túnel de vento com pressão negativa, possuía um grupo de seis exaustores, com seis pás de 53 polegadas e motor de 1,5 cv. A alimentação das aves era realizada por três linhas de comedouro e quatro linhas de bebedouro do tipo nipple. Para manter o aviário aquecido, foram utilizados dois aquecedores à lenha. Todos os sistemas de ventilação, aquecimento, iluminação e abastecimento de água e ração eram automatizados.

Durante os dias experimentais, o protótipo permaneceu instalado no mesmo local, à 15 $\mathrm{m}$ da parede da entrada do aviário, e $3 \mathrm{~m}$ da parede lateral, junto ao solo. A Figura 3 mostra um croqui do aviário e a posição do protótipo.

Figura 3. Croqui do aviário.

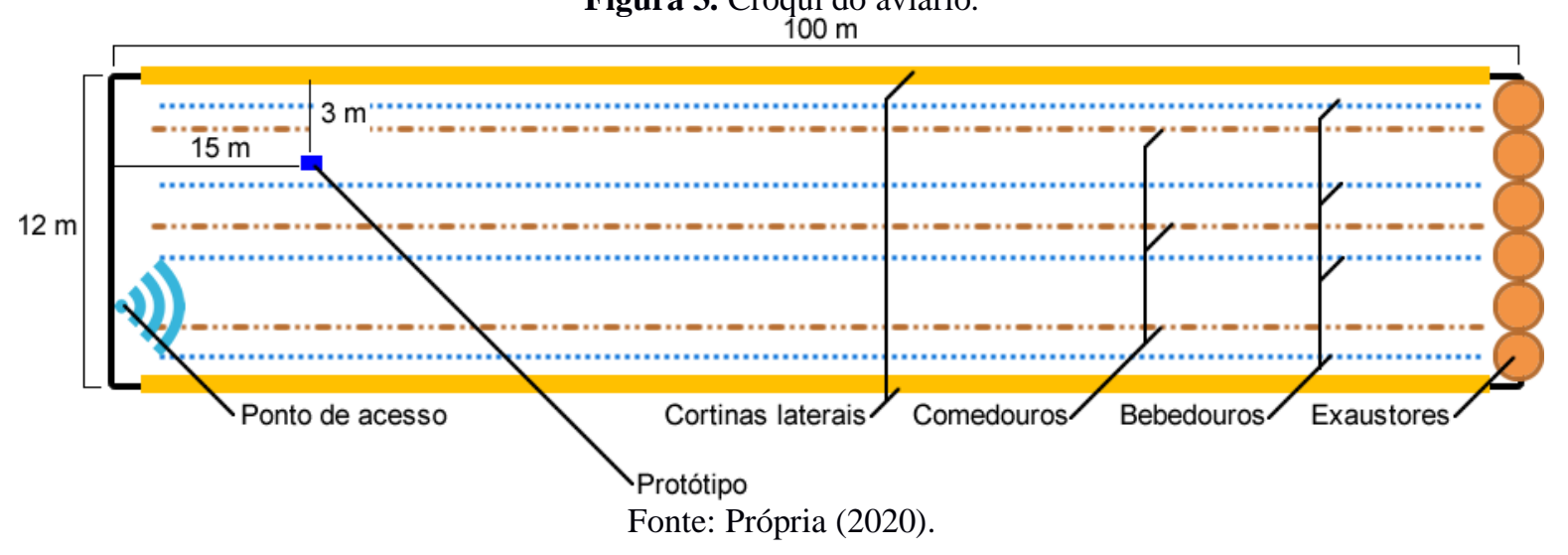

A rotina de coleta e envio dos dados ao servidor de monitoramento era feita de minuto a minuto. Após o período experimental, os dados foram organizados pela média, em grupos de quinze minutos de coleta. Para facilitar a apresentação e interpretação dos dados, gráficos de dispersão, diagramas de frequência, boxplots, e estatística descritiva foram empregados. Para 
análise da variância dos tratamentos foi utilizada a distribuição F de Snedecor, e o teste de Tukey de comparações múltiplas.

\section{Resultados e Discussão}

As coletas registradas pelo sensor MQ-135 referente às concentrações de amônia são apresentadas na Figura 4. Observa-se que a todas as leituras ficaram entre 4 e 7 ppm. Com a estatística descritiva dos dados coletados, foi possível identificar que as médias das concentrações de amônia diminuíram conforme aumenta a idade dos frangos. O mesmo acontece para a mediana e para os valores mínimos detectados.

Os gráficos de séries temporais apresentam lacunas, devido a falhas no momento da leitura dos sensores, por instabilidades na rede elétrica do aviário. O eixo X representa o período do dia em que foi realizada a leitura do sensor, e o eixo Y apresenta a concentração de amônia em ppm.

Figura 4. Concentração de amônia quantificada pelo sensor MQ-135 no período amostral.

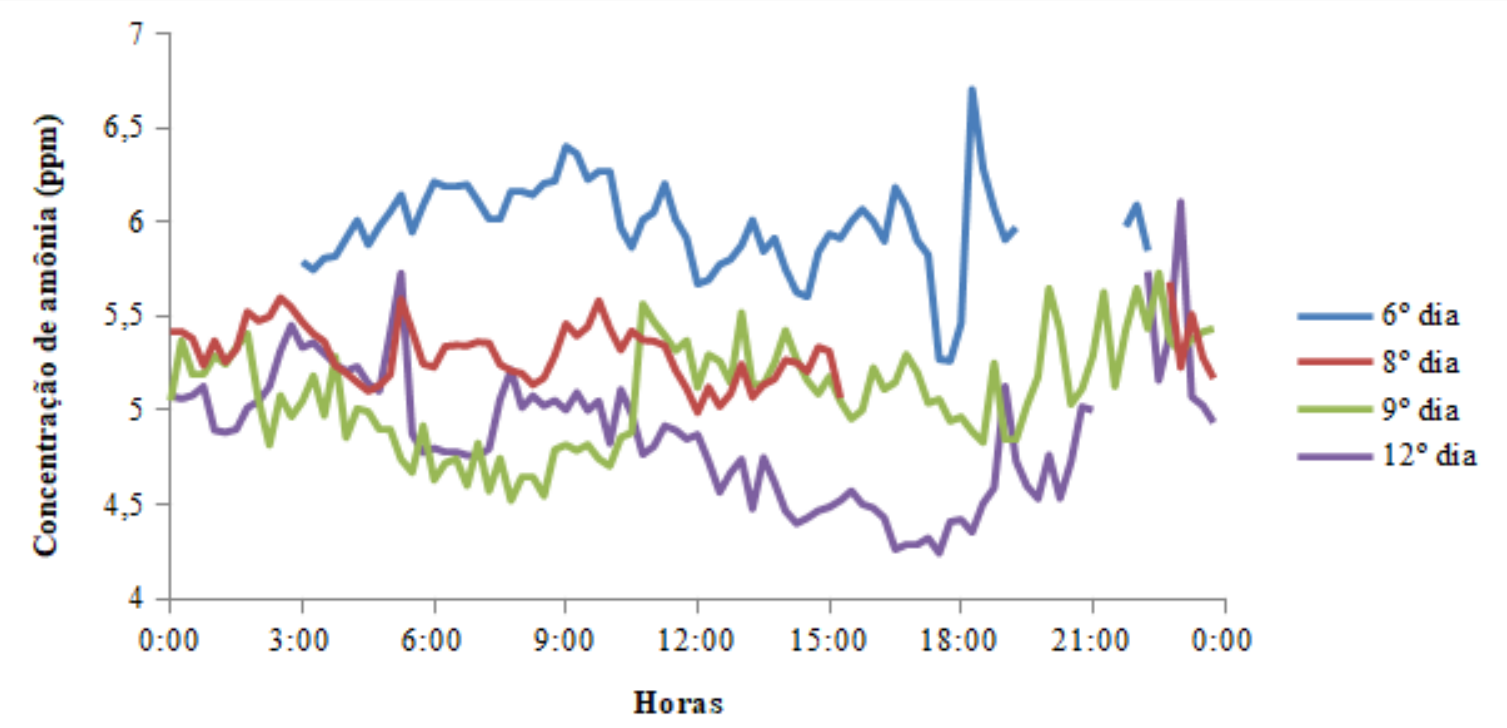

Fonte: Própria (2020).

Uma explicação para esse fenômeno pode ser o fato da ventilação se tornar mais constante conforme o desenvolvimento dos frangos, fazendo com que ocorra a troca de ar com mais frequência, diminuindo a concentração de amônia.

Todas as amostras obtiveram valores inferiores a $10 \mathrm{ppm}$. Sendo assim, o aviário apresentou condições ideais para a criação de frango de corte e limites toleráveis de insalubridade para os trabalhadores dessa unidade. 
A Figura 5 apresenta os diagramas de frequência dos quatro dias observados, referente as concentrações de amônia. Todos os tratamentos apresentaram p-valor > 0,05 no teste Kolmogorov-Smirnov (KS), indicando que não há evidências suficientes para concluir que os dados não seguem uma distribuição normal.

Figura 5. Diagramas de frequência das concentrações de amônia
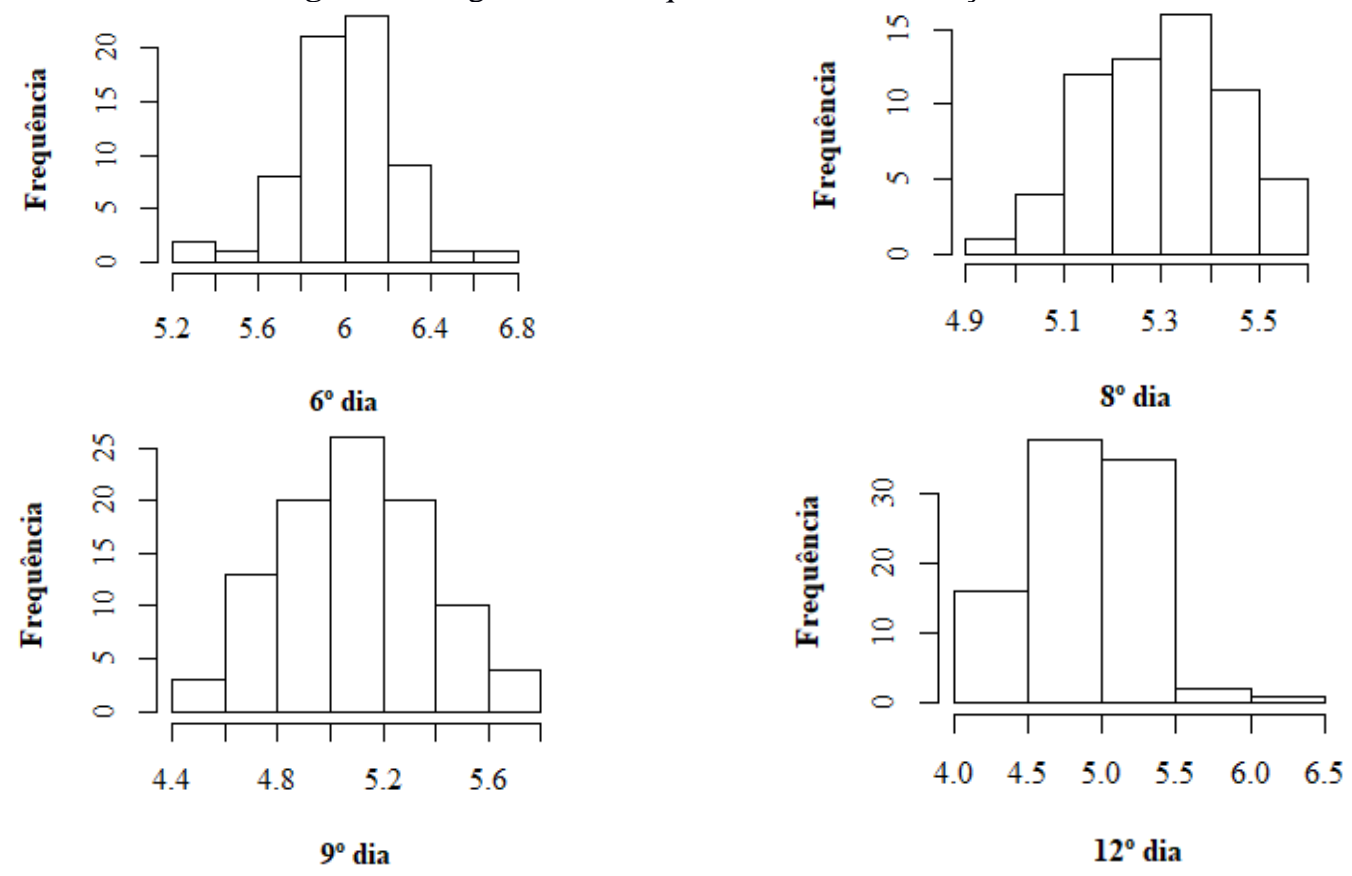

Fonte: Própria (2020).

Para identificar pontos discrepantes nas amostras, foram produzidos os boxplots, mostrados na Figura 6 com as leituras do sensor MQ-135 nos dias observados. O $8^{\circ}$ e o $9^{\circ}$ dia tiveram um comportamento semelhante, não apresentando outliers. Já o $6^{\circ}$ e $012^{\circ}$ dia apresentaram outliers em suas amostras. Em relação a variabilidade dos dados, o $9^{\circ}$ e $12^{\circ}$ dia apresentaram maior variabilidade comparando com os demais dias amostrais. Os níveis médios de amônia são decrescentes do $6^{\circ}$ ao $12^{\circ}$ dia.

Com a distribuição F de Snedecor, foi possível verificar que existe pelo menos um contraste entre as médias dos tratamentos, ao nível de 5\% de probabilidade. Ou seja, existe diferença entre as médias de concentração de amônia, entre os dias em que foram realizadas as coletas de dados.

Realizando o teste de Tukey de comparações múltiplas, observou-se que todas as médias dos tratamentos possuem diferenças entre si, a nível de 5\% de significância. Ou seja, há evidências de que as médias de concentrações de amônia variam conforme o período de alojamento. 
Figura 6. Boxplots das concentrações de amônia (ppm) dos dias observados.

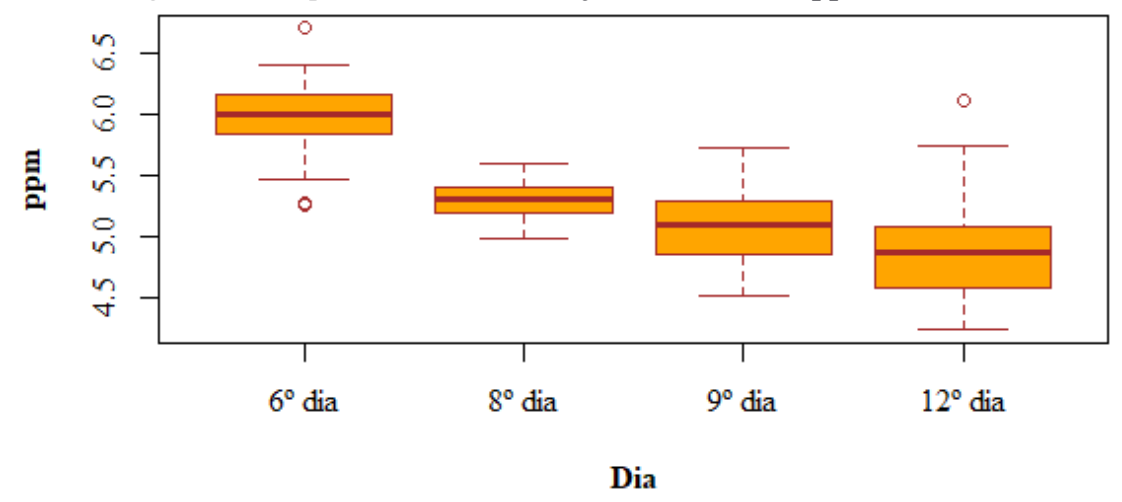

Fonte: Própria (2020).

As concentrações de dióxido de carbono foram detectadas pelo sensor MG-811, e estão apresentadas no gráfico de séries temporais da Figura 7. Por meio da análise gráfica não foi identificada uma tendência entre as séries de dados.

Figura 7. Concentração de dióxido de carbono quantificada pelo sensor MG-811 no período amostral.

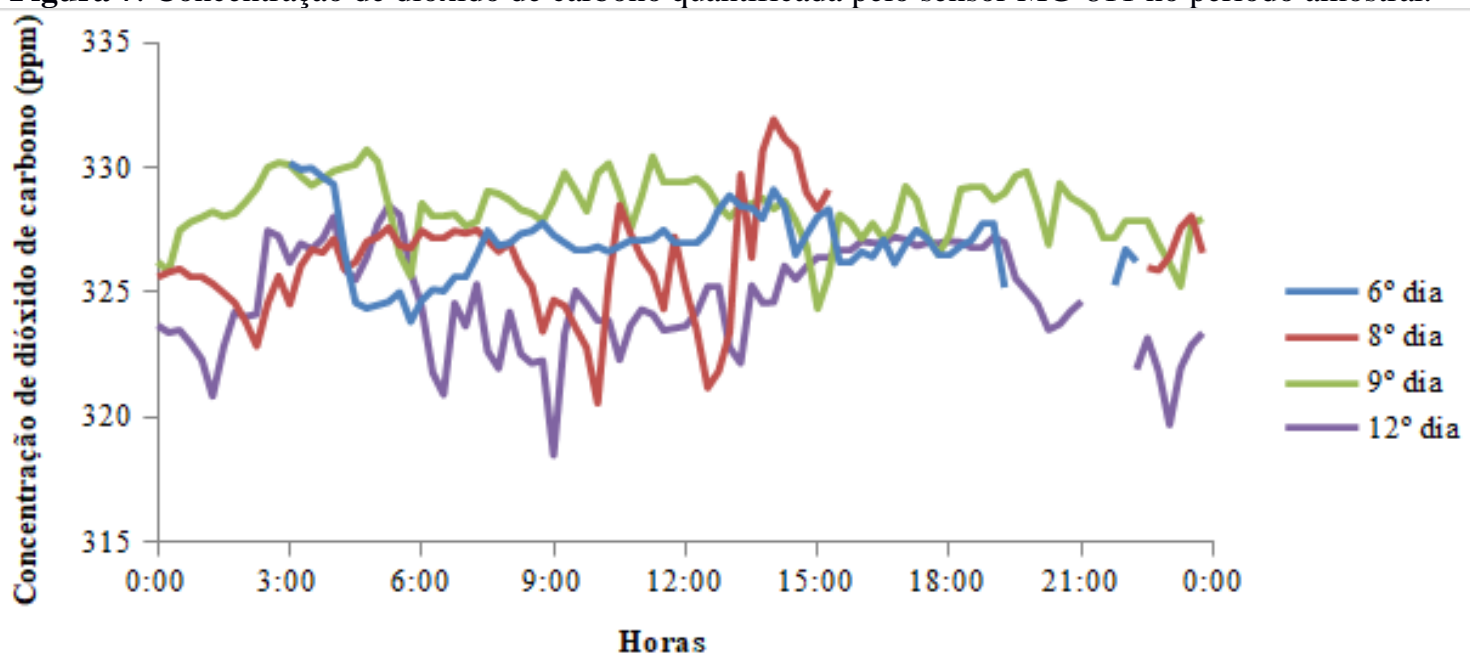

Fonte: Própria (2020).

A estatística descritiva dos dados coletados, evidenciou que as médias de concentração de dióxido de carbono variaram menos de 4 ppm entre os dias estudados, e não seguiram a tendência observada na concentração de amônia, de redução conforme a idade das aves.

A concentração mínima detectada foi de 318 ppm e a máxima de 331 ppm, dentro do nível considerado ideal para criação de frango de corte, que é inferior à 3.000 ppm. Atividades em ambientes com concentrações de dióxido de carbono acima de 3.900 ppm são consideradas insalubres, portanto, não se verificou essa condição no aviário experimental. 
A Figura 8 mostra os diagramas de frequência dos quatro dias observados, referente as concentrações de dióxido de carbono (ppm). Utilizando o teste $\mathrm{KS}$, apenas os dados do $12^{\circ}$ dia apresentaram p-valor maior que 0,05 . Ou seja, não há evidências suficientes para concluir que os dados não seguem normalidade apenas para a amostra do $12^{\circ}$ dia.

Figura 8. Diagramas de frequência das concentrações de dióxido de carbono
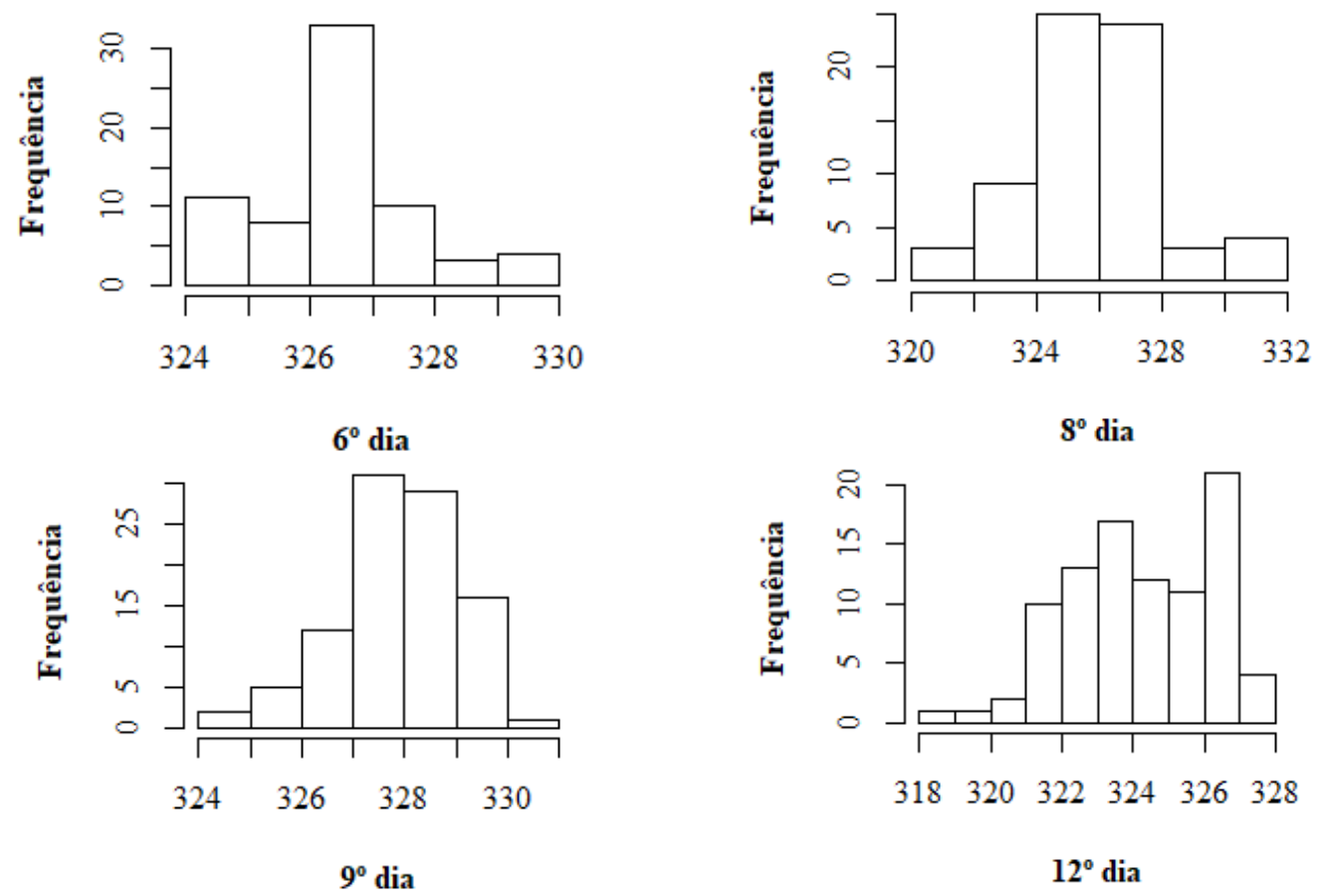

Fonte: Própria (2020).

Com auxílio do boxplot da Figura 9, é possível identificar pontos discrepantes nas amostras do $6^{\circ}, 8^{\circ}$ e $9^{\circ}$. Apenas o $12^{\circ}$ não apresentou outlier em seu conjunto de dados. As maiores variabilidades são observadas no $8^{\circ}$ e $12^{\circ}$ dia. Os níveis médios de dióxido de carbono são próximos, variando em torno de 325 ppm à 328 ppm.

Figura 9. Boxplots das concentrações de dióxido de carbono (ppm) dos dias observados.

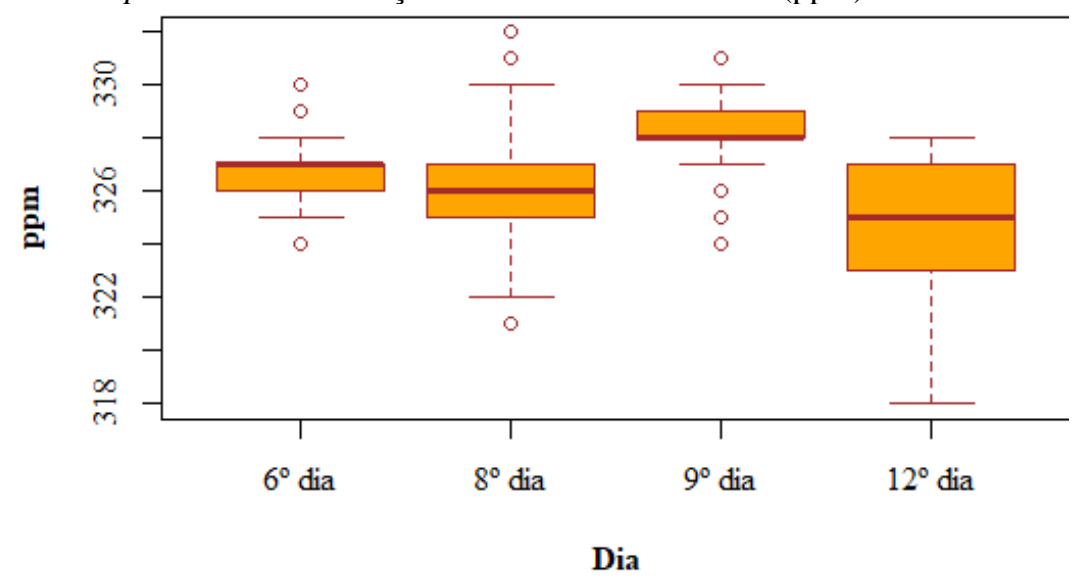

Fonte: Própria (2020).

[266]

CIÊNCIA, TECNOLOGIA E INOVAÇÃO: DO CAMPO À MESA. RECIFE: EDITORA IIDV, 2020 
Verificou-se que pelo menos uma média dos tratamentos se diferencia das demais, utilizando a distribuição F de Snedecor, ao nível de 5\% de probabilidade, e utilizando o teste de Tukey de comparações múltiplas, observou-se que o $6^{\circ}$ e $8^{\circ}$ dia não apresentaram diferenças significativas em suas médias de concentrações. Ou seja, há evidências de que as concentrações de dióxido de carbono não apresentaram variações significativas estatisticamente, em determinados períodos de alojamento.

Os dados de temperatura e umidade do ar foram coletados com o sensor modelo BME280. Esse sensor mostrou-se eficiente pelo tempo de resposta das leituras e número reduzido de falhas em relação a outros sensores testados. As coletas de temperatura são apresentadas na Figura 10.

Figura 10. Temperatura ambiente $\left({ }^{\circ} \mathrm{C}\right)$ quantificada pelo sensor BME280 no período amostral.

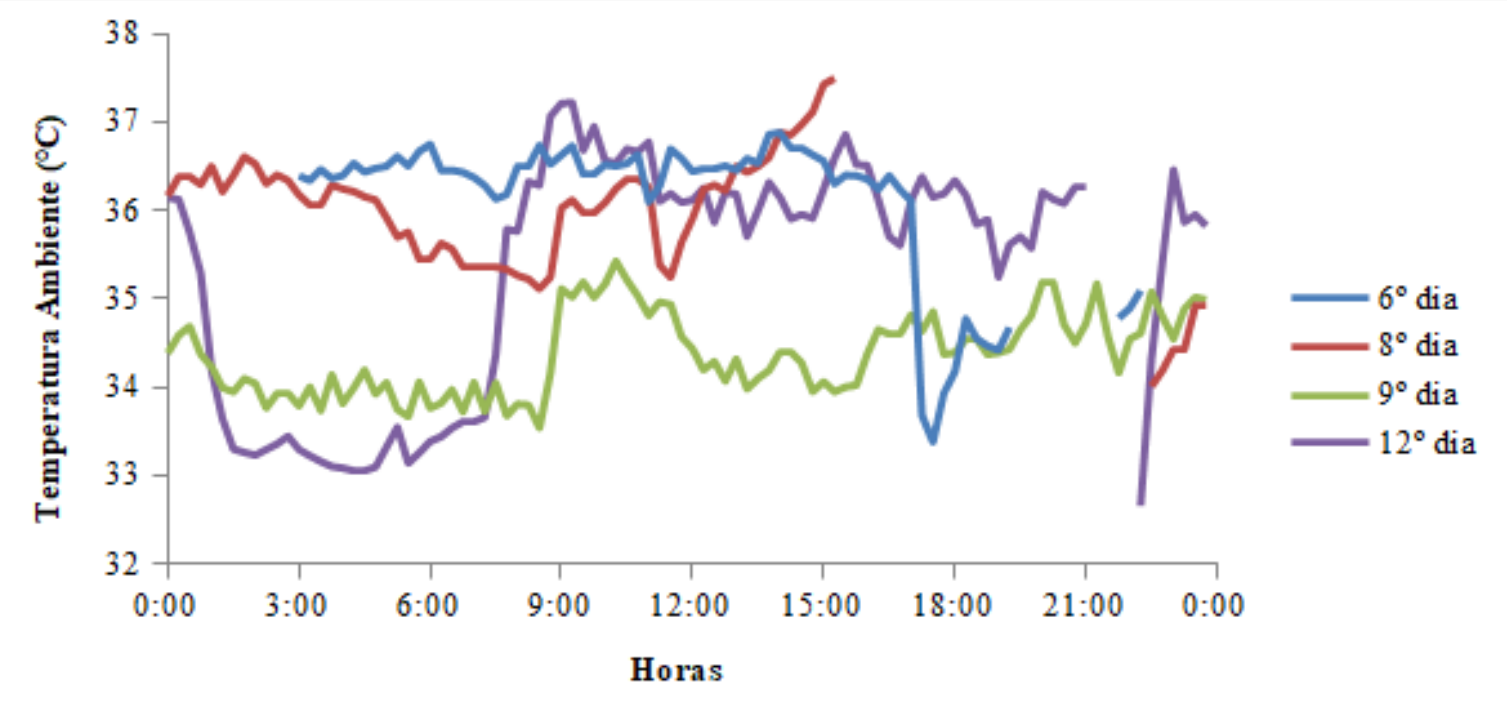

Fonte: Própria (2020).

Nessa representação gráfica é possível observar que no $6^{\circ}$ dia, a temperatura mantevese entre $36{ }^{\circ} \mathrm{C}$ e $37{ }^{\circ} \mathrm{C}$ até as $17 \mathrm{~h}$, mostrando um comportamento de estabilidade em relação aos demais dias. Isso pode ser explicado, pois, nos dias iniciais do lote produtivo, a ventilação é mínima para evitar choques de temperatura e favorecer o desenvolvimento saudável das aves. Nos demais dias experimentais, observa-se que a variação de temperatura é maior com o passar do tempo.

Com a estatística descritiva, foi possível observar que a média de temperatura foi decrescente entre o $6^{\circ}$ e $9^{\circ}$ dia. No $12^{\circ}$ dia a média sofreu aumento de $1^{\circ} \mathrm{C}$ em relação ao $9^{\circ}$ dia. 
Isso ocorre devido a ventilação mínima ser suspensa a partir do $10^{\circ}$ dia de alojamento. A Figura 12 apresenta os diagramas de frequência das temperaturas observadas.

Figura 12. Diagramas de frequência das temperaturas
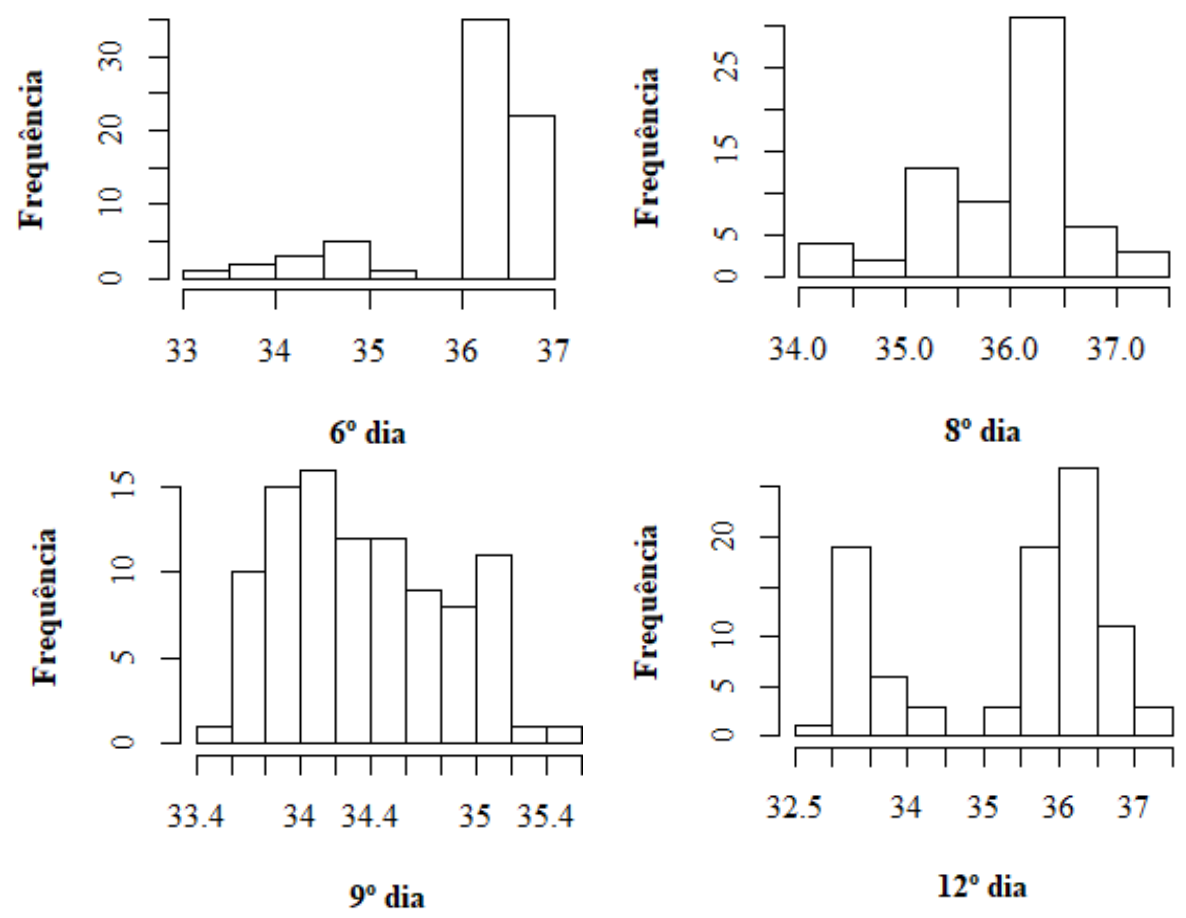

Fonte: Própria (2020).

Os dados do $6^{\circ}$ e $12^{\circ}$ apresentaram p-valor menor do que 0,05 no teste KS, logo, essas amostras não seguem uma distribuição normal. O boxplot da Figura 13 mostra que apenas os dados do $6^{\circ}$ dia apresentaram pontos discrepantes. Esses pontos discrepantes foram localizados em uma sequência de leituras no $6^{\circ}$ dia a partir das $17 \mathrm{~h}$, indicando um possível incidente no sistema de aquecimento, considerando a queda repentina na temperatura do ambiente. Os valores médios da temperatura foram decrescentes até o $9^{\circ}$ dia.

Utilizando a distribuição F de Snedecor, foi possível identificar que pelo menos um dos tratamentos apresenta diferença em relação aos demais, ao nível de 5\% de probabilidade. Com o teste de Tukey de comparações múltiplas, observou-se que o $6^{\circ}$ e $8^{\circ}$ dia não apresentaram diferenças significativas em suas médias de temperatura. Ou seja, há evidências de que as temperaturas não apresentam diferenças significativas nos períodos iniciais de alojamento.

Quanto à umidade relativa do ar, os dados são apresentados na Figura 14, e observa-se que os valores do $6^{\circ}$ e $12^{\circ}$ dia são inferiores, variando na maior parte do dia entre $50 \%$ e $55 \%$ no $6^{\circ}$ dia, e entre $50 \%$ e $60 \%$ no $12^{\circ}$ dia.

A estatística descritiva desses dados revelou que a média da umidade relativa aumentou 
até o $9^{\circ}$ dia, variando entre $54 \%$ e $61 \%$ e no $12^{\circ}$ dia, a média foi de $56 \%$.

Figura 13. Boxplots das temperaturas (Celsius) dos dias observados.

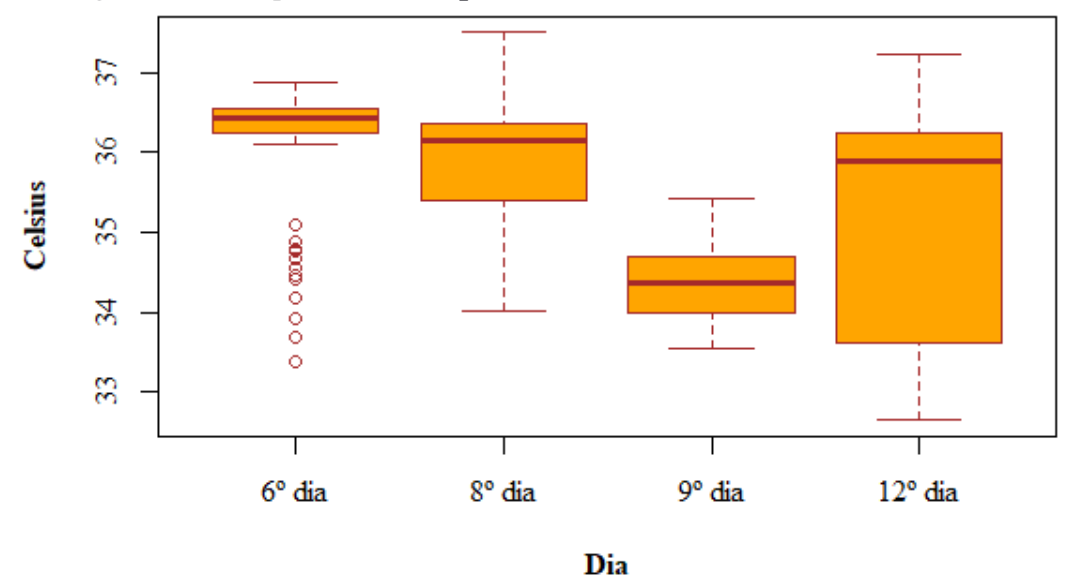

Fonte: Própria (2020).

Figura 14. Umidade relativa do ar (\%) quantificada pelo sensor BME-280 no período amostral.

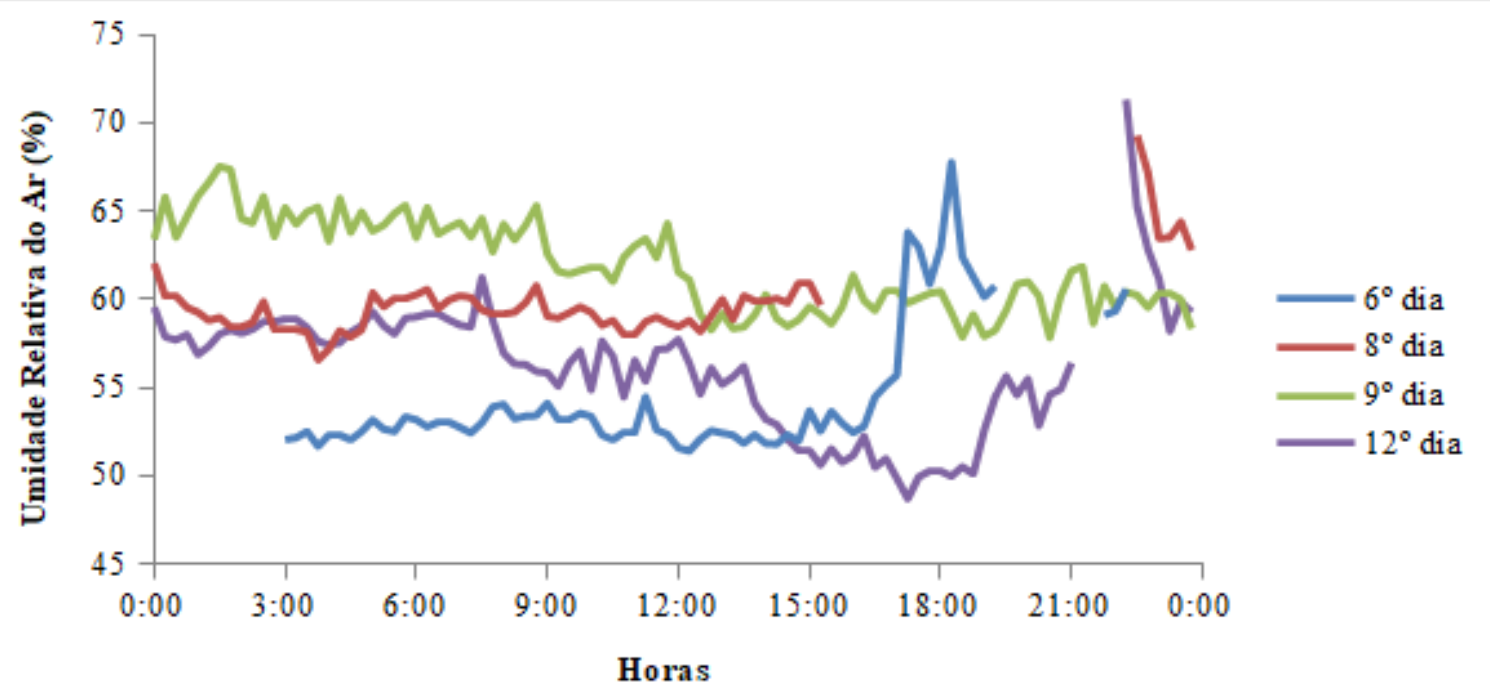

Fonte: Própria (2020).

Os valores mínimos variaram de $48 \%$ a 57\%, e máximos de $67 \%$ a $71 \%$. O nível ideal de umidade do ar é entre $50 \%$ e $60 \%$, e, em alguns momentos dos dias estudados, as incidências ultrapassaram esses limites. Os diagramas de frequência da Figura 15 mostram que os dados não apresentaram normalidade.

Sobre pontos discrepantes, a Figura 16 apresenta o boxplot onde apenas no $9^{\circ}$ dia não foram detectados outliers nas amostras. As amostras apresentam uma tendência crescente da variabilidade dos dados conforme os dias de alojamento. Os valores médios foram crescentes até o $9^{\circ}$ dia. 
Figura 15. Diagramas de frequência das umidades relativa do ar.
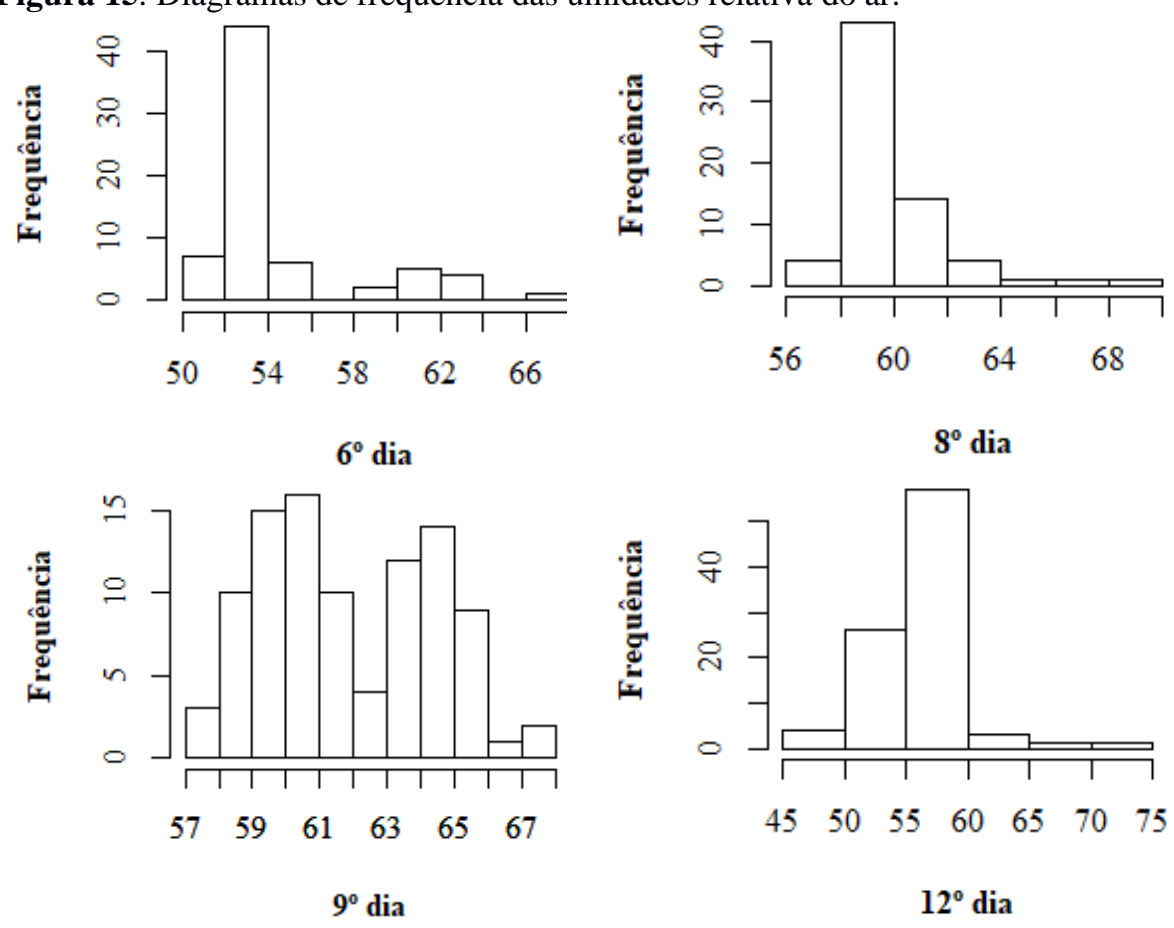

Fonte: Própria (2020).

Figura 16. Boxplots das umidades relativa do ar $(\%)$ dos dias observados.

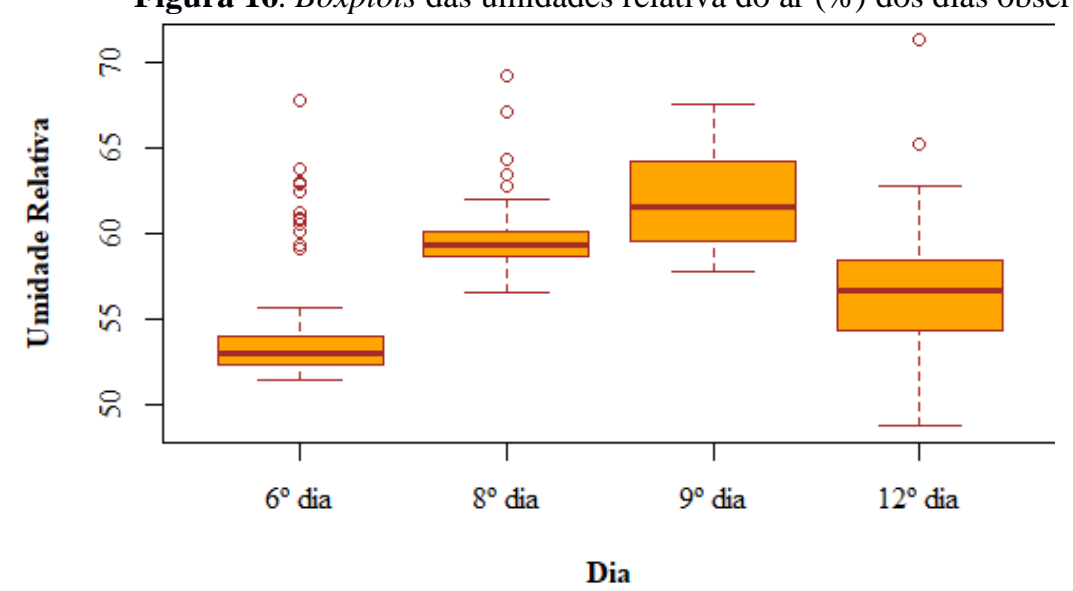

Fonte: Própria (2020).

Com a distribuição F de Snedecor, evidenciou-se que pelo menos um dos tratamentos apresenta diferença em relação aos demais, ao nível de 5\% de probabilidade. O teste de Tukey de comparações múltiplas, mostrou que todos os tratamentos possuem diferenças significativas em suas médias de umidade relativa do ar. Sendo assim, pode-se afirmar que, a umidade relativa do ar apresenta variações significativas estatisticamente, nos períodos de alojamento observados. 
Os valores mínimos variaram de $48 \%$ a 57\%, e máximos de $67 \%$ a $71 \%$. O nível ideal de umidade do ar é entre 50\% e 60\%, e, em alguns momentos dos dias estudados, as incidências ultrapassaram esses limites.

\section{Conclusões}

Com o desenvolvimento desse estudo, o avicultor pode observar de maneira contínua, o controle da ambiência aérea do aviário. Os níveis de concentração de amônia e dióxido de carbono detectados estão dentro dos limites aceitáveis de qualidade do ar para criação de frango de corte, e dos limites toleráveis de insalubridade para os trabalhadores.

As análises estatísticas evidenciaram que em determinados dias, alguns fatores ambientais observados não apresentaram diferenças significativas nas médias. Foi o caso das concentrações de dióxido de carbono e da temperatura do ar, no $6^{\circ}$ e $8^{\circ}$ dia. Isso denota que o aviário em questão possui um sistema de automação eficiente capaz de manter o ambiente controlado.

A concentração de gases no aviário durante o período em que foram realizados os testes, não atingiu valores elevados. Porém, o mesmo protótipo pode ser utilizado em outros ambientes onde pode haver alta concentração de gases, como em frigoríficos, onde o gás amônia é muito utilizado nos sistemas de refrigeração e eventualmente acontecem vazamentos, ou em espaços confinados onde há o acúmulo de gases tóxicos.

\section{Referências}

ARAÚJO, F. G. Bem-estar e Ambiência das Aves. Urutaí,: IFGO, 2013. 102 p. Disponível em:

http://proedu.rnp.br/bitstream/handle/123456789/1471/Bem_Estar_e_Amb_das_Aves_WEB. pdf. Acesso em: 14 ago. 2020.

ARAÚJO, G. C.; BUENO, M. P.; BUENO, V. P.; SPROESSER, R. L.; SOUZA, I. F. Cadeia produtiva da avicultura de corte: avaliação da apropriação de valor bruto nas transações econômicas dos agentes envolvidos. Gestão \& Regionalidade, São Caetano do Sul, v. 24, n. 72, p. 6-16, $\quad$ set./dez. 2008. Disponível https://seer.uscs.edu.br/index.php/revista_gestao/article/view/95/58. Acesso em: 14 ago. 2020.

BRASIL. Ministério do Trabalho e Emprego. NR 15 - Atividade e operações insalubres. Brasília: Ministério do Trabalho e Emprego, 1978. Disponível em: https://enit.trabalho.gov.br/portal/images/Arquivos_SST/SST_NR/NR-15-atualizada2019.pdf. Acesso em: 14 ago. 2020.

COBB. Manual de Manejo de Frangos de Corte. 2008. Disponível em: https://wp.ufpel.edu.br/avicultura/files/2012/04/Cobb-Manual-Frango-Corte-BR.pdf. Acesso em: 15 ago. 2020. 
FRANCO, A. S. M. A avicultura no Brasil. Análise conjuntural. 2017. Curitiba, PR. v.39, n.1-2/jan./fev. Disponível em: http://www.ipardes.gov.br/biblioteca/docs/bol_39_1_c.pdf. Acesso em: 14 ago. 2020.

LOPES, J. C. O. Técnico em avicultura. Floriano: Edufpi, 2011. 94 p. Disponível em: http://pronatec.ifpr.edu.br/wp-content/uploads/2013/06/Avicultura.pdf. Acesso em: 14 ago. 2020.

OIE. World Organisation for Animal Health, Terrestrial Animal Health Code. Disponível em https://www.oie.int/standard-setting/terrestrial-code/access-online. Acesso em: 14 ago. 2020.

OLIVEIRA, P. A. V.; MONTEIRO, A. N. T. R. Emissão de amônia na produção de frangos de corte. In: CONFERÊNCIA FACTA, Campinas, 2013. Anais. Campinas: Facta, 2013. 1 CDROM.

http://ainfo.cnptia.embrapa.br/digital/bitstream/item/91032/1/final7197.pdf. Acesso em: 14 ago. 2020.

OVIEDO-RONDON, E. O. Tecnologias para mitigar o impacto ambiental da produção de frangos de corte. R. Bras. Zootec., Viçosa, v. 37, n. spe, p. 239-252, Julho 2008. DOI: https://doi.org/10.1590/S1516-35982008001300028.

Disponível

em:

http://www.scielo.br/scielo. Acesso em: 03 ago. 2020.

ROSS. Manual De Manejo De Frangos Ross. 2018. Disponível em: https://en.aviagen.com/assets/Tech_Center/Ross_Broiler/Ross-BroilerHandbook2018-EN.pdf. Acesso em: 14 ago. 2020.

SOUSA, D. P.; OSAKI, M. Caracterização do Mercado Internacional de Carne de Frango Brasil X Estados Unidos. In: XLIII Congresso de Sociedade Brasileira de Economia, Adminsitração e Sociologia Rural, 2005, Ribeirão Preto. Disponível em: https://www.cepea.esalq.usp.br/br/documentos/texto/artigo-publicado-no-xliii-congresso-dasober-caracterizacao-do-mercado-internacional-de-carne-de-frango-brasil-x-estadosunidos.aspx. Acesso em: 14 ago. 2020.

TINOCO, I. F. F. Avicultura Industrial: Novos Conceitos de Materiais, Concepções e Técnicas Construtivas Disponíveis para Galpões Avícolas Brasileiros. Rev. Bras. Cienc. Avic., Campinas, v. 3, n. 1, p. 01-26, Janeiro 2001. DOI: https://doi.org/10.1590/S1516635X2001000100001. Disponível em: http://www.scielo.br/scielo. Acesso em: 03 agosto 2020.

WEATHERSPARK. Condições meteorológicas características de Cascavel em abril. Disponível em: https://pt.weatherspark.com/m/29585/4/Condições-meteorológicascaracterísticas-de-Cascavel-Brasil-em-abril. Acesso em: 14 ago. 2020. 


\title{
CAPÍTULO 19: FARINHAS DE RESÍDUOS DA FILETAGEM DE TILÁPIA COM SABOR
}

\section{CHAPTER 19: FLOURS OF TILAPIA FILLING WASTE WITH FLAVOR}

\author{
Melina Franco Coradini ${ }^{1}$; Stefane Santos ${ }^{2}$; Gislaine Oliveira ${ }^{3}$; Isabela Julio Iwassa ${ }^{4}$; Maria Luiza \\ Rodrigues de Souza ${ }^{5}$
}

\begin{abstract}
Resumo
O objetivo do trabalho foi elaborar farinhas a partir de carcaças de tilápia, adicionando sabores, além de avaliá-las quanto aos seus aspectos físico-químicos e microbiológicos. Para a elaboração das farinhas as carcaças foram, lavadas, cozidas, prensadas, moídas e desidratadas. A partir da farinha padrão de tilápia foram produzidas as farinhas salgada e doce, totalizando três tratamentos. A farinha padrão apresentou o maior teor de proteico e de minerais, 55,39 e $28,12 \%$ respectivamente. Enquanto, que a farinha salgada de tilápia apresentou o maior teor de lipídios totais, 7,47\%, além de uma maior porcentagem de ácidos graxos ômega-3 na fração lipídica $1,14 \%$. O pH da farinha padrão de tilápia foi próximo da 7,06, porém não houve contaminação microbiológica do produto, estando todas as farinhas aptas para o consumo. Conclui-se que a farinha de tilápia padrão é a mais indicada para a inclusão em produtos alimentícios, onde o objetivo seja o aumento do teor proteico e de minerais, entretanto, analisando a fração lipídica a farinha salgada de tilápia é a mais indicada.
\end{abstract}

Palavras-Chaves: Ácidos graxos, Carcaça, Oreochromis niloticus, Pescado, Proteína.

\begin{abstract}
The objective of the work was to prepare flours from tilapia carcasses, adding flavors, in addition to evaluating them in terms of their physical-chemical and microbiological aspects. The carcasses were prepared for washing the flours, washed, cooked, pressed, ground and dehydrated. Salty and sweet flours were produced from standard tilapia flour, totaling three treatments. The standard flour had the highest protein and mineral content, 55.39 and $28.12 \%$ respectively. Whereas, the salted tilapia flour had the highest total lipid content, $7.47 \%$, in addition to a higher percentage of omega-3 fatty acids in the $1.14 \%$ lipid fraction. The $\mathrm{pH}$ of the standard tilapia flour was close to 7.06, but there was no microbiological contamination of the product, with all the flours suitable for consumption. It is concluded that the standard tilapia flour is the most suitable for inclusion in food products, where the objective is to increase the protein and mineral content, however, analyzing the lipid fraction, the tilapia salted flour is the most indicated.
\end{abstract}

Keywords: Carcass, Fatty acids, Fish, Oreochromis niloticus, Protein.

\section{Introdução}

Em 2016, a produção aquícola mundial foi de 110,2 milhões de toneladas, do total produzido pela aquicultura, 80 milhões de toneladas, foram de pescado destinados para a

\footnotetext{
${ }^{1}$ Pós-graduação em Zootecnia, Universidade Estadual de Maringá, melinacoradini@gmail.com

2 Pós-graduação em Zootecnia, Universidade Estadual de Maringá, stefane.pescap@ gmail.com

${ }^{3}$ Pós-graduação em Zootecnia, Universidade Estadual de Maringá, gislaine_oliveira14@ @otmail.com

${ }^{4}$ Pós-graduação em Engenharia Química, Universidade Estadual de Maringá, isa_iwassa@ @otmail.com

${ }^{5}$ Professora, Universidade Estadual de Maringá, mlrsouza.uem@gmail.com
} 
produção de alimentos (FAO, 2018). Entre todas as espécies de peixes a tilápia é a mais cultivada no Brasil, além disso, ela é o peixe mais introduzido e cosmopolita do mundo, presente em mais de 140 países, devido principalmente as suas características de alta adaptabilidade a produtividade (BEZERRA \& ANGELINI, 2016).

O consumo da carne de pescado é impulsionado pelo seu valor nutritivo, textura da carne e fatores relacionados aos métodos de captura, beneficiamento e processamento. Observar as formas de como o pescado, incluindo a tilápia, é beneficiados e os produtos que são elaborados a partir dele é de extrema importância para a definição das qualidades nutricionais, microbiológicas e os rendimentos do mesmo. Outro aspecto que deve se observado é sua forma de comercialização, no caso da tilápia, é majoritariamente em filés (BOSCOLO \& FEIDEN, 2007; GONÇALVES, 2011).

Da massa total do peixe o filé chega a até 40\% (SOUZA \& MACEDO-VIEGAS, 2001), portanto, há um elevado percentual de resíduos gerados durante o processamento da tilápia. Entre os resíduos estão as cabeças e vísceras que correspondem a 36\%, o espinhaço com nadadeiras (carcaça) que chegam a $22 \%$, as aparas com $3 \%$ e as peles que variam entre 8 e $10 \%$ do total do peso ao abate da tilápia (SILVA et al., 2016).

Paralelo a grande quantidade de resíduos e subprodutos gerados no processamento da tilápia do Nilo, há também a qualidade dessa matéria-prima, pois o valor nutricional desse material é de significativa importância, e quando coletado de forma adequada dentro da unidade de beneficiamento, o mesmo, pode ser destinado para a alimentação humana. Souza et al (2017) relataram que a farinha de tilápia do Nilo elaborada apenas com o espinhaço e a carne remanescente do processo de filetagem, apresenta teores médios de 51,13\% de proteína bruta, 5,82\% de lipídios totais e 37,66\% de cinzas, sendo que desses até 9,37\% são de Cálcio. Franco et al. (2013), relataram ainda, que as peles de tilápia do Nilo in natura, podem apresentar até $29,08 \%$ de proteína bruta, isso exemplifica o grande potencial nutricional desses subprodutos da indústria pesqueira.

A farinha de peixe geralmente é elaborada de forma padrão, sem a adição de ingredientes que promovam a inclusão de sabores para esse produto, diversos trabalhos já foram realizados com a utilização de farinhas de pescado em alimentos, tanto doces, quanto salgados (VERDI et al., 2020; VITORINO et al., 2020; Franco et al., 2013), porém a adição de sabor na farinha de peixe não é usual, além de ser um fator com grande potencial para a melhora da qualidade sensorial e dependendo do ingrediente utilizado, até nutricional dos produtos.

O objetivo do trabalho foi elaborar farinhas a partir de carcaças, resíduos do processo de filetagem da tilápia, com formulações salgado e doce, além de avaliá-las em relação aos seus 
aspectos físico-químicos e microbiológicos.

\section{Material e Métodos}

As farinhas foram produzidas no laboratório de tecnologia do pescado na fazenda experimental de Iguatemi (FEI), pertencente à Universidade Estadual de Maringá (UEM). O resíduo utilizado, remanescente da filetagem do peixe, foi a carcaça sem a cabeça, a pele e as vísceras, para elaboração das farinhas de tilápia (Oreochromis niloticus). A matéria-prima foi proveniente da empresa Smart-Fish (Rolândia/PR), o material foi transportado em caixas isotérmicas a uma temperatura de $0^{\circ} \mathrm{C}$ e congeladas a $-18^{\circ} \mathrm{C}$ até o momento da fabricação do produto.

Para a obtenção da farinha de tilápia, utilizaram as carcaças (espinhaço e carne remanescentes do processo de filetagem), retirando as nadadeiras, cauda, resquícios de pele e de partes aderentes dos sistemas gastrintestinais, reprodutor e rins. Após o preparo das matériasprimas, utilizou-se $5 \mathrm{~kg}$ de carcaça já limpa para a produção de cada tratamento com três repetições cada.

A metodologia para a obtenção da farinha de carcaça de tilápia, padrão (sem sabor), foi a mesma que a descrita por Souza et al. (2017), onde o material foi lavado, pesado, sanitizado com $0,1 \mathrm{mg} / \mathrm{Kg}$ de peroxitane ${ }^{\circledR} 1512 \mathrm{AL}$ e submetido ao cozimento em panela de pressão com antioxidante $(0,5 \mathrm{mg} / \mathrm{kg}$ de BHT, antioxidante), por 60 minutos. Após foi realizada a prensagem em prensa hidráulica com capacidade de 10 toneladas, para as retiradas do excesso de água e gordura, e as carcaças foram moídas em moedor de carne (modelo CAF-10). As massas obtidas foram desidratadas em estufa de secagem de ar forçada a $60^{\circ} \mathrm{C}$, por 24 horas. Após o produto desidratado o mesmo foi triturado e novamente moído em moinho tipo faca (Willye - modelo TE-650), por fim, a farinha foi embalada a vácuo e armazenada em freezer até o momento das análises e da adição dos sabores.

A partir da farinha de carcaça de tilápia padrão (sem sabor), foram produzidas farinhas de tilápia salgada e doce resultando, portanto, em três tratamentos, tratamento $1=$ farinha de tilápia natural, tratamento $2=$ farinha salgada de tilápia e tratamento $3=$ farinha doce de tilápia, os ingredientes utilizados para a adição de sabor no produto estão descritos na Tabela 1. 
Tabela 1. Ingredientes e as quantidades utilizadas na elaboração das farinhas salgada e doce de tilápia.

\section{Ingredientes}

Quantidade (g)

\begin{tabular}{lc}
\hline Farinha salgada de tilápia & \\
\hline Farinha de carcaça de tilápia (padrão) & 200 \\
Gergelim & 33 \\
Óleo de gergelim & 6 \\
Glutamato sódico & 1 \\
Sal & 3 \\
Nori & 10 \\
Molho fermentado de soja & 7,5 \\
Orégano & 1 \\
Alho em pó desidratado & 1 \\
Cebola e salsa desidratadas & 20 \\
Linhaça & 50 \\
\hline Farinha doce de tilápia & 200 \\
\hline Farinha de carcaça de tilápia (padrão) & 150 \\
Açúcar mascavo & 1 \\
Orégano & 20 \\
Canela em pó & 50 \\
Cacau em pó & 1 \\
Cravo de índia em pó & 15 \\
Gengibre em pó & 9 \\
Baunilha & 100 \\
\hline
\end{tabular}

Na elaboração da farinha salgada, a base de farinha de carcaça de tilápia (padrão) foi misturada com óleo de gergelim e molho fermentado de soja em um recipiente em placa de aquecimento a $150{ }^{\circ} \mathrm{C}$, onde se obteve uma massa homogênea, posteriormente todos os ingredientes desidratados (Tabela 1) foram adicionados ao recipiente, que permaneceu na mesma temperatura, durante 10 minutos, sempre em movimentação com uma colher de pau, para não queimar. Já para o preparo da farinha doce, foi adicionado o orégano na água, em função das suas propriedades antioxidantes e após três minutos de fervura, ele foi adicionado a farinha de carcaça de tilápia (padrão) e o açúcar mascavo. Após a massa estar bem homogeneizada, adicionaram-se ao processo os demais ingredientes (Tabela 1), deixando por 
10 minutos em cozimento na placa de aquecimento em uma temperatura de $150^{\circ} \mathrm{C}$. A massa obtida foi para a estufa a $60^{\circ} \mathrm{c}$ por $24 \mathrm{~h}$, depois foi moída em um moedor tipo faca (Willye modelo TE-650). Após o resfriamento das farinhas elas foram embaladas e acondicionadas a uma temperatura de $-18^{\circ} \mathrm{C}$ até o momento das análises físico-químicas e microbiológicas.

A análise de composição química foi realizada no LANA - Laboratório de Alimentos e Nutrição Animal da Universidade Estadual de Maringá. Para a determinação dos teores de umidade, cinzas e a quantificação dos minerais cálcio e fósforo, as análises foram realizadas seguindo a metodologia da AOAC (2005). Os teores de proteína bruta foram avaliados pelo método de semimicro Kjeldahl (SILVA \& QUEIROZ, 2002) e para a extração dos lipídios totais se empregou o método Bligh \& Dyer (1959).

O valor calórico (VC) foi determinado segundo Souci et al. (2000), obtido pela soma da multiplicação do teor de proteína bruta (PB), lipídios totais (LT) e carboidratos (CB) multiplicados pelos fatores 4,9 e 4 , respectivamente. Seguindo a fórmula: VC $(\mathrm{Kcal} / \mathrm{Kg})=$ $\mathrm{PBx} 4+\mathrm{LPx} 9+\mathrm{CBx} 4$.

O perfil de ácidos graxos foi determinado de acordo com a metodologia descrita por Hartman \& Lago (1973), aproximadamente $100 \mathrm{mg}$ de lipídios de cada tratamento foi transmetilada, usando uma solução de cloreto de amônia e ácido sulfúrico, em metanol como agente esterificante. Os ésteres de ácidos graxos foram isolados e analisados em cromatógrafo gasoso (Agilent, modelo 7890 ), acoplado a um detector de massas (Agilent 5975C), utilizando uma coluna ZB- Wax Polietileno Glicol (30 m de comprimento x 0,25 mm de diâmetro interno x $0,25 \mu \mathrm{m}$ de espessura do filme). O gás de arraste foi o Hélio (He) e o fluxo de injeção foi de 1 $\mathrm{ml} / \mathrm{min}$ Split 1:10. A temperatura inicial da coluna foi estabelecida em $50^{\circ} \mathrm{C}$, mantida por 2 minutos, sendo então elevada para $220^{\circ} \mathrm{C}$ a uma taxa de $4^{\circ} \mathrm{C} /$ min e mantida por 7 minutos. A temperatura do injetor utilizada foi de $250^{\circ} \mathrm{C}$. A identificação dos ácidos graxos foi realizada pela comparação dos tempos de retenção dos ésteres metílicos das amostras com os de padrões autênticos (Sigma).

As análises microbiológicas foram realizadas no laboratório de Microbiologia e Microscopia de Alimentos da Universidade Estadual de Maringá - UEM. Foram amostrados $100 \mathrm{~g}$ de cada tratamento, sendo analisados para o número mais provável (NMP) de Coliformes a $35^{\circ} \mathrm{C}$ e $45^{\circ} \mathrm{C}$, contagem de Staphylococcus coagulase positiva em unidade formadora de colônia (UFC)/grama e de Salmonella spp, de acordo com APHA (2001). O protocolo microbiológico seguiu os padrões recomendados pela Resolução RDC n ${ }^{\circ} 12$, de 2 de janeiro de 2001, da Agência Nacional de Vigilância Sanitária (BRASIL, 2001). 
Para a medição do $\mathrm{pH}$, foi utilizada amostra homogeneizada de farinha (10 gramas) com água destilada (1:10 amostra/água). O homogeneizado foi submetido aos eletrodos do pHmetro (DM 22, Digimed, São Paulo, Brasil) por 5 minutos, quando foi procedida a leitura do $\mathrm{pH}$. A atividade de água das amostras de cada tratamento foi determinada, utilizando o aparelho da marca Aw Sprint - Novasina TH-500.

O delineamento experimental foi inteiramente ao acaso, foi realizada uma ANOVA e os resultados significativos submetidos ao teste de Tukey a $5 \%$ de probabilidade, testando as diferenças entre os três tratamentos. Para toda a análise foi utilizado o programa SAS Inst. Inc., Cary, NC, USA (2000). Não foi realizada análise estatística para os resultados da microbiologia e do perfil de ácidos graxos.

\section{Resultados e Discussão}

São muitos os produtos que podem ser elaborados utilizando resíduos de peixes, gerados pelas indústrias beneficiadoras de pescado, entre eles a farinha de peixe é um dos mais produzidos, apesar disso, existe uma falta de padronização em relação aos valores nutricionais desse produto, sendo ele elaborado para a alimentação humana, ou para a alimentação animal (ARRUDA et al., 2006).

De acordo com os resultados da composição química e do valor calórico das farinhas de tilápia, houve diferenças significativas entre os tratamentos para todos os nutrientes avaliados (Tabela 2).

Tabela 2. Composição química, cálcio, fósforo e valor calórico de farinhas obtidas a partir de carcaça de tilápia padrão, salgada e doce.

\begin{tabular}{|c|c|c|c|c|c|}
\hline \multirow{2}{*}{$\begin{array}{l}\text { Composição } \\
\text { química (\%) }\end{array}$} & \multicolumn{3}{|c|}{ Farinhas de carcaça de tilápia } & \multirow{2}{*}{$\begin{array}{c}\text { Valor de } \\
\text { p. }\end{array}$} & \multirow{2}{*}{$\begin{array}{l}\text { C.V. } \\
(\%)\end{array}$} \\
\hline & Padrão & Salgada & Doce & & \\
\hline Umidade & $3,53 \pm 1,04^{\mathrm{b} 1}$ & $6,06 \pm 0,46^{\mathrm{a}}$ & $4,11 \pm 0,46^{\mathrm{b}}$ & $<0,0001$ & 2,10 \\
\hline Proteína & $55,39 \pm 17,23^{\mathrm{a}}$ & $26,64 \pm 11,52^{c}$ & $32,45 \pm 5,71^{b}$ & $<0,0001$ & 1,14 \\
\hline Lipídios & $4,26 \pm 0,84^{\mathrm{b}}$ & $7,47 \pm 2,37^{\mathrm{a}}$ & $3,57 \pm 1,53^{\mathrm{b}}$ & $<0,0001$ & 5,41 \\
\hline Minerais & $28,12 \pm 8,58^{\mathrm{a}}$ & $17,71 \pm 1,83^{\mathrm{b}}$ & $12,78 \pm 6,76^{\mathrm{c}}$ & $<0,0001$ & 1,43 \\
\hline Carboidratos & $0,04 \pm 29,51^{\mathrm{c}}$ & $42,04 \pm 12,49^{a}$ & $46,56 \pm 17,01^{\mathrm{a}}$ & $<0,0001$ & 1,85 \\
\hline Cálcio & $5,16 \pm 2,81^{\mathrm{a}}$ & $1,04 \pm 1,31^{\mathrm{b}}$ & $0,85 \pm 1,50^{\mathrm{b}}$ & $<0,0001$ & 9,21 \\
\hline Fósforo & $5,46 \pm 2,63^{\mathrm{a}}$ & $1,78 \pm 1,05^{\mathrm{b}}$ & $1,26 \pm 1,57^{\mathrm{bc}}$ & $<0,0001$ & 5,63 \\
\hline V.C. ${ }^{3}(\mathrm{Kcal} / 100 \mathrm{~g})$ & $260,07 \pm 56,70^{b}$ & $342,03 \pm 25,26^{\mathrm{a}}$ & $348,20 \pm 31,43^{\mathrm{a}}$ & $<0,0001$ & 1,27 \\
\hline
\end{tabular}


O teor de umidade da farinha salgada de tilápia foi o mais elevado dentre todos os tratamentos, 6,06\% (Tabela 2), porém, a concentração de umidade desse tratamento ainda é inferior a máxima estabelecida para produtos similares com origem do pescado, segundo o Regulamento da Inspeção Industrial e Sanitária de Produtos de Origem Animal (RIISPOA, 2017) esses produtos não devem conter mais que 12\% de umidade em sua composição.

A farinha padrão apresentou $55,39 \%$ de proteína em sua composição, seguida pelas farinhas doce e salgada, 32,45 e 26,64\%, respectivamente. O tratamento um também apresentou o maior teor de minerais, $28,12 \%$, seguido pelos tratamentos dois, $17,71 \%$ e três, $12,78 \%$. A diminuição desses nutrientes se deve a adição dos produtos utilizados nas farinhas salgada e doce, já que os ingredientes possuem maiores concentrações de outras frações como os carboidratos.

A utilização de ingredientes com altos teores de carboidratos nas farinhas salgada e doce fica evidente, quando se observam as suas composições, já que esses tratamentos apresentam um teor médio de 44,3\% para esse nutriente, enquanto que a farinha padrão possui um teor de $0,04 \%$, pois se trata de um produto exclusivamente de origem animal (Tabela 2).

De acordo com Souza et al. (2017) farinhas de tilápias elaboradas, também com carcaças, assim como a farinha padrão do presente trabalho, apresentaram teores médios de 1,78\% para umidade, 51,13\% para proteínas, 5,82\% para lipídios e 37,66\% para cinzas e não apresentaram carboidratos em sua composição. Os mesmos autores citam ainda uma alta concentração de cálcio e fósforo para a farinha de tilápia, 9,37 e 6,08\%, respectivamente, esses valores são superiores aos encontrados na farinha padrão de tilápia que foram de 5,16\% para cálcio e 5,46\% para fósforo.

Em relação ao teor lipídico a tilápia é um peixe que possui uma baixa fração, quando comparado a outros, o filé de tilápia cru possui 5,82\% de lipídios totais (SIMÕES et al., 2007), enquanto que o salmão chega a até 18,81\% (TONIAL et al., 2010). Em se tratando de farinhas elaboradas com essas espécies de peixes, a farinha de carcaça de salmão apresenta uma média de 9,3\% de lipídios (SOUZA et al., 2017), enquanto, que a farinha salgada de tilápia, do presente trabalho, apresentou $7,47 \%$, um teor inferior quanto comparada com a farinha da outra espécie de peixe. Entretanto, além do teor de lipídios totais, quando estuda-se sobre composição de produtos a base de pescado é importante observar também, o perfil dos ácidos graxos encontrados.

Como durante a obtenção das farinhas é natural que ocorra a lixiviação de alguns nutrientes, foram avaliados os perfis de ácidos graxos dos três tratamentos. Sendo assim, foram 
detectados um total de 25 ácidos graxos na farinha padrão, 24 ácidos graxos na farinha salgada e 23 ácidos graxos na farinha doce (Tabela 3).

Tabela 3. Perfil de ácidos graxos de farinhas obtidas a partir de carcaça de tilápia padrão, salgada e doce.

\begin{tabular}{|c|c|c|c|}
\hline Ácidos graxos (\%) & Padrão & Salgada & Doce \\
\hline Ácido Láurico C12:0 & 0,0039 & 0,0031 & 0,0046 \\
\hline Ácido Mirístico C14:0 & 0,1221 & 0,0463 & 0,0601 \\
\hline Ácido Pentadecílico C15:0 & 0,0123 & 0,0047 & 0,0062 \\
\hline Ácido Palmítico C16:0 & 0,9917 & 0,8951 & 0,8464 \\
\hline Ácido Palmitoleico C16:1(9) $\omega 7$ & 0,2357 & 0,0811 & 0,1087 \\
\hline Ácido Margárico C17:0 & 0,0178 & 0,0088 & 0,0110 \\
\hline Ácido Cis-10-hepadecanóico C17:1 & 0,0158 & 0,0078 & 0,0073 \\
\hline Ácido Esteárico C18:0 & 0,3260 & 0,4691 & 0,7158 \\
\hline Ácido Oleico C18:1(9) $\omega 9$ & 1,3857 & 2,3356 & 1,1933 \\
\hline Ácido Vacênico C18:1(11) $\omega 7$ & 0,1184 & 0,1005 & 0,0719 \\
\hline Ácido Linoleico C18:2(9,12) $\omega 6$ & 0,4480 & 2,1382 & 0,2785 \\
\hline Ácido Gama Linolênico GLA C18:3(6,9,12) $\omega 6$ & 0,0347 & 0,0105 & 0,0160 \\
\hline Ácido Alfa Linolênico C18:3(9,12,15) $\omega 3$ & 0,0297 & 1,1352 & 0,0187 \\
\hline Ácido Linoleico conjugado CLA C18:2(9,11) $\omega 6$ & 0,0085 & 0,0026 & 0,0040 \\
\hline Ácido Estearidônico C18:4(6,9,12,15) $\omega 3$ & 0,0025 & 0,0000 & 0,0000 \\
\hline Ácido Araquídico C20:0 & 0,0122 & 0,0398 & 0,0247 \\
\hline Ácido Gadoleico C20:1 $\omega 11$ & 0,0800 & 0,0370 & 0,0386 \\
\hline Ácido Eicosadienóico C20:2(11,14) $\omega 6$ & 0,0290 & 0,0105 & 0,0124 \\
\hline Ácido Di-homo-alfa-Linolênico C20:3(11,14,17) $\omega 3$ & 0,0092 & 0,0021 & 0,0040 \\
\hline Ácido Di-homo-gama-Linolênico DGLA C20:3(8,11,14) $\omega 6$ & 0,0327 & 0,0103 & 0,0000 \\
\hline Ácido Araquidônico C20:4(5,8,11,14) $\omega 6$ & 0,0719 & 0,0190 & 0,0315 \\
\hline Ácido Eicosapentaenóico EPA C20:5(5,8,11,14,17) $\omega 3$ & 0,0041 & 0,0064 & 0,0021 \\
\hline Ácido Behênico C22:0 & 0,0061 & 0,0187 & 0,0073 \\
\hline Ácido Erúcico C22:1(13) $\omega 9$ & 0,0069 & 0,0096 & 0,0026 \\
\hline Ácido Lignocérico C24:0 & 0,0072 & 0,0100 & 0,0049 \\
\hline Ácidos graxos monoinsaturados & 1,8425 & 2,5716 & 1,4224 \\
\hline Ácidos graxos poli-insaturados & 0,6703 & 3,3348 & 0,4032 \\
\hline Ácidos graxos insaturados (AGPI) & 2,5128 & 5,9064 & 1,8256 \\
\hline Ácidos graxos saturados (AGS) & 1,4993 & 1,4596 & 1,6810 \\
\hline Ômega $3(\omega 3)$ & 0,0455 & 1,1437 & 0,2480 \\
\hline
\end{tabular}




\begin{tabular}{|c|c|c|c|}
\hline Ômega $6(\omega 6)$ & 0,6248 & 2,1911 & 0,3424 \\
\hline Ômega $9(\omega 9)$ & 1,3926 & 2,3452 & 1,1959 \\
\hline Relação ômega 6/ômega 3 ( $\omega 6 / \omega 3)$ & 13,7318 & 1,9158 & 1,3806 \\
\hline Relação AGPI/AGS & 1,6760 & 4,0465 & 0,1446 \\
\hline
\end{tabular}

Entre os ácidos graxos encontrados nas diferentes farinhas de tilápia destacam-se os ácidos graxos palmítico, palmitoleico, oleico, linoleico e alfa-linolênico, entretanto, esses ácidos graxos apareceram em quantidades diferentes nos três tratamentos. Em relação aos ácidos graxos poli-insaturados eles foram encontrados em maior quantidade na farinha salgada de tilápia, o seu teor foi de 3,33 ou 44,88\%, em relação à quantidade de lipídios totais, esse valor é alto quando comparado com o relatado por Ferreira et al. (2007) para filé de tilápia cru, cujo teor relatado foi de $22,97 \%$.

A relação ômega-6/ômega-3 é utilizada para analisar o teor nutricional dos lipídios nos alimentos. O Departamento de Saúde da Inglaterra (HMSO, 1994) recomenda uma razão de no máximo 4, sendo assim, os valores encontrados nas farinha salgada e doce estão dentro do padrão estabelecido por esse órgão. Já a farinha padrão de tilápia apresentou uma relação mais alta do que a recomendada, o que é justificado pela baixa concentração de ácidos graxos da série ômega-3 presente nesse tratamento. Ferreira et al. (2007) relataram que a razão ômega6/ômega-3 do filé de tilápia do Nilo in natura foi de 6,64.

A inclusão de outros ingredientes nas farinhas salgada e doce alterou a relação ômega6/ômega-3. A linhaça, por exemplo, é rica em ácidos graxos poli-insaturados da série ômega3, como o alfa-linolênico, chegando a um teor de até $63,26 \%$, em relação à quantidade de lipídios totais dessa semente, sendo assim, a sua utilização contribuiu para o aumento desse tipo de ácido graxo (NOVELO \& POLLONIO, 2012).

O Departamento de Saúde da Inglaterra determina ainda que índices inferiores a 0,45 para a razão ácidos graxos poli-insaturados/saturados potencializam o risco de aumento do colesterol sanguíneo. A farinha doce de tilápia foi a única a apresentar um valor inferior ao recomendado, aproximadamente 0,14 , indicando que esse tratamento é o menos indicado para a prevenção deste tipo de comorbidade, já os tratamentos 1 e 2, farinhas padrão e salgada apresentaram valores superiores 1,68 e 4,05, respectivamente, estando dentro das recomendações (HMSO, 1994).

Tanto a atividade de água, quanto o $\mathrm{pH}$ das farinhas de tilápia apresentaram diferenças significativas a $5 \%$ de probabilidade. As farinhas padrão e doce apresentaram atividades de água similares, 0,19 e 0,21, respectivamente, entretanto, a farinha salgada de tilápia apresentou 
uma atividade de água superior 0,42, assim como, a maior umidade (Tabela 2), isso ocorreu provavelmente por causa da inclusão de alimentos com maiores concentrações lipídica, como o óleo de gergelim, por exemplo, já que a introdução deste tipo de ingrediente proporciona uma menor perda de água durante a segunda desidratação da farinha salgada, realizada durante a sua obtenção.

$\mathrm{O}$ pH do pescado propicia condições que estimulam a multiplicação microbiana, pois a sua carne possui um $\mathrm{pH}$ próximo a neutralidade, além de grande atividade de água (OLIVEIRA et al., 2008). Por esses e outros fatores a elaboração de produtos como farinhas proporciona um maior tempo de estocagem para esse tipo de alimento de origem animal, já se observou a cima que a com a elaboração da farinha a atividade de água obtida foi baixa, entretanto os pH 7,06 para a farinha padrão, 6,54 para a farinha salgada e 7,68 para a farinha doce é um fator relevante para a contaminação microbiana, já que estão próximos a neutralidade.

Mesmo com o pH da farinha padrão de tilapia sendo próximo a neutralidade $(7,09)$ e os demais 6,54 (salgada) e 7,68 (doce) a qualidade microbiana das farinhas de tilápia, estavam dentro dos limites exigidos pela legislação brasileira para produtos derivados do pescado (BRASIL, 2001). O Número mais Provável de Coliformes a $35^{\circ}$ e $45^{\circ}\left({ }^{1} \mathrm{NMP} / \mathrm{g}\right)$ foi menor que 3, a contagem de Estafilococos Coagulase Positiva (UFC/g) foi inferior a $1 \times 10^{2}$ e a pesquisa de Salmonella Spp. em $25 \mathrm{~g}$ de amostra foi ausente, esse resultado mostra a importância de que os resíduos de pescado destinados ao processamento se transformando em subprodutos, devem ser obtidos seguindo os critérios de Boas Práticas e Fabricação (BPF) (Tabela 4).

Tabela 4. Microbiologia de farinhas obtidas a partir de carcaça de tilápia padrão, salgada e doce.

\begin{tabular}{|c|c|c|c|c|}
\hline $\begin{array}{l}\text { Farinhas } \\
\text { de carcaça } \\
\text { de tilápia }\end{array}$ & $\begin{array}{c}\text { Coliformes } \\
\text { fecais a } 35^{\circ} \mathrm{C} \\
\left(\mathrm{NMP}^{1 / g}\right)\end{array}$ & $\begin{array}{c}\text { Coliformes } \\
\text { fecais a } 45^{\circ} \mathrm{C} \\
\left(\mathrm{NMP}^{1} / \mathrm{g}\right)\end{array}$ & $\begin{array}{c}\text { Contagem de } \\
\text { Estafilococos coagulase } \\
\text { positiva }\left(\mathrm{UFC}^{2} / \mathrm{g}\right)\end{array}$ & $\begin{array}{c}\text { Pesquisa } \\
\text { de Salmonella } \\
\text { Spp em 25g }\end{array}$ \\
\hline Natural & $<3$ & $<3$ & $1 \times 10^{2}$ & AUSENTE \\
\hline Salgada & $<3$ & $<3$ & $1 \times 10^{2}$ & AUSENTE \\
\hline Doce & $<3$ & $<3$ & $1 \times 10^{2}$ & AUSENTE \\
\hline
\end{tabular}

${ }^{1} \mathrm{NMP}=$ Número Mais Provável; ${ }^{2} \mathrm{UFC}=$ Unidade Formadora de Colônia.

Os resultados obtidos deixam clara a possibilidade do consumo das farinhas de tilápia sem e com sabor, sem riscos à saúde, quando se leva em conta a contaminação microbiológica. Isso mostra que durante a obtenção das matérias-primas, transporte, manipulação e 
processamento dos produtos, houve uma preocupação com as condições higiênico-sanitárias dos ingredientes, utensílios e ambientes utilizados.

\section{Conclusões}

Todas as farinhas estavam dentro dos padrões microbiológicos e aptas para o consumo.

A farinha de tilápia padrão é a mais indicada para a inclusão em produtos alimentícios, onde o objetivo seja o aumento do teor proteico e de minerais, entretanto, em se tratando da fração lipídica a farinha com a formulação salgada de tilápia é a mais indicada para o consumo.

\section{Referências}

APHA- AMERICAN PUBLIC HEALTH ASSOCIATION. Compendium of methods for the microbiological examination of foods. Ed. 4, Washington, DC, p. 2001. 1219, 2001.

ARRUDA, Lia Ferraz de et al. Nutritional aspects of Nile tilapia (Oreochromis niloticus) silage. Food Science and Technology, v. 26, n. 4, p. 749-753, 2006.

ASSOCIATION OF OFFICIAL ANALYTICAL CHEMISTS [AOAC]. Official methods of analyses of the association of analytical chemists (18th ed.). Gaithersburg, US, 2005.

BEZERRA, Luis Artur Valões; ANGELINI, Ronaldo. Aquicultura de tilápia no Brasil: produção ilimitada pela ciência. Boletim da Associação Brasileira de Limnologia, v. 42, p. 17-24, 2016.

BLIGH, E. G.; DYER, W. J. A rapid method of total lipid extraction and purification. Canadian Journal of Biochemistry, Ottawa, v. 37, p. 911-17, 1959.

BOSCOLO, W. R.; FEIDEN, A.; SIGNOR, A. A. Farinha de resíduos da indústria de filetagem de tilápias. Industrialização de tilápias. Toledo: GFM Gráfica \& Editora, p. 135-150, 2007.

BRASIL. Ministério da Saúde. Agência Nacional de Vigilância Sanitária. Resolução RDC n. 12, de 02 de janeiro de 2001. Regulamento Técnico sobre os padrões microbiológicos para alimentos. Disponível em: <http://portal.anvisa.gov.br/wps/wcm/connect/a47bab8047458b909541d53fbc4c6735/RDC_1 2_2 01.pdf?M OD=AJPERES>. Acesso em: 23 de maio de 2020. 
DEPARTMENT OF HEALTH COMMITTEE ON MEDICAL ASPECTS OF FOOD POLICY. Nutritional aspects of cardiovascular disease. London: HMSO, 1994.

FAO. FOOD AND AGRICULTURE ORGANIZATION OF THE UNITED NATIONS.The State of World gonFisheries and Aquaculture 2018 - Meeting the sustainable development goals. p. 7-69, 2018.

FERREIRA, Milena Wolff et al. Efeito dos métodos de cocção sobre a composição química e perfil lipídico de filés de Tilápia do Nilo (Oreochromis niloticus Linnaeus 1757). Ciência e Agrotecnologia, v. 31, n. 3, p. 798-803, 2007.

FRANCO, M.L.R.S.; ABREU, B. B.; SACOMANNI, A. P. O. ; VESCO, A. P. D. ; VIEIRA, V. I. ; MIKCHA, J. M. G.; GASPARINO, E. ; DELBEM, A.C.B. Elaboración de cookies y galletasconinclusión de harina de pescado. Infopesca Internacional, v. 53, p. 30-33, 2013.

GONÇALVES, A. A. Tecnologia do pescado: ciência, tecnologia, inovação e legislação, Editora: Ateneu, São Paulo, p. 95-99, 2011.

HARTMAN, L., \& LAGO, R.C.A. Rapid preparation of fatty acids methyl esters. Laboratory Practice, v. 22, n. 6, p. 475-476, 1973.

NOVELlo, D.; POLLONIO, M. A. R. Caracterização físico-química e microbiológica da linhaça dourada e marrom (Linum Usitatissimum L.). Rev Inst Adolfo Lutz, v 71, p. 291-300, 2012.

OLIVEIRA, N.M.S.; OLIVEIRA, W.R.M.; NASCIMENTO, L.C.S.; VICENTE, J.M.S.F; FIORINI, E.; EVANGELISTA, J.; BRESSAN, M.C. Avaliação físico-química de filés de tilápia (Oreochromis niloticus) submetidos à sanitização. Food Science and Technology, Campinas, v. 28, n.1, p. 83-89, 2008.

RIISPOA - Regulamento da Inspeção Industrial e Sanitária de Produtos de Origem animal. Ministério da Agricultura, Pecuária e Abastecimento. Seção II - Derivado do Pescado, Artigo 466, 2017.

SAS. Institute (Cary, USA). SAS/STAT Userees guide, version 6. 4.ed., Cary. v.1. 943p, 2000.

SILVA, D.J.; QUEIROZ, A.C. Análise De Alimentos: Métodos Químicos e Biológicos, Viçosa, Universidade Federal De Viçosa, Ed. 3, p. 235, 2002. 
SILVA, L. M.; SAVAY-DA-SILVA, L. K.; ABREU, J. G.; FIGUEIREDO, E. E. S. Determinação de índices morfométricos que favorecem o rendimento industrial de filés de tilápia (Oreochromis niloticus). Boletim Instituto de Pesca, v. 42, n. 1, p. 252-257, 2016.

SIMÕES, M. R.; RIBEIRO, C. F. A.; RIBEIRO, S. C. A.; PARK, K. J.; MURR, F. E. X. Composição físico-química, microbiológica e rendimento do filé de tilápia tailandesa (Oreochromis niloticus). Ciência e Tecnologia de Alimentos, v. 27, n. 3, p. 608-613, 2007.

SOUCI, S. W.; FACHMAN, H.; KRAUT, E. Foods Composition and Nutrition Tables. Medpharm Scientific Publishers, Ed. 6, 2000.

SOUZA, M.L.R.; MACEDO-VIEGAS, E.M. Comparação de quatro métodos de filetagem utilizado para a tilápia do Nilo (Oreochromis niloticus) sobre o rendimento do processamento. Infopesca Internacional, Uruguay, p.26-31, 2001.

SOUZA, M. L. R.; YOSHIDA, G. M.; VASCONCELOS, G. A.; MOURA, L. B.; XAVIER, T. O.; GOES, E. S. R. Formulation of fish waste meal for human nutrition. Acta Scientiarum: Technology, v. 39, p. 525-531, 2017.

TONIAL, I. B; OLIVEIRA D. F; BRAVO C. E.C; SOUZA N. E; MATSUSHITA M; VISENTAINER J.V. Caracterização FísicoQuímica e Perfil Lipídico do Salmão (Salmo salar L.). Rev Alim. Nutr., v. 21, p. 93-98, 2010.

VERDI, R.; GASPARINO, E.; CORADINI, M. F.; CHAMBO, A. P. S.; FEOHRMANN, A. C.; GOES, E. S. R.; SOUZA, M. L. R. Inclusion of dehydrated mix of tilapia and salmon in pizzas. Food Science and Technology, Ahead of Print, 2020.

VITORINO, K. C.; CHAMBO, A. P. S.; CORADINI, M. F.; MATIUCCI, M. A.; MICHKA, J. M. G.; GOES, E. S. R.; GONÇALVES, A. A.; SOUZA, M. L. R. Cereal Bars Flavored with Fish Protein Concentrate from Different Species. Journal of aquatic food product technology, v 29, p. 65-72, 2020. 


\title{
CAPÍTULO 20: FORTALECIMENTO DA PEDAGOGIA DA ALTERNÂNCIA NA CASA FAMILIAR RURAL DE SÃO LUÍS - MA: ORIENTAÇÕES TÉCNICAS EM AVICULTURA CAIPIRA AOS EDUCANDOS
}

\section{CHAPTER 20: STRENGTHENING THE PEDAGOGY OF ALTERNANCE IN THE RURAL FAMILY HOUSE OF SÃO LUÍS - MA: TECHNICAL GUIDELINES FOR FREE-RANGE POULTRY FARMING FOR STUDENTS}

\author{
Erislayne Batalha dos Santos ${ }^{1}$; Victor Leite Bernardino ${ }^{2}$; Carlos Ferreira de Souza ${ }^{3}$; Nancyleni \\ Pinto Chaves Bezerra ${ }^{4}$; Danilo Cutrim Bezerra ${ }^{5}$
}

\section{Resumo}

A Pedagogia da Alternância é uma metodologia do ensino que conjuga diferentes experiências formativas tendo como finalidade a formação integral. Nesse contexto, objetivou-se contribuir para o fortalecimento da pedagogia da alternância na Casa Familiar Rural de São Luís - MA por meio de orientações técnicas em avicultura caipira à 17 jovens educandos. Para atingir o objetivo proposto, o estudo foi dividido em três etapas: (i) reunião com a direção da escola para apresentação pormenorizada do projeto; (ii) visitas técnicas à CFR-MA para identificação das demandas da escola, afim de diagnosticar a situação do processo formativo dos jovens educandos no que se refere à parte técnica/específica; e, (iii) assessoramento técnico dos jovens educandos e suas famílias para a produção racional das aves caipiras. Com os resultados desse trabalho fica evidente que o projeto está concatenado à metodologia pedagógica da escola. Foi possível perceber ganhos no ensino-aprendizagem dos alunos, por meio da articulação teoria e prática, estudo e trabalho, pontos norteadores da Pedagogia da Alternância. Como os estudantes são multiplicadores da informação espera-se que estes possam replicar as atividades racionais da avicultura caipira em propriedades rurais e na comunidade e contribuir com a geração de renda e transferência de tecnologia.

Palavras-chave: agricultura familiar, galinha caipira, educação do campo.

\begin{abstract}
Pedagogy of Alternation is a teaching methodology that combines different training experiences with the purpose of integral training. In this context, the objective was to contribute to the strengthening of the pedagogy of alternation in the Rural Family House of São Luís - MA through technical guidance in free-range poultry farming to 17 young students. To achieve the proposed objective, the study was divided into three stages: (i) meeting with the school management to present the project in detail; (ii) technical visits to the CFR-MA to identify the demands of the school, in order to diagnose the situation of the training process of young

\footnotetext{
${ }^{1}$ Curso de Zootecnia, Universidade Estadual do Maranhão, batalhaerislayne@ gmail.com

${ }^{2}$ Curso de Zootecnia, Universidade Estadual do Maranhão, leitevitor913@ gmail.com

${ }^{3}$ Curso de Zootecnia, Universidade Estadual do Maranhão, souzacarloszoo049@gmail.com

${ }^{4}$ Doutora em Biotecnologia, Universidade Estadual do Maranhão, nancylenichaves@ hotmail.com

5 Doutor em Biodiversiadde e Biotecnologia, Universidade Estadual do Maranhão, danilocbezerra15@gmail.com
} 
students with regard to the technical / specific part; and, (iii) technical advice to young students and their families for the rational production of free-range birds. With the results of this work, it is evident that the project is linked to the school's pedagogical methodology. It was possible to perceive gains in students' teaching-learning, through the articulation of theory and practice, study and work, guiding points of Pedagogy of Alternation. As students are multipliers of information, it is expected that they will be able to replicate the rational activities of free-range poultry farming in rural properties and in the community and contribute to the generation of income and technology transfer.

Keywords: family farming, free-range chicken, rural education.

\section{Introdução}

A Pedagogia da Alternância (PA) é uma proposta de educação rural voltada ao desenvolvimento integral do jovem do meio rural e tem, direta e indiretamente, reflexos na melhoria da qualidade de vida das famílias e na comunidade em que essas escolas estão inseridas, não se atendo apenas a temas rurais, mas também urbanos, garantindo na proposta a sua integralidade (GNOATTO et al., 2006).

A proposta da PA atende diferentes públicos, não somente agricultores familiares, já que o Campo não é lugar exclusivo desses, mas, também de filhos de outros trabalhadores que residem nesse espaço, trabalham, ganham a vida e tem a oportunidade de acessar essa proposta educativa-pedagógica (SOUZA; COSTA; VERGÜTZ, 2016).

$\mathrm{Na}$ PA o educando permanece um período em casa e outro na escola, ou seja, nas Casas Familiares Rurais (CFRs), com alternância de momentos em sua formação. Nessa proposta, a família/comunidade e a escola rompem com a ideia não construtiva que, ainda, permanece nos dias atuais e trata a escola como a principal responsável pela educação e desconsidera a família, a comunidade e as relações socioculturais estabelecidas no meio em que os alunos encontramse inseridos (COSTA, 2012).

A partir de uma visão que considera os jovens e o meio em que estão inseridos, a PA alcançou espaço e respaldo em outros países, sendo considerada uma referência metodológica preocupada com a formação integral dos educandos. De igual forma, as CFRs ocuparam espaço no Brasil e ampliaram sua atuação no território nacional.

A demanda premente por experiências como as CFRs no Maranhão ratifica a importância da agricultura familiar enquanto atividade econômica, notadamente em um Estado marcado historicamente pela agricultura não patronal, apesar das condições desfavoráveis que é essa perpassou e passa, entre elas, a perda de jovens para as cidades, por uma série de fatores. 
É na ampliação desse debate e na oferta de outras possibilidades aos jovens do campo, por meio da educação, que a gestão da CFR de São Luís - MA se debruça cotidianamente, mesmo com todas as dificuldades encontradas. O currículo nessa unidade de ensino básico contempla a formação geral e a específica: a primeira é constituída por disciplinas como português, arte, língua estrangeira, matemática, ciências, história, geografia, filosofia, religião e educação física; e a segunda, destinada à formação específica para o trabalho no meio rural, é composta pelas disciplinas de Zootecnia e Agricultura, onde são trabalhados diferentes assuntos (avicultura, caprino-ovinocultura, bovinocultura, suinocultura, fisiologia e reprodução animal entre outros).

Considerando a importância da PA, os gestores das CFR de São Luís - MA têm constantemente buscado parcerias para viabilizar a realização de suas atividades. Diante desse cenário, com vistas a atender as demandas foi executado por esta mesma equipe de trabalho no ano de 2018/2019 o projeto de extensão intitulado “AVICULTURA CAIPIRA: uma proposta da zootecnia para a Escola Casa Familiar Rural de São Luís - MA” cujo objetivo específico foi criar um lote de aves, como estação demonstrativa de avicultura caipira nessa instituição de ensino básico, e posterior doação à escola de forma que os educandos acompanhassem integralmente o ciclo produtivo das aves caipiras.

O projeto supracitado ganhou visibilidade por sua importância sócioeconômica e uma empresa multinacional doou para a CFR material para construção de aviários nas casas de alguns alunos, além dos pintainhos e ração. Porém uma lacuna desse projeto foi a não contemplação de assessoria técnica aos educandos e suas respectivas famílias para a garantia da sustentabilidade da atividade (avicultura caipira).

Nesse interim, destac-se que a avicultura caipira em pequenas propriedades é um sistema alternativo, que consiste em uma cultura dirigida ao agricultor familiar, capaz de organizar de forma gerenciada a atividade de criação destas aves. Esse sistema alternativo de criação pode melhorar a qualidade de vida das famílias, seja pela maior oferta de carne e ovos de qualidade na sua alimentação, ou pela possibilidade de venda do excedente, uma vez que aumenta de forma substancial e eficiente a capacidade produtiva do plantel (SOUZA JÚNIOR, 2011).

Embora seja reconhecida como uma fonte de alimentos de alta qualidade protéica (carne e ovos), e tenha se transformado ao longo dos tempos em um dos pratos típicos conhecidos em todo o território brasileiro, a forma de criação do frango caipira é precária em termos zootécnicos, com prejuízos para a sua produtividade, segundo Souza Júnior (2011). Desa forma, pela parceria já estabelecida entre a Universidade Estadual do Maranhão 
(UEMA/Curso de Zootecnia) e comunidade a partir da extensão universitária, bem como a importância dessa parceria para promover ações de Desenvolvimento Rural, é que se desenvolveu-se a presente pesquisa com o objetivo principal de contribuir para o fortalecimento da pedagogia da alternância na Escola Casa Familiar Rural de São Luís - MA por meio de orientações técnicas em avicultura caipira aos jovens educandos. E como objetivo secundário, melhorar a qualidade de vida das famílias que possam estar em situação de vulnerabilidade alimentar com o acesso à alimentação saudável e aumento da renda com a possibilidade de comercialização das aves caipiras.

\section{Material e Métodos}

\section{Local de estudo}

O estudo foi realizado com 17 jovens educandos da CFR de São Luís - MA contemplados com a construção de aviários e suas respectivas famílias. A referida escola apresenta modalidade de ensino de Educação de Jovens e Adultos - EJA/Ensino Fundamental. Está localizada no povoado de Santa Helena, Quebra-Pote, área rural do Município de São Luís - MA (Figura 1), no período de setembro de 2019 a março de 2020.

Figura 1. Escola Casa Familiar Rural de São Luís, estado do Maranhão

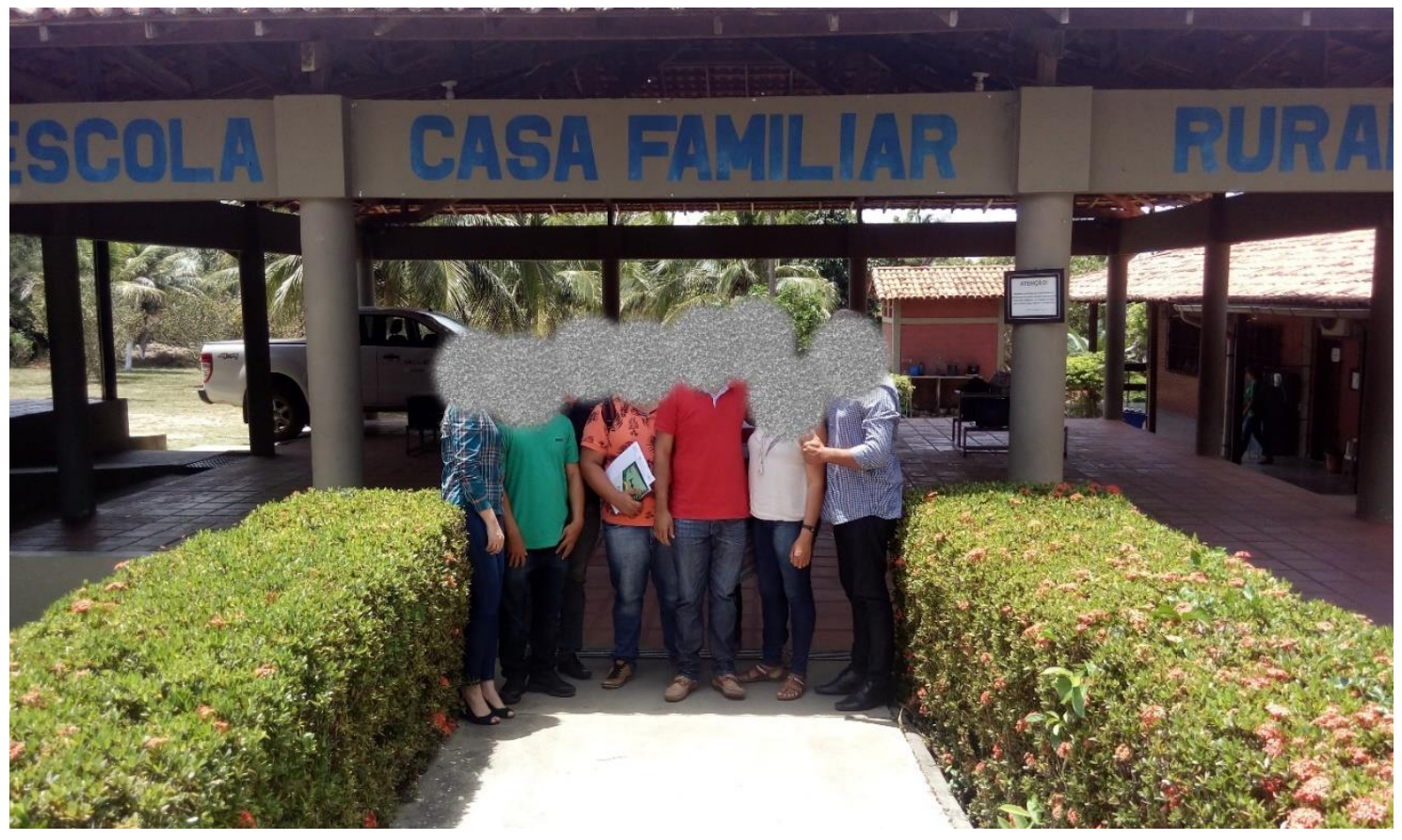

Fonte: Própria (2020). 
A CFR de São Luís - MA foi construída em uma parceria entre a Prefeitura Municipal de São Luís - MA e ALUMAR e, iniciou suas atividades no ano de 2001. A ECFR é mantida e administrada pela Secretaria Municipal de Educação (SEMED) da Prefeitura Municipal de São Luís. A escola possuia no período de execução da pesquisa 55 alunos, divididos em duas turmas. Estes são de classe média baixa, moradores de bairros periféricos e, principalmente da zona rural de São Luís - MA. A escola apresenta um quadro de seis professores, um técnico de nível superior e uma diretora. Ainda, um secretário, uma cozinheira e, dois funcionários responsáveis pelos serviços gerais da escola.

A estrutura física da ECFR é composta por uma sala de aula, uma sala de professores, uma secretaria, uma biblioteca, dois dormitórios, uma cozinha, banheiros, duas áreas livres, onde uma é denominada de quadra esportiva e a outra é a praça de recreação e, um campo para a execução das atividades de agropecuária, onde estão implantadas as unidades pedagógicas, como um aviário e três tanques escavados para a produção de peixes.

\section{Etapas do Estudo}

A primeira etapa do trabalho consistiu de uma reunião com a direção da escola (gestor, docentes e técnicos) para apresentação pormenorizada do projeto. A segunda etapa se efetivou por meio de visitas técnicas à CFR-MA para identificação das demandas da casa, afim de diagnosticar a situação do processo formativo dos jovens educandos no que se refere à parte técnica/específica. Já, na terceira etapa, foi realizada o assessoramento técnico dos jovens educandos e suas famílias para a produção racional das aves caipiras.

\section{Resultados e Discussão}

Para a implementação de qualquer atividade produtiva, esta deve ser submetida em sua fase inicial ao planejamento, seguido da orientação e assistência técnica. Em se tratando da avicultura caipira, a atividade demanda controle dos conceitos de sustentabilidade, sanidade e integração. Por isso, a importância desse estudo na oferta de assessoramento técnico às famílias com possibilidade de garantir a sustentabilidade das criações e sua reprodução ao longo do tempo.

No sentido de educar os estudantes a aprender de maneira autônoma e participativa, com o sentimento de partícipes do processo de construção do conhecimento, o presente projeto é uma importante ferramenta pedagógica no processo de ensino aprendizagem.

Os resultados desse trabalho são apresentados em conjunto por serem semelhantes entre os educandos. 


\section{a) Visitas Técnicas à Casa Familiar Rural de São Luís - MA}

Foram realizadas quatro visitas técnicas à CFR de São Luís - MA em que a primeira se pautou no planejamento das atividades (definição dos conteúdos a serem trabalhados, ferramentas pedagógicas utilizadas, carga horária e datas e quantidade de visitas às casas dos alunos).

Nesse momento do projeto, apesar de não ser objeto do estudo, houve uma conversa com a diretora da escola para uma melhor compreensão do perfil dos educandos da escola, que podem ser assim sumarizados: filhos de trabalhadores autônomos, agricultores rurais, empregadas domésticas, mães precoces, muitos dos pais não puderam frequentar os bancos escolares na idade prevista, pois, tinham que trabalhar para ajudar no orçamento familiar. E as famílias dos educandos procuram a escola na esperança de um futuro melhor aos seus filhos. Para eles, a escolarização significa a ampliação dos horizontes.

Mediante conversas e reuniões com diretor, professores, técnico e alunos houve a construção conjunta das atividades do presente projeto em congruência com o calendário das alternâncias e temas geradores ${ }^{4}$, resgatando a essência da Pedagogia da Alternância no enfoque da disciplina Zootecnia, módulo Avicultura.

Em função de atividades recentes sobre a avicultura caipira realizadas pela mesma equipe em um projeto anterior na mesma unidade de ensino, nas três visitas técnicas subsequentes, realizaram-se palestras educativas com os educandos contemplados e estas apresentaram um cunho eminentemente de revisão dos assuntos já trabalhados anteriormente, entre eles: manejo nutricional, sanitário e reprodutivo, boas práticas de fabricação, higiene e higienização no abate e preservação do meio ambiente.

Os conhecimentos teóricos foram transmitidos aos alunos por meio de aulas expositivas dialogadas com utilização de projetor multimídia, tipo data show. Nas palestras também foram utilizadas imagens e situações do cotidiano para dinamizar e contextualizar as capacitações. Nessa etapa do trabalho foram capacitados $100 \% \quad(n=17)$ dos alunos contemplados com material para construção de aviários em suas residências, além dos pintainhos e ração (Figura 2).

\footnotetext{
${ }^{4}$ Tema Gerador: tema ponto de partida para o processo de construção da descoberta que emerge das necessidades e anseios da comunidade. Estes devem ser extraídos da prática de vida dos educandos
} 
Figura 2. Jovens educandos da Casa Familiar Rural de São Luís - MA em capacitação teórica sobre avicultura

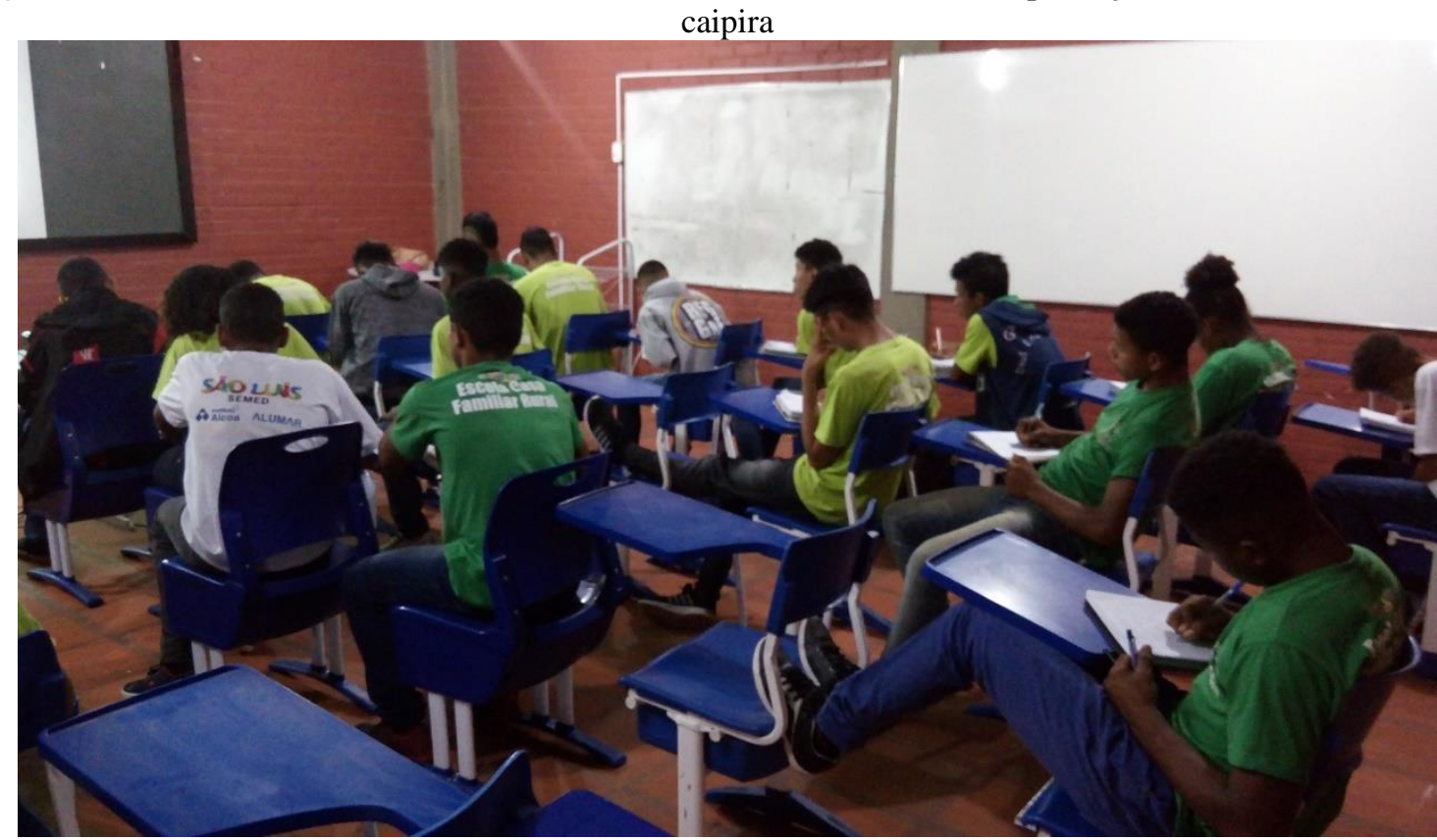

Fonte: Própria (2020).

Para Trajber e Mendonça (2007), dentre as funções mais relevantes das instituições educacionais está, sobretudo, seu potencial de transformação e influência em sua comunidade de abrangência. E é justamente por meio das temáticas voltadas para a educação sanitária, e nesse contexto a produção correta de alimentos, que a escola pode contribuir significativamente para a sociedade, criando canais de diálogo com a população, possibilitando discutir e refletir criticamente acerca do papel dos cidadãos.

Com o intuito de abordar a temática avicultura caipira utilizou-se as palestras como recurso didático. Esta de acordo com Behar, Passerino e Bernardi (2007) permite uma maior clareza na constituição da comunicação entre os participantes. Nesta perspectiva, abriram-se espaços discursivos em sala de aula, onde os estudantes puderam expressar seus pensamentos por meio da relação comunicativa entre aluno-aluno e aluno-professor como estrutura necessária para o fortalecimento do papel do professor como agente transformador e inovador no ambiente escolar e social.

Considera-se que as capacitações teóricas realizadas nesse momento do projeto se constituíram em um indicador, tanto quantitativo como qualitativo do projeto, pelo entendimento de que a educação é um processo ativo e contínuo capaz de educar e desenvolver consciência crítica no público-alvo. A educação sanitária é o processo de disseminação, construção e apropriação de conhecimentos, por parte dos participantes das diversas etapas das cadeias produtivas associadas às atividades agropecuárias e pela população em geral. Assim, o 
conhecimento das exigências de uma criação de aves caipiras de forma racional, por atividades educativas, pode reduzir a ocorrência de doenças, mortalidade, desperdício de ração e contribuir para uma matéria-prima de melhor qualidade.

\section{b) Assessoramento Técnico aos Jovens Educandos da Casa Familiar Rural de São Luís -} MA

Foram realizadas três (03) visitas técnicas com finalidade de assessoramento a cada um dos 17 educandos e suas famílias. A metodologia contemplou além dos treinamentos teóricos realizados em sala de aula previamente, explicações teórico-práticas sobre manejo para as famílias dos educandos, em suas próprias áreas, onde foram vistoriadas e analisadas as infraestruturas dos aviários, os tipos de animais pré-existentes (aves e outros), as vegetações naturais disponíveis (frutas, capim, arbustos, insetos) para o alimento alternativo destas aves, observando as normas sanitárias e os cuidados com a criação.

As referidas visitas tiveram a finalidade de identificar os principais entraves na produção avícola caipira local. Nessa etapa do trabalho de extensão (terceira etapa), também foram discutidos assuntos relativos ao manejo nutricional, sanitário e reprodutivo, boas práticas de fabricação, higiene e higienização no abate e preservação do meio ambiente. Os conhecimentos foram transmitidos por meio de conversa formal e atividades práticas in locu.

Na primeira visita técnica que aconteceu no momento de entrega dos 20 pintainhos às famílias, foi relatado por $100 \%$ das famílias alguma experiência de criação de aves domésticas (galinhas). Nesse momento, foi constatada na casa dos 12 educandos, a construção de aviários cobertos com disposição de comedouros e bebedouros. No espaço aberto, percebeu-se a existência de piquete para que as aves após 25 dias de alojamento pudessem ficar soltas para ciscar, buscar alimentos (como insetos e plantas), além de terem acesso à banho de sol. Contudo, para cinco jovens a estutura do aviário, equipamentos e utensílios não estavam completamente adequadas para o alojamento dos animais, sobretudo, no que se refere à não telagem das áreas laterais dos aviários, não colocação de comedouros e bebedourose presença de aves adultas nos aviários (Figura 3). 
Figura 3. Estrutura não conforme para alojamento de pintainhos na casa de um educando da Casa Familiar Rural

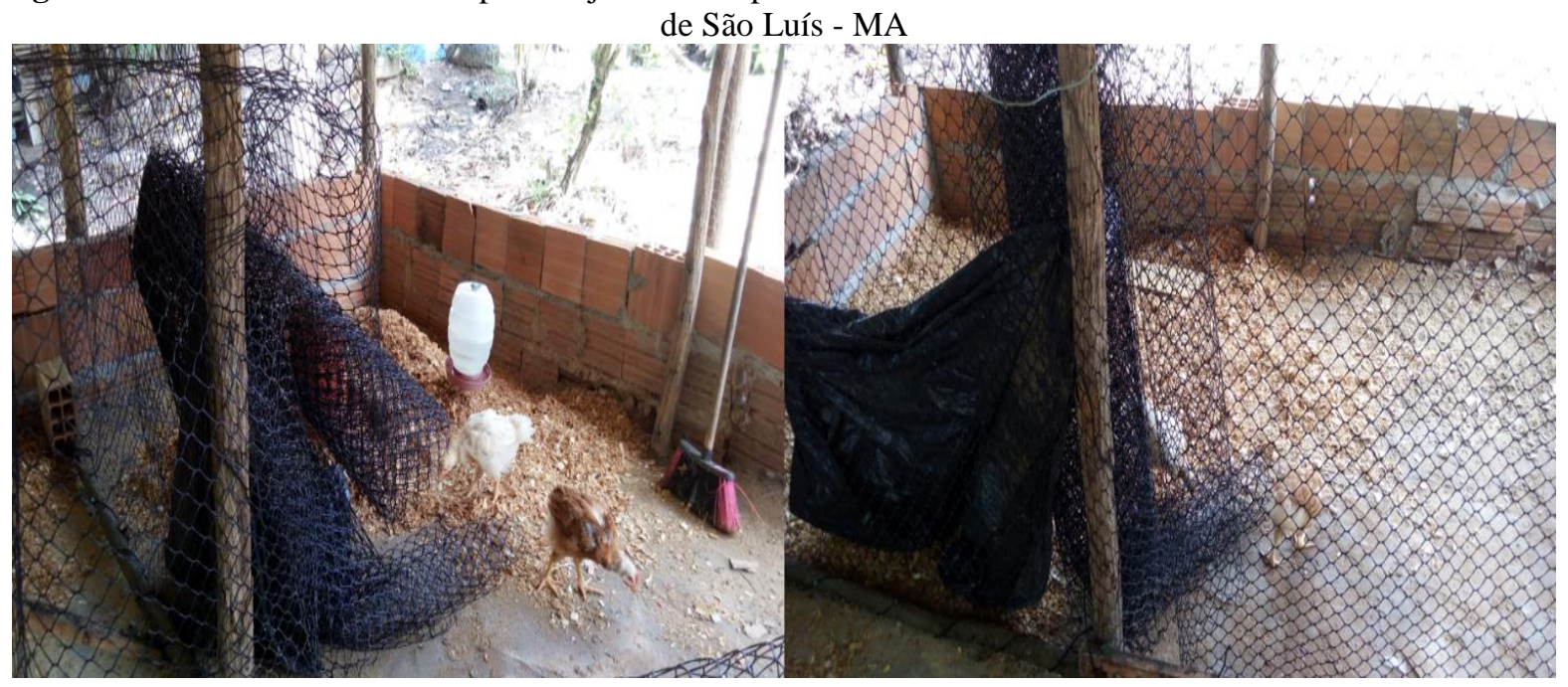

Fonte: Própria (2020).

Para esses alunos houve, nesse momento a improvisação de campânula, telas divisórias e círculo de proteção (Figura 4), além bebedouros e comedouros com materiais presentes na área. E, ocorreu intensificação na orientação técnica dessas famílias sobre a necessidade dos cuidados com essa fase da produção para o sucesso da criação.

Figura 4. Adequação de estrutura de aviário como materias para localidade para alojamento de pintainhos na casa de um educando da Casa Familiar Rural de São Luís - MA

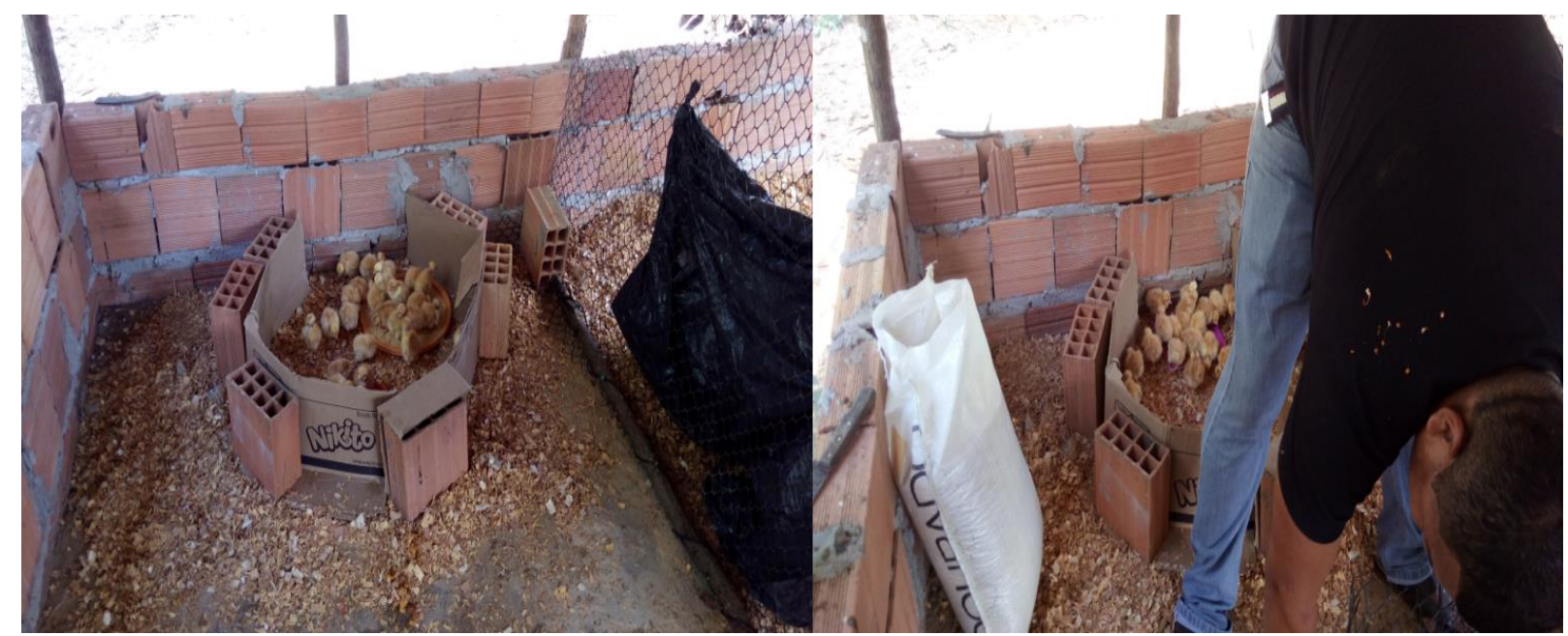

Fonte: Própria (2020).

Nas demais visitas técnicas que acompanharam as fases produtivas subsequentes não foram constatadadas inadequações no manejo executado por parte das famílias. Mediante os resultados alcançados foi viabilizado uma visita técnica com os alunos a um Instituto Federal de Educação, Ciência e Tecnologia para que os educandos pudessem compreender mais sobre os processo de produção de galinhas caipiras e a possibilidade da utilização de materias 
alternativos na criação (Figura 5).

Figura 5. Visita técnica com os alunos da Casa Familiar Rural de São Luís - MA ao Instituto Federal de Educação, Ciência e Tecnologia para maior compreensão da avicultura capira.

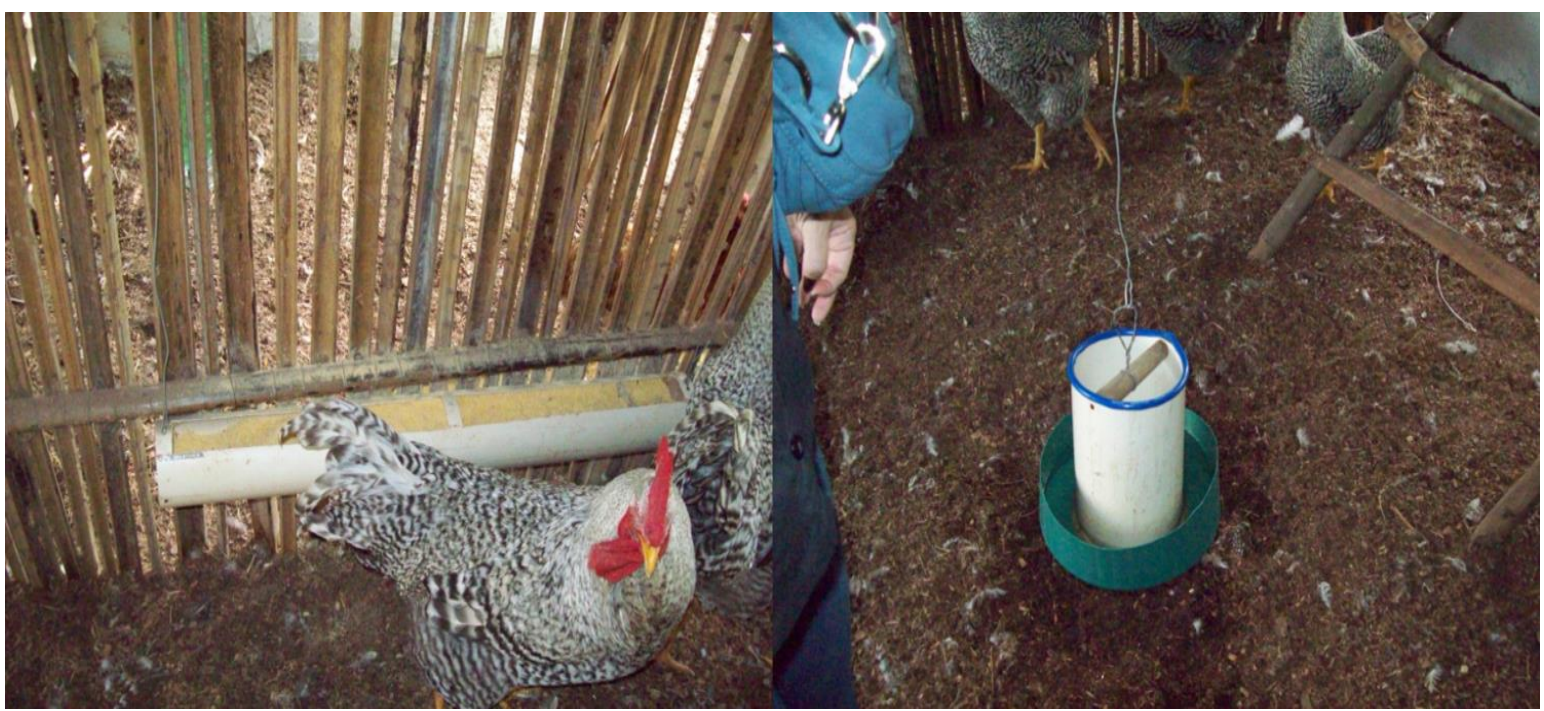

Fonte: Própria (2020).

Para Cruz, Chagas e Botelho (2013), a avicultura familiar apresenta as seguintes vantagens: a) utilização de terras fracas e desvalorizadas, na implantação da atividade; b) baixo investimento em instalações e equipamentos; c) melhoria da qualidade da dieta do produtor e sua família através do incremento protéico; d) fixação do produtor na propriedade; e) asseguramento de renda complementar ao orçamento familiar. Como desvantagens: a) necessidade de maior área para a implantação do sistema de produção; b) crescimento lento e produção de ovos das linhagens de aves inferior ao sistema industrial (convencional); c) maior exposição das aves a possíveis agentes patogênicos.

Especficamente a última informação do parágrafo supracitado, um ponto importante a ser destacado neste projeto, está em consonância com as exigências sanitárias que o Ministério da Agricultura, Pecuária e Abastecimento (MAPA) disciplina, pois no Brasil, por suas características próprias, é difícil controlar a criação de aves caipiras que ficam totalmente soltas. Desta forma, neste projeto foi apresentada uma forma controlada de criação, despetando nos alunos e suas famílias mudanças no manejo, não deixando de existir uma criação rústica, porém, com orientação sanitária correta, contribuindo com a melhoria na saúde animal, assim como nq seguranças dos alimentos produzidos.

Nesse enfoque foi realizada, também, uma oficina prática na casa de um dos educandos com alcance aos demais alunos sobre a aplicação de medicamentos e vacinas nas aves (Figura $6)$. 
Figura 6. Jovens educandos da Casa Familiar Rural de São Luís - MA em oficina prática sobre vias de aplicação de medicamentos e vacinas em aves.

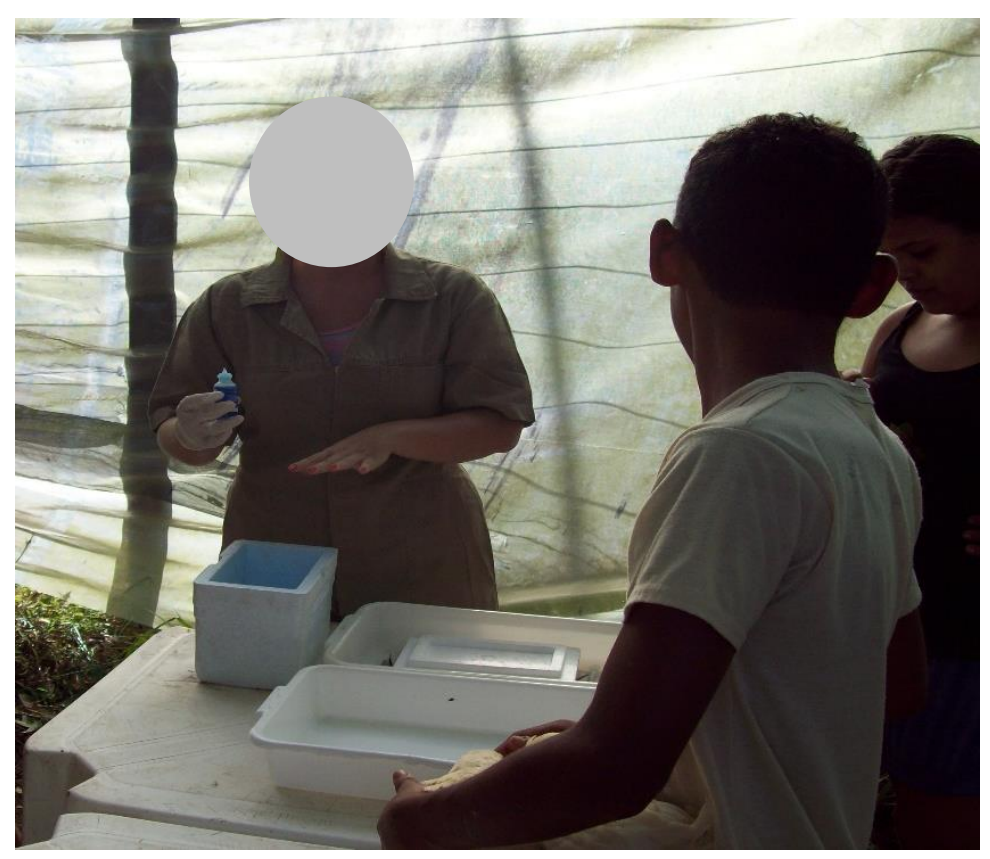

Fonte: Própria (2020).

A criação caipira de galinhas em comunidades pequenas não possui a intenção de competir com a avicultura industrial, mas representa um grande potencial como componente para estruturar o desenvolvimento local, conforme destacado por Fraxe et al. (2007), além de preencher um nicho de mercado com produtos originados de um sistema alternativo de produção e com isso atender aos consumidores com uma alimentação mais natural, de acordo com Cruz (2011).

Ao final deste trabalho, os educandos possuíam uma média de $925 \%$ de aves vivas. Quanto às atividades de manejo, a atuação dos educando e seus familiaresem relação ao proposto no projeto, foi adequada. Dessa forma, o mesmo alcançou o objetivo previamente estabelecido com consequentemente aumento no incremento protéico na alimentação das famílias e possibilidades de geração de fonte alternativa de renda com a venda de alguns animais.

\section{Conclusões}

A Pedagogia da Alternância é uma proposta educacional para os agricultores e seus filhos. Essa tem por objetivo o desenvolvimento de um ensino adaptado às realidades dos jovens, profissionalizando-os, tendo como premissa a construção do conhecimento em conjunto: escola, família e jovens, sujeitos de seu próprio desenvolvimento. 
Fica evidente, que a pesquisa realizada está concatenado à metodologia pedagógica da Casa Familiar Rural de São Luís - MA. Diante dos resultados obtidos foi perceptível ganhos no ensino-aprendizagem dos alunos, por meio da articulação teoria e prática, estudo e trabalho, pontos norteadores da Pedagogia da Alternância.

Não há dúvida que assessoramento técnico os educandos poderão ter potencial para serem empreendedores nas redes de produção, atuando em favor do desenvolvimento do meio rural. Como os estudantes são multiplicadores da informação espera-se que estes possam continuar a replicação da produção de aves caipiras em suas áreas rurais e na comunidade e contribuir com a geração de renda e transferência de tecnologia.

\section{Referências}

BEHAR, P. A.; PASSERINO, L.; BERNARDI, M. Modelos Pedagógicos para Educação a Distância: pressupostos teóricos para a construção de objetos de aprendizagem. In: Revista Novas Tecnologias na Educação, Rio Grande do Sul, v. 5, n. 2, p.1-12, 2007.

CRUZ, F. G. G.; CHAGAS, E. O DAS; BOTELHO, T. R. P. Avicultura familiar como alternativa de desenvolvimento sustentável em comunidades ribeirinhas do Amazonas. INTERAÇÕES, Campo Grande, v. 14, n. 2, p. 197-202, jul./dez. 2013.

COSTA, J. P. R. Escola família agrícola de Santa Cruz do Sul - EFASC: uma contribuição ao desenvolvimento da região do Vale do Rio Pardo a partir da pedagogia da alternância. 2012. 226f. Dissertaçã (Mestrado em Desenvolvimento Regional) - Universidade de Santa Cruz do Sul, Santa Cruz do Sul, 2012.

CRUZ, F.G.G. Avicultura caipira na Amazônia. Manaus: Grafi sa, 2011. 114p.

FRAXE, T. J. P. et al. Comunidades ribeirinhas amazônicas: modos de vida e uso dos recursos naturais. Manaus: EDUA, 2007. 223p.

GNOATtO, A. A.; RAMOS, C. E. P.; PIACESKI, E. E.; BERNARTT, M. de L. Pedagogia da alternância: uma proposta de educação e desenvolvimento no campo. In: XLIV CONGRESSO DA SOBER “Questões Agrárias, Educação no Campo e Desenvolvimento”, 2006, Fortaleza. 
SOUZA, M. B. DE; COSTA, J. P. R.; VERGÜTZ, C. L. B. A pedagogia da alternância e o ensino de história: o caso da escola família agrícola de Santa Cruz do Sul. Ágora, v.17,n. 02, p. 53-67, 2016.

SOUZA JÚNIOR, D. I. de. Criação de frango caipira visando a produção orgânica em pequenas propriedades no município de Bocaiúva do Sul - PR. 2011. 68 p. Monografia (Trabalho de Conclusão de Curso) - Universidade Tuiuti do Paraná, Paraná, 2011.

TRAJBER, R.; MEDONÇA, P. R. Educação na diversidade: o que fazem as escolas que dizem que fazem educação ambiental. Brasília: Secretaria de Educação Continuada, Alfabetização e Diversidade, 2007. 262 p. 


\title{
CAPÍTULO 21: INFLUÊNCIA DO SECAMENTO PARCIAL DO SISTEMA RADICULAR NA QUALIDADE DE FRUTOS DO MARACUJÁ
}

\section{CHAPTER 21: INFLUENCE OF PARTIAL ROOTZONE DRYING ON FRUIT QUALITY OF PASSION FRUIT}

\author{
Gyovanni Keidy Zan Minakawa ${ }^{1}$; Nicolas Souza Soares ${ }^{2}$; Eduarda Alves Brexó ${ }^{3}$ Adriana Smanhotto \\ Soncela ${ }^{4}$; Rosimaldo Soncela ${ }^{5}$
}

\begin{abstract}
Resumo
A agricultura irrigada consome uma elevada quantidade de água no mundo, a técnica de secamento parcial da zona radicular pode ser uma alternativa para garantir a produtividade e reduzir a água aplicada. O objetivo deste trabalho foi avaliar o efeito da técnica do secamento parcial da zona radicular na produção e qualidade de frutos do maracujazeiro cultivar BRS Rubi do Cerrado, na Região do Vale do Ivinhema. O experimento foi instalado no campo experimental do Instituto Federal de Mato Grosso do Sul, campus Nova Andradina. O delineamento foi em blocos casualizados, com quatro tratamentos e três repetições. Os tratamentos consistiram em redução de $25 \%$ e $50 \%$ da ETc, alternando a cada 07 dias; irrigação plena, ou seja, $100 \%$ da ETc, alternando a cada 07 dias; irrigação plena, $100 \%$ da ETc - com irrigação dos dois lados da planta. Foram realizadas avaliações de comprimento do fruto, diâmetro médio do fruto, peso médio do fruto, casca e polpa. Não foram observadas diferenças na qualidade física dos frutos entre os tratamentos aplicados, indicando uma possibilidade na redução da lâmina de irrigação através da técnica do secamento parcial da zona radicular sem impacto negativo sobre os frutos.
\end{abstract}

Palavras-Chave: Manejo de irrigação, Irrigação Localizada, Maracujazeiro.

\begin{abstract}
Irrigated agriculture consumes a high amount of water in the world, the partial root zone drying technique can be an alternative to ensure productivity and reduce applied water. This paper aimed to evaluate the effect of the partial rootzone drying technique on production and quality of passion fruit from Cultivar BRS Rubi do Cerrado at Vale do Ivinhema region. The experiment was installed in the experimental field of Federal Institute of Education, Science and Technology of Mato Grosso do Sul, Nova Andradina campus. The design was in randomized blocks, with four treatments and three replications. The treatments consisted in $25 \%$ and $50 \%$ ETc reduction alternating every 7 days; full irrigation, that is, $100 \%$ of ETc, alternating every 07 days; full irrigation, $100 \%$ of ETc - irrigating both sides of the plant. Evaluations of fruit length, average fruit diameter, average fruit weight, peel and pulp were performed. No differences were observed in the physical quality of the fruits between the treatments applied, indicating a possibility in reducing the irrigation depth through the technique of partial drying of the root zone without negative impact on the fruits.
\end{abstract}

\footnotetext{
${ }^{1}$ Curso Bacharelado em Agronomia, Instituto Federal de Mato Grosso do Sul, gyovanni.minakawa@estudante.ifms.edu.br

${ }^{2}$ Curso Bacharelado em Agronomia, Instituto Federal de Mato Grosso do Sul, nicolas.soaresdiy@gmail.com

${ }^{3}$ Curso Bacharelado em Agronomia, Instituto Federal de Mato Grosso do Sul, dubrexo@gmail.com

${ }^{4}$ Doutora em Agronomia - Irrigação e Drenagem, Instituto Federal de Mato Grosso do Sul, adriana.smanhotto@ifms.edu.br

${ }^{5}$ Doutor em Engenharia Agrícola, Instituto Federal de Mato Grosso do Sul, rosimaldo.soncela@ifms.edu.br
} 
MINAKAWA, et al.

Keywords: Irrigation management, Localized irrigation, Passion fruit tree.

\section{Introdução}

O maracujazeiro-amarelo (Passiflora edulis f. flavicarpa) pertencente à família Passifloraceae, é uma frutífera nativa da região tropical da América do Sul, apresenta um ciclo semi-perene. Seu desenvolvimento é favorecido em regiões com temperaturas médias mensais entre $21^{\circ} \mathrm{C}$ a $32{ }^{\circ} \mathrm{C}$, e com precipitação pluviométrica anual entre $800 \mathrm{~mm}$ a $1750 \mathrm{~mm}$ (SOUSA; BORGES, 2011).

O Brasil é o maior produtor mundial de maracujá, no ano de 2015-2017 a produção mundial atingiu 1,4 milhões de toneladas, onde o Brasil contribui com cerca de 0,9 milhões de toneladas, a cultura é disseminada em todo o país, sendo que, no ano de 2018, a produção brasileira foi de 602.651 t (SATO et al., 1992; SANTOS et al., 2009; IBGE, 2018; ALTENDORF, 2018). Apesar de ser o maior produtor, possui uma baixa produtividade, mas proporciona um ótimo retorno econômico (MELETTI et al., 2010).

Nos últimos 30 anos, o cultivo de maracujá teve uma crescente expansão, ocupando um lugar de destaque na fruticultura tropical. Além disso, é de grande importância social no oferecimento de empregos no campo, tanto para micros até grandes produtores.. A cultura é uma ótima opção para os produtores, pois entra em produção rapidamente, oferta diferentes linhas de mercados, além de agregação de valor ao produto e os fruticultores optam, pois geram renda semanalmente durante o período de colheita (MELETTI et al., 2010; FALEIRO; JUNQUEIRA, 2016).

A cultura do maracujazeiro apresenta uma elevada demanda hídrica. De acordo com Ruggiero et al. (1996) e Costa (2008), quando exposta a uma deficiência hídrica prolongada, ocasiona paralisação vegetativo, atraso no florescimento, queda de flores e frutos, afetando negativamente na produtividade e qualidade de frutos. Por outro lado, o excesso de umidade no solo possibilita o aparecimento de patogênicos, mas comumente o desenvolvimento de podridões radiculares, no qual é um dos fatores limitantes da cultura (CASTRO; KLUGE, 1998).

A irrigação proporciona aos produtores maior garantia de produção, melhora na utilização dos recursos naturais e aumenta a produtividade, logo permite melhor retorno financeiro (SOUSA et al., 2001; ARAÚJO et al., 2012). O sistema por gotejamento tem sido preferível pelos produtores, pois permite condições de umidade e aeração no solo, favorecendo o pleno desenvolvimento das plantas e a produção do maracujazeiro (LIMA et al., 2011). 
De acordo com Costa et al. (2000), o método de irrigação que destaca-se é de irrigação localizada tanto por gotejamento ou microaspersão, de forma a controlar a lâmina de água aplicada e a maior eficiência do uso d'água. Além disso, reduz a disseminação de patógenos e minimizar a perda por evaporação, percolação e escoamento superficial.

Para obter uma produção satisfatória e um bom retorno financeiro, deve-se optar por um manejo de irrigação racional, aplicando-se no período correto a quantidade adequada de água. Conforme Sampaio et al. (2010), a agricultura irrigada consome uma elevada quantidade de água no mundo, com uma tendência de escassez dos recursos hídricos, dessa forma é necessário empregar técnicas de irrigação que otimiza a eficiência do uso de água.

De acordo com FAO (2002), para aumento da eficiência do uso de água, a técnica de irrigação com déficit hídrico, é uma alternativa para agricultura irrigada, podendo levar maiores ganhos econômicos. Esse método entende-se em irrigar alternadamente lados diferentes de uma planta, em frequências que dependerão do sistema solo-planta-atmosfera.

O déficit hídrico controlado pela estratégia do secamento parcial do sistema radicular tem indicado que é possível aumentar a eficiência de uso da água pelas culturas, com redução do crescimento vegetativo, mantendo-se a produção em uma escala satisfatória (DRY; LOVEYS, 1998).

Considera-se que o sistema radicular passa a metabolizar uma maior quantidade de ácido abscísico (ABA), que se transloca pelo eixo vascular, concentrando-se na parte aérea e promovendo o fechamento parcial dos estômatos e, conseguinte, resulta em menor evaporação de água para a atmosfera (GOWING et al., 1990; DAVIES; ZHANG, 1991; DAVIES et al., 2002).

Normalmente as plantas abrem seus estômatos para captar $\mathrm{CO}_{2}$ e perdem água nas trocas gasosas. Contudo, as plantas devem ser capazes de detectar o déficit de umidade no solo e equilibrar seu consumo de água. Com isso, o mecanismo regulador estomático ativa-se antes da água disponível no solo seja escassa (FARQUHAR; SHARKEY, 1982; JONES, 2014; CARVALHO, 2015).

Para Davies; Zhang (1991) e Jones (2014), a técnica de secamento parcial da zona radicular, entende-se que as raízes no solo em processo de secagem, emite um sinal que alcança a parte aérea, comunicando o fechamento estomático e redução de perda de água pela transpiração, logo, esse fechamento estomático reduz a perda de água, não comprometendo drasticamente a fotossíntese.

No entanto, o método de secamento parcial do sistema radicular em frutíferas ainda são pouco pesquisado, não tendo resultados consolidados da técnica, em função da heterogeneidade 
dos solos cultivados, assim como, a resposta de crescimento da planta nas diferentes estações do ano. Dessa forma, há necessidade de conhecer com maior precisão a resposta das culturas ao déficit, uma vez que varia de espécie e estágio de crescimento (FAO, 2002).

O objetivo deste trabalho foi verificar os efeitos da técnica do secamento parcial da zona radicular sobre a produtividade do maracujazeiro, assim como, os índices de produção e qualidade dos frutos a fim de determinar a quantidade de água que pode reduzir sem interferência negativa na produção.

\section{Material e Métodos}

O experimento foi conduzido nas dependências do Instituto Federal de Educação, Ciência e Tecnologia de Mato Grosso do Sul - IFMS, localizado na Fazenda Santa Bárbara, s/n, situada a $20^{\circ} 04^{\prime} 47,98^{\prime \prime}$ e a $53^{\circ} 57^{\prime} 16,46^{\prime \prime}$ W com altitude de 357 metros, no município de Nova Andradina - MS. O solo é classificado como Latossolo Vermelho Distroférrico de textura arenosa (EMBRAPA, 2006).

O clima predominante na região é o tropical, quente e semiúmido, marcado por chuvas no verão e períodos secos durante o inverno. O índice pluviométrico anual é elevado com média variável de 1.400 a $1.700 \mathrm{~mm}$, apresentando déficit hídrico entre abril e dezembro (EMBRAPA, 2006).

O delineamento utilizado no experimento foi em blocos casualizados, com quatro manejos de irrigação e três repetições, totalizando 12 parcelas experimentais. Cada parcela foi composta por seis plantas, espaçadas de $5 \mathrm{~m}$ entre plantas e $3 \mathrm{~m}$ entre linhas de plantas, sendo que quatro plantas foram úteis e as demais serviram com bordadura. Os manejos da irrigação foram baseados na redução da lâmina bruta calculada, sendo: redução de $25 \%$ da ETc, alternando a cada 07 dias (T1); redução de 50\% da ETc, alternando a cada 07 dias (T2); irrigação plena, ou seja, 100\% da ETc, alternando a cada 07 dias (T3); irrigação plena, ou seja, $100 \%$ da ETc - testemunha - com irrigação dos dois lados da planta (T4).

O volume de água aplicado no tratamento testemunha foi estimado pela evapotranspiração da cultura (BERNARDO et al., 2006), calculado por meio das medidas de evapotranspiração de referência (ETo), utilizando uma média de ETo de 4,2 $\mathrm{mm} \mathrm{dia}^{-1}$, obtida através do trabalho realizado por Flumignan et al. (2016), através do banco de dados da Estação Agrometeorológica da Embrapa Agropecuária Oeste, localizada em Dourados, MS e pelo coeficiente da cultura (Kc) médio igual a 0,6 (CARVALHO et al., 2001), de acordo com a Equação 1. 
MINAKAWA, et al.

$$
\mathrm{ET}_{c}=E T_{0} * \mathrm{Kc}
$$

Sendo:

$\mathrm{Et}_{\mathrm{c}}=$ evapotranspiração da cultura, em $\mathrm{mm} \mathrm{dia}^{-1}$;

$\mathrm{ET}_{0}=$ evapotranspiração de referência, em $\mathrm{mm} \mathrm{dia}^{-1}$;

$\mathrm{Kc}=$ coeficiente da cultura do maracujá.

O tempo de irrigação (Equação 2) foi determinado para cada manejo, uma vez que em cada linha foi colocado dois emissores gotejadores autocompensantes de $4 \mathrm{~L} \mathrm{~h}^{-1}$ de acordo com o fabricante distantes $30 \mathrm{~cm}$ de cada planta. Também foi realizado o teste de vazão média dos gotejadores e ajustado para o tempo de irrigação.

$$
T i=\frac{I T N}{I a}
$$

Sendo:

$\mathrm{Ti}$ = tempo de irrigação, horas;

ITN = Lâmina Bruta de Irrigação $(\mathrm{mm})$, determinada pela evapotranspiração da cultura calculada na equação 1;

Ia = Intensidade de Aplicação, calculada em $\mathrm{mm} \mathrm{h}^{-1}$, conforme equação 3.

$$
I a=\frac{q * n}{E_{p} * E_{l p}}
$$

Sendo:

Ia = Intensidade de Aplicação, calculada em $\mathrm{mm} \mathrm{h}^{-1}$;

q= vazão dos gotejadores (média de $4,158 \mathrm{~L} \mathrm{~h}^{-1}$ );

$\mathrm{n}=$ número de gotejadores por planta (2 para os manejos alternados e 4 para os manejos de irrigação plena dos dois lados);

$\mathrm{E}_{\mathrm{p}}=$ espaçamento entre plantas, metros;

$\mathrm{E}_{\mathrm{lp}}=$ espaçamento entre linhas de plantas, metros.

A lâmina de irrigação calculada foi de $2,52 \mathrm{~mm} \mathrm{dia}^{-1}$, e os tempos de irrigação variaram de 4,54 horas (irrigação plena, 100\% da ETc, alternando a cada 07 dias e irrigação plena, 100\% da ETc - testemunha - com irrigação dos dois lados da planta), 3,40 horas (redução de 25\% da ETc, alternando a cada 07 dias) e 2,27 horas (redução de 50\% da ETc, alternando a cada 07 dias). 
O estudo foi conduzido no período de março de 2019 a julho de 2020. Foi realizada a coleta do solo para a caracterização da área experimental, nas profundidades de $0-20 \mathrm{~cm}, 20$ $-40 \mathrm{~cm}$ e $40-60 \mathrm{~cm}$ (Tabela 1).

Tabela 1. Caracterização química do solo antes da instalação do experimento nas diferentes profundidades.

\begin{tabular}{|c|c|c|c|c|c|c|c|c|c|c|c|c|c|}
\hline MO & $\mathrm{P}$ & B & $\mathrm{S}$ & $\mathrm{Ca}$ & $\mathrm{Mg}$ & $\mathrm{K}$ & $\mathrm{Al}$ & $\begin{array}{c}\mathrm{H}+\mathrm{A} \\
1\end{array}$ & $\begin{array}{c}\text { Som } \\
\text { a de } \\
\text { base } \\
s\end{array}$ & $\begin{array}{l}\text { CTC } \\
\text { pH } 7\end{array}$ & $\begin{array}{c}\text { CTC } \\
\text { efeti } \\
\text { va }\end{array}$ & $\begin{array}{c}\text { Sat. } \\
\text { Al }\end{array}$ & $\begin{array}{c}\text { Sat. } \\
\text { Bases }\end{array}$ \\
\hline $\mathrm{g} / \mathrm{dm}^{3}$ & -----. & $\mathrm{mg} /$ & ----- & ----- & ----- & $\ldots$ & molc & $m^{3}$ & 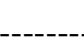 & & ------. & & $\%$ \\
\hline
\end{tabular}

$00-20$

\begin{tabular}{llllllllllllll}
10,54 & 4,73 & 0,15 & 4,29 & 0,62 & 0,2 & 0,04 & 0,52 & 4,99 & 0,86 & 5,85 & 1,38 & 37,68 & 14,7 \\
\hline
\end{tabular}

$20-40$

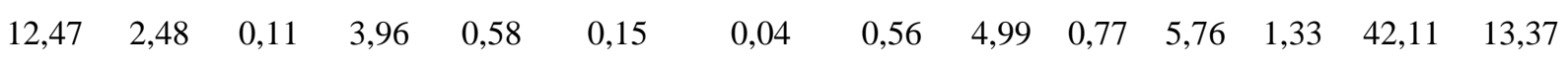

$40-60$

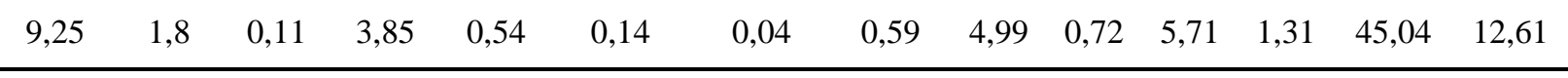

A área foi preparada utilizando arado de aiveca na profundidade de $40 \mathrm{~cm}$ e finalizado com duas gradagem aradora intermediaria. Após foram abertas covas de plantio com perfurador de solo acoplado ao trator, aplicando $200 \mathrm{~g}$ de calcário dolomítico, $50 \mathrm{~g}$ de $\mathrm{P}_{2} \mathrm{O}_{5}, 50 \mathrm{~g}$ de $\mathrm{K}_{2} \mathrm{O}$ e $8 \mathrm{~L}$ de esterco de curral em cada cova.

As mudas foram produzidas no mês março de 2019, utilizando a variedade Rubi do Cerrado e a semeadura das sementes foi feita em tubetes, utilizando um substrato com $50 \%$ solo e 50\% húmus de minhoca, ao surgir as primeiras folhas verdadeiras foi aplicado uma solução nitrogenada com 0,6 g de uréia diluída em 2 L de água, para o arranque inicial das plântulas, esse processo foi repetido por $3 \mathrm{vez}$ a cada sete dias. Quando as plantas atingiram 4 folhas expandidas, foram transplantadas para sacos plásticos de polietileno.

O sistema de irrigação localizada foi instalado, composto por um conjunto motobomba de $1 \mathrm{cv}$ e em cada parcela experimental foram instaladas duas linhas laterais de polietileno de $16 \mathrm{~mm}$, com 2 emissores gotejadores do lado direito e 2 do lado esquerdo, totalizando 4 
MINAKAWA, et al.

gotejadores por planta. No início de cada linha lateral foi instalado registro para abertura e fechamento, o que permitia a alternância dos manejos.

As plantas foram transplantadas na área experimental, após 120 dias da emergência, sendo estaqueadas, e amarradas com fitas plásticas (fitilhos) para auxiliar na condução até os arames e assim, evitar tombamentos e danificações. Após o plantio foi feito a adubação de acordo com Lima et al. (1994) e Andrade (2004). Aplicando-se 10 g de N e K por planta e após 30 dias do transplante realizando novamente.

A condução da cultura, foi do tipo espaldeira vertical, onde o tutoramento foi feito com auxílio de varões até as plantas alcançarem o arame da parreira, no qual foram implantadas numa altura de 2,20 m do solo. As brotações laterais foram sendo retiradas até alcançarem o arame e após a dominância apical foi cortada, estimulando as brotações laterais. As brotações, sempre eram conduzidas lateralmente pelo arame e realizada poda dos ramos laterais quando encontravam os ramos da outra planta.

No período de floração, observou um baixo número de insetos polinizadores, principalmente a mamangava (Xylocopa spp.), principal inseto polinizador. Dessa forma, realizou-se a polinização manual, com auxílio de hastes flexíveis de algodão, de forma alternada, transferindo os grãos de pólen de uma planta para outra, já que estas exigem polinização cruzada, sendo realizado nas horas mais quentes do dia das 11:00 AM às 15:00 PM, período em que grande parte das flores se mantém abertas e aptas a serem polinizadas.

A colheita dos frutos foi realizada de fevereiro a julho de 2020. A coleta dos frutos seguiu a metodologia de Hafle et al. (2009), conforme os frutos foram apresentando amadurecimento e caiam ao solo, eram realizadas as coletas e os frutos devidamente identificados, conforme a linha de irrigação e planta, diferindo-se dentre os tratamentos.

Foram realizadas as avaliações de peso médio dos frutos (g), peso médio de casca $(\mathrm{g})$ e peso médio de polpa (g), pesando-se em uma balança semi analítica, de acordo com a metodologia Instituto Adolfo Lutz (2008). Também foram feitas as análises do comprimento e diâmetro do fruto, utilizando-se paquímetro digital e os resultados expressos em milímetros $(\mathrm{mm})$.

Os dados foram submetidos à análise de variância pelo teste $\mathrm{F}$ e as médias dos tratamentos foram comparadas pelo teste Tukey ao nível de 5\% de probabilidade. Utilizandose o software SISVAR, versão 4.3 (FERREIRA, 2011), para realização dos cálculos estatísticos. 


\section{Resultados e Discussão}

Na Tabela 2 pode ser observado o resumo da análise de variância para os parâmetros avaliados. Verifica-se, que as variáveis analisadas para qualidade de frutos não apresentaram significância de acordo com os tratamentos aplicados. Tal fato, corrobora Crisóstomo; Naumov (2009) que relataram que o maracujazeiro apresenta uma moderada resistência ao estresse hídrico.

Tabela 2. Resumo da análise de variância para a obtenção dos valores de F, para o peso do fruto, peso da casca, peso da polpa, diâmetro e comprimento dos frutos de maracujá.

\begin{tabular}{|c|c|c|c|c|c|c|}
\hline \multirow[b]{2}{*}{$\begin{array}{c}\text { Fontes de } \\
\text { variação }\end{array}$} & \multirow[b]{2}{*}{ GL } & \multicolumn{5}{|c|}{$\mathrm{F}$} \\
\hline & & Peso Fruto ${ }^{* *}$ & Peso Casca ${ }^{* *}$ & Peso Polpa ${ }^{* *}$ & Diâmetro & Comprimento \\
\hline & & \multicolumn{3}{|c|}{ 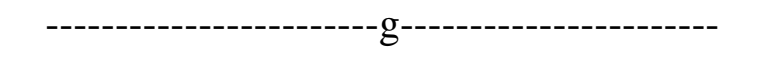 } & \multicolumn{2}{|c|}{-------------'mm-------------- } \\
\hline $\begin{array}{l}\text { Tratamen } \\
\text { to }\end{array}$ & 3 & $0,61^{\mathrm{ns}}$ & $1,18^{\mathrm{ns}}$ & $0,87^{\mathrm{ns}}$ & $0,43^{\mathrm{ns}}$ & $0,65^{\mathrm{ns}}$ \\
\hline Bloco & 2 & $0,04^{*}$ & $0,84^{\mathrm{ns}}$ & $2,51^{\mathrm{ns}}$ & $3,21^{\mathrm{ns}}$ & $0,18^{\mathrm{ns}}$ \\
\hline $\mathrm{CV}$ & & 17,04 & 15,40 & 32,75 & 9,51 & 10,58 \\
\hline MG & & 174,12 & 116,15 & 57,12 & 76,72 & 91,68 \\
\hline
\end{tabular}

* indica que o valor de F é significativo e "ns" que o valor de F não é significativo ao nível de $5 \%$ de significância. $\mathrm{CV}=$ coeficiente de variação. $\mathrm{MG}=$ média geral. $\mathrm{GL}=$ graus de liberdade. ${ }^{* *}$ Utilizou-se a transformação $\sqrt{x}$.

Observa-se pela Tabela 3, as médias obtidas para cada tratamento em função das variáveis analisadas. Nota-se que mesmo não apresentando diferença, o menor peso médio dos frutos foi de 159,59 g observado no tratamento com irrigação plena $100 \%$ da ETc alternando a cada 7 dias e o maior de 187,4 g no tratamento com irrigação plena 100\% da ETc aos dois lados.

Os resultados médios obtidos foram maiores que os observados por Hurtado-Salazar et al. (2015), com uma variação de peso dos frutos de 130,06 g a 157,43 g, avaliando duas espécies de passifloráceas silvestres como porta-enxertos relacionando com as características físicas e químicas dos frutos do maracujazeiro-amarelo em ambiente protegido. Greco et al. (2014), avaliaram frutos em 32 genótipos, e os pesos dos frutos variaram de 145,7 g a 155,6 g, menor que os obtidos neste trabalho.

Conforme Weber (2016) o peso médio encontrado na maior parte dos maracujás azedos melhorados geneticamente ficam em torno de 230 gramas. Os resultados obtidos neste trabalho também estão dentro de acordo com a informações da Embrapa a cultivar BRS Rubi do Cerrado tem seu peso dentro da faixa de 120 a 300 gramas, porém a média se concentra em 170 gramas (FALEIRO et al., 2015). 
MINAKAWA, et al.

Tabela 3. Valores médios de peso de fruto, peso da casca, peso da polpa, diâmetro e comprimento dos frutos do maracujazeiro, em relação aos tratamentos observados.

\begin{tabular}{cccccc}
\hline Tratamentos & $\begin{array}{c}\text { Peso Fruto } \\
(\mathrm{g})\end{array}$ & $\begin{array}{c}\text { Peso Casca } \\
(\mathrm{g})\end{array}$ & $\begin{array}{c}\text { Peso Polpa } \\
(\mathrm{g})\end{array}$ & $\begin{array}{c}\text { Diâmetro } \\
(\mathrm{mm})\end{array}$ & $\begin{array}{c}\text { Comprimento } \\
(\mathrm{mm})\end{array}$ \\
\hline T1 & $183,63 \mathrm{a}$ & $127,28 \mathrm{a}$ & $71,03 \mathrm{a}$ & $78,07 \mathrm{a}$ & $90,41 \mathrm{a}$ \\
T2 & $165,82 \mathrm{a}$ & $109,62 \mathrm{a}$ & $58,02 \mathrm{a}$ & $77,02 \mathrm{a}$ & $89,64 \mathrm{a}$ \\
T3 & $159,59 \mathrm{a}$ & $114,77 \mathrm{a}$ & $44,45 \mathrm{a}$ & $74,76 \mathrm{a}$ & $92,46 \mathrm{a}$ \\
T4 & $187,43 \mathrm{a}$ & $132,91 \mathrm{a}$ & $55,35 \mathrm{a}$ & $77,02 \mathrm{a}$ & $94,20 \mathrm{a}$ \\
\hline
\end{tabular}

Letras minúsculas iguais na coluna não diferem entre si de acordo com o Teste de Tukey ao nível de $5 \%$ de significância. $\mathrm{T} 1=$ redução de $25 \%$ da ETc alternando a cada 7 dias; $\mathrm{T} 2$ = redução de $50 \%$ da ETc alternando a cada 7 dias ; T3 = irrigação plena 100\% da ETc alternando a cada 7 dias e T4= irrigação plena 100\% da ETc aos dois lados.

Verifica-se pela Tabela 3 que não houve diferença entre os tratamentos no peso de casca e peso de polpa. Nota-se que a redução de $50 \%$ da ETc alternando a cada 7 dias, obteve a menor média no peso de casca e entretanto a irrigação plena alternando a cada 7 dias teve menor média em relação ao tratamento com redução de $25 \%$ da ETc e alternância a cada 7 dias, ficando este com a média próxima a encontrada no tratamento com a irrigação plena nos dois lados, indicando que o déficit de água não influenciou sobre o peso da casca.

Quanto ao peso da polpa (Tabela 3) a média do tratamento com a redução de $25 \%$ da ETc com alternância dos lados a cada 7 dias foi maior que as demais médias, enquanto as médias dos tratamentos de redução de $50 \%$ da ETc e de $100 \%$ da ETc com alternância a cada 7 dias em ambos foram bem próximas.

Para o diâmetro (Tabela 3), o tratamento que apresentou menor valor médio de diâmetro de fruto foi a irrigação plena $100 \%$ da ETc alternando a cada 7 dias $(74,76 \mathrm{~mm})$ e o maior valor $78,07 \mathrm{~mm}$ foi o verificado no tratamento com redução de $25 \%$ da ETc alternando a cada 7 dias.

Já para o comprimento médio de fruto, observou-se no tratamento com redução de 50\% da ETc alternando a cada 7 dias o menor valor $(89,64 \mathrm{~mm})$ e o maior no tratamento com irrigação plena $100 \%$ da ETc aos dois lados $(94,20 \mathrm{~mm})$ (Tabela 03).

As dimensões obtidas estão de acordo com os valores observados por Negreiros et al. (2007) e Andrade Neto et al. (2015). Com base nas dimensões, verifica-se que não houve diferença na redução de lâmina d'água aplicada, evidenciando a possibilidade de redução de água aplicada sem decréscimo significativo na qualidade dos frutos.

Através das dimensões dos frutos, pode-se observar que os frutos analisados possuíam o formato ovalado o que de acordo com Santos (2011), o formato ovalado tem preferência por parte das indústrias, pois estes apresentarem $10 \%$ a mais de suco em relação aos frutos redondos. Ainda de com Medeiros (2009), os brasileiros preferem frutos ovalados. No entanto, 
MINAKAWA, et al.

Negreiros et al. (2007), verificaram que o rendimento de polpa não apresentou relação com a forma redonda ou ovalada dos frutos.

Também observou-se que os frutos com maior diâmetro apresentaram maior peso de polpa (Tabela 3), indicando que há uma tendência de os frutos de maior diâmetro terem maior volume de suco o que também foi observado por Negreiro et al., (2007).Verifica-se que o peso da polpa foi $38,68 \%$ do peso do fruto para o tratamento com redução de $25 \%$ da ETc alternando a cada 7 dias enquanto que o tratamento irrigação plena 100\% da ETc alternando a cada 7 dias apresentou $27,85 \%$ de polpa em relação ao peso do fruto.

Observa-se através dos valores médios dos parâmetros avaliados que mesmo submetido ao maior estresse hídrico de 50\% de redução da ETc, os valores foram satisfatórios na qualidade dos frutos, o que possibilitaria a redução da lâmina bruta aplicada sem que houvesse prejuízos na qualidade física dos frutos do maracujazeiro.

Estudos realizados por Santos (2017) com mamoeiro, cultivar Tainung número 1 do grupo formosa submetido à irrigação com secamento parcial da zona radicular, irrigação fixa e irrigação plena, observou que peso médio dos frutos também não apresentou diferença, corroborando com os resultados encontrados no presente estudo.

O mesmo comportamento foi verificado em trabalho realizado por Santos et al. (2010) que verificaram que a técnica do secamento parcial com 50\% da ETc em lima ácida não diferiu do tratamento com esse mesmo déficit e sem alternância de lados da irrigação, em termos de produtividade, diâmetro e peso dos frutos, independentemente do período de alternância dos lados de irrigação.

Nota-se que a técnica de secamento parcial da zona radicular com alternância de 7 dias foi suficiente para redução da água disponível do lado submetido ao secamento para os parâmetros avaliados, permitindo a redução da lâmina de água aplicada sem interferência na produção e qualidade dos frutos do maracujazeiro.

Esta técnica é possível pois quando ocorre um intervalo em que parte da zona radicular de um lado da planta decresce a absorção de água, a planta passa à reduzir o processo transpiratório, devido ao aumento da metabolização de ácido abscísico, o que promove o fechamento parcial dos estômatos das folhas.

\section{Conclusões}

O manejo de irrigação com uso do secamento parcial aplicado no maracujazeiro não apresentou diferenças, podendo ser uma forma de economía de água sem perda significativa na qualidade de frutos. A redução de 50\% da lâmina com alternância de lados irrigados da planta 
a cada 7 dias não diferiram entre si do tratamento com aplicação da lâmina total nos dois lados da planta.

\section{Referências}

ALLEN, R. G.; PEREIRA, L. S.; RAES, D.; SMITH, M. Crop evapotranspiration: guidelines for computing crop water requirements. Rome: FAO, 1998. 300 p. (Irrigation and Drainage Paper, 56).

ALTENDORF, S. Minor tropical fruits: Mainstreaming a niche market. Food Outlook, Estados Unidos, p.69-74, 2018.

ANDRADE NETO, R. de C.; RIBEIRO, A. M. A. de S.; ALMEIDA, U. O. de; NEGREIROS, J. R. da S. Caracterização física de frutos de genótipos de maracujazeiro azedo produzido no Acre. In: ENCONTRO NACIONAL DA AGROINDÚSTRIA, 2015, Bananeiras. Semear ciência, colher tecnologia: anais. Bananeiras: Ufpb, 2015. 7 p.

ANDRADE, L. R. M. de. Corretivos e fertilizantes para culturas perenes e semiperenes. In: SOUSA, D. M. G. de; LOBATO, E. (Ed.) Cerrado: correção do solo e adubação. Planaltina, DF: Embrapa Cerrados, 2004. p. 317- 366.

ARAÚJO, H. F. de; COSTA, R. N. T.; CRISÓSTOMO, J. R.; SAUNDERS, L. C. U.; MOREIRA, O. da C.; MACEDO, A.B. M.. Produtividade e análise de indicadores técnicos do maracujazeiro-amarelo irrigado em diferentes horários. Revista Brasileira Engenharia Agrícola Ambiental, Campina Grande, v. 16, n. 2, p.159-164, 2012.

BERNARDO, S.; SOARES, A. A.; MANTOVANI, E. C. Manual de Irrigação. 8. Ed. Viçosa, MG: UFV, 2006. 625 p.

CARVALHO, A. J. C. de; MARTINS, D. P.; MONNERAT, P. H.; BERNARDO, S.; SILVA, J. A. da. Teores de nutrientes foliares no maracujazeiro-amarelo associados à estação fenológica, adubação potássica e lâminas de irrigação. Revista Brasileira de Fruticultura, [s.1.], v. 23, n. 2, p. 403-408, ago. 2001.

CARVALHO, G. C. Secamento parcial do sistema radicular no cultivo da acerola em condições do bioma da chapada diamantina. 2015. $80 \mathrm{f}$. Tese (Doutorado) - Curso de Engenharia Agrícola, Universidade Federal Rural de Pernambuco, Recife, 2015.

CASTRO P. R. C.; KLUGE, R. A. Ecofisiologia de fruteiras tropicais: abacaxizeiro, maracujazeiro, mangueira, bananeira e cacaueiro. São Paulo: Nobel, 1998. 111 p.

COSTA, A. de F. S. da; COSTA, A. N. da; VENTURA, J. A.; FANTON, C. J.; LIMA, I. de M.; CAETANO, L. C. S.; SANTANA, E. N. de.. Recomendações técnicas para o cultivo do maracujazeiro. Vitória: Incaper, 2008. 56 p.

COSTA, E. L. da; SOUSA, F. V. de; NOGUEIRA, L. C.; SATURNINO, H. M. Irrigação da cultura do maracujazeiro. Informe Agropecuário, Belo Horizonte, v. 21, n. 206, p. 59-66, 2000 . 
CRISÓSTOMO, L. A.; NAUMOV, A. Adubando para alta produtividade e qualidade: fruteiras tropicais do Brasil. Fortaleza: Embrapa Agroindústria Tropical, 2009. 238p

DAVIES, W. J.; WILKINSON, S.; LOVEYS, B. Stomatal control by chemical signalling and the exploitation of this mechanism to increase water use efficiency in agriculture. New Phytologist, v.153, p.449-460, 2002.

DAVIES, W. J.; ZHANG, J. H. Root signals and the regulation of growth and development of plants in drying soil. Annual Review of Plant Physiology and Plant Molecular Biology, v.42, p. 55-70, 1991.

DRY, P., LOVEYS, B.R. Factors influencing grapevine vigour and the potential for control with partial root-zone drying. Australian Journal of Grape and Wine Research, v.4, p. 140148, 1998.

EMBRAPA; Sistema brasileiro classificação de solos. 2. ed. EMBRAPA: São Paulo. 2006. Disponível em:<https://www.agrolink.com.br/downloads/sistema-brasileiro-de-classificacaodos-solos2006.pdf> Acesso em: 03 fev. 2020.

FALEIRO, F. G.; JUNQUEIRA, N. T. V. (Ed.). Maracujá: o produtor pergunta, a Embrapa responde. Brasília, DF: Embrapa, 2016. 341 p. (Coleção 500 perguntas, 500 respostas).

FALEIRO, F. G.; JUNQUEIRA, N. T. V.; OLIVEIRA, E. J.; MACHADO, C. F.; PEIXOTO, J. R.; COSTA, A. M.; GUIMARÃES, T. G.; JUNQUEIRA, K. P. Caracterização de germoplasma e melhoramento genético do maracujazeiro assistidos por marcadores moleculares - fase 2: resultados de pesquisa 2008-2012. Planaltina: Embrapa Cerrados, 2015.

FAO - Food and Agriculture Organization Of the United Nations. Deficit irrigation practices. Rome: FAO, p. 102, 2002. (WATER REPORTS 22).

FARQUHAR, G. D.; SHARKEY, T. D. Stomatal conductance and photosynthesis. Annual Review of Plant Physiology, v.33, p.317-345,1982.

FERREIRA, D. F. Sisvar: a computer statistical analysis system. Ciência e Agrotecnologia, v. 35, n.6, p. 1039-1042, 2011.

FLUMIGNAN, D. L.; FIGUEIREDO, L. H. S.; SILVA, J. A. da; FIETZ, C. R.; COMUNELLO, E. Evapotranspiração de referência (ETo) na região de Dourados, Mato Grosso do Sul. Dourados: Embrapa Agropecuária Oeste, 2016. 6 p. (Embrapa Agropecuária Oeste. Comunicado técnico, 215)

GOWING, D.J.; DAVIES, W.J.; JONE, H.G. A positive root-sourced signal as an indicator of soil drying, in apple, Malus x domestica Borkh. Journal of Experimental Botany, v.41, p.1535-1540, 1990.

GRECO, S. M. L.; PEIXOTO, J .R.; FERREIRA, L. M. Avaliação física, físico-química e estimativas de parâmetros genéticos de 32 genótipos de maracujazeiro-azedo cultivados no distrito federal. Bioscience Journal, Uberlândia, v.30, suppl.1,p.360-370, 2014. 
HAFLE, O.M.; RAMOS, J.D.; LIMA, L.C. de O.; FERREIRA, E.A.; MELO, P.C. de. Produtividade e qualidade de frutos do maracujazeiro-amarelo submetido à poda de ramos produtivos. Revista Brasileira de Fruticultura, Jaboticabal, v.31, n.3, 763-770, 2009.

HURTADO-SALAZAR, A.; SILVA, D. F. P. da; SEDIYAMA, C. S.; BRUCKNER, C. H. Caracterização física e química de frutos de maracujazeiro-amarelo enxertado em espécies silvestres do gênero passiflora cultivado em ambiente protegido. Revista Brasileira de Fruticultura, [S.L.], v. 37, n. 3, p. 635-643, set. 2015.

IBGE - INSTITUTO BRASILEIRO DE GEOGRAFIA E ESTATÍSTICA - Produção Agrícola Municipal - Cultura Temporárias e Permanentes : Maracujá, 2018.

INSTITUTO ADOLFO LUTZ. Normas analíticas do Instituto Adolfo Lutz. Métodos químicos e físicos de análise de alimentos. $4^{\circ}$ edição, São Paulo, 2008. p.1020.

JONES, H. G. Plants and microclimate: a quantitative approach to environmental plant physiology. 3 ed. Cambridge: Cambridge University Press, 2014.

LIMA, A. A.; BORGES, A. L.; FANCELLI, M.; CARDOSO, C. E. L. Maracujá: sistema de produção convencional. In: PIRES, M. de M.; JOSÉ, A. R. S.; CONCEIÇÃO, A. O. da (Org.). Maracujá: avanços tecnológicos e sustentabilidade. Ilhéus: Editus, 2011. 221p.

LIMA, A. A.; SANTOS FILHO, H. P.; FRANCELlI, M.; SANCHES, N. F.; BORGES, A. L. A cultura do maracujá. Brasília: EMBRAPA-SPI, 1994. 76p.

MEDEIROS, S.A.F.; YAMANISHI, O.K.; PEIXOTO, J.R.; PIRES, M.C.; JUNQUEIRA, N.T.V.; RIBEIRO, J. G.B.L. Caracterização físico-química de progênies de maracujá-roxo e maracujá-azedo cultivados no Distrito Federal. Revista Brasileira de Fruticultura., Jaboticabal, v. 31, n. 2, p. 492-499, 2009.

MELETTI, L.M.M.; OLIVEIRA, J.C.; RUGGIERO, C. Maracujá. Jaboticabal: FUNEP, 2010. (Série Frutas Nativas, 6.)

NEGREIROS, J. R. da S.; ÁLVARES, V. de S.; BRUCKNER, C. H.; MORGADO, M.Antônio D.; CRUZ, C. D. Relação entre características físicas e o rendimento de polpa de maracujáamarelo. Revista Brasileira de Fruticultura, [S.L.], v. 29, n. 3, p. 546-549, 2007.

RUGGIERO, C.; SÃO JOSÉ, A. R.; VOLPE, C. A.; OLIVEIRA, J. C. de; DURIGAN, J. F.; BAUMGARTNER, J. G.; SILVA, J. R. W.; NAKAMURA, K.; FERREIRA, M. E.; KAVATI, R.; PEREIRA, V. de P. Maracujá para exportação: aspectos técnicos da produção. Brasília, DF: EMBRAPA-SPI, 1996. 64 p. (FRUPEX. Publicações Técnicas,19).

SAMPAIO, A. H. R.; COELHO FILHO, M. A.; COELHO, E. F.; DANIEL, R.; MACHADO, V. V.; CARVALHO, G. C.; SANTANA, E. B. J. Déficit hídrico e secamento parcial do sistema radicular em pomar de lima ácida. Pesquisa Agropecuária Brasileira, v.45, n.10, p.11411148, 2010.

SANTOS, C. E. M. dos; BRUCKNER, C. H.; CRUZ, C. D.; SIQUEIRA, D. L. de; PIMENTEL, L. D.. CARACTERÍSTICAS FÍSICAS DO MARACUJÁ-AZEDO EM FUNÇÃO DO 
GENÓTIPO E MASSA DO FRUTO. Revista Brasileira de Fruticultura, Jaboticabal, v. 31, n. 4, p.1102-1110, 2009.

SANTOS, D. L.. Efeito do secamento parcial da zona radicular do mamoeiro (Carica papaya L.) em uma condição edafoclimática do semiárido da Bahia. 2017. 70 f. Dissertação (Mestrado) - Curso de Engenharia Agrícola, Universidade Federal de Viçosa, Viçosa, 2017.

SANTOS, J. L. V. dos. Qualidade dos frutos e ponto de colheita das cultivares de maracujá: BRS gigante amarelo, BRS ouro vermelho, BRS sol do cerrado. 2011. $124 \mathrm{f}$. Dissertação (Mestrado) - Curso de Produção Vegetal, Centro de Ciências e Tecnologias Agropecuárias, Universidade Estadual do Norte Fluminense Darcy Ribeiro, Campos dos Goytacazes, 2011.

SATO, G. S.; CHABARIBERY, D.; BESSA JÚNIOR, A. de A.. PANORAMA DA PRODUÇÃO E DE MERCADO DO MARACUJÁ. Informações Econômicas, São Paulo, v. 22, n. 6, p.17-30, 1992.

SOUSA, V. F. de; BORGES, A. L. Irrigação e fertirrigação na cultura do maracujá. In: SOUSA, V. F. de; MAROUELli, W. A.; COELHO, E. F.; PINTO, J. M.; COELHO FILHO, M. A. (Ed.). Irrigação e fertirrigação em fruteiras e hortaliças. Brasília, DF: Embrapa Informação Tecnológica, 2011. Cap. 17, p. 501-522.

SOUSA, V. F. de; BORGES, A. L.; COELHO, E. F.; VASCONCELOS, L. F. L.; VELOSO, M. E. da C.; OLIVEIRA, Á. S. de; NETTO, A. de O. A.. Irrigação e Fertirrigação do Maracujazeiro. 32. ed. Teresina: Embrapa Meio-norte, 2001. 46 p.

WEBER, D. Avaliação de maracujazeiros em condições de clima temperado : produção, qualidade e compostos bioativos. 2016. 124 f. Tese (Doutorado) — Programa de PósGraduação em Agronomia. - Faculdade de Agronomia Eliseu Maciel, Universidade Federal de Pelotas, Pelotas, 2016. 


\title{
CAPÍTULO 22: INOVAÇÕES EM PROTEÍNAS ALTERNATIVAS: UMA REVISÃO SOBRE ALIMENTOS PLANT-BASED
}

\section{CHAPTER 22: ALTERNATIVE PROTEIN INOVATION: A REVIEW ABOUT PLANT-BASED FOOD}

\author{
Felipe O Giacomelli ${ }^{1}$; Mariana B Pinton ${ }^{2}$; Sarah B S da Silva ${ }^{3}$; Suslin R Thiel ${ }^{4}$; Paulo C B \\ Campagnol $^{5}$
}

\begin{abstract}
Resumo
O aumento de consumo de produtos processados vegetais é uma tendência mundial. Os consumidores escolhem dietas à base de plantas por diversos motivos. Os produtos à base de plantas podem ser benéficos à saúde dependendo da matéria prima base utilizada na formulação, podendo ser classificado até como um alimento funcional. A indústria de análogos da carne começou nos Estados Unidos no século XIX, estabelecendo-se com mais força entre 1970 e 1990, mas no Brasil esta classe de produtos é mais recente. Os primeiros produtos à base de plantas encontrados no Brasil foram as bebidas vegetais (atendendo consumidores com intolerância/alergia a componentes do leite), depois surgiram as carnes de primeira geração. Em sequência surgiram as carnes vegetais de segunda geração e os ovos veganos. Atualmente já existe conhecimento e tecnologia para produzir produtos à base de plantas de forma eficiente e sustentável, atendendo as demandas de crescimento da população sem os efeitos negativos da produção tradicional. O mercado de proteínas alternativas é extremamente promissor, já que existe um aumento na procura de substitutos de carne, com diversas oportunidades de crescimento e sem líderes definidos até o momento.
\end{abstract}

Palavras-Chave: Plant-based, Inovação, carne vegetal, leite vegetal, ovo vegetal.

\begin{abstract}
The increase in consumption of processed vegetable products is a worldwide trend. Consumers choose plant-based diets for a variety of reasons. Plant-based products can be beneficial to health depending on the raw material used in the formulation, and can even be classified as a functional food. The meat analog industry started in the USA in the 19th century, establishing itself more strongly between 1970 and 1990, but in Brazil this class of products is more recent. The first plant-based products found in Brazil were vegetable drinks (serving consumers with intolerance / allergy to milk components), after first-generation meats appeared. In sequence, second generation vegetable meats and vegan eggs appeared. Currently, there is already knowledge and technology to produce plant-based products efficiently and sustainably, meeting the demands of population growth without the negative effects of traditional production. The alternative protein market is extremely promising, since

\begin{tabular}{|c|c|c|c|c|c|c|c|c|c|}
\hline $\begin{array}{l}{ }^{1} \text { Discente do Programa de } \\
\text { felipegiacomelli95@gmail.com }\end{array}$ & Pós & Graduação & em & Ciência & e & Tecnologia & & Alimento & IFS \\
\hline $\begin{array}{l}{ }^{2} \text { Discente do Programa de } \\
\text { mbpinton@gmail.com }\end{array}$ & Pós & Graduação & em & Ciência & $\mathrm{e}$ & Tecnologia & em & Alimentos, & UFSM, \\
\hline $\begin{array}{l}{ }^{3} \text { Discente do Programa de } \\
\text { sarahbiancass17@gmail.com }\end{array}$ & Pós & Graduação & em & Ciência & $\mathrm{e}$ & Tecnologia & em & Alimentos, & \\
\hline $\begin{array}{l}{ }^{4} \text { Discente do Programa de } \\
\text { suslin thiel@ hotmail.com }\end{array}$ & Pós & Graduação & em & Ciência & & Tecnologia & em & Alimentos, & OIN \\
\hline $\begin{array}{l}{ }^{5} \text { Docente do Programa de } \\
\text { paulocampagnol@gmail.com }\end{array}$ & Pós & $\mathrm{Grad}$ & em & Ciência & & Tecnologia & em & Alimentos, & \\
\hline
\end{tabular}
\end{abstract}


there is an increase in the demand for meat substitutes, with several growth opportunities and without defined leaders.

Keywords: Plant-based, Inovation, vegetable meat, vegetable milk, vegetable egg

\section{Introdução}

A substituição de proteína animal por proteínas alternativas é uma opção para os consumidores que se interessam em produtos que ofereçam benefícios à saúde. No entanto, realizar mudanças de dietas a base de carne para produtos plant-based exigirá uma profunda transição social e um desafio árduo (Boer e Aiking, 2017). As práticas alimentares são complexas e influenciadas por diversos fatores de interação, como contexto social, crença, preferências de gosto e tradições culinárias (Hartmann e Sirgrist, 2017).

Os desafios principais são os tecnológicos, a falta de informação e o consumismo. O marketing é um bom aliado para melhorar o consumo desses produtos de origem vegetal, levando a um aumento na procura e desenvolvimento na produção de alternativas à base de carne. A tentativa de simular características sensoriais, como textura e sabor, de produtos cárneos mostra-se difícil, principalmente no que diz respeito à construção de tecido semelhante ao músculo (Sha e Xiong, 2020). O desafio dos processos de estruturação de textura semelhante ao dos produtos cárneos já foi estudado e é bem elucidado no artigo de revisão de Dekkers et al. (2018). De acordo com Graça et al. (2019), sabor, aroma e aparência são fatores que afetam a aceitação e o consumo desses produtos. A inovação na tecnologia de processamento e as formulações criativas de produtos continuarão melhorando as características de qualidade. As inclusões de uma variedade de aditivos, a fim de produzir textura, suculência, sabor à carne, levantam preocupações sobre nutrição, segurança alimentar, rótulo limpo, custo e confiança do consumidor (Sha e Xiong, 2020). Geralmente, os preços de produtos alternativos são mais altos em comparação com produtos cárneos. Isso se deve ao processamento e a alta dependência de ingredientes a aditivos funcionais, apresentando um desafio econômico às indústrias.

O aumento de consumo de produtos processados vegetais é uma tendência mundial. Os consumidores escolhem dietas à base de plantas por diversos motivos, como: saúde (física e mental) (Aydar et al., 2020; Sebastiani et al., 2019; Reipurth et al., 2019), preocupações ambientais (Jansenn et al., 2016), questões éticas e crenças religiosas (Dyett et al., 2013) e gosto pessoal. 
Segundo Jansenn et al. (2016), em uma tabela comparativa de razões para alimentação a base de plantas, o fator saúde foi o apontado como mais importante, uma vez que pode implicar intolerâncias e alergias. Os substitutos de produtos de origem animal são necessários para consumidores que apresentem estas incompatibilidades imunológicas com os compostos do alimento. Segundo uma pesquisa realizada pela Biblioteca Nacional de Medicina dos EUA (2020) houve uma redução na digestão da lactose em $65 \%$ da população mundial. Estudo este corroborado com os dados que cerca de $75 \%$ da população tenha sintomas de intolerância a lactose (Aydar et al., 2020; Silva et al., 2020). Também pode-se relacionar o consumo de produtos de origem animal com a possibilidade de aumento da ocorrência de doenças cardiovasculares e neurodegenerativas (Sarni e Baroni, 2018) e aumento no colesterol (Aydar et al., 2020).

Além dos possíveis problemas que os produtos de origem animal podem causar, os alimentos à base de plantas apresentam muitos benefícios para a saúde, como demonstrado na tabela 1. No entanto, não se deve subestimar a deficiência de micronutrientes essenciais de produtos e dietas à base de plantas que levam ao aumento do risco de desnutrição (Sebastiani et al., 2019).

Tabela 1: Benefícios do consumo de produtos à base de plantas e dietas vegetarianas

\begin{tabular}{ll}
\hline \multicolumn{1}{c}{ Benefício } & \multicolumn{1}{c}{ Referência } \\
\hline Alimento funcional & Omoni \& ALuko, 2005 \\
Alimento nutracêutico & Wang et al., 2015 \\
Melhor perfil lipídico & Berkow \& Barnard, 2005 \\
Redução da pressão arterial & Pistollato et al., 2018 \\
Redução de distúrbios neurodegenerativos & \\
(Alzheimer) & Zujko \& Witkowska, 2014 \\
Rica atividade antioxidante & Aydar et al., 2020 \\
Rico em minerais, fibras e AG insaturados & Snowdon \& Phillips APUD Associação \\
Redução do risco de Diabetes tipo 2 & Dietética Americana, 2009 \\
Redução do colesterol, redução risco de & Rawal et al., 2015 \\
câncer e modulação do sistema imunológico & \\
\hline
\end{tabular}

O objetivo desta revisão é descrever as principais fontes alternativas de proteínas, como "carne" a base de plantas, "leite" e "ovos" vegetais, assim como um breve relato do

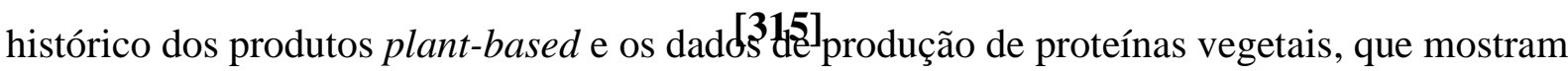


um aumento no interesse e consumo por estes produtos e também que grandes empresas e startups estão desempenhando um papel importante na criação destes alimentos, representando uma menor dependência de animais para a alimentação.

\section{Desenvolvimento}

\section{Históricos de produtos plant-based}

A indústria de "carnes" de origem vegetal nos Estados Unidos remonta ao século XIX (Braun, 2016) e várias das principais empresas de carne à base de plantas foram estabelecidas entre 1970 a 1990. No entanto, o mercado de "carne" de origem vegetal permaneceu pequeno e relativamente estagnado até recentemente, uma vez que foi visto como limitado a veganos e vegetarianos. No entanto, nos últimos anos ocorreu uma grande expansão desse mercado, o que pode ser atribuído a várias razões, incluindo a mudança para biomimética. Essa abordagem para a produção de "carne" através de plantas só começou em 2012 com o lançamento das tiras de frango da empresa Beyond Meat, e decolou com o lançamento de 2016 do "Impossible burger" e do "Beyond Burger", os quais tiveram sucesso nos principais estabelecimentos de fast-food (GFI, 2020).

As cinco maiores empresas de alimentos do mundo desenvolveram mais alimentos à base de plantas nos EUA em 2019. Uma combinação de fatores levou a um mercado em expansão para a "carne" à base de plantas. Entre 2017 e 2019, as vendas no varejo de "carne" à base de plantas cresceram $31 \%$, enquanto as vendas totais de carne no varejo nos EUA cresceram apenas 5\% (GFI, 2020).

As mudanças iniciadas pelo "leite" à base de plantas e impulsionado pela "carne" à base de plantas elevou a indústria de alimentos à base de plantas como um todo, com crescentes categorias, como ovos de origem vegetal que também tiveram um aumento da inovação e crescimento. $\mathrm{O}$ futuro está chegando rapidamente, com as principais empresas de alimentos e produtores de proteínas, como Tyson e Nestlé, fazendo grandes mudanças em alimentos à base de plantas, uma enxurrada de atividades de startups e investidores causaram a aceleração das vendas desses alimentos em 2019 (GFI, 2020).

Para o Brasil, 2019 foi o ano em que ocorreram as grandes mudanças. A Fazenda Futuro iniciou suas atividades em maio. Quase ao mesmo tempo, a startup Behind The Foods iniciou suas atividades no setor. A Superbom, que já operava no mercado, aumentou seu portfólio de produtos e passou a oferecer uma linha de produtos vegetais análogos aos tradicionais. Dando continuidade a esse movimpento de expansão, pouco depois foi lançado o Incrível Burger da Seara Alimentos, que logo se tornou uma linha inteira de produtos, a linha 
Incrível. Também em 2019, a Marfrig lançou um hambúrguer vegetal em parceria com a rede de fast food Burger King e depois anunciou o aumento da sua oferta de produtos vegetais através da marca Revolution. Essa sequência de lançamentos prova que o Brasil é capaz de oferecer soluções no setor de forma rápida e diversificada (GFI Brasil, 2020).

No Brasil, as duas redes varejistas (Extra e Pão de Açúcar) do segmento alimentar que entraram e ofereceram de maneira pioneira as marcas com os primeiros lançamentos de itens plant-based, as vendas dessa categoria de produtos cresceram a uma média constante acima de $150 \%$ desde a segunda quinzena de maio de 2019, data em que teve início a venda do primeiro hambúrguer feito de plantas, significando uma comercialização que quase triplicava a cada mês. Especificamente na linha de hambúrgueres, os produtos feitos com ingredientes à base de plantas consolidaram uma representação de $1 / 3$ da venda bruta total dos hambúrgueres congelados comercializados nacionalmente nas lojas das redes (Agro Planning, 2020).

\section{Dados de produção}

Durante muitos anos, alternativas à base de plantas, tanto para carne, leite e ovos, foram amplamente consideradas de interesse de veganos e vegetarianos. As carnes vegetais surgiram no mercado global como uma alternativa para o consumo de carne. A expectativa é que o produto seja consumido por quem quer diminuir a quantidade de proteína animal ingerida, o que é comumente chamado de "flexitariano" (Freitas, 2020). Ao longo da última década, os principais promotores desses produtos têm impulsionado constantemente as visões da indústria e da mídia popular sobre como será o futuro dos alimentos (Carrington, 2018). Houve investimentos substanciais no desenvolvimento de carnes a base de plantas e cultivadas em laboratório. Esses produtos atraíram investimentos de bilhões de dólares de alguns dos maiores nomes dos negócios globais, incluindo Bill Gates e Richard Branson (Sexton et al., 2019). De acordo com Yaffe-Bellany (2020), muitas das principais empresas de alimentos começaram a investir em carne a base de plantas ou alternativas veganas anos atrás. Mas, o ritmo acelerou nos últimos meses.

Já está em fase de teste uma impressora 3D que produz bifes à base de plantas. Chamada de "Alt-Steak", construída pela startup israelense Redefine Meat. A startup planeja lançar suas impressoras 3D em escala industrial para distribuidores de carne em 2021 (Reuters, 2020). Redes de lanchonetes como a KFC anunciaram uma parceria com a empresa russa 3D Bioprinting Solutions para fabriq3̆ utiliza em sua formulação células de frango em conjunto com material vegetal, sendo assim, 
benéfico ao meio ambiente, por não envolver sacrifício animal. Os testes finais da bioimpressão de nuggets vão ocorrer em Moscou ainda este ano (Fioratti, 2020).

Atualmente, passamos por uma pandemia causada pelo coronavírus SARS-CoV-2, o qual foi identificado em Wuhan na China e causou a COVID-19, sendo em seguida disseminada e transmitida de pessoa a pessoa. Essa situação levou ao aumento da demanda de carnes de origem vegetal. Frigoríficos fecharam quando o coronavírus adoeceu e levou a morte diversos trabalhadores, centenas de lanchonetes ficaram sem matéria-prima para produção de seus hambúrgueres. Essa situação, não diminuiu a demanda por carne nos Estados Unidos. Mas, os problemas nas indústrias de carnes impulsionaram os substitutos de carne à base de plantas, os quais tiveram um salto de $35 \%$ nas vendas durante esse período. Empresas como Impossible Foods e Beyond Meat expandiram suas vendas de forma expressiva com a pandemia. Mesmo antes do coronavírus, o interesse pela carne a base de plantas estava aumentando, mas agora, pela primeira vez, os substitutos feitos com proteínas vegetais estão com preços mais competitivos e mais fáceis de encontrar (Nierenberg, 2020). Na figura 1, é mostrado como as vendas de alimentos dispararam durante a pandemia. Podese observar que a taxa de vendas de carne foi superada pela das alternativas baseadas em plantas.

Figura 1: Aumento de vendas de carne a base de plantas

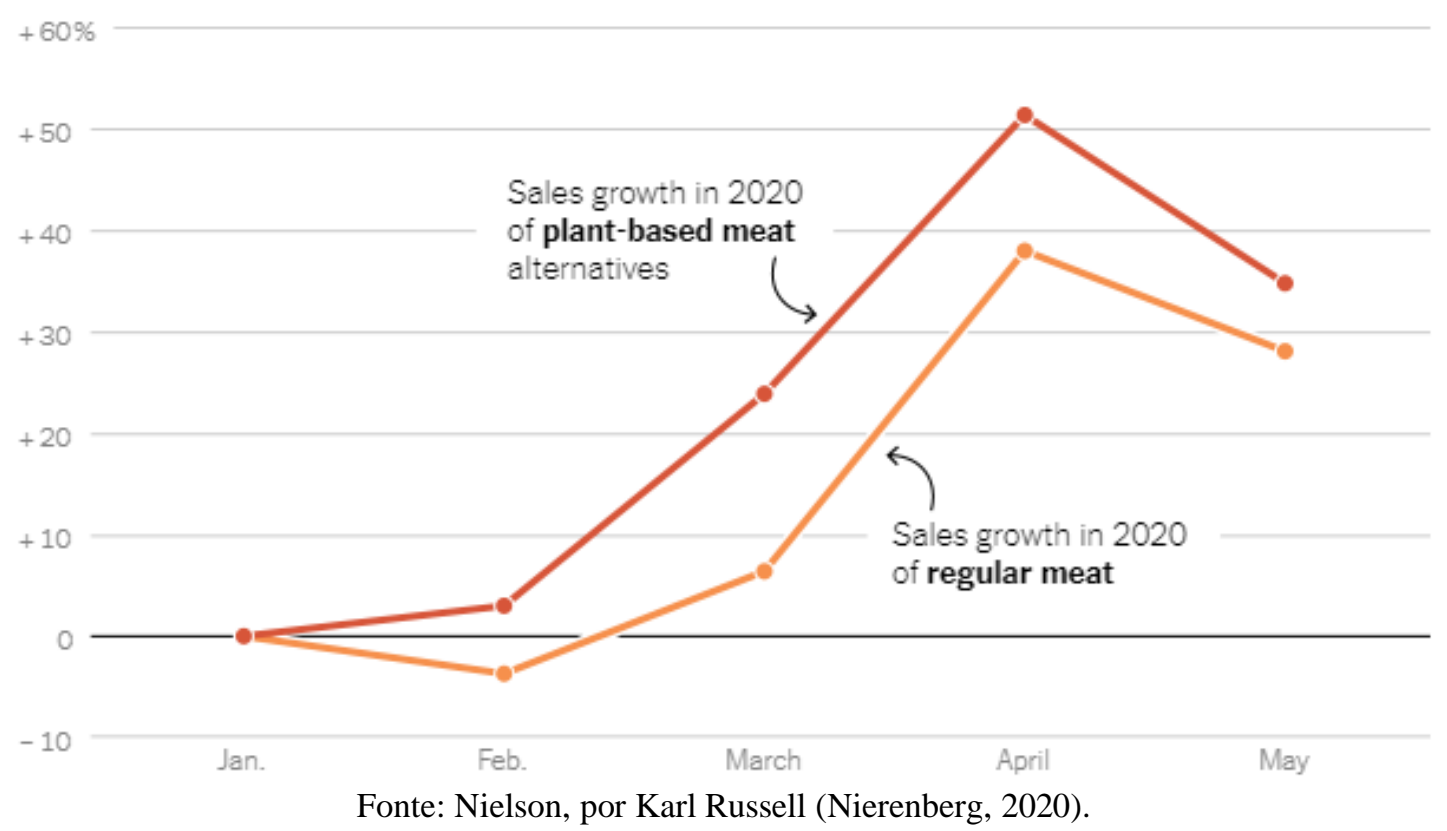

De 2015 a 2019, a busca por "carne vegetal" por brasileiros, na plataforma Google, aumentou $150 \%$. De acordo com a pesquis $[3 \mathbf{3} 5 \mathbf{5}] \%$ dos 4.335 respondentes, estão dispostos a reduzir o consumo de carne pelo menos uma vez por semana (Freitas, 2020). A startup 
Fazenda Futuro surgiu no Rio de Janeiro com a proposta de desenvolver alimentos somente com ingredientes à base de plantas, que emulam o gosto, textura e suculência da carne animal (Oliveira, 2020). O fundador da Fazenda Futuro, Marcos Leta, comenta no anúncio da foodtech que "o objetivo é liderar a transformação em uma categoria que nunca trouxe inovação ao consumidor, e trabalhar com tecnologia e propósito sem causar um impacto negativo ao meio ambiente". Com isso, a startup se lançou no mercado brasileiro e europeu com produtos à base de vegetais como carne moída, hambúrgueres, almondegas, linguiças, todos equivalentes aos produtos cárneos. Atualmente, vem expandindo sua atuação pelo mundo. Após expandir para outros países da América Latina, chegou em fevereiro de 2020, a Holanda. E, em julho, começou a exportação de sua carne vegetal para os Emirados Árabes, sendo vendida por meio de e-commerce em Dubai (Oliveira, 2020). A Fazenda Futuro é líder do mercado brasileiro no ramo de carne vegetal. Mas, não está livre de concorrências. A NotCo, startup chilena, produz diversos alimentos feitos de plantas e irá lançar o seu "nãohambúrguer" no Brasil, ainda este ano (Freitas, 2020). A empresa norte-americana Beyond Meat está chegando ao mercado brasileiro com quatro produtos à base de plantas, hambúrgueres, carne moída e dois tipos diferentes de linguiças (Delorenzo, 2020).

Buscar alternativas para driblar o consumo excessivo de carne é uma tendência que veio para ficar. Até 2050, o mundo precisará alimentar 10 bilhões de pessoas e produzir o dobro de proteína (Godfray et al., 2019). Embora a carne seja uma fonte comum de proteínas, métodos convencionais de produção são insustentáveis. Estima-se que a produção pecuária seja responsável por $14,5 \%$ das emissões de gases do efeito estufa, assim como, um dos maiores usuários industriais de água e terra (Gerber et al., 2013). As proteínas alternativas representam uma ampla categoria de produtos que ecoam no movimento em direção a menor dependência de animais para alimentação (Ong et al., 2020). Análises de ciclo de vida ambiental constatam que as carnes de origem vegetal e cultivadas terão emissões de gases de efeito estufa drasticamente mais baixas em relação à carne bovina ou de aves cultivadas em fazendas (Mattick et al., 2015).

\section{Fontes alternativas de proteínas}

A produção contemporânea de alimentos de origem animal tem sofrido muitas críticas negativas devido os impactos que causam na esfera ambiental, da saúde e de bem-estar animal (Trusts \& Hopkins, 2008). Em resposta a estas questões, com inovação tecnológica e investimentos financeiros, foram lançados p[319]os de proteínas alternativas (Broad, 2019). 
A inovação começou de forma inexpressiva com a primeira geração de produtos à base de plantas, que buscavam oferecer alternativas aos produtos de origem animal (hambúrgueres de soja, proteína texturizada de soja (PTS) e leites vegetais) principalmente aos consumidores com restrição alimentar (GFI, 2020). Os avanços em ciência de alimentos (tecnologia de sabores e processos de extrusão) levaram a uma capacidade aprimorada de criar alimentos à base de plantas que imitam os produtos animais originais (Broad, 2019).

\section{Carnes a base de Plantas}

Os análogos de carne à base de plantas têm uma longa história na culinária cultural global e, nas últimas décadas, foram produzidos em massa e comercializados diretamente para principalmente consumidores vegetarianos, ocupando um nicho atraente em restaurantes e lojas (Broad, 2020). Estes produtos análogos aos tradicionais (a base de carne) são produzidos com a combinação de matéria prima vegetal (grãos, frutas, tubérculos, raízes tuberosas, entre outros) aromas para imitar o sabor e a textura de produtos animais existentes através de uma abordagem biomimética (GFI, 2020a) ou ainda por rota biotecnológica (agricultura celular) que isola células animais e desenvolve as chamadas carnes cultivadas (Mouat et al., 2019).

Grande parte dos produtos à base de plantas encontrados no Brasil atualmente, são produzidos a partir de soja nacional ou ervilha importada. Considerando o crescimento previsto para o mercado de proteínas alternativas, será necessário não apenas aumentar a oferta desses produtos como também diversificar a opção de proteínas em suas composições (GFI, 2020; Godfray, 2019; Broad, 2019; Broad, 2020). Na tabela 2 encontram-se as "carnes vegetais" comercializadas atualmente no Brasil. 
Tabela 2: Produtos à base de plantas industrializados no Brasil

\begin{tabular}{|c|c|}
\hline Produto análogo & Empresa produtora \\
\hline \multirow{10}{*}{ Hambúrguer } & Behind the Foods; \\
\hline & $B R F$ \\
\hline & Fazenda Futuro; \\
\hline & Goshen; \\
\hline & $J B S$ \\
\hline & Marfrig; \\
\hline & Sotille; \\
\hline & Superbom; \\
\hline & The New Butchers; \\
\hline & Vegabom \\
\hline \multirow{2}{*}{$\begin{array}{l}\text { Almôndega } \\
\text { Carne Moída }\end{array}$} & Fazenda Futuro \\
\hline & Fazenda Futuro; \\
\hline \multirow{3}{*}{ Linguiças } & Goshen; \\
\hline & Superbom; \\
\hline & Vegabom \\
\hline \multirow{2}{*}{ Embutidos Fatiados } & Goshen; \\
\hline & Superbom \\
\hline \multirow{2}{*}{ Nuggets } & $B R F$ \\
\hline & $J B S$ \\
\hline \multirow[t]{2}{*}{ Tiras de Frango } & The New Butchers \\
\hline & Goshen; \\
\hline \multirow[t]{2}{*}{ Empanados } & Superbom; \\
\hline & Vegabom \\
\hline
\end{tabular}

Fonte: adaptado de GFI Brasil, 2020

A produção de carne à base de plantas ainda é realizada em sua maioria a partir da técnica de extrusão, mas já existem outros métodos (tecnologia de células Couette (cisalhamento) e a impressão 3D) sendo estudados e avançando para soluções viáveis em qualidade e capacidade de produção (GFI, 2020b).

Estudos mais avançados sobre texturização de proteínas permitiu que produtos de carne reestruturados progredissem de "migalhas" (usadas em hambúrgueres) a pedaços e 
pedaços cortados em cubos, oferecendo maior versatilidade para produção de produtos à base de "carne vegetal". Embora o sabor e a textura da carne à base de plantas sejam os principais motivos para atrair o consumidor, as inovações projetam produtos que realmente imitem a experiência completa da carne (da aparência "ao ponto" até ao aroma característico) (GFI, 2020b). O aroma tem sido estudado através da separação por cromatografia gasosa, onde identifica-se os "aromas essenciais da carne". Como o aroma característico é transformado durante a cocção, ainda não foi possível encontrar os precursores certos para as carnes vegetais (Jacobsen, 2016).

\section{5 "Leites" vegetais}

Em vista da crescente demanda por produtos e derivados sem leite no mercado mundial, o desenvolvimento de novos produtos é de primordial importância para as empresas, pois esses novos produtos estão diretamente relacionados às necessidades e tendências de consumo da população (Silva et al., 2020).

A demanda do consumidor por alternativas ao leite de vaca aumentou como resultado de pessoas serem intolerantes ao leite de vaca, incluindo intolerância à lactose e alergia ao leite de vaca (Jeske et al., 2018), além de estilos de vida como o vegetarianismo e o veganismo. A estratégia usada por esses indivíduos e pela indústria de alimentos tem sido o "leite" à base de plantas. Porém, é essencial mencionar que existem alternativas para indivíduos com intolerância à lactose, como produtos sem lactose e o uso da enzima lactase, no entanto, para indivíduos alérgicos e veganos, a única opção é o "leite" à base de plantas (Vanga \& Raghavan, 2018).

A bebida à base de plantas mais consumida é a de soja. No entanto, o consumo deste produto é limitado pela alergia à soja, que afeta cerca de $0,5 \%$ da população em geral (Katz et al., 2014), apesar de existirem também alergias em relação a outras oleaginosas, portanto, são necessárias outras alternativas para atender este público.

De acordo com Aydar et al. (2020), Pineli et al., (2015) e Wang et al. (2018), existem diversos substitutos, como amêndoa, caju, coco, avelã, amendoim, gergelim, porca de tigre, aveia, arroz, cânhamo, nozes, quinoa e grão de bico. No entanto, estes possuem características sensoriais, estabilidade e composição nutricional diferentes do leite de vaca (Sethi et al., 2016) principalmente em relação ao teor de proteínas, gorduras e minerais. Na tabela 3 a seguir são mostradas diferentes bebidas à base de plantas e seu respectivo valor nutricional em relação ao teor de proteína, gordura e cinzas. 
Tabela 3: Valor nutricional proteína, gordura e cinzas $(\mathrm{g} / 100 \mathrm{~g})$ de diferentes bebidas à base de plantas.

\begin{tabular}{|c|c|c|c|c|}
\hline Bebidas vegetais & Proteína & Gordura & Cinzas & Autor \\
\hline Grão de bico & $1,21 \pm 0,01$ & $0,34 \pm 0,01$ & $0,15 \pm 0,00$ & Wang et al., \\
\hline Soja amarela & $2,09 \pm 0,01$ & $0,74 \pm 0,02$ & $0,22 \pm 0,01$ & 2018. \\
\hline Amêndoa (Marca 1) & $2,11 \pm 0,09$ & $4,40 \pm 0,11$ & $0,35 \pm 0,04$ & \multirow{16}{*}{$\begin{array}{c}\text { Jeske et al., } \\
2017\end{array}$} \\
\hline Amêndoa (Marca 2) & $0,41 \pm 0,02$ & $1,18 \pm 0,05$ & $0,55 \pm 0,00$ & \\
\hline Amêndoa (Marca 3) & $0,95 \pm 0,39$ & $3,69 \pm 0,11$ & $0,21 \pm 0,02$ & \\
\hline Caju & $0,87 \pm 0,10$ & $2,50 \pm 0,10$ & $0,23 \pm 0,01$ & \\
\hline Coco & $0,08 \pm 0,00$ & $0,84 \pm 0,00$ & $0,52 \pm 0,01$ & \\
\hline Avelã & $0,36 \pm 0,00$ & $1,56 \pm 0,05$ & $0,52 \pm 0,00$ & \\
\hline Cânhamo & $0,08 \pm 0,04$ & $2,44 \pm 0,23$ & $0,42 \pm 0,01$ & \\
\hline Macadâmia & $0,29 \pm 0,01$ & $2,62 \pm 0,06$ & $0,25 \pm 0,01$ & \\
\hline Aveia & $0,70 \pm 0,19$ & $0,38 \pm 0,06$ & $0,2 \pm 0,00$ & \\
\hline Quinoa & $0,22 \pm 0,04$ & $2,32 \pm 0,13$ & $0,17 \pm 0,01$ & \\
\hline Arroz & $0,32 \pm 0,04$ & $0,85 \pm 0,06$ & $0,14 \pm 0,02$ & \\
\hline \multirow[t]{2}{*}{ Arroz escuro } & $0,07 \pm 0,00$ & $0,95 \pm 0,04$ & 0,10 & \\
\hline & & & 0,010 & \\
\hline Soja & $2,72 \pm 0,06$ & $2,11 \pm 0,04$ & $0,61 \pm 0,04$ & \\
\hline Soja (UHT) & $3,70 \pm 0,03$ & $2,04 \pm 0,11$ & $0,34 \pm 0,02$ & \\
\hline Leite pasteurizado & $3,70 \pm 0,14$ & $3,28 \pm 0,05$ & $0,62 \pm 0,01$ & \\
\hline Grão de bico & $2,1 \pm 0,07$ & $0,39 \pm 0,2$ & $0,37 \pm 0,11$ & \multirow{6}{*}{$\begin{array}{c}\text { Rincon et al., } \\
2020\end{array}$} \\
\hline Coco & $1,04 \pm 0,31$ & $7,42 \pm 1,68$ & $0,32 \pm 0,09$ & \\
\hline $90 \%$ Grão de bico e $10 \%$ coco & $2,09 \pm 0,16$ & $1,08 \pm 0,28$ & $0,4 \pm 0,11$ & \\
\hline $80 \%$ Grão de bico e $20 \%$ coco & $1,96 \pm 0,07$ & $1,74 \pm 0,35$ & $0,33 \pm 0,05$ & \\
\hline $70 \%$ Grão de bico e $30 \%$ coco & $1,9 \pm 0,18$ & $3,25 \pm 1,15$ & $0,32 \pm 0,08$ & \\
\hline $50 \%$ Grão de bico e $50 \%$ coco & $1,54 \pm 0,09$ & $3,43 \pm 0,38$ & $0,33 \pm 0,07$ & \\
\hline Quinoa & $1,7 \pm 0,01$ & $0,2 \pm 0,1$ & - & Pineli et al., \\
\hline Arroz & $0,30 \pm, 036$ & $1,11 \pm 0,35$ & - & 2015 \\
\hline
\end{tabular}

Jeske et al. (2017), analisaram diferentes marcas disponíveis comercialmente, já os autores Wang et al. (2018), Rincon et al. (2020) e Pineli et al. (2015), produziram as bebidas vegetais. Em relação a tabela 3, analisando os dados pode-se perceber grandes diferenças para 
os teores de proteínas, gorduras e cinzas entre todas as bebidas vegetais. Houve uma discrepância nos teores para a mesma oleaginosa, por exemplo a amêndoa.

A soja é a oleaginosa que se destaca em relação às demais mencionadas na tabela 3. É a bebida vegetal que mais se assemelha pela quantidade de proteínas do leite de vaca, no entanto, conforme estudo de Vasconcelos et al. (2006), a soja não possui dois aminoácidos essenciais (metionina e fenilalanina) ao contrário do leite de vaca.

A falta de aminoácidos essenciais em vegetais é um dos grandes problemas, o grão de bico, ervilha, feijão, quinoa, linhaça, cânhamo e tremoço não possuem o aminoácido essencial triptofano (Sánchez-Vioque et al. 1999; Chan e Phillips, 1994; Mattila et al. 2018). Outras fontes também não possuem alguns aminoácidos não essenciais como a cisteína e a tirosina em soja, prolina em grão de bico e cisteína em ervilha (Vasconcelos et al., 2006; SánchezVioque et al. 1999; Chan e Phillips, 1994). Rincon et al. (2020) produziram bebidas vegetais através de diferentes formulações com grão de bico e coco, o que pode ser interessante para promover um equilíbrio em relação aos nutrientes. No entanto, ainda existem poucos estudos na literatura.

Em relação ao conteúdo de cinzas, a bebida vegetal de soja possui uma quantidade similar que o leite de vaca, porém, o seu conteúdo de cálcio é 10 vezes menor que o leite de vaca integral (TACO, 2011). Entanto, uma alternativa seria promover o enriquecimento de cálcio em bebidas vegetais (Casé et al., 2005). Porém, a sedimentação do cálcio adicionado ainda permanece um problema, pois foi demonstrado que as bebidas de soja fortificada com cálcio não sacudido atingiram em média apenas $31 \%$ de sua reivindicação no rótulo e apenas 59\% quando sacudidas (Heaney \& Rafferty, 2006). Já o conteúdo de magnésio em leite integral e desnatado de vaca é de $10 \mathrm{mg} / 100 \mathrm{~mL}$ e na bebida de soja é em torno de $15 \mathrm{mg}$ /100 mL (TACO, 2011).

Os vários componentes bioativos presentes nas plantas que impactam a absorção de nutrientes também merecem discussão. $\mathrm{O}$ ácido fítico está presente em muitos cereais e leguminosas e é descrito como um anti-nutriente devido à sua capacidade de se ligar a minerais essenciais e oligoelementos (incluindo cálcio, zinco, ferro, magnésio e cobre) para criar complexos insolúveis desses minerais que inibem sua absorção no intestino. A presença de ácido fítico natural diminui a biodisponibilidade do cálcio da farinha de arroz, farinha de soja para 46,53\%, 10,70\% e 3,77\%, respectivamente (Dendougui \& Schwedt, 2004). São necessárias mais pesquisas para quantificar com mais precisão o efeito de anti-nutrientes e baixa resolubilização do cálcio na absorção total de cálcio de alternativas comuns ao leite à base de plantas (Chalupa-Krebzdak et al., 2018). 
Cabe destacar, no entanto, que as bebidas vegetais contêm componentes funcionalmente ativos com propriedades promotoras da saúde que atraem consumidores preocupados com a saúde (Sethi et al., 2016). Compostos fenólicos, ácidos graxos insaturados, atividade antioxidante e compostos bioativos como fitoesteróis e isoflavonas tornam os substitutos do leite à base de plantas uma excelente opção (Aydar et al., 2020). As bebidas obtidas a base de vegetais são ricas em antioxidantes que reduzem o risco de doenças cardiovasculares, câncer, aterosclerose e diabetes, impedindo que os radicais livres oxidem ácidos nucleicos, proteínas, lipídios e DNA (Maleki et al., 2015). Vinson \& Cai (2012), analisaram os níveis de polifenóis livres e totais em amêndoa, castanha do Brasil, caju, macadâmia, amendoim, nozes, pistache e nozes, e todas apresentaram uma alta concentração, que variou entre 11,1 a $107 \mu \mathrm{mol}$ de catequina / g. É importante ressaltar, no entanto, que parte desses compostos bioativos benéficos à saúde são perdidos durante o processamento (Aydar et al., 2020).

O grande desafio da indústria, no entanto, é produzir bebidas vegetais com características sensoriais similares ao leite de vaca. Isto possibilitará atingir um novo mercado, que é atualmente composto quase em sua totalidade por consumidores que possuem intolerâncias e alergias ao leite de vaca ou que não consomem produtos de origem animal.

\section{“Ovos" vegetais}

O ovo plant-based é um produto à base de plantas que substitui o ovo convencional proporcionando a mesma textura e sabor. O ovo plat-based oferece as mesmas vantagens do ovo convencional podendo ser usado na elaboração de produtos de panificação e em outros setores. Ele é produzido com a combinação de ingredientes vegetais como amido de batata, farinha de tapioca, bicarbonato de sódio, fibra de casca de psyllium, tofu de seda, entre outros. É uma opção ideal para o público vegano, vegetariano, ovolactovegetariano e para indivíduos intolerantes ou alérgicos ao ovo. Além disto, tem como vantagens em relação ao ovo tradicional a maior vida útil, a maior facilidade para transporte e armazenagem e além disso, possui uma maior segurança microbiológica (Gonçalves, 2019).

Várias indústrias estão se adequando a nova demanda dos consumidores, com isso podemos esperar diversas opções de ovo plant-based. Por exemplo, a JUST é uma empresa americana que produz um ovo líquido planted-based que tem como ingrediente principal a proteína de feijão mungo (Guerrero, 2018). Outro exemplo é a empresa Mantiqueira, que é a maior produtora de ovo convencional do Brasil. Esta empresa lançou a sua primeira formulação de ovo plant-based em pó, o qual contém proteína de ervilha, amido de ervilha e 
linhaça dourada. Esse ingrediente tem características muito similares a um ovo convencional quando adicionado de água, podendo ser utilizado para a elaboração de bolos e pães sem afetar a qualidade tecnológica e sensorial dos produtos (Mantiqueira, 2019). Já a startup americana de tecnologia Clara Foods pretende lançar claras de ovos plant-based produzidas à partir de leveduras de cerveja e açúcar (Ata News, 2018).

\section{Considerações Finais}

Segundo dados da $F A O / O N U$ a demanda da agricultura precisa aumentar em quase $50 \%$ para suprir as necessidades de alimentos da população em 2050, levando em consideração a projeção que seremos 9,7 bilhões de pessoas no planeta. A produção de produtos à base de plantas é mais sustentável que a produção tradicional, principalmente para as carnes vegetais, apresentando-se como uma ótima alternativa de proteína análoga. As indústrias de alimentos estão em constante inovação, uma vez que os consumidores sempre buscam novos produtos. Nos últimos anos notou-se um aumento nos produtos anunciados como veganos, sem laticínios e éticos (o que significa que os produtores não contribuem para a crueldade animal). À medida que novas tendências crescem, o cenário se torna mais competitivo com a presença de produtos adicionais.

\section{Referências}

AGRO PLANNING. Em um ano, alimentos plant-based se consolidam no cardápio do consumidor brasileiro. 2020.2 Disponível em: https://www.agroplanning.com.br/2020/07/06/em-um-ano-alimentos-plant-based-seconsolidam-no-cardapio-do-consumidor-brasileiro/. Acesso em: 28 de julho 2020.

AIKING, Harry. Future protein supply. Trends in Food Science \& Technology, v. 22, n. 23, p. 112-120, 2011.

ASSOCIAÇÃO DIETÉTICA AMERICANA. Position of the American Dietetic Association: Vegetarian diets. J. Amer. Diet. Assoc. v. 109, p. 1266-1282, 2009.

AYDAR, E.F.; TUTUNCU, S.; OZCELIK, Be.. Plant-based milk substitutes: Bioactive compounds, conventional and novel processes, bioavailability studies, and health effects. Journal of Functional Foods, v. 70, p. 103975, 2020.

BERKOW, S.E.; BARNARD, N.D. Blood pressure regulation and vegetarian diets. Nutrition reviews, v. 63, n. 1, p. 1-8, 2005.

BIBLIOTECA NACIOANL DE MEDICINA DOS EUA. Lactose intolerance. Genetics Home Reference. Acesso em: 25 de julho de 2020 <https://ghr.nlm.nih.gov/condition/lactoseintolerance>. 
BOER, J.; AIKING, H.. Pursuing a low meat diet to improve both health and sustainability: How can we use the frames that shape our meals?. Ecological economics, v. 142, p. 238-248, 2017.

BRAUN, W. Meat analogues: Just like your adventist mother used to make. 2016. Disponível em: ttps://www.huffpost.com/entry/meat-analogues-just-

BROAD, G.M. Making Meat, Better: The Metaphors of Plant-Based and Cell-Based Meat Innovation. Environmental Communication, p. 1-14, 2020.

BROAD, G.M. Plant-based and cell-based animal product alternatives: an assessment and agenda for food tech justice. Geoforum, v. 107, p. 223-226, 2019.

CARAZZAI, Estelita Hass. Trump agora promete acabar com política que separa famílias de refugiados. Folha de S.Paulo, São Paulo, 20 de jun. de 2018. Disponível em: <https://www1.folha.uol.com.br/mundo/2018/06/trump-agora-promete-acabar-com-politicaque-separa-familias-de-refugiados.shtml>. Acesso em: 20 de jun. de 2018.

CARRINGTON D. 2018. The new food: meet the startups racing to reinvent the meal. Guardian. Acesso: www.theguardian.com/environment/2018/apr/30/lab-grown-meat-how-abunch-of-geeksscared-the-meat-industry, acesso 25, julho, 2020.

CASÉ, F.; DEliZA, R.; ROSENTHAL, A.; MONTOVANI, D.; FERBERG, I. 2005. Produção de "leite" de soja enriquecido com cálcio. Ciência Tecnologia Alimentos, v.25. p. 86-91, 2005.

CHALUPA-KREBZDAK, S.; LONG, C.J.; BOHRER, B.M. Nutrient density and nutritional value of milk and plant-based milk alternatives. International dairy journal, v. 87, p. 84-92, 2018.

CHAN, C.; PHILLIPS, R. D. Amino acid composition and subunit constitution of protein fractions from cowpea (Vigna unguiculata L. Walp) seeds. Journal of Agricultural and Food Chemistry, v.42. p. 1857-1860, 1994.

CROWE, F. L.; APPLEBY, P. N.; TRAVIS, R. C.; KEY, T. J. Risk of hospitalization or death from ischemic heart disease among British vegetarians and nonvegetarians: Results from the EPIC-Oxford cohort study. Am. J. Clin. Nutr. v. 97. p.597-603, 2013.

DEKKERS, B. L.; BOOM, R. M.; VAN DER GOOT, A. J. 2018. Structuring process for meat analogues. Trends in Food Science \& Technology, v.81, p. 25 - 36.

DENDOUGUI, F.; SCHWEDT, G. 2004. In vitro analysis of binding capacities of calcium to phytic acid in different food samples. European Food Research and Technology, v.219. p. 409-415, 2004.

Do que é feito o N.ovo. Mantiqueira, 2019. Disponivel em : https://www.ovosmantiqueira.com.br/conheca-o-n-ovo?localidade=sp 
DYETT, P.A.; SABATÉ, J.; HADAD, E.; RAJARAM, S.; SHAVLIK, D.. Vegan lifestyle behaviors. An exploration of congruence with health-related beliefs and assessed health indices. Appetite, v. 67, p. 119-124, 2013.

Empresa investe na criação de "claras de ovos" veganas. Ata News, 2018. Disponive em: https://atanews.com.br/noticia/8312/empresa-investe-na-criacao-de--claras-de-ovos--veganas

FIORATII, C. 2020. KFC pretende vender nuggets produzidos por bioimpressão 3D. Acesso: https://super.abril.com.br/ciencia/kfc-pretende-vender-nuggets-produzidos-por-bioimpressao3d/, Acesso dia 25 julho, 2020.

FREITAS, T. 2020. Brasileiros pesquisam 150\% mais "carne vegetal". Acesso: https://www.startse.com/noticia/startups/brasileiros-carne-vegetal-fazenda-futuro, Acesso dia 25 julho, 2020.

GERBER, P.J. et al., 2013. Tackling climate change through livestock - A global assessment of emissions and mitigation opportunities. Food and Agriculture Organization of the United Nations (FAO), Rome.

GFI BRASIL. Industria de Proteínas Alternativas. 2020. Disponível em: https://gfi.org.br/wp-content/uploads/2020/06/GFI_2020_IndProtAlternativas.pdf. Acesso em: 28 de julho 2020.

GFI. The Good Food Institute. 2019 U.S. State of the Industry Report Plant-Based Meat, Eggs,and Dairy. 2020. Disponível em: https://www.gfi.org/files/soti/INN-PBMED-SOTIR2020-0507.pdf. Acesso em: 28 de julho 2020.

GODFRAY, H. C. J. et al. Meat: the future series Alternative Proteins. In: World Economic Forum. 2019.

GONÇALVES, F. N. A crescente demanda por ovo vegano. Vegan Business, 3 de setembro de 2019. Disponivel em: https://veganbusiness.com.br/a-crescente-demanda-por-ovo-vegano/

GRAÇA, J.; GODINHO, C.A.; TRUNINGER, M.. Reducing meat consumption and following plant-based diets: Current evidence and future directions to inform integrated transitions. Trends in Food Science \& Technology, v. 91, p. 380-390, 2019.

GUERRERO, C. J. San Francisco company makes vegan scrambled egg substitute that tastes like real eggs. ABC news, EUA, 21 de julho de 2018. Disponivel em: https://abc7news.com/eggs-egg-substitute-perfect-scrambled-mung-bean/3795652/

HARTMANN, C.; SIEGRIST, M. Consumer perception and behaviour regarding sustainable protein consumption: A systematic review. Trends in Food Science \& Technology, v. 61, p. 11-25, 2017.

HEANEY, R. P.; RAFFERTY, K. 2006. The settling problem in calcium-fortified soybean drinks. Journal of the American Dietetic Association, v.106. p. 1793, 2006. 
HERRERO, M. Feeding the planet: key challenges. In: Energy and protein metabolism and nutrition in sustainable animal production. Wageningen Academic Publishers, Wageningen, 2013. p. 27-34..

JACOBSEN, R. The biography of a plant-based burger. Pacific Standard, 2016. Acesso em 28/07/2020 em < https://psmag.com/news/the-biography-of-a-plant-based-burger>.

JANSSEN, M; BUSCH, C.; RODIGER, M.; HAMM, U.. Motives of consumers following a vegan diet and their attitudes towards animal agriculture. Appetite, v. 105, p. 643-651, 2016.

JESKE, S.; ZANNINI, E.; ARENDT, E. K. 2017. Evaluation of Physicochemical and Glycaemic Properties of Commercial Plant-Based Milk Substitutes. Plant Foods Hum Nutr, v. 72. p. 26-33, 2017.

JESKE, S.; ZANNINI, E.; ARENDT, E.K. Past, present and future: The strength of plantbased dairy substitutes based on gluten-free raw materials. Food research international, v. 110, p. 42-51, 2018.

KATZ, Y.; GUTIERREZ-CASTRELLOM, P.; GONZÁLEZ, M. G.; RIVAS, R.; LEE, B. W.; ALARCON, P. 2014. A comprehensive review of sensitization and allergy to soy-based products. Clinical Reviews in Allergy and Immunology, v.46. p. 272-281, 2014.

MALEKI, N.; KHODAIYAN, F.; MOUSAVI, S. M. 2015. Antioxidant activity of fermented Hazelnut milk. Food Science and Biotechnology, v.24. p. 107-115, 2015.

Mantiqueira lança ovo vegano. 9 de maio de 2019.Disponível em: https://www.aviculturaindustrial.com.br/imprensa/mantiqueira-lanca-ovo-vegano/20190509$\underline{150519-\mathrm{m} 392}$

MATILLA, P.; MAKINEN, S.; EUROLA, M.; JALAVA, T.; PIHLAVA, J. M.; HELlSTROM, J.; PIHLANTO, A. 2018. Nutritional Value of Commercial Protein-Rich Plant Products. Plant Foods for Human Nutrition, v. 73. p.108-115, 2018.

MATTICK, C. S.; LANDIS, A. E.; ALlENBY, B. R. 2015. A case for systemic environmental analysus of cultured meat. Journal of Integrative Agriculture, v. 15, -. 249 254.

MICHA, R.; PEÑALV, J. L; CUDHEA, F.; IMAMURA, F.; Rehm, C. D.; MOZAFFARIAN, D. 2017. Association between dietary factors and mortality from heart disease, stroke, and type 2 diabetes in the United States. JAM,. v. 317. p. 912-924, 2017.

MOUAT, M.J.; PRINCE, R.; ROCHE, M.M. Making value out of ethics: The emerging economic geography of lab-grown meat and other animal-free food products. Economic Geography, v. 95, n. 2, p. 136-158, 2019.

NIERENBERG, A. 2020. Plant-based "meats" catch on in the pandemic. Acesso: https://www.nytimes.com/2020/05/22/dining/plant-based-

meatscoronavirus.html?searchResultPosition=2 . Acesso dia 25, julho, 2020. 
OLIVEIRA, A. 2020. Foodtech brasileira Fazenda Futuro começa a exportar para Dubai. Acesso: https://www.sunoresearch.com.br/noticias/fazenda-futuro-comeca-exportar-dubai/, Acesso dia 25, julho, 2020.

ONG, S.; CHOUDHURY, D.; NAING, M.W. Cell-based meat: Current ambiguities with nomenclature. Trends in Food Science \& Technology, 2020.

Orlich, M.J.; Singh, P.N.; Sabaté, J.; Jaceldo-Siegl, K.; Fan, J.; Knutsen, S.; Beeson, W.L.; Fraser, G.E. 2013. Vegetarian dietary patterns and mortality in Adventist Health Study 2. JAMA Intern. Med., v.173. p. 1230-1238, 2013.

PINELI, L. L. O.; BOTELHO, R. B. A.; ZANDONADI, R. P.; SOLORZANO, J. L.; OLIVEIRA, G. T.; REIS, C. E.; TEIXEIRA, D. S. 2015. Low glycemic index and increased protein content in a novel quinoa milk. LWT - Food Science and Technology, v. 63. p. 1261-1267, 2015.

RAWAL, G.; YADAV, S.; NAGAYACH, M.S.. Phytosterols and the health. Medico Research Chronicles, v. 2, n. 3, p. 441-444, 2015.

REIPURTH, M.F.S.; HORBY, L.; GREGERSEN, C.G.; BONKE, A.; PEREZ CUETO, F.J.A. Barriers and facilitators towards adopting a more plant-based diet in a sample of Danish consumers. Food quality and preference, v. 73, p. 288-292, 2019.

REUTERS, 2020. Bife à base de plantas é produzido por impressora 3D em negócio de startup israelense. Acesso: https://g1.globo.com/bemestar/viva-voce/noticia/2020/06/30/bife-abase-de-plantas-e-produzido-por-impressora-3d-em-negocio-de-start-up-isralense.ghtml, Acesso dia 25, julho, 2020.

RINCON, L.; BOTELHO, R. B. A.; ALENCAR, E. R. 2020. Development of novel plantbased milk based on chickpea and coconut. LWT, v. 128. 109479, 2020.

RUBY, M. B. 2012. Vegetarianism: a blossoming field of study. Appetite, v.58. p. 141-150, 2012.

SÁNCHEZ-VIOQUE, R.; CLEMENTE, A.; VIOQUE, J.; BAUTISTA, J.; MILLÁN, F. 1999. MillánProtein isolates from chickpea (Cicer arietinum L.): Chemical composition, functional properties and protein characterization. Food Chemistry, v. 64. p. 237-243, 1999.

SARNI, A. R.; BARONI, L.. Milk and Parkinson disease: Could galactose be the missing link. Mediterranean Journal of Nutrition and Metabolism, v. 12, n. 1, p. 91-118, 2018.

SEBASTIANI, G.; BARBERO, A.H.; BORRÁS-NOVELL, C.; CASANOVA, M.A.; ALDECOA-BILBAO, V.; ANDREU-FERNANDEZ, V.; TUTUSAUS, M. P.; MARTINEZ, S.F.; ROIG, M.D.G.; GARCIA-ALGAR, O.. The effects of vegetarian and vegan diet during pregnancy on the health of mothers and offspring. Nutrients, v. 11, n. 3, p. 557, 2019.

SETHI, S.; TYAGI, S. K.; ANURAG, R. K. 2016. Plant-based milk alternatives an emerging segment of functional beverages: A review. Journal of Food Science and Technology, v.53. p. 3408-3423, 2016. 
SEXTON, A. E.; GARNETT, T.; LORIMER, J. 2019. Framing the future of food: The contested promises of alternative proteins. Environment and Planning E: Nature and Space, v. 0, p. $1-26$.

SHA, L.; XIONG, Y. L. 2020. Plant protein-based alternatives of reconstructed meat: Science, technology, and challenges. Trends in Food Science \& Technology, v. 102, p. 51 61.

SILVA, A.R.A.; SILVA, M.M.N.; RIBEIRO, B.D.. Health issues and technological aspects of plant-based alternative milk. Food Research International, v. 131, p. 108972, 2020.

SLADE, P. 2018. If you build it, will they eat it? Consumer preferences for plant-based and cultured meat burguers. Appetite, v. 125, p. 428 - 437.

SNOWDON, D.A.; PHILLIPS, R.L. Does a vegetarian diet reduce the occurrence of diabetes?. American journal of public health, v. 75, n. 5, p. 507-512, 1985.

TACO. Tabela brasileira de composição de alimentos. Campinas: NEPA- UNICAMP, 2011. 161 p. Disponível em : https://www.cfn.org.br/wpcontent/uploads/2017/03/taco_4_edicao_ampliada_e_revisada.pdf. Acesso em 20 julho 2020.

TRUSTS, P.C.; HOPKINS, J.. Putting meat on the table: Industrial farm animal production in America. A Report of the Pew commission on industrial Farm Animal Production, 2008. v. 22. p. 112-120, 2011.

VANGA, S. K.; RAGHAVAN, V. 2018. How well do plant based alternatives fare nutritionally compared to cow's milk? Journal of Food Science \& Technology, v. 55. p. 1020, 2018.

VASCONCELOS, I. M.; CAMPELLO, C. C.; OLIVEIRA, J. T. A.; CARVALHO, A. F. E.; SOUZA, D. O. B.; MAIA, F. M. M. 2006. Brazilian soybean Glycine max (L.) Merr. cultivars adapted to low latitude regions: seed composition and content of bioactive proteins. Brazilian Journal of Botany, v.29. p.617-625, 2006.

VISON, J. A.; CAI, Y. 2012. Nuts, especially walnuts, have both antioxidant quantity and efficacy and exhibit significance potential health benefits. Food Funct., v.3,. p.134-140, 2012.

WANG, F.; ZHENG, J.; YANG, B.; JIANG, J., FU, Y.; LI, D.. Effects of vegetarian diets on blood lipids: a systematic review and meta-analysis of randomized controlled trials. Journal of the American Heart Association, v. 4, n. 10, p. e002408, 2015.

WANG, S.; CHELIKANI, V.; SERVENTI, L. 2018. Evaluation of chickpea as alternative to soy in plant-based beverages, fresh and fermented. LWT, v. 97. p. 570-572, 2018.

YAFFE-BELLANY, D. 2020. The new makers of plant-based meat? Big meat companies. Acesso: https://www.nytimes.com/2019/10/14/business/the-new-makers-of-plant-based-meatbig-meat-companies.html/, acesso dia 25, julho, 2020. 


\title{
CAPÍTULO 23: PLANTA BAIXA PADRÃO PARA AGROINDUSTRIALIZAÇÃO DO MEL NO ESTADO DO MARANHÃO COM VISTAS À GERAÇÃO DE RENDA PARA AGRICULTORES FAMILIARES
}

\section{CHAPTER 23: LOW STANDARD PLANT FOR HONEY AGROINDUSTRIALIZATION IN THE STATE OF MARANHÃO WITH VIEWS OF INCOME GENERATION FOR FAMILY FARMERS}

\author{
Alanna Raíssa de Araújo Silva ${ }^{1}$; Celly Sousa Corrêa ${ }^{2}$; Aline Brito Silva ${ }^{3}$; Danilo Cutrim Bezerra ${ }^{4}$; \\ Nancyleni Pinto Chaves Bezerra ${ }^{5}$
}

\begin{abstract}
Resumo
Objetivou-se elaborar uma proposta de planta baixa padrão para agroindustrialização do mel no estado do Maranhão com vistas à geração de renda para agricultores familiares. Para a efetivação do estudo, este foi realizado em duas etapas: (i) pesquisa documental para a caracterização socioeconômica dos agricultores familiares por meio de levantamento de informações na agência de defesa agropecuária do estado; e, (ii) elaboração de planta baixa individual padrão respeitando as normas da engenharia e da produção segura de alimentos, mas, congruentes à situação sócio-econômica da população avaliada. Com a caracterização do perfil socioeconômico obteve-se as seguintes informações: (i) dominância do gênero masculino na atividade; (ii) predominância do ensino fundamental incompleto; (iii) maioria compreendida na faixa etária de 41 a 50 anos; (iv) renda familiar não ultrapassa dois salários; e, (iv) a apicultura não é a principal fonte de renda para as famílias. Com a planta elaborada da unidade de extração e beneficiamento de produtos das abelhas para agroindustrialização de mel concebe-se um quadro de prospecção de evolução local das famílias que resultará em renda, além de contribuir com o desenvolvimento regional e econômico. Com a proposta espera-se que esta se reverta em mudanças positivas do perfil socioeconômico dos agricultores familiares.
\end{abstract}

Palavras-chave: agroindústria familiar, apicultura, desenvolvimento rural.

\begin{abstract}
The objective was to develop a proposal for a standard low plant for agro-industrialization of honey in the state of Maranhão with a view to generating income for family farmers. In order to carry out the study, it was carried out in two stages: (i) documentary research for the socioeconomic characterization of family farmers through information gathering at the state's agricultural defense agency; and, (ii) elaboration of a standard individual floor plan respecting the norms of engineering and safe production of food, but, congruent with the socio-economic situation of the evaluated population. With the characterization of the socioeconomic profile, the following information was obtained: (i) male dominance in the activity; (ii) predominance of incomplete elementary education; (iii) majority comprised in the 41 to 50 age group; (iv) family income does not exceed two salaries; and, (iv) beekeeping is not the main source of

\footnotetext{
${ }^{1}$ Programa de Pós-graduação Profissonal em Defesa Sanitária Anima (Curso de Mestrado), Universidade Estadual do Maranhão, raissaaged@gmail.com

${ }^{2}$ Curso de Medicina Veterinária, Universidade Estadual do Maranhão, cellysousa@gmail.com

${ }^{3}$ Coordenadoria de Inspeção de Produtos de Origem Animal, Agência Estadual de Defesa Agropecuária do Estado do Maranhão, cipaaged@ hotmail.com

${ }^{4}$ Doutor em Biodiversidade e Biotecnologia, Universidade Estadual do Maranhão, danilocbezerra15@gmail.com

${ }^{5}$ Doutora em Biotecnologia, Universidade Estadual do Maranhão, nancylenichaves@hotmail.com
} 
income for families. With the elaborated plant of the unit for the extraction and processing of bee products for agro-industrialization of honey, a framework for prospecting the local evolution of families is conceived that will result in income, in addition to contributing to the regional and economic development of the territory. With the proposal, it is expected that this will result in positive changes in the socioeconomic profile of family farmers.

Keywords: family agribusiness, beekeeping, rural development.

\section{Introdução}

A agricultura familiar (AF) apresenta significativa representatividade no Brasil. O Instituto Brasileiro de Geografia e Estatística (IBGE, 2017), por meio do censo agropecuário realizado no ano de 2016, traduz em números essa representatividade: "dos cinco milhões de estabelecimentos agropecuários do Brasil, o equivalente a $77 \%$ pratica a AF. Esses estabelecimentos ocupam $23 \%$ da área total dos estabelecimentos agropecuários e do valor total da produção nacional. Geram, ainda, 67\% do pessoal ocupado no meio rural brasileiro”.

O Maranhão é um estado com forte potencial agropecuário, apresenta diversidade de produção e possui grande parte de sua comunidade rural que sobrevive dos frutos do trabalho da $\mathrm{AF}$ e fornece alimento para milhares de consumidores. Localizado na Região Nordeste, o Maranhão, é composto por 217 municípios, com características semelhantes no que se refere à divisão fundiária e aos aspectos socioeconômicos em que predomina a pequena propriedade rural de base familiar. A economia, pautada na agropecuária, disponibiliza matérias-primas como frutas, hortaliças, grãos (arroz, feijão e milho), mandioca, ovos, carnes, leite e mel.

A produção de mel pela AF assume grande importância no Maranhão. De acordo com o último censo agroepecuário do IBGE, o Estado produziu no ano de 2016, 1.700 toneladas de mel, ficando atrás somente dos estados da Bahia (3.590 toneladas) e Piauí (3.000 toneladas). No ranking nacional, o Maranhão ocupa a oitava colocação, sendo o estado do Rio Grande do Sul o maior produtor do país (IBGE, 2017).

Contudo, a agroindustrialização do mel por meio das agroindústrias familiares, que apresenta como finalidade agregar valor e renda aos pequenos produtores rurais, ainda, é incipiente no Brasil. Pelos aspectos supracitados que evidenciam a importância da AF para o País e o Maranhão, houve a necessidade dos governos discutirem e implantarem políticas públicas que promovessem a formalização das agroindústrias familiares para que estas aumentem seu mercado de comercialização.

No estado do Maranhão, a agroindústria familiar, foi transformada em Política Pública por meio da Lei Estadual n ${ }^{\circ} 10.086$, de 20 de maio de 2014, que dispõe sobre a habilitação sanitária de estabelecimento agroindustrial familiar, de pequeno porte ou artesanal, para 
elaboração e comercialização de produtos da agroindústria no estado da Maranhão e dá outras providências. A referida lei em seu Artigo $1^{\circ}$ institui: "todo estabelecimento agroindustrial familiar, de pequeno porte ou artesanal, que elabore e comercialize produtos no âmbito do Estado do Maranhão, será habilitado pelo órgão de controle ou de defesa sanitária competente, nos termos desta Lei e de seu regulamento" (MARANHÃO, 2014).

Ainda no âmbito das políticas públicas, no ano de 2014, foi criado na Coordenadoria de Inspeção de Produtos de Origem Animal (CIPA) da Agência Estadual de Defesa Agropecuária do estado do Maranhão (AGED-MA), o setor de Agroindústria Familiar, Pequeno Porte e Artesanal do Serviço de Inspeção Estadual (S.I.E) com a premissa de registrar e fiscalizar as agroindústrias familiares, de pequeno porte e artesanal, gerando emprego e renda ao pequeno produtor rural. O referido setor da AGED-MA constatou no ano de sua criação a inexistência de agroindústrias registradas no SIE.

Face ao panorama apresentado, questões centrais devem integrar as discussões da AF como, a natureza e a sustentabilidade das organizações constituídas, o que perpassa, invarialvelmente, pelo aspecto da qualidade dessas agroindústrias e não, meramente, a quantidade. Ao se reportar às agroindústrias familiares, a implantação destas dependerá de sua formalização. Para isso, são necessários diferentes tipos de registros, como os relativos à questão fiscal e tributária do grupo de agricultores familiares, além dos de ordem sanitária e ambiental. Especificamente sobre a regularização sanitária, esta se refere ao licenciamento sanitário da agroindústria familiar e seus produtos - processo que permitirá a fabricação dos produtos em conformidade com normas sanitárias vigentes e a posterior inserção dos produtos elaborados no mercado, com segurança e qualidade.

Ainda referente à regularização sanitária, existe a necessidade da apresentação de plantas e memoriais que descrevem como será a construção do empreendimento e quais os materiais utilizados, o que representa um gargalo para muitos agricultores familiares pelo custo financeiro e burocrático associado. Nesse contexto, objetivou-se elaborar uma proposta de planta baixa padrão para agroindustrialização do mel no estado do Maranhão com vistas à geração de renda para agricultores familiares.

\section{Material e Métodos}

\section{Tipo do estudo}

Este trabalho é classificado quanto à natureza do método em pesquisa qualitativa e quanto à utilização dos resultados em pesquisa aplicada. Segundo Gerhardt e Silveira (2009), “a pesquisa qualitativa é voltada para a compreensão de um grupo social sem a preocupação 
com representação numérica" e "a pesquisa aplicada leva o conhecimentos para aplicação prática, envolvendo verdades e interesses locais". Quanto aos fins da pesquisa, é do tipo pesquisa descritiva, ou seja, têm como objetivo primordial a descrição das características de determinada população ou fenômeno ou o estabelecimento de relações entre variáveis (GIL, 2008).

\section{População do estudo e levantamento do perfil socioeconômico}

A população de estudo foi composta por apicultores com agroindústrias familiares em processo de registro na CIPA, Setor de Agroindústria Familiar, Pequeno Porte e Artesanal da AGED-MA. O instrumento de coleta das informações foi a pesquisa bibliográfica documental, por meio de levantamento de informações em cadastros do agricultor familiar no setor de inspeção estadual do estado do Maranhão em que foi possível o levantamento das seguintes informações: (i) município de origem; (ii) gênero; (iii) faixa etária; (iv) escolaridade; (v) renda; (vi) tempo na atividade; (vii) apicultura como atividade principal; (vii) participação em ententidade associativa; e, (ix) área da propriedade.

\section{Planta baixa individual padrão}

É importante ressaltar que este trabalho teve parceria com a AGED-MA e a Agência Estadual de Extensão Rural e Pesquisa Agropecuária do Maranhão (AGERP-MA) que trabalham junto aos apicultores, população alvo deste estudo. O Programa de Pós-graduação Profissional em Defesa Sanitária Animal da Universidade Estadual do Maranhão (UEMA), também, foi parceiro na execução da pesquisa.

A planta baixa individual padrão para uma Unidade de Extração e Beneficiamento de Produtos das Abelhas foi elaborado por meio de uma equipe multidisciplinar (fiscais estaduais agropecuários/médicos veterinários, técnicos, engenheiros, arquitetos e graduanda em medicina veterinária) em consonância com a Norma Brasileira (NBR) 13532 de 1995 que trata da elaboração de projetos e edificação (ABNT, 1995); Lei Estadual 10.086/2014 que dispõe sobre a habilitação sanitária de estabelecimento agroindustrial familiar, de pequeno porte ou artesanal (MARANHÃO, 2014); Instrução Normativa $\mathrm{n}^{\circ} 11$, de 20 de outubro de 2000, que aprova o Regulamento Técnico de Identidade e Qualidade do Mel (BRASIL, 2000); e, o Decreto 9.013 de 2017 que aprova o Regulamento de Inspeção Industrial e Sanitária de Origem Animal - RIISPOA (BRASIL, 2017).

A equipe também produziu o memorial econômico-sanitário para a unidade de extração e beneficiamento de produtos das abelhas, além do memorial descritivo que discrimina os materiais a serem utilizados no projeto e uma planilha de equipamentos e 
utensílios necessários para as atividades atinentes ao beneficiamento do mel na agroindústria.

\section{Resultados e Discussão}

Foram lavantadas nove agroindústrias de mel em processo de registro na AGED-MA. Destas, seis $(66,67 \% ; n=6 / 9)$ com processo de formalização vigente ${ }^{4}$; contudo, apenas um proprietário $(11,11 \% ; n=1 / 9)$ entregou o projeto de construção das agroindústrias.

Rosário, Carolina e Maranhãozinho, são os municípios de origem dos agricultores familiares e os locais para futura implantação das agroindústrias familiares de mel. Segundo a regionalização do governo do estado do Maranhão em regiões de planejamento (MARANHÃO, 2008), os referidos municípios estão localizados, respectivamente, nas regiões do Baixo Munim, Chapada da Mesas e Gurupi que apresentam em comum potencialidades para realização da apicultura e meliponicultora.

Marques et al. (2011) destacam que o desenvolvimento da atividade apícola no estado do Maranhão fundamenta-se na existência de vegetação, condições edáficas e climáticas, diversidade de espécies disponíveis nas diferentes situações de habitats que podem proporcionar grande disponibilidade de néctar e pólen. Portanto, a apicultura representa uma possibilidade real de negócio e inclusão social, mesmo para quem dispõe de poucos recursos.

Adicionalmente, a apicultura é uma atividade que não exige dedicação exclusiva, propiciando aos apicultores desenvolverem atividades concomitantes sem prejuízo à criação de abelhas. Isso possibilita ocupação aos membros da família e viabiliza a geração de renda, assegurando a diversificação da produção na pequena propriedade. Segundo Schneider (2010), a combinação de múltiplas ocupações dos agricultores familiares, desenvolvidas no próprio estabelecimento ou fora dele, caracteriza a pluriatividade da agricultura familiar.

Referente às variáveis socioeconômicas, a pesquisa bibliográfica documental permitiu conhecer o perfil dos apicultores com agroindústrias familiares em processo de formalização vigente no estado do Maranhão (Tabela 1).

\footnotetext{
${ }^{4}$ Formalização vigente: caracterizada por movimentação do mesmo com a inclusão de documentos requeridos pelo S.I.E
} 
Tabela 1. Característica socioeconômicas de agricultores familiares com agroindústrias de mel em processo de formalização vigente no órgão de defesa agropecuária do estado do Maranhão, 2020.

\begin{tabular}{|c|c|c|c|}
\hline \multicolumn{2}{|c|}{ Variáveis } & \multirow{2}{*}{$\begin{array}{c}\text { Quantidade } \\
06\end{array}$} & \multirow{3}{*}{$\begin{array}{c}\begin{array}{c}\text { Percentual } \\
(\%)\end{array} \\
100 \\
00\end{array}$} \\
\hline & Masculino & & \\
\hline Gênero & Feminino & 00 & \\
\hline \multirow{3}{*}{ Faixa etária } & $31-40$ & 01 & 16,67 \\
\hline & $41-50$ & 05 & 83,33 \\
\hline & $>50$ & 00 & 00 \\
\hline \multirow{3}{*}{ Escolaridade } & Fundamental incompleto & 06 & 100 \\
\hline & Médio Completo & 00 & 00 \\
\hline & Superior completo & 00 & 00 \\
\hline \multirow{2}{*}{$\begin{array}{l}\text { Renda } \quad \text { (salários } \\
\text { mínimos) }\end{array}$} & Até 2 & 06 & 100 \\
\hline & $>5$ & 00 & 00 \\
\hline \multirow{2}{*}{$\begin{array}{l}\text { Tempo na atividade } \\
\text { de apicultura (anos) }\end{array}$} & 02 a 05 anos & 00 & 00 \\
\hline & $\geq 05$ & 06 & 100 \\
\hline \multirow{2}{*}{$\begin{array}{l}\text { Apicultura como } \\
\text { atividade principal }\end{array}$} & Sim & 00 & 00 \\
\hline & Não & 06 & 100 \\
\hline \multirow{2}{*}{$\begin{array}{l}\text { Participa de alguma } \\
\text { entidade associativa }\end{array}$} & Sim & 06 & 100 \\
\hline & Não & 00 & 00 \\
\hline \multirow{2}{*}{$\begin{array}{l}\text { Área da propriedade } \\
\text { (hectares) }\end{array}$} & 0,5 a 01 & 05 & 83,33 \\
\hline & até 05 & 01 & 16,67 \\
\hline
\end{tabular}

Fonte: Própria (2020).

A partir da obtenção do perfil dos apicultores, pode-se constatar que $100 \%$ destes são profissionais com baixo nível de escolaridade e do gênero masculino e a maioria $(83,33 \%)$ está compreendidos na faixa etária de 41 a 50 anos. Todos trabalham na atividade há pelo menos cinco anos, o que evidencia conhecimento e experiência em relação à apicultura.

A renda dos agricultores familiares é de dois salários mínimos e 100\% destes não tem a apicultura como atividade principal. De posse dessas informações, pode-se enquadrar os referidos agricultores familiares na diversificação da produção como forma de reprodução familiar. Para Silva e Mendes (2015), a diversificação das atividades produtivas é uma importante estratégia de reprodução da $\mathrm{AF}$, pois, não apenas diversifica a variedade de produtos comercializáveis, como também assegura a subsistência da família. E esta pode ser compreendida como forma de resistência ao modelo capitalista que se incorporou no meio rural.

Acerca da discussão sobre a rentabilidade da apicultura para os agricultores familiares avaliados, é importante destacar o papel da Assistência Técnica e Extensão Rural (ATER) no sucesso de qualquer atividade. A ATER é fundamental em qualquer atividade comercial e ao se reportar à assistência técnica rural pode-se inferir que esta é uma atividade essencial para o 
desenvolvimento da AF, sobretudo, no que se refere a inserção e viabilização de novas práticas produtivas.

Quanto ao nível de organização dos agricultores familiares constatou-se que estes estão organizados em associação ou cooperativa o que permite aos mesmos algumas vantagens, como assistência técnica e acesso a linhas de crédito. Para Mumic, Aguiar e Livramento (2015), os pequenos produtores rurais encontram dificuldades na comercialização de seus produtos no meio urbano e encontram nos incentivos e meios que a associação lhes oferecem, oportunidades para se desenvolverem e competirem no mercado.

Os apicultores com agroindústria familiar em processo de registro são produtores com até cinco hectares de área, classificados como empreendimentos da agricultura familiar de acordo com Lei $\mathrm{n}^{\mathrm{o}} 10.086$ de 2014:

"empreendimento de propriedade sob a gestão individual ou coletiva de
agricultores familiares, nos termos do art. $3^{\circ}$ da Lei Federal $\mathrm{n}^{\circ} 11.326$, de 24
de julho de 2006 , com área útil construída não superior a $250 \mathrm{~m}^{2}$ (duzentos e
cinquenta metros quadrados), que, por motivação de natureza econômico e
social, visam agregar valor aos produtos que não conseguem comercializar
"in natura", e dispõem de instalações mínimas conforme critérios definidos
em regulamento (MARANHÃ 2014 ).

Voltando à questão da agroindustrialização, foram contabilizados três apicultores com processo de registro das agroindústrias vencidos e cinco com processos vigentes, porém apenas um apresentou o projeto de construção das agroindústrias. Com a pesquisa bibliográfica documental, não foi possível determinar as causas da não movimentação do processo a mais de dois anos, bem como a não apresentação do projeto de construção. Mas, pode-se pontuar como possíveis gargalos a questão financeira ou burocrática. Nesse interim, para o registro sanitário de agroindústrias familiares são exigidos documentos, entre eles o projeto técnico da construção constituído por planta baixa e memoriais descritivo e econômico-sanitário da construção (plantas de layout de equipamentos, localização, cortes e fachadas e hidráulica), o que representa custo por demandar de profissional habilitado para a execução do mesmo.

No sentido de reduzir as situações de não movimentação de processos de formalização e ao mesmos tempo, fomentar a agroindustrialização de mel oriundo da AF no Maranhão, elaborou-se uma proposta de planta baixa individual padrão já aprovada no órgão de defesa e inspeção do Maranhão que será disponibilizada aos agricultores familiares que manifestarem interesse e, assim, facilitar a tramitação dos processos de registro. 
A planta padrão elaborada refere-se à construção de uma Unidade de Extração e Beneficiamento de Produtos das Abelhas ${ }^{5}$ em consonância com o Decreto n ${ }^{\circ}$ 9.013, de 29 de março de 2017, respeitando as normas da construção civil (engenharia) e da produção segura de alimentos, mas, congruentes à situação sócio-econômica dos agricultores familiares (Figura 1).

Figura 1. Modelo de fachada com nome de fantasia de uma unidade de extração e beneficiamento de produtos das abelhas para agroindustrialização de mel oriundo da agricultura familiar no estado do Maranhão.

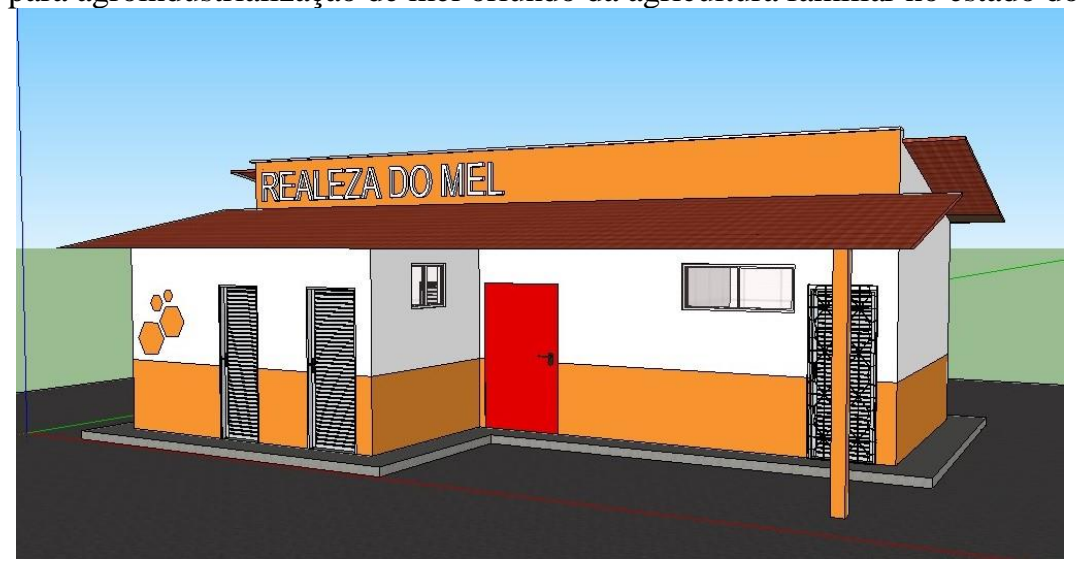

Fonte: Própria (2020).

Na planta padrão da Unidade de Extração e Beneficiamento de Produtos das Abelhas constam instalações adequadas, respeitando o layout de produção que indica por onde entrará a matéria-prima e o caminho que a mesma percorrerá no interior das instalações até ser expedida como mel centrifugado, decantado e envasado em garrafas plásticas de 280 gramas (produto final) (Figura 2). A capacidade de beneficiamento mensal da agroindústria será de 2,8 toneladas. Este será proveniente de unidade familiar de apicultores em que trabalharão até cinco agricultores familiares.

${ }^{5}$ Unidade de Extração e Beneficiamento de Produtos das Abelhas: estabelecimento destinado ao recebimento de matérias-primas de produtores rurais, à extração, ao acondicionamento, à rotulagem, à armazenagem e à expedição dos produtos de abelhas, facultando-se o beneficiamento e o fracionamento (BRASIL, 2017). 
Figura 2. Planta padrão de unidade de extração e beneficiamento de produtos das abelhas para agroindustrialização de mel oriundo da agricultura familiar no estado do Maranhão.

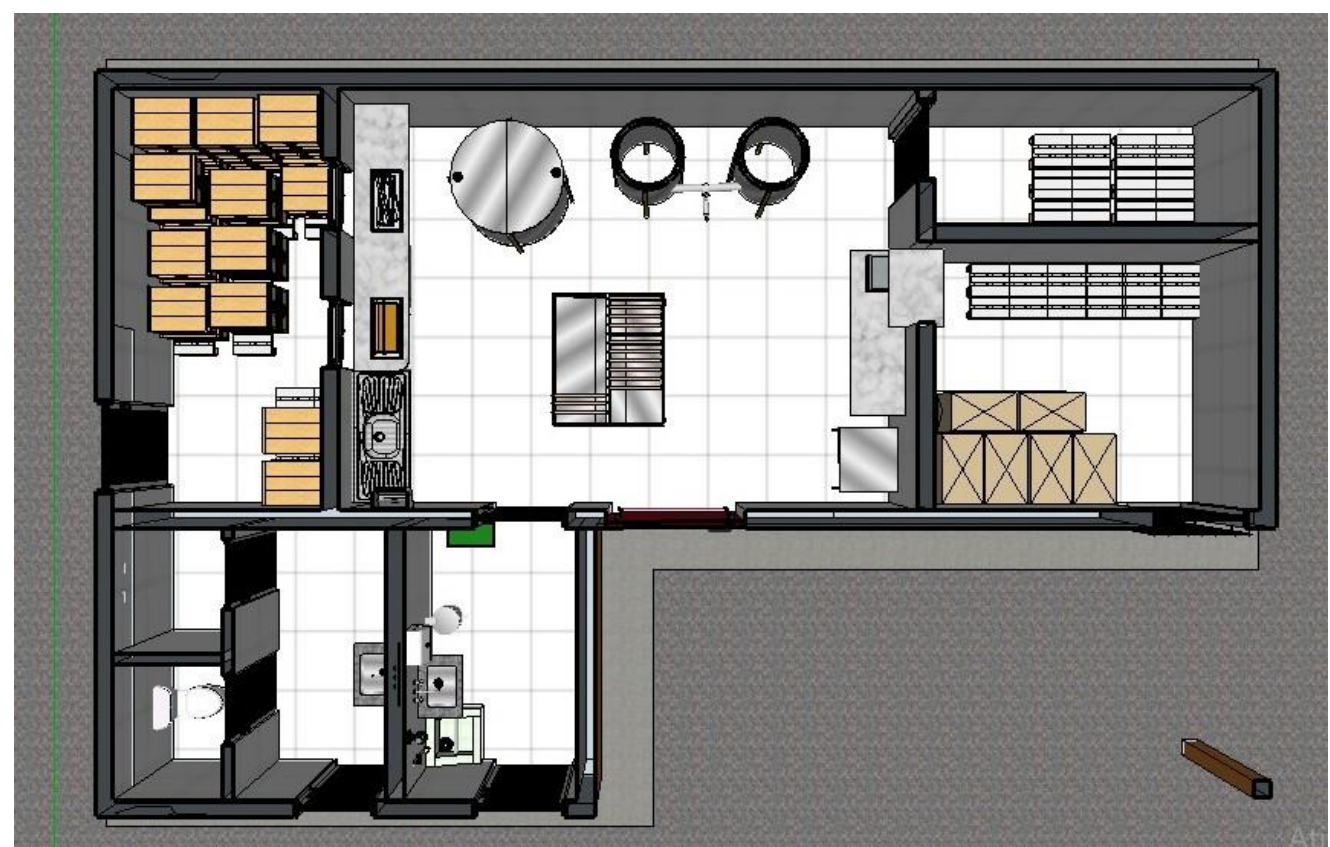

Fonte: Própria (2020).

O local para recepção da matéria-prima, com $6,64 \mathrm{~m}^{2}$ de área, tem capacidade para recebimento e armazenamento de 27 melgueiras. A recepção situa-se no interior da agroindústria e será coberta, o que minimizará o acesso de vetores, animais sinantrópicos e poeira. Dessa área, os quadros serão retirados das melgueiras e passarão para a sala de extração por meio de um óculo. Nessa sala, com área útil de $18,50 \mathrm{~m}^{2}$, os quadros serão desoperculados em mesa desoperculadora e na sequência o mel será colocado na centrífuga. Após essa etapa, será filtrado com o auxílio de uma peneira que estará sobre um balde de material inoxidável ou de material plástico resistente e atóxico com capacidade de $25 \mathrm{Kg}$.

O mel armazenado no balde será conduzido para decantadores e permanecerá neste, por no mínimo 48 horas, em seguida será colocado na maquina envasadora por meio de balde para posterior envase em embalagem primária (garrafas plásticas de 280 gramas). Logo após, o mel embalado e rotulado, será colocado em embalagens secundárias (caixas de papelão) e passará por meio de um ocúlo para uma área com $6,49 \mathrm{~m}^{2}$, denominada área de armazenamento e expedição em que será mantido sobre estrados de polipropileno até a expedição. O mel embalado será transportado em caminhonete para ser comercializado no mercado local e regiões circunvizinhas dentro do estado.

Na planta padrão consta ainda um depósito de embalagens com área de 3,41 $\mathrm{m}^{2}$ para o acondicionamento de embalagens e um vestiário e banheiro com área de $5,02 \mathrm{~m}^{2}$. Atenção singular foi dispensada à segurança com a existência de bloqueio sanitário, composto de lava 
botas, tapete sanitário, lavatório de mãos, dispensador de sabão líquido, papel toalha e lixeira com tampa com acionamento pedal, e uma saída de emergência e disposição de extintores de incêndio.

Será disponibilizado aos agricultores familiares o memorial econômico-sanitário e alguns dos aspectos constantes nesse documento são sumarizados abaixo:

- Fonte de abastecimento de água: a unidade de extração e beneficiamento de produtos das abelhas será abastecido por água potável. Da fonte de abastecimento, a água será captada e distribuída por rede; será clorada por meio da instalação de bomba dosadora na entrada da caixa. Então, será armazenada em caixa d'água com capacidade para 1.000 litros que compreenderá o reservatório da agroindústria.

- Fiscalizações sanitárias: As fiscalizações na agroindústria serão periódicas e não haverá sala destinada ao serviço de inspeção oficial. Planilhas de controle e formulários serão mantidos na Unidade Local de Sanidade Animal e Vegetal a qual o estabelecimento estará vinculado.

- Destino das águas servidas: A instalação hidráulica será completa e pronta para ser instalada na sua rede de esgoto e ser alimentada por um ponto hidráulico. O setor administrativo terá esgotamento sanitário separado do esgoto industrial, sendo que o sistema de esgoto será composto de fossa séptica para água proveniente da área administrativa e uma estação de tratamento de esgoto (ETE) para área de produção conforme projeto sanitário.

Será disponibilizado aos agricultores familiares o memorial descritivo que sumariza os materiais a serem utilizados no projeto (Tabela 2). Estes foram escolhidos, essencialmente, com vistas a não transmissão de substâncias indesejáveis à matéria-prima e ao produto acabado e, nas áreas de manipulação, ponderou-se para as condições higiênico-sanitárias das paredes, pisos, teto, portas e janelas que, de maneira geral, serão impermeáveis e laváveis, e planejadas no sentido de minimizar o acúmulo de sujeira e condensação de água.

$\mathrm{O}$ custo total da obra é de $\mathrm{R} \$$ 82.274,16 valor considerado baixo para um estabelecimento elaborador de alimentos, mas, adequado às exigências sanitárias e pautado, sobretudo, na questão sócio-econômica da população amostrada. 
Tabela 2. Memorial descritivo de unidade de extração e beneficiamento de produtos das abelhas para agroindustrialização de mel oriundo da agricultura familiar no estado do Maranhão.

\begin{tabular}{ll}
\hline \multicolumn{1}{c}{ Dados da Obra } & \multicolumn{1}{c}{ Especificações } \\
\hline Clientes & Agricultores familiares de mel \\
Natureza do estabelecimento & Unidade de extração e beneficiamento de produtos das \\
abelhas \\
Área a ser construída & $50,97 \mathrm{~m}^{2}$ \\
Área útil & $44,32 \mathrm{~m}^{2}$ \\
Recuo do alinhamento da rua & $5,0 \mathrm{~m}$ \\
Duração provável da obra & 90 dias \\
Pé direito das áreas limpa e suja & $3,50 \mathrm{~m}$ \\
Área coberta & $103,00 \mathrm{~m}^{2}$ \\
Madeiramento e cobertura & Cobertura em telha tipo chapa ondulada com estrutura de \\
& madeira \\
Forro & Policloreto de vinila \\
Portas & Alumínio \\
Óculos & Alumínio \\
& Revestimento interno cerâmica branca \\
Revestimento geral & Paredes até $2,00 \mathrm{~m}$ de cerâmica branca e o restante de \\
& reboco liso com argamassa de cimento e areia na \\
Pavimentação externa & proporção de $1: 5$ \\
Esquadrias & Blocos de concreto intertravado de 10 cm de espessura \\
Impermeabiliação & Janelas de alumínio e vidro de correr \\
Instalação d'água & Feita com polímetros \\
Sistema de esgoto & Tubos de policloreto de vinilo (PVC), com caixa d'água \\
Pintura geral & elevada de 1.000 litros \\
Custo provável da obra & Ligado a fossas sépticas , sumidouros \\
\hline
\end{tabular}
Fonte: Própria (2020).

De igual forma será disponibilizada aos agricultores familiares planilha de equipamentos, conforme sumarizado na Tabela 3. O custo com os equipamentos será de $\mathrm{R} \$$ 20.297,85, o que resultará em valor total da unidade de extração e beneficiamento de produtos das abelhas no valor de $\mathrm{R} \$ 102.572,01$ (obra + equipamentos). Em referência aos equipamentos a serem utilizados na agroindustrialização do mel, estes serão de material resistente, não absorvente e não corrosivo, no sentido de evitar que odores, sabores e substâncias tóxicas sejam transmitidas à matéria-prima e ao produto acabado, seja por contato direto ou indireto. 
Tabela 3. Relação de equipamentos e utensílios para a unidade de extração e beneficiamento de produtos das abelhas para agroindustrialização de mel oriundo da agricultura familiar no estado do Maranhão.

\begin{tabular}{lcc}
\multicolumn{1}{c}{$\begin{array}{c}\text { Equipamentos e } \\
\text { Utensílios }\end{array}$} & Quantidade & Valor (R\$) \\
\hline Centrífuga para 64 & 01 & $6.000,00$ \\
quadros & 02 & 240,00 \\
Peneira inox & 02 & 46,00 \\
Baldes plásticos atóxicos & 04 & 200,00 \\
Bandejas Polietileno & 01 & $3.200,00$ \\
Mesa desoperculadora & 02 & $2.900,00$ \\
para 64 quadros & 01 & $5.000,00$ \\
Decantador de 400kg & 01 & 579,00 \\
Envasadora & 01 & 350,00 \\
Armário para embalagem & 01 & 97,85 \\
Armário para utensílios & 05 & 125,00 \\
Armário para produtos de & 26 & $1.560,00$ \\
limpeza & & $\mathbf{2 0 . 2 9 7 , 8 5}$ \\
Garfo desoperculador & & \\
Paletes plásticos & \multicolumn{1}{c}{ Total } &
\end{tabular}

Fonte: Própria (2020).

Nesse ponto da discussão é oportuno enfatizar que a agroindústria familiar é uma estratégia de reprodução social importante para as famílias rurais de um local, área ou território, sobretudo, referente aos aspectos econômico, social e produtivo. Do ponto de vista econômico e produtivo esta atividade é sinônimo de geração de renda, empregos e divisas para o local e os agricultores familiares que a praticam e ajudar a evitar o exôdo rural. Portanto, a agroindústria cumpre um importantíssimo papel social, ou seja, mantém o homem no meio rural trabalhando, produzindo e vivendo com a sua família.

\section{Conclusões}

Os apicultores com agroindústria de mel em processo de registro no estado do Maranhão apresentam o seguinte perfil socioeconômico: gênero masculino, nível educacional baixo, longa experiência com a atividade produtiva, apesar desta não configurar como atividade principal na propriedades rural, estando de alguma forma organizados em associações ou cooperativas. Com a planta individual padrão da unidade de extração e beneficiamento de produtos das abelhas para agroindustrialização de mel concebe-se um quadro de prospecção da evolução de desenvolvimento local das famílias com a agroindustrialição do mel que resultará em renda, além de contribuir com o desenvolvimento regional e econômico do território, bases fundamentais da agricultura familiar. Com a 
proposta espera-se que esta se reverta em mudanças positivas do perfil socioeconômico dos agricultores familiares.

\section{Referências}

ASSOCIAÇÃO BRASILEIRA DE NORMAS TÉCNICAS. NBR 13532. Elaboração de projetos de edificações - Arquitetura. 1995. Disponível em: https://www2.unifap.br/arquitetura/files/2013/01/NBR-13532-Projeto-de-Arquitetura-.pdf. Acesso em: 02 jun 2020.

BRASIL. Ministério da Agricultura, Pecuaria e Abastecimento. Instrução Normativa $n^{\circ} 11$, de 20 de outubro de 2000. Aprova o Regulamento Técnico de Identidade e Qualidade do Mel. Diário Oficial [da] República Federativa do Brasil, Brasília, DF, 23 de outubro de 2000. Disponível em: http://www.dourados.ms.gov.br/wp-content/uploads/2016/05/RTIQ-Melcompleto-IN-11_2000.pdf. Acesso em: 02 jun 2020.

BRASIL. Presidência da República. Decreto n ${ }^{\circ} 9.013$ de 29 de março de 2017. Regulamenta a Lei $\mathrm{n}^{\circ} 1.283$, de 18 de dezembro de 1950 , e a Lei $\mathrm{n}^{\circ} 7.889$ de 23 de novembro de 1989 que dispõe sobre a inspeção industrial e sanitária de produtos de origem animal. Diário Oficial [da] República Federativa do Brasil, Brasília, DF, 29 de março de 2017. Disponível em: http://www.planalto.gov.br/ccivil_03/_ato2015-2018/2017/decreto/D9013.htm. Acesso em: 02 jun 2020.

GERHARDT, T. E.; SILVEIRA, D. T. (org). Métodos de Pesquisa. Porto Alegre: Editora da UFRGS, 2009.

GIL, A. C. Métodos e técnicas de pesquisa social. São Paulo: Atlas, 2008. 220p.

INSTITUTO BRASILEIRO DE GEOGRAFIA E ESTATÍSTICA. 2017. Censo Agroepecuário. Disponível em: https://censos.ibge.gov.br/agro/2017/resultados-censo-agro2017.html. Acesso em: 02 jun 2020.

MARANHÃO. Governo do Estado do Maranhão. Secretaria de Estado do Planejamento e Orçamento. Regiões de Planejamento do Estado do Maranhão. Instituto Maranhense deEstudos Socioeconômicos e Cartográficos, Universidade Estadual do Maranhão .São Luís: SEPLAN, 2008. 103 p.

MARANHÃO. Governo do Estado do Maranhão. Lei no 10.086, de 20 de maio de 2014. Dispõe sobre a habilitação sanitária de estabelecimento agroindustrial familiar, de pequeno porte ou artesanal, para elaboração e comercialização de produtos da agroindústria no Estado da Maranhão e dá outras providências. Diário Oficial [do] Estado do Maranhão, São Luís, MA, 20 de maio de 2017. Disponível em: http://www.aged.ma.gov.br/files/2017/06/LEI10.086-AGROINDUSTRIA-FAMILIAR.pdf Acesso em: 02 jun 2020.

MARQUES Jr., L. et al. Levantamento da flora apícola em Santa Luzia do Paruá. Sudoeste da Amazônia, Maranhão. Acta Botanica Brasilica, v. 25, n. 1, p.141-149. 2011.

MUMIC, B.; AGUIAR, K. A. P.; LIVRAMENTO, D. E. do. A importância do associativismo na organização de produtores rurais. Revista de Iniciação Científica da LIBERTAS, v. 5, n. 1, p. 5-22, 2015. 
SCHNEIDER, S. A. A pluriatividade na agricultura familiar, 2.ed. Porto Alegre: Editora da UFRGS, 2010.

SILVA, J. M.; MENDES, E. P. P. Agricultores familiares e reprodução social: as comunidades Cruzeiros dos Martírios e Paulistas no município de Catalão (GO). In: NEVES, A.F. et al. (orgs.). Coletânea Interdisciplinar em Pesquisa, Pós-Graduação e Inovação. v 1. [livro eletrônico]. São Paulo: Blucher, 2015. 


\title{
CAPÍTULO 24: QUALIDADE DE OVOS DE GALINHA SUBMETIDOS A DIFERENTES CONDIÇÕES DE ARMAZENAMENTO E TEMPO DE ESTOCAGEM UTILIZANDO IMAGEM TÉRMICA EM NOVA ANDRADINA/MS
}

\author{
CHAPTER 24: QUALITY OF CHICKEN EGGS SUBMITTED TO DIFFERENT \\ STORAGE CONDITIONS AND STORAGE TIME USING THERMAL IMAGE IN \\ NOVA ANDRADINA/MS
}

\author{
Grazieli Suszek ${ }^{1}$; Walter Patris Freire Decleva ${ }^{2}$; Andressa Martins da Nobrega ${ }^{3}$; Ana Flávia Basso \\ Royer ${ }^{4}$ Mauro de Lima ${ }^{5}$
}

\section{Resumo}

O ovo sempre foi um alimento com alta taxa de consumo no Brasil, principalmente por ser nutricionalmente completo, possuir grande quantidade de proteína e ter um custo relativamente baixo. O presente trabalho tem como objetivo avaliar a qualidade dos ovos de poedeiras de 60 semanas da linhagem Embrapa 51 (casca marrom), sistema de criação comercial em gaiola, sob duas condições de armazenamento (temperatura não controlada e refrigerado) e em diferentes tempos de estocagem (frescos, 7, 14 e 21 dias), utilizando imagens térmicas. O experimento foi desenvolvido no IFMS campus de Nova Andradina, foram utilizados ovos de aves da linhagem Embrapa 51 presentes em um galpão para aves de postura em ambiente não controlado. Foram coletados dados de qualidade interna e externa dos ovos e obtida imagem térmica com auxilio de uma câmera Flier®. Verificou-se a existência de interdependência entre os fatores temperatura de conservação x período de estocagem dos ovos. Pelas imagens térmicas foi possivel observar que ovos refrigerados mantêm melhor estrutura, contribuído para um ovo de melhor qualidade, assim a utilização de imagem é capaz de mensurar parâmetros para análise de ovos de forma não destrutiva.

Palavras-Chave : Flier,Temperatura, Qualidade

\begin{abstract}
The egg has always been a food with a high consumption rate in Brazil, mainly because it is nutritionally complete, has a large amount of protein and has a relatively low cost. The present work aims to evaluate the quality of the 60-week-old laying eggs of the Embrapa 51 line (brown shell), a commercial breeding system in a cage, under two storage conditions (uncontrolled and refrigerated temperature) and at different storage times. (fresh, 7, 14 and 21 days), using thermal images. The experiment was carried out on the IFMS campus of Nova Andradina, using eggs from birds of the Embrapa 51 line present in a shed for laying birds in an uncontrolled environment. Internal and external quality data of the eggs were collected and thermal image was obtained with the aid of a Flier ${ }^{\circledR}$ camera. It was verified the existence of interdependence between the factors temperature of conservation $\mathrm{x}$ period of storage of eggs. Through the thermal images it was possible to observe that refrigerated eggs maintain better structure, contributing to a better quality egg, so the use of image is able to measure parameters for egg analysis in a non-destructive way.
\end{abstract}

\footnotetext{
${ }^{1}$ Engenheiro Agrícola, Professor, Instituto Federal do Mato Grosso do Sul, grazieli.suszek@ifms.edu..br

2 Agronomia, Instituto Federal do Mato Grosso do Sul, walter.decleva@estudante.ifms.edu..br

${ }^{3}$ Veterinária, Universidade Estadual de Maringá, andressanobrega@live.com

${ }^{4}$ Zootecnista, Professor, Instituto Federal do Mato Grosso do Sul, ana.royer@ifms.edu..br

${ }^{5}$ Engenheiro Agrícola, Professor, Instituto Federal do Mato Grosso do Sul, mauro.lima@ifms.edu..br
} 
Keywords: Thermal images, Destructive, Temperature, Quality

\section{Introdução}

O ovo sempre foi um alimento com alta taxa de consumo no Brasil, principalmente por ser nutricionalmente completo, possuir grande quantidade de proteína e ter um custo relativamente baixo. A refrigeração não é obrigatória no Brasil, assim os ovos comerciais são acondicionados, desde o momento da postura até a distribuição final, em temperaturas não controladas, sendo, em alguns casos, refrigerados apenas nas casas dos consumidores. MENDES (2010) explica que a qualidade dos ovos de consumo inclui um conjunto de características que define a aceitabilidade do produto pelos consumidores, sendo determinada por diversos aspectos externos e internos. Os aspectos externos referentes à qualidade do ovo estão relacionados à qualidade da casca, ao considerar sua estrutura e higiene. Ainda afirma que os aspectos internos consideram características relativas ao albúmen, gema, câmara de ar, cor, odor, sabor e manchas de sangue, determinadas somente após a quebra do ovo.

Uma das medidas mais utilizadas para avaliação da qualidade dos ovos é a Unidade Haugh (UH), que apesar das críticas a respeito da unidade, possui grande importância na avicultura de postura (ALLEONI e ANTUNES, 2001).

Esse método é uma expressão matemática que correlaciona a altura do albúmen espesso, obtida através de micrômetro tripé, corrigida para o peso do ovo. Sendo que, quanto maior o valor da UH melhor a qualidade do ovo, pois à medida que ele envelhece a proporção de albumina líquida aumenta em detrimento da densidade. A perda de gás carbônico resulta em uma alteração no sabor do ovo em decorrência do aumento da alcalinidade, além das inúmeras reações químicas que ocorrem no seu interior, envolvendo o ácido carbônico (H2CO3,) (MORENG e AVENS, 1990).

SOUZA et al. (2001) destacam que em ovos sob condições de temperatura ambiente, são afetadas negativamente as características físicas da casca, albúmen e gema, bem como a qualidade interna do ovo como um todo. De acordo com o Programa de Controle da Qualidade preconizado pelo Departamento de Agricultura Americano, ovos considerados de qualidade excelente devem apresentar valores de UH acima de 72; ovos de qualidade alta, entre 60 e 72 UH (Egg..., 2000). Além disso, autores como SCOTT \& SILVERSIDES (2000) e ALLEONI E ANTUNES (2001) argumentam que com a estocagem dos ovos, ocorre aumento do pH e diminuição da altura do albúmen (AA), com consequente 5 diminuições 
dos valores de UH. Ocorre também perda de peso do albúmen, que resulta em diminuição do peso do ovo.

Esses fatos foram observados por JONES et al. (2002) em sua pesquisa, na qual constataram que para a manutenção da alta qualidade dos ovos o tempo e a temperatura são fatores importantes que devem ser controlados durante o período de armazenamento, corroborando com os resultados obtidos por VÉRAS et al. (1999) e BARBOSA et al. (2004) que constataram que o peso dos ovos e as unidades Haugh foram alterados em função do tempo e do ambiente de armazenamento.

SANTOS et al. (2009) também estudaram o efeito da temperatura e estocagem em ovos e concluíram que o aumento do período de estocagem, independente da temperatura de conservação, ocasionou perda de peso dos ovos e reduções na gravidade específica, nas unidades Haugh e na coloração da gema crua. Os ovos mantidos em temperatura de refrigeração apresentaram menor perda de peso e melhores índices de porcentagem de clara, gravidade específica, unidades Haugh e coloração da gema crua, quando comparados aos ovos conservados em temperatura não controlada.

Em se tratando de qualidade, LEANDRO et al. (2005) comentaram que a redução da qualidade interna dos ovos está associada, principalmente, à perda de água e de dióxido de carbono, durante o período de estocagem. Esta perda é proporcional à elevação da temperatura do ambiente, pois acelera as reações físico-químicas levando à degradação da estrutura da proteína presente na albumina espessa, tendo como produto das reações a água ligada às grandes moléculas de proteínas que passam para a gema por osmose. Neste contexto a busca por forma de análises não destrutivas que possibilitam o monitoramento de parâmetros que permitem avaliar a qualidade do ovo torna-se importante para o setor produtivo.

Assim a termografia é uma técnica que permite o registro do campo de temperaturas de uma cena focalizada, através da medição da energia radiante infravermelha emitida pelos objetos do campo de visão da câmera termográfica. Logo, com a utilização de câmera térmica é possível visualizar e analisar como a temperatura e o tempo de armazenamento influenciam na qualidade dos ovos.

\section{Material e Métodos}

O experimento foi desenvolvido em laboratório com ovos de aves da linhagem Embrapa 51 acondicionadas em um galpão para aves de postura pertencente ao Instituto Federal de Mato Grosso do Sul, câmpus Nova Andradina. 
Estudou-se o efeito isolado e a interação de dois fatores: temperatura de conservação (temperatura não controlada e de refrigeração) e período de estocagem (fresco, 7, 14 e 21 dias) resultando no fatorial $2 \times 3$, o que correspondeu a 6 combinações de temperatura $\times$ período de estocagem com 4 repetições de 4 ovos/cada em que cada ovo representou uma unidade experimental. Os dados observados foram avaliados mediante análise de variância com o auxílio do programa estatístico SISVAR e as médias, quando significativas, foram submetidas à comparação ao teste de Tukey a 5\% de significância. Os ovos foram coletados no período da tarde, identificados e armazenados à temperatura não controlada, entre 24 a $36^{\circ} \mathrm{C}$, e em ambiente refrigerado entre 5 a $8^{\circ} \mathrm{C}$.

As imagens térmicas foram obtidas com uma câmera térmica Flir one®pro lightning, com precisão de +2 oC, resolução térmica de 120 x 160 pixels e com faixa de temperatura de -20 oC a +400 oC. Para isso a câmera foi posicionada a $15 \mathrm{~cm}$ do alvo, colocado em local plano e iluminado naturalmente, conforme mostrado na Figura 1.

Figura 1: Imagem térmica.

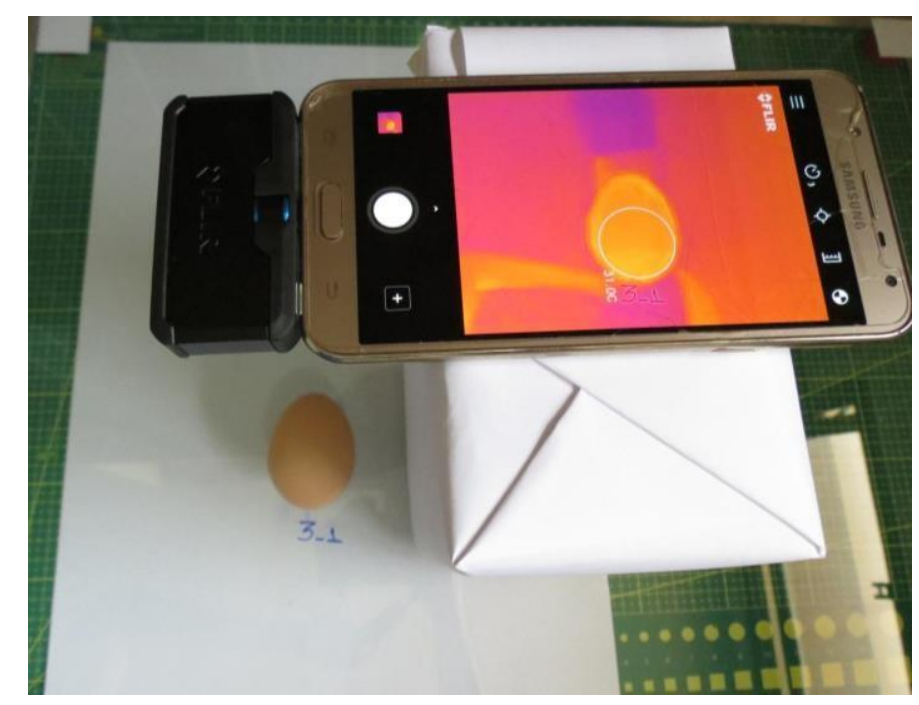

Fonte: Própria (2020)

As imagens foram processadas utilizando software de processamento de imagens Flir Tools®, sendo avaliados quanto a diferença de temperatura e investigada a anatomia do ovo, conforme Figura 2.

Na Figura 2 apresenta-se a anatomia do ovo, com suas estruturas externas e internas. Conforme a Figura 2 em destaque, as membranas dividem-se em interna e externa e é composta por uma rede de fibras protéicas que envolvem o albúmen e a câmara de ar no pólo maior do ovo, onde as membranas encontram-se separadas, sendo importante para manutenção do ovo. 
Figura 2: Anatomia de um ovo

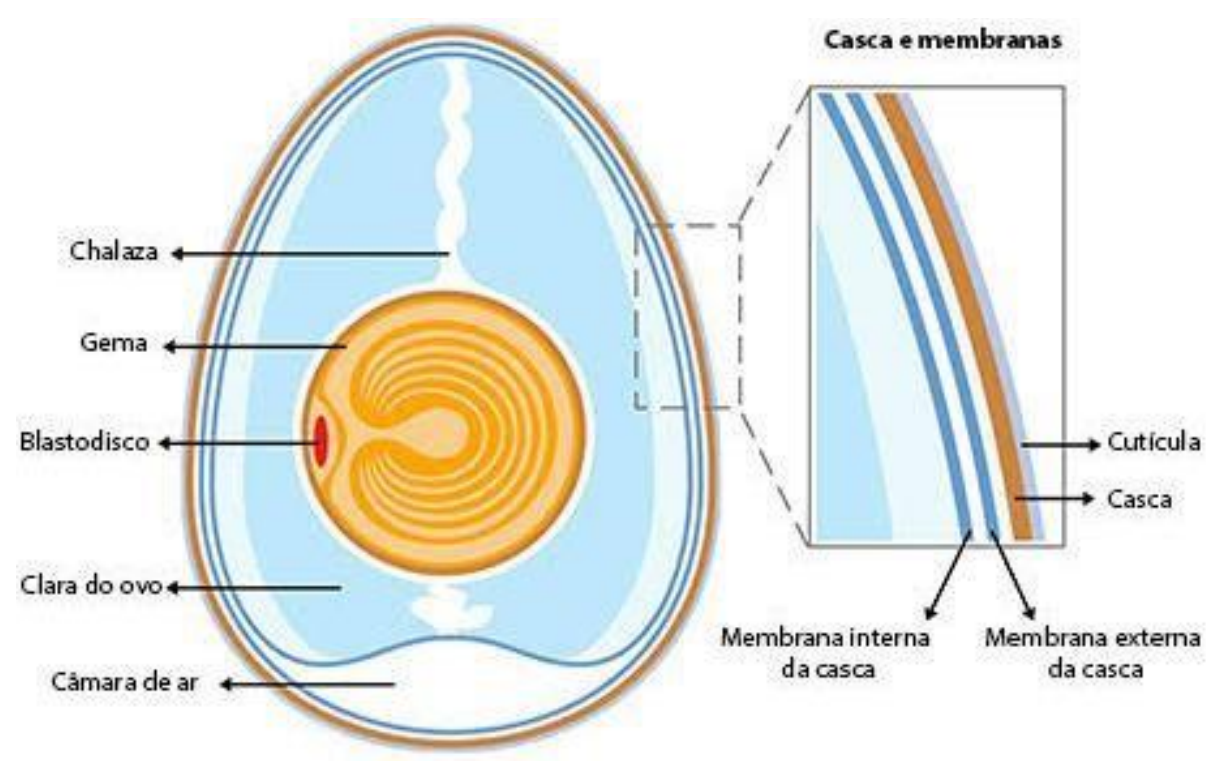

Fonte: Horst (2007)

A perda de peso dos ovos (\%), seguiu a metodologia proposta por BARBOSA et al., (2004), onde os ovos foram pesados no primeiro dia do período experimental e armazenados. Ao final do período experimental, os ovos de cada tratamento foram novamente pesados e pela diferença entre o peso no início e no final do tempo de armazenagem, mensurou-se a perda de peso em gramas de 6 amostras. Este valor foi dividido pelo peso do ovo no início do armazenamento e multiplicado por cem, gerando os dados de perda de peso em porcentagem.

As variáveis avaliadas foram perda de peso dos ovos (\%) e as características relativas à qualidade interna e externa dos ovos, sendo as externas: tamanho (Figuras 3 e 4) e peso (Figura 5) e de acordo com JARDIM filho et al., (2008) variáveis internas: Unidade Haugh, porcentagem de gema, porcentagem de albúmen e espessura de casca. 
Figura 3: Determinação do diâmetro do ovo.

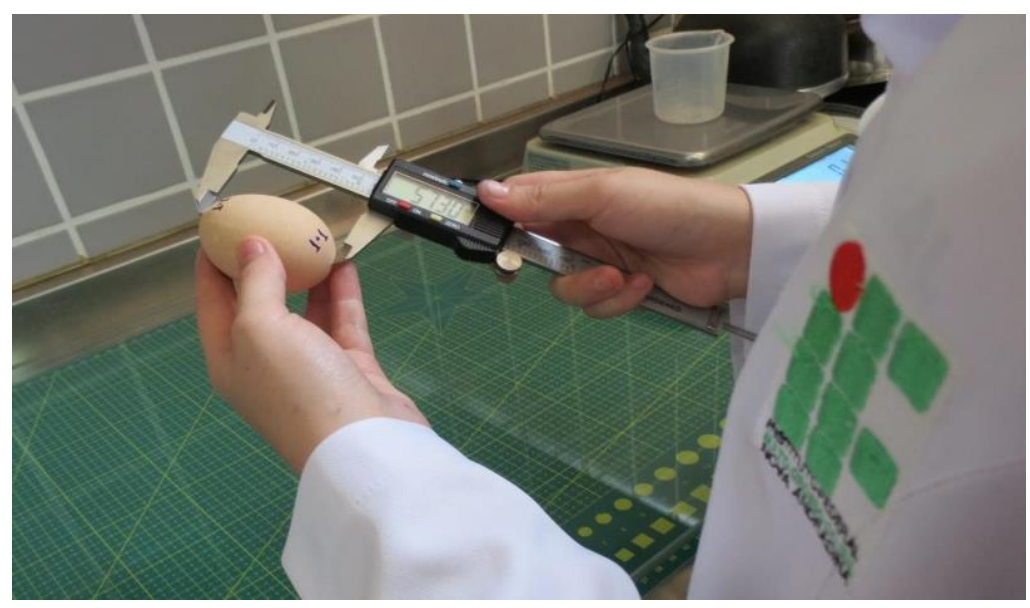

Fonte: Própria (2020)

Figura 4: Tamanho do ovo.

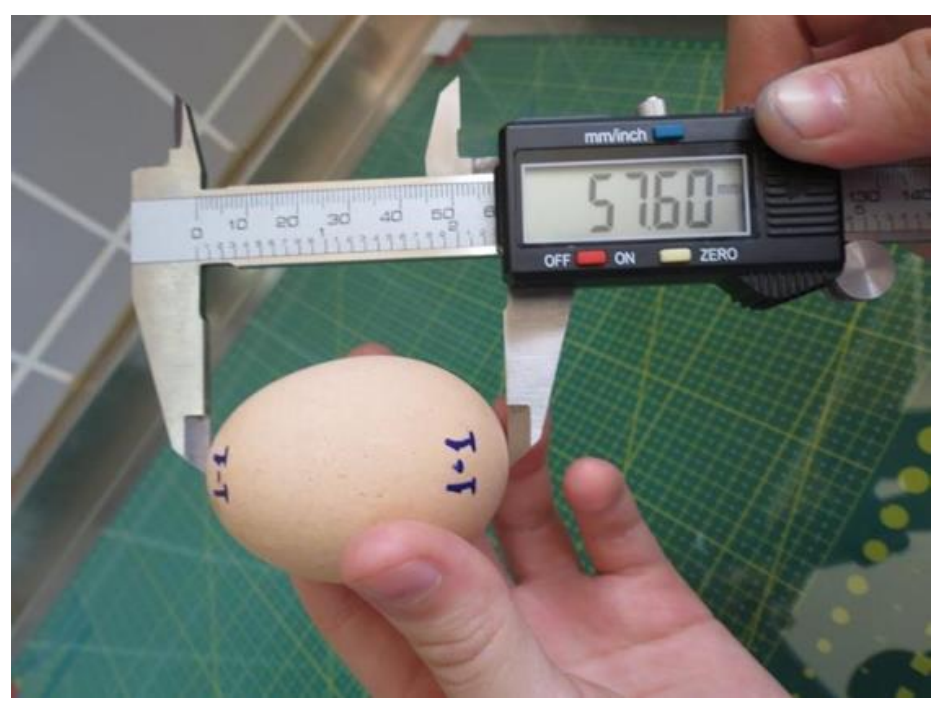

Fonte: Própria (2020)

Figura 5: Pesagem do ovo

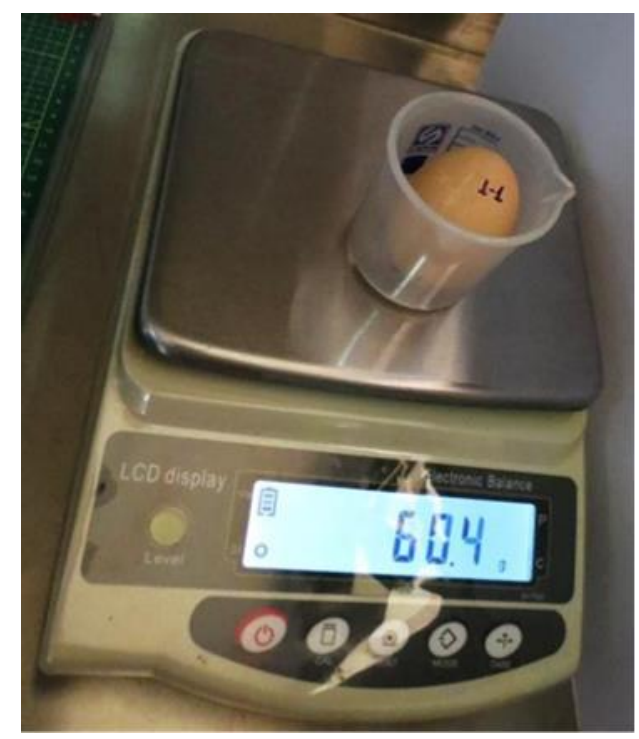

Fonte: Própria (2020) 
Para a determinação da Unidade Haugh os ovos foram quebrados sobre uma superfície plana de vidro (Figura 6) para a obtenção da altura e diâmetro de albúmen e da altura, diâmetro e peso de gema com uso de micrômetro e balança digital (Figuras 7, 8, 9, 10 e 11). A porcentagem de albúmen foi determinada por diferença: 100 - (\% de gema $+\%$ de casca $)$.

Figura 6: Ovo sobre superfície de vidro

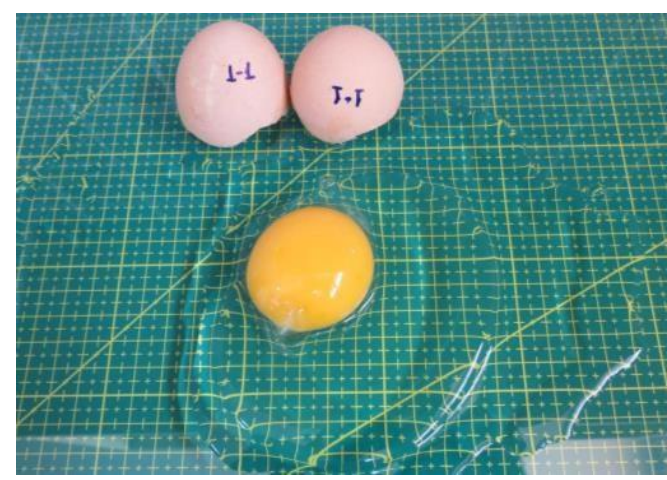

Figura 8: Diâmetro de albúmen.

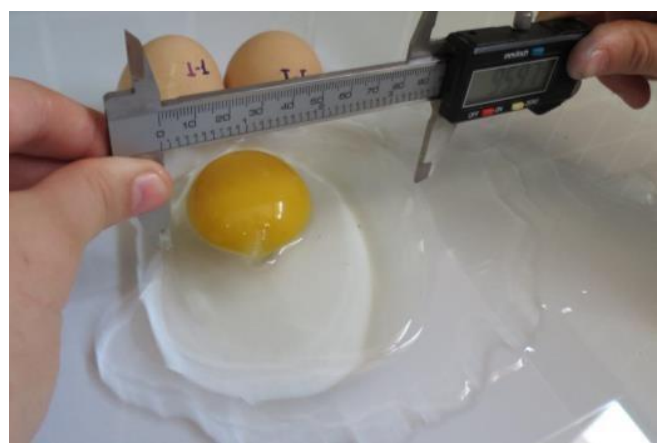

Figura 10: Diâmetro de gema.

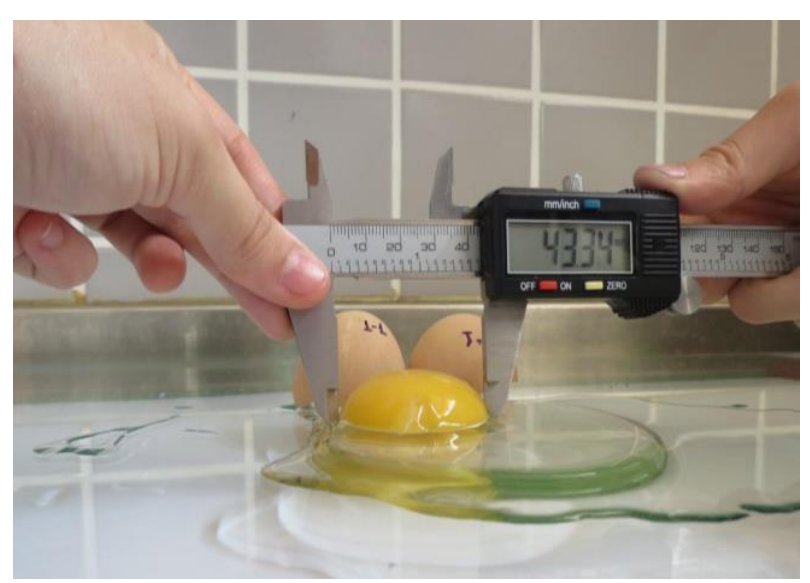

Figura 7: Altura de albúmen.

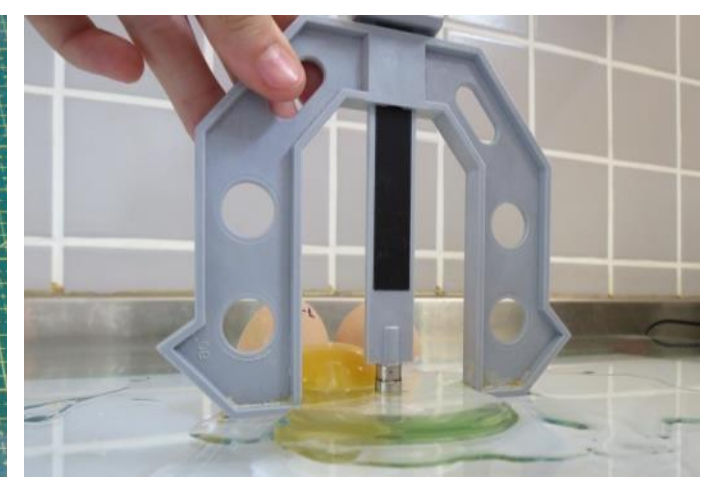

Figura 9: Altura de gema.

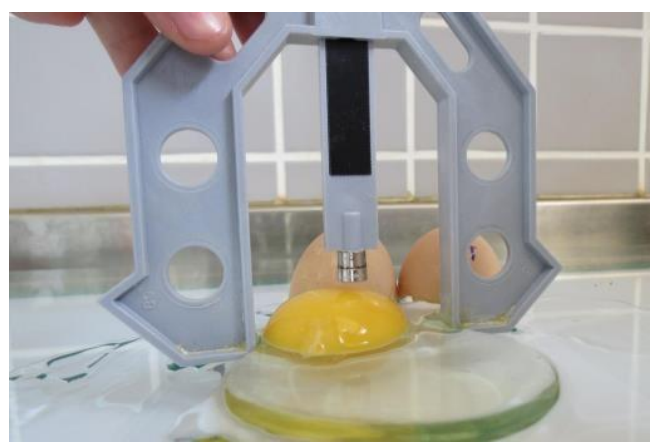

Figura 11: Peso de gema.

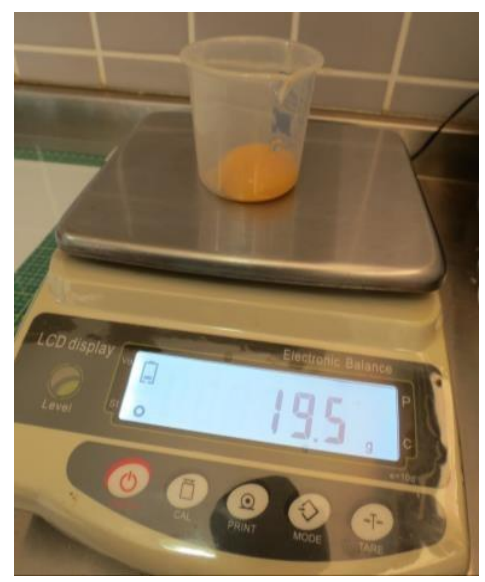

Fonte: Própria (2020)

As cascas resultantes dessa quebra foram lavadas e secas em temperatura ambiente e depois pesadas para o cálculo da porcentagem de casca (Figura 12).

Posteriormente, foram determinadas suas espessuras com medidas em três pontos distintos da região mediana, sendo utilizado micrômetro digital (Figura 13). 
Figura 12: Peso de casca.

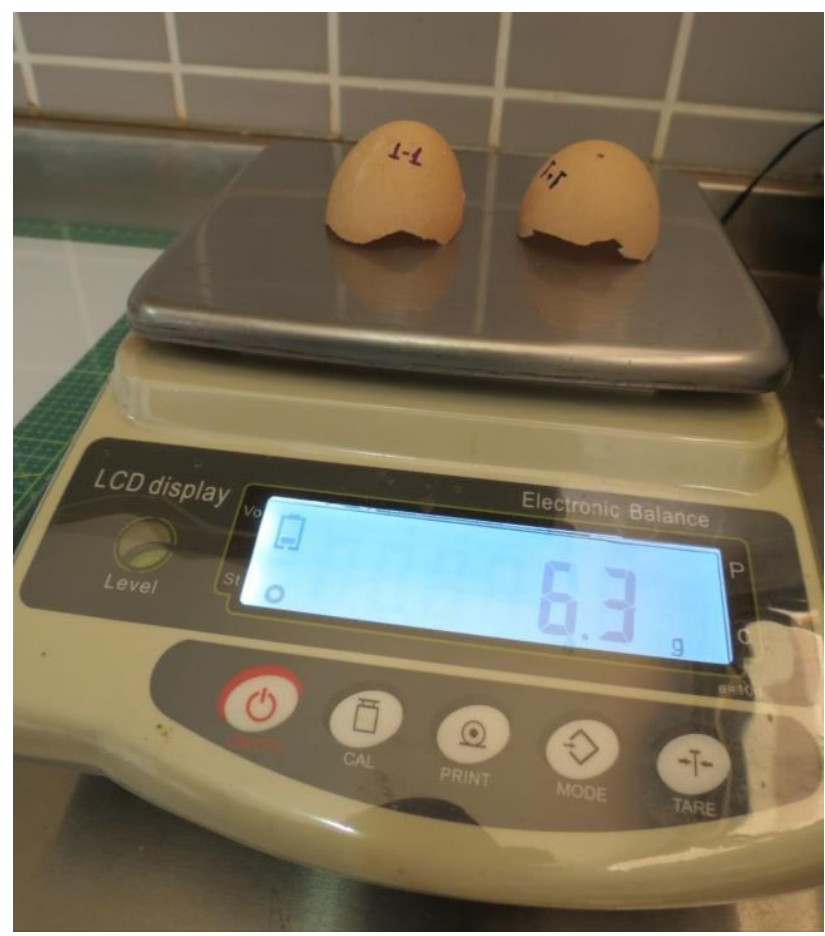

Fonte: Própria (2020)

Figura 13: Espessura de casca

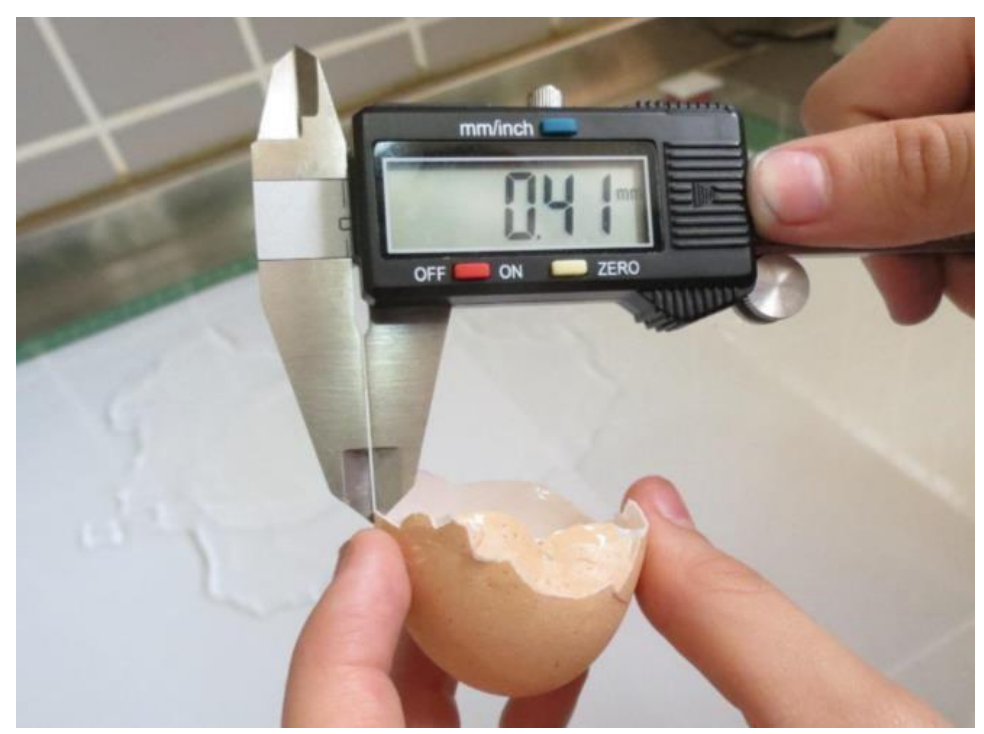

Fonte: Própria (2020)

\section{Resultados e Discussão}

Na tabela 1 encontram-se os resultados do efeito da temperatura e período de estocagem sobre a qualidade dos ovos de poedeiras comerciais avaliados no galpão avícola do IFMS Campus de Nova Andradina. Observou-se que nas temperaturas não controladas e refrigerados os ovos estocados durante 21 dias obtiveram perda de peso com relação a 7 e 14 dias, apesar de não apresentar diferença significativa segundo análise de Tukey a 5\%. 
Ocorreu essa perda de peso, provavelmente, devido à redução de água do albúmen (proporção diminui em função do período de estocagem), como pode ser observado no resultado para \% do albúmen dos ovos.

Em 21 dias de estocados, os resultados médios obtidos de porcentagem da gema na temperatura não controlada, apresentam maior peso do que em 7 e 14 dias, pois à medida que o ovo envelhece, a umidade do albúmen incorpora-se à gema, aumentando seu tamanho. Já com relação a albúmen, a relação é inversa, pois quando mantidas em temperatura não controlada, a porcentagem de albúmen foi menor quanto a refrigeração (14 e 21 dias de estocagem). ORNELLAS (1979) e SANTOS et al. (2009), relataram que, à medida que o ovo envelhece, a albúmen vai perdendo sua consistência, verificado também durante o processo de análise de qualidade, onde observou-se dificuldades de mensuração do albúmen com 21 dias de estocagem a temperatura não controlada.

Tabela 1. Efeito da temperatura e período de estocagem sobre a qualidade dos ovos de poedeiras comerciais avaliados no galpão avícola do IFMS Campus de Nova Andradina.

\begin{tabular}{|c|c|c|c|c|}
\hline \multirow{2}{*}{ Temperatura } & \multicolumn{4}{|c|}{ tempo de estocagem } \\
\hline & Frescos & 7 dias & 14 dias & 21 dias \\
\hline & \multicolumn{4}{|c|}{ Peso do ovo } \\
\hline Ambiente & $63,72^{A}$ & $62,82^{2 \mathrm{~A}}$ & $66,25^{\text {aA }}$ & $58,97^{\mathrm{aA}}$ \\
\hline \multirow[t]{2}{*}{ Refrigeração } & - & $61,62^{\mathrm{aA}}$ & $64,92^{\mathrm{aA}}$ & $58,08^{\mathrm{aA}}$ \\
\hline & \multicolumn{4}{|c|}{ Temperatura do Ovo } \\
\hline Ambiente & $30,05^{\mathrm{C}}$ & $28,95^{\mathrm{bB}}$ & $32,35^{\mathrm{bB}}$ & $25,52^{\mathrm{bA}}$ \\
\hline \multirow[t]{2}{*}{ Refrigeração } & - & $5,52^{\mathrm{aA}}$ & $7,3^{\mathrm{aA}}$ & $4,3^{\mathrm{aA}}$ \\
\hline & \multicolumn{4}{|c|}{ Unidades Haugh dos ovos (UH) } \\
\hline Ambiente & $84,65^{\mathrm{B}}$ & $66,09^{\mathrm{aAB}}$ & $29,95^{\mathrm{aA}}$ & $46,02^{\mathrm{aAB}}$ \\
\hline \multirow[t]{2}{*}{ Refrigeração } & - & $86,05^{\mathrm{b}}$ & $85,26^{\mathrm{bA}}$ & $73,98^{\mathrm{bA}}$ \\
\hline & \multicolumn{4}{|c|}{ Percentagem da gema nos ovos } \\
\hline Ambiente & $30,39^{A}$ & $32,83^{\mathrm{aA}}$ & $31,67^{\mathrm{bA}}$ & $33,6^{\mathrm{aA}}$ \\
\hline \multirow[t]{2}{*}{ Refrigeração } & - & $31,45^{\mathrm{aA}}$ & $32,53^{a A}$ & $33,4^{\mathrm{aA}}$ \\
\hline & \multicolumn{4}{|c|}{ Percentagem do albúmen nos ovos } \\
\hline Ambiente & $60,68^{\mathrm{aB}}$ & $57,94^{\mathrm{aA}}$ & $59,29^{\mathrm{aAB}}$ & $57,08^{a A}$ \\
\hline \multirow[t]{2}{*}{ Refrigeração } & - & $59,85^{\mathrm{aA}}$ & $59,20^{\mathrm{bA}}$ & $58,08^{a A}$ \\
\hline & \multicolumn{4}{|c|}{ Percentagem da casca nos ovos } \\
\hline Ambiente & $8,92^{\mathrm{aA}}$ & $9,23^{\mathrm{aA}}$ & $9,04^{\mathrm{aA}}$ & $9,31^{\mathrm{aA}}$ \\
\hline \multirow[t]{2}{*}{ Refrigeração } & - & $8,69^{\mathrm{aA}}$ & $8,27^{\text {aA }}$ & $8,51^{\mathrm{aA}}$ \\
\hline & \multicolumn{4}{|c|}{ Índice de Gema (IG) } \\
\hline Ambiente & $0,42^{\mathrm{C}}$ & $0,35^{\mathrm{aB}}$ & $0,27^{\mathrm{aA}}$ & $0,26^{\mathrm{aA}}$ \\
\hline Refrigeração & & $0,47^{\mathrm{bA}}$ & $0,46^{\mathrm{bA}}$ & $0,50^{\mathrm{bA}}$ \\
\hline
\end{tabular}

Nas colunas, médias seguidas por pelo menos uma letra minúscula igual não difere estatisticamente entre si, pelo teste de Tukey ( $>$ > 0,05); nas linhas, médias seguidas por pelo menos uma letra maiúscula igual não difere estatisticamente entre si, pelo teste de Tukey $(\mathrm{p}>0,05)$. 
Em ambas as temperaturas a porcentagem de casca foi maior em 7 e 21 dias. Em temperatura não controlada, independentemente do tempo de estocagem, os ovos apresentaram menor valor de unidades Haugh, quando comparados aos ovos mantidos refrigerados.

O presente estudo, conforme Tabela 2, constatou que houve interação significativa entre a temperatura de conservação e o período de estocagem dos ovos em relação aos: parâmetros de unidades Haugh, \% de gema, \% de albúmen e IG. Assim, verifica-se a existência de interdependência entre os fatores temperatura de conservação x período de estocagem dos ovos, para os parâmetros citados.

Tabela 2. Comportamento das interações temperatura de conservação $\times$ período de estocagem $(\mathrm{T} \times \mathrm{E})$ sobre diversos parâmetros.

\begin{tabular}{|l|c|}
\hline Parâmetros & Significância (T $\times \mathrm{E})$ \\
\hline Peso do ovo & $\mathrm{NS}$ \\
\hline Temperatura do Ovo & $\mathrm{S}$ \\
\hline Unidades Haugh dos ovos (UH) & $\mathrm{S}$ \\
\hline Percentagem da gema nos ovos & $\mathrm{NS}$ \\
\hline Percentagem do albúmen nos ovos & $\mathrm{S}$ \\
\hline Percentagem da casca nos ovos & $\mathrm{S}$ \\
\hline Índice de Gema (IG) & \\
\hline
\end{tabular}

$S=$ significativo $(p<0,05)$; e NS = não significativo $(p>0,05)$.

Verificou-se que os ovos mantidos refrigerados apresentaram menor perda de peso e melhores índices de percentagem do albúmen, unidades Haugh e índice de gema, quando comparados aos ovos conservados em temperatura não controlada. O aumento do período de estocagem dos ovos, independente da temperatura de conservação, ocasionou perda na estrutura dos ovos, porém verificou-se reduções na unidade Haugh e índice de gema nos mantidos à temperatura não controlada conforme maior o período de estocagem.

Através da utilização da câmera térmica foi possível a obtenção das imagens apresentadas na Figura 14.

Verificou-se que os ovos armazenados em temperatura não controlada tiveram uma degradação maior nas propriedades internas, podendo ser verificado nas imagens que os ovos se mantiveram em temperaturas altas, nos ovos refrigerados, observou-se uma conservação da sua estrutura durante os 21 dias de armazenamento. 
Figura 14: Comparação entre imagens térmicas de ovos armazenados em temperatura não controlada e sob refrigeração.
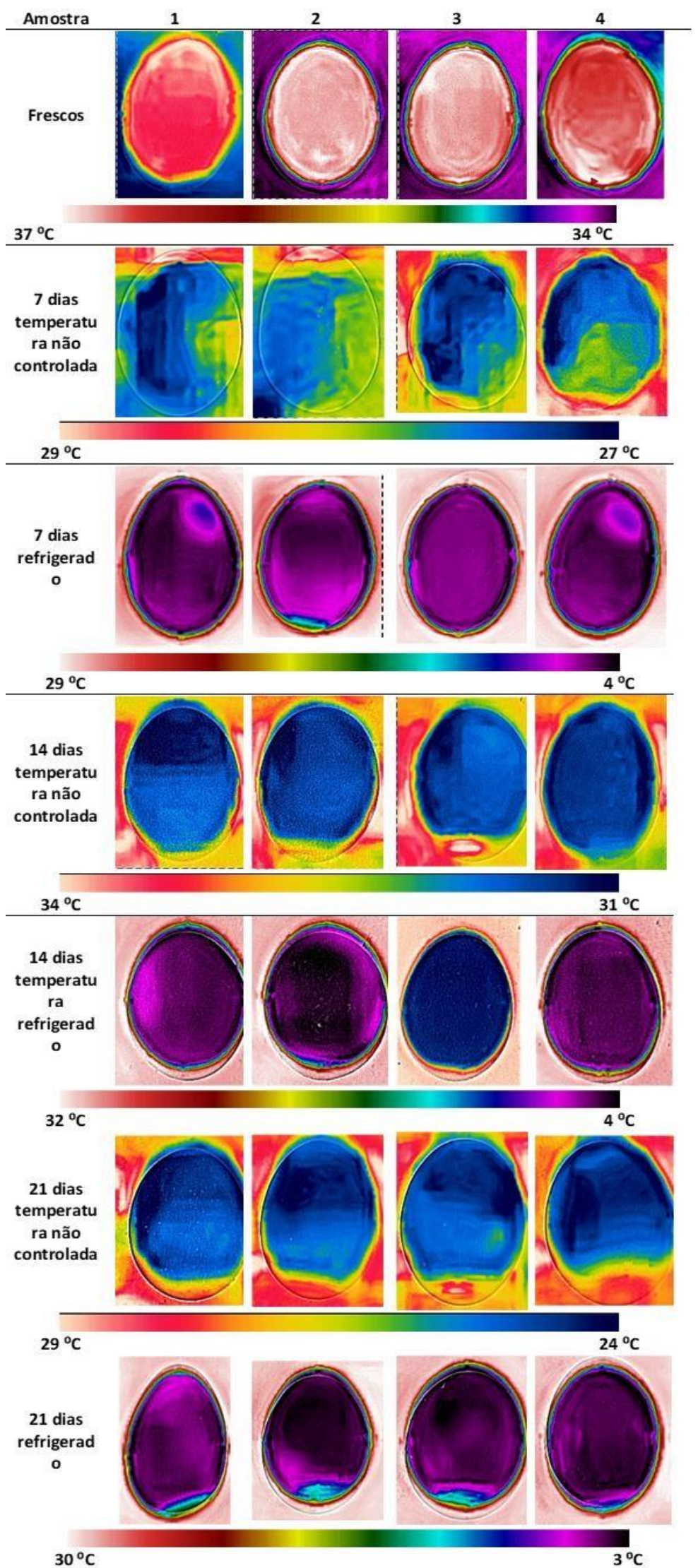

Fonte: Própria (2020) 
Conforme pode ser observado na Figura 15, com 21 semanas os ovos que foram mantidos sob refrigeração a manutenção das estruturas (Figura 5) foi também conservada sendo observada também a câmara de ar no canto inferior direito. Por fim esse método para análise de ovos, utilizando imagens térmicas pode contribuir para análise não destrutiva de qualidade de ovos em produção comercial, precisando, porém, de mais análises científicas para validação.

Figura 15: Observação das membranas interna e externa do ovo armazenado em refrigeração após 21 dias, feitas através do uso de imagens térmicas, e no canto inferior direito a câmara de ar.

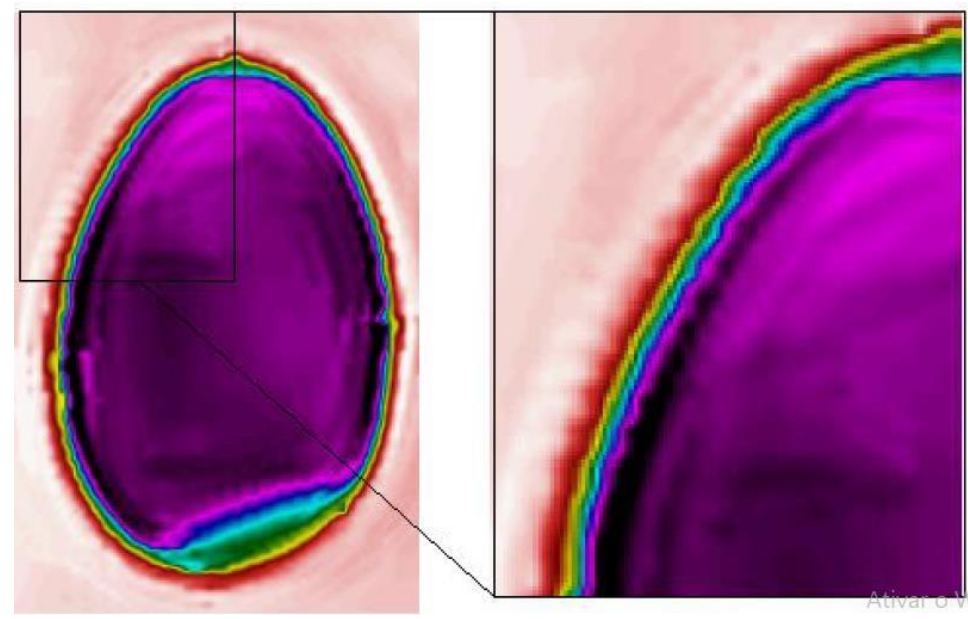

Fonte: Própria (2020)

\section{Conclusões}

Verificou-se a existência de interdependência entre os fatores temperatura de conservação x período de estocagem dos ovos, para os parâmetros citados. Ovos mantidos refrigerados apresentaram menor perda de peso e melhores índices de percentagem do albúmen, unidades Haugh e índice de gema, quando comparados aos ovos conservados em temperatura não controlada durante todo o tempo de armazenamento.

Contata-se que é possível pelas imagens térmicas observar que ovos refrigerados mantêm melhor estrutura, contribuído para um ovo de melhor qualidade. Foi percebido visualmente a localização da câmara de ar, nos ovos refrigerados com 21 semanas.

Desta forma, a utilização de imagens térmicas pode ser capaz de mensurar parâmetros para análise de ovos, contribuindo, portanto, para análise não destrutiva de qualidade de ovos em produção comercial

\section{Referências}

ALLEONI, A. C. C., ANTUNES, A. J. Unidade Haugh como medida da qualidade de ovos de galinha armazenados sob refrigeração. Scientia Agrícola, Piracicaba, v. 58, n. 4, p. 681 - 685, 
2001. Disponível em: 〈http://www.scielo.br/pdf/sa/v58n4/6283.pdf>. Acesso em: 26 de abril de 2018.

BARBOSA, N. A. A. et al. Efeito da temperatura e do tempo de armazenamento na qualidade interna de ovos de poedeiras comerciais. Brazilian Journal Poultry Science, v. 60, n. Supl 6, p. 60-65, 2004.

EGG-Grading Manual. Washington: Department of Agriculture/Agricultural Marketing Services. 2000. (Agricultural Handbook, 75). Disponível em:

<https://naldc.nal.usda.gov/download/CAT11094176/PDF>. Acesso em: 17 de outubro de 2019.

HAUGH, R. R. The Haugh unit for measuring egg quality. United States Egg Poultry Magazine, v.43, p.552-555, 1937.

HORST, F. Anatomia de um ovo. 2007

Instituto Brasileiro de Geografia e Estatística. Indicadores IBGE: Estatística da Produção Pecuária março de 2018. Rio de Janeiro: Instituto Brasileiro de Geografia e Estatística; 2018. Disponível em:

<https://biblioteca.ibge.gov.br/visualizacao/periodicos/2380/epp_2018_mar.pdf>. Acesso em 26 abril 2018.

JONES, D. R. et al. Effects of cryogenic cooling of shell eggs on egg quality. Poultry Science, v.81, n. 5, p. 727-733, 2002. Disponível em: <https://doi.org/10.1093/ps/81.5.727> Acesso em: 17 de outubro de 2019.

LEANDRO, Nadja Susana Mogyca et al. Aspectos de qualidade interna e externa de ovos comercializados em diferentes estabelecimentos na região de Goiânia. 2005. Disponível em: <https://www.revistas.ufg.br/vet/article/view/358/333>. Acesso em: 17 de outubro de 2019.

MENDES, F. R. Qualidade física, química e microbiológica de ovos lavados armazenados sob duas temperaturas e experimentalmente contaminados com Pseudomonas aeruginosa. 2010.72f. Dissertação (Mestrado em Ciência Animal) - Escola de Veterinária, Universidade Federal de Goiás, Goiânia. Disponível em:

〈https://ppgca.evz.ufg.br/up/67/o/Tese2014_Sandra_Gherardi.pdf >. Acesso em: 26 de abril de 2018.

MORENG, R.E.; AVENS, J.S. Ciência e produção de aves. São Paulo: Roca, 1990. p. 227249.

ORNELLAS, L. H. Técnica dietética 3. ed. Rio de Janeiro, Júlio C. Reis-Livraria, 1979.

PISSINATI, A.; OBA, A.; YAMASHITA, F.; SILVA, C. A.; PINHEIRO, J. W.; ROMAN, J. M. M.

Internal quality of eggs subjected to different types of coating and stored for 35 days at $25^{\circ} \mathrm{C}$.

Semina: Ciências Agrárias, v.35, n.1, p.531-540, 2014. Disponível em: 
<http://www.uel.br/revistas/uel/index.php/semagrarias/article/view/13587/14099>. Acesso em: 24 de julho.

SANTOS, Maria do Socorro Vieira et al. Efeito da temperatura e estocagem em ovos.

Ciência e Tecnologia de Alimentos, v. 29, n. 3, p. 513-517, 2009. Disponível em:

<http://www.scielo.br/pdf/cta/v29n3/a09v29n3.pdf>. Acesso em: 17 de outubro de 2019.

SOUZA, P. A. Ovos e refrigeração. Avicultura Industrial, São Paulo, v.3, p. 44-45, 2001.

SCOTT, T. A.; SILVERSIDES, T. B. The effect of storage and strain of hen on egg quality.

Poultry Science, v.79, p.1725-1729, 2000. Disponível em:

<https://doi.org/10.1093/ps/79.12.1725>. Acesso em: 23 de julho de 2019.

VÉRAS, A. L. et al. Avaliação da qualidade interna de ovos armazenados em dois ambientes em diferentes tempos. Conferência APINCO de ciência e Tecnologia Avícolas. Trabalhos de Pesquisa Avícola. São Paulo. Brazilian Journal Poultry Science, supl. Prêmio Lamas, p. 55, 1999. 


\title{
CAPÍTULO 25: QUEIJO DE MANTEIGA PRODUZIDO COM LEITE DE CABRA: AVALIAÇÃO BROMATOLÓGICA
}

\section{CHAPTER 25: BUTTER CHEESE PRODUCED WITH GOAT MILK: BROMATOLOGICAL EVALUATION}

\author{
Fabiana Augusta Santiago Beltrão ${ }^{1}$; Isabelly da Silva Ramalho²; Aliou Toro Lafia ${ }^{3}$; \\ Catiele Silva de Oliveira ${ }^{4}$, Laíza Soliely Costa Gonçalves ${ }^{5}$
}

\begin{abstract}
Resumo
Dentre os produtos de lacticínios, no Nordeste o queijo de manteiga e a manteiga da terra são os mais difundidos. Uma das grandes preocupações dos consumidores ocorre na hora de escolha entre derivados de leite caprino. Objetivou-se neste trabalho desenvolver e padronizar formulações para o processamento de queijo de manteiga e estudar o efeito dos diferentes tipos de leite. $\mathrm{Na}$ obtenção dos queijos de manteigas, foram utilizados dois tratamentos, sendo um com leite caprino. Foram analisadas as características microbiológicas e físico-químicas a fim de avaliar o efeito do tipo de leite em componentes nutricionais em queijo de manteiga. Os resultados das análises microbiológicas das amostras de queijo de manteiga elaborados atenderam os padrões microbiológicos estabelecidos pela legislação e estão propícios para o consumo humano sem risco a saúde. Os resultados das análises físico-químicas mostraram que os valores foram significativos para todos os parâmetros determinados nos diferentes queijos de manteiga elaborados, com exceção da atividade de água. A porcentagem dos componentes nutricionais presentes no queijo de manteiga é um fator depende da origem do leite e dos diferentes ingredientes.
\end{abstract}

Palavras-Chave : Controle de qualidade, Físico-química,Microbiologia, Nutricional,Textura.

\begin{abstract}
Among dairy products, in the Northeast butter cheese and butter from the land are the most widespread. One of the major concerns of consumers occurs when choosing between dairy and goat milk products. The objective of this work was to develop and standardize formulations for the processing of butter cheese and to study the effect of different types of milk. In obtaining the cheese from butters, two treatments were used, one with goat milk and the other with bovine milk. Microbiological and physical-chemical characteristics were analyzed in order to evaluate the effect of the type of milk on nutritional components in butter cheese. The results of the microbiological analyzes of the butter cheese samples prepared met the microbiological standards established by the legislation and are conducive to human consumption without risk to health. The results of the physical-chemical analyzes showed that the values were significant for all the parameters determined in the different butter cheeses made, with the exception of water activity. The percentage of nutritional components present in butter cheese is a factor depending on the origin of the milk and the different ingredients.

\footnotetext{
${ }^{1}$ Docente, Universidade Federal da Paraíba, fasb.15@ @otmail.com

${ }^{2}$ Bel. em Agroindústria, Universidade Federal da Paraíba, isabellyramalho@gmail.com

${ }^{3}$ Mestrando em Tecnologia de Alimentos, PPGTA, Universidade Federal da Paraíba, zime1990@gmail.com

${ }^{4}$ Bel. em Agroindústria, Universidade Federal da Paraíba Paraíba, catielesilva.16@gmail.com

${ }^{5}$ Bel. em Agroindústria, Universidade Federal da Paraíba, laizasolielyc@gmail.com
} 
Keywords: Quality control; Physicochemical; Microbiology; Nutritional; Texture.

\section{Introdução}

De acordo a Embrapa (2019) a agropecuária leiteira brasileira está em cada vez mais crescente devido a forte demanda do mercado nacional e internacional do leite e seus derivados. Os principais subprodutos do leite são: o iogurte, o requeijão, diversos tipos de queijos e o doce de leite entre outros. A produção de queijo de manteiga está inserida entre as atividades de grande importância no cenário atual de desenvolvimento do território nordestino, onde é explorada notadamente por populações rurais e representa a principal fonte de renda de uma expressiva parcela dos pequenos produtores.

O setor de Laticínios no Brasil cresceu significativamente nas últimas décadas, devido principalmente aos diversificados produtos derivado de leite que se encontra no mercado, os quais têm grande aceitação no mercado (ALMEIDA FILHO, 2020). O queijo de manteiga é provavelmente um produto muito popular e de maior importância econômica no Brasil e principalmente no nordeste do país. O leite de cabra mais que o leite bovino, é um dos alimentos funcionais mais encontrados no mercado alimentício, devido, além do seu alto valor nutritivo reduz risco das doenças crônicas e melhora às funções fisiológicas. Comparado à leite bovino, o leite de cabra possui maior digestibilidade, sendo recomendado na nutrição de crianças e de idosos e, uma alternativa para pessoas alérgicas à leite bovino. Mesmo com crescente demanda do leite de cabra no mercado de consumo, a sua distribuição se encontra restrita no Brasil (SANTOS et al., 2019).

Em sua composição básica, o leite caprino é similar ao leite de vaca, possui um alto valor nutricional, devido aos níveis mais baixos de caseína $\alpha$-s1 que é considerado como o desencadeador das reações alérgicas, o leite de cabra é a melhor alternativa que pode substituir o leite bovino para pessoas alérgicas. No entanto, o consumo de leite de cabra e seus derivados podem gerar benefícios adicionais, por exemplo, baixa alergenicidade e melhor absorção da fração lipídica quando comparado ao leite bovino. Também por possuir maiores quantidades de ácidos graxos de cadeia média e curta e, apresenta maior digestibilidade devido as partículas de gorduras no leite de cabra são menores que no leite bovino, (RAMOS \&NASCIMENTO, 2019).

Segundo Pellegrini et al. (2012) as qualidades nutricionais do leite caprino não se diferem as do leite do leite bovino em alguns aspectos, como no teor de lactose e de gordura, mas o leite caprino supera em alguns aspectos nutricionais como no caso de proteínas. O leite cabra e seus derivados são os promissores do mercado de laticínios 
devido principalmente as suas características nutricionais que reflete a atual tendência alimentares.

O queijo de manteiga é um dos derivados de leite mais procurado e mais consumido. Segundo Nunes Leite et al. (2020) o queijo de manteiga se refere ao produto obtido através da coagulação do leite com adição de ácidos orgânicos de grau alimentício, cuja massa é submetida à dessoragem, lavagem e fusão, deve-se acréscimo exclusiva de manteiga de garrafa ou manteiga da terra. A denominação Queijo de Manteiga ou Queijo do Sertão está reservada ao produto cuja base láctea não contenha gordura e/ou proteína e/ou outros produtos de origem não láctea (MAPA, 2001).

Por muito tempo o leite de cabra e seus derivados foram objetos de rejeição pós conferem um sabor específico que os diferenciam do leite bovino. $\mathrm{O}$ conhecimento sobre as caraterística nutricionais e as modificações que podem ocorrer nas suas componentes como no perfil de ácidos graxos fazem a maior aceitação do leite de cabra e seus derivados nos últimos anos (CATUNDA et al., 2016).

Com este trabalho foi objetivou-se desenvolver e avaliar as características físicoquímicas e microbiológicas de queijos de manteiga de leite de cabra e compará-lo com o queijo de manteiga de leite de vaca.

\section{Material e Métodos}

O leite de cabra foi coletado no Setor de Caprinocultura do Centro de Ciências Humanas Sociais e Agrárias - Campus III (UFPB). O leite bovino foi adquirido no Setor de Bovinocultura no mesmo Campus. Os leites foram adquiridos sob temperatura de refrigeração de $5^{\circ} \mathrm{C}$, transportado em recipiente isotérmico até o Laboratório Pesquisa e Desenvolvimento de Produtos Laticínios (PDLAT/UFPB), onde ocorreu a fabricação dos queijos.

Foram desenvolvidas duas formulações de queijo, diferindo-se da origem do leite, uma com $100 \%$ de leite de vaca e outra com $100 \%$ de leite caprino, como mostra a Tabela 1. 
Tabela 1: Formulação dos queijos de manteiga

\begin{tabular}{lcc}
\hline & \multicolumn{2}{c}{ TRATAMENTOS } \\
\cline { 2 - 3 } INGREDIENTES & QMB & QMC \\
Leite bovino (L) & 10 & - \\
Leite caprino $(\mathrm{L})$ & - & 10 \\
Soro ácido $(\% / \mathrm{g})$ & $1,1 \%$ à $3,2 \%$ & $1,1 \%$ à $3,2 \%$ \\
$\mathrm{NaCL}(\% / \mathrm{g})$ & $0,017 \%$ à $0,833 \%$ & $0,017 \%$ à $0,833 \%$ \\
$\mathrm{NaHCO}_{3}(\% / \mathrm{g})$ & $30 \%$ à $50 \%$ & $30 \%$ à $50 \%$ \\
Manteiga de terra $(\% / g)$ &
\end{tabular}

$\mathrm{QMB}=$ queijo de manteiga Bovino, $\mathrm{QMC}=$ queijo de manteiga caprino

O processo de elaboração de queijos segue o fluxograma descrito na Figura 1. Quando o leite é recebido no laticínio é filtrado para remover sujidades oriundas da ordenha. Depois da filtragem o leite sofre o processo de desnatação e o creme serve para fabricação de manteiga de terra entre outro. A seguir, na etapa de coagulação ocorre adição do soro ácido na regulação do pH e emprego de água morna na regulação da temperatura. Esse processo de fermentação pode durar 6 à 12 h. O coagulo formado é quebrado para facilitar a dessoragem. Para retirar o soro, a massa é lavada sucessivamente com leite, água e, leite mais água, essa lavagem ocorre duas vezes e pode levar 6 à $12 \mathrm{~h}$. Depois da segunda lavagem, a massa é submetida à cozimento de 15 à 25 minutos, retira o soro até o ponto. Nessa massa é adicionada a quantidade de $\mathrm{NaCL}(1,1 \%$ à $3,2 \%)$ e de $\mathrm{NaHCO}_{3}(0,017 \%$ à $0,833 \%)$. A fusão da massa ocorre 10 à 20 minutos e adiciona-se da manteiga de terra (30 a 50\%). Depois de 5 a 15 minutos de cozimento chega o ponto de queijo de manteiga. 
Figura 1: Fluxograma simplificado da elaboração de queijo de manteiga

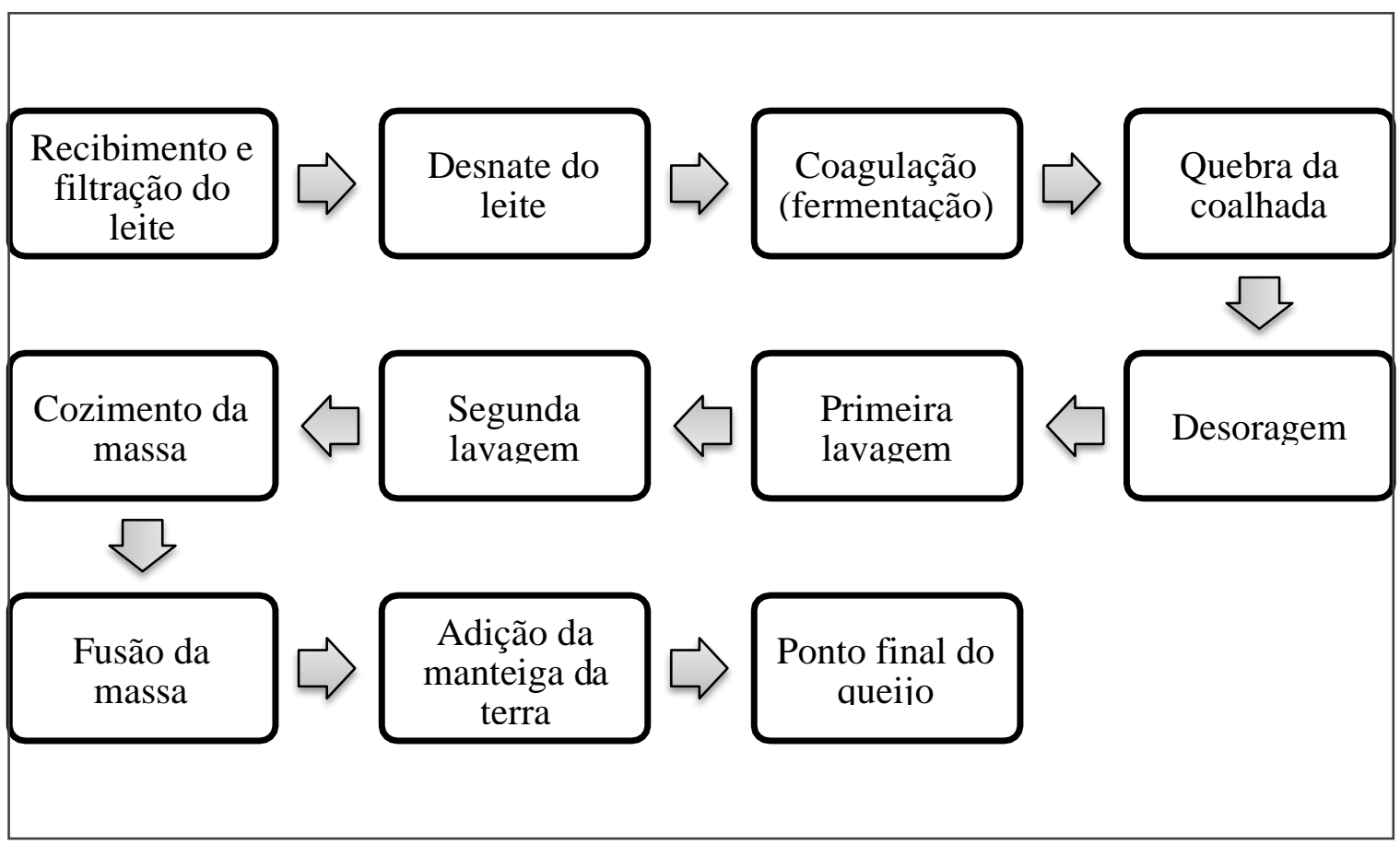

As análises microbiológicas foram realizadas no Laboratório de Microbiologia de Alimentos do CCHSA da UFPB Campus III. Sendo realizadas em triplicatas seguindo o regulamento técnico sobre os padrões microbiológicos para alimentos conforme as exigências da Agência Nacional de Vigilância Sanitária (ANVISA, 2001), foram feito pesquisas de coliformes à $35^{\circ} \mathrm{C}$, coliformes à $45^{\circ} \mathrm{C}$, Estafilococos coagulase positivo e pesquisa de Salmonella spp. (25g) de acordo com Ministério da Agricultura, Pecuária e Abastecimento Mapa (2001), que trata do regulamento Técnico Geral para a Fixação dos Requisitos Microbiológicos de Queijos, em que os queijos de manteiga bovino e caprino devem obedecer aos critérios estabelecidos.

As metodologias seguiram aquelas descritas no manual da American Public Health Association (APHA, 2001).

As análises físico-químicas foram realizadas no Laboratório de Análises Físicoquímicas de Alimentos do CCHSA UFPB Campus III. A qualidade física-química dos queijos de manteiga foram avaliados por meio de parâmetros para determinação de atividade de água, pH e acidez total pelo método Instituto Adolfo Lutz (IAL, 2008) e a determinação de umidade, proteína, lipídeos e cinza de acordo com metodologia proposta pela AOAC (2000). Sendo elas realizadas da seguinte forma: 
- Atividade de Água (Aw): determinada pelo aparelho medidor, modelo AQUALAB 4TE de marca DECAGON DEVICES (USA),

- $\mathrm{pH}$ : mensurado através do auxílio do pHmetro do modelo Tec-2, da marca TECNAL,

- Acidez Total Titulável: por meio de método de titulação, sendo analisada a acidez em ácido láctico,

- Para a determinação de umidade foi a de secagem em estufa a $105^{\circ} \mathrm{C}$ até peso constante,

- A determinação de proteína foi feita pelo método de Kjeldahl,

- O teor de lipídeos foi realizado pelo método de Bligh-Dyer,

- A cinza foi determinada pelo método de incineração da amostra em mufla a $550^{\circ} \mathrm{C}$. As determinações dos parâmetros de textura das amostras foram realizadas após 07 dias de maturação. O perfil de textura dos queijos foi determinado através de teste de dupla compressão de amostras com peso constante, contidas nas embalagens plásticas, utilizando cilindro de alumínio de $25 \mathrm{~mm}$ de diâmetro (P25), em analisador de textura TAXT2 (Stable Micro Systems, Haslemere, Reino Unido). Os dados foram coletados através do programa “Texture Expert for Windows" - versão 1.20 (Stable Micro Systems).

A determinação da cor instrumental foi realizada em colorímetro Minolta, modelo CR- 300, utilizando o sistema CIELAB. No espaço colorimétrico CIELAB, definido por $\mathrm{L}^{*}, \mathrm{a}^{*}, \mathrm{~b}^{*}$, a coordenada $\mathrm{L}^{*}$ corresponde à luminosidade, $\mathrm{a}^{*} \mathrm{e} \mathrm{b}^{*}$ referem-se às coordenadas de cromaticidade verde (-) /vermelho (+) e azul (-) / amarelo (+), respectivamente.

Foi utilizado o delineamento inteiramente casualizado com dois tratamentos (QMB e QMC). Os resultados dos testes foram avaliados através do teste de Tukey a 5\% de probabilidade para comparação das médias, com a utilização do software SAS®, versão 9.1, licenciado para a UFPB.

\section{Resultados e Discussões}

Os resultados das análises microbiológicas se encontram na Tabela 2. Os resultados mostram que a qualidade microbiológica dos queijos foi excelente, pós, os valores se encontram dentro do padrão estabelecido pela legislação. As boas práticas de fabricação de alimentos foram rigorosamente adotadas como recomenda a Agência Nacional de Vigilância Sanitária (ANVISA, 2001). As boas práticas de fabricação de alimentos se referem a um conjunto de medidas que devem ser adotadas pelas indústrias 
alimentícias e pelos serviços de alimentação, a fim de garantir a qualidade higiênicosanitária e a conformidade dos alimentos com os regulamentos técnicos. O consumo dos queijos elaborados não promovera risco à saúde dos consumidores nestas condições.

Tabela 2: Resultados das análises microbiológicas dos queijos de manteiga

MICRO ORGANISMOS

Coliformes 350C NMP/g

Coliformes $450 \mathrm{C} \quad \mathrm{NMP} / \mathrm{g}$

Sthap.goag.positiva $25 / \mathrm{g}$

Fungos Filamentosos e não

filamentosos

Salmonella spp/25 g

\section{AMOSTRA}

QMC

$<3$

$<3$

$<1 \times 10^{2}$

$<1 \times 10^{2}$

Ausente

\section{QMB}

$<3$

$<3$

$<1 \times 10^{2}$

$<1 \times 10^{2}$

QMC (Queijo de manteiga de leite de cabra) \& QMV (Queijo de manteiga de leite de vaca)

A elaboração de queijo no Brasil compreende a produção a nível industrial e nível artesanal. Na produção industrial o controle de qualidade é muito mais que na produção artesanal. O risco de contaminação microbiológica é mais alto na produção artesanal. Alexandre et al (2016) verificaram a presença de coliformes em amostras adquiridas no comércio e observaram a presença em mais de $80 \%$ das amostras de queijo de manteiga analisadas. A contaminação por coliformes hipoteticamente pode ser de origem dos vendedores por falta de higiene, pode ser da origem da matéria prima de baixa qualidade microbiológica levando a uma contaminação cruzada ou mesmo dos autores na hora de coleta das amostras. Nas amostras de queijos avaliadas neste trabalho não houve crescimento de coliformes a $35{ }^{\circ} \mathrm{C}$ nem a $45{ }^{\circ} \mathrm{C}$. A ausência de coliformes nas amostras analisadas é devida da experiência profissional dos queijeiros da Universidade Federal da Paraíba, tendo noção das boas praticas de fabricação de alimentos.

De acordo com Sousa et al. (2014) as vias de contaminação dos queijos podem variar, as principais fontes são leite de baixa qualidade microbiológica, o manipulador é veículo de contaminação e o ambiente de processamento mal higienizado. No leite cru, a principal fonte de contaminação provém da mastite bovina, na qual Staphylococcus coagulase positiva é o principal agente etiológico. Foi identificada neste trabalho a presença de Staphylococcus coagulase positiva em todas as amostras sem exceder os limites de tolerância da legislação. As contagens foram inferiores a $1 \times 10^{2}$ enquanto a 
legislação estabelece uma tolerância de até $1 \times 10^{3}$. Os resultados de Evangelista-Barreto et al. (2016) excederam os padrões legislativas estabelecidas para a contagem de Staphylococcus coagulase positiva em queijo. Os autores encontraram 8,20 x $10^{5} \mathrm{em}$ queijo coalho e $3,30 \times 10^{3}$ em queijo de manteiga. A qualidade das matérias primas de elaboração dos queijos era baixa ou as boas práticas de fabricação não foram rigorosamente adotadas colocando em risco a saúde dos consumidores.

Os Fungos filamentosos dependendo do objetivo podem ser de caracteres benéficos ou maléficos. Têm sido utilizados para a produção de medicamentos e alimentos nos processos fermentativos e degradação natural de resíduos ambientais há tempos (TAKAHASHI et al, 2017). Se não houver aplicação de barreiras que impedem o crescimento dos fungos, os queijos principalmente aqueles com alta umidade como queijo de manteiga apresentam condições favoráveis para o desenvolvimento dos fungos. Houve o crescimento desses microrganismos nos queijos de manteiga elaborados nesta pesquisa sem passar os limites da legislação. Silva (2012) em seu trabalho de pesquisa verificou a presença de vários tipos de fungos em queijos de manteiga e obteve resultados positivos indicando a presença desses microrganismos.

Salmonella é potencialmente capaz de causar infecção alimentar, e a presença dessa bactéria classifica os queijos como produtos impróprios para consumo humano. Neste trabalho a Salmonella foi ausente implicando a obediência total as boas práticas de fabricação e qualidade de matérias-primas. Alexandre et al. (2016) verificaram a presença de Salmonella em 37,5\% das amostras analisadas. Neste trabalho a pesquisa de Salmonella mostra sua ausência em todas as amostras como se deseja. Evangelista-Barreto et al. (2016) notaram também a ausência de Salmonella em amostras de queijo coalho e de queijo-manteiga, este mostra que não houve uma contaminação fecal tanto da matéria prima como também da parte dos manipuladores.

A Tabela 3 mostra os resultados das análises físico-químicas realizadas de queijos de manteiga elaborados. Os teores de umidades, 53,45 \% e 64,92 \% das amostras QMB e QMC respectivamente apresentaram uma diferença significativa $(\mathrm{P}<0,05)$, enquanto os valores de atividades de água foram iguais $(0,94 \%)$ nos dois tipos de queijos. Os queijos de manteigas in natura não sofrem nenhum processo de desidratação faz com que apresentam teores de umidade um pouco altos e alta atividade de água. Para fixação da qualidade microbiológica é muito importante os queijos sejam armazenados sob refrigeração evitando assim o desenvolvimento de microrganismos. Segundo Seixas et al. (2015) a estação do ano tem uma grande influencia no teor de umidade de queijo de 
manteiga, os autores verificaram em queijo de manteiga em media 50,52\% de umidade no período chuvoso e 42,73\% de umidade durante a estação seca. Medeiros (2016) encontrou em máxima 55,19\% de umidade em queijo de manteiga.

Tabela 3: Resultado das analise físico-químicas dos diferentes queijos de manteiga

\begin{tabular}{lcc}
\hline \multirow{2}{*}{ COMPONENTES (\%) } & \multicolumn{2}{c}{ AMOSTRA } \\
\cline { 2 - 3 } & QMB & QMC \\
\hline Lactose & $0,15^{\mathrm{a}}$ & $0,11^{\mathrm{b}}$ \\
Proteína & $25,9^{\mathrm{a}}$ & $21,5^{\mathrm{b}}$ \\
Umidade & $53,45^{\mathrm{b}}$ & $64,92^{\mathrm{a}}$ \\
Gordura & $12,89^{\mathrm{a}}$ & $11,80^{\mathrm{b}}$ \\
Cinza & $3,05^{\mathrm{a}}$ & $1,76^{\mathrm{b}}$ \\
Acidez & $0,49^{\mathrm{a}}$ & $0,21^{\mathrm{b}}$ \\
pH & $4,62^{\mathrm{b}}$ & $4,98^{\mathrm{a}}$ \\
Aw & $0,94^{\mathrm{a}}$ & $0,94^{\mathrm{a}}$
\end{tabular}

Médias seguidas de letras diferentes em mesma linha diferem entre si significativamente $(\mathrm{P}<0,05)$ pelo teste de Tukey.

O queijo de manteiga do leito bovino apresentou maior teor de proteína $(25,9 \%)$ e maior teor de gordura $(12,89 \%)$ que o queijo de manteiga caprino. A composição do leite pode ter influenciada, alguns fatores, como idade, raça, ocorrência de doenças, ambiente, manejo, alimentação, temperatura, estação do ano, quantidades e intervalos de ordenha afeta a qualidade do leite positivamente tanto negativamente. A qualidade de leite pode interferir na qualidade dos derivados. Esses fatores podem ter influenciados no teor proteico e da gordura dos queijos de manteigas elaborados. Em média Seixas et al. (2015) encontraram $25,17 \%$ de proteínas em queijo de manteiga, aproximadamente igual ao valor encontrado neste trabalho. Medeiros (2016) na sua pesquisa encontrou um valor mínimo de gordura de $23,33 \%$ e $27,05 \%$ sendo o máximo em queijos de manteiga. Para Silva et al. (2015), o teor de proteína variou entre $16,74 \%$ e $28,35 \%$, e o teor de gordura variou entre $19,33 \%$ e $26,95 \%$ em queijos coloniais. Isso mostra que o tipo de queijo tem influencia em seus componentes nutricionais desde que as formulações e o processamento sejam diferentes.

A amostra de queijo QMB apresentou menor $\mathrm{pH}(4,62)$ que a amostra QMC $(4,98)$. Em contrario a amostra QMC apresentou menor acidez $(0,21)$ que a amostra QMB $(0,49)$, 
um resultado já esperado. Quando soube o $\mathrm{pH}$ a acidez diminui. A alta acidez do queijo de manteiga de leite bovino deve ter ocorrido pela fermentação da lactose que foi alto nesta amostra (QMB). Como o queijo de manteiga do leite caprino apresentou menor lactose não houve fonte de açúcar suficiente que pode ser fermentado produzindo acido láctico. Os menores valores de $\mathrm{pH}$ e de acidez encontrados por Sousa et al. (2014) em queijo são 5,18 e 0,12 respectivamente. Schwan et al. (2014) encontram pH variando entre 6,11 e 6,99 e, acidez variou entre 4,11 e 6,17 em queijos com leite pasteurizado.

Em relação ao teor de cinzas, houve uma diferença significativa $(\mathrm{p}<0,05)$ entre as amostras, o queijo de manteiga de leite bovino apresentou maior valor de cinza (3,05\%). Maior valor de cinza indica a presença de mais compostos inorgânicos. Como os leites utilizados na elaboração dos queijos são de diferentes origens em relação à espécie e o tipo de alimentação submetido aos animais, esses fatores houveram impacto no teor de cinzas nos queijos. As vacas recebem mais suplementos de sais minerais que as cabras para equilibrar a dieta dos animais, isso explica o alto valor de cinza em queijo de manteiga do leite bovino. Os valores de cinzas determinados por Silva et al. (2015) foram ainda maiores, pois os autores encontraram em queijos coloniais valor de cinza variando de $3,06 \%$ a $6,99 \%$.

Houve uma diferença significativa $(\mathrm{p}<0,05)$ em relação aos teores de lactose. A amostra QMB apresentou maior valor de lactose $(0,15 \%)$ que a amostra QMC $(0,11 \%)$. Os valores de lactose ficaram abaixo aos valores determinados por Dickel et al. (2016) que variaram entre $0,18 \%$ e $0,48 \%$. A lactose é o principal carboidrato de leite e de produtos derivados lácteos. É um dissacarídeo composto por glicose e galactose. Grande parte de lactose pode perdida durante o processamento de queijos ou pode ocorre hidrólise de lactose por alguns microrganismos presente, durante a maturação, isso justifica o baixo teor de lactose em queijos do que no leite.

A cor é um dos parâmetros mais importante dos alimentos sendo esta a primeira sensação sensorial que o consumidor percebe. A cor de um alimento mesmo sem obrigatoriamente relacionada com os valores nutricionais, desperta a curiosidade de consumidores.

Os dados da análise de cor dos queijos de manteiga elaborados estão apresentados na Tabela 4. Verificou-se que relativamente ao parâmetro L* (luminosidade), o queijo de manteiga de leite de cabra foi o que apresentou o maior valor $(30,33)$, sendo, portanto, mais claro que o queijo de manteiga de leite de vaca. Essa variação de luminosidade que pode ser justificado pela presença de alto teor de cálcio no leite caprino. Outra hipótese é a 
presença dos glóbulos de gorduras que dispersa a luz atribuindo a coloração mais clara ao queijo.

Tabela 4: Resultado da analise de cores dos queijos de manteiga elaborados

\begin{tabular}{llll}
\hline Parâmetros & L & A & B \\
\hline QMV & $26,10^{\mathrm{b}}$ & $2,39^{\mathrm{a}}$ & $7,23^{\mathrm{b}}$ \\
QMC & $33,50^{\mathrm{a}}$ & $0,04^{\mathrm{b}}$ & $15,70^{\mathrm{a}}$
\end{tabular}

Médias seguidas de letras diferentes na mesma coluna diferem entre si significativamente $(\mathrm{P}<0,05)$ pelo teste de Tukey.

Em relação à coordenada $\mathrm{a}^{*}$, os valores encontrados foram positivos indicando a presença de pigmentos vermelhos nos queijos de manteiga. Os valores apresentaram uma diferença significativa a $95 \%$ de probabilidade. A amostra de queijo de leite bovino obteve o valor mais alto $(3,29)$, indicador da predominância da cor vermelha do que no queijo de leite caprino, que se pode à ocorrência de reações de Maillard. A presença de pigmentos vermelhos nos queijos pode estar também ligada com a alimentação em que os animais foram submetidos.

Para parâmetro $b^{*}$ os valores foram diferentes significativamente $(\mathrm{P}<0,05)$. Os valores foram positivos para as duas amostras indicando a presença de pigmentos amarelos sendo maior em queijo de manteiga de leite caprino $(15,70)$. A presença de pigmentos amarelos deve ser proveniente da manteiga da terra adicionada durante a elaboração de queijos. A manteiga da terra apresenta uma coloração mais amarelada. Santos et al. (2011) observaram uma diferença significativa do parâmetro $b^{*}$ em diferente queijos feitos de leite caprino, bovino e misto.

A análise de textura mostrou que houve uma diferença significativa $(\mathrm{p}<0,05)$ entre a textura das duas amostras de queijo. A amostra QMB foi mais dura com $1,10 \%$ de dureza e QMC com 0,87\% de dureza sendo mais suave. A textura de queijo depende da sua formulação e do tipo de processo de obtenção dos queijos. A textura é um parâmetro ligado a coesividade, dureza, resiliência, adesividade, gomosidade e elasticidade que são função da facilidade de mastigabilidade facilitando a digestão. Quando mais suave é um alimento, mais rápido ocorre o processo de digestão (OLIVEIRA et al., 2016).

\section{Conclusão}

As análises microbiológicas mostraram que houve boas praticas de fabricação dos 
queijos atendendo os padrões da legislação. Portando os resultados das análises físicoquímicas dos queijos mostraram que a origem de leite tem grande influencias na composição nutricional de seus derivados. O queijo de manteiga de leite caprino é diferente do queijo de manteiga de leite bovino em relação à quantidade de nutrientes presentes neles.

\section{REFERÊNCIAS}

AGÊNCIA NACIONAL DE VIGILÂNCIA SANITÁRIA. Resolução n.12, de 02 de janeiro de 2001. A Diretoria Colegiada da Agência Nacional de Vigilância Sanitária aprova o regulamento técnico sobre padrões microbiológicos para alimentos. Disponible em

<<http://portal.anvisa.gov.br/documents/33880/2568070/RDC_12_2001.pdf/15ffddf63767- 4527-bfac-740a0400829b >> acesso 11/04/2020.

Alexandre, A. P. S., de Aquino, A. B., de Lyra, D. G., \& Froehlich, A. Butter cheese microbiological contamination risk to health consumer. Brazilian Journal of Veterinary Medicine, 38(2), 121-124, 2016.

ALMEIDA FILHO, DE., G. F., BITENCOURT, E., FERREIRA, E. C., OLIVEIRA, V. S., $\&$

LOUREIRO, G. E. Avaliação do ciclo de vida do queijo muçarela de um laticínio na região norte do Brasil. Revista Produção Online, v. 20, n. 1, p. 316-339, 2020.

AOAC. Official Methods of Analysis of the Association of Official Agricultural Chemists. 11. ed. Washington: AOAC International, 2000.

APHA, American public. Health association. Compendium of methods for the microbiological examination of foods. 4th ed. Washinghton D.C.: APHA, P.676, 2001.

CATUNDA, K. L. M.; AGUIAR, E. M. de.; SILVA, J. G. M. da; RANGEL, A. H. do. N. Leite caprino: características nutricionais, organolépticas e importância do consumo. Revista Centauro, v.7, n.1, p 34 - 55, 2016.

DICKEL, C., JUNKES, J. K., TONIAL, I. B., \& DE CASTRO-CISLAGHI, F. P. Determinação do teor de sódio e lactose em queijos mussarela e colonial consumidos na região sudoeste do paraná. Revista do Instituto de Laticínios Cândido Tostes, v.71, n.3, p.144-152, 2016. 
Embrapa. Anuario, Leite, 2019. Edição Digital em embrapa.br/gado-de-leite.

EVANGELISTA-BARRETO, N. S., DA FRANÇA SANTOS, G. C., DOS SANTOS SOUZA, J., DE SOUSA BERNARDES, F., \& SILVA, I. P. (2016). Queijos artesanais como veiculo de contaminação de Escherichia coli e estafilococos coagulase positiva resistentes a antimicrobianos. Revista Brasileira de Higiene e Sanidade Animal, v. 10, n. 1, p. 55-67, 2016.

INSTITUTO ADOLFO LUTZ (IAL). Normas analíticas do Instituto Adolfo Lutz: métodos químicos e físicos para análise de alimentos. $4^{\mathrm{a}}$ ed., Editora Adolfo Lutz, São Paulo, 2008.

MAPA. Ministério da Agricultura, Pecuária e Abastecimento 2001. Disponível em:

<<https://wp.ufpel.edu.br/inspleite/files/2016/03/Instru\%C3\%A7\%C3\%A3o-

normativa- n\%C2\%B0-30-de-26-de-junho-de-2001.pdf>> acesso em 06/04/2020.

MEDEIROS, J. M. S. de. Produção artesanal de queijos: avaliação das condições de processamento, da qualidade higiênico sanitária e físicoquímica de queijos tipo coalho e manteiga. (Dissertação) Universidade Federal Rural do Semi-Árido, Mossoró/RN, 2016.

MINISTÉRIO DA AGRICULTURA, PECUÁRIA E ABASTECIMENTO

SECRETARIA DE DEFESA AGROPECUÁRIA. INSTRUÇÃO NORMATIVA Nº 30, DE 26 DE JUNHO

DE 2001. Disponível: http://www.agais.com/normas/leite/queijo_manteiga.htm <<acesso $12 / 04 / 20>>$.

NUNES LEITE, A. I., DE MEDEIROS, U. K., VICENTINI, N. M., DOS ANJOS, V., \& $\mathrm{DE}$

FRANÇA MEDEIROS, I. Tipos de variações de espectro infravermelho de queijo de manteiga adulterado com óleo vegetal. Revista Brasileira de Gestão Ambiental, v. 14, n. 1, p. 54-59, 2020.

OLIVEIRA, J. F. F. de.; AMARAL, A. K. D. F. J. do.; \& AQUINO, J. D. S. Mastigação: avaliação clínica, textura alimentar e tendências tecnológicas. Revista Brasileira de Ciências da Saúde, v.20, n.2, 2016.

PELLEGRINI, L. G., CASSANEGO, D. B., GUSSO, A. P., MATTANNA, P. \& SILVA, S.

V. Características físico-químicas de leite bovino, caprino e ovino. Synergismus scyentifica UTFPR, v.07, n.1, 2012. 
RAMOS, G. L. DE P. A.; NASCIMENTO, J. DOS S. Characterization of Acinetobacter spp. from raw goat Milk. Ciência Rural, v. 49, n. 10, 2019.

SANTOS, B. M., OLIVEIRA, M. E. G. D., SOUSA, Y. R. F. D., MADUREIRA, A. R. M. F.

M., PINTAdO, M. M. E., GOMES, A. M. P., .. \& QUEIROGA, R. D. C. R. D. Caracterização físico-química e sensorial de queijo de coalho produzido com mistura de leite de cabra e de leite de vaca. Revista do Instituto Adolfo Lutz, v.7; n.3, p.302-310, 2011.

SANTOS, J. V. I. dos; JUNIOR, A. C. de L.; ARAÚJO, T. G. P.; FARIAS, B. J. P. \& LISBOA, A. C. C. Avaliação da qualidade do leite de cabra em uma propriedade no município de Monteiro - PB. Revista Craibeiras de Agroecologia, v. 4, n. 1, p. e7682, Campina Grande-PB, 2019.

Schwan, A. M., Maldonado, J. G. S., Pivatto, L., \& de Souza, C. F. V. ELABORAÇÃO E AVALIAÇÃO DA QUALIDADE DE QUEIJOS FUNCIONAIS. Revista Destaques Acadêmicos, v.6, n.4, 2014.

SEIXAS, V. N. C., FÉLIX, M. R., SILVA, G. M. D., PERRONE, Í. T., \& CARVALHO, A.

F. D. Caracterização do Queijo do Marajó tipo manteiga produzido em duas estações do ano. Ciência Rural, v.45, n.4, p. 730-736, 2015.

Silva, V. L. D. M. (2012). Caracterização físico-química e de fungos filamentosos em queijo de manteiga comercializado no estado de Alagoas. (Dissertação), Faculdade de Nutrição da Universidade Federal de Alagoas, Maceió, 2012.

SILVA, F. da.; DA SILVA, G. I. S. E. L. E., TONIAL, I. B., \& DE CASTRO-CISLAGHI, F.

P. Qualidade microbiológica e físico-química de queijos coloniais com e sem inspeção, comercializados no sudoeste do Paraná. Boletim do Centro de Pesquisa de Processamento de Alimentos, v.33, n.2, 2015.

SOUSA, A. Z. B. D., ABRANTES, M. R., SAKAMOTO, S. M., SILVA, J. B. A. D., LIMA,

P. D. O., LIMA, R. N. D., ... \& PASSOS, Y. D. B. Aspectos físico-químicos e microbiológicos do queijo tipo coalho comercializado em estados do nordeste do Brasil. Arquivos do Instituto Biológico, v.81, n.1, p.30-35, 2014. 
SOUSA, Z. B. de.; ABRATES, M. R. \& SAKAMOTO, S. M. Aspectos físico-químicos e microbiológicos do queijo tipo coalho comercializado em estados do nordeste do Brasil. Arquivos do Instituto Biológico, v.81, n.1, p.30-35, 2014.

TAKAHASHI, J. A., LIMA, G. S., DOS SANTOS, G. F., LYRA, F. H., HUGHES, A. F., \& GONÇALVES, F. A. G. Fungos filamentosos e química: velhos conhecidos, novos aliados. Revista virtual de química, v.9, n.6, p.2351-2382, 2017. 


\title{
CAPÍTULO 26: SECAGEM EM CAMADA DE ESPUMA E CARACTERIZAÇÃO FÍSICO QUÍMICA DA POLPA DE GUAVIRA (Campomanesia adamantium)
}

\section{CHAPTER 26: DRYING IN LAYER OF THE FOAM, AND THE CHARACTERIZATION OF PHYSICAL-CHEMICAL, PULP OF GUAVIRA (Campomanesia Adamantium)}

\author{
Djeiniffer Juliane Rodrigues ${ }^{1}$; Claudinéia Aparecida Queli Geraldi²; Raquel Aparecida Loss, ${ }^{3}$
}

\begin{abstract}
Resumo
A guavira (Campomanesia Adamantium) é uma fruta natural do cerrado, rica em vitamina $\mathrm{C}$, e disponível alguns meses do ano. Objetivou-se avaliar a cinética de secagem da polpa de guavira em camada de espuma, e a influência da temperatura em suas propriedades físico-químicas. A secagem foi realizada em três temperaturas 50,60 e $70^{\circ} \mathrm{C}$. Representando as curvas da cinética de secagem utilizou-se modelos matemáticos Henderson e Pabis, Midilli e Kucuk e Page. A polpa in natura e desidratada foram analisadas em relação ao teor de umidade, cinzas, vitamina C, acidez e pH. Destacou-se os modelos de Midilli e Kucuk e Page, com correlação superior a 0,99, o modelo de Page foi o que melhor representou os dados experimentais. O teor de umidade da polpa in natura foi de $81,37 \%$ e as polpas desidratadas a 50,60 e $70^{\circ} \mathrm{C}$ foram de $9,4 \%, 7,2 \%$, $4,0 \%$, atendendo à resolução RDC $\mathrm{n}^{\circ} 263$ da Anvisa. O teor de vitamina $\mathrm{C}$, cinzas e acidez aumentaram de acordo com a temperatura e o $\mathrm{pH}$ permaneceu inalterado. Recomenda-se a secagem a $70^{\circ} \mathrm{C}$, uma vez que o tempo de secagem é menor e a elevação da temperatura não comprometeu as características físico químicas da polpa.
\end{abstract}

Palavras-Chave : Conservação; vida útil; sazonalidade.

\begin{abstract}
Guavira (Campomanesia Adamantium) is a fruit originally from Cerrado region, rich in vitamin $\mathrm{C}$ and only in season for some months of the year. This paper aimed at evaluating the kinetics of foam layer drying of Guariva pulp, and the influence of temperature on its physical-chemical properties. The drying process was carried out at three temperatures 50,60 and $70{ }^{\circ} \mathrm{C}$. In order to represent the drying kinetics curves, three mathematical models were used, Henderson and Pabis, Midilli and Kucuk, and Page. Both in natura and dehydrated pulps were analyzed for their moisture, ash, vitamin $\mathrm{C}$, acidity and $\mathrm{pH}$ contents. The Midilli and Kucuk and Page models stood out with a correlation greater than 0.99, the Page model was the one which best represented the experimental data. The moisture content of the in natura pulp was $81.37 \%$ whereas the moisture content of the dehydrated pulps at $50^{\circ} \mathrm{C}$ was $9.4 \%$, at $60^{\circ} \mathrm{C}$ was $7.2 \%$, and at $70{ }^{\circ} \mathrm{C}$ was $4.0 \%$, which is in accordance with the ANVISA resolution 263 . The contents of vitamin $\mathrm{C}$, ash and acidity increased according to the temperature, but the $\mathrm{pH}$ remained unchanged. It is recommended to dry at $70^{\circ} \mathrm{C}$, since the drying time is shorter and the rise in temperature did not compromise the physical-chemical characteristics of the pulp.
\end{abstract}

Keywords: Conservation; Self-life; seasonality.

\footnotetext{
${ }^{1}$ Engenharia de Produção Agroindustrial, UNEMAT: Universidade do Estado do Mato Grosso, djeini_juliane@hotmail.com

${ }^{2}$ Doutora, Faculdade de Arquitetura e Engenharia - Universidade do Estado de Mato Grosso, raquelloss@unemat.br

${ }^{3}$ Doutora, Faculdade de Arquitetura e Engenharia - Universidade do Estado de Mato Grosso, claudigeraldi@onda.om.br
} 


\section{Introdução}

Segundo a Secretaria de Agricultura e Abastecimento (SEAB), o Brasil ocupa a terceira colocação no ranking mundial da produção de frutas, com uma produção de 40,2 milhões de toneladas (SEAB, 2017). No entanto, os produtores enfrentam muitos problemas com relação a conservação destes alimentos devido ao excesso de umidade, oscilações na temperatura advindas das alterações climáticas com estações chuvosas ou secas, além de perdas ocasionadas pela ação do homem como, o transporte em grandes distâncias, manuseio incorreto ou excessivo e acondicionamento não adequado. Tais fatores favorecem a atuação de enzimas oxidantes resultando em alterações na composição das frutas (PEREIRA; BRAVIN; OLIVO, 2017). Outro fator que causa instabilidade para o setor é a sazonalidade do produto, representada principalmente em espécies de origem nativa, como a guavira, que amadurecem apenas nos meses de novembro e dezembro (EMBRAPA, 2015).

Campomanesia adamantium, comumente conhecido como "guavira" ou "guabiroba" floresce entre setembro e outubro, e frutificação entre novembro e dezembro. Seus frutos são saborosos, cítricos e levemente adocicados, sendo consumidos in natura ou usados na indústria alimentícia como aromatizantes na indústria de bebidas, licores, sucos, doces e sorvetes (OLIVEIRA et al., 2017).

A secagem é provavelmente um dos métodos mais antigo usado para preservar os alimentos. Frutas e vegetais são secos para inibir a atividade enzimática microbiana e a deterioração da qualidade. Como resultado da redução da atividade de água as mudanças físicas e químicas se minimizam durante o armazenamento aumentando o prazo de validade do material seco. Além de reduzir os custos de transporte e armazenamento uma vez que se reduz o peso e o volume do produto seco (ARAL e BESE, 2016). Diante da sazonalidade da guavira somado ao seu alto teor de água torna-se necessário desenvolver tratamentos pós-colheita, como a secagem, para preservar as suas características e disponibilizá-la para comercialização por períodos mais longos ou para posterior processamento.

A secagem em camada de espuma é um método relativamente simples e de baixo custo, que se baseia no uso de agentes estabilizadores de espuma durante a secagem. As vantagens deste método são as menores temperaturas e tempo de secagem, atribuídos à maior área de superfície exposta ao ar, permitindo maiores taxas de secagem em relação a outras técnicas de secagem (FRANCO et al., 2016).

Neste contexto o objetivo do presente estudo é aplicar a técnica de secagem em camada de espuma, verificando a influência da temperatura nas propriedades físico-químicas da polpa de guavira. Para alcançar o objetivo geral, os seguintes objetivos específicos foram delineados; 
a) obter a cinética de secagem da polpa de guavira em diferentes temperaturas. b) representar os dados de secagem por modelos matemáticos. c) determinar as características físico-químicas da polpa de guavira antes e após a secagem.

\section{Material e Métodos}

As análises foram realizadas nos laboratórios da Universidade do Estado de Mato Grosso, na cidade de Barra do Bugres - MT. Sendo eles, Laboratório de Química e Laboratório de Matérias Primas para Produção de Biodiesel (LMPPB).

Para o desenvolvimento deste trabalho utilizou-se como matéria-prima, a guavira, proveniente da cidade de Rio Brilhante, Estado de Mato Grosso do Sul - Brasil, e o aditivo emulsificante Emustab seleta (composto por monoglicerideos de ácidos graxos, monoestearato de sorbitana, polioxietileno de monoestearato de sorbitana e sorbato de potássio) adquirido no comércio local de Barra do Bugres - MT.

As frutas foram despolpadas e trituradas em um liquidificador doméstico até homogeneidade. Adicionou-se emulsificante na concentração de $4 \%$ em relação a massa de polpa e a mistura agitada em batedeira doméstica por 8 minutos em velocidade máxima, obtendo a espuma.

Na realização da secagem, a espuma foi distribuída em placas de Petri (10 g em cada placa) e submetida a estufa de circulação forçada de ar (Quimis 0314 M222), na qual algumas amostras foram acondicionadas a $50^{\circ} \mathrm{C}$, outras a $60^{\circ} \mathrm{C}$ e outras a $70^{\circ} \mathrm{C}$. Para a obtenção da curva de secagem, mediu-se a massa a cada 15 minutos até que a mesma ficasse constante. As curvas de secagem foram realizadas em triplicata. As massas obtidas foram convertidas em razão de umidade, conforme Equação 1.

$$
R U=\frac{U^{*}-U e^{*}}{U i^{*}-U e^{*}} \quad \text { Equação } 1
$$

Sendo, Ue* o teor de água de equilíbrio do produto; Ui* o teor de água inicial do produto; $\mathrm{U}^{*}$ o teor de água em um ponto qualquer da curva de secagem. Todas as umidades foram expressas em base seca.

Os dados da cinética de secagem, foram representados pelos modelos empíricos de Henderson e Pabis (1961), Page (1949) e Midilli e Kucuk (2002) (Tabela 1) para verificar qual se ajusta ao comportamento real da perda de umidade ao longo do tempo. A escolha do melhor 
modelo foi realizada por meio do coeficiente de determinação $\left(\mathrm{R}^{2}\right)$, pelo erro médio padrão e pelo princípio da parcimônia.

Tabela 1 - Modelos matemáticos utilizados para descrever a cinética de secagem.

DESIGNAÇÃO DO MODELO MODELO

\begin{tabular}{lc}
\hline Henderson e Pabis & $R U=a \exp (-k t)$ \\
\hline Page & $R U=\exp \left(-k t^{n}\right)$ \\
Midilli e Kucuk & $R U=\exp \left(-k t^{n}\right)+b t$ \\
\hline & Fonte: Elaborado pelos autores (2019).
\end{tabular}

Onde: RU razão do teor de umidade do produto, adimensional; t é o tempo de secagem, min; k, constante de secagem, $\min ^{-1}$, e a, b, n são os coeficientes dos modelos.

As amostras foram submetidas à análise de $\mathrm{pH}$, umidade, cinzas, acidez e vitamina $\mathrm{C}$ antes e após a secagem. Todas as análises foram realizadas em triplicata, para maior confiabilidade nos resultados obtidos.

Para a determinação do $\mathrm{pH}$ mediu-se $3 \mathrm{~g}$ de polpa de guavira diluída em 30mL de água destilada. O mesmo foi determinado por meio de um pHmetro de bancada (TECNOPON Mpa 210), previamente calibrado com solução tampão de pH 4,0 e 7,0, segundo o método 017/IV do manual do Instituto Adolfo Lutz (2008).

Na determinação de umidade mediu-se $10 \mathrm{~g}$ de amostra em placa de Petri, previamente tarada e seca, e colocadas em estufa com circulação de ar a $105^{\circ} \mathrm{C}$ até massa constante, conforme metodologia 012/IV do Manual do Instituto Adolfo Lutz (2008).

O teor de ácido ascórbico foi determinado a partir da metodologia 364/IV do manual do Instituto Adolfo Lutz (2008), na qual utilizou-se 5g de amostra diluída, 50mL de água destilada, com adição dos reagentes ácido sulfúrico a $20 \%$, iodeto de potássio a $10 \%$ e solução de amido a $1 \%$, e posteriormente titulou-se com iodato de potássio.

O teor de cinzas determinou-se conforme metodologia 018/IV do Instituto Adolfo Lutz (2008). Em cadinhos secos e tarados, foi medido $5 \mathrm{~g}$ de amostra e aquecidas na mufla a $550^{\circ} \mathrm{C}$, até obtenção de uma coloração branca ou acinzentada.

A acidez foi determinada por titulação potenciométrica com $\mathrm{NaOH} 0,1 \mathrm{~mol} / \mathrm{L}$, sendo os resultados expressos em \% de ácido cítrico, conforme método 016/IV do manual Instituto Adolfo Lutz (2008).

A comparação entre as médias foi realizada por meio de regressão linear e aplicação do teste de Tukey $(\mathrm{p}<0,05)$, utilizando softwares estatísticos. 


\section{Resultados e Discussão}

\section{Cinética de secagem}

As análises de curvas de secagem e a determinação do teor de água do produto permitem compreender melhor o processo, e deste modo possibilitam escolher o procedimento, tratamento, equipamento e temperatura adequados para se realizar a desidratação do alimento, com objetivo de manter a qualidade sensorial e tecnológica (SILVA, 2019). A Figura 1 representa os dados experimentais da cinética de secagem obtidas por meio secagem em estufa de circulação de ar, nas temperaturas as de 50,60 e $70^{\circ} \mathrm{C}$.

Figura 1 - Curva de secagem em camada de espuma da polpa de guavira em diferentes temperaturas

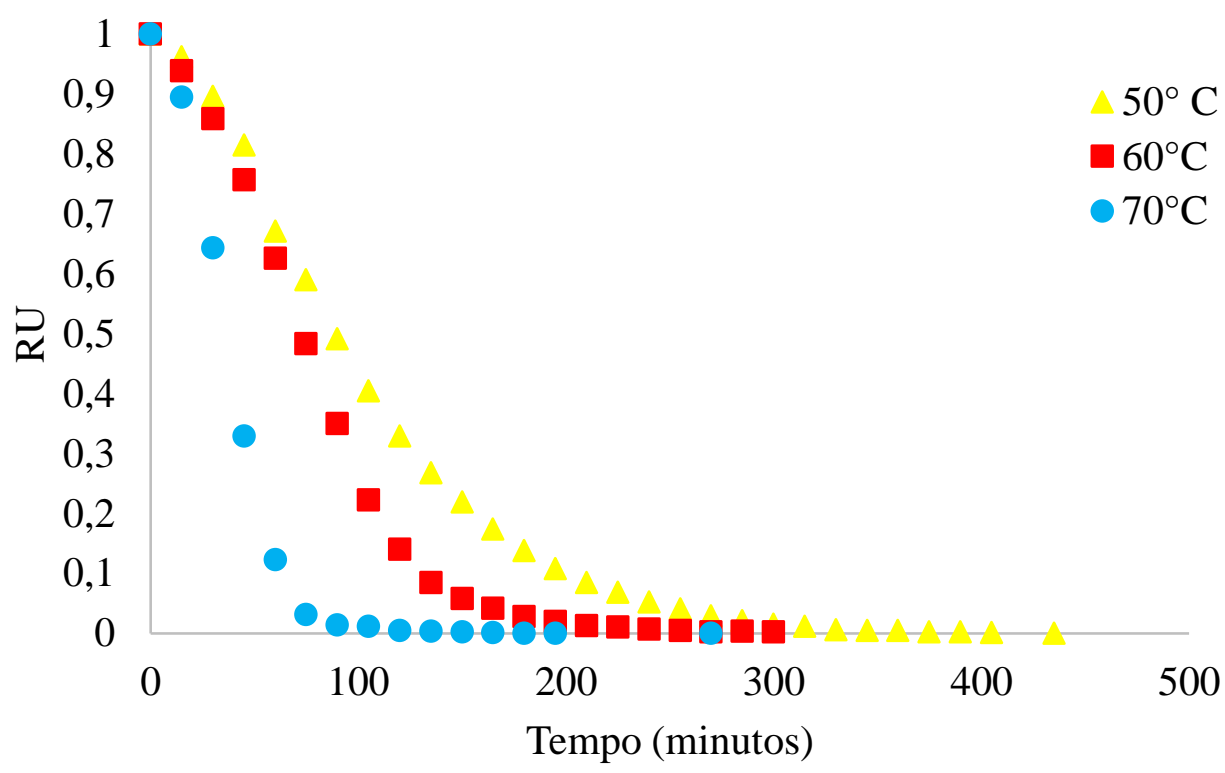

Fonte:

Elaborado pelos autores (2019).

As curvas da cinética obtidas apresentaram comportamento típico de secagem, conforme descrito por Fellows (2006), Silva (2019), e Celestino (2010). O início do processo é caracterizado pelo período de taxa constante, no qual água no alimento não apresenta nenhuma resistência para ser eliminada, uma vez que a água do interior do alimento difunde para a superfície deste na mesma velocidade da água evaporada, e este, permanece com a superfície úmida até a umidade crítica, representada na Tabela 2. 
Tabela 2 - Umidade crítica nas temperaturas 50,60 e $70^{\circ} \mathrm{C}$

\begin{tabular}{ccc}
\hline Temperatura & Tempo (min) & Umidade livre crítica $\left(\mathbf{K g H}_{2} \mathbf{O} / \mathbf{K g s s}\right)$ \\
\hline $\mathbf{5 0}^{\circ} \mathbf{C}$ & 300 & 1,051 \\
\hline $\mathbf{6 0}^{\circ} \mathbf{C}$ & 210 & 1,090 \\
\hline $\mathbf{7 0}^{\circ} \mathbf{C}$ & 105 & 1,118 \\
\hline
\end{tabular}

Fonte: Elaborado pelos autores (2019).

Após a umidade crítica, tem-se início o período de taxa decrescente, reduzindo o teor de umidade livre reduz além do crítico, 0,094, 0,073, 0,040 $\mathrm{KgH}_{2} \mathrm{O} / \mathrm{Kg}$ Ss, para as temperaturas de 50,60 e $70^{\circ} \mathrm{C}$, respectivamente, e a taxa de secagem se aproxima de zero, sendo chamado de ponto de equilíbrio, ou seja, o alimento fica em equilíbrio com o ar de secagem.

O tempo necessário para alcançar a umidade de equilíbrio foi maior para $50^{\circ} \mathrm{C}(300$ minutos), enquanto que esse tempo foi reduzido para 210 minutos para $60^{\circ} \mathrm{C}$ e 105 minutos para $70^{\circ} \mathrm{C}$. Esta diminuição no tempo de secagem pode ser explicada pela premissa de que o aumento da temperatura aumenta a pressão de vapor na amostra, e consequentemente causa a remoção da umidade do interior da polpa da guavira mais rapidamente à superfície. Aral e Bese (2016), encontraram a mesma diminuição no tempo de secagem após o aumento da temperatura em estudos da secagem de frutos do espinheiro branco.

As curvas de secagem foram representadas a partir de modelos matemáticos, sendo que, na Tabela 3 são apresentados os valores dos parâmetros estatísticos utilizados para a comparação entre os três modelos analisados por meio de regressão não linear. 
Tabela 3 - Parâmetros ajustados dos modelos para a cinética de secagem da polpa de guavira em camada de

\begin{tabular}{|c|c|c|c|c|}
\hline Modelo & Parâmetro & $\begin{array}{l}\text { espuma } \\
\mathbf{5 0}^{\circ} \mathbf{C}\end{array}$ & $60^{\circ} \mathrm{C}$ & $7^{\circ} \mathrm{C}$ \\
\hline \multirow{5}{*}{$\begin{array}{l}\text { Handerson } \\
\text { e Pabis }\end{array}$} & $\mathrm{a}$ & 1,274069 & 1,193782 & 1,000010 \\
\hline & $\mathrm{k}\left(\min ^{-1}\right)$ & 0,011723 & 0,016033 & 0,032443 \\
\hline & $\mathrm{n}$ & 0,000000 & 0,000000 & 0,000000 \\
\hline & $\begin{array}{l}\text { Coeficiente de } \\
\text { determinação R }\end{array}$ & 0,986068 & 0,973920 & 0,968662 \\
\hline & Erro & 0,982936 & 1,242921 & 0,820304 \\
\hline \multirow{5}{*}{$\begin{array}{c}\text { Midilike } \\
\text { Kucuk }\end{array}$} & $\mathrm{a}$ & 1,007082 & 0,999622 & 1,005116 \\
\hline & $\mathrm{k}\left(\min ^{-1}\right)$ & 0,000889 & 0,000289 & 0,000547 \\
\hline & $\mathrm{n}$ & 1,484823 & 1,821534 & 2,001636 \\
\hline & $\begin{array}{l}\text { Coeficiente de } \\
\text { determinação R }\end{array}$ & 0,999535 & 0,999319 & 0,999610 \\
\hline & Erro & 0,141440 & 0,209155 & 0,099886 \\
\hline \multirow{4}{*}{ Page } & $\mathrm{k}\left(\min ^{-1}\right)$ & 0,001022 & 0,000165 & 0,001509 \\
\hline & $\mathrm{n}$ & 1,457283 & 1,946679 & 1,733741 \\
\hline & $\begin{array}{c}\text { Coeficiente de } \\
\text { determinação R }\end{array}$ & 0,999498 & 0,999623 & 0,998097 \\
\hline & Erro & 0,142144 & 0,187894 & 0,215303 \\
\hline
\end{tabular}

Fonte: Elaborado pelos autores (2019).

Sendo: $\mathrm{k}$ o coeficiente de secagem $\left(\mathrm{min}^{-1}\right)$, a e $\mathrm{n}$ são constantes dos modelos e t: tempo de secagem (min).

Para verificar o grau de adequação dos modelos estudados aos dados experimentais obtidos na secagem em camada de espuma da guavira em diferentes temperaturas, observou-se a magnitude do coeficiente de determinação $\mathrm{R}$, os menores valores para o erro médio, bem como a quantidade de parâmetros de cada modelo.

Neste contexto é possível verificar que os modelos de Midilik e Kucuk, e Page, são os que possuem maior ajustes aos valores experimentais da secagem, isso por que nas três temperaturas obteve-se valores de R acima de 0,99. Além disso, segundo Cardoso et al. (2017) é importante ressaltar que para representar o fenômeno da secagem os valores aceitáveis de $\mathrm{R}$ devem ser superiores a 0,998. Desta forma, tanto o modelo de Midilik e Kucuk, quanto o de Page atende essas recomendações (Tabela 3). Resultados similares foram encontrados para a secagem de Moringa oleífera L. onde o modelo de Midilik e Kucuk, na temperatura $60^{\circ} \mathrm{C}$ foi a mais satisfatório (NASCIMENTO; BIAGI; OLIVEIRA, 2015). Moscon et al. (2017), observou evento semelhante na secagem de grãos de quinoa, nas temperaturas de 40,60 e $70^{\circ} \mathrm{C}$. Estudos 
realizados por Rigueto et al. (2018) analisando a cinética de secagem em camada de espuma da polpa de uvaia verificaram resultados semelhantes quanto à adequação dos modelos de Midilik e Kucuk e Page. Leal, Geraldi e Klassen (2016) ao analisarem a cinética de secagem em camada de espuma do abacaxi, acerola e carambola, nas mesmas condições de temperatura, também atestaram resultados semelhantes, como melhor adequação do modelo de Page.

$\mathrm{O}$ modelo de Handerson e Pabis foi o modelo que apresentou valores para R muito variados e disformes. No entanto, ao analisar a polpa de buriti Cardoso et al. (2017) constatou que este modelo foi mais representativo. Este fato pode ser explicado pelo fato de que a guavira como buriti são frutas de espécies diferentes, nativas e sazonais e, portanto, possuem comportamentos variados, além disso elas possuem composição de frutos diferentes.

Segundo Moscon et al. (2017), o coeficiente de determinação entre 0 e 1 mesmo mostrando a força de relação entre os dados, não constitui um critério suficiente se analisado de forma isolado. Deste modo avalia-se também o erro médio além dos parâmetros, a, k e n.

Os valores de erro médio relativo indicam desvio dos dados experimentais em relação à curva estimada pelo modelo, assim, o modelo que apresenta menor magnitude no que tange ao erro é o modelo com maior ajuste aos valores observados. O ideal é que o erro seja o mais próximo de zero, consideram-se modelos com valores de erro médio relativo superiores a $10 \%$ inadequados para a descrição de um determinado fenômeno de secagem, (ARAÚJO et al. 2017). Desta forma, em relação ao erro, todos os modelos utilizados podem ser considerados satisfatórios. No entanto, o modelo de Handerson e Pabis apresenta valores mais elevados. Enquanto que os modelos de Midilik e Kucuk e de Page apresentam erros próximos entre si, com exceção da temperatura de $70^{\circ} \mathrm{C}$, que o modelo de Midilik e Kucuk apresenta um erro menor. Resultados similares foram encontrados também na secagem em camada delgada de crambe a $45,60,75^{\circ} \mathrm{C}$ (COSTA et al., 2015), na secagem em camada de espuma de polpa de manga (GUIMARÃES et al., 2017) e também para secagem de folhas de hortelã (GASPARIN; CHRIST e COELHO, 2017).

Em se tratando dos parâmetros dos modelos tais como, "a", "k" e "n", pode se observar que o coeficiente "a" tende a diminuir conforme se aumenta a temperatura nos modelos Handerson e Pabis e Midiliki e Kucuk. Enquanto que, o coeficiente "k", possui tendência de ter seus valores aumentados conforme a alteração das temperaturas de 50 para $70^{\circ} \mathrm{C}$, isso ocorre devido a dependência deste parâmetro com a temperatura. Esse comportamento também foi observado por Alexandre (2005), em seu estudo de cinética de secagem em camada de espuma da polpa de pitanga, e por Silva et al. (2008), ao estudar cinética de secagem em camada de 
espuma da polpa de tamarindo e por Silva Filho et al. (2016) no estudo da cinética de secagem de polpa de manga.

No parâmetro "n” também é possível verificar dependência direta com a temperatura conforme aumento de 50 para $70^{\circ} \mathrm{C}$, este possui aumento considerável em seus valores. Esta dependência também foi constatada por Araújo et al. (2017) no estudo da secagem em camada de espuma da polpa de acerola ao testar o modelo de Page. A qualidade dos ajustes dos modelos aos dados experimentais pode ser melhor visualizada na Figura 2. 
RODRIGUES D.J., GERALDI C.A.Q e LOSS R.A.

Figura 2 - Modelagem dos dados experimentas pelos modelos de Handerson e Pabis, Midilick e Kucuk e Page em diferentes temperaturas: a) $50^{\circ} \mathrm{C}$; b) $60^{\circ} \mathrm{c} \mathrm{e} \mathrm{c)} 70^{\circ} \mathrm{C}$

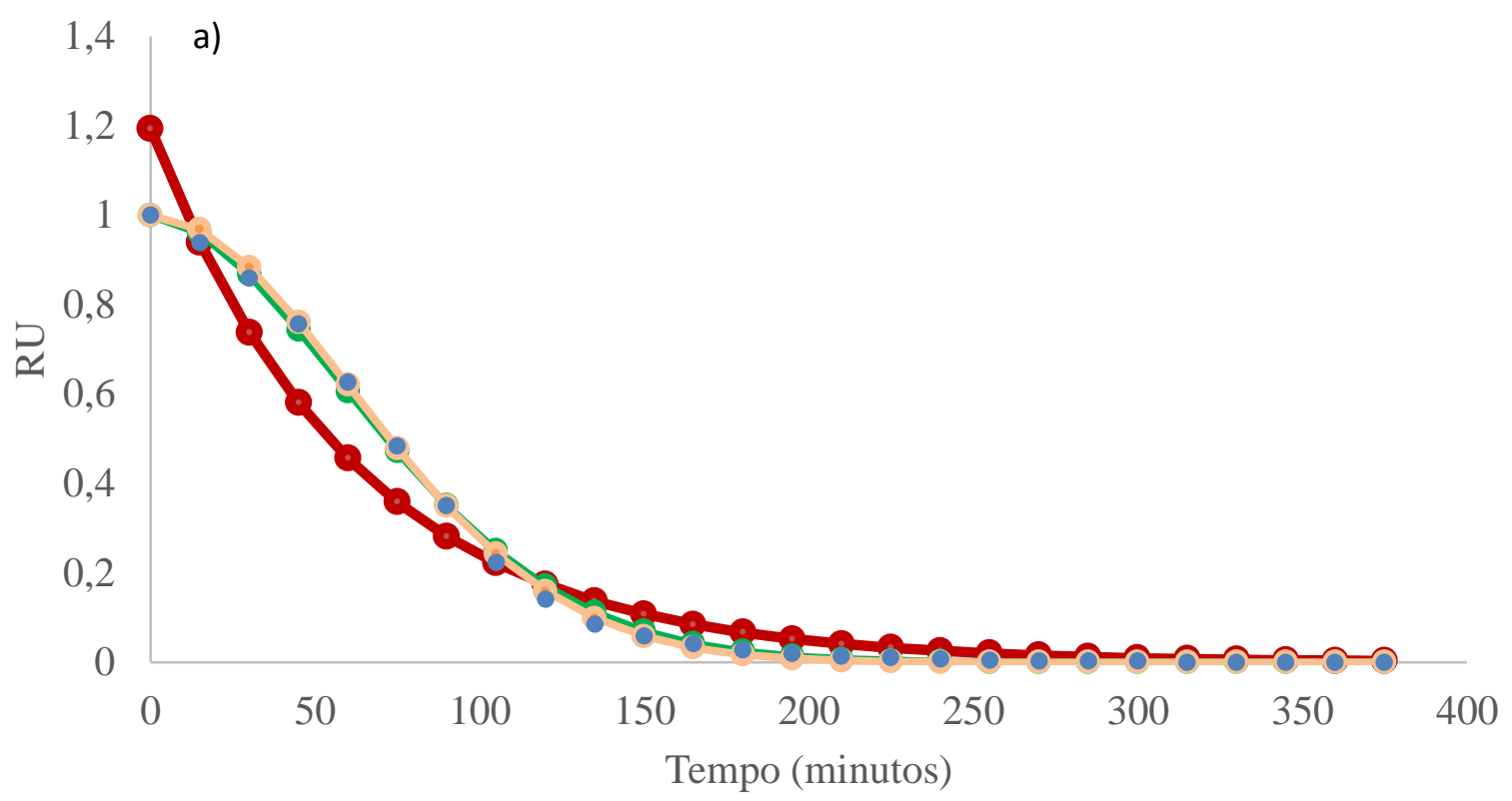

- Dados Experimentais -Handerson e Pabis —-Midilik e Kucuk —-Page

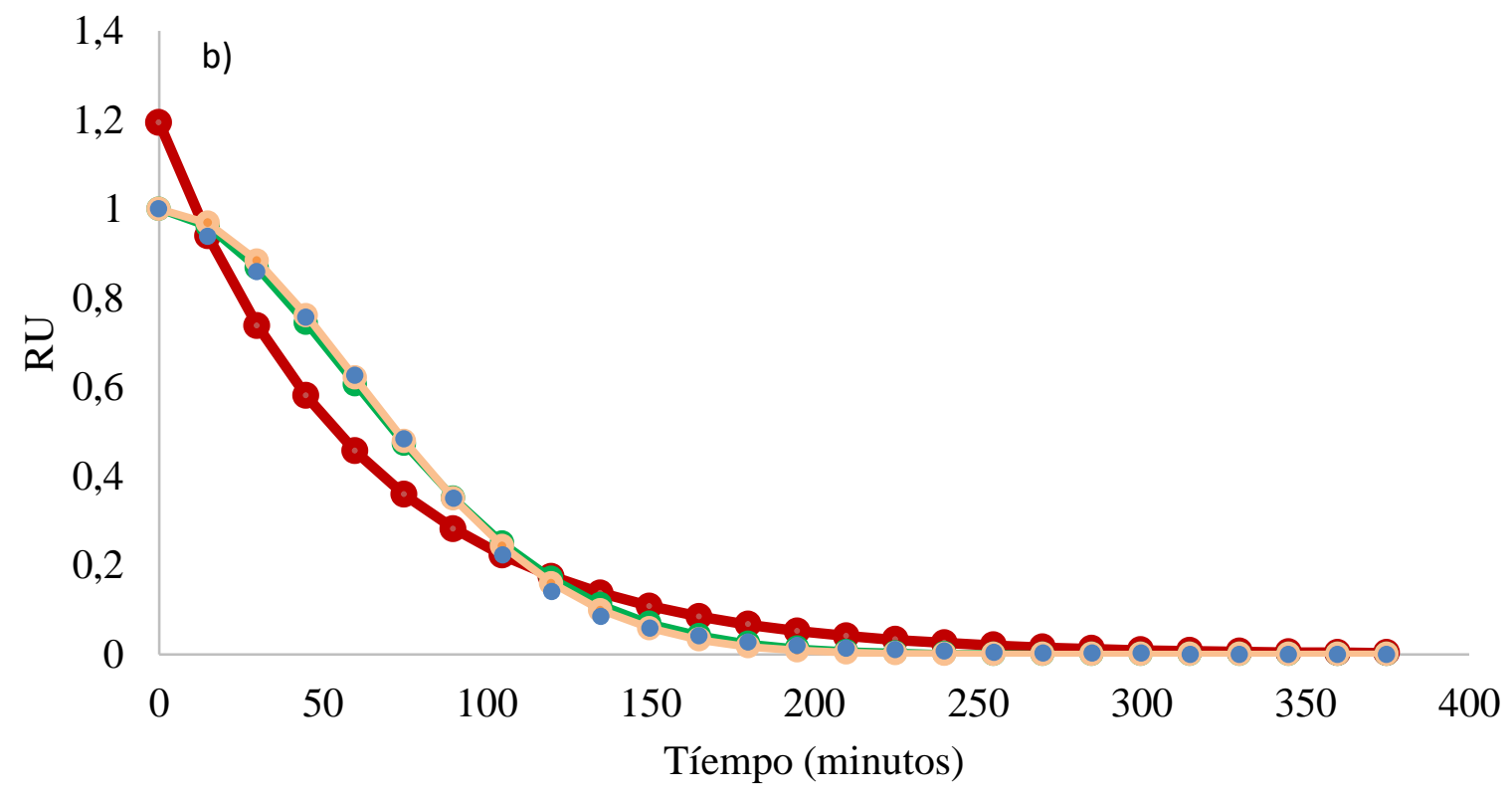

- Dados Experimentais - - Handerson e Pabis - - Midilik e Kucuk $-\odot-$ Page 


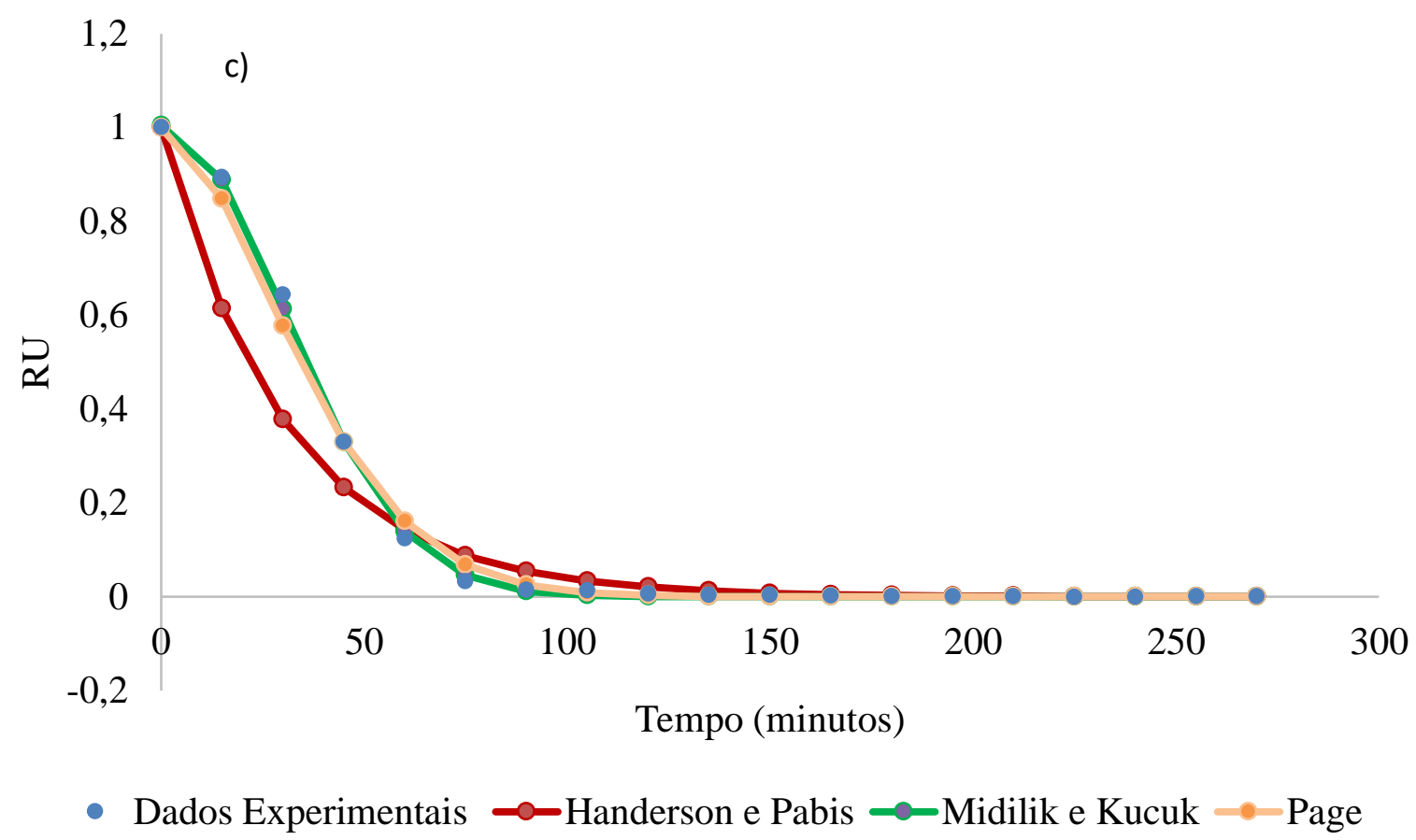

Fonte: Elaborado pelos autores (2019).

Por meio da Figura 2 é possível observar que tanto o modelo de Midilik e Kucuk quanto o modelo de Page se ajustam de forma satisfatória a curva dos dados experimentais. Contudo, no que tange ao número de parâmetros dependentes da temperatura o modelo de Page se sobressai em relação ao primeiro, uma vez que o mesmo possui apenas dois coeficientes, enquanto que o modelo de Midilik e Kucuk apresenta 4 coeficientes. Desta forma, o modelo de Page foi considerado o que melhor representa os dados experimentais.

\section{Análises Físico-químicas}

A guavira é uma planta nativa do cerrado brasileiro, presente nas regiões centro-oeste e sudeste, ela apresenta comportamento sazonal e pode ser consumida tanto na forma in natura, como na indústria de alimentos e bebidas. Seus frutos possuem atributos de qualidade como elevada acidez, ácido ascórbico (vitamina C), minerais, fibras alimentares e hidrocarbonetos, (VIEIRA et al., 2018). Desta forma as análises físico-químicas contribuem para o aprimoramento do conhecimento sobre a espécie, aproveitando suas formulações para agregar valor aos produtos desenvolvidos a partir dela (RESENDE et al., 2019). Neste contexto, os atributos analisados no presente estudo foram a vitamina $\mathrm{C}$, umidade, cinzas, acidez e $\mathrm{pH}$ na guavira in natura e desidratada. 
$\mathrm{O}$ pH é um indicador químico, que indica a concentração de íons de hidrogênio $\left(\mathrm{H}^{+} \mathrm{e}\right.$ $\mathrm{H}_{3} \mathrm{O}^{+}$) em um meio, sendo responsável pela característica ácida deste. Os valores inferiores a 7,0 indica meio ácido, valores superiores a 7,0 meio básico ou alcalino e igual a 7,0 meio neutro (CUNHA et al., 2016). Por meio da Tabela 4 é possível observar que o pH da amostra se manteve estável durante a desidratação, mostrando que a temperatura não influencia na alteração do $\mathrm{pH}$, isso ocorre devido a secagem ser um processo de retirada de água, que por sua vez, possui $\mathrm{pH}$ neutro, deste modo a retirada da mesma não altera o $\mathrm{pH}$ da amostra.

Tabela 4 - $\mathrm{pH}$ das polpas de guavira in natura e desidratadas em diferentes temperaturas

\begin{tabular}{ccc}
\hline Polpa & $\mathbf{p H}$ & $\mathbf{C V}(\boldsymbol{\%})$ \\
\hline in natura & $4,55 \pm 0,021^{\mathrm{a}}$ & 0,47 \\
$50^{\circ} \mathrm{C}$ & $4,51 \pm 0,040^{\mathrm{a}}$ & 0,93 \\
$60^{\circ} \mathrm{C}$ & $4,47 \pm 0,014^{\mathrm{a}}$ & 0,32 \\
$70^{\circ} \mathrm{C}$ & $4,47 \pm 0,014^{\mathrm{a}}$ & 0,32 \\
\hline
\end{tabular}

Letras iguais na mesma coluna, médias são iguais, pelo teste de Tukey ao nível de significância de $5 \%$ ( $<0,005)$. Fonte: Elaborado pelos autores (2019).

$\mathrm{O}$ pH da guavira entre 4,4 a 4,6 favorece a conservação da fruta, pois inibe a atividade de enzimas que causam oxidação e, na faixa de pH 4 e 4,5 a microbiota que se desenvolve no alimento é restrita, proporcionando maior tempo de prateleira para alimentos que apresentam este intervalo de pH (TELLES, 2012). Scalon et al. (2012) encontraram resultados similares ao analisar a polpa de guavira in natura, obtendo um $\mathrm{pH}$ variando entre 3,9 e 4,4, sob diferentes revestimento e temperaturas de armazenamento. Demenciano et al. (2015) ao analisar a polpa congelada da guavira registraram pH de 4,32 que é próximo ao encontrado neste estudo.

A umidade presente nas frutas é uma das características que a tornam altamente perecíveis pois, torna o ambiente favorável a proliferação de micro-organismo que oxidam e a putrificam. O alimento quando desidratado apresenta um percentual mínimo de umidade, denominada de umidade residual, que contribui para a inibição do crescimento de microorganismos patogênicos e deteriorantes. Na Tabela 5 pode-se verificar o teor de umidade encontrado na guavira in natura e os teores de umidade residual encontrado posterior a secagem.

Tabela 5 - Umidade da polpa de guavira in natura e desidratada em diferentes temperaturas

\begin{tabular}{ccc}
\hline Polpa & Umidade (\%) & CV (\%) \\
\hline in natura & $81,37 \pm 0,008^{\mathrm{a}}$ & 1.07 \\
$50^{\circ} \mathrm{C}$ & $9,40 \pm 0,001^{\mathrm{b}}$ & 1,08 \\
$60^{\circ} \mathrm{C}$ & $7,20 \pm 0,002^{\mathrm{c}}$ & 2,63 \\
$70^{\circ} \mathrm{C}$ & $4,00 \pm 0,002^{\mathrm{d}}$ & 4,69 \\
\hline
\end{tabular}

Letras iguais na mesma coluna, médias são iguais, pelo teste de Tukey ao nível de significância de 5\% (p<0,005).

Fonte: Elaborado pelos autores (2019). 
A umidade final obtida em todas as temperaturas, está de acordo com padrão de umidade estabelecido pela legislação brasileira, que determina um teor inferior a $25 \%$ em produtos de frutas secas ou desidratadas (ANVISA, 2005). Contudo a secagem do presente estudo foi realizada em manto de camada de espuma, ou seja, após a desidratação da polpa de guavira o produto obtido foi uma farinha. Neste contexto comparou-se os resultados obtidos no presente com a legislação estabelecida a produtos desidratados em forma de farinhas de origem vegetal, teor de $15 \%(\mathrm{~m} / \mathrm{m})$, constatando assim que o índice de umidade encontrado neste trabalho está de acordo com o preconizado pela ANVISA.

Poucos estudos com relação a caracterização físico-química de guavira (Campomanesia adamantium), nas mesmas condições são encontrados na literatura, porém comparando a cinética de secagem de frutas da mesma família, a família Myrtaceae, resultados similares são encontrados por Machado et al. (2012) ao estudar a cinética de secagem do abacaxi da variedade pérola, observou que a umidade residual a $70^{\circ} \mathrm{C}$ é bem menor comparado a demais temperaturas.

Santos (2018) afirma que leveduras e bactérias são susceptíveis a crescimento e manifestação em materiais com umidade em torno de $30 \%$. Portanto, o produto da desidratação de polpa de guavira é ideal para armazenamento, aumentando de forma considerável sua vida útil. Estes valores também foram encontrados com estudos de farinhas obtidas com sementes de araçá-amarelo e araçá-vermelho, através da secagem por meio de convecção natural, em temperatura ambiente, por Mayer (2015) que obteve índices de umidade de 7,56\% e 11,34\%.

O teor de cinzas trata-se da quantidade de substâncias minerais presentes nos alimentos, após a queima do material, retirando toda a matéria orgânica e umidade do produto restando somente o produto inorgânico. Na Tabela 6 estão apresentados os teores de cinzas obtidos por meio da calcinação da polpa de guavira, in natura e após desidratação em estufa de circulação de ar.

Tabela 6 - Teor de cinzas da polpa de guavira in natura e desidratadas em diferentes temperaturas

\begin{tabular}{ccc}
\hline Polpa & Cinzas $(\%)$ & CV (\%) \\
\hline in natura & $0,61 \pm 0,0001^{\mathrm{a}}$ & 1,41 \\
$50^{\circ} \mathrm{C}$ & $2,60 \pm 0,0003^{\mathrm{b}}$ & 1,42 \\
$60^{\circ} \mathrm{C}$ & $2,62 \pm 0,0002^{\mathrm{b}}$ & 0,84 \\
$70^{\circ} \mathrm{C}$ & $2,55 \pm 0,0003^{\mathrm{c}}$ & 1,56 \\
\hline
\end{tabular}

Letras iguais na mesma coluna, médias são iguais, pelo teste de Tukey ao nível de significância de 5\% (p<0,005).

Fonte: Elaborado pelos autores (2019). 
Pela Tabela 6 verifica-se que houve um aumento significativo no teor de cinzas do produto in natura para os desidratados, aumento de cerca de $226 \%$ de material inorgânico, ou seja, aumento de minerais na amostra. Segundo Wijewardana et al. (2016), este aumento no teor de cinzas ocorre devido a remoção de umidade que tende a aumentar a concentração de nutrientes. Elias et al. (2008) também encontrou aumento significativo no teor de cinzas após desidratação de polpa de caqui, aumento de cerca de 100\%, Nunes et al. (2017) ao analisar a cinética de secagem em estufa de circulação de ar forçada de resíduos de abacaxi obteve conteúdo de cinzas nos valores 2,82, 2,87 e 2,86 g (100g-1) nas temperaturas de 50, 60 e $70^{\circ} \mathrm{C}$ respectivamente, valores próximos aos encontrados neste estudo e nas mesmas condições de temperatura.

Outro fator que influenciou no conteúdo das cinzas foi a adição de emustab para a formação da espuma, para posterior secagem. O emustab que é um tipo de emulsificante tem em sua composição eletrólitos minerais, moléculas tensoativas, estabilizantes com cristais líquidos e macromoléculas dissolvidas na fase contínua, está composição implica no aumento da massa de material inorgânico da amostra, uma vez que ela auxilia na concentração de nutrientes (FERREIRA, 2011).

Rigueto et al. (2018), verificando a cinética de secagem da uvaia (Eugenia pyriformis) em camada de espuma, utilizando o mesmo método descrito no presente sob mesma condição de temperatura, também registrou a o aumento da concentração do conteúdo de cinzas da polpa in natura para a desidratada com teores de $0,24 \%$ para a amostra in natura e 2,62, 2,95, 3,24 $\%$ para os tratamentos de 50,60 e $70{ }^{\circ} \mathrm{C}$.

Um estudo publicado pelo IBGE - Instituto Brasileiro de Geografia e Estatística, com relação a composição dos alimentos (1999), apresentou teores centesimais (g/100g) de umidade e cinzas para a guavira, de $82,8 \%$ e $0,7 \%$, respectivamente, valores muito próximos a este estudo onde o conteúdo de umidade foi de $81,37 \%$ e cinzas $0,61 \%$.

A vitamina $\mathrm{C}$ é um micronutriente indispensável ao consumo humano, o Ministério da Saúde recomenda a ingestão diária de 45mg desta vitamina (BRASIL, 2004). Alguns estudos já haviam comprovado o elevado teor de ácido ascórbico presente nos frutos maduros de guavira assim como os valores encontrados no presente estudo e apresentados na Tabela 7. 
Tabela 7 - Teor vitamina $\mathrm{C}$ da polpa de guavira in natura e desidratadas em diferentes temperaturas

\begin{tabular}{ccc}
\hline Polpa & Vitamina C $(\mathbf{m g} / \mathbf{1 0 0 g})$ & CV $(\boldsymbol{\%})$ \\
\hline in natura & $629,29 \pm 15,5^{\mathrm{a}}$ & 2,46 \\
$50^{\circ} \mathrm{C}$ & $561,76 \pm 26,0^{\mathrm{b}}$ & 4,63 \\
$60^{\circ} \mathrm{C}$ & $894,42 \pm 44,4^{\mathrm{c}}$ & 4,97 \\
$70^{\circ} \mathrm{C}$ & $1438,48 \pm 3,2^{\mathrm{d}}$ & 0,22 \\
\hline
\end{tabular}

Letras iguais na mesma coluna, médias são iguais, pelo teste de Tukey ao nível de significância de 5\% (p<0,005).

Fonte: Elaborado pelos autores (2019).

O teor de vitamina $\mathrm{C}$ para a guavira in natura encontrado neste trabalho é alto em relação á valores encontrados na literatura, Dresch et al. (2015) e Vallilo et al. (2006) registraram um teor de $234 \mathrm{mg}$ em $100 \mathrm{~g}$ de polpa guavira. Este resultado está atribuído ao de fato de que no presente estudo a análise foi realizado com o conjunto polpa + casca, devido à dificuldade de extração da polpa. A casca por sua vez, assim como as folhas e frutos da guavira, também é rica em ácido ascórbico e demais composições. Segundo Oliveira et al. (2017) o conjunto folhas, casca, frutos de $C$. adamantium possuem propriedades medicinais, incluindo antiinflamatórias, antidiarréicas e anti-sépticas. Além disso, um estudo recente realizado por Alves et al. (2017) mostraram que frutos de guavira apresentaram maior teor de ácido ascórbico em comparação a outras espécies da família Myrtacea, como cagaita e cajueiro do cerrado.

Nota-se também na Tabela 8, que o conteúdo de ácido ascórbico diminui quando a polpa é desidratada a $50^{\circ} \mathrm{C}$, que pode ter ocorrido devido ao prolongado tempo de exposição da amostra nessa temperatura, um a vez que a exposição à luz e ao ar interferem negativamente na conservação do ácido ascórbico (CARDOSO et al., 2015).

Em oposto ao ocorrido na temperatura de $50^{\circ} \mathrm{C}$ nas temperaturas de 60 e $70^{\circ} \mathrm{C}$ este nutriente se concentrou apresentando um aumento significativo em comparação a amostra in natura. $\mathrm{O}$ aumento da vitamina $\mathrm{C}$ nestes tratamentos pode ser atribuído a crescente perda de massa ao longo das avaliações, como a amostra apresenta cerca de $80 \%$ de umidade, a perda da mesma contribuiu para a alta concentração do nutriente (OSHIRO, 2012). Comportamento similar foi observado por Leal, Geraldi e Klassen, (2016), ao analisar a secagem em camada de espuma do abacaxi, acerola e carambola, verificaram que o teor de vitamina tende a ser concentrado com o aumento da temperatura, inibindo as perdas por tempo de exposição.

O que caracteriza a guavira como uma fruta ácida além do $\mathrm{pH}$ abaixo de 7 , é a sua acidez, apresentada na Tabela 8. A acidez apresentou o mesmo comportamento que a vitamina $\mathrm{C}$, tendendo a se concentrar conforme aumentou-se a temperatura e diminuiu-se o tempo de exposição. Como já exposto a diminuição de massa de água faz com que nutrientes se concentrem, assim, quanto menor a umidade do produto maior sua concentração nutricional. 
Tabela 8 - Acidez da polpa de guavira in natura e desidratadas em diferentes temperaturas

\begin{tabular}{ccc}
\hline Polpa & Acidez $(\%)$ & CV (\%) \\
\hline in natura & $8,27 \pm 0,16^{\mathrm{a}}$ & 1,96 \\
$50^{\circ} \mathrm{C}$ & $18,66 \pm 0,15^{\mathrm{b}}$ & 0,59 \\
$60^{\circ} \mathrm{C}$ & $26,37 \pm 0,48^{\mathrm{c}}$ & 2,62 \\
$70^{\circ} \mathrm{C}$ & $29,09 \pm 0,31^{\mathrm{d}}$ & 1,08 \\
\hline
\end{tabular}

Letras iguais na mesma coluna, médias são iguais, pelo teste de Tukey ao nível de significância de 5\% (p<0,005).

Fonte: Elaborado pelos autores (2019).

Observa-se que, por mais que o $\mathrm{pH}$ permaneça quase inalterado nos três tratamentos propostas ainda assim o teor de acidez aumentou em relação a amostra in natura. Breda (2012), ao verificar a vida útil da guavira em pó desidratada pelo método de camada de espuma em ambientes controlados, registrou que, embora a acidez do produto em pó variasse de $15 \%$ a $25 \%$ o pH também permanecia na faixa de 4,12 a 4,7, apresentando variações somente após 80 dias de armazenamento. O que significa que apesar de, as concentrações de ácidos totais aumentarem em decorrência a desidratação, este aumento só implicara alterações no $\mathrm{pH}$ conforme algum tempo de armazenamento.

Muitos são os fatores que explicam a elevada acidez e constância do pH nas amostras, como por exemplo o método utilizado para determinação de acidez. Este método, se limita a valores de acidez detectáveis por titulação e as substâncias responsáveis por esta acidez detectável aparente são: os fosfatos e citratos (minerais), a caseína e albumina (proteínas) e gás carbônico dissolvido. Sabendo que a guavira é rica em sais e minerais alcalinos, que por sua vez tem ação neutralizadora de pH (BACCAR, 2016), é possível detectar acidez na polpa da fruta mesmo mantendo seu $\mathrm{pH}$ inalterado.

Outro componente detectável por meio de titulação é o ácido cítrico que é um ácido orgânico fraco, frequentemente encontrado nas frutas, sua acidez é devida aos três grupos carboxilas - $\mathrm{COOH}$ que podem perder um próton em soluções. Como consequência forma-se um íon de citrato, os citratos, por sua vez são controladores de pH nas soluções ácidas (FOOD INGREDIENTS BRASIL, 2014). Deste modo explica altas concentrações de acidez detectada na titulação, mesmo sem a alteração do $\mathrm{pH}$.

Um grande número de espécies da família Myrtaceae apresentam ocorrências de compostos fenólicos de estrutura simples, como os ácidos fenólicos ou taninos hidrolisáveis (ROCHA et al., 2011). Ácidos fenólicos são outro exemplo de como conteúdo de acidez pode ter sido concentrado na fruta conforme retirou-se a umidade. 


\section{Conclusões}

No que se refere a cinética de secagem observou-se que o tempo de secagem diminui de acordo com o aumento da temperatura. Quanto a adequabilidade dos modelos matemáticos constatou-se que os modelos de Midilli e Kucuck, e Page se sobressaem em relação ao de Handerson e Pabis, em todos os critérios verificados, o coeficiente de determinação. Contudo o modelo de Page foi escolhido para representar os dados experimentais pois possui menor número de parâmetros.

As características físico-químicas da farinha de polpa de guavira apresentaram comportamento similar estre elas, as quais após a secagem foram concentradas apresentando um aumento significativo no teor de cinzas, vitamina $\mathrm{C}$ e acidez em relação ao da polpa in natura. O teor de umidade após a obtenção da farinha está em acordo com o preconizado pela legislação vigente.

Deste modo, com os resultados apresentados fica evidente que o método de secagem em camada de espuma é uma alternativa eficiente para produzir e comercializar a guavira e outras frutas de característica sazonal, além de abrir a possibilidade para a produção de novos produtos da farinha de polpa de guavira. Contudo são necessários estudos mais amplos que comprovem a validade do método para outras frutas, contribuindo assim para a expansão da cadeia de suprimentos da indústria alimentícia.

\section{Referências}

ALEXANDRE, H. V. Secagem da polpa de pitanga e armazenamento do pó. 2005. 108 f. Tese de Doutorado. Dissertação (Mestrado em Engenharia Agrícola)-Universidade Federal de Campina Grande, Campina Grande. 2005.

ALVES, A.; DIAS, T.; HASSIMOTTO, N.; NAVES, M. Ascorbic acid and phenolic contents, antioxidant capacity and flavonoids composition of Brazilian Savannah native fruits. Food Science and Technology, v. 37, 564-569, 2017.

ANVISA. BRASIL. Agência Nacional de Vigilância Sanitária. Consulta Pública nº 80. Diário Oficial da União - Brasília, DF, Brasil, 2019.

ARAL, S; BEŞE, A. V. Convective drying of hawthorn fruit (Crataegus spp.): effect of experimental parameters on drying kinetics, color, shrinkage, and rehydration capacity. Food chemistry, v. 210, p. 577-584, 2016.

ARAÚJO, C. S; MACEDO, L. L; VIMERCATI, W. C; OLIVEIRA, A. DO N; E SARAIVA, S. H. Cinética de secagem de acerola (Malpighia emarginata DC) pelo processo foammat. Revista Univap, 22(40), 206. 2016. 
ARAÚJO, W. D; GONELI, A. L. D; CORRÊA, P. C; FILHO, C. P. H; MARTINS, E. A. S. Foam-mat drying kinetics for acerola and adjustment of the mathematical models. Brazilian Journal of Food Technology, v.20, 2017. n.17, 2017.

BACCAR, L. C. M. Equilíbrio do pH e saúde, medicina alternativa. Portal da Educação. 2016.

BAPTESTINI, F. M.; CORREAA, P. C.; JUNQUEIRA, M. S.; RAMOS, A. M; VANEGAS, J. D; B. COSTA, C. F. Modelagem matemática da secagem de espuma de graviola. Revista Brasileira de Engenharia Agrícola e Ambiental, v.19, p.1203-1208, 2015.

BRASIL. Consulta Pública $n^{\circ}$ 80, de 13 de dezembro de 2004. Regulamento técnico sobre ingestão diária recomendada (IDR) de proteína, vitaminas e minerais. Brasília: Agência Nacional de Vigilância Sanitária - ANVISA, 2004.

BREDA, C. A. Desidratação da polpa do fruto da guavira (campomanesia adamantium) pelo processo em camada de espuma. Dissertação (Mestrado em Ciência e Tecnologia Ambiental). Universidade Federal da Grande Dourados. Dourados - MS. 2011.

CARDOSO, I. R. M; ZUNIGA, A. D. G; FRONZA, P; MACIEL, A. G; E FERREIRA, J. DA S. Análise da cinética e modelagem matemática da secagem da polpa de buriti (Mauritia flexuosa). Engevista, v. 19, n. 5, 1188-1197. 2017.

CARDOSO, J. A. D. C; ROSSALES, R. R; LIMONS, B; REIS, S. F; SCHUMACKER, B. D. $\mathrm{O}$; e HELBIG, E. Teor e estabilidade de vitamina $\mathrm{C} e m$ sucos in natura $\mathrm{e}$ industrializados. Mundo saúde (Impr.), v. 39, n.4, 460-469. 2015.

CELESTINO, S.M.C. Princípios de Secagem de Alimentos. Embrapa Cerrados. Planaltina. p $10,2010$.

COSTA, L. M; RESENDE, O; GONÇALVES, D. N; \& DE OLIVEIRA, D. E. C. Modelagem matemática da secagem de frutos de crambe em camada delgada. Bioscience Journal, 31(2). 2015 .

CUNHA, M. F; RIBEIRO, L. M. P; DAMASCENO, K. A; ALVES, A. N; GONÇALVES, R. M. S; E GONÇALVES, C. A. A. Acidez, sua relação com pH e qualidade de geleias e doces em barra. Boletim técnico IFTM, n. 2, p. 14-19. 2016.

DEMENCIANO, S.C; NANTES, E. C. S; CAMPOS, R. P; MILÃO, E,C; CALARGE, A. Parâmetros físico-químicos a polpa de guavira congelada. Anais de congresso. Simpósio Latino Americano de Ciências de Alimentos, v. 2. 2015.

DRESCH, D. M; SCALON, S. P. Q; MUSSURY, R. M; e MASETTO, T. E. Do desiccation and storage of Campomanesia adamantium (Cambess.) O. Berg (Myrtaceae) seeds affect the formation and survival of seedlings. African Journal of Agricultural Research, v. 10 n. 33, 3216-3224. 2015.

ELIAS, N. D. F; BERBERT, P. A; MOLINA, M. A. B. D; VIANA, A. P; DIONELLO, R. G; \& QUEIROZ, V. A. V. Avaliação nutricional e sensorial de caqui cv Fuyu submetido à desidratação osmótica e secagem por convecção. Food Science and Technology, 28(2), 322328. 2008. 
EMBRAPA Florestas. Valor Nutricional da Guabiroba. Conservação da Biodiversidade e Valoração da Floresta de Araucária. Embrapa Florestas. Columbo - PR. 2015.

FERREIRA, C. N. P. Determinação da Análise Química e Propriedades Emulsificantes e Espumantes da Farinha de Girassol. Trabalho de Conclusão (Graduação em Engenharia Química). Instituto municipal de Ensino Superior de Assis - IMESA e Fundação Educacional do Município de Assis - FEMA, Assis - SP, 2011.

FOOD INGREDIENTS BRASIL. Aplicações do ácido cítrico na indústria de alimentos. Revista Food Ingredients Brasil, v. 1, n. 30. 2014.

FRANCO, T. S; PERUSSELLO, C. A; ELLENDERSEN, L. N; \& MASSON, M. L. Effects of foam mat drying on physicochemical and microstructural properties of yacon juice powder. LWT-Food Science and Technology, 66, 503-513, 2016.

FREITAS, B. S.; CAVALCANTE, M. D.; CAGNIN, C.; SILVA, R. M. D; Plácido, G. R; de Oliveira, D. E. Physical-chemical characterization of yellow mombin (Spondias mombin L.) foam-mat drying at different temperatures. Revista Brasileira de Engenharia Agrícola e Ambiental, v. 22, n. 6, p. 430-435, 2018.

GASPARIN, P. P; CHRIST, D; COELHO, S. R. M. Secagem de folhas Mentha piperita em leito fixo utilizando diferentes temperaturas e velocidades de ar. Revista Ciência Agronômica, v. 48, n. 2, p. 242-250, 2017.

GONELLA, J. S. L. Análise dos processos de negócios da gestão de cadeia de suprimentos de polpa de frutas a partir da relação entre agroindústria processadora e produtor rural familiar. Dissertação (Mestrado em Agronegócio e Desenvolvimento). Universidade Estadual Paulista "Júlio de Mesquita Filho". Tupã - SP, 2018.

GUIMARÃES, M. K. A; FIGUEIRÊDO, R; QUEIROZ, MELO, A. J. de. Foam-mat drying kinetics of keitt mango pulp. Revista Caatinga, v. 30, n. 1, p. 172-180, 2017.

HENDERSON, S. M.; PABIS, S. Grain drying theory I. Temperature effect on drying coefficient. Journal of Agricultural Engineering Research, v. 6, n. 3, p. 169-174, 1961.

IAL (INSTITUTO ADOLFO LUTZ). Métodos físico-químicos para análise de alimentos. 4 ed. São Paulo: IAL, 2008. 1018p.

IBGE. Estudo nacional da despesa familiar - ENDEF: Tabela de Composição dos Alimentos. ed. 5. Rio de Janeiro, 1999, p. 49.

LEAL, A. K; GERALDI, C. A. Q; KLASSEN, T. influência da temperatura de secagem através do método de camada de espuma, na concentração de ácido ascórbicos, nas polpas dos frutos de abacaxi, acerola e carambola. XVI Encontro Brasileiro sobre Ensino de Engenharia Química. Fortaleza - CE. 2016.

LOPES, A. C. S.; MENEZES, M. C.; M. ARAÚJO, L. O ambiente alimentar e o acesso a frutas e hortaliças: "Uma metrópole em perspectiva". Saúde e Sociedade. v.26, p 3, 2017.

MACHADO, A. M; DE SOUZA, M. C; DA SILVA, M; JUNQUEIRA, S. H. S; \& TEIXEIRA, L. J. Q. Cinéticas de secagem do abacaxi cv. Pérola. Enciclopédia Biosfera, Centro Científico Conhecer, Goiânia, v.8, n.15; p. 428. 2012. 
MAYER, R. Caracterização físico-química das sementes de araçá-amarelo e potencial antioxidante do óleo das sementes em óleo de girassol induzido à oxidação, Dissertação (Mestrado em Ciência e Tecnologia de Alimentos). Universidade Estadual de Ponta Grossa, Ponta Grossa, 2015.

MIDILLI, A.; KUCUK, H.; YAPAZ, Z. A new model for single-layer drying. Drying Technology, New York, v.20, n.7, p.1503-1513, 2002.

MOSCON, E. S; MARTIN, S; SPEHAR, C. R; DEVILLA, I. A; E JUNIOR, F. RM; Cinética de secagem de grâos de quinoa (Chenopodium quinoa W.). Revista Engenharia na Agricultura-Reveng, v. 25, n. 4, p. 318-325, 2017.

NASCIMENTO, V. R; BIAGI, J. D; OLIVEIRA, R. de. Modelagem matemática da secagem convectiva com radiação infravermelha de grãos de Moringa oleifera. Revista Brasileira Engenharia Agrícola Ambiental, v. 19, p. 686-692, 2015.

NUNES, J. S; LINS, A. D. F; GOMES, J. P; DA SILVA, W. P; \& DA SILVA, F. B. Influência da temperatura de secagem nas propriedades físico-química de resíduos abacaxi. Agropecuária Técnica, v. 38, n. 1, 41-46. 2017.

OLIVEIRA, J. D. D; ALVES, D. K. M; MIRANDA, M. L. D; ALVES, J. M; XAVIER, M. N; CAZAL, C. D. M; e ALVES, C. C. F. Chemical composition of essential oil extracted from leaves of Campomanesia adamantium subjected to different hydrodistillation times. Ciência Rural, v. 47, n. 1. 2017.

OSHIRO, A. M. Conservação Pós-Colheita De Frutos E Sementes De Guavira (Campomanesia adamantium Camb.) Em Diferentes Embalagens e Temperaturas. Tese (Doutorado em Agronomia). Universidade Federal da Grande Dourados, Dourados - MS, 2012.

PAGE, G. E. Factors influencing the maximum of air-drying shelled corn in thin layer. Thesis Dissertation (M.Sc.) - Purdue University, Indiana, 1949.

PEIXOTO, F. N; PINHEIRO, J. A. Gestão de estoques um estudo de caso sobre controle das perdas de produtos hortifrutigranjeiros. Diálogos - Economia e Sociedade. v.1, n 1, 2017.

PEREIRA, B. M.; BRAVIN, G. P. O.; OLIVO, A. M. Aplicação do controle da qualidade no setor de hortifrúti de um supermercado visando a redução de perdas. Colloquium Exactarum, v. 9, n. Especial, Jul-Dez, 2017, p. 172- 177. Presidente Prudente - SP, 2017.

RESENDE, K. K. O; SOUSA, S; GUEDES, S. F; E LOSS, R. A. Cinética de secagem e avaliação físico-química de fruta-pão (Artocarpus altilis) variedade seminífera. Journal Of Neotropical Agriculture, v. 6, n. 1, p. 74-81. 2019.

RIGUETO, C. V. T; EVARISTO, L. M; GERALDI, C. A. Q; \& COVRE, L. Influência da temperatura de secagem de uvaia (Eugenia pyriformis) em camada de espuma. Engevista, v.20, n.4, p. 537-547, 2018.

ROCHA, W. S; LOPES, R. M; SILVA, D. D; VIEIRA, R. F; SILVA, J. D; e AGOSTINICOSTA, T. D. S. Compostos fenólicos totais e taninos condensados em frutas nativas do cerrado. Revista Brasileira de Fruticultura, v. 33, n.4, 1215-1221. 2011. 
SANTOS, R. F. Aproveitamento de frutas nativas para elaboração de farinhas e incorporação em biscoitos tipo cookies. $88 \mathrm{f}$. Dissertação (Mestrado em Tecnologia de Alimentos) - Universidade Tecnológica Federal do Paraná, Londrina, 2018.

SCALON, S. P. Q; OSHIRO, A. M; DRESCH, D. M. Conservação pós-colheita de guavira (Campomanesia adamantium Camb.) Sob diferentes revestimentos e temperaturas de armazenamento. Revista Brasileira de Fruticultura, v. 34, n. 4, p. 1022-1029, 2012.

SEAB - SECRETARIA DA AGRICULTURA E ABASTECIMENTO. Análise da conjuntura agropecuária safra 2016/17. Andrade, P. F. S. Departamento rural, Estado do Paraná. 2017.

SILVA FILHO, E. D. S.; FIGUEIRÊDO, R. M. F.; QUEIROZ, A. J. M.; GUIMARÃES, M. K. A. Cinética de secagem em camada de espuma da polpa da manga cv. Haden. Comunicata. Scientiae; Bom Jesus, v.7, n.3, p.354-361, Ago./Out. 2016.

SILVA, J. A. S. L. Desidratação de ervas condimentares: análise do processo de secagem. Trabalho de Conclusão de Curso Graduação em Nutrição. Universidade Federal de Pernambuco. Vitória de Santo Antão. 2019.

SILVA, M. R.; LACERDA, D. B. C. L.; SANTOS, G. G.; MARTINS, D. M. O. Caracterização química de frutos nativos do cerrado. Ciência Rural, Santa Maria, v. 38, n. 6, p. 1790-1793, 2008.

TELLES, E, O. Microrganismos deteriorantes, patogênicos e tecnológicos - fatores intrínsecos e extrínsecos. VPS 22012 - Higiene e Segurança Alimentar. 2012.

VALLILO, M. I; LAMARDO, L. C. A; GABERLOTTI, M. L; OLIVEIRA, E. D; e MORENO, P. R. H. Composição química dos frutos de Campomanesia adamantium (Cambessédes) $\mathrm{O}$. Berg. Ciência e tecnologia de alimentos, v. 26, n. 4, 725-955. 2006.

VIEIRA, M; PELloSO, I. A; ZÁRATE, N. A. H; DAVIDE, L. M. C; SANTOS, M. C; \& CARNEVALI, T. Diversidade fenotípica em caracteres de frutos e germinação de sementes de Campomanesia adamantium Camb. Revista de la Facultad de Agronomía, 117. 2018.

WIJEWARDANA, R. M. N. A; NAWARATHNE， S. B; WICKRAMASINGHE， I; GUNAWARDANE, C. R; WASALA, W. M. C. B; \& THILAKARATHNE, B. M. K. S. Retention of physicochemical and antioxidant properties of dehydrated bael (Aegle marmelos) and palmyra (Borassus flabellifer) fruit powders. Procedia Food Science, v. 6, 170-175. 2016. 


\title{
CAPÍTULO 27: VARIABILIDADE ESPACIAL E TEMPORAL DA RESISTÊNCIA DO SOLO À PENETRAÇÃO NA REGIÃO DO VALE DO IVINHEMA/MS
}

\section{CHAPTER 27: SPATIAL AND TEMPORAL VARIABILITY OF SOIL RESISTANCE TO PENETRATION IN THE REGION OF IVINHEMA VALLEY / MS}

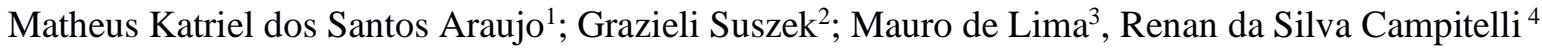

\begin{abstract}
Resumo
O estudo qualidade física do solo através da resistência do solo a penetração é uma boa forma de se verificar a eficiência de diferentes sistemas de manejo, e com isso, as suas implicações na qualidade física do solo, refletindo diretamente no desenvolvimento radicular da planta. Desta forma esse trabalho teve por objetivo avaliar a variabilidade espacial e temporal da compactação do solo em área agrícola na região do vale do Ivinhema-MS. Esse trabalho foi desenvolvido em área experimental pertencente ao Instituto Federal de Mato Grosso do Sul campus de Nova Andradina/MS. Na área experimental, foram implantadas as seguintes culturas, Soja (2017/2018) e Brachiaria brizantha cv. Marandu (2018/2019). Para a realização do trabalho, foi elaborado um Grid regular com malha amostral de $15 \times 20 \mathrm{~m}$, totalizando 24 pontos amostrais. Em cada ponto amostral foi realizada uma avaliação de resistência a penetração, determinação da umidade gravimétrica do solo e altimetria. Os dados obtidos das análises foram submetidos à análise estatística descritiva, para elaboração dos mapas foi utilizado o Software ArcGIS usando interpolação por IQD. Foi possível identificar variabilidade na área experimental através da avaliação da resistência do solo a penetração e encontrar correlação significativa entre resistência e a umidade do solo.
\end{abstract}

Palavras-Chaves: Agricultura de Precisão, Compactação do solo, Umidade do solo, Física do solo.

\begin{abstract}
The study of physical soil quality through soil resistance to penetration is a good way to verify the efficiency of different management systems, and with this, its implications on the physical quality of the soil, directly reflecting on the root development of the plant. Thus, this work aimed to evaluate the spatial and temporal variability of soil compaction in an agricultural area in the Ivinhema-MS valley region. This work was developed in an experimental area belonging to the Federal Institute of Mato Grosso do Sul - campus of Nova Andradina / MS. In the experimental area, the following crops, Soja (2017/2018) and Brachiaria brizantha cv. Marandu (2018/2019). In order to carry out the work, a regular grid with a $15 \times 20 \mathrm{~m}$ sample grid was elaborated, totaling 24 sample points. At each sampling point, an assessment of resistance to penetration, determination of soil gravimetric moisture and altimetry were performed. The data obtained from the analyzes were submitted to descriptive statistical analysis, for the elaboration of the maps the ArcGIS Software was used using IQD interpolation. It was possible to identify variability in the experimental area through the assessment of soil resistance to penetration and to find a significant correlation between resistance and soil

\footnotetext{
${ }^{1}$ Bacharelado em Agronomia, Instituto Federal de educação, ciência e tecnologia de Mato grosso do sul, matheus.araujo@novaandradina.org

${ }^{2}$ Doutorado em Engenharia Agrícola, Instituto Federal de educação, ciência e tecnologia de Mato grosso do sul, grazieli.suszek@ifms.edu.br

${ }^{3}$ Graduação em Engenharia Agrícola, Instituto Federal de educação, ciência e tecnologia de Mato grosso do sul, mauro.lima@ifms.edu.br

${ }^{4}$ Tecnólogo em Produção de Grãos, Instituto Federal de educação, ciência e tecnologia de Mato grosso do sul, renan.campitelli159@gmail.com.br
} 
moisture.

Keywords: Precision agriculture, Soil compaction, Soil moisture, Soil physics.

\section{Introdução}

O estudo da resistência a penetração do solo é um indicativo sobre o manejo da qualidade física dos solos, visto que essa propriedade apresenta relação com diversos atributos do solo, tais como os indicadores do grau de compactação, como a densidade, porosidade, conteúdo de água e textura do solo (CANCIAN, 2015). Em solos cultivados, é de fundamental importância para escolha do sistema de preparo mais adequado ao crescimento e desenvolvimento das culturas (RIBON e TAVARES FILHO, 2008).

A compactação do solo pode ser um fator limitante para a produção agrícola, gerando impacto na reorganização das partículas e agregados, o que por sua vez limita a adsorção, absorção de nutrientes, infiltração e redistribuição de água e trocas gasosa, afetando a produtividade dos cultivos (MORAES et al, 2020).

De acordo com FLOWERS \& LAL (1998), a principal causa da compactação em solos agrícolas é o tráfego de máquinas em operações de preparo do solo, semeadura, tratos culturais e colheita. Desta forma deve-se utilizar formas alternativas para a descompactação do solo sem causar grande impacto em sua estruturação.

Uma forma alternativa promissora é a descompactação biológica sem a degradação do solo com o uso de forrageiras e leguminosas capazes de ultrapassarem as camadas de compactação com seus sistemas radiculares vigorosos (RETKA, 2018), visto que após a decomposição das raízes obtém-se melhores condições do solo, por formarem bioporos no solo aumentando aspectos como a disponibilidade hídrica favorecendo a recuperação do solo (SANTOS et al, 2014).

Segundo Cancian (2015), a realização de avaliações da qualidade física do solo através da resistência do solo a penetração é uma boa forma de se verificar a eficiência de diferentes sistemas de manejo, e com isso, as suas implicações na qualidade física do solo, refletindo diretamente no desenvolvimento radicular da planta.

Desta forma, a análise da correlação entre os atributos do solo e a resistência a penetração poderia revelar dados importantes referentes aos futuros manejos desta área, possibilitando que possíveis intervenções possam ser realizadas com a finalidade de potencializar maiores produtividades e a obtenção de áreas mais homogêneas.

Para Bernardi et al. (2014) o conhecimento da variabilidade da produção é útil para qualquer cultura, sejam aquelas cultivadas em pequenas áreas ou em grandes extensões de terra. 
Desta forma é indispensável utilizar técnicas e métodos que indique ao produtor onde ocorre a variabilidade em sua propriedade agrícola, para que desta maneira possa se ter uma melhor produtividade. Desta forma o estudo da variabilidade dos atributos de solo possibilita aperfeiçoar o manejo em áreas agrícolas por meio de um gerenciamento que leve em consideração informações pontuais de solo e das culturas (AMADO, LEMAINSKI e SCHENATO, 2009).

Este trabalho teve por objetivo avaliar a variabilidade espacial e temporal da compactação do solo em área agrícola na região do vale do Ivinhema-MS.

\section{Material e Métodos}

A área experimental pertencente ao Instituto Federal de Mato Grosso do Sul- Fazenda Santa Bárbara, está localizada no município de Nova Andradina Estado do Mato Grosso do Sul, situada em $-22^{\circ} 08^{\prime} 22,65^{\prime}$ ' S e a $-53^{\circ} 46^{\prime} 89,60^{\prime}$ 'W (Figura 01), o clima da região é classificado, segundo Köeppen, como tropical subtropical úmido e mesotérmico, com índices pluviométricos superiores a $1100 \mathrm{~mm}$ anuais, possuindo altitude média de $357 \mathrm{~m}$, o solo da área é caracterizado como Latossolo Vermelho de textura arenosa conforme Santos et al. (2018), solo da área é composto por $82,68 \%$ de areia $2,6 \%$ de silte e $14,72 \%$ de argila.

Figura 1: Localização do experimento em Nova Andradina/MS.

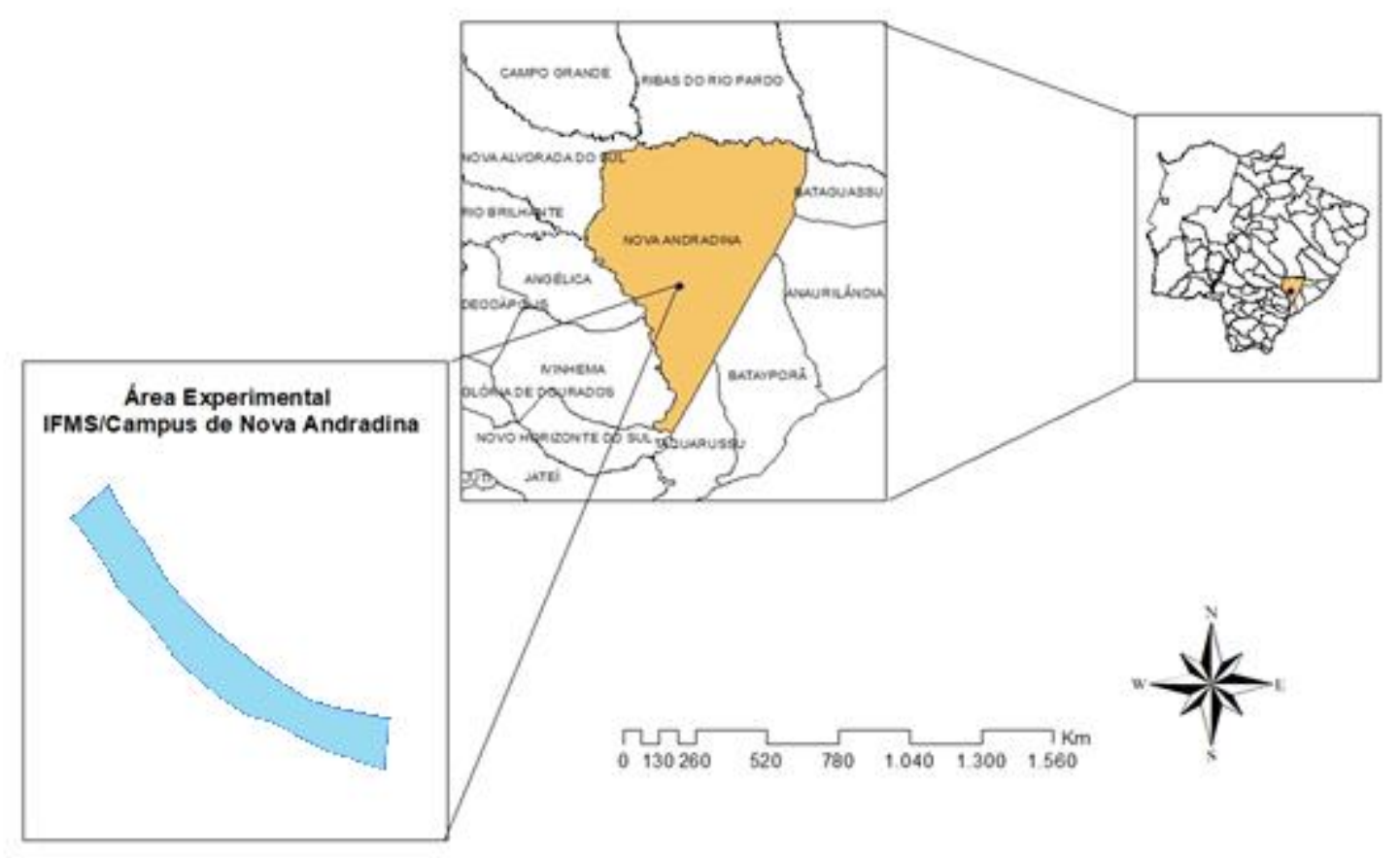

Fonte: Própria (2020). 
Durante o desenvolvimento do trabalho na área experimental, foram implantadas as seguintes culturas, Soja (2017/2018) e Brachiaria brizantha cv. Marandu (2018/2019). Para a realização do trabalho, foi elaborado um Grid regular com dimensão de malha amostral de $15 \times 20 \mathrm{~m}$, onde foram escolhidos 24 pontos amostrais (Figura 02), georreferenciados utilizandose GPS 76CSx da Garmin. Em cada ponto amostral foi realizada avaliação da resistência do solo a penetração e coleta de solo para determinação da umidade, nos meses de março/2018, abril/2019 e outubro/2019.

Figura 2: Distribuição dos pontos amostrais na área na experimental.

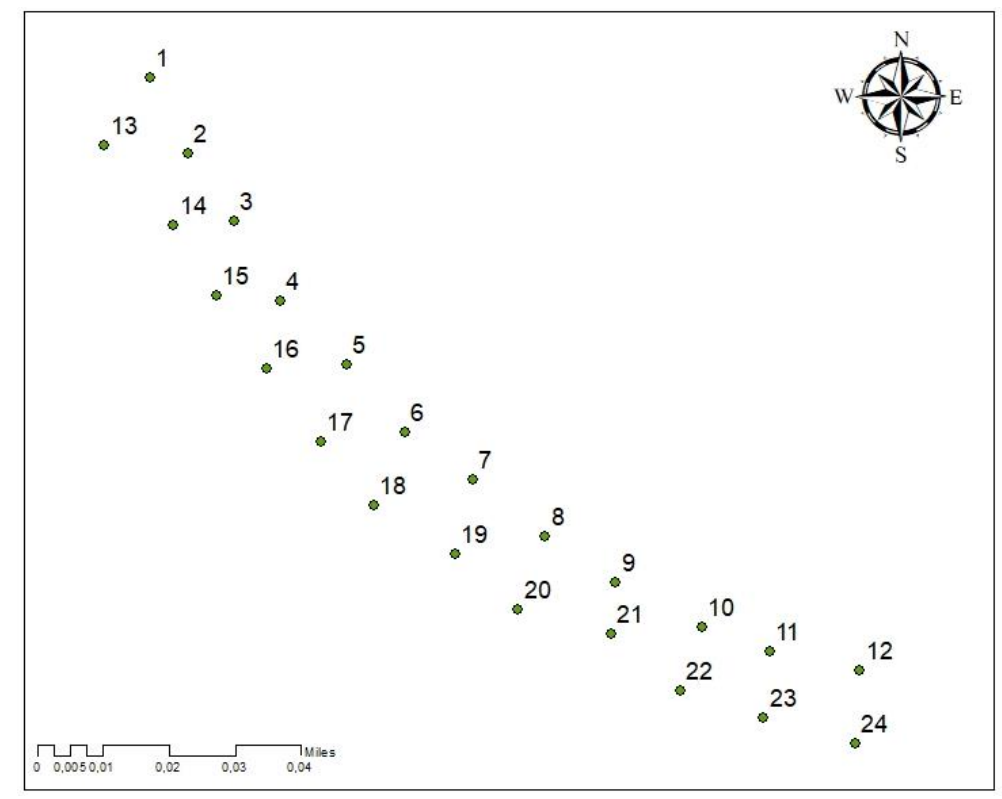

Fonte: Própria (2020).

A resistência mecânica à penetração realizada em março de 2018 foi obtida utilizando um penetrômetro de impacto, modelo IAA/Planalsucar-Stolf, com metodologia para coleta de dados sugerida por Stolf (1991), sendo utilizado para avaliação de 2018. Os resultados obtidos em impactos $\mathrm{dm}^{-1}$ foram convertidos em resistência dinâmica (MPa) por meio da equação 1 (Stolf, 1991). Para conversão da RP em kgf cm equação 1 pela constante 0,0981, dada por:

$\mathrm{RP}\left(\mathrm{Kgf} \mathrm{cm}^{-2}\right)=5,6+6,89 \mathrm{~N}\left(\right.$ impactos $\left.\mathrm{dm}^{-1}\right)$

Onde RP: resistência a penetração.

As avaliações de 2019, foi utilizado o penetrômetro eletrônico, modelo FALKER PenetroLOG - PLG1020, com aptidão eletrônica para aquisição de dados. Este penetrômetro foi configurado para registrar leituras a cada $0,01 \mathrm{~m}$ de incremento de profundidade, trabalhando em velocidade de penetração constante. Os dados referentes ao penetrômetro Falker foram extraídos da memória digital e analisados a uma profundidade máxima de 0,2 m. 
Para o processamento dos dados de resistência à penetração, foi utilizado o Software PenetroLOG. Em relação aos dados dos dois aparelhos utilizados os autores Vogel et al. (2017) e Lima, León e Silva (2013) relatam que os mesmos apresentam similaridade entre os dados.

Durante as avaliações de resistência do solo a penetração, também foram coletadas amostras de solo na profundidade de $0-20 \mathrm{~cm}$, para determinação da umidade através do método gravimétrico (Santos et al., 2018), assim as amostras foram coletadas utilizando trado holandês (Figura 03), posteriormente as amostras foram envolvidas em papel alumínio, e levadas ao laboratório de solos e nutrição de plantas do IFMS, campus Nova Andradina-MS, para pesagem e secagem em estufa a $105^{\circ} \mathrm{C}$ por 24 horas (Figura 04).

Figura 3: Coleta das amostras de solo, utilizando trado holandês.

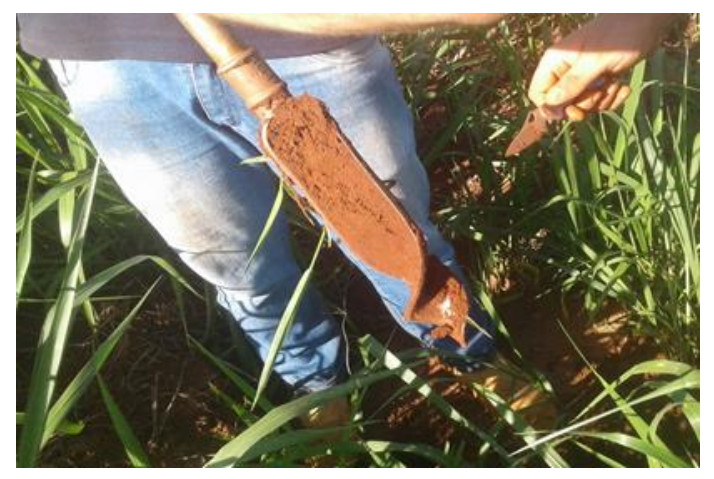

Fonte: Própria (2019).

Figura 4: Amostras de solo em estufa para realização da secagem.

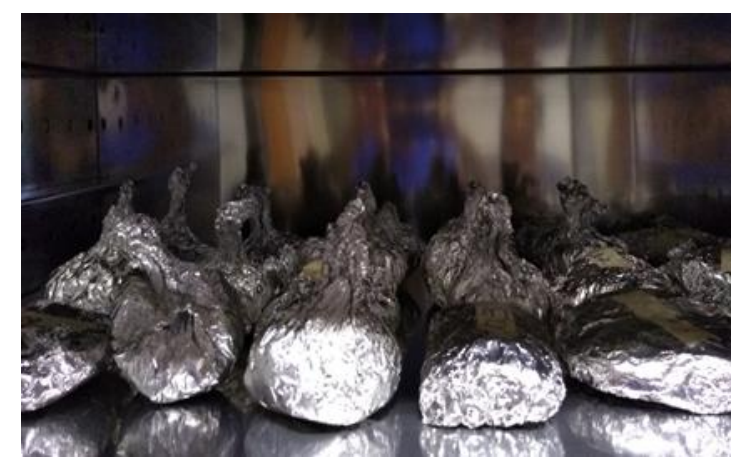

Fonte: Própria (2019).

Posteriormente os dados foram submetidos à análise exploratória, para obtenção das medidas de posição (média e mediana), medida de dispersão (desvio-padrão) e medidas de forma da distribuição (coeficiente de variação), avaliado de acordo com (Gomes, 2000), sendo também realizadas análises de correlação de Pearson e teste de normalidade, verificada através dos testes de Anderson Darling e Kolmogorov Smirnov (5\% de significância).

Para elaboração dos mapas temáticos da área experimental foi utilizado o software ArcGIS, onde os dados foram interpolados utilizando o interpolador inverso do quadrado da 
distância (IQD), interpolador determinístico univariado de médias ponderadas, ou seja, quanto mais distante um ponto observado estiver do estimado, menor será sua influência sobre o valor de inferência. Este método é considerado de acurácia satisfatória quando comparado a krigagem, podendo, em alguns casos, apresentar resultados semelhantes (SOUZA et al., 2010). Além disso a similaridade dos mapas temáticos construídos a partir dos dados coletados foi avaliada por meio de análise visual dos mapas.

\section{Resultados e Discussão}

$\mathrm{Na}$ Tabela 01 são apresentados os valores obtidos na coleta dos dados, referente à estatística descritiva das variáveis estudadas na camada de 0-0,20 m do solo. De acordo com a média da resistência do solo a penetração apresentou valores acima do estabelecido para o desenvolvimento radicular das plantas apenas na primeira análise em 2018, segundo Canarache (1990) valores acima de 2,5 MPa começam a restringir o pleno crescimento das raízes da maioria das plantas. Já Bergamin et al. (2010), observou que valores acima de 0,64 MPa apresenta limitação ao desenvolvimento de raízes da cultura do milho.

Tabela 1- Análise estatística dos dados de resistência do solo (MPa) e teor de umidade (\%).

\begin{tabular}{|c|c|c|c|c|c|c|c|}
\hline & \multirow{3}{*}{ Altitude (m) } & \multicolumn{2}{|c|}{$1^{\mathrm{a}}$ Análise: } & \multicolumn{2}{|c|}{$2^{\mathrm{a}}$ Análise: } & \multicolumn{2}{|c|}{$3^{\mathrm{a}}$ Análise: } \\
\hline & & \multicolumn{2}{|c|}{ Março/2018 } & \multicolumn{2}{|c|}{ Abril/2019 } & \multicolumn{2}{|c|}{ Out./2019 } \\
\hline & & $\mathrm{R}(\mathrm{MPa})$ & $\mathrm{h}(\%)$ & $\mathrm{R}(\mathrm{MPa})$ & $\mathrm{h}(\%)$ & $\mathrm{R}(\mathrm{MPa})$ & $\mathrm{h}(\%)$ \\
\hline Média & 344,02 & 3,40 & 7,04 & 0,40 & 6,69 & 0,45 & 5,99 \\
\hline Mediana & 338,51 & 3,32 & 6,98 & 0,40 & 6,86 & 0,42 & 6,01 \\
\hline Máximo & 374,80 & 5,38 & 8,83 & 0,59 & 8,56 & 0,70 & 7,18 \\
\hline Mínimo & 331,06 & 1,94 & 5,90 & 0,21 & 3,32 & 0,20 & 4,21 \\
\hline D.P. & 11,89 & 0,82 & 0,68 & 0,08 & 1,02 & 0,12 & 0,63 \\
\hline C.V. & 3,46 & 24,12 & 9,72 & 20,05 & 15,30 & 26,80 & 10,55 \\
\hline Curtose & 0,62 & 0,31 & 0,70 & 1,22 & 4,72 & $-0,01$ & 1,43 \\
\hline Assimetria & 1,18 & 0,24 & 0,63 & 0,12 & $-1,59$ & 0,42 & $-0,60$ \\
\hline Normalidade & Não & Sim & Sim & Sim & Sim & Sim & Sim \\
\hline
\end{tabular}

* R - Resistencia do solo a penetração, h - Umidade do solo, D.P. - Desvio Padrão, C.V. - Coeficiente de variação, Out.- Outubro.

Fonte: Própria (2020).

Em conformidade com os resultados apresentados na Tabela 01, nota-se que no teste de normalidade das 3 análises de resistência do solo a penetração e de umidade do solo, mostraram distribuição normal, já a altitude da área experimental não apresentou distribuição normal. 
Resultado semelhante foi relatado por Silva et al (2004) e por Cancian (2015). Segundo Ivo e Filho (1997), a normalidade da distribuição dos dados é a premissa básica para aplicação da maioria dos testes de significância. Isso determina a necessidade de uma maior atenção a esta medida quando se comparam dados, isso indica também a validação do uso da média de tendência central de determinado conjunto de dados (CANCIAN, 2015).

$\mathrm{Na}$ Tabela 01 pode-se observar também que a altitude, a $1^{\circ}$ análise de umidade e a Resistencia do solo a penetração apresentaram coeficiente de assimetria positivos variando de 1,18 a 0,12 , já os demais atributos apresentaram coeficiente de assimetria negativos com valores entre -0,60 a -1,59. Além disso, observando-se o coeficiente de curtose percebe-se que somente a $3^{\circ}$ análise de resistência do solo a penetração mostrou-se negativo $(-0,01)$, porém os demais atributos avaliados apresentaram coeficiente de curtose positivo com valores variando entre 0,31 a 4,72. Resultado similar foi obtido por Oliveira et al. (2018).

De acordo com Dalchiavon et al. (2012) a variabilidade de um atributo pode ser classificada conforme a magnitude de seu coeficiente de variação $(\mathrm{CV})$ como baixo $(\mathrm{CV}<$ $10 \%)$, médio $(10 \%<\mathrm{CV}<20 \%)$, alto $(20 \%<\mathrm{CV}<30 \%)$ e muito alto (CV > 30\%).

Com base nos resultados apresentados na Tabela 01, pode-se observar que as 3 avaliações de resistência do solo a penetração apresentaram Coeficiente de Variação (CV) alto, indicando que esses dados apresentam comportamento heterogêneo na área experimental. Por outro lado o teor de umidade do solo na $1^{\circ}$ análise e a altitude apresentaram coeficiente de variação baixo, e as demais análises apresentaram valores considerados médios, desta forma na $1^{\circ}$ analise a umidade do solo e a altitude demostram distribuição homogênea na área avaliada e nas demais análises o comportamento mostra-se heterogêneo. Resultados semelhantes foram relatados por Campos et al. (2012) e por Souza et al. (2006). Segundo relata Silva et al. (2004) na superfície e até a profundidade de $12 \mathrm{~cm}$, o solo sofre os maiores efeitos do tráfego de máquinas, da atividade biológica e de ciclos de umedecimento e secagem que provocam grande variabilidade e dispersão dos valores de RP.

Nos valores de máximo e mínimo das análises de resistência a penetração do solo apresentados na Tabela 01 , nota-se que na $1^{\circ}$ avaliação houve maiores valores de RP, isso deve ao manejo realizado na cultura anterior. De acordo Richart et al. (2005), algumas práticas de manejo do solo e das culturas provocam alterações nas propriedades físicas do solo, as quais podem ser permanentes ou temporárias. Já nas demais análises de resistência do solo a penetração constatou-se redução nos valores máximo e mínimo, isso ocorre pelo fato do uso de gramineas do gênero Brachiaria favorecer na descompactação biológica do solo (NETO et al., 2015). 
De acordo com a Tabela 02, pode-se observar a correlação de Pearson (r) entre a Resistencia do solo a penetração e a umidade do solo. Conforme Filho e Júnior (2009) uma correlação perfeita (-1 ou 1) indica que a contagem de uma variável pode ser determinada exatamente ao se saber a contagem da outra, no outro oposto, uma correlação de valor zero indica que não há relação linear entre as variáveis. Para interpretação das análises do coeficiente de correlação utilizou-se a proposta estabelecida por Dancey e Reidy (2006).

Tabela 2. Coeficiente de correlação de Pearson dos atributos avaliados.

\begin{tabular}{lcccccc}
\hline & \multicolumn{2}{c}{$1^{\circ}$ Análise } & \multicolumn{2}{c}{$2^{\circ}$ Análise } & \multicolumn{2}{c}{$3^{\circ}$ Análise } \\
\cline { 2 - 8 } & $\mathrm{R}(\mathrm{Mpa})$ & $\mathrm{h}(\%)$ & $\mathrm{R}(\mathrm{Mpa})$ & $\mathrm{h}(\%)$ & $\mathrm{R}(\mathrm{Mpa})$ & $\mathrm{h}(\%)$ \\
\hline Corr. Alt. & $-0,24$ & $\underline{0,53}$ & $-0,14$ & 0,13 & 0,07 & $-0,10$ \\
\hline Correlação & & 0,23 & & & 0,11 & \multicolumn{2}{c}{$\underline{0,31}$} &
\end{tabular}

$* \geq 0,60$ ou $\mathrm{r} \geq-0,60$ (Correlação Forte - Em negrito); $0,30 \leq \mathrm{r}<0,60$ ou $-0,60<\mathrm{r} \leq-0,30$ (Correlação Moderada - Em itálico e sublinhado); -0,30 < r < 0,30 (Correlação Fraca - Fonte normal) (Dancey e Reidy, 2006). R Resistencia do solo a penetração, h - Umidade do solo, Corr. Alt. - Correlação com Altitude.

Fonte: Própria (2020).

Conforme demonstra na Tabela 02, pode-se observar que houve correlação moderada $(0,30 \leq \mathrm{r}<0,60$ ou $-0,60<\mathrm{r} \leq-0,30)$ entre a resistência do solo a penetração e a umidade do solo na $3^{\circ}$ análise, já nas demais análises ocorreu correlação fraca entre os atributos avaliados, resultado semelhante foi relatado por Carvalho et al. (2006). Segundo Beltrame et al. (1981), a umidade pode alterar a coesão entre as partículas do solo. Já para Silveira et al. (2010), quando o solo está seco ou apresenta baixo conteúdo de água, suas partículas apresentam-se mais próximas e difíceis de serem separadas por qualquer força externa. Conforme relata Dedecek e Gava (2005), os solos arenosos possuem elevada macroporosidade, sua compactação tem que ser extremamente alta para haver redução drástica dessa porosidade. Já os solos argilosos, principalmente quando com umidade acima da capacidade de campo, tendem a ser compactados facilmente, diminuindo sua porosidade e podendo formar camadas compactadas.

$\mathrm{Na}$ Tabela 02 nota-se também que houve correlação moderada entre a $1^{\circ}$ analise de umidade do solo e a altitude da área experimental, esse resultado também foi relatado por Ribeiro (2010). Segundo Ferreira et al. (2010) quando se tem baixa declividade da superfície do solo tem-se, também, escoamento com baixa velocidade e, consequentemente, a capacidade de transporte fica limitada à vazão de escoamento.

Nas Figuras 05, 06 e 07 são apresentados os mapas de resistência a penetração e umidade do solo, para a $1^{\mathrm{a}}, 2^{\mathrm{a}}$ e $3^{\mathrm{a}}$ análises respectivamente. As escalas dos mapas foram padronizadas na divisão por quartis do ArcGIS, tendo por objetivo padronizar os mapas e com 
isso conseguir realizar a comparação visual, percebeu-se que todos os mapas apresentaram variabilidade espacial.

Figura 5: Mapas de resistência a penetração e umidade do solo resultantes da $1^{\circ}$ análise (Março/2018).

Mapa de resistência do solo a penetração

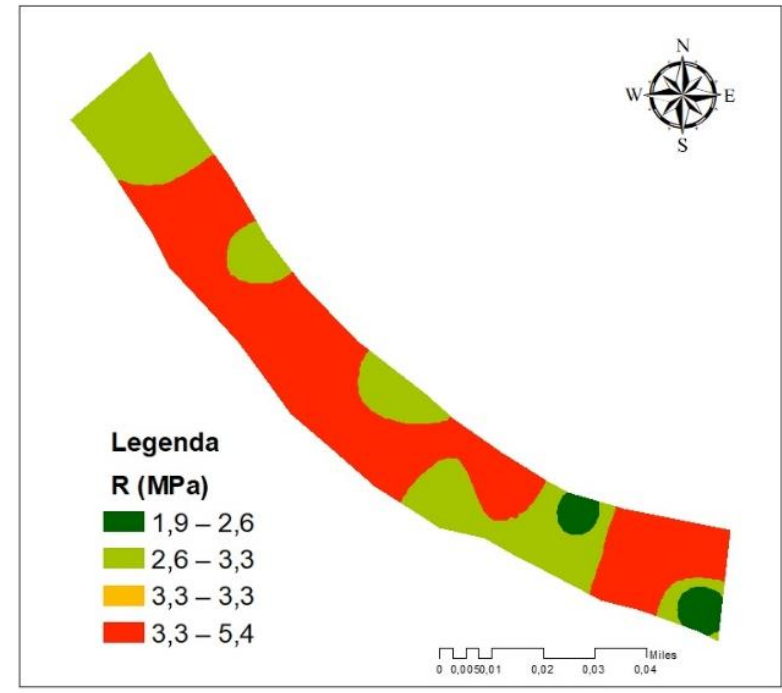

Mapa do teor de umidade do solo

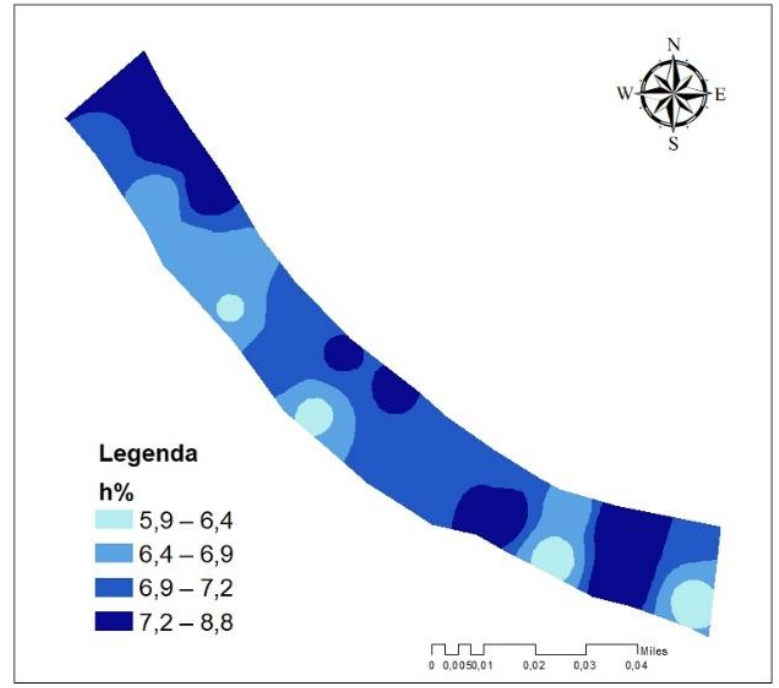

Fonte: Própria (2020).

De acordo com a Figura 05 não foi possível observar influência da umidade na resistência do solo a penetração. Além disso no mapa de resistência a penetração, percebe-se que na região central da área houve predominância de valores altos de resistência do solo a penetração, já no sentido noroeste os valores tendem a diminuir, o mesmo ocorre na região sudeste do mapa. De acordo com Barber (1994), os valores de resistência do solo à penetração a partir de 2,0 a 3,0 MPa dificultam o desenvolvimento radicular de culturas como a soja, causando deficiência de aeração no solo e menor drenagem interna. Segundo Cancian (2015), altos valores de resistência do solo a penetração são influenciados pelo manejo realizado na área agrícola.

Na Figura 06 observou-se variabilidade espacial nos dois mapas, porém também não houve correlação visual entre os mapas. O mapa de resistência do solo a penetração, apresentou os valores mais altos predominante nas regiões nordeste e sudeste do mapa, ja na região central do mapa ocorre predominância de valores que variam de médio a baixa resistência.

Além disso, houve redução nos niveis de resistência do solo a penetração, isso ocorreu devido a influência da Brachiaria brizantha cv. Marandu na descompactação do solo. Resultado semelhante foi relatado por Calonego et al. (2011), o cultivo de braquiária em consórcio com o milho por dois anos consecutivos melhorou as condições estruturais do solo, com redução da resistência mecânica à penetração, e consequentemente, aumento do intervalo 
hídrico ótimo (IHO). De acordo com Razuk (2002), uma das características atribuídas às gramíneas e, em particular, a Brachiaria brizantha cv. Marandu é a abundante produção de raízes e capacidade de estruturação do solo. Essas propriedades têm papel importante na capacidade de armazenamento de água no solo, absorção de nutrientes, melhoria de características físicas e aumento no teor de matéria orgânica do solo.

Figura 6: Mapas de resistência a penetração e umidade do solo resultantes da $2^{\circ}$ análise (Abril/2019).

Mapa de resistência do solo a penetração

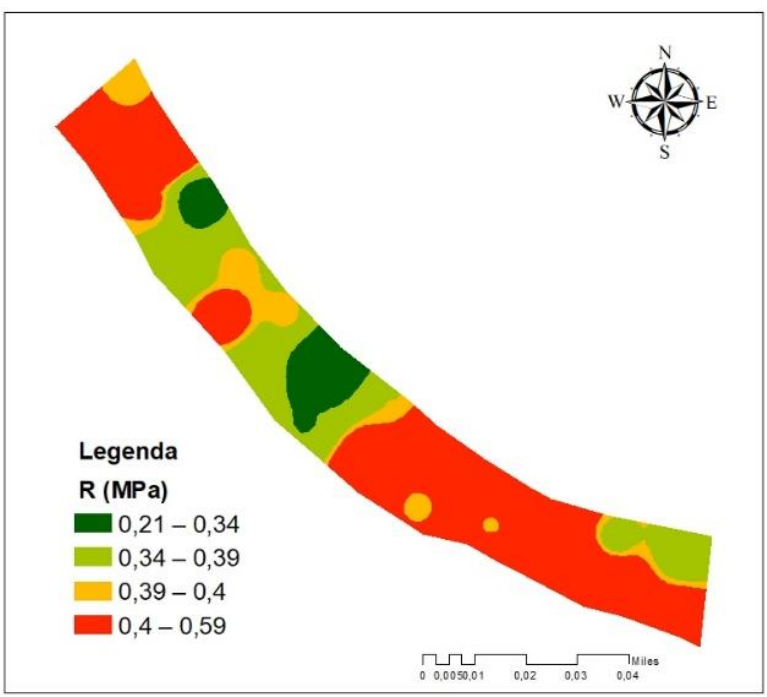

Mapa do teor de umidade do solo

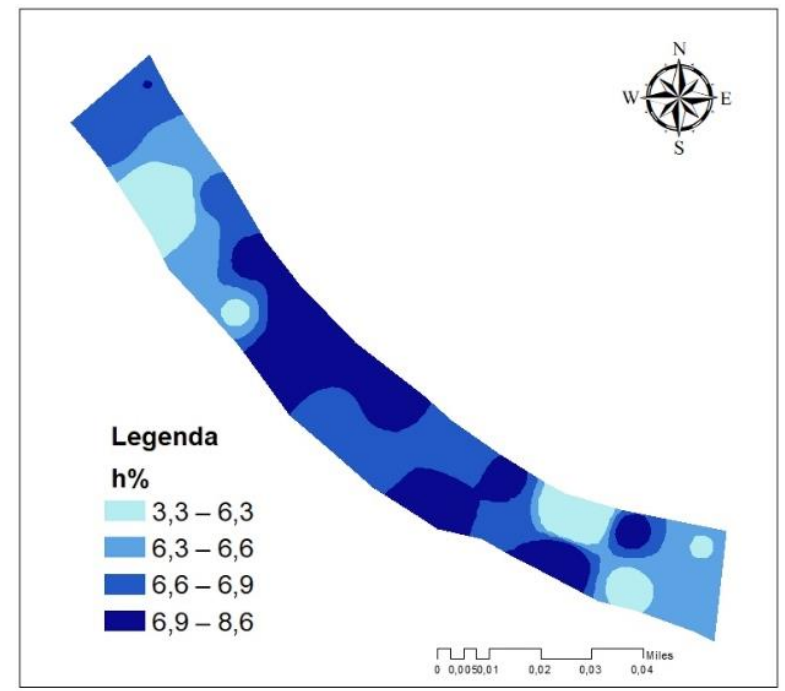

Fonte: Própria (2020).

Figura 7: Mapas de resistência a penetração e umidade do solo resultantes da $3^{\circ}$ análise (Outubro/2019).

Mapa de resistência do solo a penetração

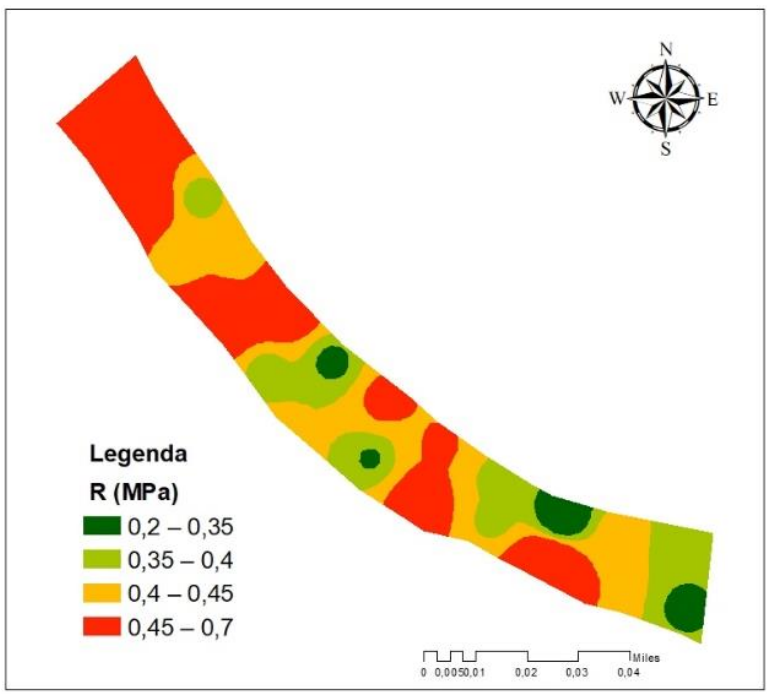

Mapa do teor de umidade do solo

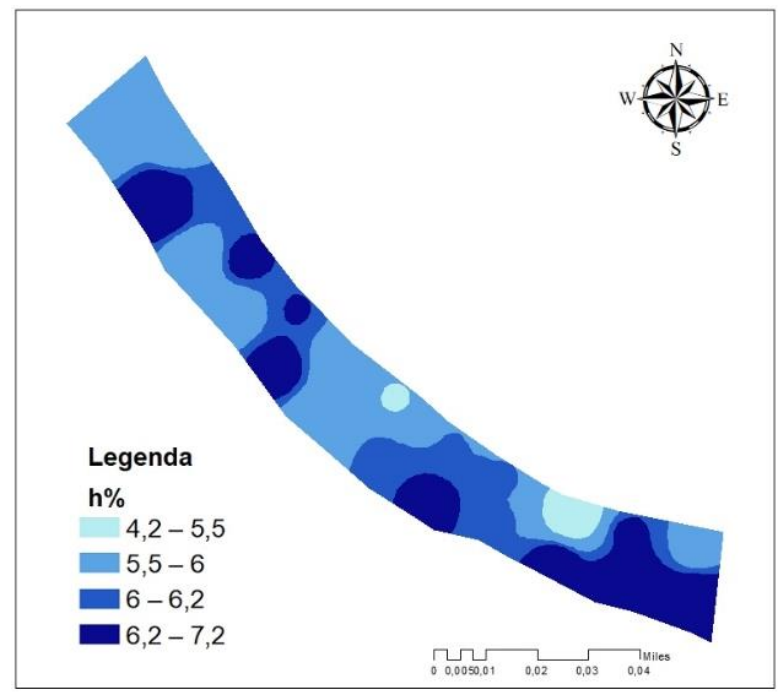

Fonte: Própria (2020). 
Também houve variabilidade espacial entre os atributos avaliados na $3^{\circ}$ análise (Figura 07), nota-se também a existência correlação entre umidade e resistência do solo a penetração em algumas regiões da área experimental. Desta forma observando-se o mapa de resistência do solo a penetração verifica-se que na região noroeste do mapa houve predominância de valores altos de resistência, onde esse fato pode ter sido influenciado pela baixa umidade naquela localidade. Já na região sudeste apresentou menores valores de resistência e maior teor de umidade do solo. De acordo com Cancian (2015), quando o teor de água aumenta, a resistência do solo a penetração tem seus valores diminuídos pela redução das forças de coesão que atuam entre as partículas de solo, o que ocasiona um aumento das forças de adesão, mudando a consistência de friável para plástica, e desta forma, alcançando valores limitantes ao crescimento de raízes em condições de baixo teor de umidade no solo.

De acordo com o resultado das 3 avaliações realizada na área experimental, pode-se notar que houve variabilidade espacial e temporal dos atributos avaliados, e que o estudo dessa variabilidade é indispensável para identificar áreas que necessitam de manejo e correção.

Figura 8: Mapa de altitude da área experimental.

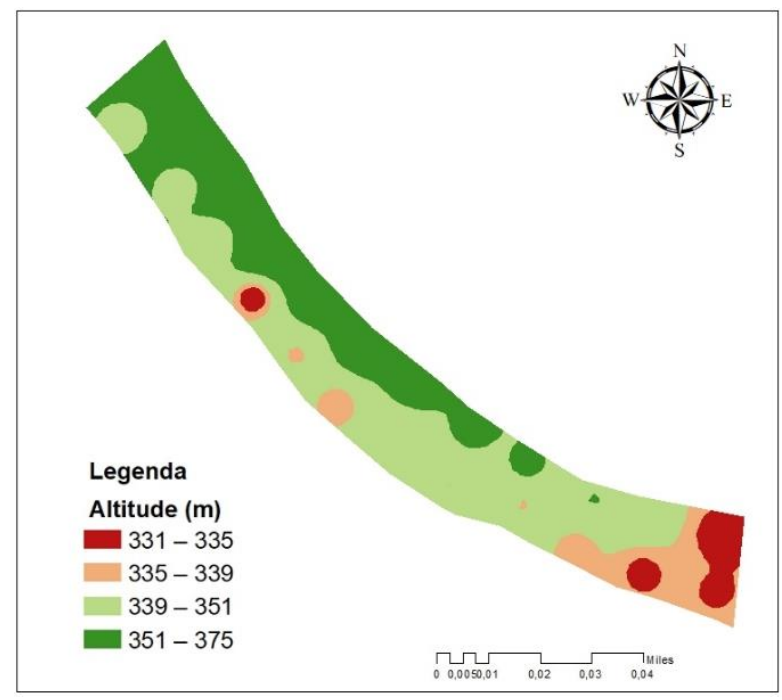

Fonte: Própria (2020).

Com base na Figura 08, nota-se que o mapa de altitude apresenta variabilidade na área experimental. Além disso, pode-se observar que na região nordeste do mapa foram obtidos maiores valores de altitude, já na região sudeste há predominância de menores níveis de elevação.

Realizando uma comparação visual entre o mapa de altitude e os mapas da $1^{\circ}$ análise (Figura 05) pode-se observar que na região de maiores altitude obteve-se predominância 
de maior umidade do solo, e predomínio de valores com menor resistência do solo a penetração. Já a comparação do mapa de altitude com mapas da $2^{\circ}$ análise (Figura 06) é possível observar que houve correlação entre os mapas, visto que na região sudeste da área apresentou menores valores de altitude, porém maiores valores de resistência do solo a penetração e menor teor de umidade do solo. Na comparação do mapa de altitude com os mapas da $3^{\circ}$ análise (Figura 07), observou-se que na região sudeste onde houve menores valores de altitude obteve-se predominância de maiores valores de umidade e menor resistência do solo a penetração.

\section{Conclusões}

Foi possível identificar variabilidade na área experimental através da avaliação espacial da resistência do solo a penetração e encontrar correlação significativa entre resistência do solo a penetração e a umidade do solo, e também entre a altitude e a umidade do solo.

A primeira avaliação da resistência do solo a penetração apresentou alto niveis de compactação, já nas demais avaliações ocorreu diminuição nos níveis de compactação do solo, devido a presença da Brachiaria brizantha cv. Marandu que influenciou na descompactação do solo.

O uso do mapeamento espacial e temporal dos atributos mostrou-se eficiente para identificação das áreas que necessitam de manejo diferenciado, mostrando que as técnicas de agricultura de precisão são ferramentas importantes para um tratamento adequado das áreas cultivadas.

\section{Referências}

AMADO, T. J. C.; PES, L. Z.; LEMAINSKI, C. L.; SCHENATO, R. B. Atributos químicos e físicos de Latossolos e sua relação com rendimentos de feijão e milho irrigados. Revista Brasileira de Ciência do Solo, Cap. 33, p. 831-843, 2009.

BERNARDI, A. C. C; Et al. Agricultura de precisão: resultados de um novo olhar. 1.ed. Brasília, DF: Embrapa, 2014.

BELTRAME, L.F.S.; GONDIN, L.A.P. \& TAYLOR, J.C. Estrutura e compactação na permeabilidade de solos do Rio Grande do Sul. Revista Bras. Ci. Solo, 5:145-149, 1981

CALONEGO, J. C.; BORGHI, E. \& CRUSCIOL, C. A. C. Intervalo hídrico ótimo e compactação do solo com cultivo consorciado de milho e braquiária. Revista Brasileira de Ciência do Solo, 35:2183-2190, 2011. 
CAMPOS, M.C.C.; Et al. Variabilidade espacial da resistência do solo à penetração e umidade em áreas cultivadas com mandioca na região de Humaitá, AM. Revista Agro@mbiente Online, v. 6, n. 1, p. 09-16, 2012.

CANCIAN, L. C. Variabilidade espacial da resistência a penetração, granulometria e umidade do solo. 2015. 59 f. Dissertação (Mestrado em Agronomia) - Curso de Pós-graduação em Agronomia, Universidade Federal de Santa Maria, RS. 2015.

CARVALHO, G.J.; Et al. Correlação da produtividade do feijão com a resistência à penetração do solo sob plantio direto. Revista Bras. Eng. Agríc. Ambiental, v.10, n.3, p.765-771, 2006.

DALCHIAVON, F.C.; Et al. Variabilidade espacial de atributos da fertilidade de um Latossolo Vermelho Distroférrico sob Sistema Plantio Direto. Revista Ciência Agronômica, v.43, p. 453-461, 2012.

DANCEY, C.; REIDY, J.. Estatística sem matemática para psicologia: usando SPSS para Windows. Porto Alegre: Artmed, 2006.

DEDECEK, R.A.; GAVA, J.L. Influência da compactação do solo na produtividade da rebrota de eucalipto. Rev. Árvore, Viçosa, vol. 29 n. 3, 2005.

FERREIRA, A.O.; Et al. Influência da declividade e de níveis de cobertura do solo no processo de erosão com chuva simulada. Revista Verde, Mossoró, v.5, n.5, p. 182 - 190. 2010.

FILHO, D.B.F.; JÚNIOR, J.A.S. Desvendando os Mistérios do Coeficiente de Correlação de Pearson (r). Revista Política Hoje, v. 18, n. 1, 2009.

FLOWERS, M.D., LAL, R. Axle load and tillage effects on soil physical properties and soybean grain yield on a mollic ochraqualf in northwest Ohio. Soil \& Tillage Research, Amsterdam, v.48, p.21-35, 1998.

GOMES, F.P. Curso de estatística experimental. $14^{\mathrm{a}}$ ed. Piracicaba, Degaspari. 200. 477p.

IVO, C.T.C.; FILHO, A.A.F. Estatística pesqueira: Aplicações em engenharia de pesca. Fortaleza, Tom Gráfica, 1997. 193 p.

LIMA, R. P.; LEÓN, M. J.; SILVA, A. R. Comparação entre dois penetrômetros na avaliação da resistência mecânica do solo à penetração. Rev. Ceres. Viçosa. v.6, n.4, p. 577-581, jul/ago, 2013.

MORAES, M.P. Et al. Correlação entre os penetrômetros manual e automático na determinação da resistência mecânica a penetração em latossolo vermelho. In: AMARAL, L.P. Congresso sul americano de Agricultura de Precisão e máquinas precisas. 5. ed. Não me toque: CESPOL, 2020. p 82 - 89.

NETO, J.F.; Et al. Biological soil loosening by grasses from genus Brachiaria in croplivestock Integration. Acta Scientiarum. Maringá, v. 37, n. 3, p. 375-383, 2015.

OLIVEIRA, D.G.; Et al. Correlação espacial de atributos físicos do solo e produtividade de tomate industrial. Revista Agro@mbiente On-line, v. 12, n. 1, p. 1-10, 2018. 
RAZUK, R.B. Avaliação do sistema radicular de acesso de Brachiaria brizantha e suas relações com atributos químicos e físicos do solo. 2002. 56 f. Dissertação (Mestrado) Universidade Federal de Mato Grosso do Sul, Dourados, 2002.

RIBON, A.A.; TAVARES FILHO, J. Estimativa da resistência mecânica à penetração de um Latossolo Vermelho sob cultura perene no norte do Estado do Paraná. Revista Brasileira de Ciência do Solo, v.32, p.1817-1825, 2008.

RIBEIRO, G.F.; Estudo dos fatores do meio físico que influenciam a capacidade de infiltração das águas da bacia hidrográfica vargens de caldas, Minas Gerais. 2010. 96 f. Dissertação (Mestrado) - Universidade estadual de Campinas, Campinas, 2010.

RICHART, A.; Et al. Compactação do solo: causas e efeitos. Ciências Agrárias, Londrina, v. 26, n. 3, p. 321-344, 2005.

RETKA, W.; Efeito da cultura do nabo forrageiro na descompactação do solo. 2018. 52 f. Trabalho de Conclusão de Curso (Graduação) - Universidade Tecnológica Federal do Paraná, Francisco Beltrão, 2018.

SANTOS, F.S., et al. A utilização de plantas de cobertura na recuperação de solos compactados. Acta Iguazu, Cascavel, v.3, n.3, p. 82-91, 2014.

SANTOS, H. G.; et al. Sistema Brasileiro de Classificação de Solos. 5. Brasília: 2018. 355 p.

SILVA, V.R.; Et al. Variabilidade espacial da resistência do solo à penetração em plantio direto. Ciência Rural, Santa Maria, v.34, n.2, p.399-406, 2004.

SILVEIRA, D.C.; Et al. Relação umidade versus resistência á penetração para um argissolo amarelo distrocoeso no recôncavo da Bahia. Revista Bras. Ci. Solo, v.34, p.659-667, 2010.

SOUZA, G.S. de et al. Krigagem ordinária e inverso do quadrado da distância aplicados na especialização de atributos químicos de um argissolo. Scientia Agraria, Curitiba, v. 11, n. 1, 2010. p $73-81$

SOUZA, Z.M.; Et al. Dependência espacial da resistência do solo à penetração e do teor de água do solo sob cultivo contínuo de cana-de-açúcar. Ciência Rural, Santa Maria, v.36, n.1, p.128-134, 2006.

STOLF, R. Teoria e teste experimental de fórmulas de transformação dos dados de penetrômetro de impacto em resistência do solo. Revista Bras. de Ciência do Solo, 15:229235, 1991.

VOGEL, Gabriel Felipe et AL. Avaliação dos penetrômetros de impacto e eletrônico na determinação da resistência mecânica à penetração do solo. Revista Scientia Agrária, Curitiba, v. 18, p.6-6, 29 set.2017. 


\title{
CAPÍTULO 28: CONSUMO DE CERVEJA: DESCRIÇÃO DOS CONSUMIDORES NA REGIÃO AGRESTE DE PERNAMBUCO
}

\section{CHAPTER 28: BEER CONSUMPTION: DESCRIPTION OF CONSUMERS IN THE AGRESTE DE PERNAMBUCO REGION}

\author{
Giovanna Raissa de Souza Lima ${ }^{1}$; Daniele dos Santos Bernardo ${ }^{2}$; Gerla Castello Branco Chinelate ${ }^{3}$
}

\begin{abstract}
Resumo
O presente estudo teve por objetivo caracterizar o perfil do consumidor de cerveja do agreste de Pernambuco de acordo com suas preferências de mercado e hábitos de consumo, este justifica-se por ser mais uma contribuição quanto ao planejamento de tomada de decisões e redução de riscos de rejeição de novos produtos. Para realização da pesquisa foi utilizado formulário eletrônico através da plataforma google forms que foi divulgado por meio das redes sociais (Instagram, WhatsApp e Twitter). No questionário constavam perguntas como gênero, estado civil, faixa etária, alguns hábitos de consumo como locais de preferência para realização da compra e consumo, e algumas especificidades com relação ao conhecimento sobre os tipos e estilos de cerveja como a diferença entre os tipos Lager e Ale. O questionário obteve 165 respondentes, todos residentes do Agreste de Pernambuco e maiores de 18 anos. Por fim, foi concluído que o perfil do consumidor de cervejas caracterizado através desta pesquisa é predominante por mulheres, universitárias, sem renda definida, que não conhecem muito sobre as diferenças de tipo e estilo das cervejas e que preferem comprar suas bebidas em supermercados e realizar o consumo em suas próprias residências.
\end{abstract}

Palavras-Chave : Cerveja, Consumo, Agreste, Pernambuco

\begin{abstract}
This study aimed to characterize the profile of beer consumers in the Agreste of Pernambuco region according to their market preferences and consumption habits, this is justified because it is a further contribution to planning decision making and reducing the risks of rejection of new products. To carry out the research it was used an electronic form through the google forms platform which was disclosed through social networks (Instagram, WhatsApp and Twitter). The questionnaire included questions such as gender, marital status, age group, some consumption habits as places of preference to make the purchase and consumption, and some specificities regarding the knowledge about the types and styles of beer as the difference between the Lager and Ale types. The questionnaire obtained 165 respondents, all residents of Agreste de Pernambuco and over 18 years old. Finally, it was concluded that the profile of the beer consumer characterized through this survey is predominant by women, college students, without defined income, who do not know much about the differences in type and style of beers and who prefer to buy their beverages in supermarkets and consume in their own homes.
\end{abstract}

Keywords: Beer, Consumer, Agreste, Pernambuco

Engenharia de Alimentos, Universidade Federal do Agreste de Pernambuco (UFAPE), raissalima984@gmail.com

${ }^{2}$ Licenciada em História, Universidade de Pernambuco (UPE), Pós-Graduanda em Educação, cultura e diversidade, UNIASSELVI, danielesbernardo23@gmail.com

${ }^{3}$ Doutora, Professora da Universidade Federal do Agreste de Pernambuco (UFAPE), gerla.chinelate@ufape.edu.br 


\section{Introdução}

A cerveja é uma bebida fermentada muito conhecida entre pessoas de todo o mundo, sua diversidade de estilos, cores e sabores vem tomando cada vez mais espaço no mercado brasileiro. Tomar cerveja para muitos vai além de consumir uma bebida alcoólica, é uma experiencia gastronômica. Não se tem certeza de sua origem, mas acredita-se que sua descoberta tenha ligação com o início da prática da agricultura, e que remontam as origens da própria civilização (Barth, 2013).

De acordo com a instrução normativa $\mathrm{n}^{\circ}$ 65, de 10 de dezembro de 2019, “cerveja é a bebida resultante da fermentação, a partir da levedura cervejeira, do mosto de cevada malteada ou de extrato de malte, submetido previamente a um processo de cocção adicionado de lúpulo ou extrato de lúpulo" (MAPA, 2019). Estima-se que existam aproximadamente 20 mil tipos de cerveja no mundo. O MAPA (Ministério da Agricultura, Pecuária e Abastecimento) publicou um artigo com informações sobre o setor cervejeiro, e nele consta que a produção mundial de cerveja em 2016 foi de 1,95 bilhões de hectolitros, e no Brasil esse número foi de 140 milhões, a maior parte da produção ficou concentrada em São Paulo e no Rio Grande do Sul (MAPA, 2017).

O mercado cervejeiro é um dos que mais empregam no País, isso se dá por conta da sua extensa cadeia produtiva que vai desde as plantações de cevada até os pequenos mercados que comercializam a bebida, segundo a CervBrasil (Associação Brasileira da Indústria da Cerveja), o setor cervejeiro nacional é responsável por 1,6\% do PIB (produto interno bruto) nacional, por 2,7 milhões de empregos, em 2017 gerou um faturamento de 107 bilhões de reais, o setor gera cerca de R 21 bilhões de impostos ao ano (CERVBRASIL, 2018).

No estado de Pernambuco a produção de cerveja conta com 24 marcas e 11 fábricas diferentes, além de produzir 2,5 milhões de litros por ano de acordo com uma matéria publicada no jornal Folha de Pernambuco (FOLHA DE PERNAMBUCO, 2018). Além das fábricas existem as chamadas "cervejarias ciganas", que não tem estrutura de fábrica própria e terceirizam toda a sua produção, elas não estão registradas, mas tem papel importante na economia, uma vez que também geram empregos.

Diante disso, fica evidente a importância de conhecer o perfil do consumidor pois este é o principal responsável por fazer esse ramo de mercado tornar-se cada dia maior. O objetivo do presente estudo foi analisar e descrever o perfil dos consumidores de cerveja do Agreste de Pernambuco quanto a alguns aspectos como suas preferências, predileções de mercado e o nível de conhecimento sobre os tipos e estilos de cerveja, além disso, deixar este estudo a disposição de empresas cervejeiras para consulta, com o intuito de que possam pensar em estratégias e 
ações de marketing de acordo com as preferências de seu público alvo. O mesmo justifica-se por ser mais uma contribuição quanto ao planejamento de tomada de decisões e redução de riscos quanto a rejeição de novos produtos e no ato de atrair clientes para o seu produto, pois como SENKO (2018) menciona em seu artigo, conhecer clientes seus clientes melhor, pensar em estratégias para obter maior satisfação e consequentemente gerar lucros maiores, são pontos que pode-se utilizar para definição de seu público-alvo, posicionamento no mercado e estratégias de marketing.

Para tal fim, foram realizadas algumas perguntas aos consumidores de cerveja do agreste de Pernambuco por meio de questionário eletrônico com a finalidade de traçar um perfil de acordo com as respostas obtidas com a pesquisa, nela constavam questões como gênero, faixa etária, estado civil, escolaridade ou nível de instrução, renda mensal, hábitos de consumo e preferências entre estilos e tipos de cervejas, bem como questionou-se acerca de seus conhecimentos sobre estes.

Para embasar a busca pelos resultados esperados nessa pesquisa específica foram utilizadas dados de autores como Arruda (2018), Garcia (2019), Nardi (2018), Pedrosa (2011) e Senko (2018), nos quais buscou-se analisar os estudos de caráter similar acerca de perfis de consumo e álcool e assim observar com veemência os resultados obtidos no que se refere aos dados sobre a região foco desse estudo.

\section{Material e Métodos}

O método utilizado para realização da análise foi o de amostragem por conveniência, ele é descrito por Mattar em seu livro Pesquisa de marketing, esse método se aplica a pesquisas exploratórias (Mattar, 2014), sob a perspectiva da pesquisa exploratória a principal vantagem de utilizar esse método é o baixo custo para realização da análise e os resultados fornecem um parâmetro geral do que foi estudado.

O questionário foi composto ao todo por 16 (dezesseis) perguntas e elaborado através da plataforma gratuita do Google, a Google forms (https://docs.google.com/forms). A divulgação do formulário foi realizada por meios eletrônicos através de redes sociais (WhatsApp, Twitter e Instagram) num período de 20 (vinte) dias. A escolha dos respondentes foi aleatória e todos foram voluntários. A pesquisa foi realizada de forma totalmente virtual devido ao cumprimento das medidas de isolamento e distanciamento social, seguindo as orientações da Organização Mundial da Saúde (OMS), em virtude da pandemia mundial do Covid-19.

Para avaliar o perfil do consumidor foram realizadas perguntas quanto ao gênero, idade, 
escolaridade ou nível de instrução, estado civil e renda mensal. Os entrevistados foram questionados também a respeito de seu conhecimento prévio sobre os tipos de cerveja, como por exemplo a diferença entre as famílias Lager e ALE e quais os tipos dentre cada uma dessas famílias que eles mais consumiam.

Quanto as preferências e hábitos de consumo, foi questionado sobre a preferência por cervejas artesanais ou comerciais, aos que consumiam cerveja artesanal foi questionado se consumiam preferencialmente cervejas da região em que residiam ou de outras regiões, também foi questionado a frequência de consumo, o fator mais importante na hora da compra, em que local costuma consumir e comprar e os que não consumiam cerveja foram indagados sobre o motivo de não o fazerem.

Para realizar o cálculo da análise da unidade amostral (número mínimo de respostas para o formulário) foi utilizada a ferramenta online Calculator.net (https://www.calculator.net/sample-size-calculator.html), com nível de confiança de 80\%, margem de erro de $5 \%$ e número de habitantes, segundo o banco de dados geográficos (Agreste, 2007) correspondente a 2.103.740.

\section{Resultados e Discussão}

O questionário foi destinado a consumidores de cerveja do Agreste de Pernambuco, os quais responderam de forma voluntária e aleatória, foram obtidas 165 respostas. Conforme o cálculo de análise amostral realizado pela ferramenta online supracitada, Calculator.net, o número mínimo necessário para obter $80 \%$ de confiabilidade era de 153 respondentes ao formulário, como o número obtido foi de 165 respostas, acabou superando um pouco o número mínimo de amostragem de acordo com a população total estimada do Agreste de Pernambuco.

No que se refere ao perfil dos consumidores de cerveja que responderam o formulário, $61,2 \%$ são do gênero feminino, e 38,8\% são do gênero masculino, correspondendo a 101 e 64 respondentes, respectivamente (Figura 1). 
Figura 1. Distribuição de gênero dos 165 participantes que responderam voluntariamente o formulário sobre o perfil dos consumidores de cerveja do Agreste de Pernambuco.

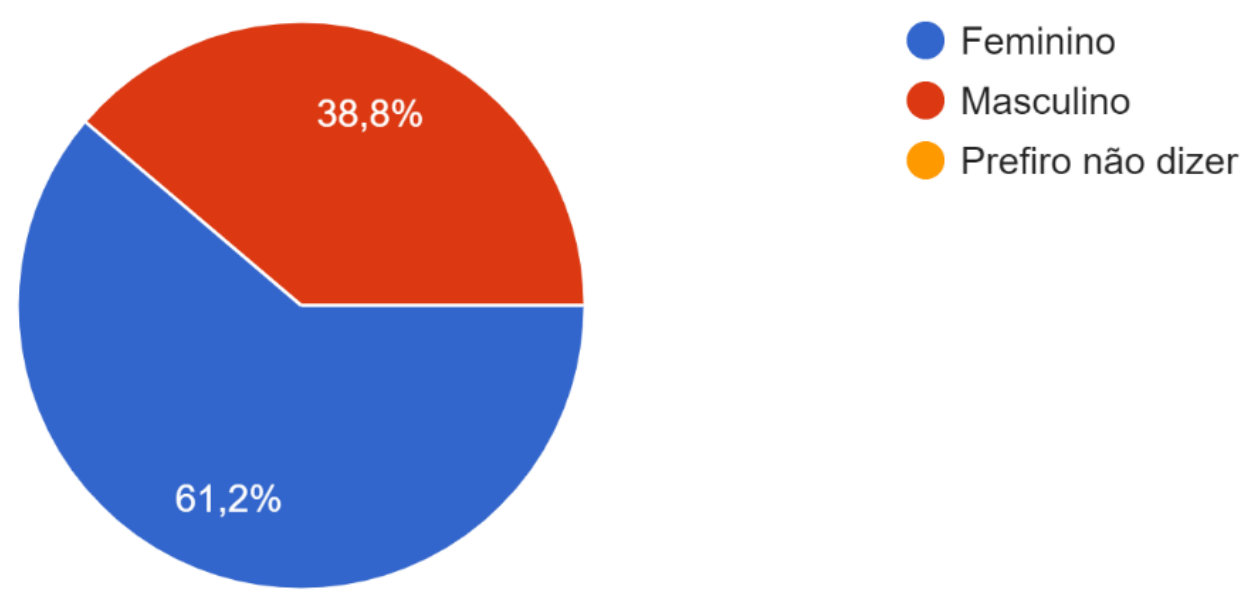

Fonte: Própria (2020).

Entretanto, nem todos que responderam o questionário consomem cerveja, entre as 101 mulheres que responderam o questionário, 19 não consomem cerveja, e entre os 64 homens que responderam o questionário, 5 não consomem cerveja, ainda assim o percentual de consumo por mulheres é superior ao dos homens. Esse ponto especifico diverge da pesquisa publicada pela Mind Miners (2018), que obteve um percentual igual entre homens e mulheres, isso mostra um possível aumento na participação do público feminino no consumo de cervejas, o que pode ser visualizado na figura 2 abaixo:

Figura 2. Gênero dos consumidores de cerveja do agreste de Pernambuco.

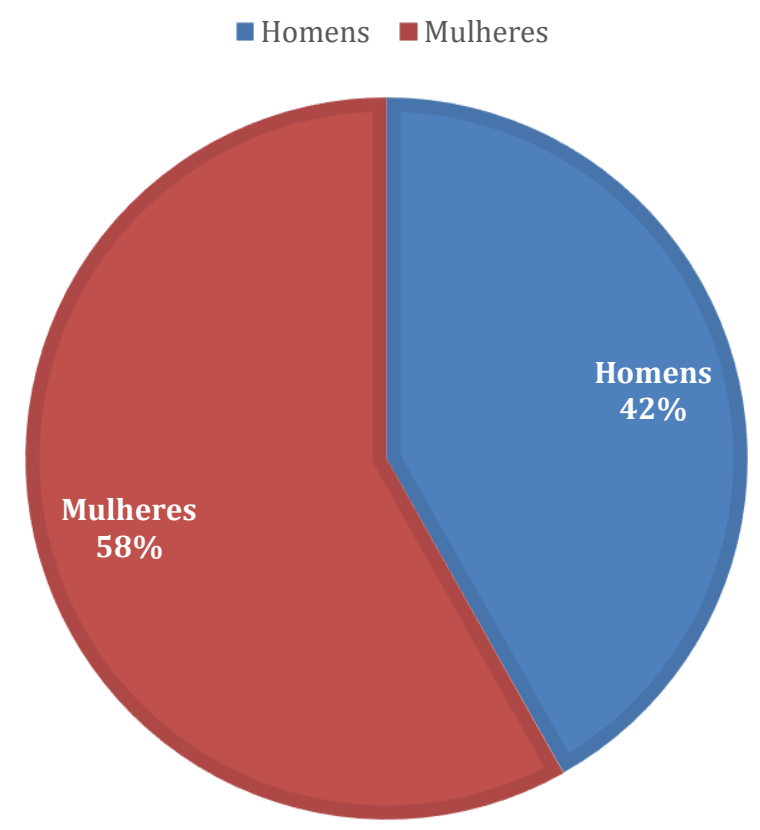

Fonte: Própria (2020). 
No que se refere a idade dos participantes, foi questionado em qual faixa etária os respondentes estavam inclusos, a grande maioria, 71,5\% respondeu ter entre 18 e 25 anos, totalizando 118 respondentes, divergindo novamente com a pesquisa realizada pela Mind Miners (2018), a qual obteve um resultado de que a faixa etária dos consumidores era de 31 a 40 anos, quando nessa pesquisa essa faixa etária obteve apenas $6,1 \%$ das respostas, sendo a faixa etária com o menor número de consumidores de acordo com a pesquisa, como é visto na figura 3 abaixo:

Figura 3. Faixa etária dos respondentes.

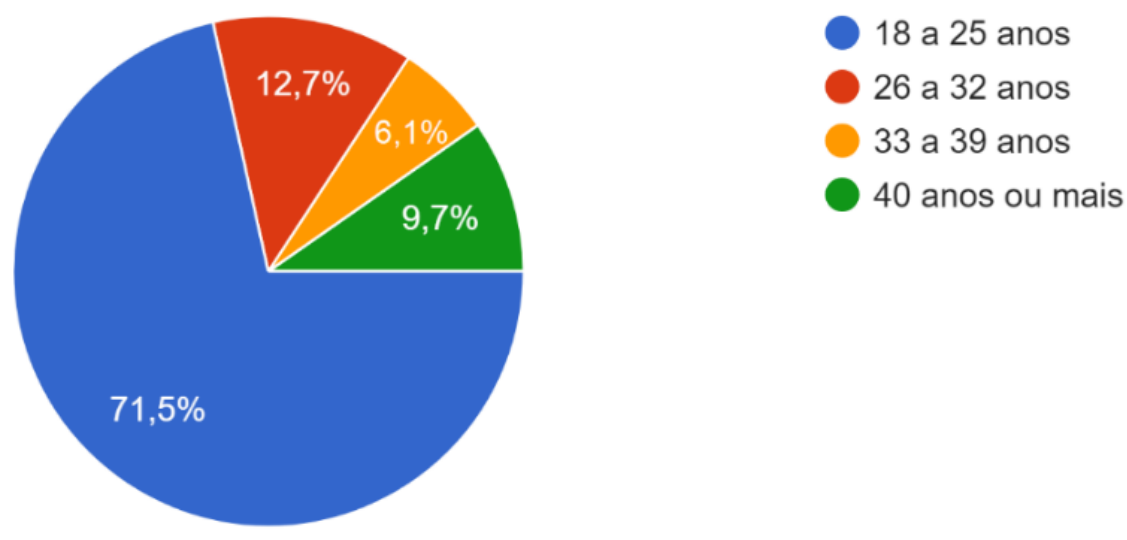

Fonte: Própria (2020).

Em relação a escolaridade ou nível de instrução, a maioria dos que responderam afirmaram ter o ensino superior incompleto, sendo assim 78 dos respondentes são universitários, em 2011 foi publicada uma pesquisa sobre consumo de álcool entre estudantes universitários por Pedrosa et al. (2011) e a cerveja ficou em primeiro lugar como a bebida mais consumida entre os jovens, com $35,4 \%$, seguida do vinho que obteve $27,1 \%$, confirmando que os universitários são um público consideravelmente massivo no que se refere ao consumo de bebidas alcóolicas, especialmente a cerveja.

No que concerne ao estado civil dos respondentes, 79,4\% afirmaram ser solteiros, o que equivale a 131 pessoas, totalizando a grande maioria das repostas, seguido por casados e divorciados, que totalizaram $14,5 \%$ e $4,2 \%$ respectivamente, os últimos $2,1 \%$ são pessoas que afirmaram estar em uma união estável (figura 4). Comparando esse resultado com o da pesquisa de Costa (2008) os resultados foram bem semelhantes, em sua pesquisa a maioria dos respondentes declarou ser solteiro, com $60,3 \%$ do total, e o restante apontou a condição de casado $(33,7 \%)$, ou outros $(6 \%)$. O estado civil solteiro é o que apresenta maior número de respostas na pesquisa de Oliveira e Moraes (2018) também foram obtidos resultados semelhantes, ele pontua que "a quantidade de consumidores solteiros $(55,8 \%)$ sobrepõe-se em relação aos consumidores casados $(37,8 \%)$ de forma considerável" (OLIVEIRA;MORAES, 
2018).

Figura 4. Estado civil dos respondentes.

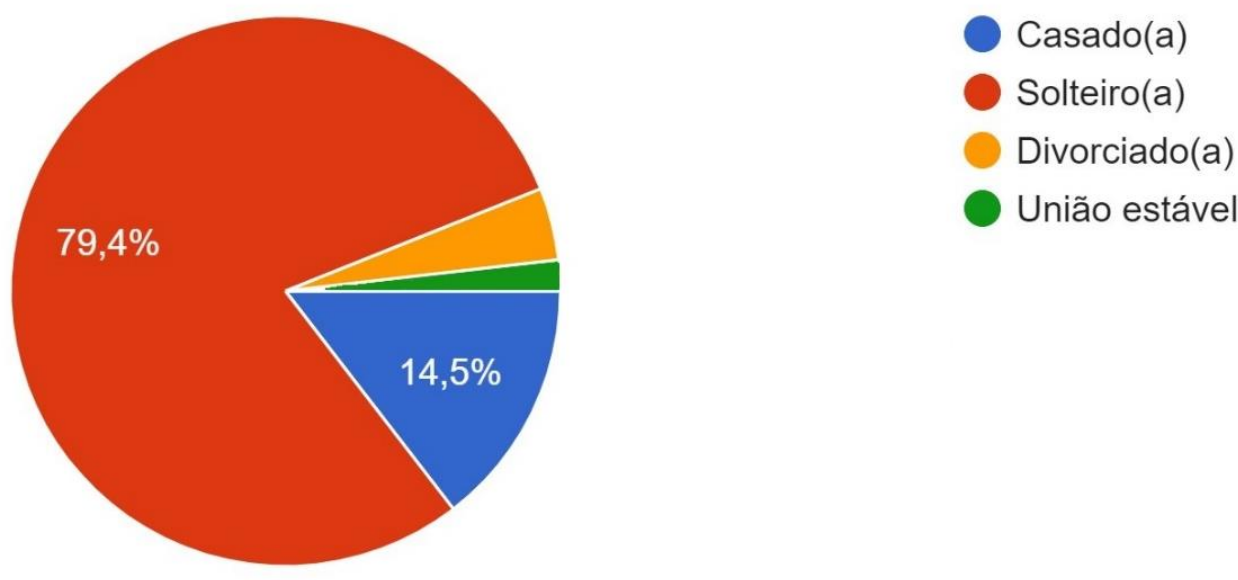

Fonte: Própria (2020)

Referente a renda mensal, as respostas estão apresentadas na figura 5 abaixo, como podemos constatar, a maioria dos consumidores de cerveja que responderam a pesquisa não possuem renda definida, seguidos de quem recebe até um salário mínimo, que totalizou 32,7\% dos resultados. Já na pesquisa de Garcia (2019), realizada em Mogi Guaçu - SP e que tratava de consumidores de cerveja artesanal, ela constatou que a maioria dos homens e mulheres que responderam sua pesquisa recebiam de 3 a 4 salários mínimos, essa diferença de renda pode ser consequência das preferências de cada público, pois cervejas artesanais geralmente são mais caras que as comerciais.

Figura 5. Renda mensal dos respondentes.

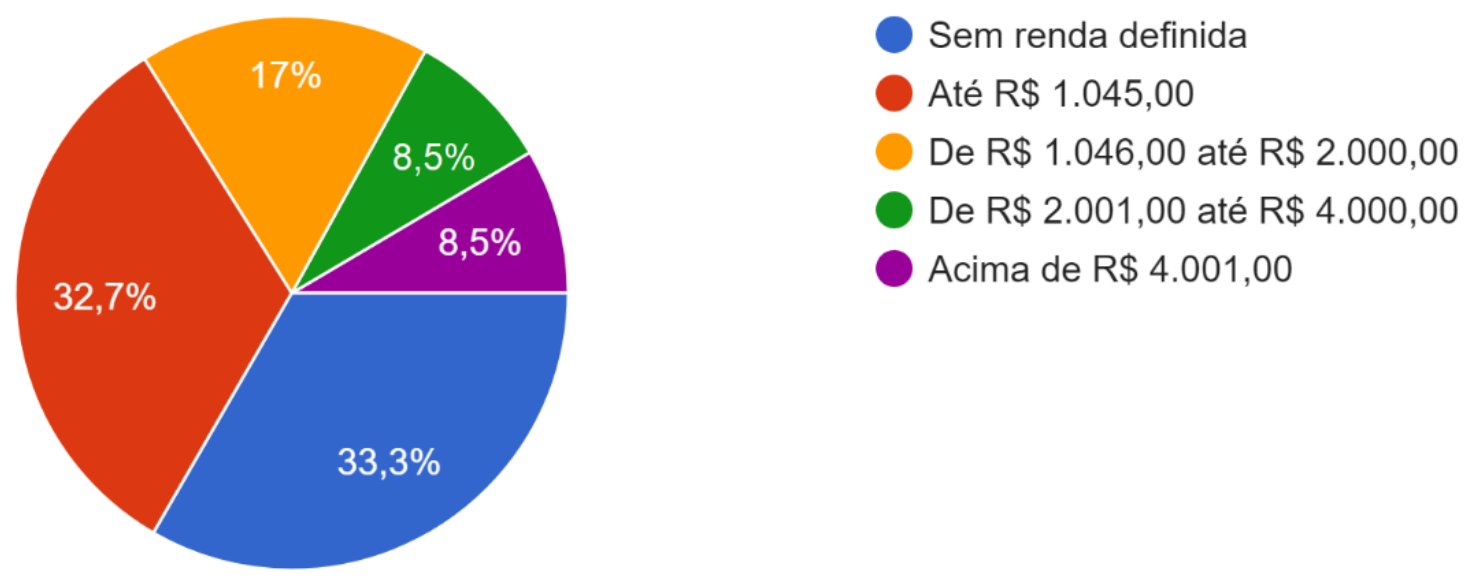

Fonte: Própria (2020).

Sobre os tipos de cerveja, foi questionado aos respondentes se eles conheciam a diferença entre as famílias Lager que são cervejas de baixa fermentação e ALE, que são as 
cervejas de alta fermentação, e a maioria respondeu que não conhecia a diferença, $78,8 \%$ das respostas, como pode ser visto na figura 6 abaixo.

Figura 6. Abordagem acerca do conhecimento dos consumidores sobre a diferença entre Lager e Ale.

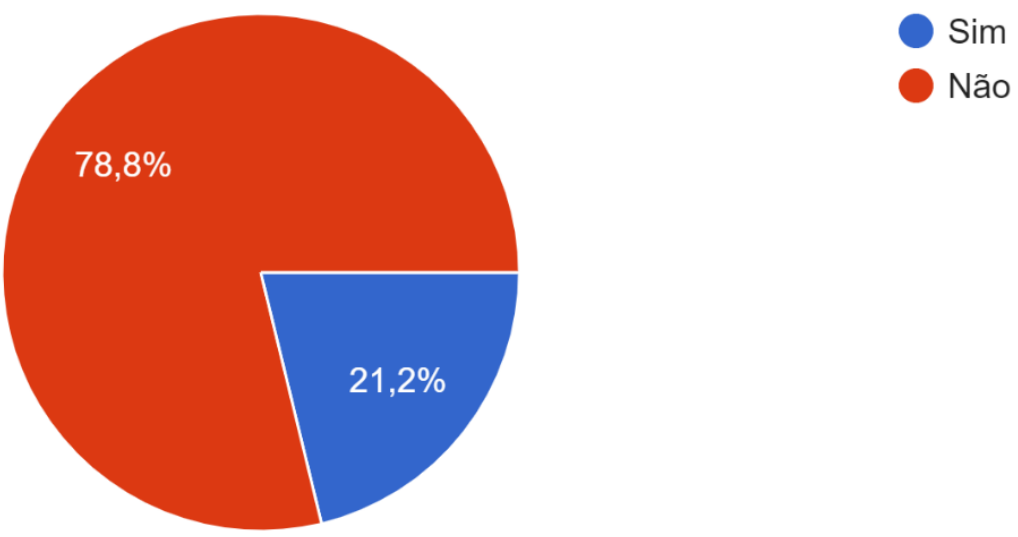

Fonte: Própria (2020).

Dentro das famílias Lager e ALE existem vários estilos de cerveja, indagou-se aos consumidores quais estilos de cerveja eles mais consumiam, essa pergunta foi dividida em duas, uma para os estilos pertencentes a família ALE e outra para os estilos pertencentes a família Lager, como podemos observar nas figuras 7 e 8 abaixo:

Figura 7. Estilos de cerveja da família ALE mais consumidos pelos respondentes.

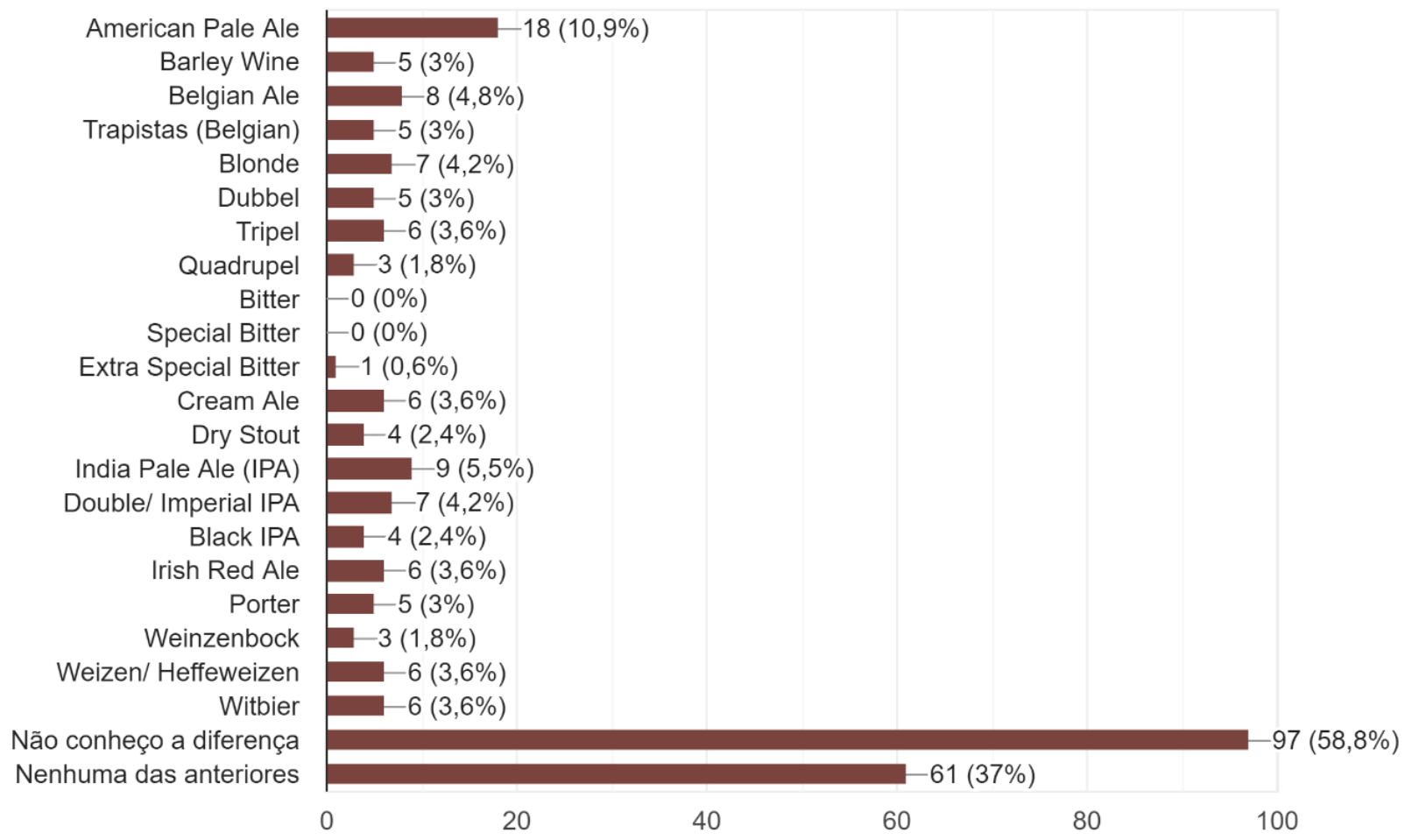

Fonte: Própria (2020).

Como podemos observar na figura 7 acima, os estilos de cerveja mais consumidos da 
família ALE são, American Pale Ale com 10,9\% das respostas, India Pale Ale (IPA) com 5,5\% das respostas e Belgian Ale com 4,8\%. Dos que responderam, 58,8\% não conhece a diferença entre os estilos e $37 \%$ não consome nenhum dos estilos mencionados. Na figura 8 abaixo temos os estilos mais consumidos da família Lager:

Figura 8. Estilos de cerveja da família Lager mais consumidos pelos respondentes.

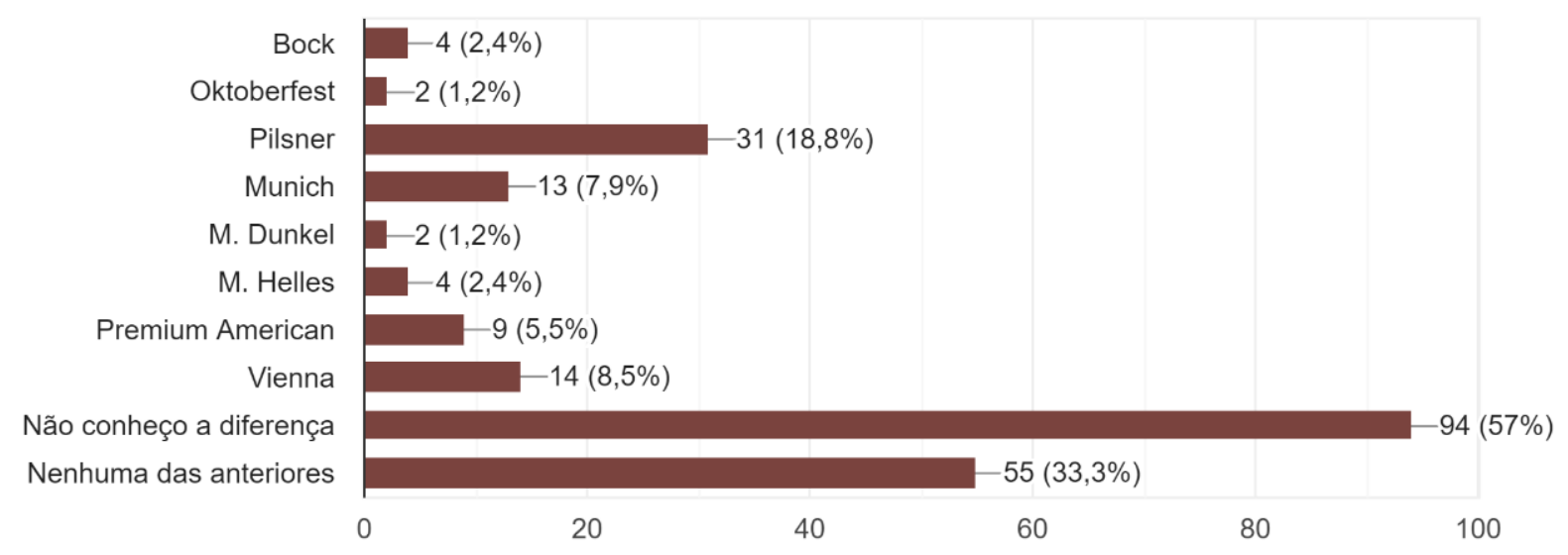

Fonte: Própria (2020).

Conforme os dados obtidos na figura 8 acima, os estilos de cerveja da família Lager mais consumidos pelos que responderam o formulário são, Pilsner com 18,8\% das respostas, Vienna com 8,5\% e Munich com 7,9\% das respostas. Dos que responderam, $57 \%$ não conhece a diferença entre os estilos e 33,3\% não consome nenhum dos estilos mencionados. Um fato interessante sobre as duas últimas perguntas é que em ambas a maioria dos respondentes afirmaram não conhecer a diferença entre os estilos de cerveja, o que indica a possibilidade de que a maioria das pessoas não se atentem a isso quando consomem suas cervejas. Dentre todos os estilos o que apresentou maior preferência foi o Pilsner com 18,8\% de representatividade, SENKO et al. (2018), obteve resultados semelhantes em sua pesquisa realizada na cidade de Curitiba - PR, ela ainda comentou que Pilsner é "um estilo de bebida leve e refrescante, de baixo teor alcóolico e dificilmente deixa de agradar os consumidores, é marcante na memória sensorial." (SENKO et al., 2018).

Também foi questionado no formulário se os consumidores tinham preferência de consumo por cervejas artesanais ou comerciais, o resultado pode ser visto na figura 9, onde mostra que $54,5 \%$ tem predileção por cervejas comerciais, no entanto a revista online Beer Art publicou uma matéria em 2018 onde afirma com base em pesquisas que os hábitos dos consumidores tem mudado e que as cervejas artesanais veem ganhando espaço no mercado (BEER ART, 2018). Então, apesar de não ser o tipo de cerveja mais apreciada, a cerveja artesanal tem ganhado cada vez mais público e mercado. 
Figura 9. Preferência dos consumidores por cervejas artesanais e comerciais.

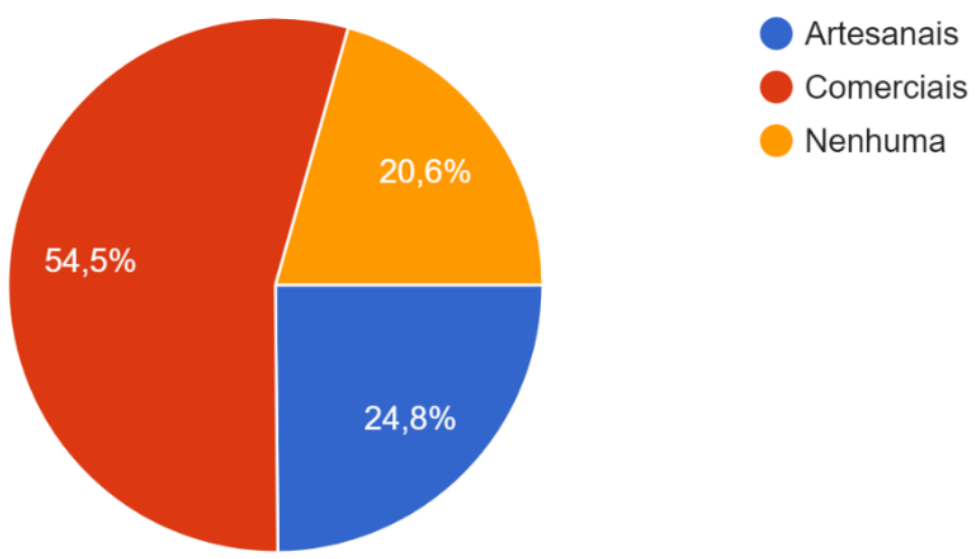

Fonte: Própria (2020).

Como mencionado anteriormente, o mercado de cervejas artesanais tem tomado uma grande proporção no mundo todo e em Pernambuco não é diferente, o estado já acumula mais de 25 rótulos, 13 fabricas e o setor produz mais de 200 mil litros de cerveja por mês (FOLHA DE PERNAMBUCO, 2019). Com a expansão do mercado é comum que ocorram cada vez mais exportações e importações desses produtos, e cabe ao consumidor escolher e dar preferência a origem do que vai consumir. Diante disso, questionou-se aos consumidores de cerveja artesanal do agreste de Pernambuco acerca da preferência da origem de suas cervejas, se optavam por rótulos da região que residiam ou de outras regiões e as repostas obtidas foram dispostas na figura 10 abaixo:

Figura 10. Preferência da origem das cervejas artesanais por consumidores do Agreste de Pernambuco.

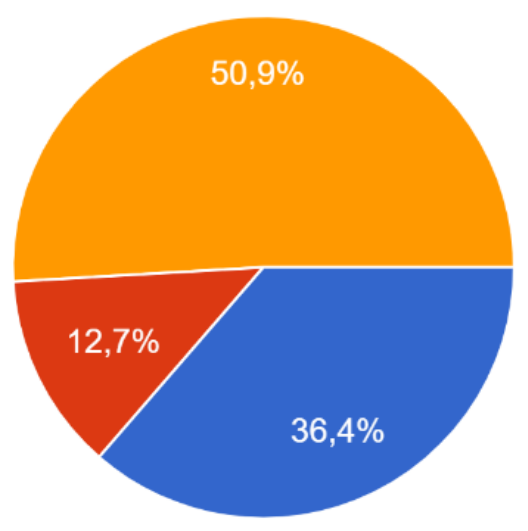

Cervejas artesanais da região em que reside

Cervejas artesanais de outras regiões

Não consumo

Fonte: Própria (2020).

Dos que afirmaram consumir cerveja artesanal, 36,4\% optam por cervejas da região em que residem, favorecendo o comercio local. Os negócios locais são o combustível de grande parte da economia, e a promoção desse tipo de consumo gera ganhos para toda a região, tendo algumas vantagens como promoção do desenvolvimento social pois o consumidor ajuda a 
fortalecer os pequenos negócios e estes são estimulados a inovar, o dinheiro circula mais em seu bairro o que promove o desenvolvimento local e esse consumo local pode afetar até o trânsito pois as pessoas precisam se deslocar bem menos pela cidade, (SEBRAE, 2020).

Sobre os hábitos de consumo, questionou-se com que frequência os respondentes consumiam cerveja, como podemos observar na figura 11 abaixo, o número de respostas para semanalmente e mensalmente foram próximas, entretanto a maioria respondeu consumir mensalmente, com $29,7 \%$ das respostas.

Figura 11. Frequência de consumo de cerveja.

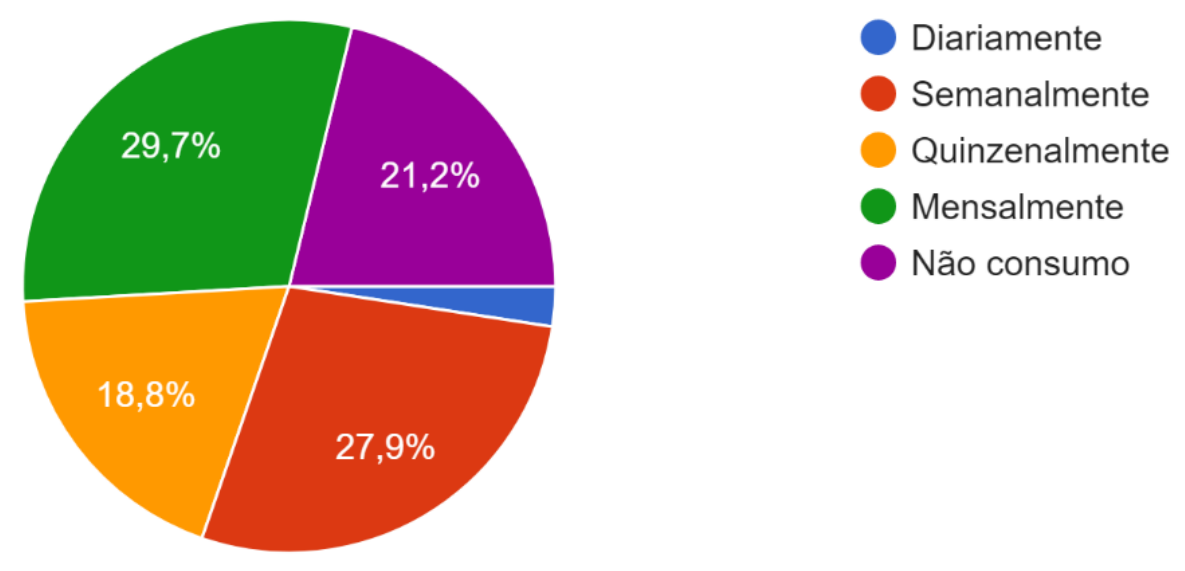

Fonte: Própria (2020).

Os dados apresentados na figura 11 acima nos revela que cada consumidor consome de acordo com sua vontade e não necessariamente existe uma frequência definida para isto, esses dados variam de acordo com a rotina e as vontades de cada consumidor. O menor número de resposta foi para a opção diariamente, com apenas $2,4 \%$.

Sobre as motivações de consumo, indagou-se o que os consumidores julgavam ser o fator mais importante na hora de comprar a cerveja. Os resultados foram distribuídos na figura 12 abaixo e surpreendem por apresentar o tipo da cerveja como principal atributo de influência na compra, pois em perguntas anteriores os consumidores demonstraram não saber diferenciar famílias e estilos de cerveja. 
Figura 12. Fatores importantes na hora da compra da cerveja.

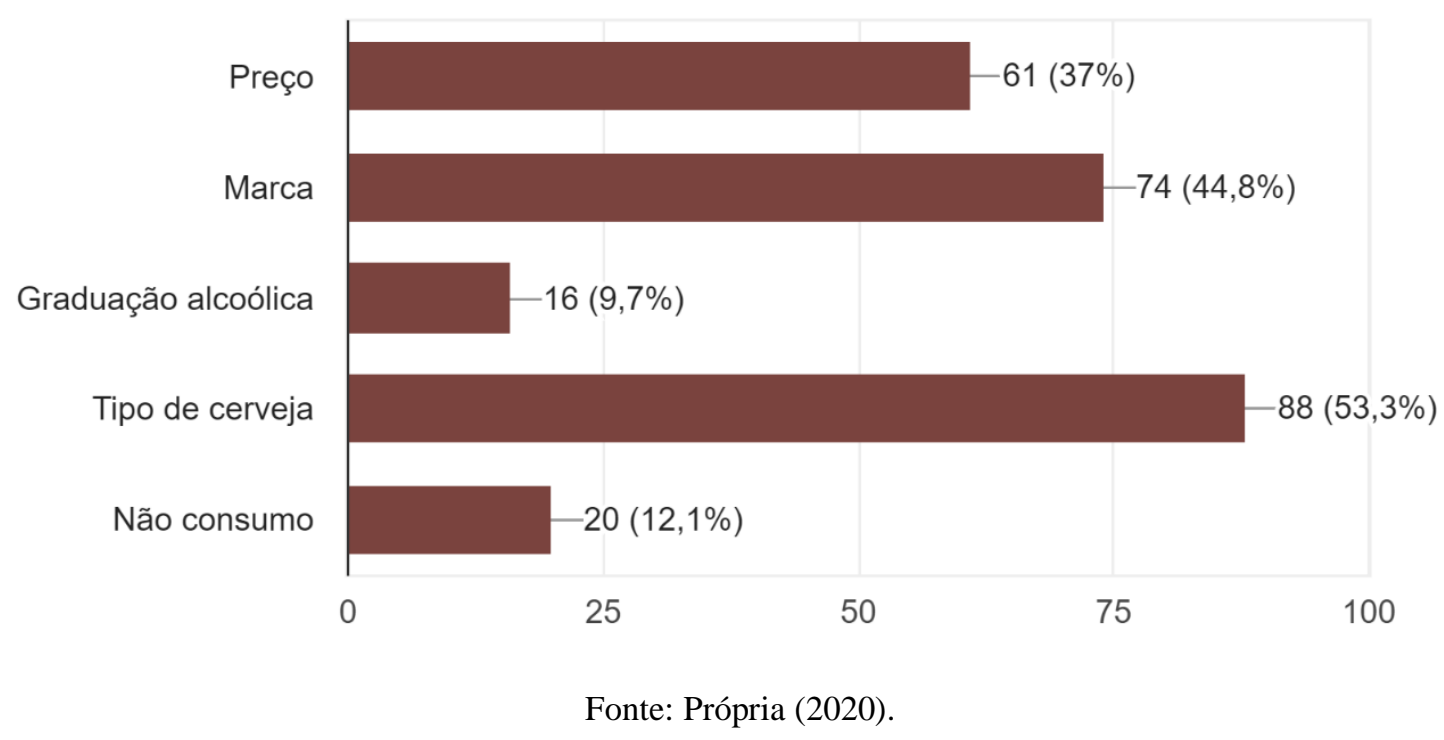

Como é visto acima, o atributo de maior influência no que se trata do momento da compra da cerveja foi o tipo, com 53,3\% das respostas, esses resultados divergem da pesquisa realizada por ARRUDA (2018), que obteve o sabor como resultado do principal atributo de influência na hora da compra da cerveja com $30 \%$ das respostas, seguido de preço e o tipo que obtiveram $18 \%$ e $13 \%$ respectivamente. O segundo atributo de maior influência na hora da compra da cerveja de acordo com os resultados é a marca. De acordo com Tagnin e Giraldi (2012), conforme citado por (Filho, 2018), os atributos mais importantes no momento da avaliação das alternativas possíveis de compra da cerveja são: teor alcoólico, composição, procedência, novidade, sabor, temperatura e qualidade, fama, preço, benefício agregado, mídia, promoção, disponibilidade, embalagem, marca, conveniência, recomendação, harmonização e reputação. No entanto o teor alcóolico foi o atributo com menos porcentagem de repostas nesta pesquisa, com apenas $9,7 \%$.

Nas definições mercadológicas, averiguou-se que $81,8 \%$ dos que responderam à pesquisa, adquirem suas cervejas em supermercados, $37,6 \%$ em bares e $24,8 \%$ em distribuidoras de bebidas (figura 13). Nardi (2018) alcançou resultado semelhante em sua pesquisa, a maioria dos consumidores que participaram do seu estudo também optaram por comprar cerveja em supermercados pois alegam que o preço é mais acessível que em outros estabelecimentos. Na opção outros, obteve-se respostas como: postos de combustíveis e eu faço minha própria cerveja, como pode ser visto na figura 13 abaixo: 
Figura 13. Local de compra da cerveja.

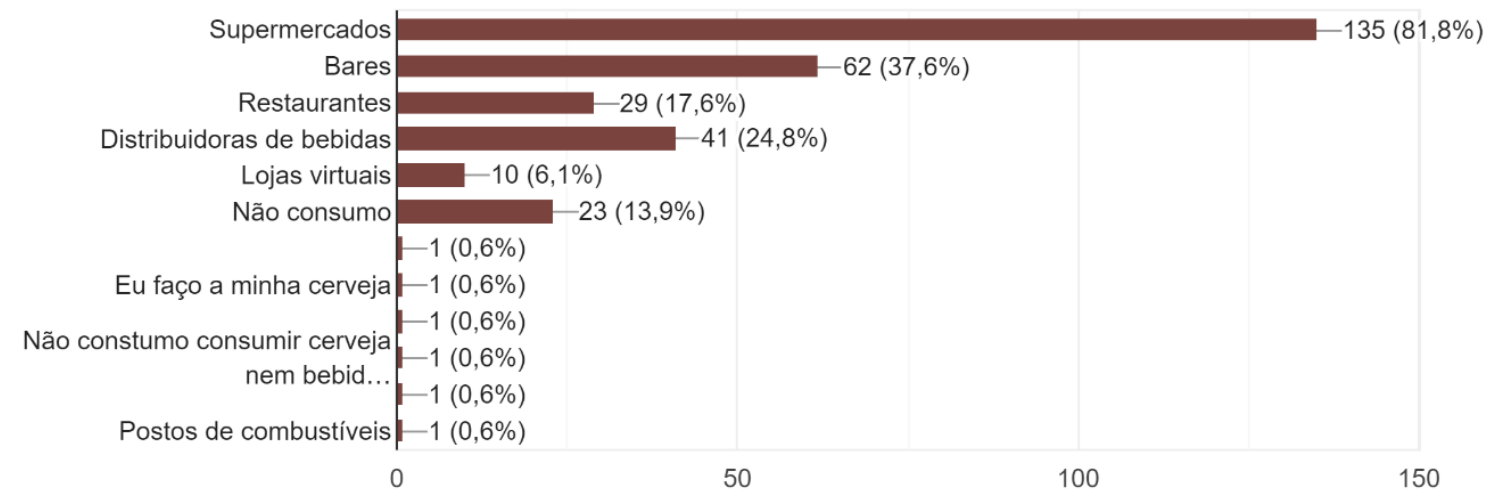

Fonte: Própria (2020).

Além do local de compra, também foi questionado aos respondentes o local que lhes era de preferência para realizar o consumo da cerveja (figura 14), 77\% dos respondentes afirmaram preferência pelo consumo em suas próprias casas, $52 \%$ em bares e $44 \%$ em festas. Costa (2008) em sua pesquisa obteve dados bem diferentes, os seus resultados mostram que os respondentes gostam bastante de beber em clubes, festas, bares e restaurantes ou nas residências de amigos ou colegas. Em contrapartida, os respondentes têm menor preferência em tomar cervejas em suas próprias residências.

Figura 14. Local de consumo da cerveja.

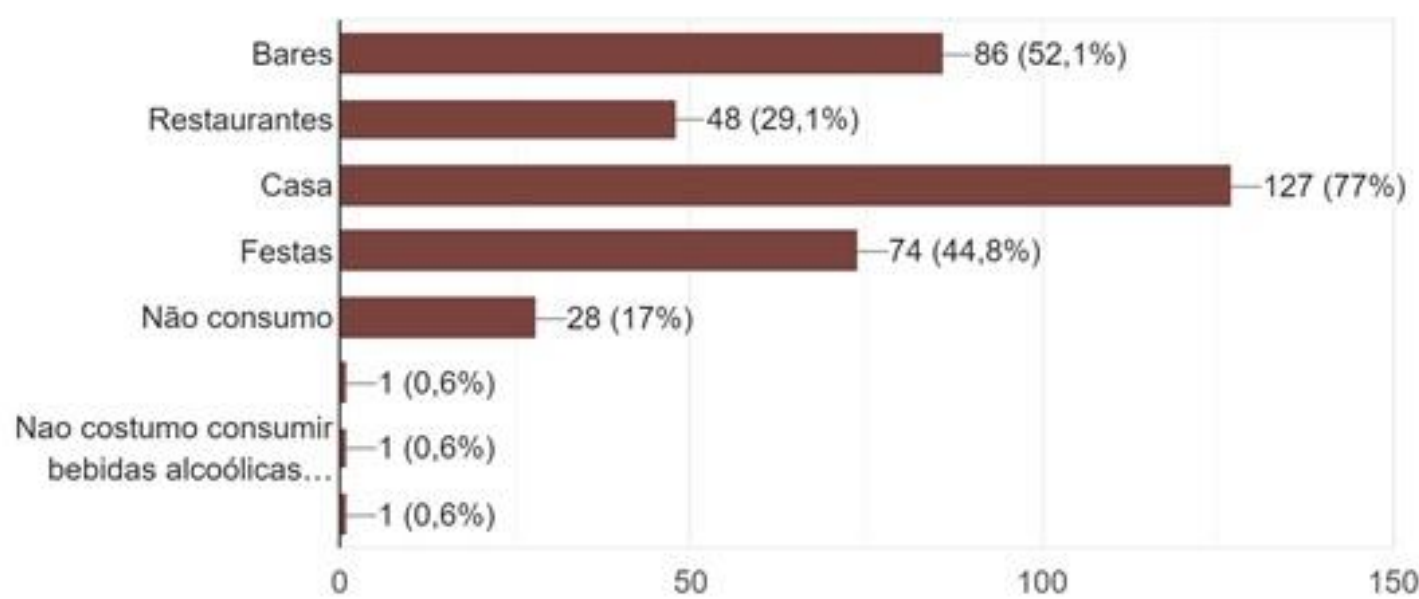

Fonte: Própria (2020).

Alguns motivos foram apontados para justificar o não consumo desta bebida, o que apresentou maior porcentagem de respostas foi "não gosto", com 43,3\%. A segunda e a terceira maiores porcentagens foram das respostas "preço" e "não consumo bebidas alcoólicas", ambas com 18,5\%. Houveram também outras justificativas como "doença", "tempo" e "prefiro destilados" 


\section{Conclusões}

Conforme a pesquisa realizada, pode-se concluir que o perfil do consumidor de cerveja do Agreste de Pernambuco é composto em sua maioria por mulheres, entre 18 e 25 anos, que estão cursando o ensino superior e não possuem renda definida. Em relação a frequência de consumo e comportamento, pode- se afirmar que o a maioria consome mensalmente, compram sua cerveja principalmente em supermercados, bares e distribuidoras de bebidas e o local onde preferem realizar o consumo da bebida é em casa, festas e bares.

Em relação a preferência de consumo e o conhecimento sobre os tipos de cerveja, podese afirmar que a maioria dos consumidores não conhecem a diferença entre os tipos Lager e ALE, e nem conhecem a diferença entre os tipos de cerveja apesar de consumir das duas famílias. O estilo da família Lager mais consumido é o Pilsner e da família ALE o estilo mais consumido é o American Pale Ale. Pode-se concluir também que o consumidor tem preferência por cervejas comerciais, e não só levam em consideração o valor, mas também o tipo de cerveja.

Os resultados descritos e a análise dos dados indicam que a pesquisa atingiu adequadamente seus objetivos, além disso, acreditasse que traga informações relevantes para gestores de industrias do ramo cervejeiro do agreste de Pernambuco quanto as preferências de seu público, trazendo informações que podem ajudar no direcionamento de ações de marketing.

Os resultados da pesquisa estão restritos apenas a região estudada, no caso o Agreste Pernambucano, portanto seria relevante uma replicação em outras regiões do estado e até do país para um estudo mais amplo da temática abordada e maior número de pessoas ouvidas, melhorando também os resultados futuros. Por fim, sugere-se que seja realizada pesquisas com finalidades semelhantes a essas, com o interesse em conhecer as preferências do público alvo com relação a outras categorias de bebidas alcóolicas, como vinho, uísque, vodka, cachaça, dentre outros.

\section{Referências}

AGRESTE Pernambucano. In: Geo Geral: Banco de Dados Geográfico. [S. l.], 28 abr. 2007. Disponível em: http://geogeral.com/h/m/b/brpea.htm. Acesso em: 6 ago. 2020.

ARRUDA, L.L.A. Análise do perfil do consumidor de cervejas artesanais de Cuiabá - MT. Orientador: Prof. Dr. Alencar Garcia Bacarji. 2018. 28 p. Trabalho de Conclusão de Curso (Bacharelado em Engenharia de Alimentos) - Instituto Federal de Educação Ciência e Tecnologia de Mato Grosso, Campus Cuiabá-Bela Vista, Cuiabá - MT, 2018.

BARTH, Roger. The chemistry of beer: the science in the suds. [S. l.: s. n.], 2013. 
BEER ART. Um estudo sobre o consumo de cerveja no Brasil. Beer Art, [S. l.], p. 00, 9 jul. 2018. Disponível em: https://revistabeerart.com/news/estudo-consumo-cerveja-brasil. Acesso em: 8 ago. 2020.

CERVBRASIL: Dados do setor cervejeiro nacional. [S. l.], 9 ago. 2018. Disponível em: http://www.cervbrasil.org.br/novo_site/dados-do-setor/. Acesso em: 14 ago. 2020.

COSTA, F.J. Comportamento do consumidor de cerveja: Proposta de uma tipologia baseada na imagem e nas intenções em relação à marca. Revista de Negócios, $[S . l$.$] , v. 12,$ n. 4, p. 71-85, 2008.

FILHO, E.R.M. Comportamento do consumidor de cervejas especiais: motivos que levam os consumidores a optarem pelo produto. Orientador: Prof. MSc. Erika Costa Vieira Gagliardi. 2018. 32 p. Trabalho de Conclusão de Curso (Bacharelado em Administração) FACULDADE DE TECNOLOGIA E CIÊNCIAS SOCIAIS APLICADAS - FATECS, Brasília, 2018.

FOLHA DE PERNAMBUCO. Cervejas artesanais: um negócio em expansão. Folha de Pernambuco, Recife, 14 abr. 2019. Disponível em: https://www.folhape.com.br/economia/cervejas-artesanais-um-negocio-em-expansao/101889/. Acesso em: 9 ago. 2020.

FOLHA DE PERNAMBUCO. Arte de fazer cerveja volta a fazer parte da vida dos pernambucanos. Folha de Pernambuco, Recife, 05 ago. 2018. Disponível em: https://www.folhape.com.br/economia/arte-de-fazer-cerveja-volta-a-fazer-parte-da-vida-dospernambucanos/76929/. Acesso em: 13 ago. 2020.

GARCIA, Monise. Pesquisa de mercado. In: GARCIA, Monise. Pesquisa de mercado do consumo de cerveja artesanal no município de Mogi Guaçu/SP. Orientador: Prof. Dr. José Guilherme Lembi Ferreira Alves. 2019. Trabalho de Conclusão de Curso (Bacharelado em Engenharia de Alimentos) - Universidade Federal de Lavras, Lavras - MG, 2019.

MATTAR, F.N.; OLIVEIRA, B.; MOTTA, S.L.S. PESQUISA DE MARKETING: Metodologia, planejamento, execução e análise. 7.ed. Rio de janeiro: Elsevier Editora Ltda, 2014.

MINISTÉRIO DA AGRICULTURA PECUÁRIA E ABASTECIMENTO. A CERVEJA NO BRASIL: O ministério da agriculta informando e esclarecendo. [s. l.], 25 ago. 2017. Disponível em: https://www.gov.br/agricultura/pt-br/assuntos/inspecao/produtosvegetal/publicacoes/a-cerveja-no-brasil-28-08.pdf/view. Acesso em: 4 ago. 2020.

MINISTÉRIO DA AGRICULTURA, PECUÁRIA E ABASTECIMENTO. Instrução normativa $\mathbf{n}^{\circ}$ 65, de 10 de dezembro de 2019. [S. l.], 11 dez. 2019. Disponível em: http://www.in.gov.br/en/web/dou/-/instrucao-normativa-n-65-de-10-de-dezembro-de-2019232666262. Acesso em: 16 jul. 2020.

NARDI, R.G. Comportamento do consumidor: Análise dos consumidores de cerveja artesanal nas cidades de Lajeado, Estrela e Teutônia / RS. 2018. Trabalho de conclusão de curso (Bacharel em Administração de Empresas.) - Universidade do Vale do Taquari UNIVATES, [S. l.], 2018. 
OLIVEIRA, M.X.; MORAES, Y.S.S. Perfil do consumidor de cervejas especiais em Caparaó e região. Pensar Acadêmico 2018, [s. l.], 2018. Disponível em: http://pensaracademico.unifacig.edu.br/index.php/semiariocientifico/article/download/798/69 9. Acesso em: 14 ago. 2020.

PEDROSA, A. A. S.; et al. Consumo de álcool entre estudantes universitários. SCIELO, [ $s$. l.], v. 27, n. 8, ago 2011. DOI https://doi.org/10.1590/S0102-311X2011000800016. Disponível em: $\quad$ https://www.scielo.br/scielo.php?script=sci_arttext\&pid=S0102311X2011000800016\#: :text=A\%20preval\%C3\%AAncia\%20de\%20uso\%20de,visto\%20anu nciada\%20em\%20alguma\%20propaganda. Acesso em: 7 ago. 2020.

SEBRAE. Comprar do comerciante do seu bairro é um grande negócio para todos. SEBRAE, $\quad[S . \quad l],$.$\quad p. 00,27$ mar. 2020. Disponível em: https://m.sebrae.com.br/sites/PortalSebrae/artigos/comprar-do-pequeno-negocio-e-um-grandenegocio-para-

todos,383af1b0a59f0710VgnVCM1000004c00210aRCRD\#: :text=Import\%C3\%A2ncia\%20 de\%20apoiar\%20o\%20com\%C3\%A9rcio,e\%20melhor\%20distribui\%C3\%A7\%C3\%A3o\%20 de\%20renda. Acesso em: 9 ago. 2020.

SENKO, L.V. et al. Análise do Perfil do Consumidor de Cervejas Artesanais em Curitiba. Revista Eletrônica Multidisciplinar - UNIFACEAR, [S. l.], ano 7, v. 3, p. 00, 1 dez. 2018. Disponível em: http://revista.facear.edu.br/artigo/\$/analise-do-perfil-do-consumidor-decervejas-artesanais-em-curitiba. Acesso em: 8 ago. 2020. 


\title{
CAPÍTULO 29: ELABORAÇÃO DO LICOR DE ROMÃ E CANELA: QUALIDADE FÍSICO-QUÍMICA E MICROBIOLOGICA
}

\section{CHAPTER 29: ELABORATION OF POMEGRANATE AND CINNAMON LIQUOR: PHYSICO-CHEMICAL AND MICROBIOLOGICAL QUALITY}

\author{
, Crisliane Camargo de Sá ${ }^{1}$; Joseane Cristina Pinheiro Pombo ${ }^{2}$; Vanessa Albres Botelho ${ }^{3}$
}

\begin{abstract}
Resumo
O setor de bebidas alcoólicas apresenta relevância econômica no Brasil, com destaque para o crescimento do consumo de licores à base de frutas, o que impulsiona o processamento de frutas pouco exploradas tecnologicamente pela agroindústria, como a romã. O objetivo deste estudo foi elaborar um licor à base de romã e canela e avaliar sua qualidade físico-química e microbiológica. O licor foi avaliado quanto aos parâmetros físico-químicos como $\mathrm{pH}$, acidez, densidade, teor alcoólico, cinzas, extrato seco, sólidos solúveis, açucares (redutores, não redutores e totais) e compostos fenólicos totais; e microbiológicos quanto a presença de Salmonella spp., coliformes, bolores e leveduras. O licor apresentou boa qualidade devido aos valores satisfatórios de $\mathrm{pH}(4,5)$, acidez $(16,67 \mathrm{meq} / \mathrm{L})$, densidade $(1,09 \mathrm{~g} / \mathrm{mL})$, teor alcoólico $(24 \% \mathrm{v} / \mathrm{v})$, cinzas $(0,03 \%)$, extrato seco $(27,94 \mathrm{~g} / \mathrm{L})$, sólidos solúveis totais $\left(30,40{ }^{\circ} \mathrm{Brix}\right)$, açúcares totais $(50,20 \%)$, açúcares redutores $(13,13 \%)$, açucares não redutor $(35,21 \%)$ e compostos fenólicos totais (1041 mg GAE/L). Os resultados da análise microbiológica estão de acordo ao estabelecido pela legislação, o que indica as boas condições sanitárias durante a fabricação da bebida devido a ausência de Salmonella spp., coliformes, bolores e leveduras.
\end{abstract}

Palavras-Chave : Agroindústria, Bebidas alcoólicas, Processamento de frutas.

\begin{abstract}
The alcoholic beverages sector has economic relevance in Brazil, with emphasis on the growth of consumption of fruit-based liquors, which encourages the fruit processing that are not technologically exploited by the agribusiness, such as pomegranate. The study objective was to develop an pomegranate and cinnamon-based liquor and assess quality physicochemical and microbiological. The liquor was evaluated by physico-chemical parameters, such as $\mathrm{pH}$, acidity, density, alcohol content, ash, dry extract, soluble solids, sugars (reducing, non-reducing and total) and total phenolic compounds; and microbiological by analyses of Salmonella spp., coliforms, molds and yeasts. The liquor showed good quality due to satisfactory $\mathrm{pH}(4.5)$, acidity $(16.67 \mathrm{meq} / \mathrm{L})$, density $(1.09 \mathrm{~g} / \mathrm{mL})$, alcohol content $(24 \% \mathrm{v} / \mathrm{v})$, ash $(0.03 \%)$, dry extract $(27.94 \% \mathrm{~g} / \mathrm{mL})$, total soluble solids $\left(30.40{ }^{\circ} \mathrm{Brix}\right)$, total sugars $(50.20 \%)$, reducing sugars $(13.13 \%)$, non-reducing sugars $(35.21 \%)$ and total phenolic compounds (1041 mg GAE/L). The results of the microbiological analysis are in accordance with the established by the legislation, which indicates the good sanitary conditions during the manufacture of the drink due to the absence of Salmonella spp., Coliforms, molds and yeasts.
\end{abstract}

Keywords: Agribusiness, Alcoholic beverages, Fruit processing.

\section{Introdução}

Devido à sua característica tropical, grande extensão territorial e as mais diversas

\footnotetext{
${ }^{1}$ Graduada em Engenharia de Alimentos, Universidade Federal do Pará, criscamargodesa@gmail.com

${ }^{2}$ Graduada em Engenharia de Alimentos, Universidade Federal do Pará, pombojcp@gmail.com

${ }^{3}$ Prof $^{\mathrm{a}}$ Dr $^{\mathrm{a}}$ do curso de Engenharia de Alimentos, Universidade Federal do Pará, vanessalbres@ufpa.br
} 
condições climáticas, o Brasil é o terceiro maior produtor de frutas do mundo, produzindo uma grande quantidade de frutas ao longo do ano. As frutas são uma alternativa para o desenvolvimento e recuperação da economia local, pois apresentam boa aceitação na população, podendo serem processadas para obter diversos produtos como polpas, geléias, sucos, vinhos, licores, entre outros (PINTO et al., 2017). Dentre estas frutas, destaca-se a Romã (Punica granatum L.), que apesar de ser originaria da Ásia é amplamente encontrada por todo Brasil (SOUSA et al., 2018).

Há um interesse crescente na romã como uma fruta saudável de grande benefício a dieta humana devido a presença de constituintes nutricionais, como vitamina $\mathrm{C}$, fitonutrientes que atuam como antioxidantes, fonte de vitamina B5 (ácido pantotênico) e potássio (ATAÍDE et al., 2018). Dentre os fitonutrientes, destacam-se flavonóides (apigenina e narigenina), antocianinas (cinidina, delfinidina e pelargonidina), taninos (punicalagina), alcalóides, ácido ascórbico, ácidos fenólicos (cafeico, catequínico, clorogênico, orto e paracumárico, elágico, gálico e quínico), ácidos graxos conjugados (ácido púnico) e o ácido ursólico, que isolados ou em combinação, são responsáveis pela atividade antioxidante da fruta (OLIVEIRA et al., 2010; NASCIMENTO JÚNIOR et al., 2016; DANDACHI et al., 2017).

Segundo Almeida et al. (2019), o Brasil se destaca também como um dos maiores produtores de bebidas alcoólicas do mundo, com destaque para o crescimento do consumo de licores de frutas. De acordo com a legislação vigente, licor é a bebida com graduação alcoólica de 15 a $54 \%$ em volume, a $20{ }^{\circ} \mathrm{C}$, com percentual de açúcar superior a 30g/L, elaborado com álcool etílico potável de origem agrícola, destilado alcoólico simples de origem agrícola ou ainda bebidas alcoólicas, adicionada de extrato ou substâncias de origem vegetal ou animal, substâncias aromatizantes, saborizantes, corantes e outros aditivos permitidos em ato administrativo complementar (BRASIL, 2009).

As especiarias são largamente utilizadas como aromatizantes de licores, pois são consideradas agentes de conservação que aumentam o tempo de vida dos alimentos devido possuírem propriedade antioxidantes e ação antimicrobiana, reduzindo ou eliminando bactérias patogênicas, além de agregar valor aos alimentos, permitindo sua diferenciação e diversificação, através de um paladar único (CARRIJO et al., 2012). Uma alternativa é a canela (Cinnamomum zeylanicum), nativa do Sri Lanka (antigo Ceilão) e introduzida no Brasil pelos portugueses (LINGUANOTTO NETO et al., 2016). Trata-se de uma planta aromática que, além de apresentar atividade antifúngica e antibacteriana, possui ainda propriedades antiespasmódica, carminativa, estimulante, tônica, digestiva, adstringente, afrodisíaca, antisséptica, antioxidante, aperiente, hipertensora, sedativa e vasodilatadora 
(GOMES et al., 2018).

Existem basicamente três processos para obtenção do extrato alcoólico: por destilação, por adição de essência e por maceração. A maceração é uma operação unitária, comum em licores naturais produzidos a partir de frutas, que consiste na extração sólido-líquido ou lixiviação, neste processo a matéria-prima fica em contato por um tempo com uma solução hidroalcoólica. O tempo de extração é um fator importante no processamento de licores para garantir a completa extração dos componentes desejáveis e as fontes de álcool potável podem ser o álcool de cereais, vodca, cachaça, conhaque e o uísque. Em seguida, ocorre a filtração para obtenção do extrato alcoólico que contém os elementos essenciais que conferirão cor, sabor e aroma ao produto (TEIXEIRA et al., 2011; TEIXEIRA et al., 2012). De acordo com Oliveira et al. (2016), os segredos da qualidade dos licores de frutas estão na combinação perfeita de seus componentes, especialmente a matéria-prima (álcool), a fruta utilizada e o açúcar, bem como nos processos de preparação (infusão) e maturação, que resultarão em um produto integrado com harmonia entre cor, aroma e sabor.

O processamento de licores é uma tecnologia simples, uma vez que, não exige técnicas complexas ou equipamentos de alta complexidade por parte do produtor, e quando produzido de forma apropriada resulta em bebidas de excelente qualidade, com extensa vida de prateleira e que podem ser comercializadas em temperatura ambiente, evitando assim, a onerosa cadeia do frio (TEIXEIRA et al., 2010; TEIXEIRA et al., 2012). Além de agregar valor ao fruto, estender sua vida pós-colheita e possibilitar o aumento na renda de pequenos agricultores (OLIVEIRA et al., 2015; SOUZA et al., 2019).

O mercado de licores de frutas pode ser facilmente explorado, pelo uso de fontes renováveis (ALMEIDA et al., 2019), impulsionando o uso de uma grande variedade de frutas no processamento de licores, a exemplos do camu-camu (VIEIRA et al., 2010), açaí (ALVES; MENDONÇA, 2011), limão (REYES-LINARES et al., 2011), maracujá (DIAS et al., 2011), umbu (PEREIRA et al., 2012), abacaxi (PINTO et al., 2017), maçã (STADNIK et al., 2015), tangerina (SILVA et al., 2017), amora preta (LUNA-RAMÍREZ et al., 2017), graviola (OLIVEIRA et al., 2019), goiaba (ALMEIDA; GHERARDI, 2018), manga (SANTOS et al., 2018), jabuticaba (ALMEIDA; GHERARDI, 2019), uva (COELHO et al., 2019) entre outras, entretanto, são escassos trabalhos de processamento de licores de romã.

Considerando-se a necessidade de consumidores que anseiam por novidades no setor de bebidas e estudos que explorem o potencial tecnológico da fruta romã. Objetivou-se a elaboração de um licor à base de romã e canela, bem como a avaliação de sua qualidade físico-química e microbiológica. 


\section{Material e Métodos}

\section{Material}

Os materiais utilizados para a produção do licor foram a fruta romã, vodka com teor alcoólico de 37,5\% (v/v), canela, açúcar refinado e água potável, todos obtidos em supermercados da região metropolitana de Belém-Pará. O experimento foi realizado no Laboratório de Engenharia Química da Universidade Federal do Pará (UFPa).

\section{Elaboração do licor}

O processamento do licor consistiu das etapas de infusão, maceração, filtração, preparo e adição do xarope, envelhecimento (maturação e tranchage), clarificação, envase e armazenamento (Figura 1). Inicialmente, a fruta romã e a canela foram selecionadas, lavadas em água potável, sanitizadas por imersão em solução de cloro (50 ppm/20 minutos), com posterior enxágue e descascamento manual da romã. Em seguida, realizada a infusão por imersão da canela em pau (5\%) e da polpa e semente de romã (95\%) na solução alcoólica (Vodka) para que ocorresse o processo de maceração por um período de 12 dias à temperatura ambiente $\left(25^{\circ} \mathrm{C}\right)$, com subsequente filtração em filtros de nylon. Para o preparo do xarope, houve a adição do açúcar refinado $(400 \mathrm{~g})$ em água potável $(200 \mathrm{~mL})$ e submetidos ao cozimento até atingir concentração de $65^{\circ}$ Brix, com posterior adição do xarope à temperatura ambiente $\left(28^{\circ} \mathrm{C}\right)$ ao licor macerado e filtrado. Durante o envelhecimento, houve a maturação do licor por 32 dias, onde foi realizado o processo de tranchage a cada oito dias para acelerar o processo de envelhecimento do licor. Por fim, o licor elaborado foi submetido a clarificação pelo método de colagem (adição de $10 \mathrm{~g}$ de gelatina para cada litro de licor), seguido de envase em frascos de vidro âmbar e armazenamento à temperatura ambiente $\left(25^{\circ} \mathrm{C}\right)$.

Figura 1. Fluxograma do processamento do licor de romã e canela.

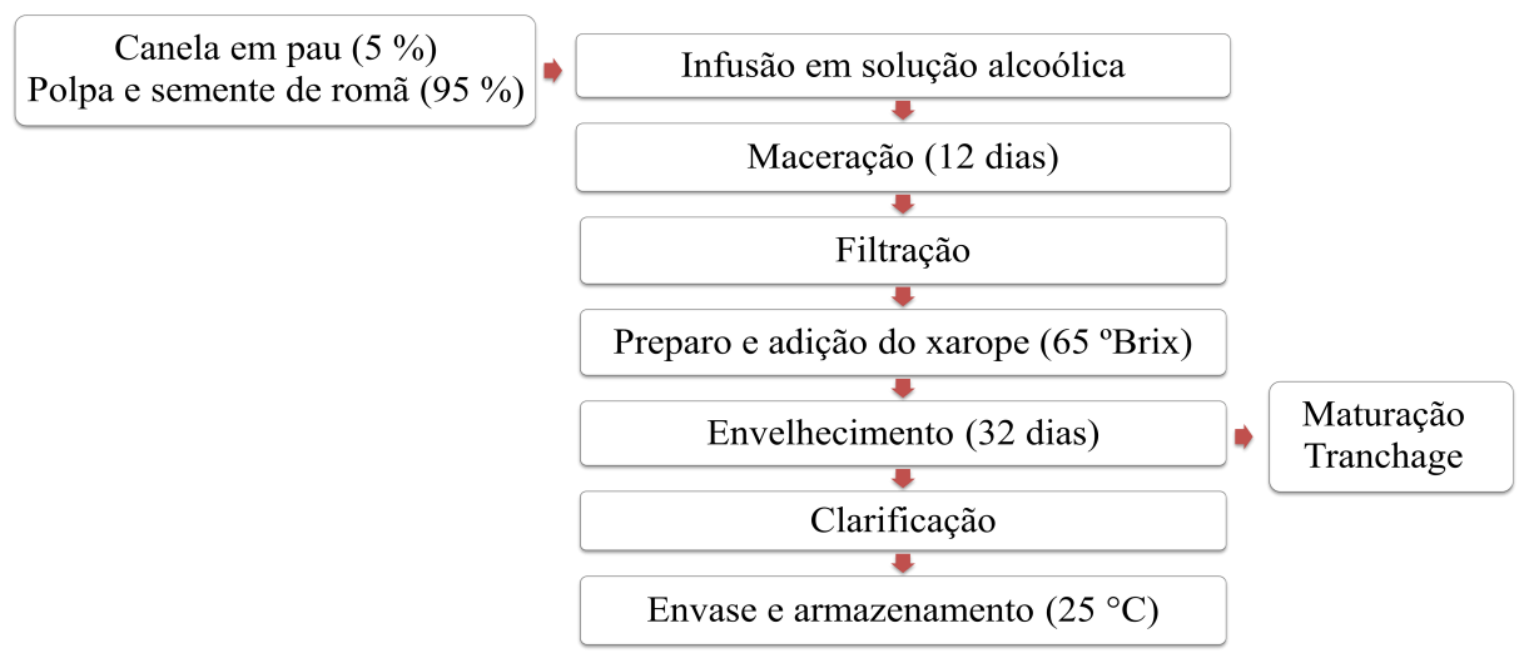

Fonte: Própria (2020). 


\section{Composição físico-química do licor}

Para a determinação da composição centesimal do licor foram utilizadas as metodologias recomendadas pela Association of Official Analytical Chemists (2005): pH em potenciômetro (Marconi- MA 522, São Paulo, Brazil) (método $\mathrm{n}^{\circ}$ 981.12); acidez total titulável (método $\mathrm{n}^{\circ}$ 942.15A); densidade relativa pelo método de deslocamento de fluido em picnômetro (método $\mathrm{n}^{\circ}$ 985.19); cinzas por calcinação em mufla a $550{ }^{\circ} \mathrm{C}$ (método $\mathrm{n}^{\circ}$ 940.26); Extrato seco (método $n^{\circ}$ 940.26); açúcares totais, redutores e não redutores pelo método de Lane-Eynon (método $\mathrm{n}^{\circ}$ 920.183b). Adicionalmente, foram realizadas as análises de sólidos solúveis totais, por leitura direta em refratômetro de bancada (Quimis Q767BD, Diadema, São Paulo, Brazil); O teor alcoólico realizado de acordo com as normas analíticas do Instituto Adolfo Lutz (2008); e compostos fenólicos totais segundo a metodologia proposta por Singleton e Rossi (1965), em espectrofotômetro (SHIMADZU modelo UV 1203, Japão) no comprimento de onda de $750 \mathrm{~nm}$. Para os cálculos de fenólicos totais, foi utilizada uma curva padrão de ácido gálico (20 a 100 mg/L), os resultados foram expressos em mg de ácido gálico (GAE)/100 g.

\section{Avaliação microbiológica}

O licor foi submetido às analises microbiológicas quanto à presença de Salmonella spp., bolores, leveduras, coliformes totais e termotolerante, segundo os métodos descritos pela American Public Health Association (2001).

Para a análise de Salmonella spp, o pré-enriquecimento ocorreu com a homogeneização de $25 \mathrm{~mL}$ da amostra em $225 \mathrm{~mL}$ de água peptonada tamponada $0,1 \%$, incubada a $35^{\circ} \mathrm{C} / 24$ horas. No enriquecimento seletivo, transferiu-se $1 \mathrm{~mL}$ da amostra do préenriquecimento para tubo contentdo $10 \mathrm{~mL}$ de Caldo Selenito Cistina (incubado à $37{ }^{\circ} \mathrm{C} / 24$ horas), $1 \mathrm{~mL}$ para $10 \mathrm{~mL}$ do caldo tetrationato e $1 \mathrm{~mL}$ para $10 \mathrm{~mL}$ do caldo Rappaport Vassiliadis soja (incubados à $43^{\circ} \mathrm{C} / 24$ horas). Para o plaqueamento diferencial foi semeada uma alçada de cada meio do caldo de enriquecimento seletivo para placas ágar Salmonellashigella (SS) e ágar xilose lisina desoxicolato (XLD) e incubadas em placas em posição invertida a $35^{\circ} \mathrm{C} / 24$ horas. Para a confirmação bioquímica, as colônias típicas em ágar foram confirmadas em ágar tríplice açúcar ferro (TSI) e em ágar lisina ferro (LIA) com o auxílio de uma agulha de inoculação por picada e estrias na rampa. Os tubos foram incubados em estufa de $35^{\circ} \mathrm{C} / 24$ horas e então foram avaliadas a utilização dos açúcares e $\mathrm{H}_{2} \mathrm{~S}$ pelas cepas.

A contagem dos coliformes totais e termotolerantes foi determinada pelo método do número mais provável (NMP). $25 \mathrm{~mL}$ da amostra foi homogeneizada em $225 \mathrm{~mL}$ de solução 
salina peptonada $0,1 \%$ e feitas as diluições seriadas para inoculação. O teste presuntivo foi realizado com a inoculação de alíquotas da amostra em três séries de três tubos, contendo tubos de Durhan e caldo lauril sulfato triptose (LST), sendo incubados em estufa a $35^{\circ} \mathrm{C} / 24$ 48 horas. Para confirmação da presença de coliformes, alíquotas de tubos de LST com crescimento microbiano e produção de gás foram transferidas para tubos de caldo verde brilhante $2 \%$ (VB) e caldo Escherichia coli (EC). Para os coliformes totais, os tubos de VB foram incubados à $35^{\circ} \mathrm{C} / 24$ horas, enquanto para os coliformes termotolerantes, os tubos de EC foram incubados à $45^{\circ} \mathrm{C} / 48$ horas.

Para a contagem de Bolores e Leveduras, homogeneizou-se $25 \mathrm{~mL}$ da amostra em 225 $\mathrm{ml}$ de água peptonada alcalina (diluição $10^{-1}$ ) e feitas as diluições sucessivas (diluição $10^{-2} \mathrm{e}$ diluição $10^{-3}$ ). Para o plaqueamento, foi feita a homogeneização e transferência de $1 \mathrm{~mL}$ de cada diluição para as placas de Petri esterilizadas, sendo adicionado $15 \mathrm{~mL}$ de Agar batata dextrose acidificado com ácido tartárico a $10 \%$ e então homogeneizado com movimentos circulares em forma de um oito. Por fim, deixou-se solidificar o Agar e feita a incubação das placas em posição invertida a $22-25^{\circ} \mathrm{C} / 5$ dias.

\section{Resultados e Discussão}

\section{Composição físico-química}

Os resultados das análises físico-químicas do licor de romã e canela estão na Tabela 1.

Tabela 1. Composição físico-química do licor de romã e canela

\begin{tabular}{lc}
\hline Composição & Valores (Média \pm Desvio Padrão) \\
\hline $\mathrm{pH}$ & $4,50 \pm 0,02$ \\
Acidez (meq/L) & $16,67 \pm 2,49$ \\
Densidade $(\mathrm{g} / \mathrm{mL})$ & $1,093 \pm 0,01$ \\
Teor Alcoólico (\% v/v) & $24,00 \pm 0,10$ \\
Cinzas $(\%)$ & $0,033 \pm 0,01$ \\
Extrato Seco (\% g/mL) & $27,94 \pm 0,81$ \\
Sólidos Solúveis Totais $\left({ }^{\circ}\right.$ Brix) & $30,40 \pm 0,10$ \\
Açúcares Totais $(\%)$ & $50,20 \pm 4,19$ \\
Açúcares Redutores $(\%)$ & $13,13 \pm 0,27$ \\
Açucares não Redutor $(\%)$ & $35,21 \pm 4,24$ \\
Compostos Fenólicos Totais (mg GAE/L) & $1041 \pm 0,00$ \\
\hline
\end{tabular}

Fonte: Própria (2020). 
SÁ, C.C.; POMBO, J.C. e BOTELHO, V.A.

O licor apresentou valor de $\mathrm{pH}(4,5)$ próximo aos valores da fruta romã (pH 3,0 a 4,0) mencionados por Moreira et al. (2015). Tal valor se encontra próximo aos resultados de Teixeira et al. (2012), Passos et al. (2013), Almeida e Gherardi (2018), Santos et al. (2018) e Almeida e Gherardi (2019) para os licores de abacaxi (pH 4,40 e 4,46), cenoura com laranja ( $\mathrm{pH} 4,43)$, goiaba ( $\mathrm{pH} 4,15)$, uva ( $\mathrm{pH} 4,20$ ), manga ( $\mathrm{pH} 4,51)$ e jabuticaba ( $\mathrm{pH} 4,08$ e 4,19), respectivamente. Enquanto, Viera et al. (2010), Oliveira e Santos (2011), Dias et al. (2011) e Pereira et al. (2012) observaram valores inferiores na elaboração dos licores de camu-camu (pH 3,60), açaí (pH 3,52), maracujá amarelo (pH 3,57) e umbu (pH 3,58), respectivamente. Já Silva et al. (2017) relataram valores superiores para licores de casca de tangerina (pH 6,04 e 6,35). A variação observada é atribuída as diferentes características e concentrações das frutas utilizadas na elaboração dos licores, além das diferentes condições durante o processo de maceração e envelhecimento.

Segundo Teixeira et al. (2010), com o passar do tempo de maceração os ácidos orgânicos da matéria-prima são extraídos provocando o abaixamento do $\mathrm{pH}$ até atingir o equilíbrio, esse tempo de extração durante a maceração varia de acordo com as matériasprimas utilizadas (frutas e soluções alcoólicas). Simões et al. (2014), mencionam a influência das diferentes fontes alcoólicas no tempo de extração durante a maceração, os autores verificaram que o tempo de estabilização do $\mathrm{pH}$ do extrato foi maior quando foi utilizada a fonte alcoólica a $96,5^{\circ} \mathrm{GL}$ do que a $40^{\circ} \mathrm{GL}$. Oliveira et al. (2015), observaram que os licores de graviola processados com a maior concentração de polpa revelaram os menores valores de $\mathrm{pH}$ devido à maior proporção de polpa/álcool nas formulações ao final da maceração. LunaRamírez et al. (2017), relataram o aumento do $\mathrm{pH}$ do licor de amora preta ( $\mathrm{pH} 4,05$ a 4,28) durante o processo de envelhecimento por 180 dias. Franco e Landgraf (2005) relataram que baixos valores de $\mathrm{pH}$ são importantes, uma vez que, este fator limita o crescimento de bactérias patogênicas e deteriorantes, além de aumentar a vida útil do produto.

A acidez do licor $(16,67 \mathrm{meq} / \mathrm{L})$ está entre os valores dos licores mistos de cenoura com laranja e maracujá (12,0 e 27,8 meq/L) obtidos por Passos et al. (2013). De acordo com Silva et al. (2017), o baixo valor de ácidos encontrado na casca de tangerina $(0,15 \%$ ácido cítrico) contribuiu para as baixas concentrações de acidez dos licores das cascas de tangerina (0,16 a 0,20 \% ácido cítrico). Moreira et al. (2015), mencionam a baixa acidez da fruta romã (0,6 a 0,8 \% ácido cítrico), o que contribui para baixa acidez do licor. Segundo Ataíde et al. (2018), a romã além de ácido cítrico, apresenta ácidos orgânicos que incluem ácido málico, acético, fumárico, tartárico e láctico. As diferentes metodologias de extração dos componentes aromáticos das matérias-primas devido aos diferentes período de infusão 
SÁ, C.C.; POMBO, J.C. e BOTELHO, V.A.

durante a etapa de maceração das bebidas estão relacionadas com o arraste de ácidos orgânicos para a solução alcoólica (OLIVEIRA et al., 2015), bem como o tempo de envelhecimento do licor. Luna-Ramírez et al. (2017), observaram a redução da acidez do licor de amora preta $(0,2048$ a 0,0896 g ácido cítrico/100 mL) durante os 180 dias de envelhecimento. Segundo Almeida et al. (2012), quanto menor a presença de ácidos em licores de frutas mais agradável e melhor será o produto ao paladar dos provadores.

O licor apresentou densidade relativa $(1,0939 \mathrm{~g} / \mathrm{mL})$ entre os valores do licor de amora preta $(1,0709$ a 1,1692 $\mathrm{g} / \mathrm{mL})$ observados por Luna-Ramírez et al. (2017) e próximos aos valores do licor da casca de tangerina $(1,13 \mathrm{~g} / \mathrm{mL})$ mencionado por Viana et al. (2011), licor de açaí $(1,1225 \mathrm{~g} / \mathrm{mL})$ relatado por Oliveira e Santos (2011) e licores de uva e manga $(1,0565$ e 1,0924 g/mL) obtidos por Santos et al. (2018). Luna-Ramírez et al. (2017), relaciona o aumento da densidade do licor com o aumento dos sólidos solúveis na solução hidroalcoólica durante o processo de envelhecimento, por isso é importante a clarificação do licor no final do processo. Segundo Santos et al. (2018), a densidade relativa dos licores é de fundamental importância uma vez que pode evidenciar um possível excesso de borra deixada pela filtração do licor, sendo importante o processo de clarificação da bebida para remover quaisquer partículas em suspensão que possam conferir ao produto uma turvação indesejada e até mesmo a formação de depósito no fundo do frasco de acondicionamento do produto acabado.

O teor alcoólico do licor ( $24 \%$ v/v) está em conformidade com a legislação brasileira, que preconiza variação de 15 a 54 \% (v/v) de álcool para licores de frutas (BRASIL, 2009). Dias et al. (2011) e Santos et al. (2018) reportaram teores alcoólicos próximos aos observados neste estudo em licor de maracujá amarelo (21\% v/v) e licor de manga e uva (24,9 e 25,6 \% v/v), respectivamente. Enquanto, Passos et al. (2013), Oliveira et al. (2016), Pinto et al. (2017), Almeida e Gherardi (2018) e Almeida e Gherardi (2019) encontraram valores inferiores em licores mistos de cenoura com laranja e com maracujá (18\% v/v), graviola $(15,03$ a $16,69 \%$ v/v), abacaxi $(18,93$ a $19,57 \%$ v/v), goiaba $(15 \%$ v/v) e jabuticaba $(14,33$ e 14,37 \%), respectivamente. Já Silva et al. (2017) relataram, em licores de casca de tangerina, valores superiores $(25,57$ e 30,80 \% v/v). De acordo com Luna-Ramírez et al. (2017), o processo de envelhecimento contribui para a redução do teor alcoólico de licores, em seu estudo com licor de amora preta houve a redução do teor alcoólico (58 a 17 \% v/v) durante os 180 dias de envelhecimento, o que pode explicar as variações encontradas em pesquisas com licores. Porém, segundo Simões et al. (2014), a maioria dos licores industriais de frutas possui um teor alcoólico, declarado em rótulo, entre 18 e $25 \%$ em volume, sendo que o mais comum é que haja preferência por aqueles cujo teor alcoólico seja inferior a $25 \%$ em volume. Assim, 
o teor alcoólico é um parâmetro importante na avaliação da aceitabilidade das bebidas alcoólicas, pois à medida que aumenta o teor alcoólico, ocorre uma diminuição na aceitabilidade do produto (BARROS et al., 2008).

O teor de cinzas $(0,03 \%)$ foi semelhante ao valor obtido por Oliveira e Santos (2011), para o licor de açaí $(0,05 \%)$. Segundo Santos et al. (2010), a fruta romã possui baixo teor de cinzas $(0,46 \%)$, o que permiti pressupor que houve baixa migração dos componentes minerais da semente para o álcool durante o processo de maceração, bem como pode ocorrido a perda por volatilização ou pela interação entre os constituintes da amostra.

O extrato seco do licor $(27,94 \%)$ está na faixa dos valores do licores de graviola $(27,56$ a 36,48 \%) observado por Oliveira et al. (2016) e o licor de uva e manga $(24,29$ e $39,63 \%$ ) encontrado por Santos et al. (2018). De acordo com Oliveira et al. (2016), existe uma relação entre o extrato seco e os sólidos solúveis totais presentes no xarope, os autores observaram que os licores de graviola formulados com xarope na concentração de $70{ }^{\circ}$ Brix apresentaram maiores extratos secos (36,48 e 33,40\%), quando comparados aos xaropes na concentração de $50{ }^{\circ}$ Brix $(27,56$ e 28,02 \%), indicando à interferência da sacarose, uma vez que, a sacarose que atua como um sólido se dissolve em maior proporção no xarope, o que afeta a quantidade de sólidos no extrato seco obtidos após a evaporação do álcool. Este fato é confirmado por Santos et al. (2018), que observou durante seu experimento que ao evaporar toda a parte líquida das amostras, restou somente um melado viscoso, relacionado a quantidade do açúcar adicionado ao licor, bem como da quantidade de açúcar da própria fruta adicionado ao mesmo, o que fez com que as amostras não secassem totalmente.

O licor apresentou teores de sólidos solúveis totais (SST) de 30,40 ${ }^{\circ}$ Brix próximo aos valores do licor de camu-camu (33 ${ }^{\circ}$ Brix) encontrado por Viera et al. (2010) e entre os valores do licor de abacaxi $\left(27,4\right.$ a $31^{\circ}$ Brix) observado por Teixeira et al. (2012) e licores mistos de cenoura com laranja e com maracujá (30 e $31{ }^{\circ}$ Brix) obtidos por Passos et al. (2013). Enquanto, Oliveira e Santos (2011), Teixeira et al. (2011), Pereira et al. (2012) e Santos et al. (2018) encontraram valores superiores em licores de açaí (38,6 ${ }^{\circ}$ Brix), maracujá amarelo (48 ${ }^{\circ}$ Brix), umbu (47 ${ }^{\circ}$ Brix) e manga $\left(39^{\circ}\right.$ Brix $)$, respectivamente. Já Almeida et al. (2012), Almeida e Gherardi (2018) e Almeida e Gherardi (2019) relataram valores inferiores em licores de casca de tangerina (23,25 a 23,83 ${ }^{\circ}$ Brix), goiaba (19 ${ }^{\circ}$ Brix) e jabuticaba $(24$ e 27 ${ }^{\circ}$ Brix), respectivamente. Segundo Oliveira et al. (2015), é comum a variação de SST nessas bebidas devido a concentração dos xaropes utilizados com o objetivo de aumentar os açúcares dos licores. Este fato ocorre porque a legislação permite extensa faixa de utilização de açúcar em licores de frutas, preconizando valores superiores a $30 \mathrm{~g} / \mathrm{L}$ (BRASIL, 2009). Outro fator 
SÁ, C.C.; POMBO, J.C. e BOTELHO, V.A.

que contribui com teor de SST do licor é a adição de frutas devido a extração dos açúcares da fruta durante o processo de maceração. Santos et al. (2010), relataram elevado teor de SST na fruta romã (12,89 ${ }^{\circ}$ Brix). Luna-Ramírez et al. (2017), mencionam a influência do tempo do processo de envelhecimento na concentração dos SST, pois observaram o aumento dos SST (30 a $32{ }^{\circ}$ Brix) no licor de amora preta durante os 180 dias de seu envelhecimento. De acordo com Santos et al. (2018), maiores concentração de SST com a evolução da maturação é devido aos processos de biossíntese ou ainda pela degradação de polissacarídeos; esse parâmetro representa uma das melhores formas de avaliar o grau de doçura do produto e a eficácia da clarificação do licor, uma vez que, altos teores de SST significa que a bebida não foi devidamente clarificada.

O licor apresentou valores elevados de açúcares totais (50,20\%), açúcares redutores $(13,13 \%)$ e açúcares não redutores $(35,21 \%)$. O valor dos açúcares totais foi superior aos valores relatados na literatura por Dias et al. (2011), Oliveira e Santos (2011), Pereira et al. (2012) e Silva et al. (2017) para os licores de maracujá amarelo (26,42 \%), açaí (40,50 \%), umbu (45\%) e cascas de tangerina (28,36 e 34,99\%), respectivamente. Enquanto o valor dos açúcares redutores está entre aos resultados obtidos por Dias et al. (2011) e Pereira et al. (2012) em licores de maracujá amarelo (12\%) e umbu (18,46\%), respectivamente. Já o resultado para açúcares não redutores se encontra de acordo com o especificado pela legislação brasileira que estabelece teor igual ou superior a $30 \%$ para licor, o mesmo foi observado por Oliveira e Santos (2011) em licor de açaí (31,76 \%). O licor foi denominado de seco, conforme relatado na legislação, o licor seco é a bebida que contém mais de trinta gramas por litro e no máximo cem gramas por litro de açúcares (BRASIL, 2009). Oliveira et al. (2016), observaram que os licores de graviola formulados com xarope na concentração de $70{ }^{\circ}$ Brix apresentaram maiores teores de açúcares totais (17,61 e 17,97\%), quando comparados aos xaropes na concentração de $60{ }^{\circ}$ Brix $\left(15,47\right.$ a 15,56) e $50{ }^{\circ}$ Brix $(12,63$ e $12,79 \%$ ), demonstrando que a concentração de açúcar utilizado no xarope fará toda diferença nesse parâmetro. Segundo Barros et al. (2008), a combinação adequada de açúcar e teor alcoólico desempenha papel fundamental na aceitação dos licores.

O licor demonstrou ser boa fonte de compostos fenólicos totais (1041 mg GAE/L) com valor superior aos valores encontrados por Pinto et al. (2017) e Santos et al. (2018) em licores de abacaxi (290 a $400 \mathrm{mg}$ GAE/L), uva (83,129 mg GAE/L) e manga (14,518 mg GAE/L), respectivamente. Segundo Carmo et al. (2016), a fruta romã apresenta elevados teores de compostos fenólicos (6,815 e 8,123 mg GAE/g). Pinto et al. (2017) observaram que os compostos fenólicos totais aumentaram com o aumento da concentração de frutas na 
SÁ, C.C.; POMBO, J.C. e BOTELHO, V.A.

bebida alcoólica durante a maceração. Além da quantidade de frutas, o solvente de maceração (fonte extratora) e o processo de amadurecimento (envelhecimento) irão influenciar na quantidade desses compostos (NASCIMENTO et al., 2010). Segundo Simões et al. (2014), a fonte extratora com graduação alcoólica de $96,5^{\circ} \mathrm{GL}$ mostrou-se mais efetiva na extração dos pigmentos do fruto (absorbância) quando comparada a bebida com $40^{\circ} \mathrm{GL}$. Luna-Ramírez et al. (2017) reportaram o aumento dos compostos fenólicos de 43.70 a 50.85 (mg GAE/mL) durante o processo de envelhecimento do licor de amora preta por 180 dias. Os compostos fenólicos são componentes desejáveis em alimentos e bebidas devido sua capacidade antioxidante e benefícios funcionais e nutracêuticos.

$\mathrm{Na}$ Tabela 2, são expressos os resultados das análises microbiológicas (Salmonella spp., coliformes, bolores e leveduras), comparados aos padrões exigidos pela legislação vigente afim de atestar a qualidade sanitária do produto.

Tabela 2. Resultados das análises microbiológicas do licor de romã e canela.

\begin{tabular}{lcc}
\hline Microorganismos & Contagem & *Parâmetro \\
\hline Salmonella spp. & Ausente & Ausente em 25 g \\
Coliformes Totais & $<3 \mathrm{NMP} / \mathrm{mL}$ & - \\
Coliformes Termotolerantes & $<3 \mathrm{NMP} / \mathrm{mL}$ & Máx. 10 NMP/g \\
Bolores e Leveduras & $<15 \mathrm{UFC} / \mathrm{mL}$ & - \\
\hline
\end{tabular}

Fonte: Própria (2020) e *BRASIL (2001).

Os resultados da contagem de Salmonella spp., coliformes, bolores e leveduras, situam-se dentro dos parâmetros propostos pela legislação vigente (BRASIL, 2001). Os estudos de Oliveira e Santos (2011) e Melo Neto et al. (2013), referentes aos licores de açaí e cacau também apresentaram ausência de Salmonella spp., coliformes, bolores e levedura, o que confirma o licor como uma bebida com ótima qualidade microbiológica. Além do teor alcoólico da bebida e da adição das matérias-primas terem contribuido para atividade antimicrobiana da mesma. Segundo Sousa et al. (2018), os compostos bioativos presentes na romã revelam ação antimicrobiana contra diferentes espécies bacterianas, com eficácia maior na inibição de bactérias Gram-positivas quando comparadas as Gram-negativas. Gomes et al. (2018), afirmam que a canela apresenta potencial fungicida e bactericida. Tais resultados garantem a conservação do produto, prolongando sua vida útil. Portanto, o licor elaborado apresentou qualidade microbiológica satisfatória, indicando também que a bebida foi submetida a condições higiênico-sanitárias adequadas durante seu processamento, garantindo o atendimento aos requisitos mínimos de qualidade para o consumo humano. 
SÁ, C.C.; POMBO, J.C. e BOTELHO, V.A.

\section{Conclusão}

O licor de romã e canela foi classificado como licor seco. A bebida produzida apresentou boas características físico-químicas devido aos valores de satisfatórios de $\mathrm{pH}$, acidez, densidade, cinzas, extrato seco, açúcares totais, açúcares redutores e açucares não redutor, bem como teor alcoólico e sólidos solúveis totais dentro dos parâmetros exigidos pela legislação, além de altas concentrações de compostos fenólicos totais, quando comparados com os relatados na literatura. Em relação às análises microbiológicas, a ausência de Salmonella spp. e contagem de coliformes, bolores e leveduras de acordo com o exigido pela legislação brasileira, indica as boas condições higiênico-sanitárias durante a fabricação da bebida, o que confirma sua qualidade. Desta forma, o licor desenvolvido apresenta potencial de comercialização, sendo viável sua produção, por tratar-se de uma tecnologia simples de fácil armazenagem e extensa vida de prateleira, constituindo uma alternativa econômica para o aproveitamento da fruta e geração de renda a pequenos produtores.

\section{Referências}

ALMEIDA, E. L.; LIMA, L. C.; BORGES, V. T. N.; MARTINS, R. N.; BATALINI, C. Elaboração de licor de casca de tangerina. Alimentos e Nutrição, v. 23, n. 2, p. 259-265, 2012.

ALMEIDA, J. C.; ALMEIDA, P. P.; GHERARDI, S. R. M. Potencial uso dos frutos da aceroleira (Malpighiae marginata) para produção de licores. Multi-Science Journal, v. 2, n. 1, p. 7-11, 2019.

ALMEIDA, J. C.; GHERARDI, S. R. M. Elaboração, caracterização físico-química e aceitabilidade de licor de goiaba. Multi-Science Journal, v. 1, n. 13, p. 390-393, 2018.

ALMEIDA, J. C.; GHERARDI, S. R. M. Elaboração, caracterização físico-química e aceitabilidade de licor de jabuticaba. Revista de Engenharias da Faculdade Salesiana, n. 10, p. 20-24, 2019.

ALVES, Y. F. M.; MENDONÇA, X. M. F. D. Elaboração e caracterização sensorial e funcional de um licor típico amazônico a base de açaí (Euterpe oleracea). Revista Brasileira de Tecnologia Agroindustrial, v. 5, n. 2, p. 559-572, 2011. Doi:10.3895/S198136862011000200008

AMERICAN PUBLIC HEALTH ASSOCIATION (APHA). Compendium of Methods for the Microbiological Examination of Foods. $4^{a}$ ed. Washington: APHA, 2001. p. 600.

ASSOCIATION OF OFFICIAL ANALYTICAL CHEMISTS (AOAC). Official Methods of Analysis of the AOAC. $18^{\text {th }}$ ed. Gaithersburg, M.D, USA, 2005.

ATAÍDE, E. M.; SILVA, M. S.; BASTOS, D. C.; SOUZA, J. M. A. Qualidade pós-colheita de romã comercializada no semiárido pernambucano. Agrarian Academy, v. 5, n. 9; p. 429- 
436, 2018. Doi:10.18677/Agrarian_Academy_2018a42

BARROS, J. C.; SANTOS, P. A.; ISEPON, J. S.; SILVA, J. W.; SILVA, M. A. P. Obtenção e avaliação de licor de leite a partir de diferentes fontes alcoólicas. Global Science and Technology, v. 1, n. 4, p. 27-33, 2008.

BRASIL. Agência Nacional de Vigilância Sanitária - Anvisa. Regulamento Técnico sobre padrões microbiológicos para alimentos. Resolução-RDC $\mathrm{n}^{\circ} 12$, de 02/01/01, Diário Oficial da União. Brasília, DF, 10 de jan. 2001. Seção 1.

BRASIL. Ministério da Agricultura, Pecuária e Abastecimento. Decreto $\mathrm{n}^{\circ}$ 6.871, de 4 de Julho de 2009. Dispõe sobre a padronização, a classificação, o registro, a inspeção, a produção e a fiscalização de bebidas. Diário Oficial [da] Republica Federativa do Brasil. Brasília, DF, 05 de jun. 2009.

CARMO, M. C. L.; AlCÂNTARA, B. K.; ALENCAR, S. M.; BEZERRA, R. M. N. Influência das técnicas de cultivo na atividade antioxidante de romã. Multi-Science Journal, v. 1, n. 4, p. 3-6, 2016.

CARRIJO, K. F.; PRAXEDES, C. I. S.; NOBRE, F. S. D.; FRASÃO, B. S.; DUARTE, M. T.; CUNHA, F. L. Condimentos e especiarias empregados no processamento de alimentos: considerações a respeito de seu controle físico-químico. PUBVET, v. 6, n. 26, p. 1-27, 2012.

COELHO, B. E. S.; NÉZIO, E. P. X.; ARAÚJO, A. A.; COELHO, C. L.; SOUSA, K. S. M.; BRAGA, A. C. D. Desenvolvimento e avaliação sensorial do licor de uva Cv. Isabel. Nucleus, v. 16, n. 2, p. 379-387, 2019. Doi:10.3738/1982.2278.3648

DIAS, S. C., CARDOSO, R. L., BATISTA, D. V. S., SANTOS, D. B., ASIS, S. S. Caracterização físico-química e sensorial do licor de corte do maracujá amarelo. Enciclopédia Biosfera, v. 7, n. 13, p. 1405-1412, 2011.

FRANCO, B. D. G.M.; LANDGRAF, M. Microbiologia dos alimentos. 1 ed. São Paulo: SP, 2005. $196 \mathrm{p}$.

GOMES, E. M. C.; FIRMINO, A. V.; PENA, R. C. M.; ALMEIDA, S. S. M. S. Efeito inibitório in vitro de extratos de Cinnamomum zeylanicum blume no controle de Cylindrocladium candelabrum. Ciência Florestal, v. 28, n. 4, p. 1559-1567, 2018. Doi: $10.5902 / 1980509835103$

INSTITUTO ADOLFO LUTZ. Métodos físico-químicos para análise de alimentos. $4^{\mathrm{a}}$ ed., $1^{\mathrm{a}}$ ed. digital. São Paulo: IAL, 2008. 1020 p.

LINGUANOTTO NETO, N.; FREIRE, R.; LACERDA, I. Misturando sabores: receitas e harmonização de ervas e especiarias. São Paulo: Senac, 2016. 160 p.

LUNA-RAMÍREZ， K. Y.; ARELLANO-CÁRDENAS， S.; GARCÍA-PINILLA， S.; CORNEJO-MAZÓN, M. Kinetic analysis of the stability of antioxidants in blackberry (Rubus fruticosus L.) liquor. Revista Mexicana de Ingeniería Química, v. 16, n. 1, p. 121-130, 2017. 
MELO NETO, B. A.; CARVAlHO, E. A.; MELlO D. L. N.; ANJOS A. C.; FERREIRA A. C. R.; SACRAMENTO C. K. Classificação de amêndoas e qualidade de liquor de cacau (Theobroma cacao L.) superior bahia. Revista Brasileira de Produtos Agroindustriais, v. 15, n. 4, p. 391-396, 2013. Doi:10.15871/1517-8595/rbpa.v15n4p391-396

MOREIRA, I. S.; ROCHA, R. H. C.; PAIVA, E. P.; SILVA, H. S.; SOUSA, F. A. Biometria e componentes físico-químicos de romã armazenada sob refrigeração. Pesquisa Agropecuária Tropical (Agricultural Research in the Tropics), v. 45, n. 2, p. 209-215, 2015. Doi:10.1590/1983-40632015v4532501

NASCIMENTO JÚNIOR, B. J.; SANTOS, A. M. T.; SOUZA, A. T.; SANTOS, E. O.; XAVIER, M. R.; MENDES, R. L.; AMORIM, E. L. C. Estudo da ação da romã (Punica granatum $\mathrm{L}$.) na cicatrização de úlceras induzidas por queimadura em dorso de língua de ratos Wistar (Rattus norvegicus). Revista Brasileira de Plantas Medicinais, v. 18, n. 2, p. 423432, 2016. Doi:10.1590/1983-084X/15_125

NASCIMENTO, N. T.; FRUTUOSO, A. E.; MORAES, K. F.; SOARES, D. L.; SILVA, E. D. L.; FARIAS, M. D. Elaboração de um licor funcional a base de Acerola (Malpighia emarginata) com Abacaxi (Ananas comosus). In: Congresso de pesquisa e inovação da rede norte e nordeste de educação tecnológica, 2010, Maceió-AL. Anais do Congresso de pesquisa e inovação da rede norte e nordeste de educação tecnológica, 2010.

OLIVEIRA, E. N. A.; SANTOS, D. C.; GOMES, J. P. ROCHA, A. P. T.; ALBUQUERQUE, E. M. B. Estabilidade física e química de licores de graviola durante o armazenamento em condições ambientais. Revista Brasileira de Engenharia Agrícola e Ambiental, v.19, n.3, p.245-251, 2015. Doi:10.1590/1807-1929/agriambi.v19n3p245-251

OLIVEIRA, E. N. A.; SANTOS, D. C. Processamento e avaliação da qualidade de licor de açaí (Euterpe oleracea Mart.). Revista do Instituto Adolfo Lutz, v. 70, p. 534-41, 2011.

OLIVEIRA, E. N. A.; SANTOS, D. C.; SANTOS, Y. M. G.; BUCHWEITZ, P. R.; GOMES, J. P. Soursop liquor processing: influence of the process variables on the physical and chemical characteristics. Revista Caatinga, v. 29, n. 1, p. 246-256, 2016. Doi:10.1590/198321252016v29n129rc

OLIVEIRA, E. N. A.; SANTOS, D. C.; SANTOS, Y. M. G.; OliVEIRA, F. A. A. Aproveitamento agroindustrial da graviola (Annona muricata L.) para produção de licores: avaliação sensorial. Journal of Biotechnology and Biodiversity, v.7, n.2, p. 281-290, 2019. Doi:10.20873/jbb.uft.cemaf.v7n2.alvesoliveira

OLIVEIRA, L. P.; PINHEIRO, R. C.; VIEIRA, M. S.; PAULA, J. R.; BARA, M. T. F.; VALADARES, M. C. Atividade citotóxica e antiangiogênica de Punica granatum L., Punicaceae. Revista Brasileira de Farmacognosia, v. 20, n. 2, p. 201-207, 2010.

PASSOS, F. R.; CRUZ, R. G.; SANTOS, M. V.; FERNANDES, R. V. B.Avaliação físicoquímica e sensorial de licores mistos de cenoura com laranja e com maracujá. Revista Brasileira de Produtos Agroindustriais, v. 15, n. 3, p. 211-218, 2013.

PEREIRA, K. S.; LEITE, D. S.; SANTOS, P. L. S.; CARDOSO, R. L. Preparo, caracterização físico-química e aceitabilidade de Licor de corte de Spondias tuberosa. 
SÁ, C.C.; POMBO, J.C. e BOTELHO, V.A.

Enciclopédia Biosfera, v.8, n.15, p. 1337-1344, 2012.

PINTO, V. Z.; RODRIGUES, V. N.; SANTOS, D. F.; SANTOS, G. H. F.; BITENCOURT, T. B. Market research, elaboration and characterization of pineapple liqueur. Revista Produção e Desenvolvimento, v.3, n.3, p. 34-42, 2017.

REYES-LINARES, A.; PINO-ALEA, J.; MOREIRA-OCANTO, V. Aspectos generales sobre la elaboración del licor de limón. ICIDCA, v. 45, n. 1, p. 13-19, 2011.

SANTOS, E. H. B.; BATISTA, F. P. R.; PEREIRA, L. M.; CAMPOS, L. M. A.; CASTRO, M. S.; AZEVÊDO, L. C. Composição físico-química dos frutos de romã (Punica granatum L.). In: Congresso de pesquisa e inovação da rede norte e nordeste de educação tecnológica, 2010, Maceió-AL. Anais do Congresso de pesquisa e inovação da rede norte e nordeste de educação tecnológica, 2010.

SANTOS, K. M.; MACHADO, M. A.; GOMES, P. O. M. Caracterização físico-química, determinação de minerais e avaliação do potencial antioxidante de licores produzidos artesanalmente. Multi-Science Journal, v. 1, n. 12, p. 54-61, 2018.

SILVA, R. C.; AMORIM, A. B. F.; FEITOSA, R. M.; OLIVEIRA, E. N. A.; FEITOSA, B. F.; AMADEU, L. T. S. Licor fino de casca de tangerina: processamento e caracterização. Arquivos Brasileiros de Alimentação, v.2, n. 3, p. 164-173, 2017.

SIMÕES, L. S.; TEIXEIRA, L. J. Q.; SARAIVA, S. H.; JUNQUEIRA, M. S. ESTUDO DA Extração dos componentes do abacaxi em função do teor alcoólico e do tamanho da partícula para a produção de licor de abacaxi. Revista Brasileira de Produtos Agroindustriais, v. 16, n. 3, p. 239-246, 2014. Doi:10.15871/1517-8595/rbpa.v16n3p239-246

SOUSA, N. C. F.; GONZAGA, L. F.; RODRIGUES, J. F. S.; FERNANDES, E. S. Propriedades farmacológicas de Punica granatum L (romã): uma revisão de literatura. Revista Ceuma Perspectivas, v. 31, n. 1, p. 57-67, 2018. Doi:10.24863/rccp.v31i1.181

STADNIK, P.; BORGES, S.; BORGES, D. Avaliação da qualidade de licor de maçã com hortelã (Mentha s. p.) elaborado com açúcar orgânico em substituição ao açúcar convencional. Revista Connection Line, n. 12, p. 77-83, 2015.

TEIXEIRA, L. J. Q.; SIMÕES, L. S.; SARAIVA, S. H.; JUNQUEIRA, M. S.; SARTORI, M. A. Determinação da proporção de açúcar e fruta necessários para conferir os atributos ideais ao licor de abacaxi. Enciclopédia Biosfera, v. 8, n. 14, p. 1883-1889, 2012.

TEIXEIRA, L. J. Q.; ROCHA, C. T.; JUNQUEIRA, M. S.; CARNEIRO, J. C. S.; SARAIVA, S. H. Determinação da cinética de extração alcoólica no processamento de licor de café. Enciclopédia Biosfera, v. 6, n. 9, p. 1-9. 2010.

TEIXEIRA, L. J. Q.; ROCHA, C. T.; JUNQUEIRA, M. S.; CARNEIRO, J. C. S.; SARAIVA, S. H. Comparação da cinética de extração em licores de café utilizando diferentes fontes alcoólicas: álcool de cereais e cachaça. Enciclopédia Biosfera, v. 7, n. 12, p.1-15, 2011.

VIANA, L. F.; MUNHOZ, C. L.; SOUZA, A. R. M.; SANTANA, L. M.; MACIEL, V.; CALIARI, M. Development and characterization of the tangerine peel liquor with different 
SÁ, C.C.; POMBO, J.C. e BOTELHO, V.A.

alcoholic bases. Acta Scientiarum. Technology, v. 33, n. 1, p. 95-100, 2011. Doi: 10.4025/actascitechnol.v33i1.7873

VIERA, V. B.; RODRIGUES, J. B.; BRASIL, C. C. B.; ROSA, C. S. Produção, caracterização e aceitabilidade de licor de camu-camu (Myrciaria dúbia (H.B.K.) McVaugh). Alimentação e Nutrição, v. 21, n. 4, p. 519-522, 2010. 


\title{
CAPÍTULO 30: ESTUDO DA CINÉTICA DE SECAGEM E CARACTERIZAÇÃO FÍSICO-QUÍMICA DA POLPA DE PITANGA (Eugenia uniflora)
}

\section{CHAPTER 30: STUDY OF DRYING KINETICS AND PHYSICAL AND CHIMICAL CHACACTERIZATION OF PITANGA PULP (Eugenia uniflora)}

\author{
Claudinéia Aparecida Queli Geraldi ${ }^{1}$; Maria Fernanda Alves Faria Andrade ${ }^{2}$; Fabiano de \\ Paula Pereira Machado ${ }^{3}$ Raquel Aparecida Loss ${ }^{4}$; Sumaya Ferreira Guedes ${ }^{5}$
}

\section{Resumo}

O Brasil apresenta clima diversificado, o que permite a produção de diversos tipos de frutas, destacando-se como produtor frutícola mundial, porém, desperdícios ocorrem devido ao uso de técnicas inadequadas de colheita, pós-colheita, armazenamento, transporte e além da sazonalidade. Portanto, o presente estudo objetivou a realização da cinética de secagem em camada de espuma em diferentes temperaturas e análise das propriedades físico-químicas da polpa de pitanga. Os modelos matemáticos utilizados foram de Midilli e Kucuk e Page, porém o que apresentou melhor ajuste foi o de Page. Em relação às características físico-químicas, a polpa in natura apresentou valor de $\mathrm{pH}$ de 3,12 e para as polpa seca de 3,12 e 3,13. O teor de cinzas para a polpa in natura foi de 0,27 e para as polpas secas variou de 2,11 a $2,16 \%$ e o teor de vitamina $\mathrm{C}$ concentrou com a secagem, destacando-se a secagem da polpa a $60{ }^{\circ} \mathrm{C}$ que apresentou $74,37 \mathrm{mg} / 100 \mathrm{~g}$ de vitamina C. A acidez total titulável para a polpa in natura foi de 3,014 e para as polpas secas variou de 15,7 a $15,88 \mathrm{~g}$ de ácido/100g. Os valores de umidade reduziram com a elevação da temperatura de secagem

Palavras-Chave : Frutas, conservação de alimentos, modelagem matemática.

\begin{abstract}
Brazil has a diverse climate, which allows the production of several types of fruit, standing out as a world fruit producer, however, waste occurs due to the use of inappropriate harvesting, post-harvesting, storage, transport and seasonality techniques. Therefore, the present study aimed to perform the kinetics of drying in foam layer at different temperatures and analysis of the physicochemical properties of pitanga pulp. The mathematical models used were from Midilli and Kucuk and Page, but the best adjustment was Page. In relation to the physicalchemical characteristics, the pulp in natura $\mathrm{pH}$ value of 3.12 and for dry pulp 3.12 and 3.13. The ash content for the flesh pulp was 0.27 and for the dry pulp it varied from 2.11 to $2.16 \%$ and the vitamin $\mathrm{C}$ content concentrated with drying, with the pulp drying at $60{ }^{\circ} \mathrm{C}$ standing vitamin C $74.37 \mathrm{mg} / 100 \mathrm{~g}$ vitamin $\mathrm{C}$. The titratable total acidity for the fresh pulp was 3.014 and for the dry pulp it varied from 15.7 to $15.88 \mathrm{~g}$ of acid/100g. The humidity values decreased with increasing druing temperature.
\end{abstract}

Keywords: Fruit, food conservation, mathematical modeling.

\footnotetext{
${ }^{1}$ Agronomia, Universidade do Estado de Mato Grosso, claudigeraldi@onda.com.br

${ }^{2}$ Engenharia de Alimentos, Universidade do Estado de Mato Grosso, fernaandafarias@ gmail.com

${ }^{3}$ Engenharia de Alimentos, Universidade do Estado de Mato Grosso, fmachado@ unemat.br

${ }^{4}$ Engenharia de Alimentos, Universidade do Estado de Mato Grosso, raquelloss@ unemat.br

${ }^{5}$ Doutora, Universidade do Estado de Mato Grosso, su_sumaya@yahoo.com.br
} 


\section{Introdução}

O Brasil é um país que se destaca como um dos maiores produtores frutícolas mundiais. Isso está diretamente ligado ao fato de ser um país continental com climas variados, possibilitando uma imensa capacidade de produzir variados tipos de frutas, desde as de clima tropical até as que necessitam de clima temperado para seu cultivo. No entanto, estimativas apontam para desperdícios na produção, devido a técnicas inadequadas de colheita, póscolheita, armazenamento, transporte e sazonalidade (DANTAS, 2010).

Eugenia uniflora comumente conhecida como pitanga, possui elevado valor nutricional e atributos sensoriais de grande aceitação pelo consumidor. Possui proteínas, lipídeos e uma quantidade significante de carboidratos. Com relação ao potencial funcional é rica em compostos fenólicos, flavonoides e possui atividade antioxidante (SILVA, 2016; VOLPATO et al, 2015).

O nome pitanga é oriundo da palavra indígena tupi pyrang, a qual tem o significado de vermelho profundo, essa fruta possui outras denominações em diferentes regiões do Brasil e outros países, como cereja pitanga, pitango, cereja brasileira, ibitanga, cereja do Suriname cerejeira de Cayenne (BRASIL, 2015; EMBRAPA, 2015).

A pitanga é uma baga (fruto pequeno, carnoso e com semente no seu interior) que tem em média $23 \%$ de caroço e $77 \%$ de polpa, apresenta de 1,5 a 3 centímetros de diâme tro e é fixada na pitangueira através de um pedúnculo com comprimento de aproximadamente dois a três centímetros (BOURSCHEID et al., 2011; EMBRAPA, 2015; SILVA, 2016). A Figura 1, reforça a aparência atrativa de pitangas maduras coletadas na região do Centro-Oeste do Brasil.

Figura 1. Pitangas maduras da região Centro-Oeste do Brasil.

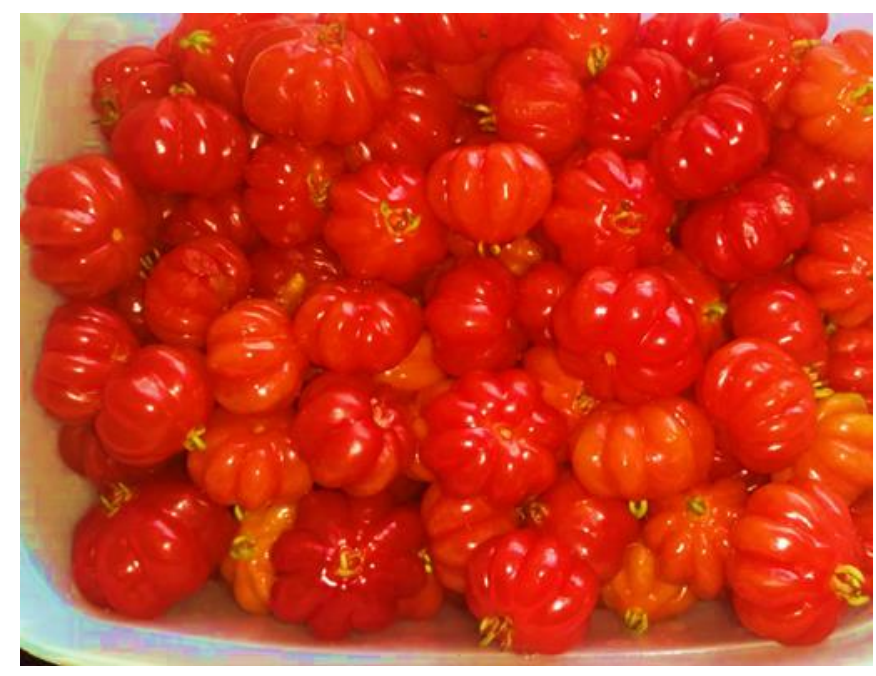

Fonte: Própria (2019). 
A pitanga é caracterizada pelo seu sabor, o qual possui equilíbrio entre ácido e doce, aroma agradável, bela aparência, possuindo uma coloração alaranjada, vermelha ou roxa, além dos aspectos nutricionais que são desejáveis, visto que a polpa dessa fruta é rica em antocianinas, flavonoides, carotenoides e antioxidantes, também apresenta um alto teor de vitaminas, sendo a vitamina A, complexo B e C, além disso os sais minerais também estão presentes na pitanga, entre eles encontram-se o ferro, fósforo e cálcio (BOURSCHEID et al., 2011; LIMA et al., 2017; SILVA, 2016; VOLPATO et al, 2015).

As substâncias antioxidantes são capazes de absorver os radicas livres existentes nos organismos, impedindo danos realizados pela oxidação, desta forma têm a capacidade de retardar o envelhecimento precoce, além disso é possível prevenir doenças crônicas, cardiovasculares, catarata e alguns tipos de câncer (EMBRAPA, 2015; SILVA, 2010). Para a ingestão desses compostos recomenda-se o consumo de frutas e vegetais, em especial de coloração avermelhada, lilás, azul, violeta, os quais possuem antocianinas, e aquelas de coloração amarelo pálido e marfim, cujos têm flavonoides em sua composição (PEREIRA, 2012).

Entretanto, devido à perecibilidade, não é possível transportá-la in natura para mercados consumidores mais distantes preservando seu potencial nutricional, funcional e sensorial. Como alternativa, a secagem em camada de espuma é indicada para a produção de alimentos a partir polpas de frutas com o objetivo de disponibilizar ao consumidor produtos com o máximo de características nutricionais e funcionais preservadas. O produto desidratado oferece outras vantagens como maior período de conservação e facilidade para transporte (EMBRAPA, 2010).

A técnica de secagem, cujo intuito de remover a água livre do produto através da aplicação de calor, impede assim a deterioração, além de facilitar o transporte. Estudos apontam que a secagem em camada de espuma tem influência mínima sobre as propriedades, tanto físicoquímicas, quanto nutricionais das polpas de fruta, mantendo-as o com as características próximas a do estado in natura (EMBRAPA, 2010; SILVA, 2015).

Este método de secagem consiste na formação de uma espuma por meio da adição de agentes emulsificantes nas polpas de frutas, através da incorporação de ar por agitação, permitindo uma maior facilidade para remoção de umidade, reduzindo o tempo de processo. Os produtos em pó, provenientes de polpas de frutas estão sendo muito utilizados nas indústrias alimentícias, devido ao seu baixo custo de processamento em relação a sua conservação, transporte, armazenamento e embalagens (SILVA, 2008). 
A cinética de secagem é a velocidade na qual o alimento perde umidade, sendo influenciada pela composição do mesmo, umidade relativa e velocidade do ar e a temperatura aplicada para a realização do processo (SILVA, 2015).

Como a pitanga é uma fruta muito sensível, desta forma a sua durabilidade pós-colheita é muito baixa, sendo necessária a aplicação de algum tratamento para aumentar a sua vida útil, uma alternativa é a utilização de secagem em camada de espuma, a qual o produto final resulta em um pó com umidade baixa e características físico químicas e sensoriais muito próximas da fruta in natura (ALEXANDRE et al., 2014).

Portanto, o presente estudo objetivou a realização da cinética de secagem em camada de espuma e analisar as propriedades físico-químicas em diferentes temperaturas das polpas de pitanga in natura e secas.

\section{Material e Métodos}

As análises foram realizadas no Laboratórios da Universidade do Estado de Mato Grosso - Campus Deputado Estadual Renê Barbour. As pitangas foram coletada no munícipio de Barra do Bugres localizado no Estado de Mato Grosso - Brasil. O aditivo emulsificante Emustab® seleta (composto por monoglicerideos de ácidos graxos, monoestearato de sorbitana, polioxietileno de monoestearato de sorbitana e sorbato de potássio) foi adquirido no comércio local.

\section{Obtenção da espuma}

As frutas foram higienizadas, despolpadas e trituradas em liquidificador doméstico até a homogeneização completa. Em seguida, o emulsificante foi adicionado na concentração de $5 \%$ em relação à massa da polpa e a mistura agitada em batedeira doméstica em velocidade máxima por 8 minutos. A espuma resultante foi distribuída em placas de Petri (aproximadamente $10 \mathrm{~g}$ em cada placa), as quais foram acondicionadas em estufa com circulação forçada de ar para a realização da secagem.

\section{Secagem da polpa da pitanga}

As secagens das espumas das polpas de pitanga foram realizadas nas temperaturas de $60 \mathrm{C}$ e $70^{\circ} \mathrm{C}$, sendo finalizada ao atingir o equilíbrio (massa constante). Após a secagem, o produto foi retirado das placas de Petri com auxílio de uma espátula, acondicionados em embalagem de polietileno e armazenadas no congelador até realização das análises. 


\section{Modelagem matemática}

Para analisar o comportamento da perda de umidade ao decorrer da secagem foram utilizados os modelos semi-empíricos de Midilli e Kucuk (2002), Page (1949), Henderson e Pabis (1961) e para descrever o comportamento da secagem (Quadro 1). O modelo escolhido para representar a cinética de secagem da polpa de pitanga em camada de espuma, foi o que apresentou melhor ajuste, avaliado através do coeficiente de determinação $\left(\mathrm{R}^{2}\right)$, pelo erro médio padrão e pelo princípio da parcimônia.

Quadro 1. Modelos matemáticos utilizados para descrever a cinética de secagem
\begin{tabular}{|c|c|}
\hline Designação do Modelo & Modelos matemáticos \\
\hline Midilli e Kucuk & $\mathrm{RX}=\mathrm{a} \exp \left(-\mathrm{kt}^{\mathrm{n}}\right)+\mathrm{bt}$ \\
\hline Page & $\mathrm{RX}=\exp \left(-\mathrm{kt}^{\mathrm{n}}\right)$ \\
\hline Henderson e Pabis & $\mathrm{RX}=\mathrm{a} \exp (-\mathrm{kt})$ \\
\hline
\end{tabular}

Onde: RX corresponde a razão de umidade do produto, adimensional; t é o tempo de secagem, min; $\mathrm{k}$, constante de secagem, $\min ^{-1}$, e a, b, n são os coeficientes dos modelos.

\section{Análises fisico-químicas}

As amostras foram submetidas às análises de $\mathrm{pH}$, cinzas, vitamina $\mathrm{C}$, e acidez total titulável e umidade todas realizadas em triplicata, para maior confiabilidade nos resultados obtidos, seguindo a metodologia do Intituto Adolfo Lutz (2008).

\section{Análises de antocianinas totais e compostos fenólicos totais}

\section{Preparo dos extratos}

Amostras de pitanga in natura e após a secagem foram diluídas em solução de etanol $70 \%$ e submetidas à extração por agitação durante $24 \mathrm{~h}$. Em seguida, as amostras foram filtradas a vácuo e centrifugadas por 10 minutos. O sobrenadante foi armazenado em fracos âmbar em refrigeração em ausência de luz para análises físico-químicas.

\section{Antocianinas totais}

O conteúdo de antocianinas totais dos extratos foi quantificado pelo método de $\mathrm{pH}$ único (Lee e Francis, 1972). A determinação de antocianinas foi realizada diluindo alíquota dos extratos com solução etanol: $\mathrm{HCl} 1,5 \mathrm{~mol} \cdot \mathrm{L}^{-1}(85: 15, \mathrm{v} / \mathrm{v})$. Após a diluição, foi realizada medida da absorbância por espectrofotometria a $535 \mathrm{~nm}$. O teor de antocianinas foi calculado utilizando a equação: $A=\varepsilon_{1 \mathrm{~cm}}$. b. C'

Em que: $A$ = Absorbância (Abs) em $535 \mathrm{~nm} ; \varepsilon_{1 \mathrm{~cm}}=$ Coeficiente de absortividade (98,2 L.cm 
${ }^{1} \cdot \mathrm{g}^{-1}$ ) - considerando cianidina-3-glicosídeo (FULEKI e FRANCIS, 1968); C' = Concentração $\left(\mathrm{g} . \mathrm{L}^{-1}\right), \mathrm{b}=$ espessura da cubeta $(1 \mathrm{~cm})$. O conteúdo total de antocianinas foi expresso em $\mathrm{mg} / 100 \mathrm{~g}$ de polpa.

\section{Compostos fenólicos totais}

O teor de compostos fenólicos totais foi determinado de acordo com metodologia de Genovese et al., (2008).

Em tubos de ensaios foram pipetados $0,6 \mathrm{ml}$ do extrato obtido, $3 \mathrm{~mL}$ do reagente FolinCiocalteu e, após 3 minutos adicionados 2,4 mL da solução carbonato de sódio 7,5\% (p/v), e aguardar 1 hora em ausência de luz. Posteriormente foi realizada a leitura no espectrofotômetro a uma absorbância de $760 \mathrm{~nm}$. Foi utilizado como padrão de referência o ácido gálico. Os resultados foram expressos em mg equivalentes de ácido gálico por 100 gramas de amostra.

\section{Resultados e Discussão}

\section{Cinética de secagem}

Como a secagem foi realizada em camada de espuma, o procedimento apresentou rapidez devido à aeração existente na amostra. Na Figura 2 é possível observar as curvas de secagem em camada de espuma nas temperaturas de 60 e $70{ }^{\circ} \mathrm{C}$.

Figura 2. Curvas de secagem em camada de espuma, nas temperaturas de 60 e $70{ }^{\circ} \mathrm{C}$.

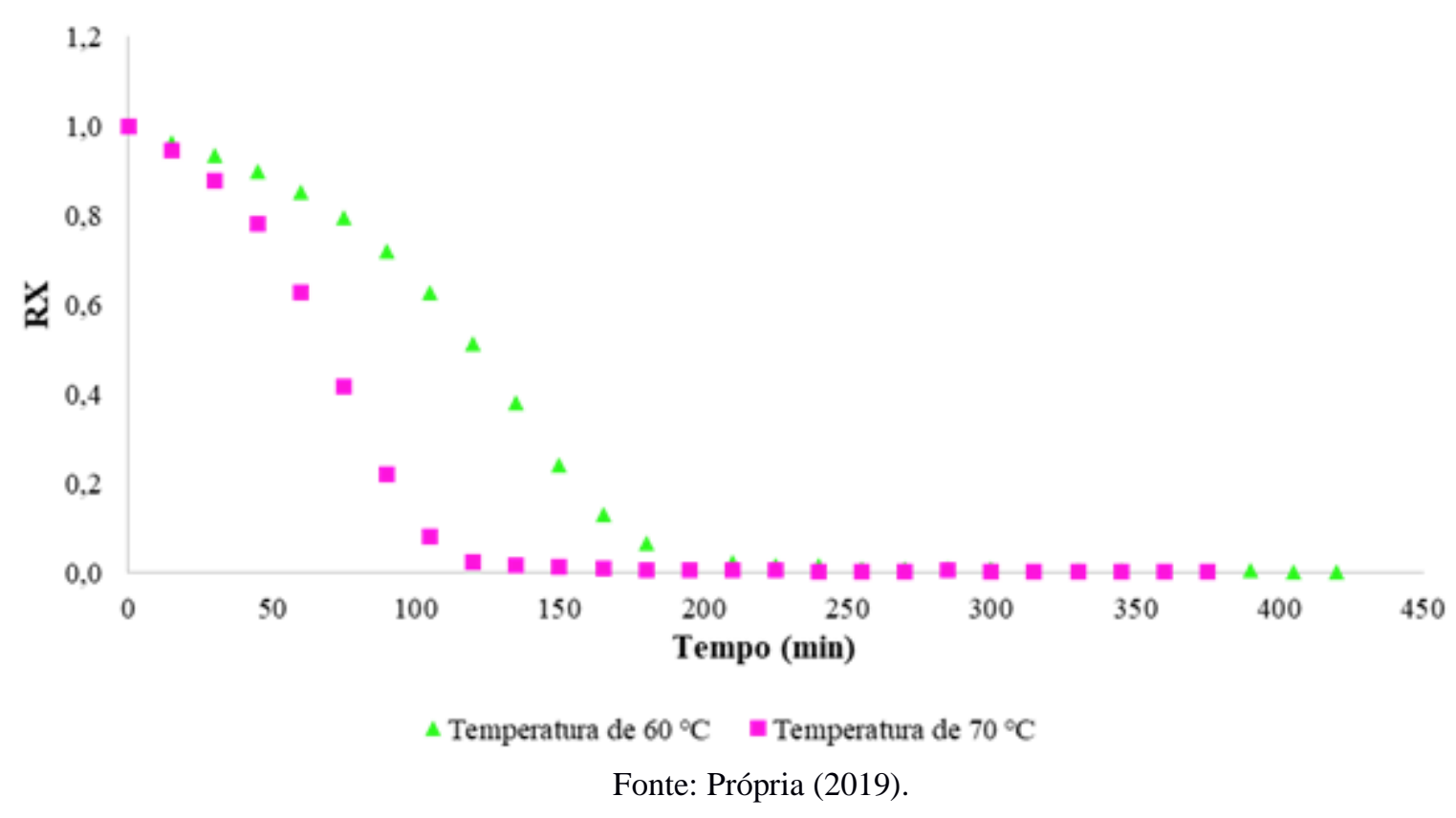


É notório que a amostra submetida à temperatura de $70{ }^{\circ} \mathrm{C}$ atingiu a umidade de equilíbrio com menor tempo quando comparada com a de $60{ }^{\circ} \mathrm{C}$, visto que, com a temperatura mais elevada a perda de água acontece com maior facilidade, desta forma adiantando o processo de secagem, esse fator também foi observado na secagem de acerola (ARAÚJO et al., (2017) e uvaia (RIGUETO et al., 2018). Conforme aumentou-se a temperatura, o tempo de secagem reduziu, ficando em torno de 230 e 150 minutos para as temperaturas de 60 e $70{ }^{\circ} \mathrm{C}$ respectivamente.

A medida na qual a temperatura aumenta a inclinação da curva também aumenta, pois com a temperatura elevada existe uma maior quantidade de calor transferido do ar para a amostra e consequentemente a migração de água do interior para a superfície da amostra ocorre com maior velocidade (REIS et al., 2012). Esse fator pode ser observado na Figura 2, visto que a curva de $70^{\circ} \mathrm{C}$ possui maior inclinação do que a de $60{ }^{\circ} \mathrm{C}$.

\section{Modelagem Matemática}

Na Tabela 1 é possível observar os parâmetros dos modelos matemáticos que foram utilizados para representar a cinética de secagem da pitanga a $60{ }^{\circ} \mathrm{C}$, sendo os modelos de Midilli e Kucuk e Page, apresentando coeficientes de determinação $\left(\mathrm{R}^{2}\right)$ de 0,985961 e 0,996584 respectivamente. É importante ressaltar que o modelo de Henderson e Pabis foi testado, mas os modelos escolhidos apresentaram maior coeficiente de determinação e menor erro.

Tabela 1. Parâmetros dos modelos matemáticos ajustados para a cinética de secagem em camada de espuma da pitanga a $60{ }^{\circ} \mathrm{C}$.

\begin{tabular}{cccc}
\hline Parâmetros & Midilli e Kucuk & Page & Henderson e Pabis \\
\hline $\mathrm{a}$ & 1,092654 & - & 1,316839 \\
$\mathrm{~b}$ & 0,000000 & - & - \\
$\mathrm{k}\left(\mathrm{min}^{-1}\right)$ & 0,000354 & 0,000014 & 0,011477 \\
$\mathrm{n}$ & 1,661881 & 2,289229 & - \\
$\mathrm{R}^{2}$ & 0,985961 & 0,996584 & 0,943303 \\
Erro & 1,338369 & 0,674172 & 2,672400 \\
\hline
\end{tabular}

Fonte: Própria (2019).

O modelo que melhor se ajustou a secagem a $60{ }^{\circ} \mathrm{C}$ foi o de Page, visto que apresentou menor erro $(0,674)$ e um maior coeficiente de determinação $\left(R^{2}=0,996584\right)$ (Tabela 1$)$. 
Entre os três modelos matemáticos apresentados na Tabela 2, o modelo de Page e Midilli e Kucuk foram os que se ajustaram adequadamente a cinética de secagem à $70{ }^{\circ} \mathrm{C}$, visto que apresentaram correlação de 0,993455 para Midilli e Kucuk e 0,996027 para Page, porém o modelo de Henderson e Pabis não se ajustou como o esperado, visto que o coeficiente de determinação $\left(\mathrm{R}^{2}\right)$ foi menor que os demais e o erro maior. $\mathrm{O}$ modelo que melhor se ajustou à cinética de secagem à $70{ }^{\circ} \mathrm{C}$ foi o de Page, o qual teve maior coeficiente de determinação e menor erro.

Tabela 2. Parâmetros dos modelos matemáticos ajustados para a cinética de secagem em camada de espuma da

\begin{tabular}{cccc}
\multicolumn{4}{c}{ pitanga a $70^{\circ} \mathrm{C}}$. \\
\hline Parâmetros & Midilli e Kucuk & Page & Henderson e Pabis \\
\hline $\mathrm{a}$ & 1,002477 & - & 1,268298 \\
$\mathrm{~b}$ & 0,000004 & - & - \\
$\mathrm{k}\left(\mathrm{min}^{-1}\right)$ & 0,000425 & 0,000169 & 0,019490 \\
$\mathrm{n}$ & 1,810642 & 2,003234 & - \\
$\mathrm{R}^{2}$ & 0,993455 & 0,996027 & 0,953642 \\
Erro & 0,589005 & 0,461205 & 1,522815
\end{tabular}

Fonte: Própria (2019).

Através da Figura 3 é possível observar o ajuste dos modelos Midilli e Kucuk e Page aos dados experimentais, obtidos através da cinética de secagem em camada de espuma da polpa de pitanga.

Figura 3. Ajuste dos modelos de Midilli e Kucuk e Page para secagem em camada de espuma da polpa de pitanga a $60{ }^{\circ} \mathrm{C}$.

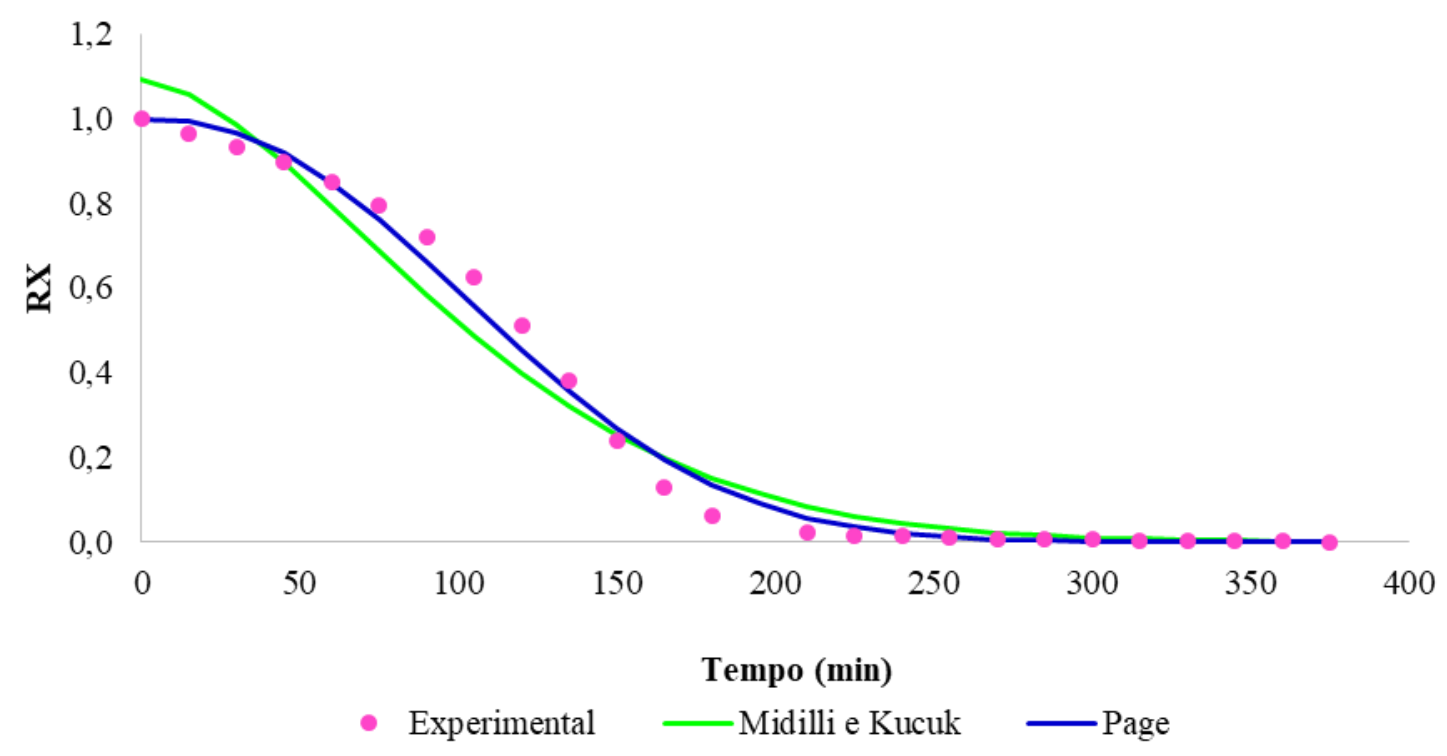

Fonte: Própria (2019). 
Na Figura 4 estão apresentados os ajustes dos modelos matemáticos Midilli Kucuk, na secagem da polpa de pitanga a $70{ }^{\circ} \mathrm{C}$

Figura 4. Ajuste dos modelos de Midilli e Kucuk e Page para secagem em camada de espuma da polpa de pitanga a $70{ }^{\circ} \mathrm{C}$

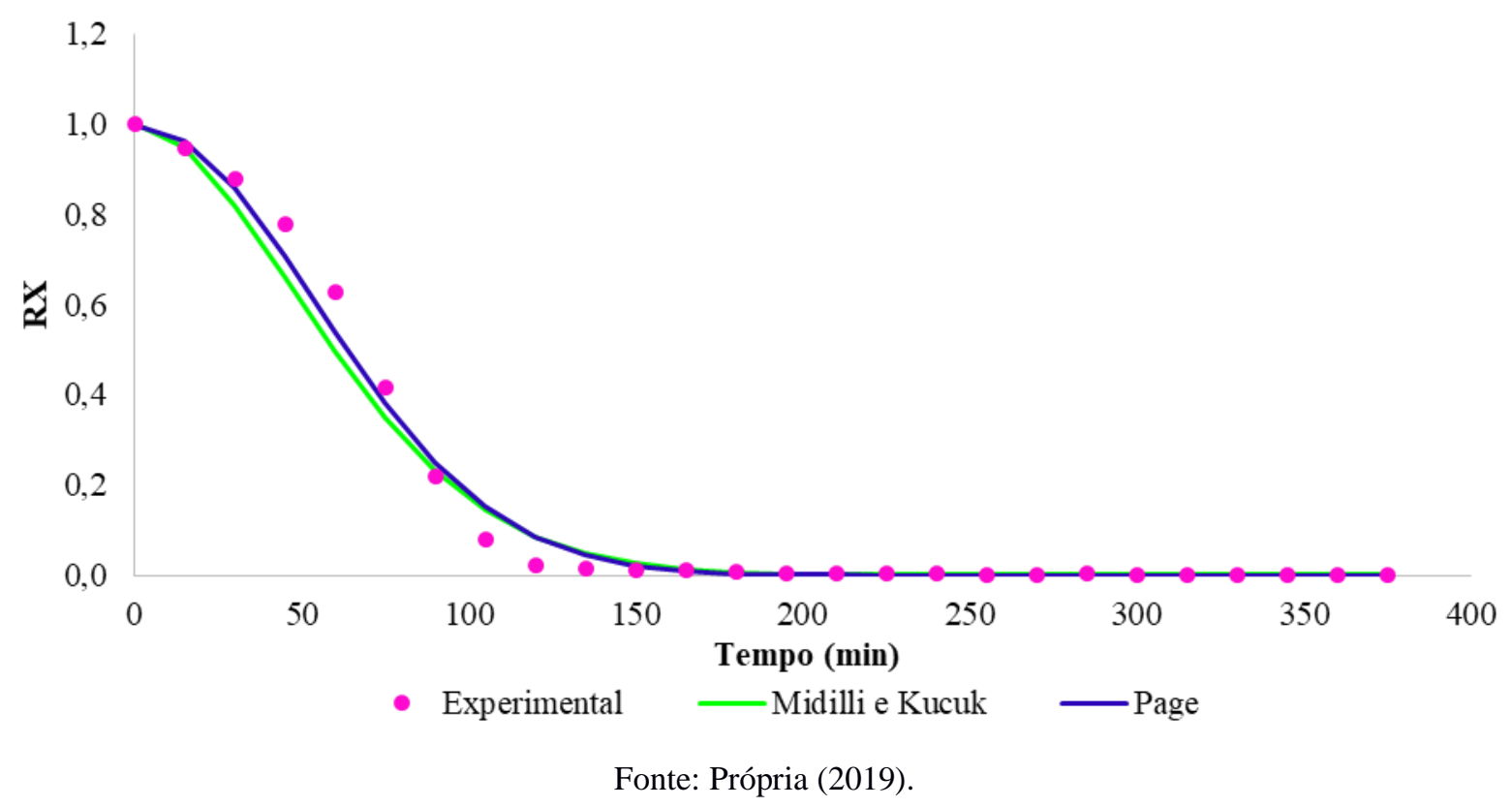

O modelo semi-empírico de Page apresentou excelente ajuste em cinética de secagem em camada de espuma à temperatura de $70{ }^{\circ} \mathrm{C}$ realizada com acerola (ARAÚJO et al., 2017), manga (GUIMARÃES et al., 2017), uvaia (RIGUETO et al., 2018), tamarindo (SILVA et al., 2008), cenoura (DELMIRO, 2016) e mandacaru (MELO et al., 2013), com correlações de 0,997; 0,998; 0,996 0,998; 0,994 e 0,998 respectivamente. O modelo Page também se ajustou adequadamente à secagens em camada de espuma realizadas à $60^{\circ} \mathrm{C}$ em manga (GUIMARÃES et al., 2017), uvaia (RIGUETO et al., 2018), tamarindo (SILVA et al., 2008) e acerola (ARAÚJO et al., 2017), obtendo coeficiente de determinação de 0,999; 0,994; 0,997 e 0,997.

Rigueto et al. (2018) realizou a cinética de secagem em camada de espuma de uvaia em diferentes temperaturas, o modelo semi-empírico de Midilli e Kucuk apresentou ótimo ajuste nas curvas geradas com as temperaturas de 70 e $60{ }^{\circ} \mathrm{C}$, obtendo coeficiente de correlação de 0,989 e 0,993 respectivamente. No estudo realizado por Silva (2008) esse modelo também se ajustou excelentemente na cinética de secagem em camada de espuma de tamarindo nas temperaturas de 60 e $70{ }^{\circ} \mathrm{C}$, onde os ambos coeficientes de correlação foram equivalentes a 0,998 . 


\section{Análises fisico-químicas da pitanga}

Os resultados da caracterização físico-química da polpa in natura e do pó obtido através da formação de uma espuma com adição de $5 \%$ de emulsificante e submetida a secagem a 60 e $70{ }^{\circ} \mathrm{C}$ estão apresentados na Tabela 3.

Tabela 3. Caracterização físico-química da polpa de pitanga in natura e após a secagem em camada de espuma.

\begin{tabular}{l|c|c|c}
\hline \multicolumn{1}{c}{ Parâmetros } & \multicolumn{1}{c}{ In natura } & Polpa seca a 60 \\
& & \\
\hline $\mathrm{pH}$ & $3,12 \pm 0,05^{\mathrm{a}}$ & $3,12 \pm 0,01^{\mathrm{a}}$ & Polpa seca a 70 $^{\circ} \mathbf{C}$ \\
\hline Cinzas (\%) & $0,27 \pm 0,003^{\mathrm{a}}$ & $2,11 \pm 0,05^{\mathrm{b}}$ & $2,16 \pm 0,02^{\mathrm{b}}$ \\
\hline Vitamina C (mg/100g) & $33,78 \pm 0,79^{\mathrm{a}}$ & $74,37 \pm 2,13^{\mathrm{b}}$ & $59,27 \pm 1,0^{\mathrm{c}}$ \\
\hline Acidez Total Titúlavel (g/100g) & $3,01 \pm 0,02^{\mathrm{a}}$ & $15,88 \pm 0,16^{\mathrm{b}}$ & $15,7 \pm 0,012^{\mathrm{b}}$ \\
\hline Umidade (\%) & $90,52 \pm 0,021^{\mathrm{a}}$ & $16,27 \pm 0,94^{\mathrm{b}}$ & $13,46 \pm 0,16^{\mathrm{c}}$ \\
\hline Antocianinas (mg/100g de polpa) & $1,01 \pm 0,001^{\mathrm{a}}$ & $6,24 \pm 0,012^{\mathrm{b}}$ & $4,46 \pm 0,02^{\mathrm{c}}$ \\
\hline Compostos Fenólicos (mg de & $114,09 \pm 0,11^{\mathrm{a}}$ & $660,27 \pm 0,04^{\mathrm{b}}$ & $684,9 \pm 0,21^{\mathrm{b}}$ \\
ácido gálico/100g de polpa) & & & \\
\hline
\end{tabular}

Fonte: Própria (2019).

Os resultados foram expressos como média \pm desvio padrão. Média nas colunas seguidas por letras diferentes na mesma linha são estatisticamente diferentes $(p<0,05)$.

Os resultados encontrados na caracterização físico-química da polpa de pitanga in natura estão de acordo com a literatura, dado que, Vergara et al., (2016) encontraram pH de 3,35 e teor de cinzas equivalente a 0,26\%. Além disso, Batista et al., (2014) obtiveram 90,6\% de teor de umidade e Rodrigues et al., (2016) encontraram 25,06 mg de vitamina C/100g de polpa, valores próximos dos apresentados na Tabela 3.

Alexandre et al., (2014) realizaram a cinética de secagem em camada de espuma de pitanga à $70{ }^{\circ} \mathrm{C}$. Para a formação da espuma foi adicionado $7,5 \%$ de do emulsificante e estabilizante Emustab ${ }^{\circledR}$ e 4,5\% do espessante comercial Super Liga Neutra ${ }^{\circledR}$. Na caracterização físico-química do pó oriundo da secagem foi obtido teor de umidade de 20,40\% e pH de 2,8, valores relativamente próximos aos apresentados na Tabela 3 para pó de pitanga seco a $70{ }^{\circ} \mathrm{C}$, sendo $13,46 \%$ e 3,13 , respectivamente. Existe uma pequena diferença entre os valores, fator que pode estar relacionado com a composição da espuma, pois no presente trabalho utilizou-se apenas 5\% do emulsificante/estabilizante Emustab®.

Conforme a Normativa número 01 de 07 de janeiro de 2000 do Ministério da Agricultura, Pecuária e Abastecimento, a polpa de pitanga deve apresentar acidez mínima de $0,92 \mathrm{~g}$ de ácido/100g de polpa. Por conseguinte, o resultado referente a acidez total titulável da 
polpa de pitanga in natura (3,01 g de ácido/100g de amostra) exposto na Tabela 3 encontra-se dentro dos padrões estabelecidos pelo MAPA (BRASIL, 2000).

Batista et al., (2014) encontrou acidez total titulável em pitangas da região da Bahia equivalente à $1,86 \mathrm{~g}$ de ácido/100g de fruta, valor inferior ao determinado do presente estudo (Tabela 3). Entretanto, a acidez total titulável pode variar conforme o grau de maturação da fruta, visto que frutas no estádio de maturação mais avançado apresentam menor acidez; além disso, o solo no qual foi cultivada e o clima podem influenciar nas características físicoquímicas e nutricionais, justificando a diferença, visto que, as frutas foram cultivadas em diferentes estados (ALEXANDRE, 2014; HAMACEK, 2012.).

Como esperado, o teor de umidade reduziu bruscamente após a secagem, pois esse processo visa a remoção de água livre do alimento. Conforme a temperatura é elevada o teor de umidade reduz, dado que o teor de umidade do pó seco a $60^{\circ} \mathrm{C}(16,27 \%)$ é maior que a do pó seco à $70{ }^{\circ} \mathrm{C}(13,46 \%)$ e ambos apresentam teores inferiores à polpa in natura $(90,52 \%)$. Contudo a secagem do presente estudo foi realizada em manto de camada de espuma, ou seja, após a desidratação da polpa pitanga, o produto obtido foi uma farinha. Neste contexto comparou-se os resultados obtidos no presente com a legislação estabelecida a produtos desidratados em forma de farinhas de origem vegetal, teor de $15 \%(\mathrm{~m} / \mathrm{m})$, constatando assim que o índice de umidade encontrado neste trabalho na temperatura de $70^{\circ} \mathrm{C}$ está de acordo com o preconizado pela Agência Nacional de Vigilancia Sanitária.

Fatores como o tipo da fruta, estádio de maturação e condições climáticas estão diretamente relacionados com a quantidade de antocianinas e compostos fenólicos quantificados, justificando a diferença do teor de antocianinas $(1,01 \mathrm{mg} / 100 \mathrm{~g}$ de fruto) e compostos fenólicos (114,09 mg de ácido gálico/100g de polpa) da polpa in natura encontrados no presente estudo comparados aos de Vergara et al., (2016), o qual obteve 86,15 mg de ácido gálico/100 g de fruto de compostos fenólicos e 3,91 mg/100g de fruto de antocianinas, como as amostras de Vergara et al., (2016) foram coletadas no município de Pelotas no Rio Grande do Sul, é esperada essa oscilação devido aos diferentes climas, solos e talvez grau de maturação (ALMEIDA et al., 2011; CHIRINOS et al., 2010; EMBRAPA, 2010; ZANATTA et al., 2005).

A polpa in natura apresentou teor de compostos fenólicos inferior a polpa seca à temperatura de $60{ }^{\circ} \mathrm{C}$ e $70{ }^{\circ} \mathrm{C}$, sendo $114,09 \mathrm{mg}$ de ácido gálico/100g de polpa (in natura), 660,27 mg de ácido gálico/100g de polpa (polpa seca à $60^{\circ} \mathrm{C}$ ) e $684,9 \mathrm{mg}$ de ácido gálico/100g de polpa (polpa seca à $70^{\circ} \mathrm{C}$ ) (Tabela 3). O mesmo aconteceu para antocianinas, onde a polpa in natura obteve $1,01 \mathrm{mg} / 100 \mathrm{~g}$ de polpa, polpa seca à $60{ }^{\circ} \mathrm{C} 6,24 \mathrm{mg} / 100 \mathrm{~g}$ de fruto e polpa seca à $70{ }^{\circ} \mathrm{C} 4,46 \mathrm{mg} / 100 \mathrm{~g}$ de polpa. Isso acontece pois quando a polpa é transformada em 
espuma e submetida ao processo de secagem, seus componentes são concentrados devido a remoção de água livre, como a secagem em camada de espuma é um processo relativamente rápido, apresenta influência mínima sobre as propriedades, tanto físico-químicas, quanto nutricionais das polpas de fruta (EMBRAPA, 2010).

Esse fato justifica também o teor de vitamina $\mathrm{C}$ e cinzas, sendo que o pó resultante da secagem à 60 e $70{ }^{\circ} \mathrm{C}$ apresentou valores significativamente maiores comparados a polpa in natura (Tabela 3). Além disso, o emulsificante adicionado para obtenção da espuma possui natureza lipídica, consequentemente elevando o teor de cinzas da amostra seca (SANTOS, 2014).

\section{Conclusões}

A secagem em camada de espuma é uma alternativa de conservação de polpa de frutas, dado que, com a redução da água livre do alimento sua vida útil aumenta consideravelmente, além disso, o produto final apresenta boas características nutricionais, pois através da secagem existe a concentração dos componentes das frutas, vitamina $\mathrm{C}$ por exemplo.

Com o aumento da temperatura de 60 para $70{ }^{\circ} \mathrm{C}$, o tempo de secagem diminuiu, conforme esperado, visto que houve uma maior transferência de calor. Os modelos utilizados neste estudo (Page e Midilli e Kucuk) se ajustaram satisfatoriamente a cinética de secagem em camada de espuma da polpa de pitanga nas condições estudadas.

Deste modo, com os resultados apresentados fica evidente que o método de secagem em camada de espuma é uma alternativa eficiente para produzir e comercializar a polpa de pitanga e outras frutas de característica sazonal, além de abrir a possibilidade para a produção de novos produtos da farinha de polpa de pitanga. Contudo são necessários estudos mais amplos que comprovem a validade do método para outras frutas, contribuindo assim para a expansão da cadeia de suprimentos da indústria alimentícia.

\section{Referências}

ALEXANDRE, V. H.; de FIGUEIRÊDO, R. M. F.; QUEIROZ, A. J. DE M.; de OLIVEIRA, E. N. A. Armazenamento de pitanga em pó. Campina Verde - PB, 2014. Andrade, P. F. de S. Fruticultura. Paraná, 2016.

ALMEIDA, M.M.B. et al. Bioactive compounds and antioxidant activity of fresh exotic fruits from northeastern Brazil. Food Research International, v.44, p.2155-2159, 2011.

ANVISA. BRASIL. Agência Nacional de Vigilância Sanitária. Consulta Pública nº 80. Diário

Oficial da União - Brasília, DF, Brasil, 2019. 
ARAÚJO, C. DA S.; MACEDO L. L.; VIMERCATI, W. C.; SARAIVA, S. H.; OLIVEIRA, A. DO N.; TEIXEIRA, L. J. Q. Cinética de secagem de acerola em leito de espuma e ajuste de modelos matemáticos. Brazilian Journal of Food Technology, v. 20. 2017

BATISTA, A.D.; FONSECA, A.A.O.; COSTA, M.A.P.C.; BITTENCOURT, N.S. Caracterização física, físico-química e química de frutos de pitangueiras oriundas de cinco municípios baianos. Magistra, v.26, n.3, p.393-402, 2014.

BOURSCHEID, K.; VIEIRA, N. K.; LISBÔA, G. N.; KINUPP, V. F.; de BARROS I. B. I. Espécies Nativas da Flora Brasileira de Valor Econômico Atual ou Potencial: Eugenia uniflora Pitangueira. Brasília, 2011.

Brasil, Ministério da Agricultura, pecuária e Abastecimento - MAPA. 2000. Instrução Normativa $\mathrm{n}^{\circ}$ 01, de 7 de Janeiro de 2000. Regulamento da Lei ${ }^{\circ}$ 8.918, de 14 julho de 1994 , aprovado pelo Decreto $\mathrm{n}^{\mathrm{o}} 2.314$, de 4 de setembro de 1997, que dispõe sobre o regulamento técnico geral para fixação dos padrões de identidade e qualidade para polpa de fruta. Diário Oficial [da] República Federativa do Brasil. Brasília, DFCAMPOS, E. M.; SARTORELLI, P.A.R. Guia de árvores com valor econômico. São Paulo: Agroicone, 2015.

CHIRINOS, R.; GLARZA J.; BETALLELUZ-PALLARDEL, I.; PEDRESCHI, R.; CAMPOS D. Antioxidant compounds and antioxidant capacity of Peruvian camu camu Myrciaria dubia (H.B.K.) McVaugh) fruit at different maturity stages. Food Chemistry, London, v. 120, p. 1019-1024, 2010.

DANTAS, S.C.M. Desidratação de polpas de frutas pelo método foam-mat. Natal. 2010.

DELMIRO, T. M. Secagem da cenoura (daucus carota 1.) pelo método foam-mat. UNIVERSIDADE FEDERAL DO RIO GRANDE DO NORTE. Natal, 2016.

EMBRAPA. Princípios de Secagem de Alimentos. Planaltina-DF, 2010.

EMBRAPA. Valor nutricional da pitanga. Colombo - Pr. 2015.

GENOVESE, M.L.; PINTO, M.S.; GONÇALVES, A.E.S; LAJOLO, F.M. Bioactive compounds ande antioxdant capacity of exotic fruits and commercial frozen pulps from Brazil. Food Science ande Technology International, p. 2017-214, 2008.

GUIMARÃES, M. K. A.; FIGUEIRÊDO, R. M. F.; QUEIROZ, A. J. de M. Cinética de secagem em camada de espuma da polpa de manga cv. Keitt. Rev. Caatinga. v. 30, n. 1, p. 172 $-180,2017$.

HAMACEK, F. R.; Caracterização física, química e valor nutricional de espécies frutíferas do cerrado de Minas Gerais. Dissertação (Mestrado em Ciência da Nutrição). Universidade Federal de Viçosa, Viçosa, 2012.

HENDERSON, S. M.; PABIS, S. Grain drying theory I. Temperature effect on drying coefficient. Journal of Agricultural Engineering Research, v. 6, n. 3, p. 169-174, 1961.

INSTITUTO ADOLFO LUTZ. Métodos físico-químicos para análise de alimentos. 4 ed. São Paulo: Instituto Adolfo Lutz. 2008. 
LEE, D. H.; FRANCIS, F. J. Standardization of Pigment Analyses in Cranberries. HortScience, Stanford, v. 7, n. 1, p. 83-84, 1972.

LIMA, A. B. M.; DANTAS, S. C. de M.; JÚNIOR, S. M. de P.; DANTAS, T. N. P.; de MEDEIROS M. F. D. Influência dos adjuvantes na secagem da polpa de pitanga em leito de jorro. São Paulo, 2017.

MAPA - Ministério da Agricultura, Pecuária e Abastecimento. Plano nacional de desenvolvimento da fruticultura. 2016.

MELO, K. S.; FIGUEIRÊDO, R. M. F.; QUEIROZ, A. J. M.; FERNANDES, T. K. S.; BEZERRA, M. C. T. Secagem em camada de espuma da polpa do fruto do mandacaru: experimentação e ajustes de modelos matemáticos. Revista Caatinga, Mossoró, v. 26, n. 2, p. 10-17, 2013.

MIDILLI, A.; KUCUK, H.; YAPAZ, Z. A new model for single-layer drying. Drying Technology, New York, v.20, n.7, p.1503-1513, 2002.

PAGE, G. E. Factors influencing the maximum of air-drying shelled corn in thin layer. Thesis Dissertation (M.Sc.) - Purdue University, Indiana, 1949.

REIS, R C.; CORRÊA, P. C.; DEVILlA, I. A.; SANTOS, E. S.; ASCHERI, D. P. R.; SERVULO, A. C. O.; SOUZA, A. B. M. 2013. Drying of yam starch (Discorea ssp.) and glycerol filmogenic solutions at different temperatures. LWT - Food Science and Technology, v. 50, n. 2, p. 651-656. 2012.

RIGUETO, C. V. T.; EVARISTO, L. M.; GERALDI, C. A. Q.; COVRE, L. Influência da temperatura de secagem de uvaia (Eugenia pyriformis) em camada de espuma. Engevista, v. 20, n.4, p.537-547, 2018.

RODRIGUES, L. V.; MARQUES-BUNGART, G. A.; TOBAL T. M. Geleia de pitanga: caracterização bioativa, nutricional e sensorial. In: Congresso Brasileiro de Ciência E Tecnologia de Alimentos, Gramado. Anais. Gramado: FAURGS, 2016.

SANTOS, C. A.; LIRENY, C. C. M.; GONÇALVES, A. G. Emulsificantes: atuação como modifi cadores do processo de cristalização de gorduras. Ciência Rural, Santa Maria, v.44, n.3, p.567-574, 2014.

SILVA, A. S.; GURJÃO, K. C. DE O.; ALMEIDA, F. DE A. C.; BRUNO, R. DE L. A.; PEREIRA, W. E. Desidratação da polpa de tamarindo pelo método de camada de espuma. Ciência e Agrotecnologia, Lavras, v. 32, n.6, p. 1899-1905, 2008

SILVA, E.S; OLIVEIRA, J; MACHADO, A.V; COSTA, R.O. Secagem de Grãos e Frutas: Revisão Bibliográfica. Revista Brasileira de Agrotecnologia (Garanhuns - PE - Brasil) v.5,n.1,p. 19-23, 2015.

SILVA, S. DE M. Pitanga. Revista brasileira de fruticultura. v. 28, n. 1, p. 1 - 159. Areia PB. 2016. 
VERGARA, L.P.; SOUZA, V.R.D.; CHIM, J.F.; RODRIGUES, R.S.; FRANZON, R.C. Compostos bioativos em polpa de pitanga vermelha. In: Congresso Brasileiro de Ciência $\mathrm{E}$ Tecnologia de Alimentos, Gramado. Anais. Gramado: FAURGS, 2016.

VOLPATO, C.; LONGHI, A.; SPERB, M. Frutas nativas: alimentos locais, sabores e ingredientes especiais. Passo Fundo - RS. 2015.

ZANATTA, C.F; CUEVAS, E., BOBBIO, F.O; WINTERHALTER P.; MERCADANTE, A.Z. Determination of anthocyanins from camucamu (Myrciaria dubia) by HPLC-PDA, HPLC-MS, and NMR. Journal of Agricultural and Food Chemistry, v.53, p.9531- 9535, 2005. 


\title{
CAPÍTULO 31: IOGURTE PROBIÓTICO DE PITAYA COM CUPUAÇU: AVALIAÇÃO FÍSICO-QUÍMICA, MICROBIOLÓGICA E COMPORTAMENTO REOLÓGICO
}

\section{CHAPTER 31: PROBIOTIC YOGURT OF PITAYA WITH CUPUASSU: PHYSICO- CHEMICAL EVALUATION, MICROBIOLOGICAL AND RHEOLOGICAL BEHAVIOR}

\author{
Pombo, Joseane Cristina Pinheiro ${ }^{1}$; Pompeu, Kelem Pina²; Sá, Crisliane Camargo de ${ }^{3}$; Botelho, \\ Vanessa Albres ${ }^{4}$
}

\begin{abstract}
Resumo
A busca por uma alimentação mais saudável, impulsiona a indústria de alimentos a desenvolver novos produtos, uma alternativa é a adição de polpas de frutas na produção de iogurtes, diversificando seus sabores e melhorando seus atributos de qualidade. O objetivo deste estudo foi elaborar o iogurte probiótico à base de leite bovino adicionado da mistura das polpas das frutas pitaya e cupuaçu, afim de avaliar sua composição físico-química e microbiológica, bem como seu comportamento reológico. Foram realizadas análises físico-químicas $(\mathrm{pH}$, acidez, umidade, cinzas, proteínas, gorduras, carboidratos, composto fenólico total e valor calórico), microbiológicas (Salmonella spp., Coliformes totais e termotolerantes) e o estudo da viscosidade (comportamento reológico) do iogurte. O iogurte apresentou valor de $\mathrm{pH}(4,48)$, acidez $(0,94 \%$ de ácido lático), umidade $(78,1 \%)$, cinzas $(0,78 \%)$, proteínas $(3,69 \%)$, carboidratos $(14,4 \%)$, gorduras $(3,03 \%)$, composto fenólico total (7,69 mg GAE/100g) e valor calórico $(99,61 \mathrm{Kcal})$ satisfatórios. As análises microbiológicas indicaram boas condições sanitárias do produto, sem presença de Salmonella spp. e contagem de coliformes dentro dos limites estabelecidos pela legislação. O estudo reológico indicou o iogurte como fluido nãonewtoniano (pseudoplástico) de alta viscosidade. As características apresentadas pelo iogurte, fazem dele um produto atrativo, com grande potencial comercial.
\end{abstract}

Palavras-Chave : Iogurte, Pitaya, Cupuaçu, Microbiologia, Reologia.

\begin{abstract}
The search for a healthier diet, drives the food industry to develop new products, an alternative is the addition of fruit pulps in the production of yogurts, diversifying their flavors and improving their quality attributes. The aim of this study was to prepare probiotic yogurt based on bovine milk added from the mixture of the pulps of pitaya and cupuaçu fruits, in order to evaluate its physical-chemical and microbiological composition, as well as its rheological behavior. Physical-chemical analyzes ( $\mathrm{pH}$, acidity, humidity, ash, proteins, fats, carbohydrates, total phenolic compounds and caloric value), microbiological analyzes (Salmonella spp., total and thermotolerant coliforms) and the study of the viscosity (rheological behavior) of yogurt were performed. Yogurt had a $\mathrm{pH}$ value (4.48), acidity (0.94 \% lactic acid), moisture (78.1\%), ash $(0.78 \%)$, protein $(3.69 \%)$, carbohydrates $(14.4 \%)$, fats $(3.03 \%)$, total phenolic compounds (7.69 mg GAE/100 g) and satisfactory caloric value $(99.61 \mathrm{Kcal})$. Microbiological analyzes indicated good health conditions for the product, without the presence of Salmonella spp. and counting of coliforms within the limits established by legislation. The rheological study indicated yogurt as a non-Newtonian fluid (pseudoplastic) with high viscosity. The

\footnotetext{
${ }^{1}$ Graduada em Engenharia de Alimentos, Universidade Federal do Pará, pombojcp@gmail.com

${ }^{2}$ Graduada em Engenharia de Alimentos, Universidade Federal do Pará, kelempompeu@ yahoo.com.br

${ }^{3}$ Graduada em Engenharia de Alimentos, Universidade Federal do Pará, crislliane@ hotmail.com

${ }^{4}$ Prof $^{\mathrm{a}}$ Dr $^{\mathrm{a}}$ do curso de Engenharia de Alimentos, Universidade Federal do Pará, vanessalbres@ufpa.br
} 
characteristics of yogurt make it an attractive product with great commercial potential.

Keywords: Yogurt, Pitaya, Cupuassu, Microbiology, Rheology,

\section{Introdução}

O leite é um dos alimentos mais consumidos no mundo, pois apresenta, em sua composição, diversos nutrientes, como: proteínas, minerais, vitaminas, gorduras, açúcares, potássio, fósforo, riboflavina, magnésio, zinco e cálcio, que são essenciais para o bom funcionamento do organismo. Através do processamento do leite são produzidos inúmeros alimentos, como: bebidas lácteas, queijos, doces de leite, manteigas e iogurtes, afim de agregar valor ao produto e possibilitar seu armazenamento por um maior período de tempo (BARROS el al., 2019).

Dentre os derivados do leite de maior popularidade e consumo, destaca-se o iogurte, que é resultante da fermentação do açúcar do leite (a lactose) por bactérias lácticas, mediante ação de cultivos protosimbióticos de Streptococcus salivarius subsp. thermophilus e Lactobacillus delbrueckii subsp. bulgaricus podendo ser acompanhadas por outras bactérias láticas como Lactobacillus acidophilus ou cultivos do gênero Bifidobacterium, devendo estes microrganismos permanecerem viáveis, ativos e abundantes no produto final durante seu prazo de validade (ORIENTE et al., 2019). Durante a fermentação ocorre a hidrolise parcial de proteínas, gorduras e lactose, tornando o iogurte de fácil digestão, além de altamente nutritivo, rico em proteínas, carboidratos, ácido fólico, vitaminas A, vitaminas do complexo B e sais minerais, como cálcio, fósforo, zinco e magnésio (FERNANDES et al., 2016; SILVA et al., 2017; RAMOS et al., 2019). O consumo de iogurte está associado a benefícios a saúde, estudos demonstram efeitos do consumo de leite e derivados no gerenciamento do peso corporal, devido à liberação de hormônios que estimulam a saciedade (SILVA et al., 2020). A vantagem mais concreta sobre a saúde associada ao consumo do iogurte é a redução da má absorção de lactose em caso de pessoas intolerantes a este componente do leite (GARMUS et al., 2016).

Segundo Oliveira et al. (2019) a produção de iogurte e de outros tipos de leites fermentados cresce em todo o mundo, com destaque para o mercado brasileiro. A procura por alimentos com qualidade, praticidade, propriedades funcionais, segurança e preços acessíveis vem crescendo e, assim, as inovações na elaboração dos produtos é objetivo constante na indústria de alimentos, que visa agregar atributos de qualidade diferencial ao produto (MOURA et al., 2016). Assim, diferentes tipos ou variedades de iogurte entraram no mercado em resposta a preferência do consumidor (MAGALHÃES; TORRE et al., 2018). Durante a produção de iogurte tem se adicionado polpa de frutas para diversificar os sabores e melhorar as 
propriedades físico-química e nutricionais (PÁDUA et al., 2017). Sabores diferentes dos tradicionais estão surgindo, com crescente demanda por frutas regionais exóticas como a pitaya e o cupuaçu.

A pitaya (Hylocereus polyrhizus) conhecida como "Dragon Fruit" é uma fruta exótica nativa do sul do México e da América Central (LIRA et al., 2020). Dentre as várias espécies de pitayas, destaca-se a pitaya que apresenta a cor da polpa vermelha devido à presença dos altos níveis de pigmentos betalaínas (SANTOS et al., 2020). O fruto possui propriedades nutracêuticas, nas quais é rico em fibras, vitamina $\mathrm{C}$, minerais e fitoalbuminas, altamente valorizados por suas propriedades antioxidantes (TZE et al., 2012). A polpa tem a presença de carboidratos, ácido ascórbico, vitamina E, vitaminas B1, B2 e B3, polifenóis, potássio, magnésio, cálcio, betacaroteno, licopeno e oligossacarídeos não digeríveis com característica prebiótica (GARCIA et al., 2020). Segundo Liao et al. (2020) a fruta está atraindo muito interesse devido à sua fascinante cor vermelho-púrpura e suas atividades biológicas potenciais, como capacidade antioxidante, capacidade de eliminação de radical livre, proteção do coração, efeitos anti-inflamatório, antibacteriano e anti-obesidade.

O cupuaçu (Theobroma grandiflorum Schum) é uma fruta tropical nativa da Amazônia brasileira. A polpa branca amarelada de sabor ácido e aroma intenso, é rica em fibra alimentar e possui alto valor nutricional devido a presença de compostos fenólicos e ácido ascórbico (CLÍMACO et al., 2019; POMBO et al., 2020). A polpa da fruta é a sua parte com maior importância comercial e reúne as melhores condições de aproveitamento industrial, pois apresenta excelentes características de sabor, aroma e textura, com alto potencial econômico, usada como ingrediente na fabricação de sorvetes, sucos, licores, vinhos, geléias e outros produtos, como iogurtes, em vez de ser consumida in natura (PUGLIESE et al., 2013; PEREIRA et al., 2017). Segundo Costa et al. (2017), o cupuaçu por ser uma fonte natural de antioxidantes tem sido amplamente estudado, uma vez que, o consumo de antioxidantes estão associados a redução de danos oxidativos ao DNA linfocítico e aos riscos de patologias induzidas por estresse oxidativo, como câncer, doenças de Alzheimer e Parkinson.

Devido à adoção de hábitos mais saudáveis pelos consumidores, as indústrias de alimentos precisam inovar e desenvolver produtos com ótimas características físicas e químicas, que supram as necessidades nutricionais e possuam funções benéficas à saúde e bemestar de quem os consome, além de garantir a qualidade microbiológica desses produtos. Nesse contexto, o objetivo desta pesquisa foi elaborar o iogurte probiótico à base de leite bovino adicionado da mistura das polpas das frutas pitaya e cupuaçu, afim de avaliar sua composição físico-química e microbiológica, bem como seu comportamento reológico. 


\section{Material e Métodos}

\section{Material}

O iogurte foi elaborado a partir do leite bovino integral UHT (Manacá), açúcar refinado (União), leite em pó desnatado (Molico), fermento lácteo (BioRich ${ }^{\circledR}$ ), contendo as bactérias Bifidobacterium bifidum, Lactobacillus acidophilus e Streptococcus thermophilus, polpa comercial de cupuaçu (CAMTA) e a fruta in natura pitaya, todos adquiridos na região metropolitana de Belém-Pará. O experimento foi realizado no Laboratório de Engenharia Química da Universidade Federal do Pará (UFPa).

\section{Processamento da polpa de fruta}

A pitaya in natura passou pelo processo de lavagem, sanitização em solução clorada (50 ppm/15 minutos), seguida de enxágue e despolpamento manual. Por fim, a polpa da fruta foi submetida ao tratamento térmico em banho-maria $\left(85^{\circ} \mathrm{C} / 3\right.$ minutos $)$, afim de prevenir a contaminação microbiológica do produto, com posterior, armazenamento em pote de vidro sob refrigeração $\left(4^{\circ} \mathrm{C}\right)$ até o momento de sua adição ao iogurte.

\section{Elaboração do iogurte}

Para o processo de elaboração do iogurte probiótico sabor pitaya com cupuaçu (Figura 1), o leite bovino integral UHT (1000 mL) acrescido de leite em pó desnatado (4 \%) e açúcar refinado $(10 \%)$ foram submetidos ao tratamento térmico $\left(90{ }^{\circ} \mathrm{C} / 5\right.$ minutos), seguido do resfriamento a $45^{\circ} \mathrm{C}$ para a inoculação de três sachês de fermento lácteo $(0,12 \%)$. Após a inoculação do fermento, ocorreu a homogeneização por completo da mistura, que foi acondicionada em vidraria (Erlenmeyer) devidamente fechada e incubada em estufa $\left(45^{\circ} \mathrm{C} / 3\right.$ 4 horas) para que ocorresse a fermentação. Quando o iogurte atingiu pH 4,6 foi armazenamento sob refrigeração ( $4{ }^{\circ} \mathrm{C} / 13$ horas) para cessar seu processo fermentativo e promover sua estabilidade. Posteriormente, foram realizados testes degustativos preliminares, objetivando o equilíbrio das características palatáveis das duas polpas de frutas adicionadas ao iogurte natural e na proporção de modo a não ultrapassar o limite estabelecido pela legislação para ingredientes não lácteos. Após a escolha da melhor proporção pitaya:cupuaçu, as polpas de frutas pitaya (14 $\%)$ e cupuaçu (6 \%) foram adicionadas ao iogurte natural probiótico, seguido de homogeneização. Segundo a legislação, os ingredientes opcionais não lácteos, sós ou combinados deverão estar presentes em uma proporção máxima de $30 \%(\mathrm{~m} / \mathrm{m})$ do produto final (BRASIL, 2007). Por fim, o iogurte adicionado das polpas de frutas foi envasado em pote de vidro e armazenado sob refrigeração $\left(4^{\circ} \mathrm{C}\right)$ até o momento da realização das análises. 
POMBO, et al.

Figura 1. Fluxograma do processo de elaboração do iogurte probiótico sabor pitaya com cupuaçu.

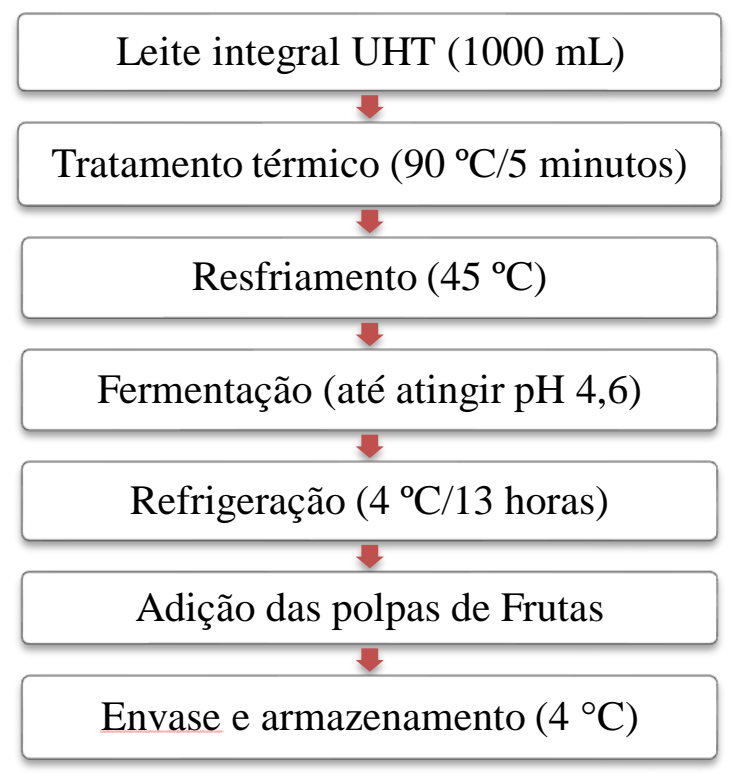

Fonte: Própria (2020).

\section{Avaliação físico-química}

A avaliação físico-química foi determinada de acordo com as metodologias da AOAC (1997): umidade em estufa a $105{ }^{\circ} \mathrm{C}$, até peso constante (método 920.151); cinzas por calcinação em mufla a $550{ }^{\circ} \mathrm{C}$ (método 940.26); proteína bruta pelo método de Kjedhal utilizando fator de conversão de nitrogênio-proteína de 6,38 (método 920.152); lipídios pela extração por Soxhlet (método 963.15); acidez titulável total (método 942.15A); pH em potenciômetro (Marconi- MA 522, São Paulo, Brazil) (método 981.12); e carboidratos totais pelo método da diferença. Adicionalmente, foram determinados o valor calórico calculado utilizando os fatores de Atwater descritos por Mahan e Escott-Stump (2005) e o teor de composto fenólico totais (CFT) segundo a metodologia proposta por Singleton e Rossi (1965), em espectrofotômetro (SHIMADZU modelo UV 1203, Japão) no comprimento de onda de 750 nm. Para os cálculos de fenólicos totais, foi utilizada uma curva padrão de ácido gálico (20 a $100 \mathrm{mg} / \mathrm{L}$ ), os resultados foram expressos em mg de ácido gálico (GAE)/100 g.

\section{Avaliação microbiológica}

O iogurte foi submetido as análises microbiológicas de contagem de Salmonella spp., coliformes totais e termotolerantes de acordo com as metodologias descritas pela American Public Health Association (2001).

Para a análise de Salmonella spp, o preparo da amostra ocorreu com a homogeneização de $25 \mathrm{~mL}$ da amostra em $225 \mathrm{~mL}$ de água peptonada tamponada como método de préenriquecimento em caldo não seletivo, sendo incubada a $35^{\circ} \mathrm{C}$ por 24 horas. No enriquecimento 
POMBO, et al.

seletivo, transferiu-se $1 \mathrm{~mL}$ da amostra do pré-enriquecimento para tubo contentdo $10 \mathrm{~mL}$ de Caldo Selenito Cistina (incubado à $37^{\circ} \mathrm{C}$ por 24 horas), $1 \mathrm{~mL}$ para $10 \mathrm{~mL}$ do caldo tetrationato e $1 \mathrm{~mL}$ para $10 \mathrm{~mL}$ do caldo Rappaport Vassiliadis soja (incubados à $43{ }^{\circ} \mathrm{C}$ por 24 horas). Para o plaqueamento diferencial foi semeada uma alçada de cada meio do caldo de enriquecimento seletivo para placas ágar Salmonella-shigella (SS) e ágar xilose lisina desoxicolato (XLD) e incubadas em placas em posição invertida a $35^{\circ} \mathrm{C}$ por 24 horas. Para a confirmação bioquímica, as colônias típicas em ágar foram confirmadas em ágar tríplice açúcar ferro (TSI) e em ágar lisina ferro (LIA) com o auxílio de uma agulha de inoculação por picada e estrias na rampa. Os tubos foram incubados em estufa de $35^{\circ} \mathrm{C}$ por 24 horas e então foram avaliadas a utilização dos açúcares e $\mathrm{H}_{2} \mathrm{~S}$ pelas cepas.

A contagem dos coliformes totais e termotolerantes foi determinada pelo método do número mais provável (NMP). Para o preparo da amostra foi homogeneizado $25 \mathrm{~mL}$ do iogurte em 225 mL de solução salina peptonada $0,1 \%$ e feitas as diluições seriadas para inoculação. $\mathrm{O}$ teste presuntivo foi realizado com a inoculação de alíquotas da amostra em três séries de três tubos, contendo tubos de Durhan e caldo lauril sulfato triptose (LST), sendo incubados em estufa a $35^{\circ} \mathrm{C}$ por 24 a 48 horas. Para confirmação da presença de coliformes, alíquotas de tubos de LST com crescimento microbiano e produção de gás foram transferidas para tubos de caldo verde brilhante $2 \%$ (VB) e caldo Escherichia coli (EC). Para os coliformes totais, os tubos de VB foram incubados à $35^{\circ} \mathrm{C}$ por 24 horas, enquanto para os coliformes termotolerantes, os tubos de EC foram incubados à $45^{\circ} \mathrm{C}$ por até 48 horas.

\section{Comportamento reológico}

A propriedade reológica foi determinada segundo Vidal et al. (2004), em um viscosímetro (Brookfield modelo LVDV-II, EUA), utilizando um Spindle (DIN-85). Foi empregado um banho termostático Haake B3 (Haake, Karlsruhe, Alemanha) a temperatura de $10{ }^{\circ} \mathrm{C}$ e os dados de viscosidade aparente e taxa de cisalhamento foram obtidos utilizando-se o software WinGather ${ }^{\circledR}$ (versão V1.1, Brookfield Engineering Laboratories, EUA).

\section{Resultados e Discussão}

\section{Composição físico-química}

A Tabela 1 apresenta os resultados da composição físico-químicas do iogurte probiótico elaborado com leite bovino e sabor natural de frutas (pitaya e cupuaçu). 
Tabela 1. Composição físico-química do iogurte sabor pitaya e cupuaçu.

\begin{tabular}{lc}
\hline Composição & Valores (Média \pm Desvio Padrão) \\
\hline $\mathrm{pH}$ & $4,48 \pm 0,02$ \\
Acidez (g ac. lático/100 g) & $0,94 \pm 0,01$ \\
Sólidos Totais (\%) & $21,9 \pm 0,20$ \\
Umidade (\%) & $78,1 \pm 0,20$ \\
Cinzas (\%) & $0,78 \pm 0,30$ \\
Proteína (\%) & $3,69 \pm 0,50$ \\
Gordura (\%) & $3,03 \pm 0,30$ \\
Carboidrato (\%) & $14,4 \pm 0,80$ \\
CFT (mg GAE/100g) & $7,69 \pm 0,02$ \\
Valor Calórico (Kcal) & $99,61 \pm 0,60$
\end{tabular}

Fonte: Própria (2020).

O valor de $\mathrm{pH}(4,48)$, indicam que o iogurte está dentro do parâmetro de qualidade permitido e estabelecido pela legislação brasileira, que é pH entre 3,6 e 4,5 (BRASIL, 2007). Semelhantes resultados foram citados por Oliveira et al. (2017) para o iogurtes de coco e morango ( $\mathrm{pH} 4,42$ e 4,54) e por Leite et al. (2018) para o iogurte da polpa de juçara (pH 4,37 a 4,52). Segundo Mühlbauer et al. (2012), o ideal para leites fermentados é pH próximo a 4,5, uma vez que, valores de $\mathrm{pH}$ inferiores a 4,0 podem levar a contração do coágulo devido à redução da hidratação das proteínas, causando dessoramento do produto e consequentemente à rejeição dos consumidores, enquanto valores de pH maiores que 4,5 favorecem a separação do soro. Outros trabalhos na literatura reportam a redução do $\mathrm{pH}$ com a adição de polpa de fruta em iogurtes, isso se deve ao $\mathrm{pH}$ da polpa do cupuaçu que varia de 2,97 a 3,46 (CLÍMACO et al., 2019; POMBO et al., 2020) e da polpa de pitaya que varia de 3,48 a 4,88 (ABREU et al., 2012; PÉREZ-LOREDO et al., 2016). De acordo com Egea et al. (2019), os valores do pH tem sua importância relacionada a conservação do iogurte e podem variar de acordo com as condições de fermentação (quantidade de inóculo utilizado, tempo de fermentação e disponibilidade de nutrientes), etapas do processamento (adição de ingredientes como polpa de frutas após o processo fermentativo) e temperatura de transporte e armazenamento.

A acidez do iogurte $(0,94 \mathrm{~g}$ ácido lático/100 g) está de acordo com o exigido pela legislação, que estabelece acidez entre 0,6 e 1,5 g ácido lático/100 g (BRASIL, 2007). O valor de acidez também esta próximo aos valores de acidez do iogurte de polpa de abacaxi e mel de 
abelha $(0,80$ a $0,93 \%)$ citados por Paiva et al. (2015) e do iogurtes com polpa de noni e acerola (0,86 a 0,93 \%) obtido por Moura et al. (2016). Segundo Barbosa e Gallina (2017), a importância da acidez está relacionada com as suas características sensoriais, assim como, a viabilidade dos microrganismos presentes no produto. Gallina et al. (2018) afirma que a baixa acidez favorece a aceitabilidade do produto pelos consumidores e ocasiona um menor decréscimo das células viáveis do microrganismo probiótico.

O alto teor de sólidos totais $(21,9 \%)$ está relacionado a adição dos ingredientes no iogurte, o que reduziu o teor de umidade $(78,1 \%)$ do mesmo, similar aos valores de umidade do iogurte de jaca (74,5 e 78,87 \%) obtido por Medeiros et al. (2011), iogurte de polpa de abacaxi e mel de abelha (74,4 e 79,7 \%) mencionado por Paiva et al. (2015) e dos iogurtes de coco e morango (79,70 e 78,99 \%) citados por Oliveira et al. (2017). Segundo Gambelli et al. (1999), a umidade do iogurte depende do tipo de leite e teor de sólidos solúveis disponíveis. Portanto, o valor encontrado demonstra que o leite integral (maior teor de gordura), leite em pó desnatado, açúcar refinado e adição de polpas de frutas (maior teor de sólidos solúveis) contribuíram para a diminuição da umidade do iogurte probiótico sabor pitaya com cupuaçu. Oliveira et al. (2019) afirma que a umidade de um alimento está relacionada com sua estabilidade, qualidade e composição e pode afetar o armazenamento, a embalagem e o processamento.

O resultado do teor de cinzas $(0,78 \%)$ se encontra entre os valores do iogurte de polpa de abacaxi e mel de abelha (0,75 a 0,99 \%) obtido por Paiva et al. (2015) e o iogurte da polpa de juçara (0,76 a 0,92\%) citado por Leite et al. (2018). De acordo com Pádua et al. (2017), o teor de cinzas de um alimento representa o conteúdo mineral que permanece após a queima de matéria orgânica de uma amostra. Silva et al. (2017) afirma que os minerais encontrados em maior quantidade em produtos lácteos, como o iogurte, são o cálcio, magnésio, fósforo e potássio. Os teores satisfatórios de cinzas encontrados nesse trabalho correspondem a quantidade de minerais contidos no leite e nas polpas das frutas. Geralmente, o valor de cinzas do leite UHT varia entre 0,65 a 0,85 \% conforme Guimarães et al. (2018), enquanto para polpa do cupuaçu varia entre 0,46 a 1,03 \% afirma Pugliese at al. (2013) e para polpa de pitaya vermelha varia de 0,36 a 0,63 \% (ABREU et al., 2012; GARCÍA-CRUZ et al., 2013). Apesar da legislação não possuir valores estabelecidos para o teor de cinzas, este parâmetro podem ser consideradas como uma medida geral de qualidade de alimentos, uma vez que, maiores teores de cinzas retratam maiores teores de minerais, sendo as cinzas solúveis mais desejáveis, já que as insolúveis representam metais (MESQUITA et al., 2012). 
O iogurte apresentou teor de proteína $(3,69 \%)$ de acordo com o preconizado pela legislação, que prevê um mínimo de 2,9\% de proteína (BRASIL, 2007). O valor protéico esta entre os valores do iogurte de polpa de abacaxi e mel de abelha (2,98 a 4,39\%) citados por Paiva et al. (2015) e similar ao valor de iogurte probiótico de frutas vermelhas (3,51\%) obtido por Gallina et al. (2018). O iogurte é uma excelente fonte de proteína de alta qualidade, promovendo saciedade (WEBB et al., 2014). De acordo com Magalhães e Torres (2018), a proteína influencia fortemente na textura do iogurte, principalmente na formação e firmeza do gel, impactando na percepção sensorial do consumidor.

Quanto ao teor de gordura (3,03\%), o iogurte elaborado foi classificado como iogurte integral, uma vez que, a legislação estabelece padrões máximos de 0,5 para iogurte desnatado, entre 0,6 e 2,9 para iogurte parcialmente desnatado, entre 3,0 a 5,9 para iogurte integral, e mínimo de 6,0 para iogurte com creme (BRASIL, 2007). Os resultados obtidos estão em concordância aos encontrados por Costa et al. (2012) para o iogurte sabor Juçaí (2,37 a 3,10 \%) e por Barbosa et al. (2013) para o iogurte sabor pêssego (2,83 a 3,13 \%). O teor de gordura do leite afeta favoravelmente a qualidade do iogurte, a gordura estabiliza a contração do gel protéico, previne a separação do soro no produto final e afeta a percepção sensorial do produto, responsável pela textura mais macia e cremosa (RIBEIRO et al., 2019). Segundo Magalhães e Torres (2018), a gordura influencia na textura do iogurte, contribuindo para gomosidade, firmeza e adesividade, influenciando na percepção sensorial destes atributo.

O teor de carboidrato $(14,4 \%)$ se encontra na faixa dos valores do iogurte de jaca $(13,15$ a 17,41\%) citados por Medeiros et al. (2011) e o iogurte sabor de polpa de manga Tommy Atkins (10,84 a 14,87 \%) obtido por Barbosa et al. (2018). Em iogurtes de leite de vaca aromatizados e adoçados, o teor de carboidratos é, em média, 14,00\% (HAULY et al., 2005). O carboidrato presente no leite é a lactose, sendo esse constituinte predominante. Segundo Tamanini et al. (2011) o leite UHT apresenta entre 4,14 a 4,66 \% de lactose, o valor de carboidrato encontrado no iogurte se revela alto, não só pela adição do açúcar refinado (Sacarose), mas também pela presença das polpas de frutas na formulação do produto. Pugliese et al. (2013) obtiveram valores de carboidratos variando de 5,02 a $11 \%$ para polpa de cupuaçu, enquanto para polpa de pitaya vermelha são mencionados valores variando de 9,82 a 10,02 \% (GARCÍA-CRUZ et al., 2013; PÉREZ-LOREDO et al., 2016), justificando o teor de carboidrato encontrado no produto final.

O teor de compostos fenólicos totais (CFT) foi avaliado afim de identificar a influência do processamento do iogurte na ocorrência da perda desses compostos presentes nas frutas. Portanto, o resultado dos CFT observados no iogurte com adição das polpas de frutas $(7,69 \mathrm{mg}$ 
$\mathrm{GAE} / 100 \mathrm{~g}$ ) foi menor quando comparado aos teores presente inicialmente na polpa in natura da pitaya $(22,47 \mathrm{mg}$ GAE/100 g) e na polpa comercial do cupuaçu (19,21 mg GAE/100 g). Segundo Leite et al. (2018), nos iogurtes com adição de polpa de Juçara, o conteúdo de fenólico total variou de 30,49 a 117,84 mg de GAE/ $100 \mathrm{~g}$, devido ao teor inicial da polpa de Juçara (812,32 mg de GAE/ 100 g). Moura et al. (2016) também obtiveram valores elevados de compostos fenólicos para o iogurte com polpa de noni e acerola (59,13 a 78,97 mg GAE/100 g), com destaque para presença da acerola (835,25 mg GAE/100 g). Portanto, o menor teor de compostos fenólicos no iogurte elaborado é devido aos menores teores desse constituinte nas frutas adicionadas, bem como as perda que ocorrem durante o processamento e armazenamento. De acordo com Fang e Bhandari (2012), os compostos fenólicos são geralmente sensíveis a condições ambientais adversas, incluindo temperaturas desfavoráveis, luz, pH, umidade, enzima e oxigênio e, portanto, são suscetíveis a reações degradantes durante o processamento e armazenamento do produto.

O iogurte integral apresentou baixo valor calórico $(99,61 \mathrm{kcal})$ quando comparado ao valor obtido por Macedo et al. (2014) para o iogurte integral de polpa de caju adoçado com mel (282 kcal). Porém, semelhante aos valores observado por Barbosa et al. (2018) para os iogurtes semi-desnatados sabor de polpa de manga Tommy Atkins (66,47 a 89,18 kcal). Rodas et al. (2001) afirma que a maior ou menor adição de açúcares, o enriquecimento do produto com substâncias que aumentem o teor de sólidos podem, provavelmente, colaborar na variabilidade e aumento do valor calórico dos produtos. Segundo Abreu et al. (2012), a polpa da pitaya é pouco calórica $(44,87 \mathrm{kcal})$, bem como a polpa de cupuaçu $(41,24$ a 48,47 kcal) conforme Franklin e Nascimento (2020), o que explica o baixo valor calórico do iogurte.

\section{Análises Microbiológicas}

Na Tabela 2, são expressos os resultados das análises microbiológicas (salmonella spp. e coliformes totais e termotolerantes), comparados aos padrões exigidos pela legislação vigente afim de atestar a qualidade sanitária do produto.

Tabela 2. Resultados das análises microbiológicas do iogurte probiótico sabor pitaya com cupuaçu.

\begin{tabular}{lcc}
\hline Microorganismos & Contagem & *Parâmetro \\
\hline Salmonella spp. & Ausente & Ausente em $25 \mathrm{~g}$ \\
Coliformes Totais & $24 \mathrm{NMP} / \mathrm{g}$ & Máx. $100 \mathrm{NMP} / \mathrm{g}$ \\
Coliformes Termotolerantes & $0,9 \mathrm{NMP} / \mathrm{g}$ & Máx. $10 \mathrm{NMP} / \mathrm{g}$ \\
\hline
\end{tabular}

Fonte: Própria (2020) e *BRASIL (2001). 
O iogurte apresentou ausência de Salmonella spp. e contagem de coliformes dentro dos limites propostos pela legislação vigente (BRASIL, 2001). Os resultados obtidos estão em concordância aos encontrados para os iogurtes sabor Juçaí (COSTA et al., 2012), à base de pitaia (Hylocereus undatus), enriquecido com quinoa e sucralose (FERNANDES et al., 2012) e sabor de polpa de manga Tommy Atkins (BARBOSA et al., 2018), todos em conformidade com a legislação. Segundo Luz et al. (2020), os coliformes totais são microrganismos indicativos das boas condições higiênico-sanitária na produção de determinado alimento, que possibilitam a verificação de contaminação fecal (coliformes termotolerantes). Enquanto a Salmonella spp. é o patógeno mais frequentemente envolvido em surtos alimentares no Brasil, a contaminação dos alimentos por esta bactéria pode ocorrer ao longo da cadeia de produção, falhas durante o manuseio de alimentos, incluindo falta de higiene pessoal e ambiental, armazenamento em temperaturas inadequadas e contaminação cruzada podem aumentar o risco de contaminação (FINGER et al., 2019). Portanto, os resultados foram satisfatórios, pois atenderam aos requisitos mínimos de qualidade para o consumo humano e evidenciam domínio de boas práticas de fabricação e manipulação do iogurte.

\section{Comportamento reológico}

A Figura 2 representa o comportamento reológico do iogurte, apresentando a curva da viscosidade em função da taxa de cisalhamento.

Figura 2. Curva da viscosidade em função da taxa de cisalhamento do iogurte.

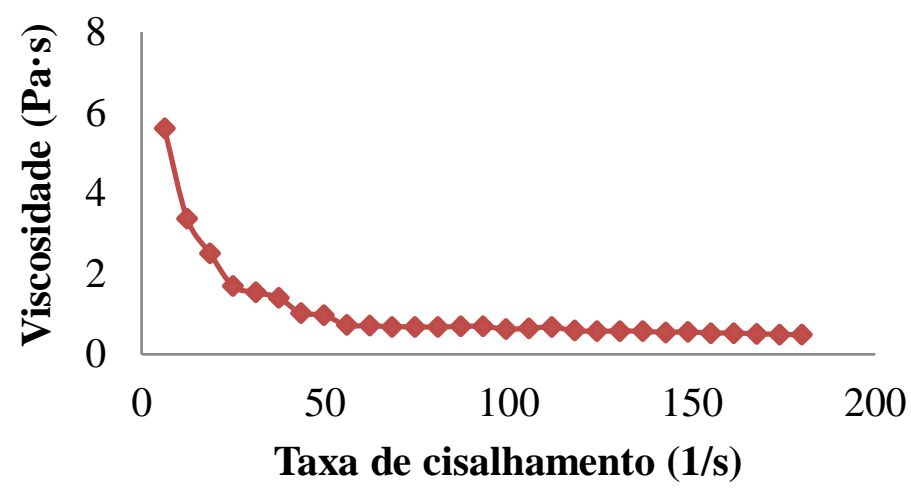

Fonte: Própria (2020).

A viscosidade do iogurte foi 5, 6122 (Pa.s), o que dificultava seu escoamento pelo copo, sendo classificado de alta viscosidade. Segundo Bonato et al. (2006), existe o iogurte de baixa viscosidade que escorre facilmente do copo, iogurte de alta viscosidade, que escoa com dificuldade do copo e iogurte gelificado, que não escorre do copo. De acordo com Tamime e Robinson (1988), outra classificação bastante utilizada, refere-se à estrutura física do coágulo, 
sendo o iogurte probiótico sabor pitaya com cupuaçu classificado como batido, uma vez que depois de completa a fermentação, ocorreu a quebra da estrutura do gel do iogurte natural pela homogeneização das polpas de frutas no mesmo, com posterior envase em embalagens. Mathias et al. (2013) observou que quanto maior o teor de sólidos da mistura destinada à elaboração do iogurte, maior foi a viscosidade do produto final e que o menor valor de histerese obtido ocorreu no iogurte com maiores teores de gordura, indicando o potencial caráter protetor deste componente à reologia do produto. Silveira et al. (2016), também menciona que o teor de gordura agi como estabilizante, aumentando a firmeza do iogurte e produzindo microestruturas mais densas quando comparado com iogurtes com baixa concentração de gordura. De acordo com Gurjão et al. (2015), a viscosidade é a propriedade física de um líquido de resistir ao fluxo induzido pelo cisalhamento; é dependente da natureza físico-química da substância, da temperatura da substância, da pressão, da taxa de cisalhamento e do tempo.

Observa-se na figura 2, que o iogurte apresentou comportamento de fluido nãonewtoniano com características pseudoplásticas. De acordo com Mathias et al. (2013), quando a viscosidade é não linear, o fluido é classificado como não-newtoniano, podendo ter características pseudoplásticas, quando apresentam diminuição da viscosidade conforme aumenta a taxa de cisalhamento aplicada. Isso acontece em função do enfraquecimento das interações existentes entre as moléculas do produto e da diminuição da energia de interação entre elas com o aumento da taxa de cisalhamento (EGEA et al., 2019). O mesmo comportamento reológico foi descrito para o iogurte de cajá (GURJÃO et al., 2015), iogurte integral com sabor morango (EGEA et al., 2019) e iogurte integral com polpa de achachairu (BARROS et al., 2019). O comportamento reólogico é importante não só como medida de qualidade, mas também em projetos, avaliação e operação dos equipamentos processadores de alimentos (bombas, tubulações, trocadores de calor, sistemas de agitação e envase) evitandose, desta maneira, um sub ou super dimensionamento (PELEGRINE et al., 2015).

\section{Conclusões}

A adição das polpas de pitaya e cupuaçu na formulação de iogurte probiótico é uma alternativa bastante viável do ponto de vista tecnológico. A adição das polpas de frutas influenciaram significativamente na composição físico-química do iogurte, aumentando a acidez e reduzindo o teor de umidade e $\mathrm{pH}$ do produto, o que assegura sua conservação por maior tempo, bem como apresentou baixo valor calórico com valores satisfatórios de proteínas, gorduras e carboidratos com presença de minerais e compostos fenólicos totais, atribuindo ao produto propriedades nutricionais atrativas. $\mathrm{O}$ iogurte apresentou segurança microbiológica 
POMBO, et al.

com ausência de Salmonella spp. e contagem de coliformes totais e termotolerantes em conformidade com a legislação, sendo indicado ao consumo sem oferecer risco à saúde humana. Além disso, o iogurte apresentou boa viscosidade, confirmando seu comportamento de fluido não-newtoniano com características pseudoplásticas.

\section{Referências}

ABREU, W. C.; LOPES, C. O.; PINTO, K. M.; OLIVEIRA, L. A.; CARVALHO, G. B. M.; BARCELO, M. F. P. Características físico-químicas e atividade antioxidante total de pitaias vermelha e branca. Revista Instituto Adolfo Lutz, v.71, n.4, p. 656-661, 2012.

AMERICAN PUBLIC HEALTH ASSOCIATION. Compendium of Methods for the Microbiological Examination of Foods. $4^{\text {th }}$ ed. Washington, DC: APHA, 2001.

ASSOCIATION OF OFFICIAL ANALYTICAL CHEMISTS. Official methods of analysis of the Association of Official Analytical Chemists. $16^{\text {th }}$ ed. Washington, DC: AOAC, 1997.

BARBOSA, A. F.; LOPES, F. J.; SILVA, V. R. O.; SILVA, M. H. L.; MINIM, V. P. R.; SILVA, R. C. S. N. Aceitação sensorial de iogurte sabor pêssego acrescido de diferentes concentrações de aroma e polpa por meio da técnica de mapa de preferência. Revista do Instituto de Laticínio Cândido Tostes, v. 68. 390, p. 52-58, 2013. Doi:10.5935/22386416.20130008

BARBOSA, M. S.; GONÇALVES, G. F. L.; LIMA, L. K.; OLIVEIRA, S. C. P. L.; NETO, J. F. Iogurte com redução calórica enriquecido de aveia com sabor de polpa de manga Tommy Atkins congelada. Revista Principia - Divulgação Científica e Tecnológica do IFPB, n. 43, p. 23-31, 2018. Doi:10.18265/1517-03062015v1n43p23-31

BARBOSA, P. P. M.; GALLINA, D. A. Viabilidade de bactérias (Starter e Probióticas) em bebidas elaboradas com iogurte e polpa de manga. Revista do Instituto de Laticínios Cândido Tostes, v. 72, n. 2, p. 85-95, 2017. Doi: 10.14295/2238-6416.v72i2.580

BARROS, S. L.; SANTOS, N. C.; ALMEIDA, R. D.; SILVA, V. M. A.; ALMEIDA, R. L. J.; NASCIMENTO, A. P. S. Comportamento reológico e perfil de textura de iogurte integral com polpa de achachairu (Garcinia humilis). Revista Principia - Divulgação Científica e Tecnológica do IFPB, n. 47, p. 145-152, 2019. Doi:10.18265/1517-03062015v1n47p145-152.

BRASIL. Agência Nacional de Vigilância Sanitária - Anvisa. Regulamento Técnico sobre padrões microbiológicos para alimentos. Resolução-RDC n ${ }^{\circ} 12$, de 02/01/01, Diário Oficial da União. Brasília, DF, 10/01/2001. Seção 1.

BRASIL. Ministério da Agricultura, Pecuária e Abastecimento. Secretaria de defesa agropecuária. Departamento de inspeção de produtos de origem animal. Instrução Normativa $n^{\circ}$ 46, de 23 de outubro de 2007. Regulamento Técnico de Identidade e Qualidade (RTIQ) de Leites Fermentados. Diário Oficial da União. Brasília, DF, 24/10/2007. Seção 1.

BONATO, E. P; HELENO, G. J. B.; HOSHINO, N. A. Leites Fermentados e Queijos. Florianópolis: UFSC, 2006. 
CLÍMACO, G. N.; ABREU, V. K. G.; LEMOS, T. O.; PEREIRA, A. L. F. Mixed Nectar of Cupuassu (Theobroma grandiflorum) and Green Tea and the Effect of Preservatives and Storage on Nutritional and Sensorial Characteristics. Journal of Food and Nutrition Research, v. 7, n. 5, p. 361-369, 2019. Doi:10.12691/jfnr-7-5-5

COSTA, M. P.; MONTEIRO, M. L. G.; FRASAO, B. S.; SILVA, V. L. M.; RODRIGUES, B. L.; CHIAPPINI, C.C. J.; CONTE-JUNIOR, C. A. Consumer perception, health information, and instrumental parameters of cupuassu (Theobroma grandiflorum) goat milk yogurts. Journal of Dairy Science, v. 100, n. 1, p. 157-168, 2017. Doi:10.3168/jds.2016-11315

COSTA S. N. G.; MENDES F. M.; ARAUJO O. I.; PEREIRA S. S. C. Desenvolvimento de um Iogurte Sabor Juçaí (Euterpe edulis Martius): Avaliação Físico-química e Sensorial. Revista Eletrônica TECCEN, v. 5, n. 2 p. 43-58, 2012. Doi: 10.21727/teccen.v5i2.484

EGEA, M. B.; GOMES, A. C. G.; LIMA, M. S.; TAKEUCHI, K. P. Relação entre as características físico-químicas e reológica e o valor comercial de iogurte integral com sabor morango. Segurança Alimentar e Nutricional, v. 26, n. 1, p. 1-11, 2019. Doi: 10.20396/san.v26i0.8652948

FANG, Z.; BHANDARI, B. Spray drying, freeze drying and related processes for food ingredient and nutraceutical encapsulation, in N. Garti and D.J. McClements (ed), Encapsulation technologies and delivery systems for food ingredients and nutraceuticals. UK: Woodhead Publishing, 2012. p. 73-109. Doi:10.1533/9780857095909.2.73

FERNANDES, A. F. C.; COLPA, P. C.; PAIVA, E. F. F.; PAIVA, L. C.; NACHTIGALL, A. M.; BOAS, B. M. V. Vida de prateleira de iogurte sabor café. Coffee Science, v. 11, n. 4, p. 538-543, 2016. http://www.sbicafe.ufv.br:80/handle/123456789/8249

FINGER, J. A. F. F.; BARONI, W. S. G. V.; MAFFEI, D. F.; BASTOS, D. H. M.; PINTO, U. M. (2019). Overview of Foodborne Disease Outbreaks in Brazil from 2000 to 2018. Foods, 8(10):1-10 art. 434. Doi:10.3390/foods8100434

FRANKLIN, B.; NASCIMENTO, F. C. A. Plantas para o futuro: compilação de dados de composição nutricional do araçá-boi, buriti, cupuaçu, murici e pupunha. Brazilian Journal of Development, v. 6, n. 3, p. 10174-10189, 2020. Doi:10.34117/bjdv6n3-046

GALLINA, D. A.; ORMENESE, R. C. S. C.; GARCIA, A. O. Iogurte probiótico com polpa de frutas vermelhas: caracterização físico química e microbiológica, aceitabilidade sensorial e viabilidade dos probióticos. Revista do Instituto de Laticínios Cândido Tostes, v. 73, n. 4, p. 196-208, 2018. Doi: 10.14295/2238-6416.v73i4.681

GAMBELLI, L.; BELLONI, P.; INGRAO, G.; PIZZOFERRATO, L.; SANTARONI, G. P. Minerals and trace elements in some Italian dairy products. Journal of Food Composition and Analysis, v. 12, p. 27-35, 1999.

GARCIA, W. S.; GAIA, W. J. A.; SARDINHA, A. P. A.; ROSÁRIO, L. F. Estudo do mercado e perfil do consumidor do fruto da Pitaya Vermelha, no município de Tomé-AÇU/PA / Market study and consumer profile of the fruit of Pitaya Red, in county of Tomé-AÇU/PA. Brazilian Applied Science Review, v. 4, n. 2, p. 418-436, 2020. 
GARMUS, T. T.; BEZERRA, J. R. M. V.; RIGO, M.; CÓRDOVA, K. R. V. Avaliação sensorial e físico-química de iogurte enriquecido com farinha de linhaça. Ambiência, v. 12, n. 1, p. 251-258, 2016. Doi:10.5935/ambiencia.2016.01.15

GUIMARÃES, B. C.; VENTURINI, K.; SEGATTO, M. Controle de Qualidade de Leites UHT Comercializados em Vitória, Espírito Santo. Multi-Science Research, v. 1, n. 1, p. 19-35, 2018.

GURJÃO, F. F.; CARNEIRO, G. G.; PESSOA, T.; SILVA, D. R. S.; PÊ, P. R. Comportamento reológico de iogurte de cajá comercializado em Campina Grande, Paraíba. Revista Verde, v. 10, n. 2, p. 257-260, 2015. Doi:10.18378/rvads.v10i2.2939

HAULY, M. C. O.; FUCHS, R. H. B.; FERREIRA, S. H. P. Suplementação de iogurte de soja com frutooligossacarideos: características probióticas e aceitabilidade. Revista de Nutrição, v. 18, n. 5, p. 613-622, 2005. Doi: 10.1590/S1415-52732005000500004

LEITE, S. T.; ROBERTO, C. D.; SILVA, P. I.; CARVALHO, R. V. Polpa de juçara: fonte de compostos fenólicos, aumento da atividade antioxidante e da viabilidade de bactérias probióticas de Iogurte. Revista Ceres, v. 65, n. 1, p. 16-23, 2018. Doi: 10.1590/0034737X201865010003

LIAO, H.; ZHU, W.; ZHONG, K.; LIU, Y. Evaluation of colour stability of clear red pitaya juice treated by thermosonication. LWT - Food Science and Technology, v.121, 2020. Doi: 10.1016/j.lwt.2019.108997

LIRA, S. M.; DIONÍSIO, A. P., HOLANDA, M. O.; MARQUES, C. G.; SILVA, G. S.; CORREA, L. C.; SANTOS, G. B. M.; ABREU, F. A. P.; MAGAlHÃES, F. E. A.; REBOUÇAS, E. L.; GUEDES, J. A. C.; OLIVEIRA, D. F.; GUEDES, M. I. F.; ZOCOLO, G. J. Metabolic profile of pitaya [Hylocereus polyrhizus (F.A.C. Weber) Britton \& Rose] by UPLC-QTOF-MS ${ }^{\mathrm{E}}$ and assessment of its toxicity and anxiolytic-like effect in adult zebrafish, Food Research International, v. 127, 2020. Doi: 10.1016/j.foodres.2019.108701

LUZ, D. A.; OLIVEIRA, M. V. S.; MOUCHREK, A. N.; BANDEIRA, M. G. A.; FILHO, V. E. M. Elaboração, caracterização nutricional e microbiológica de iogurtes com adição de coco queimado e calda de coco, preparados a partir de polpa de coco verde da espécie (Cocus nucifera L.). Brazilian Journal of Development, v. 6, n. 3, p. 12283-12295, 2020. Doi:10.34117/bjdv6n3-187

MACEDO, M. A.; MENEZES, C. C.; PORTELA, J. V. F.; ARCANJO, S. R. S.; MOURA, M. R.; OLIVEIRA, A. M. C. Efeito da adição de polpa de caju sobre as qualidades sensoriais de iogurte integral adoçado com mel de abelha. Revista do Instituto de Laticínios Cândido Tostes, v. 69, n. 1, p. 7-16, 2014. Doi: 10.14295/2238-6416.v69i1.301

MAGALHÃES, A. U.; TORRE, A. C. G. D. Composição química e análise sensorial do iogurte grego comercializado no sul do estado de Minas Gerais. Revista do Instituto de Laticínios Cândido Tostes, v. 73, n. 1, p. 10-18, 2018. Doi: 10.14295/2238-6416.v73i1.607

MAHAN, L. K.; ESCOTT-STUMP, S. Alimentos, nutrição \& dietoterapia. 11. ed. São Paulo: Roca, 2005. 
MATHIAS, T. R. S. ANDRADE, K. C. S.; ROSA, C. L. S.; SILVA, B. A. Avaliação do comportamento reológico de diferentes iogurtes comerciais. Brazilian Journal of Food Technology, v. 16, n. 1, p. 12-20, 2013. Doi:10.1590/S1981-67232013005000004

MEDEIROS, C. T.; MOURA, S. A.; ARAÚJO, B. K.; AQUINO, L.C.L. Elaboração de iogurte de jaca: avaliação físico-química, microbiológica e sensorial. Scientia Plena, v. 7, n. 9, p. 14, 2011.

MESQUITA, C. S. V. R.; NETO, F. A.; TEIXEIRA, F.; SILVA, O. V. Elaboração, análise físico-química e aceitação do iogurte com adição do tamarindo "doce" (Tamarindus indica L.). Revista Brasileira de Produtos Agroindustriais, v.14, n.4, p.381-387, 2012.

MOURA, A. A. C.; AROUCHA, E. M. M.; GÓIS, V. A.; LEITE, R. H. L.; FERREIRA, R. M. A.; SILVA, M. C. P. Iogurtes com polpa de noni e acerola: avaliação físico-química, atividade antioxidante e perfil sensorial. B.CEPPA, v. 34, n. 2, p. 1-10, 2016. Doi: 10.5380/cep.v34i2.53181

MÜHLBAUER, F. B.; CESAR, G. M.; JUNQUEIRA, P. C. L. G. ; SOUZA, A. D.; ROBERTO FURLAN, M. R. Avaliação das características físicas e químicas da polpa e do iogurte de uvaia. Thesis, n.17, p. 60-77, 2012.

OLIVEIRA, J. F.; GARCIA, L. N. H.; PASTORE, V. A. A.; RAGHIANTE, F.; POSSEBON, F. S.; PINTO, JOSÉ P. A. N.; MARTINS, O. A. M. Qualidade de iogurtes de coco e morango. Revista Brasileira de Higiene e Sanidade Animal, v.11, n.4, p. 416-425, 2017.

OLIVEIRA, C. D.; PAULO, F. J.; OLIVEIRA, J. C. C.; FERREIRA, B. A.; RIBEIRO, B. P.; FAGUNDES, K. R. M.; CLAUDINO, T. O. Caracterização físico-química do iogurte tipo sundae sabor jabuticaba. Brazilian Journal of Development, v. 5, n. 6, p. 5091-5097, 2019.

ORIENTE, S. F.; SILVA, P. I. S.; GOUVEIA, D. S.; MOTA, M. M. A.; DANTAS, R. L.; SANTIAGO, A. M. Elaboração e caracterização físico-química de iogurtes de ameixa adicionados da farinha de chia. Magistra, v. 30, p. 78-85, 2019.

PÁDUA, H. C.; SILVA, M. A. P.; SOUZA, D. G.; MOURA, L. C.; PLÁCIDO, G. R.; COUTO, G. V. L.; CALIARI, M. Iogurte sabor banana (Musa AAB, subgrupo prata) enriquecido com farinha da casca de jabuticaba (Myrciaria jabuticaba (Vell.) Berg.). Global Science and Technology, v.10, n.01, p.89-104, 2017.

PAIVA, Y. F.; DEODATO, J. N. V.; SILVA, E. E. V.; SILVA, E. V; ARAÚJO, A. S. Iogurte adicionado de polpa de abacaxi, base mel: Elaboração, perfil microbiológico e físico-químico. Revista Verde, v. 10. , n. 5 p. 22-26, 2015. Doi: 10.18378/rvads.v10i5.3908

PELEGRINE, D. H. G.; AGUIAR, L. F. S.; IODELIS, A. Iogurte de goiaba enriquecido com cereais: correlação da textura com os parâmetros sensoriais. Revista de Ciência \& Tecnologia, v. 18, n. 36, p. 7-22, 2015. DOI:10.15600/2238-1252/rct.v18n36p25-40

PEREIRA, A. L. F.; FEITOSA, W. S. C.; ABREU, V. K. G.; LEMOS, T. O.; GOMES, W. F.; NARAIN, N.; RODRIGUES, S. Impact of fermentation conditions on the quality and sensory properties of a probiotic cupuassu (Theobroma grandiflorum) beverage. Food Research International, v. 100, p. 603-611, 2017. Doi: 10.1016/j.foodres.2017.07.055 
PÉREZ-LOREDO, M. G.; GARCÍA-OCHOA, F.; BARRAGÁN-HUERTA, B. E. Comparative Analysis of Betalain Content in Stenocereus Stellatus Fruits and Other Cactus Fruits Using Principal Component Analysis. International Journal of Food Properties, v. 19, n. 2, p. 326-338, 2016. DOI: 10.1080/10942912.2015.1022259

POMBO, J. C. P; MEDEIROS, H. H. B. R; PENA, R. S. Optimization of the spray drying process for developing cupuassu powder. Journal of Food Science Technology, 2020. Doi: 10.1007/s13197-020-04487-2

PUGLIESE, A. G.; TOMAS-BARBERAN, F. A.; TRUCHADO, P.; GENOVESE, M. I. Flavonoids, proanthocyanidins, vitamin $\mathrm{C}$, and antioxidant activity of Theobroma grandiflorum (Cupuassu) pulp and seeds. Journal of Agricultural and Food Chemistry, v. 61, p.2720 2728, 2013. Doi: 10.1021/jf304349u

RAMOS, G. D.; DIAS, S. L. S.; FERREIRA, I. M.; SILVA, A. M. O.; CARVALHO, M. G. Vida de prateleira de iogurte de cajá com Bacillus clausii: avaliação química, físico-química e microbiológica. Revista Brasileira de Higiene e Sanidade Animal, v.13, n.4, p. 424-439, 2019. Doi: $10.5935 / 1981-2965.20190033$

RIBEIRO, E.; CUBO, M. F.; SALEM, R. D. S. Desenvolvimento e caracterização físicoquímica de iogurte sem lactose adicionado de chia (Salvia hispanica L.). Revista UNINGÁ Review, v. 34, n. 1, p. 26-39, 2019.

RODAS, B. A. M.; RODRIGUES, S. M. M. R.; SAKUMA, H.; TAVARES, Z. L.;SGARBI, R. C.; LOPES, C. C. W. Caracterização físico-química, histológica e viabilidade de bactérias lácticas em iogurtes com frutas. Ciência Tecnologia de Alimentos, v. 21, n. 3, p.304-309, 2001. Doi:10.1590/S0101-20612001000300009

SANTANA, A. T. M. C.; BACHIEGA, P.; MORZELLE, M. C.; ABREU, L. R. SOUZA, E. C. Avaliação sensorial de iogurte à base de pitaia (Hylocereus undatus), enriquecido com quinoa (Chenopodium quinoa) e sucralose. Revista do Instituto de Laticínio Cândido Tostes, v. 67, n. 389, p. 21-25, 2012. Doi:10.5935/2238-6416.20120074

SANTOS, G. B. M.; DIONÍSIO, A. P.; MAGALHÃES, H. C. R.; ABREU, F. A. P; LIRA, S. M.; LIMA, A. C. V.; SILVA, G. S.; GUEDES, J. A. C.; ARAUJO, I. M. S.; ARTUR, A. G., PONTES, D. F., ZOCOLO, G. J. Effects of processing on the chemical, physicochemical, enzymatic and volatile metabolic composition of pitaya (Hylocereus polyrhizus (F.A.C. Weber) Britton \& Rose), Food Research International, v. 127, 2020. Doi: 10.1016/j.foodres.2019.108710

SILVA, A. G. F.; BESSA, M. M.; SILVA, J. R. Elaboração e caracterização físico-química e sensorial de iogurte light prebiótico adoçado com mel. Revista do Instituto de Laticínios Cândido Tostes, v. 72, n. 2, p. 74-84, 2017. Doi: 10.14295/2238-6416.v72i2.577

SILVA, R. T.; ASSIS, B. B. T.; MONÇÃO, E. C.; FERNANDES, J. M.; SILVA, M. E. S.; GRILO M. M. S., COUTINHO, T. P. A.; CONCEIÇÃO, M. M. Análise microbiólogica e fisico-química de iogurte tipo grego adicionado de geleia de pitanga (eugenia uniflora 1. .). Brazilian Journal of Development, v. 6, n. 5, p. 24660-24677, 2020. Doi:10.34117/bjdv6n5063 
SILVEIRA, M. P.; ROCHA, L. O. F.; CASTRO, A. L.; BRANDÃO, D. C.; GUEDES, T. J.; FERNANDES, M. K. O. Avaliação da qualidade de Labneh (iogurte grego): estudo com consumidores. Revista do Instituto de Laticínios Cândido Tostes, v. 71, n. 2, p. 65-74, 2016. Doi: $10.14295 / 2238-6416 . v 71 i 2.505$

SINGLETON, V. L.; ROSSI, J. A. Colorimetry of total phenolics with phosphomolybdicphosphotungsticacid reagentes. American Journal of Enology and Viticulture, v.16, p. 144 $158,1965$.

TAMANINI, R.; BELOTI, V.; JÚNIOR, J. C. R.; SILVA, L. C. C.; YAMADA, A. K.; SILVA, F. A. Contribuição ao estudo da qualidade microbiológica e físico-química do leite UHT. Revista do Instituto de Laticinio Cândido Tostes, v. 66, n. 382, p. 27-33, 2011.

TAMIME, A. Y.; DEETH, H. C. Fermented milks and their future trends. Part II. Technological aspects. Journal of Dairy Research, v. 55, n. 2, p. 281-307, 1988. Doi: https://doi.org/10.1017/S002202990002611X

TZE, N. L.; HAN, C. P.; YUSOF, Y. A.; LING, C. N.; TALIB, R. A.; TAIP, F. S.; AZIZ, M. G. Physicochemical and Nutritional Properties of Spray-dried Pitaya Fruit Powder as Natural Colorant. Food Science and Biotechnology, v. 21, n. 3, p. 675-682, 2012. Doi: 10.1007/s10068-012-0088-z

VIDAL, J. R. M. B.; PELEGRINE, D. H.; GASPARETTO, C. A. Efeito da temperatura no comportamento reológico da polpa de manga (mangífera indica L-Keitt). Ciência e Tecnologia de Alimentos, v. 24, n. 1, p. 39-42, 2004. Doi: 10.1590/S0101-20612004000100008

WEBB, D.; DONOVAN, S. M.; MEYDANI, S. N. The role of yogurt in improving the quality of the American diet and meeting dietary guidelines. Nutrition reviews, v. 72, n. 3, p. 180 189, 2014. Doi: 10.1111/nure.12098. 


\title{
CAPÍTULO 32: MODELAGEM MATEMÁTICA DA LIOFILIZAÇÃO DE FRUTAS E AVALIAÇÃO SENSORIAL DO PRODUTO PROCESSADO
}

\section{CHAPTER 32: MATHEMATICAL MODELING OF FREEZE DRYING OF FRUITS AND SENSORY EVALUATION OF THE PROCESSED PRODUCT}

\author{
Emanueli Backes ${ }^{1}$; Felipe Rodolfo Pereira da Silva²; Saraspathy N. T. G. de Mendonça ${ }^{3}$; Carolina
} Castilho Garcia ${ }^{4}$

\begin{abstract}
Resumo
Frutas são alimentos perecíveis, portanto, sua desidratação contribui para o aumento de sua vida útil. A liofilização vem recebendo destaque dentre as operações de secagem, já que os produtos não são submetidos a altas temperaturas. $\mathrm{O}$ objetivo do presente trabalho foi modelar a cinética de liofilização de tangerinas e uvas e avaliar sensorialmente as frutas desidratadas. A liofilização foi realizada com frutas congeladas à pressão de $70 \mathrm{~Pa}$ e aquecimento a $60{ }^{\circ} \mathrm{C}$ por 48 h. Os dados experimentais foram ajustados à lei de Fick e a modelos empíricos/semi empíricos. Foram avaliados sensorialmente cor, sabor, aroma, textura e impressão global dos consumidores com base em uma escala hedônica de nove pontos. A lei de Fick representou satisfatoriamente os dados experimentais de desidratação das frutas. O modelo de Page foi o que melhor representou a liofilização das uvas e o Aproximação da difusão, a das tangerinas. Aproximadamente $65 \%$ das notas atribuídas pelos provadores às frutas desidratadas situaramse entre os termos "gostei ligeiramente" e "gostei muito" para todos os quesitos avaliados. A textura das frutas desidratadas apresentou média superior a 7,0. Os resultados mostraram que há mercado para produtos inovadores, como uvas e tangerinas liofilizadas.
\end{abstract}

Palavras-Chave : Cinética de secagem, Coeficiente de difusão, Aceitação sensorial, Escala hedônica.

\begin{abstract}
Fruits are perishable foods, therefore, their dehydration contributes to the increase of their shelf life. Freeze drying has been highlighted among the drying operations, since the products are not submitted to high temperatures. The objective of the present work was to model the kinetics of freeze-drying of tangerines and grapes and to sensorially evaluate the dehydrated fruits. Lyophilization was performed with frozen fruits at a pressure of $70 \mathrm{~Pa}$ and heating at $60{ }^{\circ} \mathrm{C}$ for $48 \mathrm{~h}$. The experimental data were adjusted to Fick's law and to empirical/semi-empirical models. Consumers' color, flavor, aroma, texture and global impression were sensorially evaluated based on a hedonic scale of nine points. Fick's law represented satisfactorily the experimental data of dehydration of the fruits. Page model was the one that best represented the freeze drying of the grapes and Diffusion approximation model, that of the tangerines. Approximately $65 \%$ of the scores attributed by the consumers to dehydrated fruits were between the terms "I liked it a little" and "I liked it a lot" for all the items evaluated. The texture of dehydrated fruits showed score higher than 7.0. The results showed that there is a market for innovative products, such as freeze dried grapes and tangerines.
\end{abstract}

Keywords: Drying kinetics, Diffusion coefficient, Sensory acceptance, Hedonic scale.

\footnotetext{
${ }^{1}$ Doutoranda em Ciência de Alimentos, Universidade Estadual de Maringá, emanuelibackes@outlook.com

${ }^{2}$ Engenheiro de Alimentos, Universidade Tecnológica Federal do Paraná, floripa0911@ hotmail.com

${ }^{3}$ Doutora em Ciência dos Alimentos, Universidade Tecnológica Federal do Paraná, saraspathy@ yahoo.com.br

4 Doutora em Engenharia e Tecnologia de Alimentos, Universidade Tecnológica Federal do Paraná, carolinacgarcia@utfpr.edu.br
} 


\section{Introdução}

A fruticultura é responsável por mais de $40 \%$ da produção agrícola brasileira, sendo o consumo de frutas considerado um importante parâmetro na análise de questões sociais, econômicas e alimentares (MACHADO et al., 2015).

Segundo dados da FAO, a produção brasileira de frutas esteve entre as dez maiores do mundo, com mais de 600 mil toneladas, em 2018. Nesse mesmo ano, o país foi o sexto maior produtor de tangerinas (quase 1 milhão de toneladas) e ocupou a $15^{\mathrm{a}}$ posição no ranking mundial de produção de uvas (1.591.986 toneladas) (Food and Agriculture Organizatin of the United Nations, FAOSTAT, 2020).

A aceitação da tangerina pelos consumidores está associada a parâmetros como o tamanho, a coloração, a quantidade de suco produzido e a relação sólidos solúveis/acidez titulável (MOREIRA et al., 2012). A qualidade das frutas deve ser também analisada levandose em consideração seu valor nutritivo, pois essas são a fonte de $90 \%$ da vitamina C necessária ao bom funcionamento do corpo humano. Os teores de ácido ascórbico são variáveis entre os frutos cítricos e normalmente diminuem com o armazenamento (LIMA et al., 1999).

A uva Itália é a principal variedade de uva fina de mesa do país, sua produção pode alcançar $50 \mathrm{t} \mathrm{ha}^{-1} \mathrm{ano}^{-1}$. Entretanto, são produzidas cerca de 5 a $15 \%$ de frutas com alguma inadequação para a comercialização, pois os cachos podem apresentar bagas murchas ou ainda com tamanho reduzido (COSTA et al., 2015).

É possível aumentar a vida útil de alimentos através de seu processamento. Técnicas de desidratação resultam na redução da atividade de água, do desperdício, facilitando o transporte e a distribuição, além de agregar valor ao produto. As frutas secas como a banana, a tangerina, a uva, o abacaxi, a manga e o mamão são importantes ingredientes para a formulação de diversos alimentos como cereais, panetones, chocolates, entre outros.

Há diversas técnicas de secagem, sendo a liofilização indicada quando a manutenção de aromas e da estrutura da fruta fresca devem ser preservados. Nessa operação de desidratação ocorre o congelamento e a remoção de determinado solvente, primeiramente por sublimação e a posteriori por dessorção. Usualmente, a perda de solvente deve ocorrer até que os valores de atividade de água impeçam a atividade biológica e/ou microbiológica no produto seco (VIEIRA et al., 2012).

A operação de secagem é dividida em três etapas: período de indução, período de taxa constante e período de taxa decrescente. No período de taxa decrescente de secagem, a difusão da água do interior do sólido até sua superfície é o fenômeno determinante para a velocidade da operação, podendo ser modelado segundo a lei de Fick. 
A modelagem matemática de operações e processos industriais vem sendo largamente utilizada para sua descrição e simulação, sendo mais eficazes e de menor custo do que a experimentação. O uso de modelos e de parâmetros operacionais levam à simulação matemática muito próxima da situação real, apresentando, portanto, resultados bastante eficientes.

O sucesso do lançamento de um novo produto no mercado depende de vários fatores, dentre os quais tem-se a qualidade sensorial do mesmo, já que resultados obtidos em testes de aceitabilidade demonstra possível interesse dos consumidores, podendo confirmar sua comercialização.

Quando são buscados dados referentes a aceitação de algum produto, é comum o uso da escala hedônica, que está intrinsicamente correlacionada ao estado psicológico consciente dos provadores, proporcionando dados que indicam se o alimento é agradável ou não aos potenciais consumidores. Os dados são convertidos em scores numéricos, possibilitando estudos matemáticos sistematizados (ISAAC et al., 2012).

O objetivo do presente trabalho foi modelar a cinética de liofilização da uva Itália e da tangerina, por meio de modelos matemáticos que possibilitem o estudo/implantação/otimização da operação. Além disso, os produtos desidratados foram avaliados sensorialmente para verificar sua aceitação e intenção de consumo.

\section{Material e Métodos}

As frutas foram compradas em mercado local, em Medianeira, PR, nos meses de outubro a dezembro de 2017. As mesmas foram lavadas em água corrente e separadas do engaço, no caso das uvas; e descascadas e separadas em gomos, no caso das tangerinas.

A liofilização das frutas foi realizada em um liofilizador Labconco Freeze Zone 6 (Labconco Corporation, Kansas City, MO, EUA), sob pressão de $70 \mathrm{~Pa}$ e à temperatura de aquecimento de $60{ }^{\circ} \mathrm{C}$, por $48 \mathrm{~h}$. O congelamento das frutas foi realizado em freezer doméstico $\left(\mathrm{T} \approx-18^{\circ} \mathrm{C}\right)$ por $24 \mathrm{~h}$ previamente à desidratação.

Para acompanhar a cinética da liofilização foram realizadas pesagens sucessivas periódicas das amostras em diferentes intervalos de tempo. Dessa forma, as uvas e as tangerinas foram pesadas nos tempos $0,90,180,270,360,450,630,810,990,1170$ e 2880 minutos. Nesse caso, o aquecimento das amostras deu-se por convecção natural do ar ambiente.

Previamente à liofilização das uvas, suas cascas foram perfuradas com um palito de dentes para facilitar o transporte de massa, uma vez que estudos preliminares apontaram a inviabilidade da liofilização das frutas inteiras pela dificuldade da difusão da água através de sua casca, tornando muito longo o tempo de operação. 
Antes, após a secagem das frutas foi determinada, em triplicata, sua umidade, por método gravimétrico em estufa a $105^{\circ} \mathrm{C}$ até peso constante, segundo metodologia proposta pela AOAC (1995).

Para o cálculo do coeficiente de difusão da água durante a liofilização foram utilizadas soluções integradas de Crank (1975), apropriada ao formato da fruta. Para as uvas considerouse formato de esfera, inserindo a esfericidade na solução de Crank, Eq. 1, como proposto por Falade e Abbo (2007). As tangerinas foram consideradas como placas infinitas, Eq. 2, e a sua espessura foi obtida através da média da medida de 18 frutas frescas escolhidas casualmente.

$$
\begin{aligned}
& R X=\frac{\bar{X}_{t}-X_{e q}}{X_{0}-X_{e q}}=\frac{6}{\pi^{2}} \sum_{n=1}^{\infty} \frac{1}{n^{2}} \exp \left(-n^{2} \pi^{2} \frac{D_{e f} t}{\psi^{2} R_{e q}{ }^{2}}\right) \\
& R X=\frac{\bar{X}_{t}-X_{e q}}{X_{0}-X_{e q}}=\frac{8}{\pi^{2}} \sum_{n=1}^{\infty} \frac{1}{(2 n-1)^{2}} \exp \left[-(2 n-1)^{2} \frac{\pi^{2} D_{e f} t}{z^{2}}\right]
\end{aligned}
$$

Em que: $\overline{X_{t}}$ é a umidade em cada intervalo de tempo; $X_{e q}$ é a umidade de equilíbrio após certo tempo de secagem; $X_{0}$ é a umidade inicial do sólido; $R X$ é o adimensional de umidade; $z$ é a meia espessura da placa, em $\mathrm{cm} ; R_{e q}$ é o raio equivalente, em $\mathrm{cm}$, calculado segundo Falade e Abbo (2007), Equações 3 a 9; $\psi$ é a esfericidade; $D_{e f}$ é o coeficiente de difusão efetivo da água, $\mathrm{em} \mathrm{cm}^{2} \mathrm{~s}^{-1}$.

O raio equivalente foi calculado segundo as Equações 3 a 9 (FALADE; ABBO, 2007).

$R_{e}=\frac{3 V_{p}}{S_{p}}=\Psi R_{e q}$

$V_{p}=\frac{4}{3} \pi a^{2} b$

$S_{p}=2 \pi a^{2}+\left(\frac{\pi b^{2}}{e}\right) \ln \left(\frac{1+e}{1-e}\right)$

$e=\left[1-\left(\frac{b}{a}\right)^{2}\right]^{1 / 2}$

$S_{e}=4 \pi R_{e}{ }^{2}$

$\Psi=\frac{s_{e}}{S_{p}}$

$R_{e q}=\frac{R e}{\Psi}$

Em que: $R_{e}$ é o raio da esfera; $V_{p}$ e $S_{p}$ são o volume e a área superficial da uva; $\Psi$ é a esfericidade das frutas; $R_{e q}$ é o raio equivalente; $a$ e $b$ são os raios do maior e do menor semi eixo das uvas, respectivamente; $S_{e}$ é a área superficial da esfera; $e$ é a excentricidade.

Além disso, os dados experimentais da liofilização das frutas foram ajustados a oito modelos empíricos ou semi empíricos, Eqs. 10 a 17, apresentados na Tabela 1. 
Tabela 1. Modelos empíricos ou semi empíricos usados para descrever a secagem de alimentos

\begin{tabular}{lc} 
Modelo & Equação \\
\hline Verma & $R X=a e^{-k t}+(1-a) e^{-k_{1} t}$ \\
Page & $R X=e^{-k t^{n}}$ \\
Newton & $R X=e^{-k t}$ \\
Logarítmico & $R X=a e^{-k t}+c$ \\
Henderson e Pabis & $R X=a e^{-k t}$ \\
Henderson e Pabis & $R X=a e^{-k t}+b e^{-k_{0} t}+c e^{-k_{1} t}$ \\
modificado & $R X=a e^{-k t}+(1-a) e^{-k a t}$ \\
Exponencial de Dois Termos & $R X=a e^{-k t}+(1-a) e^{-k b t}$ \\
Aproximação da Difusão & $R$
\end{tabular}

Em que: $R X$ representa o adimensional de umidade; $t$, o tempo de secagem, em $\mathrm{h} ; k, k_{o}$ e $k_{l}$ são as constantes de secagem, em $\mathrm{t}^{-1} ; a, b, c$ e $n$ são os coeficientes dos modelos.

Fonte: Adaptado de Sousa et al. (2011)

O ajuste dos dados experimentais aos modelos matemáticos foi avaliado a partir do coeficiente de determinação $\left(R^{2}\right)$, e dos valores dos parâmetros estatísticos: erro quadrático médio (RMSE, Equação 18) e erro médio relativo ( $P$, Equação 19). Os maiores valores de $R^{2}$, os menores valores de $S E$ e erro médio relativo abaixo de $10 \%$ indicam melhores ajustes aos modelos (SOUSA et al., 2011).

$R M S E=\sqrt{\frac{\sum_{i=1}^{N}\left(x_{\text {calc }}-x_{\text {exp }}\right)^{2}}{n}}$

$P=\frac{100}{n} \sum_{i=1}^{N} \frac{\left|x_{\text {exp }}-x_{\text {calc }}\right|}{x_{\text {exp }}}$

Em que: $x_{\text {exp }}$ é o valor experimental; $x_{\text {calc }}$ é o valor predito pelo modelo; $n$ é o número de observações experimentais.

Previamente à avaliação sensorial das frutas liofilizadas, as seguintes análises microbiológicas foram realizadas em duplicata: coliformes a $45^{\circ} \mathrm{C}$ e Salmonella sp., de acordo com a Resolução RDC n ${ }^{\circ}$ 12, de 2 de janeiro de 2001, que aprova o Regulamento Técnico sobre padrões microbiológicos para alimentos (BRASIL, 2001), seguindo metodologias propostas pela (AOAC, 2013).

Após a aprovação do Comitê de Ética em Pesquisa da UTFPR, parecer consubstanciado $\mathrm{n}^{\circ}$ 2.214.544 foi realizada a análise sensorial das frutas liofilizadas em duas academias da cidade de Medianeira, PR, para verificar sua aceitação. Deve ser ressaltado que a opção pela 
realização dos testes em academias está relacionada ao fato de este ser o público com maior propensão ao consumo desses alimentos, como snacks para lanches rápidos e saudáveis.

A avaliação sensorial foi realizada com 117 consumidores de ambos sexos, sendo esses alunos e funcionários das Academias de ginástica Superação e Universitária, em Medianeira, PR, com idade entre 18 e 65 anos, os quais foram esclarecidos sobre a pesquisa em questão. Não participaram pessoas com doenças como gastrite, úlcera, diabetes, alérgicos à tangerina e/ou uva, ou com alguma outra restrição a estas frutas, ou que não gostem de tangerina e/ou uva. Os avaliadores foram alertados da importância da leitura e compreensão do Termo de Consentimento Livre e Esclarecido e todos assinaram o termo.

Foi aplicado teste de aceitação (GUAGLIANONI; FARIA, 2011), sendo servidas duas amostras: um gomo de tangerina e uma unidade da uva, ambas liofilizadas. As amostras foram servidas monadicamente e foram avaliadas com escala hedônica de 9 pontos, na qual 9 corresponde a GOSTEI MUITÍSSIMO e 1, a DESGOSTEI MUITÍSSIMO, obtendo com isso dados referentes a impressão global, cor, aroma, sabor e textura. As amostras foram servidas em pratos plásticos descartáveis codificados com três dígitos escolhidos ao acaso. Foi servida água mineral sem gás para a higienização da boca e do palato entre cada amostra.

Juntamente com o teste de aceitação foi realizada uma pesquisa de intenção de compra (SILVA; COSTA; NASCIMENTO, 2017) das frutas liofilizadas. Para esse teste foi utilizada uma ficha resposta com escala estruturada em 5 pontos oscilando de CERTAMENTE NÃO COMPRARIA à CERTAMENTE COMPRARIA; e uma pesquisa de mercado com questões sobre idade, sexo, escolaridade, renda per capita e consumo de frutas frescas e de frutas desidratadas.

Os resultados foram submetidos à análise de variância (ANOVA).

\section{Resultados e Discussão}

A umidade média das uvas e das mexericas in natura foi de $89,6 \pm 0,4 \%$ (b.u.) e $80,2 \pm$ $0,5 \%$ (b.u.) e após a liofilização foi de 5,0 $\pm 0,2 \%$ (b.u.) e 6,0 $\pm 0,3 \%$ (b.u.), respectivamente.

Durante a liofilização das frutas verificou-se redução contínua da umidade das amostras ao longo do tempo, sendo que sua umidade reduziu rapidamente no início da secagem e, posteriormente, essa velocidade diminuiu no decorrer do tempo de operação.

Na Tabela 2 são apresentados os coeficientes de difusão da água durante a liofilização das tangerinas e das uvas, obtidos a partir da Equações 1 e 2, respectivamente, assim como os parâmetros estatísticos utilizados para avaliar o ajuste dos dados experimentais à lei de Fick. 
Tabela 2. Coeficiente de difusão efetivo da água, $D_{e f}$, em $\mathrm{m}^{2} \mathrm{~s}^{-1}$, durante a liofilização das frutas e parâmetros estatísticos utilizados para avaliar o ajuste dos dados experimentais à lei de Fick.

\begin{tabular}{ccccc}
\hline Fruta & $\boldsymbol{D}_{\boldsymbol{e f}}$ & $\boldsymbol{R}^{\mathbf{2}}$ & $\boldsymbol{P}(\boldsymbol{\%})$ & $\boldsymbol{R M S E}$ \\
\hline Tangerina & $1,0 \cdot 10^{-6}$ & 0,99 & 1,05 & $8,7 \cdot 10^{-4}$ \\
Uva & $2,4 \cdot 10^{-6}$ & 0,98 & 4,69 & $4,7 \cdot 10^{-3}$ \\
\hline
\end{tabular}

Fonte: Próprio autor (2017).

O coeficiente de determinação $\left(R^{2}\right)$ maior que 0,90 , o erro médio relativo $(P)$ menor que $10 \%$ e o erro quadrático médio (RMSE) próximo de zero, indicam bom ajuste dos dados experimentais à lei de Fick, indicando que o mesmo representa adequadamente o fenômeno de secagem das duas frutas.

Vieira et al. (2012) obtiveram os coeficientes de difusão da água ao avaliarem a cinética de liofilização e os parâmetros de qualidade - conteúdo de vitamina $\mathrm{C}$, reidratação e textura de fatias de abacaxi em função da espessura e da temperatura de congelamento. Os coeficientes obtidos foram da ordem de grandeza de $10^{-10}$, menores que os obtidos no presente estudo, cujas ordens foram de $10^{-6}$. Essa diferença nos resultados está possivelmente relacionada à microestrutura dos alimentos, que influencia consideravelmente a transferência de massa. Considerando que as uvas foram perfuradas previamente à liofilização, certamente os danos causados às cascas facilitaram o transporte de massa. Possivelmente, as tangerinas apresentam estrutura mais porosa que os abacaxis, facilitando a desidratação.

Nas Tabelas 3 e 4 são apresentados os valores de $R^{2}, P(\%)$ e $R M S E$ para o ajuste dos dados experimentais aos modelos empíricos e semi empíricos (Eqs. 10 a 17, Tabela 1) avaliados para a operação de secagem das uvas e das tangerinas.

Verificou-se que para a maioria dos modelos o coeficiente de determinação foi elevado, maior que 0,95 , o valor de $P$, inferior a $10 \%$ e o de $R M S E$, baixo, próximo de zero. Segundo Sousa et al. (2011), esses valores indicam bom ajuste dos dados experimentais aos modelos, mostrando que os mesmos representam de forma satisfatória a operação de liofilização. Ao estudarem a cinética da secagem de sementes do nabo forrageiro em um secador convectivo experimental, os autores também obtiveram bons ajustes dos dados a modelos empíricos e semi empíricos (SOUSA et al., 2011).

Avaliando os parâmetros estatísticos constatou-se que o modelo de Page foi o que melhor representou a operação de liofilização das uvas, com $R^{2}$ igual a $0,99, P$ igual a $1,38 \%$ e $R M S E$ igual a 0,00002. Para as tangerinas o modelo que melhor representou a liofilização foi o de Aproximação da difusão, com $R^{2}$ igual a $0,99, P$ igual a $0,71 \%$ e $R M S E$ igual a 0,001 . 
BACKES, et al.

Tabela 3. Parâmetros estatísticos para o ajuste dos dados experimentais de liofilização da uva Itália aos modelos empíricos e semi empíricos.

\begin{tabular}{lccc}
\hline Modelo & $\boldsymbol{R}^{\mathbf{2}}$ & $\boldsymbol{P}(\boldsymbol{\%})$ & $\boldsymbol{R M S E}$ \\
\hline Newton & 0,99 & 0,89 & $0,9 \cdot 10^{-3}$ \\
Page & 0,99 & 0,01 & $0,02 \cdot 10^{-3}$ \\
Handerson e Pabis & 0,99 & 0,83 & $0,9 \cdot 10^{-3}$ \\
Logarítmico & 0,99 & 0,74 & $0,9 \cdot 10^{-3}$ \\
Aproximação da difusão & 0,99 & 0,45 & $0,6 \cdot 10^{-3}$ \\
Verma & 0,99 & 0,45 & $0,1 \cdot 10^{-3}$ \\
Henderson e Pabis modificado & 0,99 & 0,83 & $1,7 \cdot 10^{-3}$ \\
Exponencial de dois termos & 0,99 & 0,04 & $0,04 \cdot 10^{-3}$ \\
\hline
\end{tabular}

Fonte: Próprio autor (2017).

Tabela 4. Parâmetros estatísticos para o ajuste dos dados experimentais de liofilização da tangerina aos modelos empíricos e semi empíricos.

\begin{tabular}{lccc}
\hline Modelo & $\boldsymbol{R}^{\mathbf{2}}$ & $\boldsymbol{P}(\boldsymbol{\%})$ & $\boldsymbol{R M S E}$ \\
\hline Newton & 0,97 & 4,76 & $4,0 \cdot 10^{-3}$ \\
Page & 0,99 & 1,59 & $1,5 \cdot 10^{-3}$ \\
Handerson e Pabis & 0,99 & 2,39 & $1,2 \cdot 10^{-3}$ \\
Logarítmico & 0,99 & 2,35 & $2,3 \cdot 10^{-3}$ \\
Aproximação da difusão & 0,99 & 0,71 & $1,7 \cdot 10^{-3}$ \\
Verma & 0,97 & 4,76 & $4,7 \cdot 10^{-3}$ \\
Henderson e Pabis modificado & 0,99 & 0,85 & $1,2 \cdot 10^{-3}$ \\
Exponencial de dois termos & 0,99 & 1,93 & $1,7 \cdot 10^{-3}$
\end{tabular}

Fonte: Próprio autor (2017).

Rudy et al. (2015) estudaram a liofilização de cranberries às temperaturas de 30, 50 e $70{ }^{\circ} \mathrm{C}$ sob pressão constante e observaram que o modelo Logarítmico foi o que melhor representou os dados experimentais da secagem das frutas inteiras; e que os modelos de Wang e Singh e de Page ajustaram melhor os dados de secagem das polpas das frutas.

Cabe ressaltar que os modelos empíricos e semi empíricos são matematicamente menos complexos que a lei de Fick, sendo de mais fácil solução e, assim, permitindo o cálculo do tempo de operação de forma facilitada e, por vezes, mais rápida. Por outro lado, esses modelos não são fenomelógicos e, portanto, não possibilitam o cálculo de coeficientes de difusão da 
água durante a operação.

Nas Figuras 1 e 2 são apresentadas as uvas e as tangerinas antes e após a liofilização, sendo possível observar que a cor e o formato das tangerinas sofreram pouca alteração com a operação. Nas uvas desidratadas, é possível observar pontos escurecidos na casca, que foi rompida previamente à operação, com o intuito de acelerar a liofilização. Possivelmente, o rompimento da casca das frutas resultou em danos estruturais, que propiciaram a ocorrência da reação de Maillard, ocasionando o escurecimento visualizado.
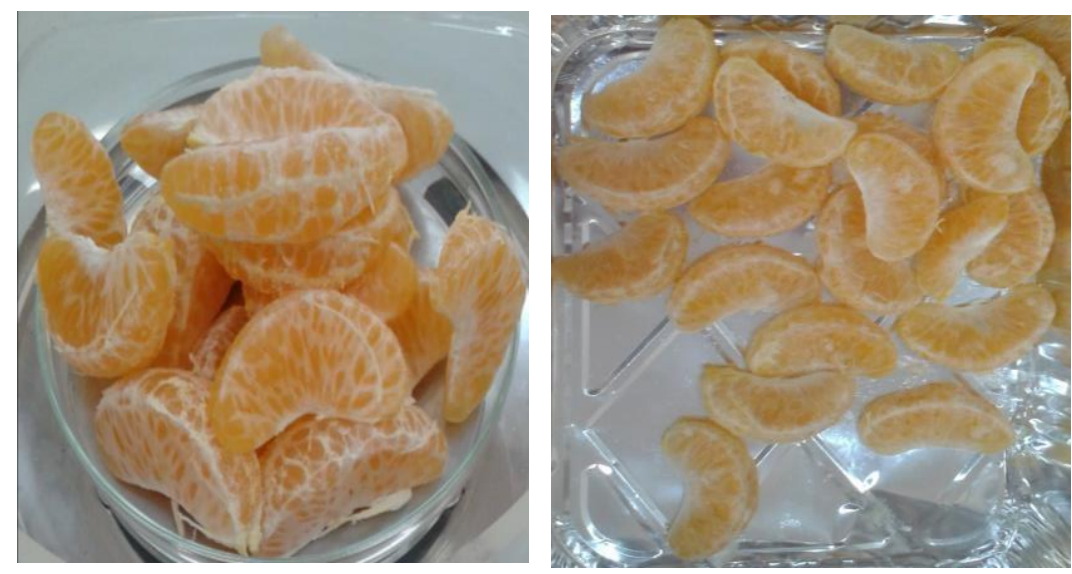

Figura 1. Tangerinas in natura (à esquerda) e após (à direita) a operação de liofilização. Fonte: Próprio autor (2017).
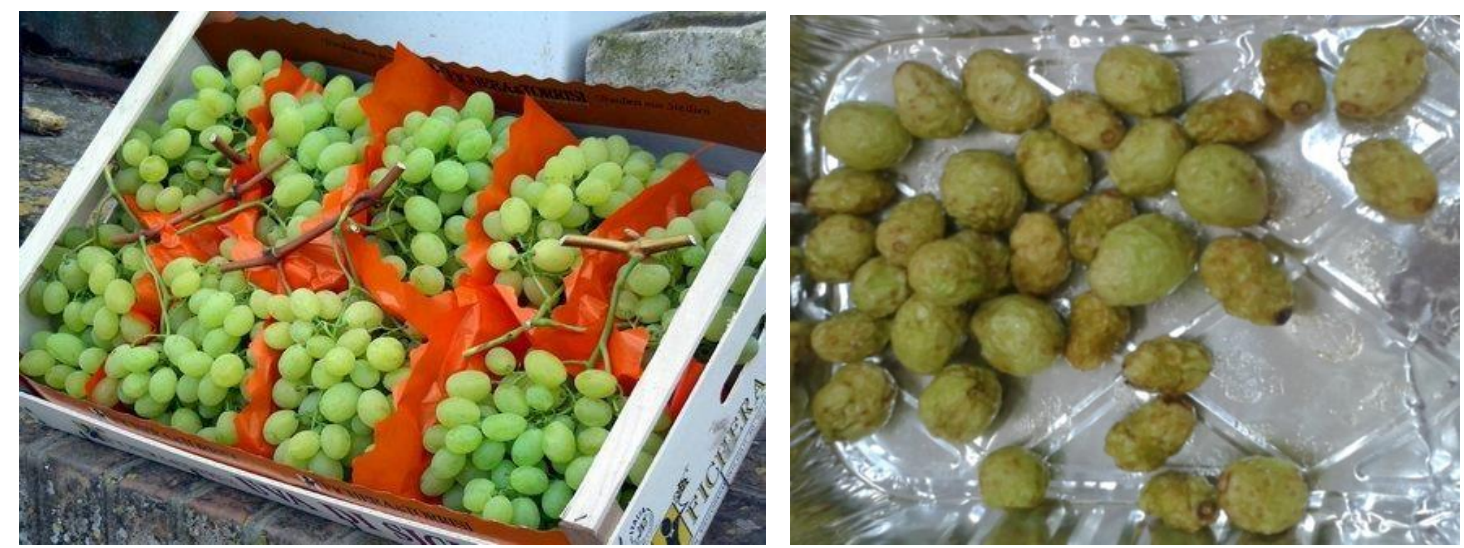

Figura 2. Uvas Itália in natura (à esquerda) e após (à direita) a operação de liofilização. Fonte: Próprio autor (2017).

As análises microbiológicas das frutas secas apresentaram contagens de coliformes termotolerantes menores que $1,0 \cdot 10^{1} \mathrm{UFC} / \mathrm{g}$ para as tangerinas e para as uvas liofilizadas e ambas apresentaram ausência de Salmonella sp. em 25 g, o que está de acordo com os valores propostos pela $\mathrm{RDC}^{\circ} 12$ de 2 de janeiro de 2001 (BRASIL, 2001). Esses resultados revelaram que boas práticas de manipulação foram realizadas durante o processamento das frutas, 
garantindo segurança para o consumo dos alimentos e possibilitando a avaliação sensorial das mesmas.

As Figuras 3 e 4 apresentam a distribuição percentual das notas obtidas para os atributos sensoriais para as uvas e para as tangerinas liofilizadas, respectivamente.

Figura 3. Distribuição das notas obtidas para os atributos cor, sabor, aroma, textura e impressão global na avaliação sensorial das uvas liofilizadas.

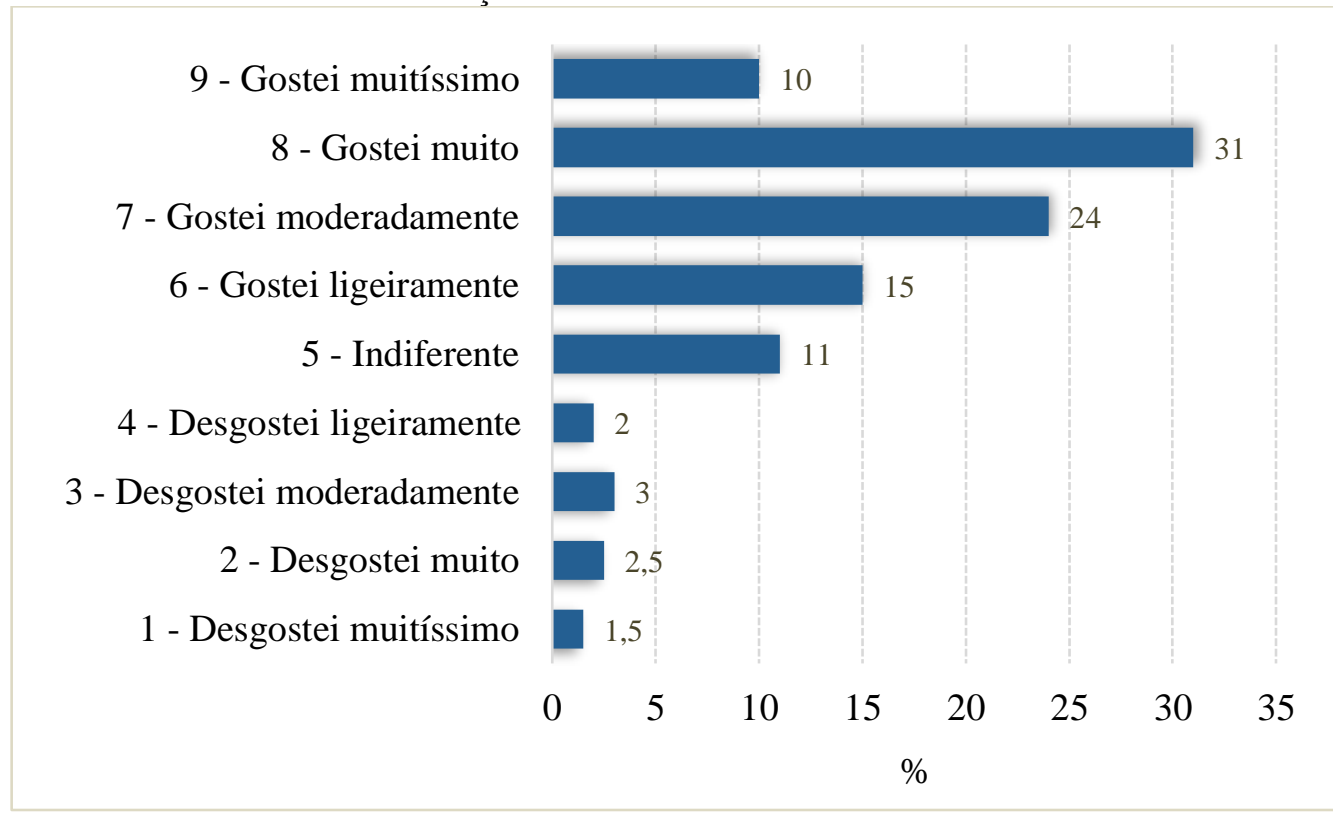

Fonte: Próprio autor (2017).

Figura 4. Distribuição das notas obtidas para os atributos cor, sabor, aroma, textura e impressão global na avaliação sensorial das tangerinas liofilizadas.

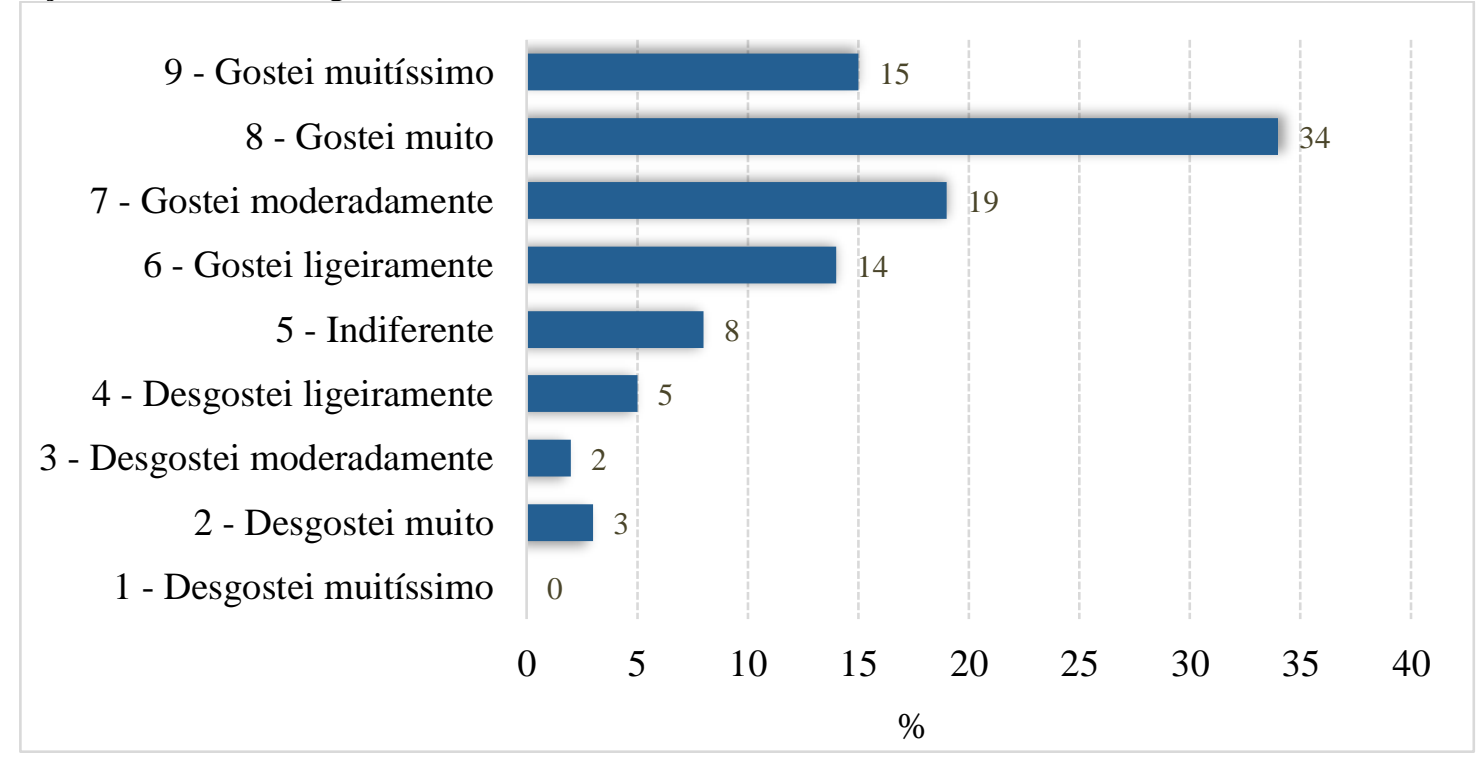

Fonte: Próprio autor (2017).

É possível verificar através da Figura 3 que, para as uvas, 70\% das notas para os quesitos analisados situaram-se entre os termos hedônicos "gostei ligeiramente" e "gostei muito". 
Comportamento semelhante foi observado para as tangerinas, na Figura 4, sendo que 67\% das notas ficaram entre os mesmos termos hedônicos. Esse resultado indica boa aceitação das frutas liofilizadas pelos consumidores.

Para as uvas, o atributo textura obteve as maiores notas, apresentado média de 7,2 $\pm 1,6$. Para as tangerinas, a textura e a cor apresentaram as notas mais elevadas, sendo que os valores médios foram 7,2 $\pm 1,7$ para a textura e 7,2 $\pm 1,5$ para a cor das frutas desidratadas. Esse fato ressalta que as frutas estavam crocantes e com boa aparência após a liofilização, como pode ser confirmado na Figura 1.

Quanto ao sabor, as médias das notas foram de 6,5 $\pm 1,7$ para as uvas e 6,5 \pm 1,9 para as tangerinas. Muitos provadores comentaram que as frutas apresentavam-se azedas, possivelmente devido ao efeito de concentração dos ácidos presentes nas frutas com a remoção da água; ou com amargor residual, em virtude da presença de suas sementes. Por esse motivo, os autores sugerem que mais estudos devem ser conduzidos utilizando frutas mais maduras e/ou variedades sem sementes.

A impressão global dos avaliadores com relação à tangerina liofilizada encontrou-se no termo hedônico "gostei muito", com nota média de 7,0. Para as uvas, a nota média foi de 6,7 para o atributo impressão global, possivelmente afetado pelas notas em torno de 6,5 dos atributos cor e sabor, afetados negativamente pelo rompimento da casca e presença das sementes.

Fonseca et al. (2011) afirmam que para um produto ser considerado aceito a nível de suas propriedades sensoriais é preciso que os índices de aceitabilidade sejam no mínimo igual a 7,0. Assim, pode-se inferir que a uva e a tangerina liofilizadas apresentaram a textura e a textura e a cor, respectivamente, aceitas pelos consumidores. As médias das notas para o sabor das frutas foi próximo do valor de referência, 6,5, mostrando que, com pequenas modificações, os produtos seriam aceitos pelos consumidores. Para contornar a insatisfação relacionada ao amargor da semente seria interessante trabalhar com uma variedade híbrida sem sementes (MATSUMOTO, 2001), tais como a tangerina Dekopon, apresentada na Figura 5. 
Figura 5. Tangerina hibrida Dekopon.

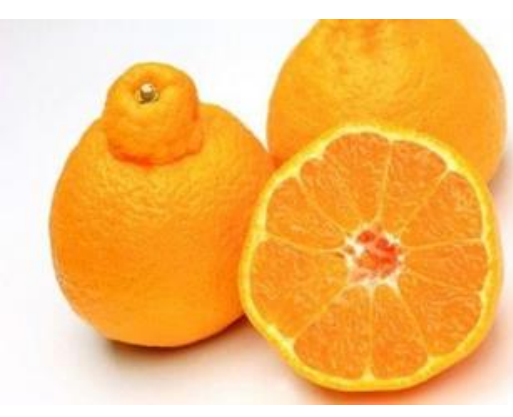

Fonte: MATSUMOTO (2001).

Para as uvas, seria interessante trabalhar com outra variedade de coloração mais escura, para "mascarar" o escurecimento da casca devido à sua ruptura, necessária para acelerar a transferência de massa e viabilizar a operação de liofilização das frutas. A variedade Benitaka seria uma opção, por apresentar bagas escuras, evitando a perda da qualidade na aparência. Além da aparência, com o objetivo de evitar o amargor, seria possível trabalhar com frutas sem sementes, sendo a cultivar BRS Vitória, apresentada na Figura 6, interessante para estudos de liofilização de uvas, por serem de casca escura e não possuírem sementes (SOLUÇÕES TECNOLÓGICAS, 2012).

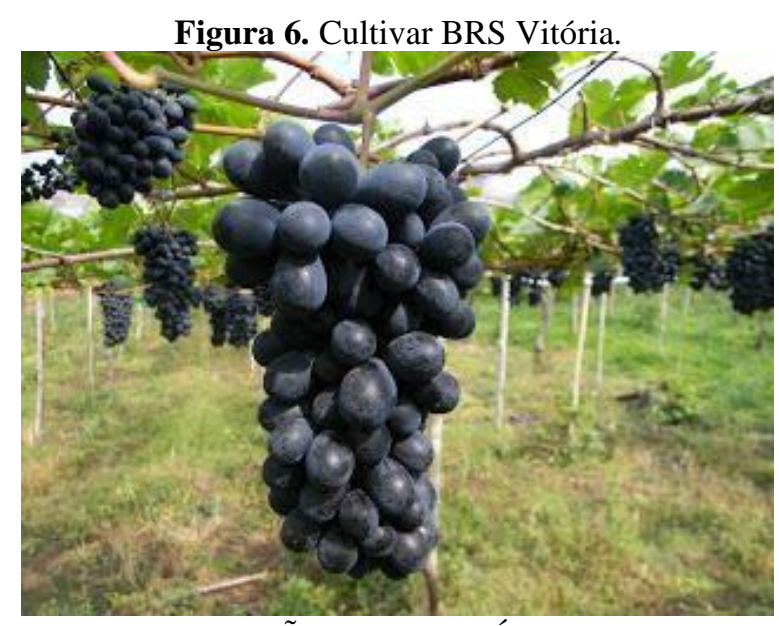

Fonte: SOLUÇÕES TECNOLÓGICAS (2012).

Com relação à intensão de compra das uvas liofilizadas, 35,9\% dos julgadores certamente comprariam, $16,2 \%$, possivelmente comprariam e 31,6\% talvez comprassem. Para as tangerinas, $31,6 \%$ dos avaliadores certamente comprariam as frutas liofilizadas, $20,5 \%$ possivelmente comprariam e $27,4 \%$ talvez comprassem.

Dentre os entrevistados, constatou-se que apenas $13 \%$ consome frutas frescas mais de três vezes por semana, $49 \%$ não consome frutas desidratadas e $29 \%$ consome frutas desidratadas de vez em quando, demonstrando que poucos apresentam hábitos mais saudáveis de 
alimentação, pois a recomendação de ingestão de frutas pela OMS é de 400 gramas por dia (KOPKO, 2020). É possível que os resultados fossem melhores se o hábito de alimentação dos entrevistados fosse diferente.

\section{Conclusões}

A lei de Fick e os modelos empíricos e semi empíricos testados foram adequados para representar as operações de liofilização de uvas Itália e tangerinas. A lei de Fick, por ser fenomenológica, permitiu o cálculo do coeficiente de difusão da água durante a desidratação, enquanto os demais modelos avaliados permitem cálculos rápidos do tempo de operação.

A tangerina liofilizada apresentou resultados promissores, com boa aceitabilidade dos atributos sensoriais de textura, cor e impressão global. Para a uva Itália, a técnica de secagem utilizada afetou negativamente as características sensoriais percebidas do produto, com exceção do atributo textura.

A intenção de compra positiva por parte dos julgadores enfatiza a relevância deste estudo, que utilizou de uma tecnologia de desidratação eficaz para desenvolver um produto de fácil transporte e armazenamento e de alta qualidade nutricional e sensorial.

\section{Referências}

ASSOCIATION OF OFFICIAL ANALYTICAL CHEMISTS (A.O.A.C.). Official Methods of Analysis. 16. ed. v. I e II. Washington: AOAC, 1995.

ASSOCIATION OF OFFICIAL ANALYTICAL CHEMISTS (A.O.A.C.). Official Methods of Analysis. 18. ed. v. I e II. Washington: AOAC, 2013.

BRASIL. ANVISA. Resolução - RDC nº 12, de 2 de janeiro de 2001. Aprova o Regulamento Técnico sobre Padrões Microbiológicos para Alimentos. Brasília: Agência Nacional de Vigilância Sanitária, 2001.

COSTA, J. D. D.; NETO, A. F.; NUNES, S. M.; RYBKA, A. C. P.; BIASOTO, A. C. T.; FREITA, S. T. Caracterização físico-química de uva itália desidratada. Revista Iberoamericana de Tecnología Postcosecha, v. 16, p. 273-280, 2015.

CRANK, J. The Mathematics of Diffusion. 2d Ed. London: Clarendon Press, 1975.

FALADE, O. K.; ABBO, S. E. Air-drying and rehydration characteristics of date palm (Phoenix dactylifera L.) fruits. Journal of Food Engineering, v. 79, n. 2, p. 724-730, 2007.

FAOSTAT - Food and Agriculture Organizatin of the United Nations. Disponível em: <http://www.fao.org/faostat/en/\#data/QC/visualize>. Acesso em: 20/07/2020.

FONSECA, R. S.; SANTO, F. V. R. D.; SOUZA, G. B.; PEREIRA, C. A. M. Elaboração de barra de cereais com casca de abacaxi. Órgano Oficial de la Sociedad Latinoamericana de 
Nutrición, v. 61, n. 2, p. 216-223, jul./set. 2011.

GUAGLIANONI, D.G.; FARIA, J.B. Testes de aceitação em amostras de cachaça: avaliação de métodos estatísticos e de número mínimo de julgadores. Alimentos e Nutrição, v. 22, n. 1, p. 21-25, jan./mar. 2011.

ISAAC, V.; CHIARIL, B. G.; MAGNANIL, C.; CORRÊA, M. A. Análise sensorial como ferramenta útil no desenvolvimento de cosméticos. Revista de Ciências Farmacêuticas Básica e Aplicada, v. 33, n. 4, p. 479-488, 2012.

KOPKO, G. Ministério da Saúde lança livro para estimular o consumo de alimentos saudáveis. Disponível em: < http://www.blog.saude.gov.br/index.php/35387-ministerio-da-saude-lancalivro-para-estimular-o-consumo-de-alimentos-saudaveis>. Acesso em: 20/07/2020.

LIMA, L. C.; BOAS, E. V. B. V.; REIS, J. M. R.; CHITARRA, A. B. Qualidade dos frutos de tangerina 'ponkan', armazenamento sob temperatura ambiente. Revista Científica UNIFENAS, v. 06, p. 27-31, 1999.

MACHADO, A. V.; SOUZA, J. A.; NOVAES, R. S. Estudo cinético da secagem da uva isabel para a produção de uva passa. Revista Verde de Agroeconomia e Desenvolvimento Sustentável, v. 10, p. 47-51, jan./mar., 2015.

MATSUMOTO, R.; 'Shiranuhi', A late-maturing Citrus Cultivar. Bulletin of the National Institute of Fruit Tree Science, v. 35, n. 7, p. 115-120, jan-mar, 2001.

MOREIRA, R. A.; RAMOS, J. R.; SILVA, F. O. R.; COSTA, A. C. Qualidade de tangerina 'Ponkan' em função do raleio químico. Pesquisa Agropecuária Tropical, v. 42, p. 303-309, 2012.

RUDY, S.; DZIKI, D.; KRZYKOWSKI, A.; GAWLIK-DZIKI, U.; POLAK, R.; RÓZYLO, R.; KULIG, R. Influence of pre-treatments and freeze-drying temperature on the process kinetics and selected physico-chemical properties of cranberries (Vaccinium macrocarpon Ait.). LWTFood Science and Technology, v. 63, n. 1, p. 497-503, 2015.

SILVA, D. C.; COSTA, K. K. B.; NASCIMENTO, A. D. P. Elaboração de iogurte sabor goiaba enriquecido com farinha de palma. Revista Agropecuária Técnica, v. 1, n. 1, p. 4751, 2017.

SOLUÇÕES TECNOLÓGICAS. Uva BRS Vitória. Embrapa, 2012. Disponível em: $<$ https://www.embrapa.br/busca-de-solucoes-tecnologicas/-/produto-servico/1163/uva-brsvitoria >. Acesso em: 20/07/2020.

SOUSA, K. A.; RESENDE, O.; CHAVES, T. H.; COSTA, L. M. Cinética de secagem do nabo forrageiro (Raphanus sativus L.). Revista Ciência Agronômica, v. 42, n. 4, p. 883-892, 2011.

VIEIRA, A. P.; NICOLETI, J. F.; TELIS, V. R. N. Liofilização de fatias de abacaxi: avaliação da cinética de secagem e da qualidade do produto. Brazilian Journal of Food Technology, v. 15, n. 1, p. 50-58, jan./mar. 2012. 


\title{
CAPÍTULO 33: PALMA E CHIA UTILIZADOS COMO SUBSTITUTOS DEESTABILIZANTES EM SORVETE DE UMBU
}

\section{CHAPTER 33: PALMA AND CHIA USED AS SUBSTITUTES FOR STABILIZERS IN UMBU ICE CREAM}

\author{
José Iago dos santos Aragão ${ }^{1}$; Anny Kelly Vasconcelos de Oliveira Lima²
}

\begin{abstract}
Resumo
O objetivo deste estudo foi o desenvolvimento de um sorvete, a fim de avaliar a viabilidade do emprego da mucilagem de chia e palma em substituição ao estabilizante liga neutra. O processo de elaboração ocorreu em três etapas: desenvolvimento do produto, caracterização física e físico-química. Foi elaborado um delineamento estatístico (DCCR), onde foram desenvolvidas doze diferentes formulações. Após testes preliminares, foram selecionadas cinco formulações: F1 (30 g de chia); F2(30g de palma); F3 (42,6 g de chia + 17,4 de palma) e F4 (17,4g de Chia + 42,6g de palma) e F5 controle (15,2g de liga neutra), foram realizadas análises de acidez titulável; potencial hidrogeniônico $(\mathrm{pH})$; sólidos solúveis; overrun e derretimento. As formulações quando comparadas com a controle apresentaram resultados satisfatórios, quanto a taxa de derretimento e overrun. Dessa maneira pôde-se afirmar que para o sorvete de umbu substituindo o estabilizante industrial pelo estabilizante natural de origem vegetal está dentro dos padrões estabelecidos na legislação vigente para overrun, sólidos solúveis e derretimento.

Palavras-chave: Salvia hispanica; Gelados comestíveis; Opuntia ficus-indica.
\end{abstract}

\begin{abstract}
The aim of this study was the development of an ice cream, in order to assess the viability of using chia and palm mucilage to replace the neutral alloy stabilizer. The elaboration process took place in three stages: product development, physical and physical-chemical characterization. A statistical design (DCCR) was developed, in which twelve different formulations were developed. After preliminary tests, five formulations were selected: F1 (30g of chia); F2 (30g of palm); F3 (42.6 g of chia +17.4 palm) and F4 (17.4 g of Chia $+42.6 \mathrm{~g}$ of palm) and F5 control (15.2 g of neutral alloy), titratable acidity analyzes were performed; hydrogen potential $(\mathrm{pH})$; soluble solids; overrun and melt. The formulations when compared to the control showed satisfactory results, as far as the rate of melting and overrun. In this way it could be said that for umbu ice cream replacing the industrial stabilizer with the natural stabilizer of plant origin it is within the standards established in the current legislation for overrun, soluble solids and melting.
\end{abstract}

Keywords: Salviahispanica; Edible ices; Opuntia ficus-indica.

\footnotetext{
${ }^{1}$ Bacharelado em Agroindústria, Universidade Federal de Sergipe- UFS Campus Sertão, iagoaragao7@ gmail.com

2 Professora Doutora, Núcleo de graduação em Agroindústria, Universidade Federal de Sergipe- UFS Campus Sertão, annykellyv@gmail.com
} 


\section{Introdução}

Gelados comestíveis, também denominados sorvetes, são sobremesas cujo consumo vem crescendo nos últimos anos, sobretudo aqueles modificados. Consistem em um sistema coloidal, que forma emulsão com gotículas de gordura, proteínas, ar e cristais de gelos dispersos na fase aquosa (ALMEIDA, et al. 2016).

O sorvete recebe designações diversas de acordo com sua composição ou quanto a sua técnica de fabricação e apresentação. Do ponto de vista nutricional, o sorvete é tido como um alimento completo com elevado valor nutritivo, pois além de fornecer proteínas, carboidratos, lipídeos, cálcio, fósforo e outros minerais é rico em vitaminas A, B1, B2, B6, C, D, E e K (ARBUCKLE, 1986).

O mercado brasileiro de sorvetes tem se tornado cada vez mais atrativo e a prova disso é que o país já é o sexto maior produtor mundial estando atrás dos Estados Unidos, China, Rússia, Japão e Alemanha. Segundo a Associação Brasileira das Indústrias e do Setor de Sorvetes (Abis), embora o consumo per capita ainda seja de 5,44 litros/ano a perspectiva é que este produto ganhe cada vez mais relevância na economia. Ainda de acordo com a Abis, a estimativa é que a indústria de sorvetes cresça de 3\% a 5\% em 2019. O mercado de sorvetes exige renovação constante, dinamismo e a oferta de novas opções aos consumidores (ABIS, 2019).

Os sorvetes atendem uma demanda de produtos especialmente modificados, acolhendo aos consumidores com alguma restrição alimentar, como os diabéticos e os intolerantes à lactose, além daqueles com adição de ingredientes funcionais. Esses ingredientes, por sua vez, conferem efeitos adicionais à saúde, cujas características são relativas ao papel metabólico ou fisiológico do componente sobre o crescimento, desenvolvimento, manutenção e outras funções normais do organismo humano. Dentre os ingredientes em que suas alegações de saúde têm sido estudadas destaca-se a chia, cuja ingestão resulta em efeitos benéficos à saúde, além de melhorar o valor nutritivo do produto. A chia possui alto índice de ômega 3, cálcio, fósforo, fibras, proteínas e sobretudo sua adição não tem influência nas características organolépticas do produto. Ajuda a reduzir os níveis de triglicerídeos, ótima fonte de proteína vegetal, reduz o risco de diabetes, anti-inflamatório e contém todos aminoácidos essenciais (COATES \& AYERZA, 1996).

O umbu, no entanto, é outra matéria-prima nutritiva, considerada uma fruta rica em vitamina $\mathrm{C}$, e além disso possuir um excelente sabor e aroma, apresenta também boa aparência e qualidade nutritiva, essa fruta chega a apresentar em média $68 \%$ de rendimento em polpa, podendo ser consumida in natura na forma de sucos e refrescos, bem como em sorvetes. $\mathrm{O}$ 
umbu é explorado de forma extrativista, o que constitui uma excelente fonte de renda complementar para as comunidades locais, em virtude da crescente demanda por frutos tropicais. (NEVES et al. 2005; CARVALHO et al. 2008).

A palma forrageira (Opuntia ficus-indica Mill) é uma planta típica de regiões semiáridas, cultivada principalmente para alimentação de animais em épocas de estiagem, podendo também ser utilizada na alimentação humana (BEZERRA et al., 2012). Essa planta pode ainda ser utilizada como antioxidante, agente anti-inflamatório e na prevenção de úlceras devido às suas propriedades medicinais (LEE et al., 2002).

Teixeira et al., (1999) ressalta que bem adaptada morfologicamente às intempéries do semiárido, a palma possui grande quantidade de água, é rica em resíduos minerais como cálcio, magnésio, sódio e potássio e vitaminas A, C e do complexo B, apresentando elevado teor de carboidratos solúveis além de alto coeficiente de digestibilidade da matéria seca. Vale lembrar que o reconhecimento do valor nutricional da palma tem motivado, nos últimos anos, o desenvolvimento de trabalhos, objetivando introduzir a verdura de palma na dieta alimentar do nordestino.

Adicionar ingredientes com elevado valor nutricionais, sem comprometer o sabor dos alimentos, é uma prática de relevância para se constituir uma dieta saudável. Nesse contexto a chia é particularmente interessante, pois além de melhorar o valor nutricional, é uma importante matéria-prima quando se fala em elaborar alimentos funcionais (COATES \& AYERZA, 1996). Sobretudo sua adição não tem influência nas características organolépticas do produto. Ajuda a reduzir os níveis de triglicerídeos, ótima fonte de proteína vegetal, reduz o risco de diabetes, anti-inflamatório e contém todos aminoácidos essenciais.

A obtenção de sorvetes pela mistura de leite integral, polpa de palma, polpa de umbu e semente de chia, pode resultar em um produto com qualidade nutricional e potencialmente funcional com características sensoriais atrativas. Sendo a ideia de substituir parcialmente ou totalmente o estabilizante (liga neutra) pela chia, e a adição da polpa da palma com o intuito de enriquecer o produto, mostra-se merecedora de um estudo mais aprofundado, que poderá ampliar a gama de opções de produtos a serem formulados com a adição de tais ingredientes.

\section{Metodologia}

O estudo foi desenvolvido na Universidade Federal de Sergipe - Campus do Sertão, no laboratório multidisciplinar 03, em Nossa Senhora da Glória - Sergipe. O desenvolvimento deste estudo compreendeu as seguintes fases: seleção da matéria-prima, elaboração de diferentes ensaios do sorvete e caracterização das diferentes formulações. 


\section{Material}

Para a preparação do sorvete foram utilizadas as seguintes matérias-primas: leite integral, leite em pó, açúcar, creme de leite, estabilizantes, emulsificante, polpa de umbu, polpa de palma e chia.

A palma forrageira utilizada no estudo foi proveniente da propriedade rural do próprio autor localizada no município de Nossa Senhora da Glória - Sergipe.

Os demais ingredientes foram adquiridos no comércio local da Cidade de Nossa Senhora da Glória -SE, com exceção do leite integral e do creme de leite os quais foram fornecidos pela empresa Betânia Lácteos localizada no município supracitado.

\section{Obtenção das mucilagens Mucilagem de chia}

Para a obtenção da mucilagem, as sementes foram submersas em água destilada na concentração de semente/água: 1:40 (peso:volume) e deixou-se em descanso por cerca de 90 min. Para a extração da mucilagem, que fica fortemente aderida à superfície da semente, empregou-se um mixer de $500 \mathrm{~W}$ de potência da marca Mondial, durante um período de 60 segundos. Para evitar o rompimento das sementes, as lâminas do mixer foram recobertas com fita adesivas. A mucilagem então foi separada da semente através de filtração em peneira simples (adaptado de MUNOZ, 2012).

\section{Mucilagem de palma}

Os cladódios de palma forrageira foram coletados nas primeiras horas do dia, acondicionados em bandejas plásticas e em seguida transportados até o laboratório, os cladódios foram lavados em água corrente e em seguida retirou-se, os acúleos (falsos espinhos) utilizando facas de aço inoxidável. Logo após foram imersos numa solução de hipoclorito de sódio a 100 ppm por 10 minutos e enxaguados, para a retirada do excesso de cloro. Os cladódios foram cortados e triturados em um liquidificador da marca Mondial e peneirados para a remoção dos fragmentos fibrosos e grossos. Após o processo de extração a mucilagem foi congelada (Adaptado de OLIVEIRA, 2015).

\section{Formulação do gelado comestível}

As formulações de sorvete foram elaboradas de acordo com o diagrama de produção apresentado na Figura 1 e processadas seguindo as normas de Boas Práticas de Fabricação (BPF). 
Figura 1. Diagrama de produção do sorvete.

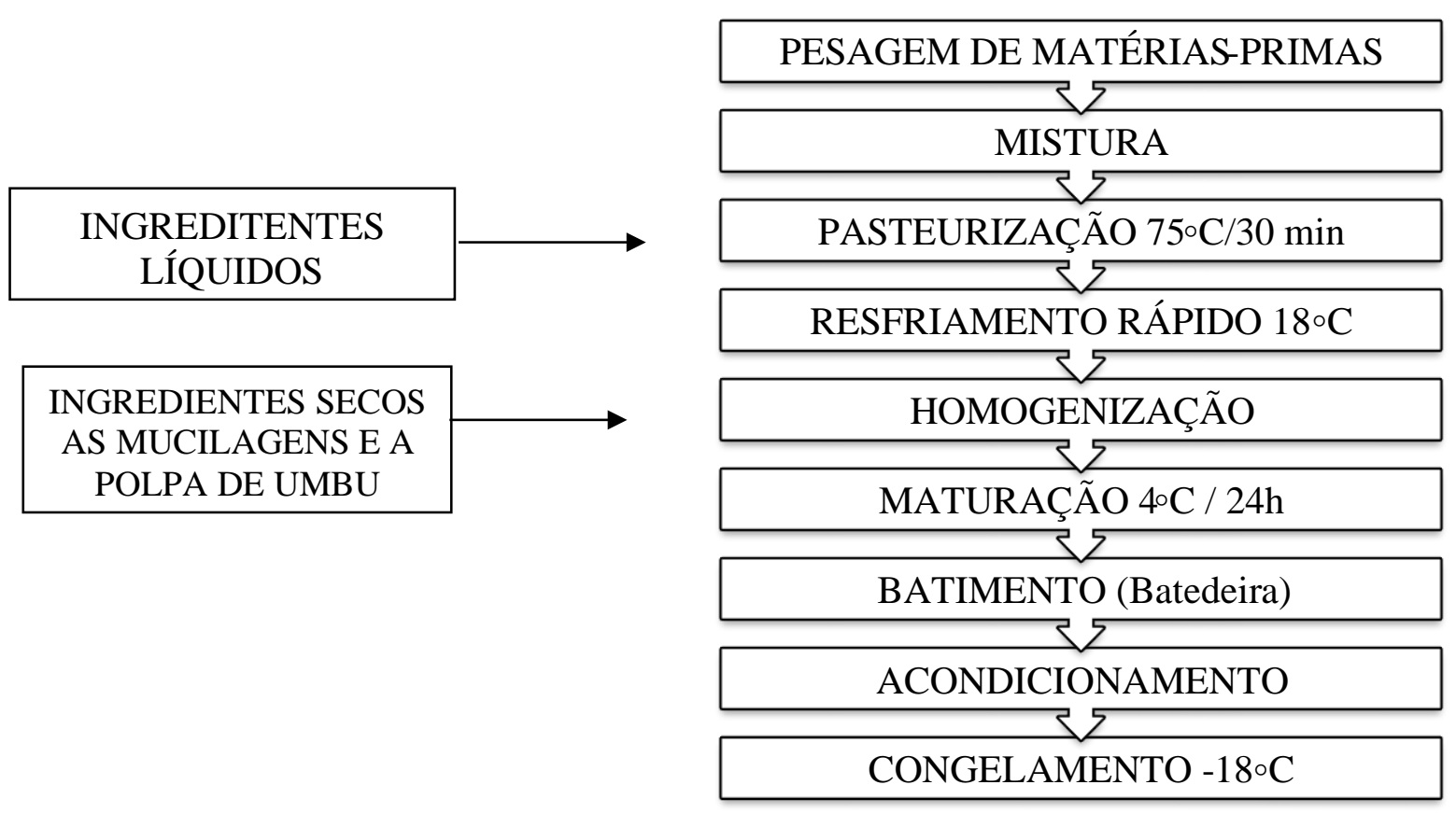

Fonte: Adaptado de Freitas, 2012.

As massas dos ingredientes foram medidas separadamente em balança digital eletrônica de precisão Sf-400. O leite e o creme de leite foram alocados em recipiente, e então pasteurizados em fogão convencional. Quando a mistura, leite e creme de leite atingiu $75^{\circ} \mathrm{C}$, a temperatura foi mantida por 15 minutos para que ocorresse a pasteurização lenta.

Após decorrido este tempo a mistura passou por um resfriamento, até que atingisse a temperatura de $18^{\circ} \mathrm{C}$, onde o recipiente da mistura foi submetido a outro recipiente contendo água gelada e gelo. Em seguida foram adicionados os ingredientes secos (leite em pó e açúcar), as mucilagens (para cada tratamento) e a polpa do umbu, e iniciou o processo de homogeneização com uso de liquidificador tradicional, por um tempo de 5 a 8 min, onde foi obtida uma calda. Logo após o processo de homogeneização a calda foi resfriada a $4^{\circ} \mathrm{C}$ por 24 h, ocorrendo a maturação.

Passado esse tempo, a calda já congelada foi submetida a batedeira junto com o emulsificante, onde ocorreu o processo de batimento por cerca de 15 minutos, para que fosse incorporado o ar e a calda então se transformasse em sorvete.

Após o sorvete pronto, o mesmo foi acondicionado em baixa temperatura $\left(-18^{\circ} \mathrm{C}\right)$ para que finalizasse o processo de congelamento, sendo mantido nesta temperatura até o momento das análises. 


\section{Planejamento experimental}

\section{Experimento inicial}

Inicialmente, utilizou-se o delineamento composto central rotacional (DCCR) $2^{2}$ (Tabela 1), foram preparadas nove diferentes formulações de sorvetes, onde misturou-se diferentes níveis das variáveis independentes "mucilagem de chia" e "mucilagem de palma". Conforme pode ser visualizado na tabela citada. O delineamento incluiu três formulações no ponto central $(0,0)$ para que fosse possível estimar a falta de ajuste dos modelos preditivos calculados.

Os limites inferiores e superiores das variáveis independentes mucilagem de chia e mucilagem de palma utilizados no experimento foram definidos com base nos estudos de Campos et al. (2015), Fukase (2017), Bernardino-Nicanor et al. (2015), Medina-Torres et al., (2003).

Tabela 1. Matriz do delineamento experimental utilizado para formulação do sorvete, com os valores reais e codificados das variáveis independentes.

\begin{tabular}{ccccc}
\hline Tratamentos & \multicolumn{2}{c}{ Variáveis codificadas } & \multicolumn{2}{c}{ Variáveis descodificadas } \\
\hline $\mathbf{1}$ & $\begin{array}{c}\text { Mucilagem de } \\
\text { Chia }\end{array}$ & $\begin{array}{c}\text { Mucilagem } \\
\text { de Palma }\end{array}$ & $\begin{array}{c}\text { Mucilagem de } \\
\text { Chia }(\%)\end{array}$ & $\begin{array}{c}\text { Mucilagem de } \\
\text { Palma (\%) }\end{array}$ \\
\hline $\mathbf{2}$ & -1 & -1 & 0,87 & 0,87 \\
\hline $\mathbf{3}$ & -1 & 1 & 2,13 & 0,87 \\
\hline $\mathbf{4}$ & 1 & -1 & 0,87 & 2,13 \\
\hline $\mathbf{5}$ & 1 & 1 & 2,13 & 2,13 \\
\hline $\mathbf{6}$ & $-1,4142$ & 0 & 0,00 & 1,50 \\
\hline $\mathbf{7}$ & 1,4142 & 0 & 3,00 & 1,50 \\
\hline $\mathbf{8}$ & 0 & $-1,4142$ & 1,50 & 0,00 \\
\hline $\mathbf{9}$ & 0 & 1,4142 & 1,50 & 3,00 \\
\hline $\mathbf{1 0}$ & 0 & 0 & 1,50 & 1,50 \\
\hline $\mathbf{1 1}$ & 0 & 0 & 1,50 & 1,50 \\
\hline $\mathbf{1 2}$ & LIGA NEUTRA & & 1,50 & 1,50 \\
\hline & & & & \\
\hline & & 0 & & \\
\hline
\end{tabular}

\section{Análises físico-químicas}

Foram realizadas análises em triplicata de acidez titulável $\left({ }^{\circ} \mathrm{D}\right)$, potencial hidrogeniônico $(\mathrm{pH})$ e sólidos solúveis $\left({ }^{\circ} \mathrm{Brix}\right)$, seguindo a metodologia preconizados pelas 
Normas Analíticas do Instituto Adolfo Lutz (2008). As formulações elaboradas também foram analisadas quanto à taxa de derretimento e overrun, de maneira adaptadas (SOLER \& VEIGA 2001).

O teor de acidez foi expresso em porcentagem (\%) de ácido láctico e os testes foram realizados por titulação, com a utilização de hidróxido de sódio e fenolftaleína.

$\mathrm{O} \mathrm{pH}$ das amostras foi determinado por phmetro digital de bancada previamente calibrado com solução tampão, indicando um valor preciso a temperatura ambiente.

O teor de sólidos solúveis foi determinado pelo uso de um refratômetro. As amostras foram inseridas em pequenas quantidades no equipamento e realizadas a leitura, contendo o resultado em grau Brix seguindo o método descrito pelo instituto Adolfo Lutz (2008).

Para indicar o ponto de derretimento foi utilizado a adaptação da metodologia de Granger et al. (2005). Em uma balança analítica, foi pesado aproximadamente $50 \mathrm{~g}$ de cada formulação em uma tela com abertura de $0,2 \mathrm{~cm}$ disposta sobre um béquer de vidro, na qual a amostra foi colhida à medida que ocorria o derretimento. Desta forma foram realizadas pesagens do sorvete a cada 10 minutos no período de 50 minutos. Para a realização do experimento, as condições de temperatura foram mantidas idênticas $\left(19^{\circ} \mathrm{C}\right)$, para as formulações, com o intuito de tornar mínima sua influência sobre o derretimento e consequentemente sob os resultados finais.

Para determinação do overrun foi empregada a equação descrita por Soler \& Veiga (2001), conforme apresentado abaixo:

\section{$\%$ OVERRUN $=$ VOLUME DO SORVETE - VOLUME DA CALDA $* 100$ VOLUME DA CALDA}

\section{Análises físico e físico-químicas iniciais}

Para as formulações iniciais elaboradas, foram analisadas as propriedades físico e físicoquímicas. A partir dos resultados obtidos, foram selecionadas as 5 formulações que apresentaram melhores índices de overun, sólidos solúveis e derretimento, para a condução da pesquisa, foram elas (Tabela 2): 
Tabela 2. Formulações selecionadas quanto às características de sólidos solúveis, overrun e derretimento.

Tratamentos Mucilagem de Chia Mucilagem de Palma *Citação no texto

(g)

(g)

\begin{tabular}{cccc}
\hline $\mathbf{1}$ & 42,6 & 17,4 & $\mathrm{C}+\mathrm{P}-$ \\
\hline $\mathbf{2}$ & 17,4 & 42,6 & $\mathrm{C}-\mathrm{P}+$ \\
\hline $\mathbf{3}$ & 0,00 & 30,0 & $\mathrm{P}$ \\
\hline $\mathbf{4}$ & 30,0 & 0,00 & $\mathrm{C}$ \\
\hline $\mathbf{5}$ & 0,00 & 0,00 & Controle
\end{tabular}

*C+P-: Maior quantidade de chia e menor de palma; C-P+: Maior quantidade de palma e menor de chia; $\mathrm{P}$ : Apenas palma; C: Apenas chia; C: Controle

Depois da seleção das melhores formulações, foi elaborado um delineamento estatístico inteiramente casualizado (DIC), com 5 tratamentos e 3 repetições, em que novamente as análises: acidez titulável, potencial hidrogeniônico $(\mathrm{pH})$ e sólidos solúveis, overrun e derretimento foram aplicadas.

\section{Análise estatística}

Os dados obtidos foram analisados com o auxílio do programa estatístico SISVAR e do Software LIBRIOFFICE 6.1. O teste ANOVA (nível de significância de 5\%), foi usado com o intuito de averiguar se houve diferença significativa entre as amostras. O teste de Tukey foi aplicado, para indicar as diferenças entre as médias.

\section{Resultados e Discussão}

\section{Análises físico-químicas e físicas Determinação de acidez}

De acordo com o Instituto Adolfo Lutz (2008), a análise de acidez titulável gera dados fundamentais do estado de conservação de um produto alimentício. Nessa pesquisa, o índice de acidez, foi maior para a formulação controle, porém na formulação 2, onde se utilizou maior quantidade de palma que de chia, o valor de acidez também esteve elevado. Tal parâmetro em sorvetes pode ser influenciado pela composição da mistura, ou seja, pela adição de leites de diferentes origens e pela utilização de frutas na formulação (GANDOLFI \& MULLER, 2014). Não existe legislação no momento, com valores de referência para a acidez titulável em sorvetes, porém as indústrias utilizam a acidez do leite como um dos parâmetros para o controle da matéria-prima (BRASIL, 2005). 
Tabela 3. Médias da acidez nas formulações de sorvete

\begin{tabular}{ccc}
\hline Tratamentos & *Formulações & Acidez \\
\hline $\mathbf{1}$ & $\mathrm{C}+\mathrm{P}-$ & $0.400 \mathrm{bc}$ \\
\hline $\mathbf{2}$ & $\mathrm{C}-\mathrm{P}+$ & $0.406 \mathrm{~b}$ \\
\hline $\mathbf{3}$ & $\mathrm{P}$ & $0.386 \mathrm{bc}$ \\
\hline $\mathbf{4}$ & $\mathrm{C}$ & $0.383 \mathrm{c}$ \\
\hline $\mathbf{5}$ & Controle & $0.663 \mathrm{a}$
\end{tabular}

*C+P-: Maior quantidade de chia e menor de palma; C-P+: Maior quantidade de palma e menor de chia; P: Apenas palma; C: Apenas chia; C: Controle

Se considerar a acidez do leite entre 0,14 e 0,18 g de ácido lático em $100 \mathrm{~mL}$, os valores obtidos para as cinco formulações foram superiores, conforme estabelecido na Instrução Normativa $n^{\circ}$. 76/2018 (BRASIL, 2018). Silva (2013) elaborou um sorvete de umbu (Spondias tuberosa) e Umbu Cajazeira (Spondias sp), e reportou valores superiores aos estabelecidos pela IN $n^{\circ} .76 / 2018$, de 0,39\% ácido lático para o umbu e 0,60 \% de ácido lático para o umbu cajá resultados semelhantes aos encontrados nesta pesquisa. Pinto (2017), desenvolveu um sorvete a base de polpa de mandacaru e xique-xique que são cactáceas como a palma, e encontrou valores médios entre 0,21 a 0,32 .

Gandolf (2014) elaborou um sorvete com chia e mel e obteve resultados que variaram entre 0,12 a 0,126 (\% ácido lático), bem inferiores aos encontrados nesta pesquisa, o que reforça a ideia que a acidez do produto se dá pela escolha da matéria prima, já que o mel não se classifica como um produto de alta acidez. Os resultados aqui obtidos foram superiores, em todas as formulações, aos encontrados na literatura e nas normativas, o que certamente se deve ao fato do fruto do umbu assim como as frutas do gênero spondias, possuir alta acidez o que resultou em produtos com características ácidas.

\section{Determinação do Potencial hidrogeniônico (pH)}

O potencial hidrogeniônico das formulações de sorvete foram próximos a neutralidade em média 5,05. (Tabela 4)

Tabela 4. pH médio nas formulações de sorvete

\begin{tabular}{ccc}
\hline Tratamentos & *Formulações & $\mathrm{pH}$ \\
\hline $\mathbf{1}$ & $\mathrm{C}+\mathrm{P}-$ & $5,030 \mathrm{bc}$ \\
\hline $\mathbf{2}$ & $\mathrm{C}-\mathrm{P}+$ & $5,013 \mathrm{c}$ \\
\hline $\mathbf{3}$ & $\mathrm{P}$ & $5,070 \mathrm{ab}$ \\
\hline $\mathbf{4}$ & $\mathrm{C}$ & $5,086 \mathrm{a}$ \\
\hline $\mathbf{5}$ & Controle & $5,080 \mathrm{ab}$ \\
\hline
\end{tabular}

*C+P-: Maior quantidade de chia e menor de palma; C-P+: Maior quantidade de palma e menor de chia; P: Apenas palma; C: Apenas chia; C: Controle 
$\mathrm{O}$ pH dos sorvetes analisados tiveram uma variação de 5,013 a 5,086 e apresentaram semelhança significativa em todos os tratamentos $(\mathrm{p}<0,05)$, exceto entre as formulações 2 (maior conteúdo de palma) e 4 (só chia na formulação) as quais apresentaram respectivamente o menor e o maior índice de pH nas amostras (Tabela 4). No Brasil a legislação no 266 de 2005 não menciona valores de pH como referência para sorvetes (BRASIL, 2005).

Fidelis et al. (2015) elaborou um sorvetes de Mandacaru (Cereus jamacaru) e Figo da Índia (Opuntia fícus indica L. Mill), e encontrou um valor de 3,09, no entanto os valores de pH encontrados nesta pesquisa foram maiores, já quando comparados com os valores encontrados na pesquisa de Pinto (2017) onde o autor elaborou um sorvete de polpa de mandacaru e xiquexique e obteve valores de $\mathrm{pH}$ variando de 5,8 a 6,19, os valores de $\mathrm{pH}$ obtidos aqui foram menores. Certamente a elevação do $\mathrm{pH}$ das amostras se dá ao fato de que a polpa de umbu congelada, como a utilizada neste estudo, possui um pH em torno de $(4,34)$ (RODRIGUES, et al. 2010).

$\mathrm{Na}$ literatura não foi encontrado pesquisas que relatem o uso de chia e palma em sorvetes, o que impossibilita confirmações de outros estudos. Porém através desse estudo e de pesquisas sobre as duas matérias primas mencionadas, foi possível observar que tanto a palma quanto a chia influenciam no pH do sorvete. Gusmão (2016) encontrou na mucilagem de chia valor de pH de 7,06 e a palma de acordo com Queiroz (2020) possui um pH de 4,46.

\section{Determinação dos sólidos solúveis (SS)}

A quantidade de sólidos solúveis (SS) entre todas as formulações não diferiu estatisticamente entre si (Tabela 5).

Tabela 5. Médias da análise de Sólidos solúveis (SS) nas Formulações de sorvete

\begin{tabular}{ccc}
\hline Tratamentos & *Formulações & Sólidos solúveis $\left({ }^{\circ}\right.$ Brix $)$ \\
\hline $\mathbf{1}$ & $\mathrm{C}+\mathrm{P}-$ & $35.6 \mathrm{a}$ \\
\hline $\mathbf{2}$ & $\mathrm{C}-\mathrm{P}+$ & $35.3 \mathrm{a}$ \\
\hline $\mathbf{3}$ & $\mathrm{P}$ & $35.3 \mathrm{a}$ \\
\hline $\mathbf{4}$ & $\mathrm{C}$ & $36.0 \mathrm{a}$ \\
$\mathbf{5}$ & Controle & $35,0 \mathrm{a}$
\end{tabular}

*C+P-: Maior quantidade de chia e menor de palma; C-P+: Maior quantidade de palma e menor de chia; P: Apenas palma; C: Apenas chia; C: Controle

Certamente, esses valores encontrados nas formulações estudadas se devem, às várias fontes de açúcar encontradas no produto, como o açúcar adicionado como parte da receita, o açúcar da polpa de umbu, e do o açúcar do leite. Em relação à legislação, todas as formulações 
apresentaram valores acima do mínimo estabelecido pela legislação vigente que é de $28 \%$ (BRASIL, 2005).

Os sólidos solúveis (SS) obtidos nesta pesquisa foram superiores aos valores observados no estudo de Fidelis et al. (2015), que produziram sorvetes e iogurtes a partir dos frutos de figo da índia e mandacaru e encontraram um índice de 21,66 ${ }^{\circ}$ Brix. Clarke (2005) reportou que os teores de sólidos solúveis em sorvetes convencionais elaborados com leite variam de $28 \%$ a $40 \%$, que corrobora com os valores encontrados neste estudo.

\section{Análises físicas}

\section{Overrun}

As formulações contendo as mucilagens de chia e palma apresentaram comportamento de overrun semelhantes (superior a 50\%). As formulações F1 e F4, que utilizavam mais chia na preparação, apresentaram um rendimento próximo da formulação controle F5, enquanto aquelas formulações com maior quantidade de palma apresentaram menor rendimento quando comparados as outras (Figura 2). O overrun é considerado uma das etapas mais importantes da elaboração de sorvetes, pois o mesmo influencia diretamente na sua qualidade e no rendimento (SOLER, 2001).

De acordo com a Resolução RDC n ${ }^{\circ} 266$, de 22 de setembro de 2005, os sorvetes podem conter no máximo $110 \%$ de ar incorporado no produto, não havendo um mínimo exigido (BRASIL, 2005). Dessa maneira, os sorvetes elaborados estão dentro do padrão estabelecido pela legislação vigente.

Figura 2- Taxa de rendimento do sorvete

\section{Rendimento do sorvete (\%)}

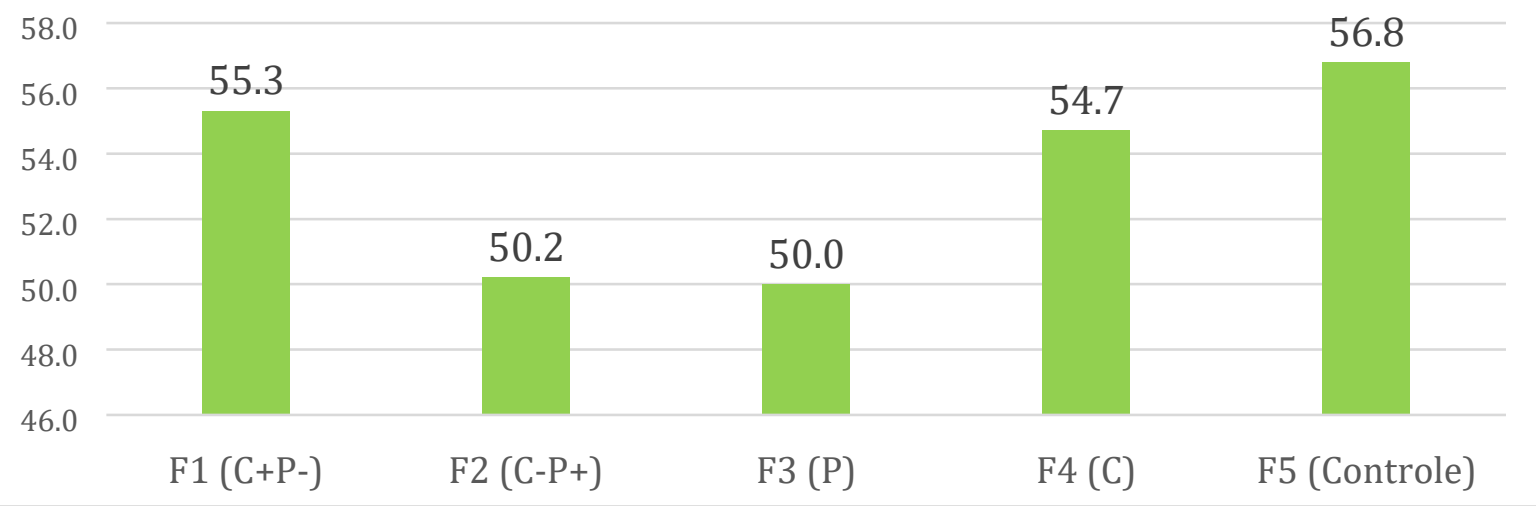

*C+P-: Maior quantidade de chia e menor de palma; C-P+: Maior quantidade de palma e menor de chia; $\mathrm{P}$ : Apenas palma; C: Apenas chia; C: Controle 
Os sorvetes comerciais geralmente possuem uma incorporação de ar em torno de 60 a 100\% (FELLOWS, 2006), assim a utilização do estabilizante natural em substituição ao industrial apresentou resultados satisfatórios, tendo em vista que as formulações: F1 contendo (42,6 g de chia e 17,4 g de palma) e F4 contendo (30 g de chia) apresentaram índices de overrun próximo da média comercial. Além disso, a baixa incorporação de ar, quando comparada com os sorvetes comerciais, é comum em formulações artesanais (FREELAND-GRAVES \& PECKHAN 1996).

\section{Determinação da Taxa de Derretimento}

A taxa de derretimento das formulações de sorvetes estão apresentados na Figura 3. De acordo com Soler (2001), o sorvete drenado deve-se formar um líquido homogêneo com boa fluidez, com pouca espuma e apresentar a aparência do sorvete antes do congelamento.

Figura 3 - Taxa de derretimento do sorvete

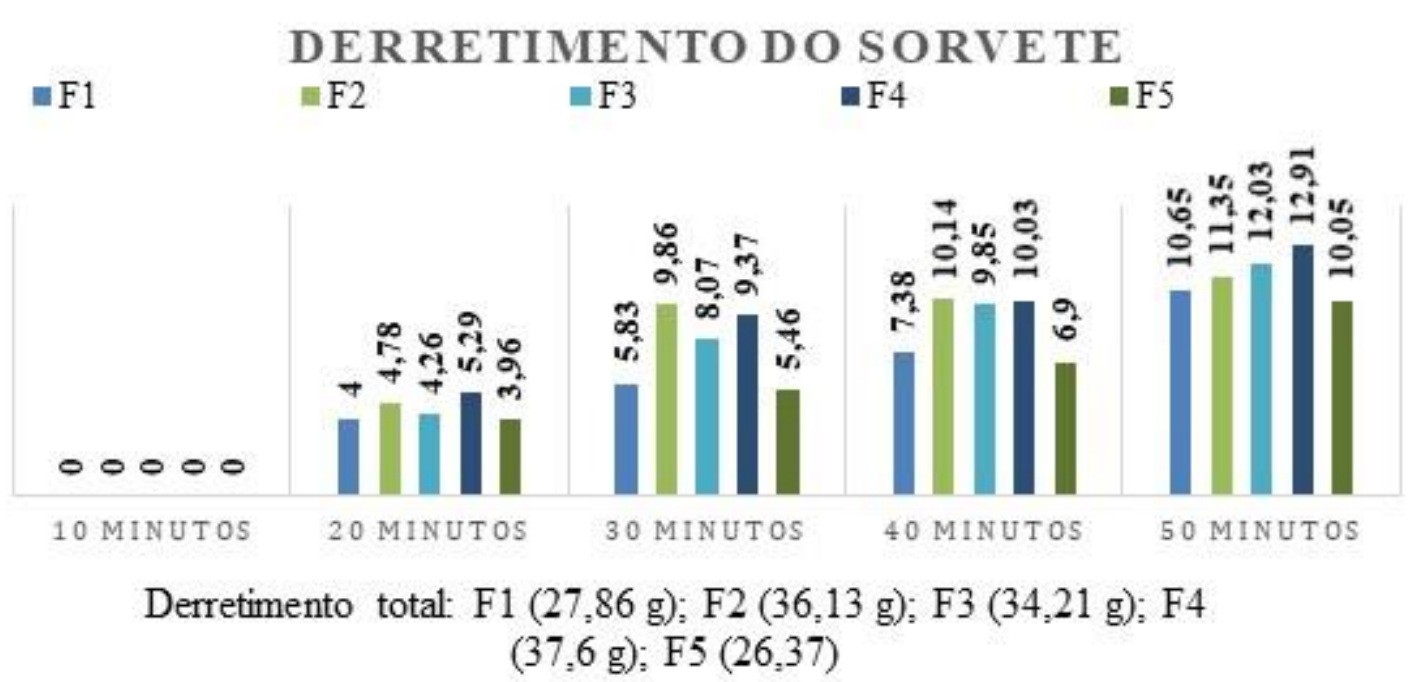

*F1-: Maior quantidade de chia e menor de palma; F2: Maior quantidade de palma e menor de chia; F3: Apenas palma; F4: Apenas chia; F5: Controle

Ao final da avaliação, a formulação que mais derreteu (50 min) foi a F4 (contendo apenas a mucilagem de chia), sendo a taxa de derretimento de 75,2\%, equivalente a 37,6g. Enquanto a formulação controle F5 (liga neutra) teve um derretimento de 26,37g do sorvete derretido, um percentual de 52,72\%.

Comparando as formulações F1, F2, F3 e F4, contendo as mucilagens de chia e palma com a formulação controle $\mathrm{F} 5$, podemos dizer que a formulação que se apresentou melhor foi a formulação F1 (42,6g de chia, 17,4g de palma), a qual teve um derretimento de 27,86g, um percentual de $55,72 \%$ próximo da formulação controle. 
Através do exame visual dos sorvetes durante a análise, foi possível perceber que não ocorreu derretibilidade total no tempo máximo estipulado (50 minutos). De acordo com o estudo de Soller e Veiga (2001) pode estar associado a quantidade de estabilizante empregado na formulação, neste caso representado pela mucilagem de chia e mucilagem de palma.

Sepúlveda et al., (2007) destacaram que a Opuntia spp. pode ser considerada uma fonte potencial de polissacarídeos (mucilagem) que poderiam ser aproveitadas como hidrocoloide pela indústria de alimentos. Damodaran (2007) menciona em seu estudo que ao adicionar hidrocolóides aos sorvetes esses retardam a taxa de desenvolvimento dos cristais de gelo, devido à elevação da viscosidade da fase líquida, desenvolvendo uma rede tridimensional o que diminui a mobilidade da água. Assim os sorvetes elaborados com a mucilagem de palma e chia apresentaram boa estabilidade, haja visto que os primeiros gotejamentos de todas as amostras ocorreram aos 20 minutos. Sendo este o tempo ideal para o início do derretimento em temperatura ambiente (SOLER, 2001).

\section{Conclusões}

A aplicação da mucilagem de chia e da palma na elaboração do sorvete de umbu se mostra viável por apresentarem resultados satisfatórios quanto à estabilidade do sorvete.

O sorvete elaborado neste estudo apresentou características físicas e físico-químicas adequadas. Haja vista, que os resultados obtidos estão dentro dos padrões estabelecidos na legislação vigente para overrun e sólidos solúveis.

A formulação que possui maior proporção de chia e menor de palma (Formulação 1), apresentou índice de overrun próximo ao controle, bem como próximo dos padrões comerciais.

Com base nos resultados obtidos neste estudo, pode-se afirmar que as mucilagens de chia e palma podem ser utilizadas como estabilizantes na fabricação de sorvetes, tendo em vista que o sorvete elaborado nesta pesquisa apresentou índices satisfatórios quanto ao rendimento e derretimento.

Dessa forma, a partir dos resultados, afirma-se que os sorvetes elaborados com mucilagem de palma e chia apresentam potencial, e deve ser explorado regionalmente valorizando matérias-primas regionais como a palma e o umbu.

\section{Recomendações}

Por ser um sorvete inovador, recomenda-se que diversos aspectos sejam melhorados, dessa maneira indica-se que sejam feitas mais análises do produto, a fim de avaliar outras características, aplicando para isso análises complementares, como as instrumentais de textura 
e plasticidade; viscosidade; avaliação de fibra alimentar; testes de composição proximal e avaliação sensorial, onde pode ser obtido resultados que incluem atributos como: Sabor, Textura, e Cor.

\section{Referências}

AOAC.ASSOCIATION OF OFFICIAL ANALYTICAL CHEMISTS.Oficial methods of analysis.16. Ed., Arlington.937p.

AOAC.ASSOCIATION OF OFFICIAL ANALYTICAL CHEMISTS.Oficial methods of analysis.18. Ed., Washington, 2005.

AUGUSTO, M. M. M.; FONTANA, C. V.; PADILHA, E.; RODRIGUES, A. P.; SILVESTRINI, M. Elaboração de sorvete sabor chocolate com teor de gordura reduzido utilizando soro de leite em pó. Rio Grande, 2006. Disponível em: https://periodicos.furg.br/vetor/article/viewFile/296/87. Acesso em: 27 ago. 2019.

BRASIL. Agência Nacional de Vigilância Sanitária - Anvisa. Resolução RDC n 267, de 25 de setembro de 2003 - Regulamento Técnico para Gelados Comestíveis e Preparos para Gelados Comestíveis, 2003.

BEZERRA, J. D; SANTOS, M. G; SVEDESE, V. M; LIMA, D. M; FERNANDES, M. J; PAIVA, L. M; MOTA, C. M. Richness of endophytic fungi isolated from Opuntia ficus-indica Mill. (Cactaceae) andpreliminaryscreening for enzyme production. World

Journal.Microbiol.Biotechnol.v. 28, p. 1989-1995, 2012.

BRASIL. Agência Nacional de Vigilância Sanitária - Anvisa. Portaria $n^{\circ}$ 266, de 22 de setembro de 2005- Regulamento Técnico para Gelados Comestíveis e Preparos para Gelados Comestíveis, 2005.

CARVALHO, P. C. L.; RITZINGER, R.; SOARES FILHO, W. S.; LEDO, C. A. S. Características morfológicas, físicas e químicas de frutos de populações de umbu cajazeira no estado da Bahia. Revista Brasileira de Fruticultura.140-147. 2008.

CLARKE, C. The Science of ice cream. Cambrige: Royal Society of Chemistry, 2004.

DAMODARAN, S. Inhibition of ice crystalgrowth in ice cream mix by gelatinhydrolysate. Journal of Agricultural and Food Chemistry. v. 55, p. 10918- 10923, 2007.

FELLOWS, Tecnologia do processamento de alimentos: princípios e prática. Porto Alegre: Artmed, 2006.

FERREIRA, J. C., CAVAlCANTI-MATA, M. E. R. M., BRAGA, M. E. D. Cinética de congelamento de polpa de umbu a duas temperaturas criogênicas In: Congresso Latino americana y del Caribe de Ingenieria Agrícola, 2000, Irapuato. Anais, 2000. 
FIDELIS. V. R. de L., PEREIRA. E. M., SILVA.W. P, GOMES. J. P., SILVA. L. A. Produção de sorvetes e iogurtes a partir dos frutos figo da índia e mandacaru. Revista Verde (Pombal PB - Brasil), VOL. 10. p. 17 - 21, 2015.

FREITAS, Aline. DESENVOLVIMENTO DE UM SORVETE DE ABACATE COM CALDA DE BANANA. 2012. $41 \mathrm{f}$. TCC (GRADUAÇÃO)- Curso de Tecnologia em Alimentos, Universidade Tecnológica Federal do Paraná, Ponta Grossa, 2012.

FREELAND-GRAVES, J. H.; PECKHAM, G. C. Foundations of Food Preparation.6. ed. New Jersey: Prentice-Hall, 1996.

GANDOLFI, Angela Maria Copini; MÜLLER, Terezinha Poposki. Elaboratingan ice cream addedwithhoneybee and Chia. 2014. 41 f. Trabalho de Conclusão de Curso (Graduação) Curso Superior de Tecnologia em Alimentos. Universidade Tecnológica Federal do Paraná. Francisco Beltrão, 2014.

GIULIETTI, A. M.; HARLEY, R. M.; QUEIROZ, L. P.; BARBOSA, M. R. V.; NETA, A. L. B.; FIGUEIREDO, M. A. Espécies endêmicas da caatinga. In: SAMPAIO, E.V.S.B.; GRANGER, C.; LEGER, A.; BAREY, P.; LANGENDORFF, V.; CANSELL, M. Influence of formulation on the structural networks in ice cream. InternationalDairy Journal, Barking, Inglaterra, v. 15, n. 3, p. 255-262, 2005.

GUSMÃO, Roberto da Silva. MÉTODOS EXTRATIVOS DE MUCILAGEM DE SEMENTE DE CHIA (Sálvia hispânica) PARA POTENCIAL USO EM OFTALMOLOGIA. 2016. 68 f. Dissertação (Mestrado) - Curso de Oftalmologia e Ciências Visuais, Unifesp - Universidade Federal de São Paulo, São Paulo, 2016.

LEE, J. C; et al. Antioxidant property of an ethanol extract of the stem of Opuntiaficusindicavar.saboten. Journal Agriculture Food Chemistry, n. 50, p. 6490-6496, 2002.

MUÑOZ, L. A. AGUILERA, J. M. RODRIGUEZ-TURIENZO, B. L.; COBOS, A, A.; DIAZ, A, O. Caracterization and microstructure of films made from mucilage of Salvia hispânica and whey protein concentrate. Journal of Food Engineering, v.111, p.511-518. 2012.

PINTO, Mirella. DESENVOLVIMENTO DE SORVETE À BASE DE POLPA DE MANDACARU E XIQUEXIQUE. 2017. 46 f. Dissertação (Graduação) - Instituto Federal de Educação e Tecnologia do Piaui, Teresina- Pi, 2017

REINOLDS, S. G.; ARIAS, E.; General background on Opuntia. Disponível em:<http://www.fao.org/ DOCREP /005/2808E/y2808e04.htm> Acesso em 26 de ago. 2019.

RODRIGUES, F. F. G.; NASCIMENTO, E. M. M.; FURTADO, C. A. N.; COSTA, J. G.M.. Análise físico-química de espécies de spondias oriundas do cariri cearense. Caderno de Culturas e Ciência. Vol. 1-Nº 2. 2010

SANTOS, C.A.F. Dispersão da variabilidade genética do umbuzeiro no semiárido brasileiro. Pesquisa Agropecuária Brasileira, v. 32, n. 6, p. 923-930, 1997. 
SEPÚLVEDA, E.; SÁENZ, C.; ALIAGA, E.; ACEITUNO, C. Extraction and characterization of mucilage in Opuntia spp. Journal of Arid Environments, v. 68, p. 534- 545, 2007.

SILVA. A. O. Elaboração de Sorvete e iogurte de leite de cabra com frutos do semiárido. Pág. 49. 2013.

SOLER, M. P. Sorvetes. Instituto de Tecnologia de Alimentos. Centro de Informação em Alimentos: Campinas, 2001, p. 36 e 37

SUDENE. Benefícios da cultura da palma. Disponível em: http://www.sudene.gov.br/redepalma/beneficios-da-cultura-da-palma. Acesso em: 29 de ago. 2019.

TECNOLOGIA DE ALIMENTOS. Disponível em: <http://tecalim.vilabol.uol.com.br/index.html>. Acesso em: 12.abr.2012.

TEIXEIRA, J. C; EVANGELISTA, A. R; PEREZ, J. R; TRINDADE, I. C. M; MORON, I. R. Cinética da digestão ruminal da palma forrageira (Nopalea cochenillifera (L.) Lyons-

Cactaceae) EM BOVINOS E CAPRINOS. Ciênc. e Agrotec, Lavras - Mg, v. 23, n. 1, p.179186,1999. Anual.

VALENTIM, Karina C.; SANTOS, Scheila C. Desenvolvimento de sorvete de baixa lactose com polpa de morango orgânico. Ponta Grossa, 2012. 


\title{
CAPÍTULO 34: PERFIL DOS CONSUMIDORES DE KOMBUCHA
}

\section{CHAPTER 34: PROFILE OF KOMBUCHA CONSUMERS}

\author{
Sonara de França Sousa ${ }^{1}$; Larissa Nunes Torres²; Williames Fabio de Souza Bezerra Filho ${ }^{3}$; Maria Clara Leal \\ Bezerra Barros ${ }^{4}$
}

\begin{abstract}
Resumo
Objetivou-se com o presente trabalho caracterizar o perfil dos consumidores de kombucha por meio de um questionário online. O questionário continha 13 perguntas de múltipla escolha relacionadas aos aspectos socioeconômicos e ao padrão de consumo, tais como: se fazem o uso de bebidas alcoólicas; a frequência e o tipo de bebida mais consumida; se conhecem uma bebida probiótica; se já ouviram falar sobre kombucha; se já consumiram e sabem dos benefícios associados à esta bebida; se conhecem o processo de fabricação da kombucha e se a mesma é comumente encontrada no mercado de sua região. De acordo com os resultados obtidos, os respondentes são em sua maioria mulheres, entre 21 e 30 anos, apresentam pós-graduação e renda mensal entre 1 e 2 salários mínimos. A maioria dos participantes fazem o uso de álcool $(66,4 \%)$ ao menos uma vez por semana, sendo a cerveja a bebida mais consumida $(55,7 \%)$. A maioria dos respondentes afirmaram saber o que é uma bebida probiótica e conhecerem os benefícios associados à kombucha, no entanto, essa bebida não apresenta uma disponibilidade no mercado consumidor $(79,77 \%)$ apesar de se mostrar bastante promissora no segmento de alimentos funcionais.
\end{abstract}

Palavras-Chave : bebidas probióticas, mercado consumidor, saúde.

\begin{abstract}
The objective of this study was to characterize the profile of kombucha consumers through an online questionnaire. The questionnaire contained 13 multiple-choice questions related to socioeconomic aspects and consumption patterns, such as: whether they use alcoholic beverages; the frequency and type of drink most consumed; if they know a probiotic drink; if you've heard of kombucha; if they have already consumed and know the benefits associated with this drink; the kombucha manufacturing process is known and whether it is commonly found in the market in your region. According to the results obtained, the respondents are mostly women, between 21 and 30 years old, have postgraduate studies and monthly income between 1 and 2 minimum wages. Most participants use alcohol (66.4\%) at least once a week, with beer being the most consumed beverage (55.7\%). Most respondents stated that they know what a probiotic drink is and know the benefits associated with kombucha, however, this drink does not have an availability in the consumer market (79.77\%) despite being very promising in the functional food segment.
\end{abstract}

Keywords: probiotics drinks, consumer market, health.

1Doutora em Engenharia de Processos, Universidade Federal do Agreste de Pernambuco, sonara_franca@yahoo.com.br

2Engenharia de Alimentos, Universidade Federal de Agreste de Pernambuco, larissan.torres159@ gmail.com

3Engenharia de Alimentos, Universidade Federal de Agreste de Pernambuco, williamesfabio_2001@outlook.com

4Engenharia de Alimentos, Universidade Federal do Agreste de Pernambuco, mclaraleal.engalimentos@gmail.com 


\section{Introdução}

De acordo com a Portaria $\mathrm{n}^{\circ} 103$, de 20 de setembro de 2018, a kombucha é definida como sendo uma bebida gaseificada, não pasteurizada, obtida através da respiração aeróbica e fermentação anaeróbica de um mosto composto de infusão de origem vegetal e açúcares por um consórcio de bactérias e leveduras simbióticas microbiologicamente ativas, resultando em uma bebida ácida e doce (BRASIL, 2018).

Segundo Santos (2016), essa bebida era produzida há cerca de 221 anos a.C e conhecida popularmente como o "chá da imortalidade". A origem da kombucha é incerta e acredita-se que tenha surgido no nordeste da China, mais precisamente em Manchúria, já a origem do seu nome veio devido a um médico que se chamava Kombu e que levou a bebida da Coréia para o Japão para curar problemas digestivos de um Imperador e daí o nome "Kombu Chá" ou "Chá de Kombu".

Desde o seu descobrimento, existem relatos demonstrando que essa bebida pode auxiliar na redução do risco de doenças crônicas e também possui propriedades curativas, porém só na última década é que se observou uma explosão em sua popularidade, principalmente em países como os Estados Unidos, que atualmente possui um mercado bem estabelecido para esse produto (SANTOS, 2016). Já no cenário nacional, a kombucha é produzida de forma artesanal, por pessoas que se interessaram em desenvolver a bebida em casa, e só há cerca de 3 anos, indústrias de pequeno porte começaram a produzir a bebida para venda em mercados regionais. A kombucha tem sido bem aceita pelos consumidores, especialmente como alternativa ao refrigerante por ser gaseificada, conter baixo teor de açúcar e poucas calorias (CITRUS, 2018).

Diante disso, objetivou-se com o presente trabalho caracterizar o perfil dos consumidores de kombucha por meio de um questionário online, visando obter informações sobre seus hábitos, motivações, conhecimento e disponibilidade da bebida no mercado local.

\section{Material e Métodos}

Essa pesquisa foi realizada por meio de um questionário online elaborado na plataforma Google ${ }^{\circledR}$ Forms, compartilhado nas redes sociais via link a um grupo de 262 pessoas que se autodeclaram serem maiores de 18 anos.

O questionário continha 13 perguntas de múltipla escolha relacionadas aos aspectos socioeconômicos dos respondentes (gênero, faixa etária, escolaridade e renda mensal) e ao padrão de consumo, tais como: se fazem o uso de bebidas alcoólicas, a frequência do uso de bebidas alcoólicas e o tipo de bebida mais consumida, sendo estas duas últimas perguntas respondidas apenas pelos os que afirmaram fazer o uso de álcool. 
Todos os participantes responderam ainda se eles conheciam o conceito de uma bebida probiótica, se já ouviram falar em kombucha, se já consumiram a kombucha e sabiam dos benefícios associados à esta bebida, se conhecem o processo de fabricação da kombucha e se a mesma é comumente encontrada no mercado de sua região.

Os dados obtidos foram dispostos em uma planilha eletrônica em forma de banco de dados (Excel for Windows), analisados quantitativamente e os resultados dispostos em forma de gráficos, sendo discutidos conforme os tópicos pesquisados.

\section{Resultados e Discussão}

De acordo com os resultados apresentados nas Figuras 1, 2, 3 e 4, a maioria dos indivíduos eram do sexo feminino (82,10\%), com faixa etária entre 21 e 30 anos (40,5\%), nível de escolaridade pós-graduação $(33,6 \%)$ e apresentavam renda mensal entre 1 e 2 salários mínimos $(31,3 \%)$.

$\mathrm{Na}$ literatura disponível não foi encontrado trabalhos relacionados aos perfis dos consumidores de kombucha, sendo os dados comparados à outros tipos de bebidas, como por exemplo, Yassin (2019), analisando o perfil de consumo de bebidas do tipo smoothies, verificou que, dos 500 voluntários que responderam o questionário online, 84,2\% eram do sexo feminino, com idade entre 19 e 35 anos (74,2\%) e renda familiar mensal de 4 a 10 salários mínimos (48\%). Já segundo Martins (2019), analisando o comportamento de 82 indivíduos consumidores de cervejas artesanais no município de Santana do Livramento (RS), observou que $76 \%$ eram do sexo masculino, com idade entre 26 a 35 anos (48\%), apresentavam ensino superior completo (44\%) e renda mensal entre 2.500 a 5.000 reais (39\%). 
Figura 1. Gênero dos participantes que responderam o questionário.

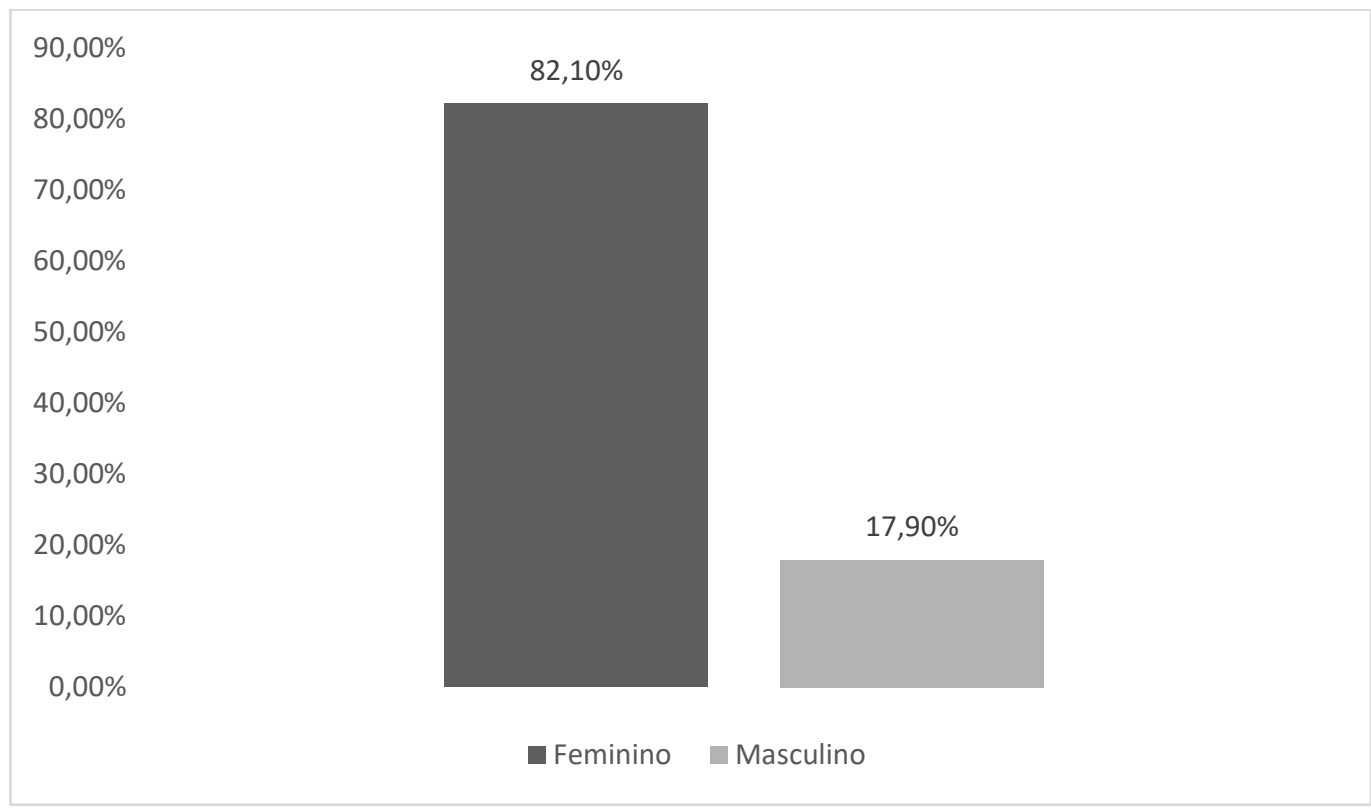

Fonte: Própria (2020)

Figura 2. Faixa etária dos participantes que responderam o questionário.

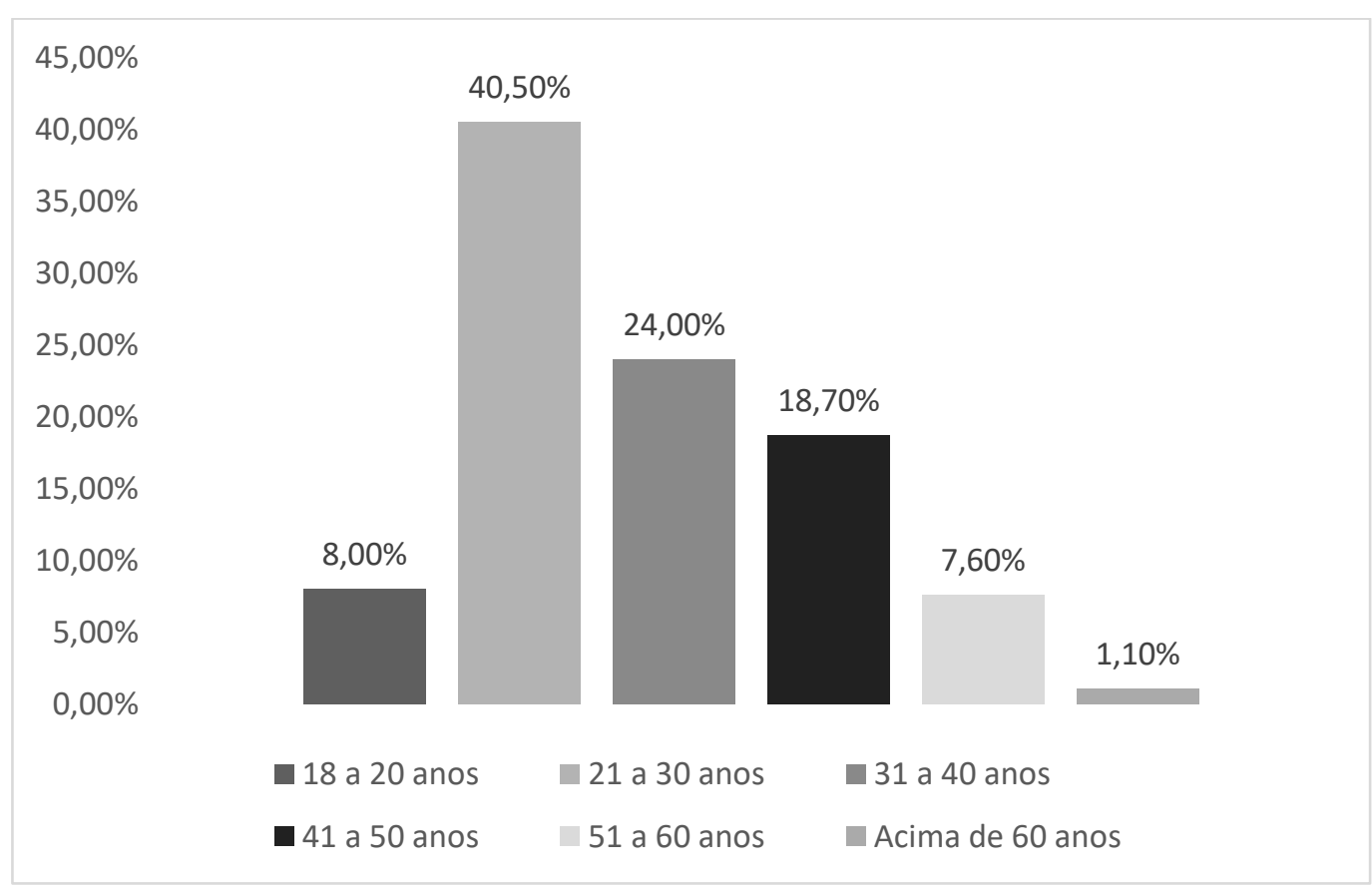

Fonte: Própria (2020) 
Figura 3. Nível de escolaridade dos participantes que responderam o questionário.

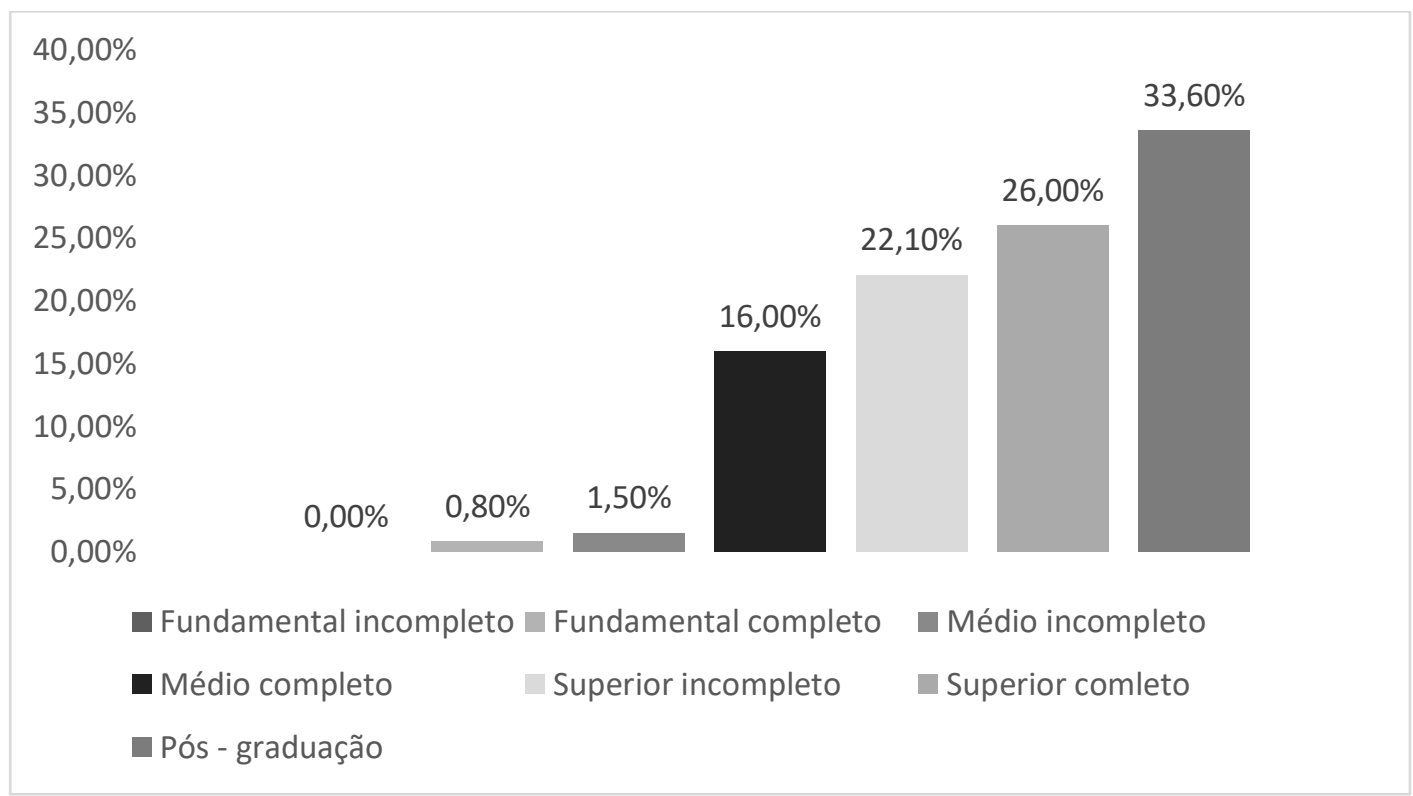

Fonte: Própria (2020)

Figura 4. Renda mensal dos participantes que responderam o questionário.

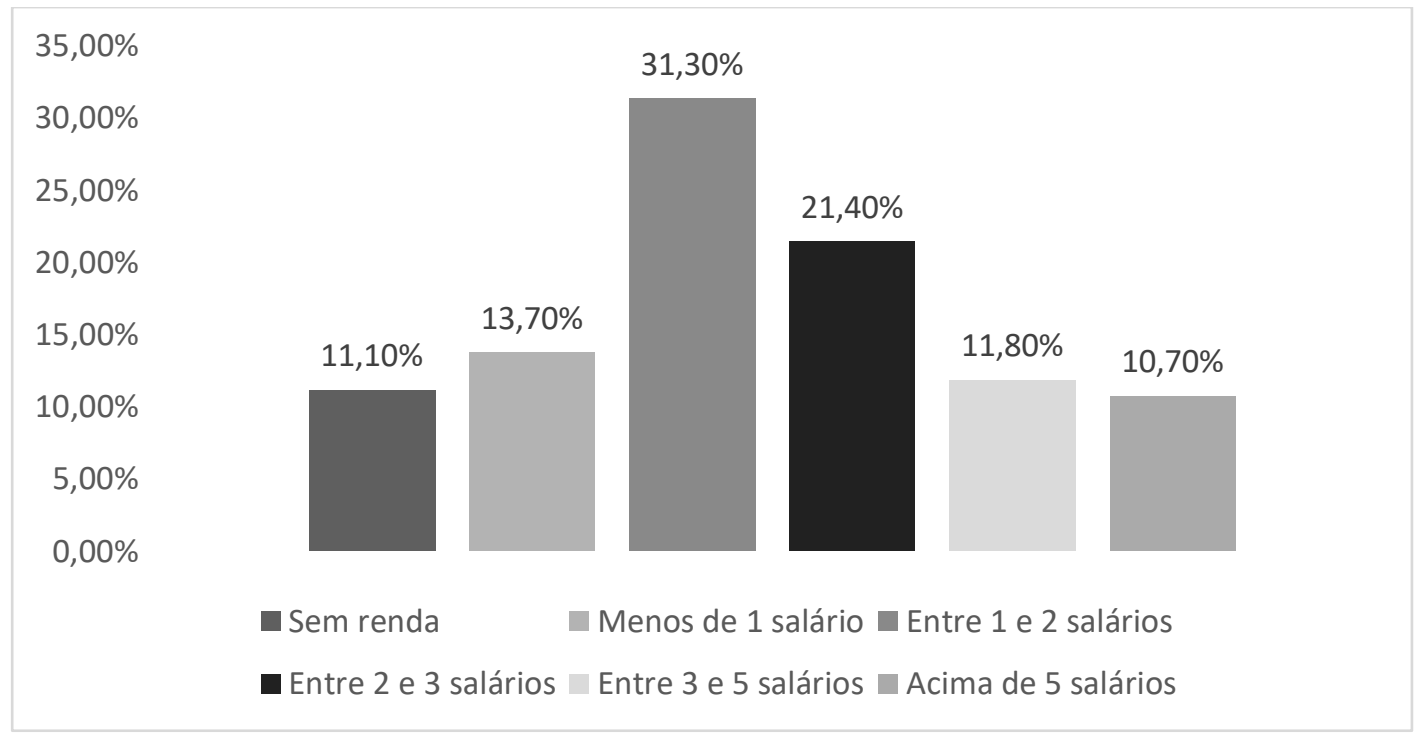

Fonte: Própria (2020)

Na Figura 5 foi perguntado aos participantes se eles fazem o uso de bebidas alcoólicas, $66,4 \%$ responderam que sim. A kombucha pode ser classificada como sendo uma bebida não alcoólica (até 0,5\% de teor alcoólico) e alcoólica (mais de 0,5\% de teor alcoólico) segundo a Instrução Normativa n 41 de 2019 (BRASIL, 2020). De acordo com Chen e Liu (2000), a concentração de etanol no kombucha aumenta com o tempo de fermentação, atingindo valor máximo aproximado de 5,5 g/L no vigésimo dia de fermentação, seguida de uma redução lenta. Sua produção ocorre através da fermentação da glicose, e posteriormente sofre uma segunda oxidação para produzir ácido acético. 
Figura 5. Participantes que fazem ou não o uso de bebidas alcoólicas.

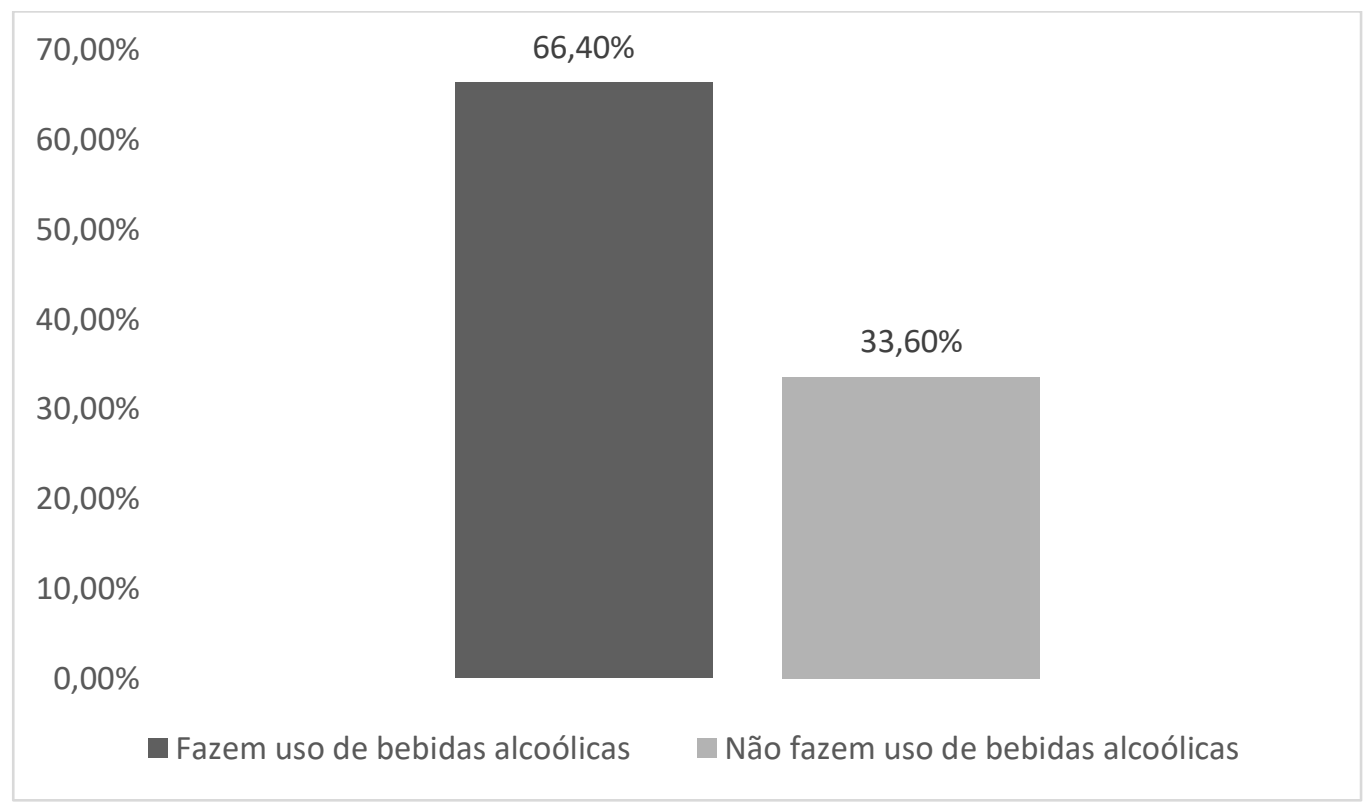

Fonte: Própria (2020)

As Figuras 6 e 7 referem-se à frequência e ao tipo de bebidas alcoólicas mais consumidas, respectivamente, estas por sua vez, foram respondidas apenas pelos usuários que afirmaram ser consumidores de bebidas alcoólicas, conforme o item anterior (Figura 5).

Figura 6. Frequência do consumo de bebidas alcoólicas.

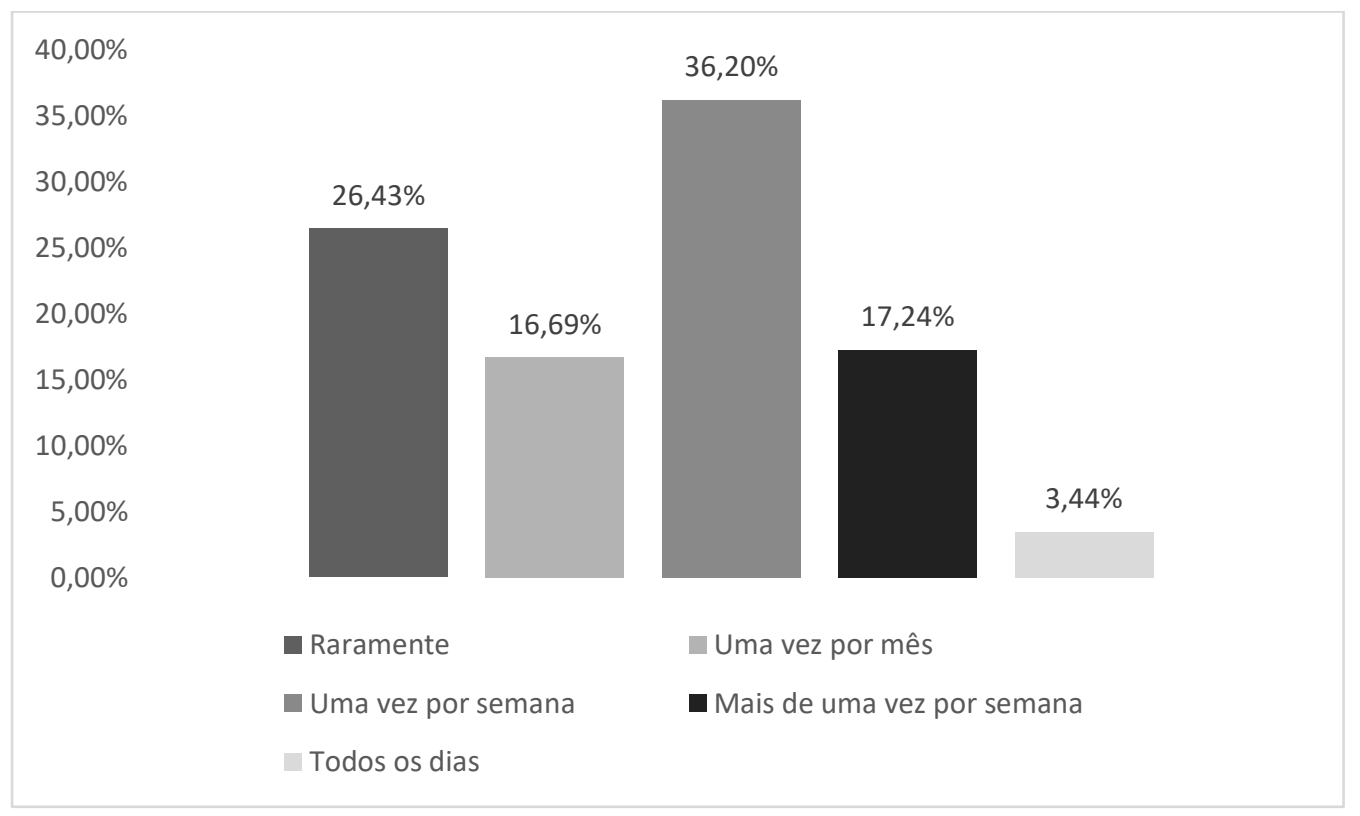

Fonte: Própria (2020)

Figura 7. Tipos de bebidas mais consumidas. 


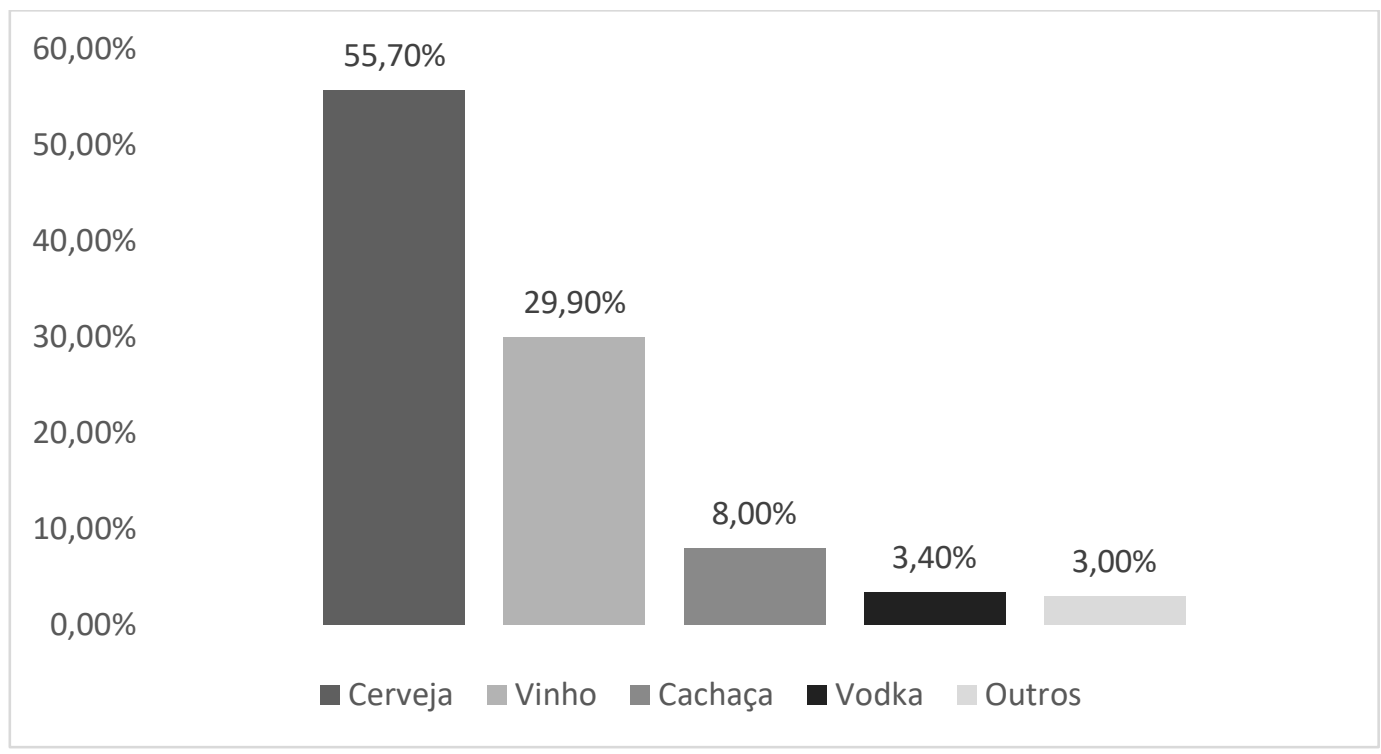

Fonte: Própria (2020)

Observa-se que, 36,2\% responderam que consomem bebida alcoólica uma vez por semana e que a cerveja é o tipo de bebida mais consumida (55,7\%), seguida pelo vinho (29,9\%). Pelicioli et al. (2017) ao avaliarem o perfil de 1.877 universitários brasileiros consumidores de álcool, verificaram que a frequência de consumo entre os respondentes variou de duas a quatro vezes ao mês (46,9\%) a mensal (40\%) e quanto ao tipo de bebida ingerida, houve predomínio de fermentados $(41,1 \%)$ em relação a destilados $(23,2 \%)$.

Na Figura 8 foi perguntado a todos os consumidores se eles sabem o que é uma bebida probiótica, 71,3\% responderam que sim. É possível notar uma crescente demanda por alimentos ditos como funcionais, ou seja, aqueles que segundo a ANVISA, quando consumidos como parte de uma dieta usual, produzem efeitos metabólicos e/ou fisiológicos benéficos à saúde, sendo considerados seguros para consumo sem supervisão médica (BRASIL, 1999).

Atualmente os alimentos funcionais são vistos como uma imagem positiva pelos consumidores, pelo fato de fornecerem benefícios à saúde sendo considerados como um novo caminho para uma alimentação saudável. Além disso, representam inovação comparada aos alimentos convencionais (COELHO, 2009).

Entre os vários micro-organismos considerados probióticos estão os gêneros Lactobacillus e Bifidobacterium pois são os gêneros que têm sido mais isolados da porção do trato gastrointestinal de um humano saudável (COELHO, 2009). Coppola e Turnes, (2004) comentam que também podemos considerar os gêneros Lactococcus, Enterococcus, Saccharomyces e Propionibacterium como espécies probióticas. Segundo Buriti e Saad, (2007) as espécies L. casei, L. Paracasei, L acidophilus e L. rhamnosus são de grande 
importância para a indústria de laticínios, devido ao seu emprego na produção de leites fermentados e na fabricação de queijos para a melhoria de qualidade do produto.

Figura 8. Conhecimento dos participantes sobre o que é uma bebida probiótica

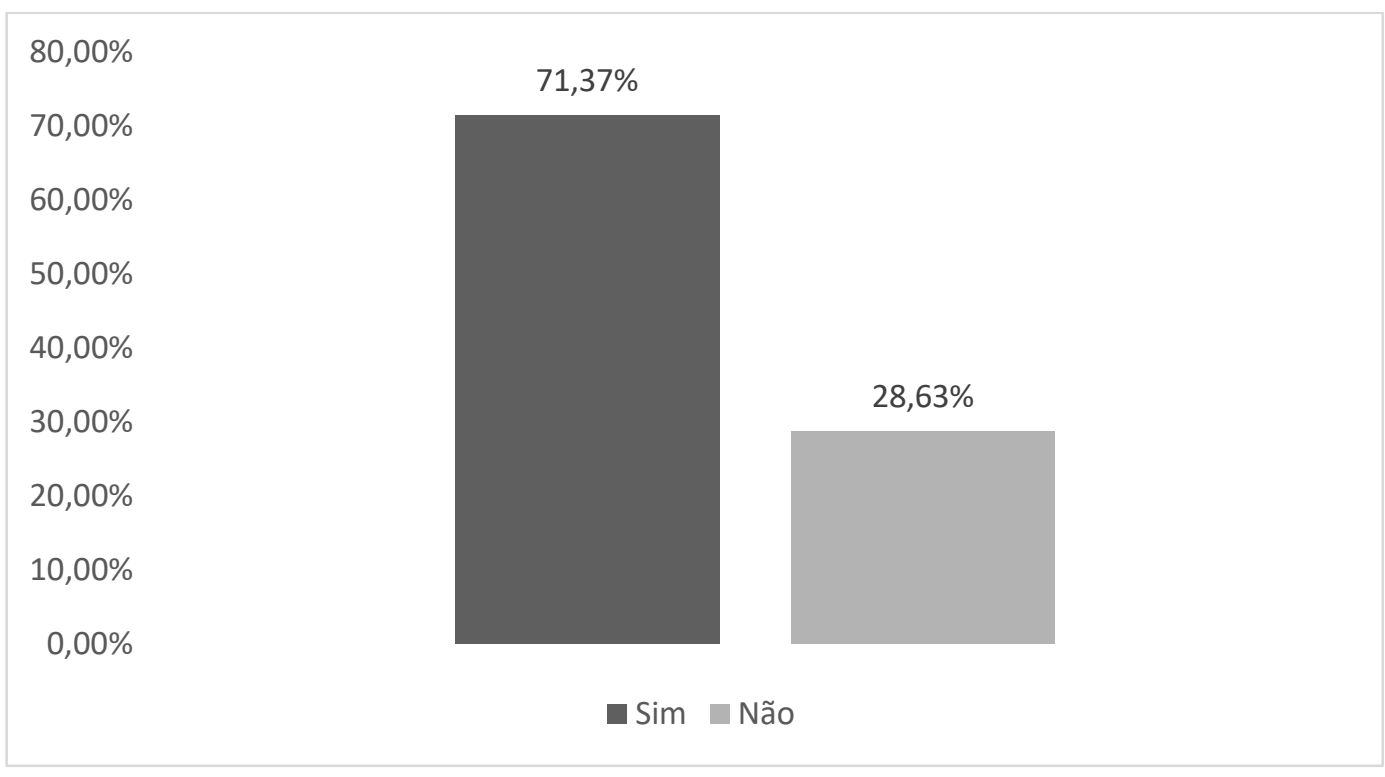

Fonte: Própria (2020)

Nas Figuras 9, 10 e 11 foram questionados se os participantes já ouviram falar da kombucha, se já a consumiram e se conhecem os benefícios associados à essa bebida, respectivamente. Em resposta, 62,59\% dos entrevistados já tinham ouvido falar da bebida, $44,27 \%$ afirmaram já ter consumido e 52,67\% disseram conhecer os benefícios kombucha.

Desde o seu descobrimento, existem relatos demonstrando que essa bebida pode auxiliar na redução do risco de doenças crônicas e também possui propriedades curativas, porém só na última década é que se observou uma explosão em sua popularidade principalmente em países como os Estados Unidos, que atualmente possui um mercado bem estabelecido para esse produto (SANTOS, 2016). Entretanto, ainda não existem comprovações científicas de seus reais benefícios, mas sabe-se que é uma bebida que apresenta grande potencial biotecnológico.

Um dos benefícios já estudados é a sua atividade antioxidante, relacionada com o aumento da imunidade, alívio de inflamações e artrites. Jayabalan et al. (2008) relataram a potencial habilidade de eliminação de radicais livres pelo chá de kombucha preparado a partir de chá verde e chá preto. Segundo os autores, os compostos fenólicos, a atividade de reação com radical DPPH e o radical superóxido foram aumentados ao longo do tempo de fermentação, enquanto o poder de redução, a capacidade de eliminação de radicais hidroxílicos e a capacidade de peroxidação antilipídica foram reduzidos. 
SOUSA, et al.

Figura 9. Participantes que já ouviram falar da kombucha.

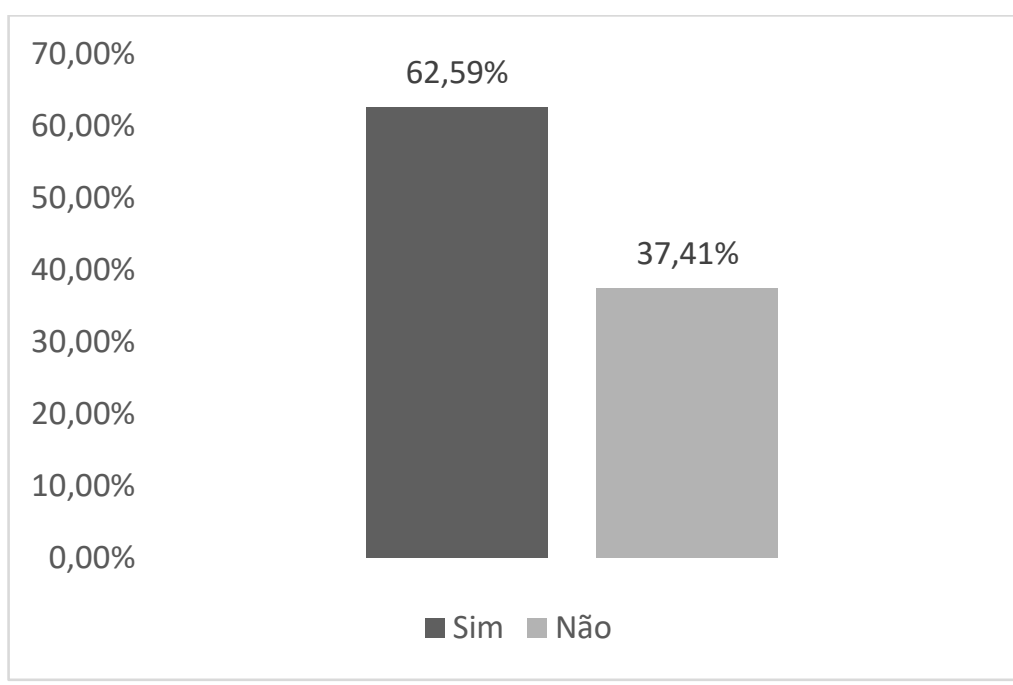

Fonte: Própria (2020)

Figura 10. Participantes que já consumiram a kombucha.

\begin{tabular}{|l|l|}
\hline $60,00 \%$ & $55,73 \%$ \\
$50,00 \%$ & $44,27 \%$ \\
$40,00 \%$ & \\
$30,00 \%$ & \\
$20,00 \%$ & \\
$10,00 \%$ & \\
$0,00 \%$ & - Nim Não \\
\hline
\end{tabular}

Fonte: Própria (2020)

Figura 11. Conhecimento dos benefícios associados à saúde pelo consumo de kombucha.

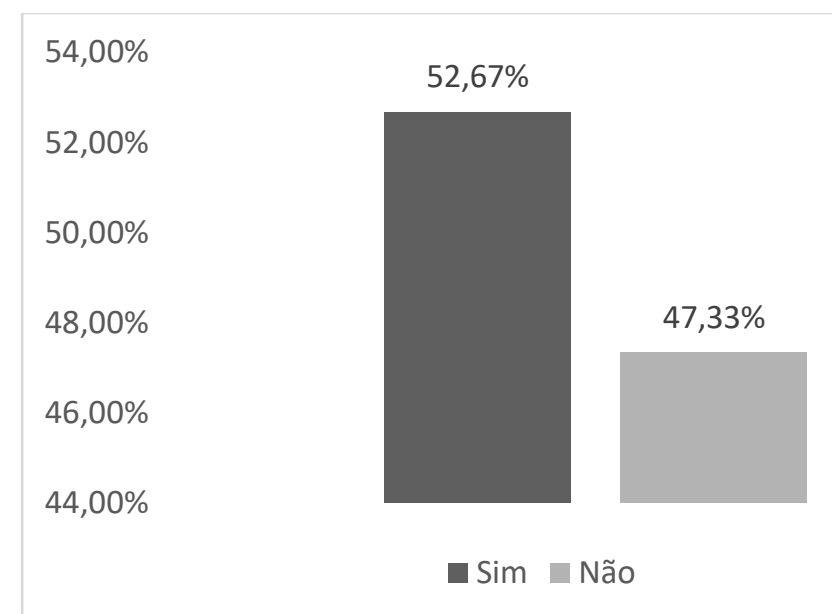

Fonte: Própria (2020) 
Na Figura 12 foi questionado se os participantes conheciam o processo de fabricação da kombucha. Observa-se que apenas 50,76\% disseram saber, enquanto 49,24\% responderam que não sabem como a bebida é produzida. A produção de kombucha ocorre a partir da infusão de chá verde ou preto adoçado com açúcar, que é substrato da reação de fermentação. As características sensoriais e a composição química da kombucha são dependentes de fatores como o tipo de chá e açúcar utilizado para o procedimento, dos microrganismos presentes no SCOBY (visto que a sua composição varia de produtor para produtor), além das condições de fermentação, como tempo e temperatura. O tempo de fermentação pode variar de 7 a 12 dias, considerando que quanto mais tempo o produto ficar fermentando mais ácido será o sabor, enquanto a temperatura pode variar de 22 a $30^{\circ} \mathrm{C}$ (DUFRESNE e FARNWORTH, 2000).

Estudos reportam que o espectro microbiano da bebida é dominado por bactérias ácidoacéticas e leveduras (CHAKRAVORTYA et al., 2016). Sabe-se que a composição microbiana da cultura do chá de kombucha varia de uma cultura para outra, dependendo de fatores como a localização geográfica, o clima, as espécies locais de bactérias e leveduras e a origem do inóculo (WATAWANA et al., 2015).

Figura 12. Conhecimento sobre o processo de fabricação da kombucha por parte dos participantes.

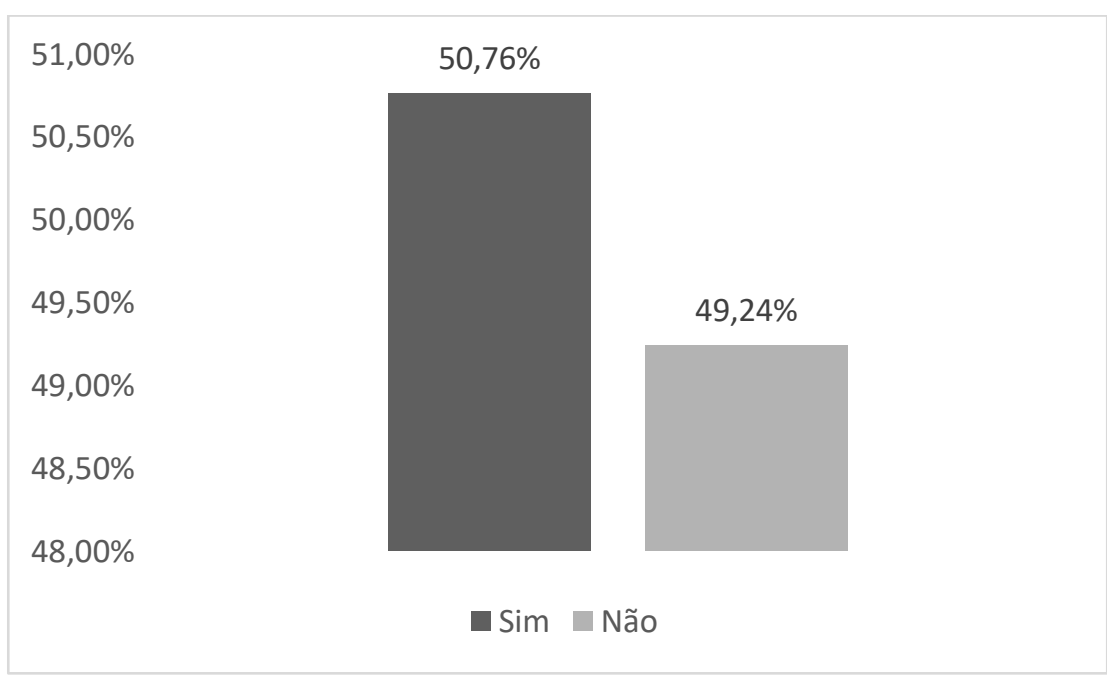

Fonte: Própria (2020)

A Figura 13 refere-se à disponibilidade da kombucha nos mercados consumidores. A maioria dos participantes $(79,77 \%)$ responderam que essa bebida não é facilmente encontrada. A kombucha ainda está em processo de popularização no Brasil e atende perfeitamente às atuais tendências do mercado.

Segundo a Brasil Food Trends (2020), a tendência denominada "saudabilidade e bemestar" vem desencadeando diversos segmentos de consumo, entre os quais é possível destacar 
a procura de alimentos funcionais, que têm como diferencial trazer benefícios ao desempenho físico e mental, saúde cardiovascular, saúde intestinal, entre outros.

Os probióticos ainda possuem sua aplicabilidade muito limitada à indústria de laticínios, sendo a retentora de grande parte do mercado de alimentos funcionais, e é de fundamental importância o desenvolvimento de novos produtos adicionados dessas culturas para a ampliação desse mercado e aceitação por novos consumidores, pois não são todos que podem ou apreciam produtos lácteos (COELHO, 2009).

Figura 13. Disponibilidade da kombucha nos mercados consumidores

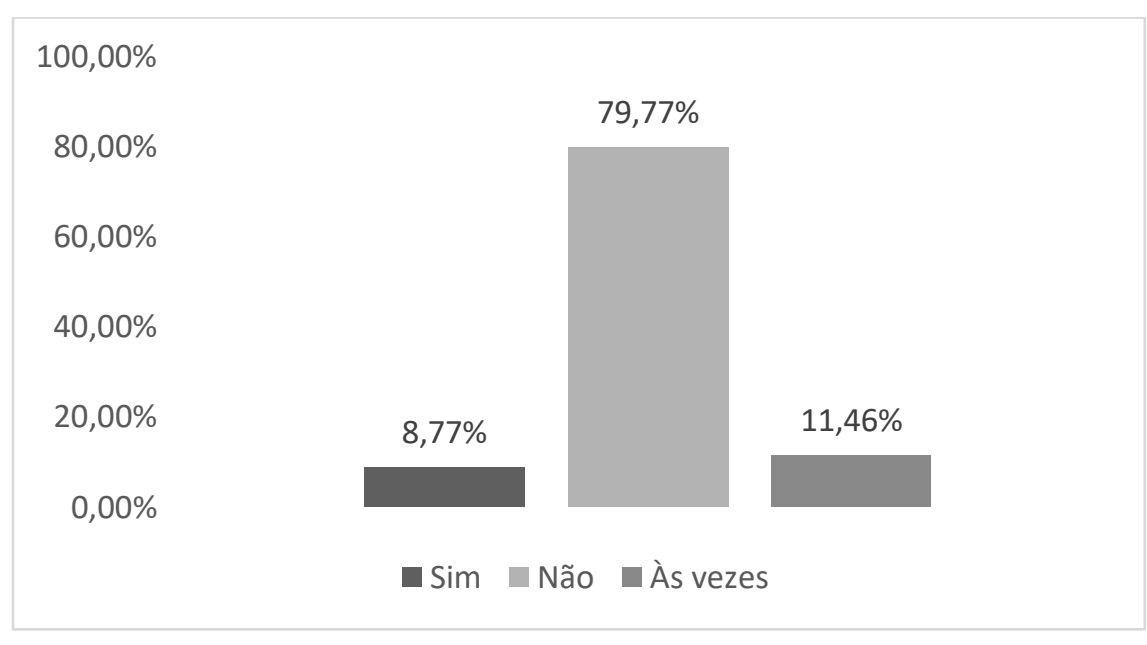

Fonte: Própria (2020)

\section{Conclusões}

Os respondentes são em sua maioria mulheres, entre 21 e 30 anos, apresentam pós-graduação e renda mensal entre 1 e 2 salários mínimos. Os participantes fazem o uso de álcool ao menos uma vez por semana, sendo a cerveja a bebida mais consumida.

A maioria dos respondentes afirmam saber o que é uma bebida probiótica e conhecem os benefícios associados à kombucha, no entanto, essa bebida não apresenta uma disponibilidade no mercado consumidor apesar de se mostrar bastante promissora no segmento de alimentos funcionais.

\section{Referências}

ASSOCIAÇÃO NACIONAL DOS EXPORTADORES DE SUCOS CÍTRICOS. Produção de Kombucha se multiplica no Brasil. São Paulo: CITRUS, 23 out. 2018. Disponível em: http://www.citrusbr.com/noticias/?id=312621. Acesso em 3 de julho de 2020. 
BRASIL. Portaria n ${ }^{\circ} 398$ de 30 de abril de 1999. Estabelece as diretrizes básicas para análise e comprovação de propriedades funcionais e ou de saúde alegadas em rotulagem de alimentos. Brasília: ANVISA, 1999.

BRASIL. Portaria $n^{\circ} 103$ de 20 de setembro de 2018. Instrução Normativa que visa estabelecer em todo território nacional o padrão de identidade e qualidade de kombucha. Diário Oficial da União, Brasília, n. 188, seção 1, p. 18, 28 set. 2018.

BRASIL Food Trends 2020. São Paulo: FIESP; ITAL, 2010. Disponível em: http://www.brasilfoodtrends.com.br/. Acesso em 04 de julho de 2020.

BRASIL. Instrução Normativa $n^{0} 41$ de 17 de setembro de 2019. Estabelecer o Padrão de Identidade e Qualidade da Kombucha. Disponível em: http://www.in.gov.br/en/web/dou//instrucao-normativa-n-41-de-17-de-setembro-de-2019-216803534. Acessado em 15 de julho de 2020.

BURITI; F. C. A; SAAD, S. M. I. Bactérias do grupo Lactobacillus casei: caracterização, viabilidade como probióticos em alimentos e sua importância para a saúde humana. Arquivos latino americanos de nutrição, v. 57, n. 4, p. 373 - 380. 2007.

CHAKRAVORTYA, S.; BHATTACHARYA, S.; CHATZINOTAS, A.; CHAKRABORTY, W.; BHATTACHARYA, D.; GACHHUI, R. Kombucha tea fermentation: Microbial and biochemical dynamics. International Journal of Food Microbiology, v. 220, 63-72, 2016.

CHEN, C.; LIU, B. Y. Changes in major components of tea fungus metabolites during prolonged fermentation. Journal of Applied Microbiology, v. 89, n. 5, p. 834-839, 2000.

COELHO, J. C. Elaboração de bebida probiótica a partir do suco de laranja fermentado com Lactobacillus casei. Orientadora: Sueli Rodrigues. 2009. 95 f. Dissertação de Mestrado (Ciências e tecnologia de alimentos) - Universidade Federal do Ceará, Fortaleza, 2009.

COPPOLA, M. M.; TURNES, C.G. Probióticos e resposta imune. Ciência rural, v. 34, n. 4, p. $1297-1303.2004$. 
DUFRESNE, C.; FARNWORTH, E. Tea, Kombucha, and health: a review. Food Research International, v. 33, n. 6, p. 409-421, 2000.

JAYABALAN R. et al. Changes in free radical scavenging ability of kombucha tea during fermentation. Food Chemistry, v. 109, n. 1, p. 227-234, 2008.

MARTINS, D. Comportamento do consumidor de cervejas artesanais no município de Santana do Livramento. Orientador: João Garibaldi Almeida Viana. 2019. 25 f. Trabalho de conclusão de curso (Bacharelado em Administração) - Universidade Federal do Pampa, Campus Santana do Livramento, Santana do Livramento, 2019

PELICIOLI, M et al.. Perfil do consumo de álcool e prática do beber pesado episódico entre universitários brasileiros da área da saúde. J Bras Psiquiatr., v.66, n.3, p.150-156, 2017.

RIBEIRO, E. S. S. Elaboração e caracterização de bebida probiótica a partir de suco de cajá fermentado Lactobacillus acidophilus NRRL B-4495. Orientado: Francisco Canindé Sousa Junior. 2020. 86 f. Dissertação de Mestrado ( Nutrição) - Universidade Federal do Rio Grande do Norte, Natal, 2020.

SANTOS, M. J. Kombucha: caracterização da microbiota e desenvolvimento de novos produtos alimentares para uso em restauração. Orientadora: Catarina Prista. 2016. $119 \mathrm{f}$. Dissertação de Mestrado (Ciências Gastronômicas) - Universidade Nova de Lisboa, Lisboa, 2016.

WATAWANA, M. I.; JAYAWARDENA, N.; GUNAWARDHANA, C. B.; WAISUNDARA, V. Y. Health, Wellness, and Safety Aspects of the Consumption of Kombucha. Journal of Chemistry, article ID 591869, p. 1-11, 2015.

YASSIN, L. S. Desenvolvimento de Smoothie fermentado por microorganismos da Komucha com base no perfil de consumo, composição química, compostos bioativos e descrição sensorial. Orientador: Alessandro Nogueira. 2019. 112 f. Tese de Doutorado ( Ciência e Tecnologia de Alimentos)- Universidade Estadual de Ponta Grossa, Ponta Grossa, 2019. 


\title{
CAPÍTULO 35: PERFIL SENSORIAL E AVALIAÇÃO FÍSICA DE COOKIES COM FARINHA MISTA EXTRUDADA DE CASCAS E ALBEDO DE MARACUJÁ E ARROZ
}

\section{CHAPTER 35: SENSORY PROFILE AND PHISICAL EVALUATION OF COOKIES WITH EXTRUDED MIXED FLOUR OF PEEL AND PASSION FRUIT ALBEDO AND RICE}

Valéria França de Souza ${ }^{1}$; Nandara Gabriela Mendonça Oliveira ${ }^{2}$; Rafael Henrique de Almeida Ferreira ${ }^{3}$, Alyne Alves Nunes Oliveira ${ }^{4}$, José Luís Ramirez Ascheri ${ }^{5}$

\begin{abstract}
Resumo
Os co-produtos (cascas e albedo) de maracujá é um resíduo que pode ser aproveitado na forma de farinha. $\mathrm{O}$ arroz apresenta característica de hipoalergenicidade, com flavor suave e isento de glúten. Este trabalho teve como objetivo desenvolver formulações de biscoitos tipo cookie sem glúten contendo uma farinha mista extrudada de cascas e albedo de maracujá(Passiflora edulis flavicarpa Degener) e arroz (Oryza sativa L.) e avaliação física. Para os cookies avaliou-se a aceitabilidade sensorial e avaliação física. A análise sensorial do cookies foi realizada com 100 julgadores não treinados, utilizando uma escala hedônica de 9 pontos, mediante a assinatura do Termo de Consentimento Livre e Esclarecido. Para determinar a avaliação física do cookies foi realizado valores médios da massa, volume aparente, volume específico, diâmetro, espessura e fator de expansão. Os resultados obtidos mostram que das três formulações (Fb8, Fb12 e Fb13) desenvolvidas, duas (Fb8 e Fb13) obtiveram aceitação por parte dos julgadores. Os resultados da avaliação física indicaram que o diâmetro e o fator de expansão obtiveram os maiores valores. Portanto, concluí-se que o uso de co-produtos (cascas e albedo de maracujá) na fabricação de farinha para cookies pode ser uma alternativa viável para o consumo por portadores de doença celíaca.
\end{abstract}

Palavras-Chave : fruta, cereal, extrusão termoplástica, biscoito, free glúten.

\begin{abstract}
Passion fruit co-products (peels and albedo) is a residue that can be used in the form of flour. Rice is hypoallergenic, with a mild flavor and free of gluten. This work aimed to develop gluten-free cookie type formulations containing a mixed flour extruded from peel and passion fruit albedo (Passiflora edulis flavicarpa Degener) and rice (Oryza sativa L.) and physical evaluation. Sensory acceptability and physical evaluation were evaluated for cookies. Sensory analysis of cookies was performed with 100 untrained judges, using a hedonic scale of 9 points, by signing the Informed Consent Form. To determine the physical evaluation of cookies, average values of mass, apparent volume, specific volume, diameter, thickness and expansion factor were performed. The results obtained show that of the three formulations (Fb8, Fb12 and Fb13) developed, two (Fb8 and Fb13) obtained acceptance by the judges. The results of the physical evaluation indicated that the diameter and the expansion factor obtained

\footnotetext{
${ }^{1}$ Doutora do Curso de Pós Graduação em Ciência e Tecnologia de Alimentos, Universidade Federal Rural do Rio de Janeiro, vssouzafrana@gmail.com

${ }^{2}$ Graduanda em Engenharia de Alimentos, Universidade Federal Rural do Rio de Janeiro, nandaragabriela@yahoo.com.br

${ }^{3}$ Mestrando do Curso de Mestrado em Ciência e Tecnologia em Alimentos, Instituto Federal do Sudeste de Minas Gerais, rafaelhenrique93@gmail.com

${ }^{4}$ Doutoranda do Curso de Pós Graduação em Higiene Veterinária e Processamento Tecnológico de Produtos de Origem Animal , Universidade Federal Fluminense do Rio de Janeiro, alves.alyne@ hotmail.com

${ }^{5}$ Pesquisador da Embrapa Agroindústria de Alimentos, Rio de Janeiro, joseascheri@gmail.com
} 
the highest values. Therefore, it was concluded that the use of co-products (peels and passion fruit albedo) in the manufacture of flour for cookies can be a viable alternative for consumption by people with celiac disease.

Keywords: fruit, cereals, thermosplastic extrusion, biscuit, free glúten.

\section{Introdução}

O Brasil é o maior produtor mundial de maracujá (IBGE, 2018), sendo que $60 \%$ desta produção é destinada ao consumo in natura e o restante destinado a industrialização (MELETTI, 2011). De acordo com dados fornecidos pelo Instituto Brasileiro de Geografia e Estatística (IBGE, 2018) o Brasil colheu em 2018 uma área de aproximadamente 42.731 hectares, com uma produção por volta de 602.651 toneladas, destacando a região nordeste como a maior produtora. O maracujá também pode ser considerado uma rica fonte de carotenóides, pigmentos responsáveis pela cor amarela intensa de seu suco. Esses nutrientes, juntamente com flavonóides, também presentes, possuem caráter antioxidante, atuando na prevenção de doenças crônicas(ZERAIK et al., 2010). Vale destacar que devido ao seu "flavour" único e delicado, os frutos do maracujá têm sido assunto de diversas pesquisas, resultando na caracterização de inúmeros constituintes voláteis. Nesse sentido mais de 40 substâncias já foram identificadas, com ésteres, aldeídos, cetonas e alcoóis, responsáveis pelo aroma desta fruta (ZERAIK, 2010). Zucolotto et al., (2012) identificaram várias substâncias bioativas nos frutos, folhas e cascas presentes em várias espécies de Passiflora edulis, tendo como componente principal os flavonóides C-glicosídeos.

Além disso, alguns estudos apontam para o potencial benéfico da casca do maracujá é composta pelo flavedo (parte com coloração) e albedo (parte branca), sendo este rico em pectina, espécie de fibra solúvel que auxilia na redução das taxas de glicose no sangue, fonte de vitamina B3, ferro, cálcio e fósforo (CÓRDOVA et al., 2005). Do ponto de vista tecnológico, Yapo e Koffi (2006) destacam que a casca de maracujá amarelo é, em especial, uma boa fonte de pectina de baixa metoxilação. Zeraik e Yariwake (2012), ao avaliar extratos de cascas de maracujá azedo (amarelo), observaram alta capacidade antioxidante. As propriedades funcionais da casca do maracujá, especialmente aquelas relacionadas ao teor e o tipo de fibras, fazem com que a casca de maracujá não seja mais considerada um resíduo industrial, uma vez que pode ser utilizada na elaboração de novos produtos na forma de farinha (GALISTEO, DUARTE, ZARZUELO, 2008). Segundo Zeraik ; Yariwake (2012), as cascas podem ser utilizadas para produção de vários alimentos, contribuindo assim para reduzir grandes quantidades de resíduos orgânicos gerados no processamento de suco de fruta. 
Para Abud e Narain (2009), as cascas de maracujá devem ser considerada como farinha de fibras residual do maracujá amarelo, devido às suas características e propriedades funcionais, tornando-as de grande potencial econômico e nutricional.

O arroz é o alimento básico mais importante para a nutrição humana, amplamente consumido, e capaz de fornecer energia e nutrientes para mais da metade da população mundial (PANG et al., 2018). Além de não ser alergênica, a farinha de arroz é um produto versátil, tem sabor suave, baixos níveis de sódio e alta proporção de amido facilmente digerível (NABESHIMA e EL-DASH,2004; SIVARAMAKRISHNAN et al.,2004; OLIVEIRA et al., 2014). O uso da farinha de arroz permite melhorar a qualidade nutricional dos produtos por extrusão, como também apresentar pequenos tamanhos dos grânulos de amido, alta proporção de amidos facilmente digeríveis e ampla faixa de teor de amilose (AWOLU et al., 2015).

A extrusão termoplástica de alimentos é definida como um processo termomecânico pelo qual, materiais amiláceos e/ou proteáceos são plastificados com água e cozidos em um tubo, pela combinação de câmbios de pressão, transferência de calor e massa e cisalhamento mecânico (BERK, 2009).

O Brasil tem importante posição como exportador de biscoitos, sendo que os principais mercados, em 2017, foram Angola, Venezuela, Cuba, Argentina, Estados Unidos (EUA), Uruguai, Paraguai, Peru, Chile e Japão (ABIMAPI,2018).

Segundo BRAM et al.(2009) e GÖKMEN et al. (2008), os “cookies” são definidos como produtos assados à base de cereais que possuem altos níveis de açúcar e de gordura e baixos níveis de água (1-5\%). Os biscoitos tipo cookie, tem as características peculiares, possuem crocância referente a massa que leva menos líquido se comparado com outros biscoitos e a modulagem (GISSLEN, 2014).

Atualmente, no mercado nacional e internacional, é possível encontrar biscoitos isentos de glúten, porém, muitos produtos disponíveis no mercado não apresentam boa aceitação pelos consumidores (ZUCCO et al., 2011). Os biscoitos tipo cookie podem ser reformulados por farinhas isentas de glúten, tornando-se assim uma opção para pessoas que possuem alergia e/ou intolerância à proteína gliadina, contida no glúten (RAHAIE et al., 2014).

A doença celíaca é caracterizada como uma desordem sistêmica autoimune, desencadeada pela incapacidade de digestão da proteína conhecida como glúten (principal fração proteica presente nos cereais trigo, centeio, triticale, cevada) em indivíduos geneticamente predispostos (FENACELBRA, 2010). Na presença de doença celíaca, os 
alimentos que contêm glúten devem ser substituídos por outros, como por exemplo: milho, arroz, soja, batata e mandioca, de forma que a dieta atenda às necessidades nutricionais de acordo com a idade do indivíduo (FARO 2008; LA BARCA et al., 2010). Apesar de sua crescente oferta, os produtos livres de glúten nem sempre têm boa qualidade sensorial e possuem custo elevado. Daí a importância da pesquisa e desenvolvimento de novos produtos que se enquadrem nessa categoria (FERREIRA et al., 2009).

Este trabalho teve como objetivo desenvolver formulações de biscoitos tipo cookie sem glúten contendo uma farinha mista extrudada de cascas e albedo de maracujá(Passiflora edulis flavicarpa Degener) e arroz (Oryza sativa L.) e avaliação física.

\section{Material e Métodos}

\section{Obtenção das matérias primas}

\section{Arroz}

O arroz (Oryza sativa L.) sob a forma de grãos polidos, da marca Tio João, classe longo fino tipo 1 , em embalagem de $5 \mathrm{Kg}$ e mantidas à temperatura ambiente até o processo de moagem.

\section{Maracujá}

O maracujá (Passiflora Edulis Flavicarpa Degener) para a extração da casca (epicarpo) e do albedo (mesocarpo) foram adquiridos no comércio local da cidade do Rio de Janeiro.

Os experimentos foram desenvolvidos na planta-piloto de cereais da Embrapa Agroindústria de Alimentos, localizado em Guaratiba, Rio de Janeiro, RJ.

\section{Obtenção da farinha de arroz}

$\mathrm{O}$ arroz foi retirado das embalagens em que são comercializados e moídos em moinho de disco, com peneira de abertura de $1 \mathrm{~mm}$, obtendo-se então a farinha de arroz branco.

\section{Obtenção da farinha de cascas e albedo de maracujá}

O preparo da farinha de maracujá (casca + albedo) foi realizado em frutas in natura. As frutas foram selecionadas, lavadas em água corrente, para retirada de sujeiras e sanitizadas com água clorada (20ppm) de cloro residual livre durante 20 minutos). Em seguida foram lavadas novamente em água corrente para a retirada do cloro residual. Foi feita a divisão do maracujá em 4 partes (despolpamento), em seguida foi retirada a polpa e, a casca e o albedo foram secos em estufa a $70^{\circ} \mathrm{C}$ durante 4 horas. Após a secagem, as cascas e albedo foram pesados e acondicionados em sacos plásticos para serem posteriormente moídos. As amostras secas foram moídas em moinho de facas-martelo Marca TREU com peneira de $1 \mathrm{~mm}$, em seguida 
moinho de disco com abertura de $2 \mathrm{~mm}$ e posterior o moinho de perten com peneira de $0,8 \mathrm{~mm}$ obtendo-se a farinha da casca e albedo de maracujá com granulometria adequada. A determinação da distribuição granulométrica realizada em triplicata da farinha de (casca+albedo) foi determinada em um analisador e tamanho de partícula a laser Analysette 22 (Fritsch, Idar-Oberstein, Alemanha). Os experimentos foram realizados em triplicata. A farinha de casca e albedo de fruto foi acondicionada em sacos plásticos, identificadas e mantidas armazenadas a temperatura de refrigeração de $4^{\circ} \mathrm{C}$ para posterior uso.

\section{Delineamento Experimental}

Foi utilizado o delineamento experimental composto central (Tabelas 1 e 2 ) visando reduzir as combinações e otimizar o processo de coleta e análise de dados, segundo BOX et al (1987). Foram analisados as variáveis independentes, temperatura na terceira zona do canhão; formulação da farinha de arroz e farinha de casca e de albedo de maracujá e umidade de processamento.

Tabela 1. Níveis das variáveis independentes do processo de elaboração dos extrudados expandidos.

\begin{tabular}{llllll}
\hline Variáveis & $-\alpha=1,682$ & -1 & 0 & +1 & $+\alpha=1,682$ \\
$\mathrm{X}^{1}$ & 99,6 & 120 & 150 & 180 & 200,4 \\
$\mathrm{X}^{2}$ & 14,64 & 16 & 18 & 20 & 21,36 \\
$\mathrm{X}^{3}$ & 1,6 & 5 & 10 & 15 & 18,4 \\
\hline $\mathrm{X}^{1}$ - Temperatura das zonas para extrusora Brabender $\left({ }^{\circ} \mathrm{C}\right)$ &
\end{tabular}

$\mathrm{X}^{2}$ - Umidade de processamento $(\%)$

$\mathrm{X}^{3}$ - Formulação da farinha da casca e albedo de maracujá (\%); a diferença da percentagem corresponde à farinha de arroz 
Tabela 2. Delineamento completo do desenho experimental.

\begin{tabular}{|c|c|c|c|c|c|c|}
\hline \multirow[t]{2}{*}{ Experimento } & \multicolumn{6}{|c|}{ Níveis Codificados das Variáveis Níveis Decodificados das Variáveis } \\
\hline & $\mathrm{x}^{1}$ & $x^{2}$ & $\mathrm{x}^{3}$ & $\mathrm{X}^{1}$ & $\mathrm{X}^{2}$ & $\mathrm{X}^{3}$ \\
\hline 01 & +1 & +1 & +1 & 180 & 20 & 15 \\
\hline 02 & -1 & +1 & +1 & 120 & 20 & 15 \\
\hline 03 & +1 & -1 & +1 & 180 & 16 & 15 \\
\hline 04 & -1 & -1 & +1 & 120 & 16 & 15 \\
\hline 05 & +1 & +1 & -1 & 180 & 20 & 5 \\
\hline 06 & -1 & +1 & -1 & 120 & 20 & 5 \\
\hline 07 & +1 & -1 & -1 & 180 & 16 & 5 \\
\hline 08 & -1 & -1 & -1 & 120 & 16 & 5 \\
\hline 09 & $+1,68$ & 0 & 0 & 200,4 & 18 & 10 \\
\hline 10 & $-1,68$ & 0 & 0 & 99,6 & 18 & 10 \\
\hline 11 & 0 & $+1,68$ & 0 & 150 & 21,36 & 10 \\
\hline 12 & 0 & $-1,68$ & 0 & 150 & 14,64 & 10 \\
\hline 13 & 0 & 0 & $+1,68$ & 150 & 18 & 18,4 \\
\hline 14 & 0 & 0 & $-1,68$ & 150 & 18 & 1,6 \\
\hline 15 & 0 & 0 & 0 & 150 & 18 & 10 \\
\hline 16 & 0 & 0 & 0 & 150 & 18 & 10 \\
\hline 17 & 0 & 0 & 0 & 150 & 18 & 10 \\
\hline 18 & 0 & 0 & 0 & 150 & 18 & 10 \\
\hline 19 & 0 & 0 & 0 & 150 & 18 & 10 \\
\hline 20 & 0 & 0 & 0 & 150 & 18 & 10 \\
\hline
\end{tabular}

$\mathrm{x}^{1}, \mathrm{x}^{2}$ e $\mathrm{x}^{3}=$ níveis codificados

$\mathrm{X}^{1}=$ Temperatura das zonas para extrusora Brabender $\left({ }^{\circ} \mathrm{C}\right)$

$\mathrm{X}^{2}=$ Umidade de processamento $(\%)$

$\mathrm{X}^{3}=$ Formulação da farinha da casca e albedo e maracujá (\%)

Utilizou-se neste estudo três diferentes combinações dos melhores tratamentos $T_{8}, T_{12}$ e $\mathrm{T}_{13}$. Os experimentos das variáveis foram (farinha de casca e albedo de maracujá + arroz) $\mathrm{T}_{8}:$ 5:95; $\mathrm{T}_{12}: 10: 90$ e $\mathrm{T}_{13}: 18,4: 81,6$; umidade de processamento $\mathrm{T}_{8}: 16 \%, \mathrm{~T}_{12}: 14,64 \%$ e $\mathrm{T}_{13}$ : $18 \%$ e a temperatura na $3^{\mathrm{a}}$ zona da extrusora do $\mathrm{T}_{8}: 120^{\circ} \mathrm{C}, \mathrm{T}_{12}$ e $\mathrm{T}_{13}: 150^{\circ} \mathrm{C}$.

Utilizou-se o delineamento em metodologia de superfície de resposta do tipo central composto rotacional de $2^{\mathrm{a}}$ ordem em testes preliminares para 20 tratamentos. As variáveis independentes foram codificados $(-\alpha,-1,0,+1,+\alpha)$ de acordo com a matriz circular de $3 \mathrm{~mm}$, temperatura na $1^{\mathrm{a}}$ zona $60^{\circ} \mathrm{C}$; e temperatura na $2^{\mathrm{a}}$ zona $100^{\circ} \mathrm{C}$. As temperaturas na $1^{\mathrm{a}}$ e $2^{\mathrm{a}}$ zona foram fixas no experimento. Os parâmetros variáveis foram controle da temperatura na $3^{\mathrm{a}}$ zona de aquecimento do canhão da extrusora. Previamente a etapa de preparação da farinha mista, as amostras formuladas em diferentes percentagens de farinha de arroz e farinha de casca e albedo de maracujá foram homogeneizadas por 5 minutos e acondicionadas para os diferentes níveis de umidade e formulação (ASCHERI e CARVALHO, 2015). A farinha mista foi ajustada a umidade inicial em triplicata de acordo com o delineamento experimental. 
As amostras formuladas da farinha mista foram acondicionadas para os diferentes níveis de umidade e formulação.

Os teores de umidade inicial das farinhas mistas foram determinados por gravimetria através da dessecação do material a $105^{\circ} \mathrm{C}$ até peso constante em estufa (INSTITUTO ADOLFO LUTZ, 1985).

Após a determinação da umidade das farinhas mistas, a equação (1) foi usada para estabelecer a quantidade de água a ser adicionada às amostras, a fim de se alcançar os níveis de umidade estabelecidos para cada formulação.

$$
\mathrm{Y}=\left[\frac{(\mathrm{Uf}-\mathrm{Ui}) \times \mathrm{Pa}}{100-\mathrm{Uf}}\right]
$$

Onde:

$\mathbf{Y}=$ quantidade de água a ser adicionada $(\mathrm{mL})$

$\mathbf{U f}=$ umidade final (\%) (base seca)

$\mathbf{U i}=$ umidade inicial $(\%)$ (base seca)

$\mathbf{P a}=$ peso da amostra $(\mathrm{g})$

\section{Análise Estatística}

O processamento dos dados e a análise estatística foram realizados com auxílio do programa computacional Statistica Six Sigma, versão 7.0, com as variáveis independentes codificadas.

\section{Condições do Processo de Extrusão}

Para a elaboração dos extrudados foi utilizado uma extrusora monorosca, marca Brabender, modelo DSE 20 DN, (Duisburg, Alemanha), com sistema de extrusão através de fricção mecânica, taxa de compressão do parafuso (3:1), taxa de alimentação: $2,5 \mathrm{Kg} / \mathrm{h}$, sistema de refrigeração pneumático, para controle de temperatura na camisa de extrusão, velocidade de rotação do parafuso a $140 \mathrm{rpm}$, capacidade de produção aproximada de $16 \mathrm{Kg} . \mathrm{h}^{-1}$ e matriz de saída circular de $3 \mathrm{~mm}$ de espessura.

\section{Processo de Extrusão Termoplástica}

As farinhas mistas de casca e albedo de maracujá e arroz foram processadas em uma extrusora monorosca.

O início da extrusão do material formulado foi realizado após as três zonas do parafuso (alimentação, transição e alta pressão) alcançarem as temperaturas pré estabelecidas. A 
temperatura da $1^{\mathrm{a}}$ zona foi mantida em $60^{\circ} \mathrm{C}$, a temperatura da $2^{\mathrm{a}}$ zona a $100^{\circ} \mathrm{C}$ e a temperatura da $3^{\mathrm{a}}$ zona variou conforme o delineamento experimental (Tabela 2).

Os extrudados expandidos após a saída da matriz foram secos em um secador com circulação de ar forçado a $70^{\circ} \mathrm{C}$ por 4 horas ou até que a umidade final seja inferior a $4 \%$ (base seca).

\section{Desenvolvimento das formulações}

A Tabela 3 contém as formulações dos biscoitos tipo cookie sem glúten elaborados com farinha de extrudados mista de cascas e albedo de maracujá e arroz.

Tabela 3. Formulações desenvolvidas para elaboração de biscoitos do tipo cookie sem glúten à base de farinha de extrudados mista de cascas e albedo de maracujá e arroz com substituição parcial de 5\%,10\% e 18,4\%.

\begin{tabular}{lccc}
\hline \multicolumn{4}{c}{ Tipos de Formulações de Farinha de cascas e albedo de maracujá } \\
\hline Ingredientes & $\begin{array}{c}5 \% \\
\left(\mathrm{Fb}_{8}\right)^{*}\end{array}$ & $\begin{array}{c}10 \% \\
\left(\mathrm{Fb}_{12}\right)^{*}\end{array}$ & $\begin{array}{c}18,4 \% \\
\left(\mathrm{Fb}_{13}\right)^{*}\end{array}$ \\
\hline Amido de milho (g) & 160 & 120 & 80 \\
Farinha extrudada (casca e albedo & 40 & 80 & 120 \\
de maracujá e arroz (g) & & & \\
Açúcar refinado (g) & 80 & 80 & 80 \\
Gordura de palma (g) & 60 & 60 & 60 \\
Bicarbonato de sódio (g) & 2 & 2 & 2 \\
Sal refinado (g) & 1 & 1 & 1 \\
Lecitina de soja (ml) & 2 & 2 & 2 \\
Baunilha (ml) & 2 & 2 & 4 \\
Soro de Leite (g) & 4 & 4 & 2 \\
Gema de ovo (ud) & 2 & 2 & 2 \\
Bicarbonato de amônia(g) & 2 & 2 & \\
\hline
\end{tabular}

NOTA: Porcentagens dos ingredientes calculadas em relação ao peso do amido de milho.

* valores correspondentes a \% de farinha da casca e albedo de maracujá; Fb: Formulação do biscoito

Fonte: Valéria F. de Souza

\section{Processamento de biscoitos}

Para a obtenção do biscoito tipo cookies com as farinhas mistas de extrudados de cascas e albedo de maracujá e arroz, foram obtidas a partir de um delineamento inteiramente casualizado, com três tratamentos de misturas para cookies. $\mathrm{O}_{8}$ com $5 \%$ de farinha de cascas e albedo de maracujá (FCAM) e 95\% de farinha de arroz (FA) e o $\mathrm{T}_{12}$ com $10 \%$ de FCAM e $90 \%$ de FA e o $\mathrm{T}_{13}$ com $18,4 \%$ de FCAM e $81,6 \%$ de FA, respectivamente. Para o processamento dos biscoitos tipo cookies composta por amido de milho ( $\mathrm{T}_{8}: 160 \mathrm{~g}$, $\left.\mathrm{T}_{12}: 120 \mathrm{~g}, \mathrm{~T}_{13}: 80 \mathrm{~g}\right)$, farinha extrudada de cascas e albedo de maracujá e arroz $\left(\mathrm{T}_{8}: 40 \mathrm{~g}, \mathrm{~T}_{12}: 80 \mathrm{~g}\right.$, $\mathrm{T}_{13}: 80 \mathrm{~g}$ ) e demais ingredientes fixos para os $\mathrm{T}_{8}, \mathrm{~T}_{12}$ e $\mathrm{T}_{13}$ com adição de açúcar refinado $(80 \mathrm{~g})$, gordura de palma $(60 \mathrm{~g})$, bicarbonato de sódio $(2 \mathrm{~g})$, sal refinado (1g), lecitina de soja $(2 \mathrm{ml})$, baunilha $(2 \mathrm{ml})$, soro de leite $(4 \mathrm{~g})$, gema de ovo(2 uds) e bicarbonato de amônia $(2 \mathrm{~g})$. 
Todos os ingredientes foram pesados separadamente em uma balança digital e as misturas para cookies foram obtidas em duas fases, onde se elaborou primeiro um creme com: lecitina de soja, açúcar refinado, gordura de palma, soro de leite, sal e ovos). Essa, fase onde se produziu o creme, foi efetuada por 3 minutos e na segunda fase fez-se a incorporação das farinhas (farinha extrudada de cascas e albedo de maracujá e arroz, amido de milho, bicarbonato de amônia, baunilha e fermento) ao creme para homogeneização na batedeira planetária (Arno Deluxe SX80, Brasil) por 5 minutos para a obtenção da massa. Após o processo de mistura, é realizada a abertura da massa laminar a $(2 \mathrm{~cm})$ sendo então estendida com o auxílio de um rolo em uma superfície de mármore e moldar com forma retangular obtendo-se a modelagem do biscoito. Após essa etapa foi realizada o corte da massa. Em seguida, os biscoitos foram assados em fôrma previamente forrada com papel manteiga, o forneamento ocorreu a $220^{\circ} \mathrm{C}$, por 10 minutos, em forno elétrico industrial pré-aquecido (Marca Suggar). Após o forneamento os biscoitos foram resfriados à temperatura ambiente. Após uma hora de resfriamento, foram realizadas as análises físicas dos cookies, com exceção da força de quebra, que foi realizada posteriormente, com biscoitos armazenados em temperatura ambiente e colocados em recipientes fechados hermeticamente. Após o resfriamento foram acondicionados em embalagens plásticas hermeticamente fechados.

\section{Avaliação Física dos Produtos Panificáveis}

A avaliação física foi realizada em três biscoitos em um único experimento, sendo determinados os valores médios da massa, volume aparente, volume específico, diâmetro, espessura e fator de expansão.

\section{Rendimento}

Os produtos panificáveis antes e após o forneamento foram pesados, e o rendimento (R) foi determinado através da fórmula abaixo.

$$
R=\frac{\text { Peso antes do forneament }(g)}{\text { Peso após } o \text { forneamenb }(g)}
$$

\subsubsection{Diâmetro e espessura}

O diâmetro dos biscoitos após o forneamento foi determinado com régua de escala milimetrada, e a espessura com paquímetro expressa em milímetros, após o forneamento de acordo com os procedimentos descritos no método 10-50D da INSTITUTO ADOLFO LUTZ, 1985. 


\section{Fator de expansão}

O fator de expansão (FE) foi determinado pela razão entre os valores de diâmetro e espessura dos biscoitos após o forneamento (AACC, 1995).

$$
F E=\frac{\text { Diâmetrodo produto }(\mathrm{mm})}{\text { Espessurado produto }(\mathrm{mm})}
$$

\section{Volume específico}

O volume específico (VE) dos produtos elaborados foi calculado pela relação entre o volume aparente (determinado pelo método de deslocamento da massa ocupada (de sementes de painço), e o peso dos biscoitos após o forneamento (determinando o seu volume em proveta graduada) (EL-DASH, CAMARGO e DIAZ, 1982). A determinação do volume específico foi realizado com 10 repetições. O cálculo será feito como abaixo disposto.

$$
V E=\frac{\text { Volume do produto }\left(\mathrm{cm}^{3}\right)}{\text { Peso do produto }(\mathrm{g})}
$$

\section{Análise sensorial dos biscoitos}

Esse estudo foi submetido e aprovado pelo Comitê de Ética na Pesquisa da Universidade Federal Rural do Rio de Janeiro sob o protocolo de $n^{\circ} 379 / 2013$ e os julgadores que participaram da análise sensorial assinaram um Termo de Consentimento Livre e Esclarecido elaborado com a Resolução n¹96/96 do Conselho Nacional de Saúde.

Os biscoitos foram avaliados sensorialmente no laboratório de Análise Sensorial na Embrapa Agroindústria de Alimentos, para os atributos de aparência, aroma, sabor, textura e aceitação. Foi constituída por julgadores da Instituição da Empresa (Embrapa Agroindústria de Alimentos localizado em Guaratiba-RJ) e Universidade Federal Rural do Rio de Janeiro (UFRRJ), incluindo estudantes e funcionários vinculado a ela.

O painel foi constituído por 100 julgadores não treinados, de ambos os sexos e faixas etárias, os quais avaliaram os biscoitos tipo cookie sem glúten com farinha mista extrudada de cascas e albedo de maracujá e arroz, respectivamente pela escala hedônica de aceitação. Segundo IFT (1981), cita que os julgadores não necessitam de treinamento, porém, são selecionados para representar uma população alvo. 
Cada julgador recebeu três amostras, com os diferentes tratamentos, pesando aproximadamente variando entre 5,56 a 9,22g cada, distribuídas em blocos completos casualizados de forma aleatória em pratos descartáveis e identificados com códigos de três dígitos.

Foi fornecido aos julgadores água mineral à temperatura ambiente para limpeza das papilas gustativas e uma ficha de avaliação sensorial, a qual continha uma escala estruturada de 9 pontos, ancorada pelos eixos:1, correspondente "desgostei extremamente, e 9, a gostei extremamente (STONE e SIDEL, 1985).

\section{Resultados e Discussão}

\section{Avaliação Física dos Produtos Panificáveis}

$\mathrm{Na}$ Tabela 4 estão os resultados da avaliação física do biscoito tipo cookie com farinha de cascas e albedo de maracujá e arroz.

Tabela 4. Características físicas dos biscoitos tipo cookies contendo cascas e albedo de maracujá

\begin{tabular}{|c|c|c|c|c|c|c|c|}
\hline Formulações & MAF(g) & $\operatorname{MDF}(\mathrm{g})$ & DDF(cm) & $\mathbf{E}(\mathbf{c m})$ & $\mathbf{F E}$ & $\mathbf{V A}(\mathbf{m L})$ & VE(mL.g $\left.{ }^{-1}\right)$ \\
\hline $\begin{array}{l}5 \% \text { de farinha } \\
\text { de cascas e } \\
\text { albedo de } \\
\text { maracujá }\end{array}$ & $\begin{array}{c}6,924 \pm \\
0,731516^{\mathrm{a}}\end{array}$ & $\begin{array}{c}5,701 \pm \\
0,625805^{\mathrm{a}}\end{array}$ & $\begin{array}{c}5,3349 \pm \\
0,142165^{a}\end{array}$ & $\begin{array}{c}0,685 \pm \\
0,112492^{\mathrm{a}}\end{array}$ & $\begin{array}{c}7,9963 \pm \\
1,421624^{\mathrm{a}}\end{array}$ & $\begin{array}{c}84,5 \pm \\
5,502525^{a}\end{array}$ & $\begin{array}{c}14,9132 \pm \\
1,17469796^{a}\end{array}$ \\
\hline $\begin{array}{lr}10 \% & \text { de } \\
\text { farinha } & \text { de } \\
\text { cascas } & \mathrm{e} \\
\text { albedo } & \text { de } \\
\text { maracujá } & \end{array}$ & $\begin{array}{c}6,806 \pm \\
0,590503^{b}\end{array}$ & $\begin{array}{c}5,794 \pm \\
0,52865^{\text {a }}\end{array}$ & $\begin{array}{c}4,9846 \pm \\
0,296036^{a}\end{array}$ & $\begin{array}{c}0,6726 \pm \\
0,10488^{a}\end{array}$ & $\begin{array}{c}7,621 \pm \\
1,612821^{\mathrm{a}}\end{array}$ & $\begin{array}{c}86,5 \pm \\
2,415229^{a}\end{array}$ & $\begin{array}{c}15,054 \pm \\
1,4978062^{\mathrm{a}}\end{array}$ \\
\hline $\begin{array}{lr}18,4 \quad \% & \text { de } \\
\text { farinha } & \text { de } \\
\text { cascas } & \mathrm{e} \\
\text { albedo } & \text { de } \\
\text { maracujá } & \end{array}$ & $\begin{array}{c}7,845 \pm \\
0,622276^{c}\end{array}$ & $\begin{array}{c}6,827 \pm \\
0,538476^{b}\end{array}$ & $\begin{array}{c}5,0229 \pm \\
0,122078^{a}\end{array}$ & $\begin{array}{c}0,6034 \pm \\
0,078952^{\mathrm{a}}\end{array}$ & $\begin{array}{c}8,4435 \pm \\
1,035903^{b}\end{array}$ & $\begin{array}{c}79,5 \pm \\
1,581139^{a}\end{array}$ & $\begin{array}{c}11,7001 \pm \\
0,80205354^{a}\end{array}$ \\
\hline
\end{tabular}

Letras diferentes na mesma coluna possuem diferença significativa pelo teste de Tukey $(\mathrm{p}<0,05)$. MAF: massa antes forneamento; MDF: massa depois do forneamento; DDF: diâmetro depois do forneamento; E: espessura; FE: fator de expansão (DDF/E); VA: volume aparente; VE: volume específico(VA/MDF).F $5 \%$ de farinha de cascas e albedo de maracujá; $F_{12}$ : Formulação com $10 \%$ de farinha de cascas e albedo de maracujá e $\mathrm{F}_{13}$ : Formulação com 18,4\% de farinha de cascas e albedo de maracujá.

Fonte: Valéria F. de Souza 
As características físicas dos cookies (Tabela 4), mostra que não houve aumento no diâmetro após o forneamento de todas as amostras, não havendo diferença entre as formulações (F8, F12 e F13) dos cookies.

O diâmetro dos cookies (Tabela 4) apresentou maiores valores entre as melhores formulações $\left(\mathrm{F}_{8}, \mathrm{~F}_{12}\right.$ e $\left.\mathrm{F}_{13}\right)$ comparado aos citados por Oliveira e Curta (2014) identificaram o diâmetro para os cookies elaborados com farinha de banana verde foi de 3,9. Por outro lado, Silva, Pinto e Soares (2018) identificaram o aumento no diâmetro do cookie depois do forneamento foi de 6,15 resultado superior a $[518$ presente estudo.

Verifica-se que o fator de expansão dos cookies apresentou maiores valores com substituição parcial de farinha de cascas e albedo de maracujá entre as formulações $\left(\mathrm{F}_{8}-5 \%\right.$, $\mathrm{F}_{12}-10 \%$ e $\left.\mathrm{F}_{13}-18,4 \%\right)$. Assim, pelo presente estudo verifica-se que o fator de expansão apresentou resultados maiores que Feddern et al. (2011) para fibra do farelo de arroz e farelo de trigo (contendo 10\%, 20\% e 30\%) adicionada na massa que reduziu a expansão dos biscoitos. De acordo com Santos, Storck e Fogaça (2014) os valores de fator de expansão dos biscoitos de farinha de casca de limão variaram de 5,9 a 6,4. Por outro lado, Silva, Pinto e Soares (2018) identificaram o fator de expansão para cookie enriquecido de farinha de amêndoa de pequi foi de 0,42 .

No estudo de Mariani et al.(2015), os biscoitos sem glúten, elaborados a partir de farinha de arroz, farelo de arroz e farinha de soja apresentaram menor fator de expansão (4,45\% com farinha de arroz e farinha de soja), (4,77\% com farelo de arroz e farinha de soja) e $(5,09 \%$ com farinha de arroz, farelo de arroz e farinha de soja). No presente estudo, observou-se um aumento na expansão dos cookies quando se aumentou o teor de farinha de cascas e albedo de maracujá conforme a Tabela 4.

Os cookies contendo $5 \%$ de cascas e albedo de maracujá apresentaram maior espessura. Por outro lado, Feddern et al. (2011) relatou que os biscoitos elaborados na proporção de 10 e $30 \%$ de farelo de arroz apresentaram maior espessura. As fibras das formulações $\mathrm{F}_{12}$ e $\mathrm{F}_{13}$ contendo $10 \%$ e 18,4\% de cascas e albedo de maracujá apresentaram menor espessura. Para Mariani et al.(2015), a espessura de biscoito tipo cookie elaborados com farinha de arroz, farelo de arroz e farinha de soja apresentaram menor espessura comparados ao presente estudo. A espessura dos cookies elaborados com farinha de cascas e albedo de maracujá e arroz após o forneamento não diferiram estatisticamente entre si ( $p>0,05)$. Comparando os resultados obtidos com Oliveira e Curta (2014) que desenvolveram cookie isento de glúten obtido com biomassa e farinha de banana (Musa paradisíaca) verde verificaram que após o forneamento a espessura foi de 0,8 . Verifica-se que a espessura dos 
cookies da Tabela 4 apresentou valores menores em relação ao citado por Oliveira e Curta (2014). Tal fato pode ser explicado pelos ingredientes e isentos de quantidade de água elaborados para os cookies, mesmo utilizando percentuais diferenciados de farinha de cascas e albedo de maracujá e arroz entre as formulações.

O volume específico dos cookies na Tabela 4 não afetou estatisticamente.

As massas dos cookies antes e depois do forneamento apresentaram diferença significativa entre si para as formulações na Tabela 4.

Não houve diferença significativa $(p>0,05)$ entre as formulações de cookies, quanto ao volume aparente conforme a Tabela 4.

\section{Aceitabilidade dos biscoitos tipo cookies}

A Tabela 5 mostram o índice de aceitação com relação aos diferentes atributos avaliados para os biscoitos tipo cookie sem glúten à base de arroz e cascas e albedo de maracujá com as distintas formulações.

Tabela 5. Médias e desvio padrão do teste de aceitação sensorial dos biscoitos tipo cookies utilizando concentrações de farinha de cascas e albedo de maracujá adicionada a farinha de arroz.

\begin{tabular}{|c|c|c|c|c|c|c|c|c|c|c|c|c|}
\hline & \multicolumn{4}{|c|}{$\begin{array}{c}\text { Fb8 } \\
5 \% * \\
\end{array}$} & \multicolumn{3}{|c|}{$\begin{array}{c}\mathbf{F b}_{12} \\
10 \% *\end{array}$} & & \multicolumn{4}{|c|}{$\begin{array}{c}\mathbf{F b}_{13} \\
18,4 \%\end{array}$} \\
\hline Aparência & 6,26 & \pm & 1,91 & b & 5,82 & \pm & 1,97 & b & 6,98 & \pm & 1,50 & a \\
\hline Aroma & 6,91 & \pm & 1,44 & a & 5,91 & \pm & 1,74 & b & 6,75 & \pm & 1,45 & a \\
\hline Sabor & 6,70 & \pm & 1,55 & a & 5,41 & \pm & 2,11 & b & 6,63 & \pm & 1,62 & a \\
\hline Textura & 6,90 & \pm & 1,50 & a & 4,72 & \pm & 1,95 & b & 7,06 & \pm & 1,49 & a \\
\hline Aceitação & 6,68 & \pm & 1,50 & a & 5,26 & \pm & 1,95 & b & 6,75 & \pm & 1,49 & a \\
\hline
\end{tabular}

Letras diferentes em cada linha significa que as amostras foram significativamente diferentes $(\mathrm{p}<0,05)$

*Porcentagem da farinha de cascas e albedo de maracujá incorporada à farinha de arroz.

Fonte: Valéria F. de Souza

Adicionalmente, no estudo de Nascimento et al. (2020) sobre a elaboração de biscoito com a farinha da casca do maracujá (Passiflora edulis), nas proporções de $10 \%$ e $20 \%$ da farinha, com a nota entre 8 e 7 (gostei muito e gostei moderadamente) obteve melhor aceitabilidade em relação a aceitação global comparado ao presente estudo. Ainda, os biscoitos com maior índice de aceitabilidade foram os com $5 \%$ e $18,4 \%$ e os com menor índice de aceitabilidade foi o com $10 \%$ da farinha da casca e albedo de maracujá.

Quanto ao atributo aparência, as formulações diferiram estatisticamente entre si $(\mathrm{p}<0,05)$. Esses resultados apresentados da elaboração de biscoito com a farinha da casca do maracujá (Passiflora edulis) citado por Nascimento et al. (2020) podem ser considerados superiores 
comparados as formulações com farinha de casca e albedo de maracujá em relação ao atributo aparência. Ramos et al. (2018) reportaram médias de aceitabilidade para aparência superiores $(8,0$ e 7,1$)$ ao desta pesquisa.

A Tabela 5 mostra que a diferença de aroma das formulações diferiram estatisticamente entre si $(\mathrm{p}<0,05)$. Esses índices são muito inferiores (Tabela 5) se comparados aos biscoitos elaborados com 10\%, 20\% e 30\% nas formulações de farinha da casca do maracujá (Passiflora edulis) desenvolvidos por Nascimento et al. (2020). Já para os autores Ramos et al. (2018) relataram a aceitabilidade de biscoitos tipo cookie enriquecidos com farinha de jatobá e afirmaram que os biscoitos adicionados de $10 \%$ e $20 \%$ de farinha de jatobá a sua formulação não diferiram estatisticamente entre si $(\mathrm{p}<0,05)$ em relação ao aroma.

Com relação ao sabor, foi demonstrado diferença estatística significativa $(p<0,05)$ entre as formulações. Para as Fb8 e Fb13 apresentaram semelhanças neste atributo. Por outro lado, os biscoitos com farinha da casca do maracujá (Passiflora edulis) elaborados por Nascimento et al.(2020) apresentaram para o atributo sabor as formulações $\mathrm{A}(8,30)$ e $\mathrm{B}(7,42)$ maiores aceitabilidade. Ramos et al.(2018) ao avaliarem sensorialmente biscoitos tipo cookie com farinha de jatobá, obtiveram médias superiores ao deste trabalho para o atributo sabor.

Quanto à textura, a melhor formulação foi a Fb13. Nascimento et al. (2020) elaboraram três formulações de biscoitos com farinha da casca do maracujá, e obtiveram no atributo textura valor maior de aceitação nas formulações $A(7,85)$ e $B(7,69)$. Assim pelo presente estudo verifica-se que os resultados apresentados para textura de biscoito com farinha da casca e albedo de maracujá e arroz foram inferiores quando comparado as formulações A e B, de biscoitos processados com farinha da casca do maracujá (Passiflora edulis) citado por Nascimento et al. (2020). Por outro lado, Ramos et al. (2018) estudou a aceitabilidade dos biscoitos tipo cookie enriquecidos com farinha de jatobá e mencionaram que para o atributo crocância os biscoitos não apresentaram diferença significativa nas formulações elaboradas com $10 \%$ e $20 \%$ de farinha de jatobá. Neste estudo encontramos valores superiores quanto à textura para cookies formulados com 18,4\% de farinha de cascas e albedo de maracujá e arroz em comparação aos encontrados por Oliveira et al. (2017) nas formulações B $(6,94)$ e C $(6,44)$.

\section{Conclusões}

Os biscoitos cookie isento de glúten enriquecidos com farinha mista de cascas e albedo de maracujá e arroz apresentaram aumento de diâmetro e do fator de expansão. 
Sensorialmente, os biscoitos mais aceitáveis quanto à aparência, textura e aceitação foram os biscoitos com 18,4\% da Fb13, sendo aqueles com 5\% da Fb8 considerados com melhor aroma e sabor.

A aceitabilidade da Fb13 foi satisfatória, indicando que o cookie desenvolvido apresenta potencial para inclusão em produtos isentos de glúten.

A incorporação de $18,4 \%$ de farinha de cascas e albedo de maracujá em biscoitos, verifica-se que os biscoitos mais apreciados constaram daqueles com maior percentual de fibras.

Em relação aos biscoitos contendo $10 \%$ de farinha de cascas e albedo de maracujá foram considerados os menos aceitáveis quanto aos atributos sensoriais.

Portanto, concluí-se que o uso de co-produtos (cascas e albedo de maracujá) na fabricação de farinha para cookies pode ser uma alternativa viável para o consumo por portadores de doença celíaca.

\section{Referências}

ABIMAPI. Associação Brasileira das Indústrias de Biscoitos, Massas. Disponível em http://www.investimentosenoticias.com.br/noticias/negocios/abimapi-registra-crescimento-de50-das-exportacoes-em-2017. Acesso em outubro de 2018.

ABUD, A.K.S.; NARAIN, N. Incorporação da farinha de resíduo do processamento de polpa de fruta em biscoitos: uma alternativa de combate ao desperdício. Brazilian Journal of Food Technology, v.12, n.4, p.257-265, 2009.

AMERICAN ASSOCIATION OF CEREAL CHEMISTS (AACC). Approved methods of American Association of Cereal Chemists. $9^{\text {th }}$ ed. St. Paul, 1995.

ASCHERI, J. L. R.; CARVALHO, C.W.P. Apostila do curso anual em processo de extrusão de alimentos: aspectos tecnológicos para o desenvolvimento e produção de alimentos para consumo humano e animal. Rio de Janeiro: Embrapa Agroindústria de Alimentos. 2015. 100p.

AWOLU, O.O.; OLUWAFERANMI, P.M.; FAFOWORA, O. I.; OSEYEMI, G. F. Optimization of the extrusion process for production of ready-to-eat snack from rice, cassava and kersting's groundnut composite flours. LWT- Food Science and Technology, v.64, n.1, p.18-24, 2015.

BERK, Z. Food process engeneering and technology. Academic Press. New York, 2009. p.333-350.

BOX, G. E. P. Exploration of maxima and ridge systems with second-order response surfaces. In: Empirical model-building and response surfaces. Eds. G. E. P. Box John Wiley \& Sons, New York. 1987. p.304-322. 
BRAM, P.; FAISAL,T.; GREET, K.; KRISTOF, B.; HANS, G.;MARTINE, W.; JANA, D. The role of sugar and fat in sugar-snap cookies: structural and textural properties. Journal of Food Engineering, v.90, n.3, p. 400-408, 2009.

CÓRDOVA, K. R. V.; GAMA, T. M. M.T. B.; WINTER, C.M.G.; KASKANTZIS NETO G.; FREITAS, R. J. S. Características físico-químicas da casca do maracujá amarelo (Passiflora edulis flavicarpa Degener) obtida por secagem. Boletim do Centro de Pesquisa de Processamento de Alimentos. Curitiba, v.23, n.2, p.221-230, 2005.

EL-DASH, A.A.; CAMARGO, C.O.; DIAZ, N. M. Fundamentos da tecnologia de panificação. Série Tecnologia Agroindustrial. São Paulo: Fundação Tropical de Pesquisas e Tecnologia Agroindustrial, 1982. 349p.

FARO, H.C. Doença celíaca: revisão bibliográfica.2008. 95f. Monografia (Especialização em Pediatria) - Hospital Regional da Asa Sul, Brasília, 2008.

FEDDERN, V.; DURANTE, V.V.O.; MIRANDA, M.Z.; MELLADO, M. L. M. S. Avaliação física e sensorial de biscoito tipo cookie adicionados de farelo de trigo e arroz. Brazilian Journal of Food Technology, v.14, n.4, p.267-274, 2011.

FENACELBRA- Federação Nacional das Associações de Celíacos do Brasil. Guia orientador para celíacos. Ministério da Justiça. 2010.

FERREIRA, S.M.R.; LUPARELLI, P.C.; SCHIEFERDECKER, M. E.M.; VILELA, R.M. Cookies sem glúten a partir da farinha de sorgo. Archivos Latinoamericanos de Nutrición, v.59, n.4, p.433-440, 2009.

GALISTEO, M.; DUARTE, J.; ZARZUELO, A. Effects of dietary fibers on disturbances clustered in the metabolic syndrome. Journal of Nutritional Biochemistry, v.19, n.2, p. 7184, 2008.

GISSlEN, W. Panificação \& Confeitaria Profissionais. Le Cordon Bleu. Academia de Artes Culinárias de Paris. 5ed. Barueri: Manole, 2014.

GÖKMEN, V.; SERPEN, A.; AÇAR, O.C.; MORALES, F.J. Significance of furosine as heatinduced marker in cookies. Journal of Cereal Science, v.48, n.3, p.843-847, 2008.

IBGE. Instituto Brasileiro de Geografia e Estatística. Produção Agrícola Municipal, 2018.

INSTITUTE OF FOOD TECHNOLOGISTS. Sensory Evaluation Division. Sensory evaluation guide for testing food and beverage products. Food Technology., v.35, n.11, p.50$59,1981$.

INSTITUTO ADOLFO LUTZ. Normas analíticas do Instituto Adolfo Lutz. $3^{\text {a }}$ edição. São Paulo, v.1, p.533, 1985.

LA BARCA, A.M.; ROJAS-MARTÍNEZ, M.E.; ISLAS-RUBIO, A.R.; CABRERACHÁVEZ, F. Glúten-freee breads and cookies of raw and popped amaranth flours with 
attractive technological and nutritional qualities. Plant Foods for Human Nutrition, Dordrecht, v.65, n.3, p.241-246, 2010.

MARIANI, M.; OLIVEIRA, V.R.; FACCIN, R.; RIOS, A. O.; VENZKE, J.G. Elaboração e avaliação de biscoitos sem glúten a partir de farelo de arroz e farinhas de arroz e soja. Brazilian Journal of Food Technology, Campinas, v.18, n.1, p.70-78, 2015.

MELETTI, L.M.M. Avanços na cultura do maracujá no Brasil. Revista Brasileira de Fruticultura, Jaboticabal,v.33, n.spe1, p.83-91, 2011.

NABESHIMA, E. H.; EL-DASH, A. A. Modificação química da farinha de arroz como alternativa para o aproveitamento dos subprodutos do beneficiamento do arroz. Boletim do Centro de Pesquisa Processamento de Alimentos, Curitiba, v.22, n.1, p.107-120, 2004.

NASCIMENTO, N.C.; MEDEIROS, H.I.R.; PEREIRA, I.C.; OLIVEIRA, R.E.S.; MEDEIROS, I. L.; JÚNIOR, F.C.M. Elaboração do biscoito com a farinha da casca do maracujá (Passiflora edulis). Research, Society and Development, v.9, n.7, e501974333, 2020.

OLIVEIRA, D. I.; KOLAKOWSKI, A.P.; SIMÕES, D.R.S.; LOS, P.R.; DEMIATE, I.M. Biscoitos tipo cookie sem glúten formulados com farelo de feijão, farinha de arroz e amido de mandioca. Revista Brasileira de Tecnologia Agroindustrial, Ponta Grossa, v.11, n.2, p. 2502-2522, 2017.

OLIVEIRA, A.; CURTA, C. C. Cookie isento de glúten obtido com biomassa e farinha de banana (Musa paradisíaca)verde. Paraná, 2014. Dissertação de Graduação em Alimentos.

OLIVEIRA, C. A. O.; ANSELMI, A. A.; KOLLING, FINGER, M. I. F.; DALLA, CORTE, V. F.; DILL, M. D. Farinha de arroz e derivados como alternativas para a cadeia produtiva do arroz. Revista Brasileira de Produtos Agroindustriais, Campina Grande, v.16, n.3, p.291297, 2014.

PANG, Y.; AHMED, S.; XU, Y.; BETA, T.; ZHU,Z.; SHAO, Y.; BAO, J. Bound phenolic compounds and antioxidant properties of whole grain and bran of white, red and black rice. Food Chemistry, v.240, p.212-221, 2018.

RAMOS, F.S.A.R.; SANTOS, T.C.; FERREIRA,T.H.B.; GOMES, M.C.S.; MUNHOZ, C.L. Aceitabilidade de biscoito tipo cookie enriquecidos com farinha de jatobá. Cadernos de Agroecologia, v.13,n.2, 2018.

RAHAIE, S.; GHARIBZAHEDI, S. M. T.; RAZAVI, S.H.; JAFARI, S.M. Desenvolvimentos recentes sobre novas fórmulas baseadas em ingredientes nutrientes para a produção de pão saudável-funcional:uma revisão. Journal of Food Science and Tecnology, Mysore, v.51, n.11, p.2896-2906, 2014.

SANTOS, D. S. D.; STORCK, C. R.; FOGAÇA, A.O. Biscoito com adição de farinha de casca de limão. Ciência da Saúde, Santa Maria, v.15, n.1, p.123-135, 2014. 
SILVA, S.R.; PINTO, E. G.; SOARES, D. Biscoito tipo cookie de farinha de amêndoa de pequi: avaliação física e química. Enciclopédia Biosfera, Goiânia, v.15, n.27, 1401-1410, 2018.

SIVARAMAKRISHNAN, H.P.; SENGE, B.; CHATTOPADHYAY,P.K. Rheological properties of rice dough for making rice bread. Journal of Food Engineering, Essex, v.62, n.1, p.37-45, 2004.

STONE, H.; SIDEL, J. L. Sensory Evaluation Practices. Academic Press, Orlando, 1985. 310 p.

YAPO, B.M.; KOFFI, K. L. Yellow passion fruit rind - A potential source of low-methoxyl pectin. Journal of Agricultural and Food Chemistry, Whasington, v.54, n.7, p.2738-2744, 2006.

ZERAIK, M.L.; YARIWAKE, J.H. Analysis of passion fruit rinds (Passiflora edulis):isoorientin quantification by HPTLC and evaluation of antioxidant (radical scavenging) capacity. Química Nova, São Paulo, v.35, n.3, p.541-545, 2012.

ZERAIK, M. L.; PEREIRA, C. A. M.; ZUIN, V.G.; YARIWAKE,J.H. Maracujá: um alimento funcional?. Revista Brasileira de Farmacognosia, Curitiba, v.20, n.3, p.459-471, 2010 .

ZUCOLOTTO, S.M.; FAGUNDES, C.; REGINATTO, F.H.; RAMOS, F.A.; CASTELLANOS, L.; DUQUE, C.; SCHENKEL, E.P. Analysis of C-glycosyl flavonoids from South American Passiflora Species by HPLC-DAD and HPLC-MS. Phytochemical Analysis, v.23, p.232-239, 2012.

ZUCCO, F.; BORSUK, Y.; ARNTFIELD, S.D. Physical and nutritional evaluation of wheat cookies supplemented with pulse flours of different particles sizes. LWT- Food Science and Tecnology, Campinas, v.44, n.10, p.2070-2076, 2011. 


\title{
CAPÍTULO 36: USO DE REVESTIMENTO ATIVO EM FRUTOS: UMA TECNOLOGIA EMERGENTE
}

\section{CHAPTER 36: USE OF ACTIVE COATING IN FRUITS: AN EMERGING TECHNOLOGY}

\author{
Isamara Reis Gomes ${ }^{1}$; Éder Dutra Resende ${ }^{2}$; Daniele Pereira do Amaral ${ }^{3}$;
}

\begin{abstract}
Resumo
O uso de revestimento ativo para a conservação pós-colheita de frutos é uma tecnologia emergente e coerente com os compromissos da sociedade com a sustentabilidade do planeta, visto que com o grande acumulo de resíduos de embalagens não biodegradáveis, junto com a dificuldade de reciclagem da maior parte dessas, o estímulo de desenvolver embalagens biodegradáveis a partir de fontes renováveis e contribuir para a preservação da qualidade dos frutos é uma alternativa viável e promissora. Entre os polímeros naturais, o amido vem ganhando destaque devido sua grande disponibilidade em escala mundial, alto rendimento de extração, valor nutricional, baixo custo, biodegrabilidade e biocompatilidade. O objetivo deste trabalho foi apresentar esta tecnologia emergente e suas aplicações na conservação de diferentes frutos. O uso de revestimento ativo em frutas tem se mostrado uma tecnologia na pós - colheita com grande potencial para a conservação do tempo de vida de frutas, visto que garantem um aumento do tempo de vida de prateleira das frutas, são sustentáveis, de fácil aquisição e de custo acessível, porém é necessário maior incentivo em pesquisas com revestimento ativos e desenvolvimento de novos trabalhos para ampliar a aplicação e desenvolvimento de revestimentos ativos.
\end{abstract}

Palavras-Chave: Revestimento ativo, conservação pós- colheita e amido.

\begin{abstract}
The use of active coating for post-harvest fruit conservation is an emerging technology and consistent with society's commitments to the sustainability of the planet, given that with the large accumulation of non-biodegradable packaging waste, along with the difficulty of recycling the most of these, the incentive to develop biodegradable packaging from renewable sources and contribute to the preservation of fruit quality is a viable and promising alternative. Among natural polymers, starch has been gaining prominence due to its great availability on a world scale, high extraction yield, nutritional value, low cost, biodegradability and biocompatibility. The objective of this work was to present this emerging technology and its applications in the conservation of different fruits. The use of active coating on fruits has proven to be a post-harvest technology with great potential for conserving the life of fruits, since they guarantee an increase in the shelf life of fruits, they are sustainable, easy to acquire and of affordable cost, but greater incentive is needed in research with active coatings and development of new works to expand the application and development of active coatings.
\end{abstract}

Keywords: Active coating, post-harvest conservation and starch.

\footnotetext{
${ }^{1}$ Mestranda Produção Vegetal, UENF, isamarareisgomes@gmail.com

${ }^{2}$ Professor Dr. na área de tecnologia de alimentos, UENF, eresende@uenf.br

${ }^{3}$ Doutora em Produção Vegetal, UENF, dani.alimento@gmail.com
} 
GOMES, I.R; RESENDE, E.D e AMARAL, D.P.

\section{Introdução}

Segundo a FAO (2019), o Brasil é considerado o terceiro maior produtor de frutas do mundo, graças as suas condições climáticas propícias consegue produzir uma grande variedade de diversas frutas.

A técnica mais comum e usual para conservação de frutas em sua fase pós - colheita é uso de cadeias de frios, com baixas temperaturas e com atmosfera controlada, a fim de conservar por mais tempo a fruta (COSTA e CLEMENTE, 2012).

O uso de revestimento ativo em frutos tem sido considerado uma tecnologia emergente, que é capaz de manter as condições do fruto por mais tempo, sem geração de resíduos tóxicos e contribuindo para a preservação da textura e do valor nutricional, reduzindo as trocas gasosas superficiais e a perda ou ganho excessivo de água no fruto (TURHAN, 2010).

A motivação para o aumento de interesse e atividade de pesquisa em filmes e revestimentos biodegradáveis está associada à crescente necessidade do consumidor por alimentos saudáveis e estáveis e também à conscientização em relação aos efeitos ambientais nocivos dos resíduos não biodegradáveis resultantes das embalagens (HASSAN et al., 2018).

Segundo Maia (2000), os revestimentos comestíveis são películas que apresentam espessuras variadas, provenientes de substâncias naturais ou sintéticas, que não apresentam riscos à saúde do consumidor, por passarem pelo trato gastrointestinal sem causar nenhum tipo de dano.

O uso de revestimentos comestíveis na conservação de frutos, intactos ou minimamente processados, em pós-colheita, é considerado uma tecnologia emergente e de grande potencial, principalmente para aplicações sobre frutos de origem tropical (ASSIS E BRITO, 2014). Seu uso proporciona mais vantagens quando comparado com os materiais sintéticos, sendo atóxico, podem ser incorporados com aditivos, retardam a perda de água e são de baixo custo. Atualmente, pesquisas têm levado ao desenvolvimento de novas abordagens ambientalmente sustentáveis com base em polímeros biodegradáveis, que não só convertem os subprodutos da indústria de alimentos em valor agregado a componentes formadores de filme, mas também, reduzem os requisitos de embalagem (MAQBOOL ET AL., 2011).

Filmes e revestimentos biodegradáveis vêm sendo bastante utilizados ao longo dos anos, pois apresentam diversos efeitos quando aplicados em frutas e hortaliças, como: retarda a perda de umidade; diminui as trocas gasosas; aumenta a integridade estrutural, promovendo maior proteção física contra injúrias; retém componentes voláteis, constituintes do odor e do sabor; e atua como veículo de aditivos alimentícios, como, por exemplo, agentes antimicrobianos e antioxidantes (SALGADO et al., 2015). 
GOMES, I.R; RESENDE, E.D e AMARAL, D.P.

\section{Desenvolvimento}

\section{Diversos tipos de revestimento}

As coberturas e revestimentos comestíveis podem ter origem animal ou vegetal, ou formarem um composto com a combinação de ambas. Os mais empregados são polissacarídeos, ceras (lipídios) e proteínas e o tipo a ser utilizado, depende do objetivo desejado com o revestimento aplicado e das características do produto a ser revestido (ASSIS E BRITO, 2014).

Os materiais empregados nos revestimentos podem ser classificados em: hidrofóbicos e hidrofílicos (ASSIS ET AL., 2008).

Hidrofílicos: possuem em sua estrutura grupos amino ou hidroxila e carboxila $(\mathrm{OH}$, $\mathrm{COO}-, \mathrm{NH}_{3}$ ) caracterizados por ligações covalentes polares. Possuem cadeia carbônica com sítios parcialmente carregados positivamente e outros carregados negativamente o que favorece o acúmulo e o rearranjo de moléculas polares, e principalmente da água, em torno desses sítios. São representados por polissacarídeos, como a celulose, a quitina, a goma xantana, a goma guar, a pectina, o amido e os polissacarídeos polieletrólitos, como a carboximetilcelulose, a quitosana e o alginato. Já os materiais hidrofóbicos são formados por moléculas cujas ligações tendem a ser eletricamente neutras, que não configuram regiões polares definidas. Na presença de água esses materiais tendem a se aglomerarem e excluir as moléculas polares de sua redondeza. São representados pelas proteínas hidrofóbicas, óleos e ácidos graxos, em que predominam substituintes de cadeia alifática, parafinas e alcoóis de cadeia longa (ASSIS E BRITO, 2014).

As coberturas hidrofílicas são mais indicadas para superfícies fatiadas, frutas com aspectos brilhantes que apresentem alta molhabilidade ou presença de cargas superficiais. Por terem afinidade por água, as coberturas hidrofílicas preservam o aspecto hidratado, mantendo por mais tempo a superfície brilhante (ASSIS E BRITO, 2014).

Segundo dados publicados na literatura diversos são os materiais que podem ser empregados na formação de revestimento, utilizados em diferentes frutos na condição intacta ou fatiada para o prolongamento da vida útil. Foram utilizados para maçã quitosana e alginato (PILON ET AL., 2013; MOLDÃO-MARTINS ET AL., 2003), para o mamão fécula de mandioca e quitosana (CASTRICINI ET AL., 2012; DOTTO ET AL., 2008), para o abacaxi alginato e fécula de mandioca (AZARAKHSH ET AL., 2012; BIERHALS ET AL., 2011), para uva óleo de babosa e getanina com amido (VALVERDE ET AL., 2005; FAKHOURI ET AL., 2007), para o morango amido de mandioca (GARCIA ET AL., 2012), para o melão alginato e quitosana (RAYBAUDI-MASSILIA ET AL., 2008; KRASAEKOOPT E MABUMRUNG, 2008), para goiaba quitosana com amido e celulose com carnaúba (SOARES ET AL., 2011; MCGUIRE E HALLMAN 1995), para pêra alginato e amido (OMS-OLIU ET AL., 2008; 
GOMES, I.R; RESENDE, E.D e AMARAL, D.P.

BOTREL ET AL., 2010), para banana carragina e quitosana (BICO ET AL., 2009; MALMIRI ET AL., 2011), manga fécula de mandioca e quitosana (SCANAVACA JR. ET AL., 2007; CHIEN ET AL., 2007).

O amido pode ser usado em combinação com outros polímeros ou compostos para melhorar as propriedades funcionais da matriz polimérica, que também pode transportar compostos ativos para controlar melhor o prazo de validade do produto (SAPPER E CHIRALT, 2018).

\section{Preparo e aplicação do revestimento ativo}

Segundo Assis e Brito (2014), a formação do revestimento ativo e sua aplicação em frutos podem ser divididos em nove etapas, conforme ilustra a figura 1, até que se forme uma membrana aderida a cutícula dos frutos ou sobre as estruturas celulósicas das polpas.

O revestimento é obtido pela solubilização dos polímeros em um solvente que geralmente é a água, mas pode ser etanol ou ácido também e pode ou não receber o acréscimo de aditivos, como agentes antimicrobianos, antioxidantes entre outros, obtendo-se uma solução ou dispersão filmogênica (GONTARD et al., 1994).

Durante o processo de formação do revestimento é importante que a evaporação do

solvente ocorra de forma espontânea e lenta, para evitar que se formem bolhas e consequentemente uma cobertura porosa, pois isso influenciaria na barreira que o revestimento faz no fruto (STEWARD et al., 2000). 
GOMES, I.R; RESENDE, E.D e AMARAL, D.P.

Figura 1. Etapas para formação do revestimento ativo.

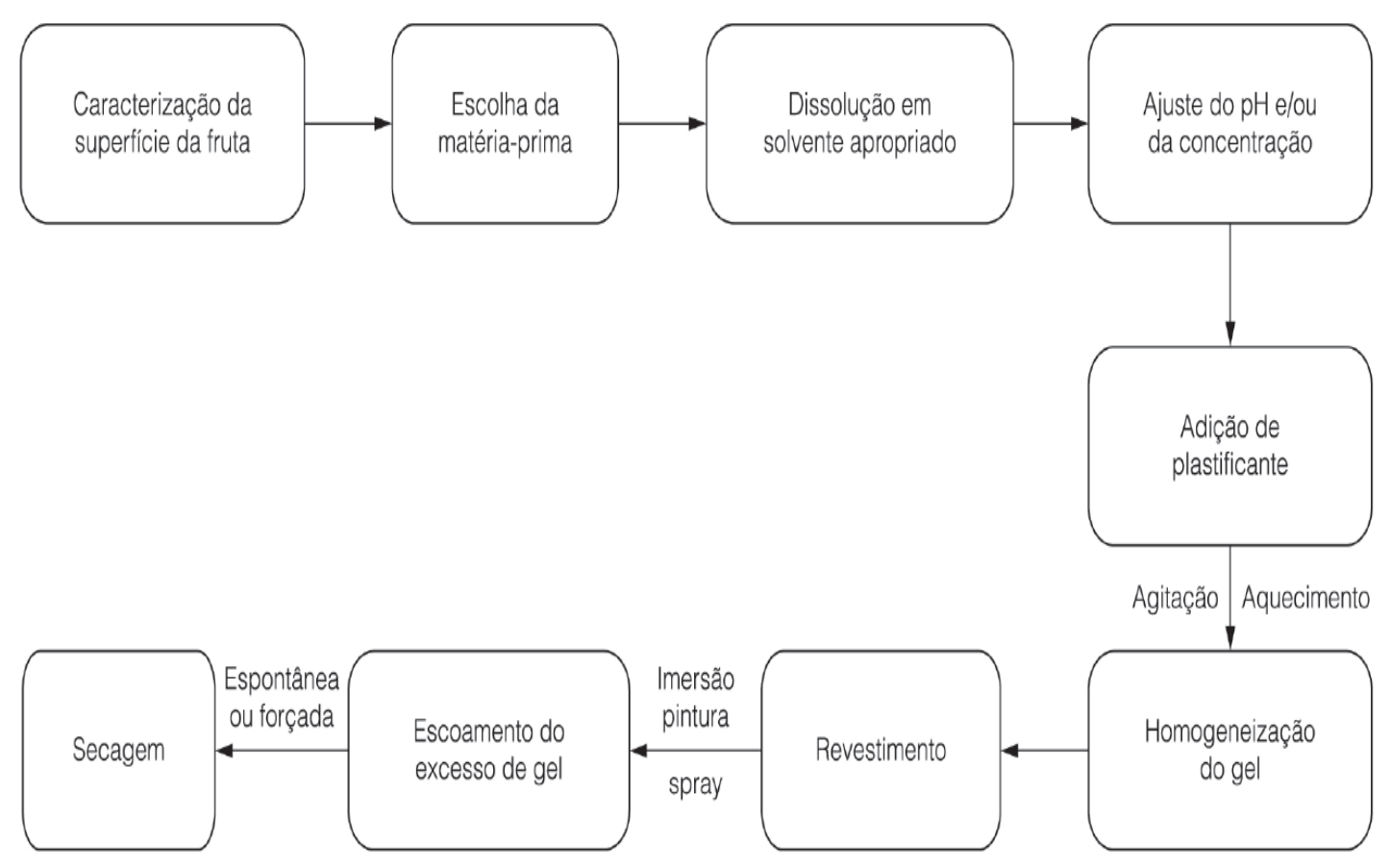

Fonte: Assis e Brito, (2014).

Existem técnicas diferentes para a formação da cobertura em frutos, como uso de pincel, spray e imersão (CHLEBOWSKA SMIGIEL AL., 2007; ANDRADE ET AL., 2012). Mas a técnica mais comum e mais eficiente é o uso da imersão, pois garante que toda a superfície do fruto entre em contato com a solução filmogênica e uma leve agitação nos frutos garante o desprendimento de bolhas e uma deposição de cobertura homogênea.

Ao ser imerso em uma solução filmogênica, o fruto forma uma cobertura pela deposição das espécies poliméricas dissolvidas no meio, estabelecendo ligações, fracas e fortes, com a superfície do fruto. Diversos modelos têm sido propostos para a deposição de estruturas poliméricas e subsequente formação de filmes sobre superfícies sólidas. Nesses modelos, as características do absorvente (a casca) e do absorvato (compostos diluídos na solução filmogênica) são as que definem que tipo de mecanismo será predominante na formação da cobertura (MYERS, 1991; PARIA E KHILAR, 2004). A formação do recobrimento pode ser generalizada segundo a sequência ilustrada na Figura 2. 
GOMES, I.R; RESENDE, E.D e AMARAL, D.P.

Figura 2. Sequência ilustrativa da formação de uma cobertura comestível: (a) imersão do fruto em solução filmogênica (polímeros em solução); (b) atração entre o absorvato (composto diluído na solução filmogênica) e o absorvente (casca); (c) formação da cobertura com evaporação do solvente e reticulação do polímero.

(a)<smiles></smiles>

Processo de adsorção
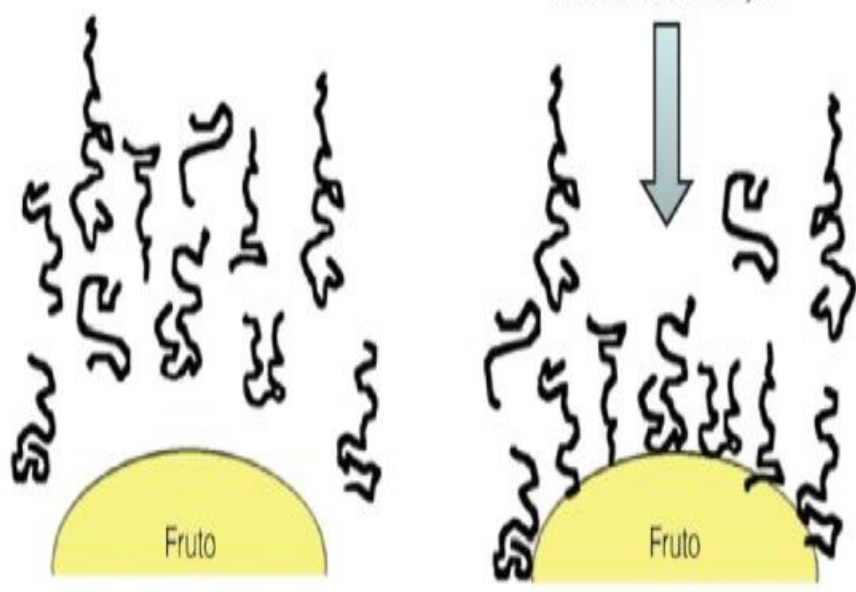

Evaporaçăa do solvente e reticulaçăo ou cura

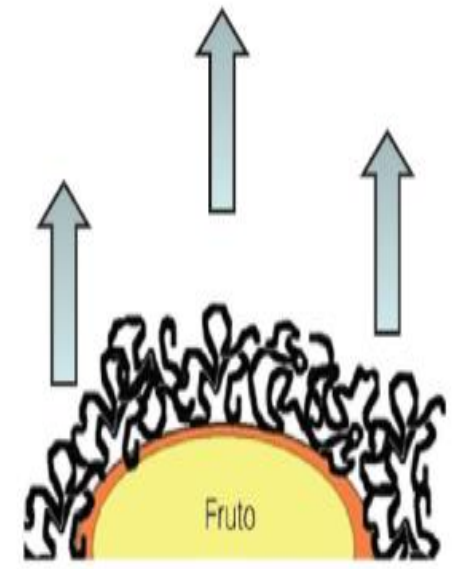

Fonte: Assis e Britto, (2014).

\section{Revestimento a base de amido de mandioca}

O amido é um dos polissacarídeos mais abundantes e importantes na natureza, sendo o mais utilizado para elaboração de coberturas comestíveis em razão do menor custo e alta disponibilidade, fácil manipulação e comestibilidade. Além disso, ele é biodegradável quando lançado no meio ambiente, contribuindo para uma menor poluição ambiental (SAPPER E CHIRALT, 2018).

De modo geral, os amidos contêm cerca de 20 a 30\% de amilose e 70 a $80 \%$ de amilopectina, podendo variar com a fonte botânica, o que confere características específicas ao amido. Variedades mutantes de milho, denominadas de amidos com alto teor de amilose, apresentam um teor de amilose de até $85 \%$, enquanto as variedades comerciais costumam apresentar no máximo 60\%. Em contra partida, certos amidos cerosos contêm apenas amilopectina (CEREDA, 2002). 
Figura 3. Estrutura da amilose.

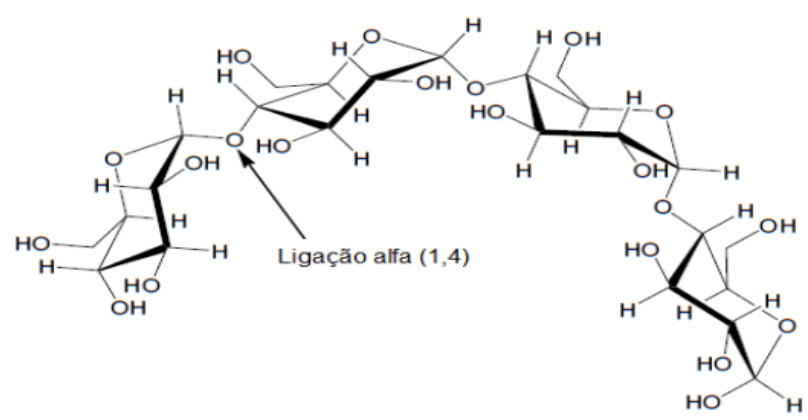

Fonte: Adaptado de WADUGE, 2002.

Figura 4. Estrutura da amilopectina.

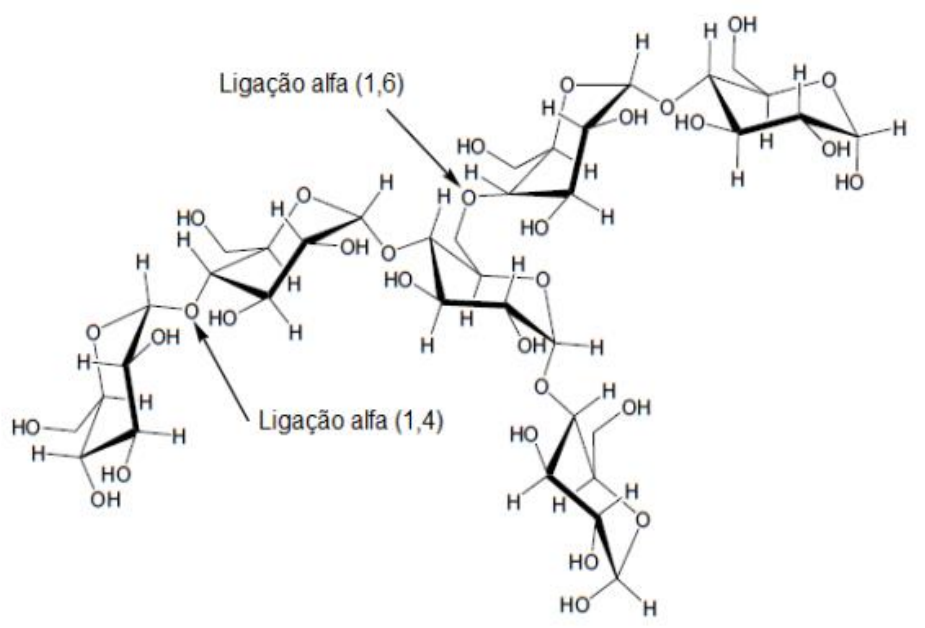

Fonte: Adaptado de WADUGE, 2002.

A fécula (amido) de mandioca é reconhecida por formar películas resistentes e transparentes, sendo eficientes barreiras à perda de água dos alimentos. Na sua forma natural ou modificada, ela é muito utilizada como película visando a conservação após a colheita de produtos frescos (CHITARRA E CHITARRA, 2008).

A formação do revestimento de fécula de mandioca é obtido através da geleificação da fécula durante o aquecimento de uma solução de amido e água à temperatura de $70{ }^{\circ} \mathrm{C}$, promovendo uma ruptura das estruturas cristalinas do grânulo de amido e a absorção de água que entumece a sua estrutura de forma irreversível. Depois da gelatinização do amido e após o resfriamento, quando se atinge a temperatura ambiente, ocorre a retrogradação, ou seja, a reorganização das moléculas por ligações de hidrogênio e forma-se um revestimento resistente e transparente (PARKER E RING, 2001). [542] 
GOMES, I.R; RESENDE, E.D e AMARAL, D.P.

\section{Discussão}

Segundo Assis e Brito (2008), o uso de revestimentos comestíveis embora esteja em processo de desenvolvimento, tem apresentado resultados significativos, como uma prática auxiliar na conservação de produtos perecíveis e, principalmente, daqueles minimamente processados, cujo tempo de prateleira é consideravelmente reduzido em função dos processos aos quais esses produtos foram submetidos. Os revestimentos comestíveis também são veículo para a incorporação de ingredientes funcionais, tais como antioxidantes, compostos aromáticos, agentes antimicrobianos e nutracêuticos (óleos essenciais) (MORADI ET AL., 2012).

Revestimento à base de fécula de mandioca com concentrações de $2 \%$ e $4 \%$ utilizados em mamão formosa manteve o teor de sólidos solúveis totais, acidez titulável, promoveu o aumento do índice de maturação e de vitamina $\mathrm{C}$, além de reduzir a perda de massa, diâmetro, espessura, firmeza da fruta e polpa (NUNES ET AL., 2017).

Em morangos o revestimento de fécula de mandioca na concentração de $3 \%$ foi eficiente para reduzir a taxa de respiração dos frutos, retardar a perda de peso e firmeza de morangos durante o armazenamento de 12 dias (GARCIA ET AL., 2012).

O revestimento com fécula de mandioca nas concentrações de 3 e $5 \%$ em mamões retardam o desenvolvimento da coloração amarela da casca, porém este desenvolvimento é parcial mantendo os frutos firmes por mais tempo, os frutos apresentam menor perda de massa fresca e reduz a taxa respiratória (CASTRICINI ET AL., 2010).

Segundo Pereira et al. (2006), frutos de mamão formosa tiveram sua vida útil póscolheita prolongada em quatro dias com revestimentos comestíveis à base de fécula de mandioca a $1 \%$ e $3 \%$, sem terem sua qualidade prejudicada em função do retardamento do processo de maturação.

\section{Considerações Finais}

O uso de revestimento ativo em frutas tem se mostrado uma tecnologia emergente na área de pós - colheita e com grande potencial para a conservação do tempo de vida de frutos, visto que garantem um aumento do tempo de vida de prateleira das frutos, são sustentáveis, de fácil aquisição e de custo acessível.

Dentre os polímeros usados, vale destacar o amido que apresenta bons resultados no prolongamento da vida útil de diferentes frutos, inclusive do mamão. Porém é necessário maior incentivo em pesquisas com revestimento ativo e desenvolvimento de novos trabalhos para ampliar a aplicação e desenvolvimento de revestimentos ativos com novas fontes de polímeros e utilizá-los em novos frutos e em outros alimentos. 
GOMES, I.R; RESENDE, E.D e AMARAL, D.P.

Ainda que seja improvável que os filmes e revestimentos ativos possam substituir a embalagem sintética convencional, pesquisas são necessárias e podem ajudar a diminuir os milhões de toneladas de plásticos que são consumidos na atualidade, e minimizar os danos que a embalagem convencional provocam na qualidade de vida no planeta.

\section{Referências}

ANDRADE, R. D.; SKURTYS, O.; OSORIO, F. A. Atomizing spray systems for application of edible coatings. Comprehensive Reviews in Food Science and Food Safety, Chicago, v. 11, n. 3, p. 323-337, 2012.

ASSIS, O. B. G.; FORATO, L. A.; BRITTO, D. Revestimentos comestíveis protetores em frutos minimamente processados. Higiene Alimentar, São Paulo, v. 22, n. 160, p. 99-106, 2008 .

ASSIS, ODILIO BENEDITO GARRIDO; BRITTO, DOUGLAS de. Revisão: coberturas comestíveis protetoras em frutas: fundamentos e aplicações. Brazilian Journal of Food Technology, v. 17, n. 2, p. 87-97, 2014.

AZARAKHSH, N.; OSMAN, A.; GHAZALI, H. M.; TAN, C. P.; MOHD-ADZAHAN, N. Optimization of alginate and gellan based edible coating formulations for fresh-cut pineapples. International Food Research Journal, Selangor, v. 19, n. 1, p. 279-285, 2012.

BICO, S. L. S.; RAPOSO M. F. J.; MORAIS, R. M. S. C.; MORAIS, A. M. M. B. Combined effects of chemical dip and/or carrageenan coating and/or controlled atmosphere on quality of fresh-cut banana. Food Control, Amsterdam, v. 20, n. 5, p. 508-514, 2009.

BIERHALS, V. S.; CHIUMARELLI, M.; HUBINGER, M. D. Effect of cassava starch coating on quality and shelf life of fresh-cut pineapple (Ananas comosus L. Merril cv "Pérola"). Journal of Food Science, Chicago, v. 76, n. 1, p. E62-E72, 2011.

BOTREL, D. A.; SOARES, N. F. F.; CAMILlOTO, G. P.; FERNANDES. R. V. B. Revestimento ativo de amido na conservação pós-colheita de pera Williams minimamente processada. Ciência Rural, Santa Maria, v. 40, n. 8, p.1814-1820, 2010. 
GOMES, I.R; RESENDE, E.D e AMARAL, D.P.

CARNEIRO, Lucia Cesar. Revestimentos à base de amido na conservação pós-colheita de pedúnculos de caju anão precoce e goiabas paluma. Orientadora: $\operatorname{Prof}^{\mathrm{a}} \operatorname{Dr}^{\mathrm{a}}$ Angelita da Silveira Moreira. Tese de doutorado (Programa de Pós graduação em Ciência e tecnologia de alimentos) - Faculdade de agronomia Eliseu Maciel, universidade Federal de Pelotas, Pelotas, 2019.

CASTRICINI, A.; CONEGLIAN, R. C. C.; DELIZA. R. Starch edible coating of papaya: effect on sensory characteristics. Ciência e Tecnologia dos Alimentos, Campinas, v. 32, n. 1, p. 8492, 2012.

CASTRICINI, ARIANE; CONEGLIAN, REGINA CELI CAVESTRÉ; DA SILVA VASCONCELLOS, MARCO ANTONIO. Qualidade e amadurecimento de mamões 'golden'revestidos por película de fécula de mandioca. Revista Trópica: Ciências Agrárias e Biológicas, v. 4, n. 1, 2010.

CEREDA, M. P. Propriedades gerais de amido. São Paulo. Fundação Cargill, v. 1. 221p. (Série: Culturas de tuberosas amiláceas latino-americanas), 2002.

CHIEN, P-J.; SHEU, F.; YANG, F-H. Effects of edible chitosan coating on quality and shelf life of sliced mango fruit. Journal of Food Engineering, Amsterdam, v. 78, n. 1, p. 225-229, 2007.

CHITARRA, M. I. F.; CHITARRA, A. B. Pós-colheita de frutas e hortaliças: fisiologia e manuseio. Lavras, Editora UFLA, 2008.

CHLEBOWSKA - SMIGIEL, A.; GNIEWOSZ, M.; SWINCZAK, E. An attempt to apply a pullulan and pullulan-protein coatings to prolong apples shelf-life stability. Acta Scientiarum Polonorum Technologia Alimentaria, Poznan, v. 6, n. 1, p. 49-56, 2007.

COSTA, J. M. C. DA; CLEMENTE, E. Refrigeration and cold chain effect on fruit shelf life. In: RODRIGUES, S.; FERNANDES, F. A. N. (Ed.). Advances in fruit processing technologies. Boca Taton: CRC Press, p. 287-330. http://dx.doi.org/10.1201/ b12088-13, 2012. 
GOMES, I.R; RESENDE, E.D e AMARAL, D.P.

DOTTO, G. L.; GREVINELI, A. C.; OlIVEIRA, A.; PONS, G.; PINTO, L. A. A. Uso de quitosana como fi lme microbiológico para o aumento da vida útil de mamões papaia. In: Congresso de iniciação científica e encontro de pós-graduação, 17., 2008, Pelotas. Anais eletrônicos. Pelotas: Universidade Federal de Pelotas, 2008. Disponível em <www.ufpel.edu.br/ cic/2008/cd/pages/pdf/CA. $>$ Acessado em: maio de 2020.

FAKHOURI, F. M., FONTES, L. C. B., GONÇALVES, P. V. D. M., MILANEZ, C. R., STEEL, C. J., \& COLLARES-QUEIROZ, F. P. Filmes e coberturas comestíveis compostas à base de amidos nativos e gelatina na conservação e aceitação sensorial de uvas Crimson. Food Science and Technology, 27(2), 369-375, 2007.

FAO. Food and Agriculture Organization of the United Nations, 2019. Disponível em: <http://www.fao.org/statistics/en/>. Acessado em: Maio de 2020.

GARCIA, L. C.; PEREIRA, L. M.; SARANTÓPOULOS, C. I. G. L.; HUBINGER M. D. Effect of antimicrobial starch edible coating on shelf-life of fresh strawberries. Packaging Technology and Science, Hoboken, v. 25, n. 7, p. 413-425, 2012.

GONTARD, N.; DUCHEZ, C.; CUQ, J.; GUILBERT, S. Edible composite films of wheat gluten and lipids: Water vapor permeability and other physical properties. International Journal Food Science Technology, v. 29, n. 39-50, 1994.

HASSAN, B.; CHATHA, S. A. S.; HUSSAIN, A. I.; ZIA, K. M.; \& AKHTAR, N. Recent advances on polysaccharides, lipids and protein based edible films and coatings: A review. International journal of biological macromolecules, v. 109, p. 1095-1107, HONG, 2018.

KRASAEKOOPT, W.; MABUMRUNG, J. Microbiological evaluation of edible coated freshcut cantaloupe. Kasetsart Journal (Natural Science), Bangkok, v. 42, n. 3, p. 552-557, 2008.

MAIA, L. H.; PORTE, A.; SOUZA, V. F. Filmes comestíveis: aspectos gerais, propriedades de barreira a umidade e oxigênio. Boletim do Centro de Pesquisa de Processamento de Alimentos, Curitiba, v. 18, n. 1, p.105-128, 2000. 
GOMES, I.R; RESENDE, E.D e AMARAL, D.P.

MALMIRI, H. J.; OSMAN, A.; TAN, C. P.; RAHMAN, R. A. Development of an edible coating based on chitosan-glycerol to delay 'Berangan' banana (Musa sapientum cv. Berangan) ripening process. International Food Research Journal, Selangor, v. 18, n. 3, p. 989-997, 2011.

MAQBOOL, M.; ALI, A.; ALDERSON, P. G.; ZAHID, N.; SIDDIQUI, Y. Postharvest Biology and Technology Postharvest application of gum arabic and essential oils for controlling anthracnose and quality of banana and papaya during cold storage. Postharvest Biology and Technology, v. 62, n. 1, p. 71-76, 2011.

MCGUIRE, R. G.; HALLMAN, G. J. Coating guavas with cellulose or carnauba-based emulsions interferes with postharvest ripening. HortScience, Alexandria, v. 30, n. 2, p. $294-$ 295, 1995.

MOLDÃO-MARTINS, M.; BEIRÃO-DA-COSTA, S. M.; BEIRÃO DA - COSTA, M. L. The effects of edible coatings on postharvest quality of the "Bravo de Esmolfe" apple. European Food Research and Technology, Berlin, v. 217, n. 4, p. 325-328, 2003.

MORADI, M., TAJIK, H., ROHANI, S. M. R., OROMIEHIE, A. R., MALEKINEJAD, H., ALIAKBARLU, J., \& HADIAN, M. Characterization of antioxidant chitosan film incorporated with Zataria multiflora Boiss essential oil and grape seed extract. LWT-Food Science and Technology, 46(2), 477-484, 2012.

MYERS, D. Surface, interfaces, and colloids: principles and applications. New York: VCH Publishers, 1991.

NUNES, A. C. D., NETO, A. F., NASCIMENTO, I. K., DE OLIVEIRA, F. J., \& MESQUITA, R. V. C. Armazenamento de mamão formosa revestido à base de fécula de mandioca. Revista de Ciências Agrárias, 40(1), 254-263, 2017.

OMS-OLIU, G.; SOLIVA-FORTUNY, R.; MARTÍN-BELLOSO, O. Edible coatings with antibrowning agents to maintain sensory quality and antioxidant properties of fresh-cut pears. Postharvest Biology and Technology, Amsterdam, v. 50, n. 1, p. 87-94, 2008. 
GOMES, I.R; RESENDE, E.D e AMARAL, D.P.

PARIA, S.; KHILAR, K. C. A review on experimental studies of surfactant adsorption at the hydrophilic solid--water interface. Advances in Colloid and Interface Science, Amsterdam, v. 110, n. 3, p. 75-95, 2004.

PARKER, R.; RING, S. G., 2001. Aspects of the physical chemistry of starch. Journal of Cereal Science, Norwich, v. 34, p. 1-17, 2001.

PEREIRA, M. E. C., SILVA, A. S. D., BISPO, A. S. D. R., SANTOS, D. B. D., SANTOS, S. B. D., \& SANTOS, V. J. D. Amadurecimento de mamão formosa com revestimento comestível à base de fécula de mandioca. Ciência e Agrotecnologia, 30(6), 1116-1119, 2006.

PILON, L.; SPRICIGO, P. C.; BRITTO, D.; ASSIS, O. B. G.; CALBO, A. G., FERRAUDO, A. S., FERREIRA, M. D. Effects of antibrowning solution and chitosan-based edible coating on the quality of fresh-cut apple. International Journal of Postharvest Technology and Innovation, Geneve, v. 3, n. 2, p. 151-164, 2013.

RAYBAUDI - MASSILIA, R. M.; MOSQUEDA - MELGAR, J.; MARTÍN - BELLOSO, O. Edible alginate-based coating as carrier of antimicrobials to improve shelf-life and safety of fresh-cut melon. International Journal of Food Microbiology, Amsterdam, v. 121, n. 3, p. 313-32, 2008.

SALGADO, P. R.; ORTIZ, C. M.; MUSSO, Y. S.; DI GIORGIO, L.; MAURI, A. N. Edible films and coatings containing bioactives. Current Opinion in Food Science, v. 5, p. 86-92, 2015.

SAPPER, MAYRA; CHIRALT, AMPARO. Starch-based coatings for preservation of fruits and vegetables. Coatings, v. 8, n. 5, p. 152, 2018.

SCANAVACA JR., L.; FONSECA, N.; PEREIRA, M. E. C. Uso de fécula de mandioca na pós-colheita de manga 'surpresa'. Revista Brasileira de Fruticultura, Jaboticabal, v. 29, n. 1, p. 67-71, 2007. 
GOMES, I.R; RESENDE, E.D e AMARAL, D.P.

SOARES, N. F. F.; SILVA, D. F. P.; CAMILLOTO, G. P.; OLIVEIRA, C. P.; PINHEIRO, N. M.; MEDEIROS, E. A. A. Antimicrobial edible coating in post-harvest conservation of guava. Revista Brasileira de Fruticultura, Jaboticabal, v. 33, n. 1, p. 281-289, 2011.

STEWARD, P. A.; HEARN, J.; WILKINSON, M. C. An overview of polymer latex fi lm formation and properties. Advances in Colloid and Interface Science, Amsterdam, v. 86, n. 3, p. 195-267, 2000.

TURHAN, K. N. Is edible coating an alternative to MAP for fresh and minimally processed fruits? Acta Horticulturae, Leuven, v. 876, n. 1, p. 299-305, 2010.

VALVERDE, J. M.; VALERO, D.; MARTÍNEZ-ROMERO, D.; GUILLÉN, F.; CASTILLO, S.; SERRANO, M. Novel edible coating based on aloe vera gel to maintain table grape quality and safety. Journal of Agricultural and Food Chemistry, Easton, v. 53, n. 20, p. 7807-7813. 2005. 


\title{
CAPÍTULO 37: TECNOLOGIAS EMERGENTES: UMA NOVA ABORDAGEM PARA REDUZIR SÓDIO E FOSFATO EM PRODUTOS CÁRNEOS
}

\section{EMERGING TECHNOLOGIES: A NEW APPROACH TO REDUCE SODIUM AND PHOSPHATE IN MEAT PRODUCTS}

\author{
Yasmim Sena Vaz Leães ${ }^{1}$; Mariana Basso Pinton²; Letícia Pereira Correa ${ }^{3}$; Alexandre José Cichoski ${ }^{4}$; \\ Paulo Cezar Bastianello Campagnol ${ }^{5}$
}

\section{Resumo}

Os aditivos são utilizados em produtos cárneos com diversas finalidades e, dentre os principais, estão o sal $(\mathrm{NaCl})$, que apresenta ação antimicrobiana, realça o sabor dos produtos, extrai e solubiliza proteínas; e o fosfato, que atua sinergicamente com o $\mathrm{NaCl}$, para reter a água do produto. Entretanto, o consumo em excesso de ambas substâncias está atrelado a diversos problemas de saúde, o que gera um problema de saúde pública e grande demanda por produtos com maior saudabilidade. A redução pode ocorrer de várias formas, mas pincipalmente por substituição parcial por outros sais, ou através de tecnologias verdes, tendo como principais a alta pressão hidrostática (APH), campo elétrico pulsado (CEP), ultrassom (US) e água eletrolisada básica (AEB). O trabalho objetivou destacar os principais e mais recentes estudos voltados à aplicação de APH, CEP, US e AEB como estratégia na redução de $\mathrm{NaCl}$ e fosfato em diferentes produtos cárneos, bem como explicar os princípios de cada uma das tecnologias e os possíveis fenômenos que possibilitaram a redução desses aditivos.

Palavras-Chave: alta pressão hidrostática, campo elétrico pulsado, ultrassom, água eletrolisada básica, tecnologias emergentes.

\begin{abstract}
Additives are used in meat products for various purposes. The main ones are salt $(\mathrm{NaCl})$, which has an antimicrobial action, improve the flavor of the products, extracts and solubilizes proteins; and phosphate, which acts synergistically with $\mathrm{NaCl}$, to retain the product water. However, the excessive consumption of both substances is linked to several health problems, which generates a public health problem and great demand for products with greater health. The reduction can occur in several ways, but mainly by partial replacement with other salts, or through green technologies, with high hydrostatic pressure (HHP), pulsed electric field (PEF), ultrasound (US) and basic electrolyzed water as main (BEW). The aim of this work was to highlight the main and most recent studies focused on the application of APH, CEP, US and AEB as a strategy to reduce $\mathrm{NaCl}$ and phosphate in different meat products, as well as explaining the principles of each of the technologies and the possible phenomena that enabled the reduction of these additives.
\end{abstract}

Keywords: high hydrostatic pressure, pulsed electric field, ultrasound, basic electrolyzed water, emerging technologies.

\section{Introdução}

\footnotetext{
${ }^{1}$ Doutoranda em Ciência e Tecnologia dos Alimentos, Universidade Federal de Santa Maria, yasmimsvl@ hotmail.com

${ }^{2}$ Doutoranda em Ciência e Tecnologia dos Alimentos, Universidade Federal de Santa Maria, mbpinton@gmail.com

${ }^{3}$ Graduanda em Tecnologia dos Alimentos, Universidade Federal de Santa Maria, pereiracorreal@gmail.com

${ }^{4}$ Doutor em Tecnologia de Alimentos (UFPR), Professor da Universidade Federal de Santa Maria, cijoale@ gmail.com

5 Doutor em Tecnologia de Alimentos (UNICAMP), Professor da Universidade Federal de Santa Maria, paulocampagnol@gmail.com
} 
LEÃES, Y.S.; PINTON, M. B.; CORREA, L.P.; CICHOSKI, A.J.; CAMPAGNOL, P. C. B.

Aditivos são utilizados em produtos cárneos com as mais diversas finalidades, seja para a segurança do alimento, a conservação (efeito antioxidante e antimicrobiano), adquirir características específicas de cor, textura, sabor, aroma, ou para conferir características tecnológicas que afetam diretamente o rendimento do produto final, ao evitar que ocorram perdas de frações aquosas e/ou lipídicas. Porém, sabe-se que o consumo excessivo desses aditivos está relacionado ao aumento nos problemas de saúde, fazendo-se necessário encontrar alternativas que proporcionem sua redução e promovam o consumo de produtos com maior saudabilidade, ao mesmo tempo em que nenhuma das características citadas sejam afetadas (THANGAVELU et al., 2019). Nesse sentido, o aditivo mais estudado atualmente quanto alternativas para sua redução é o sal $(\mathrm{NaCl})$. $\mathrm{O}$ fosfato, apesar de recente, também vem ganhando espaço nesses estudos (PINTON et al., 2021).

$\mathrm{O} \mathrm{NaCl}$ é um ingrediente cujas funcionalidades influenciam diretamente na qualidade microbiológica, sensorial (como realçador de sabor) e, sobretudo, tecnológica de produtos cárneos. Os íons $\mathrm{Cl}^{-}$presentes no $\mathrm{NaCl}$ doam as cargas negativas às proteínas, fazendo com que elas se afastem e assim retenham mais água, o que confete maior rendimento ao produto final. Entretanto, o sódio contido em sua molécula, quando consumido em excesso, está atrelado à diversos problemas de saúde, tais como aumento no risco de doenças cardiovasculares, infarto, acidente vascular cerebral, obesidade, etc (INGUGLIA et al., 2017).

$\mathrm{O}$ fosfato atua sinergicamente com o $\mathrm{NaCl}$ na extração e solubilização das proteínas, bem como no aumento da capacidade de retenção de água (CRA) ao promover aumento no $\mathrm{pH}$ do produto e consequente distanciamento do ponto isoelétrico (PI). Além disso, ele também possui atividade antioxidante sobre os produtos cárneos. Porém, ele é de especial preocupação ao grupo de pessoas com problemas renais, uma vez que afeta a capacidade de expelir ácidos ocasionando um acúmulo nos níveis de fosfato, o que ocasiona no aumento de até $40 \%$ na taxa de mortalidade dessas pessoas. Além disso, em pessoas que não possuem problemas renais, ele prejudica a absorção de cálcio, ocasionando a maior propensão a doenças ósseas (PINTON et al., 2019).

Desta forma, entende-se que há uma demanda cada vez maior pela saudabilidade desses produtos, o que implica na redução desses aditivos. Acerca disso, os estudos envolvendo a redução de $\mathrm{NaCl}$ e fosfato são contemplados principalmente por dois segmentos atualmente: redução por substituição parcial por outros sais $\left(\mathrm{KCl}, \mathrm{CaCl}_{2}\right.$, ou $\mathrm{MgCl}_{2}$ ); e/ou pela aplicação de novas tecnologias, sendo estas capazes de promoverem modificações na estrutura da matriz alimentar de forma a compensar a redução desses compostos no produto. Dentre as novas tecnologias estudadas objetivando redução de 
LEÃES, Y.S.; PINTON, M. B.; CORREA, L.P.; CICHOSKI, A.J.; CAMPAGNOL, P. C. B.

$\mathrm{NaCl}$ e fosfato, as mais utilizadas são a alta pressão hidrostática (APH), o campo elétrico pulsado (CEP), o ultrassom (US) e, recentemente, a água eletrolisada básica (AEB) em conjunto com o ultrassom (BHAT et al., 2020; LEÃES et al., 2020; PINTON et al., 2020; PINTON et al., 2019; WANG et al., 2018).

Elas são consideradas "tecnologias verdes" ou "tecnologias emergentes" por apresentarem características ecologicamente corretas, uma vez que otimizam o uso de recursos naturais, economizam a energia utilizada e reduzem custos na indústria de alimentos, e vem ganhando cada vez mais espaço em relação às técnicas convencionais de processamento e conservação (ALARCÓN-ROJO, 2019; FLORES et al., 2018). Essas tecnologias vêm apresentando resultados positivos na redução de $\mathrm{NaCl}$ e fosfato, sem necessariamente utilizar da substituição parcial por outros sais. Isso porque elas promoveram ação sobre as proteínas da carne, principais responsáveis pela retenção de água e consequente manutenção da textura em diversos produtos cárneos (CICHOSKI et al., 2019).

Desta forma, o presente trabalho objetivou destacar os principais e mais recentes estudos voltados à aplicação de APH, CEP, US e AEB como estratégia na redução de $\mathrm{NaCl}$ e fosfato em diferentes produtos cárneos, bem como explicar os princípios de cada uma das tecnologias e os possíveis fenômenos que possibilitaram a redução desses aditivos.

\section{Alta Pressão Hidrostática (APH)}

O tratamento com alta pressão hidrostática é considerado um processo não térmico, alternativo aos tratamentos térmicos, permitindo a inativação de microrganismos patogênicos e deteriorantes nos alimentos (JÚNIOR et al., 2019). Aumenta o prazo de validade dos produtos, pois atua como um processo de pasteurização a frio, afetando minimamente os atributos sensoriais e nutricionais dos alimentos (ANDREOU et al., 2017).

A aplicação de alta pressão é baseada em dois princípios que determinam o comportamento dos alimentos sob pressão. O princípio Le Châtelier, princípio importante subjacente aos efeitos no equilíbrio da reação. Qualquer fenômeno acompanhado por uma diminuição no volume será aprimorado por um aumento da pressão e vice-versa. Transições de fase associadas com uma diminuição de volume são afetadas, enquanto as acompanhadas com aumento de volume são inibidas (GUILLOU et al., 2017). A aplicação de pressão leva a alterações físicas e químicas. Aumento na pressão contribui para uma diminuição na distância intermolecular média entre as moléculas. A compressão física durante o tratamento de alta pressão resulta em um aumento de temperatura através 
LEÃES, Y.S.; PINTON, M. B.; CORREA, L.P.; CICHOSKI, A.J.; CAMPAGNOL, P. C. B.

do aquecimento adiabático $\pm 3{ }^{\circ} \mathrm{C}$ por $100 \mathrm{MPa}$, dependendo da composição dos alimentos. Já as alterações químicas são mínimas. Somente ligações não covalentes, como hidrogênio e ligações iônicas, interações hidrofóbicas nos alimentos são interrompidas pela pressão (POTTIER et al., 2017; GUILLOU et al., 2017). O segundo princípio associado aos efeitos da alta pressão é o princípio isostático, que afirma que a pressão é instantaneamente e uniformemente transmitida por todo o produto sem gradiente de pressão. Deste modo, a pressão é caracterizada como pressão isostática.

O processo de alta pressão opera descontinuamente em um produto embalado (geralmente sob vácuo) para evitar os riscos de contaminação após o tratamento. A embalagem deve ser flexível para suportar até $600 \mathrm{MPa}$. O produto é introduzido no recipiente de tratamento cilíndrico, normalmente horizontal, com um volume interno variando de 50 a $525 \mathrm{~L}$ para dispositivos industriais atualmente disponíveis comercialmente. $\mathrm{O}$ vaso é preenchido com um fluido transmissor de pressão (geralmente água) e depois pressurizado usando uma bomba de alta pressão variando de 100 a 600 $\mathrm{MPa}$, e as vezes até $900 \mathrm{MPa}$. A pressão aplicada diretamente, por um sistema de pistão, ou indiretamente, por um sistema de bomba hidráulica, é transmitida isostaticamente dentro do vaso de pressão, permitindo que o alimento seja instantaneamente e uniformemente tratado independente do volume e da geometria. A pressão é mantida por um tempo de espera, geralmente 1 - 5 minutos, e, em seguida, a abertura de uma válvula causa despressurização quase instantânea do vaso. Todo o processo é realizado a uma temperatura de 4 a $20{ }^{\circ} \mathrm{C}$ (POTTIER et al., 2017, SOLADOYE; PIETRASIK, 2018). O processo de alta pressão apresenta diversas vantagens em relação a outras tecnologias não térmicas, como baixo consumo de energia, baixo risco de contaminação, e, além disso, é uma tecnologia de processamento ecológica (HUANG et al., 2017).

\section{Efeito da APH nos produtos cárneos para redução de aditivos}

As indústrias cárneas têm como objetivo prolongar a vida útil de carnes e produtos cárneos sem uso de conservantes químicos e sem afetar as qualidades sensoriais. A tecnologia de alta pressão pode oferecer algumas oportunidades para atingir esse objetivo. Muitos estudos demonstraram que o tratamento de alta pressão pode ser usado para produzir produtos cárneos com baixo teor de aditivos como, por exemplo, sódio e fosfato (O’FLYNN et al., 2014; O’NEILL et al., 2015; TAMM et al., 2016; PIETRASIK et al., 2016).

Recentemente, Pietrasik et al. (2017) utilizaram APH (600 MPa, 3 minutos, $8{ }^{\circ} \mathrm{C}$ ) para avaliar a qualidade de salsichas com redução ou substituição de $50 \%$ de $\mathrm{NaCl}$ por $\mathrm{KCl}$. Os autores reportaram que o uso de APH estendeu a vida útil das salsichas por até 
LEÃES, Y.S.; PINTON, M. B.; CORREA, L.P.; CICHOSKI, A.J.; CAMPAGNOL, P. C. B.

12 semanas e melhorou a textura devido a melhorar a retenção de umidade. Já O’Neil et al. (2018) utilizaram uma combinação de substitutos de sal (Artisalt TM - teor de redução de 0,50 e 100\%), APH $(0,300,600 \mathrm{MPa})$ e antimicrobianos (Inbac TM teor de 0,2, 0,3 e $0,4 \%$ ) no desenvolvimento de presunto cozido. A substituição de 50\% do substituto de sal não causou alterações nos atributos testados. O estudo mostrou que a melhor combinação das variáveis testadas para o desenvolvimento de presunto cozido com baixo teor de sal é de $54 \%$ de substituição de sal, uso de $535 \mathrm{MPa}(\mathrm{APH})$ e $0,3 \%$ de concentração de Inbac TM.

Zheng et al. (2019) utilizaram alta pressão (200 MPa) e reduziram a quantidade de sal em linguiça de frango. Os resultados mostraram efeitos benéficos na qualidade tecnológica de linguiças como textura relativamente mais resistente e elástica e diminuição na perda de cozimento. No estudo de Wang et al. (2018) foi combinado APH (200 MPa) com baixos níveis de $\mathrm{CaCl}_{2}(<40 \mathrm{mM})$ aumentando a solubilidade das proteínas miofibrilares, o que garantiu propriedades funcionais no peito de frango.

De acordo com os estudos citados, é possível produzir produtos cárneos com concentrações reduzidas de sal utilizando alta pressão, sem que ocorra a perda das propriedades tecnológicas, sensoriais e microbiológicas e ainda, aumentando a vida útil. O uso da tecnologia de alta pressão hidrostática pode aumentar o desdobramento das proteínas e a funcionalidade de ligação de água, havendo potencial para aplicação em formulação com quantidade reduzida de sal. A tecnologia de alta pressão é uma tecnologia viável que pode compensar parcialmente a redução de sal, atendendo as qualidades tecnológicas dos produtos e também a segurança microbiológica.

\section{Campo Elétrico Pulsado (CEP)}

Em meados do século XX, começou a ser aplicado o tratamento por campo elétrico pulsado (CEP) para processamento de alimentos e produtos agrícolas (SITZMANN et al., 2016).

O CEP garante a segurança microbiana do produto sem afetar significativamente o valor organoléptico e nutricional do alimento sendo processado, devido ao acúmulo mínimo de calor durante o tratamento (BEKHIT et al., 2017), o que garante a produção de produtos de qualidade.

Essa tecnologia envolve o uso de pulsos de campo elétrico de curta duração (variando de nanossegundos a milissegundos) com força de campo elétrico de 0,1 a 80 $\mathrm{kV} / \mathrm{cm}$ aplicada a um alimento entre dois eletrodos (BHAT et al., 2018). Tem potencial de substituir o processamento térmico tradicional, como por exemplo, a pasteurização, o 
LEÃES, Y.S.; PINTON, M. B.; CORREA, L.P.; CICHOSKI, A.J.; CAMPAGNOL, P. C. B.

que pode melhorar a eficiência do processo e a qualidade do produto final (BEKHIT et al., 2017).

O CEP provoca alterações estruturais locais e uma rápida quebra da membrana celular que pode ser permanente ou temporária, dependendo da intensidade e das condições de tratamento. Deste modo, o tratamento do CEP consiste na aplicação de um campo elétrico externo que leva à quebra da membrana celular, induzindo mudanças estruturais. Esse fenômeno é conhecido como eletroporação ou eletro-permeabilização (TOEPFL et al., 2014). A eletroporação depende de muitos fatores, como parâmetros do CEP (amplitude do pulso, número e duração dos pulsos elétricos), propriedades celulares (tamanho, forma, orientação) e parâmetros da membrana (temperatura, força iônica) (SAULIS, 2010). Os parâmetros do processo do CEP podem ser ajustados dependendo da aplicação desejada. A diversidade de matérias-primas e a disponibilidade de equipamentos de CEP podem afetar as condições de processo (GÓMEZ et al., 2019).

A eletroporação envolve a formação de poros e aumenta a permeabilidade das membranas biológicas (OSTERMEIER et al., 2018). Essa permeabilidade aumentada da membrana facilita a troca de componentes intracelulares com o ambiente da célula e pode induzir certos efeitos úteis que não foram totalmente explorados (BHAT et al., 2018), como por exemplo, a melhor difusão de sal, extração de compostos ou alterações nas propriedades físicas.

\section{Efeito do CEP na difusão de aditivos em produtos cárneos}

Existem diversas pesquisas de aplicação de CEP em bebidas alcóolicas (YANG et al., 2016; RICCI et al., 2018), produtos lácteos (BUCKOW et al., 2014; SHARMA et al., 2014) e ovos de aves (ESPINA et al., 2014; YOGESH, 2016) e em controle de microrganismos (BARBA et al., 2017; GABRIC et al., 2017).

O tratamento com CEP também pode ser uma boa estratégia para alterar as propriedades em produtos cárneos, (BEKHIT et al., 2016). De acordo com Gómez et al. (2019) a absorção das substâncias comuns usadas nos períodos de cura dos produtos cárneos, como sal, nitritos e especiarias, poderia ser melhorada após o tratamento com $\mathrm{CEP}$, devido à ruptura parcial dos tecidos celulares e seu efeito nos processos de transferência de massa. No entanto, ainda são poucos os estudos relacionados com CEP e aditivos alimentares.

Contudo, Bhat et al (2020) comprovaram o uso de CEP na redução de sódio em músculo Semimembranosos, onde o tratamento permitiu uma redução direta de $\mathrm{NaCl}$ com uma melhor difusão do sal na matriz da carne, sem danos na qualidade sensorial e estabilidade oxidativa e microbiana dos produtos. Autores como McDonnell et al. (2014) 
LEÃES, Y.S.; PINTON, M. B.; CORREA, L.P.; CICHOSKI, A.J.; CAMPAGNOL, P. C. B.

demonstraram que há potencial de aceleração de salga em carne suína (M. Longissimus thoracis e Lumborum LTL). Comprovaram uma maior perda de cozimento e efeitos na textura, como aumento da dureza e mastigação, talvez pelo aumento da solubilização das fibras devido a maior concentração de $\mathrm{NaCl}$, associado ao aumento da perda de água durante o cozimento. Os parâmetros utilizados foram: força de campo $\left(1,2 \mathrm{Kv} / \mathrm{cm}^{3}\right)$, frequência $(100 \mathrm{~Hz})$, número de pulso (300 pulsos) e tempo (3 ms) e, ainda, atuaram para o aumento da difusão salina $\left(175 \mathrm{~kg} / \mathrm{m}^{3} \mathrm{de} \mathrm{NaCl}\right)$.

\section{Ultrassom (US)}

O ultrassom é uma onda sonora em uma frequência que excede o limiar da audição humana $(20 \mathrm{kHz})$. É uma forma de energia vibracional produzida por um transdutor de ultrassom que converte energia elétrica em energia acústica (CHEN et al., 2020), portanto, é uma forma de energia mecânica não ionizante, não invasiva e não poluente. É considerado um método emergente com um grande potencial para controlar, melhorar e acelerar processos sem prejudicar a qualidade dos alimentos (ALARCON-ROJO et al., 2019), alterando as propriedades físicas, químicas e funcionais.

Em um sistema de ultrassom, a energia elétrica é transformada em energia vibracional, que pode induzir cavitação. A energia da cavitação produz efeitos químicos, físicos ou biológicos. Vários estudos relataram os efeitos do ultrassom no processamento de carne, alterando as propriedades físicas, químicas e funcionais, podendo auxiliar na cura, maciez e, ainda, beneficiar na redução de aditivos químicos (INGUGLIA et al., 2017).

O ultrassom é uma onda sonora caracterizada por vários parâmetros como a frequência (número de ciclos repetidos por unidade de tempo), a mudança na onda sonora (deslocamento máximo de partículas ou nível máximo do sinal acústico) durante um único período de tempo (amplitude), a distância entre pontos correspondentes consecutivos da mesma fase (comprimento de onda), a velocidade de propagação da onda (velocidade do som) e a perda gradual de intensidade do som através de um meio (coeficiente de atenuação) (NOWAK et al., 2017). O US é dividido em três regiões de frequência, todas acima do limiar da audição humana. O ultrassom de potência é de 16 a $100 \mathrm{kHz}$. O ultrassom de alta frequência é de $100 \mathrm{kHz}$ a $1 \mathrm{MHz}$, enquanto que o ultrassom de diagnóstico é de 1 a $10 \mathrm{MHz}$ (INGUGLIA et al., 2017).

A base das aplicações do ultrassom na faixa de frequência de $20 \mathrm{kHz}$ a $1 \mathrm{MHz}$ é a cavitação acústica, que ocorre em regiões sob ondas de alta amplitude que se alternam rapidamente e consiste no crescimento e colapso de bolhas de gás em um meio líquido, resultando em modificações físicas dos tecidos musculares (GONZALES-GONZALEZ 
LEÃES, Y.S.; PINTON, M. B.; CORREA, L.P.; CICHOSKI, A.J.; CAMPAGNOL, P. C. B.

et al., 2020). Portanto, a cavitação é a formação de bolhas na fase líquida quando a pressão negativa é aplicada e a distância entre as moléculas é pelo menos o dobro da distância de van der Waals. Quando a bolha é exposta a mudanças na pressão acústica, dois possíveis cenários podem ocorrer: a bolha entra em um ciclo continuo de expansão-compressão (estado conhecido como cavitação estável) ou a bolha cresce para um tamanho crítico pelo qual ela entra em colapso instantaneamente (cavitação transitória) (NOWAK et al., 2017). Bolhas estáveis são consideradas bolhas fracamente e simetricamente oscilantes, enquanto que bolhas transitórias são consideradas bolhas de cavitação ativa. O colapso das bolhas é um processo quase adiabático e resulta na geração de altas temperaturas (> $\left.5000{ }^{\circ} \mathrm{C}\right)$ e altas pressões (300 - $\left.1000 \mathrm{~atm}\right)$ (NOWAK et al., 2017).

A cavitação produz forças físicas intensas que incluem forças de cisalhamento, ondas de choque e turbulências, alterando potencialmente as propriedades funcionais das proteínas por métodos físicos ou químicos. Durante a sonicação, as bolhas são formadas rapidamente e colapsam intensamente, o que pode ser um dos motivos das alterações químicas e físicas. $\mathrm{O}$ aumento da pressão e temperatura nas proximidades dessas cavidades é à base das mudanças no meio exposto ao ultrassom (AMIRI et al., 2018). Nos produtos cárneos, os microjatos, causados por bolhas implodentes, colidem com a superfície das miofibrilas, causando micro fissuras e alterando a estrutura dos produtos (BARRETO et al., 2018). Siró et al. (2009) explica que a cavitação causada pelo ultrassom abre canais entre as miofibrilas, o que facilita a penetração de salmouras, melhorando assim, a difusão dos aditivos.

\section{Efeito do US na redução de aditivos nos produtos cárneos}

Barreto et al. (2018) avaliaram os efeitos da redução de sal com o auxílio do US em presuntos cozidos. O ultrassom reduziu a liberação total de fluidos, os presuntos apresentaram uma maior capacidade de retenção de água, o que resultou na melhoria dos parâmetros de textura e aceitação sensorial.

Pela primeira vez, a cinética de difusão de salmoura ativada no interior da carne assistida por ultrassom foi estudada por Krasulya et al. (2019). De acordo com esses autores, as salmouras com diferentes concentrações de $\mathrm{NaCl}$ à base de água eletro ativada, tem velocidade de propagação diferente. Quanto maior a concentração de salmoura, mais intensivo é o processo de penetração de substâncias salgadas nas amostras, portanto, o uso de salmoura ativada por cavitação pode contribuir para uma melhor difusão dos ingredientes e aceleração dos processos físico-químicos e bioquímicos que ocorrem durante o tratamento da salmoura reduzindo o tempo de cura da carne. Outro ponto importante é o tempo de cura, em um quatro dias de cura, a salmoura tratada permeou 
LEÃES, Y.S.; PINTON, M. B.; CORREA, L.P.; CICHOSKI, A.J.; CAMPAGNOL, P. C. B.

toda a profundidade do músculo com $3 \%$ de $\mathrm{NaCl}$. Pode-se argumentar que o uso de salmoura ativada por cavitação pode reduzir o tempo de salmoura da carne.

Cichoski et al. (2019) avaliaram atributos tecnológicos em emulsões cárneas submetidas a diferentes modos de operação do ultrassom, como os modos operacionais normal, degas e sweep. De acordo com os resultados, o uso de $60 \%$ de amplitude, $25 \mathrm{kHz}$ de frequência e modo normal foram os parâmetros mais eficazes para melhoria da qualidade tecnológica das emulsões cárneas. Esses resultados deram embasamento para outros estudos utilizando ultrassom como estratégia para redução de aditivos químicos, como os citados abaixo.

Pinton et al. (2019) avaliaram o efeito do ultrassom na redução de fosfatos em emulsões cárneas. Provaram que com o uso de 18 minutos de tratamento de US $(60 \%$ amplitude, frequência de $25 \mathrm{kHz}$, potência nominal de $1000 \mathrm{~W}$, modo normal) aumentou o rendimento de cozimento com redução de $50 \%$ de fosfato, e ainda, melhorou a estabilidade de emulsão. Leães et al (2020) utilizaram ultrassom em diferentes tempos (10 e $20 \mathrm{~min}$ ) para reduzir $\mathrm{NaCl}$ em produtos cárneos emulsionados. Estes autores obtiveram resultados semelhantes em relação à estabilidade da emulsão e rendimento de cozimento, com reduções de até $20 \%$ de $\mathrm{NaCl}$ no tempo de 20 minutos de ultrassom sem afetar a qualidade tecnológica do produto quando comparado ao padrão. Em estudo mais recente realizado por Pinton et al. (2020), foi investigada a ação do US em conjunto com diferentes sais substitutos de $\mathrm{NaCl}\left(\mathrm{KCl}, \mathrm{CaCl}_{2}\right.$, or $\left.\mathrm{MgCl}_{2}\right)$ em emulsões cárneas com teor reduzido de sal e fosfato. Através desse estudo, foi possível reduzir cerca de $50 \%$ do $\mathrm{NaCl}$ utilizando a combinação de 27 min de US e $0,5 \%$ de $\mathrm{KCl}$, sem comprometer características físico-químicas, tecnológicas e oxidativas.

Estes resultados na redução de fosfato e sal nas emulsões estão atrelados a, basicamente, três fatores: 1) a modificação na estrutura das proteínas promovidas pelo US, permitindo a exposição das cadeias laterais polares e apolares dos aminoácidos (permitindo a ligação da água e da gordura); 2) a melhor difusão de fosfato e $\mathrm{NaCl}$ na massa; 3) e a redução e padronização do glóbulo de gordura, evitando assim que eles coalesçam e se separem da fase aquosa, aspecto importante na estabilidade de uma emulsão. Assim, quando cozidas, também apresentaram efeitos positivos na estabilidade do gel oriundo da agregação proteica promovida pelo cozimento, o que influenciou diretamente na textura do produto (CICHOSKI et al., 2019; INGUGLIA et al., 2017; CHEMAT, 2011).

\section{Água eletrolisada (AE)}


LEÃES, Y.S.; PINTON, M. B.; CORREA, L.P.; CICHOSKI, A.J.; CAMPAGNOL, P. C. B.

A obtenção da AE ocorre através do processo de eletrólise, que consiste na passagem de uma solução salina (geralmente $\mathrm{NaCl}$ ) por uma câmara dotada de uma célula de eletrolisação. Essa célula geralmente é separada por uma membrana, originando dois polos: o ânodo (-) e o cátodo (+), os quais originam dois produtos distintos: a água eletrolisada ácida (AEA) e a água eletrolisada básica (AEB), respectivamente (ATHAYDE et al., 2018; HUANG et al., 2008).

Durante a eletrólise, ocorre migração dos íons $\mathrm{Cl}^{-}$para o ânodo e dos íons $\mathrm{Na}^{+}$ para o cátodo. Os principais produtos da $\mathrm{AEA}$ são $\mathrm{Cl}_{2}$ dissolvido, ácido hipocloroso $(\mathrm{HOCl})$ e ácido clorídrico $(\mathrm{HCl})$ diluído, e esta possui um $\mathrm{pH}$ ácido $(<3.0)$ e potencial de oxirredução $(\mathrm{POR})>1000 \mathrm{mV}$. A AEB tem como principais produtos o hidróxido de sódio $(\mathrm{NaOH})$, uma pequena quantidade de cloro na forma de hipoclorito $\left(\mathrm{OCl}^{-}\right)$e também $\mathrm{H}_{2}$, tendo como principal característica o pH alcalino (> 10.0) e POR de -800 a $900 \mathrm{mV}$ (CUI et al., 2009).

Entretanto, um dos maiores problemas em relação à AEA está a sua instabilidade (uma vez que o cloro se apresenta na forma de gás) e sua corrosividade. Desta forma, a fim de contornar esses fatores, há a produção de um terceiro tipo de água: a água eletrolisada fracamente ácida (AEFA), gerada a partir da mistura de AEA e AEB, sem a separação do ânodo e cátodo por membrana. Essa água possui $\mathrm{pH}$ mais próximo da neutralidade, entre 6,0 e 6,5 e POR de 800 a $900 \mathrm{mV}$, apresentando cerca de $95 \%$ do cloro na forma de ácido hipocloroso $(\mathrm{HClO}), 5 \%$ na forma de íon hipoclorito $\left(\mathrm{OCl}^{-}\right)$e traços de $\mathrm{Cl}_{2}$ (AFARI; HUNG, 2018; ATHAYDE et al., 2018).

Os estudos realizados na área de alimentos utilizaram concentrações de salmoura que variaram de 0,01 a 5\%, para diferentes matrizes alimentares e finalidades. Diversos trabalhos evidenciaram a eficácia da $\mathrm{AE}$ em processos de sanitização, já tendo sido aplicada em hortaliças, carne de frango, carne suína e superfícies de manipulação de alimentos e tendo efeito sobre diversos microrganismos patogênicos e deteriorantes, como Listeria monocytogenes, Escherichia coli, Salmonella, Shewanela, coliformes, mesófilos e psicrotróficos em diferentes matrizes alimentares (WANG et al., 2019; WANG et al., 2018; AFARI; HUNG, 2018; SHENG et al., 2018; ATHAYDE et al., 2017; LI et al., 2016; SHIMAMURA et al., 2016; OVISSIPOUR et al., 2015; LEE et al., 2014; SUN et al., 2012). Essas variações na concentração são decorrentes de que as propriedades físico-químicas e efeitos da $\mathrm{AE}$ variam de acordo com a concentração $\mathrm{NaCl}$, tempo de eletrólise ou fluxo de água (ATHAYDE et al., 2018; RHAMAN; KHAN; OH, 2010).

Essa eficácia ocorre devido à presença do cloro, mais predominante na AEA e AEFA, as quais são estudadas em separado ou combinadas também com AEB a fim de 
LEÃES, Y.S.; PINTON, M. B.; CORREA, L.P.; CICHOSKI, A.J.; CAMPAGNOL, P. C. B.

avaliar a eficácia de ação antimicrobiana. Algumas vantagens em relação a outros agentes sanitizantes tradicionais, são a desinfecção eficaz, fácil operação, baixo custo e ambientalmente correta (JADEJA; HUNG, 2014).

Em relação a esta tecnologia, embora o equipamento de eletrólise tenha um custo elevado, a produção da $\mathrm{AE}$ é simples e há possibilidade de diversas adaptações na aplicação, podendo ser utilizada na forma de spray, por imersão ou gelo, constituindo-se de um processo simples, com eficiente capacidade antimicrobiana (ATHAYDE et al., 2018; HUANG et al., 2008; SUN et al., 2012). Assim, constata-se que a maior parte dos estudos são voltados ao uso dos diferentes tipos de AE em processos de sanitização na indústria de alimentos, objetivando redução ou eliminação de carga microbiana, sendo a AEA ou a AEFA mais explorada nesses estudos. Em relação à $\mathrm{AEB}$, são poucos os estudos que tratam de sua aplicação em alimentos, e em boa parte esta é aplicada em combinação com AEA e AEFA a fim de potencializar a ação antimicrobiana.

\section{Aplicação da AEB em alimentos e seu uso como estratégia na redução de NaCl em produtos cárneos}

A AEB possui características que não são necessariamente voltadas à ação antimicrobiana, porém ainda são pouco exploradas. Seu pH alcalino e o $\mathrm{NaOH}$ contido nela podem conferir modificações na textura dos produtos. Em estudo realizado por Hara et al. (2003), foi avaliada a aplicação de AEA e AEB em baixas concentrações em conjunto e individualmente nas propriedades oxidativas e sensoriais do Tofu, e observaram modificações no teor de proteína com a AEB em reação à AEA e água comum. Isso porque a solubilidade da proteína é geralmente melhorada quando o valor do $\mathrm{pH}$ é distante do ponto isoelétrico (PI). O pH alcalino da AEB afetou a solubilidade da proteína de soja e, portanto, alterou o teor de proteína do tofu. Isso influenciou diretamente na textura, a qual apresentou-se mais macia nas amostras com AEB, ao mesmo tempo em que houve maior retenção de água.

Além disso, estudos foram realizados em relação ao $\mathrm{NaOH}$ em emulsões cárneas. Knipe, Olson e Rust (1985) avaliaram a ação do $\mathrm{NaOH}$, em separado ou combinado com vários tipos de fosfatos na elaboração de emulsão cárnea, e constataram que a concentração de $0,075 \%$ de $\mathrm{NaOH}$ foi suficiente para aumentar o $\mathrm{pH}$ da emulsão e a proteína solubilizada, quando agindo em conjunto com o fosfato. Sobre isso, é importante ressaltar que a $\mathrm{AE}$ possui uma diversificação de aplicações, o que permite que ela seja associada a outras tecnologias alternativas, potencializando seus efeitos (FLORES et al, 2018). 
LEÃES, Y.S.; PINTON, M. B.; CORREA, L.P.; CICHOSKI, A.J.; CAMPAGNOL, P. C. B.

Nesse sentido de aplicação conjunta com outra tecnologia, Leães et al. (2020) avaliaram a ação do US em diferentes tempos em conjunto com a AEB sobre características tecnológicas e físico-químicas de emulsões cárneas com diferentes concentrações de $\mathrm{NaCl}: 2.5 \%, 2.25 \%, 2.00 \%, 1.75 \%, 1.50 \%$ e $1.25 \%$. A AEB utilizada

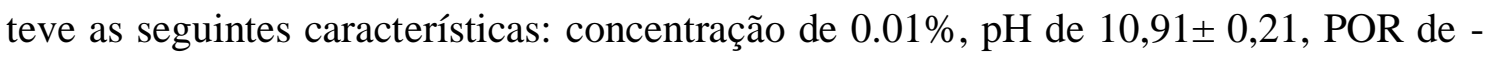
$330 \mathrm{mV} \pm 4,15$ e concentração de cloro livre (CCL) de 1,2 mg/L. Foi observado que a substituição da água por AEB na formulação possibilitou mais $10 \%$ na redução de $\mathrm{NaCl}$ em emulsão cárnea, agindo em conjunto com o US no tempo de $20 \mathrm{~min}$, que havia conferido $20 \%$ de redução. Proporcionando, assim, uma redução total de $30 \%$, considerando fatores como rendimento (\%), liberação de água e gordura (\%), textura e cor.

Outros trabalhos já evidenciaram a ação da AEB em matrizes cárneas, mas não com o propósito de redução. Vinnikova e Porkina (2016) avaliaram salmoura elaborada com AEB em relação ao rendimento em carne suína, e observaram aumento no rendimento e redução da perda de umidade em até 7,3\% após tratamento térmico quando comparado ao padrão (somente com água). Віннікова е Пронькіна (2015), ao avaliarem ação da AEB em carne moída bovina e suína, as quais posteriormente foram utilizadas para a elaboração de salsicha (utilizando a concentração de $2.5 \mathrm{de} \mathrm{NaCl}$ ), observaram redução significativa na perda de umidade do produto. Em ambos estudos, o resultado foi relacionado ao aumento do $\mathrm{pH}$ promovido pela AEB.

Acerca disso, no estudo realizado por Leães et al. (2020), três mecanismos foram identificados como possíveis causas: 1) o pH da AEB, que aumentou o pH das emulsões cárneas, distanciando-as do PI e fornecendo efeito semelhante ao do fosfato nesse sentido, auxiliando em maior retenção de água; 2) a pequena quantidade de cloro livre presente na $\mathrm{AEB}$, que pode ter auxiliado a potencializar a solubilização das proteínas; 3) e o $\mathrm{NaOH}$ presente, que poderia ter atuado na solubilização das proteínas e também em modificações nos glóbulos de gordura, visto que a redução na liberação de gordura foi significativamente $(\mathrm{p}<0.001)$ menor em relação aos demais tratamentos somente com água na formulação e aplicação de US (BAI; NYU; XIANG, 2019; XARGAIÓ et al., 2006; KONOMATSU, 2003).

Decorrente que a aplicação de AEB em alimentos ainda é pouco explorada, observa-se a necessidade de investigar qual a ação desta em produtos cárneos, uma vez que, conforme os trabalhos mencionados, o seu elevado $\mathrm{pH}$, bem como a presença de $\mathrm{NaOH}$ e cloro, podem trazer efeitos benéficos a este tipo de produto no que diz respeito a rendimento e textura, aspectos de extrema importância na viabilidade de utilização de novas tecnologias. Entretanto, é importante também investigar a ação da AEB em 
LEÃES, Y.S.; PINTON, M. B.; CORREA, L.P.; CICHOSKI, A.J.; CAMPAGNOL, P. C. B.

conjunto ou em separado ao US que diz respeito às modificações nas características microbiológicas, oxidativas e sensoriais desses produtos

\section{Considerações Finais}

As tecnologias de APH, CEP, US e AEB apresentaram efeitos expressivos nas características físico-químicas, tecnológicas, microbiológicas, oxidativas e sensoriais de produtos cárneos com teor reduzido de $\mathrm{NaCl}$ e fosfato, constituindo-se como alternativas viáveis na promoção da saudabilidade desses produtos. Elas podem ser úteis para promover diversas modificações na estrutura de matrizes cárneas, a começar pelas proteínas, contribuindo diretamente no aumento do rendimento do produto final, o qual é um aspecto de extrema importância quanto a viabilidade na aplicação.

Além disso, os estudos apresentados não evidenciaram alterações na estabilidade oxidativa, e também demonstraram que essas tecnologias tem ação benéfica sobre as características microbiológicas (eliminando microrganismos deteriorantes) e sensoriais. Entretanto, recomenda-se a continuidade nesses estudos, a fim de complementar aspectos que faltaram serem elucidados.

Em relação à $\mathrm{APH}$, necessita-se ampliar os estudos em relação à redução de fosfato; o CEP necessita ser mais explorado em relação aos efeitos que ele pode proporcionar aos produtos cárneos como presunto, produtos marinados, emulsões cárneas e etc., bem como verificar se esse efeito ocorre também em relação à redução de fosfato. Os estudos voltados para o uso do US são os que mais avançaram, pois já se tem resultados sobre sua ação em diferentes matrizes cárneas e em relação ao fosfato em emulsões, o que poderia ser aplicado em outros produtos a fim de verificar se também há eficácia. Em relação à ação da AEB, entende-se que ela consiste em uma tecnologia complementar. Entretanto, ainda é necessário dar prosseguimento ao estudo com as emulsões, avaliando a ação dela em separado ou em conjunto ao US sobre as características microbiológicas, estabilidade oxidativa e qualidade/perfil sensorial.

\section{Referências}

ALARCON-ROJO A.D.; CARRILLO-LOPEZ L.M.; REYES-VILLAGRANA R.; HUERTA-JIMÉNEZ M.; GARCIA-GALICIA I.A. 2019. Ultrasound and meat quality: A review. Ultrasonics - Sonochemistry, v. 55, p. 369-382, 2019.

AFARI, G. K.; HUNG, Y. C. 2018. A meta-analysis on the effectiveness of electrolyzed water treatments in reducing foodborne pathogens on different foods. Food Control, v. 93, p. 150-164, 2018. 
AMIRI A.; SHARIFIAN P.; SOLTANIZADEH N. 2018. Application of ultrasound treatment for improving the physicochemical, functional and rheological properties of myofibrillar proteins. International Journal of Biological Macromolecules, v. 111, p. 139-147, 2018.

ANDREU V.; DIMOPOULOS G.; ALEXANDRAKIS Z.; KATSAROS G.; OIKONOMOU D.; TOEPFL S.; HEINZ V.; TAOUKIS P. 2016. Shelf-life evaluation of virgin olive oil extracted from olives subjected to nonthermal pretreatments for yield increase. Innovative Food Science and Emerging Technologies, v. 40, p. 52-57, 2016.

ATHAYDE, D. R.; FLORES, D. R. M.; SILVA, J. S.; GENRO, A. L. G.; SILVA, M. S.; KLEIN, B.; MELLO, R.; CAMPAGNOL, P. C. B.; WAGNER, R.; MENEZES, C. R.; BARIN, J. S.; CICHOSKI, A. C. 2017. Application of electrolyzed water for improving pork meat quality. Food Research International, v. 100, p. 757-763, 2017.

ATHAYDE, D. R.; FLORES, D. R. M.; SILVA, J. S.; GENRO, A. L. G.; SILVA, M. S.; CAMPAGNOL, P. C. B.; WAGNER, R.; MENEZES, C. R.; CICHOSKI, A. C. 2018. Characteristics and use of electrolyzed water in food industries. International Food Research Journal, v. 25, n. 1, p. 11-16, 2018.

BAI, Y.; NIU, L.; XIANG, Q. 2019. Application of Electrolyzed Water in Red Meat and Poultry Processing. Chapter 5. In: DING, T.; OH, D.; LIU, D. (org.). Electrolyzed Water in Food: Fundamentals and Applications. Hangzhou: Springer, Singapore, 274p, 2019.

BARBA F.J.; KOUBAA M.; PRADO-SILVA L.; ORLIEN V.; SANT'ANA A.S. 2017. Mild processing applied to the inactivation of the main foodborne bacterial pathogens: A review. Trends in Food Science \& Technology, v. 66, p. 20-35, 2017.

BARRETO T.L.; POLLONIO M.A.R.; TELIS-ROMERO J.; BARRETO A.C.S. 2018. Improving sensory acceptance and physicochemical properties by ultrasound application to restructured cooked ham with salt $(\mathrm{NaCl})$ reduction. Meat Science, v. 145, p. 55-62, 2018.

BEKHIT A.E.D.A.; SUWANDI V.; CARNE A.; VEM R.; HOPKINS D.L. 2016. Effect of repeated pulsed electric field treatment on the quality of hot-boned beef loins and topsides. Meat Science, v. 111, p. 139-144, 2016.

BHAT Z.F.; MORTON J.D.; MANSON S.L.; BEKHIT A.E.D.A. 2018. Current and future prospects for the use of pulsed electric field in the meat industry. Critical Reviews in Food Science and Nutrition, v. 59, p. 1660-1674, 2018.

BHAT Z.F.; MORTON J.D.; MASON S.L.; BEKHIT A.E.D.A. 2019. Pulsed electric field operates enzymatically by causing early activation of calpains in beef during ageing. Meat Science, v. 153, p.144-151, 2019.

BHAT Z.F.; MORTON J.D.; MASON S.L.; BEKHIT A.E.D.A. 2020. The application of pulsed electric field as a sodium reducing strategy for meat produts. Food Chemistry, v. 306, 2020.

ВІННІКОВА, Л. Г., ПРОНЬКІНА К. В. 2015. Вплив фракцій електроактивованої води на функціональнотехнологічні властивості яловичини та свинини. ВосточноЕвропейский журнал передовых технологий, v. 75, p. 36-43, 2015. 
BUCKOW R.; CHANDRY P.S.; NG S. Y.; MCAULEY C.M.; SWANSON B.G. 2015. Opportunities and challenges in pulsed electric field processing of dairy products. International Dairy Journal, v. 34, p.199-212, 2015.

CHEMAT, F.; ZILL-E-HUMA; KHAN, M. K. 2011. Applications of ultrasound in food technology: Processing, preservation and extraction. Ultrasonics Sonochemistry, v. 18, n. 4, p. 813-835, 2011.

CHEN, F.; ZHANG M.; YANG C. 2020. Application of ultrasound technology in processing of ready-to-eat fresh food: A review. Ultrasonics Sonochemistry, v. 63, 2020.

CICHOSKI A.J.; SILVA M.S.; LEÃES Y.S.V.; BRASIL C.C.B.; MENEZES CR, BARIN J.S.; WAGNER R.; CAMPAGNOL P.C.B. 2019. Ultrasound: A promising technology to improve the technological quality of meat emulsions. Meat Science, v. 148, p. 150-155, 2019.

CUI, X.; YUCHAO, S.; ZHENGXIANG, S.; HONGWEI, X.; WEI, C. 2009. Physicochemical properties and bactericidal efficiency of neutral and acidic electrolyzed water under diferente different storage conditions. Journal of Food Engineering, v. 91, n. 4, p. 582-6, 2009.

ESPINA L.; MONFOT S.; ÁLVARES I.; GARCÍA-GONZALO D.; PAGÁN R. 2014. Comnination of pulsed electric fields, mild heat and essential oils as na alternative to the ultrapasteurization of liquid whole egg. International Journal of Food Microbiology, v. 189, p. 119-125, 2014.

FLORES, D. R. M. et al. 2018. Application of ultrasound in chicken breast during chilling by

immersion promotes a fast and uniform cooling. Food Research International, v. 109, p. 59-64, 2018.

GABRIĆ D.; BARBA F.; ROOHINAJAD S.; GHARIBZAHEDI S.M.T.; RADOJČIN M.; PUTNIK P.; KOVAČEVIĆ D.B. 2017. Pulsed electric fields as na alternative to termal processing for preservation of nutritive and physicochemical properties of beverages: A review. Journal of Food Process Engineering, v. 41, p. 1-14, 2017.

GÓMEZ B.; MUNEKATA P.E.S.; GAVAHIAN M.; BARBA F.J.; MARTÍ-QUIJAL F.J.; BOLUMAR T.; CAMPAGNOL P.C.B.; TOMASEVIC I.; LORENZO J.M. 2019. Application of pulsed electric fields in meat and fish processing industries: A review. Food Research International, v. 123, p. 95-105, 2019.

GONÇALVES C.; ABREU S.; PADRÃO P.; PINHO O.; GRAÇA P.; BREDA J.; SANTOS R.; MOREIRA P. 2016. Sodium and potassium rinary excretion and dietary intake: a cross-sectional analysis in adolescentes. Food \& Nutrition Research, v. 60, p. $1-11$.

GONZALEZ-GONZALEZ, L.; ALARCON-ROJO, A. D.; CARRILLO-LOPEZ, L. M.; GARCIA-GALICIA, I. A.; HUERTA-JIMENEZ, M.; PANIWNYK, L. 2020. Does ultrasound equally improve the quality of beef? An insight into longissimus lumborum, infraspinatus and cleidooccipitalis. Meat Science, v. 160, 2020. 
GUILLOU S.; LERASLE M.; SIMONIN H.; FEDERIGHI M. 2016. High-pressure processing of meat and meat products. In: CUMMINS, E. J.; LYNG, J. G. (Org.). Emerging Technologies in Meat Processing: Production, Processing and Technology. Edited by Cummins EJ, Lyng JG. John Wiley \& Sons, p. 37-101, 2016.

HARA, Y. H.; ATSUDA, H. M.; RAI, E. A. 2003. Effects of Weakly Electrolyzed Water on Properties of Tofu (Soybean Curd). Food science and technology research, v. 9, n. 4, p.

$332-337,2003$.

HUANG H. W.; WU S. J.; LU J. K.; SHYU Y. T.; WANG C. Y. 2017. Current status and future trends of high-pressure processing in food industry. Food Control, v. 72, p. 1 $-8,2017$.

HUANG, Y. R.; HUNG, Y.; HSU, S.; HUANG, Y.; HWANG, D. 2008. Application of electrolyzed water in the food industry. Food Control, v. 19, n. 4, p. 329-345, 2008.

INGUGLIA, E. S.; ZHANG, Z.; TIWARI, B. K.; KERRY, J. P.; BURGESS, C. M. 2017. Salt reduction strategies in processed meat products - A review. Trends in Food Science and Technology, 59, 70-78, 2008.

JADEJA, R.; HUNG, Y. C. 2014. Efficacy of near neutral and alkaline pH electrolyzed oxidizing waters to control Escherichia coli O157: H7 and Salmonella Typhimurium DT 104 from beef hides. Food Control, v. 41, n. 1, p. 17-20, 2014.

JUNIOR L. M.; ANJOS C. A. R. 2018. Effect of high-pressure processing on characteristics of flexible packaging for foods and beverages. Food Research International, v. 119, p. 920-930, 2018.

KRASULYA O.; TSIRULNICHENKO L.; POTOROKO I.; BOGUSH V.; NOVIKOVA Z.; SERGEEV A.; KUZNETSOVA T.; ANANDAN S. 2019. The study of changes in raw meat salting using acoustically activated brine. Ultrasonics Sonochemistry, v. 50, p. 224-229, 2019;

KNIPE, C. L.; OLSON, D. G.; RUST, R. E. 1985. Effects of Selected Inorganic Phosphates,

Phosphate Levels and Reduced Sodium Chloride Levels on Protein Solubility, Stability and

pH of Meat Emulsions. Journal of Food Science, v. 50, n. 4, p. 1010-1013, 1985.

KONOMATSU, A.; SUGIBAYASHI, K.; OKAJIMA, M.; ISHII, F. 2003. Preparation and stability of surfactant free emulsions using electrolyzed deoxidized and ionized water. Mater.

Technol., v. 21, p. 273-285, 2003.

LEÃES Y.S.V.; PINTON M.B.; ROSA C.T.A.; ROBALO S.S.; WAGNER R.; MENEZES C.R.; BARIN J.S.; CAMPAGNOL P.C.B.; CICHOSKI A.J. 2020. Ultrasound and basic electrolyzed water: A green approach to reduce the technological defects caused by $\mathrm{NaCl}$ reduction in meat emulsions. Ultrasonics Sonochemistry, v. 61, 2020 .

LEE, N. Y. KIM, N. H.; JANG, S.; SANG, J. H.; LEE, S. H.; HWANG, I. G.; RHEE, M. S. 2014. Decontamination efficacy of neutral electrolyzed water to eliminate indigenous 
flora on a large-scale of cabbage and carrot both in the laboratory and on a real processing line. Food Research International, v. 64, p. 234-240, 2014.

LI, J.; DING, T.; LIAO, X.; CHEN, S.; YE, X.; LIU, D. 2017. Synergetic effects of ultrasound and slightly acidic electrolyzed water against Staphylococcus aureus evaluated by flow cytometry and electron microscopy. Ultrasonics Sonochemistry, v. 38, p. 711$719,2017$.

MCDONNELL C. K.; ALLEN P.; CHARDONNEREAU F. S.; ARIMI J. M.; LYNG J. G. 2014. The use of pulsed electric fields for accelerating the salting of pork. LWT Food Science and Technology, v. 59, p. 1054 - 1060, 2014.

NOWAK K.W.; ROPELEWSKA E.; BEKHIT A.E.D.A.; MARKOWSKI M. 2017. Ultrasound applications in the meat industry. In: Advances in Meat Processing Technology. Edited by Bekhit EDA. CRC Pres, p. 3-32, 2017.

O'NEIL C.M.; CRUZ-ROMERO M.C.; DUFFY G.; KERRY J.P. 2018. Shelf life extension of vacuum-packed salt reduced frankfurters and cooked ham through the combined application of high pressure processing and organic acids. Food Packaginf and Shelf Life, v. 17, p. 120-128, 2018.

O’NEIL C.M.; CRUZ-ROMERO M.C.; DUFFY G.; KERRY J.P. 2018. The application of response surface methodology for the development of sensory accepted low-salt cooked ham using high pressure processing and a mix of organic acids. Innovative Food Sceince \& Emerging Technologies, v. 45, p. 401-411, 2018.

O'FLYNN C.C.; CRUZ-ROMERO M.C.; TROY D.; MULLEN A.M.; KERRY J.P. 2014. The application of high-pressure treatment in the reduction of salt levels in reducedphosphate breakfast sausages. Meat Science, v. 96, p. 1266-1274, 2014.

OSTERMEIER R.; GIERSEMEHL P.; SIEMER C.; TOPFL S.; JA“GER H. 2018. Influence of pulsed electric field (PEF) pre-treatment on the convective drying kinetics of onions. J Food Eng, v. 237, p. 110-117, 2018.

OVISSIPOUR, M.; AL-QADIRI, H. M.; SABLANI, S. S.; GOVIDAN, B. N.; ALALAMI, N.; RASCO, B. 2015. Efficacy of acidic and alkaline electrolyzed water for inactivating Escherichia coli O104: H4, Listeria monocytogenes, Campylobacter jejuni, Aeromonas hydrophila, and Vibrio parahaemolyticus in cell suspensions. Food Control, v. 53, p. 117- 123, 2015.

PIETRASIK Z.; GAUDETTE N.J.; JOHNSTON S.P. 2016. The use of high pressure processing to enhance the quality and shelf life of reduced sodium naturally cured restructured cooked hams. Meat Science, v. 116, p. 102 - 109, 2016.

PIETRASIK Z.; GAUDETTE N.J.; JOHNSTON S.P. 2017. The impact of high hydrostatic pressure on the functionality and consumer acceptability of reduced sodium naturally cured wieners. Meat Science, v. 129, p.127-134, 2017.

PINTON, M. B.; SANTOS, B. A.; LORENZO, J. M.; CICHOSKI, A. J.; BOEIRA, C. P.; CAMPAGNOL, P. C. 2021. Green technologies as a strategy to reduce $\mathrm{NaCl}$ and phosphate in meat products: an overview. Current Opinion in Food Science, v. 40, p. $1-5,2021$. 
PINTON, M. B.; SANTOS, B. A.; CORREA, L. P.; LEÃES, Y. S. V.; CICHOSKI, A. J.; LORENZO, J. M.; SANTOS, M.; POLLONIO, M. A. R.; CAMPAGNOL, P. C. B. 2020. Ultrasound and low-levels of $\mathrm{NaCl}$ replacers: A successful combination toproduce lowphosphate and low-sodium meat emulsions. Meat Science, v. 170, 2020.

PINTON M.B.; CORREA L.P.; FACCHI M.M.X.; HECK R.T.; LEÃES Y.S.V.; CICHOSKI A.J.; LORENZO J.M.; SANTOS M.; POLLONIO M.A.P.; CAMPAGNOL P.C.B. 2019. Ultrasound: A new approach to reduce phosphate contente of meat emulsions. Meat Science, v. 152, p. 88-95, 2019.

POTTIER L.; VILLAMONT G.; LAMBALLERIE M. 2017. Applications of high pressure for healthier foods. Current Opinion in Food Science, v. 16, p. 21 - 27, 2017.

RAHMAN, S. M. E.; JIN, Y. G.; OH, D. H. 2010. Combined Effects of Alkaline Electrolyzed

Water and Citric Acid with Mild Heat to Control Microorganisms on Cabbage. Journal of

Food Science, v. 75, n. 2, p. 111-115, 2010.

RICCI A.; PARPINELLO G.P.; VERSARI A. 2018. Recent advances and applications of pulsed electric fields (PEF) to improve polyphenol extraction and color release during red winemaking. Beverages, v. 4, p. 1-12, 2018.

SAULIS G. 2010. Electroporation of ceel membranes: The fundamental effects of pulsed electric fields in food processing. Food Engineering Reviews, v. 2, p. 52 - 73, 2010.

SHARMA P.; BREMER P.; OEY I.; EVERETT D.W. 2014. Bacterial inactivation in whole milk using pulsed electric field processing. International Dairy Journal, v. 35, p. 49-56, 2014.

SHENG, X.; SHU, D.; TANG, X.; ZANG, Y. 2018. Effects of slightly acidic electrolyzed water on the microbial quality and shelf life extension of beef during refrigeration. Food Science and Nutrition, v. 6, n. 7, p. 1975-1981, 2018.

SHIMAMURA, Y.; SHINKE, M.; HIRAISHI, M.; TSCHUIYA, Y.; MASUDA, S. 2016. The application of alkaline and acidic electrolyzed water in the sterilization of chicken breasts and beef liver. Food Science \& Nutrition, v. 41, n. 3, p. 431-440, 2016.

SIRÓ I.; VÉN C.; BALLA C.; JÓNÁS G.; ZEKE I.; FRIEDRICH L. 2009. Application of na ultrasonic assisted curing technique for improving the diffusion of sodium chloride in porcine meat. Journal of Food Engineering, v. 91, p. 353-362, 2009.

SITZMANN W.; VOROBIEV E.; LEBOVKA N. 2016. Applications of electricity and specifically pulsed electric fields in food processing: Historical backgrounds. Innovative Food Science and Emerging Technologies, v. 37, p. 302-311, 2016.

SOLADOYE O. P.; PIETRASIK Z. 2018. Utilizing high pressure processing for extended shelf life meat products. Reference Module in Food Science, p. 1-8, 2018.

SUMAN, S. P.; JOSEPH, P. 2012. Myoglobin Chemistry and Meat Color. Annual Review of Food Science and Technology, v. 4, n. 1, p. 79-99, 2012. 
TAMM A.; BOLUMAR T.; BAJOVIC B.; TOEPFL S. 2016. Salt (NaCl) reduction in cooked ham by a combined approach of high pressure treatment and the salt replacer $\mathrm{KCl}$. Innovative Food Science and Emerging Technologies, v. 36, p. 294-302, 2016.

THANGAVELU, K. P.; KERRY, J. P.; TIWARI, B. K.; MCDONNELL, C. K. 2019. Novel processing technologies and ingredient strategies for the reduction of phosphate additives in processed meat. Trends in Food Science and Technology, v. 94, p. 43-53, 2019.

TOEPFL S.; SIEMER C.; SALDAÑA-NAVARRO G.; HEINZ V. 2014. Overview of pulsed electric fields processing dor food. Emerging Technologies for Food Processing, v. 2, p. 93-114, 2014.

VINNIKOVA, L. G.; PRONKINA, K. V. 2016. The changes of characteristics of the pork whole muscle meat products while using the electrolyzed water. Харчова наука i технологія, v. 10, n. 2, p. 19-23, 2016.

XARGAIÓ, M.; LAGARES, J.; FERNÁNDES, E.; BORREL, D.; JUNCÁ, G. 2006. Una solución definitive para mejorar la textura de la carne. Departamento Tecnológico de Metalquimia, 2006.

WANG, H.; QI, J.; DUAN, D.; DONG, Y.; XU, X.; ZHOU, G. 2019. Primary concerns regarding the application of electrolyzed water in the meat industry. Food Control, v. 95, p. $50-56,2019$.

WANG Y.; ZHOU Y.; LI P.; WANG X.; CAI K.; CHEN C. 2018a. Combined effect of $\mathrm{CaCl} 2$ and high pressure processing on the solubility of chicken breast myofibrillar proteins under sodium-reduced conditions. Food Chemistry, v. 269, p. 236-243, 2018 a.

WANG, H.; QI, J.; DUAN, D.; DONG, Y.; XU, X.; ZHOU, G. 2018b. Combination of a novel designed spray cabinet and electrolyzed water to reduce microorganisms on chicken carcasses. Food Control, v. 86, p. 200-206, 2018 b.

YANG N.; HUANG K.; LYU C.; WANG J. 2016. Pulsed electric field technology in the manufacturing processes of wine, beer, and rice wine: A review. Food Control, v. 61, p. $28-38,2016$.

YOGESH K. 2015. Pulsed electric field processing of egg products: A review. Journal Food Science Technology, v. 53, p. 934-945, 2015.

ZHENG H.; HAN M.; YANG H.; TANG C.; XU X.; ZHOU G. 2017. Application of high pressure to chicken meat batters during heating modifies physicochemical properties, enabling salt reduction for high-quality products. LWT - Food Science and Technology, v. 84, p. 693-700, 2017. 


\title{
CAPÍTULO 38: ENCAPSULAÇÃO DE ÓLEOS ESSENCIAIS PARA APLICAÇÃO EM ALIMENTOS: UMA REVISÃO
}

\section{CHAPTER 38: ENCAPSULATION OF ESSENTIAL OILS FOR FOOD APPLICATION: A REVIEW}

\author{
Amanda Schuencker da Silva Moreira ${ }^{1}$, Eliana da Silva Gulão ${ }^{2}$
}

\begin{abstract}
Resumo
A interação entre proteínas e polissacarídeos pode resultar em novos produtos com propriedades superiores aos polímeros originais com grande potencial tecnológico, e neste sentido, uma importante técnica é encapsulação, especialmente de ingredientes lipídicos, como óleos essenciais. As cápsulas ou esferas formadas possuem potencial para facilitar o emprego de óleos essenciais em alimentos e na indústria farmacêutica, preservando sua atividade biológica, agregando valor nutricional e propriedades tecnológicas. O objetivo deste trabalho foi realizar uma revisão de literatura sobre óleos essenciais e diferentes técnicas de encapsulação para preservação destes compostos. Para realizar a pesquisa foram utilizadas as seguintes palavras-chave: óleo essencial; óleos vegetais; encapsulação; microencapsulação nas bases de dados: Science direct, Scielo e PubMed. Como resultado foi constatada a importância dos óleos essenciais como antimicrobianos naturais para aplicação em alimentos devido aos terpenos presentes em sua composição e, uma vez que são compostos instáveis, pesquisas científicas demonstram a eficiência na encapsulação e preservação da atividade biológica através de diferentes técnicas, com ênfase na importância dos fatores envolvidos no processo, como a escolha dos polímeros para o revestimento do núcleo e a temperatura envolvida na encapsulação para maior preservação dos óleos essenciais.
\end{abstract}

\section{Palavras-chave: óleo essencial; encapsulação; polímeros}

\begin{abstract}
The interaction between proteins and polysaccharides can result in new products with properties superior to the original polymers with great technological potential, and in this sense, an important technique is encapsulation, especially of lipid ingredients, such as essential oils. The capsules or spheres formed have the potential to facilitate the use of essential oils in food and in the pharmaceutical industry, preserving their biological activity, adding nutritional value and technological properties. The objective of this work was to perform a literature review on essential oils and different encapsulation techniques for the preservation of these compounds. To carry out the research, the following keywords were used: essential oil; vegetable oils; encapsulation; microencapsulation in the databases: Science direct, Scielo and PubMed. As a result, it was verified the importance of essential oils as natural antimicrobials for application in foods due to the terpenes present in their composition and, since they are unstable compounds, scientific research demonstrates the efficiency in encapsulation and preservation of biological activity through different techniques, with emphasis on the importance of the factors involved in the process, such as the choice of polymers for the core coating and the temperature involved in the encapsulation for greater preservation of essential oils.
\end{abstract}

Key-words: essential oil; encapsulation; polymers

${ }^{1}$ Estudante de Nutrição. Universidade Estácio de Sá, amanda.schuencker@ gmail.com

${ }^{2}$ Docente. Departamento de Nutrição. Universidade Estácio de Sá, eliana.gulao@estacio.br 


\section{Introdução}

Os óleos essenciais (OEs) despertam grande interesse em diversos setores. Como produtos naturais possuem características físico-químicas interessantes, com alto valor agregado por possuírem propriedades biológicas diversas e relevantes, como por exemplo, atividade antimicrobiana, repelente, propriedades terapêuticas e nutricionais (ASBAHANI et al., 2015; DEANS; RITCHIE, 1987; MARTINS et al., 2014).

A indústria de alimentos também apresenta uma demanda crescente de OEs devido a suas importantes aplicações como conservantes de alimentos, adição em embalagens de alimentos e combate a patógenos que podem gerar intoxicação ou infecção alimentar (ASBAHANI et al., 2015).

Numerosos estudos demonstraram a eficiência de OEs em baixas doses contra alguns patógenos bacterianos encontrados na indústria de alimentos e produtos cárneos (BAKKALI et al., 2008; BELLIK, 2014; NOSHIRVANI et al., 2017; SINGH et al., 2008). Pesquisas revelaram que, a partir dessas classes, uma série de compostos possui atividade antioxidante e antibacteriana (BALCÃO et al., 2013; DEANS; RITCHIE, 1987; OUEDRHIRI et al., 2016). Por esta razão, os óleos essenciais são uma alternativa aos conservantes químicos e, portanto, são usados na preparação de alimentos seguros com impacto positivo na saúde dos consumidores (BURT, 2004; GUTIERREZ; BARRY-RYAN; BOURKE, 2008).

Nos últimos anos, a demanda por produtos contendo óleos essenciais vem crescendo e ainda espera-se expandir e aumentar sua diversidade. Óleos essenciais podem ser responsáveis por diferentes fragrâncias e sabores, sendo componentes importantes em produtos domésticos, como por exemplo, produtos de lavanderia, em cosméticos ou como aditivos em alimentos devido às propriedades funcionais dos diversos óleos essenciais existentes. Publicações e patentes publicadas recentemente na área de microencapsulação sugerem que os setores industrial e acadêmico estão empenhados em explorar essa área, especialmente nas indústrias de cosméticos e alimentos (MARTINS et al., 2014).

Pesquisas revelaram que a partir de óleos essenciais uma série de compostos possui atividade antioxidante e antibacteriana (BALCÃO et al., 2013; DEANS; RITCHIE, 1987; OUEDRHIRI et al., 2016), no entanto, são compostos voláteis de difícil aplicação na indústria de alimentos, por isso, a microencapsulação torna-se uma técnica atraente na preservação de compostos instáveis, facilitando sua aplicação nos mais variados setores alimentares. Desta forma, o objetivo deste trabalho é apresentar 
uma revisão de literatura sobre óleos essenciais e seu potencial para aplicação em alimentos através das técnicas de microencapsulação.

\section{Revisão de Literatura}

\section{Óleos essenciais e seus compostos bioativos}

Mesmo sem registros científicos que comprovem a eficiência medicinal das plantas, o ser humano sempre fez o uso desse recurso para se aliviar queixas e tratar dores (SANTIN, 2014). O conhecimento de potencial curativo das ervas vai além da sabedoria popular, a ciência constantemente vem buscando validar tais informações através da pesquisa. Segundo Bizzo (2020) as indústrias alimentícias, o setor de cosméticos, perfumaria e governos vêm demonstrando grande interesse em explorar e reconhecer cientificamente tratamentos com compostos biologicamente ativos encontrados nas plantas, devido a resultados positivos de pesquisas científicas e baixo custo-benefício (FERREIRA 2017; SOUZA 2017). Seu uso se aplica amplamente em conservação de produtos alimentares, herbicidas, antissépticos, antifúngicos, inseticidas, anti-helmínticos, anticonvulsivantes e antimicrobianos (MARQUES 2020; VALVERDE 2020; VERBER 2015).

As plantas conhecidas como medicinais e aromáticas têm em comum aleloquímicos, chamados terpenos, mononoterpenos, sesquiterpenos e de fenilpropanoides (BIZZO, 2020), voláteis e aromáticos identificados a partir de um metabolismo secundário das plantas. Estas substâncias são muito utilizadas em larga escala na produção de fragrâncias em perfumarias. Seus odores característicos e específicos funcionam como um mecanismo de autoproteção ou atração, sendo os terpenos responsáveis pelas propriedades organolépticas de cada planta e suas propriedades olfativas podem ser percebidas por humanos, animais, microrganismos e outras plantas (CRUZ-SILVA, 2016; NETTO; BARRETO, 2011).

Os terpenos exercem várias funções e em uma mesma planta podem ser extraídos e encontrados diversos tipos de terpenos. Em um estudo feito com o orégano (Oreganum Vulgare) foram identificados 12 terpenoídes com funções antifúngicas (SANTIN, 2014). Os terpenos protegem as plantas de fatores relacionados ao ambiente físico, níveis de iluminação, exposição a raios ultravioleta (UV), conteúdos de água e nutrientes do solo. Os monoterpenos são quem têm o poder de repelir ou atrair insetos polinizadores e seus compostos biologicamente ativos são capazes de mudar o ambiente 
onde são plantados, interferindo diretamente na produção e colheita de outras espécies de plantas e no crescimento de pragas. Em seu estudo realizado por Cruz-Silva (2016) foi observado que esses compostos são responsáveis por inibir o crescimento de ervas daninhas, fungos, tendo a função de proteger o solo dos estresses causados por baixa reposição hídrica, inibindo assim o crescimento de microrganismos. Cada terpeno tem suas propriedades medicinais específicas e suas quantidades podem variar de acordo com o período de colheita e maturação da planta. Os terpenos são a origem dos óleos essenciais aromáticos e são eles que definem o comportamento dessas plantas (CRUZSILVA, 2016).

Óleos essenciais são produtos ricos em compostos biologicamente ativos, insolúveis em água, obtidos através da destilação por arraste com vapor d'água ou por meio de prensagem mecânica a frio ou por extração de solventes orgânicos, sendo o éter um dos principais (BIZZO; HOVELL; REZENDE, 2020). Esses processos podem ser combinados para potencializar a extração e seus compostos biologicamente ativos podem ser encontrados em partes específicas das plantas, por isso estudos sugerem a investigação de todos os componentes das plantas como raízes, caules, folhas, flores, frutos, cascas e sementes, onde geralmente se concentram as maiores parte dos lipídeos (CRUZ-SILVA, 2016; FERREIRA, 2017; VERBER, 2015).

Os óleos essenciais são misturas químicas complexas de substâncias voláteis que se diferenciam de óleos fixos e fatores como o período de colheita, tipo de solo, contato com luz, metodologia de extração do óleo influenciam diretamente na quantidade de terpenos e qualidade do produto final (FERREIRA, 2017).

Na natureza, os óleos essenciais desempenham um papel importante na proteção das plantas como antibacterianos, antivirais, antifúngicos, inseticidas e também contra herbívoros, reduzindo seu apetite por tais plantas. Eles também podem atrair alguns insetos para favorecer a dispersão de pólens e sementes, ou repelir outros indesejáveis. Eles são caracterizados por dois ou três componentes principais em concentrações razoavelmente altas (20\% a 70\%) em comparação com outros componentes presentes em quantidades vestigiais, como por exemplo: carvacrol (30\%) e timol (27\%) são os principais componentes do óleo essencial de Origanum compactum, linalol (68\%) do óleo essencial de Coriandrum sativum, 1,8-cineol (50\%) do óleo essencial de Cinnaumum camphora, $\alpha$-felendreno (36\%) e limoneno (31\%) do óleo essencial de 
sementes de Anethum graveolens, mentol (59\%) e mentona (19\%) de óleo essencial de Mentha piperita (BAKKALI et al., 2008).

Em geral, os óleos essenciais representam uma pequena fração da composição vegetal (menos de 5\% da matéria seca vegetal) e compreendem principalmente terpenos (isoprenos) e terpenóides. Os primeiros compostos são monoterpenos (têm 10 átomos de carbono e representam mais de $80 \%$ da composição dos OEs) e sesquiterpenos (têm 15 átomos de carbono). Estes podem apresentar estruturas acíclicas de hidrocarbonetos, assim como estruturas mono, di ou tricíclicas. Os segundos, também chamados isoprenoides, são derivados oxigenados de terpenos de hidrocarbonetos, tais como álcoois, aldeídos, cetonas, ácidos, fenóis, éteres e ésteres. Os terpenos representam uma grande classe dos hidrocarbonetos naturais mais abundantes. Estes têm vários potenciais já estudados, como por exemplo, contra doenças como o câncer (EBADA; LIN; PROKSCH, 2010), malária (PARSHIKOV; NETRUSOV; SUTHERLAND, 2012) e doenças cardíacas (LIEBGOTT et al., 2000), outros mostram propriedades inseticidas (ROSSI; CANAVOSO; PALACIOS, 2012). O bloco de construção fundamental dos terpenos é a unidade de isopreno (2-metil-1,3-butadieno). É representado pela fórmula estrutural geral $(\mathrm{C} 5 \mathrm{H} 8) n$ onde $n$ é o número de unidades de isopreno ligadas (ASBAHANI et al., 2015; BAKKALI et al., 2008; OMONIJO et al., 2017).

Em estudo conduzido por Valverde (2020), sobre a Solidagum Chilensis chamada popularmente de "arnica" no Brasil, planta originária do Chile, tendo suas propriedades medicinais conhecidas desde o século 13, foi possível identificar a volatilidade na presença de diferentes tipos de terpenos que se alteraram de acordo com as partes da planta, tipos de extração, período de colheita e secagem, como pode ser observado na Tabela 1. Observaram também maior perda de terpenos nas partes de inflorescência que passaram por secagem do que na extração de inflorescências frescas, devido à alta volatilidade desses compostos químicos. Todas as amostras indicaram respostas significativamente positivas para as atividades antinoceptivas, que é a capacidade de percepção da dor observada em humanos, porém seus resultados indicam a viabilidade de utilização dos extratos compostos do Solidago Chilensis na criação de novos fármacos.

Estudos de óleos essenciais têm-se ampliado com o intuito de aumentar ou estimular a imunidade, reduzir do uso prolongado de antibióticos e amenizar resistências infecciosas (MARQUES, 2020; OLIVEIRA, 2016; SANTIN, 2014). Sua 
aplicação é de vasta amplitude, sendo possível sua aplicação em embalagens de alimentos, como conservantes naturais atuando na preservação do prazo de validade de produtos alimentícios e evitando ou inibindo a proliferação de microrganismos patogênicos (FERREIRA, 2017).

Tabela 1. Comparação dos principais compostos voláteis nas amostras analisadas das partes aéreas de S. chilensis detectadas / extraídas por SPME e hidrodestilação.

\begin{tabular}{ccc}
\hline Parte aérea & Compostos principais & $\begin{array}{c}\text { Método de detecção / } \\
\text { extração }\end{array}$ \\
\hline Hastes centrais & $\begin{array}{c}\text { Germacreno D, acetato de bornila, } \gamma \text { - } \\
\text { elemeno, } \beta \text {-cariofileno, limoneno } \\
\text { Germacreno D, } \gamma \text {-elemeno, acetato de } \\
\text { bornila, espatulenol, } \beta \text {-cariofileno }\end{array}$ & SPME \\
Inflorescências & Germacreno D, $(\mathrm{Z})$ - $\beta$-farneseno, $\beta$ - & SPME \\
secas & cariofileno, acetato de bornila & \\
& Germacreno $\mathrm{D}, \beta$-cariofileno, $\gamma$-elemeno, & hidrodestilação \\
acetato de bornila & SPME \\
Inflorescências & Limoneno, germacreno D, acetato de & \\
frescas & bornila & Hidrodestilação \\
& Germacreno D, limoneno, $\gamma$-elemeno, $\beta$ - & \\
\hline
\end{tabular}

Fonte: Valverde, 2020

A evolução científica vem permitindo perceber que as maiores riquezas estão em nos recursos naturais, sendo o Brasil responsável pela importação de 5\% de óleos essenciais cítricos produzidos mundialmente, chegando a ser o maior produtor do óleo de laranja (BIZZO; HOVELL; REZENDE, 2020). Pesquisas envolvendo as propriedades de óleos essenciais também são realizadas em casos clínicos. No estudo de Santin (2014) pode-se observar a eficácia do óleo essencial de Oreganum Vulgare para o tratamento de otite em cães que estavam alocados na "micoteca do Centro de Diagnóstico e Pesquisa em Micologia Veterinária da UFPel”, causadas pelo fungo Malassia Pachydermatis. O óleo de orégano utilizado nessa pesquisa foi extraído 
através do arraste por vapor seguindo todas as normas da farmacopéia brasileira IV, embora o método de extração tenha sido citado ele foi efetuado por uma empresa que de distribuição do ativo. Após o óleo passar por cromatografia realizou-se a preparação de uma solução de $5 \mathrm{~g}$, contendo em sua composição $0,04 \mathrm{~g}$ de "L-1 ( $\alpha$-pineno, canfeno, $\beta$ pineno, mirceno, $\alpha$-terpineno, p-cimeno, limoneno," 0,0018g “-cineol, terpinoleno, linalol, 4- terpineol, $\alpha$-terpineol, timol e carvacrol)". Cada ativo encontrado foi comparado a especificidade de tempo das amostras.

Após a incubação dos fungos em placas de Petri a $35^{\circ} \mathrm{C}$ por 72 horas foram realizadas as leituras de CIM e CFM. Os dados revelaram que o CIM 50 e $90 \%$ demonstraram inibição fúngica, sendo eles mais sensíveis as amostras de CIM 90\%. Com o objetivo de identificar a ação antifúngica do óleo essencial foi realizada análise de cromatografia identificando como componentes majoritários: timol, terpineno, 4terpineol e carvacrol. Destes componentes ao que mais se destacam e dão as características expressadas pelo Oreanum Vulgare são o timol e o carvacrol. Mas os grandes responsáveis pela ação antifúngia deste óleo são o $\alpha$-terpineno e o 4-terpineol. Nesse estudo concluíram que o óleo essencial de orégano é capaz de sensibilizar e descontinuar a ação fungicida do M. pachydermatis, logo, seu uso comprovou-se eficaz e muito promissor no tratamento de otites e dermatites em cães (SANTIN, 2014).

Pesquisas envolvendo OEs também são realizadas na intenção de promover uma alimentação com um melhor controle microbiológico evitando o surgimento de doenças transmitidas por alimentos, também conhecidas como DTAs. Por não existir um padrão de análise internacional ou nacional, facilmente estudos com os mesmos componentes e tipos de OEs e microrganismos podem apresentar resultados diferentes. $\mathrm{O}$ ambiente no qual essas plantas estão inseridas também alteram significativamente a quantidade de terpenos presentes nos OEs. Estudos também destacam a maior sensibilidade de bactérias Gram-positivas ao uso de OEs, uma vez que as espécies Gram-negativas vêm demonstrando maior resistência, aumentando a necessidade de promover estudos mais focados no mecanismo de ação dos OEs em suas estruturas físico-químicas. A alta quantidade de metodologias de análises e a falta de padrões nos ensaios podem dificultar a identificação correta dos resultados (BERALDO, 2013; MILEZZI, 2012; MAJOLO, 2014; SANTURIO, 2011).

As ervas aromáticas ou temperos são usados constantemente nas cozinhas para potencializar o sabor dos alimentos pois se destacam por seus sabores característicos e 
capacidade antimicrobiana. No estudo realizado por Tofino-Rivera (2017), na Colômbia, objetivou-se substituir o uso de conservadores químicos na produção de linguiças artesanais por OEs de tomilho e cravo-da-india. Os autores constataram primeiramente que a espécies de Salmonella spp, Staphylococcus aureus e Escherichia coli foram os microrganismos mais comumente encontrados na contaminação desses embutidos cárneos específicos.

A extração de ambos os óleos foi através da técnica de "hidrodestilação a vapor" e sua composição química determinada através da cromatografia gasosa, sendo observado no óleo essencial de tomilho $46 \%$ de timol e $26 \%$ de para-cimeno, enquanto no óleo de cravo houve maior prevalência de eugenol (84\%). Os preparos das linguiças artesanais foram divididos em três grupos: um grupo contendo o OE de cravo $(0,5$ $\mathrm{mL} / \mathrm{kg})$, outro com OE de tomilho $(0,5 \mathrm{~mL} / \mathrm{kg})$ e outro grupo contendo adição de uma mistura de conservadores químicos, contendo nitrato $(0,03 \%)$, fosfato de potássio $(0,3 \%)$ e benzoato $(0,05 \%)$. Após, as linguiças artesanais e cruas foram embaladas a vácuo observando a preservação de cada produto em relação ao crescimento microbiológico e as características sensoriais das mesmas durante o armazenamento por 24 dias. Como principais resultados os autores observaram que as amostras contendo OEs apresentaram inibição in vitro de $28,3 \mathrm{~mm}$ e $27,3 \mathrm{~mm}$ respectivamente contra a Salmonella spp, Staphylococcus aureus e Escherichia coli. Apesar de os conservantes químicos serem responsáveis por menor desenvolvimento microbiano nos produtos finais, os embutidos produzidos com os OEs se destacaram nos atributos cor e sabor nas análises sensoriais conduzidas, além de também demonstrarem satisfatória conservação (TOFINO-RIVEIRA, 2017).

\section{Microencapsulação de óleos essenciais}

Encapsulação é o processo pelo qual vários ingredientes alimentícios podem ser armazenados dentro de um invólucro ou revestimento microscópico para proteção e/ou posterior liberação. Mais especificamente a encapsulação é o processo de envolver pequenas partículas, um líquido ou um gás dentro de uma camada de revestimento ou dentro de uma matriz. Tradicionalmente a encapsulação não utiliza cápsulas maiores que $3 \mathrm{~mm}$ de comprimento. De uma forma geral, cápsulas que possuam tamanho em um intervalo de $100 \mathrm{~nm}$ a $1000 \mathrm{~nm}$ são classificadas como microcápsulas e as que possuem 
tamanho entre $1 \mathrm{~nm}$ e 100nm são classificados como nanocápsulas (SOBEL; VERSIC; GAONKAR, 2014).

A escolha do material adequado para encapsulação do ingrediente alimentício depende do desempenho físico e propriedades químicas do agente ativo. No entanto, na maioria das circunstâncias, é essencial que a seleção dos materiais deva mostrar ao menos duas características importantes: excelentes propriedades de barreira e excelente propriedade de formação de filme. Para encapsulação de compostos lipofílicos é importante que também possua propriedade surfactante (VASISHT, 2014).

Vários fatores devem ser considerados para ajudar na escolha dos polímeros da matriz, incluindo material de núcleo, morfologia, distribuição do tamanho de partícula, quantidade da produção, orçamento e disponibilidade de processo. Em muitos casos, os objetivos e expectativas originais de desenvolvimento da cápsula ou esfera podem precisar ser ajustados para acomodar uma limitação de material no sentido de estabilidade ou processamento da microencapsulação. Por exemplo, as microesferas com uma grande quantidade de amido modificado podem ser apropriadas para utilização através do processo de secagem por atomização ou spray dryer, e, isto pode ser comercialmente justificável quando o óleo essencial encapsulado ou outro composto é armazenado num saco selado a vácuo. Nesse caso, o amido modificado serve simplesmente como um componente de matriz de mascaramento de sabor em uma forma encapsulada. Por outro lado, as microcápsulas baseadas em gelatina oferecem uma alta capacidade de armazenamento do núcleo quando produzidas pelo processo de coacervação complexa (COMUNIAN et al., 2017; VASISHT, 2014).

Tecnologias sofisticadas e diferentes materiais foram desenvolvidos ao longo dos anos (BEIRÃO-DA-COSTA et al., 2013; GARCÍA-SALDAÑA et al., 2016; NAWONG et al., 2016; YANG et al., 2016) e uma variedade extremamente ampla de funcionalidades pode agora ser alcançada através da microencapsulação. Algumas tecnologias de encapsulação, embora cientificamente impressionantes, podem não ser apropriadas para todas as aplicações. Quando a encapsulação é usada para evitar a degradação excessiva de um ingrediente sensível, para reduzir o aparecimento de sabores voláteis durante o cozimento ou para economizar em um ingrediente caro, o custo em uso deve, na verdade, ser menor do que o ingrediente não encapsulado. No entanto, se a encapsulação fornecer ao ingrediente uma propriedade única que não é alcançável sem encapsulação, o custo em uso pode ser considerado superior. Todavia, o 
custo do processo deve ser considerado e especialmente a indústria de alimentos também visa tecnologias limpas e econômicas, por isso, também se faz necessária pesquisa por técnicas simples e também eficientes (GOUIN, 2004; LIDERT, 2005).

A liberação controlada de ingredientes alimentícios é uma funcionalidade chave que pode ser fornecida pela encapsulação. Uma liberação oportuna e direcionada melhora a eficácia dos aditivos alimentares e amplia a gama de aplicação de ingredientes alimentícios, melhorando assim a relação custo-benefício para o fabricante de alimentos. Aditivos reativos, sensíveis ou voláteis (vitaminas, culturas, compostos voláteis) podem ser transformados em ingredientes estáveis através da microencapsulação. Com propriedades de liberação controlada cuidadosamente ajustadas, a encapsulação não é mais apenas uma técnica de valor agregado, mas uma fonte de ingredientes novos com propriedades atrativas e que anteriormente eram de difícil aplicação (GOUIN, 2004; MARTÍN et al., 2015).

Diferentes métodos foram propostos para a produção de micro ou nanocápsulas (BELŠČAK-CVITANOVIĆ et al., 2016; CHEW; NYAM, 2016; ERATTE et al., [s.d.])., 2016). Geralmente, essas técnicas podem ser divididas em duas categorias principais: métodos químicos e físicos; este último pode ser subdividido em técnicas físico-químicas e físico-mecânicas.

A técnica de microencapsulação por spray drying é um processo comercial de relativo baixo custo que é usado principalmente para o encapsulamento de fragrâncias, óleos e aromas. Tem sido amplamente utilizada na secagem de alimentos sensíveis ao calor, produtos farmacêuticos e outras substâncias devido à rápida evaporação do solvente das gotículas. Embora na maioria das vezes seja considerado um processo de desidratação, a secagem por atomização também pode ser usada como um método de encapsulação quando retém materiais "ativos" dentro de uma matriz protetora, que é essencialmente inerte ao material que está sendo encapsulado (MAHDAVI et al., 2014).

Uma pesquisa onde foi realizada a encapsulação do óleo essencial de tomilho foi avaliado o potencial antimicrobiano in vitro e in situ do $\mathrm{OE}$ em produtos cárneos do tipo hambúrguer. Microcápsulas de caseína-maltodextrina foram produzidas por secagem por pulverização (spray dryer) e avaliadas quanto à eficiência de encapsulação, estabilidade térmica, compostos químicos e morfologia, além da atividade antimicrobiana nos hamburguers após cocção. Como resultado, os autores observaram que que as cápsulas contendo o óleo essencial foram responsáveis pela inibição in vitro e in situ nas amostras de 
hambúrguer de quatro diferentes espécies de microrganismos: Staphylococcus aureus, Escherichia coli, Listeria monocytogenes e Salmonella Typhimurium. Além disto, as cápsulas apresentaram alta eficiência de encapsulação e estabilidade térmica o que permitiu maior proteção e estabilidade dos óleos essenciais. A morfologia porosa das cápsulas possivelmente permitiu a liberação do óleo essencial no produto permitindo a ação antimicrobiana.

Embora a técnica de spray dryer seja bem difundida na indústria de alimentos, existem algumas desvantagens dessa técnica, como: a produção de micropartículas não uniformes; limitação na escolha de materiais de parede (deve possuir baixa viscosidade em concentrações relativamente altas); produção de pós muito finos que podem necessitar de processamento adicional; pode causar alterações em materiais sensíveis ao calor; e principalmente, pode haver perdas na fase final de recuperação do produto (MAHDAVI et al., 2014).

A liofilização é uma técnica de desidratação por congelamento, na qual a exclusão da água dos alimentos é feita por sublimação, à baixa pressão, a partir dos produtos previamente congelados. De uma forma geral, os liofilizadores mantêm os alimentos congelados a uma temperatura entre -40 e $-90^{\circ} \mathrm{C}$ e, em seguida, com o aumento gradativo da temperatura, a água congelada é retirada sob a forma de vapor. A liofilização ocorre em três estágios: congelamento do alimento em um ultrafreezer ou nitrogênio líquido, remoção da água por sublimação e secagem dos alimentos (FELLOWS et al., 2006). A vantagem de utilizar a liofilização está no fato de ser utilizada baixa temperatura, o que contribui por manter as propriedades nutricionais e sensoriais do produto final, ou ainda manter suas características funcionais, especialmente em compostos instáveis como os pigmentos, sendo possível manter sua cor e seu sabor natural (ORDÓÑEZ PEREDA; MURAD, 2005). No entanto, trata-se de uma operação lenta com custo muito elevado, o que pode acarretar custos adicionais da produção. Em alguns casos, como na aplicação de óleos, ingredientes voláteis ou sujeitos a oxidação, o uso de baixas temperaturas durante o processo de encapsulação é recomendado para evitar a ocorrência de reações indesejáveis e volatilização do produto.

Um estudo pesquisou o efeito da temperatura na secagem do óleo essencial de coentro (Coriandrum sativum L.) através da secagem natural (ao sol), sombra, fornos mecânicos $\left(40\right.$ e $\left.60^{\circ} \mathrm{C}\right)$, forno microondas $(500$ e $700 \mathrm{~W})$ e por liofilização. Os óleos 
essenciais foram analisados por cromatografia gasosa contendo detector de chamas (GC-FID) e cromatografia de massas (GC / MS). O maior rendimento de óleo essencial foi obtido nas amostras liofilizadas seguido pela amostra seca à sombra. No total, 39 componentes foram determinados nos óleos essenciais de coentro fresco e seco. Os componentes principais foram decanal (0-37,5\%), cis-fitol (1,0-34,1\%), 1-tetradecanol $(0-31,7 \%)$. As porcentagens de decanal e n-decanol no óleo diminuíram significativamente quando o material vegetal foi seco em estufa a $60{ }^{\circ} \mathrm{C}$ ou microondas. Desta forma, os autores concluíram que a secagem utilizando baixas temperaturas, como a liofilização, são mais adequadas a substâncias instáveis como os óleos essenciais (GHASEMI PIRBALOUTI; SALEHI; CRAKER, 2017).

Atualmente uma das técnicas físico-químicas mais empregadas na encapsulação de óleos essenciais é a coacervação complexa. A técnica pode ser usada para encapsulação, imobilização de enzimas, formação de filmes de embalagem e produção de emulsões ou géis alimentares. Os coacervados formados também são usados como encapsulantes, aditivos, emulsionantes e modificadores de viscosidade na indústria alimentícia (EGHBAL; CHOUDHARY, 2018) porém, para isso, faz-se necessário o entendimento dos parâmetros que influenciam na interação polimérica para obter as melhores condições de formação dos coacervados e consequente microencapsulação. A seguir, serão apresentados os principais tópicos envolvidos na formação dos complexos coacervados.

A coacervação refere-se ao fenômeno de separação de fases entre dois polieletrólitos opostamente carregados em duas fases líquidas: uma fase densa carregada de polieletrólitos e uma fase diluída, sendo a fase densa denominada fase de coacervado e a fase diluída conhecida como fase de equilíbrio (COMERT; DUBIN, 2017; LIU et al., 2017). A fase de coacervado inicia-se com o surgimento de partículas normalmente micrométricas, que sofrem coalescência, formando uma separação de fases macroscópica (JHO et al., 2017).

Diferentes óleos essenciais já foram encapsulados pela técnica da coacervação complexa devido a relativa facilidade da técnica, baixo custo e baixas temperaturas empregadas (CHANG et al., 2006; HERNÁNDEZ-NAVA et al., 2020; LV et al., 2014; PENG et al., 2014; YANG et al., 2016).

Em uma pesquisa conduzida por LV et al., (2014) foram formadas nanocápsulas de óleo essencial de jasmin resistentes a maiores temperaturas através da coacervação 
complexa utilizando como material de parede gelatina e goma arábica e reticuladas pela enzima transglutaminase. Sua capacidade de resistência ao calor a $80{ }^{\circ} \mathrm{C}$ foi avaliada por características morfológicas (tamanho, índice de polidispersidade e potencial zeta) e os resultados mostraram que as nanocápsulas reticuladas em condições alcalinas podem suportar o banho-maria a temperatura de $80{ }^{\circ} \mathrm{C}$ por $7 \mathrm{~h}$.

Emulsões estabilizadas por biopolímeros através da coacervação complexa representam uma importante técnica na encapsulação de óleos essenciais. O encapsulamento do OE de Eucalyptus citriodora através desta técnica aumentou a estabilidade de seus fitoesteróis durante a pasteurização (POUDEL et al., 2019), enquanto maior estabilidade contra a oxidação do óleo vegetal foi obtida por secagem por pulverização das emulsões (VÉLEZ-ERAZO; CONSOLI; HUBINGER, 2020). No entanto, foi constatada maior acessibilidade e estabilidade do licopeno encapsulado por emulsões estabilizadas pela coacervação complexa (ZHAO et al., 2020) desta forma, é importante destacar a importância em pesquisar os fatores envolvidos nas diferentes técnicas de encapsulação para garantir o objetivo de sua aplicação ao final do processo.

\section{Considerações Finais}

Este estudo demonstrou o potencial de óleos essenciais obtidos em diferentes vegetais para aplicação em alimentos devido a presença de compostos bioativos, especialmente os terpenos, que possuem atividade antimicrobiana, anti-inflamatória e repelente, no entanto, devido à instabilidade destes compostos as técnicas de encapsulação são atraentes na preservação da atividade biológica dos mesmos. Dentre as diferentes técnicas existente, a coacervação complexa e técnicas físico-químicas como sistemas emulsionados são bem indicadas para encapsular óleos essenciais devido a sua facilidade no processo e baixas temperaturas utilizadas preservando compostos voláteis, além da possibilidade de utilizar diferentes polímeros como material de parede envolvendo o núcleo contendo o óleo essencial garantindo uma alta eficiência de rendimento e encapsulação. No entanto, a pulverização ou spray dryer é amplamente utilizada sendo também responsável pela preservação de óleos essenciais a partir da escolha correta dos polímeros encapsulantes. A encapsulação é uma tecnologia versátil capaz de garantir maior estabilidade térmica ao óleo essencial sendo possível assim sua aplicação no processamento de alimentos. 


\section{Referências:}

ASBAHANI, A. El et al. Essential oils: From extraction to encapsulation. International Journal of Pharmaceutics, v. 483, n. 1-2, p. 220-243, 2015. DOI: 10.1016/J.IJPHARM.2014.12.069.

BAKKALI, F.; AVERBECK, S.; AVERBECK, D.; IDAOMAR, M. Biological effects of essential oils - A review. Food and Chemical Toxicology, v. 46, n. 2, p. 446-475, 2008. DOI: http://dx.doi.org/10.1016/j.fct.2007.09.106.

BALCÃO, Victor M.; COSTA, C. I.; MATOS, C. M.; MOUTINHO, C. G.; AMORIM, M.; PINTADO, M. E.; GOMES, A. P.; VILA, Marta M.; TEIXEIRA, José A. Nanoencapsulation of bovine lactoferrin for food and biopharmaceutical applications. Food Hydrocolloids, v. 32, n. 2, p. 425-431, 2013. DOI: 10.1016/j.foodhyd.2013.02.004.

BERALDO, C.; DANELUZZI, N. S.; SCANAVACCA, J.; DOYAMA, J. T.; FERNANDES, J. A.; MORITZ, C. M. F.; Eficiência de óleos essenciais de canela e cravo-da-índia como sanitizantes na indústria de alimentos. Pesquisa Agropecuária Tropical, Goiânia, v. 43, p. 436-440, 2013 . DOI: https://doi.org/10.1590/S198340632013000400006.

BEIRÃO-DA-COSTA, S.; DUARTE, C.; BOURBON, A. I.; PINHEIRO, A. C.; JANUÁRIO, M. I. N.; VICENTE, A. A.; BEIRÃO-DA-COSTA, M. L.; DELGADILLO, I.. Inulin potential for encapsulation and controlled delivery of Oregano essential oil. Food Hydrocolloids, v. 33, n. 2, p. 199-206, 2013. DOI: http://dx.doi.org/10.1016/j.foodhyd.2013.03.009.

BELLIK, Y.. Total antioxidant activity and antimicrobial potency of the essential oil and oleoresin of Zingiber officinale Roscoe. Asian Pacific Journal of Tropical Disease, v. 4, p. 40-44, 2014. DOI: http://dx.doi.org/10.1016/S2222-1808(14)60311-X.

BELŠČAK-CVITANOVIĆ, A.; BUŠIĆ, A.; BARIŠIĆ, L.; VRSALJKO, D.; KARLOVIĆ, S.; ŠPOLJARIĆ, I.; VOJVODIĆ, A.; MRŠIĆ, G.; KOMES, D.. Emulsion templated microencapsulation of dandelion (Taraxacum officinale L.) polyphenols and $\beta$-carotene by ionotropic gelation of alginate and pectin. Food Hydrocolloids, v. 57, p. 139-152, 2016. DOI: 10.1016/J.FOODHYD.2016.01.020.

BURT, S.. Essential oils: their antibacterial properties and potential applications in foods - a review. International Journal of Food Microbiology, v. 94, n. 3, p. 223253, 2004. DOI: http://dx.doi.org/10.1016/j.ijfoodmicro.2004.03.022.

CHANG, C. P.; LEUNG, T. K.; LIN, S. M.; HSU, C. C. Release properties on gelatingum arabic microcapsules containing camphor oil with added polystyrene. Colloids Surf B Biointerfaces, v. 50, p. 136-140, 2006. DOI: 10.1016/j.colsurfb.2006.04.008. 
CHEW, S. C.; NYAM, K. L. Microencapsulation of kenaf seed oil by co-extrusion technology. Journal of Food Engineering, v. 175, p. 43-50, 2016. DOI: 10.1016/J.JFOODENG.2015.12.002.

COMERT, F.; DUBIN, P. L. Liquid-liquid and liquid-solid phase separation in proteinpolyelectrolyte systems. Advances Colloid Interface Science, v. 239, p. 213-217, 2017. DOI: https://doi.org/10.1016/j.cis.2016.08.005.

COMUNIAN, T. A.; CHAVES, I. E.; THOMAZINI, M.; MORAES, I. C. F.; FERROFURTADO, R.; DE CASTRO, I. A.; FAVARO-TRINDADE, C. S. Development of functional yogurt containing free and encapsulated echium oil, phytosterol and sinapic acid. Food Chemistry, v. 237, p. 948-956, 2017. DOI: 10.1016/J.FOODCHEM.2017.06.071.

DEANS, S. G.; RITCHIE, G. Antibacterial properties of plant essential oils. International Journal of Food Microbiology, v. 5, p. 165-180, 1987. DOI: http://dx.doi.org/10.1016/0168-1605(87)90034-1.

EBADA, S. S.; LIN, W.; PROKSCH, P.. Bioactive Sesterterpenes and Triterpenes from Marine Sponges: Occurrence and Pharmacological Significance. Marine Drugs, v. 8, p. 313-346, 2010. DOI: 10.3390/md8020313.

EGHBAL, N.; CHOUDHARY, R.. Complex coacervation: Encapsulation and controlled release of active agents in food systems. Lwt, v. 90, p. 254-264, 2018. DOI: 10.1016/j.lwt.2017.12.036.

ERATTE, D.; MCKNIGHT, S.; GENGENBACH, T. R.; DOWLING, K.; BARROW, C. J.; ADHIKARI, B. P. Co-encapsulation and characterisation of omega-3 fatty acids and probiotic bacteria in whey protein isolate-gum Arabic complex coacervates. Journal of Functional Foods, DOI: http://dx.doi.org/10.1016/j.jff.2015.01.037.

FELLOWS, Peter J.; OLIVEIRA, Florencia Cladera; RUBENSAN, Jane Maria; NITZKE, Julio Alberto; THYS, Roberta Cruz Silveira. Tecnologia do processamento de alimentos : princípios e prática : Artmed, 2006.

GARCÍA-SALDAÑA, J. S.; CAMPAS-BAYPOLI, O. N.; LÓPEZ-CERVANTES, J.; SÁNCHEZ-MACHADO, D. I.; CANTÚ-SOTO, E. U.; RODRÍGUEZ-RAMÍREZ, R.. Microencapsulation of sulforaphane from broccoli seed extracts by gelatin/gum arabic and gelatin/pectin complexes. Food Chemistry, v. 201, p. 94-100, 2016. DOI: http://dx.doi.org/10.1016/j.foodchem.2016.01.087.

GHASEMI PIRBALOUTI, A.; SALEHI, S.; CRAKER, L.. Effect of drying methods on qualitative and quantitative properties of essential oil from the aerial parts of coriander. Journal of Applied Research on Medicinal and Aromatic Plants, v. 4, p. 35-40, 2017. DOI: 10.1016/j.jarmap.2016.07.006.

GOUIN, S.. Microencapsulation. Trends in Food Science \& Technology, v. 15, n. $7-$ 8, p. 330-347, 2004. DOI: 10.1016/j.tifs.2003.10.005. 
GUTIERREZ, J.; BARRY-RYAN, C.; BOURKE, P. The antimicrobial efficacy of plant essential oil combinations and interactions with food ingredients. International Journal of Food Microbiology, v. 124, n. 1, p. 91-97, 2008. DOI: http://dx.doi.org/10.1016/j.ijfoodmicro.2008.02.028.

HERNÁNDEZ-NAVA, R.; LÓPEZ-MALO, A.; PALOU, E.; RAMÍREZ-CORONA, Nelly; JIMÉNEZ-MUNGUÍA, María Teresa. Encapsulation of oregano essential oil (Origanum vulgare) by complex coacervation between gelatin and chia mucilage and its properties after spray drying. Food Hydrocolloids, [S. l.], v. 109, p. 106077, 2020. DOI: $10.1016 /$ j.foodhyd.2020.106077.

JHO, Y.; YOO, H. Y.; LIN, Y.; HAN, S.; HWANG, D. S.. Molecular and structural basis of low interfacial energy of complex coacervates in water. Advances Colloid $\begin{array}{lllllll}\text { Interface Science, } & \text { v. 239, } & \text { p. } 61-73, & \text { DOI: }\end{array}$ http://dx.doi.org/10.1016/j.cis.2016.07.003.

LIDERT, Z. Microencapsulation: An Overview of the Technology Landscape. In: ROSEN, M. R. Delivery System Handbook for Personal Care and Cosmetic Products. Norwich, NY: William Andrew Publishing, 2005. p. 181-190. DOI: http://dx.doi.org/10.1016/B978-081551504-3.50013-4.

LIEBGOTT, T.; MIOLLAN, M.; BERCHADSKY, Y.; DRIEU, K.; CULCASI, M.; PIETRI, S.. Complementary cardioprotective effects of flavonoid metabolites and terpenoid constituents of Ginkgo biloba extract (EGb 761) during ischemia and reperfusion. Basic Research in Cardiology, v. 95, n. 5, p. 368-377, 2000. DOI: $10.1007 / \mathrm{s} 003950070035$.

LIU, J.; SHIM, Y. Y.; SHEN, J.; WANG, Y.; REANEY, M. J. T. Whey protein isolate and flaxseed (Linum usitatissimum L.) gum electrostatic coacervates: Turbidity and rheology. Food Hydrocolloids, v. 64, p. 18-27, 2017. DOI: http://dx.doi.org/10.1016/j.foodhyd.2016.10.006.

LV, Y.; YANG, F.; LI, X.; ZHANG, X.; ABBAS, S.. Formation of heat-resistant nanocapsules of jasmine essential oil via gelatin/gum arabic based complex coacervation. Food Hydrocolloids, v. 35, p. 305-314, 2014. DOI: http://dx.doi.org/10.1016/j.foodhyd.2013.06.003.

MAHDAVI, S. A.; JAFARI, S. M.; GHORBANI, M.; ASSADPOOR, E.. Spray-Drying Microencapsulation of Anthocyanins by Natural Biopolymers: A Review. Drying Technology, v. 32, n. 5, p. 509-518, 2014. DOI: 10.1080/07373937.2013.839562.

MAJOLO, C.; NASCIMENTO, V.P.; CHAGAS, E.C.. CHAVES, F.C.M. Atividade antimicrobiana do óleo essencial de rizomas de açafrão (Curcuma longa L.) e gengibre (Zingiber officinale Roscoe) frente a salmonelas entéricas isoladas de frango resfriado. Revista brasileira de plantas medicinais, v. 16, p. 505-512, 2014 . DOI: https://doi.org/10.1590/1983-084X/13_109. 
MARTÍN, M. J.; LARA-VILlOSLADA, F.; RUIZ, M. A.; MORALES, M. E.. Microencapsulation of bacteria: A review of different technologies and their impact on the probiotic effects. Innovative Food Science \& Emerging Technologies, v. 27, p. 15-25, 2015. DOI: http://dx.doi.org/10.1016/j.ifset.2014.09.010.

MARTINS, I. M.; BARREIRO, M. F.; COELHO, M.; RODRIGUES, A. E. Microencapsulation of essential oils with biodegradable polymeric carriers for cosmetic applications. Chemical Engineering Journal, v. 245, p. 191-200, 2014. DOI: 10.1016/J.CEJ.2014.02.024.

MILLEZI, A. F.; CAIXETA, D. S.; ROSSONI, D. F.; CARDOSO, M. G.; PICCOLI, R. H.. Propriedades antimicrobianas in vitro dos óleos essenciais de plantas thymus vulgaris, cymbopogon citratus e laurus nobilis contra cinco importantes patógenos de origem alimentar. Ciência e Tecnologia de Alimentos, Campinas, v. 32, pág. 167-172, 2012. DOI: https://doi.org/10.1590/S0101-20612012005000021.

NAWONG, S.; OONSIVILAI, R.; BOONKERD, N.; TRUELSTRUP-HANSEN, L.. Entrapment in food-grade transglutaminase cross-linked gelatin-maltodextrin microspheres protects Lactobacillus spp. during exposure to simulated gastro-intestinal juices. Food Research International, v. 85, p. 191-199, 2016. DOI: 10.1016/J.FOODRES.2016.04.041.

NOSHIRVANI, N.; GHANBARZADEH, B.; GARDRAT, C.; REZAEI, M. R.; HASHEMI, M.; LE COZ, C.; COMA, V.. Cinnamon and ginger essential oils to improve antifungal, physical and mechanical properties of chitosan-carboxymethyl cellulose films. Food Hydrocolloids, v. 70, p. 36-45, 2017. DOI: 10.1016/J.FOODHYD.2017.03.015.

OMONIJO, F. A.; NI, L.; GONG, J.; WANG, Q.; LAHAYE, L.; YANG, C.. Essential oils as alternatives to antibiotics in swine production. Animal Nutrition, 2017. DOI: 10.1016/J.ANINU.2017.09.001.

ORDÓÑEZ PEREDA, J. A.; MURAD, F.. Tecnologia de alimentos: Artmed, p. 239$247,2005$.

OUEDRHIRI, W.; BALOUIRI, M.; BOUHDID, S.; MOJA, S.; CHAHDI, F. O.; TALEB, M.; GRECHE, H. Mixture design of Origanum compactum, Origanum majorana and Thymus serpyllum essential oils: Optimization of their antibacterial effect. Industrial Crops and Products, v. 89, p. 1-9, 2016. DOI: http://dx.doi.org/10.1016/j.indcrop.2016.04.049.

PARSHIKOV, I. A.; NETRUSOV, A. I.; SUTHERLAND, J. B. Microbial transformation of antimalarial terpenoids. Biotechnology Advances, v. 30, p. 15161523, 2012. DOI: 10.1016/J.BIOTECHADV.2012.03.010.

PENG, C.; ZHAO, S. Q.; ZHANG, J.; HUANG, G. Y.; CHEN, L. Y.; ZHAO, F. Y.. Chemical composition, antimicrobial property and microencapsulation of Mustard (Sinapis alba) seed essential oil by complex coacervation. Food Chemistry, v. 165, p. 
560-568, 2014. DOI: http://dx.doi.org/10.1016/j.foodchem.2014.05.126.

POUDEL, A.; GACHUMI, G.; WASAN, K. M.; BASHI, Z. D.; EL ANEED, A.; BADEA, I.. Development and characterization of liposomal formulations containing phytosterols extracted from canola oil deodorizer distillate along with tocopherols as food additives. Pharmaceutics, v. 11, n. 4, 2019. DOI: 10.3390/pharmaceutics11040185.

ROSSI, Y. E.; CANAVOSO, L.; PALACIOS, S. M.. Molecular response of Musca domestica L. to Mintostachys verticillata essential oil, (4R)(+)-pulegone and menthone. Fitoterapia, v. 83, p. 336-342, 2012. DOI: 10.1016/J.FITOTE.2011.11.019.

SANTURIO, D. F.; COSTA, M. M.; MABONI, G.; CAVALHEIRO, C. P.; SÁ, M. F.; DAL POZZO, M.; ALVES, S. H.; FRIES, L. L. M.. Atividade antimicrobiana de óleos essenciais de condimentos frente a amostras de Escherichia coli isoladas de aves e bovinos. Ciência Rural, Santa Maria, v. 41, p. 1051-1056, 2011. DOI: https://doi.org/10.1590/S0103-84782011005000067.

SINGH, G.; KAPOOR, I. P.; SINGH, P.; DE HELUANI, C. S.; DE LAMPASONA, M. P.; CATALAN, C. A. Chemistry, antioxidant and antimicrobial investigations on essential oil and oleoresins of Zingiber officinale. Food Chemistry Toxicology, v. 46, n. 10, p. 3295-3302, 2008. DOI: 10.1016/j.fct.2008.07.017.

SOBEL, R.; VERSIC, R.; GAONKAR, A. G.. Introduction to Microencapsulation and Controlled Delivery in Foods. In: Microencapsulation in the Food Industry : Elsevier, 2014. p. 3-12. DOI: 10.1016/B978-0-12-404568-2.00001-7.

TOFIÑO-RIVERA, A.; ORTEGA-CUADROS, M.; HERRERA-HINOJOSA, B. K.; FRAGOSO-CASTILLA, P.; PEDRAZA-CLAROS, B. Conservación microbiológica de embutido carnico artesanal con aceites esenciales Eugenia caryophyllata $Y$ Thymus vulgaris. Revista BioAgro, v. 15, p. 30-41, $2017 . \quad$ DOI: https://dx.doi.org/10.18684/bsaa(v15)ediciónespecial2.576.

VASISHT, N.. Selection of Materials for Microencapsulation. In: Microencapsulation in the Food Industry : Elsevier, 2014. p. 173-180. DOI: 10.1016/B978-0-12-4045682.00016-9.

VÉLEZ-ERAZO, E. M.; CONSOLI, L.; HUBINGER, M. Dupas. Spray drying of mono- and double-layer emulsions of PUFA-rich vegetable oil homogenized by ultrasound. Drying Technology, 2020. DOI: 10.1080/07373937.2020.1728305.

ZHAO, C.; WEI, L.; YIN, B.; LIU, F.; LIU J.; LIU, X.; WANG, J.; WANG, Y.. Encapsulation of lycopene within oil-in-water nanoemulsions using lactoferrin: Impact of carrier oils on physicochemical stability and bioaccessibility. International Journal of Biological Macromolecules, v. 153, p. 912-920, 2020. DOI: 10.1016/j.ijbiomac.2020.03.063. 


\title{
CAPÍTULO 39: ESTUDOS PRÉVIOS PARA O ENCAPSULAMENTO DE COMPOSTOS USANDO AÇAÍ, WHEY PROTEIN E CARRAGENA
}

\section{CHAPTER 39: PREVIOUS STUDIES FOR THE ENCAPSULATION OF COMPOUNDS USING AÇAÍ, WHEY PROTEIN AND CARRAGENA}

\author{
Jaqueline de Jesus Silva ${ }^{1}$; Tailane Vieira $\operatorname{Costa}^{2}$; Mirela Luz Santos ${ }^{3}$ Laís Teles da Silva e Silva ${ }^{4}$; \\ Modesto Antônio Chaves ${ }^{5}$
}

\begin{abstract}
Resumo
Diversos materiais podem ser usados como encapsulantes ou coadjuvantes do encapsulamento como é o caso da carragena, cujo objetivo desse trabalho está em verificar o efeito da carragena sobre as propriedades da solução encapsulante. Dessa forma o efeito foi testado quanto a variação do teor de sólidos solúveis, $\mathrm{pH}$ e cor dos tratamentos com 0 h e 24 h em proporções de $0 \%$ a 5\% de carragena na mistura de açaí e whey protein. Também se avaliou a estabilidade da solução utilizando microscópio óptico com uma câmera digital acoplada em uma das lentes. Dimensionou-se o diâmetro médio das bolhas e sua variação com o tempo em função do teor de carragena. O efeito sobre os sólidos solúveis (SS) e o pH do meio, observou-se pequenas alterações que podem ter contribuído ao acaso para aumentar SS e elevar o pH da solução. As coordenadas de cor sofreram efeito do tempo em todas as concentrações de carragena e do teor de carragena apenas com o tempo da análise de $0 \mathrm{~h}$ para luminosidade, em $24 \mathrm{~h}$ para o h ${ }^{\circ}$ e em 0 e 24 $\mathrm{h}$ para cromaticidade. A adição de carragena não apresentou contribuição significativa para manter a estabilidade das partículas.
\end{abstract}

Palavras-Chaves: coadjuvantes, carragena, encapsulamento, material de parede, proteína.

\begin{abstract}
Several materials can be used as encapsulants or adjuvants in the encapsulation, as is the case of carrageenan, whose objective of this work is to verify the effect of carrageenan on the properties of the encapsulating solution. Thus, the effect was tested for variation in the content of soluble solids, $\mathrm{pH}$, and color of the treatments with $0 \mathrm{~h}$ and $24 \mathrm{~h}$ in proportions of $0 \%$ to $5 \%$ of carrageenan in the mixture of açaí and whey protein. The stability of the solution was also evaluated using an optical microscope with a digital camera attached to one of the lenses. The average diameter of the bubbles and their variation with time were dimensioned according to the content of carrageenan. In the effect on soluble solids (SS) and $\mathrm{pH}$ of the medium, small changes were observed that may have contributed at random to increase SS and increase the $\mathrm{pH}$ of the solution. The color coordinates were measured in all carrageenan concentrations and carrageenan content only with the time of analysis of $0 \mathrm{~h}$ for luminosity, in $24 \mathrm{~h}$ for $\mathrm{h}^{\circ}$ and in 0 and 24 $\mathrm{h}$ for chromaticity. The addition of carrageenan did not make a significant contribution to maintaining the stability of the particles.
\end{abstract}

Keywords: adjuvants, carrageenan, encapsulation, wall material, protein.

\section{Introdução}

O processo de encapsulação consiste em transformar uma solução ou emulsão, do estado líquido para o sólido na forma de pó de modo a criar uma capsula, que com um

\footnotetext{
${ }^{1}$ Mestrado em engenharia e ciência de alimentos, UESB, jaqsali@live.com

2 Engenharia de alimentos, UESB, tai_vieira2011@hotmail.com

${ }^{3}$ Engenharia de alimentos, UESB, mirela_luz@ hotmail.com

${ }^{4}$ Mestrado em engenharia e ciência de alimentos, UESB, laiseteles.silva@gmail.com

${ }^{5}$ Doutor, UESB, modestochaves@ hotmail.com
} 
agente encapsulante forma uma capa protetora envolvendo o material de interesse em um núcleo, vários núcleos ou núcleos dispersos como microesferas (JAFARI et al., 2008). Dessa forma esse sistema de cápsula, tem a função de proteger, manter a estabilidade, evitar perdas, oxidação, controlar a liberação do material de interesse e obter produtos com maior solubilidade e melhores características sensoriais e nutricionais, podendo assim ser disponibilizados como ingredientes em outras preparações alimentícias, formando uma barreira física entre o composto encapsulado e o material de parede, que também é alimentício (FAVARO-TRINDADE e PINHO, 2008).

O composto de interesse neste caso está contido no açaí e faz referência a grande quantidade de antocianina e outros flavonoides com propriedades antioxidantes, antiinflamatórias e anticancerígenas e apresenta também elevado valor energético e proteico e como consequência, tem sido considerado um alimento funcional por gerar inúmeros benefícios à saúde (KANG et al., 2012; PORTINHO; ZIMMERMANN; BRUCK, 2012). Esses elementos podem ser degradados ao longo do processo de encapsulação, por isso, se faz necessário um estudo prévio de variáveis que possam indicar se haverá eficiência na encapsulação após a secagem da solução em estudo.

Para garantir a proteção desses elementos, a capa protetora que se forma em seu entorno pode ser constituída de diversos materiais, e os componentes protéicos tem sido amplamente utilizada como encapsulante (SANTANA et al.,2016; KYRIAKOUDI e TSIMIDOU, 2018; CHUYEN et al., 2019). A eficiência das proteínas do soro de leite como agente encapsulante se dá por sua habilidade de interagir com água, pequenos íons e outros polímeros presentes na grande área interfacial, que em geral é termodinamicamente desfavorável, essas proteínas estabilizam as gotas formadas na homogeneização e reduzem suas taxas de coalescência (WALSTRA, 2007; YANG, et al., 2020), diminuindo a tensão superficial tanto quanto os surfactantes, fazendo com que a saturação efetiva da superfície seja atingida em concentrações molares 100 vezes menores do que os surfactantes de baixo peso molecular (JAYASUNDERA et al., 2009; YANG, et. al., 2020). Logo, é possível preservar a estabilidade da emulsão e retardar a coalescência com os peptídeos contidos nas proteínas do soro de leite cujos pesos moleculares são maiores que $2 \mathrm{kDa}$ (SCHRODER et al. 2017).

Outros componentes usados no processo de encapsulação são os coadjuvantes, entre eles estão as carragenas que são grupos de galactanas sulfatadas extraídas de algas vermelhas, muito utilizadas em industrias pela capacidade que elas têm de aumentar a viscosidade de soluções e formar géis firmes (FENNEMA, DAMODARAN e PARK, 2010; BARRETT, 2018). Estudos relatam que a combinações entre carragenas e proteínas 
de várias fontes concomitantemente podem melhorar a retenção e proteção de substâncias voláteis e características das superfícies esféricas das microcápsulas (LAURENTI e GARCIA, 2013).

Presume-se que a encapsulação pode ser melhorada quando se conhece a natureza da dispersão formada antes da secagem, ao se mensurar parâmetros como distribuição e tamanho das partículas (CARMONA, 2011). As gotículas mantêm-se em movimento desordenado graças à repulsão entre suas cargas elétricas, então se recomenda a diminuição máxima do tamanho das gotículas e uniformidade entre elas para manter sua estabilidade até o momento da secagem (FRANZOL, REZENDE, 2015; Yang et. al., 2020).

É de suma importância que se estude previamente o tamanho da cápsula, pois há uma influência diretamente na liberação controlada do material do núcleo, podendo apresentar liberação em velocidade constante quando as partículas são menores, ou rápida liberação quando as partículas são maiores (SANTOS, 2014). Um dos fatores que também podem ser estudados previamente é o tipo e a composição do material de parede pois este interfere no tamanho e distribuição das partículas e em propriedades importantes de produtos encapsulados, como teor de água, solubilidade, higroscopicidade, entre outras (TONON, GROSSO e HUBINGER, 2011).

Pelos motivos supracitados, a seleção do material de parede é uma etapa crítica dos estudos prévios, pois ela tem influência direta nas propriedades da solução antes da secagem, na retenção dos voláteis durante o processo e na vida de prateleira do pó encapsulado depois da secagem (JAFARI et al., 2008). Os critérios para a seleção do material de parede estão principalmente baseados em suas propriedades físico-químicas e devem ser de baixa viscosidade, higroscopicidade, insolúveis e não reativos com o núcleo, de baixo custo e fácil acesso (TONON, GROSSO e HUBINGER, 2011; CHUYEN et al., 2019).

Vê-se que é grande a demanda de característica em um material ideal, por isso, desde muito tempo já se relatava que combinações de diferentes matérias podem resultar em um produto final de melhor qualidade e cada combinação precisa ser estudada caso a caso (FAVARO-TRINDADE e PINHO, 2008). Diante disso, o objetivo desse trabalho foi fazer um estudo prévio de possíveis interferentes do processo de encapsulamento, levando em conta o uma combinação de diferentes materiais de parede e o tempo entre o preparo da solução até um limite máximo de repouso até a hora da secagem. Avaliando para isso, as variações de sólidos solúveis (SS), pH, cor, e tamanho das partículas formadas. 


\section{Material e Métodos}

\section{Local do experimento}

O experimento foi realizado no Centro de Desenvolvimento e Difusão de Tecnologias (CEDETEC) da Universidade Estadual do Sudoeste da Bahia - Campus Itapetinga.

\section{Matéria prima}

A polpa de açaí congelada foi obtida no município de Itororó-BA, numa unidade onde se cultiva e manipula açaí orgânico, ao chegar no local do experimento foi mantida em freezer horizontal à $-18^{\circ} \mathrm{C} \pm 2^{\circ} \mathrm{C}$, por cerca de 30 dias. Antes do uso a polpa foi descongelada e filtrada por pressão positiva em filtro de tecido voil, com a finalidade de separar partículas em suspensão.

\section{Avaliação do uso da carragena}

Foi preparado uma mistura de açaí, proteína e diferentes proporções de carragena para verificar a contribuição da carragena na melhoria das propriedades da solução. As proporções estudas foram 2\%; 3\%; 4\%; 5\% obtendo-se cinco tratamentos T1, T2, T3, T4 e T5, sendo T1 a testemunha, ou seja, tratamento sem adição de carragena. Em todos os tratamentos foram mantidos o percentual fixo de material de parede de $25 \%$.

\section{Formação da solução}

A formação da solução foi realizada por meio da homogeneização de cada tratamento em um dispersor, do tipo rotor-estator de alto desempenho (modelo T18 digital ULTRA-TURRAX) na velocidade de $14000 \mathrm{rpm}$ por 10 minutos.

Os tratamentos foram submetidos a análise de sólidos solúveis, $\mathrm{pH}$, cor e tamanho e distribuição de partículas, conforme metodologias descritas nos itens seguintes.

\section{Sólidos Solúveis (SS), pH e cor da emulsão}

As medições de SS, pH e cor foram realizadas no tempo de 0 horas (h), que corresponde a análise feita logo após o término da homogeneização e após $24 \mathrm{~h}$.

A determinação do teor de SS totais dos tratamentos foi realizada por meio da refratometria em Refratômetro de bancada (DSA E-Scan), com escala graduada em ${ }^{\circ}$ Brix a $20^{\circ} \mathrm{C}$.

A medida do $\mathrm{pH}$ foi realizada em $\mathrm{pH}$-metro digital (modelo Akso) por leitura direta imergindo um eletrodo nas amostras (AOAC, 2016). 


\section{Determinação instrumental dos parâmetros de cor}

A cor foi determinada pelo sistema Hunter Lab em colorímetro Colorquest XE (HunterLab, Sunset Hills Reston, VA, EUA), iluminante D65 e observador $10^{\circ}$, com reflexão inclusa calibrado a cada batelada de medições, conforme solicitado pelo software do próprio instrumento. Foram obtidos os parâmetros de cor Lab, referentes a luminosidade, cromaticidade e o ângulo do tom a partir dos parâmetros a e b, em que foram calculadas as coordenadas cilíndricas $\mathrm{C}^{*} \mathrm{e} \mathrm{h}^{\circ}$ de acordo com as equações 1 e 2 . $C^{*}=\left(a^{2}+b^{2}\right)^{1 / 2}$

$$
h^{\circ}=\arctan \left(\frac{b}{a}\right)
$$

Onde $\mathrm{C}^{*}$ define o croma ou a cromaticidade $\mathrm{h}^{\circ}$ representa o ângulo de tom.

\section{Tamanho e distribuição das partículas}

O tamanho e a distribuição das partículas dos tratamentos foram observados em microscópio óptico, tomando-se uma alíquota em lâmina coberta por uma lamínula e medido, tomando como referência uma lâmina graduada em milímetros (mm).

Com o auxílio de uma câmera digital (MEKEY SCMOS mini USB2.0 SCMOS00350KPA) acoplada ao microscópio óptico binocular foram obtidas as imagens em 5 tempos, imediatamente após a homogeneização (0h) e após 1, 2, 3 e 24 horas, de forma a verificar a estabilidade das partículas a partir da variação dos diâmetros e sua distribuição. Com auxílio do software ImageView versão x64,3.7.10121.20171030 os dados foram coletados numa ampliação microscópica de 40X, calibrados e convertidos de pixels para $\mu \mathrm{m}$ com uma lâmina de calibração de 2,0 $\mathrm{mm}$ gerando imagens de $914,28 \mu \mathrm{m}$ por $685,71 \mu \mathrm{m}$.

\section{Análises estatísticas}

Foi realizado um delineamento inteiramente casualizado em um esquema fatorial $2 \times 5$ com 3 repetições em que testou-se a significância da interação entre o teor de carragena em 5 níveis $(0 \%, 2 \%, 3 \%, 4 \%$ e 5\%) e tempo em dois níveis (0h e 24h) por meio de análise de variância (ANOVA) e obteve-se os modelos de regressão utilizando o programa estatístico Statystical Analysis System (SAS)® Studenty.

Os diâmetros médios das bolhas foram coletados e avaliados segundo várias equações de regressão envolvendo curvas com pico sendo que a equação de Hubbert foi a que apresentou o melhor resultado. Uso-se para isso o software OriginLab $2017 \mathrm{com}$ o qual também se obtiveram gráficos de dispersões. 


\section{Resultados e Discussão}

\section{Efeito da adição de carragena}

\section{Determinação de SS}

A interação entre o teor de carragena e o tempo da análise foi não significativo $(\mathrm{P}>0,05)$ para descrever a variação no teor de SS. Em vista disso, se fez necessário avaliar a ação dos dois fatores sob SS separadamente. Para o parâmetro teor de carragena o ajuste foi muito baixo $\left(\mathrm{R}^{2}\right.$ de 0,46$)$ e o tempo da análise foi não significativo $(\mathrm{P}>0,05)$ para indicar alterações no teor de SS. Portanto, não foi possível ajustar o modelo polinomial que explicasse as possíveis variações apresentadas, podendo ser uma variação devida ao acaso.

O teor de SS variou numericamente entre 28 e $30^{\circ}$ Brix, o qual está de acordo com o valor apresentado no trabalho de encapsulamento de alimentos realizado por Jafari, Ghalenoei, e Dehnad (2017) relatando que índice semelhante a este pode gerar um material em pó com rendimento em torno de $25 \%$, densidade mínima de $0,747 \mathrm{~g} / \mathrm{mL}$, alta solubilidade e aponta que o aumento da concentração de sólidos pode ser prejudicial ao aprisionamento de compostos. Muzaffar, et al., (2016) encontraram melhores resultados de rendimento do pó com o teor do material encapsulante acima de $20 \%$. Sabe-se que as carragenas são espessantes de alto pesso molecular que aumentam o a viscosidade da solução sem alterar o seu teor de sólidos (KULKARNI e SHAW, 2016). Ou seja, neste intervalo de concentração de sólidos solúveis na mistura é possível melhorar o rendimento, a solubilidade em água e densidade, mas é possível que a alta viscosidade dificulte a fluidez na solução de alimentação e os trabalhos da área buscam sempre por materiais de parede de baixa viscosidade (KYRIAKOUDI e TSIMIDOU, 2018; CHUYEN et. al., 2019).

\section{Determinação do pH}

A interação entre o teor de carragena com o tempo da análise mostrou-se não significativa $(\mathrm{P}>0,05)$ para verificar a variação de $\mathrm{pH}$.

Ambos os fatores separadamente mostraram-se significativos $(\mathrm{P}<0,05)$ para alterar $\mathrm{pH}$ porém teor de carragena apresentou $\mathrm{R}^{2}$ de 0,22 e tempo para análise apresentou $\mathrm{R}^{2}$ de 0,25 , ou seja, não foi possível ajustar uma equação para descrever a variação de $\mathrm{pH}$ em função do teor de carragena e do tempo.

A faixa de $\mathrm{pH}$ encontrada de 5,55 a 5,80 é um valor distante do ponto isoelétrico (PI) das proteínas do soro e pode dificultar os desdobramentos. As proteínas do soro de leite, quando estão afastadas do seu ponto isoelétrico $(\mathrm{PI}=\mathrm{pH} 4,6)$ apresentam uma 
estrutura tetramerizada, (FENNEMA, DAMODARAN, e PARK, 2010), já as carragenas se estabilizam em pH 6 e são pouco afetadas pelas alterações de pH (KULKARNI e SHAW, 2016). Porém de acordo com Stone e Nickerson, (2012) a interação carragenaproteína forma um complexo estabilizado por forças eletrostáticas, de Van der Waals, interações hidrofóbicas, ligações de hidrogênio e de dissulfeto com dissacarídeos, consequentemente se torna menos disponível ao desdobramento e aprisionamento de compostos durante a encapsulação. Ou seja, não as condições de $\mathrm{pH}$ presente, não foi afetada por meio da presença ou concentração de carragena, também não puderam tornar as proteínas do soro de leite mais disponíveis ao encapsulamento de compostos.

\section{Determinação instrumental da cor}

Os dados obtidos de luminosidade estão apresentados na Tabela 1.

Tabela 1 - Luminosidade em função do teor de carragena na solução encapsulante com o tempo da análise.

\begin{tabular}{ccc}
\hline & \multicolumn{2}{c}{ Luminosidade } \\
\cline { 2 - 3 } Teor de carragena (\%) & $0 \mathrm{~h}$ & $24 \mathrm{~h}$ \\
\cline { 2 - 3 } 0 & 40,62 & 26,61 \\
2 & 76,81 & 35,73 \\
3 & 58,65 & 26,00 \\
4 & 40,97 & 27,01 \\
5 & 39,93 & 27,01 \\
\hline
\end{tabular}

Fonte: própria

De acordo com o teste $\mathrm{F}$ da análise de variância com $\mathrm{P}<0,05$ o fator tempo da análise e teor de carragena e sua interação foi significativa. A luminosidade poderia ter sido alterada simultaneamente pelo tempo da análise nas concentrações de carragena e pelo teor de carragena apenas com o tempo da análise de $0 \mathrm{~h}$, porém o fator de ajuste da equação foi de 0,15 mostrando que as alterações observadas podem ter sido devido ao acaso.

No sistema CIE L*a*b* a luminosidade representa o quanto da cor branca ou claridade e preta ou escuridão está presente na amostra, e é representada por valores que variam de 100 a 0 respectivamente (MCKEEN, 2014; BERTALMÍO, 2020). Dessa forma, os dados obtidos indicam que a luminosidade apresenta um ponto de máximo indicando claridade e depois diminui indicando escurecimento com o tempo da análise e com o teor de carragena, o que pode ser explicado pela oxidação de espécies reativas contidas nas amostras (ARAÚJO, 2006), nesse caso, é possível que seja pela oxidação das antocianinas presentes no açaí que também são responsáveis pela sua coloração original. 
A avaliação do tempo da análise de $24 \mathrm{~h}$ em função do teor de carragena mostrou que não houve alterações na luminosidade, mas no tempo de $0 \mathrm{~h}$ a luminosidade variou em função do teor de carragena. Essa variação foi representada por um modelo quadrático cujo $\mathrm{R}^{2}$ foi de 0,96 (Eq. 3) e pela Figura 1 onde mostra o efeito da concentração de carragena no tempo $0 \mathrm{~h}$ sobre a luminosidade

$L=40,041+2,580$ Car $-0,772 \operatorname{Car}^{2}$

Sendo $L$ o luminosidade da cor e Car o teor de carragena em percentual.

Figura 1 - Efeito do teor de carragena no tempo 0h sobre a luminosidade na solução encapsulante.

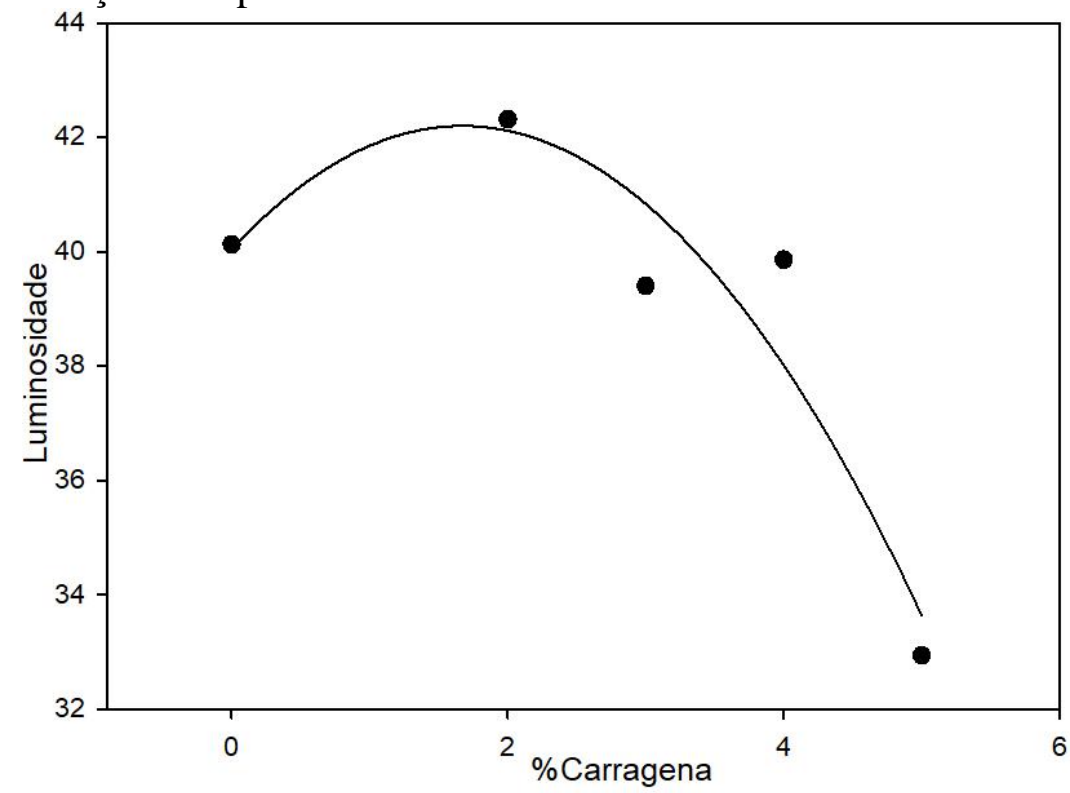

Fonte: própria.

De acordo com a imagem acima, vê-se que a luminosidade apresenta um ponto máximo e diminui com a sucessiva adição de carragena na solução. Ou seja, assim, como mostram os coeficientes da equação gerada, o aumento gradativo no teor de carragena escurece as amostras. É necessário salientar que quando há mudanças na luminosidade haverá também mudança na saturação da cor, pois no sistema CIE L*a*b*a cor é um conjunto de coordenadas que se posiciona em um espaço tridimensional, cujo eixo da luminosidade é vertical e quando houver mudança em uma das coordenadas forçará a movimentação das demais (BERTALMÍO, 2020). Como pode ser observado na avaliação da cromaticidade e ângulo $\mathrm{h}^{\circ}$.

A cromaticidade indica o quão intensa é a cor presente na amostra e é uma composição das coordenadas a* e b*, as quais ocupam os eixos horizontais no espaço e não apresentam limites numéricos específicos, mas suas posições indicam a cor da amostra, quando o valor de $\mathrm{a}^{*}$ for positivo é vermelho, se for negativo é verde, e o valor 
de b* positivo é amarelo e negativo é azul (McKeen, 2014). Desse modo, os dados obtidos da cromaticidade estão apresentados na Tabela 2.

Tabela 2 - Cromaticidade em função do teor de carragena na solução encapsulante em diferentes tempos da análise.

\begin{tabular}{ccc}
\hline & \multicolumn{2}{c}{ Cromaticidade } \\
\cline { 2 - 3 } Teor de carragena (\%) & $0 \mathrm{~h}$ & $24 \mathrm{~h}$ \\
\cline { 2 - 3 } 0 & 09,94 & 07,62 \\
2 & 09,82 & 07,82 \\
3 & 08,98 & 06,52 \\
4 & 09,33 & 07,50 \\
5 & 06,78 & 08,27 \\
\hline
\end{tabular}

Fonte: própria

$\mathrm{O}$ teste $\mathrm{F}$ da análise de variância foi significativo com $\mathrm{P}<0,05$ para o fator tempo da análise e teor de carragena e a interação entre eles. A cromaticidade foi alterada simultaneamente pelo tempo da análise com as concentrações de carragena e pelo teor de carragena com o tempo da análise.

Com os dados da tabela acima, vê-se que os dados obtidos indicam que a cromaticidade diminui com o tempo da análise com as concentrações de carragena e tanto o tempo de $0 \mathrm{~h}$ quanto de $24 \mathrm{~h}$ houveram diferenças significativas com $\mathrm{P}<0,05$ em relação as concentrações de carragena, ou seja, a presença da carragena acarreta mudança na intensidade da cor da amostra com o tempo. Tal fato foi representado por duas equações de grau 3 com respectivos $\mathrm{R}^{2}$ de 0,90 e $\mathrm{R}^{2}$ de 0,87 (Eq. 4 e 5) e os gráficos da Figura 2 que mostram o efeito da concentração de carragena no tempo da análise de 0 h e $24 \mathrm{~h}$ sobre a cromaticidade.

$C_{0 h}=9,967-1,0229 \operatorname{Car}+0,6166 \operatorname{Car}^{2}-0,1069 \operatorname{Car}^{3}$

$C_{24 h}=7,6797+0,9856 \mathrm{Car}-0,7055 \mathrm{Car}^{2}+0,1071 \mathrm{Car}^{3}$

Sendo $C_{0 h}$ a cromaticidade da cor no tempo da análise de $0 \mathrm{~h}, C_{24 h}$ a cromaticidade no tempo de $24 \mathrm{~h}$ e Car o teor de carragena em percentual. 
Figura 2 - Efeito do teor de carragena com o tempo da análise sobre a cromaticidade na solução encapsulante.

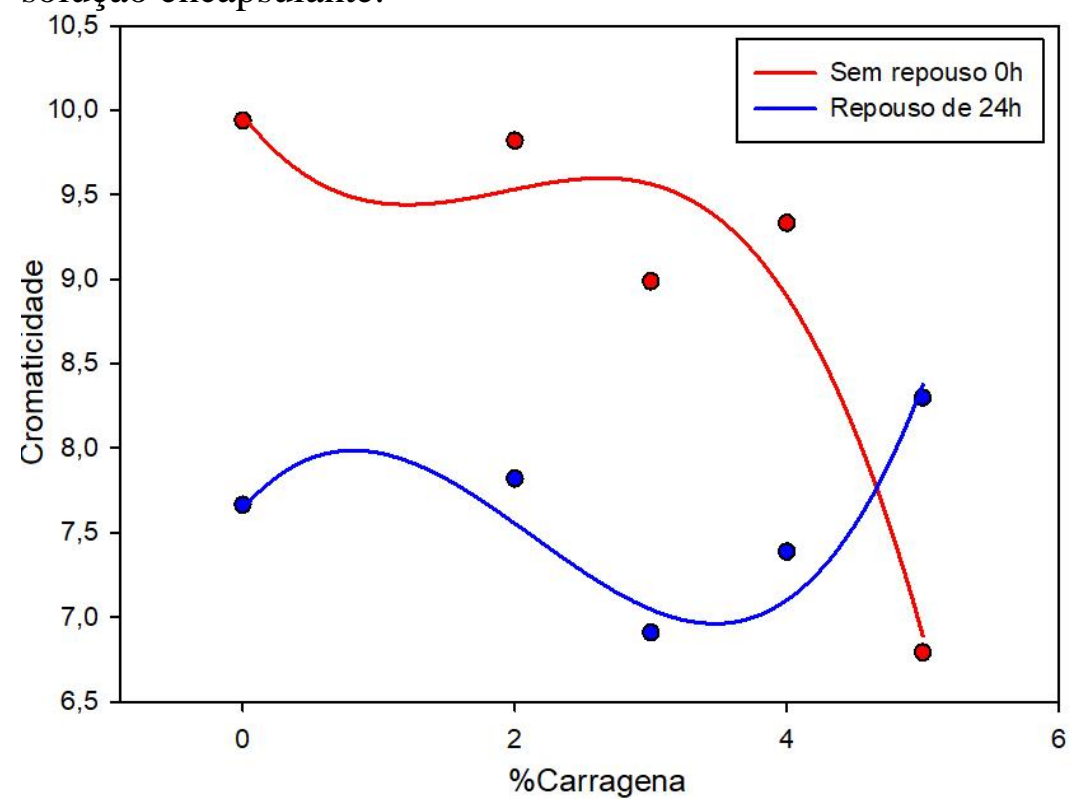

Fonte: própria

De acordo com a figura acima, a cromaticidade inicial é menor no tempo da análise de 24 h e que na concentração máxima de carragena a cromaticidade é menor no tempo $0 \mathrm{~h}$ e maior em $24 \mathrm{~h}$. Ou seja, aumento gradativo no teor de carragena reduz a cromaticidade imediatamente após a homogeneização tempo da análise de $0 \mathrm{~h}$.

Em relação ao ângulo $h^{\circ}$ tem-se que sua definição faz referência tonalidade ou a cor propriamente dita e também é obtida de uma composição das coordenadas a* e b* (BERTALMÍO, 2020). Os dados obtidos do h $^{\circ}$ estão apresentados na Tabela 3.

Tabela $3-\mathrm{h}^{\circ}$ da cor em função do teor de carragena na solução encapsulante com o tempo da análise.

Teor de carragena $(\%)$

0

2

3

4

5

\begin{tabular}{cc}
\multicolumn{3}{c}{$\mathrm{h}^{\circ}$} \\
\hline $0 \mathrm{~h}$ & $24 \mathrm{~h}$ \\
\hline 0,61 & 0,58 \\
0,62 & 0,55 \\
0,68 & 0,59 \\
0,76 & 0,58 \\
0,65 & 0,73
\end{tabular}

Fonte: própria

De acordo com o teste $\mathrm{F}$ da análise de variância com $\mathrm{P}<0,05$ os dois fatores em estudo tempo da análise e teor de carragena e a interação entre eles foram significativos, ou seja, os tratamentos foram alterados simultaneamente pelo tempo da análise nas concentrações de carragena e pelo teor de carragena com o tempo da análise de $24 \mathrm{~h}$. Nesse tempo o $\mathrm{h}^{\circ}$ diferiu significativamente pelo teste $\mathrm{F}$ da anova com $\mathrm{P}<0,05$ em relação ao tempo da análise em cada uma das concentrações de carragena e que tanto no tempo da 
análise de $0 \mathrm{~h}$ quanto em $24 \mathrm{~h}$ houveram diferenças significativas em relação as concentrações de carragena.

Tais diferenças foram representadas por equação de grau 3 com $R^{2}$ de 0,93 e $R^{2}$ de 0,81 (Eq. 6 e 7) e em gráficos na Figura 3 que mostram o efeito da concentração de carragena no tempo da análise de $0 \mathrm{~h}$ e $24 \mathrm{~h}$ sobre o $\mathrm{h}^{\circ}$.

$H_{0 h}=0,6124-0,1585 \operatorname{Car}+0,107 \operatorname{Car}^{2}-0,0148 \operatorname{Car}^{3}$

$H_{24 h}=0,5765+0,0271 \mathrm{Car}-0,0286 \mathrm{Car}^{2}+0,0058 \mathrm{Car}^{3}$

Sendo $H_{0 h} \mathrm{O} \mathrm{h}^{\circ}$ no tempo da análise de $0 \mathrm{~h}, H_{24 h} \mathrm{o} \mathrm{h}^{\circ}$ tempo da análise de $24 \mathrm{~h}$ e Car o teor de carragena em percentual.

Figura 3 - Efeito do teor de carragena tempo da análise sobre $o h^{\circ}$ na solução encapsulante.

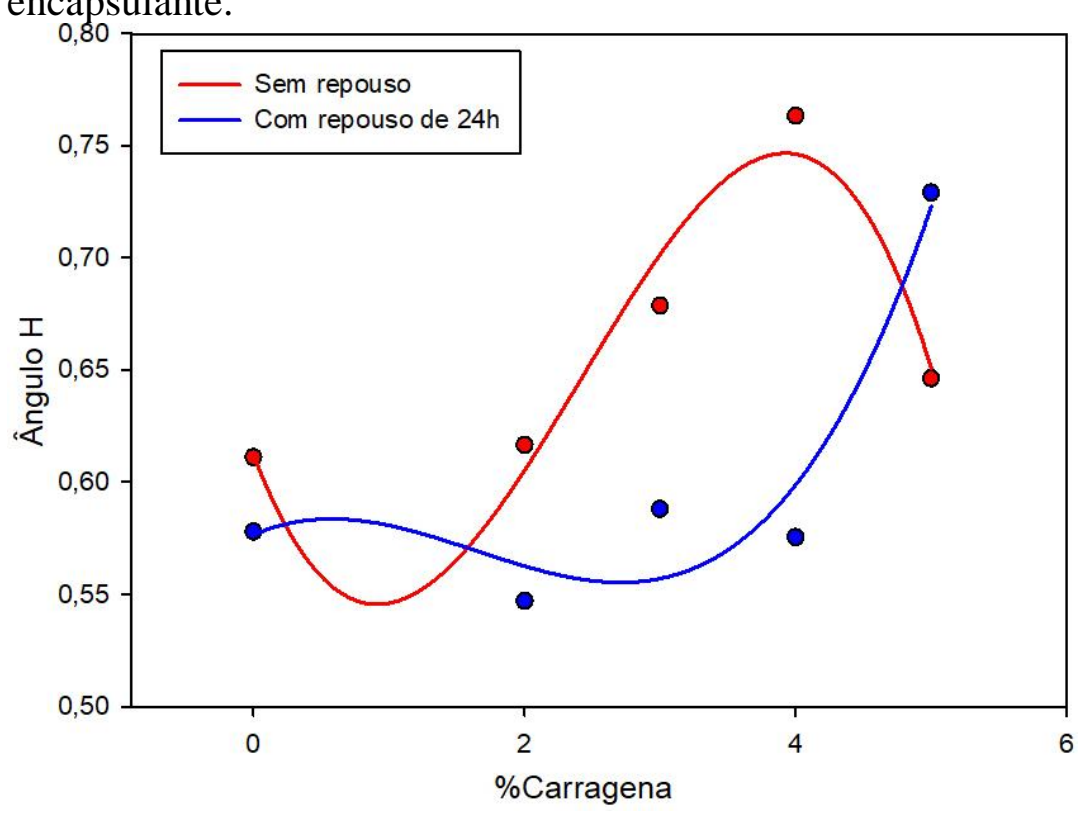

Fonte: própria.

Vê-se que $\mathrm{o} \mathrm{h}^{\circ}$ no tempo da análise de $0 \mathrm{~h}$ apresenta tendência ao aumento com aumento da concentração de carragena. Após 24 h o aumento da concentração leva ao aumento no valor do ângulo $\mathrm{H}$.

Obteve-se valores de luminosidade mínimos que variaram em torno de 40 e 26 no tempo da análise $0 \mathrm{~h}$ e $24 \mathrm{~h}$ respectivamente, a cromaticidade mínima e máxima variou entre 6,5 e 9,9 e os valores do ângulo ${ }^{\circ}$ variaram entre 0,61 a 0,76 demarcando a cor dos tratamentos em 0 h e 24 h na região avermelhada com luminosidade e saturação baixas (BERTALMÍO, 2020). É possível que essa coloração muito clara tenha forte influência dos materiais encapsulantes, que costumam ser brancos (TONON, BRABET e HUBINGER, 2009) e da incorporação de ar, que facilita o espalhamento da luz e pode ter alterado os dados de cor obtidos (ZÍLIO, 2009; CARNEIRO, 2011). 


\section{Tamanho e distribuição das partículas}

Observou-se, após a homogeneização da emulsão, a presença de bolhas em todos os tratamentos que podem ser observados nas imagens da Figura 4.

Figura 4 - Bolhas presentes após a homogeneização nos tratamentos com e sem adição de carragena em diferentes tempos de captura das imagens com ampliação de 40X.

$\mathrm{Oh}$

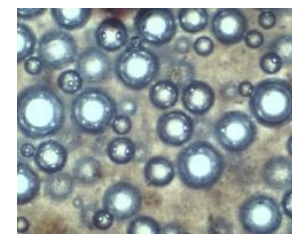

$1 \mathrm{~h}$
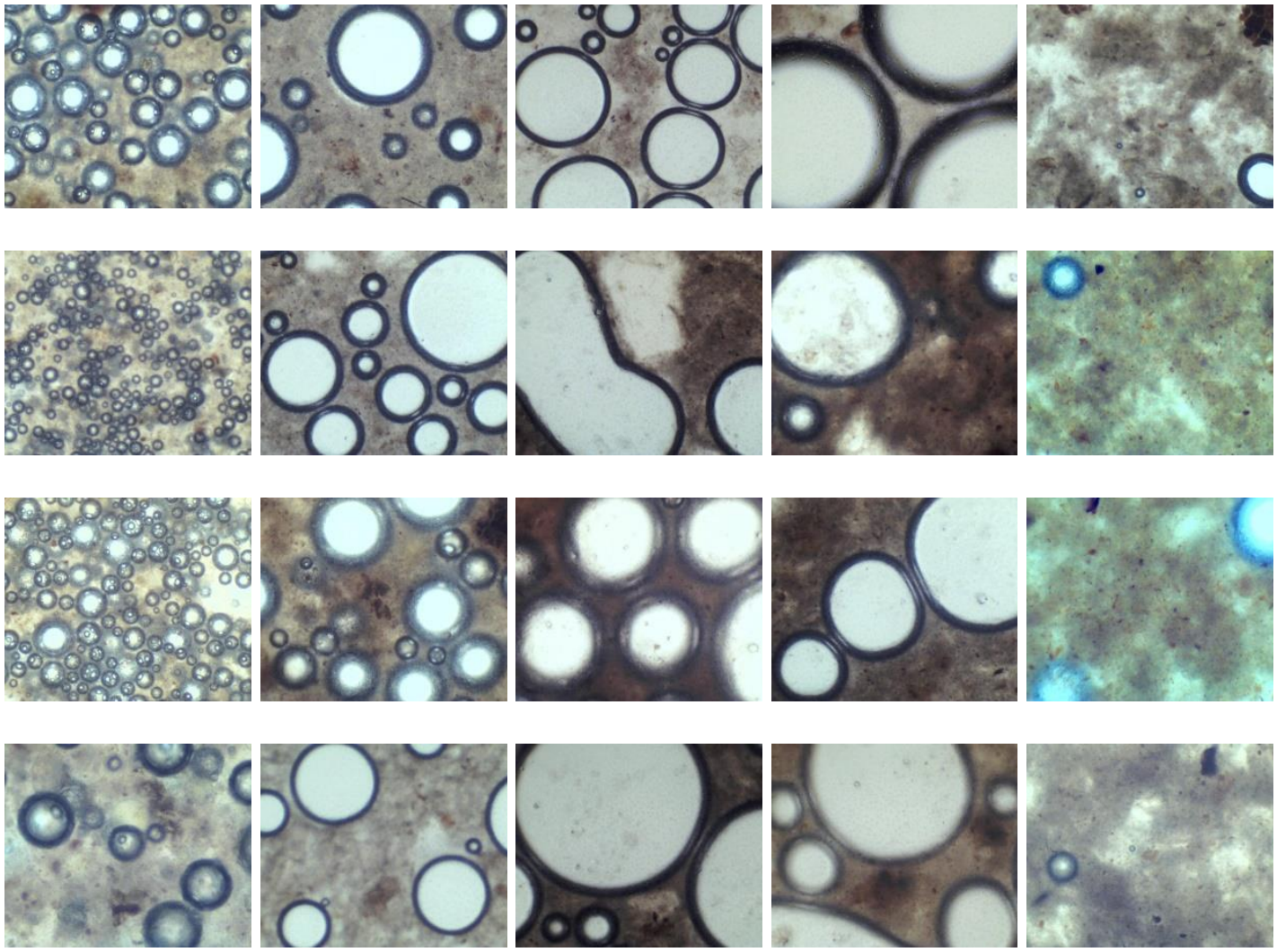

T5
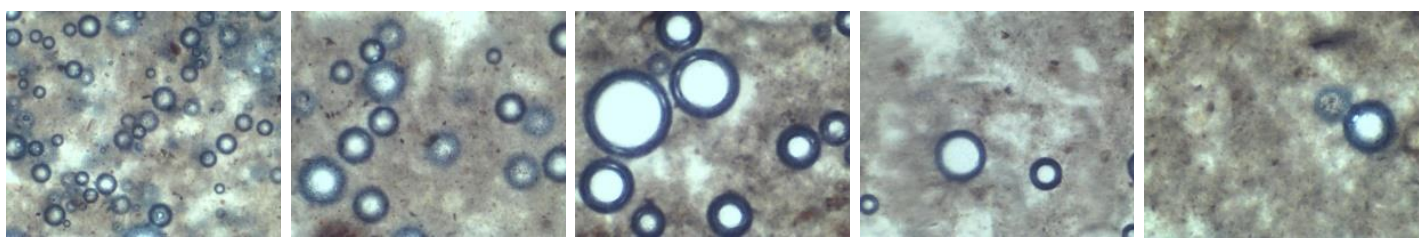

Legenda: $\mathrm{T} 1=0 \%$ carragena, $\mathrm{T} 2=1 \%$ de carragena, $\mathrm{T} 3=3 \%$ de carragena, $\mathrm{T} 4=4 \%$ de carragena e $\mathrm{T} 5=5 \%$ de carragena.

Fonte: própria.

Observou-se em todos os tratamentos que imediatamente após a homogeneização houveram inúmeras bolhas e, à medida que o tempo passou elas cresceram e movimentaram-se. Dessa maneira com 1 h, o número de bolhas menores diminui e começou a surgir gotas maiores, e em menor quantidade.

Esse comportamento continuou até $3 \mathrm{~h}$ e pareceu ter finalizado após $24 \mathrm{~h}$ permanecendo apenas algumas gotas de diâmetros menores. Os tratamentos T4 (4\%) e T5 (5\%) apresentaram menor quantidade de bolhas desde o primeiro tempo, e não apresentaram crescimento elevado em comparação com os outros. 
Vê-se que as bolhas dos tratamentos que continham carragena em concentrações crescentes não apresentaram estabilidade, como pode ser observado pelos seus desaparecimentos em todos os tratamentos. Isso se deu, possivelmente, por houver formação de interações complexas entre as proteínas do soro de leite e a carragena que diminuíram a capacidade das proteínas de formarem filmes e a película que envolve e estabiliza as bolhas como indicado por Stone e Nickerson, (2012). Além disso, Zheng, et al., (2018) mostraram que a associação da carragena com proteína produzem géis proteicos mais firmes, por tornar as proteínas do soro de leite mais resistente ao desdobramento, o que pode ser prejudicial ao uso da solução em questão como encapsulante.

A movimentação e modificações observadas nas gotas podem ter ocorrido por três outros motivos complementares que ocorrem simultaneamente nas soluções, o movimento Browniano, a maturação de Ostwald (FRANZOL e REZENDE, 2015) e a coalescência, que são comuns em sistemas termodinamicamente instáveis devido às repulsões eletrostáticas entre os componentes das dispersões (FENNEMA, DAMODARAN e PARK, 2010) e caracterizam-se pelo rompimento do fino filme que recobre gotas próximas forçando a união entre elas e pela dissolução do material de dentro no material de fora fazendo com que a pressão interna aumente e cause o crescimento de algumas partículas em função do desaparecimento de outras (FRANZOL e REZENDE, 2015). Além disso YANG, et. al., 2020 dizem que interfaces fracas e móveis podem ser obtidas na calha de Langmuir o que explica espalhamento do material presente na interface e consequentemente o desaparecimentos das partículas.

As bolhas apresentaram valores máximos em torno de $645,09 \mu \mathrm{m} ; 711,38 \mu \mathrm{m}$; $642,93 \mu \mathrm{m} ; 638,55 \mu \mathrm{m}$; e $232,78 \mu \mathrm{m}$ e mínimos $69,75 \mu \mathrm{m} ; 48,65 \mu \mathrm{m} ; 62,87 \mu \mathrm{m} ; 111,96 \mu \mathrm{m}$;

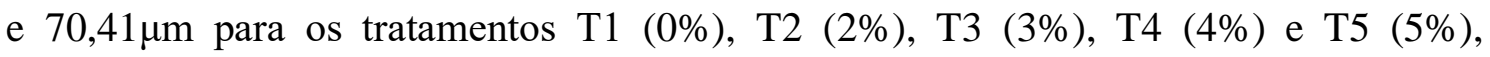
respectivamente. De acordo com YANG, et. al., 2020 as partículas de proteínas do soro de leite isalada podem apresentar valores de escala nanoméricas, porém, eles afirmam que a medida que as proteínas se encontram em sistemas agregados que esses valores podem aumentar como foi observado neste trabalho, onde houve uma solução agregando diversos compostos. Observou-se que os diâmetros variaram em relação ao tempo de captura das imagens com o teor de carragena. No ajuste de curvas por regressão, a equação de Hubbert foi a que apresentou os melhores resultados.

A Tabela 4 mostra as 5 equações obtidas da relação entre o tempo e o teor de carragena na solução encapsulante. As curvas referentes são mostradas na Figura 5. 
Tabela 1 - Equações de Hubbert obtidas, por análise de regressão, relacionando o tempo de captura das imagens, com o diâmetro médio das gotas nos tratamentos

\begin{tabular}{|c|c|c|c|c|}
\hline Tratamento & $\begin{array}{c}\text { Relação } \\
\text { Percentual de } \\
\text { carragena }\end{array}$ & Equação & $\mathrm{R}^{2}$ & \\
\hline $\mathrm{T} 1$ & 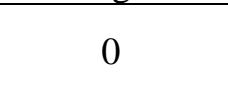 & $D m=192+\frac{4308 e^{x}}{1+e^{-x}}$ & 0,93 & (8) \\
\hline $\mathrm{T} 2$ & 2 & $D m=\frac{2500 e^{\left(\frac{x-2,3}{0,81}\right)}}{1+e^{-\left(\frac{x-2,3}{1,81}\right)}}$ & 0,98 & (9) \\
\hline $\mathrm{T} 3$ & 3 & $\begin{array}{l}\text { Dm } \\
=-113+\frac{2524 e^{\left(\frac{x-2,8}{1,1}\right)}}{1+e^{-\left(\frac{x-2,8}{1,1}\right)}}\end{array}$ & 0,98 & (10) \\
\hline $\mathrm{T} 4$ & 4 & $D m=101+\frac{2348 e^{\left(\frac{x-2}{0,4}\right)}}{1+e^{-\left(\frac{x-2}{0,4}\right)}}$ & 0,97 & (11) \\
\hline T5 & 5 & $D m=\frac{1068 e^{\left(\frac{x-2,4}{0,95}\right)}}{1+e^{-\left(\frac{x-2,4}{0,95}\right)}}$ & 0,96 & (12) \\
\hline
\end{tabular}

$\mathrm{X}$ : Tempo (h).

Dm: Diâmetro médio

Fonte: própria

Figura 5 - Relação entre o diâmetro e o tempo da captura de microcápsulas de açaí com diferentes relações proteína do leite/carragena

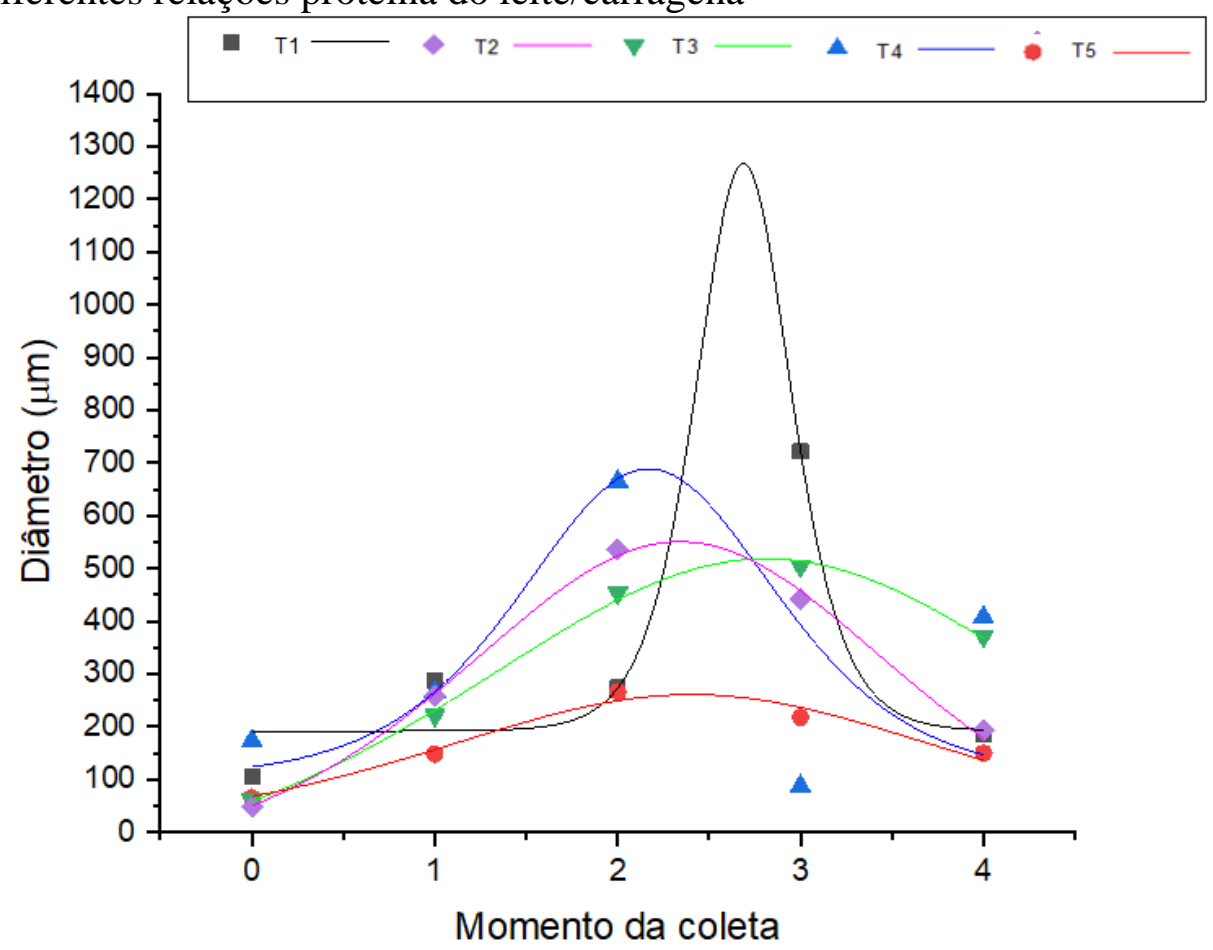

Tempo (h)

Legenda: $\mathrm{T} 1=0 \%$ carragena, $\mathrm{T} 2=1 \%$ de carragena, $\mathrm{T} 3=3 \%$ de carragena, $\mathrm{T} 4=4 \%$ de carragena e $\mathrm{T} 5=5 \%$ de carragena. Fonte: própria 
À medida que o teor de carragena aumentou, houve uma tendência a diminuição no tamanho das gotas, com exceção do tratamento com $4 \%$ de carragena. O tratamento 5\%, apresenta um comportamento mais estável, com diâmetros menores.

Com o passar do tempo, o diâmetro das cápsulas aumentou até atingir um pico e depois começou a diminuir. Embora não tenhamos encontrado na literatura referências para comparar este efeito, ele possivelmente se deu pela incorporação inicial de ar que, ao sair do produto, acabou forçando a união de capsulas que, a posteriori, se separaram novamente, quiçá por ação de forças eletrostáticas. Também se observou que o aumento na quantidade de carragena retardou o tempo do pico e diminuiu o seu valor.

Pelais (2007), observou que o diâmetro médio das gotículas de óleo da polpa de açaí aumentou devido ao alto teor proteico e lipídico. Segundo esta autora o açaí forma uma emulsão estável após o despolpamento com pouca repulsão eletrostática entre gotículas em razão da presença de fosfolipídios e proteínas que são adsorvidos na interface e dão a estabilidade necessária à essa emulsão. Logo a presença de proteína mistura com a polpa de açaí pode ter função encapsulante e não ter função estabilizante e a adição de diferentes teores de carragena não contribui para manter a estabilidade das microcápsulas o que foi verificado por meio das variações observadas nos diâmetros em função dos tempos de captura das imagens. Logo, o tratamento testemunha (que não contém carragena) apresentou-se como o mais favorável para ser aplicado ao encapsulamento da polpa de açaí.

\section{Conclusões}

Diante das verificações observadas neste trabalho, é possível concluir que muitas são as variáveis que precisam ser estudadas previamente quando se tem a intenção de encapsular compostos, principalmente quando envolve materiais de parede com natureza molecular distinta como é o caso das proteínas do soro de leite e da carragena e observouse também que o transcorrer do tempo é um fator limitante entre o preparo das amostras e a hora da secagem, pois favorece que reações indesejáveis aconteçam e alterem a solução estudada. Nesse sentido, as alterações observadas foram principalmente na cor e no tamanho das partículas, pois o teor de sólidos e o $\mathrm{pH}$ não foram afetados com as condições estudadas. Sendo que o teor de sólidos na concentração estudada apresentou um bom indicador para o encapsulamento bem-sucedido, já o pH se mostrou como um ponto crítico desse estudo, pois as proteínas podem reagir de maneira contrária ao que se espera no encapsulamento, quando elas estão distantes do seu ponto isoelétrico. Em relação ao estudo da cor pode-se observar alterações visualmente indesejáveis, principalmente quanto ao escurecimento das amostras. Outra consideração a ser feita 
nesse estudo é que os tamanhos das gostas não apresentaram estabilidade, sendo alterados tanto pelo tempo quanto pela presença da carragena na solução, podendo ser resultado da sua ineficiência para estabilizar as gostas, pelo intervalo muito espaçado de tempo ou mesmo pela concentração usada. Por isso, propõe-se que essas variáveis sejam rearranjadas em novos trabalhos.

\section{Referências}

AOAC - ASSOCIATION OF OFFICIAL ANALYTICAL CHEMISTS. Official methods of Analysis. 20. ed. Gaithersburg: Maryland, 2016.

ARAÚJO, J. M. A. Química de Alimentos: Teoria e prática. $3^{\text {a }}$ ed. Organizado por UFV. Viçosa-MG. 2006.

BARRETT, B. Viral Upper Respiratory Infection. Integrative Medicine: Fourth Edition (Fourth Edition). Elsevier Inc. 2018.

BERTALMÍO, M. Colour representation and colour gamuts. Vision Models for High Dynamic Range and Wide Colour Gamut Imaging, 131-155, 2020.

CARMONA, P. A. O. Secagem por atomização e microencapsulação de óleo de laranja: estudo das propriedades da emulsão e do tipo de material de parede sobre as características do pó, Dissertação de Mestrado apresentada à Faculdade de Engenharia de Alimentos da Universidade Estadual de Campinas para obtenção do Título de Mestre em Engenharia de Alimentos., p. 154. 2011.

CARNEIRO, H. C. F. Microencapsulação de óleo de linhaça por spray drying: influência da utilização de diferentes combinações de materiais de parede. Dissertação de mestrado em engenharia de Alimentos. Faculdade de Engenharia de Alimentos. Campinas: Universidade Estadual de Campinas. 2011.

CHUYEN, H. V., ROACH, P. D., GOLDING, J. B., PARKS, S. E., e NGUYEN, M. H. Encapsulation of carotenoid-rich oil from Gac peel: Optimisation of the encapsulating process using a spray drier and the storage stability of encapsulated powder. Powder Technology, 344, 373-379, 2019.

FAVARO-TRINDADE, C.S.; PINHO, S.C.; ROCHA, G.A. Microencapsulação de ingredientes alimentícios. Brazilian Journal of Food Technology, Campinas, v.11, p.103-112, 2008.

FENNEMA, O. R., DAMODARAN, S. E PARK, K. L. Química de Alimentos de Fennema. $4^{\mathrm{a}}$ ed. Organizado por artmed. Porto Alegre - RS. 2010.

FRANZOL, A; REZENDE, M. C. Estabilidade de emulsões: um estudo de caso envolvendo emulsionantes aniônico, catiônico e não-iônico. Polímeros v.25, São Carlos - SP. 2015.

GHARSALLAOUI, A.; ROUDAUT, G.; CHAMBIN, O.; VOILLEY, A.; SAUREL, R. Applications of secagem por spray in microencapsulation of food ingredients: An overview. Food Research International, v.40, n.9, p.1107-1121, 2007. 
JAFARI, S. M., GHALENOEI, M. G. DEHNAD, D. Influência da secagem por atomização no índice de solubilidade em água, densidade aparente e teor de antocianinas do suco de romã em pó, Dryer Techlogy, v. 311, p. 59-65. 2017.

JAFARI, S. M.; ASSADPOOR, E.; HE, Y.; BHANDARI, B. Encapsulation efficiency of food flavors and oils during spray drying. Drying Technology, v.26, n.7, p.816-835, 2008 .

JAYASUNDERA, M.; ADHIKARI, B.; ALDRED, P.; GHANDI, A. Surface modification of spray dried food and emulsion powders with surface-active proteins: A review. Journal of Food Engineering, v.93, p.266-277, 2009.

KANG, J., THAKALI, K. M., XIE, C., KONDO, M., TONG, Y. OU, B., JENSEN, G., MEDINA, M. B., SCHAUSS, A.G. WU, X. Bioactivities of açaí (Euterpe precatoria Mart.) fruit pulp, superior antioxidant and anti-inflammatory properties to Euterpe oleracea Mart., Food Chemistry, v. 133, n. 3, p. 671-677. 2012.

KULKARNI, V. S., e SHAW, C. Use of Polymers and Thickeners in Semisolid and Liquid Formulations. Essential Chemistry for Formulators of Semisolid and Liquid Dosages, 43-69, 2016.

KYRIAKOUDI, A., e TSIMIDOU, M. Z.. Properties of encapsulated saffron extracts in maltodextrin using the Büchi B-90 nano spray-dryer. Food Chemistry, 266 (April), 458$465,2018$.

LAURENTI, E. e GARCIA, S. Eficiência de materiais encapsulantes naturais e comerciais na liberação controlada de probiótico encapsulado Efficiency of natural and commercial encapsulating materials, Brazilian Journal of Food Technolog J. Food Technol, Campinas, v. 16, n. 2, p. 107-115. 2013.

MCKEEN, L. W. Introduction to the Physical, Mechanical, and Thermal Properties of Plastics and Elastomers. In The Effect of Long Term Thermal Exposure on Plastics and Elastomers (pp. 43-71), 2014.

MUZAFFAR, K., WANI, S. A., DINKARRAO, B. V., KUMAR, P. Determination of production efficiency, color, glass transition, and sticky point temperature of spray- dried pomegranate juice powder, Cogent Food \& Agriculture, v. 15, n. 1, p. 2-7. 2016.

PELAIS, C. A. N., Estudo dos fatores que influenciam na estabilidade da emulsão do açaí. Dissertação de Mestrado apresentada ao Programa de Pós-graduação em Ciência e Tecnologia de Alimentos da Universidade Federal do Pará, para obtenção do grau de Mestre em Ciência e Tecnologia de Alimentos. Belém-PA, 2007.

PORTINHO, J.A; Zimmermann, L. M; Bruck, M. R. Efeitos Benéficos do Açaí. International Journal of Nutrology, v.5, n.1, p. 15-20, jan./abr. 2012.

SANTANA, A. A. et al. CANO-HIGUITA, D. M; OLIVEIRA, R. A; TELIS, V. R. N., Influence of different combinations of wall materials on the microencapsulation of jussara pulp (Euterpe edulis) by spray drying”, Food Chemistry, v.212, p. 1-9. 2016.

SANTOS, F. G. Preparação de micro/nanopartículas de poliuretano Biodegradável carreadoras de óleo de açaí e A - tocoferol. Dissertação para a obtenção do título de mestre em engenharia e tecnologia de materiais. Porto Alegre, 2014. 
SCHRODER, A; BERTON-CARABIN, C; VENEMA; P. CORNACCHIA, L. Interfacial properties of whey protein and whey protein hydrolysates. Food Hydrocolloids v.73 129$140,2017$.

STONE, A. K. E NICKERSON, M. T. Formation and functionality of whey protein isolate e (kappa-, iota-, and lambda-type) carrageenan electrostatic complexes, Food hydrocolloids, n. v. 27(2), p. 271-277. 2012.

TONON, R. V; GROSSO, C.R.F; HUBINGER, M. D. Influence of emulsion composition and inlet air temperature on the microencapsulation of flaxseed oil by spray drying. Faculty of Food Engineering, University of Campinas, P.O. Box 6121, 13083-862, Campinas, SP, Brazil. 2011.

WALSTRA, P. The role of proteins in stabilization of emulsions. In KAUSHIK, V.; ROOS, Y.H.O. Limonene encapsulation in freeze-drying of gum Arabic-sucrose- gelatin systems. Journal of Food Engineering, v.40, p.1381-1391, 2007.

YANG, J., THIELEN, I., BERTON-CARABIN, C. C., VAN DER LINDEN, E., e SAGIS, L. M. C. Nonlinear interfacial rheology and atomic force microscopy of air-water interfaces stabilized by whey protein beads and their constituents. Food Hydrocolloids, 101(May), 105-466, 2020.

ZHENG, H. BEAMER, S.K. MATAK, K. E. JACZYNSKI, J. Effect of $\kappa$-carrageenan on gelation and gel characteristics of Antarctic krill (Euphausia superba) protein isolated with isoelectric solubilization/precipita-tion, Food Chemistry. 2018.

ZÍLIO, S. C. Óptica Moderna, IFSC-USP, p. 300. 2009. 


\title{
CAPÍTULO 40: MICROENCAPSULAÇÃO DOS EXTRATOS DE ERVA MATE (Ilex paraguariensis) EM DUAS MATRIZES E SUAS ESTABILIDADES DURANTE A DIGESTÃO IN VITRO
}

\author{
CHAPTER 40: MICROENCAPSULATION OF MATE EXTRACTS (Ilex \\ paraguariensis) IN TWO MATRICES AND THEIR STABILITIES DURING \\ IN VITRO DIGESTION
}

Vanesa Gesser Correa ${ }^{1}$, Bruna Kaori Tabada ${ }^{2}$, Kamila de Cássia Spack ${ }^{3}$, Rúbia Carvalho Gomes Corrêa ${ }^{4}$, Rosane Marina Peralta ${ }^{5}$

\begin{abstract}
Resumo
A erva mate (Ilex paraguariensis) é uma árvore nativa da América do Sul e suas folhas são utilizadas no preparo de infusões ricas em compostos fenólicos antioxidantes, principalmente ácido cafeico e ácidos clorogênicos. Estudos prévios tem mostrado uma redução da atividade antioxidante após a digestão gastrointestinal in vitro. O objetivo deste trabalho foi avaliar uma provável proteção dos bioativos dos extratos da erva mate pelo processo de microencapsulação. Microcápsulas dos extratos de erva mate foram elaboradas utilizando maltodextrina e alginato de sódio. A estabilidade ao processo de digestão gastrointestinal in vitro dos extratos livre e microencapsulados foi avaliada utilizando-se como parâmetros o teor em compostos fenólicos totais e a atividade antioxidante pelo método FRAP. Os resultados obtidos sugerem que as duas microencapsulações mostraram uma discreta tendência de proteção dos bioativos antioxidantes dos extratos quando avaliados pelo método dos fenólicos totais e pelo método FRAP.
\end{abstract}

Palavras-Chave: atividade antioxidante, digestão in vitro, erva mate, estabilidade, microencapsulação

\begin{abstract}
Yerba mate (Ilex paraguariensis) is a tree native of South America and its leaves are used in the preparation of infusions rich in antioxidant phenolic compounds, mainly caffeic acid and chlorogenic acids. Previous studies have shown a reduction in antioxidant activity after in vitro gastrointestinal digestion. The objective of this work was to evaluate a probable protection of bioactive extracts of yerba mate by the microencapsulation process. Yerba mate extract microcapsules were carried out using maltodextrin and sodium alginate. The stability to the in vitro gastrointestinal digestion process of free and microencapsulated extracts was evaluated using the content of total phenolic compounds and the antioxidant activity by the FRAP method as parameters. The results obtained suggest that the two microencapsulations showed a discrete tendency to protect the bioactive of the extracts when evaluated by total phenolic contents and by the FRAP method.
\end{abstract}

Keywords: antioxidant activity, in vitro digestion, mate herb, stability, microencapsulation.

\footnotetext{
${ }^{1}$ Pós-graduação em Ciência de Alimentos (PPC), Universidade Estadual de Maringá, :vanesagesser@gmail.com

${ }^{2}$ Engenharia de alimentos, Universidade Estadual de Maringá, bruna.kaori3@ gmail.com

${ }^{3}$ Pós-graduação em Ciência de Alimentos (PPC), Universidade Estadual de Maringá, kamilaspacki@outlook.com

${ }^{4}$ Instituto Cesumar de Ciência, Tecnologia e Inovação, UniCesumar. rubia_engalim@ @otmail.com

${ }^{5}$ PPC e PBQ, Universidade Estadual de Maringá, rmperalta@uem.br
} 
CORREA, V. G; TABADA, B. K; SPACK, K. C; CORRÊA, R. C. G; PERALTA, R. M.

\section{Introdução}

Ilex paraguariensis A. St. Hill (Aquifoliaceae), é uma planta nativa popular entre os habitantes do Paraguai, Uruguai e regiões da Argentina e Brasil da qual é obtida a erva mate. Com o uso de folhas e caules da árvore podem ser preparadas bebidas estimulantes com propriedades medicinais como o chimarrão (folhas verdes secas, preparado com água quente), tererê (folhas verdes secas, preparado com água fria) e chá mate (folhas tostadas, preparado com água quente) (BRACESCO et al., 2011; LIMA et al., 2014a) (Figuras 1 e 2).

Figura 1. Mate verde (esquerda) e mate tostado (direita) de Ilex paraguariensis
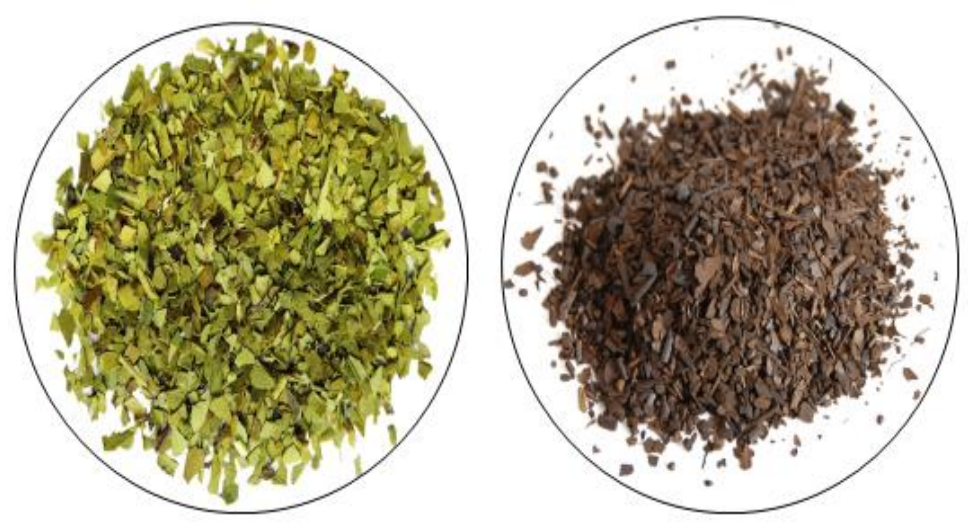

Figura 2. Principais bebidas à base de erva mate (Ilex paraguariensis)

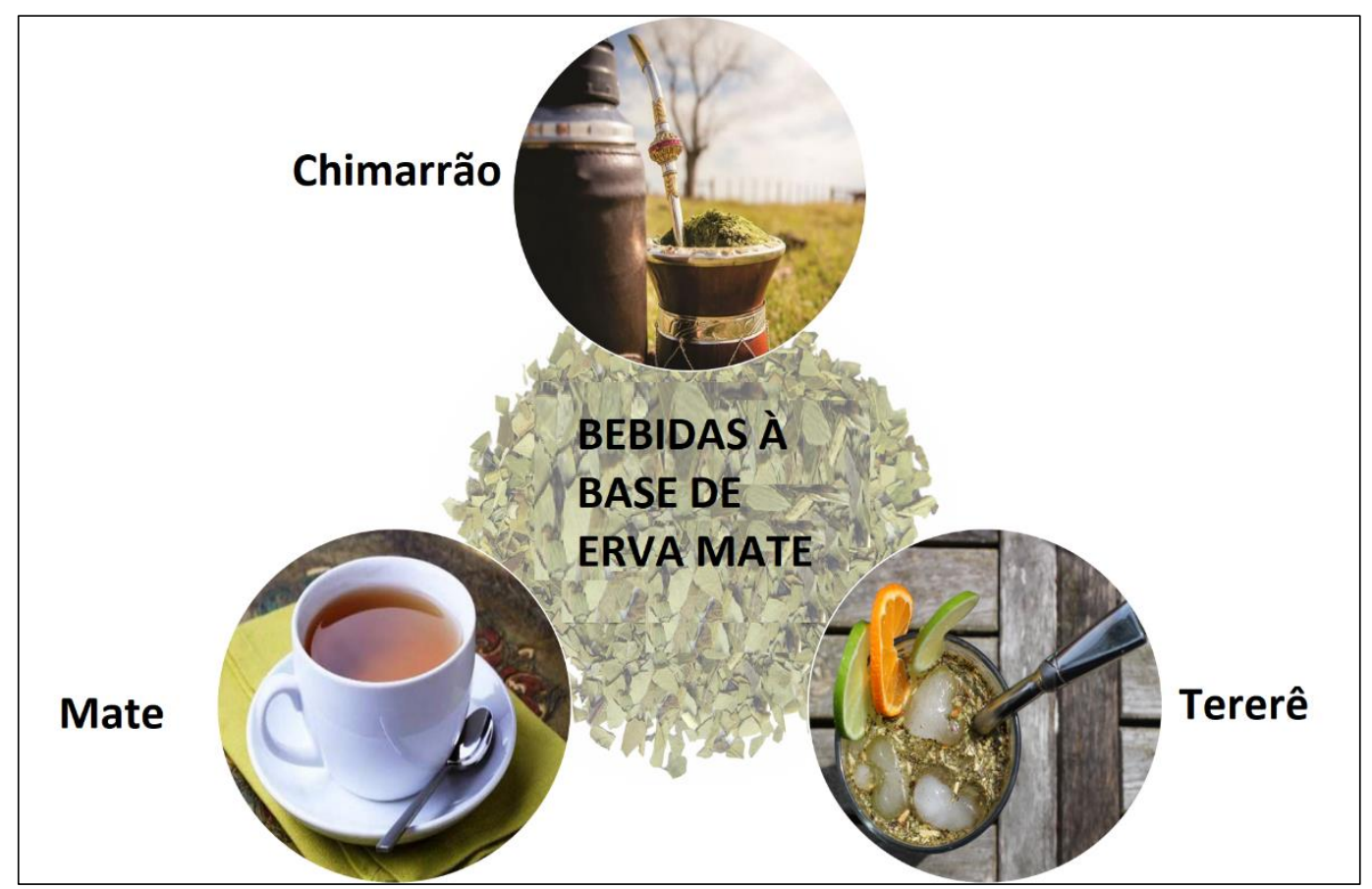

Fonte: CORREA et al., 2019 (modificado) 
O mate tem um papel social muito importante e o ato de oferecê-lo e compartilhá-lo tem conotações semelhantes às cerimônia do chá para algumas culturas orientais. O consumo per capta de erva mate chega a ser de 8-10 kg/hab/ano no Uruguai, 6,5 kg/hab/ano na Argentina e 3-5 kg/hab/ano no Sul do Brasil, estimando que nesses países o consumo de folhas secas da planta seja de 12 a 23 g/hab/dia (CORREA et al., 2019; CARDOZO JR; MORAND, 2016).

Além dos países da América do Sul, o consumo da planta tem alcançado interesse mundial. Outros países como Estados Unidos, Alemanha e Síria utilizam a Ilex paraguariensis A. St. Hil. para a produção de chás e bebidas energéticas. Mais recentemente o consumo tem se expandido para a Espanha, Itália, Austrália, França, Japão, Coreia e Rússia (CARDOZO JR; MORAND, 2016).

O consumo de produtos derivados da erva mate tem sido relacionado a benefícios à saúde como o tratamento da obesidade, melhora no perfil lipídico e na circulação sanguínea, (LIMA et al., 2014a; LIMA et al., 2014b; KIM et al., 2015; HECK; DE MEJÍA, 2007; SOUZA et al., 2015). Efeitos citotóxicos e atividade antiproliferativa de células cancerígenas, atividade antifúngica, anti-bacteriana, atividade anti-inflamatória e efeitos hepatoprotetores, neuroprotetores e antidepressivo tem também sido associados às bebidas à base da erva mate (DE MEJÍA et al., 2010; BURRIS et al., 2011).

Um paralelo interessante pode ser traçado entre Ilex paraguariensis (erva-mate) e Camellia sinensis (chá verde) (ASKARIPOUR, 2020). Ambos têm sido usados tradicionalmente para a preparação de bebidas estimulantes em dois continentes diferentes, Ásia e América do Sul. O chá verde ganhou, desde há muito, uma distribuição e aceitação quase universais, enquanto esse processo está no início para a erva mate. No entanto, os efeitos benéficos das bebidas contra vários distúrbios de saúde não são devidos aos mesmos bioativos. No chá verde, os bioativos pertencem à família das catequinas (epigalocatequina-3-galato (EGCG), epigalocatequina (EGC) e epicatequina-3-galato (ECG) são consideradas as moléculas ativas mais importantes (SERAFINI et al., 2011), enquanto para a erva mate, a família dos ácidos clorogênicos (ácido 3-O-cafeoilquínico, ácido 4-O-cafeoilquínico, ácido 5$O$-cafeoilquínico e o ácido 3,5-O-dicafeoilquínico) provavelmente são responsáveis por uma significativa parte das ações benéficas das bebidas (BRACESCO et al., 2011; SOUZA et al., 2015; CORREA et al., 2017; SILVEIRA et al., 2016; LIMA et al., 2014). Outros compostos presentes na erva mate são o ácido gálico, ácido cafeico, ácido siríngico, ácido ferúlico, ácido p-coumárico e rutina (CORREA et al., 2017; SILVEIRA et al., 2016; MURAKAMI et al., 2013). 
O reconhecimento das propriedades funcionais da erva mate despertou a atenção dos consumidores e vários produtos alimentícios tais como chocolates, barras de cereais, sorvetes, entre outros tem sido enriquecidos com seus extratos (Figura 3).

Figura 3. Produtos da área alimentícia enriquecidos com extratos de erva mate

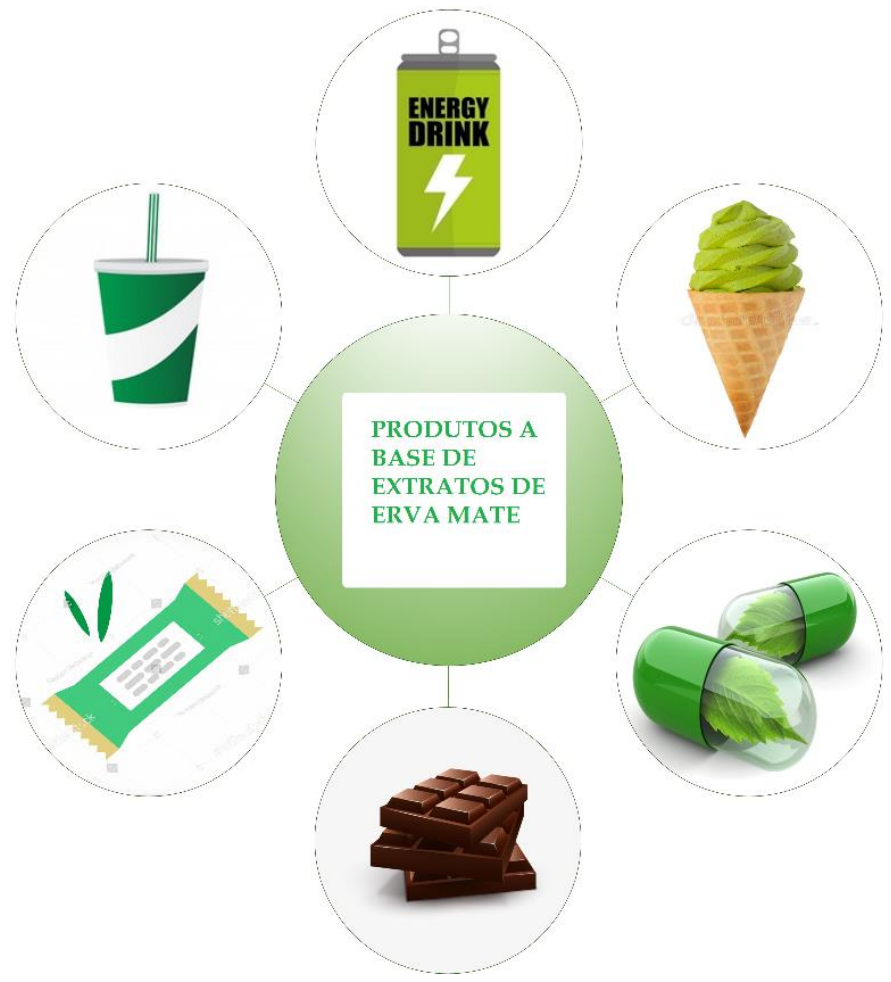

Fonte: CORREA et al., 2019 (modificado)

Estudos que mimetizam o processo de digestão têm demonstrado que os compostos bioativos da erva mate sofrem transformações durante a passagem pelas etapas do trato gastrointestinal, resultando em moléculas diferentes daquelas que são observadas no alimento ingerido (BOAVENTURA et al., 2015). As transformações ocorridas no trato gastrointestinal são decorrentes principalmente de condições fisiológicas como o pH e temperatura, ação das enzimas digestivas, tempo da digestão e pelo metabolismo da microbiota intestinal (CORREABETANZO et al., 2014; KOEHNLEIN et al., 2016). Cerca de um terço dos ácidos clorogênicos ingeridos são absorvidos a partir do intestino delgado, com uma possível contribuição do estômago; o restante atinge o intestino grosso e sofre alterações pela microbiota resultando em derivados $O$-metilados, sulfatados e glucorados, bem como em diidro metabolitos como ácido diidrocafeico (STALMACH et al., 2009; CORREA-BETANZO et al., 2014). 
Há nos dias atuais, uma crescente preocupação com a eficácia dos bioativos e muitos estudos buscam avaliar as perdas das propriedades funcionais dos alimentos durante os processos de extração, processamento, armazenamento e consumo (HENNING et al., 2014; ISOLABELLA et al., 2010; MACIAS-CORTES et al., 2020). Dentro deste contexto, a microencapsulação, um processo onde um material formador de parede é utilizado para recobrir os bioativos visando protege-los de condições adversas, vem sendo cada vez mais estudado e aplicado na área de alimentos (KUANG; OLIVEIRA; CREAN, 2010; VOLUC et al., 2019). Esta tecnologia pode ser aplicada em materiais sólidos, líquidos ou gasosos (AUGUSTIN \& HEMAR, 2008). Uma grande variedade de materiais de revestimento pode ser utilizada nas formulações. Dentre elas, citamos duas, a maltodextrose, um carboidrato nutritivo que na forma uma película protegendo o material volátil e mostra retenção na faixa de 65 a $80 \%$ do material e tem efeito antioxidante (ASCHERI et al., 2003), e o alginato de sódio, um polissacarídeo linear solúvel em água, extraído de diferentes tipos algas (ETCHEPARE et al., 2015). O alginato gelifica rapidamente na presença de íons cálcio sem alterações drásticas de temperatura, $\mathrm{pH}$ e pressão osmótica, conservando a atividade das moléculas e a viabilidade dos microrganismos.

Em um recente estudo realizado por nosso grupo foi observado que parte significativa dos compostos antioxidantes dos extratos da erva mate são perdidos durante a digestão gastrointestinal (CORREA et al. 2017). As maiores perdas foram dos ácidos 3,5-O-dicafeoilquínico e ácido 5-O-cafeoilquínico. Estas reduções causaram uma perda significativa da atividade antioxidante dos extratos. Considerando este fato, o objetivo deste trabalho foi avaliar uma provável ação protetora da microencapsulação nos bioativos antioxidantes dos extratos da erva mate submetidos ao processo de digestão gastrointestinal in vitro.

\section{Material e Métodos}

\section{Obtenção do extrato de erva mate para a microencapsulação}

O extrato de erva mate foi produzido a partir da erva adquirida no comércio de Maringá, PR. Para a extração dos compostos, $85 \mathrm{~g}$ da erva mate foram adicionados a 1,5 L de água destilada a $85^{\circ} \mathrm{C}$, permanecendo sob agitação por 5 minutos. Após o período, o material foi filtrado à vácuo, liofilizado e mantido a $-20^{\circ} \mathrm{C}$ até as análises.

\section{Quantificação de compostos fenólicos totais}

Os compostos fenólicos totais foram analisados conforme SINGLETON \& ROSSI (1965). Uma alíquota de cada amostra foi diluída convenientemente em um volume final de $2 \mathrm{~mL}$ com água 
destilada. Em seguida, adicionou-se 0,1 $\mathrm{mL}$ do reagente fenol Folin Ciocalteu e 0,3 $\mathrm{mL}$ de carbonato de sódio 1,9 M. As misturas permaneceram em repouso por 1 hora no escuro. As absorbâncias das amostras foram determinadas em espectrofotômetro no comprimento de onda $725 \mathrm{~nm}$ contra o branco. Os resultados foram expressos em equivalentes de ácido gálico (EAG).

\section{Determinação da atividade antioxidante pelo ensaio do poder redutor do íon ferro (FRAP)}

A atividade antioxidante foi avaliada pelo ensaio FRAP conforme descrito previamente (PULIDO, BRAVO, SAURA-CALIXTO, 2000). Resumidamente, $900 \mu \mathrm{L}$ de reagente FRAP foi adicionado a $90 \mu \mathrm{L}$ de água destilada e $30 \mu \mathrm{L}$ dos extratos (livres ou microencapsulados), do padrão TROLOX ou do branco (água). Após 30 min a $37^{\circ} \mathrm{C}$, as absorbâncias das amostras foram determinadas em espectrofotômetro a $595 \mathrm{~nm}$ contra o branco. Os resultados foram expressos em $\mu \mathrm{M}$ equivalente de TROLOX/mg de extrato.

\section{Processo de microencapsulação em maltodextrina e alginato de cálcio}

Para a microencapsulação, o extrato de erva mate foi ressuspenso em água e o material encapsulante (maltodextrina DE10 ou alginato de sódio em água) foram misturados na proporção de 1:1 (massa/massa) e deixados sob agitação por $30 \mathrm{~min}$. À mistura extrato-alginato de sódio adicionou-se gota a gota solução de cloreto de cálcio 0,2 M. A mistura foi mantida sob agitação por mais $30 \mathrm{~min}$. As misturas foram liofilizadas e mantidas à $-20^{\circ} \mathrm{C}$ até uso.

\section{Rendimento da microencapsulação}

O rendimento do produto (\%) foi calculado para cada experimento de microencapsulação utilizando a equação:

$$
\text { Rendimento }(\%)=\frac{\text { conteúdo em fenólicos totais do material encapsulado }}{\left(\frac{1}{2}\right) \text { conteúdo em fenólicos do extrato livre }} \times 100
$$

\section{Preparação das soluções de saliva artificial e dos fluídos gástrico e intestinal.}

As soluções de saliva artificial e dos fluídos gástrico e intestinal necessárias para a digestão gastrointestinal in vitro foram preparadas conforme previamente descrito (CORREA et al 2017). Resumidamente, a solução de saliva artificial foi preparada pela dissolução de $2,38 \mathrm{~g}$ $\mathrm{Na}_{2} \mathrm{HPO}_{4}, 0,19 \mathrm{~g}$ de $\mathrm{KH}_{2} \mathrm{PO}_{4}$ e $8 \mathrm{~g}$ de $\mathrm{NaCl}$ em $1 \mathrm{~L}$ de água destilada. $\mathrm{O} \mathrm{pH}$ da solução foi ajustado para 6,75 e adicionado alfa-amilase para obtenção de $200 \mathrm{U}$ de atividade da enzima. 
O fluído gástrico artificial foi preparado adicionando-se uma solução a 0,32\% de pepsina a uma solução $0,03 \mathrm{M}$ de $\mathrm{NaCl}, \mathrm{pH}$ 1,2. O fluído intestinal artificial foi preparado pela diluição de $0,05 \mathrm{~g}$ de pancreatina e $0,3 \mathrm{~g}$ de extrato de bile a $35 \mathrm{~mL}$ de $\mathrm{NaHCO}_{3} 0,1 \mathrm{M}$.

\section{Digestão gastrointestinal in vitro}

A digestão gastrointestinal in vitro foi realizada de acordo com metodologia previamente descrita (CORREA et al., 2017) (Figura 4). Para avaliar o comportamento dos materiais antes a após as etapas da digestão os grupos foram identificados como:

EEM-extrato de erva mate livre;

EEMOG-extrato de erva mate após a digestão oral e gástrica;

EEMOGI-extrato de erva mate após a digestão oral, gástrica e intestinal;

MCM-extrato de erva mate em microcápsulas de maltodextrina;

MCMOG- microcápsula de maltodextrina após a digestão oral e gástrica;

MCMOGI- microcápsula de maltodextrina após a digestão oral, gástrica e intestinal;

MCA- extrato de erva mate em microcápsulas de alginato de cálcio;

MCAOG- microcápsula de alginato de cálcio após a digestão oral e gástrica;

MCAOGI- microcápsula de alginato de cálcio após a digestão oral, gástrica e intestinal.

Ao final dos processos, todos os materiais foram liofilizados e armazenados a $-20{ }^{\circ} \mathrm{C}$.

Figura 4. Diagrama utilizado para digestão gastro-intestinal in vitro das amostras de extrato de erva mate livre e microencapsuladas.

\begin{tabular}{|l|l|}
\hline \multicolumn{1}{|c|}{ Diagrama da digestão in vitro } \\
\hline $1^{\mathrm{a}}$ Fase da digestão \\
$2^{\mathrm{a}}$ Fase da digestão
\end{tabular}

Fonte: CORREA et al., 2017 com modificações 


\section{Resultados e Discussão}

A Figura 5 mostra os aspectos dos extratos da erva mate após microencapsulação em maltodextrina e alginato de cálcio.

As eficiências de encapsulação foram avaliadas pela quantificação de fenólicos totais nos extratos livres e nos materiais microencapsulados. Os microencapsulados em maltodextrina e alginato mostraram uma eficiência próxima de 100\% (AHMADIAN; NIAZMAND; POURFARZARD, 2019; RIBEIRO et al., 2016).

Os três materiais (extrato de mate livre e os dois materiais microencapsulados) foram submetidos à digestão in vitro seguindo os passos descritos na Figura 4. Para metade dos materiais, a digestão foi interrompida após a fase gástrica, enquanto a outra metade foi submetida também à fase intestinal. Os materiais foram avaliados quanto ao teor em fenólicos totais (Figura 6) e atividade antioxidante pelo ensaio FRAP (Figura 7). Podemos observar que após a digestão gastrointestinal ocorreu uma redução de cerca de $30 \%$ no conteúdo em fenólicos totais e na atividade antioxidante dos extratos livres. A fase oral-gástrica foi a responsável por esta redução, considerando que, após a fase intestinal, não ocorreram novas reduções nos valores de fenólicos totais e atividade antioxidante.

Figura 5. Extrato de mate microencapsulado em maltodextrina (A) e alginato de cálcio (B)
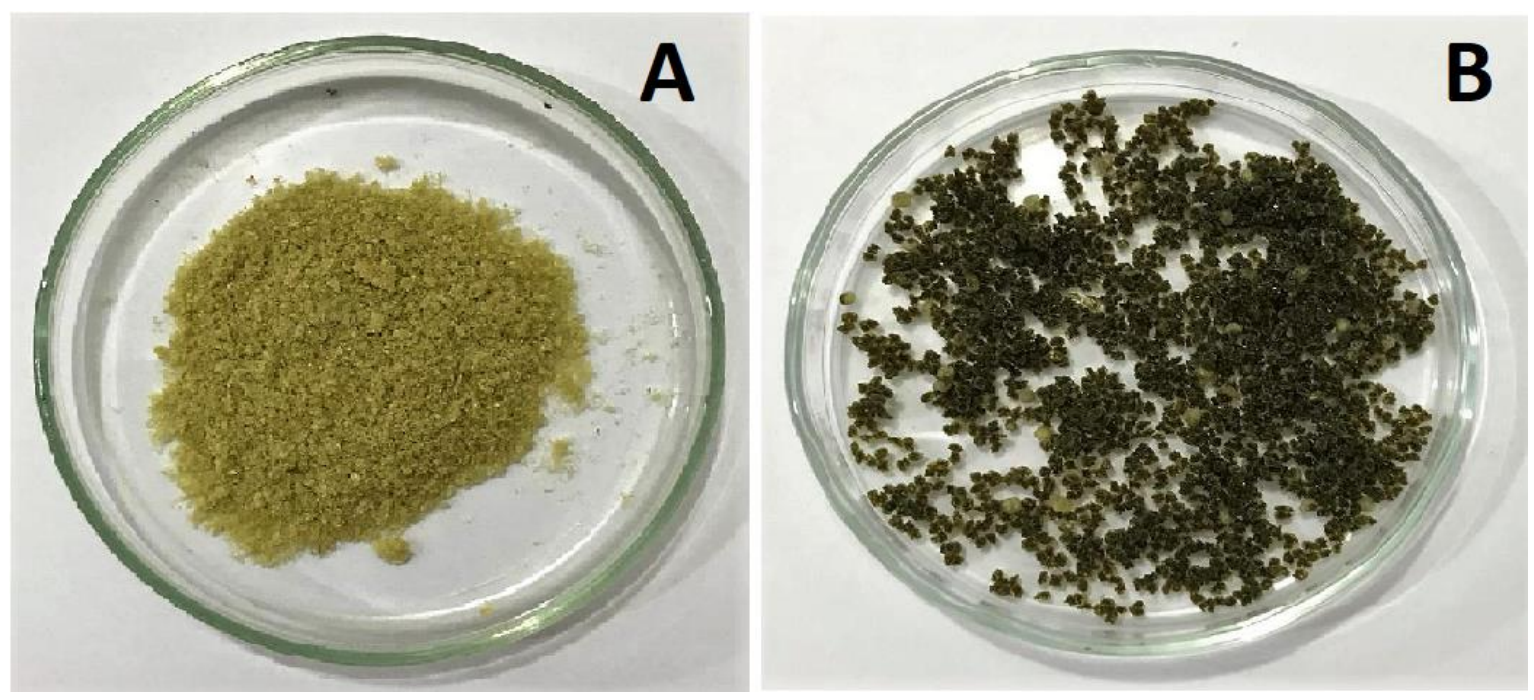

As análises indicaram uma efetiva liberação dos fenólicos microencapsulados do extrato da erva mate. Para os materiais microencapsulados, os teores em fenólicos totais foram significativamente superiores aos obtidos para os extratos brutos pós digestão gastrointestinal $(\mathrm{p} \leq 0,05)$, indicando efetiva proteção no ambiente ácido do estômago. Em relação à atividade 
antioxidante FRAP, entretanto, não foi encontrada significância estatística entre os extratos livres e microencapsulados ( $\mathrm{p} \geq 0,05)$, apesar de ser possível observar uma discreta tendência de redução das perdas das atividades antioxidantes liberadas pós digestão pelos materiais microencapsulados quando comparadas com as perdas dos extratos livres. Os resultados demonstram que os dois tipos de microencapsulação (em maltodextrina e em alginato) tiveram as mesmas eficiências protetoras quando submetidas à digestão in vitro.

Microencapsulações dos extratos de mate já foram realizadas com sucesso e tornaram o produto mais resistente ao calor e ao armazenamento (NEGRÃO-MURAKAMI et al., 2017; NUNES et al., 2015). Até o momento, entretanto, microencapsulação do mate e seu efeito protetor reduzindo as perdas durante a digestão gastrointestinal não foi estudado. Muitos fenólicos são sensíveis às variações de pH (FRIEDMAN; JÜRGENS, 2000), incluindo os ácidos clorogênicos, principal família de antioxidantes do mate (GONÇALVES et al., 2017). Estudos realizados com diferentes extratos vegetais com propriedades antioxidantes, sugerem que a microencapsulação protege os bioativos dos ambientes inóspitos encontrados no trato gastro-intestinal, como mudanças no pH e ação das enzimas digestivas. Alguns exemplos são o extrato de pétalas de açafrão encapsulado em uma mistura de maltodextrina e pectina (AHMADIAN; NIAZMAND; POURFARZARD, 2019), extrato de resíduo de pimenta (Capsicum annuum L) encapsulado em proteína de soro de leite (VULIC et al., 2019) e o extrato de polpa de alfarroba, encapsulado em metil-celulose (YDJEDD et al., 2017). Outros exemplos onde a microencapsulação protegeu os bioativos dos extratos vegetais podem ser encontrados em uma revisão recente que aborda este tema (PEANPARKDEEA; IWAMOTO, 2020). 
Figura 6. Compostos fenólicos totais após as etapas da digestão gastrointestinal. EEMextrato de erva mate livre; EEMOG- extrato de erva mate após a digestão oral e gástrica; EEMOGI- extrato de erva mate após a digestão oral, gástrica e intestinal; MCM- extrato de erva mate em microcápsulas de maltodextrina; MCMOG- microcápsula de maltodextrina após a digestão oral e gástrica; MCMOGI- microcápsula de maltodextrina após a digestão oral, gástrica e intestinal; MCA- extrato de erva mate em microcápsulas de alginato de cálcio; MCAOG- microcápsula de alginato de cálcio após a digestão oral e gástrica; MCAOGImicrocápsula de alginato de cálcio após a digestão oral, gástrica e intestinal.Não há diferença estatística entre as médias com letras iguais $(n=3)(p<0,05)$ de acordo com o teste de NewmanKeuls.

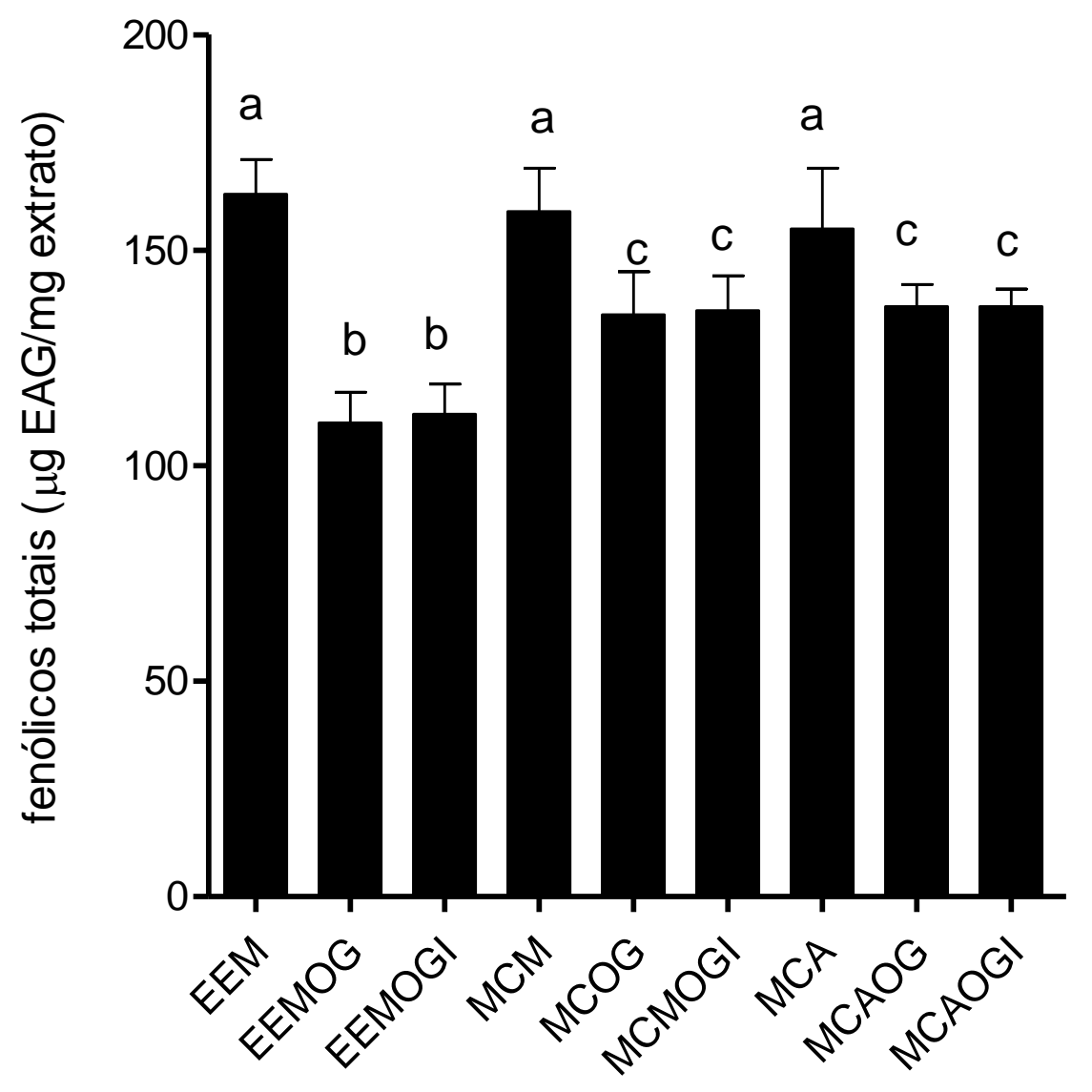


Figura 7. Atividade antioxidante avaliada pelo ensaio FRAPA após as etapas da digestão gastrointestinal. EEM- extrato de erva mate livre; EEMOG- extrato de erva mate após a digestão oral e gástrica; EEMOGI- extrato de erva mate após a digestão oral, gástrica e intestinal; MCM- extrato de erva mate em microcápsulas de maltodextrina; MCMOGmicrocápsula de maltodextrina após a digestão oral e gástrica; MCMOGI- microcápsula de maltodextrina após a digestão oral, gástrica e intestinal; MCA- extrato de erva mate em microcápsulas de alginato de cálcio; MCAOG- microcápsula de alginato de cálcio após a digestão oral e gástrica; MCAOGI- microcápsula de alginato de cálcio após a digestão oral, gástrica e intestinal.Não há diferença estatística entre as médias com letras iguais $(n=3)$ $(\mathrm{p}<0,05)$ de acordo com o teste de Newman-Keuls.

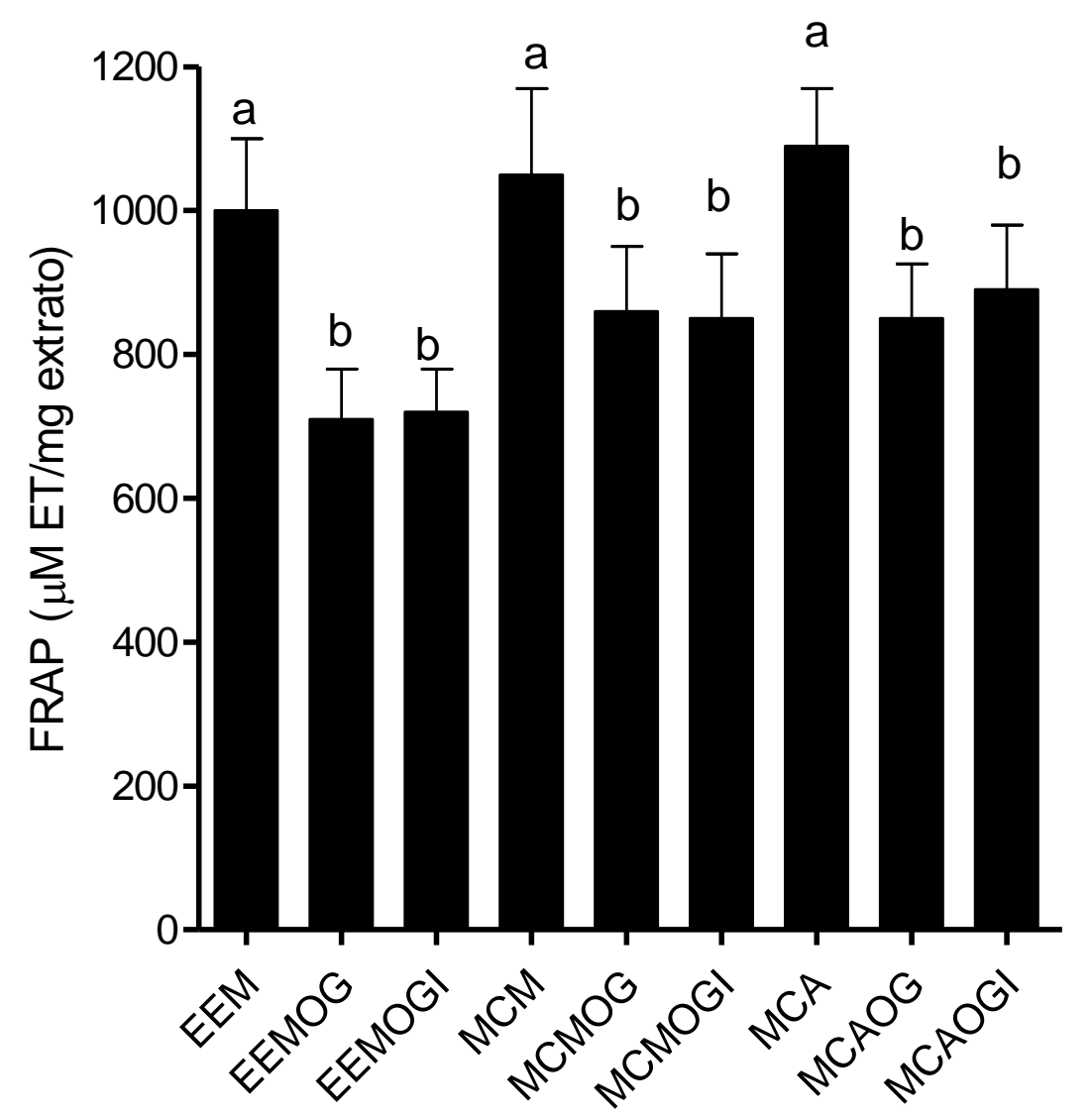

\section{Conclusões}

Neste trabalho, os extratos de erva mate ricos em compostos fenólicos antioxidantes, principalmente da família dos ácidos clorogênicos, foram microencapsulados com sucesso em malltodextrina e alginato de cálcio. A estabilidade ao processo de digestão gastrointestinal in vitro dos extratos livre e microencapsulados foi avaliada utilizando-se como parâmetros o teor em compostos fenólicos totais e a atividade antioxidante pelo método FRAP. Os resultados 
obtidos sugerem que as duas microencapsulações mostraram uma leve tendência de proteção dos bioativos antioxidantes dos extratos. Outros agentes encapsulantes e outras condições de microencapsulação estão sendo testadas em nosso laboratório visando melhorar a eficiência do processo.

\section{Agradecimentos}

Os autores agradecem o apoio financeiro da Coordenação de Aperfeiçoamento de Pessoal de Nível Superior- CAPES, Conselho Nacional de Desenvolvimento Científico e TecnológicoCNPq e Universidade Estadual de Maringá-UEM para a realização deste trabalho

\section{Referências}

AHMADIAN, Z., NIAZMAND, R., POURFARZARD, A. Microencapsulation of saffron petal phenolic extract: their characterization, in vitro gastrointestinal digestion, and storage stability. Journal of Food Science, v. 84, pp. 2745-2757, 2019

ASCHERI, D. P. R. et al. Microencapsulation of orange essential oil: Wall material selection. Food Science and Technology, v. 23, p. 1-6, 2003.

ASKARIPOUR, D. Green Tea vs Yerba Mate - Circle of Drink. Acesso em julho de 2020. https://circleofdrink.com/green-tea-vs-yerba-mate.

AUGUSTIN, M. A.; HEMAR, Y. Nano- and micro-structured assemblies for encapsulation of food ingredients. Chemical Society Reviews, v. 38, pp. 902-912, 2009

BOAVENTURA, B. C. B. et al. Effect of in vitro digestion of yerba mate (Ilex paraguariensis A. St. Hil.) extract on the cellular antioxidant activity, antiproliferative activity and cytotoxicity toward HepG2 cells. Food Research International, v. 77, pp. 257-263, 2015

BRACESCO N. et al., Recent advances on Ilex paraguariensis research: Minireview. Journal of Ethnopharmacology, v. 136, pp. 378-384, 2011

BURRIS, K. P. et al. Antimicrobial activity of yerba mate (Ilex paraguariensis) aqueous extracts against Escherichia coli O157:H7 and Staphylococcus aureus. Journal of Food Science, v. 76, pp. 456-462, 2011

CARDOZO JR, E. L.; MORAND, C. Interest of mate (Ilex paraguariensis A. St.-Hil.) as a new natural functional food to preserve human cardiovascular health-A review. Journal of Functional Foods, v. 21, p. 440-454, 2016.

CORREA, V. G. et al. . Effects of in vitro digestion and in vitro colonic fermentation on stability and functional properties of yerba mate (Ilex paraguariensis A. St. Hil.) beverages. Food chemistry, v. 237, p. 453-460, 2017.

CORREA, V. G. et al. Ilex paraguariensis A. St. Hil): a promising adjuvant in the treatment of diabetes, obesity, and metabolic syndrome. In: Mohammad Ullah; Aamir Ahmad. (Org.). 
Nutraceuticals and natural product derivatives: disease prevention \& drug discovery. 1ed.Hoboken, New Jersey, USA: Wiley-Blackwell, 2019, v. 1, p. 167-182.

CORREA-BETANZO, J. et al. Stability and biological activity of wild blueberry (Vaccinium angustifolium) polyphenols during simulated in vitro gastrointestinal digestion. Food Chemistry, v. 165, p. 522-531, 2014.

DE MEJÍA, E. G. et al. Yerba mate tea (Ilex paraguariensis): Phenolics, antioxidant capacity and in vitro inhibition of colon cancer cell proliferation. Journal of Functional Foods, v. 2, n. 1, p. 23-34, 2010.

ETCHEPARE, M. A. et al. Microencapsulation of probiotics using sodium alginate. Ciência Rural, v. 45, pp. 1319-1326, 2015

FRIEDMAN, M.; JÜRGENS, H. S. Effect of pH on the stability of plant phenolic compounds. Journal of Agricultural and Food Chemistry, 48, pp. 2101-2110, 2000

GONÇALVES, B. et al. Microencapsulation of a natural antioxidante from coffee-chlorogenic acid (3-caffeoyl quinic acid). Food Bioprocess Technology, v. 10, pp. 1521-1530, 2017

HECK, C.I.; DE MEJIA, E. G. Yerba mate tea (Ilex paraguariensis): a comprehensive review on chemistry, health implications, and technological considerations. Journal of Food Science, 72, pp. 138-151, 2007

HENNING, S. M. et al., Variability in the antioxidant activity of dietary supplements from pomegranate, milk thistle, green tea, grape seed, goji, and acai: effects of in vitro digestion. Journal of Agricultural and Food Chemistry, 62, pp. 4313-4321, 2014

ISOLABELLA, S. et al. Study of the bioactive compounds variation during yerba mate (Ilex paraguariensis) processing. Food Chemistry, 122, pp. 695-699, 2010

KIM, S.Y. et al. Anti-obesit effects of yerba mate (Ilex paraguariensis): A randomized, doubleblind, placebo-controlled clinical trial. BMC Complementary and Alternative Medicine, 15, pp. 338-345, 2015

KOEHNLEIN, E. A. et al. Analysis of a whole diet in terms of phenolic content and antioxidant capacity: Effects of a simulated gastrointestinal digestion. International Journal of Food Science and Nutrition, 67, pp. 614-623, 2016

KUANG, S. S.; OLIVEIRA, J. C.; CREAN, A. M. Microencapsulation as a tool for incorporating bioactive ingredients into food. Critical Rreviews in Food Science and Nutrition, v. 50, n. 10, p. 951-968, 2010.

LIMA, J.D.P. et al. Distribution of major chlorogenic acids and related compounds in Brazilian green and toasted Ilex paraguariensis (Maté) leaves. Journal of Agricultural and Food Chemistry, v. 64, pp. 2361-2370, 2016

LIMA, N. D. S. et al. Effec, ts of Ilex paraguariensis (yerba mate) treatment on leptin resistance and inflammatory parameters in obese rats primed by early weaning. Life Sciences, 115, pp. 29-35, 2014a 
LIMA, N.D.S. et al. Ilex paraguariensis (yerba mate) improves endocrine and metabolic disorders in obese rats primed by early weaning. European Journal of Nutrition, 53, pp. 73$82,2014 b$

MACIAS-CORTES, E. et al. Microencapsulation of phenolic compounds: Technologies and novel polymers. Revista Mexicana de Ingeniria Quimica, v. 19, pp. 491-521, 2020

MURAKAMI, A.N.N. et al. Concentration of biologically active compounds extracted from Ilex paraguariensis St. Hil. by nanofiltration. Food Chemistry, 141, pp. 60-65, 2013

NEGRÃO-MURAKAMI, A. N. et al. Influence of DE-value on maltodextrin on the physicochemical properties, antioxidante activity, and storage stability of spray dried concentrated mate (Ilex paraguariensis A. St. Hill). LWT- Food Science and Technology, v. 79 , pp. 561-567, 2017

NUNES, G. L. et al. Microencapsulation of freeze concentrated Ilex paraguariensis extract by spray drying. Journal of Food Engineering, v. 151, pp. 60-68, 2015

PEANPARKDEEA, M.; IWAMOTO S. encapsulation for improving in vitro gastrointestinal digestion of plant polyphenols and their applications in food products Food Reviews International, https://doi.org/10.1080/87559129.2020.1733595, 2020

PULIDO, R.; BRAVO, L.; SAURA-CALIXTO, F. Antioxidant activity of dietary polyphenols as determined by a modified ferric reducing/antioxidant power assay. Journal of Agricultural and Food Chemistry, v. 48, n. 8, p. 3396-3402, 2000.

RIBEIRO, A. et al. Rosemary extracts in functional foods: extraction, chemical characterization and incorporation of free and microencapsulated forms in cottage cheese. Food \& Function, v. 7, pp. 2185-2196, 2016

SERAFINI, M et al. 2011. Herbal medicine: biomolecular and clinical aspects, Herbal Medicine: Biomolecular and Clinical Aspects , BENZIE, F.F.; WACHTEL-GALOR, S. CRC Press, Boca Raton-USA.

SILVEIRA, A.D. et al., Phenolic compounds from yerba mate based beverages - A multivariate optimisation. Food Chemistry, v. 190, pp. 1159-1167, 2016

SINGLETON, V.L., ROSSI, J.A. Colorimetry of total phenolics with phosphomolybdicphosphotungstic acid reagents. American journal of Enology and Viticulture, v. 16, n. 3, p. 144-158, 1965.

SOUZA, A.H.P. et al. Phytochemicals and bioactive properties of Ilex paraguariensis: an invitro comparative study between the whole plant, leaves and stems. Food Research International, 78, pp. 286-294, 2015

STALMACH, A. et al. Bioavailability of chlorogenic acids following acute ingestion of coffee by humans with an ileostomy. Archives of Biochemistry and Biophysics, 501, pp. 98-105, 2010

YDJEDD, S. et al. Eff ect of in vitro gastrointestinal digestion on encapsulated and nonencapsulated phenolic compounds of carob (Ceratonia siliqua L.) pulp extracts and their antioxidant capacity. Journal of Agricultural and Food Chemistry, v. 65, pp. 827-835, 2017 
CORREA, V. G; TABADA, B. K; SPACK, K. C; CORRÊA, R. C. G; PERALTA, R. M.

VULIC, L. et al. Bioavailability and bioactivity of encapsulated phenolics and carotenoids isolated from red pepper waste. Molecules v. 24, pp. 2837-2847, 2019 


\title{
CAPÍTULO 41: ENCAPSULAÇÃO DE ANTIOXIDANTES NATURAIS PARA APLICAÇÃO EM ALIMENTOS: UMA REVISÃO
}

\section{CHAPTER 41: ENCAPSULATION OF NATURAL ANTIOXIDANTS FOR FOOD APPLICATION: A REVIEW}

\author{
Catarina Massena Pires ${ }^{1}$; Érica Santos Pereira ${ }^{2}$; Julia de Souza Amaral ${ }^{3}$; Eliana da Silva Gulão ${ }^{4}$
}

\begin{abstract}
Resumo
A oxidação lipídica é um importante parâmetro de conservação de alimentos, uma vez que altera suas propriedades sensoriais além de gerar a formação de radicais livres. Desta forma, antioxidantes são adicionados ao produto processado, e devido a maior preocupação pela saúde, pesquisas em busca de antioxidantes naturais vêm recebendo destaque. Os compostos bioativos com atividade antioxidante geralmente são instáveis devido a sua estrutura química, nesse sentido as técnicas de encapsulação tornam-se atraentes na preservação destas substâncias. Portanto, o objetivo deste trabalho foi de realizar uma revisão de literatura sobre a oxidação lipídica em alimentos, bem como técnicas de encapsulação para evitar estas alterações. Para realizar a pesquisa foram consultadas as bases Science direct, Scielo e PubMed utilizando as seguintes palavras-chave: encapsulação; microencapsulação; antioxidantes; compostos bioativos. Como resultado, foi observado que diferentes técnicas são aplicadas na encapsulação de antioxidantes, destacando-se as técnicas físicas spray drying e químicas como coacervação complexa e nanoemulsões. Pesquisas demonstram a importância da origem do polímero e núcleo, proporção e fatores como $\mathrm{pH}$ e temperatura a fim de alcançar rendimento e eficiência satisfatórios, além da importância de regular esses fatores de modo a projetar a liberação controlada do núcleo no alimento.
\end{abstract}

\section{Palavras-chave: antioxidantes, compostos bioativos, encapsulação}

\begin{abstract}

\footnotetext{
${ }^{1}$ Estudante de Nutrição. Universidade Estácio de Sá, catarinamassena1 @ gmail.com

${ }^{2}$ Estudante de Nutrição. Universidade Estácio de Sá, ericasantosnf@ hotmail.com

${ }^{3}$ Estudante de Nutrição. Universidade Estácio de Sá, juliasouzaamaral@ gmail.com

${ }^{4}$ Docente. Departamento de Nutrição. Universidade Estácio de Sá, eliana.gulao@estacio.br
}

Lipid oxidation is an important parameter for food conservation, since it alters its sensory properties in addition to generating the formation of free radicals. In this way, antioxidants are added to the processed product, and due to the greater concern for health, research of natural antioxidants has been highlighted. Bioactive compounds with antioxidant activity are generally unstable due to their chemical structure, so encapsulation techniques become attractive in the preservation of these substances. Therefore, the objective of this work was to carry out a literature review on lipid oxidation in foods, as well as encapsulation techniques to avoid these changes. To carry out the research, the databases Science direct, Scielo and PubMed were consulted using the following keywords: encapsulation; microencapsulation; antioxidants; bioactive compounds. As a result, it was observed that different techniques are applied in the encapsulation of antioxidants, highlighting physical techniques spray drying and chemical techniques such as complex coacervation and nanoemulsions. Research demonstrates the importance of the origin of the polymer and core, proportion and factors such as $\mathrm{pH}$ and temperature in order to achieve satisfactory yield and efficiency, in addition 
PIRES, C. M. et al.

to the importance of regulating these factors in order to project the controlled release of the core in the food.

\section{Key-words: antioxidant, bioactive compounds, encapsulation}

\section{Introdução}

A oxidação de lipídios e pigmentos em alimentos é um dos principais parâmetros de deterioração da qualidade de produtos gordurosos e/ou emulsionados, pois leva ao desenvolvimento de odores e sabores desagradáveis e à oxidação de lipídios e pigmentos, afetando negativamente a cor, aparência e aceitabilidade (GALLO; FERRACANE; NAVIGLIO, 2012; WEISS et al., 2010).

Os antioxidantes são adicionados aos alimentos processados para evitar o ranço oxidativo, para retardar o desenvolvimento de sabores indesejáveis e melhorar a estabilidade da cor. Podem ser utilizados tanto antioxidantes naturais como os sintéticos e ambos desempenham um importante papel na produção de alimentos, porém, devido a maior preocupação com a saúde pelos consumidores, têm-se aumentado a preferência pelo uso de antioxidantes naturais, principalmente provenientes de plantas (GALLO; FERRACANE; NAVIGLIO, 2012; JAYATHILAKAN et al., 2007; OHLSSON; BENGTSSON, 2002).

Atualmente produtos industrializados são elaborados com a incorporação de antioxidantes sintéticos, como o eritorbato de sódio, o qual não confere nenhum benefício à saúde do consumidor. Por essa razão, a aplicação do óleo de gengibre em produtos gordurosos e/ou emulsionados pode se tornar uma ideia inovadora, pois além de incorporar um antioxidante eficaz, estará assim obtendo um produto também com função nutritiva. As pesquisas revelaram que, a partir dessas classes, uma série de substâncias possui atividade antioxidante e antibacteriana (BALCÃO et al., 2013; DEANS; RITCHIE, 1987; OHLSSON; BENGTSSON, 2002), no entanto, são substâncias voláteis de difícil aplicação na indústria de alimentos, por isso, a microencapsulação torna-se uma técnica atraente na preservação de compostos instáveis, facilitando sua aplicação nos mais variados setores alimentares (DIMA et al., 2014; DONG et al., 2011).

As propriedades antioxidantes de ingredientes naturais nos produtos podem ser garantidas ao longo da produção e armazenamento do alimento processado por diferentes técnicas de encapsulação. Portanto, o objetivo deste trabalho foi realizar uma revisão de literatura sobre o processo da oxidação em alimentos, bem como da utilização de compostos antioxidantes para controlar tais alterações. Por sua vez, pesquisar através da literatura 
PIRES, C. M. et.al.

científica técnicas de encapsulação utilizadas para facilitar a aplicação destes princípios ativos em alimentos.

\section{Revisão de literatura}

\section{Atividade antioxidante de compostos bioativos em alimentos}

As alterações oxidativas em alimentos referem-se a modificações químicas indesejáveis que se desenvolvem quando o óleo comestível é exposto a fatores como: temperatura, oxigênio, pH, luz, entre outros (YANG et al., 2016). Essas alterações podem ocorrer durante o processamento, o armazenamento, o transporte e no preparo do produto final rico em lipídeos (OANCEA et al., 2018). Com o objetivo de prolongar a vida útil e melhoria da aparência, as indústrias utilizam o mecanismo da atividade antioxidante, um tipo de aditivo alimentar, podendo ser sintético ou natural (SHARMA et al., 2019).

O processo de peroxidação lipídica envolve as fases de iniciação, propagação e terminação. A interação entre o oxigênio triplet, luz e/ou fotossensibilizadores resultam na formação do oxigênio singlete. Este, por sua vez ativado, pode reagir com ácidos graxos insaturados, remover um átomo de hidrogênio do carbono de metileno adjacente à ligação dupla cis do ácido graxo insaturado resultando na formação de radicais livres. Os radicais gerados podem atacar outros ácidos graxos como os produtos formados no início da reação, propagando assim a oxidação. A partir desta etapa a propagação ocorre por meio da reação de radicais livres dos ácidos graxos com o oxigênio ocasionando na formação de radicais peróxidos e hidroperóxidos, insípidos e inodoros. Fatores como o calor, catálise de íons metálicos ou luz pode resultar na decomposição do hidroperóxido, gerando produtos responsáveis pelo odor, sabor e textura característicos do alimento rancificado. Uma vez iniciada, a reação continua em cadeia e termina apenas quando as reservas de ácidos graxos insaturados e oxigênio estão esgotadas. Com o esgotamento dos substratos ocorre a formação de produtos finais estáveis ou não reativos, que compreendem os derivados da decomposição de hidroperóxidos, como álcoois, aldeídos, cetonas, ésteres e outros hidrocarbonetos (RIBEIRO et al., 2019; WANG et al., 2019).

Os antioxidantes naturais, também conhecidos como antioxidantes verdes, são obtidos através de alimentos, especiarias e ervas, são alguns exemplos: alecrim, grão de café, sálvia, alho, tomilho, casca da batata, polpa da beterraba, brócolis, cenoura, aipo, ervilha, cebola e pimenta (BAŞTÜRK et al., 2018).

Nos últimos anos, foram realizados diversos estudos baseados nos antioxidantes naturais, devido à demanda dos consumidores por etiquetas sem aditivos sintéticos, com 
PIRES, C. M. et.al.

estabilidade térmica e dentro das normas de segurança (ALADEDUNYE, 2014; ALADEDUNYE; GRUCZYNSKA, 2018). Sendo assim, foi verificado que o antioxidante natural tem muitas vantagens em relação aos sintéticos, no que diz respeito a sua aceitação, benefícios aos consumidores e sua segurança (BERA; LAHIRI; NAG, 2006). No entanto, a baixa estabilidade, eficácia, baixa solubilidade e alto custo são alguns dos aspetos que limitam sua aplicação nas indústrias (SHARMA et al., 2019). Além disto, a importância dos antioxidantes é reconhecida pela Organização Mundial de Saúde (OMS) que tem argumentado a favor do aumento do consumo mundial de fontes dietéticas de antioxidantes naturais, sendo a ingestão alimentar a principal forma de aquisição desses compostos. A relevância de antioxidantes em organismos vivos, juntamente com o aumento da divulgação na mídia, aumentou os esforços para caracterizar fontes conhecidas de antioxidantes naturais para aplicação em alimentos (LORENZO et al., 2018), neste sentido, pesquisas vêm sendo realizadas para descobrir novas substâncias antioxidantes naturais.

Bera; Lahiri; Nag (2006) compararam a atividade antioxidante do extrato solúvel do cominho ajowan (Carum copticum) com à de antioxidantes sintéticos TBHQ (terc-butilhidroquinona) e BHT (di-terc-butil metil fenol) sobre a oxidação do óleo de palma. Amostras com 100 g do óleo de palma contendo diferentes concentrações dos antioxidantes foram submetidas a variadas temperaturas com o auxílio de um banho termostático, e, a formação de peróxidos acompanhada pelo ensaio de substâncias reativas ao ácido tiobarbitúrico (TBARS). Os autores observaram que todas as substâncias pesquisadas forneceram estabilidade oxidativa até a temperatura de $50^{\circ} \mathrm{C}$ e a partir do aquecimento os antioxidantes sintéticos foram mais eficazes na proteção à oxidação quando comparado ao extrato natural devido à instabilidade dos compostos fenólicos presentes no cominho diante as temperaturas mais altas. Além disso, antioxidantes sintéticos como o TBHQ e BHT possuem atividade primária que retardam ou inibem a etapa de iniciação, reagindo com o radical livre dos lipídios ou inibindo a etapa de propagação reagindo com o radical peroxil ou, radicais alcóxi. Segundo os autores, como a primeira fração do extrato de ajowan contém timol, grupamentos fenólicos em sua estrutura, previnem mais ativamente a oxidação de glicerídeos.

Em uma pesquisa realizada por Baştürk e colaboradores (2018) foi investigada a atividade antioxidante de 6 diferentes ervas: semente de urtiga (Urtica dioica L.), semente de linho (Linum usitatissimum L.), sálvia (Salvia officinalis L.), hortelã (Mentha arvensis L), sumagre (Rhus coriaria L.) e tomilho (Thymus vulgaris). Os autores avaliaram o efeito antioxidante dos extratos de cada erva contra a oxidação do óleo de milho armazenado a $60^{\circ} \mathrm{C}$, comparando seus efeitos com a utilização de antioxidantes já bem empregados: 
palmitato de ascorbila e acetato de tocoferol. As análises foram realizadas no intervalo de 6 semanas através da determinação da atividade antioxidante pelo método DPPH (2,2-difenil1- picril-hidrazil) sendo possível observar maior atividade antioxidante dos extratos de sumagre e palmitato de ascorbila. Ensaios para verificar a estabilidade oxidativa do óleo de milho durante o período de armazenamento também foram realizadas através dos métodos de TBARS, teste de oxidação acelerada (Schaal oven test) dienos e trienos conjugados. Os resultados demonstraram que amostras contendo BHT, sumagre e hortelã foram as responsáveis por maior estabilidade oxidativa do óleo durante o armazenamento do óleo.

\section{Encapsulação: técnicas e materiais}

Devido à grande funcionalidade dos compostos bioativos foi necessário o desenvolvimento de técnicas que aumentassem a sua eficácia e seu tempo de prateleira, garantindo um produto final rico em nutrientes e com estabilidade às condições adversas, sendo uma destas técnicas a encapsulação (ROSSO et al., 2019).

Microencapsulação é o processo pelo qual vários ingredientes alimentícios podem ser armazenados dentro de um invólucro ou revestimento microscópico para proteção e/ou posterior liberação. Mais especificamente, a microencapsulação é o processo de envolver pequenas partículas, um líquido ou um gás, dentro de uma camada de revestimento ou dentro de uma matriz.

Através da encapsulação é possível garantir muitos benefícios, melhorando a qualidade do produto e/ou criando novas aplicações (REBELLO, 2009). Podem ser citados alguns benefícios adquiridos por essa técnica, como: proteção da passagem do nutriente ou composto bioativo pelo sistema gastrointestinal, separação de compostos reativos, liberação controlada ou prolongada, controle de sabores e odores desagradáveis, estabilidade da cor de substâncias instáveis, proteção contra oxidação, diluição de um produto encapsulado em fórmulas alimentares, dentre outros (REBELLO, 2009; ROSSO et al, 2019). Um exemplo é a encapsulação de carotenoides que permite manter a eficácia da funcionalidade de compostos ativos, diminuindo o risco de degradação e oxidação, consequentemente aumentando seu valor nutricional (ROSSO et al, 2019).

As diferentes técnicas de encapsulação se mostram versáteis com aplicação em vários setores, como nas indústrias: farmacêutica, química, alimentícia e agrícola. Uma das razões para o uso desta tecnologia é a proteção de ingredientes, ou seja, evitar a degradação resultante da exposição a fatores ambientais adversos, como água, oxigênio, calor e luz. Tradicionalmente, isto é feito para melhorar o prazo de validade do material ativo (SOBEL; 
VERSIC; GAONKAR, 2014). A facilidade de manuseio é outra razão para encapsular, pois pode ser utilizada como um método simples para converter um ingrediente alimentar líquido em um sólido (pó). A encapsulação pode ser usada para prevenir reações e interações indesejáveis entre ingredientes alimentícios ativos. Além disso, as diferentes técnicas também oferecem a oportunidade de reduzir a volatilidade de vários ingredientes alimentícios, além da possibilidade de controlar a liberação do ativo encapsulado (LIDERT, 2005; MARTÍN et al., 2015; VASISHT, 2014).

Muitas são as técnicas de encapsulação atualmente, mas de forma geral consiste em um núcleo na região central envolvido por uma camada protetora (SILVA et al., 2003). A nomenclatura comum usada para definir as várias partes da cápsula ou esfera formadas inclui a terminologia para o material de revestimento bem como o ingrediente a ser encapsulado. $\mathrm{O}$ ingrediente a ser encapsulado é geralmente chamado de ativo, núcleo, fase interna, encapsulado ou preenchimento. O material que envolve o ativo é comumente chamado de casca, material de parede, revestimento, fase externa, fase de suporte ou membrana. Geralmente, o encapsulaste é insolúvel e não reativo ao núcleo (SOBEL; VERSIC; GAONKAR, 2014; VASISHT, 2014).

Tradicionalmente, a microencapsulação não utiliza cápsulas maiores que $3 \mathrm{~mm}$ de comprimento. De uma forma geral, cápsulas que possuam tamanho em um intervalo de $100 \mathrm{~nm}$ a $1000 \mathrm{~nm}$ são classificadas como microcápsulas e as que possuem tamanho entre $1 \mathrm{~nm}$ e 100nm são classificados como nanocápsulas (SOBEL; VERSIC; GAONKAR, 2014).

As micropartículas são subdivididas em microesferas e microcápsulas, segundo a sua estrutura, como pode ser observado na Figura 1. São denominadas microesferas as partículas compactas constituídas por uma rede polimérica, na qual a substância ativa se encontra distribuída no seu estado sólido ou molecular. Já as microcápsulas, são as partículas constituídas por um núcleo interno, contendo o agente ativo recoberto por uma camada de polímero de espessura variável (GOUIN, 2004). 
Figura 1. Ilustração esquemática representando a estrutura de microcápsulas e microesferas.

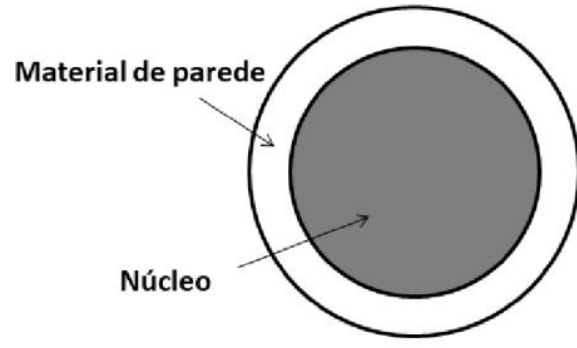

Microcápsula

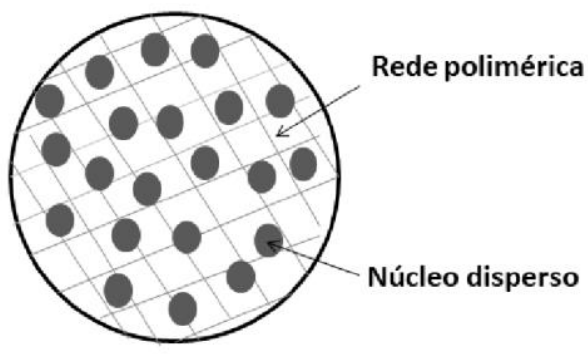

Microesfera

Fonte: Própria, 2018.

Diversos materiais podem ser usados para encapsular podendo estes ser de origem sintética ou natural. Existem algumas características essenciais para encapsulantes, como: ter boa formação de filme, baixa higroscopicidade, baixa viscosidade, sabor e odor suaves, baixo custo, ser insolúvel, liberar o produto ativo em tempo certo, não ser reativo com o núcleo e não ser tóxico. Dificilmente é encontrado um encapsulante com todas essas características, portanto se torna comum o uso de mais de uma substância como filme. A escolha do material vai ser definido a partir do material do núcleo (encapsulado), da escolha da técnica e do objetivo final do produto (PEREIRA et al., 2018). O material de parede é responsável por 1 a $80 \%$ das microcápsulas em peso e podem ser utilizados açúcares, gomas, proteínas, polissacarídeos naturais e modificados, lipídios, ceras e polímeros sintéticos.

O encapsulante deve formar um filme semi-impermeável como, por exemplo, uma membrana celular sem deformações para maior efetividade da retenção do material ativo no núcleo. Essa característica é importante para a proteção do encapsulado e o processo será dependente da concentração da mistura das substância e dos parâmetros do processo de microencapsulação em si, as escolhas serão consideradas adequadas quando formarem micropartículas íntegras, protegendo totalmente o núcleo envolto pelo filme encapsulante (ASCHERI; MARQUEZ; MARTUCCI, 2003).

O amido e seus derivados são considerados bons encapsulantes, pois possuem boa viscosidade e boa solubilidade, podendo ser utilizados na microencapsulação de substâncias voláteis. Uma desvantagem é o seu sabor desagradável, diminuindo a palatabilidade. O amido também, apresenta como desvantagem pouca proteção contra a oxidação de aromatizantes (KRISHNAN et al, 2016). Na utilização de arroz/gelatina como encapsulante observou-se 
PIRES, C. M. et.al.

que as microcápsulas, apesar de serem esféricas e compactas, formam poros, não tendo a formação de uma parede contínua, esses poros podem diminuir a eficácia da microencapsulação, como solução, pode se fazer uma segunda cobertura nas microcápsulas. Com o uso da goma arábica, observou-se a formação de um filme contínuo, sem poros ou rompimentos, ideal para a proteção do núcleo (SANTOS; FÁVARO-TRINDADE; GROSSO, 2005).

O sistema de encapsulação deve ser projetado objetivando um mecanismo de liberação. O núcleo pode ser liberado em diferentes estágios do ciclo de processamento, armazenamento e consumo, e o mecanismo a ser usado dependerá em grande parte do tipo de alimento/bebida e do local em que a carga precisa ser depositada. A água (umidade) é usada como mecanismo de liberação para depositar um ativo durante a reidratação e a dissolução de um pó alimentar quando a água é adicionada, o mesmo é aplicável quando a saliva, dissolvendo um produto alimentar pronto para consumo durante a mastigação. O calor é usado como mecanismo de liberação de um ativo após o aquecimento, cozimento ou tratamento térmico de um produto alimentício como, por exemplo, a adição de água quente ao pó alimentar usado para preparar bebidas quentes (café, chá, achocolatados) e sopas. O cisalhamento mecânico (mastigação) é usado como mecanismo de liberação durante a mastigação de um alimento pronto para o consumo. As enzimas e o pH são utilizados como mecanismo quando um agente ativo tem que ser administrado no trato gastrointestinal (isto é, na boca, no estômago, no intestino delgado ou no cólon), por exemplo, a matriz/material de parede composto por um amido (sensível à amilase na boca) é ideal para a liberação oral. Quando a matriz é composta por proteína a mesma se desintegra na presença de proteases no estômago (GAONKAR, 2014; NAZZARO et al., 2012; PARETA et al., 2014; SOBEL; VERSIC; VASISHT, 2014; YANG et al., 2016). Na indústria alimentícia existe uma grande demanda do uso das técnicas de encapsulação justificado pelo objetivo de manter a estabilidade de compostos instáveis e sensíveis, seja a ação da luz, do ar, do calor ou da água. As substâncias que mais se beneficiam dessa técnica são as oxidantes, vitaminas, ácidos graxos, como ômega 3 e probióticos (DIAS, et al, 2017; ROSSO et al, 2019; SOUZA et al, 2018).

Um estudo utilizando a técnica do spray drying utilizou como encapsulante a goma arábica, considerada um excelente encapsulante devido sua característica de baixa viscosidade em solução aquosa, tendo uma boa capacidade de formar emulsões. Através de pesquisas foi comprovado que possui uma efetiva proteção com relação à atividade oxidante dos óleos essenciais, mas apesar de suas boas características técnicas, a goma arábica possui 
PIRES, C. M. et.al.

um elevado custo limitando assim o seu uso. Em contrapartida, foi analisada também a maltodextrina que tem uma efetiva ação protetora de substâncias antioxidantes, sendo uma opção viável para encapsulação dos óleos essenciais e um custo mais acessível (ABURTO et al, 2009; SANTOS et al, 2005).

O objetivo do produto final será um dos determinantes da técnica escolhida que pode ser física, química ou físico-química. A escolha da técnica leva em conta o material ativo, o encapsulamento, a termossensibilidade e a solubilidade da substância do núcleo. A ação antioxidante, uma das funções mais benéficas das técnicas de encapsulação para compostos ativos está relacionada com a escolha do material encapsulante (OZKAN, 2018).

A oxidação pode ocorrer de duas formas, pela auto-oxidação onde ocorre reação enzimática e ação de radicais livres e pela foto-oxidação, mediada pela ação de raios ultravioletas ou pelo oxigênio. A auto-oxidação forma hidroperóxido lipídico, que pode ser oxidado a cetonas, ésteres, aldeídos, entre outros (CHOE; MIN, 2006). Os óleos essenciais, compostos funcionais muito utilizados no processamento de alimentos, são substâncias propensas a degradação oxidativa, principalmente a ação enzimática (LING, 2015). A oxidação dos óleos comestíveis gera problemas à indústria alimentícia devido à formação de substâncias indesejáveis, causando alteração no sabor, diminuição dos nutrientes e até toxicidade. Uma forma de controlar a ação oxidativa é a adição de substâncias antioxidantes à formulação, um aditivo alimentar usado para prolongar a vida útil do alimento, melhorando a qualidade e a apresentação do produto, consequentemente aumentando seu tempo de prateleira (CHOE; MIN, 2006).

Estudos onde foram realizados a encapsulação de óleos essenciais comestíveis insaturados através da técnica da nanoemulsão, mostraram os benefícios do uso de antioxidantes naturais e antioxidantes sintéticos na formulação de óleos essenciais com o objetivo de proteger da ação oxidativa. Os antioxidantes naturais, como alecrim, sálvia, menta, tomilho, semente de linho, entre outros, possuem mais estabilidade térmica e atividade antioxidante do que os sintéticos, além de potenciais benefícios à saúde. No caso dos óleos essenciais, por serem substâncias com alta volatilidade, ocorre pouca perda nos processos térmicos. Já os antioxidantes sintéticos são utilizados em grande escala devido ao seu baixo custo e ótima eficácia, mesmo sendo prejudiciais à saúde, causando, por exemplo, mutações e tumores (SHARMA et al., 2019).

Os métodos de encapsulação físicos mais utilizados são a atomização pelo spray drying, spray chilling, spray cooling, dextrução centrífuga e liofilização. As técnicas químicas se resumem em polimerização interfacial, indução molecular e polimerização in 
PIRES, C. M. et.al.

situ. Já os métodos físico-químicos incluem coacervação simples, coacervação complexa, emulsões e gelificação iônica (CHAMPAGNE; FUSTIER, 2007). O método escolhido para o processo de microencapsulação deve ser simples, de fácil reprodução, rápido e ser facilmente reproduzido em escala industrial (SILVA et al., 2003). O processo de atomização ou spray drying é um dos mais utilizados na indústria alimentícia devido às vantagens como baixo custo, fácil operação, alta produtividade e facilidade de microencapsulação de substâncias termolábeis. Essa característica relacionada a substâncias termolábeis se explica pelo curto período em que a substância entra em contado com as temperaturas elevadas (NUNES et al, 2018; BURGAIN et al, 2011). O uso de alta temperatura no método de spray drying pode não ser vantajoso para a microencapsulação de probióticos, uma vez que pode causar danos a integridade dos microrganismos, sendo uma solução o uso de encapsulantes termoprotetores visando a preservação da substância probiótica (BURGAIN et al., 2011; GOLOWCZYC et al., 2011; NAZZARO et al., 2012).

Com o avanço da tecnologia há um crescimento do uso da técnica de nanoemulsão, sendo um método de encapsulamento eficaz para substâncias antioxidantes, pois ajudam a melhorar a estabilidade, a solubilidade e a biodisponibilidade dos antioxidantes, além das já conhecidas ações de proteção das técnicas de microencapsulação. As principais vantagens reconhecidas da nanoemulsão são: o baixo uso de surfactante para a formação da emulsão e a grande área de superfície de contato, facilitando o controle da taxa de absorção (SHARMA et al., 2019).

\section{Microencapsulação de antioxidantes para aplicação em alimentos}

Alimentos com alto teor de gordura são suscetíveis a oxidação, que é uma das maiores causas de perdas na indústria (ANDRADE et al., 2019). Para evitar a oxidação de óleos e gorduras é realizada a utilização de aditivos sintéticos que podem apresentar efeito tóxico resultando em potenciais efeitos negativos à saúde. Estudos verificaram que antioxidantes naturais apresentam maior atividade antioxidante e estabilidade térmica comparados aos sintéticos, além vários deles possuírem baixo custo de extração, como partes das plantas de oliveiras, chá verde, gergelim e plantas medicinais (TAGHVAEI; JAFARI, 2015).

A fim de aumentar o tempo de prateleira e diminuir a quantidade de antioxidantes sintéticos estão sendo estudadas opções de embalagens ativas. Embora o grande interesse, existem apenas algumas opções de embalagem disponíveis comercialmente, o que pode ser atribuído às dificuldades na produção dos materiais ativos em escala industrial, à baixa 
PIRES, C. M. et.al.

eficiência da maioria dos materiais desenvolvidos em testes in vivo e à degradação de agentes ativos nos processos de extrusão (WRONA et al., 2017).

Um estudo para retardar a oxidação de gordura natural do salame utilizou um filme ativo de whey protein (isolado proteico do leite) incorporado com extrato de alecrim em embalagens de salame fatiado. Para o extrato de alecrim, $5 \mathrm{~g}$ de alecrim em pó seco foram misturados com $50 \mathrm{~mL}$ de etanol, que foi homogeneizado e evaporado. O filme de proteína de soro de leite foi composto por proteína de soro de leite, glicerol, extrato de alecrim e água ultrapura. O salame foi colocado com os dois lados em contato direto com o filme ativo e o controle (sem o extrato de alecrim), que foram armazenadas à vácuo por diferentes períodos $(0,7,15,30,60$ e 90 dias), protegidos de luz e na temperatura de $5^{\circ} \mathrm{C}$. Como indicador da oxidação lipídica, foram feitas a monitorização hexanal e ensaio TBARS. O outro teste utilizado foi análise sensorial. A embalagem ativa retardou a oxidação em 30 dias além de ter mantido a aparência do produto atraente. Mas, por outro lado, pôde-se perceber um sabor diferente no salame, um amargor que foi atribuído ao extrato de alecrim e um sabor um pouco doce relacionado ao whey e ao glicerol. As análises foram positivas, devendo apenas ser realizada uma análise sensorial mais completa, com maior número de provadores para verificar a aceitabilidade deste filme comestível no mercado (ANDRADE et al., 2019).

Para a embalagem de carne de porco moída fresca foi analisada a incorporação de extrato de chá verde na embalagem de polietileno incorporado em cápsulas inorgânicas ao material derretido e extrudado sem comprometer sua qualidade. Foram utilizadas amostras com $20 \%$ e $40 \%$ de cápsulas ativas e uma amostra sem as cápsulas com o extrato de chá verde, como amostra em branco. As análises foram feitas em triplicata utilizando os métodos DPPH e ensaio de capacidade de absorção de radical de oxigênio (ORAC), realizado pelo método otimizado para analisar a capacidade antioxidante da embalagem. As embalagens foram armazenadas em geladeira a $4{ }^{\circ} \mathrm{C}$ por 13 dias. Após 9 dias de experimento constatouse foi confirmada a liberação de uma pequena porção de agente ativo no nível de polietileno polietilo. A metamioglobina e avaliação sensorial foram significativamente melhores para carne de ambos os tipos de embalagem ativa em comparação com carne de embalagem da amostra sem o composto ativo. Constatou-se que o prazo de validade da carne de porco moída fresca foi estendido por 3 dias, comprovando a capacidade antioxidante da embalagem ativa (WRONA et al., 2017).

Dos Passos et al. (2019) avaliaram o uso de óleo de tomilho como antioxidante natural na maionese em substituição ao antioxidante sintético butilhidroxitolueno (BHT). O óleo de tomilho foi nanoencapsulado em poli $\varepsilon$-caprolactona (PCL) através de suspensão (NP-T) e 
PIRES, C. M. et.al.

foi utilizado uma nanocápsula composta apenas por PCL como amostra de controle (NP-C). O método de nanoprecipitação e o uso do PCL como material de parede proporcionaram nanopartículas contendo altos valores de óleo essencial de tomilho encapsulado com boa estabilidade física. As nanocápsulas foram aplicadas em amostras de maionese. Durante um período de oito dias, as amostras NP-T, NP-C e com antioxidante sintético foram analisadas periodicamente quanto ao valor de hidroperóxido (HP), por titulação e TBARS. Até o terceiro dia de armazenamento, não foram observadas diferenças significativas entre os valores de HP das três amostras. Após seis dias de armazenamento, a amostra sem adição de antioxidante (NP-C) continuou apresentando valores elevados de HP, indicando maior grau de oxidação lipídica enquanto os valores de HP para BHT e NP-T diminuíram. O mesmo ocorreu em relação à análise TBARS, em que as amostras sem antioxidante (NP-C) indicaram a ocorrência de maiores quantidades de malonaldeído. Concluindo que a amostra NP-T teve um desempenho semelhante ao antioxidante sintético BHT na prevenção da oxidação dos lipídios da maionese quanto aos resultados do valor do hidroperóxido (HP) e das substâncias reativas ao ácido tiobarbitúrico (TBARS).

\section{Considerações finais}

Através deste estudo foi possível concluir que a busca por antioxidantes naturais é uma demanda atual e em ascensão pela busca da substituição por antioxidantes sintéticos que não contribuem à saúde. Uma vez que os compostos bioativos advindos de substâncias naturais apresentam menor estabilidade diante a fatores adversos, as diferentes técnicas de encapsulação vêm sendo pesquisadas e cada vez mais aplicadas demonstrando ser uma importante alternativa para preservação destes compostos e facilitar sua aplicação em alimentos, alcançando resultados satisfatórios na preservação da oxidação lipídica. Diferentes técnicas podem ser aplicadas como técnicas físicas e químicas, e fatores como o material encapsulante, proporção, interação entre os polímeros, temperatura e pH devem ser pesquisados a fim de garantir maiores rendimentos e eficiência da encapsulação, além de ser possível projetar uma liberação controlada no alimento e no organismo. Atualmente, as técnicas de microencapsulação através do spray drying e coacervação complexa são as mais utilizadas, porém, técnicas de nanoencapsulação como as nanoemulsões recebem destaque pela possibilidade de maior controle na liberação do princípio ativo no alimento ou no organismo. 


\section{Referências}

ABURTO, L. C.; TAVARES, D. Q.; MARTICCI, T. Microencapsulação de óleo essencial de laranja. Ciência e Tecnologia de Alimentos, v. 18, n. 1, 1998.

ALADEDUNYE, FELIX ADEKUNLE. Natural antioxidants as stabilizers of frying oils. European Journal of Lipid Science and Technology, v. 116, n. 6, p. 688-706, 2014. DOI: 10.1002/ej1t.201300267.

ANDRADE, MARIANA A.; RIBEIRO-SANTOS, REGIANE; GUERRA, MANUELA; SANCHES-SILVA, ANA. Evaluation of the oxidative status of salami packaged with an active whey protein film. Foods, v. 8, n. 9, p. 1-15, 2019. DOI: 10.3390/foods8090387.

ASCHERI, DIEGO P. R.; MARQUEZ, MÁRCIA O. M.; MARTUCCI, ENNY T. Microencapsulação de óleo essencial de laranja: seleção de material de parede. Ciência e Tecnologia de Alimentos, v. 23, p. 1-6, 2003. DOI:10.1590/s0101-20612003000400002.

ASSIS, L. M.; ZAVAREZE, E. R.; PRENTICE-HERNANDEZ, C.; SOUZA- SOARES, L. A. Características de nanopartículas e potenciais de aplicações em alimentos. Brazilian Journal Food Technology, v. 15, n. 2, p. 99-109, 2012.

BALCÃO, VICTOR M.; COSTA, CARLA I.; MATOS, CARLA M.; MOUTINHO, CARLA G.; AMORIM, MANUELA; PINTADO, MANUELA E.; GOMES, ANA P.; VILA, MARTA M.; TEIXEIRA, JOSÉ A. Nanoencapsulation of bovine lactoferrin for food and biopharmaceutical applications. Food Hydrocolloids, v. 32, n. 2, p. 425-431, 2013. DOI: 10.1016/j.foodhyd.2013.02.004.

BAKRY, A. M.; ABBAS, S.; ALI, B.; MAJEED, H.; ABOUELWAFA, M. Y.; MOUSA, A.; LIANG, L. Microencapsulation of pila: a comprehensive review of benefits, techniques and applications. Comprehensive Reviews in Food Science and Food Safety, v. 15, n. 1, p. 143-182, 2015.

BAŞTÜRK, AYHAN; CEYLAN, MEHMET MURAT; ÇAVUŞ, MUSTAFA; BORAN, GÖKHAN; JAVIDIPOUR, ISSA. Effects of some herbal extracts on oxidative stability of corn oil under accelerated oxidation conditions in comparison with some commonly used antioxidants. LWT - Food Science and Technology, v. 89, p. 358-364, 2018. DOI: 10.1016/j.lwt.2017.11.005.

BERA, D.; LAHIRI, D.; NAG, A. Studies on a natural antioxidant for stabilization of edible oil and comparison with synthetic antioxidants. Journal of Food Engineering, v. 74, n. 4, p. 542-545, 2006. DOI: 10.1016/j.jfoodeng.2005.03.042.

BURGAIN, J.; GAIANI, C.; LINDER, M.; SCHER, J. Encapsulation of probiotic living cells: From laboratory scale to industrial applications. Journal of Food Engineering, v. 104, no. 4, p. 467-483, 2011. DOI 10.1016/j.jfoodeng.2010.12.031.

CHAKKARAVARTHI, S. Efficacy of free and encapsulated natural antioxidants in oxidative stability of edible oil: Special emphasis on nanoemulsion-based encapsulation. Trends in Food Science and Technology, v. 91, p. 305-318, 2019. DOI: 10.1016/j.tifs.2019.07.030.

CHAMPAGNE, CLAUDE P.; FUSTIER, PATRICK. Microencapsulation for the improved [631] 
delivery of bioactive compounds into foods. Current Opinion in Biotechnology, v. 18, n. 2, p. 184-190, 2007. DOI: 10.1016/J.COPBIO.2007.03.001.

CHOE, EUNOK; MIN, DAVID B. Mechanisms and factors for edible oil oxidation. Comprehensive Reviews in Food Science and Food Safety, v. 5, n. 4, p. 169-186, 2006.

DEANS, S. G.; RITCHIE, G. Antibacterial properties of plant essential oils. International Journal of Food Microbiology, v. 5, n. 2, p. 165-180, $1987 . \quad$ DOI: http://dx.doi.org/10.1016/0168-1605(87)90034-1.

DIAS, D.R.; BOTREL, D.A.; FERNANDES, R.V. Encapsulation as a tool for bioprocessing of functional foods. Current Opinion in Food Science, v.13, p. 31-37, 2017. DOI: 10.1016/j.cofs.2017.02.001.

DIMA, CRISTIAN; COTÂRLET, MIHAELA; ALEXE, PETRU; DIMA, STEFAN. Microencapsulation of essential oil of pimento [Pimenta dioica (L) Merr.] by chitosan/kcarrageenan complex coacervation method. Innovative Food Science \& Emerging Technologies, v. 22, p. 203-211, 2014. DOI: http://dx.doi.org/10.1016/j.ifset.2013.12.020.

DONG, ZHIJIAN; MA, YONG; HAYAT, KHIZAR; JIA, CHENGSHENG; XIA, SHUQIN; ZHANG, XIAOMING. Morphology and release profile of microcapsules encapsulating peppermint oil by complex coacervation. Journal of Food Engineering, v. 104, n. 3, p. 455460, 2011. DOI: 10.1016/j.jfoodeng.2011.01.011.

DOS PASSOS, RHAYSA BEATRIZ; BAZZO, GIOVANA CAROLINA; ALMEIDA, ALINE DA ROSA; NORONHA, CAROLINA MONTANHEIRO; BARRETO, PEDRO LUIZ MANIQUE. Evaluation of oxidative stability of mayonnaise containing poly $\varepsilon$ caprolactone nanoparticles loaded with thyme essential oil. Brazilian Journal of Pharmaceutical Sciences, vol. 55, p. 1-6, 2019. DOI: 10.1590/s2175-97902019000118177.

ENACHI, ELENA; BAHRIM, GABRIELA; RÂPEANU, GABRIELA; SILVI, STEFANIA; STĂNCIUC, NICOLETA. Functional evaluation of microencapsulated anthocyanins from sour cherries skins extract in whey proteins isolate. LWT v. 95, p. 129-134, 2018. DOI: 10.1016/j.lwt.2018.04.083.

GALLO, MONICA; FERRACANE, ROSALIA; NAVIGLIO, DANIELE. Antioxidant addition to prevent lipid and protein oxidation in chicken meat mixed with supercritical extracts of Echinacea angustifolia. The Journal of Supercritical Fluids, v. 72, n. 0, p. 198204, 2012. DOI: 10.1016/j.supflu.2012.08.006.

GOUIN, SÉBASTIEN. Microencapsulation: industrial appraisal of existing technologies and trends. Trends in Food Science \& Technology, v. 15, n. 7-8, p. 330-347, 2004. DOI: 10.1016/J.TIFS.2003.10.005.

GOLOWCZYC, MARINA A.; SILVA, JOANA; TEIXEIRA, PAULA; DE ANTONI, GRACIELA L.; ABRAHAM, ANALÍA G. Cellular injuries of spray-dried Lactobacillus spp. isolated from kefir and their impact on probiotic properties. International Journal of Food Microbiology, v. 144, n. 3, p. 556-560, 2011. DOI: 10.1016/j.ijfoodmicro.2010.11.005.

GÓMEZ, Belén; BARBA, Francisco J.; DOMÍNGUEZ, Rubén; PUTNIK, Predrag; BURSAĆ KOVAČEVIĆ, Danijela; PATEIRO, Mirian; TOLDRÁ, Fidel; LORENZO, Jose 
M. Microencapsulation of antioxidant compounds through innovative technologies and its specific application in meat processing. Trends in Food Science and Technology, v. 82, p. 135-147, 2018. DOI 10.1016/j.tifs.2018.10.006.

JAYATHILAKAN, K.; SHARMA, G. K.; RADHAKRISHNA, K.; BAWA, A. S. Effect of natural antioxidants on the lipid stability of fluidised bed-dried mutton. Food Chemistry, v. 100, n. 2, p. 662-668, 2007. DOI: 10.1016/j.foodchem.2005.09.083.

KRISHNAN, S.; BGOSALE, R.; SINGHAL, R. S. Microencapsulation of cardamomo oleoresin: Evaluation of blends of gum arabic maltodextrina and a medições starch as wall materials. Carbohydrate Polymers, v. 61, n. 1, p. 95- 102, 2005 . DOI: 10.1016/j.carbpol.2005.02.020

LIDERT, ZEV. MICROENCAPSULATION: AN OVERVIEW OF THE TECHNOLOGY LANDSCAPE. IN: ROSEN, MEYER R. Delivery System Handbook for Personal Care and Cosmetic Products. Norwich, NY: William Andrew Publishing, 2005. p. 181-190. DOI: 10.1016/B978-081551504-3.50013-4.

LING, T. Oxidation of polyunsaturated fatty acids and its impact on food quality and human health. Advances in Food Technology and Nutritional Sciences, v. 1, n.6, p. 135-142, 2015. DOI: 10.17140/AFTNSOJ-1-123.

LORENZO, J. M.; MUNEKATA, P. E. S.; GÓMEZ, B.; BARBA, F. J.; MORA, L.; PÉREZSANTAESCOLÁSTICA, C.; TOLDRÁ, F. Bioactive peptides as natural antioxidants in food products - A review. Trends in Food Science and Technology, v. 78, p. 136-147, 2018. DOI: 10.1016/j.tifs.2018.07.003.

MARTÍN, MARÍA JOSÉ; LARA-VILLOSLADA， FEDERICO; RUIZ, MARÍA ADOLFINA; MORALES, MARÍA ENCARNACIÓN. Microencapsulation of bacteria: A review of different technologies and their impact on the probiotic effects. Innovative Food Science \& Emerging Technologies, v. 27, p. 15-25, 2015. DOI: /10.1016/j.ifset.2014.09.010.

NAZZARO, FILOMENA; ORLANDO, PIERANGELO; FRATIANNI, FLORINDA; COPPOLA, RAFFAELE. Microencapsulation in food science and biotechnology. Current Opinion in Biotechnology, v. 23, n. 2, p. 182-186, 2012. DOI 10.1016/j.copbio.2011.10.001.

NUNES, G. L. N.; SILVA, T. M.; HOLKEM, A. T.; SCHLEY, V.; MENEZES, C. R.. Microencapsulação de culturas probióticas: princípios do método de spray drying. Ciência e Natura, v. 37, p. 132-141, 2015. DOI: 10.5902/2179-460X19742

OANCEA, A.; HASAN, MAHADI; VASILE, AIDA MIHAELA; BARBU, VASILICA; ENACHI, ELENA; BAHRIM, GABRIELA; RÂPEANU, GABRIELA; SILVI, STEFANIA; STĂNCIUC, NICOLETA. Functional evaluation of microencapsulated anthocyanins from sour cherries skins extract in whey proteins isolate. LWT, v. 95, p. 129-134, 2018. DOI: 10.1016/j.lwt.2018.04.083.

OHLSSON, THOMAS; BENGTSSON, NILS. Minimal processing technologies in the food industries: Woodhead Publishing, 2002. 
OZKAN, G et al. A review of microencapsulation methods for food antioxidante: principles, advantages, drawbacks and applications. Food Chemistry, p. 494 - 506, 2019. DOI: 10.1016/j.foodchem.2018.07.205.

PEREIRA, K. C.; MOTA-FERREIRA, D. C.; ALVARENGA, G. F.; SALVADOR P.; SANTANA, M.; SOUTO B. M. C.; GOMES, C. J. M.. Microencapsulation and release controlled by the diffusion of food ingredients produced by spray drying: A review. Brazilian Journal of Food Technology, vol. 21, 2018. DOI:10.1590/1981-6723.08317.

PLESSAS, S.; BOSNEA, L.; ALEXOPOULOS, A.; BEZIRTZOGLOU, E. Potential effects of probiotics in cheese and yogurt production: A review. Engineering in Life Sciences, v. 12, p. 433-440, 2012. DOI: 10.1002/elsc.201100122.

REBELLO, F. F. P. Microencapsulação de ingredientes alimentícios. Revista Agrogeoambiental, v. 1, n.3 2009. DOI: 10.18406/2316-1817v1n32009223

RIBEIRO, J. S.; SANTOS, M. J. M. C.; SILVA, L. K. R.; PEREIRA, L. C. L.; SANTOS, I. A.; DA SILVA, L., SUZANA, C.; DA SILVA, M. V.. Natural antioxidants used in meat products: A brief review. Meat Science, v.148, p. 181-188, 2019. DOI: 10.1016/j.meatsci.2018.10.016.

ROSENBERG, M.; YOUNG, S. Whey proteins as microencapsulating agents. Microencapsulation of anhydrous milk fat-structure evaluation. Food Structure, v. 12, p. 31-41, 1993. DOI: 10.3168/jds.S0022-0302(93)77625-0.

ROSSO, A. C.; KUZNIEWSKI, F. C.; GRIESANG, J. I.; BERTOLDO, V.; CRISTINA; OLIVEIRA, M. S.; SEVERO, J.. Boletim Técnico-Científico| Boletim Técnico-Científico, v. 5 n. 2, 2019. Disponível em: http://periodicos.iffarroupilha.edu.br/index.php/boletimtecnico-cientifico/issue/view/Boletim Técnico-Científico.

SHAHIDI, F.; HAN, X. Encapsulation do food ingredients. Critical Reviews in Food Science and Nutrition, v. 33, n.6, p. 501-547, 1993.

SANTOS, A. B. FAVARO-TRINDADE, C. S.; GROSSO, C. R. F. Preparo e caracterização de microcápsulas de oleoresina de páprica obtidas por atomização. Ciência e Tecnologia de Alimentos., v. 25, n. 2, p. 322- 326, 2005. DOI: 10.1590/S0101-20612005000200024.

SILVA, C.; RIBEIRO, A.; FERREIRA, D.; VEIGA, F. Administração oral de proteínas é peptídeos: II. Aplicação de métodos de microencapsulação. Brazilian Journal of Pharmaceutical Sciences, v. 39, n. 1, p. 1-9, 2003. DOI: 10.1590/S151693322003000100002.

SHAHIDI, FEREIDOON; HAN, XIAO QING. Encapsulation of Food Ingredients. Critical Reviews in Food Science and Nutrition, v. 33, no. 6, p. 501-547, 1993. DOI: $10.1080 / 10408399309527645$.

SHARMA, S.; CHENG, S. F.; BHATTACHARYA, B.; CHAKKARAVARTHI, S. Efficacy of free and encapsulated natural antioxidants in oxidative stability of edible oil: Special emphasis on nanoemulsion-based encapsulation. Trends in Food Science and Technology, v. 91, p. 305-318, 2019. DOI: 10.1016/j.tifs.2019.07.030.

SILVA, C.; RIBEIRO, A.; FERREIRA, D.; VEIGA, F.. Administração oral de peptídeos e 
proteínas: II. Aplicação de métodos de microencapsulação. Revista Brasileira de Ciências Farmacêuticas, v. 39, p. 1-20, 2003. DOI: 10.1590/s1516-93322003000100002.

SOBEL, R.; VERSIC, R.; GAONKAR, A. G.. Introduction to Microencapsulation and controlled delivery in foods. Microencapsulation in the Food Industry, 2014. p. 3-12. DOI:10.1016/B978-0-12-404568-2.00001-7.

SOUZA, A. L. R.; HIDALGO-CHAVEZ, D. E.; PONTES, S. M. GOMES, F. S., CABRAL, L. M. C.; TONON, R. V. Microencapsulation boy spray drying of a lycopene-rich Tomato concentrate: characterization and stability. Lebensmittel- wissenschaft technologie, v. 91, p. 286-292, 2018.

TAGHVAEI, MOSTAFA; JAFARI, SEID MAHDI. Application and stability of natural antioxidants in edible oils in order to substitute synthetic additives. Journal of Food Science and Technology, v. 52 p. 1272-1282, 2015. DOI: 10.1007/s13197-013-1080-1.

VASISHT, NIRAJ. Selection of Materials for Microencapsulation. Microencapsulation in the Food Industry, 2014. p. 173-180. DOI: 10.1016/B978-0-12-404568-2.00016-9.

WANG, C.; WANG, H.; LI, X.; ZHANG, C.. Effects of oxygen concentration in modified atmosphere packaging on water holding capacity of pork steaks. Meat Science, v. 148, p. 189-197, 2019. DOI: 10.1016/j.meatsci.2018.10.001.

WEISS, J.; GIBIS, M.; SCHUH, V.; SALMINEN, H.. Advances in ingredient and processing systems for meat and meat products. Meat Science, v. 86, n. 1, p. 196-213, 2010. DOI: 10.1016/j.meatsci.2010.05.008.

WRONA, M.; NERÍN, C.; ALFONSO, M. J.; CABALLERO, M. A.. Antioxidant packaging with encapsulated green tea for fresh minced meat. Innovative Food Science and Emerging Technologies, v. 41, p. 307-313, 2017. DOI 10.1016/j.ifset.2017.04.001.

DIMA, C.; PĂTRAŞCUA, L.; CANTARAGIU, ; PETRU, A.; ŞTEFAN, D.. The kinetics of the swelling process and the release mechanisms of Coriandrum sativum L. essential oil from chitosan/alginate/inulin microcapsules. Food Chemistry v. 195, p. 39-48, 2016. DOI: 10.1016/j.foodchem.2015.05.044. 


\title{
CAPTHER 42: NANO-DELIVERY SYSTEMS OF PESTICIDES ACTIVE AGENTS FOR AGRICULTURE APPLICATIONS - AN OVERVIEW
}

\author{
Carlos Rafael Silva de Oliveira' ${ }^{1}$; Jéssica Mulinari²; Francisco Wilson Reichert Júnior ${ }^{3}$; Afonso Henrique da \\ Silva Júnior ${ }^{4}$
}

\begin{abstract}
Agricultural protection agents used in soil and crops, when applied conventionally, may have their activity impaired against pests and vectors due to their volatilization, photodegradation, leaching, and other unwanted occurrences caused by weather conditions. These problems cause economic and environmental damage due to the high volume of applications necessary for the farmer to achieve the desired results. The indiscriminate use of free pesticides causes high environmental pollution because these compounds are cumulative in soil, water and vegetation, sometimes causing air contamination, which can cause health issues in local workers and the death of animals. In contrast, nanopesticides are an alternative emerging technology that allows the controlled release of active compounds, improving pest control performance and turning it more sustainable and in line with the concept of precision agriculture. The use of nano-delivery systems for pesticide agents uses nanostructures capable of altering the release kinetics of these compounds, providing the plantation with an adequate amount for pest elimination. This paper presents an overview of nanopesticides, addresses some current concepts of sustainability, reviews and analyzes the latest developments regarding these nanomaterials, and provides an update on their advantages and disadvantages.
\end{abstract}

Keywords: nanopesticides, controlled release, precision agriculture, emerging technologies, sustainable agriculture.

\section{Introduction}

Pesticides are a group of chemical compounds widely used in agriculture for pest control (Chart 1). Without them, crops would be devastated by opportunistic organisms that would eliminate or limit food production on a large scale (BAPAT et al., 2016; CAROLIN et al., 2020). Pesticide agents play a fundamental role in maintaining agricultural production, however, their indiscriminate use, in addition to being dangerous to the health of rural workers, can be highly harmful to the environment causing damage to the local biome and even to the soil (AKTAR; SENGUPTA; CHOWDHURY, 2009; CAROLIN et al., 2020).

\footnotetext{
${ }^{1}$ Textile Engineer (State University of Maringá - UEM), Master in Chemical Engineering (Federal University of Santa Catarina - UFSC), PhD student in Chemical Engineering (Federal University of Santa Catarina - UFSC), carlos.oliveira@posgrad.ufsc.br

${ }^{2}$ Environmental and Sanitary Engineer (Federal University of Fronteira Sul - UFFS), Master in Chemical Engineering (Federal University of Santa Catarina - UFSC), PhD student in Chemical Engineering (Federal University of Santa Catarina - UFSC), jessicamulinari15@gmail.com

${ }^{3}$ Agronomist (Federal University of Fronteira Sul - UFFS), Master in Environmental Science and Technology (Federal University of Fronteira Sul - UFFS), PhD student in Plant Genetic Resources (Federal University of Santa Catarina UFSC), chicowrj@gmail.com

${ }^{4}$ Agro-industrial Engineer (Federal University of Rio Grande - FURG), Master student in Chemical Engineering (Federal University of Santa Catarina - UFSC), afonso.ufsc@ gmail.com
}

[636] 
Chart 1. Classification of pesticides most used in agriculture, their target organisms, and some examples of products used in the field.

\begin{tabular}{|l|l|l|}
\hline \multicolumn{1}{|c|}{ Function } & Target organism & \multicolumn{1}{c|}{ Compound examples } \\
\hline Acaricide & Mites and ticks & Dicofol, Carbamate, DDT, organophosphates \\
\hline Algicide & Algae & Simazine, Dichlone, Benzalkonium chloride \\
\hline Fungicide & Fungi & Metalaxyl, Hexaconazole, Cymoxanil \\
\hline Herbicide & Weeds & Atrazine, Paraquat, Oxadiazon, Linuron \\
\hline Insecticide & Insects & DDT, Lindane, Thiacloprid, Clothianidin, Endosulfan \\
\hline Nematicide & Nematodes & Fenamiphos, Methyl bromide, Chlorpyrifos \\
\hline Rodenticide & Rats & $\begin{array}{l}\text { Zinc phosphide, Bromadiolone, Coumachlor, Coumatetralyl, } \\
\text { Warfarin }\end{array}$ \\
\hline Synergists & Several pests & Piperonyl butoxide \\
\hline
\end{tabular}

Source: Adapted from (SHARMA et al., 2020)

Research has shown that the number of bee colonies in the USA on agricultural land decreased from 4.4 million to 1.9 million between 1985 and 1997, due to the direct and indirect effects of pesticides, capable, for example, of weakening the immune system of bees against natural diseases and mites (HORRIGAN; LAWRENCE; WALKER, 2002). In the province of Quebec in Canada, a study on the Saint-Laurent River correlated problems in the development of local amphibious life with the presence of pesticides in the water, including body deformities, such as the growth of extra legs in places such as the abdomen and back and poorly developed limbs (OUELLET et al., 1997). Other studies have shown immune system impairment in dolphins, seals, and whales exposed to contaminated waters. In humans, direct exposure to organophosphate pesticides can lead to the appearance of lymphomas (KOUTROS et al., 2019). Organochlorine pesticides are highly carcinogenic and generate oxidative stress and mitochondrial cell malfunction (SCHMIDT et al., 2017), while carbamates lead to apoptosis (cell self-destruction) and the development of tumor cells in the central nervous system (PIEL et al., 2019). The widespread and poorly administered use of pesticides has increased the resistance of certain plant species to herbicides. Approximately 262 weed species (152 dicots and 110 monocots) are no longer responding to conventional herbicide active principles attacks worldwide. Currently, 513 unique cases in the world have been reported in 92 cultures in 70 countries according to Heap (2020).

The pesticide compounds, when applied conventionally, are released into the environment, directly reaching the soil, plants, water sources, and/or nearby vegetation, part of which are volatilized, contaminating the air, as shown in Figure 1. Until they reach the target 
(pests), pesticides find these barriers where they are retained and accumulated, thus requiring greater frequency and volume/concentration of application so that they can protect the crop at the expense of environmental poisoning (KUMAR et al., 2019).

Figure 1. Schematic illustration of possible routes of environmental contamination caused by the conventional application of pesticides.

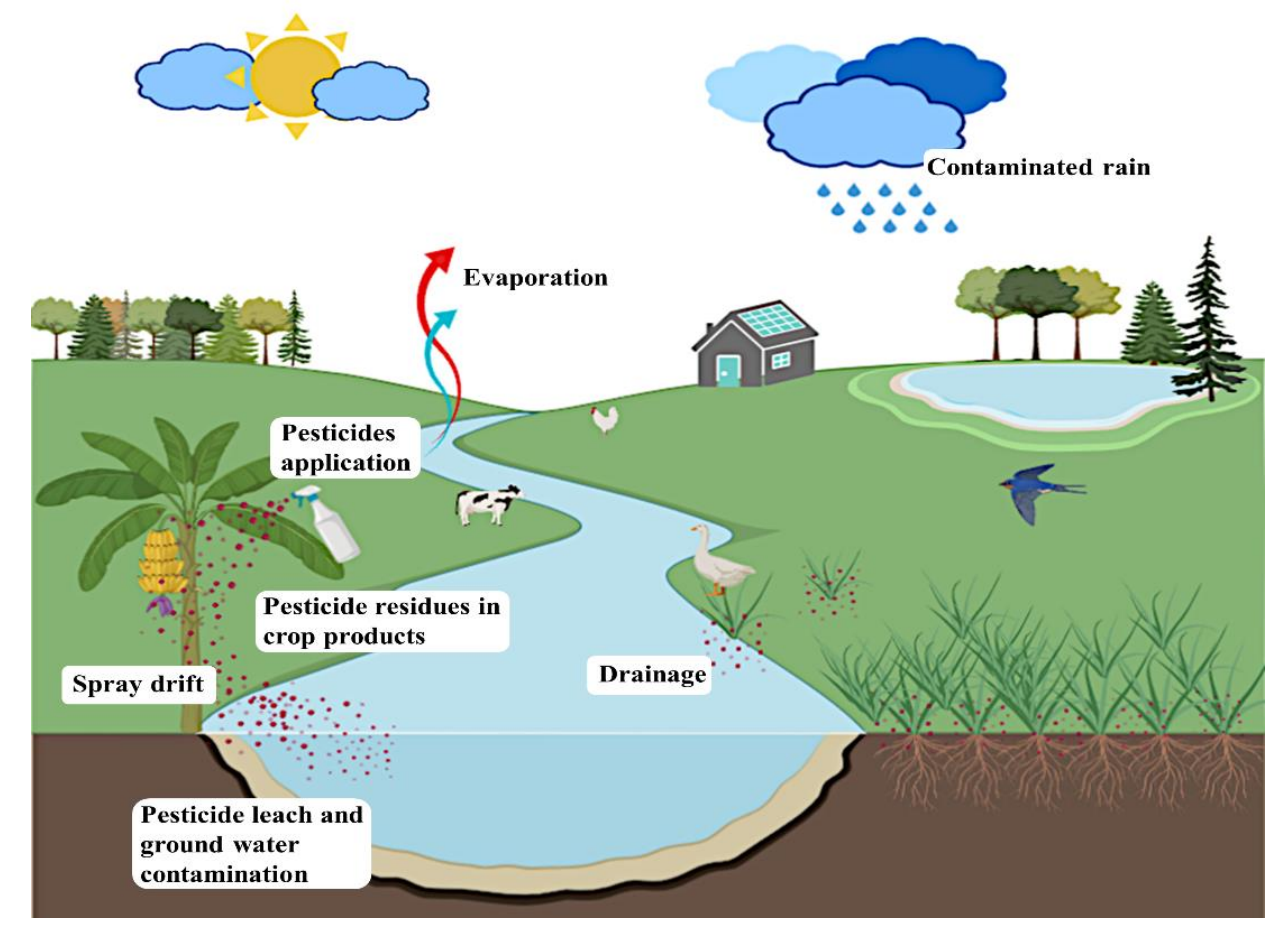

Source: Authors.

Considering that commercial pesticide formulations when applied conventionally, require large volume and frequency of applications to combat pests with unwanted environmental accumulation, the good use of pesticide agents applied to the field has become the main issue when it comes to optimizing a more safe and conscious agricultural production. It is estimated that for all pesticides applied to crops, only about $0.1 \%$ reach the target pests, leaving $99.9 \%$ of these chemical agents accumulated in the environment, raising serious environmental issues (HORRIGAN; LAWRENCE; WALKER, 2002; PIMENTEL, 2009).

In 2024 it is estimated that the global population will reach 8 billion inhabitants (ROSER; RITCHIE; ORTIZ-OSPINA, 2013). Population growth triggers an increase in the demand for food, and therefore it is safe to say that the current farming system, which is already considered unsustainable, will become unbearable if it keeps the same growth rate. The growth of the pesticide market is evident, the global pesticide market moved around $\$ 32$ billion in [638] 
2007, $\$ 56$ billion in 2012, movements of around $\$ 71$ billion are expected in 2021, and it is estimated that between 2025 and 2026 it will exceed \$100 billion (CPCM, 2016; SHARMA et al., 2017; TILMAN et al., 2001). The high discharge of pesticides into nature has bioaccumulative effects, which is why global research efforts on the use of these substances in the field are almost always to reduce the quantities of products applied without causing financial losses and reduced productivity (LECHENET et al., 2017).

Among the most promising scientific fields is nanotechnology, which has the potential to allow, at the same time, reduced use of pesticides, increased inhibition of pests in crops, increased or maintained production levels and less exposure of users to active agents during pesticides application (IRFAN et al., 2018). Since 2003, nanotechnology has been introduced in the agricultural and food industries. Initially, its applications were in food preparation and conservation, monitoring and sensing of environments and improvement of animal feed, however, it has advanced to applications in the field in the search for increased productivity through the use of nanofertilizers. More recently, it has advanced in combating pests and environmental protection with the use of nanopesticides and nanoparticles for the extraction, detection, and degradation of pesticides accumulated in the soil (BAPAT et al., 2016; HE; DENG; HWANG, 2019).

Concerns about the environment led science to find more sustainable alternatives for the application of agrochemicals in the environment, from these needs the concept of precision agriculture was originated. Precision agriculture is an innovation that follows three principles: (i) economic viability; (ii) profitability with increased production; and (iii) reduction in environmental impacts; it is recognized as a management strategy that uses information technology capable of providing accurate data for decisions associated with production in the field (ALLAHYARI; MOHAMMADZADEH; NASTIS, 2016; MONDAL; BASU, 2009; ZHANG; WANG; WANG, 2002). Nanotechnology is a tool that can improve the delivery systems of agrochemicals in cultivations in a controlled way, and also monitor the needs of the culture regarding the control of nutrients and pests through nanosensors, capable of feeding information to a system of agricultural management. Precision agriculture has spread rapidly in developed countries, research in the area began in the USA, Canada, Australia and Western Europe in the 1980s and is now worldwide (ALLAHYARI; MOHAMMADZADEH; NASTIS, 2016; MONDAL; BASU, 2009; ZHANG; WANG; WANG, 2002).

Nanostructured systems can be used as carriers of active compounds, maintaining their chemical stability against the effects of oxidation, humidity and other environmental factors, in 
addition to allowing their release into the environment in a controlled, continuous and prolonged manner (IRFAN et al., 2018). In this case, these nanometric supports doped with pesticide agents act as nano-delivery systems and can be called nanopesticides. The phenomenon of delivery of compounds in-situ occurs by mass transfer, the actives contained within the nanoparticulate support migrate by diffusion from the nucleus to the shell and, when in contact with the external environment, they can reach local pests through optimization of targeted delivery of compounds to specific target sites (ABRAHAM; PILLAI, 1996; CHEN et al., 2008; IRFAN et al., 2018; NI et al., 2011).

Generally, nano-delivery supports are prepared from biodegradable polymers such as polysaccharides (cyclodextrins, chitosan, xanthan and carboxymethylcellulose), alginic acids used to release herbicides, natural polypeptides (collagen, gelatines and amino acids), poly(lactic acid) (PLA), poly(glycolic acid) (PGA), poly(e-caprolactone) (PCL), bacterial polyesters such as polyhydroxyalkanoates (PHAs), poly( $\beta$-hydroxybutyrate) $(\mathrm{PHBs}), \operatorname{poly}(\beta-$ hydroxy-valerate) (PHV), and poly(hydroxybutyrate-co-valerate) (PHB-V), among others (DE OLIVEIRA et al., 2019; FRANCHETTI; MARCONATO, 2006; GRILLO et al., 2014; KUMAR et al., 2015; MARUYAMA et al., 2016; OLIVEIRA et al., 2018). For the reasons stated above, nanopesticides are seen as a promise of advancing agricultural technologies to make products that are less polluting, safer and more effective.

Based on the issues discussed above, the present work consists of an overview of the nano-delivery systems of active pesticide compounds used in agriculture, addressing topics related to the methods of obtaining, mechanism of action, advantages and disadvantages of these nanomaterials. Since the subject of this review is a novelty and there are few studies related to the theme in the literature, this work also sought to address current developments in the sector that may gather important information for professionals and scholars in the field.

\section{Nano-delivery systems (nanocarriers) of pesticide agents}

Conventional distribution systems are important for the application of pesticides in agriculture, these systems need to focus on improving product efficiency and managing spray diversion. A promising alternative for solving these problems is the adequate use of controlled delivery systems. The controlled delivery technique consists of releasing the pesticide compounds in adequate quantities, according to the needs of the crop, without exceeding the sufficient amounts of agrochemicals that the crop needs to overcome the target pest (TSUIJI, 2001). 
Nanotechnology has been widely considered in the adaptation and updating of conventional systems for the application of agrochemicals in the environment, searching for the global consolidation of precision agriculture (MA, 2019). Nanotechnology is the scientific and technological knowledge that uses, develops, studies, controls and/or applies materials of the order of nanometers, which structure has a diameter or at least one of its dimensions in the order of $100 \mathrm{~nm}$ or less, called nanomaterials (AUFFAN et al., 2009). Nanostructured systems can consist of nanoparticles (nanocapsules, nanospheres, nanocrystals, nanocomposites, nanotubes, nanoneedles, etc.), micro/nanoemulsions, fullerenes and biomimetic systems, which make up a wide subject to be explored in the agricultural area (GHORMADE; DESHPANDE; PAKNIKAR, 2011), as illustrated in Figure 2.

Figure 2. Some types of nanomaterials used to combat pests in agriculture.

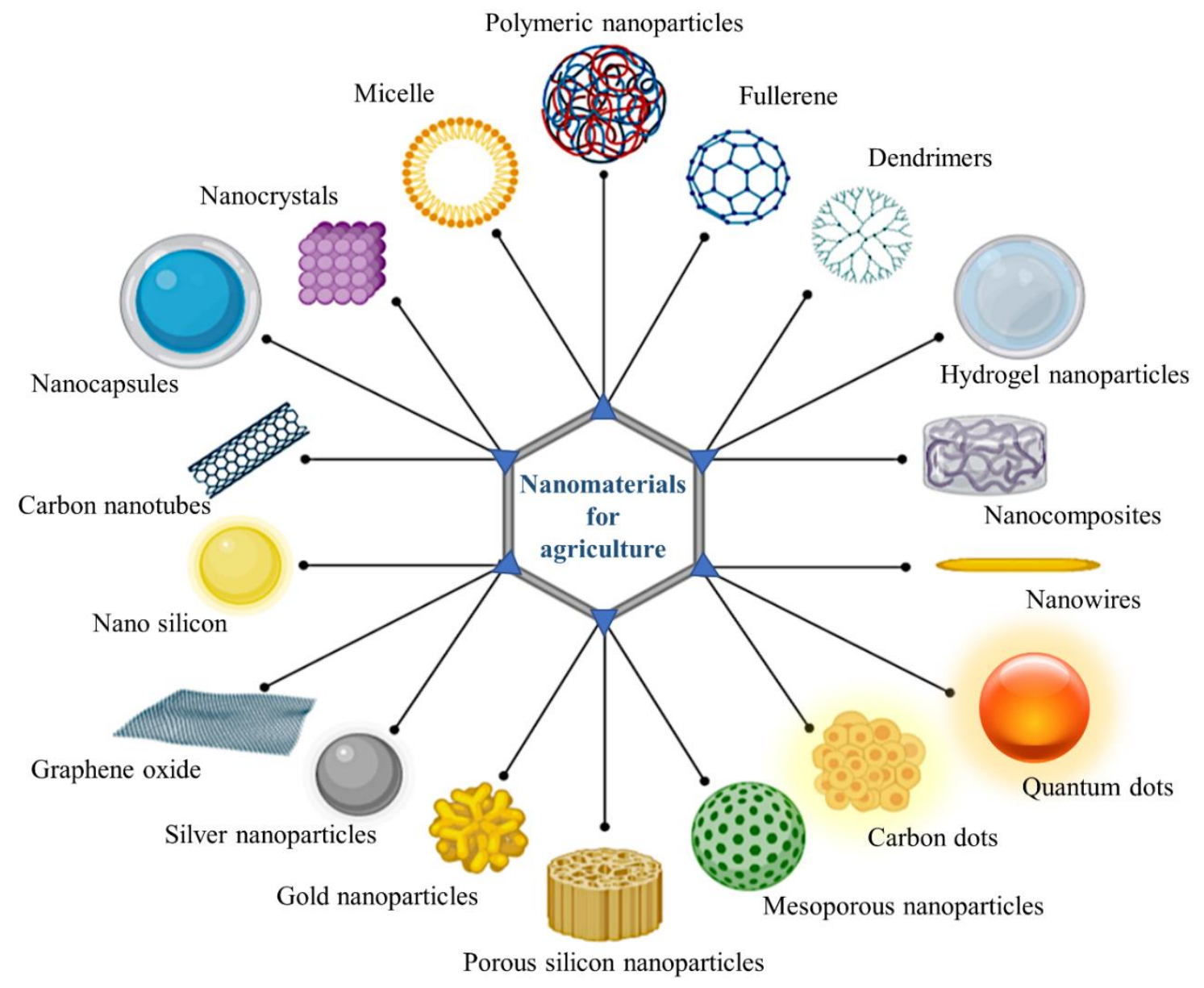

Source: Authors. 
Nanomaterials in agriculture can be used for crop protection (nanopesticides), plant nutrition (nanofertilizers), management of agricultural practices (nano[bio]sensors) and remediation (pollutant remediation nanostructured systems) (GHORMADE; DESHPANDE; PAKNIKAR, 2011). Nanostructured systems can act as transport agents for chemical compounds for cultivation, which deliver/release these substances in a slow and controlled manner, due to their small size, high surface/volume ratio, packaging of actives in a core-shell diffusion system and unique optics properties.

Several scientific researches have proven that the use of nanostructures containing active compounds behave as excellent controlled release systems for these actives. Research with particles considered to be micrometric $(10-100 \mu \mathrm{m})$, sub-micrometric $(1-10 \mu \mathrm{m})$ and nanometric $(<1 \mu \mathrm{m})$ used as support for controlled delivery of agrochemicals reported that the nanometric ones have advantages over the others because they have greater surface area per unit volume, easy fixation and accelerated mass transfer (GHORMADE; DESHPANDE; PAKNIKAR, 2011). Several materials can be used as nanoparticles or compose nanostructured systems for applications in the field such as quantum dots, metal oxides, biopolymers (synthetic or natural), clay minerals, emulsions, lipids, peptides, dendrimers, among others (PUOCI; et al., 2008).

\section{Mechanisms of action and release of active compounds}

For a chemical product of crop protection to be successful, it must remain active in the environment regardless of weather (cold, rain, heat, sun, etc.) as well as reach and penetrate the target organism (insects, phytopathogens, etc.). It must also resist the defense mechanisms of the pest, must be benign to the soil and the cultivation, inactive in non-target organisms, have profitable manufacture and offer good economic return (SMITH; EVANS; EL-HITI, 2008).

In addition to transport vehicles, nanocarriers in many cases act as a protective container for active components against adverse external conditions (high temperature, radiation, high humidity, oxidation, among others), increasing their physical and chemical stability. The nanodelivery systems must follow an intelligent principle of controlled release of the chemical compound at the destination site in a manner appropriate to the specific needs (COOPER, 2010; FLORES-CÉSPEDES et al., 2015; MARUYAMA et al., 2016). The main functions of the nanocarriers, in this case, are (i) to retain/protect the active compounds without release or loss before they reach the target; (ii) to improve the dissolution of the compounds when they reach the target, for example, improving the penetration in the plant tissues of the weeds; and (iii) to 
change/control the active release functions in neighboring environments. These functions depend directly on the size, shape, and material from which the nanocarrier is made (COOPER, 2010; FLORES-CÉSPEDES et al., 2015; MARUYAMA et al., 2016).

Various materials can be applied in the preparation of nanopesticides: from polymers (natural and synthetic), waxes/lipids, proteins/peptides to oxides and clay minerals (IRFAN et al., 2018; LI et al., 2007). The geometry of the nanostructures is related to the surface area per unit of volume, and therefore the shape of the nanocarrier is extremely important in defining the release and protection profile of the actives. These nanomaterials can be designed for (i) slow-release; (ii) quick release; (iii) selective release; (iv) moisture release; (v) release by heat; (vi) release by $\mathrm{pH}$; (vii) release by ultrasound; (viii) magnetic release; and (ix) release by DNA profile (LI et al., 2007).

Polymeric nanocapsules are the supports most commonly used as nanocarriers, mainly biodegradable polymers such as chitosan, alginate, gelatin, collagen, carboxymethylcellulose, polyethylene glycol (PEG), among others (KUMAR et al., 2018; RANI et al., 2017). Nanocapsules consist of a shell or membrane structure that surrounds the active compound and retains it in its core. Numerous factors can interfere with the delivery mechanisms of the nanocapsules, in general, the release occurs through the diffusion of the active compound contained in the nucleus through the polymeric membrane until it reaches the shell (surface), where it is finally exposed to different stimuli from the external environment (IRFAN et al., 2018). Some of the important factors that can significantly affect the controlled release mechanism of these nanostructures include the mechanical properties and level of biodegradability of the coating material, the thickness of the coating, the density of the actives, the physiology and water content of the soil (IRFAN et al., 2018). The complexity of the phenomena can include the transport of water through the coating, the condensation of water in the nucleus of the nanocapsule, the development of osmotic pressure, the dilution of the active compounds, the swelling of the granule, the modification of the micropores, among others (IRFAN et al., 2018).

In addition to the general mechanisms for releasing active compounds from their matrices, different strategies for applying these nanostructures can also be studied to improve the effectiveness of pest control in situ. Sharma et al. (2017) synthesized copper selenide nanoparticles decorated in graphene nanoparticles doped with chlorpyrifos (insecticide) for foliar application in vegetable culture. The authors developed a hydrophobic material with adhesive properties, which when applied to the leaves do not leach easily with rain. When the 
nanomaterial applied to the leaves comes in contact with the body of the larvae of Pieris rapae (worm), the nanopesticide adhere to the insect and slowly poison it until its death. The authors report that graphene acts as an adhesion support, while the pesticide agent acts by poisoning the animal organism. Copper selenide nanoparticles act in three ways: poisoning when ingested by the insect, assisting the daytime release of the insecticidal compound due to its photothermal activity, and helping in the degradation of the pesticide that remains in the leaves left in the field after the time of cultivation. The authors reported that the nano-support developed showed resistance to bad weather, controlled release, and increased larval mortality by more than $35 \%$.

The release of agrochemicals from a colloidal nanoparticle system is similar to that of other active compounds released from nanostructures. The delivery of pesticide agents incorporated and/or adsorbed on nanocarriers can occur through different mechanisms, among which it is possible to mention the release by (i) diffusion; (ii) dissolution; (iii) erosion; (iv) fragmentation; and (v) swelling, which may occur alone or together (BAKER, 1987; LIECHTY et al., 2010; PEPPAS et al., 2000), as shown in Figure 3.

Figure 3. Some of the most common mechanisms for releasing active compounds from nanocarriers.

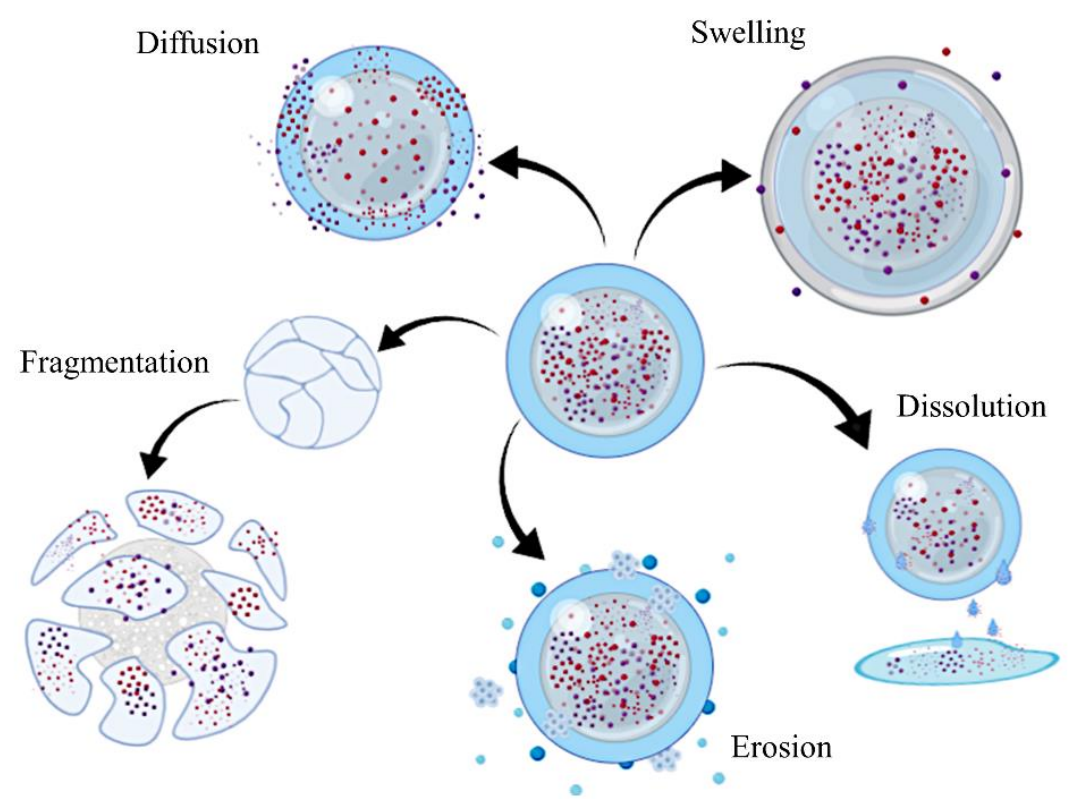

Source: Authors.

\section{Diffusion}

In this case, the release of the active compound (solute) occurs by molecular diffusion, through the matrix (support). The particle matrix can remain intact or with few changes [644] 
throughout the diffusion process, or it can undergo considerable changes due to its dissolution/fragmentation, for example (MCCLEMENTS, 2017). In this mechanism, the release rate of the actives depends on several factors, such as the chemical properties of the solute (polarity, molecular weight, volatility, among others), physical-chemical properties of the matrix (density, rheology, polarity, physical state, cross-linking state, and others), the physical characteristics of the particle (size, shape, crystallinity, etc.) and the gradient of contraction of the solute through the matrix in the core-shell direction (BAKER, 1987; LIECHTY et al., 2010; PEPPAS et al., 2000).

\section{Dissolution}

This active delivery/release mechanism occurs when the nanostructure comes in contact with specific environmental solutions or conditions capable of causing its dissolution (BAKER, 1987; MCCLEMENTS, 2017). In cases where the nanocarrier is the active compound itself, its release occurs in the medium as it dissolves. When the matrix is soluble, the active agent contained within it is released as the carrier matrix dissolves. In these cases, the release rate of the actives depends on the particle composition and the magnitude, the type and the duration of the environmental conditions that cause the dissolution (temperature, $\mathrm{pH}$, ionic strength, humidity, etc.) (BAKER, 1987; LIECHTY et al., 2010; PEPPAS et al., 2000).

\section{Erosion}

In this case, the pesticidal compounds are released as the carrier matrix erodes due to specific environmental conditions. Erosion is a process of molecular chemical degradation of the matrix, which can occur in mass (in the whole particle) or only on the surface (outside the particle). Erosion is a phenomenon that can occur due to chemical (e.g. $\mathrm{pH}$ or the presence of strong acids/bases), physical (e.g. high/low temperature), and/or biological factors (e.g. enzyme action) (MCCLEMENTS, 2017). In this type of mechanism, the release rate depends on the speed and the erosion profile. For this mechanism, as well as for the others, other phenomena can occur simultaneously, for example, secondary processes of fragmentation and dissolution can interfere in the main erosion process, in which case the release rate will be influenced by these additional variables (BAKER, 1987).

\section{Fragmentation}


In this case, the release of pesticide actives is dependent on the fragmentation rate of the carrier matrix. Fragmentation is a process in which the nanostructure acquires fractures caused by physical disturbances of climatic, mechanical, chemical, physical, or enzymatic origin (BAKER, 1987). Due to the stresses suffered, the cracked nanostructure starts to fragment, pieces are loosened and released continuously in the medium in smaller and smaller sizes until complete degradation (BAKER, 1987; MCCLEMENTS, 2017).

\section{Swelling}

This mechanism includes the system for releasing actives that occur from the swelling of the matrix, caused by solvents and environmental conditions. In this case, the particles find favorable conditions for their swelling in the environment in which they are exposed. The swelling of the particles occurs due to an increase in the internal pore size. When the pore size reaches a value similar to the molecular size of the active compound, it becomes an escape route for this compound to the external environment. In this mechanism, the pesticide release rate will depend mainly on the swelling rate and the diffusion time through the matrix (BAKER, 1987; LIECHTY et al., 2010; PEPPAS et al., 2000).

\section{Developments, applications and results: some current approaches}

This section presents an update on new developments in the field of nano-based agricultural protection, in which some works were briefly presented. Table 2 shows some relevant research carried out in the last 5 years, in which the authors developed, applied, and evaluated the use of nano-delivery systems (nanocarriers) of pesticide agents for agriculture.

Maghsoudi and Jalali (2017) investigated the performance of graphene oxide nanosheets as photoprotectors of Bacillus thuringiensis against solar UV radiation. $B$. thuringiensis is a gram-positive spore-forming bacterium widely used in crops as a biopesticide since the 1940s. Although ecologically correct, the effectiveness of this bacterium in combating pests is sometimes impaired due to its low stability to environmental factors, such as natural UV radiation that is capable of causing its death. The team tested the larval resistance for $96 \mathrm{~h}$ under radiation in the isolated presence of graphene oxide, olive oil, olive oil mixed with graphene oxide, and free spores. The authors observed that larval mortality was $56 \%, 47 \%$, $69 \%$, and $40 \%$, respectively, indicating that graphene oxide and olive oil achieved better results 
when applied together. The authors also mentioned that the results found exceed some results in the literature that use other photoprotection agents, such as molasses.

Suriyaprabha et al. (2014) used silica nanoparticles $(20-40 \mathrm{~nm})$ to treat Fusarium oxysporum and Aspergillus niger, two species of fungi that attack vegetables and legumes. The authors tested the application of nanosilica for the treatment of corn, and observed that a greater expression of phenolic compounds $(2056 \mathrm{mg} / \mathrm{mL})$ and less expression of stress-responsive enzymes $(743 \mathrm{mg} / \mathrm{mL})$ were found in leaf extracts from treated plants. The authors reported that the treated corn expressed greater resistance to Aspergillus niger, and that the same treatment carried out with silica in bulk did not present significant results in comparison to the results with nanosilica in terms of disease index and total phenol, peroxidases, polyphenol oxidase, and phenylalanine ammonia-lyase content. Therefore, they concluded that the silica nanoparticles had excellent antifungal properties and therefore can be considered as an alternative to combat phytopathogens.

Kumar et al. (2015) developed nanocapsules containing acetamiprid, a pesticidal agent. The nanocapsules were prepared by complexing alginate and chitosan polyelectrolytes and tested for controlled in vitro release under three different $\mathrm{pH}$ conditions. To obtain the nanocapsules, the team prepared two independent aqueous solutions of chitosan in acetic acid and alginate, with a corrected $\mathrm{pH}$ of 4.6 and 4.9 respectively. The pesticidal compound was ultrasonicated in the alginate solution and then a solution of calcium chloride was slowly added to the mixture. Under constant agitation, the chitosan solution was added slowly to the previous mixture. The recovery of the nanocapsules occurred after washing and centrifugation $(14,000$ $\mathrm{rpm})$. The results revealed that the maximum release occurred at $\mathrm{pH} 10$, and the lowest release at $\mathrm{pH} 4$, and that the nanoparticles showed a controlled release of the insecticide for up to $36 \mathrm{~h}$.

Maruyama et al. (2016) studied the nanoencapsulation of the herbicides imazapic and imazapyr in nanoparticles of alginate-chitosan and chitosan-tripolyphosphate, obtained by ionotropic gelation. For the preparation, they used a solution of sodium alginate in which the herbicidal compounds were added. After preparation, a solution of calcium chloride was added dropwise to obtain a pre-gel after $30 \mathrm{~min}$ of stirring. Then a solution of chitosan in acetic acid was added to the mixture and kept for $12 \mathrm{~h}$ under vigorous stirring to obtain the nanoparticles. For the preparation of chitosan-tripolyphosphate nanoparticles, the team prepared a solution of chitosan in acetic acid and later added the herbicidal compounds. Then a tripolyphosphate solution at $\mathrm{pH} 4.5$ at $8{ }^{\circ} \mathrm{C}$ was added, and the mixture was kept under stirring for $12 \mathrm{~h}$. The nanoparticles had an average size of $400 \mathrm{~nm}$ and showed excellent stability stored at room 
temperature for 30 days. In the end, they found that the nanoencapsulated herbicides showed greater efficiency and less genotoxicity when compared to the results of free compounds.

Yang et al. (2009) developed nanoparticles from polyethylene glycol (PEG) loaded with garlic essential oil to assess insecticidal activity against adult Tribolium castaneum (brown beetle). The nanoparticles prepared by the fusion dispersion method had a rounded shape and good size distribution with an average diameter of $240 \mathrm{~nm}$. The authors tested the application of free and encapsulated oil and observed that the efficacy against $T$. castaneum remained over $80 \%$ even after five months when the nanoparticles were applied, while the application of free garlic oil reached only $11 \%$ of efficacy using the same concentration. Finally, they attributed the success of the application to the controlled release of the active garlic compound into the environment.

Campos et al. (2018a) used cyclodextrins to functionalize chitosan using a nano complexation method. The obtained mixture was used to encapsulate carvacrol and linalool, which are two phenolic monoterpenes extracted from herbs with insecticidal and repellent properties. The nano complexation of the biopolymers allowed an increase in the product's life due to the greater control of release and volatilization of the encapsulated essential compounds. The same group used zein, a protein obtained from the endosperm of corn kernels to encapsulate citronella, eugenol, geraniol oils, and cinnamaldehyde, which are natural compounds used in insect control (DE OLIVEIRA et al., 2019).

Kumar, Kumar, and Dilbaghi (2017) prepared chitosan-pectin nanoparticles loaded with carbendazim (active pesticide) to combat Fusarium oxysporum and Aspergillus parasiticus. Chitosan-pectin nanoparticles were obtained by ionic interaction method. The authors separately made the dilution of chitosan in acetic acid and pectin in distilled water, under adequate sonification. Aqueous solutions of carbendazim dissolved in acetic acid, and sodium dioctyl sulfosuccinate (surfactant) were prepared. During 3 hours under vigorous stirring, the authors slowly dripped the pectin, carbendazim, and sulfosuccinate solutions simultaneously into the chitosan solution. After the reaction, the medium containing the nanoparticles was centrifuged for 1 hour at 10,000 rpm, the decanted was washed several times and lyophilized with mannitol (cryoprotectant). The authors obtained nanoparticles between 70 and $90 \mathrm{~nm}$ that showed $100 \%$ inhibition of fungi at concentrations of 0.5 and $1 \mathrm{ppm}$, while for pure carbendazim they observed 80 and $97 \%$ for the same concentrations, respectively. Based on the many tests carried out, the authors concluded that nano-formulated carbendazim is more 
effective and safer for the germination and root growth of Cucumis sativa (cucumber) seeds than the compound applied directly.

Shyla, Natarajan, and Nakkeeran (2014) chemically synthesized nanoparticles of titanium dioxide $\left(\mathrm{TiO}_{2}\right)$, zinc oxide $(\mathrm{ZnO})$ and silver $(\mathrm{Ag})$, and tested their effectiveness in combating Macrophomina phaseolina, a soil fungus that causes the root and stem rot of many plants, until their death. The synthesized nanoparticles showed an excellent average size distribution of $35-45,20-80,85-100 \mathrm{~nm}$, for $\mathrm{ZnO}, \mathrm{Ag}$, and $\mathrm{TiO}_{2}$ respectively. The best result was obtained by the application of silver nanoparticles and in lower concentrations than those used for the others. Sidhu, Barmota, and Bala (2017) produced copper sulfide nanoaquaformulations by the sonochemical method, followed by microwave irradiations in the presence of capping agents (polyvinylpyrrolidone, 4-aminobutyric acid or tri-sodium citrate). The authors tested the colloidal system in vitro for antifungal action in rice seeds. Studies have shown multiple efficacy against Alternaria alternata, Drechslera oryzae, and Curvularia luneta. The team also observed a significant reduction in seed rot and pest content in the seedlings, in addition to favorable effects on seed germination and plant growth.

Oliveira et al. (2015) prepared poly(e-caprolactone) (PCL) nanocapsules with an average diameter of $241 \mathrm{~nm}$ containing atrazine as an active pesticide. The authors tested the post-emergence herbicidal activity of nanocapsules for target plant species. The herbicidal activity was noticed even after $72 \mathrm{~h}$ in Brassica juncea; the team also observed lower toxicity of encapsulated atrazine compared to the application of the free herbicide. Guo et al. (2015) developed silica microcapsules cross-linked with carboxymethylcellulose and epichlorohydrin, containing emactite benzoate as an insecticidal agent. The authors obtained capsules with an average size of 1 and $3 \mu \mathrm{m}$ using the emulsion polymerization method, and their insecticidal action was tested against Myzus persicae. The authors observed excellent cellulase-responsive property, high efficacy against $M$. persicae, and less genotoxicity with Allium cepa. 
Chart 2. Some relevant researches on the development, application and evaluation of nanocarrier systems of pesticide agents, from the last 5 years.

\begin{tabular}{|c|c|c|c|c|c|}
\hline $\begin{array}{l}\text { Nanocarrier / (average } \\
\text { size) }\end{array}$ & Pesticide Agent & Preparation method & Application & Results & Reference \\
\hline $\begin{array}{l}\text { Nanoparticles of } \\
\text { mesoporous silica and } \\
\text { trimethylammonium / } \\
(423 \mathrm{~nm})\end{array}$ & $\begin{array}{l}2,4- \\
\text { dichlorophenoxy } \\
\text { acetic acid }\end{array}$ & $\begin{array}{l}\text { Sol-gel and } \\
\text { nanosilica graft post }\end{array}$ & $\begin{array}{l}\text { Herbicidal action } \\
\text { against dicot plants }\end{array}$ & $\begin{array}{l}\text { Electrostatic interactions were the driving } \\
\text { forces that induced the loading of } \\
\text { pesticides, and regulated the compound } \\
\text { release by decreasing leaching in the soil. }\end{array}$ & $\begin{array}{l}\text { (CAO et al., } \\
2018)\end{array}$ \\
\hline $\begin{array}{l}\text { Silica gel microparticles } \\
\text { loaded with } \mathrm{ZnO} \text { and } \\
\text { copper nanoparticles / } \\
(600 \mathrm{~nm}-1.1 \mu \mathrm{m})\end{array}$ & --- & $\begin{array}{l}\text { Chemical reaction in } \\
\text { aqueous dispersion }\end{array}$ & $\begin{array}{l}\text { Antimicrobial action } \\
\text { against Xanthomonas } \\
\text { alfafae, Pseudomonas } \\
\text { syringae, and } \\
\text { Clavibacter } \\
\text { michiganensis }\end{array}$ & $\begin{array}{l}\text { Excellent antimicrobial activity and high } \\
\text { effectiveness in the control of citrus canker } \\
\text { in Ruby grapefruit. }\end{array}$ & $\begin{array}{l}\text { (YOUNG et al., } \\
\text { 2018) }\end{array}$ \\
\hline $\begin{array}{l}\text { 2-nitrobenzyl- } \\
\text { carboxymethyl-chitosan } \\
\text { succinate micelles / } \\
(140 \mathrm{~nm})\end{array}$ & Diuron & $\begin{array}{l}\text { Graft of side chains } \\
\text { and method of } \\
\text { conjugation }\end{array}$ & $\begin{array}{l}\text { Photo-controlled } \\
\text { pesticide release }\end{array}$ & $\begin{array}{l}\text { High rate of photo-controlled release } \\
(96.8 \%) \text { for up to } 8 \mathrm{~h}(\text { at } \mathrm{pH} 7) \text { under solar } \\
\text { radiation stimulus. }\end{array}$ & (YE et al., 2015) \\
\hline $\begin{array}{l}\text { Hollow } \mathrm{TiO}_{2} \\
\text { nanoparticles doped } \\
\text { with } \mathrm{Ag} /(<50 \mathrm{~nm})\end{array}$ & --- & $\begin{array}{l}\text { Chemical reaction in } \\
\text { alcoholic dispersion }\end{array}$ & $\begin{array}{l}\text { Fungicidal action } \\
\text { against Fusarium } \\
\text { solani and Venturia } \\
\text { inaequalis }\end{array}$ & $\begin{array}{l}\text { Excellent fungicidal activity under natural } \\
\text { lighting (visible light). }\end{array}$ & $\begin{array}{l}\text { (BOXI; } \\
\text { MUKHERJEE; } \\
\text { PARIA, 2016) }\end{array}$ \\
\hline $\begin{array}{l}\text { Chitosan and gum } \\
\text { arabic nanoparticles / } \\
(\sim 226 \mathrm{~nm})\end{array}$ & $\begin{array}{l}\text { Carvacrol e } \\
\text { Linalool }\end{array}$ & Ionic gelation & $\begin{array}{l}\text { Insecticidal action } \\
\text { against Helicoverpa } \\
\text { armigera } \text { and } \\
\text { Tetranychus urticae }\end{array}$ & $\begin{array}{l}\text { Excellent insecticidal action and increased } \\
\text { mortality rate. The compounds applied } \\
\text { together showed better results than when } \\
\text { applied alone. }\end{array}$ & $\begin{array}{l}\text { (CAMPOS et } \\
\text { al., 2018b) }\end{array}$ \\
\hline $\begin{array}{l}\text { Zein nanoparticles / } \\
(278 \pm 61.5 \mathrm{~nm})\end{array}$ & Neem oil & $\begin{array}{l}\text { Anti-solvent } \\
\text { precipitation }\end{array}$ & $\begin{array}{l}\text { Investigation of toxicity } \\
\text { to non-target organisms }\end{array}$ & $\begin{array}{l}\text { The nanocapsules showed less genotoxicity } \\
\text { to Allium cepa than free Neem oil, there } \\
\text { was no change in soil biota, and safe } \\
\text { application for Caenorhabditis elegans. }\end{array}$ & $\begin{array}{l}\text { (PASCOLI et } \\
\text { al., 2019) }\end{array}$ \\
\hline $\begin{array}{l}\text { Microspheres of vinyl } \\
\text { polyacetate (PVA) / } \\
(320 \mathrm{~nm})\end{array}$ & $\begin{array}{l}\text { Emamectin- } \\
\text { benzoate (EMB) }\end{array}$ & $\begin{array}{l}\text { Microemulsion } \\
\text { polymerization }\end{array}$ & $\begin{array}{l}\text { Slow and controlled } \\
\text { release pesticide action }\end{array}$ & $\begin{array}{l}\text { Excellent photoprotective capacity of active } \\
\text { agents, good stability of microspheres } \\
\text { under natural conditions, and gradual EMB } \\
\text { release over } 200 \mathrm{~h} \text {. }\end{array}$ & $\begin{array}{l}\text { (WANG et al., } \\
\text { 2017) }\end{array}$ \\
\hline
\end{tabular}

Source: Authors 


\section{Disadvantages in the use of nanopesticides: a critical view}

Throughout the review on the use of nano-delivery systems in agriculture, it became clear that nanotechnology is undoubtedly an ally in the development of solutions for cultivation. Its gains, advantages, and benefits have been exhaustively exemplified, but it has not been mentioned what are the real challenges encountered for the wide use of these nanomaterials, the risks offered, and the disadvantages they can cause. It is clear that for many specific applications, normally under controlled conditions, the results of the use of nanocarriers have shown an increase in application effectiveness and levels of preservation of the environment never seen before (DANG et al., 2010; KIM et al., 2018). The results of serious and reputable scientific researches have indicated that the use of pesticide nano-delivery systems in the field is a viable, promising and more sustainable alternative when compared to the conventional pesticide application system, which occurs due to the indiscriminate spillage of free agrochemicals in crops and soil, most often by direct spraying (DANG et al., 2010; KIM et al., 2018). Virtually all studies are concerned with only developing some technology that shows signs of positive and sustainable results, but there is no concern with studying the financial viability and economic consequences of its use (DIMKPA; BINDRABAN, 2018).

In recent decades, a large number of patents have been issued for works related to the development and application of nanomaterials containing pesticide agents for agriculture. However, the commercialization of these materials is extremely limited due to numerous challenges and knowledge gaps around their use (KIM et al., 2018). Some of the challenges for advancing the use of nanotechnology include low investments in teaching and research/development infrastructure, the high cost of producing nanomaterials, low agricultural financial return, the resistance of the agricultural sector in the implementation of nanomaterials in the field, among other limitations that delay progression (HUANG et al., 2015; PARISI; VIGANI; RODRÍGUEZ-CEREZO, 2015). Several technical restrictions in the scope of industrial production of nanopesticides limit the advance in the use of these materials, for example, the high energy demand of the processes involved (DIMKPA; BINDRABAN, 2018). Due to their size, nanoformulations tend to form clusters, or even dissolve the matrix, which alters their surface chemical properties. The aggregation of nanoparticles transforms them into non-nanological formulations, which is contrary to their main creation objective (DIMKPA; BINDRABAN, 2018). Other obstacles that the advancement of the use of these nanomaterials face are the unknown risks that the absorption and accumulation of nanomaterials in foods can present. The presence of more resistant agrochemicals in food can contaminate the food chain 
creating imminent health hazards for humans and animals, and even for the environment (MANCHIKANTI, 2019; PENG et al., 2017; VILCHEZ-ARUANI et al., 2020).

\section{Final Considerations}

Nanopesticides are a class of materials used to combat and control pests harmful to food and crops. These materials are based on nanometric systems for the actuation and/or delivery of active compounds in the field. Thus, nano-delivery systems for pesticides have been widely studied in an attempt to find effective solutions to current problems of environmental pollution, low efficiency of conventional application systems, and less toxicity to users and food. Numerous advantages have been reported in the literature in the use of these nanomaterials, and a very promising and more sustainable future can be expected from these nanostructures compared to traditional agriculture. However, some issues that slow the advance of the use of nanopesticides in the agricultural sector have limited the evolution of industrial production and the consolidation of these materials in the market. Another worrying factor is that little is known about the possible risks that these nanoformulations can cause. Therefore, further studies and more consolidated concepts are needed regarding health safety in the use of nanomaterials, their mechanisms of action, bioaccumulation behavior, cost of processing, the economic viability of production, marketing logistics, the stability of nanoformulation stock, ways of application in the field, and financial return to the producer. For these reasons, nanopesticides are still considered an emerging, revolutionary technology, in wide expansion and very promising if treated with awareness.

\section{References}

ABRAHAM, J.; PILLAI, V. N. R. Membrane-encapsulated controlled-release urea fertilizers based on acrylamide copolymers. Journal of Applied Polymer Science, v. 60, n. 13, p. 2347 2351, 1996.

AKTAR, W.; SENGUPTA, D.; CHOWDHURY, A. Impact of pesticides use in agriculture: Their benefits and hazards. Interdisciplinary Toxicology, v. 2, n. 1, p. 1-12, 2009.

ALLAHYARI, M. S.; MOHAMMADZADEH, M.; NASTIS, S. A. Agricultural experts' attitude towards precision agriculture: Evidence from Guilan Agricultural Organization, Northern Iran. Information Processing in Agriculture, v. 3, n. 3, p. 183-189, 2016.

AUFFAN, M. et al. Towards a definition of inorganic nanoparticles from an environmental, health and safety perspective. Nature Nanotechnology, v. 4, n. 10, p. 634-641, 2009.

BAKER, R. W. Controlled Release of Biologically Active Agents. 4. ed. New York: John Wiley \& Sons, 1987. 
BAPAT, G. et al. Silica nanoparticle based techniques for extraction, detection, and degradation of pesticides. Advances in Colloid and Interface Science, v. 237, p. 1-14, 2016.

BOXI, S. S.; MUKHERJEE, K.; PARIA, S. Ag doped hollow TiO2 nanoparticles as an effective green fungicide against Fusarium solani and Venturia inaequalis phytopathogens. Nanotechnology, v. 27, n. 8, 2016.

CAMPOS, E. V. R. et al. Chitosan nanoparticles functionalized with $\beta$-cyclodextrin: A promising carrier for botanical pesticides. Scientific Reports, v. 8, n. 1, p. 1-15, 2018a.

CAMPOS, E. V. R. et al. Carvacrol and linalool co-loaded in $\beta$-cyclodextrin-grafted chitosan nanoparticles as sustainable biopesticide aiming pest control. Scientific Reports, v. 8, n. 1, p. $1-14,2018 b$.

CAO, L. et al. Positive-Charge Functionalized Mesoporous Silica Nanoparticles as Nanocarriers for Controlled 2,4-Dichlorophenoxy Acetic Acid Sodium Salt Release. Journal of Agricultural and Food Chemistry, v. 66, n. 26, p. 6594-6603, 2018.

CAROLIN, F. et al. Recent advancements in rapid analysis of pesticides using nano biosensors : A present and future perspective. Journal of Cleaner Production, v. 269, p. 122356, 2020.

CHEN, L. et al. Controlled release of urea encapsulated by starch-g-poly(l-lactide). Carbohydrate Polymers, v. 72, n. 2, p. 342-348, 2008.

COOPER, E. R. Nanoparticles: A personal experience for formulating poorly water soluble drugs. Journal of Controlled Release, v. 141, n. 3, p. 300-302, 2010.

CPCM. Crop Protection Chemicals Market by Type (Herbicides, Insecticides, and Fungicides), Origin (Synthetic, and Biopesticides), Crop Type (Cereals \& Oilseeds, Fruits \& Vegetables), Mode of Application, Form, and by Region - Global Forecasts to 2021Market Research Report. [s.l: s.n.]. Disponível em: <https://www.marketsandmarkets.com/Market-Reports/crop-protection-380.html>.

DANG, Y. et al. Trends in worldwide nanotechnology patent applications: 1991 to 2008. Journal of Nanoparticle Research, v. 12, n. 3, p. 687-706, 2010.

DE OLIVEIRA, J. L. et al. Association of zein nanoparticles with botanical compounds for effective pest control systems. Pest Management Science, v. 75, n. 7, p. 1855-1865, 2019.

DIMKPA, C. O.; BINDRABAN, P. S. Nanofertilizers: New Products for the Industry? Journal of Agricultural and Food Chemistry, v. 66, n. 26, p. 6462-6473, 2018.

FLORES-CÉSPEDES, F. et al. Preparation and Characterization of Azadirachtin AlginateBiosorbent Based Formulations: Water Release Kinetics and Photodegradation Study. Journal of Agricultural and Food Chemistry, v. 63, n. 38, p. 8391-8398, 2015.

FRANCHETTI, S. M. M.; MARCONATO, J. C. Polímeros biodegradáveis - Uma solução parcial para diminuir a quantidade dos resíduos plásticos. Quimica Nova, v. 29, n. 4, p. 811816, 2006.

GHORMADE, V.; DESHPANDE, M. V.; PAKNIKAR, K. M. Perspectives for nanobiotechnology enabled protection and nutrition of plants. Biotechnology Advances, v. 29, n. 
6, p. 792-803, 2011.

GRILLO, R. et al. Chitosan/tripolyphosphate nanoparticles loaded with paraquat herbicide: An environmentally safer alternative for weed control. Journal of Hazardous Materials, v. 278, p. 163-171, 2014.

GUO, M. et al. Preparation and characterization of enzyme-responsive emamectin benzoate microcapsules based on a copolymer matrix of silica-epichlorohydrin-carboxymethylcellulose. RSC Advances, v. 5, n. 113, p. 93170-93179, 2015.

HE, X.; DENG, H.; HWANG, H. MIN. The current application of nanotechnology in food and agriculture. Journal of Food and Drug Analysis, v. 27, n. 1, p. 1-21, 2019.

HEAP, I. The International Herbicide-Resistant Weed Database. Disponível em: <http://weedscience.org/Home.aspx>. Acesso em: 21 jun. 2020.

HORRIGAN, L.; LAWRENCE, R. S.; WALKER, P. How sustainable agriculture can address the environmental and human health harms of industrial agriculture. Environmental Health Perspectives, v. 110, n. 5, p. 445-456, 2002.

HUANG, S. et al. Nanotechnology in agriculture, livestock, and aquaculture in China. A review. [s.l: s.n.]. v. 35

IRFAN, S. A. et al. A review of mathematical modeling and simulation of controlled-release fertilizers. Journal of Controlled Release, v. 271, n. September 2017, p. 45-54, 2018.

KIM, D. Y. et al. Recent developments in nanotechnology transforming the agricultural sector: a transition replete with opportunities. Journal of the Science of Food and Agriculture, v. 98, n. 3, p. 849-864, 2018.

KOUTROS, S. et al. Non-Hodgkin lymphoma risk and organophosphate and carbamate insecticide use in the north American pooled project. Environment International, v. 127, n. September 2018, p. 199-205, 2019.

KUMAR, S. et al. Development and evaluation of alginate-chitosan nanocapsules for controlled release of acetamiprid. International Journal of Biological Macromolecules, v. 81, p. 631637, 2015.

KUMAR, S. et al. Recent advances and remaining challenges for polymeric nanocomposites in healthcare applications. Progress in Polymer Science, v. 80, p. 1-38, 2018.

KUMAR, S. et al. Nano-based smart pesticide formulations: Emerging opportunities for agriculture. Journal of Controlled Release, v. 294, n. December 2018, p. 131-153, 2019.

KUMAR, S.; KUMAR, D.; DILBAGHI, N. Preparation, characterization, and bio-efficacy evaluation of controlled release carbendazim-loaded polymeric nanoparticles. Environmental Science and Pollution Research, v. 24, n. 1, p. 926-937, 2017.

LECHENET, M. et al. Reducing pesticide use while preserving crop productivity and profitability on arable farms. Nature Plants, v. 3, n. March, p. 1-6, 2017.

LI, Z.-Z. et al. Study of UV-shielding properties of novel porous hollow silica nanoparticle 
carriers for avermectin. Pest management science, v. 63, p. 241-246, 2007.

LIECHTY, W. B. et al. Polymers for Drug Delivery Systems. Annual Review of Chemical and Biomolecular Engineering, v. 1, n. 1, p. 149-173, 2010.

MA, Y. Seed coating with beneficial microorganisms for precision agriculture. Biotechnology Advances, v. 37, n. 7, p. 107423, 2019.

MAGHSOUDI, S.; JALALI, E. Noble UV protective agent for Bacillus thuringiensis based on a combination of graphene oxide and olive oil. Scientific Reports, v. 7, n. 1, p. 7-12, 2017.

MANCHIKANTI, P. Chapter 8 - Bioavailability and environmental safety of nanobiopesticides. In: KOUL, O. B. T.-N.-B. T. AND F. P. (Ed.). . [s.1.] Academic Press, 2019. p. 207-222.

MARUYAMA, C. R. et al. Nanoparticles Based on Chitosan as Carriers for the Combined Herbicides Imazapic and Imazapyr. Scientific Reports, v. 6, n. October 2015, 2016.

MCCLEMENTS, D. J. Nanoparticle and Microparticle-based Delivery Systems: Encapsulation, Protection and Release of Active Compounds. [s.1.] CRC Press, 2017.

MONDAL, P.; BASU, M. Adoption of precision agriculture technologies in India and in some developing countries: Scope, present status and strategies. Progress in Natural Science, v. 19, n. 6, p. 659-666, 2009.

NI, B. et al. Environmentally friendly slow-release nitrogen fertilizer. Journal of Agricultural and Food Chemistry, v. 59, n. 18, p. 10169-10175, 2011.

OLIVEIRA, H. C. et al. Nanoencapsulation enhances the post-emergence herbicidal activity of atrazine against mustard plants. PLoS ONE, v. 10, n. 7, p. 1-12, 2015.

OLIVEIRA, J. L. D. et al. Zein Nanoparticles as Eco-Friendly Carrier Systems for Botanical Repellents Aiming Sustainable Agriculture. Journal of Agricultural and Food Chemistry, v. 66, n. 6, p. 1330-1340, 2018.

OUELLET, M. et al. Hindlimb Deformities (Ectromelia, Ectrodactyly) in free-living anurans from agricultural habitats. Journal of Wildlife Diseases, v. 33, n. 1, p. 95-104, 1 jan. 1997.

PARISI, C.; VIGANI, M.; RODRÍGUEZ-CEREZO, E. Agricultural nanotechnologies: What are the current possibilities? Nano Today, v. 10, n. 2, p. 124-127, 2015.

PASCOLI, M. et al. Neem oil based nanopesticide as an environmentally-friendly formulation for applications in sustainable agriculture: An ecotoxicological perspective. Science of the Total Environment, v. 677, p. 57-67, 2019.

PENG, C. et al. Fate and Transformation of CuO Nanoparticles in the Soil-Rice System during the Life Cycle of Rice Plants. Environmental Science and Technology, v. 51, n. 9, p. 49074917, 2017.

PEPPAS, N. A. et al. Hydrogels in pharmaceutical formulations. European Journal of Pharmaceutics and Biopharmaceutics, v. 50, n. 1, p. 27-46, 2000. 
PIEL, C. et al. Agricultural exposures to carbamate herbicides and fungicides and central nervous system tumour incidence in the cohort AGRICAN. Environment International, v. 130, n. May, 2019.

PIMENTEL, D. Environmental and Economic Costs of the Application of Pesticides Primarily in the United States. In: Integrated Pest Management: Innovation-Development Process. [s.1.] Springer Science, 2009. v. 1p. 89-111.

PUOCI; F. et al. Polymer in agriculture: A review. American Journal of Agricultural and Biological Science, v. 3, n. 1, p. 299-314, 2008.

RANI, R. et al. Evaluation of anti-diabetic activity of glycyrrhizin-loaded nanoparticles in nicotinamide-streptozotocin-induced diabetic rats. European Journal of Pharmaceutical Sciences, v. 106, n. April, p. 220-230, 2017.

ROSER, M.; RITCHIE, H.; ORTIZ-OSPINA, E. World Population Growth. Disponível em: $<$ https://ourworldindata.org/world-population-growth>.

SCHMIDT, J. T. et al. Dieldrin-induced neurotoxicity involves impaired mitochondrial bioenergetics and an endoplasmic reticulum stress response in rat dopaminergic cells. NeuroToxicology, v. 63, p. 1-12, 2017.

SHARMA, A. et al. Global trends in pesticides: A looming threat and viable alternatives. Ecotoxicology and Environmental Safety, v. 201, n. May, p. 110812, 2020.

SHARMA, S. et al. Anti-drift nano-stickers made of graphene oxide for targeted pesticide delivery and crop pest control. Carbon, v. 115, p. 781-790, 2017.

SHYLA, K. K.; NATARAJAN, N.; NAKKEERAN, S. Antifungal activity of zinc oxide, silver and titanium dioxide nanoparticles against Macrophomina phaseolina. Journal of Mycology and Plant Pathology, v. 44, n. 3, p. 268-273, 2014.

SIDHU, A.; BARMOTA, H.; BALA, A. Antifungal evaluation studies of copper sulfide nanoaquaformulations and its impact on seed quality of rice (Oryzae sativa). Applied Nanoscience (Switzerland), v. 7, n. 8, p. 681-689, 2017.

SMITH, K.; EVANS, D. A.; EL-HITI, G. A. Role of modern chemistry in sustainable arable crop protection. Philosophical Transactions of the Royal Society B: Biological Sciences, v. 363, n. 1491, p. 623-637, 2008.

SURIYAPRABHA, R. et al. Application of silica nanoparticles in maize to enhance fungal resistance. IET Nanobiotechnology, v. 8, n. 3, p. 133-137, 2014.

TILMAN, D. et al. Forecasting Agriculturally Driven Global Environmental Change. Science, v. 292, p. 281-292, 2001.

TSUIJI, K. Microencapsulation of pesticides and their improved handling safety. Journal of Microencapsulation, v. 18, n. 2, p. 137-147, 2001.

VILCHEZ-ARUANI, J. et al. Genomic effects of a nanostructured alumina insecticide in human peripheral blood lymphocytes in vitro. Heliyon, v. 6, n. 6, 2020. 
WANG, Y. et al. Synthesis and characterization of emamectin-benzoate slow-release microspheres with different surfactants. Scientific Reports, v. 7, n. 1, p. 1-9, 2017.

YANG, F. L. et al. Structural characterization of nanoparticles loaded with garlic essential oil and their insecticidal activity against Tribolium castaneum (Herbst) (Coleoptera: Tenebrionidae). Journal of Agricultural and Food Chemistry, v. 57, n. 21, p. 10156-10162, 2009.

YE, Z. et al. Photo-responsive shell cross-linked micelles based on carboxymethyl chitosan and their application in controlled release of pesticide. Carbohydrate Polymers, v. 132, p. 520 $528,2015$.

YOUNG, M. et al. Multimodal Generally Recognized as Safe ZnO/Nanocopper Composite: A Novel Antimicrobial Material for the Management of Citrus Phytopathogens. Journal of Agricultural and Food Chemistry, v. 66, n. 26, p. 6604-6608, 2018.

ZHANG, N.; WANG, M.; WANG, N. Precision agriculture - A worldwide overview. Computers and Electronics in Agriculture, v. 36, n. 2-3, p. 113-132, 2002. 


\title{
CHAPTER 43: NANOFERTILIZERS: AN OVERVIEW
}

\author{
Afonso Henrique da Silva Júnior ${ }^{1}$; Jéssica Mulinari² ${ }^{2}$ Francisco Wilson Reichert Júnior ${ }^{3}$; Carlos Rafael Silva de \\ Oliveira $^{4}$
}

\begin{abstract}
The adequate bioavailability of nutrients to plants is among the various difficulties of the agricultural sector. Thus, the existence of mechanisms for controlled release of the nutrients is essential for planting, as well as novel techniques that do not cause adverse effects. The use of nanotechnology in agriculture can bring many benefits, such as better use of nutrients by plants, reducing waste. Nanofertilizers are an emerging technology and a constantly expanding class of agrochemicals, representing possible solutions to the development of sustainable agriculture. Based on this, the present work aims to update and discuss some relevant topics about these nanomaterials, such as different synthesis approaches, possible mechanisms for the capture of nanofertilizers by plants, and the advantages and limitations of using these materials. Also, an overview of the main literature in the area is presented approaching current studies that use green chemistry concepts.
\end{abstract}

Keywords: sustainable agriculture, agrochemicals, emerging technologies, nanofertilizers, green chemistry.

\section{Introduction}

In the past two decades, numerous difficulties encountered in agriculture have become recurrent. Not due to the lack of space or even investment in technology, but due to the regular climatic instabilities caused by the worsening of global warming and the intense deforestation. Based on this, the precepts of sustainable agriculture have become important in agricultural research groups, such as the development of green nanomaterials, optimization of agricultural processes, breeding, rational use of pesticides, and others (DUHAN et al., 2017). Efforts by researchers around the world have been growing in the search for smart and greener solutions that can meet global food demands, due to population growth. Given this scenario, special attention is given to biodegradable materials, produced via clean and safe processes. Currently, a worldwide trend has been the manufacture of nanomaterials by green processes, whether using water as a solvent, minimizing the use of toxic reagents, or reusing agro-industrial waste. An important class of agrochemicals impacted by these precepts are fertilizers (USMAN et al.,

\footnotetext{
${ }^{1}$ Agro-industrial Engineer (Federal University of Rio Grande - FURG), Master student in Chemical Engineering (Federal University of Santa Catarina - UFSC), afonso.ufsc@gmail.com

${ }^{2}$ Environmental and Sanitary Engineer (Federal University of Fronteira Sul - UFFS), Master in Chemical Engineering (Federal University of Santa Catarina - UFSC), PhD student in Chemical Engineering (Federal University of Santa Catarina - UFSC), jessicamulinari15@gmail.com

${ }^{3}$ Agronomist (Federal University of Fronteira Sul - UFFS), Master in Environmental Science and Technology (Federal University of Fronteira Sul - UFFS), PhD student in Plant Genetic Resources (Federal University of Santa Catarina UFSC),chicowrj@gmail.com

${ }^{4}$ Textile Engineer (State University of Maringá - UEM), Master in Chemical Engineering (Federal University of Santa Catarina - UFSC), PhD student in Chemical Engineering (Federal University of Santa Catarina - UFSC), carlos.oliveira@posgrad.ufsc.br
} 
2020). Organic fertilizers are fundamental to the success of the crop, whether promoting major changes in the physical properties of the soil or increasing the productivity of the crop, which consequently increases the profitability of the producer. However, the use of this class of agrochemicals has limitations, such as low efficiency (ZULFIQAR et al., 2019). This disadvantage is common to conventional fertilizer application processes. It is estimated that around $50 \%$ of the applied nitrogen is lost to the environment, causing additional production costs and contamination of rivers, lakes, and groundwater. Therefore, the main challenges in the use of these fertilizer materials are in the strategic optimization of application, which must become more sustainable and must maintain or improve the levels of productivity and quality when used in different cultures. It is these challenges that are driving the development of nanofertilizers, seen as promising allies for the progress of agriculture (MAGHSOODI; GHODSZAD; ASGARI LAJAYER, 2020).

Nanofertilizers are nanomaterials that can consist of a carrier matrix of mineral elements. According to He, Deng and Hwang (2019), these compounds can be produced by nanoencapsulation of nutritional elements or as nanoparticulate nutrient itself. Nutrients are essential for the complete development of plants (HUSAIN JAAFRY et al., 2020) and the way they are bioavailable in the soil is crucial for the plant uptake. Another limiting factor is that these nutrients are not completely available in the soil in adequate quantities (ASGARI LAJAYER et al., 2019). For this, the producers carry out the necessary fertilization of the land according to the crop. The nutritional elements necessary for plants are divided into two major groups, micronutrients and macronutrients (ZHAO et al., 2020b). Micronutrients are minerals needed by plants in low amounts (ZHAO et al., 2020a). This group consists of iron (Fe), boron (B), chlorine $(\mathrm{Cl})$, copper $(\mathrm{Cu})$, zinc $(\mathrm{Zn})$, manganese $(\mathrm{Mn})$, and molybdenum (Mo), among others (NAIR; AUGUSTINE, 2018). The presence of traces of these elements is vital to the development cycle of plants since they are involved in the regulation of enzymes, proteins, and carbohydrates (BRIAT et al., 2020). Macronutrients are elements that must be present in plants in high quantities (SINGH; DWIVEDI, 2019). They are substances that play fundamental roles in the formation of plant tissues, fruits, and flowers, root development, conservation of water levels in the plant, and other functions (TUHY et al., 2015). This group is composed of nitrogen $(\mathrm{N})$, phosphorus $(\mathrm{P})$, potassium $(\mathrm{K})$, calcium $(\mathrm{Ca})$, magnesium $(\mathrm{Mg})$, and sulfur $(\mathrm{S})$ (LIU; LAL, 2015). Chart 1 shows the effects of some elements in different cultures. 
Chart 1. Effects of nutrients in different cultures.

\begin{tabular}{|c|c|c|c|}
\hline Element & Culture & Effects & Reference \\
\hline $\mathrm{N}$ & Phaseolus vulgaris L. & $\begin{array}{l}\text { Contributed to plant } \\
\text { growth }\end{array}$ & $\begin{array}{l}\text { (MEDEIROS et al., } \\
2010)\end{array}$ \\
\hline $\mathrm{P}$ & Brachiaria decumbens & $\begin{array}{l}\text { Promoted greater root } \\
\text { growth }\end{array}$ & $\begin{array}{l}\text { (DA SILVA et al., } \\
\text { 2011) }\end{array}$ \\
\hline $\mathrm{K}$ & Vigna unguiculata $L$. & $\begin{array}{l}\text { Improved water } \\
\text { balance and breathing }\end{array}$ & $\begin{array}{l}\text { (PRAZERES et al., } \\
2015 \text { ) }\end{array}$ \\
\hline $\mathrm{Mg}$ & Musa spp. & $\begin{array}{l}\text { Application of this } \\
\text { element recovered } \\
\text { plant growth, nutrients } \\
\text { and carbohydrates } \\
\text { status }\end{array}$ & (HE et al., 2020) \\
\hline $\mathrm{Fe}$ and $\mathrm{Cu}$ & Lactuca sativa & $\begin{array}{l}\text { The elements act on } \\
\text { growth, water content } \\
\text { and catalase activity }\end{array}$ & $\begin{array}{l}\text { (TRUJILLO-REYES } \\
\text { et al., 2014) }\end{array}$ \\
\hline $\mathrm{Fe}$ and $\mathrm{Zn}$ & Cucumis sativus & $\begin{array}{l}\text { The elements act in the } \\
\text { production of } \\
\text { antioxidant enzymes }\end{array}$ & $\begin{array}{l}\text { (MOGHADDASI et } \\
\text { al., 2017) }\end{array}$ \\
\hline $\mathrm{Cu}$ & Solanum lycopersicon & $\begin{array}{l}\text { The element act on the } \\
\text { antioxidant content }\end{array}$ & $\begin{array}{l}\text { (AHMED; } \\
\text { MUSARAN; }\end{array}$ \\
\hline $\mathrm{Cu}$ & Allium сера & $\begin{array}{l}\text { The element act } \\
\text { mainly on the mitotic } \\
\text { index }\end{array}$ & (AHMED et al., 2018) \\
\hline
\end{tabular}

Source: Authors.

There are three main approaches to the production of nanofertilizers: top-down, bottomup, and biological (PEREIRA et al., 2017). Each synthesis method has advantages and disadvantages in terms of the required process, ranging from the control of particle size, economic viability, even in the necessary yield for a given crop. Kah et al. (2018) observed an increase of approximately $30 \%$ in the absorption of nutrients with the application of nanofertilizers compared to the application of conventional fertilizers for different plant species. In the scientific field, this class of nutritional agrochemical is divided into three categories: nanostructured micronutrients, nanostructured macronutrients, and nanostructures that transport nutrients. Examples of these categories are hydroxyapatite, zinc oxide $(\mathrm{ZnO})$ and chitosan nanoparticles (SAMPATHKUMAR; TAN; LOO, 2020).

Considering the issues addressed, the great potential of nanofertilizers in the revolution and future replacement of conventional technologies is notable. In this review, an overview of nanofertilizers will be presented, discussing the following topics: different synthesis 
approaches, possible mechanisms for the capture of nanofertilizers by plants, and the advantages and limitations of the use of these nanoparticles. Figure 1 presents an illustrative scheme of the topics that were covered in the work. Also, the purpose of this review is to include the main research in the area regarding the production of these agrochemicals by green synthesis, which are unquestionable factors to reduce the impacts that modern agriculture has on the environment and on human health.

Figure 1. Topics approaches in the review.

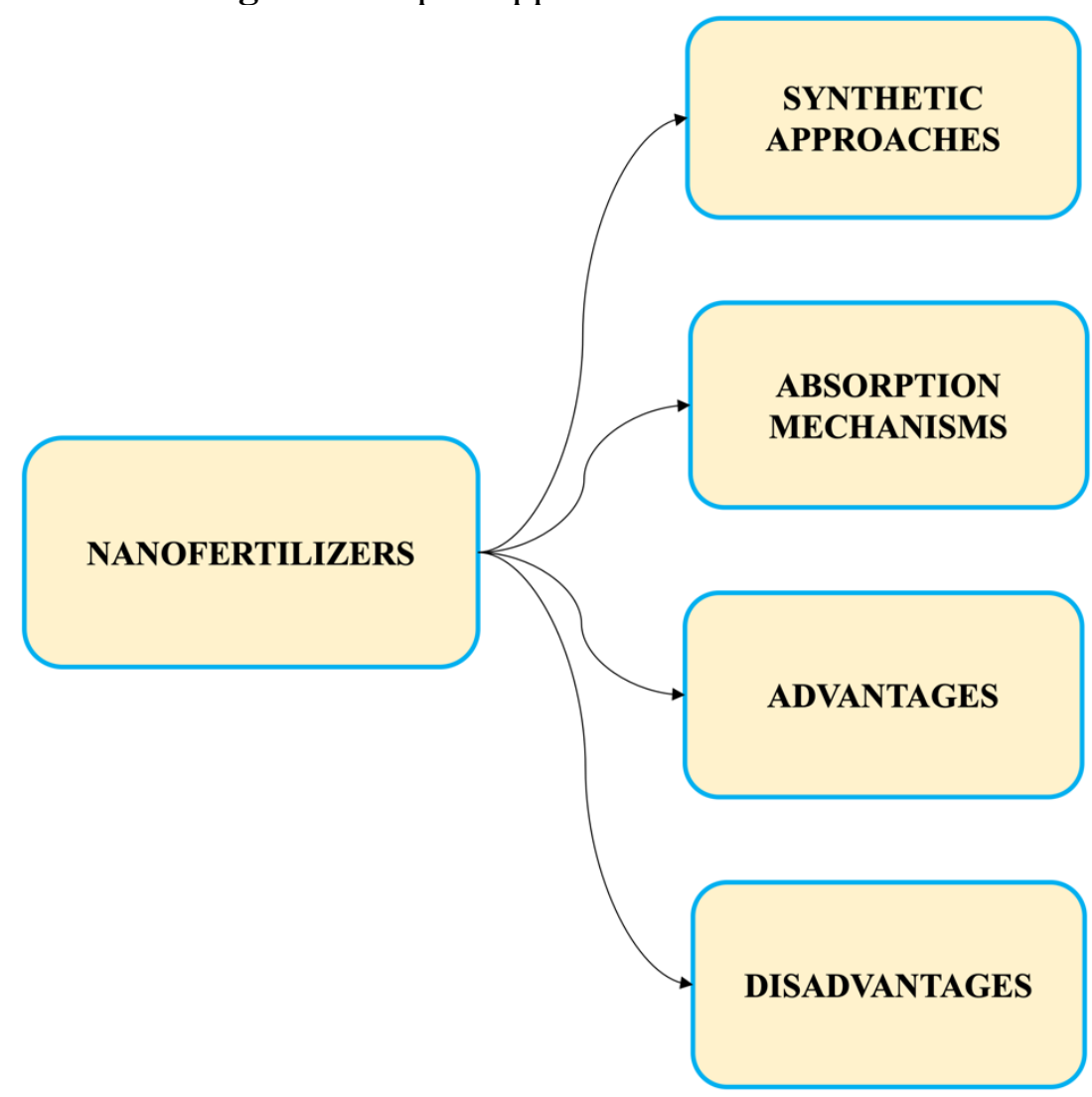

Source: Authors.

\section{Nanofertilizer production}

There are several ways to obtain nanofertilizers, such as top-down, bottom-up, and biological (Fig. 2). The top-down production process uses physical methods, starting from larger particles until reaching the nanometric scale (FEREGRINO-PEREZ et al., 2018). The techniques based on this concept have some limitations, for example, low control of uniformity and particle size. Another way of obtaining nanofertilizers is bottom-up, based on chemical reactions (ABDEL-AZIZ; RIZWAN, 2019). Bottom-up methods allow greater control of the size of the nanostructures and the reduction of impurities. Finally, another method used for the manufacture of nanofertilizers is the biological route. Microorganisms such as bacteria and 
fungi are used for biosynthesis. The advantage of obtaining nanofertilizers via biosynthesis is the low cytotoxicity of the final product (CAI et al., 2020). Therefore, it is noticed that there are numerous possibilities for the production of nanofertilizers and the challenges are diverse, such as the reduction of energy costs, better yields, and the synthesis of a material with high efficiency. With the integration of these characteristics, it is possible to manufacture agrochemicals that present high performance and sustainable applications.

Figure 2. Different nanofertilizer synthesis approaches.

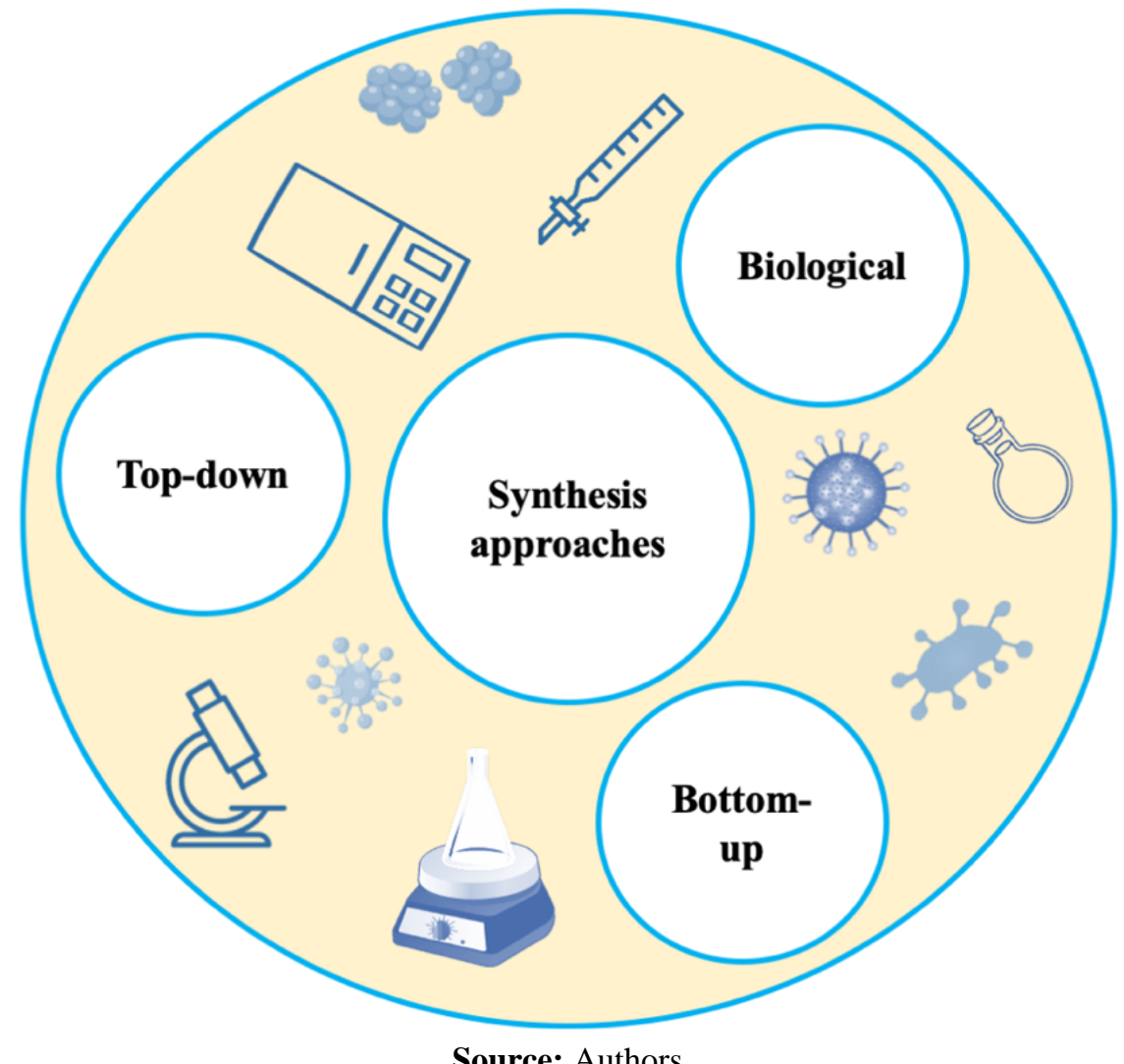

Source: Authors.

Nanofertilizers can be produced from organic or inorganic compounds. The development of inorganic nanostructures uses mainly metal oxides, such as zinc oxide $(\mathrm{ZnO})$, magnesium oxide $(\mathrm{MgO})$, and silver oxide $(\mathrm{AgO})$. As for nanomaterials obtained from organic compounds, polymers, carbon, and others are used. Sharma et al. (2020) reported the effects of nanofertilizers in a chitosan matrix doped with copper and salicylic acid in the corn crop. The synthesis of the nanoparticles was based on the encapsulation of nutrients by chitosan ion gelation. They observed satisfactory results in the application of the nanofertilizer, such as the increase in the activities of antioxidant enzymes, reduction in the content of malondialdehyde, and the increase of chlorophyll content in the leaves. 
Shebl et al. (2020) prepared ferrite nanofertilizers by microwave-assisted green hydrothermal route using hydrated zinc, manganese, and iron nitrates dissolved in water. After the appropriate mixtures and concentrations of each reagent, the medium was transferred to a $100 \mathrm{~mL}$ autoclave container and subjected to microwaves (750W). After microwave treatment, five ferrite samples were tested at different temperatures $\left(100-180^{\circ} \mathrm{C}\right)$. Finally, the material was washed and dried at $100^{\circ} \mathrm{C}$ for 6 hours. The different nanomaterials they prepared were used in different concentrations $(0,10,20$, and $30 \mathrm{ppm})$ as leaf nanofertilizers during the pumpkin planting process (Cucurbita pepo $\mathrm{L}$ ). When the nanoferrite synthesized at $160^{\circ} \mathrm{C}$ was applied to the growing pumpkin culture at a concentration of $10 \mathrm{ppm}$, an increase in yield was observed when compared to untreated pumpkins, for two consecutive seasons.

Kottegoda et al. (2017) synthesized environmentally friendly nanoparticles of urea transporters as a nutrient for different cultures. In the study, nanostructured materials could be programmed and used as a nanofertilizer. Because of the high solubility of the urea molecules, the authors incorporated them into a hydroxyapatite matrix. For the production of the nanoparticles, the authors used the bottom-up methodology, in which phosphoric acid was dispersed dropwise in a suspension of calcium hydroxide and urea under mechanical stirring. Finally, techniques were used to purify the material until the nanofertilizers were obtained. Also, the authors evaluated the study of nitrogen release in aqueous media, in which it occurred for up to one week using the synthesized nanohybrid what happens when you use pure urea.

Kumar, Ashfaq and Verma (2018) developed a procedure for the polymeric synthesis of polyvinyl acetate (PVA) starch as a substrate for the slow release of copper and zinc nutrients transported by carbon nanofibers. The authors tested the effectiveness of nanofertilizers by applying different concentrations on chickpea culture. They reported that the use of the produced nanohybrid increased the yield of chickpea plants from $46 \%$ to $96 \%$.

Therefore, it is observed that there are several alternatives for the production of nanofertilizers, making it necessary to choose the most appropriate method for each case and final application. The choice must be based on the economic viability of the production, use, preparation and final application. Another important factor to be evaluated is the performance of the final products, for this, it is necessary to know about the mechanisms of absorption of nutrients in the culture under analysis.

\section{Mechanisms for nutrient uptake by plants}

There are countless possible mechanisms of uptake of macro- and micronutrients by plants. After releasing the nanofertilizers into the environment next to the crops, the elements 
can be absorbed by different routes, such as via root, leaf, endocytosis, and/or other (IOANNOU et al., 2020). Figure 3 shows a scheme with the different routes of nutrient uptake by plants. Absorption by the roots can greatly restrict the nutrients that are captured when treated in the soil, due to the size of the pores and the elements to be absorbed. Sartori et al. (2008) reported a study in which they compared two types of absorption to verify which one showed more significance in the orange crop (Citrus sinensis (L.) Osbeck). They evaluated the mechanisms of root and leaf uptake in the development of the plant after five years of treatment, with solutions using zinc as an essential micronutrient. As a result, they reported that the root canal proved to be more efficient.

Figure 3. Routes of nutrient absorption by plants.

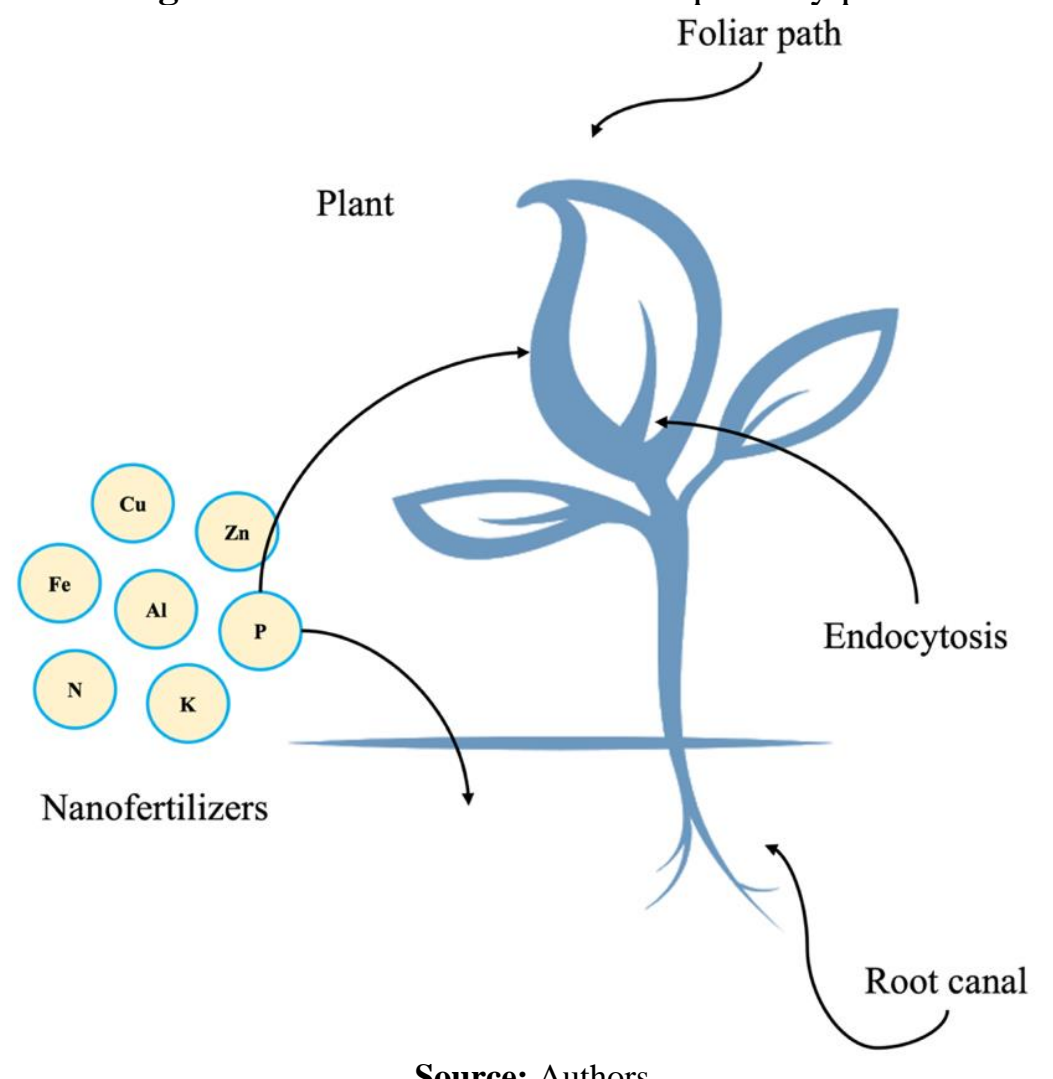

Source: Authors.

Another important route is the leaf, through this route it is possible to carry out the application of pesticides and herbicides in the plantation simultaneously with fertilization. For this reason, foliar fertilization is highly efficient and minimizes contamination. However, it has some disadvantages such as nutrient mobility and penetration through leaf cuticles. Rios, Garcia-Ibañez and Carvajal (2019) evaluated the use of Zn nanobiocarriers as a potential nanofertilizer using the foliar pathway. They used broccoli and pak-choi plants (Brassica rapa subsp. Chinensis) hydroponically cultivated in the absence of zinc. The authors tested the use 
of the zinc nanofertilizer combined with surfactant (PMP) and plant vesicles to increase the bioavailability of the nutrient. After the tests with the fertilizers combined with vesicles derived from broccoli and PMP, the authors found significant differences in the crops analyzed. The application of the fertilizer without the surfactant caused a weak increase in the concentration of $\mathrm{Zn}$ in the leaves. However, the combined use of the micronutrient with the surfactant strongly increased its leaf concentration, approximately three times compared to the previous situation. The treatment with vesicles and surfactants showed the higher concentration between the tests, almost four times the value of plants when only zinc was used.

Abdel-Aziz, Hasaneen and Omer (2019) investigated the possible effects of using chitosan nanoparticles and modified carbon nanotubes in isolated form or loaded with NPK (nitrogen, phosphorus and potassium) as fertilizers in French bean plants. The authors addressed two application techniques: seed priming, and leaf application. As a result, they observed that leaf fertilization was better than seed priming and that leaf treatment with chitosan nanoparticles reduced harvest days without reducing yield (80 days), when compared to control and seed priming treatment (110 days). The authors did not verify great changes in the results with carbon nanotubes when treated via leaf.

Although nanofertilizers enter plants mainly through the root and leaf pathways, there are other support mechanisms, such as endocytosis (SHINDE et al., 2020). The endocytosis process allows the transport of elements from the extracellular medium into the cell, through vesicles limited by membranes (FAN et al., 2015). Moghaddasi et al. (2015) conducted a study on the positive and negative effects of using rubber ash nanoparticles on plants as a zinc fertilizer. They investigated the absorption of $\mathrm{Zn}$ by the roots and the effects of these nanoparticles on the growth of cucumber. The authors reported that the capture of these nanostructures occurs at the root, for this, they used characterization techniques, such as Scanning Electron Microscopy (SEM) and Transmission Electron Microscopy (TEM). The authors attributed the entry of zinc in the cucumber culture by the roots, but with the aid of a possible posterior mechanism of endocytosis.

Apodaca et al. (2017) used bean plants (Phaseolus vulgaris) grown with copper $(\mathrm{Cu})$ nanoparticles combined with kinetin, a plant hormone. In the study, they verified the growth of the crop, the mechanisms of nutrient uptake, the copper concentrations in the roots and leaves, the chlorophyll content, and the enzymatic activity in beans with approximately 2 months of age. The authors evaluated the possible routes for the absorption of nutrients, especially copper, and found high concentrations of this element in the root tissue. The results of the research 
revealed significant levels of copper in the leaves when treated with kinetin. Thus, the role of the endocytosis mechanism in plants for the absorption of nutrients is notorious.

The works discussed above showed that some variables directly influence nutrient uptakes, such as particle size, chemical species, concentration, plant stage, external conditions of the environment, time of contact with the elements, and others. Therefore, in-depth studies of each crop are essential when using nanofertilizers as a source of nutrients.

\section{Benefits and challenges of using nanofertilizers}

Emerging technologies are constantly developing, specifically in modern agriculture. Concerns about the environment must be a fundamental factor, taking into account that natural resources are increasingly scarce, and the climatic effects are aggravated by the devastation caused by man. The search for progress and population growth generated important demands, such as high production of food in smaller spaces and less time. Therefore, the use of nanofertilizers in agriculture can serve as an ally to achieve sustainability, especially towards world food production (HU et al., 2017). Chart 2 shows the advantages and disadvantages of using nanofertilizers in agriculture.

Chart 2. The advantages and disadvantages of using nanofertilizers in modern agriculture.

\begin{tabular}{|l|l|}
\hline \multicolumn{1}{|c|}{ Advantages } & \multicolumn{1}{c|}{ Disadvantages } \\
\hline $\begin{array}{l}\text { Possibility to act as a great nutrient release } \\
\text { mechanism }\end{array}$ & Need for life cycle studies \\
\hline Reducing nutrient loss to the environment & Food security \\
\hline Numerous synthesis approaches & $\begin{array}{l}\text { Lack of long-term environmental } \\
\text { studies }\end{array}$ \\
\hline
\end{tabular}

Source: Authors.

In the last few years, the food sector has been experiencing great advances, specifically in the development of technology used in crops to supply nutrients lacking in the human diet, which is caused mainly by the advent of fast food and the low consumption of vegetables and fruits. Thus, the importance of using nanotechnology in the development of agrochemicals led to the conception of nanofertilizers. These nanoparticles act in the regulation of nutrients in different plants (HUSSAIN et al., 2018) using control mechanisms and the slow release of essential elements in the growth and germination of cultures. For example, there are studies that nanofertilizers release nutrients in up to two months, which, when compared to similar fertilizers that release in up to 10 days, have a great advantage. Another positive point of having 
a nutrient management system is that these elements are not lost to the environment (CYRIAC et al., 2020).

An additional advantage of using nanofertilizers is that they can be produced considering which nutrients are needed for a given crop because of the ease of production of these materials. Besides, the bioavailability of nutrients due to the high surface area of the nanoparticles, size, and reactivity is also a plus (REDDY PULLAGURALA et al., 2018). By providing the elements in a balanced way, nanoparticles cause cultures to eliminate several factors, such as biotic and abiotic stresses. However, the intense use of nanofertilizers in agriculture can have some disadvantages and limitations, which need special attention (YOUNES et al., 2020).

The overuse of nanofertilizers in agricultural activities can bring some unwanted and even irreversible environmental results. Also, the safety of these nanoparticles in the development of plants is another factor, as nanofertilizers can act differently in crops. Thus, the assessment of risks and the identification of the harmful effects of these nanostructures, including the evaluation of the life cycle, are essential. Another disadvantage of the indiscriminate use of nanofertilizers is their transformation in the environment due to high reactivity, being subject to unwanted reactions and changes in properties (IAVICOLI et al., 2017). Ma et al. (2017) investigated the use of $\mathrm{CeO}_{2}$ nanoparticles in cucumber plants by performing translocation and absorption analysis, which are often unwanted due to increased environmental toxicity when the nanoparticles are transformed into other species. They found that approximately $15 \%$ of cerium was reduced from $\mathrm{Ce}^{4+}$ to $\mathrm{Ce}^{3+}$ in the roots of cucumbers and the transformation products were transported by the phloem. This demonstrates that the use of nanofertilizers can cause numerous implications for the human health. Thus, the safety of food grown in the presence of nanofertilizers must be well evaluated.

\section{Conclusion}

The review approached nanofertilizers, which are a new topic in the literature under constant development. The research carried out in the area, although presenting more advantages than disadvantages in the use of these nanomaterials, is still preliminary and very specific. As a result, many studies still need to be carried out to contribute to the establishment of this technology as a viable, safe, and sustainable alternative for wide application in different cultures. The numerous synthesis approaches using renewable sources and green techniques are positive points. Also, simplicity of execution and no need for sophisticated equipment show advantageous paths for the effective insertion of these nanostructures in the field. For this, 
knowledge of all the limitations and benefits of the application of nanofertilizers is essential. These range from performance in a specific culture to the life cycle and transformations of chemical species in contact with plants. As the majority of the literature shows a promising future in the use of nanofertilizers for plant nutrition, research addressing this topic is a very active and encouraging area due to the many possibilities not yet explored.

\section{References}

ABDEL-AZIZ, H. M. M.; HASANEEN, M. N. A.; OMER, A. M. Impact of engineered nanomaterials either alone or loaded with NPK on growth and productivity of French bean plants: Seed priming vs foliar application. South African Journal of Botany, [s. 1.], v. 125, p. 102-108, 2019. Disponível em: 〈https://doi.org/10.1016/j.sajb.2019.07.005>

ABDEL-AZIZ, Heba M. M.; RIZWAN, Muhammad. Chemically synthesized silver nanoparticles induced physio-chemical and chloroplast ultrastructural changes in broad bean seedlings. Chemosphere, [s. 1.], v. 235, p. 1066-1072, 2019. Disponível em: <https://doi.org/10.1016/j.chemosphere.2019.07.035>

AHMED, Bilal et al. Chromosomal aberrations, cell suppression and oxidative stress generation induced by metal oxide nanoparticles in onion (Allium cepa) bulb. Metallomics, [s. 1.], v. 10, n. 9, p. 1315-1327, 2018.

AHMED, Bilal; KHAN, Mohammad Saghir; MUSARRAT, Javed. Toxicity assessment of metal oxide nano-pollutants on tomato (Solanum lycopersicon): A study on growth dynamics and plant cell death. Environmental Pollution, [s. 1.], v. 240, n. 2018, p. 802-816, 2018. Disponível em: <https://doi.org/10.1016/j.envpol.2018.05.015>

APODACA, Suzanne A. et al. Physiological and biochemical effects of nanoparticulate copper, bulk copper, copper chloride, and kinetin in kidney bean (Phaseolus vulgaris) plants. Science of the Total Environment, [s. 1.], v. 599-600, p. 2085-2094, 2017. Disponível em: <http://dx.doi.org/10.1016/j.scitotenv.2017.05.095>

ASGARI LAJAYER, Behnam et al. Micronutrient and heavy metal concentrations in basil plant cultivated on irradiated and non-irradiated sewage sludge- treated soil and evaluation of human health risk. Regulatory Toxicology and Pharmacology, [s. 1.], v. 104, n. August 2018, p. 141-150, 2019. Disponível em: <https://doi.org/10.1016/j.yrtph.2019.03.009>

BRIAT, Jean François et al. Reappraisal of the central role of soil nutrient availability in nutrient management in light of recent advances in plant nutrition at crop and molecular levels. European Journal of Agronomy, [s. 1.], v. 116, n. March, p. 126069, 2020. Disponível em: <https://doi.org/10.1016/j.eja.2020.126069>

CAI, Lin et al. Foliar exposure of $\mathrm{Fe} 3 \mathrm{O} 4$ nanoparticles on Nicotiana benthamiana: Evidence for nanoparticles uptake, plant growth promoter and defense response elicitor against plant virus. Journal of Hazardous Materials, [s. 1.], v. 393, n. December 2019, p. 122415, 2020. Disponível em: <https://doi.org/10.1016/j.jhazmat.2020.122415> 
CYRIAC, Jaiby et al. Synthesis of biogenic $\mathrm{ZnO}$ nanoparticles and its impact on seed germination and root growth of Oryza sativa L. and Vigna unguiculata L. Materials Today: Proceedings, [s. 1.], v. 25, p. 224-229, 2020. Disponível em: $<$ https://doi.org/10.1016/j.matpr.2020.01.107>

DA SILVA, Tácio Oliveira et al. Plantas de cobertura submetidas a diferentes fontes de fósforo em solos distintos. Semina:Ciencias Agrarias, [s. 1.], v. 32, n. 4, p. 1315-1326, 2011.

DUHAN, Joginder Singh et al. Nanotechnology: The new perspective in precision agriculture. Biotechnology Reports, [s. 1.], v. 15, n. December 2016, p. 11-23, 2017.

FAN, Lusheng et al. Endocytosis and its regulation in plants. Trends in Plant Science, [s. 1.], v. 20, n. 6, p. 388-397, 2015. Disponível em: 〈http://dx.doi.org/10.1016/j.tplants.2015.03.014> FEREGRINO-PEREZ, Ana A. et al. A general overview of the benefits and possible negative effects of the nanotechnology in horticulture. Scientia Horticulturae, [s. 1.], v. 238, n. April, p. 126-137, 2018.

HE, Hongsu et al. Changes of plant biomass partitioning, tissue nutrients and carbohydrates status in magnesium-deficient banana seedlings and remedy potential by foliar application of magnesium. Scientia Horticulturae, [s. 1.], v. 268, n. March, p. 109377, 2020. Disponível em: <https://doi.org/10.1016/j.scienta.2020.109377>

HE, Xiaojia; DENG, Hua; HWANG, Huey min. The current application of nanotechnology in food and agriculture. Journal of Food and Drug Analysis, [s. 1.], v. 27, n. 1, p. 1-21, 2019. Disponível em: 〈https://doi.org/10.1016/j.jfda.2018.12.002>

HU, Jing et al. Comparative impacts of iron oxide nanoparticles and ferric ions on the growth of Citrus maxima. Environmental Pollution, [s. 1.], v. 221, p. 199-208, 2017. Disponível em: <http://dx.doi.org/10.1016/j.envpol.2016.11.064>

HUSAIN JAAFRY, Syed Wajahat et al. Interactions among individuals of Setaria Italica at different levels of genetic relatedness under different nutrient and planting density conditions. Acta Oecologica, [s. 1.], v. 105, n. March, p. 103549, 2020. Disponível em: <https://doi.org/10.1016/j.actao.2020.103549>

HUSSAIN, Afzal et al. Zinc oxide nanoparticles alter the wheat physiological response and reduce the cadmium uptake by plants. Environmental Pollution, [s. 1.], v. 242, p. 1518-1526, 2018. Disponível em: <https://doi.org/10.1016/j.envpol.2018.08.036>

IAVICOLI, Ivo et al. Nanotechnology in agriculture: Opportunities, toxicological implications, and occupational risks. Toxicology and Applied Pharmacology, [s. 1.], v. 329, p. 96-111, 2017. Disponível em: <http://dx.doi.org/10.1016/j.taap.2017.05.025>

IOANNOU, Andreas et al. Advanced nanomaterials in agriculture under a changing climate: The way to The future? Environmental and Experimental Botany, [s. 1.], v. 176, n. April, p. 104048, 2020. Disponível em: <https://doi.org/10.1016/j.envexpbot.2020.104048>

$\mathrm{KAH}$, Melanie et al. A critical evaluation of nanopesticides and nanofertilizers against their conventional analogues. Nature Nanotechnology, [s. 1.], v. 13, n. 8, p. 677-684, 2018. Disponível em: <http://dx.doi.org/10.1038/s41565-018-0131-1> 
KOTTEGODA, Nilwala et al. Urea-Hydroxyapatite Nanohybrids for Slow Release of Nitrogen. ACS Nano, [s. 1.], v. 11, n. 2, p. 1214-1221, 2017.

KUMAR, Rahul; ASHFAQ, Mohammad; VERMA, Nishith. Synthesis of novel PVA-starch formulation-supported $\mathrm{Cu}-\mathrm{Zn}$ nanoparticle carrying carbon nanofibers as a nanofertilizer: controlled release of micronutrients. Journal of Materials Science, [s. 1.], v. 53, n. 10, p. 7150 7164, 2018. Disponível em: 〈https://doi.org/10.1007/s10853-018-2107-9>

LIU, Ruiqiang; LAL, Rattan. Potentials of engineered nanoparticles as fertilizers for increasing agronomic productions. Science of the Total Environment, [s. 1.], v. 514, n. 2015, p. 131-139, 2015. Disponível em: <http://dx.doi.org/10.1016/j.scitotenv.2015.01.104>

MA, Yuhui et al. Xylem and Phloem Based Transport of CeO2 Nanoparticles in Hydroponic Cucumber Plants. Environmental Science and Technology, [s. 1.], v. 51, n. 9, p. 5215-5221, 2017.

MAGHSOODI, Mohammad Reza; GHODSZAD, Larissa; ASGARI LAJAYER, Behnam. Dilemma of hydroxyapatite nanoparticles as phosphorus fertilizer: Potentials, challenges and effects on plants. Environmental Technology and Innovation, [s. 1.], v. 19, p. 100869, 2020. Disponível em: <https://doi.org/10.1016/j.eti.2020.100869>

MEDEIROS, Marciano De et al. Fertilizante Nitrogenado E Nitrogênio Do Solo No Desenvolvimento De Feijão E Caupi. Bragantia, [s. 1.], v. 70, n. 1, p. 206-215, 2010. Disponível em: <http://www.scielo.br/pdf/brag/v70n1/v70n1a27.pdf>

MOGHADDASI, Sahar et al. Fate and effect of tire rubber ash nano-particles (RANPs) in cucumber. Ecotoxicology and Environmental Safety, [s. 1.], v. 115, p. 137-143, 2015. Disponível em: <http://dx.doi.org/10.1016/j.ecoenv.2015.02.020>

MOGHADDASI, Sahar et al. Bioavailability of coated and uncoated $\mathrm{ZnO}$ nanoparticles to cucumber in soil with or without organic matter. Ecotoxicology and Environmental Safety, [s. 1.], v. 144, n. January, p. 543-551, 2017. Disponível em: <http://dx.doi.org/10.1016/j.ecoenv.2017.06.074>

NAIR, K. Madhavan; AUGUSTINE, Little Flower. Food synergies for improving bioavailability of micronutrients from plant foods. Food Chemistry, [s. 1.], v. 238, p. 180-185, 2018. Disponível em: <http://dx.doi.org/10.1016/j.foodchem.2016.09.115>

PEREIRA, Flávia F. et al. Investigation of nanotoxicological effects of nanostructured hydroxyapatite to microalgae Pseudokirchneriella subcapitata. Ecotoxicology and Environmental Safety, [s. 1.], v. 144, n. May, p. 138-147, 2017. Disponível em: <http://dx.doi.org/10.1016/j.ecoenv.2017.06.008>

PRAZERES, Stella Silva et al. Crescimento e trocas gasosas de plantas de feijão-caupi sob irrigação salina e doses de potássio. Revista Agro@ Mbiente on-Line, [s. 1.], v. 9, n. 2, p. 111, 2015 .

REDDY PULLAGURALA, Venkata L. et al. ZnO nanoparticles increase photosynthetic pigments and decrease lipid peroxidation in soil grown cilantro (Coriandrum sativum). Plant 
Physiology and Biochemistry, [s. 1.], v. 132, n. August, p. 120-127, 2018. Disponível em: <https://doi.org/10.1016/j.plaphy.2018.08.037>

RIOS, Juan José; GARCIA-IBAÑEZ, Paula; CARVAJAL, Micaela. The use of biovesicles to improve the efficiency of $\mathrm{Zn}$ foliar fertilization. Colloids and Surfaces B: Biointerfaces, [s. 1.], v. 173, n. September 2018, p. 899-905, 2019. Disponível em: <https://doi.org/10.1016/j.colsurfb.2018.10.057>

SAMPATHKUMAR, Kaarunya; TAN, Kei Xian; LOO, Say Chye Joachim. Developing NanoDelivery Systems for Agriculture and Food Applications with Nature-Derived Polymers. iScience, $[\mathrm{s} . \quad 1],$.$\quad v. 23, \quad$ n. 5, p. 101055, 2020. Disponível em: <https://doi.org/10.1016/j.isci.2020.101055>

SARTORI, Raul Henrique et al. Absorção radicular e foliar de65ZN e sua redistribuição em laranjeiras. Revista Brasileira de Fruticultura, [s. 1.], v. 30, n. 2, p. 523-527, 2008.

SHARMA, Garima et al. Chitosan nanofertilizer to foster source activity in maize. International Journal of Biological Macromolecules, [s. 1.], v. 145, p. 226-234, 2020. Disponível em: <https://doi.org/10.1016/j.ijbiomac.2019.12.155>

SHEBL, Ahmed et al. Template-free microwave-assisted hydrothermal synthesis of manganese zinc ferrite as a nanofertilizer for squash plant (Cucurbita pepo L). Heliyon, [s. 1.], v. 6, n. 3, p. e03596, 2020. Disponível em: 〈https://doi.org/10.1016/j.heliyon.2020.e03596>

SHINDE, Surbhi et al. Promotion of seed germination and seedling growth of Zea mays by magnesium hydroxide nanoparticles synthesized by the filtrate from Aspergillus niger. Arabian Journal of Chemistry, [s. 1.], v. 13, n. 1, p. 3172-3182, 2020. Disponível em: <https://doi.org/10.1016/j.arabjc.2018.10.001>

SINGH, Pallavi; DWIVEDI, Padmanabh. Micronutrients zinc and boron enhance stevioside content in Stevia rebaudiana plants while maintaining genetic fidelity. Industrial Crops and Products, [s. 1.], v. 140, n. August, p. 111646, 2019. Disponível em: <https://doi.org/10.1016/j.indcrop.2019.111646>

TRUJILLO-REYES, J. et al. Exposure studies of core-shell $\mathrm{Fe} / \mathrm{Fe} 3 \mathrm{O} 4$ and $\mathrm{Cu} / \mathrm{CuO} \mathrm{NPs}$ to lettuce (Lactuca sativa) plants: Are they a potential physiological and nutritional hazard? Journal of Hazardous Materials, [s. 1.], v. 267, p. 255-263, 2014. Disponível em: <http://dx.doi.org/10.1016/j.jhazmat.2013.11.067>

TUHY, Łukasz et al. Conversion of spent mushroom substrate into micronutrient fertilizer via biosorption in a pilot plant. Ecological Engineering, [s. 1.], v. 84, p. 370-374, 2015. Disponível em: <http://dx.doi.org/10.1016/j.ecoleng.2015.09.032>

USMAN, Muhammad et al. Nanotechnology in agriculture: Current status, challenges and future opportunities. Science of the Total Environment, [s. 1.], v. 721, p. 137778, 2020. Disponível em: 〈https://doi.org/10.1016/j.scitotenv.2020.137778>

YOUNES, N. A. et al. Impact of synthesized metal oxide nanomaterials on seedlings production of three Solanaceae crops. Heliyon, [s. 1.], v. 6, n. 1, p. e03188, 2020. Disponível em: <https://doi.org/10.1016/j.heliyon.2020.e03188> 
ZHAO, Cong Ying et al. Effects of soil nutrient variability and competitor identify on growth and co-existence among invasive alien and native clonal plants. Environmental Pollution, [s. 1.], v. 261, p. 113894, 2020. a. Disponível em: 〈https://doi.org/10.1016/j.envpol.2019.113894>

ZHAO, Qingzhou et al. Impacts of drought and nitrogen enrichment on leaf nutrient resorption and root nutrient allocation in four Tibetan plant species. Science of the Total Environment, [s. 1.], v. $723, \quad$ p. $138106,2020 . \quad$ b. Disponível em: <https://doi.org/10.1016/j.scitotenv.2020.138106>

ZULFIQAR, Faisal et al. Nanofertilizer use for sustainable agriculture: Advantages and limitations. Plant Science, [s. 1.], v. 289, n. September, 2019. 


\title{
CAPÍTULO 44: REVESTIMENTOS UTILIZADOS EM NANOPARTÍCULAS MAGNÉTICAS PARA IMOBILIZAÇÃO DE ENZIMAS: UMA REVISÃO
}

\section{CHAPTER 44: COATINGS USED IN MAGNETIC NANOPARTICLES FOR ENZYME IMMOBILIZATION: A REVISION}

\author{
Munique Cristiane Tavares Santos Silva ${ }^{1}$; Lígia Maria Gonçalves Fernandes ${ }^{2}$; Ana Lúcia Figueiredo \\ Porto $^{3}$; Márcia Nieves Carneiro da Cunha ${ }^{4}$; Tatiana Souza Porto ${ }^{5}$
}

\begin{abstract}
Resumo
Enzimas imobilizadas em nanopartículas magnéticas (NPMs) possuem ampla aplicabilidade em processos catalíticos industriais, devido a vantagens como: aumento da produtividade e da estabilidade operacional, facilidade de manuseio e separação, além da possibilidade de reutilização do biocatalizador. Entretanto, a imobilização direta de enzimas na superfície dessas partículas não é recomendada, em razão de sua fraca dispersibilidade aquosa e alta tendência a oxidação. Visando contornar este problema, as NPMs são geralmente revestidas com materiais inertes e impermeáveis. Desta forma, este trabalho teve como objetivo realizar uma breve busca na literatura sobre os materiais comumente utilizados para revestimento de nanopartículas magnéticas. A escolha adequada da natureza e do tipo de material utilizado possibilita o aprimoramento no processo de imobilização, além de aumentar a estabilidade e eficiência catalítica da enzima.
\end{abstract}

Palavras-Chave: imobilização enzimática, nanopartículas magnéticas, revestimento.

\begin{abstract}
Enzymes immobilized in magnetic nanoparticles (MNPs) have wide applicability in industrial catalytic processes, due to advantages such as: increased productivity and operational stability, ease of handling and separation, in addition to the possibility of biocatalyst reusing. However, direct immobilization of enzymes on the surface of these particles is not recommended, due to their poor aqueous dispersibility and high tendency to oxidation. To circumvent this problem, MNPs are generally coated with inert and impermeable materials. Thus, this work aimed to conduct a brief search in the literature on the materials commonly used for coating magnetic nanoparticles. The appropriate choice of the nature and type of material used makes it possible to improve the immobilization process, in addition to increasing stability and catalytic efficiency.
\end{abstract}

Keywords: enzymatic immobilization, magnetic nanoparticles, coating.

\footnotetext{
1 Programa de Pós Graduação em Biociência Animal, Universidade Federal Rural de Pernambuco, muniquecpc@gmail.com

${ }^{2}$ Programa de Pós Graduação em Biociência Animal, Universidade Federal Rural de Pernambuco, proflmgf@yahoo.com.br

3 Departamento de Morfologia e Fisiologia Animal, Universidade Federal Rural de Pernambuco, analuporto@yahoo.com.br

4 Departamento de Morfologia e Fisiologia Animal, Universidade Federal Rural de Pernambuco, marcianieves@yahoo.com.br

5 Doutora em Tecnologia Bioquímico-Farmacêutica, Universidade Federal do Agreste de Pernambuco, tatiana.porto@ufape.edu.br
} 


\section{Introdução}

Enzimas são biocatalizadores altamente específicos, que podem ter seu uso maximizado e melhorado através de sua imobilização. Este processo pode permitir à enzima se tornar mais estável e resistente a condições severas, como grandes intervalos de $\mathrm{pH}$ e temperatura, e também pode preservar atividade enzimática por de vários ciclos. A imobilização enzimática é uma alternativa à aplicação eficiente destes biocatalisadores nas indústrias alimentícia, química e farmacêutica. Para que o uso de enzimas imobilizadas seja economicamente viável, deve-se considerar o tipo de suporte e o método de imobilização que será empregado, visto que este irá influenciar na atividade enzimática e na posterior reutilização desses biocatalizadores (TOMBÁCZ et al., 2015).

Uma das grandes questões do processo de imobilização enzimática é a escolha do suporte, o uso de um suporte adequado é essencial para definir o tipo de imobilização a ser realizado, uma vez que o material utilizado poderá afetar significativamente as propriedades da enzima imobilizada. Os suportes podem ser orgânicos ou inorgânicos e devem ser inertes, estáveis, insolúveis no meio de reação e resistentes às forças mecânicas (GENNARI et al., 2020). O uso de suportes com núcleo magnético diminui a necessidade de centrifugação, a indesejável diluição da amostra e perdas do suporte durante as lavagens, eventos que muitas vezes complicam o uso de reatores de enzimas não-magnéticas. As separações magnéticas são relativamente rápidas, fáceis e requerem aparelhagem simples. Portanto, técnicas de separação magnética têm atualmente encontrado muitas aplicações em áreas diferentes das ciências biológicas, especialmente em escala laboratorial (SEENUVASAN, 2020)

Nanopartículas magnéticas possuem elementos magnéticos que podem ser manipulados por um campo externo, apresentam tamanhos que variam de 1 à $100 \mathrm{~nm}$, tem superfície hidrofílica e alta razão superfície/volume, podem estar em estado superparamagnético, entre outras características físicas e químicas que são fortemente influenciadas pelo seu tamanho, morfologia e estrutura cristalina (BEDÊ, 2010).

Entretanto, nanopartículas magnéticas apresentam certas limitações práticas quando utilizadas em aplicações biológicas e farmacológicas. Dentre esses empecilhos, destacam-se a tendência de se aglomerarem a fim de minimizar a energia livre superficial; baixas estabilidade e dispersividade em determinados solventes (em especial, na água); alta atividade química; facilidade em ser oxidada em ar (principalmente a magnetita) e, consequente perda de propriedades magnéticas; absorção pelo corpo; e biodegradação em meio biológico, ocasionando perda de suas propriedades originais (WU, HE e JIANG, 2008). Dessa forma, proporcionar um 
recobrimento apropriado dessas partículas mostra-se como uma boa alternativa para amenizar e/ou eliminar essas barreiras, e proporcionar maior eficiência de imobilização enzimática. Diante do exposto, este trabalho objetivou realizar uma busca bibliográfica a respeito dos diversos revestimentos utilizados em nanopartículas magnéticas, avaliando a eficiência deste revestimento na imobilização, na estabilidade e na capacidade de reutilização da enzima imobilizada.

\section{Desenvolvimento}

\section{Enzimas}

Micro-organismos são fontes atrativas para obtenção de enzimas de uso industrial, pois apresentam grande disponibilidade, taxa de crescimento rápido e fácil manipulação genética, podendo ser cultivados em grandes quantidades sob condições controladas, em meios cultivo de baixo custo e elevada produtividade. Acrescenta-se ainda a vantagem de a produção não estar condicionada às questões sazonais e geográficas (BON et al., 2009). Aplicações de enzimas microbianas em indústrias alimentícias, farmacêuticas, têxteis, papel, couro e outras são numerosas e crescem rapidamente em relação aos métodos convencionais, devido a menos danos ao meio ambiente, maior eficiência e produtos de maior qualidade (SINGH et al., 2016).

Espera-se que o mercado global de enzimas tenha no período de 2019 a 2026 uma taxa anual de crescimento de 6,75\%, passando de U\$ 8,8 bilhões em 2018 para U\$ 13,79 bilhões até 2026. Este crescimento acelerado de aproximadamente $68 \%$ no período descrito é dado devido ao uso extensivo das enzimas em diversos setores da indústria, tais como, processamento de alimentos, papel, biocombustíveis, detergentes biológicos, setores de biologia molecular, entre outros (FIORMARKETS, 2019).

$\mathrm{Na}$ indústria farmacêutica e de diagnóstico, as aplicações enzimáticas estão crescendo rapidamente. Aplicações relacionadas com o debridamento de feridas por enzimas proteolíticas com atividade colagenolítica e o bloqueio de coágulos pelas enzimas fibrinolíticas são proeminentes (SINGH et al., 2016). Um exemplo disto é a protease fibrinolitica produzida por Mucor subtilissimus UCP1262 um promissor agente antitrombótico (NASCIMENTO et al., 2016).

O uso de enzimas ou micro-organismos em preparações alimentícias é um processo antigo. A biotecnologia de alimentos, considerada como aplicações de processos biotecnológicos na produção de alimentos, começou antes de 6000 a.C. Fermentar uvas ou fabricar cerveja são exemplos dessa biotecnologia alimentar inicial, apesar de serem rudimentares, a aplicação de enzimas na tecnologia de alimentos já foi estabelecida nesses processos (TAVANO et al., 2018). Com o avanço da tecnologia, 
novas enzimas foram desenvolvidas e novas áreas de aplicação ainda estão sendo exploradas.

As enzimas são utilizadas em praticamente todos os segmentos da indústria de alimentos (panificação, laticíneos, bebidas). Um exemplo disto são as pectinases ácidas que podem ser usadas na extração, clarificação e remoção de pectina dos sucos de frutas, a maceração de vegetais para produzir pastas purês e vinificação. Quase todas as preparações comerciais de pectinases são produzidas por espécies fúngicas, pertencentes principalmente ao gênero Aspergillus. Entre eles, Aspergillus aculeatus destaca-se na produção industrial de enzimas pectinolíticas, visto que a preparação comercial Pectinex ${ }^{\circledR}$ Ultra SPL, obtido a partir deste micro-organismo, foi empregado com sucesso para clarificar e reduzir a viscosidade de sucos de frutas, como maçã, carambola e pitaya vermelha (OLIVEIRA et al., 2018).

$\mathrm{Na}$ indústria têxtil e do couro, as enzimas são utilizadas em diferentes etapas do processo de produção industrial. Na indústria têxtil as enzimas vêm sendo utilizadas no desenvolvimento de processos visando minimizar a geração de resíduos e estratégias para melhorar a qualidade do produto final (CHOI et al., 2015). As principais classes de enzimas envolvidas nos processos de pré-tratamento e acabamento do algodão são as hidrolases e as oxidorredutases. O grupo das hidrolases incluem amilase, celulase, quitinase, protease, pectinase e lipase, que estão envolvidas no biopolimento e biossouramento de tecidos, antifelting de lã, amaciamento de algodão, acabamento de jeans, acabamento de lã e modificação de fibras sintéticas. As oxidorredutases incluem catalase, lacase, peroxidase e ligninase, que estão envolvidas no bio-branqueamento, na finalização do branqueamento, na descoloração do corante, no tecido e no acabamento da lã (SINGH et al., 2018).

As enzimas proteolíticas alcalinas são preferíveis aos sintéticos convencionais devido à sua especificidade de substrato, propriedades de limpeza, melhor desempenho em temperaturas de lavagem e atenuação da poluição ambiental. Essas características garantem alta aplicabilidade nas indústrias de detergentes como agente de limpeza e na indústria de cosméticos como sabonetes enzimáticos (FERNANDES et al., 2020).

\section{Imobilização de enzimas}

A utilização de enzimas em processos industriais requer o desenvolvimento de técnicas que possibilitem a sua recuperação e reutilização, visando tornar o processo economicamente viável, o que pode ser alcançado a partir da utilização de técnicas de imobilização. A imobilização enzimática favorece a estabilidade da enzima uma vez que o processo pode alterar suas propriedades estruturais, produzindo biocatalisadores com 
elevada atividade, especificidade e estabilidade, sendo por isso considerada, nos últimos anos, a técnica mais promissora para tornar competitiva a aplicação de enzimas em larga escala (SOUZA et al., 2017).

Imobilização é um termo genérico empregado para descrever a retenção de uma biomolécula no interior de um reator ou de um sistema analítico (CARDOZO et al., 2009). A imobilização de uma enzima significa combinar a seletividade, a estabilidade e a cinética dessa enzima com as propriedades físicas e químicas do transportador em uma formulação especializada que tem como papel principal maximizar a estabilidade física e enzimática do biocatalisador (BASSO E SERBAN, 2019). Diversas técnicas e protocolos já foram descritos para imobilização de enzimas. A escolha do método e do suporte a ser empregado dependerá principalmente das características físico-químicas da enzima e das condições de uso nas quais a enzima imobilizada será submetida, É igualmente importante avaliar o tempo e os custos necessários para se viabilizar o método de imobilização escolhido, uma vez que tais parâmetros irão se refletir no processo e, portanto, nos custos do produto final (FERNANDES, LIMA e LOPES, 2010).

Bassa e Serban (2019) pontuaram as principais vantagens e desvantagens da utilização de enzimas imobilizadas em processos industriais. A imobilização de biocatalizadores oferece vantagens como a facilidade para reutilização do biocatalizador e custos reduzidos em etapas de "downstream", entretanto, esses processos apresentam algumas limitações, visto que, há uma diminuição na atividade enzimática do imobilizado em comparação a enzima livre, além de custos adicionais referentes as etapas de imobilização, como apresentado no Quadro 1. 
Quadro 1. Vantagens e desvantagens de enzimas imobilizadas em processos industriais.

\begin{tabular}{|c|c|}
\hline VANTAGENS & DESVANTAGENS \\
\hline $\begin{array}{l}\text { - Fácil separação do biocatalisador; } \\
\text { - Custos reduzidos de processamento } \\
\text { "downstream”; } \\
\text { - Uso múltiplo de biocatalisador } \\
\text { (reciclagem); } \\
\text { - Melhor estabilidade, especialmente em } \\
\text { relação a solventes orgânicos e } \\
\text { temperaturas mais altas; } \\
\text { - Uso de reatores de leito fixo ou } \\
\text { batelada sem necessidade de } \\
\text { membrana para isolar enzima do } \\
\text { produto; } \\
\text { É possível co-imobilizar com outras } \\
\text { enzimas. }\end{array}$ & $\begin{array}{l}\text { - Menor atividade enzimática em } \\
\text { comparação com a enzima nativa; } \\
\text { - Custos adicionais para transportadoras } \\
\text { e imobilização; } \\
\text { - Taxas de reação mais baixas em } \\
\text { comparação com enzimas nativas; } \\
\text { - Sujeito a incrustação; } \\
\text { - Eliminação de enzima imobilizada } \\
\text { exaurida (incineração). }\end{array}$ \\
\hline
\end{tabular}

Fonte: Basso e Serban (2019)

As técnicas de imobilização de enzimas podem ser divididas em métodos químicos e físicos (Figura 1). Os métodos químicos envolvem a formação de ligações covalentes obtidas pela ligação de éter, tio-éter, amida ou carbamato entre a enzima e o suporte ou ainda através de ligações cruzadas entre a enzima e um agente reticulante. Nos métodos físicos, a enzima quando se liga por adsorção, formando ligações mais fracas com o suporte de imobilização (ligações de hidrogênio, ligação por afinidade, forças de Van der Waals, interações hidrofóbicas e ligação iônica), ou ainda podem ser aprisionadas ou encapsuladas (FURLANI et al., 2020). As interações enzima-suporte na imobilização podem ser vistas na Figura 1.

O uso de nanopartículas magnéticas como suporte sólido atribui ao biocatalisador um dos requisitos essenciais de fácil recuperação por simples aplicação de um campo magnético externo, reduzindo os custos de energia e tempo das etapas de centrifugação. Além do que nanomateriais apresentam uma alta relação superfície/volume facilitando assim a transferência de massa (PEREIRA et al., 2015). 
Figura 1. Classificação e representação de diferentes técnicas de imobilização de enzimas.

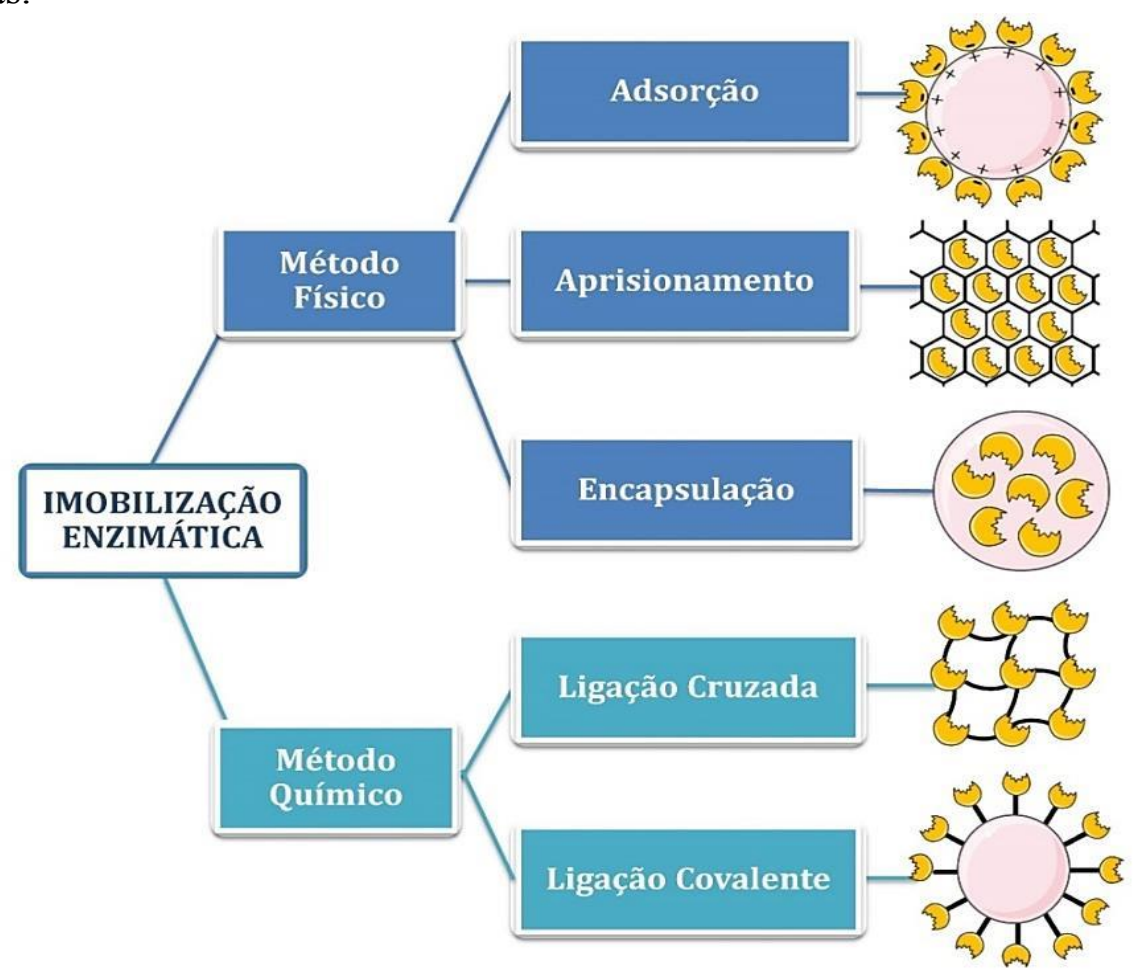

Fonte: Adaptado de Furlani et al., 2020; Souza et al., 2017.

\section{Imobilização enzimática em Nanopartículas magnéticas (NPMs)}

Nanopartículas magnéticas (NPMs) podem ser preparadas a partir de materiais de magnetização altamente saturados, tais como os metais de transição Ferro, Cobalto, Níquel e os óxidos metálicos $\mathrm{Fe}_{3} \mathrm{O}_{4}, \gamma-\mathrm{Fe}_{2} \mathrm{O}_{3}$, de acordo com vários métodos diferentes. Metais puros, como nanopartículas de ferro, possuem a maior magnetização, entretanto, também possuem alta toxicidade e são propensos à oxidação. Óxidos de metal mais estáveis e biocompatíveis, como nanopartículas são os de óxido de ferro superparamagnético, sendo preferidos, apesar de sua menor magnetização (QUAN et al., 2020). NPMs à base de óxido de ferro são mais comumente utilizadas e podem ser sintetizadas a partir de uma variedade de métodos químicos como síntese por decomposição térmica, reações hidrotermais, microemulsão e coprecipitação (FRANCISQUINI, SCHOENMAKER e SOUZA, 2010).

NPMs possuem propriedades intrínsecas interessantes para aplicações biotecnológicas, tais como: tamanho reduzido, área de superfície alta, resistência a altas temperaturas, altas interações enzimas-substrato e alta reatividade química atraindo a atenção dos cientistas. Além do que, devido à propriedade do superparamagnetismo é possível a recuperação do biocatalisador apenas por aplicação de um campo magnético ocasionando baixo estresse mecânico as enzimas (HU et al., 2009; COSTA et al., 2016). 
Embora as nanopartículas magnéticas possuam alta biocompatibilidade, mesmo sem modificação de superfície (QUAN et al., 2020). Comumente a superfície das nanopartículas é modificada visando facilitar o processo de imobilização enzimática, e contornar dificuldades como a distribuição não uniforme do tamanho da partícula e a fraca dispersibilidade aquosa, visto que, comportamentos restritos de nanomateriais em diferentes solventes limitam suas aplicações e, portanto, a modificação da superfície é uma estratégia importante que ajusta as propriedades dos nanomateriais para estender suas aplicações. A modificação da superfície pode alterar a propriedade existente ou pode introduzir propriedades completamente novas a partícula (SEENUVASAN et al., 2020).

A superfície das nanoestruturas pode ser modificada com materiais orgânicos (por exemplo, ácido láurico) e inorgânicos (por exemplo, $\mathrm{SiO}_{2}$ ) com o intuito de produzir partículas funcionalizadas (por exemplo, grupo amino) para imobilização enzimática (COSTA et al., 2016). Segundo Liu et al. (2020), a funcionalização da superfície das NPMs por compostos orgânicos é um método eficaz para aumentar a estabilidade das partículas durante o armazenamento e utilização. Além disso, as nanopartículas podem ser modificadas com certas biomoléculas para aumentar sua biocompatibilidade e melhor aplicação "in vivo", tornando-as mais específicas e expandindo o escopo de suas aplicações.

As estruturas das NPMs revestidas com compostos orgânicos podem ser divididas em núcleo-concha, matriz e concha-núcleo-concha (Figura 2), sendo formada por duas partes: um núcleo, geralmente formado por qualquer tipo de nanopartícula de óxido ferromagnético, classificado como magnetita, e uma casca/concha que pode ser um polímero, biopolímero ou biomolécula. As partículas modificadas por compostos orgânicos não só possuem as propriedades magnéticas básicas das NPMs, mas também apresentam boa biocompatibilidade e biodegradabilidade. Dentre os revestimentos inorgânicos a sílica é o material mais utilizado, devido a suas características inertes, com alta biocompatibilidade e baixa toxicidade, a sílica é um revestimento funcional para NPMs ideal para utilização no campo médico, pois permite a formação várias ligações de reticulação, além de, formar uma camada de proteção externa inerte para proteger as nanopartículas magnéticas internas (LIU et al., 2020). 
Figura 2. Estrutura principal das nanopartículas magnéticas modificadas por materiais orgânicos

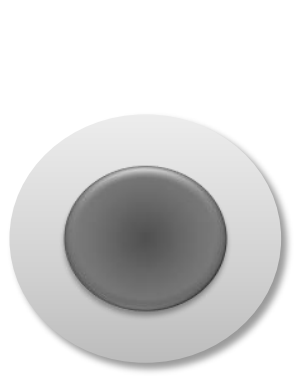

núcleo-concha

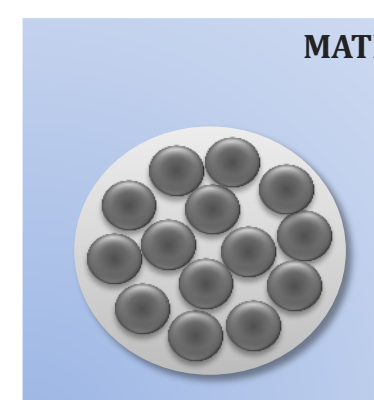

mosaico

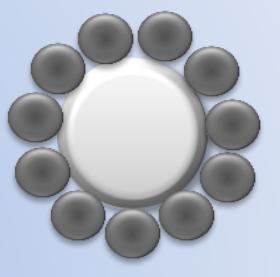

concha-núcleo

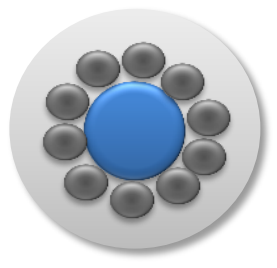

concha-núcleo-concha

Fonte: Adaptado de Liu et al., 2020

\section{Discussão}

A metodologia utilizada para a realização deste trabalho foi uma breve revisão bibliográfica, baseada em pesquisas de artigos científicos disponíveis nos bancos de dados: $\quad$ Scopus (http://www.scopus.com/); Science Direct (http://www.sciencedirect.com/), ISI Web of Science (http: //apps.isiknowledge.com) e PubMed (http://www.ncbi.nlm.nih.gov/pubmed), para a busca foi utilizado o seguinte termo de busca: ("magnetic nanoparticles") AND (coatings) AND ("enzyme immobilization”). Todo referencial teórico citado nesse artigo é meramente qualitativo sem nenhuma pretensão quantitativa.

Após a preparação das NPMs, algumas modificações devem ser realizadas para protegê-las contra agregações, oxidação e/ou alterações das cargas superfíciais, bem como, melhorar a capacidade de imobilização (DARWESH et al., 2019). A literatura traz vários estudos relacionados às NPMs recobertas com diversos materiais. Os materiais orgânicos possibilitam a preservação das características magnéticas das nanopartículas, biocompatibilidade, biodegradabilidade, além de fornecer grupos funcionais reativos (carboxila, amino, aldeído etc.) (LAURENT, et al. 2008). Exemplos desses materiais são moléculas pequenas e surfactantes, como ácido oleico, ácido cítrico, fosfanatos, aminoácidos e silanos; polímeros naturais e sintéticos, como dextran, quitosana, alginato, poli(etilenoglicol), poli(metilmetacrilato); e biomoléculas, como proteínas e anticorpos. Os materiais inorgânicos também são biocompatíveis e providenciam às nanopartículas estabilização, funcionalização e antioxidação. Pode-se citar como exemplos a sílica; metais e não-metais (ouro, prata, carbono); e óxidos metálicos e sulfetos ( $\mathrm{ZnO}, \mathrm{CaO}, \mathrm{A} 12 \mathrm{O} 3, \mathrm{ZnS})$ (TOMBÁCZ et al., 2015). A Tabela 1 mostra diferentes abordagens do uso de materiais para imobilização de enzimas. 
SILVA, M. C. T. S; FERNANDES, L. M. G; PORTO, A. L. F; CUNHA, M. N. C; PORTO, T. S.

Tabela 1. Tipos de revestimento em nanopartículas magnéticas para imobilização de diferentes enzimas.

\begin{tabular}{|c|c|c|c|c|c|}
\hline $\begin{array}{l}\mathbf{A N P M s} \\
\end{array}$ & $\begin{array}{l}\text { Revestimento } \\
\text { Orgânico / inorgânico }\end{array}$ & Enzima & $\overline{{ }^{\mathbf{B}} \mathbf{C R}}$ & $\begin{array}{c}\mathrm{C}_{\mathrm{AR}} \\
(\%) \\
\end{array}$ & Referências \\
\hline$\overline{\mathrm{Fe}_{3} \mathrm{O}_{4}}$ & Quitosana & Pectinase & 10 & $70,02 \%$ & Nouri e Khodaiyan, 2020 \\
\hline $\mathrm{Fe}_{3} \mathrm{O}_{4}$ & ${ }^{\mathrm{D}} \mathrm{CMC}$ & NovoQ & 3 & $>95 \%$ & Ni et al., 2020 \\
\hline $\mathrm{Fe}_{3} \mathrm{O}_{4}$ & ${ }^{\mathrm{D}} \mathrm{CMC}$ & Lipase & 10 & $83,9 \%$ & Hongbo Suo et al., 2020 \\
\hline $\mathrm{Fe}_{3} \mathrm{O}_{4}$ & ${ }^{\mathrm{E}} \mathrm{CMD}$ & $\mathrm{ADH}$ & $* * *$ & $* * *$ & Vasić et al., 2020 \\
\hline $\mathrm{Fe}_{3} \mathrm{O}_{4}$ & FPoli(Catechol/TEPA) & Lipase & $* * *$ & $* * *$ & Tang et al., 2019 \\
\hline $\mathrm{Fe}_{3} \mathrm{O}_{4}$ & ${ }^{\mathrm{G}} \mathrm{CS}-\mathrm{TPP}$ & Alcalase & 10 & $60 \%$ & Chen et al., 2018 \\
\hline $\mathrm{Fe}_{3} \mathrm{O}_{4}$ & Lectinas ConA & Glicose oxidase & 8 & $99 \%$ & Yong et al., 2018 \\
\hline $\mathrm{Fe}_{3} \mathrm{O}_{4}$ & Alginato/quitosana & cloroperoxidase & 25 & $25 \%$ & García-Embid et al., 2018 \\
\hline $\mathrm{Fe}_{3} \mathrm{O}_{4}$ & Quitosana & Lipase & 20 & $83 \%$ & Mendes et al., 2011 \\
\hline $\mathrm{Fe}_{3} \mathrm{O}_{4}$ & ${ }^{\mathrm{H}} \mathrm{CT} / \mathrm{PDA}$ & $\alpha$-amilase & 6 & $70 \%$ & $\begin{array}{l}\text { Manthiriyappan e Lee, } \\
2011\end{array}$ \\
\hline $\mathrm{Fe}_{3} \mathrm{O}_{4}$ & Sílica/epoxi & Lipase & 7 & $79 \%$ & Afzal et al., 2020 \\
\hline $\mathrm{Fe}_{3} \mathrm{O}_{4}$ & IPEG- triclorotriazina & Pectinase & 10 & $55 \%$ & Kharazmi et al, 2020 \\
\hline $\mathrm{Fe}_{3} \mathrm{O}_{4}$ & IPEG- triclorotriazina & Xilanase & 9 & $50 \%$ & Kharazmi et al., 2020 \\
\hline $\mathrm{Fe}_{3} \mathrm{O}_{4}$ & Álcool polivinílico & Tripsina & 8 & $56 \%$ & Sahin e Ozmen, 2020 \\
\hline $\mathrm{AuM}$ & sílica mesoporosa & Celulase & 9 & $58 \%$ & Poorakbar et al., 2018 \\
\hline $\mathrm{Fe}_{3} \mathrm{O}_{4}$ & Sílica/naringina & $\alpha$-amilase & 10 & $50 \%$ & Defaei et al., 2018 \\
\hline $\mathrm{Fe}_{3} \mathrm{O}_{4}$ & Sílica/epoxi & L-Asparaginase & 10 & $65 \%$ & Ulu et al., 2018 \\
\hline $\mathrm{Fe}_{3} \mathrm{O}_{4}$ & JPAMAM & $\alpha$-glucosidase & $* * *$ & $* * *$ & Jiang et al., 2019 \\
\hline $\mathrm{Fe}_{3} \mathrm{O}_{4}$ & Sílica & Lacase & 6 & $75 \%$ & Fortes et al., 2017 \\
\hline $\mathrm{Fe}_{3} \mathrm{O}_{4}$ & KPANI & Protease & 5 & $50 \%$ & Neto et al., 2017 \\
\hline $\mathrm{Fe}_{3} \mathrm{O}_{4}$ & LPUU & Lipase & $* * *$ & $* * *$ & Chiaradia et al., 2016 \\
\hline $\mathrm{Fe}_{3} \mathrm{O}_{4}$ & MPEIP & Tripsina & 21 & $>90 \%$ & Monteil et al., 2014 \\
\hline $\mathrm{Fe}_{3} \mathrm{O}_{4}$ & Sílica & Glicose oxidase & 12 & $90 \%$ & Ashtari et al., 2012 \\
\hline
\end{tabular}

\footnotetext{
ANPMs - Nanopartículas magnéticas

${ }^{\mathrm{B}} \mathrm{CR}$ - Número de ciclos de reuso

${ }^{\mathrm{C}} \mathrm{AR}(\%)$ - Atividade residual após os ciclos de reuso

D NPM-CMC-Nanopartículas magnéticas de carboximetilcelulose

${ }^{\mathrm{E}} \mathrm{CMD}$ - Carboximetil dextrose

F Poli (Catecol/TEPA) - Catecol/tetraetileno pentamina

${ }^{\mathrm{G}}$ CS-TPP - Quitosana+tripolifosfato de sódio

${ }^{\mathrm{H}} \mathrm{CT} / \mathrm{PDA}$-quitina e polidopamina

${ }^{\text {I }}$ PEG - Polietilenoglicol

${ }^{\mathrm{J}}$ PAMAM - poliamidoamina

K PANI - polianilina

L PUU - poli(ureia-uretano)

M PEIP - polietilenimina parcialmente fosfonada

*** - Dados não apresentados
} 


\section{Tipos de revestimentos utilizados em nanopartículas magnéticas}

\section{Quitosana}

A quitosana é amplamente utilizada como suporte para a imobilização enzimática devido às suas diferentes configurações geométricas, tais como pós, flocos, hidrogéis, membranas, fibras e outros, e a presença de grupos hidroxila e aminoácidos (KUO et al., 2012). Devido à sua versatilidade, as partículas de quitosana também podem ser utilizadas como revestimento para nanopartículas magnéticas, como descrito por Mendes et al. (2011) quando utilizaram nanopartículas magnéticas de $\mathrm{Fe}_{3} \mathrm{O}_{4}$ revestidas com quitosana para a imobilização covalente de lipase de Candida rugosa. A lipase imobilizada apresentou melhor estabilidade operacional a maiores faixas térmicas e de $\mathrm{pH}$, permanecendo estável após 13 dias de armazenamento a $25^{\circ} \mathrm{C}$ com atividade residual de $83 \%$ após 20 ciclos.

NPMs revestidas com quitosana utilizando polissacarídeo de kefiran como agente de reticulação foram utilizadas na imobilização da enzima pectinase. Os resultados obtidos mostraram uma recuperação máxima da atividade da enzima pectinase imobilizada e após um mês, a atividade remanescente da enzima imobilizada foi de 60,23\%. A pectinase imobilizada manteve sua atividade em 70,02\% após 10 ciclos. A utilização nanopartículas magnéticas de quitosana em combinação com o reticulador poli-aldeído kefiran foi um método eficiente para imobilização de pectinases (NOURI e KHODAIYAN, 2020).

Resultados que corroboram com os apresentados por Chen et al. (2018) quando utilizaram partículas magnéticas $\mathrm{Fe}_{3} \mathrm{O}_{4}$ revestidas com quitosana e tripolifosfato de sódio $\left(\mathrm{Fe}_{3} \mathrm{O}_{4}\right.$-CS-TPP) para imobilização simultânea de alcalase e tripsina. Os NPMs de $\mathrm{Fe}_{3} \mathrm{O}_{4}$ - CS-TPP foram mais estáveis do que a enzima livre em temperaturas acima $40{ }^{\circ} \mathrm{C}$. A atividade residual do imobilizado foi preservada em $86 \%$ após 35 dias de armazenamento e reteve mais de $60 \%$ de sua atividade inicial após dez vezes de reutilização sucessiva. Resultados que confirmam a potencialidade da quitosana como revestimento de NPMs para imobilização de diferentes enzimas.

Uma abordagem diferente foi utilizada por Manthiriyappan e Lee (2011) quando utilizaram a quitina como matriz protetora e dispersiva para a preparação de partículas magnéticas pelo processo de co-precipitação. Posteriormente as partículas de quitina magnética (MCT) foram modificadas com dopamina para ser utilizada como uma matriz de imobilização enzimática eficaz, oferecendo superfície aderente para enzimas. Os resultados obtidos pelos autores para a imobilização da $\alpha$-amilase demonstraram uma taxa de hidrólise de amido comparável à da enzima livre. No entanto, as atividades relativas foram maiores do que a enzima livre em faixas mais amplas de $\mathrm{pH}$ e 
temperatura. Além disso, $\alpha$-amilase imobilizada reteve mais de $70 \%$ de sua atividade original após seis vezes de uso repetido.

Várias composições de nanopartículas de óxido de ferro revestidas com polidopamina e com uma concha polissacarídica obtidas através da combinação de quitosana e alginato foram usadas para imobilizar cloroperoxidase. A enzima foi imobilizada com sucesso com uma eficiência de aprisionamento entre $92 \%$ e $100 \%$ no caso de suportes com quitosana no interior e exterior respectivamente. Uma excelente estabilidade química foi observada no caso de um invólucro interno de alginato e um revestimento externo de quitosana, juntamente com uma excelente reutilização da enzima imobilizada, que foi reciclada para catalisar até 25 ciclos de reação consecutivos (GARCÍA-EMBID et al., 2018).

\section{Carboximetilcelulose (NPM-CMC) e Carboximetil-dextrana (CMD)}

Suo et al. (2020) sintetizaram nanopartículas magnéticas de carboximetilcelulose modificadas com líquidos iônicos e utilizaram como suporte para a imobilização enzimática. A enzima lipase foi utilizada como modelo e sua atividade específica imobilizada foi 1,43 vezes maior do que a atividade da enzima livre. Segundo os autores os compósitos desenvolvidos podem ser utilizados como excelentes suportes para imobilização de enzimas para aplicações industriais. Os resultados para testes de redutibilidade da enzima imobilizada mostraram que após 10 ciclos de reuso a enzima reteve $83,9 \%$ de sua atividade inicial. Os autores atribuem essa alta atividade ao suporte magnético que facilita a separação da enzima imobilizada, reduzindo perdas durante o processo de separação.

NPMs-CMC foram utilizadas para imobilizar a enzima pheniltransferase NovQ aplicada para a produção de vitamina $\mathrm{K}$ usando menadiona hidroquinol e dimetilalil difosfato (DMAPP) como substratos. Foi observado que carboximetilcelulose (CMC) e $\mathrm{Fe}_{3} \mathrm{O}_{4}$ formaram uma estrutura núcleo-concha com alta afinidade para a enzima imobilizada, sendo um suporte promissor em bioprocesso de produção de vitamina $\mathrm{K}$ (NI et al., 2020).

Carboximetil dextrana (CMD) foi covalentemente ligado a NPMs e a influência de diferentes concentrações nas características de nanopartículas magnéticas revestidas com CMD (CMD- NPMs) foi estudada. Os CMD3- NPMs preparados foram usados como transportadores para a imobilização da enzima álcool desidrogenase (ADH). As CMD- NPMs que formam sintetizados, exibiram uma camada de revestimento CMD que forneceu propriedades magnéticas e estruturais adequadas e, portanto, podem ser 
funcionalizados e usados na imobilização de compostos bioativos, como o ADH (VASIĆ et al., 2020).

\section{Naringina}

A naringina (4,5,7-trihidroxi flavanona-7-ramnoglucosídeo) é um flavonoide amargo presente em várias frutas cítricas. Naringina é uma biomolécula natural de baixo custo e hidrofílica, biocompatível e acessível, características que justificam seu uso na funcionalização da superfície de nanopartículas magnéticas.

A imobilização de enzimas em NPMs funcionalizados com naringina pode promover um novo microambiente vantajoso, incluindo a melhoria da estabilidade e do comportamento catalítico da enzima imobilizada. A imobilização da enzima $\alpha$-amilase em NPMs revestidas de sílica e funcionalizadas com naringina via interações iônicas. Os resultados mostraram que as condições ideais para imobilização da $\alpha$-amilase no nanocarreador sintetizado ocorreram em $\mathrm{pH} 6,5$ e $55^{\circ} \mathrm{C}$.

Os experimentos de reutilização revelaram manutenção de alta atividade da $\alpha$ amilase imobilizada mesmo após 10 ciclos de reação. A estabilidade de armazenamento da enzima imobilizada melhorou em comparação com a enzima livre, mantendo $60 \%$ de sua atividade inicial após 6 semanas de armazenamento. As melhorias nas propriedades catalíticas da enzima via imobilização tornaram este nanobiocatalisador um bom candidato em aplicações bioindustriais (DEFAEI et al., 2018).

\section{Lectina}

Nanopartículas magnéticas foram revestidas com lectinas ConA (NPMConA) para imobilização da enzima glicose oxidase (GO). A distorção conformacional mínima da enzima foi alcançada com NPMs revestido pela ConA, visto que pequenos desvios no espectro de dicroísmo circular (CD) são observados em comparação com aqueles sem ConA. Em comparação com as enzimas de difusão livre, as enzimas GOx-CAT imobilizadas em ConA-NPMs resultam em atividade aumentada de 1,3 vezes, apresentando maior estabilidade, além da facilidade de reciclagem e operação garantida pelo NPMs (YOUNG et al., 2018).

\section{Catecol/poliamida (CPA)}

Nanopartículas magnéticas revestidas por um sistema binário Catecol/ tetraetileno pentamina (CPA) barato e introduzindo braços espaçadores para ligação enzimática foram sintetizadas por Tang et al. (2019). Posteriormente, os autores utilizaram a imobilização da enzima lipase como modelo do processo de imobilização. 
A lipase foi imobilizada na superfície de tais materiais magnéticos funcionalizados com amino-epóxi através de troca iônica e fixação covalente com suporte com uma capacidade de carga de $180,6 \mathrm{mg} / \mathrm{g}$ e 69,2\% de recuperação da atividade enzimática em condições otimizadas. Além disso, a lipase imobilizada exibiu a faixa de tolerância melhorada de $\mathrm{pH}$, temperatura e estabilidade de armazenamento, bem como excelente capacidade de reutilização.

\section{Sílica}

A nanoestrutura da sílica ganhou atenção na área biomédica, devido à sua química bem definida, que permite a modificação da sua estrutura pelos grupos amina, carboxila e tiol, metacrilatos, enzimas, proteínas e DNA (LIMA, 2016).

A lacase, uma enzima oxidativa com inúmeras aplicações industriais, requer novas tecnologias para sua imobilização a fim de melhorar sua atividade biocatalítica com custos reduzidos. Fortes et al. (2017) avaliaram a imobilização desta enzima em NPMs revestidas com sílica, nas condições ideais, a maior atividade de recuperação da lacase imobilizada atingiu 36,3 U/L, e apresentou atividade residual acima de 75\% após 6 ciclos consecutivos de reação. Além disto, a estabilidade térmica da lacase imobilizada foi melhorada em comparação a enzima livre.

Resultados semelhantes foram obtidos por Ashtari et al. (2012) na imobilização da glicose oxidase (GOD) em NPMs encapsuladas em sílica preparadas através do método de microemulsão. As NPMs obtidas não apresentaram qualquer atividade citotóxica contra células de carcinoma de pulmão humano e letalidade de salmoura. A ligação da enzima ao suporte foi confirmada pelos espectros de FTIR. O estudo da estabilidade de armazenamento mostrou que a glicose oxidase imobilizada reteve $98 \%$ de sua atividade inicial após 45 dias e 90\% da atividade também permaneceu após 12 usos repetidos. Melhorias consideráveis na estabilidade térmica da enzima imobilizada também foram observadas em temperaturas elevadas de até $80^{\circ} \mathrm{C}$, além disto, a atividade da enzima imobilizada foi menos sensível às mudanças de $\mathrm{pH}$ da solução.

Ulu et al. (2018) avaliou a imobilização de L-Asparaginase em NPMs revestidas com sílicas e funcionalizadas por organossilano (epóxi). A L-Asparaginase imobilizada apresentou maior atividade em valores elevados de $\mathrm{pH}$ e temperatura. Também manteve mais de $92 \%$ da atividade inicial após incubação a $55{ }^{\circ} \mathrm{C}$ por $3 \mathrm{~h}$. Em relação aos valores cinéticos, a L-Asparaginase imobilizada apresentou maior $\mathrm{V}_{\max }$ e $\mathrm{K}_{\mathrm{m}}$ menor em comparação à enzima nativa. Além disso, apresentou excelente reutilização por 12 ciclos sucessivos. Após 30 dias de armazenamento a $4{ }^{\circ} \mathrm{C}$ e $25{ }^{\circ} \mathrm{C}$, a L-Asparaginase imobilizada reteve $54 \%$ e $26 \%$ de suas atividades iniciais, enquanto a L-Asparaginase 
nativa perdeu cerca de $68 \%$ e $84 \%$ de sua atividade inicial, respectivamente. NPMs semelhantes foram utilizadas com sucesso na imobilização de lipases (AFZAL et al., 2019).

Poorakbar et al. (2018) utilizou nanopartículas magnéticas de ouro (AuM) revestidas com sílica mesoporosa para imobilização de celulase por ligação covalente com uma eficiência de ligação em 76\%. A enzima imobilizada manteve 58\% de sua atividade catalítica inicial após nove horas. Nesta pesquisa, um novo nanossistema foi desenhado como um suporte sólido para a imobilização da celulase, aumentando sua estabilidade térmica e facilitou seu armazenamento. Além disso, a enzima imobilizada pode ser aplicada em uma faixa mais ampla de temperatura e pH em comparação com a enzima livre, com separação da enzima de forma simples realizada por um ímã externo.

\section{Polietilenimina (PEIP)}

A polietilenimina parcialmente fosfonada (PEIP) foi desenvolvida como um agente de revestimento facilmente funcionalizável para nanopartículas de óxido de ferro. A imobilização por tripsina foi realizada como modelo, os resultados obtidos evidenciaram que o PEIP contribuiu para a alta estabilidade do material, por meio de uma forte ligação covalente com o grupo amino da enzima. A resistência à hidrólise e ao aumento da temperatura garantiram a obtenção de um nanomaterial magnético altamente reciclável projetado para análises proteômicas. Podendo servir para suporte de numerosas enzimas (MONTEIL et al., 2014).

\section{Álcool polivinílico}

Sahin e Ozmen (2020) avaliaram nanopartículas magnéticas revestidas com álcool polivinílico e ativadas com glutaraldeído para imobilização de tripsina. A enzima imobilizada foi mais estável do que a enzima livre a $40{ }^{\circ} \mathrm{C}$ e reteve $50 \%$ de sua atividade inicial, após 12 dias a $4{ }^{\circ} \mathrm{C}$. Apresentando atividade residual de $56 \%$ após oito reutilizações sucessivas. O desempenho da enzima imobilizada foi avaliado pela digestão do citocromo $\mathrm{C}$, fragmentos de peptídeo em solução digerida foram determinados usando espectrometria de massa MALDI-TOF. A tripsina imobilizada apresentou atividade proteolítica efetiva em menor tempo $(15 \mathrm{~min})$ do que a tripsina livre (24 h). Portanto, é possível inferir que a imobilização enzimática nas condições descritas pode ser um bioprocesso promissor para estudos de proteômica em larga escala e aplicações práticas. 


\section{Polietileno glicol (PEG)}

NPMs revestidas com polietilenoglicol via triclorotriazina com alta eficiência de carregamento, foram utilizadas para a imobilização covalente da pectinase. A enzima imobilizada mostrou atividade catalítica aprimorada, estabilidade operacional e fácil reutilização. Estudos de estabilidade térmica e de $\mathrm{pH}$ mostraram um melhor desempenho da pectinase imobilizada em comparação a enzima livre. Além disso, a enzima imobilizada reteve até 55 e 94\% de sua atividade inicial após 10 reciclagens e 125 dias de armazenamento a $25{ }^{\circ} \mathrm{C}$, respectivamente. Além disso, a redução da turbidez ocorreu em até 59\% no suco de abacaxi tratado com pectinase imobilizada, sugerindo aplicabilidade desse sistema nas indústrias de sucos e alimentos (KHARAZMI et al. 2020). Da mesma forma, Kharazmi et al. (2020) utilizaram NPMs semelhantes na imobilização de xilanase estabilizada com atividade catalítica e estabilidade melhoradas. A enzima imobilizada foi aplicada em processos de clarificação de suco de abacaxi e notavelmente, reteve 50\% de sua atividade inicial após nove reciclagens de 120 min de incubação a $50{ }^{\circ} \mathrm{C}$ a pH 4,5.

\section{Polianilina (PANI)}

A polianilina (PANI) representa uma classe de polímeros altamente promissores, em função de seu baixo custo de síntese, facilidade operacional e por apresentar propriedade condutora de elétrons, pois, dependendo das condições de síntese, o polímero pode atuar como semicondutor. A protease de Penicillium aurantiogriseum URM4622 foi imobilizada em nanopartículas magnéticas revestidas com polianilina (PANI) ativadas com glutaraldeído. A protease foi covalentemente ligada às nanopartículas via glutaraldeído a $25{ }^{\circ} \mathrm{C}$. Foram determinadas as condições ótimas para imobilização enzimática e a caracterização da enzima imobilizada mostrou um comportamento ligeiramente diferente em comparação com a enzima livre. O processo de imobilização foi capaz de reutilizar a enzima até 5 vezes mantendo mais de $50 \%$ da sua atividade inicial. Os resultados obtidos comprovam que as nanopartículas ferromagnéticas revestidas com PANI são suporte eficiente para imobilização de protease fúngica (NETO et al., 2017).

\section{Poli (uréia-uretano) (PUU)}

Chiaradia et al. (2016) avaliaram a imobilização de lipase produzida por Candida antarctica, em nanopartículas magnéticas de poli (ureia-uretano) (NPMs PUU) em uma única etapa durante a polimerização em miniemulsão interfacial. Imagens de microscopia eletrônica de transmissão mostraram a morfologia de 
nanopartículas magnéticas sintetizadas encapsuladas em nanopartículas de poli (ureiauretano) e imagens de microscopia de fluorescência confirmaram a imobilização da enzima em NPMs -PUU. Após o processo de imobilização a lipase imobilizada foi atraída por um campo magnético externo e utilizada como biocatalisador para a síntese dos ésteres etil oleato, geranil propionato e geranil oleato. Conversões de ésteres acima de $85 \%$ foram obtidas para todos os sistemas com base nos conteúdos de ácidos graxos livres medidos por titulação até pH 11 confirmando a eficiência do processo de imobilização.

\section{Considerações Finais}

A imobilização de enzimas em nanopartículas magnéticas sem revestimento faz com que elas estejam altamente susceptíveis à oxidação, diminuindo sua resposta ao campo magnético. Como consequência, o suporte apresenta uma vida útil curta, diminuindo o potencial de reuso do biocatalisador. Ademais, o produto pode ser contaminado devido à perda de magnetização da amostra, gerando problemas no processo produtivo. Desta forma, é necessário realizar o revestimento da superfície dessas partículas com materiais que possuam características compatíveis com a enzima alvo e com o bioprocesso no qual ela será empregada, garantindo assim, uma maior estabilidade e eficiência catalítica. Requisitos estes de suma importância para uso em diversos setores industriais.

\section{Referências}

AFZAL, H. A., GHORPADE, R. V., THORVE, A. K., NAGARAJA, S., ALDHUBIAB, B. E., MERAVANIGE, G., ... \& ROOPASHREE, T. S. (2020). Epoxy functionalized polymer grafted magnetic nanoparticles by facile surface-initiated polymerization for immobilization studies of Candida Antarctica lipase B. Reactive and Functional Polymers, 147, 104454.

ASHTARI, K., KHAJEH, K., FASIHI, J., ASHTARI, P., RAMAZANI, A., \& VALI, H. (2012). Silica-encapsulated magnetic nanoparticles: enzyme immobilization and cytotoxic study. International journal of biological macromolecules, 50(4), 1063-1069.

BASSO, A., \& SERBAN, S. (2019). Industrial applications of immobilized enzymes: A review. Molecular Catalysis, 479, 110607.

BEDÊ, P. M., (2010). Produção e Caracterização de Nanopartículas Polimérico Magnéticas para Aplicações Biomédicas. Dissertação de M. Sc., Instituto Militarde Engenharia, Rio de Janeiro, RJ, Brasil.

CARDOSO, C. L., MORAES, M. C. D., \& CASS, Q. B. (2009). Imobilização de enzimas em suportes cromatográficos: uma ferramenta na busca por substâncias bioativas. Química Nova, 32(1), 175-187. 
CHEN, Z., WANG, X., CHEN, Y., XUE, Z., GUO, Q., MA, Q., \& CHEN, H. (2018). Preparation and characterization of a novel nanocomposite with double enzymes immobilized on magnetic $\mathrm{Fe} 3 \mathrm{O} 4$-chitosan-sodium tripolyphosphate. Colloids and Surfaces B: Biointerfaces, 169, 280-288.

CHIARADIA, V., VALÉRIO, A., DE OLIVEIRA, D., ARAÚJO, P. H. H., \& SAYER, C. (2016). Simultaneous single-step immobilization of Candida antarctica lipase B and incorporation of magnetic nanoparticles on poly(urea-urethane) nanoparticles by interfacial miniemulsion polymerization. Journal of Molecular Catalysis B: Enzymatic, $131,31-35$.

CHOI, J. M., HAN, S. S., \& KIM, H. S. (2015). Industrial applications of enzyme biocatalysis: Current status and future aspects. Biotechnology advances, 33(7), 14431454.

COSTA, V.M., SOUZA, M. C. FECHINE, M. P. B. A., MACEDO, A.C. \& GONÇALVES, L. R. B. (2016). Nanobiocatalytic systems based on Lipase-Fe3O4 and conventional systems for isoniazid synthesis: a comparative study, Brazilian Journal of Chemical Engineering, 33(3), 661-673.

DARWESH, O. M., ALI, S. S., MATTER, I. A., ELSAMAHY, T., \& MAHMOUD, Y. A. (2020). Enzymes immobilization onto magnetic nanoparticles to improve industrial and environmental applications. In Methods in Enzymology, Academic Press, 630, 481502.

DE OLIVEIRA, R. L., DIAS, J. L., DA SILVA, O. S., \& PORTO, T. S. (2018). Immobilization of pectinase from Aspergillus aculeatus in alginate beads and clarification of apple and umbu juices in a packed bed reactor. Food and bioproducts processing, 109, 9-18.

DEFAEI, M., TAHERI-KAFRANI, A., MIROLIAEI, M., \& YAGHMAEI, P. (2018). Improvement of stability and reusability of $\alpha$-amylase immobilized on naringin functionalized magnetic nanoparticles: A robust nanobiocatalyst. International Journal of Biological Macromolecules, 113, 354-360.

FERNANDES, K. F., LIMA, C. S., \& LOPES, F. M. (2010). Técnicas de imobilização de enzimas. Revista Processos Químicos, 4(7), 53-58.

FERNANDES, L. M. G., DA CUNHA, M. N. C., DE CARVALHO SILVA, J., PORTO, A. L. F., \& PORTO, T. S. (2020). Purification and characterization of a novel Aspergillus heteromorphus URM 0269 protease extracted by aqueous two-phase systems PEG/citrate. Journal of Molecular Liquids, 113957.

FERRARA, M. A. Cap. 6 Bioprocessos para produção de enzimas. FORTES, C. C. S., SILVA, A. L. D., XAVIER, A. M. R. B., \& TAVARES, A. P. M. (2017). Optimization of enzyme immobilization on functionalized magnetic nanoparticles for laccase biocatalytic reactions. Chemical Engineering and Processing: Process Intensification, $117,1-8$.

FRANCISQUINI, E., SCHOENMAKER, J. \& SOUZA, J. A. (2014) Nanopartículas Magnéticas e suas Aplicações. In: (Ed.). Série química: Ciência e tecnologia-química supramolecular e nanotecnologia. São Paulo: Atheneu, 592p. 
FURLANI, I. L., AMARAL, B. S., OLIVEIRA, R. V., \& CASS, Q. B. (2020). Imobilização enzimática: conceito e efeitos na proteólise. Química Nova, 43(4), 463473.

GARCÍA-EMBID, S., DI RENZO, F., DE MATTEIS, L., SPRETI, N., \& M. DE LA FUENTE, J. (2018). Magnetic separation and high reusability of chloroperoxidase entrapped in multi polysaccharide micro-supports. Applied Catalysis A: General, 560, 94-102.

GENNARI, A., FÜHR, A. J., VOLPATO, G., \& DE SOUZA, C. F. V. (2020). Magnetic cellulose: Versatile support for enzyme immobilization-A review. Carbohydrate Polymers, 116646.

HU, B.; PAN, J.; YU, H.; LIU, J. \& XU, J. (2009) Immobilization of Serratia marcescens lipase onto amino-functionalized magnetic nanoparticles for repeated use in enzymatic synthesis of Diltiazem intermediate. Process Biochemistry, Elsevier, 44(9), 1019-1024.

JIANG, J., YU, Y., WANG, L., LI, J., LING, J., LI, Y., \& DUAN, G. (2019). Enzyme immobilized on polyamidoamine-coated magnetic microspheres for $\alpha$-glucosidase inhibitors screening from Radix Paeoniae Rubra extracts accompanied with molecular modeling. Talanta. 195, 127-136.

KHARAZMI, S., TAHERI-KAFRANI, A., \& SOOZANIPOUR, A. (2020). Efficient immobilization of pectinase on trichlorotriazine-functionalized polyethylene glycolgrafted magnetic nanoparticles: A stable and robust nanobiocatalyst for fruit juice clarification. Food Chemistry, 126890.

KHARAZMI, S., TAHERI-KAFRANI, A., SOOZANIPOUR, A., NASROLLAHZADEH, M., \& VARMA, R. S. (2020). Xylanase immobilization onto trichlorotriazine-functionalized polyethylene glycol grafted magnetic nanoparticles: A thermostable and robust nanobiocatalyst for fruit juice clarification. International Journal of Biological Macromolecules.

KUO, C. H., LIU, Y. C., CHANG, C. M. J., CHEN, J. H., CHANG, C., \& SHIEH, C. J. (2012). Optimum conditions for lipase immobilization on chitosan-coated $\mathrm{Fe}_{3} \mathrm{O}_{4}$ nanoparticles. Carbohydrate Polymers, 87(4), 2538-2545.

LAURENT, S., FORGE, D., PORT, M., ROCH, A., ROBIC, C., VANDER ELST, L., \& MULLER, R. N. (2008). Magnetic iron oxide nanoparticles: synthesis, stabilization, vectorization, physicochemical characterizations, and biological applications. Chemical Reviews, 108(6), 2064-2110.

LIMA, J. S., ARAÚJO, P. H. H., SAYER, C., SOUZA, A. A. U., VIEGAS, A. C., \& DE OLIVEIRA, D. (2016). Cellulase immobilization on magnetic nanoparticles encapsulated in polymer nanospheres. Bioprocess and Biosystems Engineering, 40(4), 511-518.

LIU, S., YU, B., WANG, S., SHEN, Y., \& CONG, H. (2020). Preparation, surface functionalization and application of $\mathrm{Fe} 3 \mathrm{O} 4$ magnetic nanoparticles. Advances in Colloid and Interface Science, 102165. 
MENDES, A. A., OLIVEIRA, P. C.; CASTRO, H. F. \& GIORDANO, R L. C. (2011) Application of chitosan as support for immobilization of enzymes of industrial interest. Quím. Nova [online], 34(5), 831-840.

MONTEIL, C., BAR, N., RETOUX, R., HENRY, J., BERNAY, B., \& VILLEMIN, D. (2014). Partially phosphonated polyethylenimine-coated nanoparticles as convenient support for enzyme immobilization in bioprocessing. Sensors and Actuators B: Chemical, 192, 269-274.

NASCIMENTO, T. P., SAlES, A. E., PORTO, C. S., BRANDÃO, R. M. P., DE CAMPOS-TAKAKI, G. M., TEIXEIRA, J. A. C., ... \& CONVERTI, A. (2016). Purification of a fibrinolytic protease from Mucor subtilissimus UCP 1262 by aqueous two-phase systems (PEG/sulfate). Journal of Chromatography B, 1025, 16-24.

NETO, J. M. W. D., MACIEL, J. C., CAMPOS, J. F., CARVALHO JUNIOR, L. B., MARQUES, D. A. V., LIMA, C. A. \& PORTO, A. L. F. (2017) Optimization of Penicillium aurantiogriseum protease immobilization on magnetic nanoparticles for antioxidant peptides' obtainment, Preparative Biochemistry and Biotechnology, 47(7), 644-654

NI, W., ZHENG, Z., LIU, H., WANG, P., WANG, L., WANG, H., ...\& ZHAO, G. (2020). Synthesis of the carboxymethyl cellulose magnetic nanoparticles for efficient immobilization of prenyltransferase NovQ. Carbohydrate Polymers, 235, 115955. Falta

NOURI, M., \& FARAMARZ KHODAIYAN. (2020). Green synthesis of chitosan magnetic nanoparticles and their application with poly-aldehyde kefiran cross-linker to immobilize pectinase enzyme. Biocatalysis and Agricultural Biotechnology, 101681. Falta

PEREIRA, M.G., FACCHINI, F.D.A., FILÓ, L.E.C., POLIZELI, A.M., VICI, A.C., JORGE, J.A., FERNANDEZ-LORENTE, G., PESSELA, B.C., GUISAN, J.M. \& POLIZELI, M. L. T. M. . (2015). Immobilized lipase from Hypocrea pseudokoningii on hydrophobic and ionic supports: Determination of thermal and organic solvent stabilities for applications in the oleochemical industry, Process Biochemistry, 50(4), 561-570.

POORAKBAR, E., SHAFIEE, A., SABOURY, A. A., RAD, B. L., KHOSHNEVISAN, K., MA'MANI, L., ... \& HOSSEINI, M. (2018). Synthesis of magnetic gold mesoporous silica nanoparticles core shell for cellulase enzyme immobilization: Improvement of enzymatic activity and thermal stability. Process biochemistry, 71, 92-100.

QUAN K, ZHANG Z, REN Y, BUSSCHER HJ, VAN DER MEI HC \& PETERSON BW, (2020). Possibilities and impossibilities of magnetic nanoparticle use in the control of infectious biofilms, Journal of Materials Science \& Technology.

SAHIN, S., \& OZMEN, I. (2020). Covalent immobilization of trypsin on polyvinyl alcohol-coated magnetic nanoparticles activated with glutaraldehyde. Journal of Pharmaceutical and Biomedical Analysis, 184, 113195.

SEENUVASAN, M., KUMAR, K. S., KUMAR, A., \& PARTHIBAN, R. (2020). Review on surface modification of nanocarriers to overcome diffusion limitations: An enzyme immobilization aspect. Biochemical Engineering Journal, 107574. 
SINGH, R., MITTAL, A., KUMAR, M., \& MEHTA, PK (2016). Proteases microbianas em aplicações comerciais. J Pharm Chem Biol Sei, 4 (3), 365-74.

SOUZA, L. T., VERÍSSIMO, L. A., PESSELA, B. C., SANTORO, R. R., RESENDE, R. R., \& MENDES, A. A. (2017). Imobilização enzimática: princípios fundamentais e tipos de suporte, In: RESENDE, R. R. Biotecnologia Aplicada à Agro\&Indústria. Vol 4. Editora Blucher.

SUO, H., GAO, Z., XU, L., XU, C., YU, D., XIANG, X., ...\& HU, Y. (2020). Synthesis of functional ionic liquid modified magnetic chitosan nanoparticles for porcine pancreatic lipase immobilization. Materials Science and Engineering: C, 96, 356-364.

SURESHKUMAR, M., \& LEE, C.-K. (2011). Polydopamine coated magnetic-chitin (MCT) particles as a new matrix for enzyme immobilization. Carbohydrate Polymers, 84(2), 775-780

TANG, W., CHEN, C., SUN, W., WANG, P., \& WEI, D. (2019). Low-cost mussel inspired poly (Catechol/Polyamine) modified magnetic nanoparticles as a versatile platform for enhanced activity of immobilized enzyme. International journal of biological macromolecules, 128, 814-824.

TAVANO, O. L., BERENGUER- MURCIA, A., SECUNDO, F., \& FERNANDEZLAFUENTE, R. (2018). Biotechnological applications of proteases in food technology. Comprehensive reviews in food science and food safety, 17(2), 412-436.

TOMBÁCZ, E., TURCU, R., SOCOLIUC, V., \& VÉKÁS, L. (2015). Magnetic iron oxide nanoparticles: Recent trends in design and synthesis of magnetoresponsive nanosystems. Biochemical and Biophysical Research Communications, 468(3), 442453.

TÜZMEN N, KALBURCU T. \& DENIZLI A (2012) $\alpha$-Amylase immobilization onto dye attached magnetic beads: Optimization and characterization. Journal of Molecular Catalysis B: Enzymatic,78, 16-23.

ULU, A., OZCAN, I., KOYTEPE, S., \& ATES, B. (2018). Projeto de nanopartículas core-shell de $\mathrm{Fe}_{3} \mathrm{O}_{4}$ MCM-41 funcionalizadas com epóxi para imobilização enzimática. International Journal of Biological Macromolecules, 115, 1122-1130.

VASIĆ, K., KNEZ, Ž., KONSTANTINOVA, E. A., KOKORIN, A. I., GYERGYEK, S., \& LEITGEB, M. (2020). Structural and magnetic characteristics of carboxymethyl dextran coated magnetic nanoparticles: From characterization to immobilization application. Reactive and Functional Polymers, 148, 104481.

WU, W., HE, Q. \& JIANG, C. (2008). Magnetic iron oxide nanoparticles: Synthesis and surface functionalization strategies. Nanoscale Research Letters, 3(11), 397-415.

YONG, Y., SU, R., LIU, X., XU, W., ZHANG, Y., WANG, R., ...\& LIU, Z. (2018). Lectin corona enhances enzymatic catalysis on the surface of magnetic nanoparticles. Biochemical Engineering Journal, 129, 26-32. 


\title{
CAPÍTULO 45: UMA PERSPECTIVA PARA OTIMIZAÇÃO DO ENCAPSULAMENTO DE AÇAÍ COM PROTEÍNAS DO SORO DE LEITE EM SPRAY DRYER
}

\section{CHAPTER 45: A PERSPECTIVE FOR OPTIMIZING AÇAÍ ENCAPSULATION WITH WHEY PROTEIN IN SPRAY DRYER}

Tailane Vieira Costa ${ }^{1}$; Jaqueline de Jesus Silva ${ }^{2}$; Mirela Luz Santos ${ }^{3}$; Laís Teles da Silva e Silva ${ }^{4}$; Modesto Antônio Chaves ${ }^{5}$

\begin{abstract}
Resumo
O microencapsulamento iniciou-se a partir da técnica de coacervação, usando o princípio de remoção da água presente no sistema. Atualmente outras técnicas vêm sendo exploradas para esse fim, principalmente a secagem por pulverização. A encapsulação consiste em aprisionar um composto de interesse tecnológico recobrindo-o por um material encapsulante. No setor alimentício é comum que os compostos sejam de origem vegetal e no caso da polpa de açaí, os compostos de interesse são antocianinas e flavonóides. Ambos estão associados a benefícios a saúde e os materiais encapsulantes mais usuais são os carboidratos e as proteínas. Nesse sentido as proteínas do soro de leite têm se mostrado promissora por apresentar boa capacidade formadora de filme, baixa viscosidade e outras características. Porém demais variáveis também intervém no processo e por isso é necessária uma otimização prévia. Por este motivo, o objetivo desse trabalho foi apresentar uma perspectiva para direcionar a otimização do encapsulamento da polpa de açaí, com proteínas do soro de leite em spray dryer. Tecnicamente, deve-se otimizar todas as variáveis do encapsulamento, porém 3 ou 4 já têm sido validadas na compreensão dos fenômenos e na obtenção de uma perspectiva do processo que viabilize a produção de pós com qualidade tecnológica.
\end{abstract}

Palavras-Chave: delineamento, microencapsulação, polpa de açaí, proteína, pulverização.

\begin{abstract}
Microencapsulation started with the coacervation technique, using the principle of removing water present in the system. Currently, other techniques are being explored for this purpose, mainly spray drying. Encapsulation consists of imprisoning a compound of technological interest by covering it with an encapsulating material. In the food sector it is common for compounds to be of vegetable origin and in the case of açaí pulp, the compounds of interest are anthocyanins and flavonoids. Both are associated with health benefits and the most common encapsulating materials are carbohydrates and proteins. In this sense, whey proteins have shown promise because they have good film-forming capacity, low viscosity and other characteristics. However, other variables also intervene in the process and, therefore, prior optimization is necessary. For this reason, the objective of this work was to present a perspective to direct the optimization of the encapsulation of the açaí pulp, with whey proteins in spray dryer. Technically, one must optimize all the variables of the encapsulation, but 3 or 4 have already been validated in the understanding of the phenomena and in obtaining a perspective of the process that makes the production of powders with technological quality feasible.
\end{abstract}

\footnotetext{
${ }^{1}$ Mestrado em engenharia e ciência de alimentos, UESB, jaqsali@live.com

${ }^{2}$ Engenharia de alimentos, UESB, tai_vieira2011@ @otmail.com

${ }^{3}$ Engenharia de alimentos, UESB, mirela_luz@ hotmail.com

${ }^{4}$ Mestrado em engenharia e ciência de alimentos, UESB, laiseteles.silva@gmail.com

${ }^{5}$ Doutor, UESB, modestochaves@ hotmail.com
} 
Keywords: açaí pulp, design, microencapsulation, protein, spraying.

\section{Introdução}

Os primeiros registros da microencapsulação se deu por volta de 1930 por técnicas de coacervação, cujo princípio incluía a vaporização da água presente no sistema (RÉ, 2000). Devido aos altos custos do processo, o setor alimentício levou cerca de 30 anos para dar os primeiros passos com trabalhos envolvendo encapsulação, cujos objetivos eram proteger aromas e permitir sua liberação controlada (FAVARO-TRINDADE e PINHO, 2008). Desde estão, novas técnicas foram desenvolvidas a fim de reduzir os custos e maximizar os benefícios, o que possibilitou a aplicação da tecnologia para diversas áreas do setor como a produção de aditivos, ingredientes e produtos acabados (RÉ, 2000).

Atualmente vários produtos têm sido gerados com a encapsulação, usando principalmente vegetais, a fim de aprisionar seus componentes com alguma ação benéfica ao organismo humano. Dessa forma, a polpa de açaí já tem sido empregada com este fim por possuir uma gama de componentes polifenólicos nutracêuticos, ou seja, com ação sobre a defesa do organismo e prevenção de doenças. Seus principais componentes são antocianinas e flavonoides, mas estes podem ser degradados com o aquecimento e perder suas propriedades nutracêuticas, por isso é recomendado que o processamento em altas temperaturas, como a secagem por spray drying, seja rápido (TONON, BRABET e HUBINGER, 2009; PORTINHO; ZIMMERMANN; BRUCK, 2012; SHAMAEI, et al., 2017).

A encapsulação de compostos nutracêuticos requer que haja eficiência do encapsulamento para verificar o teor desses compostos retidos no pó, e isso depende do tipo, combinação e concentração de materiais conhecidos como encapsulantes, dentre os mais comuns estão os carboidratos e as proteínas (SHAMAEI, et al., 2017; LABUSCHAGNE, 2018). As proteínas apresentam alto valor nutritivo e excelentes propriedades funcionais, capazes de interagir com vários compostos ativos e oferecer ampla proteção ao composto de interesse, além disso, apresentam capacidade formadora de filme, baixa higroscopicidade, baixa viscosidade a altas concentrações de sólidos, sabor e odor suaves, fácil reconstituição e outras (KILARA e VAGHELA, 2018; CHUYEN et al., 2019).

O processo em questão pode apresentar melhores resultados quando as variáveis independentes que aparecem antes e durante a secagem são cuidadosamente otimizadas. Por essa perspectiva, a otimização do encapsulamento da polpa de açaí é uma etapa necessário, pois define os limites das principais variáveis que atuam no processo e pode indicar os limites (MONTGOMERY, 2003) aplicáveis a outros vegetais com características semelhantes. Dessa 
forma, garante um produto final de qualidade tecnológica. Muitos estudos relacionam a qualidade com as características químicas do processo e devem ser avaliadas antes da secagem, como tipo e concentração de material encapsulante, teor de sólidos, viscosidade, formação de partículas e outras propriedades das soluções (SANTANA et al., 2016; SHAMAEI et al., 2017; LABUSCHAGNE, 2018; CUSTODIO et al., 2020). Também há correlações com as condições físicas do processo que são avaliadas durante a secagem, como a temperatura de entrada do sistema e as vazões do ar de secagem e do ar comprimido que circulam no interior do equipamento, entre outras (BOTREL et al., 2012; KO et al., 2015; GETACHEW e CHUN 2016; YANG et al., 2020). Já as variáveis que são estudadas após o processo, são as respostas e indicam o quanto a técnica foi bem-sucedida (ROCHA et al., 2019). Dessa maneira, o objetivo desse trabalho foi apresentar uma perspectiva que direcione a otimização do encapsulamento da polpa de açaí com proteínas do soro de leite em spray dryer.

\section{Desenvolvimento}

Dados históricos da encapsulação definem o processo desde os anos 70, como o empacotamento de compostos por uma fina camada polimérica, também chamada de material de parede, formando partículas. O intuito do processo é melhorar a performance do composto ou criar novas aplicações (FAVARO-TRINDADE e PINHO, 2008). O produto da encapsulação pode ser um material em pó, pastoso ou líquido, dependendo da técnica aplicada (SAIFULLAH et al., 2019). No caso do spray drying, o sistema produzirá partículas em pó, pulverizando um liquido no interior de uma câmara, onde circula ar quente concorrente ou em contracorrente (ROCHA, 2015 e CUSTODIO et al., 2020). O pó deve apresentar características coerentes ao fim que se destina, cuja qualidade é resultado de parâmetros que devem ser conhecidos e estudados caso a caso em cada processo (REZAUL et al., 2017).

A técnica de spray drying tem sido aplicada para encapsular vários elementos de origem vegetal, dentre eles, estão os óleos (CHUYEN et al., 2019), aromas (SAIFULLAH et al., 2019), diversos nutracêuticos (ROCHA, 2015; KO et al., 2015 e CUTRIM, ALVIM e CORTEZ, 2019) e até mesmo toda a polpa de um fruto (CHAUL et al., 2017 e GUEDES-OLIVEIRA et $a l ., 2018)$ com a finalidade de preservar ao máximo sua composição. Como é o caso do encapsulamento da polpa de açaí que já vem sendo estudada e muito contribuiu para ampliar a compreensão dos fenômenos que envolvem a encapsulação (TONON et al., 2009 e CUSTODIO et al., 2020). Porém ainda há muito a ser revelado no que tange ao uso do açaí como produto a ser encapsulado, pois a aplicação de um material de parede não usual, ou combinações de dois 
ou três, com diferentes concentrações e até mudanças nos parâmetros do equipamento podem apontar importantes descobertas do processo.

Enfim, muitas são as possibilidades e precisam ser exploradas, estudadas e aprendidas.

\section{Breve histórico}

A microencapsulação teve seus primeiros registros na década de 30 pela empresa americana National Cash Register Co., de Dayton, em que Barret K. Green descobriu e desenvolveu um sistema de microcápsulas por meio de coacervação que tem como princípio básico a vaporização de uma cobertura sobre partículas em suspensão (RÉ, 2000). Já na década seguinte várias patentes haviam sido desenvolvidas, as quais embasaram diversas pesquisas na área farmacêutica que se fortaleceram a partir de 1955 com a intenção de cobrir comprimidos e pílulas e permitir a liberação controlada em locais específicos no organismo humano (KURIOKASE; SATHIREDDY; PRIYA, 2015).

Nos anos 60, relata-se aplicações na área médica em que um material encapsulado também chamado de células artificiais foram utilizadas para exercer a função de rins em pacientes com falência renal (RÉ, 2000). Em 1970 a ideia de encapsulação foi aplicada para imobilização de bactérias.

O setor alimentício teve seu marco na área, com a microencapsulação de óleo essencial nos anos 60 com a intenção de prevenir a oxidação, perdas de substâncias voláteis e permitir a liberação controlada do aroma (BOTREL et al., 2012). Porém o binômio custo/benefício limitou por muito tempo a produção de microcápsulas em alimentos, até se perceber que a técnica poderia reduzir a degradação de nutrientes sensíveis a oxidação e outras condições adversas (KURIOKASE; SATHIREDDY; PRIYA, 2015), ao passo que novas técnicas foram desenvolvidas a fim de reduzir os custos e maximizar os benefícios. Hoje em dia a tecnologia estende-se a produção de aditivos, ingredientes e produto alimentício final.

Os carboidratos são os materiais mais utilizados para encapsulação, por apresentar grande diversidade e baixo custo, além de serem capazes de se ligar a compostos responsáveis pelo sabor, por outro lado, eles aumentam o valor energético do produto (LABUSCHAGNE, 2018). Já as proteínas, que apresentam alto valor nutritivo e excelentes propriedades funcionais, interagem com vários compostos ativos e oferecem ampla proteção ao passo que aumentam o valor nutricional do produto (SANTANA et al., 2016).

Vaniski, Corti e Drunkler (2017) relatam que a microencapsulação proteica envolvendo as proteínas do soro de leite, se iniciou com Barbut e Foegeding em 1993 por meio de geleificação induzida pelo frio. Picot e Lacroix, em 2004, utilizaram a secagem por [697]

CIÊNCIA, TECNOLOGIA E INOVAÇÃO: DO CAMPO À MESA. RECIFE: EDITORA IIDV, 2020 
pulverização, com a finalidade de fazer com que o produto encapsulado resistisse as condições ácidas do trato gastrointestinal e fosse liberado gradualmente no intestino grosso.

No Brasil, um dos primeiros trabalhos na área foi elaborado por Nori (1996) na Universidade de São Paulo (USP) que encapsulou o ácido cítrico por meio do spray cooling, utilizando gorduras de diferentes pontos de fusão e emulsificantes como agentes encapsulantes, com o intuito de substituir culturas iniciadoras em embutidos. Com essa prática obteve produtos cuja cor, textura e aparência não diferiram dos padrões estabelecidos. Trindade (1998) encapsulou ácido ascórbico por meio do spray dryer utilizando goma arábica e amido de arroz como material encapsulante com aplicação em presunto e bolo de carne de peru e os produtos obtidos não apresentaram diferença significativa na estabilidade da cor curada.

No que tange a cultura do açaí, Tonon et al., (2009) destaca-se por ter iniciado estudos da produção desse fruto em pó por atomização, usando diferentes concentrações de maltodextrina e diferentes temperaturas de entrada. Estes autores observaram degradação de antocianinas em temperaturas maiores que $170^{\circ} \mathrm{C}$. Também observaram que a concentração do material encapsulante não alterou a composição das antocianinas. Na figura 1 abaixo é possível ter uma visão geral dos principais fatos ocorridos ao longo do tempo.

Figura 1 - Principais marcos históricos do encapsulamento.

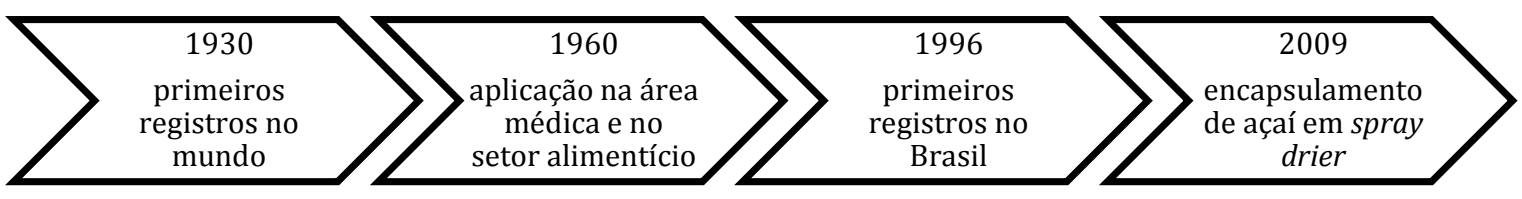

\section{Polpa de açaí}

O açaizeiro (Euterpe oleracea) é uma palmeira da família Arecaceae amplamente difundida e cultivada na região amazônica, sendo bastante importante para o desenvolvimento agroindustrial da região. O fruto tem se destacado pela importância econômica para a fruticultura regional, principalmente no estado do Pará onde a produção e a comercialização da polpa movimentam grandes quantias no mercado financeiro (NEVES et al., 2015). Segundo o IBGE (Instituto Brasileiro de Geografia e Estatística), em seu último senso agropecuário em 2016 a produção anual de açaí passou de 1,2 milhões de toneladas e a comercialização dos frutos injetou cerca de R \$ 3,9 bilhões na economia. No ano seguinte, o Pará produziu $88 \%$ na produção nacional e na Bahia o percentual foi de apenas 1,2\%, representado por 103.934 toneladas do fruto ao ano, indicando ainda um restrito consumo, porém uma grande 
possibilidade de estimular novas alternativas para alavancar a produção do estado e das demais regiões no país.

O fruto do açaí contém em sua polpa grande quantidade de flavonoides com propriedades antioxidantes, anti-inflamatórias e anticancerígenas, elevado valor energético e proteico e como consequência, tem sido considerado um alimento funcional por gerar inúmeros benefícios à saúde, além dos flavonoides, há também um elevado valor energético, por ser rico em carboidratos e lipídios diversos, como os ácidos graxos essenciais, Ômega 6 e 9, contém ainda, fibras, vitamina $\mathrm{E}$ e minerais como $\mathrm{Mn}, \mathrm{Fe}, \mathrm{Zn} \mathrm{Cu}$ e $\mathrm{Cr}$ (KANG et al., 2012; PORTINHO; ZIMMERMANN; BRUCK, 2012). Estudos feitos por Portinho, Zimmermann, Bruck, (2012) relatam que as atividades antioxidantes e anti-inflamatória estão associadas a presença de compostos fenólicos que fazem com que seu consumo esteja associado ao combate à anemia, diabetes, colesterol alto, pressão alta e no fortalecimento do sistema imunológico, nervoso, muscular e cardiovascular. Isto demonstra que, as propriedades específicas do açaí é o resultado de uma complexa mistura de compostos bioativos. Isto confere ao açaí o renomado status de "superfruta" e contribuiu ainda mais para a popularização do fruto em todo o Brasil, aumentando consideravelmente a demanda por exportação, o que explica o extraordinário crescimento na sua produção (PORTINHO; ZIMMERMANN; BRUCK, 2012).

A vida de prateleira do açaí é curta, mesmo sob refrigeração com tempo máximo de conservação de 12 horas (NOGUEIRA et al., 2013). Como consequência, cerca de 30 a 40\% dos frutos colhidos durante as safras se deterioram antes de chegar aos consumidores (OLIVEIRA et al., 2014), por isso na região Norte do país, a polpa é produzida para consumo imediato e mantida por curto período em temperatura ambiente ou refrigerada (OLIVEIRA et $a l .$, 2014). Porém o congelamento permite maior durabilidade do produto e comercialização nas demais regiões (NOGUEIRA et al., 2013).

Na maioria dos estados brasileiros o açaí é consumido após um pré-processamento dos frutos com adição de água para seu despolpamento e posterior filtração, resultando em uma bebida espessa, roxa, com textura pastosa, aparência oleosa e sabor característico, chamada popularmente de "açaí na tigela" que também origina outros produtos como suco de açaí ou vinho de açaí (OLIVEIRA et al., 2014).

\section{Caracterização da polpa de açaí}

De acordo com regulamento técnico do Ministério da Agricultura, Pecuária e Abastecimento (MAPA IN 37/2018) a polpa de açaí deve apresentar valor de pH entre 4,00 e 6,20; sólidos totais variando de 8 a 14\%, com base no teor de matéria seca, deve conter mínimo 
de 7 g. $100 \mathrm{~g}^{-1}$ de proteínas, 20 a 60 g. $100 \mathrm{~g}^{-1}$ de lipídeos, acidez total expressa em ácido cítrico máximo de 3,2 g.100 g $\mathrm{g}^{-1}$, mínimo de polifenóis de 1,80 g. $100 \mathrm{~g}^{-1}$, mínimo de antocianinas de $0,44 \mathrm{~g} \cdot 100^{-1}$, cor deve ser roxa violácea própria do açaí roxo, sabor não adocicado e não azedo e aroma característico (BRASIL, 2018). Essa regulamentação não traz referência quanto ao resíduo mineral fixo, atividade de água (aa), flavonoides e suas capacidades antioxidantes. Contudo, diversos trabalhos têm identificado esses índices, por exemplo, teores de cinzas variando entre de 0,19 a 0,26 g. $100 \mathrm{~g}^{-1}$ de matéria seca, $50 \mathrm{mg} .100 \mathrm{~g}^{-1}$ de antocianinas divididos em agliconas e cianidinas (COHEN et al., 2009) e capacidade antioxidante pela captura de radicais livres, em torno de 7698,6 $\mu$ mol TE.g ${ }^{-1}$ de matéria seca (KANG et al., 2012).

Segundo Araújo (2006), entre todos os compostos responsáveis por funções específicas como antioxidantes e anti-inflamatórias da polpa de açaí, estão os flavonoides, que são formados por um grupo hidroxil ligado diretamente a um grupo hidrocarboneto aromático, como é o caso, mais simples dos fenóis ou polifenóis, sendo necessário que o processo tecnológico ao qual a polpa de açaí venha ser submetida, não traga prejuízos na manutenção desses compostos.

Entre os flavonóides existentes na polpa de açaí, destacam-se as antocianinas, cujo termo é de origem grega e refere-se a flores de cor azul, sendo considerada como o segundo corante de maior importância do reino vegetal e é o maior grupo de corantes orgânicos naturais solúveis em água, de baixa toxicidade, que pode apresentar-se tanto na cor azul, como na cor roxa e tonalidades de vermelho, colorindo uma grande variedade de vegetais (MACIEL, 2012). Quimicamente, está inserida no grupo dos flavonoides, sua molécula é constituída por duas ou três partes, uma aglicona (antocianidina), um grupo de açúcares e, frequentemente, um grupo de ácidos orgânicos. Diferencia-se pelo número de hidroxilas, de açúcares e de ácidos ligados a eles e pelo grau de metoxilação da molécula mostrado na Figura 2 (JAFARI, GHALENOEI e DEHNAD, 2017).

Figura 2 - Estrutura química fundamental das antocianinas.

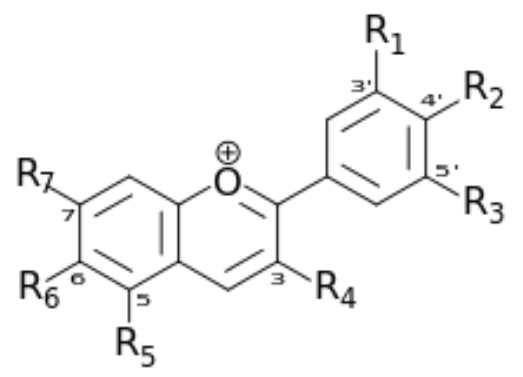

Fonte: MACIEL, 2012.

[700] 
A representação da estrutura fundamental na qual se forma uma espécie de esqueleto em que se derivam seis das agliconas mais comuns na natureza que é a pelargonidina, cianidina, delfinidina, malvidina, peonidina e petunidina, como pode ser visto na Tabela 1. Apresentamse em cores distintas influenciadas diretamente pelas condições do meio em que se encontram como as faixas de $\mathrm{pH}$, a formação de quelatos com cátions metálicos e a presença de outros pigmentos (MOLINA et al., 2010).

Tabela 1 - Caracterização das diferentes formas químicas da aglicona de antocianina

\begin{tabular}{lll}
\hline Aglicona & Substituintes & \\
\cline { 2 - 3 } & $\mathrm{R} 1$ & $\mathrm{R} 2$ \\
\hline Pelargonidina & $\mathrm{H}$ & $\mathrm{H}$ \\
Cianidina & $\mathrm{OH}$ & $\mathrm{H}$ \\
Delfinidina & $\mathrm{OH}$ & $\mathrm{OH}$ \\
Malvidina & $\mathrm{OCH}_{3}$ & $\mathrm{OCH}_{3}$ \\
Peonidina & $\mathrm{OCH}_{3}$ & $\mathrm{H}$ \\
Petunidina & $\mathrm{OCH}_{3}$ & $\mathrm{OH}$ \\
\hline
\end{tabular}

Fonte: MOLINA et al., (2010).

A estrutura responsável pela formação do pigmento é gerada com o flavilium pela perda da hidroxila e a cor da antocianina é afetada por sua estrutura, e se apresentam como umas das principais classes de flavonoides encontradas nos vegetais e principalmente no açaí, as quais também tem grande participação no efeito antioxidante no fruto (JAFARI, GHALENOEI e DEHNAD, 2017).

\section{Encapsulamento}

Em alimentos a água está presente dissolvendo solutos ou sendo a fase liquida de um sistema alimentício em dispersão (FENNEMA, DAMODARAN e PARK, 2010). Os solutos ou as partículas dispersas podem ser açucares, sais, lipídeos, proteínas ou outras partículas sólidas que ficam dispersas ou interagem entre si, física ou quimicamente (ARAÚJO, 2006). Quando estão em interações, essas partículas podem interferir nas propriedades do produto encapsulado que se deseja obter por meio da secagem em spray dryer (CUTRIM, ALVIM e CORTEZ, 2019).

O encapsulamento é um processo de empacotamento, em que certas substâncias de interesse tecnológico, são introduzidas em um sistema de cápsula, a fim de proteger, manter a estabilidade, evitar perdas, oxidação, controlar a liberação do material de interesse e obter produtos com maior solubilidade e melhores características sensoriais e nutricionais, podendo assim ser disponibilizados como ingredientes em outras preparações alimentícias, formando 
uma barreira física entre o composto encapsulado e o material de parede, que também é alimentício (FAVARO-TRINDADE e PINHO, 2008). Diversos métodos podem ser aplicados para este fim, como spray drier, spray chilling, freeze drier, coacervação, gelificação iônica e outras (CUTRIM, ALVIM e CORTEZ, 2019). O composto que fica preso no interior da microcápsula é chamado núcleo ou fase interna, enquanto que o contorno é chamado cobertura, material de parede, membrana ou encapsulante podendo apresentar diversas variações como mostra a figura 3. A formação de microcápsulas depende da solubilidade, polaridade e volatilidade do núcleo e do material de parede. (LABUSCHAGNE, 2018). Portanto, o processo de encapsulamento requer atenção quanto às características do material liquido na forma de dispersão a ser encapsulado e do equipamento de secagem (TONON, BRABET e HUBINGER, 2009).

Figura 3 - Variações apresentadas pelas cápsulas: (a) Mononuclear ou simples, (b) Capa múltipla, (c) Polinuclear ou multinúcleo, (d) Matriz, (e) Irregular.

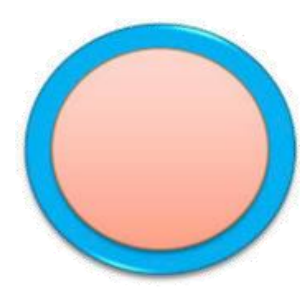

(a) Mononuclear ou simples

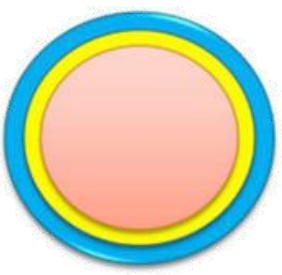

(b) capa múltipla

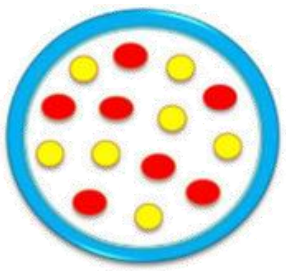

(c) Polinuclear ou multinúcleo

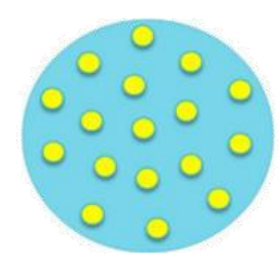

(d) Matriz

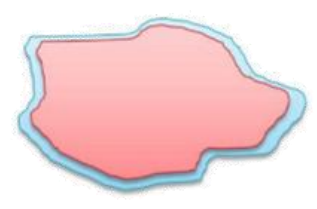

(e) Irregular

Fonte: SAIFULLAH, et al., (2019)

O estado físico das partículas dispersas em meio líquido define os sistemas de dispersões que entram no equipamento de secagem, em que as espumas são formadas por partículas de ar; as emulsões de líquidos imiscíveis; e suspensões quando as partículas são sólidas (FENNEMA, DAMODARAN e PARK, 2010), logo é possível que ocorra a pulverização de uma dispersão de natura desconhecida, se não houver um estudo prévio de suas propriedades.

Independente do estado físico, o tamanho que as partículas apresentam classificam o encapsulamento em macro $(>500 \mu \mathrm{m})$, micro $(1,0-500 \mu \mathrm{m})$ e nano $(<1,0 \mu \mathrm{m})$, sejam elas de quaisquer formatos (JAFARI, 2008; SAIFULLAH, et al., 2019). O tamanho das cápsulas merece ser estudado cuidadosamente pois, influencia diretamente na liberação controlada do material do núcleo, dessa forma, quando as partículas são menores a liberação se dá em velocidade constante e quando as partículas são maiores a liberação ocorre muito rapidamente (YANG et al., 2020). Outras características que o tamanho das cápsulas afetam é a viscosidade 
da emulsão e o próprio tamanho das partículas secas, ou seja, quanto maiores são as partículas mais viscosa é a emulsão, fazendo com que as gotas formadas durante a atomização sejam também mais volumosas, gerando consequentemente grandes partículas de pó (TONON, GROSSO e HUBINGER, 2011). Porém o principal causador dessa reação em cadeia é o tipo de material encapsulante, pois além de interferir na viscosidade, no tamanho e distribuição das partículas, ele reflete em propriedade importantes do produto final como o teor de água, solubilidade, higroscopicidade, entre outras (TONON, GROSSO e HUBINGER, 2011; CHUYEN et al., 2019).

\section{Material encapsulante}

No encapsulamento de compostos, a seleção do material de parede é crítica, pois ela tem influência nas propriedades da emulsão antes da secagem, na retenção dos voláteis durante o processo e na vida de prateleira do pó encapsulado depois da secagem e depende da natureza do material do núcleo, do processo de encapsulamento e do uso final do produto (JAFARI et al., 2008: SAIFULLAH, et al., 2019). Os critérios para a seleção do material de parede estão principalmente baseados em suas propriedades físico-químicas tais como solubilidade, massa molecular, temperatura de transição vítrea, cristalinidade, propriedades de formação de filme, capacidade emulsificante, custos e comportamento na secagem, sendo que este deve ser insolúvel, não reativo com o núcleo, mostrar propriedades constantes durante o armazenamento (LABUSCHAGNE, 2018) Os materiais mais utilizados incluem gomas (alginatos de sódio, carragena, goma arábica), carboidratos (açúcares, amido, dextrinas, xarope de milho, carragena), celuloses (acetilcelulose, carboximetilcelulose, etilcelulose, metilcelulose, nitrocelulose), lipídeos (ácido esteárico, ceras, diglicerídeos, gorduras hidrogenadas, monoglicerídeos, óleos, parafina e triestearina) e proteínas (albumina, caseína, gelatina, glúten e isolado proteico de soro de leite e de soja) (LABUSCHAGNE, 2018). Devido à dificuldade em encontrar-se um polímero ideal, a utilização de combinações de diferentes tipos de agentes formadores de cobertura deve ser estudada (FAVARO-TRINDADE; PINHO, 2008).

Trabalhos realizados por Böger, Georgetti, e Kurozawa (2018) combinaram dois materiais de parede e detectaram que a adição de maltodextrina à goma arábica não influenciou o diâmetro médio de partículas, densidade a granel em pó, eficiência do encapsulamento de óleo de semente de uva. De acordo com Saifullah, et al., (2019) a combinação de polissacarídeos com proteína pode melhorar a eficiência de encapsulamento e a funcionalidade da cápsula. Como foi mostrado por Araújo et al., (2020) que utilizaram maltodextrina e gelatina para encapsular óleo essencial de laranja, resultando pós de altos rendimentos e alta eficiência 
e a preservação das funcionalidades destas capsulas que foram as propriedades antioxidantes e antimicrobianas. Também Custódio et al., (2020) encapsulou polpa de açaí com uma mistura proteica vegetal, isolada da ervilha e concentrada do arroz, e obteve um pó de alto rendimento, teor de água aceitável de $10 \%$ e com partículas grandes, mas com alta solubilidade, sendo caracterizado como um pó instantâneo benéfico a saúde podendo ser aplicado em produtos funcionais.

\section{Proteína isolada do soro de leite}

O soro é o subproduto líquido resultante da precipitação de proteínas no leite. Sua composição é de aproximadamente $94 \%$ de água e $6 \%$ de sólidos totais, formado por 4,5\% de lactose, $0,8 \%$ de proteína e $0,7 \%$ de minerais que pode ser seco para obter subprodutos. Dessa forma, o teor de lactose pode ser reduzido, o resíduo mineral desmineralizado e o teor proteico pode ser concentrado ou isolado (SCHRODER et al., 2017). A proteína concentrada é obtida pela remoção da lactose e dos minerais, obtendo-se em torno de $25 \%$ a $80 \%$ de proteínas. O isolamento proteico se dá por meio da purificação do concentrado com teor maior que $90 \% \mathrm{em}$ base seca. A proteína hidrolisada é outro produto que pode ser obtido do soro, sendo formulada para atender funcionalidades tecnológicas, com aplicações em diversas áreas (KILARA e VAGHELA, 2018). Logo, esse isolado proteico é o que apresenta maior grau de pureza e pode apresentar maior ação da proteína no encapsulamento proteico da polpa de açaí.

As proteínas do soro do leite são solúveis em ampla faixa de $\mathrm{pH}$, apresentam um perfil de aminoácidos essenciais favoráveis a absorção intestinal (KILARA e VAGHELA, 2018). E sua estrutura globular favorece uma série de propriedades importantes ao organismo humano, a qual é mantida por pontes de dissulfeto. Os peptídeos mais abundantes em ordem decrescente de quantidade no soro é a beta-lactoglobulina (BLG) apresentado de 47 a $57 \%$, alfalactoalbumina (ALA) que está contida entre 14 a 25\%, albumina do soro bovino (BSA) representando cerca de $10 \%$, e em menor quantidade as imunoglobulinas $\left(\operatorname{Ig}^{\prime} \mathrm{s}\right)$ e glicomacropeptídeos (GMP) (HARAGUCHI; ABREU e PAULA, 2006; AUGUSTO; REZENDE, 2010 ).

Em conjunto, essas proteínas usadas como agente encapsulante são eficientes por terem a capacidade de interação molecular na interface óleo/água, estabilizando as gotas formadas na homogeneização e reduzindo as taxas de coalescência e garantindo a manutenção da estrutura durante a secagem (SCHRODER et al., 2017; YANG, et al., 2020).

Alguns trabalhos usando proteínas do soro de leite apresentaram bons resultados de encapsulação como feito por González et al., (2012) que encapsularam óleo de chia com 
proteínas do soro de leite concentrado e verificaram microcápsulas morfologicamente sólidas e com boa eficiência de encapsulação, Matta (2013) observou uma maior eficiência do encapsulamento de óleo de pequi com proteínas do soro de leite combinado a maltodextrina e microcápsulas de formato esférico e superfície livre de poros, Santana et al., (2016) encapsularam polpa de Jussara com diferentes misturas encapsulantes e perceberam que a presença do isolado proteico de soro de leite melhorou a eficiência da encapsulação e recentemente Braber et al., (2020) combinaram proteínas do soro de leite com derivado quitossano na encapsulação de probióticos e obteve uma eficiência de $91 \%$ e viabilidade do uso sob condições gastrointestinais de $90 \%$. Muitos outros tem sido apresentado mostrando o quão promissor é o uso de proteínas do soro de leite na microencapsulação de compostos.

\section{Secagem por atomização}

A secagem por atomização ou em spray dryer é a técnica mais usual na microencapsulação de alimentos por ser de fácil manipulação e baixo custo em relação a outros processos e por conferir boa qualidade ao produto final (TONON, BRABET e HUBINGER, 2009). O spray dryer é constituído de uma câmara, na qual um fluido é aspergido por um bico atomizador, enquanto uma corrente de ar quente passa pelas gotas atomizadas, evaporando a água e gerando as pequenas partículas sólidas encapsuladas (ROCHA et al., 2019). O equipamento possui dispositivos que permitem a excussão do processo, onde o compressor tem a função de enviar o ar comprimido para a câmara em diferentes velocidades; o painel de controle possibilita controlar as temperaturas de entrada e saída do ar de secagem e seu fluxo, o fluxo de alimentação, fluxo do ar comprido e pressão do ar; o bico atomizador permite a aspersão do fluido de alimentação e pode variar de diâmetro; o fluido de alimentação contem a solução que será aspergida na câmara; a câmara de secagem permite a circulação de ar e das gotas atomizadas, o ciclone resfria levemente as partículas secas, as expelem para fora e elas são recolhidas em um recipiente adequado; e a bomba peristáltica conduz o fluido de maneira controlada até o bico atomizador (LABUSCHAGNE, 2018; ROCHA et al., 2019; SAIFULLAH, et al., 2019). 
Figura 4 - Esquema do spray dryer. 1-Compressor; 2-Painel de controle; 3 -Bico atomizador; 4 -Fluido de alimentação (solução de secagem); 5- Câmera de secagem; 6 -Ciclone (saída de pó); 7 -Bomba peristáltica.

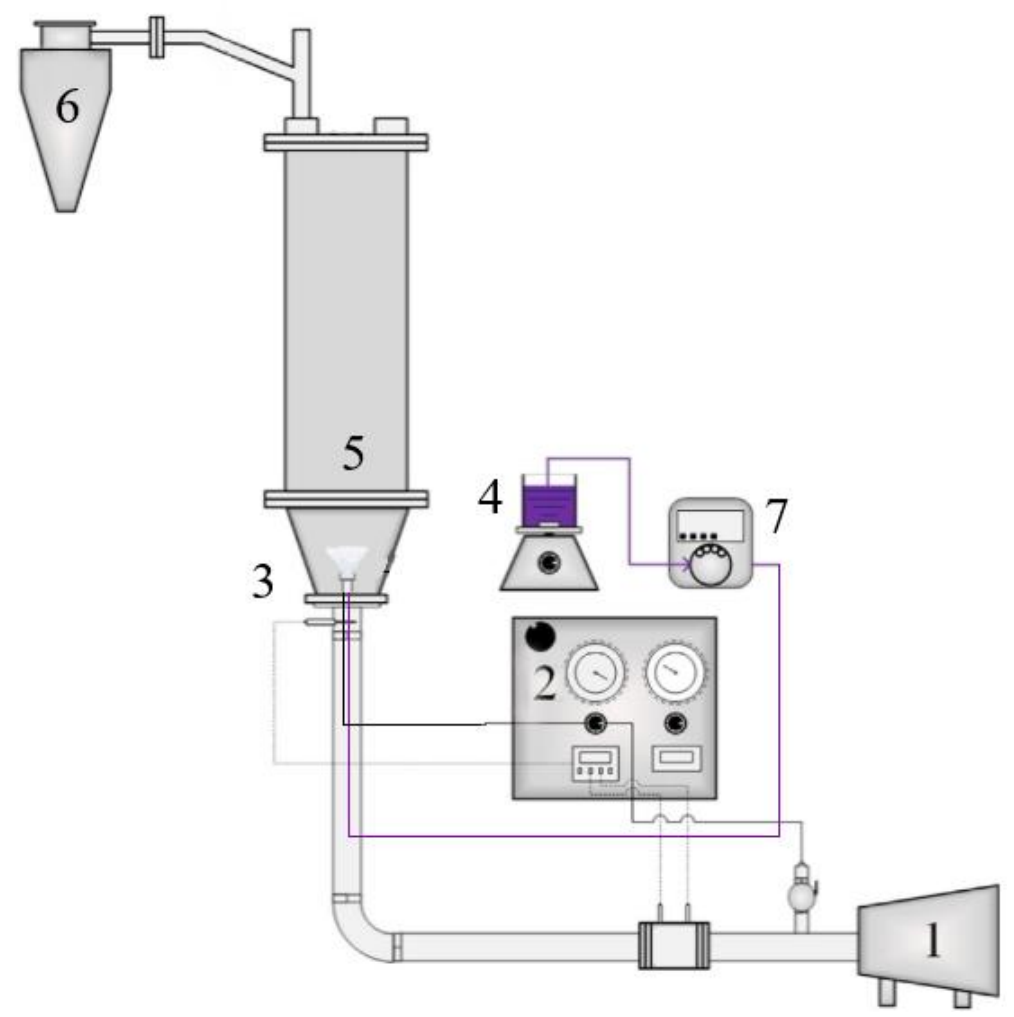

Fonte: CUSTODIO, et al., (2020) com adaptações.

De acordo com Botrel et al., (2012) é a remoção de água que garante a formação das microcápsulas. Portanto, deve haver um controle da taxa de remoção, pois ela interfere nas propriedades tecnológicas do pó, que são umidade, aa, higroscopicidade, densidade, morfologia e cor, entre outras (RAJABI et al., 2015). A aplicação de secagem por spray na microencapsulação envolve três etapas básicas: a preparação, a homogeneização e a atomização do fluido dentro da câmara de secagem (CUSTODIO et al., 2020).

No momento da secagem ocorre o contato das gotas com o ar quente, e trocas de energia e massa são estabelecidos entre a fase líquida e gasosa, fazendo com que a transferência de calor seja realizada na direção ar-produto como resultado da diferença entre temperaturas (ROCHA et al., 2019). A transferência de água é realizada em direção oposta, devido à diferença entre pressões de vapor. A taxa de secagem diminui, de modo rápido, tornando-se dependente da taxa de difusão de água através da parede e termina, na prática, quando a temperatura da partícula atinge o valor da temperatura do ar e consequentemente quando a umidade de equilíbrio da partícula é igual a umidade de equilíbrio do ar. (LABUSCHAGNE, 2018). 
A temperatura de entrada é uma variável relevante durante a secagem por atomização, pois ela é capaz de determinar a qualidade final das microcápsulas conforme relatado por Tonon, Grosso e Hubinger, (2011) e por Tonon, Brabet e Hubinger (2009), em experimentos nos quais dispersões com diferentes concentrações foram submetidas à secagem por atomização e se constatou que o aumento da temperatura é um parâmetro fundamental no encapsulamento de açaí, pois este aumento está intimamente ligado ao escurecimento do pó e aumento do diâmetro médio das partículas ao passo que reduz o teor da água, a higroscopicidade e o teor de pigmentos sensíveis ao calor, como as antocianinas, além de melhorar a aparência do pó.

Botrel et al., (2012) observaram que o fluxo de alimentação também influencia nas propriedades do pó, uma vez que, taxas em torno de 0,5 e $0,6 \mathrm{~L} \cdot \mathrm{h}^{-1}$ produziram pó com menor teor de umidade e aa. Além da temperatura de entrada e fluxo de alimentação, outras variáveis como o fluxo do ar comprimido e do ar de secagem podem também afetar o teor de água, aa e demais características do pó atomizado.

\section{Caracterização de alimentos em pó}

Os alimentos em pó podem ser classificados quanto as suas propriedades físicas e químicas que dizem respeito a sua qualidade tecnológica (BARBOSA et al., 2005). Estes alimentos devem ser avaliados quanto ao teor de água, aa, higroscopicidade, solubilidade, densidade, cor e outras propriedades relacionadas com a composição como substâncias bioativas, proteínas, resíduo mineral fixo, etc. (JAFARI, GHALENOEI e DEHNAD, 2017).

Pretende-se com a microencapsulação obter pós com baixo teor de água e aa, pois são importantes indicadores de eficiência do processo e da estabilidade ao armazenamento. Os alimentos apresentam três tipos de isotermas, a primeira (I) apresenta aa abaixo de 0,25 e a água comporta-se como um sólido por estar fortemente envolvida em interações íons e dipolos. $\mathrm{O}$ tipo II aa está entre 0,25 e 0,85 e ocorre intercâmbio entre moléculas vizinhas, onde a água exerce um efeito plastificante sobre os solutos e o tipo III a aa está acima de 0,85 e ocorre à manifestação de uma monocamada verdadeira de hidratação bem como maiores taxas de reações e maior mobilidade molecular (FENNEMA, DAMODARAN e PARK, 2010). 
Figura 5 - Três tipos de isotermas tipicamente encontrada nos alimentos. Onde UR é a umidade relativa e aa é atividade de água.

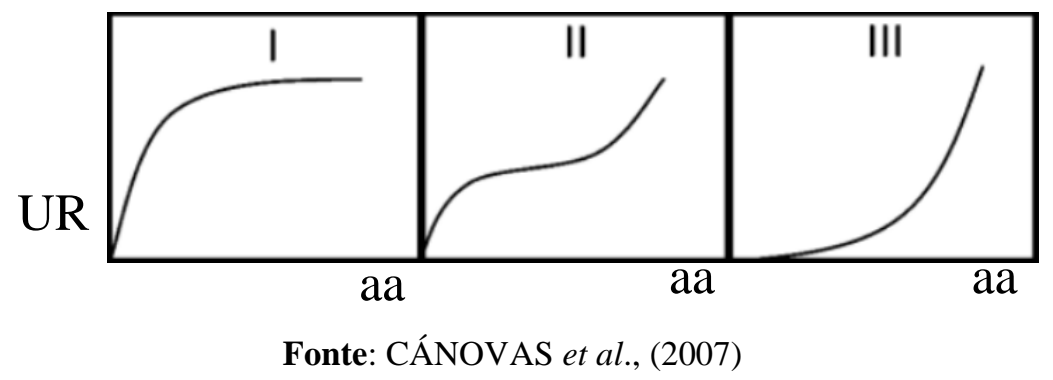

Existe uma ligeira relação da atividade de água com a umidade, por isso o recomendado é que o teor de água, das microcápsulas, esteja entre 3 a 10\% (BRABER et al., 2020) e aa entre 0.13 a 0.50 (REZAUL, SHISHIR e CHEN, 2017). Nessas faixas a água está fortemente ligada à matriz do alimento, e não oferece condições para o crescimento de microrganismos e para a oxidação lipídica (FENNEMA, DAMODARAN e PARK, 2010), como pode ser melhor observado na tabela 2 .

Figura 6 - Relação entre a atividade de água, a umidade e a velocidade de reação do alimento.

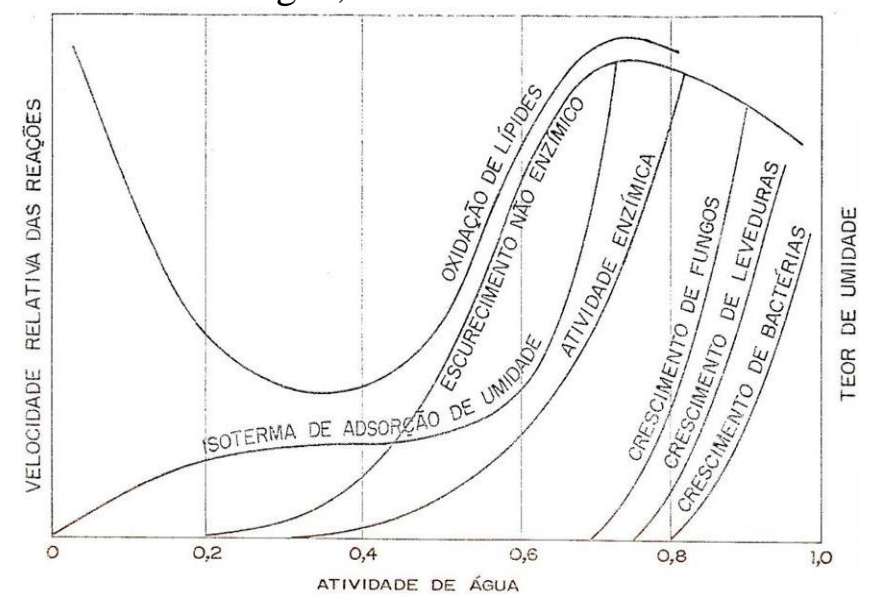

Fonte: LABUZA, (1968).

A densidade do material em pó pode ser medida na forma de densidade aparente que é referente aos espaços entre as partículas (JAFARI, GHALENOEI e DEHNAD, 2017). Quanto mais denso o material, mais empacotado ele torna-se ocupando menor volume e apresentando menor porosidade entre as partículas (CARNEIRO et al., 2013). A densidade aparente é uma propriedade importante para a conservação por que proporciona menor penetração de luz e ar atmosférico otimizando o armazenamento e transporte devido a menor demanda de espaço para acomodação (LABUSCHAGNE, 2018). 
A análise de solubilidade em água fornece dados importantes de um composto, uma vez que quando solúvel dissolve-se livremente e permanece em solução, quando insolúvel ou pouco solúvel dissolve-se lentamente e em solução, tem uma forte tendência de separar as fases. Do ponto de vista termodinâmico, a solubilidade é a concentração de um soluto em um estado de agregação (sólido, liquido ou gasoso) que se converta ao mesmo estado de agregação do solvente (ARAÚJO, 2006). A alta solubilidade do encapsulante é fundamental para prever o uso do pó como ingrediente ou como produtos alimentícios acabados (JAFARI, GHALENOEI e DEHNAD, 2017).

Higroscopicidade é a capacidade que o material tem de absorver umidade do ambiente e estabelecer um equilíbrio com ele (CAI e CORKE, 2000). A taxa de absorção de água é um importante atributo do pó e diz respeito a reconstituição, susceptibilidade a aderência e ao endurecimento desse pó, quando o armazenamento e distribuição ocorrem em ambientes de maior umidade (YAMASHITA et al., 2017). Estudos indicam que a higroscopicidade do material de parede afeta a higroscopicidade dos pós e por consequência altera o tempo de armazenamento de materiais micro encapsulados (YAMASHITA et al., 2017).

A avaliação instrumental da cor deve estar relacionada à percepção visual humana do produto para que a medida faça sentido. sistema CIE reparte a cor em três coordenadas coordenadas L, a e b do (DAWSON e ACTON, 2018). Sendo L uma coordenada vertical equivalente a luminosidade e varia de 100, muito claro, a 0 muito escuro, a e b equivalem a variações de cor do $+\mathrm{a}$ vermelho ao $+\mathrm{b}$ amarelo, -a verde e $-\mathrm{b}$ azul como mostra a figura 2 (DAWSON e ACTON, 2018). Essas coordenadas dão origem ao vetor Croma $\mathrm{C}$ e ao ângulo H que representa a saturação ou intensidade da cor que aumenta a partir do 0 no centro e a tonalidade da cor respectivamente (DAWSON e ACTON, 2018; BERTALMÍO, 2020). 
Figura 7 Representação da cor no espaço (CIELab).

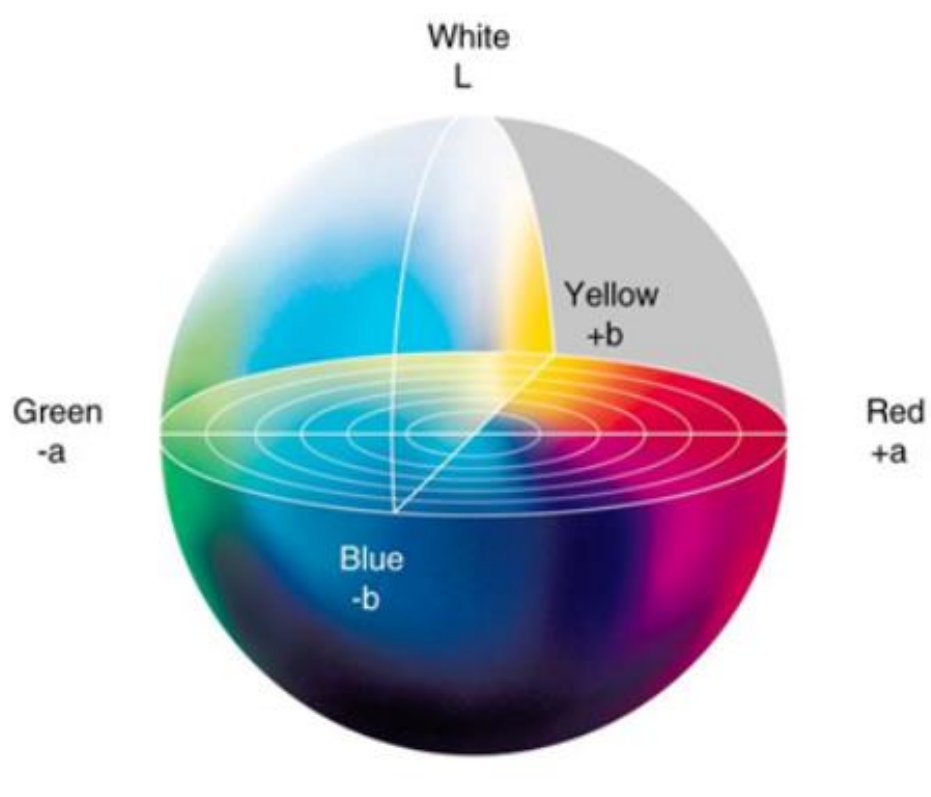

Black

Fonte: (Bertalmío, 2020).

A luminosidade (L) é um parâmetro relevante no processamento por spray dryer, pois indica a ação de agentes importantes do processo no escurecimento do pó ou do material de parede, (TONON, BRABET e HUBINGER 2009). A mudança na cromaticidade da amostra, após a secagem, pode indicar degradação de pigmentos. Ainda que os alimentos em pó sejam comprovadamente saudáveis, se o aspecto visual não for atraente, pode perder a aceitação dos consumidores (JAFARI, GHALENOEI e DEHNAD, 2017).

\section{Otimização Estatística}

A otimização estatística advém de uma necessidade de minimizar custos e tempo de implementação dos experimentos ao passo que maximiza rendimentos, produtividade e qualidade (MONTGOMERY, 2003). Consiste, inicialmente, de um planejamento experimental, de modo que, todo o espaço amostral seja explorado com um menor número possível de ensaios e, a partir de então, ajustar um modelo de regressão o qual pode ser ajustado por meio da Metodologia de Superfície de Resposta (MSR), sendo esta, uma ferramenta matemática e estatística, em que os resultados experimentais, são frutos da variação simultânea de combinações entre os níveis dos fatores que influenciam nas propriedades do processo e indicam uma região ótima (RODRIGUES e IEMMA, 2005).

$\mathrm{Na}$ área de encapsulamento de alimentos, a MSR tem sido amplamente aplicada, como exemplo, Botrel et al., (2012), encontraram combinações entre temperatura e vazão de [710] 
alimentação do ar de secagem para o encapsulamento de óleo de orégano, Ko et al., (2015) identificaram a formulação otimizada para melhorar a eficiência no encapsulamento de cúrcuma, Getachew e Chun (2016) determinaram os parâmetros mais importantes que afetam a eficiência de encapsulamento do sabor de óleo de café.

A metodologia de superfície de resposta gera o maior conhecimento sobre a natureza do fenômeno a partir de dados estatísticos otimizados gerando modelos com menor resíduo como consequência de um número reduzido de ensaios (RODRIGUES e IEMMA, 2005).

As equações pretendidas com o encapsulamento da polpa de açaí devem seguir modelos de até segunda ordem ajustadas segundo a metodologia de superfície de resposta para tratamentos com três variáveis independentes utilizando um DCCR. Segundo Silveira, Lopes e Rosa, (2017), um determinado ponto da superfície de resposta pode se apresentar longe do ponto ótimo, assim, a superfície apresentará uma curva tênue, porém há relatos de que o polinômio de segunda ordem possa representar significativamente os fenômenos observados.

\section{Considerações finais}

Ao considerar todas as variáveis que interferem diretamente na encapsulação do açaí, concluiu-se que a otimização do processo é um trabalho árduo e que requer muita cautela, pois pode ser muito grande o número de variáveis independentes, por isso, se propõe que a otimização seja dividida em duas partes, a primeira como a otimização da solução antes da secagem onde as variáveis independentes podem ser o tipo, a concentração e a combinação de materiais de parede, teor de sólidos e outras e a segunda com a otimização da secagem cujas variáveis independentes podem ser fluxo de alimentação, fluxo do ar de secagem, fluxo do ar comprimido, pressão do ar, temperatura de entrada e saída e outras. As variáveis respostas da primeira otimização podem ser a viscosidade, teor de sólidos, tamanho de distribuição de partículas, cor, teor dos compostos fenólicos, antocianinas e flavonóides e outras e da segunda podem ser teor e atividade de água, higroscopicidade, solubilidade, densidade, cor, eficiência do encapsulamento, rendimento, teor dos compostos fenólicos, antocianinas e flavonóides e outras. Dessa forma se obtém respostas bem refinadas e abrangentes dos processos numa condição que beira a perfeição, porém o que se vê na prática é apenas a otimização durante a secagem variando de 3 a 4 varáveis e fixando todas as demais, o que tem sido válido para ter uma compreensão dos fenômenos que envolvem a encapsulação e que são capazes de propor uma perspectiva do processo para elaborar pós com qualidade tecnológica dentro dos limites aceitáveis das variáveis repostas supracitadas. 


\section{Referências}

ARAÚJO, J. M. A. Química de Alimentos: Teoria e prática. $3^{\mathrm{a}}$ ed. Organizado por UFV. Viçosa-MG. 2006.

ARAÚJO, J. S. F., DE SOUZA, E. L., OLIVEIRA, J. R., GOMES, A. C. A., KOTZEBUE, L. R. V., DA SILVA AGOSTINI, D. L., CAVALCANTI, M. T. Microencapsulation of sweet orange essential oil (Citrus aurantium var. dulcis) by liophylization using maltodextrin and maltodextrin/gelatin mixtures: Preparation, characterization, antimicrobial and antioxidant activities. International Journal of Biological Macromolecules, 143, 991-999, 2020.

AUGUSTO, F. E REZENDE, M. Soro de leite e suas proteínas: composição e atividade Funcional, Ciências Biológicas e Saúde, v. 12, n. 2, p. 31-38. 2010.

BÖGER, B. R., GEORGETTI, S. R., e KUROZAWA, L. E. Microencapsulation of grape seed oil by spray drying. Food Science and Technology, v. 38 n. 2, p. 263-270, 2018.

BOTREL, D. A., BORGES, S. V. E., FERNANDES., R. V. B., VIANA, A. D. Evaluation of spray drying conditions on properties of microencapsulated oregano essential oil, International Journal of Food Science and Technology, v. 47, p. 2289-2296. 2012.

BRABER, V, N. L; DÍAZ VERGARA, L. I; ROSSI, Y. E; AMINAHUEL, C. A., MAURI, A. N., CAVAGLIERI, L. R., e MONTENEGRO, M. A. Effect of microencapsulation in whey protein and water-soluble chitosan derivative on the viability of the probiotic Kluyveromyces marxianus VM004 during storage and in simulated gastrointestinal conditions. LWT - Food Science and Technology, v. 118, p. 108-844, 2020.

BRASIL. Ministério da Agricultura, Pecuária e Abastecimento (MAPA). Instrução n ${ }^{\circ} 37$ de 08 de outubro de 2018. Regulamento técnico para fixação dos padrões de identidade e qualidade para polpas de frutas. Diário Oficial da União, Brasília, v. 194, seção 1, p. 28-48, 2018.

CAI, Y., e CORKE, H. Production and properties of spray-dried amaranthus betacyanin pigments. Journal of Food Science, v. 65,1248 e 1252. 2000.

CÁNOVAS G. V; FONTANA, A.J. JR; SCHMIDT, S. J; LABUZA, T.P. Water Activity in Foods: Fundamentals and Applications. $1^{\mathrm{a}}$ ed. Iowa, USA: IFT Press. Blackwell Publishing and the Institute of Food Technologists. 2007.

CARNEIRO, H. C. F; TONON, R. V; GROSSO, C. R. F; HUBINGER, M. D. Encapsulation efficiency and oxidative stability of flaxseed oil microencapsulated by spray drying using different combinations of wall materials. Journal of Food Engineering, v. 115, n. 4, p. 443451. 2013. Disponível em: http://dx.doi.org/10.1016/j.jfoodeng.2012.03.033

CHAUL, L. T.; CONCEIC, E. C.; BARA, M. T. F.; PAULA, J. R.; COUTO, R. O. Engineering spray-dried rosemary extracts with improved physicomechanical properties: a design of experiments issue. Revista Brasileira de farmacognosia, v. 27, p. 236-244, 2017.

CHUYEN, H. V., ROACH, P. D., GOLDING, J. B., PARKS, S. E., e NGUYEN, M. H. Encapsulation of carotenoid-rich oil from Gac peel: Optimisation of the encapsulating process using a spray drier and the storage stability of encapsulated powder. Powder Technology, v. 344, 373-379, 2019. 
COHEN, K. DE O.; OLIVEIRA, R. DE A. M.; CHISTÉ, R. C.; OLIVEIRA, M. DO S. P. DE. Boletim de Pesquisa e Desenvolvimento. Empresa Brasileira de Pesquisa Agropecuária, 2009.

CUSTODIO, G. R.; FRANQUELIN, L.; SOUZA, G. DE; NITZ, M.; ANDREOLA, K. A protein powder agglomeration process using açaí pulp as the binder: An analysis of the process parameters. Advanced Powder Technology. p. 1-11, 2020.

CUTRIM, C.S., ALVIM, I.D. e CORTEZ, M.A.S. Microencapsulação de polifenóis de chá verde por métodos de gelação iônica e resfriamento de spray. Journal of Food Science and Technology, v. 56, p. 3561-3570, 2019.

DAWSON, P. L. E ACTON, J. C. Impact of proteins on food color. Second Edi, Proteins. Food Processing. Ed. $2^{\mathrm{a}} .2018$.

FAVARO-TRINDADE, C.S.;PINHO, S.C.; ROCHA, G.A. Microencapsulação de ingredientes alimentícios. Brazilian Journal of Food Technology, Campinas, v.11, p.103-112, 2008.

FENNEMA, O. R., DAMODARAN, S. E PARK, K. L. Química de Alimentos de Fennema. $4^{\mathrm{a}}$ ed. Organizado por artmed. Porto Alegre - RS. 2010.

GETACHEW, A.T., CHUN, B. S. Optimization of coffee oil flavor encapsulation using response surface methodology. LWT - Food Science and Technology. 2016.

GONZÁlEZ, R; OLIVARES, C. J; GUERRERO, R; A., HUEZO, R; ME, CARTER, V; ALONSO, E. E. P. C. Spray drier encapsulation of essential oil of chia (Salvia hispânica L.) in whey protein concentrate polysaccharide matrices. Journal of Food Engineering, v. 111, n. 1, p. 102-109. 2012.

GUEDES-OLIVEIRA, J. M.; ALVES, V. H. M.; ANDRÉ, L. Effect of microencapsulated extract of pitaya (Hylocereus costaricensis) peel on color, texture and oxidative stability of refrigerated ground pork patties submitted to high pressure processing. Innovative Food Science and Emerging Technologies, 2018.

HARAGUCHI, F. K. ABREU, W. C. PAULA, H. Proteínas do soro do leite: composição, propriedades nutricionais, aplicações no esporte e benefícios para a saúde humana. Revista de Nutrição, Campinas, v. 19, n. 4, p. 479-488, 2006.

IBGE (Instituto Brasileiro de Geografia e Estatística). Produção da Extração Vegetal e da Silvicultura. SIDRA, Agencia de notícias IBGE, 2016.

JAFARI, S. M., GHALENOEI, M. G. DEHNAD, D. Influence of spray drying on the water solubility index, bulk density and anthocyanins content of powdered pomegranate juice. Dryer Technology, v. 311, p. 59-65. 2017.

JAFARI, S. M.; ASSADPOOR, E.; HE, Y.; BHANDARI, B. Encapsulation efficiency of food flavors and oils during spray drying. Drying Technology, v.26, n.7, p.816-835, 2008.

KANG, J., THAKALI, K. M., XIE, C., KONDO, M., TONG, Y. OU, B., JENSEN, G., MEDINA, M. B., SCHAUSS, A.G. WU, X. Bioactivities of açaí, superior antioxidant and antiinflammatory properties to Euterpe oleracea. Food Chemistry, v. 133, n. 3, p. 671-677. 2012. 
KILARA, A. E VAGHELA, MN. Proteínas de soro. Proteínas no Processamento de Alimentos, 93-126. 2018.

KO, W. C; CHANG, C. K; WANG, H. J; WANG, S. J; HSIEH, C. W. Process optimization of microencapsulation of curcumin in c-polyglutamic acid using response surface methodology. Food Chemistry. 2015.

KURIOKASE, A.B..; SATHIREDDY, P.; PRIYA, S.P. A Review on Microcapsules. Global Journal of Pharmacology, v. 9, p. 28-39, 2015.

LABUSCHAGNE, P. Impact of wall material physicochemical characteristics on the stability of encapsulated phytochemicals: A review. Food Research International, v. 107, n. 2017. p. 227-247, 2018.

LABUZA, T.P. Sorption phenomena in foods. Food Technology. v. 22, n.3, p. 15-24, 1968.

MACIEL V. B. V.; FRANCO T. T. C. M. P. Sistemas Inteligentes de Embalagens Utilizando Filmes de Quitosana como Indicador Colorimétrico de Temperatura. Faculdade de Engenharia Química, UNICAMP. Campinas - SP, 2012.

MATTA, L. M. Retenção do óleo de pequi em micropartículas de concentrado proteico de soro de leite e maltodextrina. Dissertação para a obtenção do título de mestre em ciência e tecnologia de Alimentos. Universidade federal de goiás. 2013.

MOLINA, B.; SIMÕES, F; LEAL, LEANDRO; VINICIUS, M. Obtenção de indicadores de pH coloridos. UNESP - Faculdade de Ciências e Tecnologia - Presidente Prudente. 2010.

MONTGOMERY, D.C; RUNGER, G.C.; HUBELE, N. F. Estatística aplicada à engenharia. $2^{\mathrm{a}}$ Ed. Rio de janeiro, 2003.

NEVES, L. T. B. C., CAMPOS, D. C. S., MENDES, J. K., Qualidade de frutos processados artesanalmente de açaí (euterpe oleracea mart.) e bacaba (oenocarpus bacaba mart.) Revista Brasileira de Fruticultura, v. 37, n. 3, p. 729-738. 2015.

NOGUEIRA, A. K. M.; SANTANA, A. C.; GARCIA, W. S. A dinâmica do mercado de açaí fruto no Estado do Pará: de 1994 a 2009. v. 60, n. 03, p. 324-331, 2013.

NORI, M. A. Produção de microcápsulas de ácido cítrico para utilização em produtos cárneos. Dissertação para a obtenção do título de mestre em ciências farmacêuticas, Universidade de São Paulo - USP. 79 p. São Paulo, 1996.

OLIVEIRA, M. S. P.; FARIAS NETO, J. T.; QUEIROZ, J. A. L. Cultivo e manejo do açaizeiro para produção de frutos. ENCONTRO AMAZÔNICO DE AGRÁRIAS, Anais. 20p. UFRA, 2014.

PICOT, A.; LACROIX, C. Encapsulation of Bifidobacteriain whey protein-based microcapsules and survival in simulated gastrointestinal conditions and in yoghurt. International Dairy Journal, v. 14, n. 6, p. 505-515, 2004.

PORTINHO, J.A; ZIMMERMANN, L. M; BRUCK, M. R. Efeitos Benéficos do Açaí. International Journal of Nutrology, v.5, n.1, p. 15-20, 2012. 
RAJABI, H; GHORBANI, M; JAFARI, S. M; MAHOONAK, A. S; RAJABZADEH, G. Retention of saffron bioactive components by spray drying encapsulation using maltodextrin, gum Arabic and gelatin as wall materials. Food Hydrocolloids. Iran. 2015.

RÉ, M.I. Microencapsulação: em busca de produtos “inteligentes”. Ciência Hoje, v.27, n.162, p.24-29, 2000.

REZAUL, M., SHISHIR, I. E CHEN, W. Trends in Food Science e Technology Trends of spray drying: A critical review on drying of fruit and vegetable juices, Trends in Food Science e Technology. v.65, p. 49-67. 2017.

ROCHA, J. DE C. G.; BARROS, F. A. R. DE; C, Í. T. P.; et al. Microencapsulação por atomização da mistura de extratos fenólicos. Powder Technology, v. 343, p. 317-325, 2019.

RODRIGUES, M. I.; IEMMA, A. F. Planejamento de experimentos e otimização de processos. Campinas, SP: Casa do pão editora, 2005.

SAIFULLAH, M., SHISHIR, M. R. I., FERDOWSI, R., TANVER RAHMAN, M. R., e VAN VUONG, Q. Micro and nano encapsulation, retention and controlled release of flavor and aroma compounds: a critical review. Trends in Food Science and Technology, v. 86, p. 230 $251,2019$.

SANTANA, A. A; CANO-HIGUITA, D. M; OLIVEIRA, R. A; TELIS, V. R. N., Influence of different combinations of wall materials on the microencapsulation of jussara pulp (Euterpe edulis) by spray drying", Food Chemistry, v.212, p. 1-9. 2016.

SCHRODER, A; BERTON-CARABIN, C; VENEMA; P. CORNACCHIA, L. Interfacial properties of whey protein and whey protein hydrolysates. Food Hydrocolloids v.73, p.129$140,2017$.

SHAMAEI, S., SEIIEDLOU, S. S., AGHBASHLO, M., TSOTSAS, E., e KHARAGHANI, A. Microencapsulation of walnut oil by spray drying: Effects of wall material and drying conditions on physicochemical properties of microcapsules. Innovative Food Science and Emerging Technologies, v. 39, 2017.

TONON, R. V; BRABET, C.; HUBINGER, M. D. Influência da temperatura do ar de secagem e da concentração de agente carreador sobre as propriedades físico-químicas do suco de açaí em pó. Ciência e Tecnologia de Alimentos, Campinas, v.29, n.2, p. 444-450, 2009.

TONON, R. V; GROSSO, C.R.F; HUBINGER, M. D. Influence of emulsion composition and inlet air temperature on the microencapsulation of flaxseed oil by spray drying. Faculty of Food Engineering, University of Campinas, P.O. Box 6121, 13083-862, Campinas, SP, Brazil. 2011.

TRINDADE, M. A. Microencapsulação de ácido ascórbico e avaliação de sua funcionalidade na estabilidade da cor em produtos cárneos curados. Tese de Mestrado em Engenharia de Alimentos, UNICAMP. 65 p. Campinas, 1998.

VANISKI, R. CORTI, D. DRUNKLER, D. A. Técnicas e materiais empregados na microencapsulação de probióticos. Brazilian Journal of Food Research, Campo Mourão, v. 8, n. 1, p. 156-184, 2017. 
YAMASHITA, C., MI, M., CHUNG, S., ROBERTA, C., MAYER, M. CRISTINA, I. MORAES, F. Microencapsulation of an anthocyanin-rich blackberry (Rubus spp.) by-product extract by freeze-drying, LWT - Food Science and Technology. v. 84, p. 256-262. 2017.

YANG, J., THIELEN, I., BERTON-CARABIN, C. C., VAN DER LINDEN, E., e SAGIS, L. M. C. Nonlinear interfacial rheology and atomic force microscopy of air-water interfaces stabilized by whey protein beads and their constituents. Food Hydrocolloids, v. 101, p. 105466, 2020. 


\title{
CAPÍTULO 46: USO DE ÓLEO ESSENCIAL DE PIMENTA ROSA (Schinus terebinthifolius Raddi) INCORPORADO EM REVESTIMENTOS PARA CONTROLE DE MICRORGANISMOS - REVISÃO
}

\section{CHAPTER 46: USE OF ESSENTIAL OIL OF PINK PEPPER INCORPORATED IN COATING FOR MICROORGANISM CONTROL - REVIEW}

Daniele Pereira do Amaral ${ }^{1}$; Isamara Reis Gomes ${ }^{2}$; Daniel Saraiva Lopes ${ }^{3}$ Lethycia Dos Santos Vieira da Matta $^{4}$.

\begin{abstract}
Resumo
Revestimentos e filmes ativos são técnicas inovadoras de conservação de alimentos e estas têm buscado constantemente por agentes ativos naturais compatíveis com produtos mais saudáveis. O uso dos óleos essenciais como agentes antimicrobianos naturais substitutos de aditivos artificiais, tem sido uma alternativa eficiente no controle de microrganismos. O óleo essencial de pimenta rosa tem sido identificado como um eficiente agente antimicrobiano, com ação comprovada no controle de crescimento de bactérias in vitro e após a sua incorporação em filmes de embalagens. A sua aplicação ainda não foi testada em trabalhos de desenvolvimento de revestimentos ativos aplicados na conservação de alimentos, sendo necessária a realização de investigação de concentrações efetivas para controle de bactérias e fungos, notadamente nos produtos de origem vegetal que são armazenados in natura e sofrem grandes perdas pós-colheita pelo ataque de fungos.
\end{abstract}

Palavras-Chave Schinus terebinthifolius Raddi, revestimento ativo, óleo essencial, pimenta rosa.

\begin{abstract}
Active coatings and films are innovative food preservation techniques and they are constantly looking for natural active agents compatible with healthier products. The use of essential oils as natural antimicrobial agents replacing artificial additives, has been an efficient alternative in the control of microorganisms. The essential oil of pink pepper has been identified as an efficient antimicrobial agent, with proven action in controlling the growth of bacteria in vitro and after its incorporation in packaging films. Its application has not yet been tested in the development of active coatings applied to food preservation, requiring the investigation of effective concentrations to control bacteria and fungi, notably in products of plant origin that are stored in natura and suffer great post-harvest losses due to fungi attack.
\end{abstract}

Keywords: Schinus terebinthifolius Raddi, active coating, essential oil, pink pepper.

\footnotetext{
${ }^{1}$ Doutora, Universidade Estadual do Norte Fluminense - UENF, dani.alimento@ gmail.com.br

${ }^{2}$ Mestranda em Produção Vegetal, Universidade Estadual do Norte Fluminense -UENF, isamarareisgomes@gmail.com.br

${ }^{3}$ Tecnólogo em Alimentos, Instituto Federal Fluminense, danielsaraiva15.ds@ gmail.com.br

${ }^{4}$ Biologia, Universidade Estadual do Norte Fluminense - UENF, lethyciadossantostab@gmail.com.br
} 


\section{Introdução}

A busca por novas técnicas que minimizem as perdas e auxiliem no controle de microrganismos que causam a deterioração tem sido o foco de muitas pesquisas na área de armazenamento de alimentos. Este fato está diretamente relacionado a um mercado consumidor mais competitivo e que busca alimentos saudáveis e com características mais próximas do alimento in natura (CALO et al., 2015).

As embalagens tradicionais apresentam apenas a função passiva de proteção do alimento, no entanto, técnicas inovadoras vêm sendo estudadas a fim de promover uma interação benéfica das substâncias que compõem a embalagem diretamente com o alimento, tais como, os filmes e revestimentos ativos (HAFSA et al., 2016; HAN, YU and WANG, 2014). Estas técnicas possuem como principais objetivos o aumento da validade comercial e a diminuição do índice de contaminação dos alimentos, principalmente as frutas e vegetais, que apresentam um curto período de comercialização, com elevadas perdas pós-colheita que impactam sobre a elevação do seu custo (AMARAL, 2014).

De acordo com FDA (2015), os revestimentos comestíveis devem ser seguros para uso em alimentos, e de forma geral, os revestimentos têm como base, materiais biológicos, tais como, proteínas, lipídios e polissacarídeos, sendo os mais comuns o amido, a celulose e a pectina, que são de origem natural, comumente conhecidos como biopolímeros (TZOUMAKI, BILIADERIS, VASILAKAKIS, 2009). O uso de biopolímeros naturais aplicados sobre alimentos tem apresentado grande interesse, não somente por parte de pesquisadores, mas também de produtores e comerciantes de frutas e hortaliças, isso porque o uso desses materiais de origem natural ajuda a minimizar o impacto ambiental e reduzir as perdas pós-colheita (GARCIA et al., 2010; ANSORENA; MARCOVICH; ROURA, 2011; VU et al., 2011; WRÓBLEWSKA-KREPSZTUL, et al., 2018).

A incorporação de compostos ativos naturais nos revestimentos e filmes que promovem alterações benéficas ao alimento tem sido uma alternativa ao uso de substâncias químicas, estimulando uma busca constante por produtos naturais que atuem de forma positiva para a saúde do consumidor (HAFSA et al., 2016).

Existem diversos compostos naturais que são utilizados como agentes antimicrobianos como os óleos essenciais (OE), os agentes antioxidantes como o ácido ascórbico, dentre outros, esses compostos trazem ao revestimento, além da função de barreira, a função de interação e de proteção do alimento contra agentes de deterioração, melhorando as propriedades funcionais (ZAHID et al., 2012). 
Os OE são extratos de origem vegetal que possuem em sua composição, substâncias bioativas (ASBAHANI et al., 2015). A planta Schinus terebinthifolius Raddi, conhecida como Aroeira, é uma planta nativa do Brasil, amplamente distribuída em toda América do Sul (AGRA et al., 2008). Seu fruto, popularmente conhecido como Pimenta Rosa, tem sido muito utilizado na indústria de alimentos devido ao seu sabor e aroma característico (ULIANA et al., 2016). O seu extrato tem sido considerado de alta eficiência como agente antimicrobiano e antioxidante. Entretanto, poucos trabalhos têm abordado o seu uso e a aplicação de seu OE em revestimentos de alimentos (DANNENBERG, et al. 2016).

O objetivo deste trabalho foi identificar o estado da arte na utilização do óleo essencial de pimenta rosa em revestimentos ativos e sua ação como agente antimicrobiano, tendo em vista a sua aplicação no desenvolvimento de revestimentos ativos para controle de microrganismos durante o armazenamento de alimentos.

\section{Importância das embalagens}

O conceito tradicional das embalagens para alimentos tem por premissa a função de preservar as características físicas, sensoriais, nutricionais e sanitárias dos alimentos, durante o período de comercialização (AMARAL, 2014). O conceito mais moderno vai além da função básica da embalagem, que além da função passiva de preservação e contenção, ela deve incluir aspectos de segurança, conveniência e perigo ao meio ambiente (DAINELLI et al., 2008; HAN, YU and WANG, 2014).

As embalagens ativas e Inteligentes promovem uma maior interação com o alimento e uma melhoria na preservação da qualidade do produto, bem como o aumento de sua validade comercial e segurança do alimento (GANIARI, et. al., 2017; REALINI, MARCOS, 2014; BIJI et al., 2015). Segundo o Guia da União Europeia para o Regulamento da Comissão $\mathrm{n}^{\circ} 450 / 2009$, a embalagem é denominada ativa quando fornece funções além daquelas tradicionais de proteção e de barreira inerte ao ambiente externo (UE, 2009).

As embalagens ativas podem funcionar como filmes ou como revestimentos. Os filmes consistem em películas pré-formadas e secas, compostas por uma matriz polimérica que envolve os alimentos, podendo ser incorporada ou não com agentes ativos. Já os revestimentos consistem em um gel formado por uma matriz polimérica, incorporado ou não com agentes ativos, que é aplicado na superfície do alimento (FALGUERA et al, 2011). 


\section{Importância dos revestimentos ativos}

As coberturas comestíveis ou revestimentos são definidos como uma fina camada de material comestível, depositada sobre a superfície do alimento, que tem a finalidade de inibir e/ou reduzir a perda de umidade, promover barreiras semipermeáveis à migração de solutos, às trocas gasosas, à respiração, bem como a supressão de distúrbios fisiológicos (WONG et al., 1994, BALDWIN et al., 1996; ROJAS-GRAU, TAPIA, MARTÍN-BELLOSO, 2008). Os revestimentos podem atuar também como carreadores de agentes antimicrobianos e agentes de controle de firmeza, ou até mesmo de compostos químicos que melhorem a estabilidade química e inibam as reações oxidativas (DAMODARAN; PARKIN; FENNEMA, 2010).

Diversos compostos podem ser usados na formulação dos revestimentos ativos, como polissacarídeos, proteínas, lipídios ou a combinação destes compostos. O uso de materiais provenientes de fontes renováveis, capazes de se decomporem naturalmente no ambiente, com menos efeitos ambientais, tem sido a motivação dessa proposta de inovação tecnológica, embora seu uso ainda apresente algumas limitações devido ao seu baixo desempenho, principalmente no que se refere às propriedades de barreira (SUKHIJA, SINGH, RIAR, 2016; MAJID et. al., 2018). O uso destes materiais se deve à demanda crescente por parte dos consumidores por alimentos seguros e saudáveis, que em muitos casos podem ser uma alternativa às embalagens sintéticas (ARNON-RIPS and POVERENOV, 2018).

Os trabalhos de desenvolvimento de biopolímeros têm sido amplamente difundidos e estão abrindo perspectivas para as inovações tecnológicas em revestimentos (ESPITIA et al., 2014). Os amidos em geral, têm o principal polímero usado nas formulações de revestimentos comestíveis (HENRIQUE; CEREDA; SARMENTO, 2008), tendo como principais características a boa transparência, o incremento de brilho superficial, boa resistência às trocas gasosas e também por permitir a adição de compostos ativos em sua formulação, podendo assim melhorar suas propriedades funcionais, com isso apresentando elevado potencial de uso na indústria de alimentos como alternativa na conservação (PELISSARI, et al., 2019; AHMED et al., 2017).

As propriedades especiais dos revestimentos ativos são obtidas através da incorporação direta de compostos ativos (aditivos) à matriz polimérica, conferindo propriedades específicas ao revestimento, apresentando grande potencial de uso, seja por liberar/emitir os agentes ativos (antioxidantes, antimicrobianos), reter compostos (etileno, oxigênio, água) ou neutralizar compostos indesejáveis produzidos no alimento (RESTUCCIA et al., 2010; ZANETTI et al., 2015; YILDIRIM et al., 2018). 


\section{Perspectivas do uso de óleos essenciais}

Os OE são extratos de origem vegetal que possuem em sua composição, substâncias bioativas sintetizadas pelas plantas (ASBAHANI et al., 2015). Esses extratos vegetais têm despertado grande interesse na indústria de alimentos em função da eficácia de seus componentes químicos naturais que apresentam atividades antimicrobianas e antioxidantes, agregando também valor aos produtos alimentícios em função do apelo de consumo de um produto conservado com substâncias naturais, podendo com isso serem utilizados como alternativa aos conservantes sintéticos (CALO et al., 2015; DANNENBERG et al., 2016).

Boa parte dos OE extraídos de plantas, condimentos e especiarias apresentam propriedades antimicrobianas e antioxidantes, o que possibilita seu uso na indústria de alimentos (VIUDA-MARTOS et al., 2010; ATARÉS and CHIRALT, 2016; VILELA et al., 2018). Por serem fitoquímicos naturais os OE são antimicrobianos naturais encontrados em muitas plantas, sendo eficaz em diversas aplicações, tais como, para eliminar diminuindo e/ou impedir o crescimento e a sobrevivência de microrganismos patogênicos (JUNEJA, DWIVEDI, YAN, 2012; CALLAWAY et al., 2011; LI et al., 2011, MUTHAIYAN, LIMAYEM, RICKE, 2011; ROLLER and LUSENGO, 1997, TIWARI et al., 2009).

Essas substâncias naturais (OE), derivam diretamente de um sistema biológico sem sofrer alterações ou modificações em um ambiente de laboratório são conhecidas como antimicrobianos naturais (LI et al., 2011, LÓPEZ-MALO, ALZAMORA, GUERRERO, 2000, SIRSAT, MUTHAIYAN, RICKES, 2009; NANNAPANENI et al., 2009).

Nos últimos anos, diversos artigos de revisão foram publicados sobre a incorporação de compostos antimicrobianos como os OE em materiais de embalagem, tendo destaque a eficácia da substância liberada na redução da deterioração de alimentos (SUNG et al., 2013). Acredita-se que sua ação esteja associada as nanomoléculas antimicrobianas que compõem os $\mathrm{OE}$, que supostamente inibem a respiração microbiana e aumentam a permeabilidade da membrana plasmática o que pode induzir a morte celular (AUMEERUDDY-ELALFI, GURIB-FAKIM and MAHOMOODALLY, 2015).

No entanto, seu uso diretamente sobre o alimento é muitas vezes limitado devido ao odor e sabor forte, que podem vir a causar modificações nas características sensoriais dos alimentos, podendo limitar a aceitação do produto pelos consumidores (RUIZNAVAJAS et al., 2013; ATARÉS and CHIRALT, 2016). 


\section{Potencial de uso do óleo essencial de pimenta rosa}

A planta Schinus terebinthifolius Raddi, conhecida no Brasil como Aroeira, pertence à família Anacardiácea e é uma planta nativa do Brasil, sendo amplamente distribuída em toda América do Sul, principalmente no litoral brasileiro (AGRA et al., 2008). Seu fruto comumente conhecido como Pimenta Rosa, tem sido nos últimos anos muito utilizados na indústria de alimentos devido ao seu sabor e aroma característico (ULIANA et al., 2016), além disso, o estudo da sua eficiência como agente antimicrobiano e antioxidante foi relatado na literatura por Uliana et al., 2016 (in vitro), Dannenberg, Funck, Mattei, Silva e Fiorentini, 2016 (in situ), Gois et al., 2016 (in vivo), e em embalagens ativas utilizando óleo essencial de pimenta rosa (OEPR) como componente antimicrobiano (DANNENBERG et al., 2017).

Os OE são misturas complexas de compostos voláteis que apresentam atividade antimicrobiana, atuando na planta como um mecanismo de defesa natural frente a condições adversas (ASBAHANI et al., 2015; DANNENBERG et al., 2017). Estudos realizados por Cavalcanti et al. (2015) e Gois et al. (2016), identificaram que a composição química do óleo essencial de pimenta rosa (OEPR) é composto predominantemente por mono terpenos, tais como: $\alpha$-pineno, $\beta$-pineno, mirceno e limoneno. Na maioria dos casos, o processo de extração dos OE é realizado com solventes orgânicos, ou arraste a vapor, e por serem de origem de plantas comestíveis são considerados como GRAS (Generally Recognized As Safe) pelo FDA (Food and Drug Administration) dos Estados Unidos, podendo com isso serem usados como aditivos alimentares (BURT, 2004; ASBAHANI et al., 2015; CALO et al., 2015; GHABRAIE et al., 2016).

A ação antimicrobiana dos OE pode estar associada aos seus constituintes ativos (HYLDGAARD, MYGIND, MEYER., 2012), onde pequenas moléculas de substâncias antimicrobianas entram na célula, interagindo principalmente com o mecanismo de síntese de proteínas (KHANEGHAH, et al., 2018), atuam diretamente sobre camada externa da bactéria, causando sua desnaturação, e consequentemente sua morte (NAZZARO, FRATIANNI, and MARTINO, 2013; RAI et al., 2017). A atividade antimicrobiana do óleo essencial de pimenta rosa é atribuída aos seus componentes majoritários como $\beta$-mirceno (41\%), $\beta$-cubebeno (12\%) e limoneno (9\%), que são antibacterianos conhecidos, ou um possível efeito sinérgico entre esses compostos e os compostos minoritários que compõem o óleo essencial de pimenta rosa (NGUEFACK et al., 2012; DANNENBERG et al., 2019). Resultado próximo ao obtido por Dannenberg et al. (2019) foi obtido por Gois et al. (2016), onde encontrou as concentrações de 12,36\% 
de limoneno e 10,36\% de $\alpha$-pineno em OE de frutos de S. terebinthifolius Radd. Já Uliana et al. (2016), relatou a ocorrência de $6,78 \%$ de mirceno e 4,05\% de $\alpha$-pineno em OE extraído de folhas dessa espécie (S. terebinthifolius Radd). Cavalcanti et al. (2015) ao estudar o OE obtido dos frutos de S. terebinthifolius, obteve como compostos predominantes $o$-pineno (44,9\%), $\beta$-pineno $(15,1 \%)$ e germacreno D $(17,6 \%)$.

\section{Revestimentos contendo óleo de Pimenta Rosa}

Diversos estudos vêm sendo realizados a fim de avaliar o efeito dos OE como conservantes naturais, seja por meio de sua incorporação no filme da embalagem (matriz polimérica) ou diretamente na incorporação ao produto alimentício, obtendo-se efeitos favoráveis na conservação dos alimentos (DANNENBERG et al., 2016; DANNENBERG et al., 2017). No entanto, a sua aplicação direta sobre o alimento pode afetar as características sensoriais, o que não é desejado, principalmente no caso de revestimentos de frutos e hortaliças que podem sofrer alterações de suas características organolépticas de sabor e odor (ATARÉS and CHIRALT, 2016; GHABRAIE et al., 2016).

Uma forma de se minimizar o efeito de alteração de sabor e odor nos produtos consiste em realizar a incorporação do óleo essencial de pimenta rosa nos filmes e revestimentos, que além de reduzir tal efeito negativo, também proporciona uma liberação dos compostos ativos gradualmente durante o período de armazenamento, além do que, esses compostos se concentram na parte externa do alimento, onde o grau de contaminação é maior, apresentando assim maior eficiência no controle microbiano (ASBAHANI et al., 2015; DANNENBERG et al., 2017).

O óleo de pimenta rosa tem demonstrado efeito de inibição de crescimento in vitro de bactérias dos grupos L. monocytogenes e E. coli, dois tipos de bactérias de grande importância de contaminação de produtos na indústria de alimentos (DOURADO et al., 2012). Este efeito de inibição de bactérias foi verificado também no trabalho de DANNENBERG et al. (2017), em que constatou redução significativa no crescimento de S. aureus, L. monocytogenes, E. coli e S. Typhimurium, ao avaliar a ação do OE de pimenta rosa incorporado a filmes ativos de acetato celulose nas concentrações $0,2,4$ e $6 \%(\mathrm{v} / \mathrm{v})$.

Ao contrário, no estudo realizado por Uliana et al. (2016), não se observou o efeito de inibição do crescimento de E. coli e S. aureus, mesmo nas maiores concentrações testadas, de $1 \mathrm{mg} / \mathrm{mL}(0,1 \%)$, para o EO das folhas de S. terebinthifolius. Resultado semelhante foi obtido por Aumeeruddy-elalfi, Gurib-Fakim and Mahomoodally (2015), não onde não observou atividade antimicrobiana para a OE de S. terebinthifolius contra 
cepas de $E$. coli e $P$. aeruginosa, mas indicaram que em $1 \mathrm{mg} / \mathrm{mL}(0,1 \%)$ se obtinha a concentração mínima bacteriana para $S$. aureus.

Segundo Dannenberg et al. (2019), o óleo de pimenta rosa é efetivo na inibição completa dos microrganismos S. aureus e L. monocytogenes quando aplicada na concentração de 2,72 $\mathrm{mg} \mathrm{mL}^{-1}$ em diferentes meios de cultura, destacando o seu grande potencial de utilização como agente antimicrobiano natural. Em estudos realizados por Braga et al. (2007) e El-Massry et al. (2009) ao avaliar a eficiência antimicrobiana de extrato e do óleo essencial de pimenta rosa sobre bactérias gram-positivas, constataram eficiência destes compostos, frente as bactérias, onde sua concentração mínima inibitória foi menor que $>1000 \mu \mathrm{g} / \mathrm{mL}$.

\section{Considerações Finais}

Este trabalho constatou a grande evolução da utilização de OE como agente ativo aplicado no desenvolvimento de biofilmes e revestimentos aplicados na conservação de alimentos, agregando os efeitos antimicrobianos e antioxidantes, porém existe restrição ao seu uso devido ao eventual efeito de interferência nas características organolépticas de sabor e odor dos alimentos.

No caso específico do óleo de pimenta rosa verificou-se também que ele tem grande efeito de ação antioxidante e antimicrobiano, com ação comprovada no controle de crescimento de bactérias após a sua incorporação em filmes de embalagens. A sua aplicação ainda não foi testada em trabalhos de desenvolvimento de revestimentos ativos aplicados na conservação de alimentos, sendo necessária a realização de investigação de concentrações efetivas para controle de bactérias e fungos, notadamente nos produtos de origem vegetal que são conservados in natura e sofrem grandes perdas pós-colheita pelo ataque de fungos.

\section{Referências}

AGRA, M. F.; SILVA, K. N.; BASÍLIO, I. J. L. D.; FREITAS, P. F.; BARBOSA-FILHO, J. M. Survey of medicinal plants used in the region northeast of Brazil Review. Brazilian Journal of Pharmacognosy, v.18, p. 472-508, 2008.

AHMED, I.; LIN, H.; ZOU, L.; BRODY, A. L.; LI, Z.; QAZI, I. M.; PAVASE, T. R.; LV, L. A comprehensive review on the application of active packaging technologies to muscle foods - Review. Food Control, v. 82, p. 163-178, 2017.

AMARAL, D.P. Revestimento Ativo antiescurecimento a base de proteína de soro de leite. Orientadora: Nathália Ramos de Melo. 2014. 59 f. Dissertação (Mestrado em Ciência e Tecnologia de Alimentos). Universidade Federal Rural do Rio de Janeiro, UFRRJ, 2014. 
ANSORENA, M. R., MARCOVICH, N. E. and ROURA, S. I. Impact of edible coatings and mild heat shocks on quality of minimally processed broccoli (Brassica oleracea L.) during refrigerated storage. Postharvest Biology and Technology, v. 59 (1), p. 53-63, 2011.

ARAGON-ALEGRO, L.C.; ALARCON, J.H. A.; CARDARELLI H. R.; CHIH CHIU, M.; SAAD, S.M. I. Mousse de chocolate potencialmente probiótico e simbiótico. LWT- Food Science and Technology, v.40, p. 669 - 675, 2007.

ARNON-RIPS, H. and POVERENOV, E. Improving food products' quality and storability by using Layer-by-Layer edible coatings. Trends in Food Science and Technology, 2018.

ASBAHANI, A.; MILADI, K.; BADRI, W.; SALA, M.; AIT ADDI, E. H.; CASABIANCA, H.; MOUSADIK, A.; HARTMANN, D.; JILALE, A.; RENAUD, F. N. R.; ELAISSARI, A. Essential oils: From extraction to encapsulation. International Journal of Pharmaceutics, v. 483, p. 220-243, 2015.

ATARÉS, L. and CHIRALT, A. Essential oils as additives in biodegradable films and coatings for active food packaging. Trends in Food Science and Technology, v.48, p. $51-62,2016$.

AUMEERUDDY-ELALFI， Z; GURIB-FAKIM， A.; MAHOMOODALLY, F. Antimicrobial, antibiotic potentiating activity and phytochemical profile of essential oils from exotic and endemic medicinal plants of Mauritius. Industrial Crops and Products, v.71, p. 197-204, 2015.

BALASUNDRAM, N., SUNDRAM, K. and SAMMAN, S. Phenolic compounds in plants and agro-industrial by-products: Antioxidant activity, occurrence, and potential use. Food Chemistry, v.99, p.191-203, 2006.

BALDWIN, E.A.; NISPEROS, M. O.; CHEN, X.; HAGENMAIER, R. D. Improving storage life of cut apple and potato with edible coating. Postharvest Biology and Technology, v.9, p. 151-163, 1996.

BIJI, K. B., RAVISHANKAR, C. N., MOHAN, C. O. and GOPAL, T. K. S. Smart packaging systems for food applications: A review. Journal of Food Science and Technology, v. 52(10), p. 6125-6135, 2015.

BRAGA, F. G.; BOUZADA, M. L. M.; FABRI, R. L.; MATOS, M. D. O.; Antileishmanial and antifungal activity of plants used in traditional medicine in Brazil. Journal off Ethnopharmacology, v. 111 (2), p. 396-402, 2007.

BURT, S. Essential Oils: Their Antibacterial Properties and Potential Applications in Foods. International Journal of Food Microbiology, v. 94, p. 223-253, 2004.

CALLAWAY, T.R.; CARROLL, J. A; ARTHINGTON J.D.; EDRINGTON T. S.; ANDERSON R.C.; RICKE S.C. Citrus products and their use against bacteria: potential health and cost benefits, (chap. 17). R. Watson, J.L. Gerald, V.R. Preedy (Eds.), Nutrients, dietary supplements, and nutriceuticals: Cost analysis versus clinical benefits, Humana Press, New York, NY, p. 277-286, 2011. 
CALO, J. R.; CRANDALL, P. G.; O'BRYAN, C. A.; RICKE, S. C. Essential oils as antimicrobials in food systems - a review. Food Control, v.54, p. 111-119, 2015.

CAVALCANTI, S.; DE SOUZA, M.; CRISTINA, L.; PATROCÍNIO, S.; NALESSO, M.; SIQUEIRA, D. Volatiles composition and extraction kinetics from Schinus terebinthifolius and Schinus molle leaves and fruit. Revista Brasileira de Farmacologia, v.25, p. 356-362, 2015.

DAINELLI, D., GONTARD, N., SPYROPOULOS, D., ZONDERVAN-VAN DEN BEUKEN, E. and TOBBACK, P. Active and intelligent food packaging: Legal aspects and safety concerns. Trends in Food Science and Technology, v.19, 103-112, 2008.

DAMODARAN, S.; PARKIN, K.L.; FENNEMA, O.R. Química de Alimentos. (4 ed) Porto Alegre-Br, Editora Artmed, p. 900, 2010.

DANNENBERG, G. S.; FUNCK, G. D.; MATTEI, F. J.; SILVA, W. P.; FIORENTINI, A. M. Antimicrobial and antioxidant activity of essential oil from pink pepper tree (Schinus terebinthifolius Raddi) in vitro and in cheese experimentally contaminated with Listeria monocytogenes. Innovative Food Science and Emerging Technologies, v.36, p. 120-127, 2016.

DANNENBERG, G. S.; FUNCK, G. D.; CRUXEN, C. E. S.; MARQUES, J. L.; SILVA, W. P.; FIORENTINI, A. M. Essential oil from pink pepper as an antimicrobial component in cellulose acetate film: Potential for application as active packaging for sliced cheese. LWT- Food Science and Technology, v.81, p. 314-318, 2017.

DANNENBERG, G. S., FUNCK G. D; SILVA, W. P.; FIORENTINI, A. M. Essential oil from pink pepper (Schinus terebinthifolius Raddi): Chemical composition, antibacterial activity and mechanism of action. Food Control, v.95, p.115-20, 2019.

DOURADO, M. T. Óleos essenciais e oleoresina da pimenta rosa (Schinus terebinthifolius Raddi): propriedades químicas e biológicas. Tese (Doutorado) - 120f. Programa de Pós-Graduação em Ciência e Tecnologia Agroindustrial. Universidade Federal de Pelotas. Faculdade de Agronomia Eliseu Maciel. Pelotas, 2012.

ESPITIA, P. J. P. "Filmes comestíveis de pectina: propriedades físico-mecânicas e antimicrobianas - revisão". Hydrocolloids alimentares, v. 35: p. 287-296, 2014.

FALGUERA, V., QUINTERO, J. P., JIM_ENEZ, A., MUNOZ, A. and IBARZ, A. Edible films and coatings: structures, active functions and trends in their use. Trends Food Science and Technology, v.22, p. 291-303, 2011.

FDA. Code fed. Regul. (CFR). Title 21 food drugs. Chapter I - food Drug adm. Dep. Heal. Hum. Serv. Subchapter B - food hum. Consum. (Continued), Part 182 - subst. Gen. Recognized as safe (GRAS 2016). Acessado em: 21 out 2018.

GANIARI, S., CHOULITOUDI, E. AND OREOPOULOU, V. Edible and active films and coatings as carriers of natural antioxidants for lipid food. Trends in Food Science and Technology, v.68, p.70-82, 2017.

GARCIA, L.C.; PEREIRA, L.M.; DE LUCA SARANTOPOULOS, C.I.G.; HUBINGER, M.D. Selection of edible starch coating for minimally processed strawberry. Food and Bioprocess Technology, v.3, p. 834-842, 2010. 
GHABRAIE, M.; VU, K. D.; TATA, L.; SALMIERI, S.; LACROIX. M. Antimicrobial effect of essential oils in combinations against five bacteria and their effect on sensorial quality of ground meat. LWT- Food Science and Technology, v.66, p. 332-339, 2016.

GOIS, F.D.; CAIRO, P.L.G.; CANTARELlI, V. DE S.; COSTA, L.C. DO B.; FONTANA, R.; ALLAMAN, I.B. Effect of Brazilian red pepper (Schinus terebinthifolius Raddi) essential oil on performance, diarrhea and gut health of weanling pigs. Livestock Science, v.183, p. 24-27, 2016.

Guidance to The Commission Regulation (UE) No 450/2009 of 29 May 2009 on active and intelligent materials and articles intended to come into contact with food. In Version 10. European commission health and consumers directorate-general directorate esafety of the food chain. E6- innovation and sustainability. Acesado em: 21 out 2018.

HAFSA, J.; SMACH, M. A.; BEN K. S.R.; CHARFEDDINE, B.; LIMEM, K.; MAJDOUB, H. Physical, antioxidant and antimicrobial properties of chitosan films containing Eucalyptus globulus essential oil. LWT - Food Science and Technology, v.68, p. $356-364,2016$.

HAN, Y., YU, M. and WANG, L. Physical and antimicrobial properties of sodium alginate/carboxymethyl cellulose films incorporated with cinnamon essential oil. Food Packaging and Shelf Life, v.15, p. 35 - 42, 2018.

HENRIQUE, C.M.; CEREDA, M. P.; SARMENTO, S. B. S. Características físicas de filmes biodegradáveis produzidos a partir de amidos modificados de mandioca. Ciência e Tecnologia de Alimentos, v. 28, n. 1, p. 231-240, 2008.

HYLDGAARD, M.; MYGIND, T.; MEYER, R. L. Essential oils in food preservation: mode of action, synergies, and interactions with food matrix components. Frontiers in Microbiology, v. 3, 2012.

JUNEJA, V.K.; DWIVEDI H.P.; YAN, X. Novel natural food antimicrobials. Journal of Food Science and Technology, v.3, p. 381-403, 2012.

LI, M.; MUTHAIYAN, A; O'BRYAN, C.A.; GUSTAFSON, J.E.; LI, Y.; CRANDALL, P.G. Use of natural antimicrobials from a food safety perspective for control of Staphylococcus aureus. Current Pharmaceutical Biotechnology, v.12, p. 12401254, 2011.

LÓPEZ-MALO, A.; ALZAMORA, S. M.; GUERRERO S. Natural antimicrobials from plants. S.M. Alzamora, M.S. Tapia, A. López-Malo (Eds.), Minimally processed fruits and vegetables: Fundamental aspects and applications, Aspen Publication, Gaithersburg, MD, p. 237-258, 2000.

MAJID, I.; AHMAD G. N., MOHAMMAD S. D.; NANDA, V. Novel food packaging technologies: Innovations and future prospective. Journal of the Saudi Society of Agricultural Sciences, v. 17, p. 454-462, 2018.

MUTHAIYAN, A.; LIMAYEM, A.; RICKE, S.C. Antimicrobial strategies for limiting bacterial contaminants in fuel bioethanol fermentations. Progress in Energy and Combustion Science, v.37, p. 351-370, 2011.

NANNAPANENI, R.; CHALOVA, V. I.; STORY, R.; WIGGINS K. C.; CRANDALL, P. G. RICKE S. C. Ciprofloxacin-sensitive and ciprofloxacin- 
resistant Campylobacter jejuni are equally susceptible to natural orange oil-based antimicrobials. Journal of Environmental Science and Health, 44 (2009), pp. 571-577

NGUEFACK, J.; TAMGUE, O.; DONGMO, J. L.; DAKOLE, C. D.; LETH, V.; VISMER, H. F.; NKENGFACK, A. E. Synergistic action between fractions of essential oils from Cymbopogon citratus, Ocimum gratissimum and Thymus vulgaris against Penicillium expansum. Food Control, v. 23(2), p. 377- 383, 2012.

OLIVEIRA, R. P.; SCIVITTARO, W. B. Produção de frutos de morango em função de diferentes períodos de vernalização das mudas. Horticultura Brasileira, v. 27, p. 091095, 2008.

PELISSARI, F.M., FERREIRA, D.C., LOUZADA, L.B., DOS SANTOS, F., CORRÊA, A.C., MOREIRA, F.K.V. and MATTOSO, L.H. Starch-based edible films and coatings: An eco-friendly alternative for food packaging. In Starches for Food Application, p. 359-420. Academic Press, 2019.

REALINI, C. E.; MARCOS, B. Active and intelligent packaging systems for a modern society. Meat Science, v. 98(3), p. $404-419,2014$.

RESTUCCIA, D.; SPIZZIRRI, U. G.; PARISI, O. I.; CIRILLO, G.; CURCIO, M.; IEMMA, F. New EU regulation aspects and global market of active and intelligent packaging for food industry applications. Food Control, v.21 (11), p. 1425 - 1435, 2010.

ROJAS-GRAÜ, M. A.; TAPIA, M. S.; MARTÍN-BELLOSO, O. Using polysaccharidebased edible coatings to maintain quality of fresh-cut Fuji apples. LWT-Food Science and Technology, v. 41(1), p. 139-147, 2008.

ROLLER, S.; LUSENGO, J. Developments in natural food preservatives. Agro Food Industry Hi-Tech, v. 8, p. 22-25, 1997.

RUIZ-NAVAJAS, Y., VIUDA-MARTOS, M., SENDRA, E., PEREZ-ALVAREZ, J. A., FERNÁNDEZ-LÓPEZ, J. In vitro antibacterial and antioxidant properties of chitosan edible films incorporated with Thymus moroderi or Thymus piperella essential oils. Food Control, v. 30, p. 386-392, 2013.

SÁNCHEZ-GONZÁLEZ， L.; PASTOR， C.; VARGAS， M.; CHIRALT, A.; GONZÁLEZ-MARTÍNEZ, C.; CHÁFER, M. Effect of hydroxypropylmethylcellulose and chitosan coating with and without bergamot essential oil on quality and safety of cold-stored grapes. Postharvest Biology and Technology, v. 60, n.1, p. 57-63, 2011.

SIRSAT, S. A.; MUTHAIYAN A.; RICKE S. C. Antimicrobials for foodborne pathogen reduction in organic and natural poultry production. Journal of Applied Poultry Research, v.18, p. 379-388, 2009.

SUNG S.Y.; SIN, L.T.; TEE, T. T.; BEE, S. T.; RAHMAT, A.R.; RAHMAN, W. Antimicrobial agents for food packaging applications. Trends in Food Science and Technology, v.33 (2), p. 110-123, 2013.

SUKHIJA, S.; SINGH, S.; RIAR, C. S. Isolation of starches from different tubers and study of their physicochemical, thermal, rheological and morphological characteristics. Starch-Stärke, v.68 (1-2), p.160-168, 2016. 
TI, F. M.; FERREIRA, D. C., LOUZADA, L. B., DOS SANTOS, F., CORRÊA, A. C., MOREIRA, F. K. V. and MATTOSO, L. H. Starch-Based Edible Films and Coatings: An Eco-friendly Alternative for Food Packaging. Starches for Food Application. Academic Press, pp. 359-420, 2019.

TIWARI, B. K.; VALDRAMIDIS, V. P.; O'DONNELL C. P.; MUTHUKUMARAPPAN, K.; BOURKE, P.; CULLEN. P. J. Application of natural antimicrobials for food preservation. Journal of Agricultural and Food Chemistry, v.57, p. 5987-6000, 2009.

TZOUMAKI, M. V.; BILIADERIS, C. G.; VASILAKAKIS, M. Impact of edible coatings and packaging on quality of white asparagus (Asparagus officinalis, L.) during cold storage. Food Chemistry, v.117, p. 55 - 63, 2009.

ULIANA, M. P.; FRONZA, M.; DA SILVA, A. G.; VARGAS, T. S.; DE ANDRADE, T. U.; SCHERER, R. Composition and biological activity of Brazilian rose pepper (Schinus terebinthifolius Raddi) leaves. Industrial Crops and Products, v.83, p. 235240, 2016.

VILELA, C.; KUREK, M.; HAYOUKA, Z.; ROCKER, B.; YILDIRIM, S.; ANTUNES, M. D. C.; NILSEN-NYGAARD, J.; PETTERSEN, M. K.; FREIRE, C. S. R. A concise guide to active agents for active food packaging - Review. Trends in Food Science and Technology. v. 80, p. 212-222, 2018.

VIUDA-MARTOS, M.; EL GENDY, N. G. S.; SENDRA, E.; FERNANDEZ-LOPEZ, J.; EL- RAZIK, K. A. A.; EL-SAYED, A. Chemical composition and antioxidant and antilisteria activities of essential oils obtained from some Egyptian plants. Journal of Agricultural and Food Chemistry, v.58, p. 9063-9070, 2010.

VU, K. D.; HOLLINGSWORTH R. G.; LEROUX, E.; SALMIERI, S.; LACROIX, M. Development of edible bioactive coating based on modified chitosan for increasing the shelf life of strawberries. Food Research International, v.44, p. 198-203, 2011.

WONG, W. S.; TILLIN, S. J.; HUDSON, J.S.; PAVLATH, A. E. Gas exchange in cut apples with bilayer coatings. Journal of Agricultural and Food Chemistry, v.42, p. 2278-2285, 1994.

WRÓBLEWSKA-KREPSZTUL， J.; RYDZKOWSKI， T.; BOROWSKI， G.; SZCZYPIŃSKI, M.; KLEPKA, T.; THAKUR, V. K. Recent progress in biodegradable polymers and nanocomposite-based packaging materials for sustainable environment. International Journal of Polymer Analysis and Characterization, v. 23(4), p. 383-395, 2018.

YILDIRIM, S.; RÖCKER, B.; PETTERSEN, M. K.; NILSEN-NYGAARD, J.; AYHAN, Z.; RUTKAITE, R. Active packaging applications for food. Comprehensive Reviews. Food Science and Food Safety, v.17, p.165-199, 2018.

YANG, H. J.; LEE, J. H.; WON, M.; SONG, K. B. Antioxidant activities of distiller-dried grains with solubles as protein films containing tea extracts and their application in the packaging of pork meat. Food Chemistry, v.196, p. 174 -179, 2016.

ZAHID, N. Z.; ABBASI, N. A.; HAFIZ, A. I.; HUSSAIN, A.; AHMAD, Z. Antifungal activity of local fennel (Foeniculum vulgare Mill) extracts to growth responses of some soil diseases. Afr. J. Microbiol. Res, v.6, p. 46-51, 2012. 
ZANETTI, M.; TERNUS, Z. R.; DALCANTON, F.; DE MELLO, M. M. J.; DE OLIVEIRA, D.; ARAUJO, P. H. Microbiological characterization of pure geraniol and comparison with bactericidal activity of the cinnamic acid in gram-positive and gramnegative bacteria. Journal of Microbial and Biochemical Technology, v.7, p.186-193, 2015. 


\title{
CAPÍTULO 47: A ESCOLA COMO CAMPO DE ATUAÇÃO NO FORTALECIMENTO DA ALIMENTAÇÃO SAUDÁVEL: UMA REVISÃO INTEGRATIVA
}

\section{CHAPTER 47: SCHOOL AS A FIELD OF ACTIVITY IN STRENGTHENING HEALTHY FOOD: AN INTEGRATIVE REVIEW}

Fernanda Tayla de Sousa Silva ${ }^{1}$; Roseane Saraiva de Santiago Lima²; Maria de Fátima Costa Carneiro ${ }^{3}$; Ana Thaís Campos de Oliveira ${ }^{4}$ Ana Paula Ferreira de Almeida ${ }^{5}$.

\begin{abstract}
Resumo
Introdução: A formação de hábitos e práticas comportamentais acontece principalmente durante a infância, sendo importante o desenvolvimento de ações educativas, sobretudo de Educação Alimentar e Nutricional a fim de melhorar as condições de saúde. Objetivo: Identificar a produção científica que abordasse ações de promoção da alimentação saudável realizadas em escolas. Métodos: Trata-se de uma revisão integrativa da literatura. Os dados foram obtidos através da busca eletrônica nas bases de dados Literatura Latino-Americana e do Caribe em Ciências da Saúde (LILACS), PubMed e a Scientific Electronic Library Online (SciELO). Após a identificação dos artigos científicos, foram realizadas as seguintes etapas de seleção: a leitura criteriosa dos títulos, dos resumos e na íntegra. Resultados: A amostra consistiu em 13 artigos. Discussão: Os temas mais trabalhados foram alimentação saudável, consumo de frutas, legumes, leites e derivados, pirâmide alimentar, planejamento de cardápio saudável, higiene dos alimentos e utensílios, quantidade de óleo e sal das preparações e opções de lanches saudáveis. Conclusão: Os achados citam a escola como um espaço favorável para realizar ações de promoção da alimentação saudável, ressaltando a importância dos gestores e a comunidade escolar terem o compromisso de colocar em prática os programas de alimentação e nutrição.
\end{abstract}

Palavras-Chave: Educação alimentar e nutricional, Educação infantil, Promoção da saúde.

\begin{abstract}
Introduction: The formation of habits and behavioral practices happens mainly during childhood, being important the development of educational actions, especially of Food and Nutrition Education in order to improve health conditions. Objective: To identify scientific production that addressed actions to promote healthy eating in schools. Methods: This is an integrative literature review. The data were obtained through electronic search in the databases of Latin American and Caribbean Literature in Health Sciences (LILACS), PubMed and the Scientific Electronic Library Online (SciELO). After the identification of scientific articles, the following selection steps were carried out: careful reading of titles, abstracts and in full. Results: The sample consisted of 13

\footnotetext{
${ }^{1}$ Mestranda em Tecnologia de Alimento, Instituto Federal de Educação, Ciência e Tecnologia do Ceará (IFCE) tayliinhaf@gmail.com

${ }^{2}$ Mestre pelo Programa Saúde da criança e do adolescente, Universidade Estadual do Ceará (UECE) roseane.saraiva@ifce.edu.br

3 Bacharel em Nutrição, Instituto Federal de Educação, Ciência e Tecnologia do Ceará (IFCE) fati276@yahoo.com.br

${ }^{4}$ Mestranda em Tecnologia de Alimento, Instituto Federal de Educação, Ciência e Tecnologia do Ceará (IFCE) euthaiscampos.alimentos@gmail.com.br

${ }^{5}$ Mestranda em Tecnologia de Alimento, Instituto Federal de Educação, Ciência e Tecnologia do Ceará (IFCE) ana.paula.ferreira.almeida123@gmail.com.br
} 
articles. Discussion: The most discussed topics were healthy eating, consumption of fruits, vegetables, milk and dairy products, food pyramid, planning a healthy menu, hygiene of food and utensils, quantity of oil and salt in the preparations and options for healthy snacks. Conclusion: The findings cite the school as a favorable space to carry out actions to promote healthy eating, highlighting the importance of managers and the school community being committed to putting food and nutrition programs into practice.

Keywords: Food and nutrition education, Early childhood education, Health promotion.

\section{Introdução}

A Educação Alimentar e Nutricional (EAN) objetiva assegurar o Direito Humano à Alimentação Adequada (DHAA) e promover a Segurança Alimentar e Nutricional (SAN). A EAN conceitua-se como um campo de conhecimento de prática contínua e permanente, transdisciplinar, intersetorial e multiprofissional que visa a promoção da saúde através da adoção de hábitos alimentares saudáveis de forma autônoma e voluntária (BRASIL, 2012). A garantia do DHAA envolve, muito além da oferta de alimentos saudáveis, implica em respeitar os hábitos alimentares e viabilizar o acesso aos meios necessários para a aquisição do próprio alimento e da sua família, seja através do trabalho no campo ou na cidade (GREENWOOD; FONSECA, 2018). A EAN preocupa-se com o consumo consciente, questões ligadas a sustentabilidade, ao sistema de produção, abastecimento e distribuição, desse modo, incentiva o consumo de alimentos que geram pouco impacto ao meio ambiente, que valorize a cultura alimentar e priorize a produção local (TRICHES, 2015).

O conceito de DHAA refere ao direito humano de que todas as pessoas devem ter acesso regular, permanente, diretamente ou por meio de aquisições financeiras, a alimentos seguros e saudáveis, em quantidade e qualidade suficientes (BURITY et al., 2010). A Lei Orgânica de Segurança Alimentar e Nutricional LOSAN (Lei nº 11.346, de 15 de setembro de 2006) ressalta que SAN deve estimular práticas alimentares promotoras de saúde, respeitando a diversidade cultural, a economia e o meio ambiente, enfatiza que o acesso a alimentos de qualidade não deve comprometer o acesso a outras necessidades essenciais (BRASIL, 2006).

A alimentação equilibrada ao longo da vida é fundamental para garantir o crescimento e o bom funcionamento fisiológico, bem estar e manutenção da saúde. Tratando-se especialmente da infância, período marcado pela formação dos hábitos alimentares é imprescindível que pais e educadores estimulem os bons hábitos desde cedo já que é nessa fase que ocorre o desenvolvimento dos aspectos motor, cognitivo e afetivo 
da criança, em vista disso é um período que merece atenção e cuidados (ARAUJO et al., 2018; ALVES et al., 2020).

Sendo assim, uma boa alimentação deve tornar-se uma prática desde a infância e perpetuar-se ao longo de toda a vida. Para que crianças e os adolescentes adquiram um estilo de vida saudável na fase adulta, é fundamental que sejam orientados precocemente a adoção de bons hábitos (RECH et al., 2016). Conforme Alves et al. (2020) a alimentação é primordial para o desenvolvimento da criança, e é nesse período onde ocorre a formação de grande parte das potencialidades humanas, ou seja, qualquer distúrbio que ocorra nessa fase pode gerar sérias consequências na vida adulta.

De acordo com Araújo et al. (2017) nas últimas décadas, observa-se no Brasil um aumento significativo da prevalência de sobrepeso e obesidade em todas as faixas etárias e grupos sociais, modificações no estilo de vida, como alimentação inadequada, redução do gasto calórico diário são fatores que esclarecem o crescimento acerelado desse quadro no país. O excesso de peso é considerado fator de risco para Doenças Crônicas Não Transmissíveis (DCNT), assim tornando-se necessário a implementação de políticas públicas voltadas a prevenção e tratamento da obesidade, objetivando o esclarecimento da população quanto ao consumo de alimentos saudáveis, modificar padrões de comportamento alimentar e estimular a prática de atividade física.

O ambiente escolar é citado como um espaço promissor para a realização de atividades educativas, sobretudo de EAN para promoção de hábitos saudáveis e consequentemente a prevenção e controle do sobrepeso e obesidade. A educação possibilita a ampliação do conhecimento e desenvolvimento intelectual, tornando os indivíduos conscientes dos seus direitos e deveres sociais, além de críticos no momento de fazer escolhas alimentares. A inclusão da educação alimentar na escola torna-se fundamental visto que a ingestão excessiva e inadequada de nutrientes por falta de informações e acesso a alimentos de qualidade, viola o direito humano à alimentação saudável (GREENWOOD; FONSECA, 2018). Em 2007 foi instituído pelo Ministério da Saúde, através do Decreto n ${ }^{\circ}$ 6.286/2007, o Programa Saúde na Escola (PSE), no qual refere-se à promoção da saúde e prevenção de agravos à saúde, ressaltando a importância de práticas alimentares saudáveis no ambiente escolar (ARAÚJO et al., 2017; BRASIL, 2007).

Segundo Santos (2012) às intervenções de educação alimentar devem possuir abordagens e metodologias transformadoras que assumam uma perspectiva problematizadora, ultrapassando a visão somente instrumental e instrucional da educação. Ressaltando que as práticas educativas devem ser desenvolvidas de forma interdisciplinar 
a fim de desenvolver a autonomia dos indivíduos. Destaca-se o professor como papel chave nesse processo ensino-aprendizagem, e as ações em educação devem ultrapassar a educação formal de modo que o conjunto de práticas sejam capazes de transformar o ambiente no qual os indivíduos estão inseridos (TRICHES, 2015).

Portanto, as atividades de EAN desenvolvidas no ambiente escolar, devem envolver toda a comunidade escolar, não somente os alunos, por meio da implementação de estratégias educativas em conjunto com o projeto pedagógico das escolas. A alimentação escolar na rede públicas deve ser formulada segundo as diretrizes do Programa Nacional de Alimentação Escolar (PNAE), que além de assegurar assistência alimentar aos alunos com o emprego de alimentos saudáveis e adequados, incentiva a inclusão de ações de educação alimentar e nutricional no processo ensino-aprendizagem, dessa forma envolvendo toda a comunidade escolar (CAMOZZI et al. 2015; BRASIL, 2009).

Nesse contexto, através desse estudo objetivou-se identificar a produção científica que abordasse ações de promoção da alimentação saudável realizadas no ambiente escolar, com o propósito de responder a seguinte pergunta norteadora: o ambiente escolar é um espaço favorável para as ações da promoção da saúde e educação alimentar?

\section{Desenvolvimento}

\section{Metodologia}

Realizou-se uma revisão integrativa da literatura, que é um método de análise e síntese de informações de outros estudos de forma ampla e sistemática que busca identificar, analisar e discutir métodos e resultados de outras pesquisas possibilitando assim, gerar um conhecimento mais aprofundado sobre um tema investigado (SOUSA et al., 2017). Consiste em seis etapas distintas: elaboração da pergunta norteadora, amostragem, coleta de dados, análise crítica dos estudos incluídos, interpretação dos resultados e apresentação da revisão integrativa (DE SOUZA; DA SILVA; CARVALHO, 2010).

Desse modo foi realizado um levantamento bibliográfico com o intuito de analisar publicações sobre a promoção da alimentação saudável no ambiente escolar. $\mathrm{O}$ levantamento de dados foi feito através da busca eletrônica nas bases de dados Literatura Latino-Americana e do Caribe em Ciências da Saúde (LILACS), PubMed e a biblioteca eletrônica Scientific Eletronic Library Online (SciELO).

A busca de dados foi realizada pelos pesquisadores no período de maio a junho de 2018. Para a coleta dos estudos utilizou-se a combinação dos seguintes descritores 
"Educação Nutricional" AND "Escolares" e os termos em inglês "Nutrition Education" AND "School" AND "School Health Services" nas bases de dados citadas anteriormente.

Para a seleção dos estudos foi atribuído alguns critérios de elegibilidade: estudos que tratavam do tema em questão, publicações do período de 2013 a 2018 no idioma português, inglês e espanhol que tivessem disponíveis na íntegra online e fossem artigos gratuitos. Como critérios de exclusão estudos que não abordavam a temática proposta, estudos onde as intervenções não eram realizadas em escolas, revisão de literatura, publicações no formato de monografias, dissertações e teses.

Após a identificação dos artigos científicos, foram realizadas as seguintes etapas de seleção: a leitura criteriosa dos títulos e resumos, excluindo-se os estudos que não tratavam da questão de interesse. Os estudos duplicados nas bases de dados eram excluídos utilizando-se o programa Microsoft Excel versão 2016 que possibilitou a organização e sistematização dos trabalhos. As publicações consideradas elegíveis eram lidas na íntegra e avaliadas segundo o instrumento para coleta de dados validado por Ursi, 2005 que permite organizar as informações dos trabalhos em identificação, tipos de publicações, características metodológicas dos estudos e avaliação do rigor metodológico. Após essa análise os trabalhos eram incluídos nesta revisão (SOUSA et al., 2017).

Foram encontrados 247 artigos, mas somente 13 atenderam aos critérios de elegibilidade. Na figura 1 a seguir, mostra o fluxograma das etapas de seleção dos trabalhos incluídos no estudo. 


\section{Resultados}

Figura 1. Fluxograma das etapas de seleção

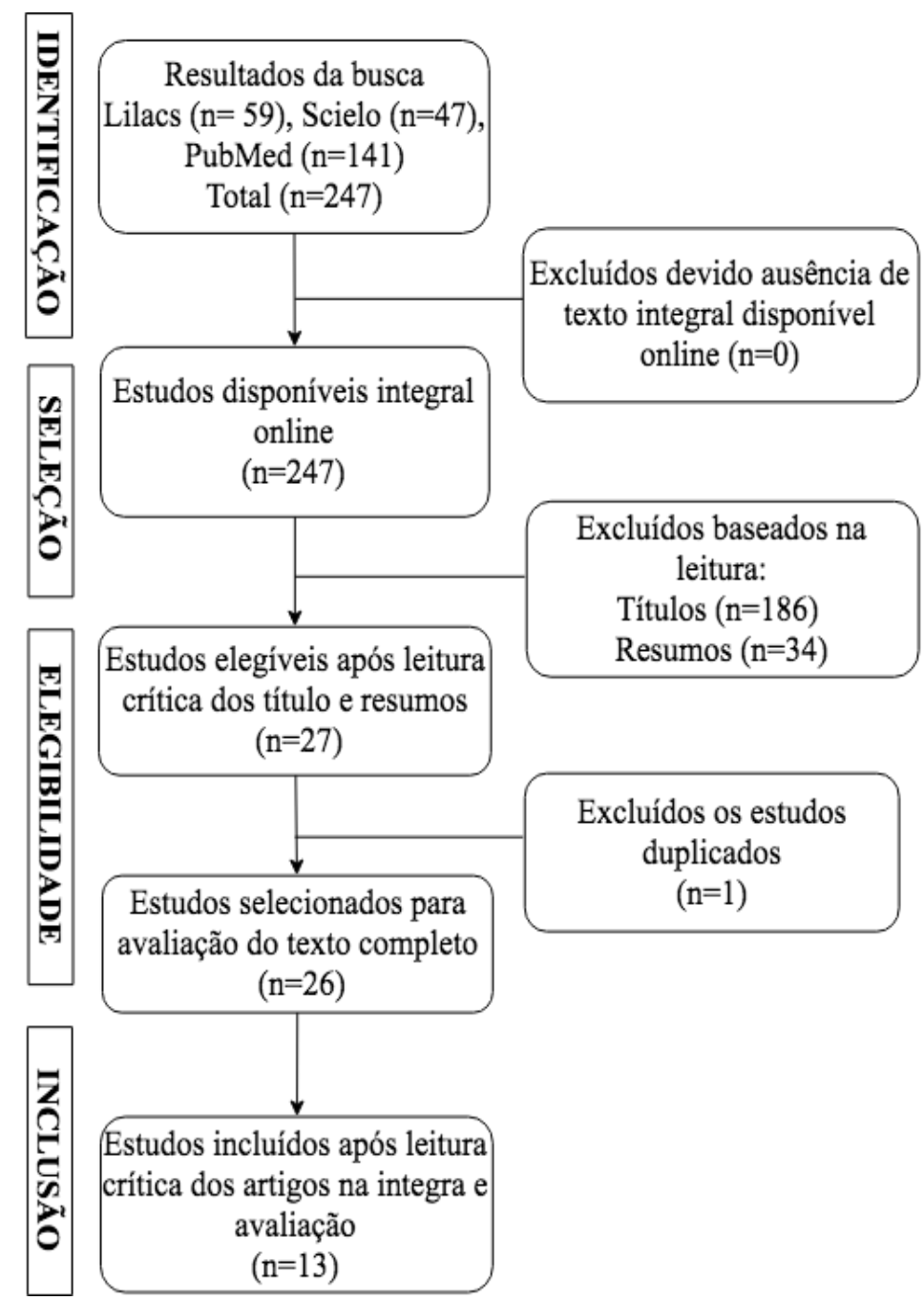

Fonte: Própria (2018).

Os artigos científicos foram respectivamente organizados e descritos no Quadro 1 a seguir conforme autor/ano, objetivos, população, intervenções e principais resultados. Dentre os trabalhos científicos selecionados, 7 apresentaram-se em língua inglesa, 4 na língua portuguesa e 2 na língua espanhola. 


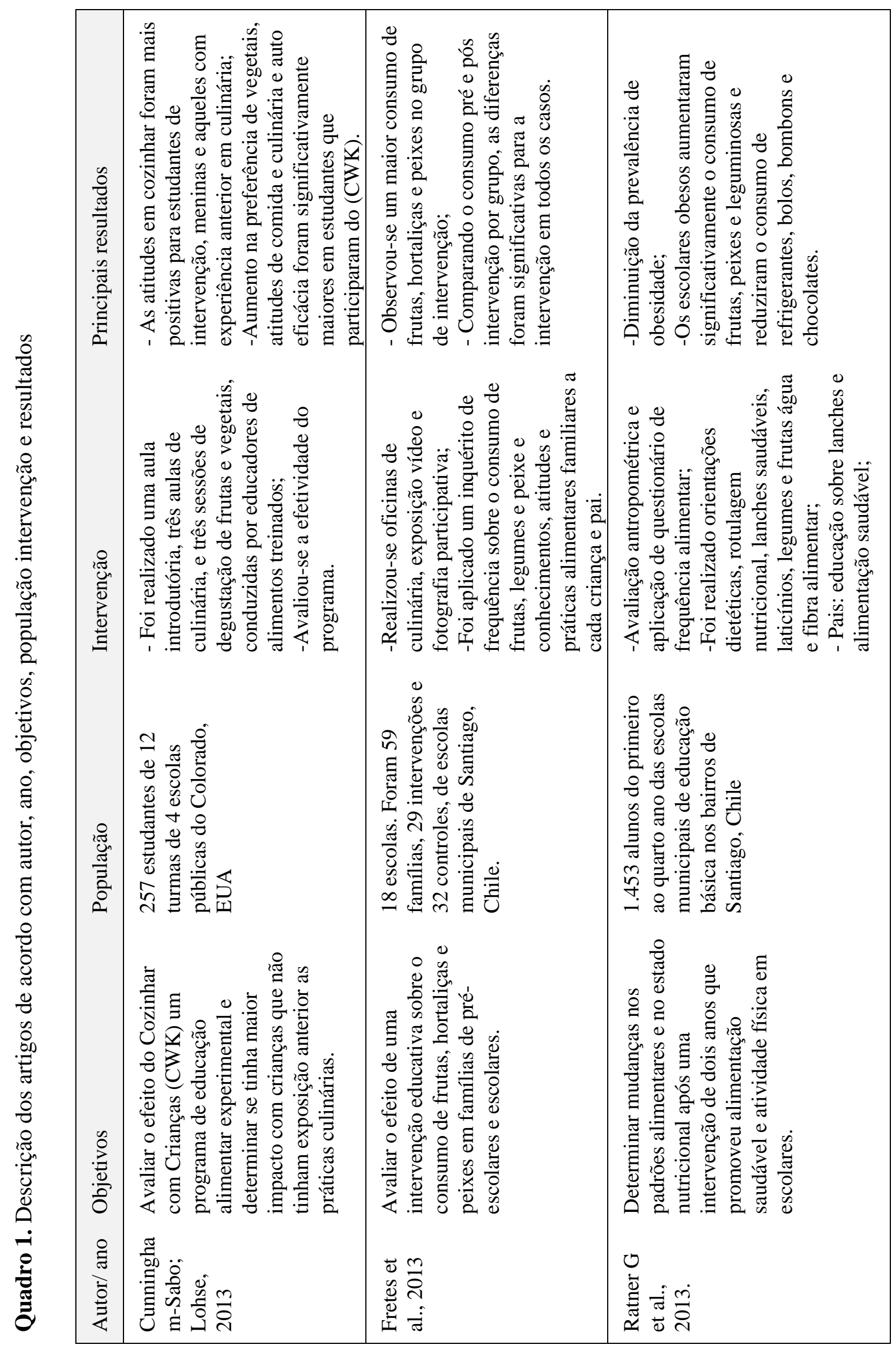




\begin{tabular}{|c|c|c|c|}
\hline 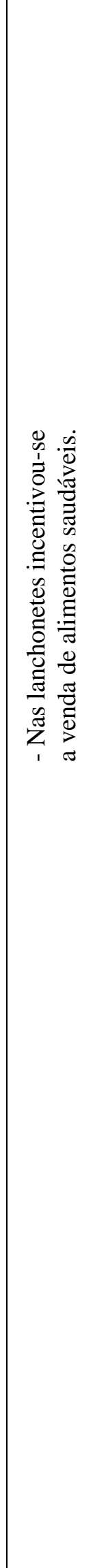 & 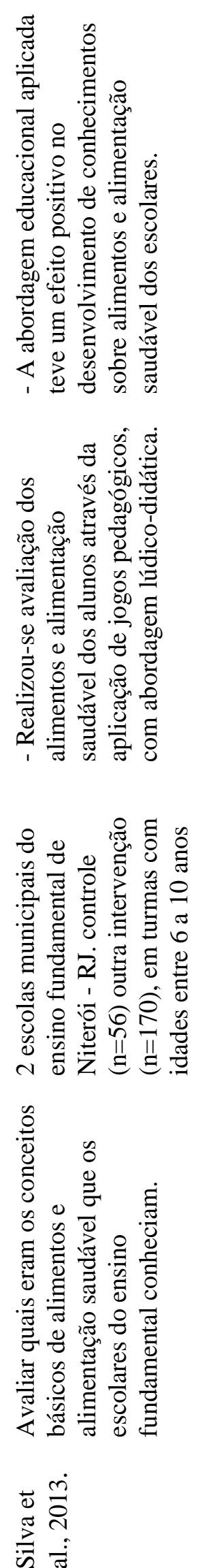 & 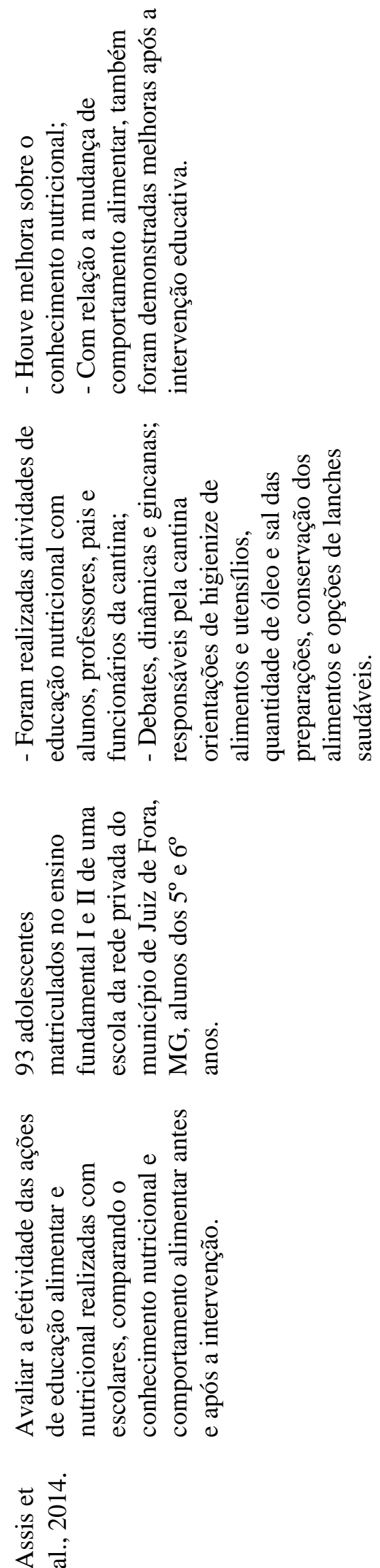 & 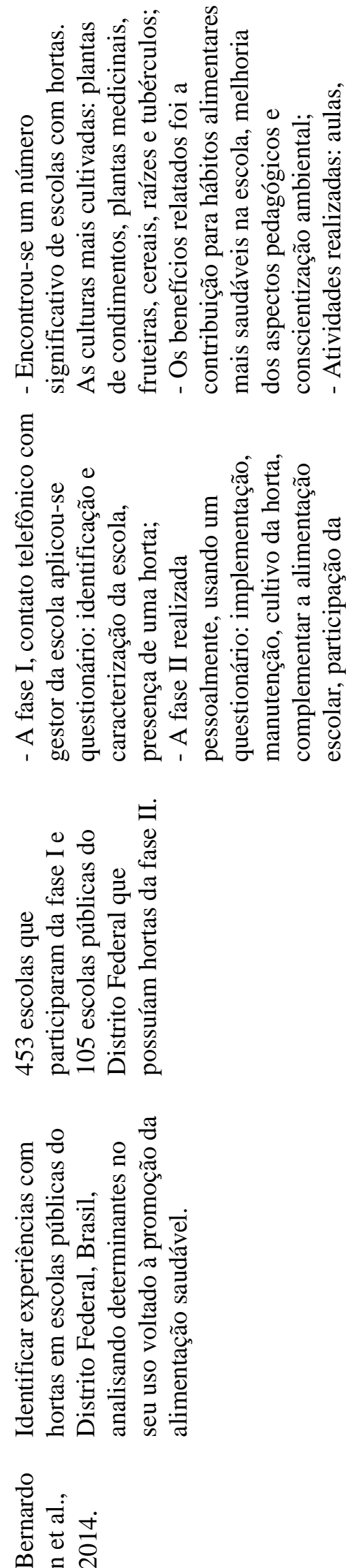 \\
\hline
\end{tabular}

[738] 


\begin{tabular}{|c|c|c|}
\hline 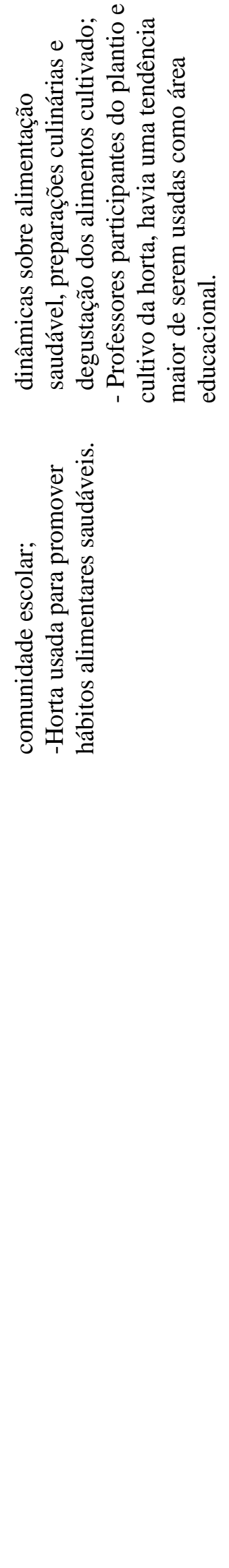 & 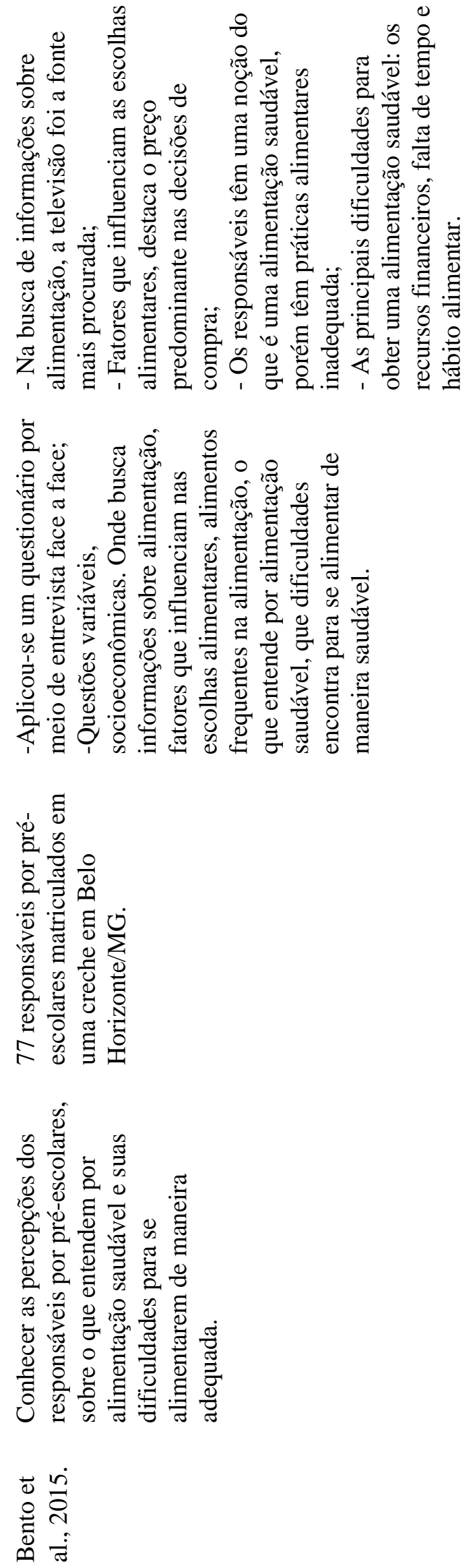 & 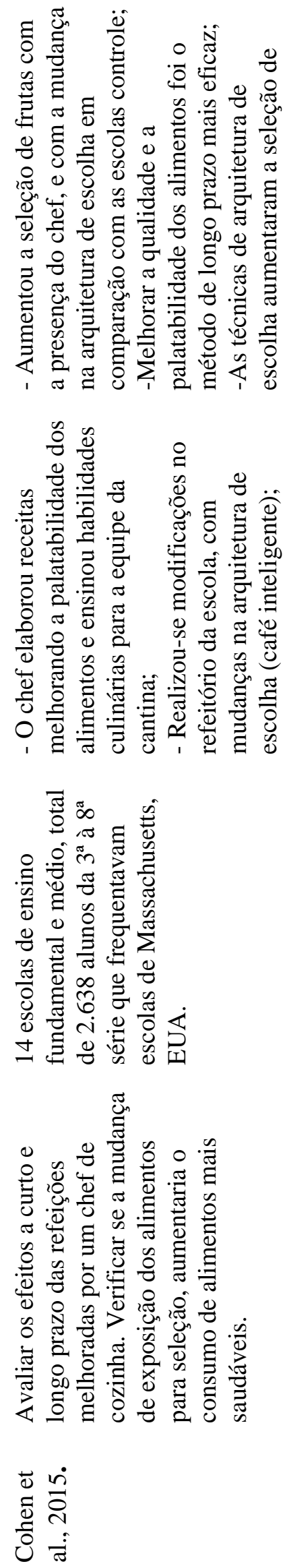 \\
\hline
\end{tabular}

[739] 


\begin{tabular}{|c|c|c|}
\hline 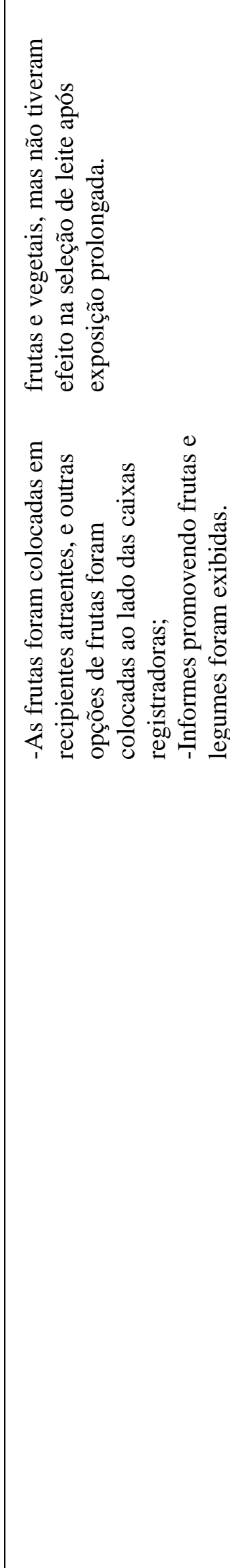 & 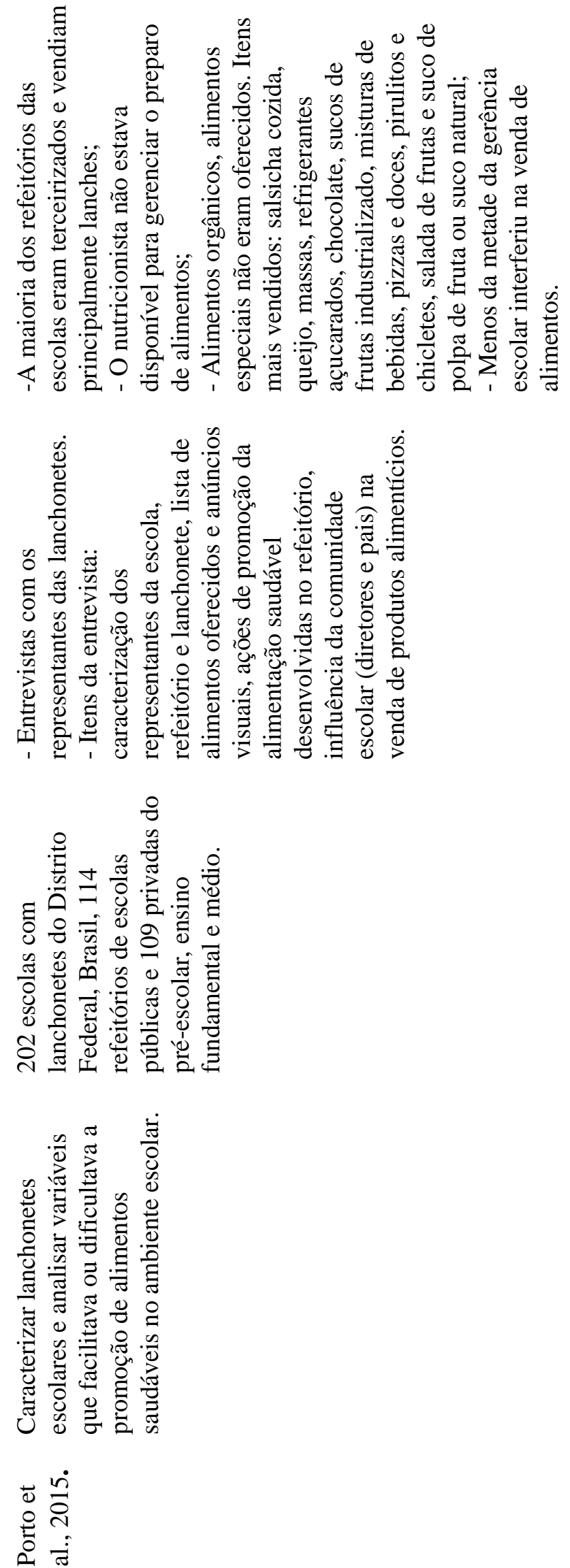 & 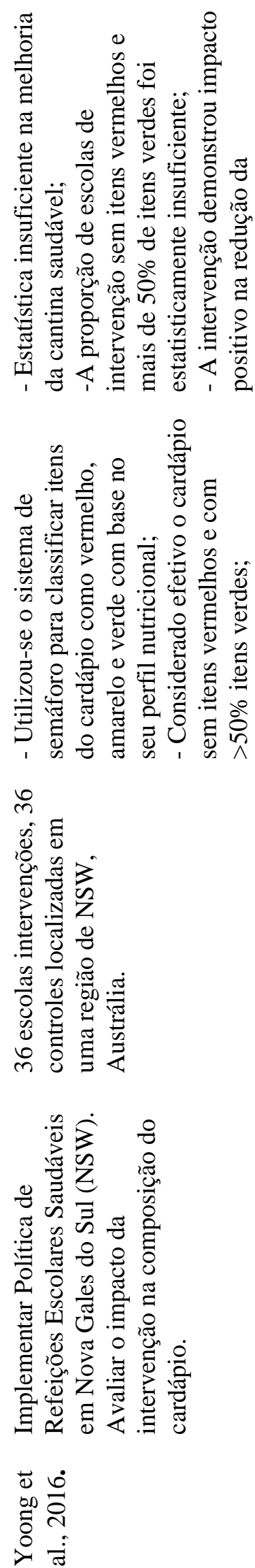 \\
\hline
\end{tabular}

[740] 


\begin{tabular}{|c|c|c|}
\hline 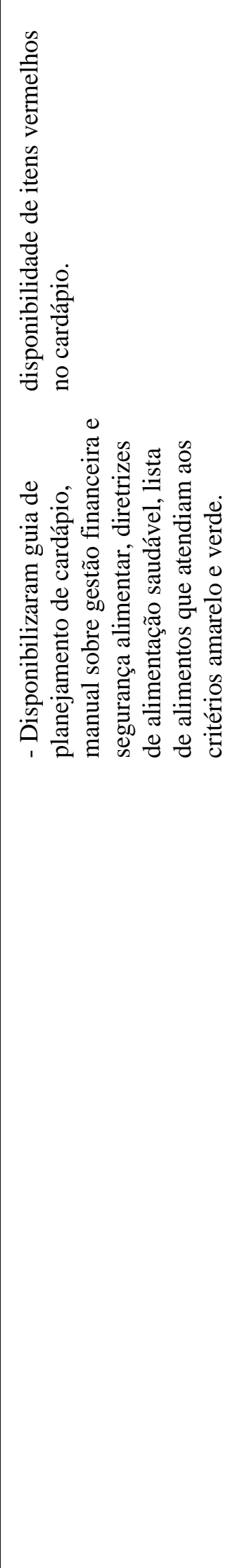 & 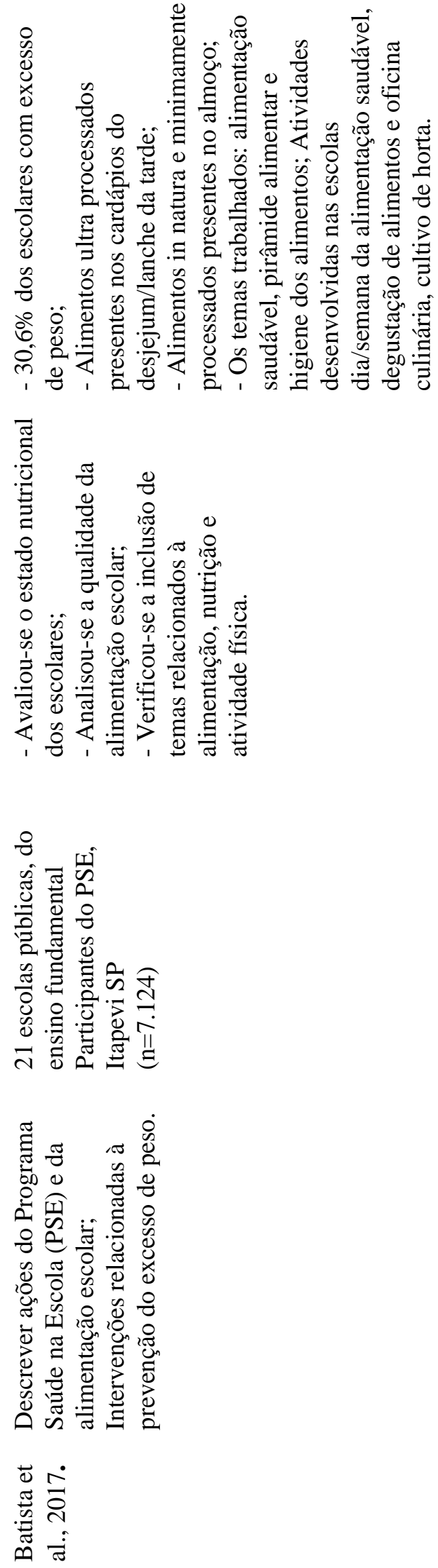 & 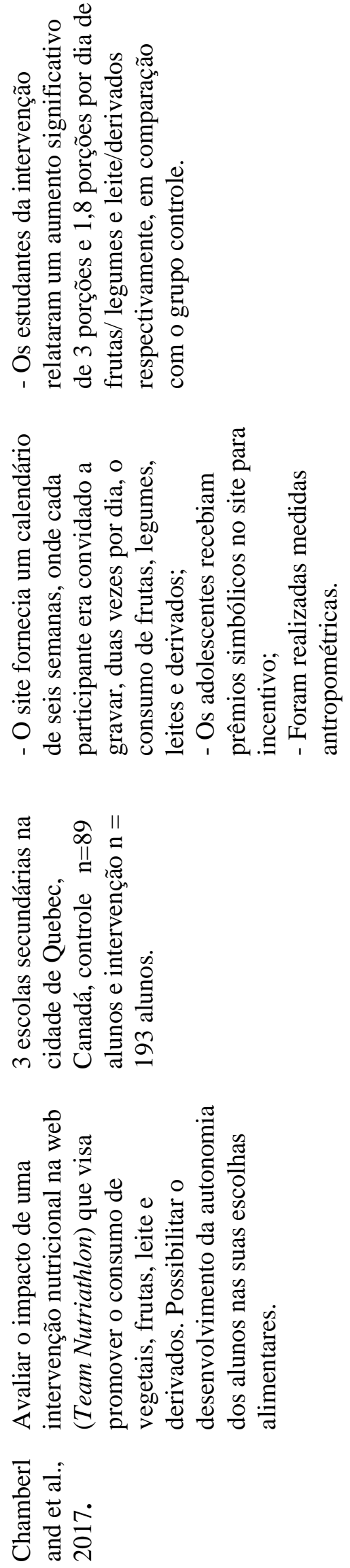 \\
\hline
\end{tabular}

[741] 


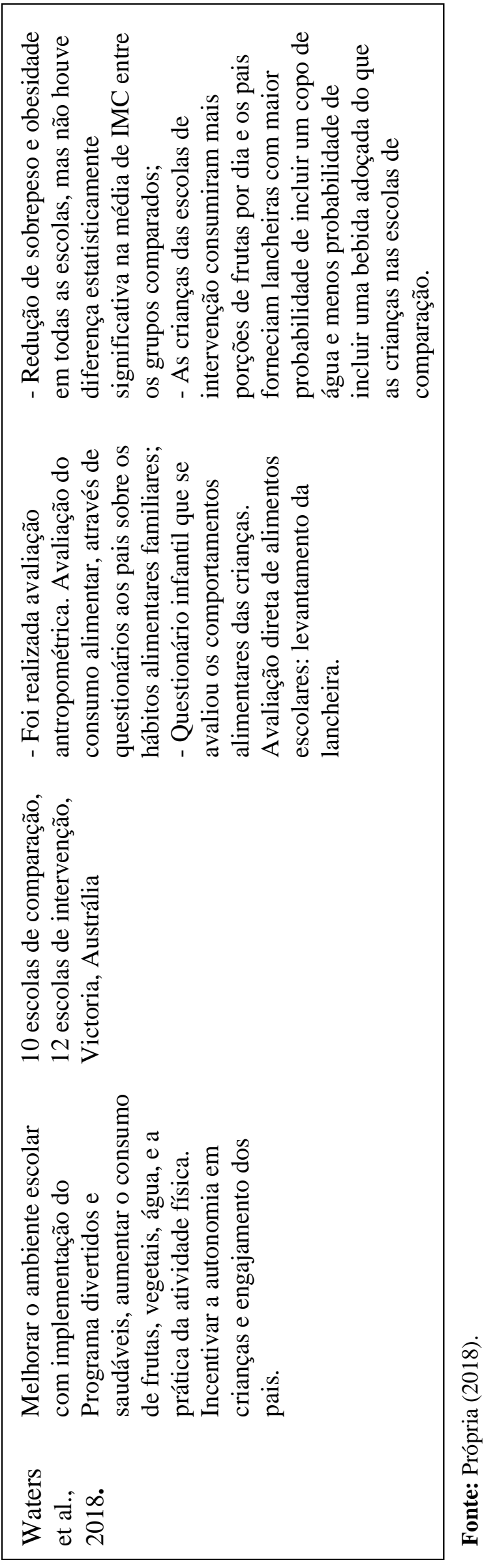

[742] 


\section{Discussão}

As ações de educação alimentar e nutricional realizadas pelos estudos citados anteriormente utilizaram as seguintes metodologias: aulas expositivas, palestras, debates, dinâmicas, gincanas, oficinas culinárias, degustação de frutas e vegetais, atividades lúdicas, exposição de vídeos, cartazes, mudanças na arquitetura de escolha dos alimentos, melhora da palatabilidade da merenda escolar, jogos lúdico-didático, jogos web e cultivo de hortas escolares. Os temas mais trabalhados foram alimentação saudável, consumo de frutas, legumes, leites e derivados, pirâmide alimentar, planejamento de cardápio saudável, higiene dos alimentos e utensílios, quantidade de óleo e sal das preparações e opções de lanches saudáveis.

Dentre as técnicas para verificação do sucesso das ações, ressalta-se avaliação antropométrica, peso, estatura e IMC, levantamento do consumo alimentar através da aplicação de inquéritos alimentares realizados antes e após as intervenções, cálculo de resto-ingesta, observações visuais e aplicação de questionários padronizados. Destaca-se o sistema de semáforo, jogos lúdicos didáticos e os jogos web, mudança na arquitetura de escolha dos alimentos as metodologias mais interativas e inovadoras entre os estudos.

As metodologias dos estudos citados anteriormente como cozinhar com crianças, orientações nutricionais com pais, crianças e donos das lanchonetes, cultivo de hortas escolares, melhorar a palatabilidade dos alimentos através de um chefe de cozinha e intervenção nutricional na web, são as abordagens que obtiveram os resultados mais significativos (CUNNINGHAM-SABO; LOHSE, 2013; RATNER et al., 2013; BERNARDON et al., 2014; COHEN et al., 2015; CHAMBERLAND et al., 2017). Referindo ao estudo Chamberland et al. (2017) apontam que os adolescentes são mais receptivos ao uso de ferramentas online, pois foram criados na evolução da tecnologia, mostrando-se uma boa metodologia para ser usada com esse público alvo.

Em contrapartida as metodologias que realizam somente antropometria, aplicação de questionários e atividades expositivas geram menos impacto quanto a mudança de hábitos alimentares e estilo de vida saudável pois, estimula menos a atenção do público alvo, dificultando assim, o processo de aprendizagem. No estudo Bento et al. (2015) realizaram aplicação de questionário semiestruturado a fim de conhecer a percepção dos pais dos escolares sobre alimentação saudável, esse estudo não realizou ações de educação nutricional, porém vale ressaltar que pesquisas de análises como esta são importantes para diagnóstico do estado nutricional, categorização socioeconômica e educacional, do público, porém não geram impacto a nível de mudança de hábitos alimentares e estilo de vida.

A implementação de políticas de alimentação saudável na escola é uma estratégia de caráter determinante na prevenção e redução da obesidade e outras doenças decorrentes da má alimentação em crianças e adolescentes, porém, o que se observa é que a maioria das escolas 
não executam de maneira adequada estes programas. No estudo Batista et al. (2017) encontraram um alto percentual de crianças com excesso de peso e associado a isso percebeuse uma oferta significativa de alimentos processados e ultraprocessados nos lanches escolares. Assim como Porto et al. (2015) demonstraram em seu estudo que a maioria dos alimentos oferecidos nas cantinas escolares eram industrializados em comparação com somente a presença do suco natural nos cardápios compondo os itens mais vendidos. A escola deve ser um local para oferta de alimentos saudáveis havendo a necessidade de melhorias nos alimentos fornecidos.

A Política de Refeitório Escolar Saudável em Nova Gales do Sul (NSW) exige que as cantinas escolares proíbam a venda de alimentos "vermelhos" ou seja, alimentos que são pobres em nutrientes e ricos em energia, como confeitaria, alimentos fritos e bebidas açucaradas e que a maioria dos itens do cardápio sejam itens "verdes" aqueles com boas fontes de nutrientes, como frutas, legumes, carnes magras (YOONG et al., 2016). Se a escola ofertar alimentos saudáveis possivelmente está contribuindo para redução de sobrepeso e obesidade além da melhoria da saúde dos escolares como mostra o estudo de Ratner et al. (2013) observaram diminuição do percentual de obesidade e as crianças aumentaram o consumo de frutas e legumes, isso pode se dar pela importância de realizar ações com pais, crianças e priorizar venda de alimentos saudáveis no ambiente escolar.

Para aceitabilidade de frutas, legumes e hortaliças no ambiente escolar no estudo Cohen et al. (2015) destacaram algumas estratégias: ofertar primeiro os alimentos mais saudáveis, é uma alternativa que se mostra promissora para adesão desses alimentos, e colocar um chef de cozinha seria uma boa opção para melhorar a palatabilidade dessas preparações de forma a possibilitar a adesão da merenda escolar.

Deve-se introduzir hábitos alimentares corretos precocemente, desde a primeira infância, proporcionando assim, que crianças e adolescentes adquiram bons hábitos alimentares e se tornem adultos mais saudável (LANNES et al., 2018). No estudo de Waters et al. (2018) destacaram que as ações em educação nutricional são mais efetivas quando há o envolvimento não somente dos escolares mas também dos seus pais ou responsáveis, já que estes são encarregados pela alimentação das crianças fora do ambiente escolar, assim como Assis et al. (2014) encontraram no estudo que envolvia alunos, professores, pais e funcionários da cantina, resultados positivos quanto a melhora do conhecimento nutricional e mudanças no comportamento alimentar.

O estudo Cunningham-Sabo; Lohse, (2013) mostra que cozinhar com crianças influência nas suas escolhas alimentares, favorecendo estimular o gosto por frutas e legumes, então incluí a culinária como uma atividade cotidiana da escola com crianças proporciona preferência por alimentos saudáveis através da experimentação direta por meio da degustação 
e do ato de brincar com a comida, já que são atividades que permitem vivenciar o alimento na prática. Assim como Bernardon et al. (2014) demonstraram que as hortas escolares proporcionam experiência de aprendizagem na prática, possibilitando conhecer as características sensoriais e este é um ótimo espaço para desenvolver atividades lúdicas de educação alimentar porém, precisa ser mais explorado pela comunidade escolar pois além de atividades educativas, têm os aspectos da sustentabilidade pois não utiliza agrotóxicos no cultivo, e os alimentos cultivados podem ser usados para complementar a alimentação escolar.

A escola enfrenta algumas dificuldades para alcançar bons resultados de promoção da alimentação saudável, segundo o estudo Waters et al. (2018) citam que as intervenções podem ser limitadas pela influência do marketing vinculado a produtos destinados às crianças que promovem alimentos não saudáveis e está fora do alcance da escola. Assim como Bento et al. (2015) demonstraram em seu estudo que os pais dos escolares utilizavam a televisão como principal meio de obter informações sobre alimentação. Já no estudo Porto et al. (2015) mostram que a pouca interferência da gestão escolar na venda de alimentos nas cantinas escolares favorece aos donos das lanchonetes ofertarem alimentos visando o lucro em detrimento da oferta de alimentos mais saudáveis.

Sendo assim, a escola um espaço social onde crianças e adolescentes passam grande parte do seu tempo, aprendendo e realizando atividades, por tanto é um ambiente propicio para desenvolver bons hábitos alimentares, alcançando estudantes nas etapas mais influenciáveis da sua vida.

\section{Considerações Finais}

Diante disso, vê-se a importância de se realizar ações que promovam e divulguem os alimentos saudáveis, para que as escolas e os gestores tenham o compromisso de executar as políticas de promoção da saúde. Assim, as crianças e os adolescente desde cedo podem se envolver com atividades relacionadas a alimentação e nutrição, visando garantir a prevenção de sobrepeso e obesidade. As metodologias educativas utilizadas como cultivo de hortas escolares, cozinhar com crianças, conhecer o alimento na prática se mostraram mais eficazes do que somente ações expositivas. Constatou-se então que a escola é um espaço ideal para realização destas atividades, principalmente quando existe um elo entre profissionais da saúde e educadores, pois juntos podem definir os melhores métodos de ensino e tornar eficaz a promoção da alimentação saudável, acredita-se que o professor é um grande influenciador de ideias entre os escolares.

Apesar da pesquisa mostrar que Educação Alimentar e Nutricional ganhou espaço nos últimos anos, é preciso ainda formular novas metodologias de ensino, que sejam inovadoras e interativas capazes de facilitar a compreensão dos alunos, desenvolver sua autonomia e 
participação de forma integral, além de aumentar o engajamento de toda a comunidade escolar, pais, professores, gestores e os profissionais da saúde.

\section{Referências}

ARAÚJO, A. L. et al. O impacto da educação alimentar e nutricional na prevenção do excesso de peso em escolares: uma revisão bibliográfica. RBONE-Revista Brasileira de Obesidade, Nutrição e Emagrecimento, v. 11, n. 62, p. 94-105, 2017.

ARAUJO, J. M. et al. Importância Dos Hábitos Alimentares Saudáveis na Infância: uma Revisão da Literatura. International Journal of Nutrology, v. 11, n. S 01, p. Trab458, 2018.

ALVES, G. M. et al. A importância da alimentação saudável para o desenvolvimento humano. Humanas \& Sociais Aplicadas, v. 10, n. 27, p. 46-62, 2020.

BATISTA, M. da S. A. et al. Ações do Programa Saúde na Escola e da alimentação escolar na prevenção do excesso de peso infantil: experiência no município de Itapevi, São Paulo, Brasil, 2014. Epidemiologia e Serviços de Saúde, v. 26, p. 569-578, 2017.

BENTO, I. C. et al. Alimentação saudável e dificuldades para torná-la uma realidade: percepções de pais/responsáveis por pré-escolares de uma creche em Belo Horizonte/MG, Brasil. Ciência \& Saúde Coletiva, v. 20, p. 2389-2400, 2015.

BERNARDON, R. et al. School Gardens in the Distrito Federal, Brazil. Revista de Nutrição, v. 27, n. 2, p. 205-216, 2014.

BRASIL, D. F. Ministério do Desenvolvimento Social e Combate à Fome. Marco de referência de educação alimentar e nutricional para as políticas públicas, MDS; Secretaria Nacional de Segurança Alimentar e Nutricional. 2012.

BRASIL. Decreto presidencial no. 6.286 de 05 de dezembro de 2007. Institui o Programa Saúde na Escola - PSE, e dá outras providências. Brasília (DF): Diário Oficial da União; 2007.

BRASIL. Lei Orgânica de Segurança Alimentar Nutricional (Losan). Lei n 11.346, de 15 de setembro de 2006. Cria o Sistema Nacional de Segurança Alimentar e Nutricional-SISAN com vistas em assegurar o direito humano à alimentação adequada e dá outras providências.

Diário Oficial da União. 2006. Disponível em: https://www.planalto.gov.br/ccivil_03/_Ato2004-2006/2006/Lei/L11346.htm. Acessado em: 16 junho 2018.

BRASIL; BRASIL. Lei n ${ }^{\circ} 11.947$, de 16 de junho de 2009. Dispõe sobre o atendimento da alimentação escolar e do Programa Dinheiro Direto na Escola aos alunos da educação básica. Diário Oficial da União, 2009.

BURITY, V. et al. Direito humano à alimentação adequada no contexto da segurança alimentar e nutricional. Brasília: Abrandh, 2010.

CAMOZZI, A. B. Q. et al. Promoção da Alimentação Saudável na Escola: realidade ou utopia?. Cadernos Saúde Coletiva, v. 23, n. 1, p. 32-37, 2015. 
CHAMBERLAND, K. et al. The impact of an innovative web-based school nutrition intervention to increase fruits and vegetables and milk and alternatives in adolescents: a clustered randomized trial. International Journal of Behavioral Nutrition and Physical Activity, v. 14, n. 1, p. 1-11, 2017.

COHEN, J. F. W et al. Effects of choice architecture and chef-enhanced meals on the selection and consumption of healthier school foods: a randomized clinical trial. JAMA pediatrics, v. 169, n. 5, p. 431-437, 2015.

CUNNINGHAM-SABO, L.; LOHSE, B. Cooking with Kids positively affects fourth graders' vegetable preferences and attitudes and self-efficacy for food and cooking. Childhood Obesity, v. 9, n. 6, p. 549-556, 2013.

DA SILVA, M. X. et al. Abordagem lúdico-didática melhora os parâmetros de educação nutricional em alunos do ensino fundamental. Ciências \& Cognição, v. 18, n. 2, p. 136-148, 2013.

DE ASSIS, M. M. et al. Avaliação do conhecimento nutricional e comportamento alimentar após educação alimentar e nutricional em adolescentes de Juiz de Fora-MG. HU Revista, v. 40, n. 3 e $4,2014$.

FRETES, G. et al. Efecto de una intervención educativa sobre el consumo de frutas, verduras y pescado en familias de niños preescolares y escolares. Archivos latinoamericanos de nutrición, v. 63, n. 1, p. 37-45, 2013.

GREENWOOD, R. L.; FONSECA, A. B. Alimentação na escola: significados e possibilidades do comer e da comida para a promoção dos direitos humanos. Revista Interdisciplinar de Direitos Humanos, v. 6, n. 1, p. 103-127, 2018.

LANNES, M. M. et al. Promoção da saúde no ambiente escolar: desenvolvimento de materiais didáticos. Revista Família, Ciclos de Vida e Saúde no Contexto Social, v. 6, p. 375-385, 2018.

PORTO, E. B. S. et al. School canteens in the Federal District, Brazil and the promotion of healthy eating. Revista de Nutrição, v. 28, n. 1, p. 29-41, 2015.

RATNER, $\mathrm{R}$ et al. Impacto de una intervención en alimentación y nutrición en escolares. Revista chilena de pediatría, v. 84, n. 6, p. 634-640, 2013.

RECH, D. C. et al. As políticas públicas e o enfrentamento da obesidade no Brasil: uma revisão reflexiva. Revista de Epidemiologia e Controle de Infecção, v. 1, n. 1, p. 192-202, 2016.

SANTOS, L. A. da S. O fazer educação alimentar e nutricional: algumas contribuições para reflexão. Ciência \& Saúde Coletiva, v. 17, n. 2, p. 455-462, 2012.

SILVA, M. X. et al. Abordagem lúdico-didática melhora os parâmetros de educação nutricional em alunos do ensino fundamental. Ciências \& Cognição, v. 18, n. 2, p. 136-148, 2013.

SOUSA, L. M. M. S. et al. Metodologia de revisão integrativa da literatura em enfermagem. 2017. 
SOUZA, M. T. de. et al. Revisão integrativa: o que é e como fazer. Einstein (São Paulo), v. 8, n. 1, p. 102-106, 2010.

TRICHES, R. M. Promoção do consumo alimentar sustentável no contexto da alimentação escolar. Trabalho, Educação e Saúde, v. 13, n. 3, p. 757-771, 2015.

WATERS, E. et al. Cluster randomised trial of a school-community child health promotion and obesity prevention intervention: findings from the evaluation of fun ' $n$ healthy in Moreland!. BMC public health, v. 18, n. 1, p. 92, 2018.

YOONG, S. L. et al. CAFÉ: a multicomponent audit and feedback intervention to improve implementation of healthy food policy in primary school canteens: a randomised controlled trial. international journal of behavioral nutrition and physical activity, v. 13, n. 1, p. $126,2016$. 


\title{
CAPÍTULO 48: APROVEITAMENTO DO ALBEDO DO MARACUJÁ NA PRODUÇÃO DE ALIMENTOS
}

\section{CHAPTER 48: USE OF THE PASSION FRUIT ALBEDO IN FOOD PRODUCTION}

Ana Thaís Campos de Oliveira ${ }^{1}$; Fernanda Tayla de Sousa Silva²; Everlândia Silva Moura Miranda ${ }^{3}$; Joene Vitória Rocha Santos ${ }^{4}$; Marlene Nunes Damaceno ${ }^{5}$

\begin{abstract}
Resumo
A industrialização do maracujá, em geral, aproveita apenas o suco, sendo eliminado cascas e sementes, gerando grande quantidade de resíduos, dessa forma o aproveitamento tecnológico desses subprodutos é uma saída para evitar desperdícios e melhorar o meio ambiente. O albedo é o tecido branco, esponjoso e celulósico, considerado principal componente da casca do maracujá, por ser rico em fibras, diversos estudos vêm sendo desenvolvidos, a fim de aproveitar suas características funcionais em alimentos, e contribuir para a saúde do consumidor. Este trabalho tem como objetivo revisar na literatura as formas de aproveitamento do albedo do maracujá na produção de alimentos, identificando assim a sua influência sobre as características físico-química e sensoriais. Para isso foi realizada uma análise sistemática em bases de dados eletrônicas utilizando os termos "passion fruit albedo" e "foods" ou "food. Os resultados mostraram diversas formas de aproveitamento e aplicação do albedo do maracujá em alimentos como doce em massa e em calda, conservas de bananas, bolos, biscoitos, barra de cereal, e em produtos cárneos como o hamburguer, atuando também de maneira positiva sobre todas as características dos produtos.
\end{abstract}

Palavras-Chave: Aproveitamento tecnológico, resíduos, subprodutos.

\begin{abstract}
The industrialization of passion fruit, in general, uses only juice, being eliminated peels and seeds, generating a large amount of waste, so the technological use of these by-products is a way to avoid waste and improve the environment. The albedo is white, spongy and cellulosic tissue, considered the main component of passion fruit peel, being rich in fibers, several studies have been developed in order to take advantage of its functional characteristics in food, and contribute to consumer health. This work aims to review in the literature the ways of using the passion fruit albedo in food production, thus identifying its influence on the physical-chemical and sensory characteristics. For this was performed a systematic analysis in electronic databases using the terms "passion fruit albedo" and "foods" or "food. The results showed several ways of using and applying passion fruit albedo in foods such as sweet in dough and in syrup, bananas in syrup, cakes, cookies, cereal bar, and meat products such as hamburgers, also acting positively on all product characteristics.
\end{abstract}

Keywords: Technological use, waste, by-products.

\footnotetext{
${ }^{1}$ Mestranda em Tecnologia de Alimentos, Instituto Federal de Educação, Ciência e Tecnologia do Ceará (IFCE), euthaiscampos.alimentos@gmail.com

${ }^{2}$ Mestranda em Tecnologia de Alimentos, Instituto Federal de Educação, Ciência e Tecnologia do Ceará (IFCE), tayliinhaf @ gmail.com

${ }^{3}$ Mestranda em Tecnologia de Alimentos, Instituto Federal de Educação, Ciência e Tecnologia do Ceará (IFCE), everlandiamoura7@yahoo.com

${ }^{4}$ Mestranda em Tecnologia de Alimentos, Instituto Federal de Educação, Ciência e Tecnologia do Ceará (IFCE), joene_vitoria@hotmail.com

${ }^{5}$ Docente, Instituto Federal de Educação, Ciência e Tecnologia do Ceará (IFCE), marlene@ @ifce.edu.br
} 


\section{Introdução}

Com origem na América do Sul, o maracujá é cultivado em todo o mundo, tendo destaque em regiões tropicais como o Brasil, que é o principal produtor e consumidor do mundo (SANTOS, 2013). O tamanho dos frutos vai variar, mas é de aproximadamente $5,5 \mathrm{~cm}$ de diâmetro. É composto por cinco partes: flavedo, albedo, arilo, polpa e sementes. A junção do flavedo e albedo compõem a casca do maracujá (MARENDA, 2015).

No Brasil, a variedade mais plantada é o maracujá amarelo ou azedo, sendo parte da espécie Passiflora edulis Sims. Praticamente todos os estados brasileiros cultivam o maracujá, o que faz gerar renda pra diversos municípios. O maracujá possui ótima qualidade nutritiva, possuindo minerais (potássio, fósforo, cálcio, sódio e ferro) e vitaminas, principalmente A e C e alcaloides, flavonoides e carotenoides. Na casca estão contidos carboidratos, proteínas e pectina. Cerca de 57,3\% (base seca) da casca do maracujá amarelo tem conteúdo abundante de fibra alimentar, principalmente pectinas que trazem benefícios a saúde humana. A pectina é uma fração de fibra solúvel, que contribui para a redução de taxas de glicose no sangue, através da sua capacidade de formar gel em meio ácido (DE ARAÚJO, 2017).

O flavedo possui grande quantidade de pectina niacina, ferro, cálcio e fósforo, além das propriedades funcionais. O albedo é o tecido branco, esponjoso e celulósico, considerado principal componente da casca do maracujá (LÓPEZ-VARGAS, 2014). Por ser rico em fibras, diversos estudos tem sido desenvolvido com ele, a fim de aproveitar suas características funcionais que auxiliam à saúde dada sua capacidade de reduzir LDL, aumentar HDL, sendo indicada no tratamento de diabetes e redução de peso. Essa grande quantidade de fibras ocorre devido a sua composição conter pectina (SPANHOLI; DE OLIVEIRA, 2009).

Na produção de alimentos a parte da matéria-prima que não é aproveitada no produto final é considerada resíduo. Na industrialização do maracujá geralmente somente o suco é aproveitado, sendo eliminado cascas e sementes, gerando grandes toneladas de resíduos, assim fazer o aproveitamento tecnológico desses subprodutos é a melhor saída para evitar desperdícios, o que agregará valor as matérias-primas antes descartadas e também dos novos produtos que serão elaborados para consumo humano (DE ARAÚJO, 2017). Como nos últimos anos a produção tem crescido, aumentou também o desperdício no meio ambiente de cascas, caroços, sementes e bagaços, que no caso do maracujá, cerca de 52\% do peso total do fruto corresponde somente a casca, assim, realizar o aproveitamento desses resíduos, ajuda na 
questão de sustentabilidade e também na economia, gerando mais ganhos para os produtores (DOS ANJOS GONÇALVES; MAGALHÃES, 2018).

Esses resíduos contém um alto teor de umidade e açúcares solúveis que ao serem expostos a condições ambientais após a extração do suco, promovem a fermentação, e assim a deterioração dos seus componentes. As tecnologias permitem fazer o aproveitamento desses resíduos industriais, diminuem o impacto ambiental gerado, possibilitando haver a elaboração de novos produtos alimentícios, agregando valor a eles principalmente por seu conteúdo nutritivo (MATIAS et al., 2018).

O albedo em sua forma desidratada pode conter cerca: 6,65\% de umidade, 8,68\% de cinza, $0,80 \%$ de lipídios, $26,41 \%$ de fibra total, 1,50\% de proteína e 55,96\% de carboidratos aproveitáveis, $\mathrm{pH} 4,45$, sólidos solúveis $4,67^{\circ}$ Brix, pectina $2,3 \%$ e açúcares totais $1,24 \%$. Seu alto teor de fibra já é bem estudado, sendo possível sua incorporação em produtos alimentícios (CORREA, 2010).

A partir dessas informações, e visando entender melhor como o albedo do maracujá atua ao ser incorporado a alimentos, esta pesquisa buscou através de análises na literatura de forma sistemática, trabalhos que abordassem essa temática, para assim compreender como o albedo do maracujá está sendo aproveitado na elaboração de alimentos. Este trabalho tem por objetivo analisar as formas de aproveitamento do albedo do maracujá na produção de alimentos, identificando assim qual a sua influência sobre as características físico-química e sensoriais dos produtos alimentícios avaliados. Para isso foi utilizando bases de pesquisas eletrônicas, através das quais foi possível analisar dados de publicações que apresentavam a temática.

\section{Desenvolvimento}

Este estudo é uma revisão sistemática, uma forma de investigação científica que objetiva reunir, avaliar e conduzir uma síntese de resultados obtidos de diversos estudos sobre o tema proposto (DA SILVA; MANNRICH, 2009). A revisão sistemática, é um método que busca

responder a uma pergunta específica sobre um determinado tema. É uma pesquisa rigorosa que sintetiza dados relacionado a uma questão. Normalmente são incluídos nessas revisões pesquisas que possuem delineamento experimental, e são considerados trabalhos originais por possuírem rigor metodológico (ERCOLE; MELO; ALCOFORADO; 2014).

Geralmente este tipo de pesquisa segue algumas etapas como, construção de um protocolo de pesquisa, formulação de uma pergunta, definição dos descritores e estratégias de buscas nas bases eletrônicas, critérios de inclusão e exclusão dos estudos, avaliação crítica dos artigos selecionados, e por último, síntese dos resultados obtidos através dos estudos 
(ERCOLE; MELO; ALCOFORADO; 2014). Assim sendo, este estudo está dividido em três etapas, como mostrado na Figura 1.

Figura 1. Fluxograma para elaboração da revisão sistemática.

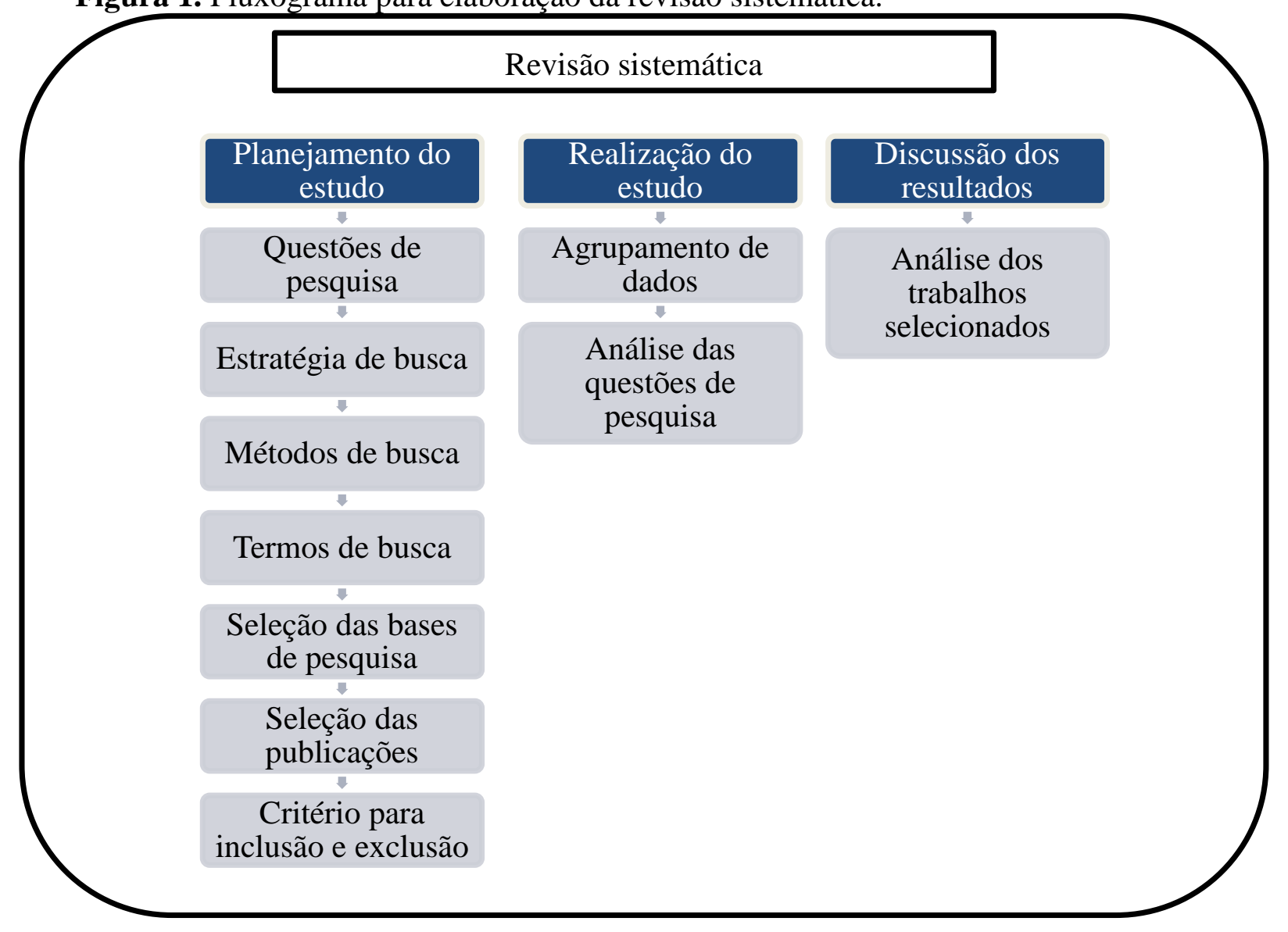

Fonte: Própria (2020).

- Planejamento do estudo

Para direcionar o estudo e assim obter as informações desejadas, foram formuladas algumas questões, para pudessem levar a um maior aprofundamento do tema e assim atender aos objetivos estabelecidos. Assim sendo, cinco questões foram elaboradas:

- Q1: Que produto foi utilizado no estudo? O objetivo dessa pergunta foi identificar quais alimentos foram aproveitados e estudados com a aplicação do albedo do maracujá.

- Q2: Como o albedo foi utilizado? Essa pergunta objetivou compreender quais as formas que o albedo do maracujá foi integrado aos alimentos.

- Q3: Quais os principais resultados que a aplicação do albedo do maracujá trouxe? A finalidade desse questionamento foi entender se a aplicação do albedo do maracujá acarretou alguma modificação e influência sobre alimento desenvolvido. 
- Q4: Quais as contribuições nutritivas que a incorporação do albedo do maracujá trouxe? Através dessa pergunta procurou-se compreender se o albedo trouxe algum benefício nutricional, já que é um subproduto do maracujá rico em fibras, se essa característica foi incorporada nos alimentos.

- Q5: Quais interferências sensoriais o albedo do maracujá promoveu? Esta pergunta buscou entender se a aplicação do albedo do maracujá promoveu alguma mudança sensorial ao alimento.

- Estratégia de busca

Definidas as questões de pesquisa, a estratégia agora foi garantir a viabilidade do estudo, sendo assegurado que os trabalhos incluídos fossem relevantes. Para isso primeiramente, determinou-se os termos de buscas, que foram traduzidos para o inglês e juntamente com os operadores lógicos “OR” e “AND”, realizou-se a pesquisa nas bases de dados eletrônicas.

Assim, baseado no tema e nas questões estabelecidas para análise, o termos escolhidos para realização da pesquisa foram: "passion fruit albedo" AND ("foods" OR "food"). Essa expressão formada junto aos operadores lógicos, teve a função de ajudar na obtenção de melhor resultados na busca. As bases de dados consultadas na pesquisa foram, Scientific Eletronic Library Online (SciELO), ScienceDirect, PubMed e Periódicos da Capes.

Com termos de busca e bases de pesquisa definidos, foi executada então a pesquisa, e aplicado parâmetros para melhor seleção dos artigos. Esses parâmetros de inclusão e exclusão foram, tipo de trabalho, que só poderia ser artigo de pesquisa, sendo excluídas as outras formas de publicação como artigos de revisão, também só foi incluído artigos publicados entre os anos de 2010 e 2020, e selecionados somente aqueles que estivessem no idioma português, inglês e espanhol.

A partir daí foram aplicados filtros para aprimorar seleção dos artigos. O primeiro filtro foi a leitura dos títulos, então os que não se enquadrassem na temática, eram excluídos. $\mathrm{O}$ segundo filtro aplicado foi a leitura dos resumos dos trabalhos, e por último, o terceiro filtro para inclusão ou exclusão foi a leitura completa do artigo. Para as publicações aceitas, foi então realizada a análise completa e aplicação das questões de estudo. Esse processo de aplicação dos filtros encontra-se na figura 2. 
Figura 2. Processo de seleção das publicações

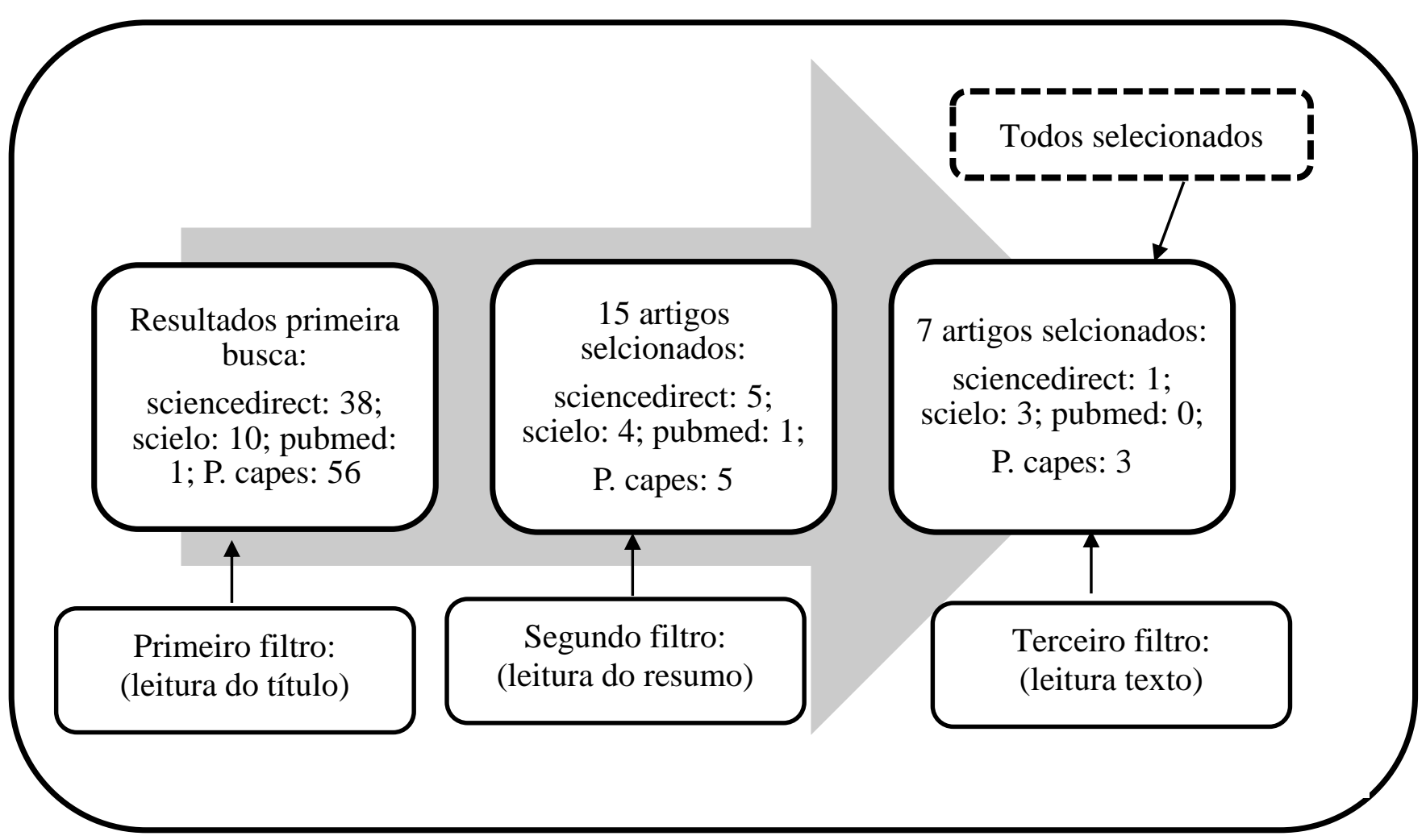

Fonte: Própria. (2020).

\section{Discussão}

Como pode ser observada na figura 2, o retorno inicial através das pesquisas com aplicação dos parâmetros tempo, tipo de publicação e idioma, foram 105 artigos, e com a aplicação dos filtros resultou em 7 artigos para realização das análises nesse estudo. Estes trabalhos estão apresentados na Tabela 1, que indica os autores, ano de publicação, títulos traduzidos e base de publicação. 
Tabela 1- identificação dos artigos selecionados

\begin{tabular}{|c|c|c|c|}
\hline ID & Referências & Títulos & Origem \\
\hline A1 & Dias et al., 2011 & $\begin{array}{l}\text { Aproveitamento do albedo do } \\
\text { maracujá na elaboração de } \\
\text { doce em massa e alterações } \\
\text { com o armazenamento }\end{array}$ & P. Capes \\
\hline A2 & Bordim et al., 2018 & $\begin{array}{l}\text { Aproveitamento Tecnológico } \\
\text { da Farinha de Subprodutos do } \\
\text { Albedo de Maracujá e do } \\
\text { Resíduo da Extração do Suco } \\
\text { da Carambola na Formulação } \\
\text { de Barras de Cereais }\end{array}$ & P. capes \\
\hline A3 & Oliveira et al., 2016 & $\begin{array}{c}\text { Avaliação físico-química e } \\
\text { sensorial de bolos elaborados } \\
\text { com resíduos de maracujá e } \\
\text { laranja }\end{array}$ & P. Capes \\
\hline A4 & $\begin{array}{l}\text { Lópes-Vargas et al., } \\
\qquad 2014\end{array}$ & $\begin{array}{l}\text { Características de qualidade } \\
\text { de hambúrguer de porco } \\
\text { adicionado de fibra de albedo } \\
\text { em pó obtido a partir de } \\
\text { maracujá amarelo (Passiflora } \\
\text { edulis var. flavicarpa) } \\
\text { coprodutos }\end{array}$ & Science direct \\
\hline A5 & Santos et al.,2015 & $\begin{array}{l}\text { Perfil livre, aceitação e } \\
\text { intenção de compra na } \\
\text { avaliação de diferentes } \\
\text { formulações de biscoitos }\end{array}$ & Scielo \\
\hline A6 & Figueiredo et al., 2013 & $\begin{array}{l}\text { Influência de parâmetros do } \\
\text { processo sobre a cor e textura } \\
\text { de doces de albedo de } \\
\text { maracujá em calda }\end{array}$ & Scielo \\
\hline A7 & Silva et al., 2012 & $\begin{array}{l}\text { Influência do teor de albedo } \\
\text { de maracujá, do ácido cítrico } \\
\text { e da relação polpa/açúcar } \\
\text { sobre a qualidade de } \\
\text { conservas de banana }\end{array}$ & Scielo \\
\hline
\end{tabular}

Fonte: Própria. (2020).

Todos os artigos selecionados foram analisados e organizados, e partir daí extraídos os dados para esta pesquisa através dos objetivos, metodologia, as soluções que os estudos propunham e as conclusões, conforme pode ser visto no quadro 1. 


\begin{tabular}{|c|c|c|}
\hline 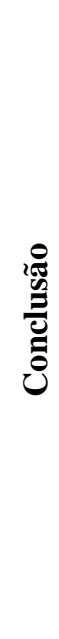 & 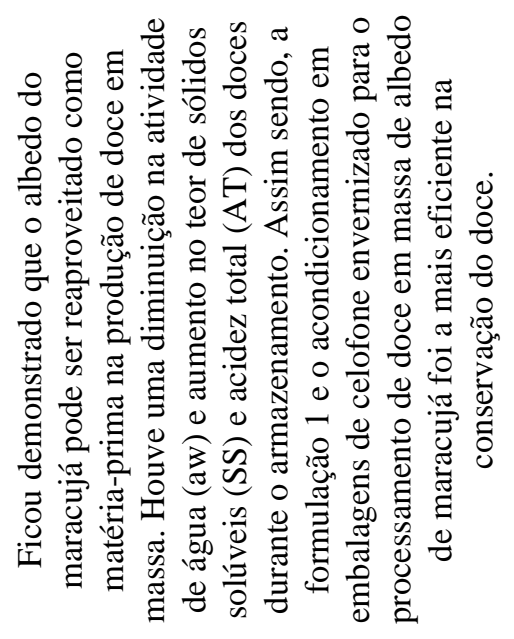 & 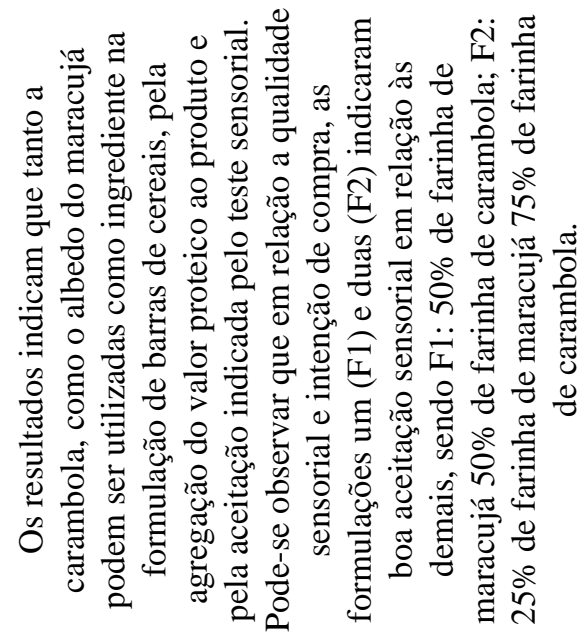 \\
\hline 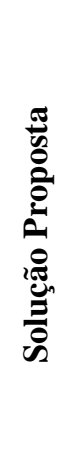 & 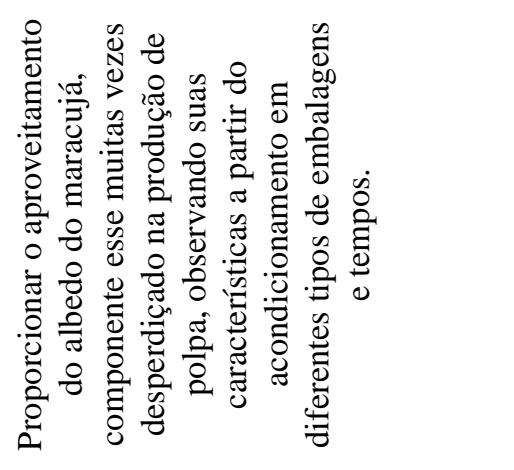 & 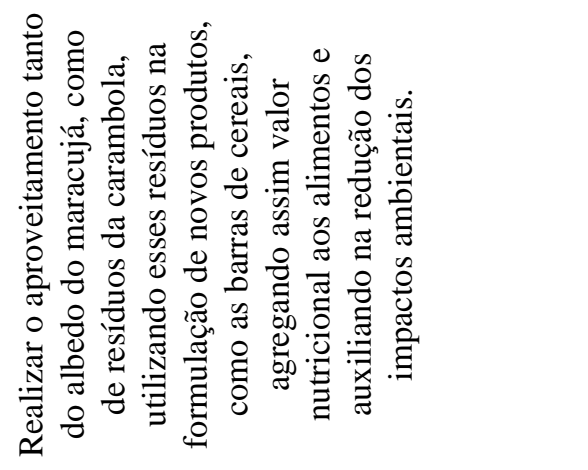 \\
\hline 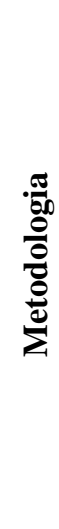 & 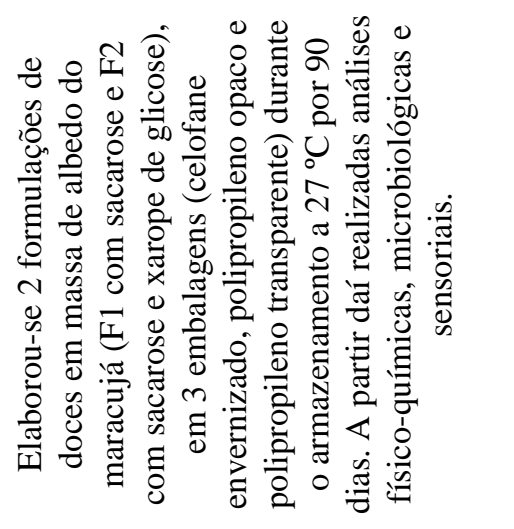 & 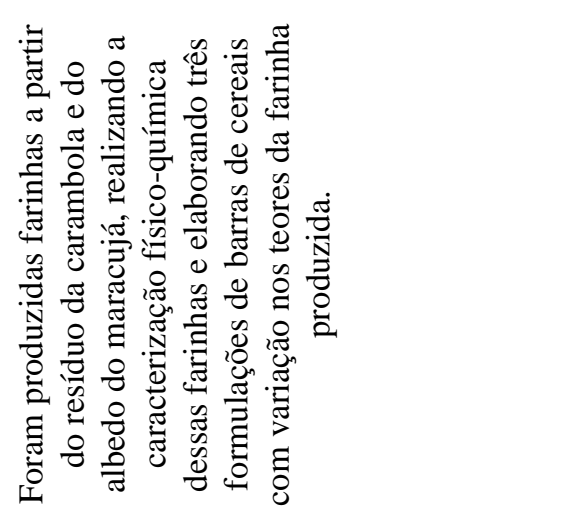 \\
\hline 苞 & 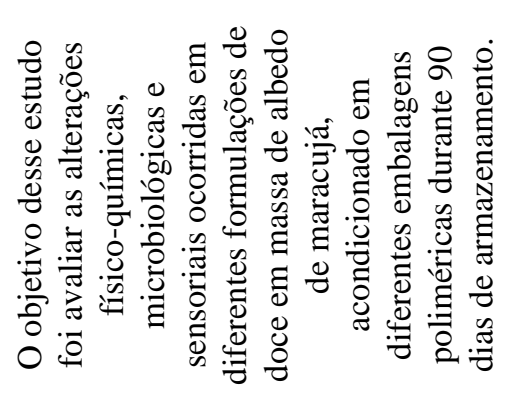 & 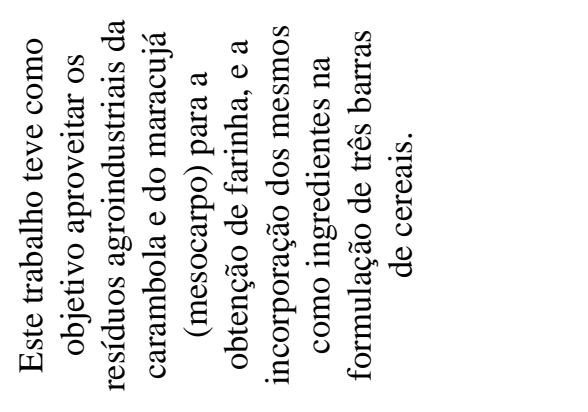 \\
\hline$\frac{8}{\tilde{\Xi}}$ & 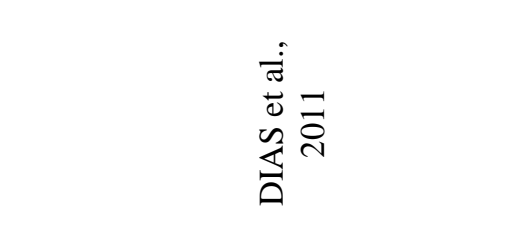 & 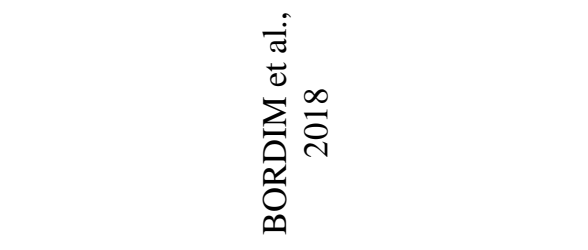 \\
\hline
\end{tabular}




\begin{tabular}{|c|c|c|}
\hline 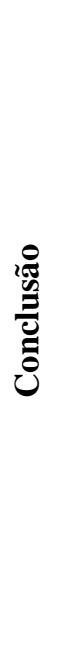 & 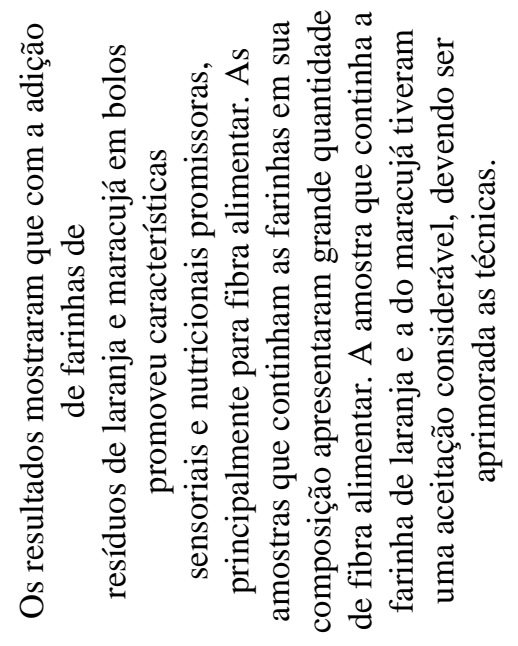 & 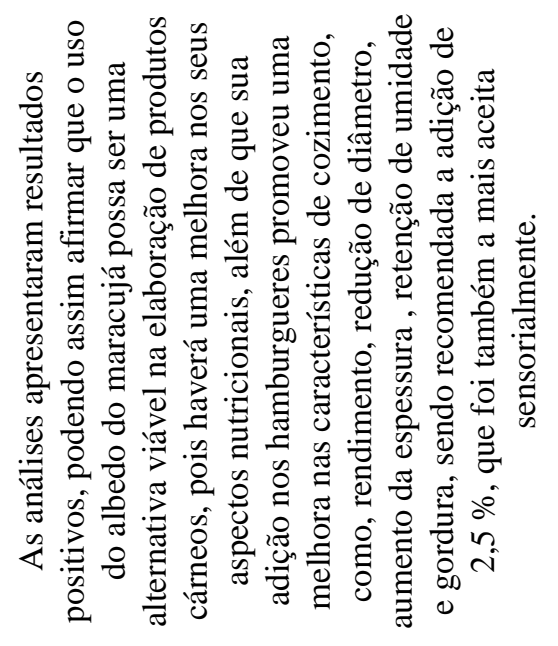 \\
\hline 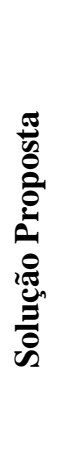 & 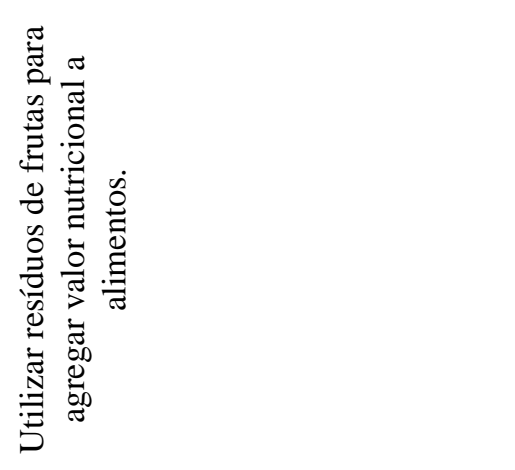 & 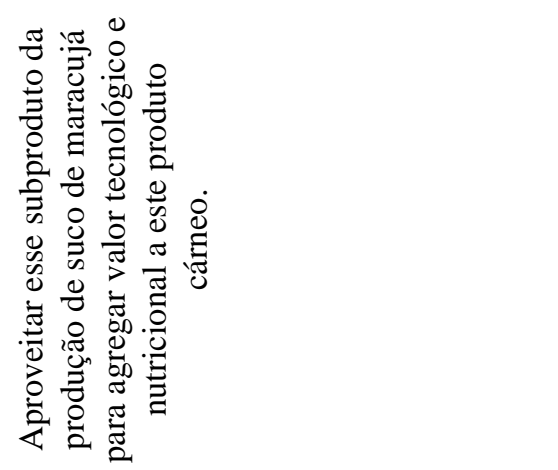 \\
\hline 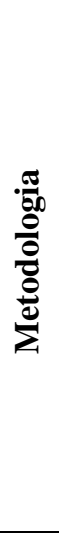 & 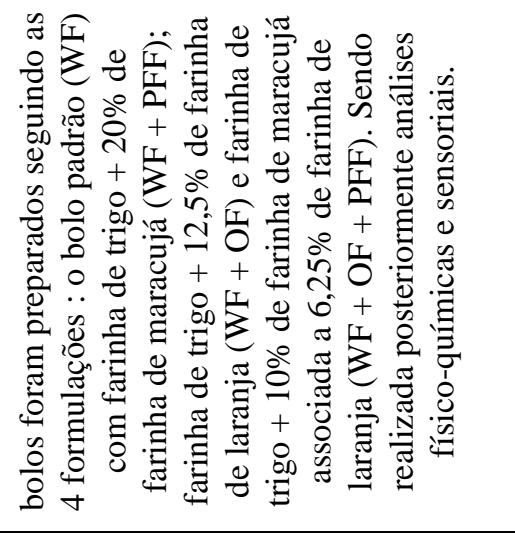 & 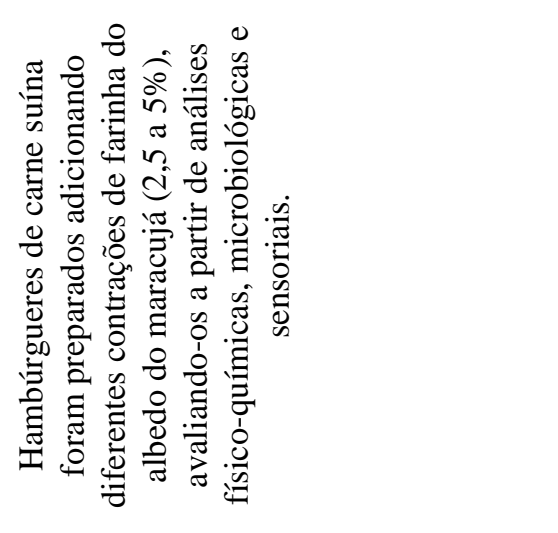 \\
\hline$\frac{\sum_{0}^{0}}{\stackrel{0}{0}}$ & 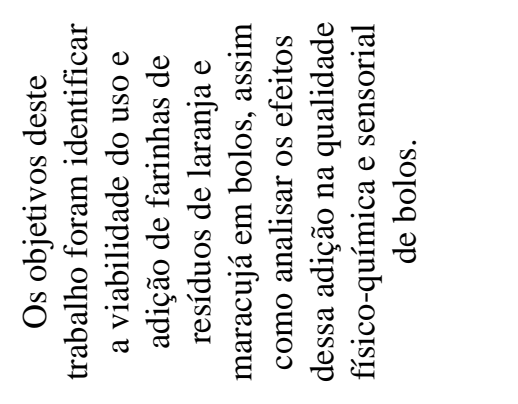 & 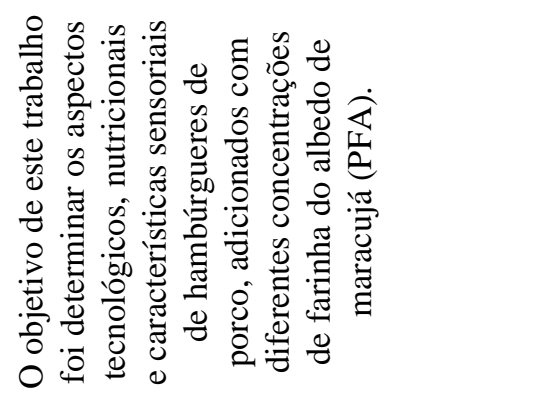 \\
\hline 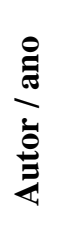 & 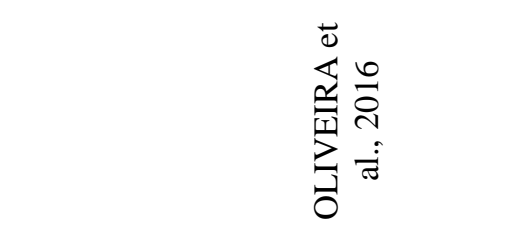 & 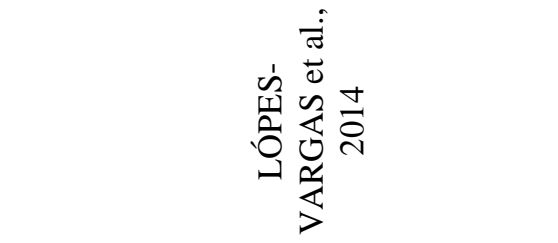 \\
\hline
\end{tabular}




\begin{tabular}{|c|c|c|}
\hline 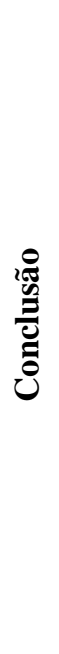 & 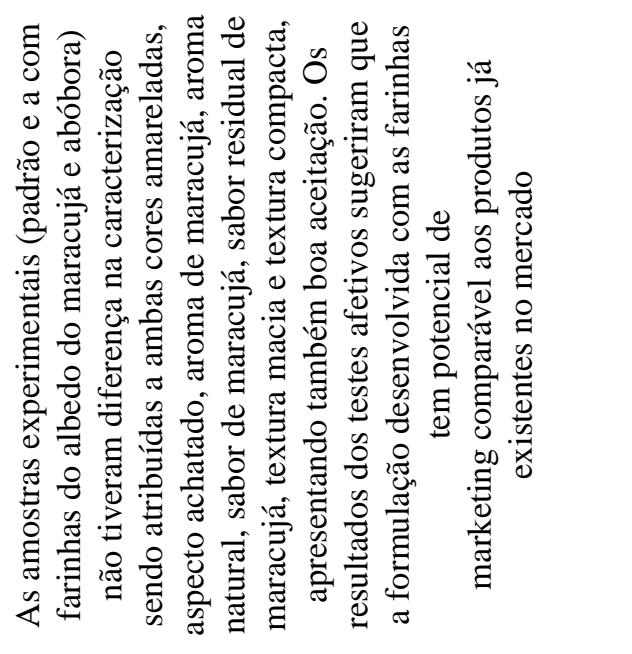 & 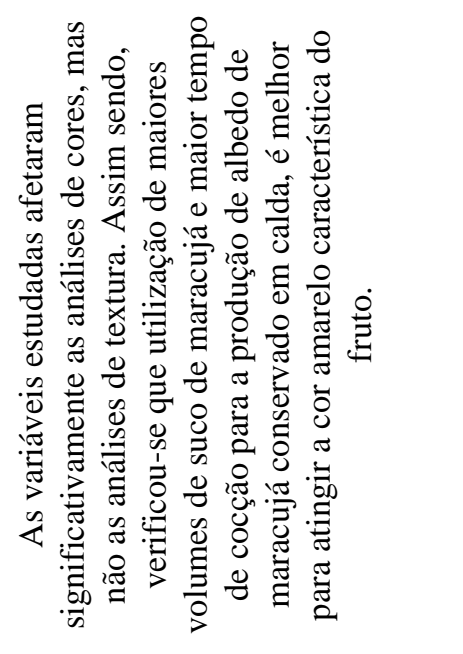 \\
\hline 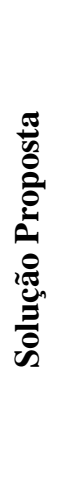 & 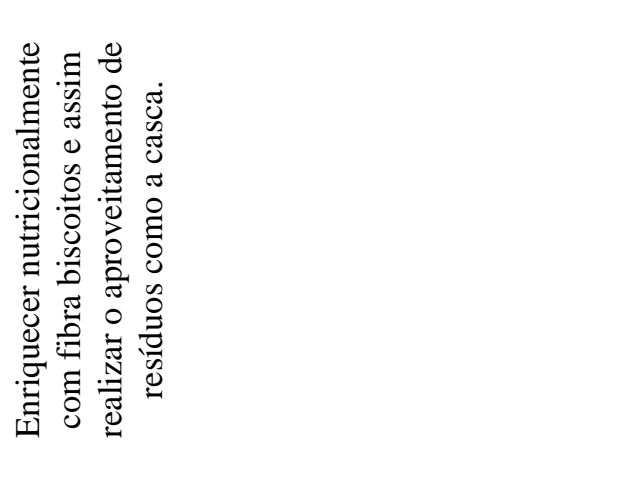 & 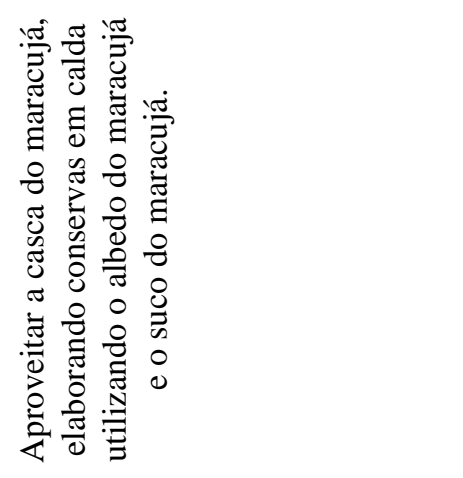 \\
\hline 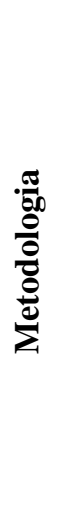 & 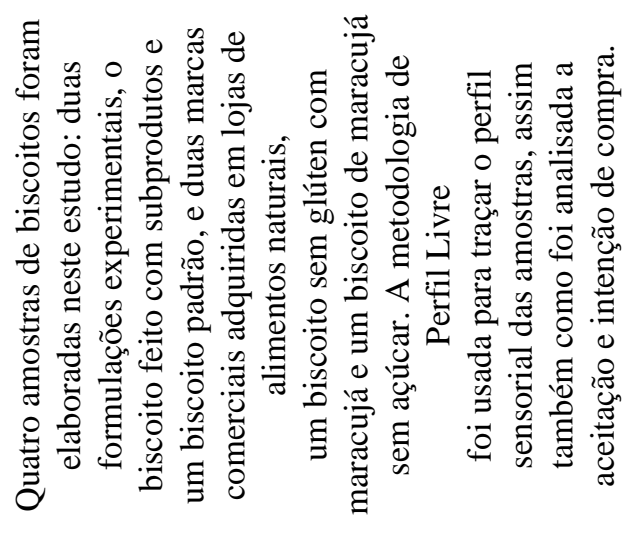 & 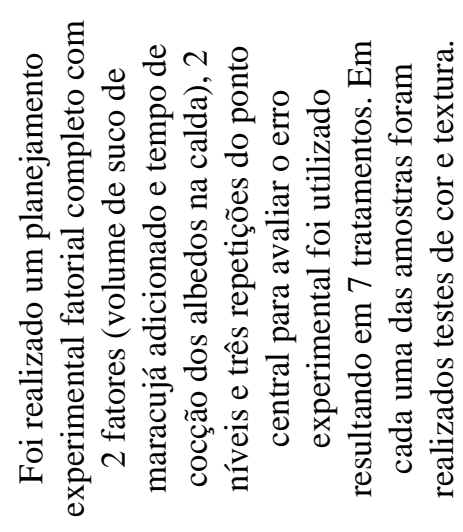 \\
\hline$\frac{\sum_{0}^{0}}{\stackrel{0}{0}}$ & 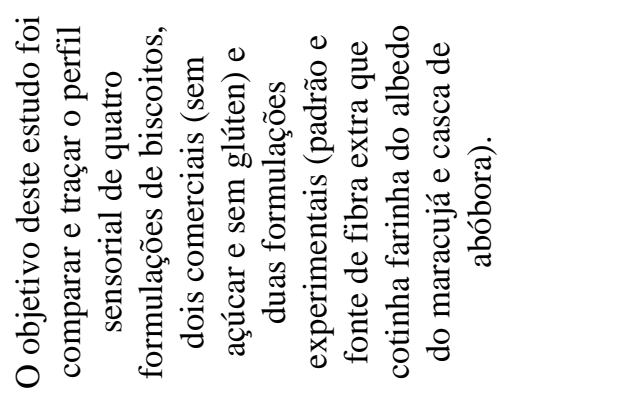 & 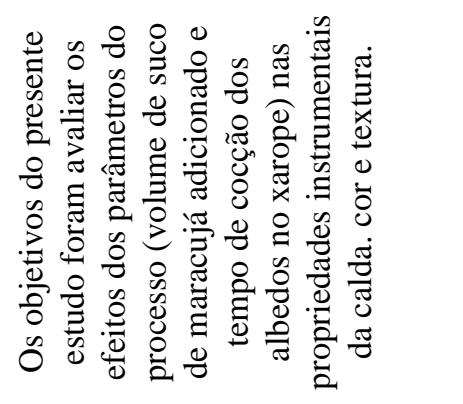 \\
\hline 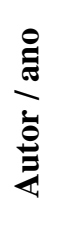 & 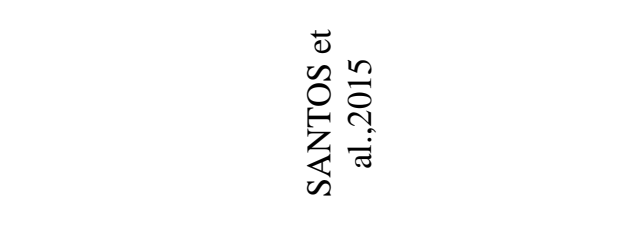 & 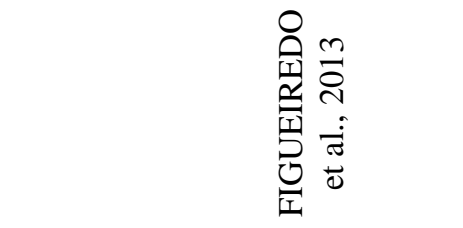 \\
\hline
\end{tabular}




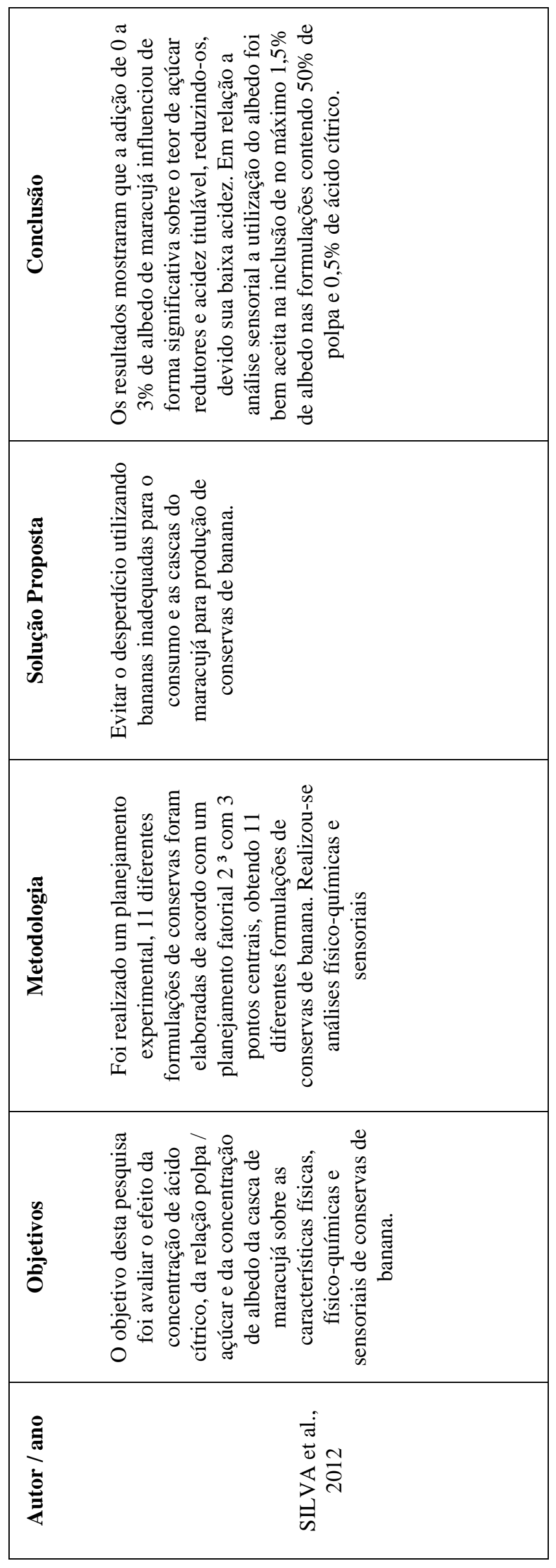

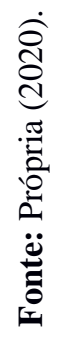

[759] 


\section{Análise das questões}

As questões elaboradas foram respondidas para cada um dos artigos, no intuito de se obter mais informações e uma maior profundidade no tema abordado, que serão discutidas a seguir.

Q1: Que produto foi utilizado no estudo?

Por meio das análises dos artigos, pode-se ver as diversas formas de se fazer o aproveitamento do albedo do maracujá e utilizá-lo em vários tipos de alimentos. No artigo A1 ele foi utilizado como matéria-prima principal para elaboração de um doce em massa, que sendo exposto à diferente embalagens e tempos de armazenamento, mostrou resultados positivos no aproveitamento desse subproduto. Outro artigo que também explorou a elaboração de doces foi o artigo A6, produzindo doce em calda com excelente qualidade. Indo para o lado da panificação e confeitaria os artigos A3 e A5 fizeram um aproveitamento interessante do albedo do maracujá, adicionando-o em bolos e biscoitos respectivamente, e no artigo A2 o albedo foi utilizado como ingrediente na produção de barra de cereais e obteve-se bons resultados. No artigo A7, o albedo foi utilizado em conservas de bananas e no artigo A4, ele foi aproveitado na produção de hambúrgueres, podendo assim ser uma opção de uso também na indústria de produtos cárneos.

Todas estas pesquisas mostram diversas possibilidades de se fazer o aproveitamento desse subproduto do maracujá, que muitas vezes é desperdiçado, podendo ser aplicado em diversas áreas na produção de alimentos.

Q2: Como o albedo foi utilizado?

Em boa parte dos alimentos abordados nesse estudo, o albedo foi aproveitado na forma de farinha como mostram os artigos A1, A2, A3, A4 e A5, respectivamente na produção de doce em massa, barra de cereal, bolo, hamburguer e biscoito, isso provavelmente se dá por haver uma melhor incorporação desse subproduto aos alimentos, facilitando assim a elaboração do produtos. Mas nos artigos A6, de doce em calda, ele foi utilizado em pedaços, e no artigo A7 conserva de banana, foi triturado. Dessa forma esses estudos mostram que é bem variável a forma de utilização do albedo do maracujá.

Q3: Quais os principais resultados que a aplicação do albedo do maracujá trouxe?

Na elaboração de doces como no artigo A1 que mostrou ser uma boa matéria para elaboração de doces em massas, podendo assim ser realizado o aproveitamento desse componente do maracujá que é desperdiçado muitas vezes, sendo também confirmado isso no artigo A6 onde a produção de doce em calda mostrou ser uma boa opção para haver o aproveitamento, assim também como na produção de conservas, artigo A7. No artigo A2 pode 
ser observada a agregação de valor nutricional ao alimento com a incorporação do albedo do maracujá, bem como no artigo A3 e A5. No artigo A4 pode ser observado que além de tornar o alimento mais saudável, também melhorou as características de cozimento como, rendimento, redução de diâmetro, aumento de espessura e retenção de gordura e umidade.

Q4: Quais as contribuições nutritivas que a incorporação do albedo do maracujá trouxe?

As contribuições nutritivas se deram principalmente pela incorporação de fibras a todos os alimentos aqui estudados. Isso se deve ao fato do albedo ser rico em pectina, espécie de fibra solúvel, que vai auxiliar o organismo na digestão, prevenir doenças cardiovasculares, gastrointestinais, diabetes e obesidade, entre outros benefícios, além de conter grande quantidade de flavonoides e vitaminas. Dessa forma, os produtos que foram incorporados o albedo do maracujá, devem conter todos os aspectos funcionais produzidos por ele.

Q5: Quais interferências sensoriais o albedo do maracujá promoveu?

Praticamente em todos os aspectos sensoriais de todos os produtos, a inclusão do albedo trouxe respostas positivas. No artigo A1 por exemplo, a formulação que continha xarope de glicose apresentou maior aceitação global e conferiu um sabor de maracujá mais acentuado e uma textura menos dura. No artigo A2, os resultados obtidos cor, sabor, odor, textura e impressão geral apresentaram escores elevados na escala hedônica, indicando assim uma boa aceitação sensorial, sendo também obtidos bons resultados na intenção de compra. No artigo A3, as amostras que continham a farinha de maracujá tiveram uma aceitação considerável, porém, precisam ser aprimorados em relação a atributos como cor e sabor que foi considerado amargo. No artigo A4, as pontuações gerais de aceitabilidade mostraram que a amostra mais apreciada foi aquela que contém $2,5 \%$ de farinha de albedo. No artigo A5, A formulação com as farinhas do albedo do maracujá e abóbora ao serem comparadas a padrão, não apresentaram diferença no perfil característico e na aceitação, demonstrando ainda boa aceitação e intenção de compra quando comparada a marcas comerciais. No artigo A6 os tratamentos da pesquisa promoveram mudanças na cor, mas não interferiram na textura, assim observou-se que quanto mais volumes de suco de maracujá e maior tempo de cozimento, poderá se obter um doce de albedo do maracujá em calda com cor amarela característica do fruto. No artigo A7, a avaliação sensorial e intenção de compra mostraram que a inclusão de no máximo 1,5\% de albedo nas formulações contendo $50 \%$ de polpa e $0,5 \%$ de ácido cítrico é positiva, tendo boa aceitação. 


\section{Discussão dos resultados}

Através das análises de cada artigo e das questões de pesquisa, foi possível observar as formas de utilização do albedo do maracujá nos mais diversos tipos de alimentos. A estratégia do aproveitamento desse subproduto da produção da polpa de maracujá foi positiva em todos os produtos aqui estudados tanto no aspecto físico-químico como sensorial.

No artigo A1, Dias et al., (2011), avaliaram alterações físico-químicas, microbiológicas e sensoriais, obtidas em diferentes formulações de doce em massa de albedo de maracujá, sob diferentes embalagens poliméricas durante 90 dias de armazenamento. Os resultados mostraram que o albedo do maracujá pode ser aproveitado, e que as condições de estudo influenciaram algumas características físico-químicas como, atividade de água (Aw), aumento no teor de sólidos solúveis (SS) e acidez total (AT) dos doces durante o armazenamento. A embalagem de celofane envernizada foi a mais positiva durante o armazenamento apresentando maior aceitação global.

No artigo A2, Bordim et al., (2018), aproveitaram os resíduos agroindustriais da carambola e do maracujá (mesocarpo) para a obtenção de farinha, e assim incorporá-las como ingredientes na formulação de três barras de cereais. Os resultados obtidos foram bons na aceitação sensorial e principalmente pela agregação do valor ao produto. Assim sendo as formulações F1: 50\% de farinha de maracujá e 50\% de farinha de carambola; e F2: 25\% de farinha de maracujá e $75 \%$ de farinha de carambola, foram as mais aceitas.

No artigo A3 Oliveira et al., (2016), identificaram a viabilidade do uso e adição de farinhas de resíduos de laranja e maracujá em bolos, mostrando através dos resultados que houve uma melhora nos aspectos nutricionais, devido com aumento no teor de fibras, bem como nos sensoriais.

No artigo A4, Lópes-Vargas et al., (2014), estudaram a influência da adição de farinha do albedo do maracujá a produtos cárneos como o hamburguer. Os resultados mostraram ser viável a sua utilização, já que teve ação positiva sobre as características de cozimento, como, rendimento, redução de diâmetro, aumento da espessura, retenção de umidade e gordura, sendo recomendada a adição de $2,5 \%$, que também foi melhor aceita sensorialmente.

No artigo A5, Santos et al., (2015), compararam e traçaram o perfil sensorial de quatro formulações de biscoitos, dois comerciais (sem açúcar e sem glúten) e duas formulações experimentais (padrão e fonte de fibra extra que continha a farinha do albedo do maracujá e casca de abóbora). As amostras experimentais (padrão e farinhas do albedo do maracujá e abóbora apresentaram boa aceitação e intenção de compra. 
No artigo A6, Figueiredo et al., (2013), avaliaram os efeitos dos parâmetros do processo (volume de suco de maracujá adicionado e tempo de cocção do albedo no xarope) nas propriedades instrumentais de doce em calda, verificando que utilização de maiores volumes de suco de maracujá e maior tempo de cocção para a produção de albedo de maracujá conservado em calda é melhor para atingir a cor amarela característica do fruto.

No artigo A7, Silva et al., (2012), avaliaram o efeito da concentração de ácido cítrico, relação polpa/açúcar e a concentração de albedo da casca de maracujá sobre as características físico-químicas e sensoriais de conservas de banana. Os resultados mostraram que a adição de 0 a 3\% de albedo de maracujá reduziu o teor de açúcar redutores e a acidez titulável. No teste sensorial a adição do albedo foi bem aceita na adição de $1,5 \%$.

\section{Considerações Finais}

Através desse estudo foi possível analisar as diversas formas de aproveitamento do albedo do maracujá na produção de alimentos, identificando também, qual a sua influência sobre as características físico-química e sensoriais. Os artigos estudados mostraram diversas formas de aproveitamento desse subproduto da industrialização do maracujá, desde a aplicação em doce em massa e em calda, conservas de bananas, bolos, biscoitos, barra de cereal, e em produtos cárneos como o hamburguer. Além disso, a incorporação do albedo do maracujá enriqueceu nutricionalmente os alimentos, com o aumento do teor de fibras, absorvendo assim seus aspectos funcionais.

Dessa forma, foi possível realizar análises dos diversos artigos aqui citados, identificando, avaliando e interpretando os resultados de maneira imparcial, para que assim se obtivessem resultados válidos.

\section{Referências}

BORDIM, J et al. Technological use of flour obtained from the byproducts of passion fruit albedo and the residue of the extraction of the star fruit juice in the formulation of cereal bars. Orbital: The Electronic Journal of Chemistry, v. 10, n. 3, p. 211-217, 2018.

CORREA, C. V. B. Processamento de biscoito a partir de ingredientes funcionais: fibra de albedo de maracujá e xilitol. Dissertação (Mestrado em Ciência de Alimentos) - Universidade Federal do Amazonas 2010.

DA SILVA, A. C. L. G; MANNRICH, G. Pilates na reabilitação: uma revisão sistemática. Fisioterapia em movimento, v. 22, n. 3, p. 449-455, 2009. 
DE ARAÚJO, B. S. Processamento e caracterização física e química de hambúrgueres formulados com pectina do maracujá amarelo. Dissertação (Mestrado) - Universidade Estadual do Sudoeste da Bahia, Itapetinga-BA, 2017.

DIAS, M. V et al. Aproveitamento do albedo do maracujá na elaboração de doce em massa e alterações com o armazenamento. Brazilian Journal of Food \& Nutrition, v. 22, n. 1, p7178, 2011.

DOS ANJOS GONÇALVES, L. D; MAGALHÃES, G. L. Hambúrguer bovino com substituição da gordura por farinha da casca de maracujá. Revista Verde de Agroecologia e Desenvolvimento Sustentável, v. 13, n. 4, p. 489-494, 2018.

ERCOLE, F. F; MELO, L.S; ALCOFORADO, C. L. G. C. Revisão integrativa versus revisão sistemática. Revista Mineira de Enfermagem, v. 18, n. 1, p. 9-12, 2014.

FIGUEIREDO, L. P et al. Influence of process parameters on the color and texture of passion fruit albedo preserved in syrup. Food Science and Technology, v. 33, n. 1, p. 116-121, 2013.

LÓPEZ-VARGAS, J. H. et al. Quality characteristics of pork burger added with albedo-fiber powder obtained from yellow passion fruit (Passiflora edulis var. flavicarpa) co-products. Meat science, v. 97, n. 2, p. 270-276, 2014.

MARENDA, F. R. B et al. Citotoxicidade de pectinas do albedo de maracujá (Passiflora edulis flavicarpa) em linhagens tumorais. Dissertação (Mestrado) - Universidade Estadual de Ponta Grossa, 2015.

MATIAS, T. G. et al. Densidade aparente dos resíduos da polpa de maracujá. Brazilian Journal of Food Technology, v. 21, e2017155, 2018.

SANTOS, D. A. M. Formulação de biscoito tipo cookie a partir da substituição percentual de farinha de trigo por farinha de casca de abóbora (curcubita maxima) e albedo de maracujá amarelo (passiflora edulis flavicarpa. Dissertação (Mestrado) - Universidade Federal do Estado do Rio de Janeiro, Rio de Janeiro, 2013.

SANTOS, D. A. M et al. Free choice profiling, acceptance and purchase intention in the evaluation of different biscuit formulations. Ciência e Agrotecnologia, v. 39, n. 6, p. 613-623, 2015 .

SILVA, I. G et al. Influence of passion fruit albedo, citric acid, and the pulp/sugar ratio on the quality of banana preserves. Food Science and Technology, v. 32, n. 2, p. 267-273, 2012.

SPANHOLI, L; DE OLIVEIRA, V. R. Utilização de farinha de albedo de maracujá (Passiflora edulis flavicarpa Degener) no preparo de massa alimentícia. Alimentos e Nutrição, v.20, n.4, p. 599-603,2009.

OLIVEIRA, Viviani Ruffo de et al. Physicochemical and sensory evaluation of cakes made with passion fruit and orange residues. Journal of Culinary Science \& Technology, v. 14, n. 2, p. 166-175, 2016. 


\title{
CAPÍTULO 49: ANÁLISE DO PERFIL DOS CONSUMIDORES DE LEITE CONDENSADO, DOCE DE LEITE E SOBREMESAS LÁCTEAS NO ESTADO DE PERNAMBUCO
}

\section{CHAPTER 49: PROFILE ANALYSIS OF CONSUMERS OF CONDENSED MILK, SWEET MILK AND MILK DESSERTS IN THE STATE OF PERNAMBUCO}

Fabiana Maria da Silva ${ }^{1}$; Ádilla Pereira d'Ávila Souza²; Jéssyca Karolina de Lima Santos³; Gerla Castello Branco Chinelate ${ }^{4}$

\begin{abstract}
Resumo
No primeiro semestre de 2020, houve um aumento no preparo de comidas caseiras, devido ao isolamento social causado pela Covid-19. Resultados de estudos mostraram que, neste período, ocorreu um aumento no consumo de doce de leite, sorvete e leite condensado, alimentos caracterizados como indulgentes. $\mathrm{O}$ objetivo deste trabalho foi traçar o perfil dos consumidores desses produtos lácteos e indicar os fatores que influenciam a compra desses produtos. Para tanto, 157 consumidores voluntários responderam um questionário contendo perguntas relacionadas ao consumo dos lácteos abordados. Os resultados evidenciaram que a maioria dos respondentes são jovens entre 16 e 25 anos, residentes do agreste pernambucano que consomem os produtos a cada 15 dias. Quando questionados sobre a influência da pandemia no consumo, aproximadamente $63 \%$ notaram um aumento no valor de algum desses produtos e acreditam que esteja relacionado com a pandemia. $\mathrm{O}$ resultado desse estudo destaca o aumento do consumo dos supracitados derivados lácteos no período da pandemia, demonstrando o apreço do consumidor por alimentos indulgentes em períodos de estresse, associado a um maior tempo em casa e reafirma a influência da confiabilidade na marca no momento de indicar um produto.
\end{abstract}

Palavras-Chave: Segurança alimentar, consumo, derivados lácteos, alimentos indulgentes, Covid-19, comfort food.

\begin{abstract}

\footnotetext{
${ }^{1}$ Engenharia de Alimentos, UFAPE, fabianamariax@gmail.com

${ }^{2}$ Engenharia de Alimentos, UFAPE, adillapereira@ hotmail.com

${ }^{3}$ Engenharia de Alimentos, UFAPE, jessycakarolinals@ gmail.com

${ }^{4}$ Doutora em Biotecnologia, Docente da UFAPE, gerla.chinelate@ufape.edu.br
}

In the first half of 2020, there was an increase in the preparation of homemade foods, due to the social isolation caused by Covid-19. Results of studies showed that in this period there was an increase in the consumption of milk jam, ice cream and condensed milk, foods characterized as indulgent. The objective of this work was to outline the profile of consumers of these dairy products and indicate the factors that influence the purchase of these products. To this end, 157 voluntary consumers answered a questionnaire containing questions related to the consumption of the dairy products addressed. The results showed that most of the respondents are young people between 16 and 25 years of age, residents of the agreste Pernambucano who consume the products every 15 days. When asked about the influence of the pandemic on consumption, approximately $63 \%$ noticed an increase in the value of some of these products and believe it is related to the 
pandemic. The result of this study highlights the increased consumption of the aforementioned dairy products during the pandemic period, demonstrating the consumer's appreciation of indulgent food in periods of stress, associated with a longer time at home and reaffirms the influence of reliability in the brand when indicating a product.

Keywords: Food safety, consumption, dairy products, indulgent foods, Covid-19, comfort food.

\section{Introdução}

Pernambuco tem uma extensão territorial de $98.067,881 \mathrm{~km}^{2}$ e uma população estimada de 9.557.071 pessoas (IBGE, 2019). Dentre os estados do Nordeste, Pernambuco é o segundo maior produtor de leite, com $21,9 \%$ do total de leite produzido na Região Nordeste, ficando atrás somente da Bahia que representa $31 \%$ da produção regional (SEBRAE, 2013). Apesar do Estado ocupar a segunda posição em termos quantitativos de produção de leite, é o sexto em consumo alimentar médio per capita (kg/ano) de leite e derivados, atrás do Ceará, Rio Grande do Norte, Bahia, Paraíba e Sergipe (SEBRAE, 2013).

A agilidade do dia a dia compromete o preparo de refeições, em virtude do menor tempo, adaptando nossa refeição para o momento conveniente, muitas vezes fora de casa. No período de isolamento, além das orientações de higiene e segurança recomendadas pela Organização Mundial de Saúde (OMS), veio o estímulo de consumir alimentos mais saudáveis para melhorar o quadro de saúde e diminuir as chances de uma imunidade frágil contra a Covid-19 para tal, surgiu a necessidade de voltar a cozinhar, a busca por alimentos saudáveis tornou-se inevitável, bem como, a retomada de hábitos já esquecidos. Para SCHUBERT (2020) essas mudanças que estamos adotando em relação aos nossos hábitos alimentares, bem como as dinâmicas de trabalho e deslocamento são resultados dessa pandemia causada pelo novo coronavírus.

É possível notar que houve um aumento no consumo de alimentos lácteos. De acordo com a UFJF (2020) um estudo coordenado Embrapa Gado de leite em parceria com Universidade Federal de Juiz de Fora (UFJF), os pesquisadores objetivaram verificar a opinião dos internautas quando ao consumo de produtos lácteos no período da quarentena, como resultado os alimentos que foram mais comentados no tweet que estavam relacionados ao coronavírus foram: sorvete, leite condensado, lactose, manteiga e doce de leite. Alguns desses são alimentos conhecidos como indulgentes, aqueles que proporcionam prazer e felicidade a quem os consome. A Indulgência está ligada ao prazer e os produtos indulgentes têm uma forte carga de regionalismo, já que passam pelo desenvolvimento do hábito de consumo (SEBRAE, 2017). 
Através desse estudo, objetivou-se traçar o perfil dos consumidores de leite condensado, doce de leite e sobremesas lácteas no estado de Pernambuco durante o cenário da pandemia, analisando quais os principais fatores que influenciam no consumo desses alimentos.

\section{Material e Métodos}

Foi realizado levantamento de artigos científicos, teses, dissertações, textos e livros do período de 2015 - 2020 nas bases de dados Scielo, Scopus e do portal CAPES, bem como a busca de textos atualizados em sites.

Os descritores utilizados para doce de leite foram: consumo de doce de leite, análise socioeconômica dos consumidores de doce de leite, padrão de consumo de doce de leite e perfil dos consumidores de doce de leite. Para o leite condensado e sobremesa láctea utilizamos como base os mesmos descritores, alterando apenas o produto.

A pesquisa para levantamento de dados foi realizada de modo individual para obtenção de maiores informações relacionadas aos produtos, devido a carência de trabalhos que discutem simultaneamente os três alimentos em discussão. Enquanto que, no questionário foram abordados em conjunto para oferecer praticidade e otimização de tempo atingindo o maior número de respondentes.

O perfil dos consumidores de leite condensado, doce de leite e sobremesas lácteas no estado de Pernambuco foi obtido através de um levantamento de dados realizados pela equipe do Grupo de Pesquisa e Desenvolvimento de Produtos Lácteos e Gestão Industrial - GPLAC da Universidade Federal do Agreste de Pernambuco - UFAPE no período de 30 de junho a 30 de julho de 2020. O questionário foi elaborado através da plataforma do Google Forms, de acesso público, online e gratuito.

O questionário de 38 perguntas buscou investigar dados pessoais, socioeconômicos, hábitos e o consumo dos produtos lácteos, leite condensado, sobremesa láctea e doce de leite, as perguntas elaboradas auxiliaram na observação direta das seguintes variáveis: Análise da frequência de consumo, percepção dos hábitos no consumo de produtos lácteos, quantidades e locais de aquisição, tipos mais conhecidos, formas de consumo, influências no momento da compra, aceitação dos produtos e as características sociais e demográficas dos consumidores. A avaliação estatística foi feita com o auxílio da ferramenta Microsoft Excel. 


\section{Resultados e Discussão}

O questionário do Google Forms atingiu 174 respostas, porém 17 declararam não morar em Pernambuco, resultando em 157 respostas válidas para a pesquisa. Os 157 indivíduos estavam dispostos em 4 regiões de Pernambuco a maioria 82,2\% (129) no agreste, $8,9 \%$ (14) na zona da mata, 5,7\% (9) região metropolitana e 3,2 \% (5) sertão, e a sua maioria 86,0 \% (135) residia em zona urbana e os demais (22) em zona rural. Onde $62,4 \%$ (98) eram do sexo feminino e 37,6\% (59) do sexo masculino, em relação à faixa etária, a maioria 75,8\% tinha entre 16 e 25 anos, 12,1\% tinham entre 26 e 35 anos, 8,9\% tinham entre 36 e 45 anos, 1,9\% tinham entre 46 e 55 anos, 0,6 \% tinha entre 56 e 65 anos, assim como 0,6\% tinha mais de 65 anos. Por se tratar de um questionário online, os dados do público entrevistado dependem diretamente do perfil de quem possui rede social e do público atingido por quem divulgou o questionário.

A maioria dos indivíduos possuía como nível de alfabetização o superior incompleto 49,7\% (78), médio completo 19,1\% (29), pós-graduação completa 9,6 \% (15), médio incompleto 18,5\% (13), 6,4 \% (10) superior completo, pós-graduação incompleta $5,1 \%$ (8), fundamental incompleto $1,9 \%$ (3) e $0,6 \%$ (1) fundamental completo. Em relação à renda dos indivíduos, a 35,7 \% (56) apresentam renda de até 1 salário mínimo, 46,5\% (73) tinha a renda entre 1 e 3 salários mínimos, 14,0\% (22) tinha a renda de 3 a 6 salários mínimos, 1,9\% (3) recebiam entre 6 e 9 salários mínimos; e outros $1,9 \%$ (3) indivíduos tinha renda superior a 9 salários mínimos. Observou-se ainda que 77,7 \% (122) destes participam de algum programa de ajuda do governo, com exceção do auxílio emergencial. 
Figura 1. Consumo de leite condensado, doce de leite e sobremesa láctea pelos respondentes.

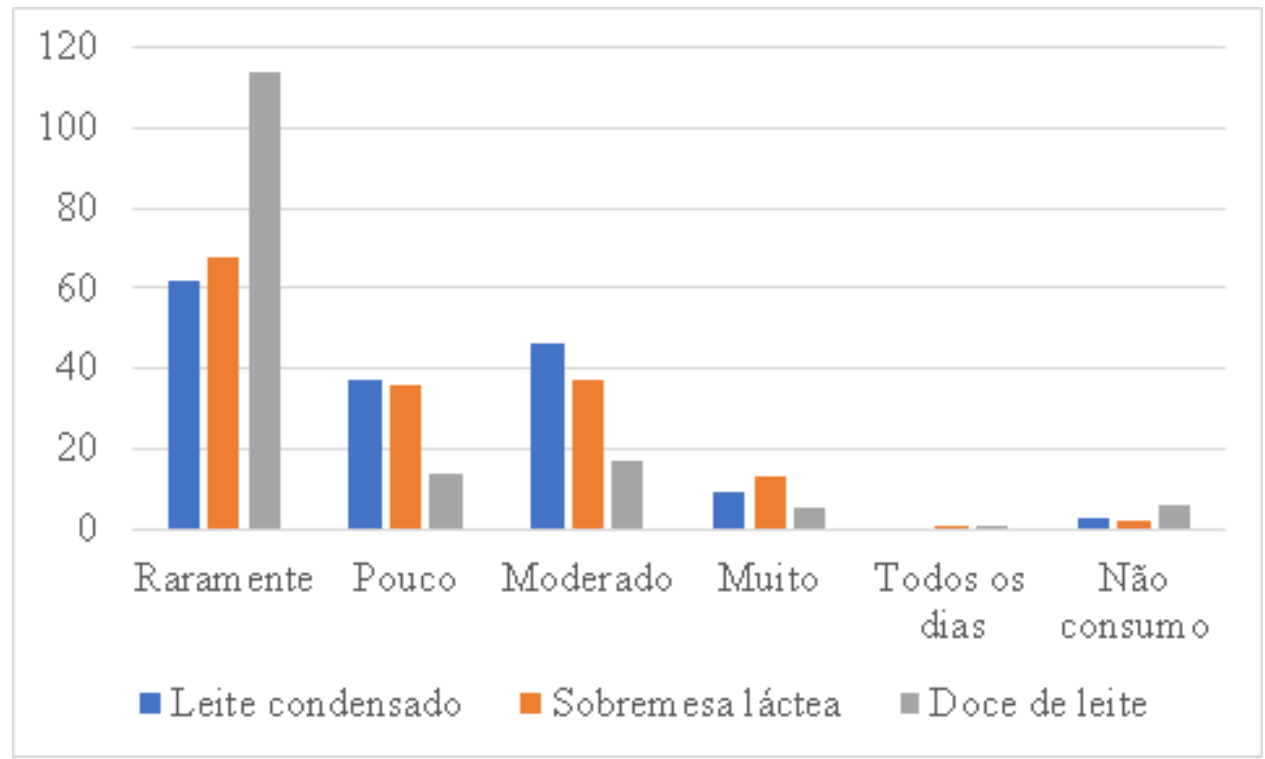

Fonte: Própria (2020)

O consumo (Figura 1) de um alimento é considerado frequente quando a sua ingestão é maior ou igual a 4 vezes na semana, e apenas 8,3\% dos indivíduos afirmaram que consomem sobremesa láctea nessas proporções, 5,7 \% o leite condensado e apenas $3,2 \%$ o doce de leite. Estes produtos não ocupam posição de destaque quanto ao consumo diário, a maioria dos indivíduos relataram que o consumo do doce de leite $(72,6 \%)$, sobremesa láctea $(43,3)$ e leite condensado $(39,5 \%)$ é raro sendo uma vez a cada 15 dias. Ao consumir esses produtos as principais emoções (Figura 2) que os indivíduos sentiram foram felicidade $(64,1 \%)$, prazer $(64,3 \%)$, bem $(50,7 \%)$, satisfação $(49,7 \%)$ e alegria $(44,1 \%)$. Isso se dá ao fato de que os produtos discutidos fazem parte dos alimentos indulgentes e do "comfort food", aqueles que oferecem sensação de prazer a quem consome. Minasse (2016) já falava que as comidas que recebem o nome de indulgentes foram associadas a situações em que têm seu valor nutricional deixado de lado, nesses alimentos e bebidas a prioridade está no prazer obtido ao consumi-los. 
Figura 2. Emoções causadas pelo consumo de doce de leite, leite condensado e sobremesas lácteas.

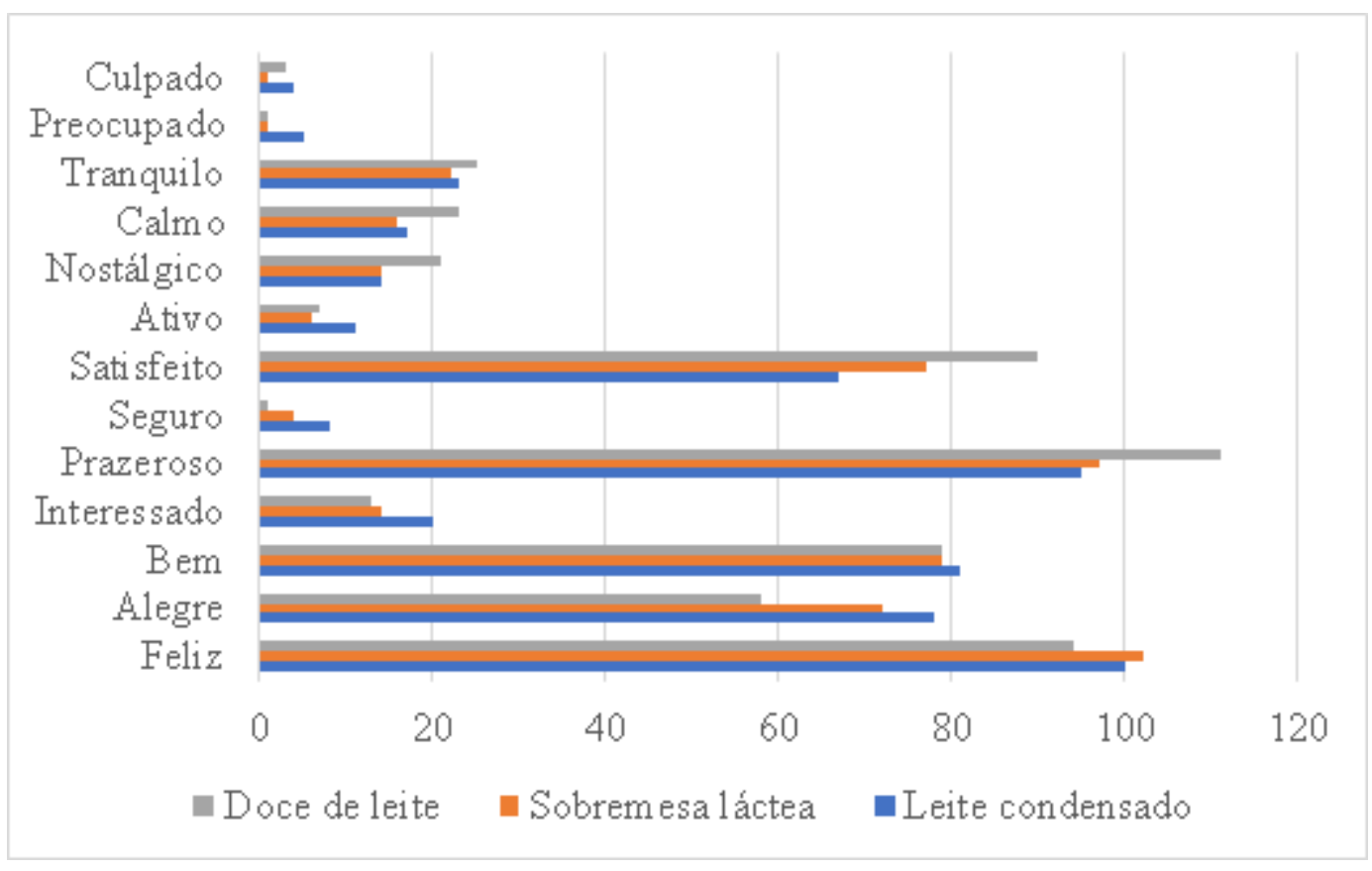

Fonte: Própria (2020)

No momento da compra 99,4\% adquire (Figura 3) o leite condensado em supermercados e o restante $(2,5 \%)$ em feiras, isso em razão de que esses alimentos são encontrados com maior frequência em supermercados. Para embalagem a preferência $(88,5 \%)$ se dar a ele em caixa do que em lata. Assim como o doce de leite que $89,2 \%$ adquire em supermercados e outros $18,1 \%$ faz ou recebem em casa de algum produtor e 45,8 \% optam pela embalagem plástica. Em relação ao tipo 93,4 \% dos indivíduos preferem o doce de leite cremoso e 6,6\% em barra. A embalagem pode ser explicada pelo fator preço, que foi uma preocupação de $62,5 \%$ dos consumidores, ficando atrás somente de qualidade sensorial com $73 \%$. 
Figura 3. Local de aquisição do leite condensado, doce de leite e sobremesa láctea.

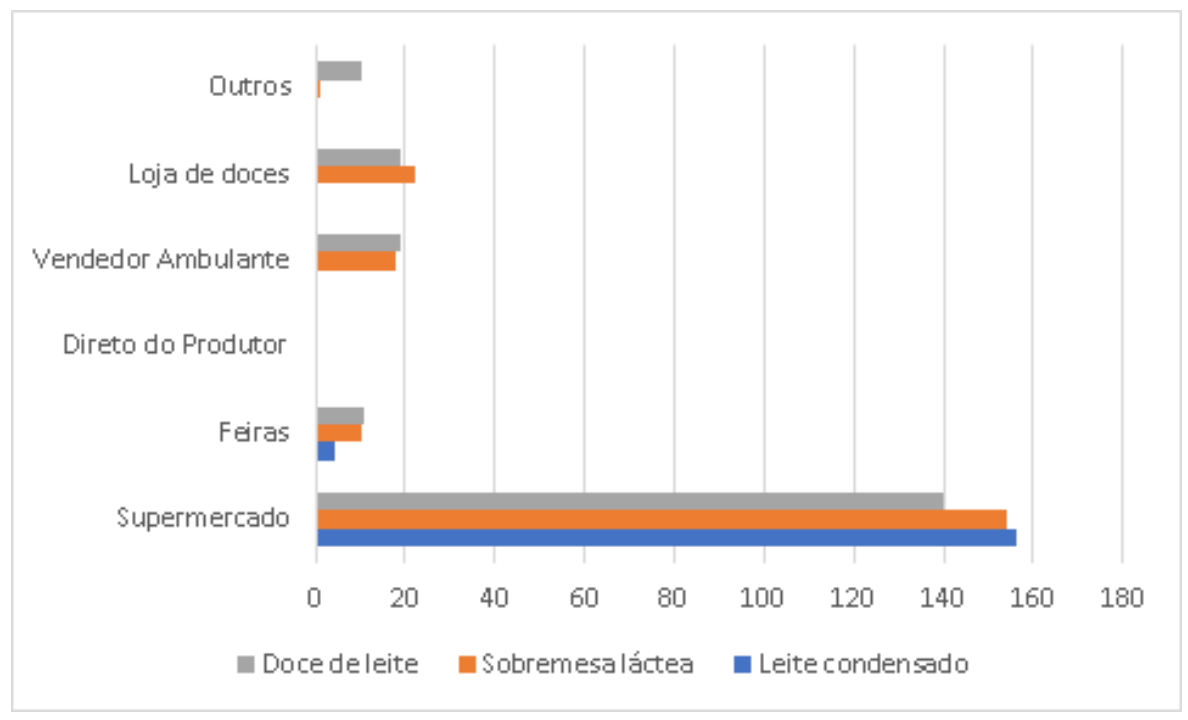

Fonte: Própria (2020)

A predominância na hora da escolha da embalagem de sobremesas lácteas são as de pote plástico $(54,8 \%)$, que está diretamente relacionado com a preferência de 79,6 \% dos indivíduos por sorvete, seguidos de 59,2 \% pudim, $58 \%$ mousse, sendo adquiridas 98,1 \% das vezes em supermercado. Em relação ao sabor (Figura 4), 78,3 \% dos indivíduos declararam que tem preferência por chocolate, outros 47,8\% morango, 36,5 $\%$ leite, $23,5 \%$ limão, 26,1 \% pelo sabor de coco, e ainda a minoria que gosta da de ameixa, baunilha cajá, creme e maracujá. Segundo França (2020) Mais de 20\% das vendas são dos sorvetes tradicionais, como chocolate, creme por exemplo. No entanto, o de leite ninho que está no mercado há quase dois anos vem crescendo. E como todo mundo já deve ter uma ideia, os de frutas também são bastante procurados no verão. Já no inverno, os sorvetes recheados é que são mais consumidos. 
Figura 4. Preferência de sabor das sobremesas lácteas.

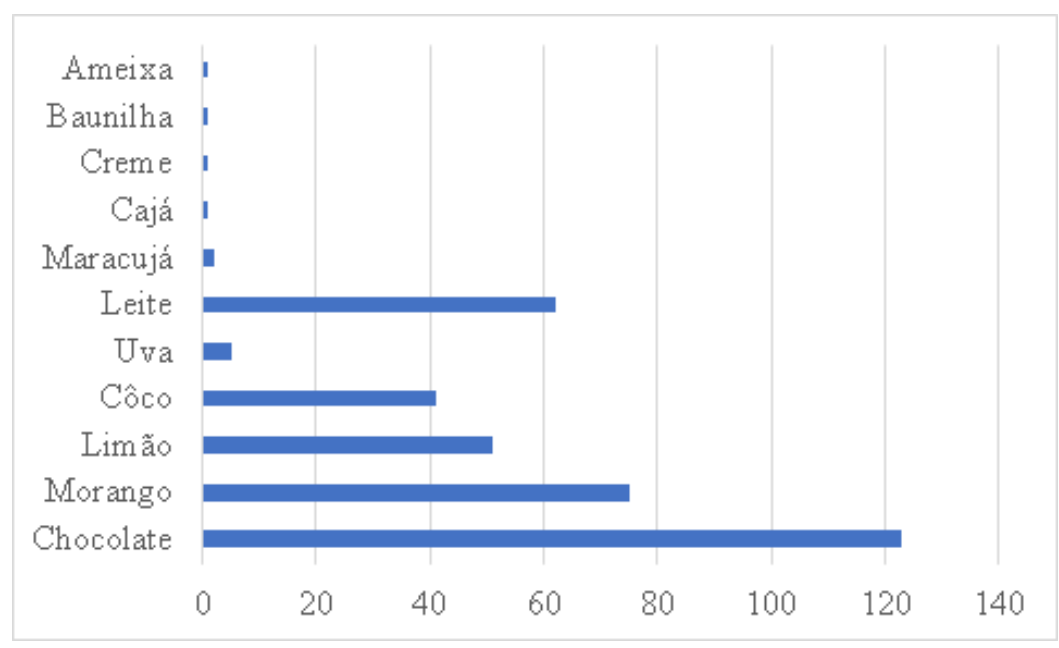

Fonte: Própria (2020)

O consumo de doce de leite (Figura 5), na maior parte, é realizado como opção de sobremesa $(54,8 \%, 67,5 \%, 75,8 \%$, respectivamente), seguido por aqueles que tem preferência em comer puro $(59,2 \%, 61,1 \%, 43,9 \%$, respectivamente) e $28,7 \%$ dos indivíduos consome como acompanhamento tanto para o doce de leite como para a sobremesa láctea. O leite condensado dentre os três foi o que teve maior índice de consumo como uso culinário $(60,0 \%)$. Aproximadamente $50 \%$ dos entrevistados relataram consumi-lo como acompanhamento para salada de fruta, e $(48,0 \%)$ como forma de lanche.

Figura 5. Forma de consumo dos produtos lácteos.

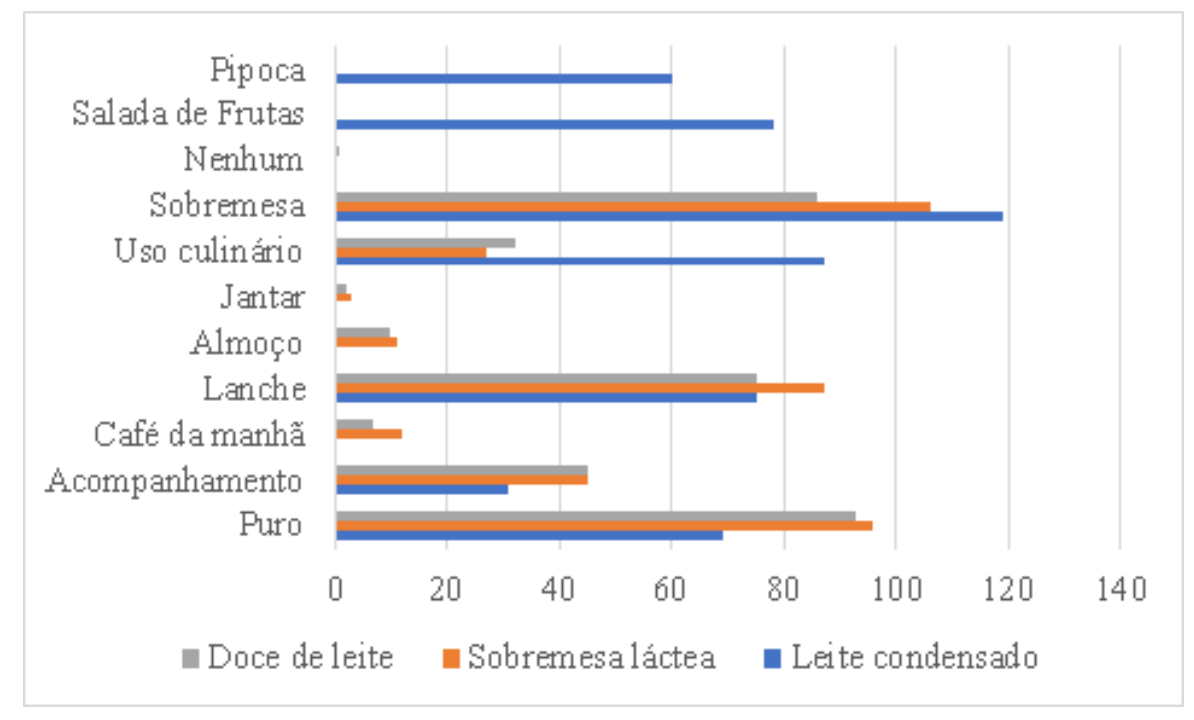

Fonte: Própria (2020).

[772] 
Quando questionados sobre o que tinha de importância para eles no processo produtivo (Figura 6) dos produtos a maioria dos indivíduos se demonstrou preocupados com a higiene tendo uma média de $86,5 \%$ e pelo sistema de inspeção $(46,9 \%)$. Cerca de $30,0 \%$ dos indivíduos demonstrou preferência por aqueles produtos que o leite utilizado no preparo é o pasteurizado, outros $28,1 \%$ prefere o doce de leite e o leite condensado do tipo artesanal. Menos de $1 \%$ dos indivíduos declararam não ter preferência. Mostra que (SILVA; DUTRA; CADIMA, 2010) estavam certos ao dissertar sobre um consumidor que está cada dia mais preocupado com sua saúde e exige que os alimentos sejam saborosos e seguros, bem como é regido pela legislação

Figura 6. Fator de importância no processo produtivo dos alimentos para os consumidores.

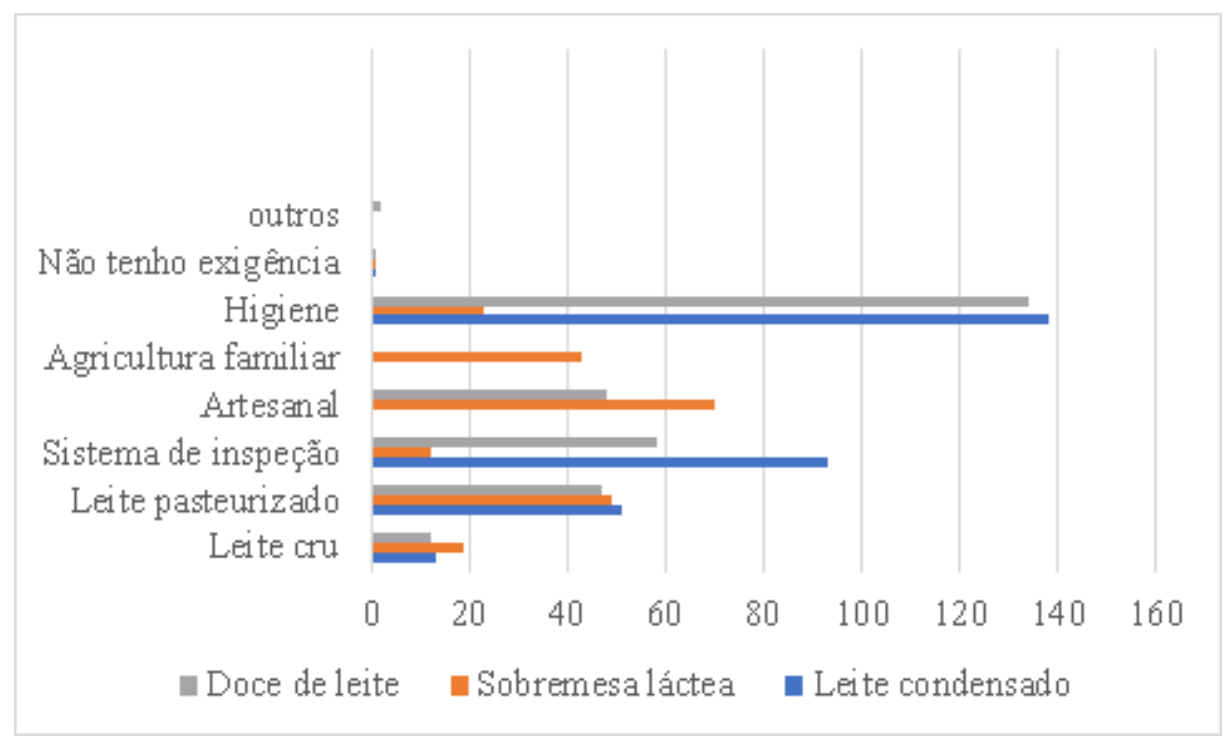

Fonte: Própria (2020)

No momento da compra do doce de leite, leite condensado e/ou sobremesas lácteas o que tem mais peso e o que os indivíduos costumam se preocupar (Figura 7) primeiramente é com a qualidade sensorial $(73,9 \%)$, seguido pelo preço $(61,1 \%)$, segurança que a marca transparece (higiene, livre de contaminantes, riscos...)(57,3\%), a origem do produto $(36,3 \%)$, informações presente no rótulo ( $28,0 \%)$ assim como características nutricionais $(16,6$ \%), se possui ou não o sistema de inspeção (municipal, estadual e federal) $(27,4 \%)$ e ainda há aqueles que ficam divididos e observam a qualidade do produto e a marca $(1,2 \%)$.] 
Figura 7. Preocupação no momento da compra.

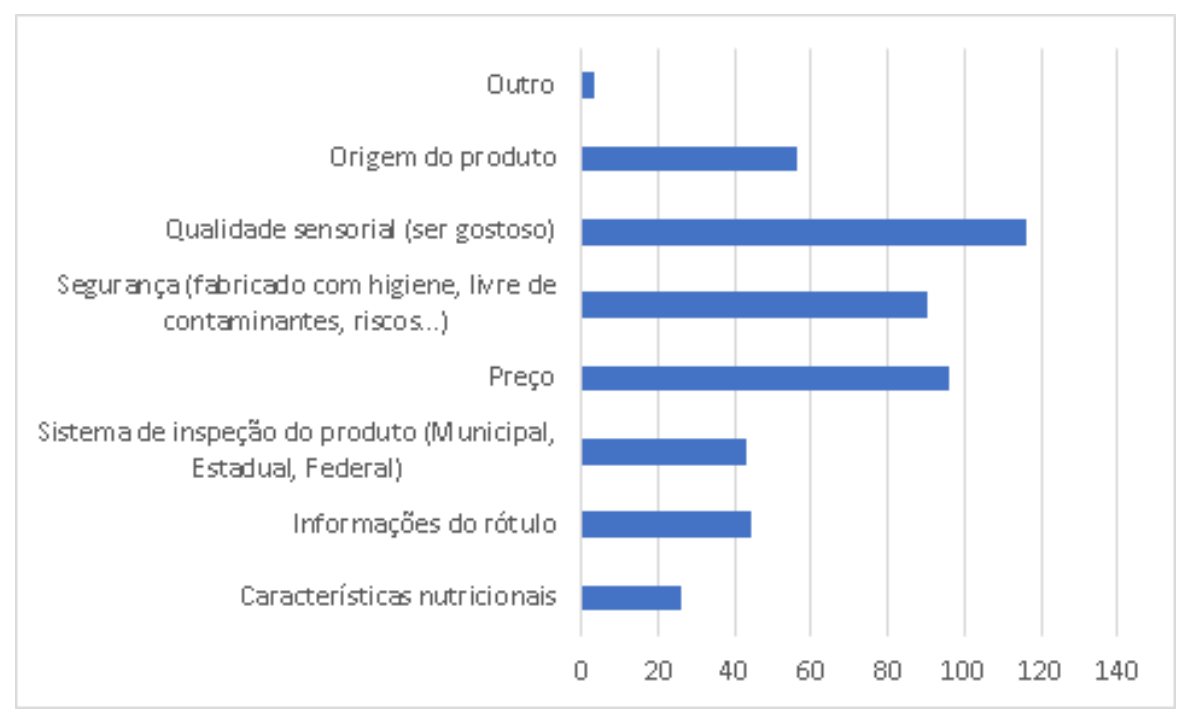

Fonte: Própria (2020)

Dos indivíduos que responderam o questionário 91,6\% afirmam que a principal razão para consumir alguns dos três produtos se deve às características sensoriais, seguido pelo aroma (33,1\%), e ainda há aqueles que optem pelo consumo por acreditarem que traz benefícios a sua saúde $(8,3 \%)$. Ao serem questionados se estariam dispostos a pagar mais por um produto (Figura 8 ), $76,4 \%$ afirmaram que pagariam mais, destes $54,1 \%$ por alimentos de origem artesanal, 39,5 \% orgânicos, 15,3\% light e 12,7 \% sem lactose. E os outros 23,6 \% afirmam que não estavam dispostos a pagar um valor maior. Quando perguntado o que seria um produto artesanal na opinião deles $84,1 \%$ considera um produto artesanal aquele que é feito de forma manual com o mínimo uso de equipamentos, $63,1 \%$ produzido pelo pequeno produtor, $36,3 \%$ produzido em pequena escala, $16,6 \%$ produzido a partir de leite cru, 3,2 \% com leite pasteurizado e $3,2 \%$ produzido de forma industrial em larga escala. O que nos revela que os alimentos artesanais são conhecidos por uma parte do público que participou do questionário e cada dia mais estão ganhando espaço no mercado. Porém alguns dos participantes ainda deixaram comentários que reforçam a necessidade de trabalho e divulgação desses alimentos, um dos comentários que chamou atenção:

"Existe uma grande desvalorização dos produtos artesanais e orgânicos, sendo difícil encontrar em mercados de cidades pequenas, se houvesse uma maior valorização desses produtos acabaria ajudando tanto a população que teria acesso a produtos diferente e 
muitas vezes mais "interessantes", e aos pequenos produtores que teriam um maior número de consumidores em potencial."

Figura 8. Sensibilidade ao preço e disposição do consumidor a pagar mais.

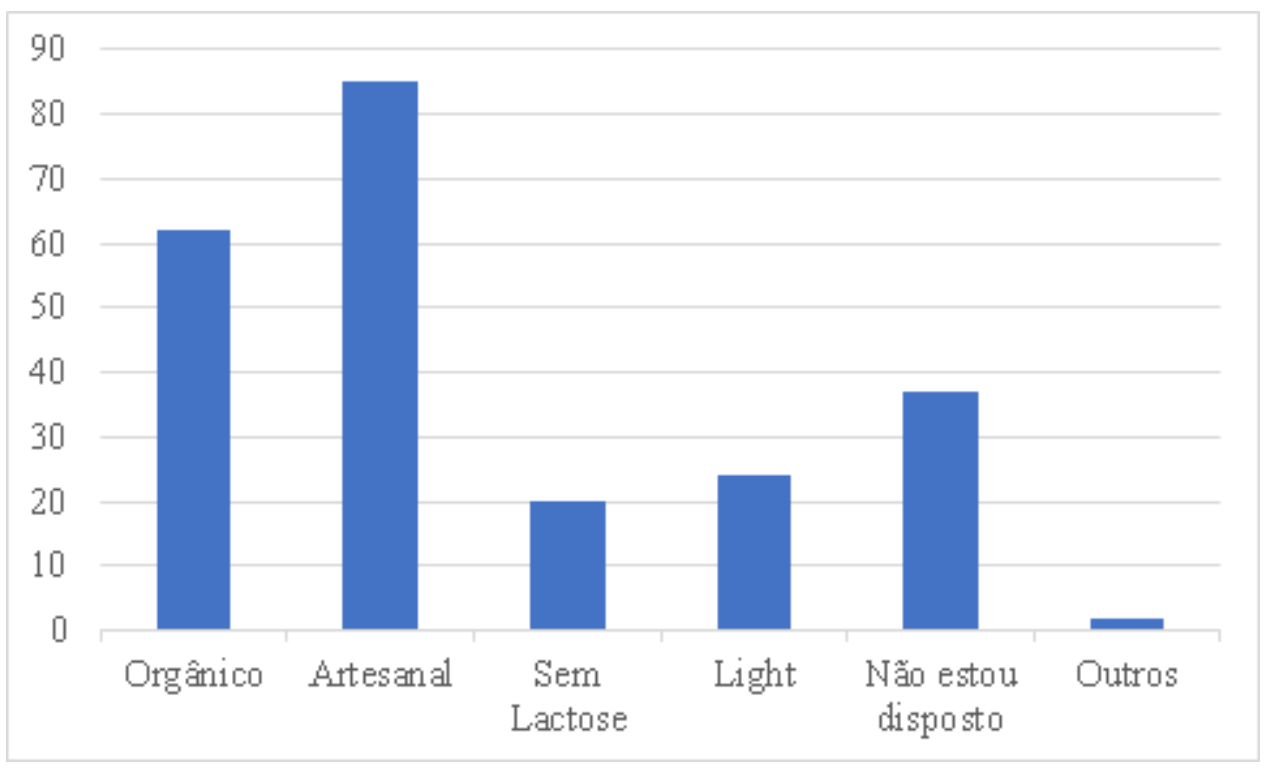

Fonte: Própria (2020)

Sendo o sabor e a marca os principais motivos para escolha do produto, visto que $66,2 \%$ compra por ser o mais gostoso e 59,2\% compra apenas de uma marca de confiança, $22,3 \%$ leva em consideração o preço, e ainda tem os que valorizam os produtos regionais $(18,5 \%)$. Outro ponto que se demonstrou importante na escolha dos produtos (Figura 9) é a opinião dos demais consumidores, uma vez que 21,7\% compra o produto através de indicações e percepções de outros consumidores acerca do produto, assim como 0,6\% consome o produto pelo mesmo motivo. A percepção de outros consumidores já era discutida por Kotler e Keller (2012), que tratavam o comportamento dos outros como um fator fundamental, quando relacionado a atitudes e opiniões alheias que poderiam vir a ajudar ou atrapalhar na decisão de compra. 
Figura 9. Fatores de influência na escolha do produto.

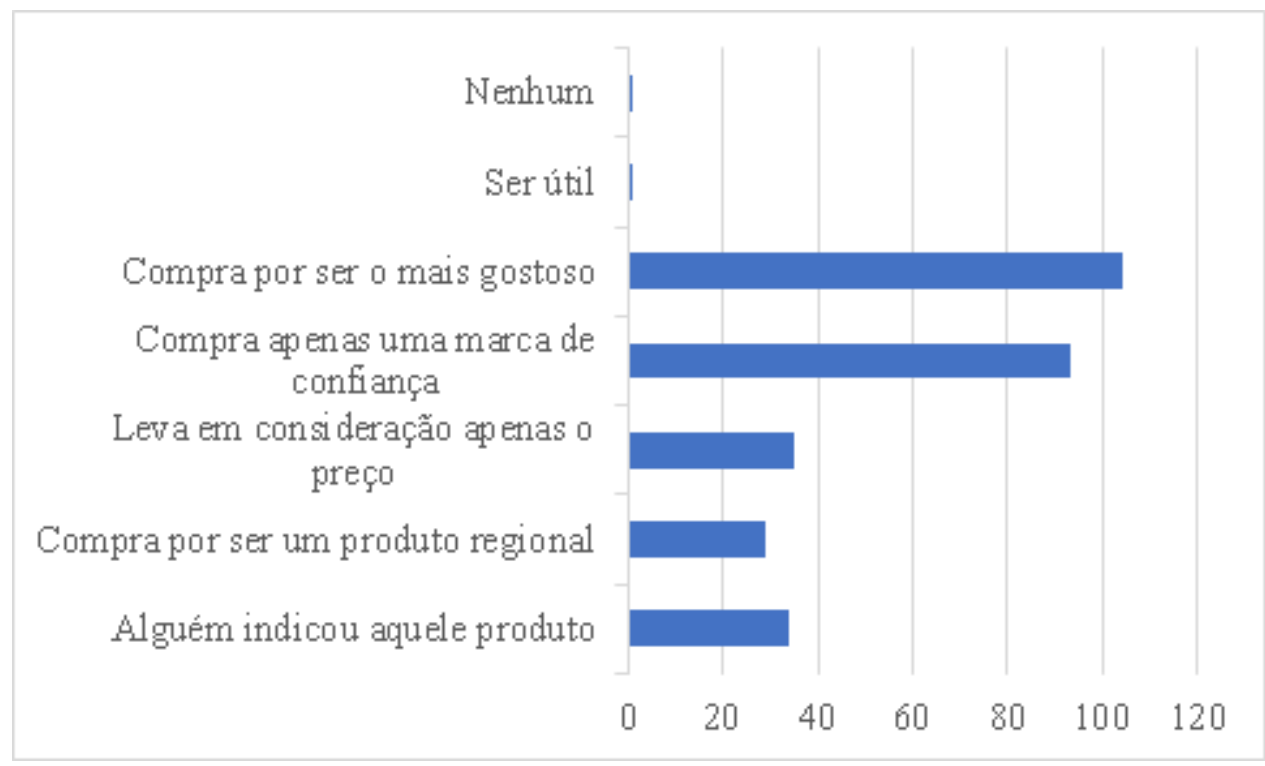

Fonte: Própria (2020)

Para efeito investigativo em cerca da pandemia que o Brasil atualmente enfrenta com a COVID-19, os 157 indivíduos foram questionados inicialmente se notou ou não um aumento no consumo (Figura 10) do doce de leite, leite condensado e sobremesas lácteas 44,6\% dos indivíduos perceberam um aumento do consumo desses produtos dentro o atual quadro que o país inteiro se encontra, $26,1 \%$ um pouco, $21,0 \%$ não, 8,3 $\%$ talvez. A grande maioria (65,5 \%) (103) não notou dificuldade (Figura 11) alguma em adquirir algum desses produtos, enquanto $20,4 \%$ acreditam que sim e desses $(22,14 \%)$ assimila isso a pandemia, e outros $14 \%$ não souberam responder. 
Figura 10. Aumento de consumo de doce de leite, leite condensado e sobremesa Láctea no período de pandemia. (Você notou se houve um aumento no valor de algum desses produtos? Acredita que está relacionado com o quadro atual em que o Brasil se encontra?)

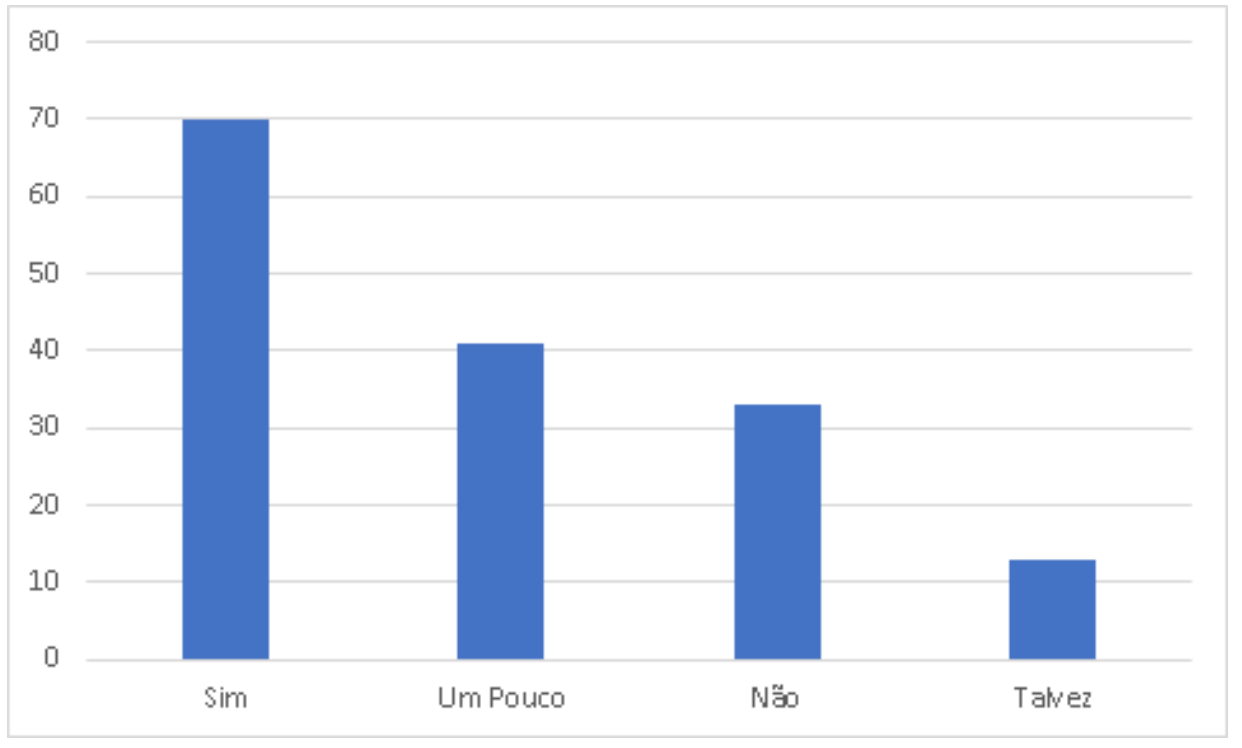

Fonte: Própria (2020).

Figura 11. Dificuldade na aquisição dos alimentos. (Você acredita que exista alguma dificuldade em adquirir o produto ou a falta do mesmo?).

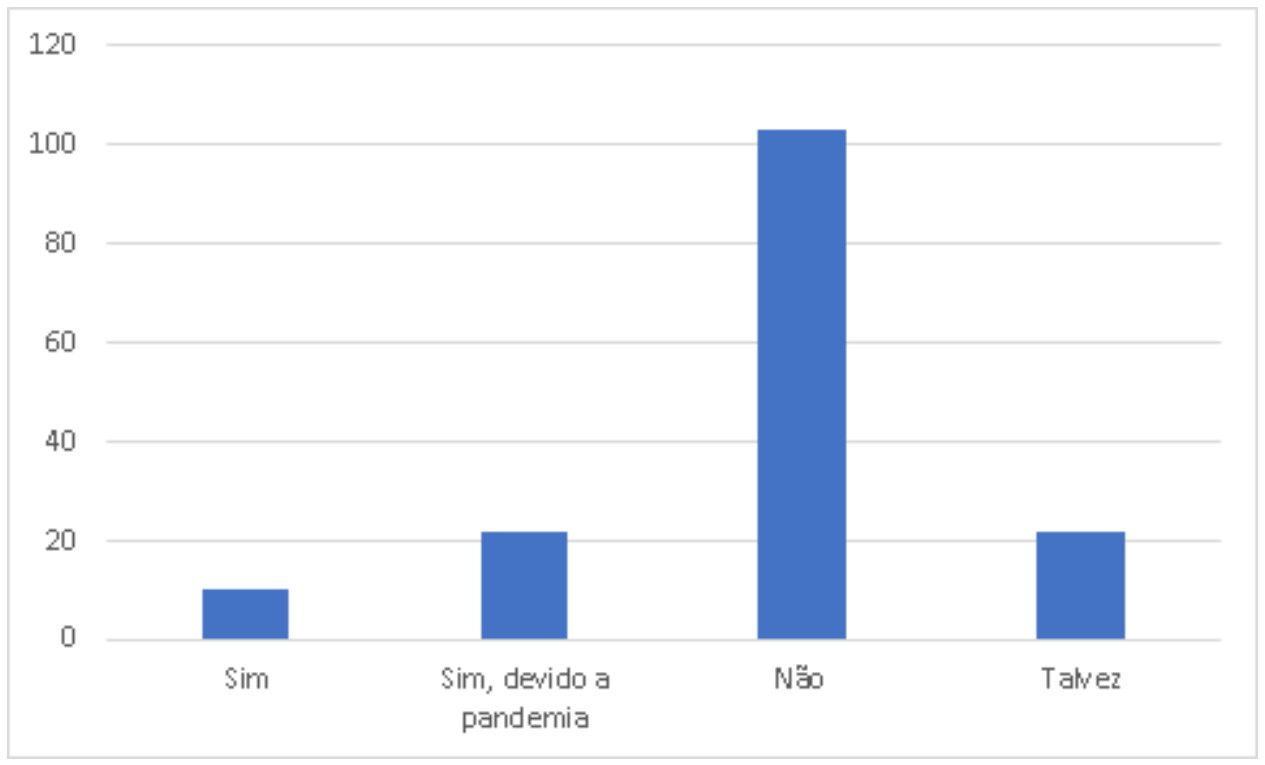

Fonte: Próprio (2020)

Em relação a precificação acerca dos produtos (Figura 12) devido à dificuldade em torno da produção e distribuição destes $63,1 \%$ dos indivíduos notaram um aumento no valor de algum desses produtos e acredita que esteja relacionado com a pandemia, 4,5 
$\%$ afirmam ter tido o aumento mas acreditam que não esteja relacionado com a pandemia e $14 \%$ não notaram aumento algum e 18,5 \% ficaram na dúvida (Figura 13).

Figura 12. Percepção acerca da precificação do doce de leite, leite condensado e sobremesa Láctea. (Você notou se houve um aumento no valor de algum desses produtos? Acredita que está relacionado com o quadro atual em que o Brasil se encontra?).

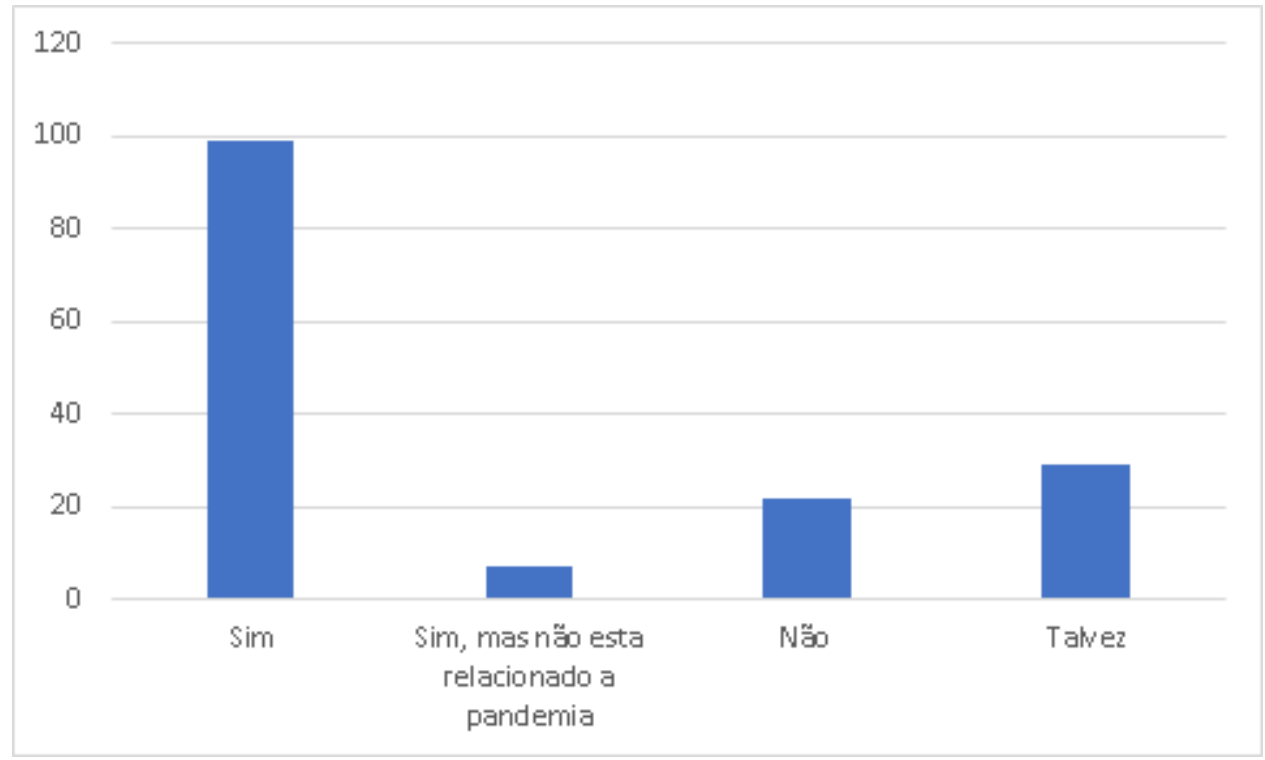

Fonte: Própria (2020)

Figura 13. Comparativo entre o acréscimo no consumo, dificuldade em adquirir e o aumento no valor dos produtos.

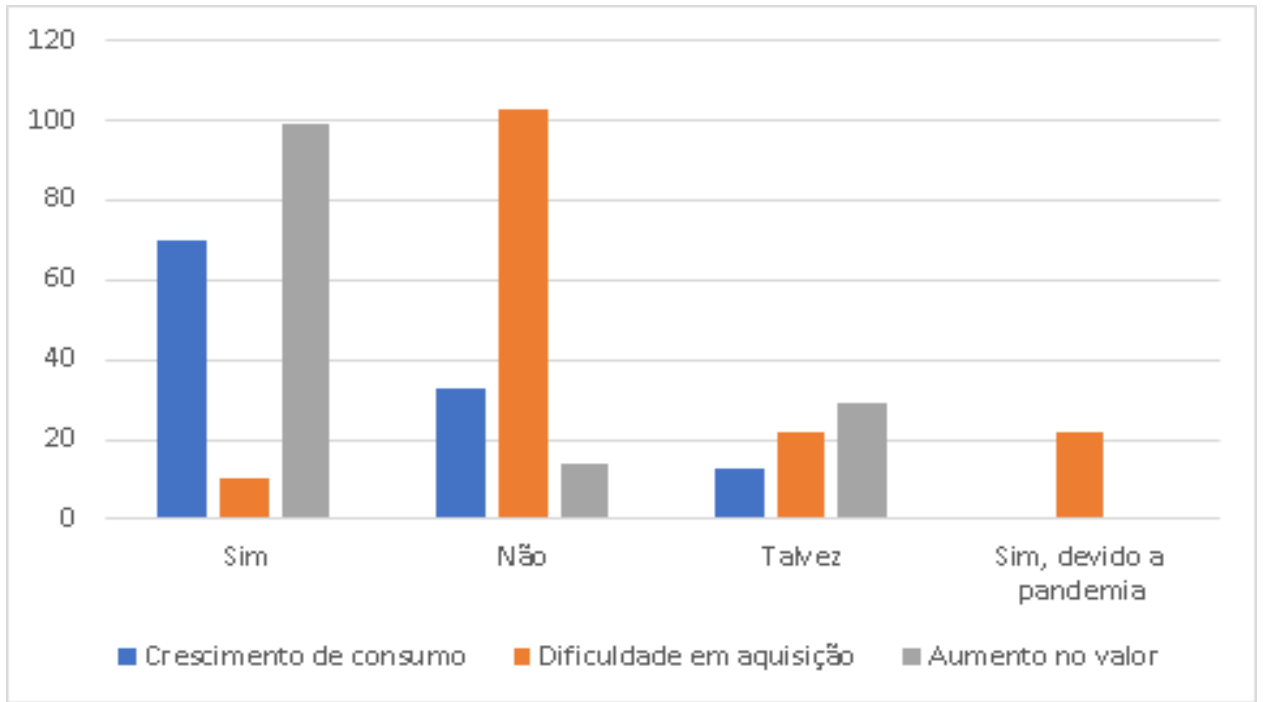

Fonte: Próprio (2020) 


\section{Conclusões}

O resultado deste estudo destaca-se por apresentar o debate sobre o que motiva o público respondente a consumir os produtos doce de leite, leite condensado e sobremesas lácteas e a relação entre o aumento ou diminuição destes na rotina do convívio com a pandemia. Observou-se a carência de pesquisas voltadas e este nicho de mercado nas condições de distanciamento e isolamento sociais quanto ao consumo de derivados do leite e as indústrias de laticínios para buscar entender os impactos de interesses e dificuldades dos consumidores, bem como, obter respostas para melhor ajudar às indústrias no que diz respeito à compreensão e fortalecimento na relação com seus clientes. As pesquisas de satisfação, inovação e confiabilidade são fatores de influência na hora da compra de um produto alimentício. foi possível identificar que o consumo de doce de leite, leite condensado e sobremesas lácteas acontecem na maior parte dos casos por jovens entre 16 e 25 anos para o preparo de sobremesas ou como acompanhamento, e que os usuários estão atentos a indicações de marca e a relação de qualidade e preço, buscando pelo custo-benefício.

Deste modo pode-se afirmar que os objetivos do artigo foram alcançados pois foi possível identificar que o consumo de doce de leite, leite condensado e sobremesas lácteas acontecem na maior parte dos casos por jovens entre 16 e 25 anos para o preparo de sobremesas ou como acompanhamento, e que os usuários estão atentos a indicações de marca e a relação de qualidade e preço, buscando pelo custo-benefício.

\section{Referências}

FRANÇA, Lucas. Calor aumenta vendas de sorvetes. Tribunahoje, Macéio-Alagoas, n. 3558, 11 jan. 2020. Cidades, p. 13. Disponível em: https://issuu.com/tribunahoje/docs/ed11e120120. Acesso em: 27 jul. 2020.

KOTLER, P.; KELLER K. L. Administração de Marketing. São Paulo: Pearson, 2012.

MINASSE, Maria Henriqueta Gimenes. Comfort food: sobre conceitos e principais características. Contextos da Alimentação - Revista de Comportamento, Cultura e Sociedade, São Paulo, v. 4, n. 2, 2016.

SCHUBERT, Maycon Noremberg. Hábitos alimentares em tempos de mudanças provocadas pela Covid-19. Porto Alegre: UFRGS, 30 mar. 2020. Disponível em: https://www.ufrgs.br/ifch/index.php/br/habitos-alimentares-em-tempos-de-mudancasprovocadas-pela-covid-19. Acesso em: 28 jul. 2020. 
SEBRAE (Brasil). Tristeza e indulgência. OS ASPECTOS DA INDULGÊNCIA NO CONSUMO DE PANIFICADOS E CONFEITARIA, Brasília, p. 4-10, 2017. Disponível em: https://bis.sebrae.com.br/bis/conteudoPublicacao.zhtml?id=19205. Acesso em: 18 jul. 2020.

SEBRAE (Pernambuco). Produção de leite na Região Nordeste e seus estados. CENÁRIOS PARA O LEITE E DERIVADOS NA REGIÃO NORDESTE EM 2020, Recife, p. 154, 2013.

SILVA, Gilvan; DUTRA, P.R.S; CADIMA, I.M. Higiene na Indústria de Alimentos. Curso técnico em alimentos- Modalidade a distância, Recife, p. 16, 2010.

UNIVERSIDADE FEDERAL DE JUIZ DE FORA (Juiz de Fora). Estudo analisa consumo de derivados lácteos durante a quarentena. Pesquisa e Inovação, Juiz de Fora, 27 abr. 2020. Disponível em: https://www2.ufjf.br/noticias/2020/04/27/estudo-analisaconsumo-de-derivados-lacteos-durante-a-quarentena/. Acesso em: 18 jul. 2020.

WANSINK, Brian; CHENEY, Matthew; CHAN, Nina. Exploring comfort food preferences across age and gender. In: Physiology \& behavior, 2003, 79, p.739-743. 


\title{
CAPÍTULO 50: APROVEITAMENTO INTEGRAL DOS ALIMENTOS COMO INSTRUMENTO DE SEGURANÇA ALIMENTAR E DESENVOLVIMENTO HUMANO: ÊXITOS E DESAFIOS
}

\section{CHAPTER 50: TOTAL FOOD UTILIZATION AS A TOOL FOR FOOD SECURITY AND HUMAN DEVELOPMENT: SUCCESSES AND CHALLENGES.}

Iasmim Pereira Oliveira ${ }^{1}$; Aurianna Coelho Barros ${ }^{2}$, Nailton Macedo de Albuquerque Júnior ${ }^{3}$, Ana Júlia de Brito Araújo $^{4}$, Silvana Belém de Oliveira Vilar ${ }^{5}$

\begin{abstract}
Resumo
A partir do extremo desperdício de alimentos no mundo, o aproveitamento integral e a elaboração de novas formulações alimentícias estimulam alternativas tecnológicas sustentáveis, que podem ser aplicadas tanto em âmbito industrial quanto doméstico. No entanto, para que isso aconteça, torna-se necessário a capacitação das famílias, respeitando as leis de segurança alimentar. O objetivo do presente trabalho foi auxiliar o desenvolvimento econômico e a qualidade de vida de adolescentes grávidas e colaboradores de uma ONG, conscientizando e induzindo a população sobre o uso das partes não convencionais dos alimentos e sua vasta riqueza nutricional. Com uma metodologia de ação educativa direta, foi possível capacitar o público alvo através de aulas práticas e teóricas, baseado em cartilhas de informações e formulações. Este método foi validado através de aplicação de questionários no local, e como resultado o presente trabalho instigou o espírito empreendedor, estimulou a autonomia das adolescentes, disseminou conhecimentos específicos, proporcionou a de trocas de saberes entre profissionais e comunidade, auxiliou no desenvolvimento econômico e social, visando a superação das desigualdades existentes. Portanto, pôde-se concluir que, ações realizadas além dos muros das instituições são necessárias e eficazes para o bem comum, assim como uma ferramenta social.
\end{abstract}

Palavras-chave: capacitação, riqueza nutricional, alternativas tecnológicas, empreendedorismo, qualidade de vida.

\begin{abstract}
From the extreme waste of food in the world, the full use and development of new food formulations stimulate sustainable technological alternatives, which can be applied both in the industrial and domestic spheres. However, for this to happen, it is necessary to empower families, respecting food security laws. The objective of this study was to assist the economic development and quality of life of pregnant adolescents and collaborators of an NGO, raising awareness and inducing the population about the use of unconventional parts of food and its vast nutritional wealth. With a direct educational action methodology, it was possible to train the target audience through practical and theoretical lessons, based on information booklets and

\footnotetext{
${ }^{1}$ Tecnóloga em alimentos, IF Sertão - PE, mimuefs@ gmail.com

${ }^{2}$ Profa. MSc. Tecnologia em alimentos, IF Sertão - PE, aurianna.coelho@ifsertao-pe.edu.br

${ }^{3}$ Tecnólogo em alimentos, IF Sertão - PE, junior.nailton99@ gmail.com

${ }^{4}$ Profa. MSc. Tecnologia em alimentos, IF Sertão - PE; ana.julia@ifsertao-pe.edu.br

${ }^{5}$ Profa. DSc. Tecnologia em alimentos, IF Sertão - PE; silvana.belem@ifsertao-pe.edu.br
} 
formulations. This method was validated through the application of questionnaires on site, and as a result the present work instigated the entrepreneurial spirit, stimulated the autonomy of adolescents, disseminated specific knowledge, provided the exchange of knowledge between professionals and community, assisted in economic and social development, aiming at overcoming existing inequalities. Therefore, it could be concluded that actions carried out beyond the walls of institutions are necessary and effective for the common good, as well as a social tool.

Keywords: training, nutritional wealth, technological alternatives, entrepreneurship, quality of life.

\section{Introdução}

O problema da fome ainda é existente e atualmente pode piorar, não só no Brasil como no mundo. Segundo o economista Daniel Balaban, chefe do escritório brasileiro do Programa Mundial de Alimentos (WFP, na sigla em inglês), da ONU, a pandemia pode levar cerca de 130 milhões de pessoas no mundo para a situação extrema pobreza e dobrar o número de habitantes com fome crônica - quem não têm alimentos suficiente no final do dia (TERRA, 2020). Entretanto, um estudo realizado pela FAO (Organização das Nações Unidas para a Alimentação e a Agricultura) em 2016, demonstrou que a produção mundial de alimentos é suficiente para alimentar 7,3 bilhões de pessoas que habitam a Terra.

Embora a produção diária de alimentos seja suficiente para alimentar a população mundial, ainda existem milhares de pessoas sofrendo com a privação quantitativa deles, a fome continua sendo um grande desafio. No mundo, estima-se que a cada ano se perde aproximadamente 1,3 bilhão de toneladas de alimentos, isso representa mais de $30 \%$ de toda produção mundial para consumo humano, e toda essa comida seria mais do que suficiente para alimentar as 821 milhões de pessoas que ainda passam fome (FAO, 2018).

Estima-se que $10 \%$ de tudo que é produzido no Brasil se torna resíduo alimentar, um número aproximado de 26 milhões de toneladas de alimentos, que alimentaria 40 milhões de pessoas, ou seja 5,5 vezes o número de habitantes famintos no país, dos quais 5,3 milhões de toneladas são de frutas e 5,6 milhões de toneladas de hortaliças (CEDES e EMBRAPA, 2018).

O desperdício e a perda de alimentos são um grave problema que precisa ser resolvido em diversos países, principalmente por conta do elevado crescimento da população mundial. De acordo com um relatório emitido pela FAO, foi registrado um aumento no número de pessoas subalimentadas em todo o planeta, subindo de 804 milhões de indivíduos em 2016 para aproximadamente 821 milhões no ano de 2017, dos quais 21,4 milhões de habitantes estão situados somente na América do Sul (FAO, 2018). 
Todavia, grande parte da população desconhece as vantagens no emprego do aproveitamento integral dos alimentos (AIA). Muitos indivíduos não buscam informações a respeito de seus benefícios, e diversos outros conhecem, mas não há interesse na prática (GONDIM et al., 2005; NUNES; BOTELHO, 2009; CEDES, 2018).

O AIA desde o início da década de 1970, é uma alternativa que veio ganhando espaço como matéria-prima de produtos perfeitamente passíveis de serem incluídos na alimentação (SIUZA, et al. 2007). Porém, convém dizer que o AIA não é só indicado para pessoas de baixa renda, mas também para toda população. Salienta-se também que a utilização dos alimentos em sua integralidade possui um potencial sustentável e ecologicamente correto permitindo a redução de gastos com alimentação da família, e estimulando a diversificação dos hábitos alimentares (SANTANA; OLIVEIRA, 2005).

O número de pessoas que aproveitam de forma integral os alimentos ainda é muito pequeno, e para aumentar esse índice é necessário compartilhar o conhecimento obtido nas instituições de pesquisa para a população, divulgando as técnicas corretas de processamento, principalmente nas escolas, creches e comunidades, tendendo o fortalecimento dessa proposta e para que ela seja incorporada aos hábitos alimentares da população (NUNES; BOTELHO, 2009; CEPS, 2018).

Para que se implementem as ações efetivas que viabilizam o AIA, se faz necessário a capacitação das famílias para o desenvolvimento de receitas de fácil manuseio, em nível doméstico, respeitando-se também as leis de segurança de alimentos, para que a qualidade das preparações seja garantida.

Arruda e Berbert (2015), destacaram as partes não convencionais (PNC) de alguns vegetais e sua importância nutricional, a exemplo de talos de beterraba, brócolis, couve, salsa e agrião, ricos em fibras, e este último rico também em ferro, cálcio e vitamina $\mathrm{C}$; cascas de frutas, batata, mandioquinha e laranja, ricas em fibras e a última também em cálcio; entrecascas de melancia e melão, ricas em fibras e potássio; folhas de cenoura, ricas em vitamina A; e, por fim, a própria água de cozimento dos alimentos, que contém, em grade parte, quantidades significativas de vitaminas hidrossolúveis.

A CODEAGRO (2016), também listou algumas das PNC dos alimentos, que possivelmente podem serem utilizadas na preparação de refeições, tais como cascas de laranja, banana, tangerina, goiaba, beterraba, melão e manga; entrecascas de: mandioca, melancia, maracujá e melão; batata inglesa, abacaxi, maracujá, mamão, abóbora, maçã folhas de beterraba, nabo, abóbora, cenoura, batata-doce, couve-flor, rabanete e brócolis; talos de espinafre, beterraba, brócolis, couve-flor e agrião; e sementes de melão, abóbora e jaca. 
A interação entre as formas de produzir e comercializar e os modos de consumo e alimentação são essenciais para desenvolver métodos sustentáveis, tanto de produção quanto de consumo. Discutir AIA é, pois, uma forma de contribuir para buscar alternativas para a oferta de produtos oriundos de partes de alimentos de grande valor nutricional (CASSOL E SCHNEIDER, 2015).

Através do uso das partes comumente inutilizadas dos vegetais, é possível não só alimentar mais pessoas, como também ponderar as carências nutricionais que possam existir, já que boa parte dos alimentos descartados apresentam elevados teores de nutrientes (LAURINDO; RIBEIRO, 2014).

Aiolfi e Basso (2013), elaboraram 3 produtos alimentares com o AIA, entre eles os autores desenvolveram um bolo feito com casca de banana, e após análise sensorial, chegaram a conclusão que o bolo obteve o maior aceitabilidade (97\%) em comparação com os outros produtos desenvolvidos.

Orloski et al. (2018), avaliaram cookies de aveia, adicionando na receita padrão 5\% de farinha de casca de abobrinha e obtiveram índice de aceitabilidade maiores à $70 \%$, concluindo que houve boa aceitabilidade no presente estudo.

Levando em consideração o estilo de desenvolvimento econômico atual, pode-se dizer que ele estimula o desperdício. Apesar da fome ser um problema social no país as técnicas para o AIA ainda são pouco conhecidas e difundidas. Diante do desperdício de alimentos, fazse necessário adotar medidas que levem a população às práticas de consumo consciente em relação à alimentação.

A partir desta perspectiva, o objetivo do presente trabalho foi capacitar adolescentes grávidas e colaboradores de uma ONG em Petrolina-PE sobre técnicas de conservação e processamento de PNC dos alimentos, bem como estimular seu desenvolvimento econômico e qualidade de vida.

\section{Material e Métodos}

O trabalho foi desenvolvido no período de maio a dezembro de 2019, público alvo escolhido foram adolescentes grávidas e mães adolescentes, de uma ONG de Petrolina - PE. Baseado em estudos de Casique, (2006); Riley , (1997); onde demonstraram que o aumento do controle das mulheres sobre suas próprias vidas e sobre seu acesso a recursos materiais e sociais é fundamental para melhorar a qualidade de vida e de saúde de mulheres e crianças. Desta forma o público alvo foi identificado, levando em consideração que, o projeto além de 
proporcionar conhecimento sobre o tema também poderia auxiliar adolescentes grávidas e/ou mães com opções viáveis de melhoria de qualidade de vida delas e de seus filhos.

Este projeto realizou uma metodologia de ação educativa direta, onde foram capacitadas adolescentes com faixa etária de 16 - 28 anos, separadas por 2 turmas de 8 jovens, através de palestras informativas e cursos de capacitação, já que se fazia necessário um embasamento teórico primeiramente para que as alunas pudessem compreender melhor o tema.

Primeiramente realizou-se um levantamento de dados e elaboração das formulações dos produtos que seriam produzidos pelas alunas, seguidos de testes destes produtos levando em consideração a facilidade de produção. Foi produzido também cartilhas (Figura 1) de informações destas receitas onde continham as formulações e textos teóricos sobre o tema abordado, para facilitar a execução/aplicação das aulas práticas.

Em sequência foram ministradas no total 15 aulas, onde as estas tiveram $4 \mathrm{~h}$ de carga horária/dia, para que fossem abordados os temas escolhidos, separadas em teoria e prática. As aulas teóricas foram divididas em três etapas, onde a primeira consistiu em informar as técnicas de higienização e segurança alimentar, assim como o passo a passo destes e das formulações. A segunda etapa abordou sobre o uso integral dos alimentos, grupos de nutrientes, pirâmide alimentar e exemplos de receitas, e a terceira etapa levou informações sobre: embalagens, armazenamento, elaboração de etiquetas e rótulo, tabela nutricional e empreendedorismo (Quadro 1). Já as aulas práticas foram para elaboração dos produtos escolhidos, exposição e sua degustação.

Todos os resultados foram avaliados no programa Excel 2013, a partir de modelagem matemática simples de média e percentagem. 
Figura 01. Cartilha de aprendizado e formulações

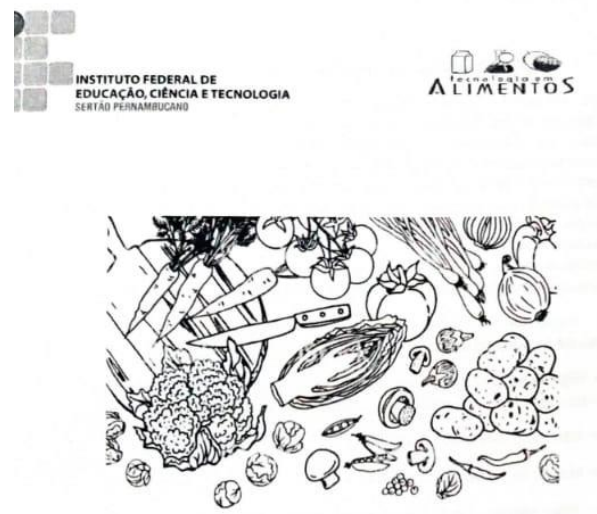

CURSO SOBRE APROVEITAMENTO INTEGRAL DOS ALIMENTOS
Bolsista: lasmim Pereira Orientadora: Silvana Belém

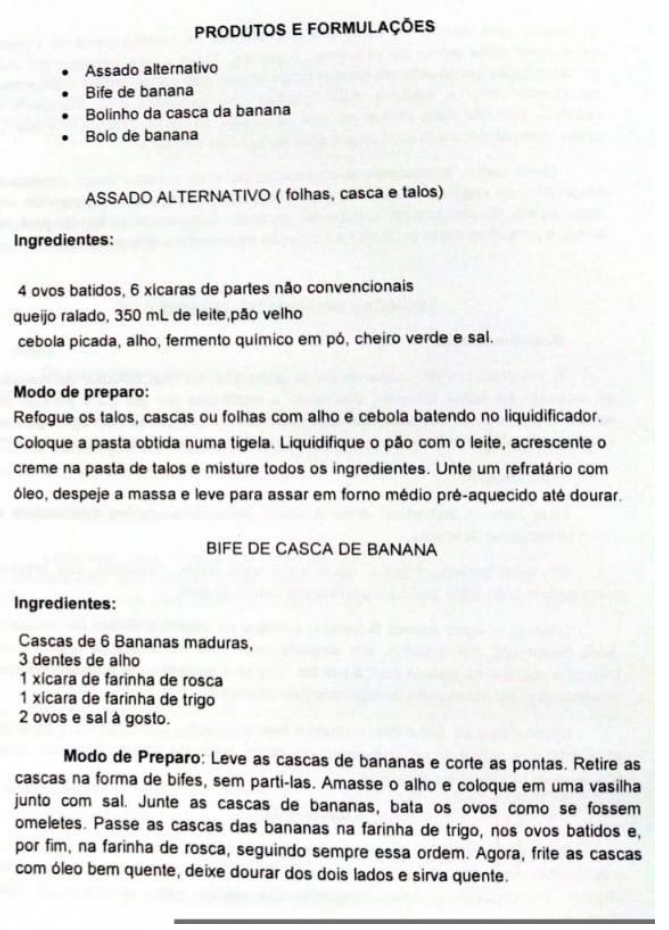

PETOLINA - 2019

Fonte: Própria (2019)

A linguagem utilizada para explanar os assuntos foi de fácil compreensão, através do uso de multimídias como slides e vídeos, estimulando a interação e a exposição dos conhecimentos a respeito do tema.

Para além disso, o curso buscou auxiliar a ONG nas suas atividades, uma vez que ela recebe semanalmente doações de alimentos, levando táticas sobre a conservação e armazenamento. Além do mais auxiliou na utilização dos resíduos alimentares do refeitório no local. 
Quadro 01. Aulas práticas e teóricas ministradas durante o curso AIA.

\begin{tabular}{|c|c|}
\hline Aulas Teóricas & Aulas Práticas (formulações) \\
\hline Introdução & $\begin{array}{l}\text { Assado alternativo, bife de casca de banana, } \\
\text { bolinho de cascas e talos e assado de chuchu; }\end{array}$ \\
\hline Higiene e manipulação & $\begin{array}{l}\text { Bolo de casca de abóbora, panqueca verde, } \\
\text { purê de abóbora com casca, bolinho de casca } \\
\text { de banana; }\end{array}$ \\
\hline Aproveitamento integral & $\begin{array}{l}\text { Strogonoff da entrecasca da melancia, arroz } \\
\text { com talos, pão de casca de banana; }\end{array}$ \\
\hline Embalagens & $\begin{array}{l}\text { Polenta nutritiva, pizza fingida, bolo de pão } \\
\text { com legumes. }\end{array}$ \\
\hline Tabelas e Rótulos & \\
\hline Empreendedorismo & \\
\hline
\end{tabular}

Fonte: Própria (2019).

Após realização das oficinas de capacitação, foi aplicado um questionário as alunas (Quadro 2), para averiguar informações pertinentes a aprendizagem gerada bem como sua aplicação.

Figura 02. Questionário, sobre o tema, aplicado nas turmas no fim do curso AIA.

\section{Questionário projeto extensão}

1 - Antes do curso você já tinha algum conhecimento sobre o tema?

2 - Você fazia o uso integral dos alimentos na sua casa antes do curso? E depois?

3 - Qual foi seu nível de aprendizado durante o curso? O curso mudou seu pensamento sobre as partes não convencionais dos alimentos?

4 - O curso mostrou como aumentar o empoderamento e autonomia feminina?

5 - O curso incentivou o empreendedorismo e a realização de novas atividades relacionadas ao tema?

6 - O curso teve impacto na sua vida? 


\section{Resultados e Discussão}

Durante o projeto foi possível compartilhar conhecimentos sobre o AIA, conservação e manipulação dos alimentos de forma eficiente, além de quebrar preconceitos que as PNC dos alimentos carregam, de uma forma cultural, em nosso país.

As adolescentes se tornaram capacitadas, para produção desses alimentos como fonte de renda, através das técnicas apresentadas e praticadas, o que tornou as jovens mais autônomas. Além de tudo foi possível mostrar maneiras de se reestruturar após uma gravidez na adolescência e que mesmo diante de algumas dificuldades pode-se empreender e ter sucesso nos seus projetos.

Segundo Pinheiro (2008), a forma de comer envolve desde a cultura até questões pessoais. O preparo, o consumo alimentar está intimamente relacionado às características culturais, condições sociais, realidade, memória familiar e cotidiano. Conhecimentos empíricos acerca dos alimentos e da nutrição habituam confundir as pessoas e contribuir para que muitas não tenham uma alimentação equilibrada e saudável (WILLIAMS, 2001). Ou seja, a falta de conhecimentos científicos, influenciam diretamente nas escolhas e hábitos da alimentação.

A educação alimentar e nutricional proporciona conhecimentos e habilidades que permitem às pessoas produzir, descobrir, selecionar e consumir os alimentos de forma adequada, saudável e segura, assim como a conscientização quanto à práticas alimentares mais saudáveis, fortalecendo culturas alimentares das diversas regiões do País, diminuindo assim o desperdício e geração de resíduos provenientes dos alimentos.

Bons hábitos de higiene e manuseio, bem como educação contínua para trabalhadores do setor de alimentos, podem ajudar a reduzir doenças transmitidas por alimentos (MARMETINI; RONQUI; ALVARENGA, 2010). Além de que estes necessitam de formação adequada para desempenhar o seu papel (OLIVEIRA, 2008).

Vale (2015) conferiu autonomia a um grupo de mulheres, com a capacidade de decidir sobre o seu próprio processo de trabalho, tais como: "planejar, tempo, ritmo de trabalho, pausa, liberdade de trabalho". Além disso, a autora destaca que a autonomia só ocorre quando as mulheres podem exercer seus direitos sem privações físicas, sociais e econômicas. O conceito de autonomia relaciona-se com a amplitude do controle da mulher sobre sua própria vida, onde uma vez que ela se sente mais capaz e independente a sua busca por conhecimento e crescimento, tanto pessoal como profissional, tende a aumentar. 
Segundo Esther Duflo (2011), o empoderamento feminino está relacionado de uma forma positiva com o desenvolvimento econômico, sendo que um fenômeno reforça o outro: “em um sentido, o desenvolvimento joga um papel importante na diminuição da desigualdade entre homens e mulheres, em outra direção, o empoderamento das mulheres pode beneficiar o desenvolvimento".

O intuito do projeto além de formar semeadores de conhecimento, buscou estimular que as atividades desenvolvidas se tornassem cotidianas na ONG, tendo em vista que ela atende muitas pessoas e recebe doações corriqueiras de alimentos, proporcionando assim segurança alimentar, eficiência no seu uso e diminuindo a formação de resíduos.

Com auxílio das cartilhas preparadas (Figura 1), foi possível facilitar o entendimento e a elaboração dos produtos, além disso foram elaboradas mais formulações do que o proposto, mostrando uma resposta positiva ao trabalho assim como também o interesse, a interação e participação das alunas.

Todos os produtos elaborados foram expostos e degustados dentro da entidade para as alunas (Figura 3) e comunidade local, mostrando que é possível elaborar receitas saborosas e nutritivas utilizando as PNC dos alimentos. Reforçando também o pensamento sobre a conscientização da população quanto ao tema, ou seja, auxiliando no entendimento de como as suas ações contribuem para um objetivo em comum.

Figura 03. Exposição e apreciação dos produtos

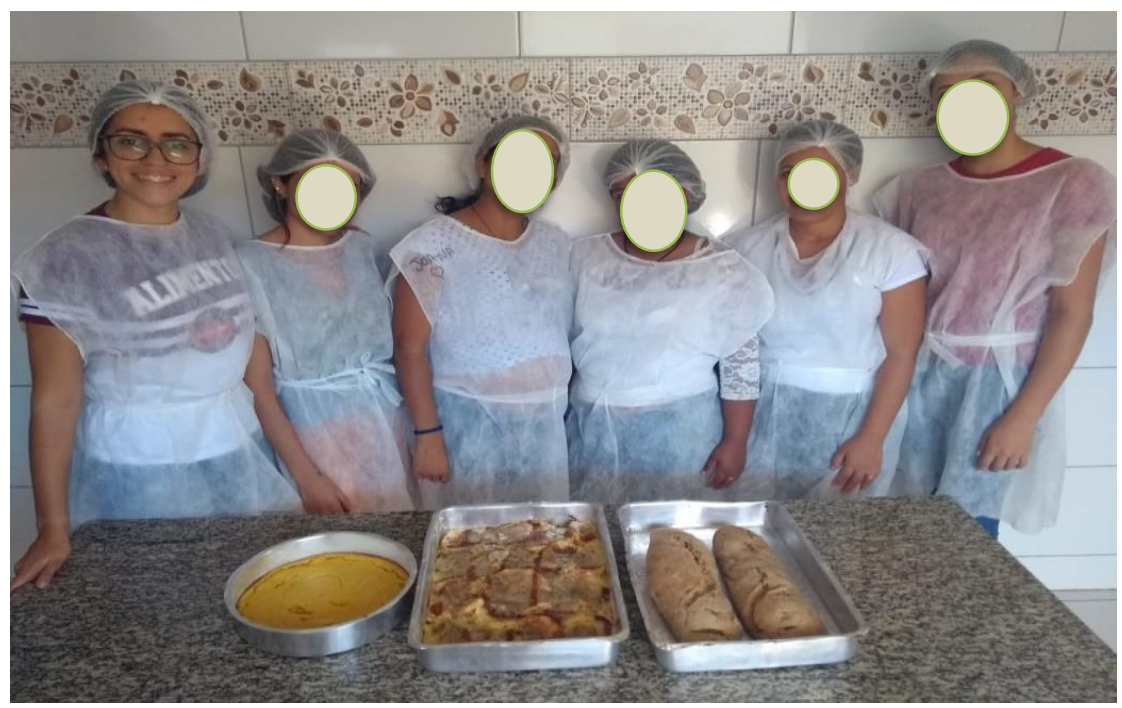

Fonte: Própria (2019) 
Ao término das capacitações, pôde-se notar que o projeto alcançou uma quantidade muito maior de pessoas, uma vez que as alunas levavam os conhecimentos adquiridos para sua casa e locais de trabalho, além de beneficiar todas as pessoas que frequentavam a ONG.

Através dos questionários (Figura 2) que foram aplicados, foi possível fazer um levantamento de dados e assim avaliar as atividades realizadas e seus impactos, assim como valida-los. Adotado assim esse procedimento, pôde-se obter as seguintes informações, anexadas abaixo:

Figura 04. Avaliação do grau de conhecimento sobre o tema, das alunas.

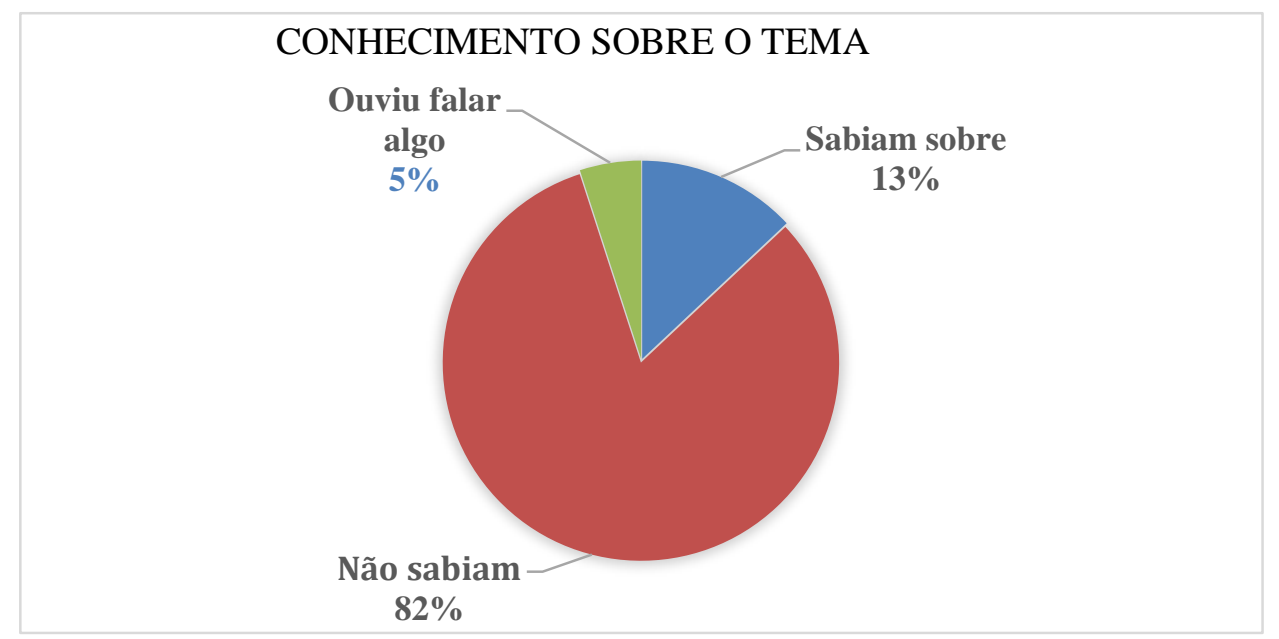

Fonte: Própria (2019)

Ao questionar sobre o conhecimento prévio do tema discutido, $82 \%$ das alunas responderam que não tinham conhecimento nenhum sobre a possibilidade da incorporação das PNC na sua alimentação. Enquanto apenas 13\% tinha algum conhecimento sobre esta pratica, e $5 \%$ já tinha ouvido ou visto algo sobre, mas não compreendia totalmente as informações. Deve-se levar em consideração também que, dentre as alunas que tinham conhecimento sobre adição das partes usualmente não aproveitadas na alimentação, nenhuma realizava o método em suas casas. Estes dados confirmam o que o AIA na mesa dos brasileiros, ainda é muito pequena.

O nível de aprendizado sobre o tema foi satisfatório (Figura 5), pois todas as alunas e a ONG passaram a utilizar os alimentos em sua integralidade, assim como foi possível mudar o pensamentolcultura sobre o uso das PNC dos alimentos. 
Figura 05. Nível de aprendizagem das formulações e nível de uso das técnicas em casa.

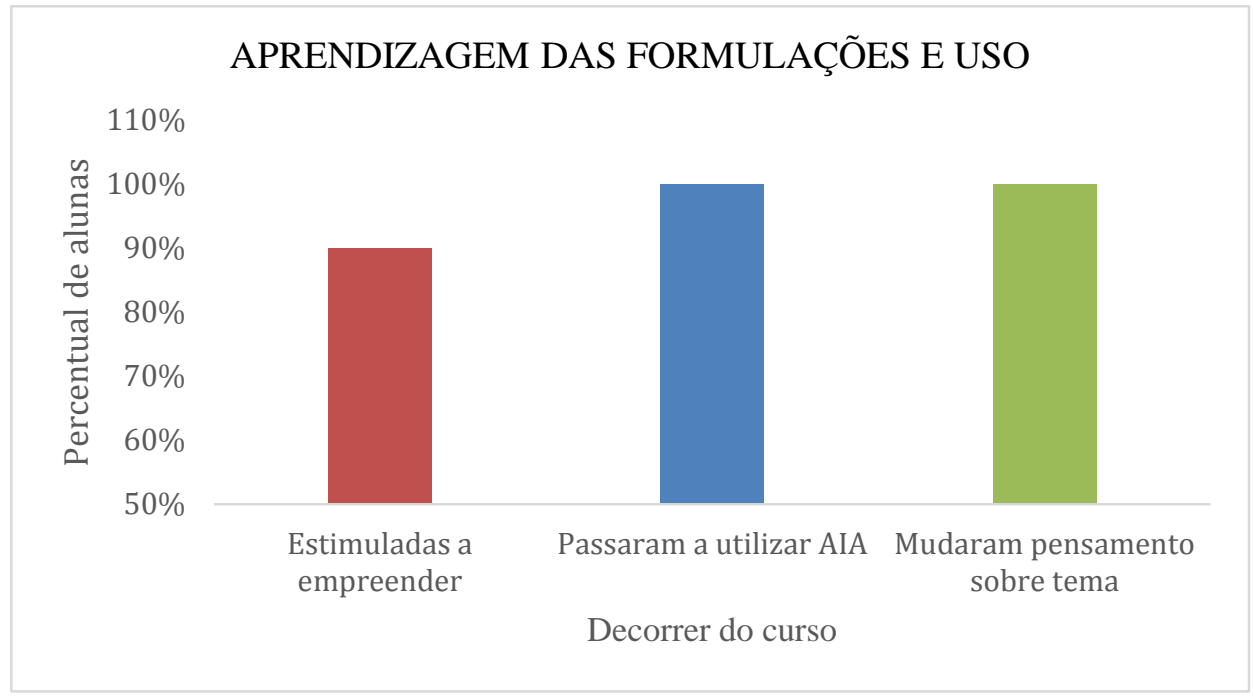

Fonte: Própria (2019)

Alguns pontos relacionados ao aumento da autonomia e realização de novas atividades a partir do curso, enquanto mulheres, também foram questionados revelando resultados positivos (Figura 6).

Figura 06. Níveis de autonomia e empoderamento feminino nas alunas após curso AIA.

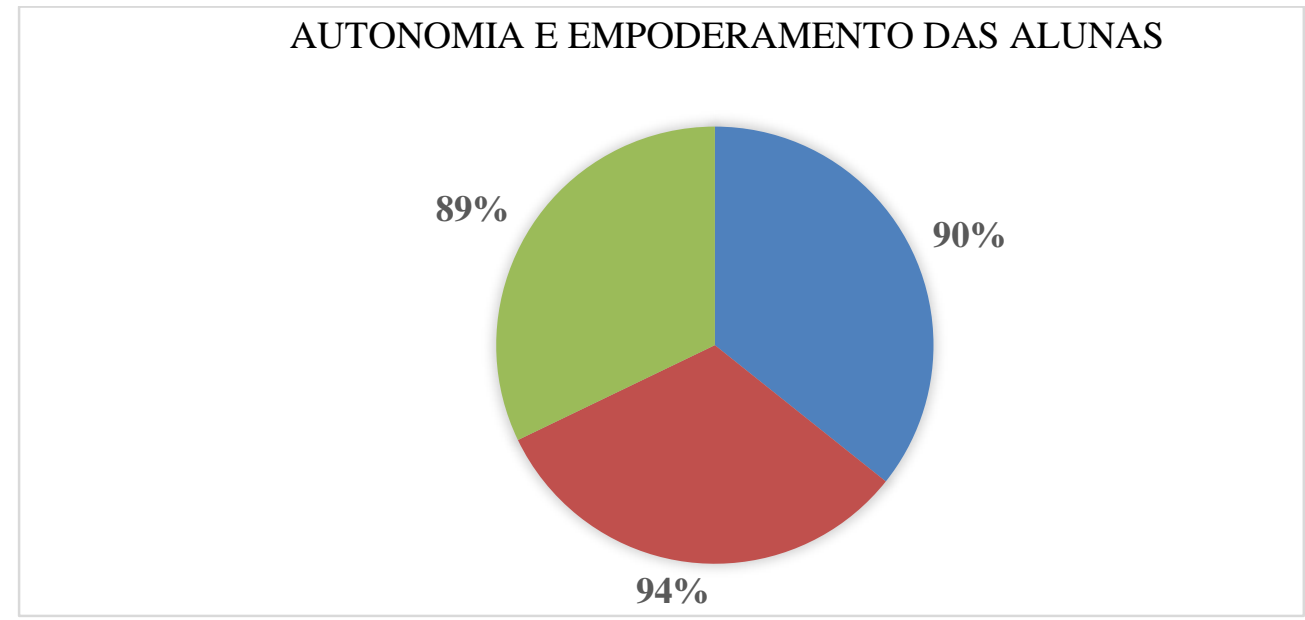

Azul: incentivou o empoderamento; Vermelho: mostrou formas de empreender; Verde: Aumentou autonomia;

Fonte: Própria (2019)

Percebe-se que, as alunas aumentaram de forma significativa a sua autoestima através da descoberta de opções de autonomia e geração de renda, assim como também foi possível incentivar empoderamento feminino (Figura 6). Segundo alguns autores, a autonomia está associada ao poder de decisão de: a) Organização do Trabalho e utilização de recursos 
(FERNANDES; MOTA, 2014; VALE, 2015); b) para Cooperação no processo de tomada de decisão e autonomia natural relacionada à tomada de decisão individual quanto corpo materno (SOARES, 2011); c) Autorização (dentro das expectativas financeiras), estimulado por políticas públicas, tendo o mesmo poder de decisão que os homens e melhorando as condições de vida, controlando os recursos obtidos com o trabalho e a destruição da família e da hierarquia estrutural (SCHEFLER, 2013).

Resultados positivos também foram constatados quanto ao início do uso dos métodos e o uso do AIA nas residências das alunas, atividade esta que não era corriqueira ou não existia, assim como a realização destas atividades dentro da ONG (Figura 7).

É notório a aceitação das técnicas do AIA, onde no início do projeto nenhuma aluna fazia o uso das PNC dos alimentos (casca, semente, talos etc.), com o passar dos dias, após explanação do conteúdo, atividades práticas e degustação dos produtos, as adolescentes passaram a utilizar essas técnicas, gradativamente, em suas casas e locais de trabalho, ou seja foi possível incorporar este hábito alimentar.

Figura 07. Crescimento do grau de utilização das técnicas de AIA.

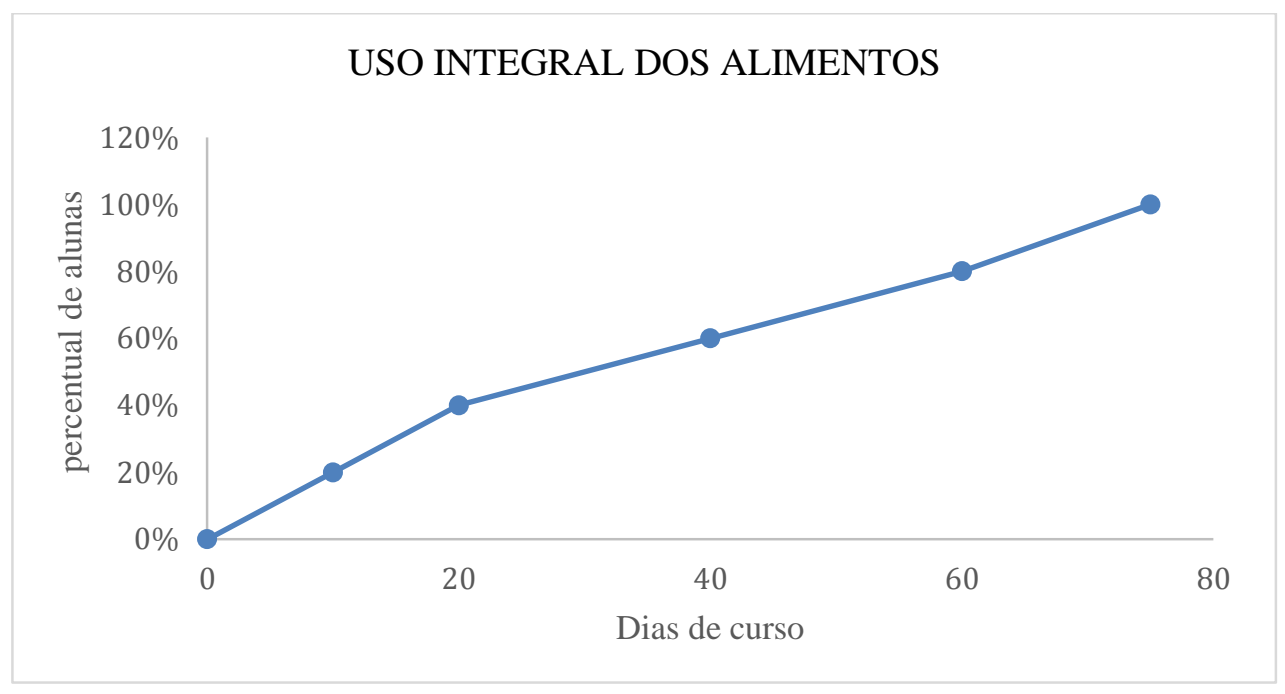

Fonte: Própria (2019)

Ao início do projeto, pouquíssimas pessoas faziam o uso do AIA elou apresentavam uma boa aceitabilidade de receitas com as PNC doa alimentos. A imagem (Figura 8) demonstra que com o decorrer do curso, esse acolhimento aumentou, uma vez que estes produtos passam a ser vistos com outra perspectiva, e no fim elas tiveram quase $100 \%$ de aprovação. Chegando à conclusão que, só o que causava um bloqueio em relação a este tipo de produto, eram os 
preconceitos sobre ele. Isso pode ser apontado com os resultados das crianças, pois não sabendo do que as receitas eram feitas, as comiam e apreciavam sem nenhum receio.

Figura 08. Nível de aceitabilidade dos produtos elaborados com AIA.

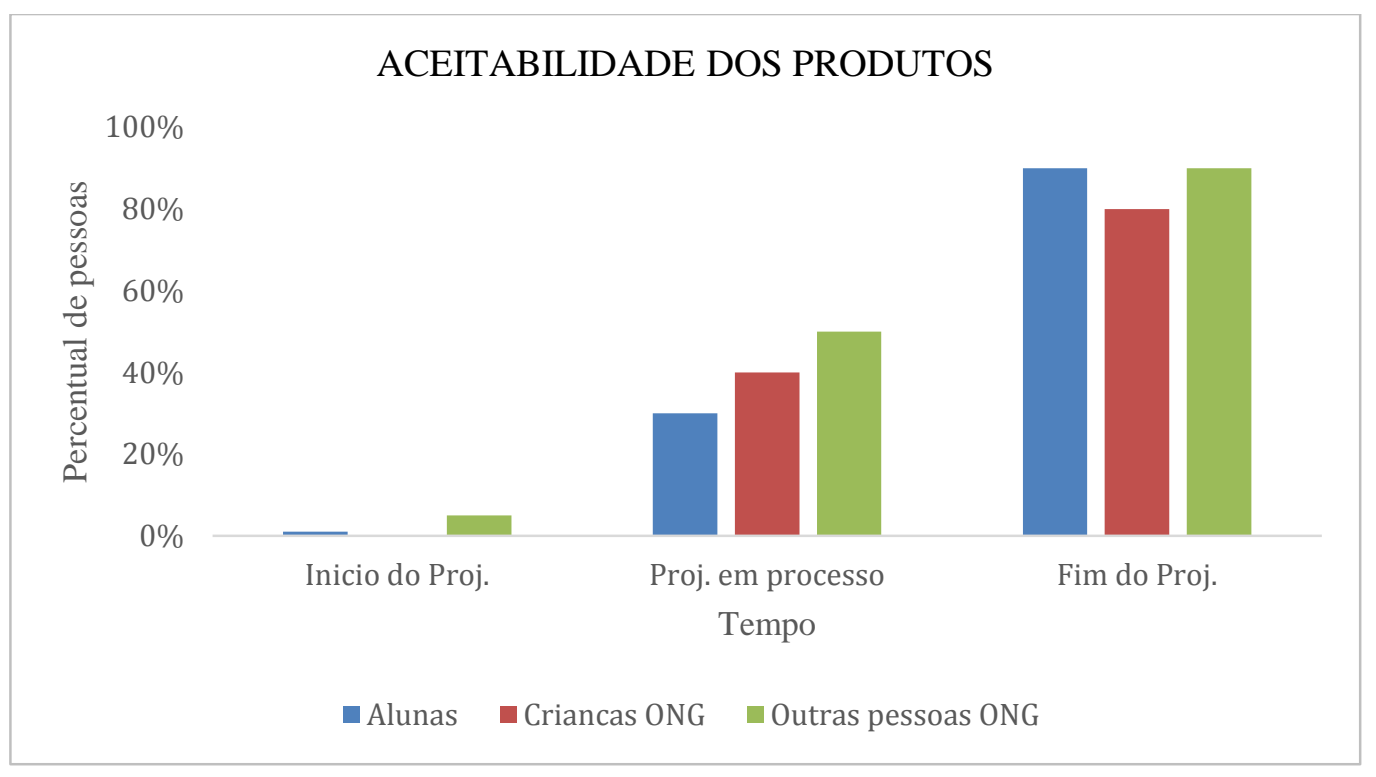

Fonte: Própria (2019)

O alimento em sua total integridade deve ser sempre utilizado por todas as classes sociais e econômicas (BADAWI, 2008), ou seja, utilizar as PNC de alimentos além de melhorar a qualidade nutricional das receitas, também é uma tática aliada para mitigar o desperdício alimentício no país assim como diminuir os impactos ambientais.

O desenvolvimento desse trabalho também pôde tornar as participantes muito mais seguras quanto a produção de insumos para aumento de renda, não só pelo uso do AIA, mas também através das técnicas de conservação, armazenamento, embalagens, etiquetas e rótulos e dicas de empreendedorismo. Estes resultados puderam ser validados também através de aplicação de questionários, nos quais as alunas responderam de forma positiva.

Entretanto durante o desenvolvimento do projeto algumas dificuldades foram encontradas como a desistência de algumas alunas, visto que no período da matricula do curso até o fim deste, quase metade das adolescentes faltaram por alguns quesitos como: serviços domésticos (cozinhar, e cuidar dos filhos), a falta de interesse sobre o tema, pois a utilização das PNC dos alimentos ainda carrega um preconceito grande pela população ( mais de $60 \%$ não aproveita integralmente os alimentos), além de que, muitas vezes os maridos influenciaram na frequência destas alunas no curso, alegando que as funções das mulheres se resumiam a afazeres domésticos. 


\section{Conclusões}

A realização desse trabalho, possibilitou interferir diretamente na vida da comunidade, além dos muros da instituição, através de ações educativas e empreendedoras. Onde o conhecimento influenciou diretamente tanto nos hábitos alimentares como também na autonomia da mulher acarretando na busca por melhoria de vida.

Foi possível, disseminar conhecimentos eliminando preconceitos sobre temas como: o uso das PNC dos alimentos, ou uso do AIA, que são vistos de uma forma errônea pela sociedade, influenciados por questões culturais e hábitos alimentares.

Por fim, a extensão se mostrou como instrumento essencial neste processo, pois possibilitou a formação do profissional cidadão e se credencia, cada vez mais, junto à sociedade como espaço de produção do conhecimento, significativo para a superação das desigualdades sociais existentes.

\section{Referências}

AGENCIA BRASIL, Brasil tem boas práticas contra desperdício, mas perdas chegam a 40\%. Disponível em : < http://agenciabrasil.ebc.com.br/economia/noticia/2017-10/brasiltem-boas-praticas-contra-desperdicio-de-alimento-mas-perdas-chegam $>$. Acesso em: 14.01.2019.

AIOLFI, A. H.; BASSO, C. Preparações elaboradas com aproveitamento integral dos alimentos. Disciplinarum Scientia| Saúde, v. 14, n. 1, p. 109-114, 2016.

BADAWI, Camilla. Aproveitamento integral dos alimentos - melhor sobrar do que faltar? São Paulo. Disponível em $<$ https://www.nutrociencia.com.br/>. Acesso em 23.08.2019.

BANCO DE ALIMENTOS - ONG. Relatório de atividades 2018. Disponível em:< https://www.bancodealimentos.org.br/wp-content/uploads/2019/04/0326-relatorio-oba2018_textorevisado_design_fim-quad_20190416.pdf>. Acesso em: 24 dez. 2019.

CASSOL, A.; SCHNEIDER, S. Produção e consumo de alimentos: novas redes e atores. Lua Nova: Revista de Cultura e Política, São Paulo, n.95, maio-ago 2015. Disponível em: <http://dx.doi.org/10.1590/0102-6445143-177/95>. Acesso em 22 jan de 2020.

CEDES - Centro de Estudos e Debates Estratégicos. Consultoria Legislativa da Câmara dos Deputados. Perdas e desperdício de alimentos - estratégias para redução. Série de cadernos de trabalhos e debates 3. Brasília, DF, pág. 260, 2018.

COLARES LGT, FIGUEIREDO VO, FERREIRA, AA, OLIVEIRA AGM. Lista de verificação de boas práticas ambientais para serviços de alimentação: elaboração, validação de conteúdo e confiabilidade Inter avaliadores. Braz J Food Technol. 2018; 21 
DUFLO, Esther. Women's empowerment and economic development. National Bureau of Economic Research Working Paper, Cambridge, n. 17702, Dec. 2011.

EMBRAPA - Empresa Brasileira de Pesquisa Agropecuária. 2018. Disponível em:< https://www.embrapa.br/tema-perdas-e-desperdicio-de-alimentos> . Acesso em: 05 maio 2019.

FAO. FAO apresenta avanços no combate às perdas e ao desperdício de alimentos. Disponível em: < http://www.fao.org/brasil/noticias/detail-events/en/c/1062706/>, acesso em 18.02.2019.

FERNANDES, T.; MOTA, D. M. da. "É sempre bom ter o nosso dinheirinho": sobre a autonomia da mulher no extrativismo da mangaba no Pará. RESR. Piracicaba, São Paulo, v. 52, $\mathrm{N}^{\mathrm{o}}$ 01, p. 009-024, jan./mar., 2014.

FORTUNATO, D. M.N. Alimentação alternativa (multimistura) e seus principais componentes. Informativo profissional do conselho de Federal de farmácia. Infamar. Brasília. V.19,n.5\8. Pg 103-110, 2007.

GONDIM, J. A. M. Composição centesimal e de minerais em cascas de frutas. Ciência e Tecnologia de Alimentos, v. 25, n. 4, p. 825-827, 2005.

HOFFMAN, R. A insegurança alimentar no Brasil. Revista cadernos de debate, São Paulo, v2 p.1-11.1994.

LAURINDO TR, RIBEIRO KAR. Aproveitamento Integral de Alimentos. Interciênc.Soc. 2014.Disponível

http://fmpfm.edu.br/intercienciaesociedade/colecao/online/v3_n2/2_aproveitamento.pdf.

LAURINDO, T. R; RIBEIRO, K. A. R. Aproveitamento Integral dos Alimentos. Interciência \& Sociedade, Mogi Guaçu, v. 3, n. 2, p.17-26, jan. 2014. Disponível em: . Acesso em:05.01.2019.

MARMETINI, P. R.; RONQUI, L.; ALVARENGA, O. V. A importância das boas praticas de manipulação para os estabelecimentos que manipulam alimentos. Revista Cientifica Facimed, p. 263-273, 2010.

Mesa Brasil Sesc. Cartilhas Educativas 2013. Disponível em: <http://www.sesc.com.br/mesabrasil/cartilhas.html> , acesso em: 03.04.2019.

MONTEIRO, B. A. Valor nutricional de partes convencionais e não convencionais de frutas e hortaliças. 2009. 62 f. Dissertação (Mestrado em Agronomia) - Faculdade de Ciências Agronômicas, Universidade Estadual Paulista, Botucatu, 2009.

NUTRO CIENCIA, Aproveitamento dos alimentos. Melhor sobrar do que faltar?. Disponível em $\quad:<$ http://www.biologia.seed.pr.gov.br/arquivos/File/sugestoes_atividades_pdf/aproveitamento_ alimentos.pdf $>$. Acesso em 24.01.2019.

OLIVEIRA, A. F.; STORTO, L. J. Tópicos em ciência e tecnologia de alimentos: resultados de pesquisas acadêmicas. Volume 2. Editora Edgard Blücher Ltda - São Paulo. Pág. 348, 2016. 
OLIVEIRA, C. C. A. BERNARDO, S. J. SARAIVA, J.M. Formação para Agentes de Merendeira da Prefeitura Municipal de Buíque - PE. In: JEPEX, 2008, Recife, PE.

ORLOSKI, A. R.; SANTOS M. B.; SANTOS, E. F.; NOVELLO, D. Cookies de aveia adicionados de farinha da casca de abobrinha: análise Fisico-química e sensorial entre crianças. Mulitemas, Campo Grande, MS, v. 23, n. 53, p. 143-157, jan./abr. 2018.

PINHEIRO, K. A. História dos hábitos alimentares ocidentais. In: Universitas Ciências da Saúde, v. 3, n. 01, p. 173 - 190, 2008.

RILEY, N. Gender, power and population change. Population Bulletin, v. 52, n. 1, May 1997.

RORIZ, R. F. C. Aproveitamento dos resíduos alimentícios obtidos das centrais de abastecimento do estado de Goiás s/a para alimentação humana. 2012. 162f. Dissertação (Mestrado em Ciência e Tecnologia de Alimentos) - Universidade Federal de Goiás, Goiânia, 2012.

SANTANA, A. F.; OLIVEIRA, L. F. Aproveitamento da casca de melancia curcubitacitrullus, shrad) na produção artesanal de doces alternativos. Alimentos e Nutrição, Araraquara, v. 16, n. 4, p. 363-368, 2005.

SCHEFLER, M. de L. N. Gênero, autonomia econômica e empoderamento. O real e o aparente: sistematização de processos de investigação-ação e/ou de intervenção social. Revista feminismos. v.1, n. 3. Set. - Dez. 2013. 20 p

SOARES, V. Mulher, Autonomia e Trabalho. In: Autonomia econômica e empoderamento da mulher: textos acadêmicos. Brasília: Fundação Alexandre de Gusmão, 2011. p. 281-301.

SOUZA PDJ, NOVELLO D, ALMEIDA JM, QUINTILIANO DA. Sensory and nutritional analysis of savory pie made with vegetable stems and peels as alternative ingredients. Alim. Nutr. 2007; 18(1):55-56.

TERRA. O Brasil está voltando ao mapa da fome. Disponível em:< https://www.terra.com.br/noticias/mundo/brasil-esta-voltando-ao-mapa-da-fome-dizmembro-da-onu,b3675cf687fbe28d3525eaff3b295a1cae29i9n5.html. Acesso em 04.07.2020.

VALE, S. R. G. A. Avaliação do perfil das quebradeiras de coco babaçu e de suas condições de trabalho no município de Itapecuru-Mirim/MA. 2015. 112 f. Dissertação (Mestrado Interinstitucional em Saúde Pública e Meio Ambiente) - Fundação Oswaldo Cruz, Escola Nacional de Saúde Pública Sérgio Arouca e Instituto Federal de Educação, Ciência e Tecnologia do Maranhão, Rio de Janeiro, 2015.

WILLIAMS, S. R. Fundamentos de Nutrição e Dietoterapia. 6. ed. Porto Alegre: Artmed, 2001, 664 p. 


\title{
CAPÍTULO 51: BACTÉRIAS ÁCIDO LÁCTICAS NA DESCONTAMINAÇÃO DE AFLATOXINAS EM LEITE BOVINO: UMA REVISÃO
}

\section{CHAPTER 51: LACTIC ACID BACTERIA IN THE DECONTAMINATION OF AFLATOXINS IN BOVINE MILK: A REVIEW}

\author{
Rosana Basso Kraus ${ }^{1}$; Pedro Rassier dos Santos ${ }^{2}$; Giniani Carla Dors ${ }^{3}$; Patrícia da Silva Nascente ${ }^{4}$; Rafael \\ Guerra Lund ${ }^{5}$
}

\begin{abstract}
Resumo
As aflatoxinas são compostos químicos tóxicos produzidos por fungos do gênero Aspergillus que podem contaminar grãos e cereais, base para rações utilizadas em bovinos. A aflatoxina $\mathrm{M}_{1}$, derivada da hidroxilação da aflatoxina $\mathrm{B}_{1}$, é encontrada no leite, mas a aflatoxina $\mathrm{B}_{1}$ também tem sido relatada e precisa ser avaliada, pois é mais tóxica que a aflatoxina $\mathbf{M}_{1}$. Assim, o objetivo deste trabalho foi revisar o efeito do uso de bactérias ácido láticas na descontaminação de aflatoxinas $\mathrm{B}_{1}$ e $\mathrm{M}_{1}$ presentes no leite e derivados lácteos. A aplicação de bactérias ácido láticas em ensaios de descontaminação de aflatoxinas tem sido promissor. Entretanto, a redução dos níveis de aflatoxinas presente no alimento depende da bactéria que será utilizada, bem como sua concentração, meio onde será realizado o ensaio, nível de contaminação inicial, tempo de contato entre micro-organismo e a aflatoxina, e a estabilidade desta ligação.
\end{abstract}

Palavras-Chave: aflatoxinas $\mathrm{B}_{1}$ e $\mathrm{M}_{1}$, descontaminação, leite, processamento de alimentos.

\begin{abstract}
Aflatoxins are toxic chemical compounds produced by fungi of the Aspergillus genus that can contaminate graisn and cereals, the basis for feed used in cattle. Aflatoxin $\mathrm{M}_{1}$, derived from the hydroxylation of aflatoxin $\mathrm{B}_{1}$, is found in milk, but aflatoxin $\mathrm{B}_{1}$ has also been reported and needs to be evaluated, as it is more toxic than aflatoxin $\mathrm{M}_{1}$. Thus, the objective of this study was to review the effect of the use of lactic acid bacteria in the decontamination of aflatoxins $\mathrm{B}_{1}$ and $\mathrm{M}_{1}$ present in milk and dairy products. The application of lactic acid bacteria in aflatoxin decontamination trials has been promising. However, the reduction in the levels of aflatoxins present in the food depends on the bacteria that will be used, as well as its concentration, medium where the test will be performed, initial contamination level, contact time between microorganism and aflatoxin, and the stability of this link.
\end{abstract}

Keywords: aflatoxins $\mathrm{B}_{1}$ and $\mathrm{M}_{1}$, milk, decontamination, food processing.

\footnotetext{
${ }^{1}$ Programa de Pós-Graduação em Bioquímica e Bioprospecção (PPGBBio), Universidade Federal de Pelotas, rosana_basso_kraus@hotmail.com

${ }^{2}$ Programa de Pós-Graduação em Microbiologia e Parasitologia (PPGMP), Universidade Federal de Pelotas, rassier1907@gmail.com

${ }^{3}$ Mestrado Profissional em Ciência e Tecnologia de Alimentos, Universidade Federal de Pelotas, Dr ${ }^{\mathrm{a}}$ em Engenharia e Ciência de Alimentos, dorsgi@yahoo.com.br

${ }^{4}$ PPGMP, Universidade Federal de Pelotas, pattsn@gmail.com

${ }^{5}$ PPGBBio, Universidade Federal de Pelotas, rafael.lund@ gmail.com
} 


\section{Introdução}

As micotoxinas são substâncias resultantes do metabolismo secundário de algumas espécies fúngicas, principalmente Aspergillus, Fusarium e Penicillium (SWEENEY; DOBSON, 1998) e podem acometer diversas culturas agrícolas antes e/ou após a colheita, durante a secagem ou armazenamento (PITT; TANIWAKI; COLE, 2013). Dentre as micotoxinas de maior ocorrência nos alimentos destacam-se as aflatoxinas (AFLA), produzidas por fungos do gênero Aspergillus, principalmente A. flavus, A. parasiticus e A. nomius (PRANDINI et al., 2009), classificando-se em B (AFLAB 1 e AFLAB ${ }_{2}$ ) e G (AFLAG 1 e $\left.\mathrm{AFLAG}_{2}\right)(\mathrm{CREPPY}, 2002)$.

$\mathrm{O}$ consumo de alimentos contaminados por $\mathrm{AFLAB}_{1}$ pelos animais resulta na conversão de 0,3 a 6,2\% em AFLAM 1 , ou seja, ocorre a hidroxilação e os metabólitos hidroxilados são convertidos em $\mathrm{AFLAM}_{1}$ sendo liberados através da urina e/ou leite (CREPPY, 2002). A presença destes contaminantes no leite afeta a segurança do alimento, pois são compostos cancerígenos e mutagênicos, representando um problema de saúde publica, (BENKERROUM, 2019; WHO, 2018). Consequentemente, inúmeros países elaboraram Limites Máximos Tolerados (LMT) destas micotoxinas em alimentos.

A partir destas considerações fica evidente a necessidade de buscar alternativas que minimizem a ocorrência deste perigo na obtenção do leite, pois as aflatoxinas são estáveis aos métodos de processamento (IHA et al., 2013). Este estudo tem por objetivo revisar o efeito do uso de bactérias ácido-láticas na descontaminação de aflatoxinas $\mathrm{B}_{1}$ e $\mathrm{M}_{1}$ presentes no leite e derivados lácteos.

\section{Desenvolvimento}

\section{Aflatoxinas em Leite e Produtos Lácteos}

O leite de boa qualidade deve apresentar baixos níveis de células somáticas e bactérias totais, ausência de micro-organismos patogênicos ou resíduos químicos como, por exemplo, antibióticos (BRASIL, 2018, 2018a). Além disso, a composição do leite cru ou pasteurizado deve ter teores mínimos de proteína, gordura e extrato seco desengordurado, os quais variam de acordo com o tipo de leite que será produzido (BRASIL, 2018) e em razão da raça do animal e do manejo (SOUZA; CARVALHO; MENDONÇA, 2010).

Além das legislações exigidas com relação à qualidade do leite, há a Resolução número 7, publicada em 18 de fevereiro de 2011, que estabelece o limite para $\mathrm{AFLAM}_{1}$ para leite líquido $\left(0,5 \mu \mathrm{g} \mathrm{kg}^{-1}\right)$, leite em pó $\left(5,0 \mu \mathrm{g} \mathrm{kg}^{-1}\right)$ e queijos $\left(2,5 \mu \mathrm{g} \mathrm{kg}^{-1}\right)$ (ANVISA, 2011). Embora alguns trabalhos relatem a presença de $\mathrm{AFLAB}_{1}$ no leite (GONÇALVES et al., 2018; 
SIBAJA et al., 2019; BECKER-ALGERI et al., 2020) a legislação só apresenta LMT para $\mathrm{AFLAM}_{1}$. A legislação de alimentos para consumo animal preconiza que qualquer matériaprima a ser utilizada diretamente ou como ingrediente para rações destinadas ao consumo animal não ultrapasse $50 \mu \mathrm{g} \mathrm{kg}^{-1}$ da somatória de AFLAs (BRASIL, 1988). As principais legislações internacionais para leite e produtos derivados, bem como de matérias-primas para consumo animal são da Comissão da Regulamentação da União Europeia (CRUE) e da Food and Drug Administration (FDA) (COMISSÃO DA UNIÃO EUROPEIA, 2020; FOOD AND DRUG ADMINISTRATION, 2020).

As AFLAs têm como característica uma estrutura policíclica derivada de um núcleo cumarina juntamente com um sistema bifurano e uma pentanona (AFLAB) ou lactona (AFLAG) (BENNETT; KLICH, 2003). A International Agency for Research on Cancer (IARC) (1993) considera a $\mathrm{AFLAB}_{1}$ um carcinógeno humano do grupo 1 , enquanto a $\mathrm{AFLAM}_{1}$ é um provável carcinógeno humano, pertencendo ao grupo $2 \mathrm{~B}$, em virtude da toxicidade da $\mathrm{AFLAB}_{1}$ ser maior, quando comparada com a $\mathrm{AFLAM}_{1}$ (CREPPY, 2002). As AFLAs têm efeito carcinogênico, teratogênico, hepatotóxico, imunossupressor, atingindo principalmente o fígado e, dependendo do nível de exposição, essa toxicidade pode ser aguda ou crônica (BENNET; KLICH, 2003). Além da toxicidade, são compostos altamente estáveis aos métodos de processamento como esterilização comercial, pasteurização ou fervura (AWASTHI et al., 2012; BAKIRCI, 2001; FERNANDES et al., 2012; GOVARIS et al., 2002; IHA et al., 2013).

A ocorrência de AFLAs têm sido relatada em grãos, rações e silagem de grãos (MOSS, 1998; O’BRIEN et al., 2005; SASSAHARA; NETTO; YANAKA, 2005; OMEIZA et al.,2018; DADZIE et al., 2019), sendo preocupante, uma vez que o sistema digestivo dos animais não é suficiente para degradar essas toxinas (OBREMSKI et al., 2009). A metabolização da $\mathrm{AFLAB}_{1}$ ocorre no fígado, através de um conjunto de enzimas do citocromo $\mathrm{P}_{450}$, que são consideradas hemoproteínas e têm como função a conversão desses compostos xenobióticos em moléculas mais hidrossolúveis (KLEIN et al., 2000; PEI et al., 2009). O principal metabólito formado é $\mathrm{AFLAB}_{1}-8,9$ epóxido, responsável pelos efeitos tóxicos agudos, mutagênicos e carcinogênicos e a AFLAM 1 (MURPHY et al., 2006).

A ocorrência das AFLAs é um problema mundial, e de acordo com estudo elaborado por Becker-Algeri et al. (2016), a partir de dados coletados até 2015, foi possível verificar que a incidência de $\mathrm{AFLAM}_{1}$ em leite e derivados lácteos é relativamente mais baixa nos países europeus (Portugal, Turquia, Itália e Croácia), independentemente do tipo de amostra. No Brasil, devido à sua extensão, diferenças de clima e produção de leite e latícinios, os 
KRAUS, R. B; SANTOS, P. R; DORS, G. C; NASCENTE, P. S; LUND, R. G.

resultados da frequência variam conforme a porcentagem de ocorrência da micotoxina $(30,7 \%$ a 100\%) e sobre os níveis de contaminação encontrados $\left(0,0018\right.$ a $\left.4,1 \mu \mathrm{g} \mathrm{L}^{-1}\right)$.

Além dos efeitos tóxicos das AFLAs, a estabilidade durante o processamento é outra problemática que vem sendo avaliada, assim como a transferência e a distribuição destas toxinas nos derivados lácteos (ALAHLAH et al., 2020; DEVECI, 2007; HASSANIN, 1994; LÓPEZ et al., 2001; SCAGLIONI et al., 2014; TADESSE; BERHANU; WOLDEGIORGIS, 2020). O Quadro 1 apresenta dados de ocorrência de AFLAM $_{1}$ e AFLAB 1 em leite e produtos lácteos nos últimos cinco anos.

Quadro 1. Frequência e ocorrência de aflatoxinas em leite e derivados lácteos relatadas na literatura.

\begin{tabular}{|c|c|c|c|c|}
\hline $\begin{array}{l}\text { País I } \\
\text { Autores }\end{array}$ & Amostra & $\begin{array}{l}\text { Frequência } \\
(\%)\end{array}$ & Mín - Máx & AFLAs \\
\hline \multirow{2}{*}{$\begin{array}{l}\text { Costa } \\
\text { Rica / } \\
\text { Chavarría } \\
\text { et al., } \\
2015\end{array}$} & Leite & $\begin{array}{l}(3 / 70) 4,3 \\
(22 / 70) 31,4 \\
(44 / 70) 62,8 \\
(1 / 70) 1,4 \\
\end{array}$ & $\begin{array}{l}<14 \mathrm{ng} \mathrm{L}^{-1} \\
20-50 \mathrm{ng} \mathrm{L}^{-1} \\
50-500 \mathrm{ng} \mathrm{L}^{-1} \\
>500 \mathrm{ng} \mathrm{L}^{-1}\end{array}$ & \multirow{2}{*}{$\mathrm{M}_{1}$} \\
\hline & Queijo & $\begin{array}{l}(44 / 70) 62,8 \\
(13 / 70) 18,6 \\
(13 / 70) 18,6) \\
\end{array}$ & $\begin{array}{l}<23 \mathrm{ng} \mathrm{kg}^{-1} \\
20-50 \mathrm{ng} \mathrm{kg}^{-1} \\
50-500 \mathrm{ng} \mathrm{kg}^{-1}\end{array}$ & \\
\hline $\begin{array}{l}\text { Brasil / } \\
\text { Sartori et } \\
\text { al., } 2015^{*}\end{array}$ & $\begin{array}{l}\text { Leite UHT } \\
\text { Leite em pó }\end{array}$ & $\begin{array}{l}(11 / 16) 69 \\
(53 / 72) 74\end{array}$ & $\begin{array}{l}0,005-0,042 \mu \mathrm{g} \mathrm{kg}^{-1} \\
0,08-1,19 \mu \mathrm{g} \mathrm{kg}^{-1}\end{array}$ & $\mathrm{M}_{1}$ \\
\hline \multirow[t]{7}{*}{$\begin{array}{l}\text { Sérvia / } \\
\text { Tomaševi } \\
\text { ć et al., } \\
2015\end{array}$} & Leite cru & $\begin{array}{l}(138 / 678) 20,3 \\
(158 / 678) 23,3 \\
(215 / 678) 31,7 \\
(118 / 678) 17,4 \\
(49 / 678) 7,2 \\
\end{array}$ & $\begin{array}{l}\leq 0,025 \mu \mathrm{g} \mathrm{kg}^{-1} \\
0,026-0,05 \mu \mathrm{g} \mathrm{kg}^{-1} \\
0,051-0,5 \mu \mathrm{g} \mathrm{kg}^{-1} \\
0,51-1,0 \mu \mathrm{g} \mathrm{kg}^{-1} \\
>1,0 \mu \mathrm{g} \mathrm{kg}^{-1}\end{array}$ & \multirow{7}{*}{$\mathrm{M}_{1}$} \\
\hline & Leite tratado termicamente & $\begin{array}{l}(121 / 438) 27,6 \\
(174 / 438) 39,7 \\
(131 / 438) 29,9 \\
(12 / 438) 2,7\end{array}$ & $\begin{array}{l}\leq 0,025 \mu \mathrm{g} \mathrm{kg}^{-1} \\
0,026-0,05 \mu \mathrm{g} \mathrm{kg}^{-1} \\
0,051-0,5 \mu \mathrm{g} \mathrm{kg}^{-1} \\
0,51-1,0 \mu \mathrm{g} \mathrm{kg}^{-1}\end{array}$ & \\
\hline & Leite em pó & $\begin{array}{l}(45 / 67) 67,1 \\
(5 / 67) 7,4 \\
(5 / 67) 7,4 \\
(1 / 67) 1,4 \\
(11 / 67) 16,4\end{array}$ & $\begin{array}{l}\leq 0,025 \mu \mathrm{g} \mathrm{kg}^{-1} \\
0,026-0,05 \mu \mathrm{g} \mathrm{kg}^{-1} \\
0,051-0,5 \mu \mathrm{g} \mathrm{kg}^{-1} \\
0,51-1,0 \mu \mathrm{g} \mathrm{kg}^{-1} \\
>1,0 \mu \mathrm{g} \mathrm{kg}^{-1}\end{array}$ & \\
\hline & Iogurte & $\begin{array}{l}(14 / 56) 25,0 \\
(20 / 56) 35,7 \\
(22 / 56) 39,2\end{array}$ & $\begin{array}{l}\leq 0,025 \mu \mathrm{g} \mathrm{kg}^{-1} \\
0,026-0,05 \mu \mathrm{g} \mathrm{kg}^{-1} \\
0,051-0,5 \mu \mathrm{g} \mathrm{kg}^{-1}\end{array}$ & \\
\hline & Sorvete & $\begin{array}{l}(7 / 21) 33,3 \\
(3 / 21) 14,2 \\
(11 / 21) 52,3 \\
\end{array}$ & $\begin{array}{l}\leq 0,025 \mu \mathrm{g} \mathrm{kg}^{-1} \\
0,026-0,05 \mu \mathrm{g} \mathrm{kg}^{-1} \\
0,051-0,5 \mu \mathrm{g} \mathrm{kg}^{-1}\end{array}$ & \\
\hline & Fórmula láctea infantil & $\begin{array}{l}(31 / 33) 93,9 \\
(2 / 33) 6,0\end{array}$ & $\begin{array}{l}\leq 0,025 \mu \mathrm{g} \mathrm{kg}^{-1} \\
0,026-0,05 \mu \mathrm{g} \mathrm{kg}^{-1}\end{array}$ & \\
\hline & Queijo branco & $(8 / 47) 17,0$ & $\leq 0,025 \mu \mathrm{g} \mathrm{kg}^{-1}$ & \\
\hline
\end{tabular}




\begin{tabular}{|c|c|c|c|c|}
\hline & & $\begin{array}{l}(11 / 47) 23,4 \\
(26 / 47) 55,3 \\
(2 / 47) 4,2\end{array}$ & $\begin{array}{l}0,026-0,05 \mu \mathrm{g} \mathrm{kg}^{-1} \\
0,051-0,5 \mu \mathrm{g} \mathrm{kg}^{-1} \\
0,51-1,0 \mu \mathrm{g} \mathrm{kg}^{-1}\end{array}$ & \\
\hline & Queijo duro & $\begin{array}{l}(6 / 27) 22,2 \\
(5 / 27) 18,5 \\
(8 / 27) 29,6 \\
(2 / 27) 7,4 \\
(6 / 27) 22,2\end{array}$ & $\begin{array}{l}\leq 0,025 \mu \mathrm{g} \mathrm{kg}^{-1} \\
0,026-0,05 \mu \mathrm{g} \mathrm{kg}^{-1} \\
0,051-0,5 \mu \mathrm{g} \mathrm{kg}^{-1} \\
0,51-1,0 \mu \mathrm{g} \mathrm{kg}^{-1} \\
>1,0 \mu \mathrm{g} / \mathrm{kg}\end{array}$ & \\
\hline & Outros lácteos & $\begin{array}{l}(27 / 71) 38,0 \\
(16 / 71) 22,5 \\
(27 / 71) 38,0 \\
(1 / 71) 1,4\end{array}$ & $\begin{array}{l}\leq 0,025 \mu \mathrm{g} \mathrm{kg}^{-1} \\
0,026-0,05 \mu \mathrm{g} \mathrm{kg}^{-1} \\
0,051-0,5 \mu \mathrm{g} \mathrm{kg}^{-1} \\
0,51-1,0 \mu \mathrm{g} \mathrm{kg}^{-1}\end{array}$ & \\
\hline \multirow{3}{*}{$\begin{array}{l}\text { Irã / } \\
\text { Bahrami; } \\
\text { Shahbazi; } \\
\text { Nikousefa } \\
\text { t, 2016* }\end{array}$} & Leite cru bovino & $(54 / 64) 84,3$ & $6,1-188,2 \mathrm{ng} \mathrm{L}^{-1}$ & \multirow[b]{3}{*}{$\mathrm{M}_{1}$} \\
\hline & Queijo & $(25 / 40) 65,5$ & $52,5-272 \mathrm{ng} \mathrm{kg}^{-1}$ & \\
\hline & Iogurte & $(10 / 42) 23,8$ & $6,3-21,3 \mathrm{ng} \mathrm{kg}^{-1}$ & \\
\hline $\begin{array}{l}\text { Brasil / } \\
\text { Gonçalves } \\
\text { et al., } \\
2017\end{array}$ & Leite fresco & $\begin{array}{l}(24 / 52) 46,2 \\
(4 / 52) 7,7 \\
(3 / 52) 5,6 \\
(19 / 52) 36,5 \\
(2 / 52) 3,8 \\
\end{array}$ & $\begin{array}{l}\leq 0,09 \mu \mathrm{g} \mathrm{L}^{-1} \\
0,1-0,25 \mu \mathrm{g} \mathrm{L}^{-1} \\
0,26-0,49 \mu \mathrm{g} \mathrm{L}^{-1} \\
\geq 0,50 \mu \mathrm{g} \mathrm{L}^{-1} \\
>1,00 \mu \mathrm{g} \mathrm{L}^{-1}\end{array}$ & $\mathrm{M}_{1}$ \\
\hline \multirow{12}{*}{$\begin{array}{l}\text { Paquistão } \\
\text { / Iqbal; } \\
\text { Asi; } \\
\text { Malik, } \\
2017^{*}\end{array}$} & Leite cru (verão) & $(19 / 32) 59,4$ & $0,4-229,6 \mathrm{ng} \mathrm{L}^{-1}$ & \multirow{12}{*}{$\mathrm{M}_{1}$} \\
\hline & Leite UHT (verão) & $(16 / 25) 64,0$ & $0,4-190,8 \mathrm{ng} \mathrm{L}^{-1}$ & \\
\hline & Leite em pó (verão) & $(9 / 32) 28,1$ & $0,4-178,5 \mathrm{ng} \mathrm{L}^{-1}$ & \\
\hline & Leite com sabor (verão) & $(12 / 25) 48,0$ & $0,4-110,1 \mathrm{ng} \mathrm{L}^{-1}$ & \\
\hline & Iogurte (verão) & $(11 / 30) 36,6$ & $0,4-158,2 \mathrm{ng} \mathrm{L}^{-1}$ & \\
\hline & Iogurte com sabor (verão) & $(10 / 25) 40,0$ & $0,4-102,5 \mathrm{ng} \mathrm{L}^{-1}$ & \\
\hline & Leite cru (inverno) & $\begin{array}{l}(29 / 42) 69 \\
69\end{array}$ & $0,4-345,8 \mathrm{ng} \mathrm{L}^{-1}$ & \\
\hline & Leite UHT (inverno) & $(26 / 35) 74,2$ & $0,4-302,9 \mathrm{ng} \mathrm{L}^{-1}$ & \\
\hline & Leite em pó (inverno) & $(12 / 32) 37,5$ & $0,4-278,4 \mathrm{ng} \mathrm{L}^{-1}$ & \\
\hline & Leite com sabor (inverno) & $(15 / 28) 53,6$ & $0,4-198,3 \mathrm{ng} \mathrm{L}^{-1}$ & \\
\hline & Iogurte (inverno) & $(15 / 36) 41,6$ & $0,4-196,3 \mathrm{ng} \mathrm{L}^{-1}$ & \\
\hline & Iogurte com sabor (inverno) & $\begin{array}{l}(17 / 30) 56,6 \\
\end{array}$ & $0,4-220,5 \mathrm{ng} \mathrm{L}^{-1}$ & \\
\hline \multirow{8}{*}{$\begin{array}{l}\text { Brasil / } \\
\text { Gonçalves } \\
\text { et al., } \\
2018^{*}\end{array}$} & Leite integral & $(19 / 26) 73,1$ & $60-3670 / 40-150 \mathrm{ng} \mathrm{L}^{-1}$ & \multirow{8}{*}{$\mathrm{M}_{1} / \mathrm{B}_{1}$} \\
\hline & Leite desnatado & $(7 / 11) 63,6$ & $40-1050 / 40-600 \mathrm{ng} \mathrm{L}^{-1}$ & \\
\hline & Leite semidesnatado & $(9 / 12) 75$ & $90-1400 /-\mathrm{ng} \mathrm{L}^{-1}$ & \\
\hline & Leite em pó integral & $(6 / 10) 60$ & $88-2800 /-\operatorname{ng~L}^{-1}$ & \\
\hline & Leite em pó infantil & $(0 / 3) 0$ & $-/-\mathrm{ng} \mathrm{kg}^{-1}$ & \\
\hline & $\overline{\text { Leite em pó integral - marca I }}$ & $(10 / 17) 58,8$ & $32-724 /-\mathrm{ng} \mathrm{kg}^{-1}$ & \\
\hline & Leite em pó integral - marca II & $(11 / 16) 68,7$ & $213-2216 /-\mathrm{ng} \mathrm{kg}^{-1}$ & \\
\hline & $\begin{array}{l}\text { Leite em pó integral - marca } \\
\text { III }\end{array}$ & $\begin{array}{l}(17 / 17) 100 \\
100\end{array}$ & $1280-2896 /-\mathrm{ng} \mathrm{kg}^{-1}$ & \\
\hline \multirow[t]{2}{*}{$\begin{array}{l}\text { Turquia / } \\
\text { Sakin et } \\
\text { al., } 2018\end{array}$} & Queijo Sürk & $\begin{array}{l}(1 / 30) 3,3 \\
(13 / 30) 43,3 \\
(9 / 30) 30 \\
(3 / 30) 10 \\
(2 / 30) 6,7 \\
(2 / 30) 6,7\end{array}$ & $\begin{array}{l}<0,035 \mu \mathrm{g} \mathrm{kg}^{-1} \\
<0,1 \mu \mathrm{g} \mathrm{kg}^{-1} \\
0,1-0,25 \mu \mathrm{g} \mathrm{kg}^{-1} \\
0,25-0,5 \mu \mathrm{g} \mathrm{kg}^{-1} \\
0,5-2 \mu \mathrm{g} \mathrm{kg}^{-1} \\
2-5 \mu \mathrm{g} \mathrm{kg}^{-1}\end{array}$ & $\begin{array}{l}\mathrm{B}_{1} \\
\mathrm{~B}_{1} \\
\mathrm{~B}_{1} \\
\mathrm{~B}_{1} \\
\mathrm{~B}_{1} \\
\mathrm{~B}_{1}\end{array}$ \\
\hline & & $\begin{array}{l}(26 / 30) 86,7 \\
\end{array}$ & $<0,059 \mu \mathrm{g} \mathrm{kg}^{-1}$ & $\mathrm{~B}_{2}$ \\
\hline
\end{tabular}




\begin{tabular}{|c|c|c|c|c|}
\hline & & $(4 / 30) 13,3$ & $<0,17 \mu \mathrm{g} \mathrm{kg}^{-1}$ & $\overline{\mathrm{B}_{2}}$ \\
\hline & & $\begin{array}{l}(25 / 30) 83,3 \\
(3 / 30) 10 \\
(2 / 30) 6,7\end{array}$ & $\begin{array}{l}<0,053 \mu \mathrm{g} \mathrm{kg}^{-1} \\
<0,14 \mu \mathrm{g} \mathrm{kg}^{-1} \\
0,14-0,25 \mu \mathrm{kg}^{-1}\end{array}$ & $\begin{array}{l}\mathrm{G}_{1} \\
\mathrm{G}_{1} \\
\mathrm{G}_{1}\end{array}$ \\
\hline & & $\begin{array}{l}(5 / 30) 16,7 \\
(6 / 30) 20 \\
(6 / 30) 20 \\
(8 / 30) 26,6 \\
(5 / 30) 16,7 \\
\end{array}$ & $\begin{array}{l}<0,061 \mu \mathrm{g} \mathrm{kg}^{-1} \\
<0,16 \mu \mathrm{g} \mathrm{kg}^{-1} \\
0,16-0,25 \mu \mathrm{g} \mathrm{kg}^{-1} \\
0,25-0,5 \mu \mathrm{g} \mathrm{kg}^{-1} \\
0,5-2 \mu \mathrm{g} \mathrm{kg}^{-1}\end{array}$ & $\begin{array}{l}\mathrm{G}_{2} \\
\mathrm{G}_{2} \\
\mathrm{G}_{2} \\
\mathrm{G}_{2} \\
\mathrm{G}_{2}\end{array}$ \\
\hline & & $\begin{array}{l}(5 / 30) 16,7 \\
(9 / 30) 30 \\
(13 / / 30) 43,3 \\
(3 / 30) 10\end{array}$ & $\begin{array}{l}<0,033 \mu \mathrm{g} \mathrm{kg}^{-1} \\
<0,07 \mu \mathrm{g} \mathrm{kg}^{-1} \\
0,07-0,25 \mu \mathrm{g} \mathrm{kg}^{-1} \\
0,25-0,5 \mu \mathrm{g} \mathrm{kg}^{-1}\end{array}$ & $\begin{array}{l}\mathrm{M}_{1} \\
\mathrm{M}_{1} \\
\mathrm{M}_{1} \\
\mathrm{M}_{1}\end{array}$ \\
\hline \multirow[t]{2}{*}{$\begin{array}{l}\text { China / } \\
\text { Xiong et } \\
\text { al., } 2018^{*}\end{array}$} & Leite pasteurizado & $\begin{array}{l}(11 / 131) 8,4 \\
(42 / 131) 32,1 \\
(23 / 131) 17,5 \\
(12 / 131) 9,2 \\
(43 / 131) 32,8 \\
\end{array}$ & $\begin{array}{l}<5 \mathrm{ng} \mathrm{L}^{-1} \\
5-49,9 \mathrm{ng} \mathrm{L}^{-1} \\
50-99,5 \mathrm{ng} \mathrm{L}^{-1} \\
100-199,9 \mathrm{ng} \mathrm{L}^{-1} \\
>200 \mathrm{ng} \mathrm{L}^{-1}\end{array}$ & \multirow[t]{2}{*}{$\mathrm{M}_{1}$} \\
\hline & Leite UHT & $\begin{array}{l}53 / 111) 47,7 \\
(56 / 111) 50,5 \\
(2 / 111) 1,8\end{array}$ & $\begin{array}{l}5 \mathrm{ng} \mathrm{L}^{-1} \\
5-49,9 \mathrm{ng} \mathrm{L}^{-1} \\
50-99,5 \mathrm{ng} \mathrm{L}^{-1}\end{array}$ & \\
\hline \multirow{4}{*}{$\begin{array}{l}\text { Brasil / } \\
\text { Sibaja et } \\
\text { al., } 2019^{*}\end{array}$} & Leite em pó integral & $(30 / 30) 100$ & $0,35-1,19 \mu \mathrm{g} \mathrm{kg}^{-1}$ & \multirow{4}{*}{$\mathrm{M}_{1}$} \\
\hline & Leite em pó desnatado & $(6 / 6 /) 100$ & $0,46-1,03 \mu \mathrm{g} \mathrm{kg}^{-1}$ & \\
\hline & $\begin{array}{l}\begin{array}{l}\text { Leite em pó sem lactose } \\
\text { semidesnatado }\end{array} \\
\end{array}$ & $(9 / 9) 100$ & $0,33-1,18 \mu \mathrm{g} \mathrm{kg}^{-1}$ & \\
\hline & $\overline{\text { Leite infantil em pó }}$ & $(6 / 6) 100$ & $0,20-0,34 \mu \mathrm{g} \mathrm{kg}^{-1}$ & \\
\hline \multirow{10}{*}{$\begin{array}{l}\text { Brasil / } \\
\text { Becker- } \\
\text { Algeri et } \\
\text { al., } 2020\end{array}$} & Leite integral UHT - PR & $(35 / 93) 37,6$ & $0,53-4,62 /-\mu \mathrm{g} \mathrm{L}^{-1}$ & \multirow{10}{*}{$\mathrm{M}_{1} / \mathrm{B}_{1}$} \\
\hline & Leite integral UHT - SC & (35/93) 37,6 & $\overline{0,34-0,93 / 1,39-1,62 \mu \mathrm{g}}$ & \\
\hline & Leite integral UHT - RS & (23/93) 24,7 & & \\
\hline & Leite semidesnatado - PR & $\begin{array}{l}(24 / 61) 39,3 \\
\end{array}$ & $-/-\mu \mathrm{gL}^{-1}$ & \\
\hline & Leite semidesnatado - SC & (23/61) 37,7 & $0,30-0,48 /-\mu \mathrm{g} \mathrm{L}-1$ & \\
\hline & Leite semidesnatado - RS & $(14 / 61) 22,9$ & $\overline{0,33-0,51 / 1,69-8,8 \mu \mathrm{g}}$ & \\
\hline & Leite desnatado - PR & $(30 / 74) 40,5$ & $\mathrm{~L}^{-1}$ & \\
\hline & Leite desnatado - SC & (24/74) 32,4 & $-/-\mu g \mathrm{~L}^{-1}$ & \\
\hline & Leite desnatado - RS & (20/74) 27,0 & $0,32-0,54 /-\mu \mathrm{g} \mathrm{L}^{-1}$ & \\
\hline & & & $\frac{0,34-0,42 /-\mu \mathrm{g} \mathrm{L}^{-1}}{-/-\mu \mathrm{g} \mathrm{L}^{-1}}$ & \\
\hline \multirow[t]{4}{*}{\begin{tabular}{|lr} 
Líbano & $/$ \\
Daou & et \\
al., $2020^{*}$
\end{tabular}} & Leite cru & $\begin{array}{l}(289 / 701) 41,2 \\
(123 / 701) 17,5 \\
(93 / 701) 13,3 \\
(196 / 701) 28 \\
\end{array}$ & $\begin{array}{l}<0,011 \mu \mathrm{g} \mathrm{L}^{-1} \\
0,011-0,024 \mu \mathrm{g} \mathrm{L}^{-1} \\
0,025-0,05 \mu \mathrm{g} \mathrm{L}^{-1} \\
>0,05 \mu \mathrm{g} \mathrm{L}^{-1}\end{array}$ & \multirow{4}{*}{$\mathrm{M}_{1}$} \\
\hline & Iogurte & $\begin{array}{l}(10 / 28) 35,7 \\
(3 / 28) 10,7 \\
(5 / 28) 17,9 \\
(10 / 28) 35,7 \\
\end{array}$ & $\begin{array}{l}<0,01 \mu \mathrm{g} \mathrm{L}^{-1} \\
0,01-0,024 \mu \mathrm{g} \mathrm{L}^{-1} \\
0,025-0,05 \mu \mathrm{g} \mathrm{L}^{-1} \\
>0,05 \mu \mathrm{g} \mathrm{L}^{-1}\end{array}$ & \\
\hline & Iogurte coado (Labneh) & $\begin{array}{l}(3 / 27) 11,1 \\
(2 / 27) 7,4 \\
(22 / 27) 81,5\end{array}$ & $\begin{array}{l}<0,01 \mu \mathrm{g} \mathrm{L}^{-1} \\
0,025-0,05 \mu \mathrm{g} \mathrm{L}^{-1} \\
>0,05 \mu \mathrm{g} \mathrm{L}^{-1}\end{array}$ & \\
\hline & Iogurte Ayran & $\begin{array}{l}(1 / 9) 11,1 \\
(1 / 9) 11,1 \\
(3 / 9) 33,3\end{array}$ & $\begin{array}{l}<0,01 \mu \mathrm{g} \mathrm{L}^{-1} \\
0,01-0,024 \mu \mathrm{g} \mathrm{L}^{-1} \\
0,025-0,05 \mu \mathrm{g} \mathrm{L}^{-1}\end{array}$ & \\
\hline
\end{tabular}




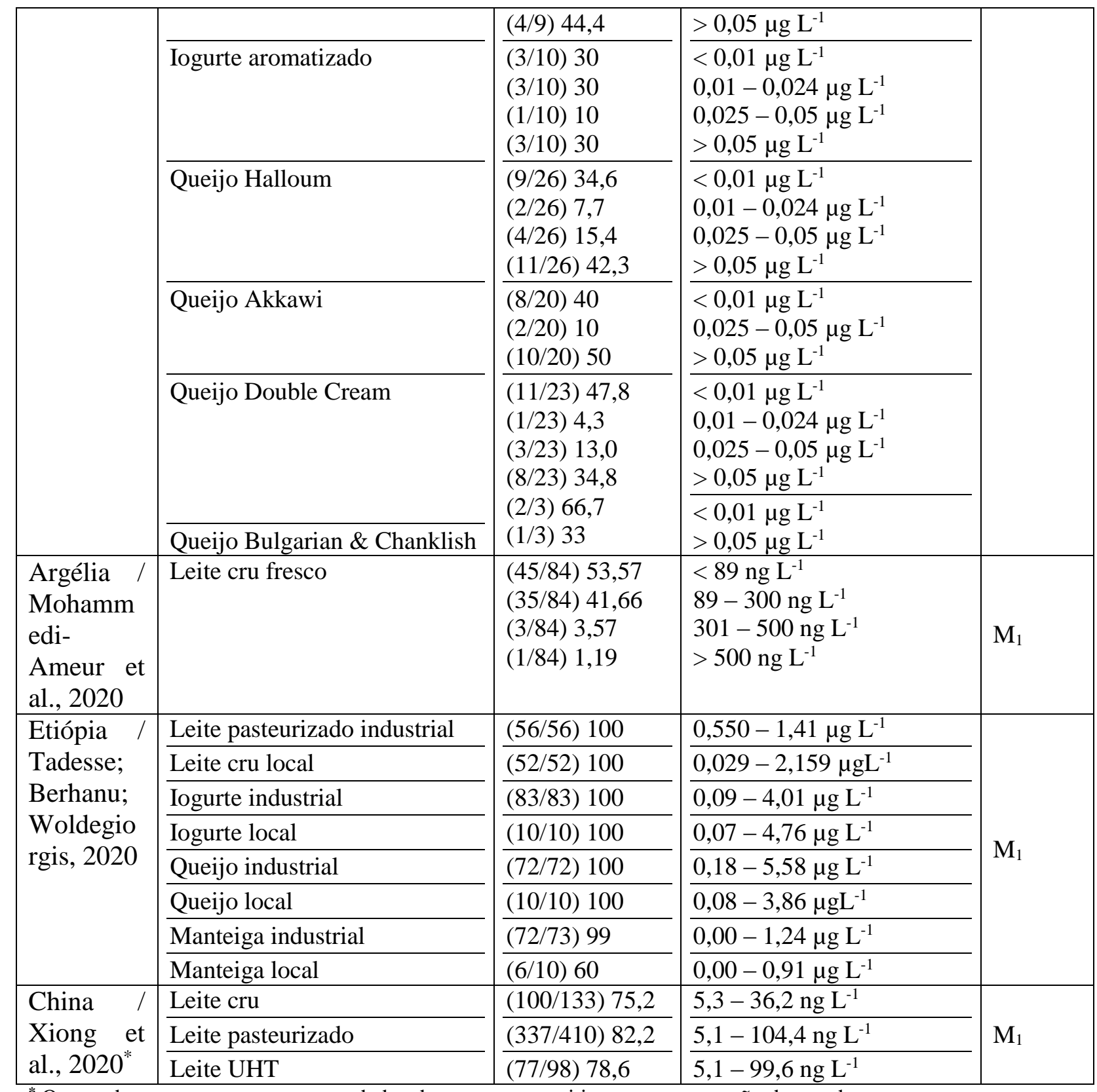

" Os estudos apresentaram somente dados das amostras positivas. - amostra não detectada.

Visando garantir a segurança do alimento, métodos de descontaminação que proporcionem a remoção e/ou redução da micotoxina, sem a formação de resíduos tóxicos, mantendo o valor nutricional $\mathrm{e}$ as propriedades tecnológicas dos alimentos, tem sido estudados (CAMPAGNOLLO et a., 2016; PARK, 2002; SANTOS et al., 2014). Destacam-se os métodos biológicos que fazem uso de enzimas ou micro-organismos, tendo como principal vantagem a eficiência quando comparado com as metodologias que fazem uso de agentes químicos e físicos (FAZELI et al., 2009; WU et al., 2009). 


\section{Bactérias ácido láticas}

Os micro-organismos mais estudados para descontaminação das AFLAs têm sido as bactérias ácido láticas (BAL), uma vez que são reconhecidas por serem organismos seguros e conseguirem se ligar com a toxina. As BAL são micro-organismos probióticos, que têm como característica a produção de ácido lático, são Gram-positivas, não produzem catalase e oxidase, e podem produzir reuterina, reconhecida como antifúngico, quando há glicerol no meio que irá ocorrer à fermentação (DALIÉ; DESCHAMPS; FORGET-RICHARD, 2010; GOURAMA; BULLERMAN, 1995; LINDGREN; DROGOSZ, 1990). Os Lactobacillus spp. são um gênero das BAL amplamente utilizado em alimentos crus, mas também podem ser aplicados em alimentos fermentados para maior preservação destes (GOURAMA; BULLERMAN, 1995). Além disso, estas bactérias fornecem propriedades funcionais e melhorias sensoriais ao produto (FABIAN et al., 2008).

A inibição do crescimento de micro-organismos produtores de AFLAs, bem como o efeito do uso de BAL tem sido avaliados em estudos in vivo (ABBÈS et al., 2016; CHEN et al., 2019; GOMAA; ABDELALL; EL-MAHDY, 2018; GUIMARÃES et al., 2018; JEBALI et al., 2018; NATEGHI et al., 2016; NDUTI et al., 2016; ONILUDE et al., 2005; SALAHABBÈS et al., 2015), e. alguns já comprovaram a capacidade dessas bactérias em reduzir ou degradar níveis da micotoxina in vitro (Quadro 2).

Quadro 2. Uso de bactérias ácido láticas na descontaminação de aflatoxinas em leite e derivados lácteos.

\begin{tabular}{|c|c|c|c|}
\hline $\begin{array}{l}\text { Autores } \\
\text { (ano) }\end{array}$ & Micro-organismo (s) & $\begin{array}{l}\text { AFLAs / } \\
\text { Meio de } \\
\text { descontamin } \\
\text { acão }\end{array}$ & Principais resultados \\
\hline $\begin{array}{ll}\text { Pierides et } \\
\text { al }(2000)\end{array}$ & $\begin{array}{l}\text { Lactobacillus } r \text { acidophillus } \\
\text { LA1; L. gasseri ATCC 33323; } \\
\text { L. rhamnosus GG; L. } \\
\text { rhamnosus LC-705; L. } \\
\text { rhamnosus 1/3; Lactococcus } \\
\text { lactis ssp. ARH74 }\end{array}$ & $\begin{array}{l}\mathrm{M}_{1}(0,15 \mu \mathrm{g} \\
\left.\mathrm{mL}^{-1}\right) / \mathrm{PBS}, \\
\text { leite integral } \\
\text { e leite } \\
\text { desnatado }\end{array}$ & $\begin{array}{l}77,0 \% \text { de redução com } L \text {. } \\
\text { rhamnosus GG viável no } \\
\text { período de } 4 \text { h em PBS. } 76,1 \% \\
\text { de descontaminação usando } L \text {. } \\
\text { rhamnosus LC-705 durante } 24 \\
\text { h em PBS; } 69,9 \text { e } 63,6 \% \text { de } \\
\text { diminuição em leite desnatado } \\
\text { e integral. }\end{array}$ \\
\hline $\begin{array}{l}\text { Haskard et } \\
\text { al (2001) }\end{array}$ & $\begin{array}{l}\text { Lactobacillus rhamnosus GG; } \\
\text { L. rhamnosus LC-705; L. } \\
\text { acidophilus LC1; L. lactis } \\
\text { subsp. lactis; L. acidophilus } \\
\text { ATCC 4356; L. plantarum; L. } \\
\text { casei Shirota; L. delbrueckii } \\
\text { subsp. bulgaricus; L. }\end{array}$ & $\begin{array}{l}\mathrm{B}_{1} \quad(10 \quad \mathrm{ng} \\
\left.\mathrm{mL}^{-1}\right) / \mathrm{PBS}\end{array}$ & $\begin{array}{l}\text { L. rhamnosus GG e } L \text {. } \\
\text { rhamnosus LC-705 ligaram } \\
78,9 \text { e } 76,5 \% \text { em } 4 \quad \mathrm{~h} \\
\text { respectivamente, e após } \\
\text { lavagens com PBS mantiveram } \\
\text { 49,5 e } 37,8 \% \text { da micotoxina. }\end{array}$ \\
\hline
\end{tabular}




\begin{tabular}{|c|c|c|c|}
\hline & $\begin{array}{lr}\text { helveticus; } & \text { Propionibacterium } \\
\text { freudenreichii } & \text { subsp. } \\
\text { shermanii JS; } & \text { Lactococcus } \\
\text { lactis subsp. } & \text { cremoris; } \\
\text { Streptococcus thermophilus }\end{array}$ & & \\
\hline $\begin{array}{l}\text { Kabak; Var } \\
\text { (2008) }\end{array}$ & $\begin{array}{l}\text { Lactobacillus } \quad \text { acidophilus } \\
\text { NCC 12; L. acidophilus NCC } \\
\text { 36; L. acidophilus NCC 68; L. } \\
\text { rhamnosus; Bifidobacterium } \\
\text { bifidum Bb13; B. bifidum NCC } \\
381\end{array}$ & $\begin{array}{l}\mathrm{M}_{1}(5 ; 10 ; 20 \\
\left.\mathrm{ng} \mathrm{mL}^{-1}\right) / \\
\text { PBS e leite }\end{array}$ & 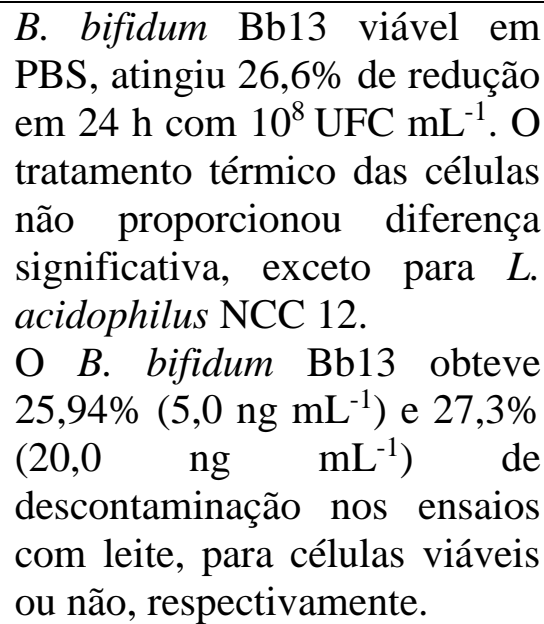 \\
\hline $\begin{array}{l}\text { Bovo et al } \\
\text { (2013) }\end{array}$ & 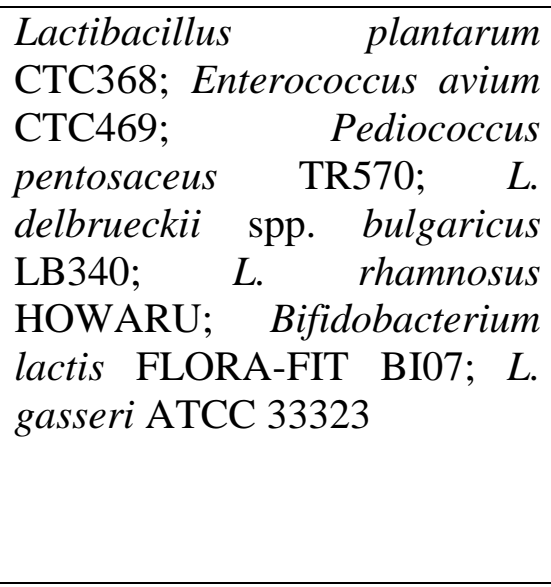 & $\begin{array}{l}\mathrm{M}_{1}(0,15 \mu \mathrm{g} \\
\mathrm{mL}^{-1} \text { no } \\
\mathrm{PBS}) \text { e }(0,5 \\
\mu \mathrm{g} \mathrm{L}^{-1} \text { no } \\
\text { leite }) / \mathrm{PBS} \text { e } \\
\text { leite } \\
\text { desnatado }\end{array}$ & $\begin{array}{l}\text { O tratamento com calor teve } \\
\text { maior capacidade de ligação } \\
\text { com a aflatoxina, usando } L \text {. } \\
\text { rhamnosus. A estabilidade do } \\
\text { complexo foi mais estável nas } \\
\text { células não viáveis. } L \text {. } \\
\text { bulgaricus atingiu } 65,6 \text { e } \\
69,1 \% \text { de ligação em PBS com } \\
15 \text { min e } 24 \text { h; no ensaio em } \\
\text { leite B. lactis obteve } 37,6 \text { e } \\
32,54 \% \text { de ligação em } 4 \text { e } 37 \\
{ }^{\circ} \text { C. }\end{array}$ \\
\hline $\begin{array}{l}\text { Ghazvini et } \\
\text { al (2016) }\end{array}$ & $\begin{array}{l}\text { Bifidobacterium bifidum PTCC } \\
\text { 1644; Lactobacillus fermentum } \\
\text { PTCC 1744; Aspergillus } \\
\text { parasiticus } \text { PTCC } 5286\end{array}$ & $\begin{array}{l}\mathrm{B}_{1} \text { e } \mathrm{G}_{1}(125 \\
\mathrm{ppb}) ; \mathrm{B}_{2} \text { e } \mathrm{G}_{2} \\
(25 \mathrm{ppb}) \quad / \\
\text { Caldo } \\
\text { tríptico de } \\
\text { soja }\end{array}$ & $\begin{array}{l}\text { B. bifidum diminuiu } \mathrm{AFLAB}_{1} \text {, } \\
\mathrm{AFLAG}_{1} \text {, e } \mathrm{AFLAG}_{2} \text { em } \\
99,9 \% \text { e AFLAB } \mathrm{B}_{2} \text { em } 99,8 \% \text {. } \\
L . \text { fermentum reduziu em } \\
99,9 \% \text { todas micotoxinas. } B . \\
\text { bifidum e } L . \text { fermentum } \\
\text { reduziram o crescimento } \\
\text { fúngico em } 81,6 \text { e } 77 \% \text {, } \\
\text { respectivamente. }\end{array}$ \\
\hline $\begin{array}{l}\text { Sedaghat et } \\
\text { al (2016) }\end{array}$ & $\begin{array}{l}\text { Lactobacillus plantarum PIN; } \\
\text { L. plantarum CAG23; L. casei } \\
\text { D31; L. pentosus H39; L. } \\
\text { plantarum NBRC 107151; L. } \\
\text { plantarum KU13; Aspergillus } \\
\text { flavus PTCC 5004 e A. } \\
\text { parasiticus PTCC 5286 }\end{array}$ & $\begin{array}{l}\text { - I Queijo } \\
\text { fresco }\end{array}$ & $\begin{array}{l}\text { L. plantarum PIN }\left(10^{8} \text { UFC }\right. \\
\left.\mathrm{mL}^{-1}\right) \text { apresentou a melhor } \\
\text { atividade antifúngica, } \\
\text { proporcionando um atraso de } \\
19 \text { e } 22 \text { dias no crescimento de } \\
\text { A. flavus e A. parasiticus, } \\
\text { respectivamente a temperatura } \\
\text { de armazenamento em } 4{ }^{\circ} \mathrm{C} \text {. }\end{array}$ \\
\hline $\begin{array}{l}\text { Ismail et al } \\
(2017)\end{array}$ & $\begin{array}{lrr}\text { Lactobacillus } & \text { plantarum } \\
\text { NRRL B-4496; L. helveticus } \\
\text { ATCC 12046; Lactococcus }\end{array}$ & $\begin{array}{l}\mathrm{M}_{1}(0,05 ; 0,1 \\
\left.\mu \mathrm{g} \quad \mathrm{L}^{-1}\right) \quad / \\
\text { Leite }\end{array}$ & $\begin{array}{l}\text { Houve } 100 \% \text { de ligação com } S \text {. } \\
\text { cerevisiae e L. helveticus na } \\
\text { mistura com os quatro micro- }\end{array}$ \\
\hline
\end{tabular}




\begin{tabular}{|c|c|c|c|}
\hline & $\begin{array}{l}\text { lactis JF 3102; Saccharomyces } \\
\text { cerevisiae HR } 125^{\mathrm{a}}\end{array}$ & & $\begin{array}{l}\text { organismos }\left(10^{10} \text { células } \mathrm{mL}^{-1}\right. \\
\left.\text { e } 0,05 \mu \mathrm{g} \mathrm{L}^{-1} \text { de AFLAM }\right) . L . \\
\text { plantarum e Lactococcus lactis } \\
\text { obtiveram } 80 \text { e } 76 \% \text { de } \\
\text { ligação. A concentração de } 0,1 \\
\mu \mathrm{g} \mathrm{L} \mathrm{L}^{-1} \text { de AFLAM } \text { A }_{1} \text { gerou } 92 ; \\
87 ; 85 ; 77 \text { e } 73 \% \text { de ligação } \\
\text { com } S . \text { cerevisiae; a mistura de } \\
\text { todos organismos, } L \text {. } \\
\text { helveticus, L. plantarum e } \\
\text { Lactococcus } \\
\text { respectivamente. }\end{array}$ \\
\hline $\begin{array}{l}\text { Kamyar; } \\
\text { Movassagh } \\
\text { ghazani, } \\
\text { (2017). }\end{array}$ & \begin{tabular}{lrc} 
Grupo 1 & - & Lactobacillus \\
acidophilus; & Bifidobacterium \\
BB-12; & \multicolumn{2}{c}{ Streptococcus } \\
thermophiles; & grupo $2 \quad-$ \\
Lactococcus & lactis & subsp. \\
cremoris; & \multicolumn{2}{c}{ Leuconostoc; } \\
Lactococcus & lactis & subsp. \\
lactis; grupo & - Debaromyces \\
hansenii; & Kluyveromyces \\
marxians subsp. marxianus
\end{tabular} & $\begin{array}{l}\text { M }(150 ; 200 \\
\left.; 250 \mathrm{ng} \mathrm{L^{-1 }}\right) \\
/ \quad \text { Kefir } \\
\text { utilizando } \\
\text { leite }\end{array}$ & $\begin{array}{l}\text { O maior nível de diminuição } \\
\text { da AFLA foi } 65 \% \text { aplicando } L \text {. } \\
\text { acidophilus, } B . \quad \mathrm{BB}-12, \quad S \text {. } \\
\text { thermophiles e } 200 \mathrm{ng} \mathrm{L}^{-1} \text {. }\end{array}$ \\
\hline $\begin{array}{l}\text { Sarlak et al } \\
(2017)\end{array}$ & 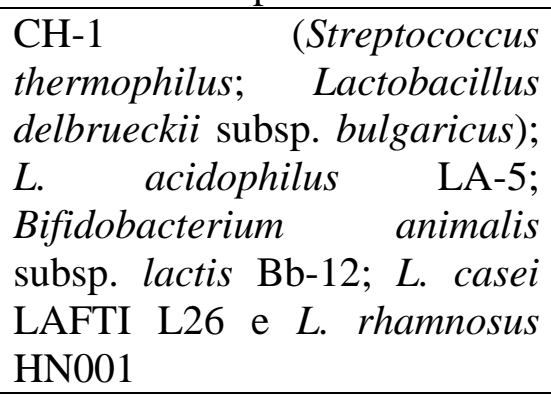 & $\begin{array}{l}\mathrm{M}_{1}(0,5 \mathrm{ppb}) \\
/ \quad \text { Leite } \\
\text { fermentado }\end{array}$ & $\begin{array}{l}\text { L. acidophilus } \text { LA-5 }(7 \text { log } \\
\text { UFC } \mathrm{mL}^{-1} \text { ) e pH } \text { final } \\
\text { fermentativo em } 4,5 \text { em } 28 \\
\text { dias de armazenamento, } \\
\text { descontaminou } 98,8 \% \text { da } \\
\text { AFLA. }\end{array}$ \\
\hline $\begin{array}{l}\text { Taheur et al } \\
\text { (2017) }\end{array}$ & $\begin{array}{l}\text { Bactérias e leveduras isoladas } \\
\text { de grãos e leite do kefir }\end{array}$ & $\begin{array}{l}\text { B }_{1}(1 \mu \mathrm{g} \mathrm{mL} \\
\left.{ }^{1}\right) / \text { Leite e } \\
\text { em caldo } \\
\text { Man, Rogosa } \\
\text { e Sharpe e } \\
\text { extrato de } \\
\text { levedura } \\
\text { peptona e } \\
\text { dextrose }\end{array}$ & $\begin{array}{l}\text { Lactobacillus kefiri e } \\
\text { Kazachstania servazzii ligaram } \\
80 \text { e } 74 \% \text { da AFLAB } \text { em leite, }_{1} \\
\text { respectivamente, a estabilidade } \\
\text { do complexo liberaram } 66 \text { e } \\
35 \% \text {, após o tratamento em pH } \\
7 ; 3 \text { e } 8 .\end{array}$ \\
\hline $\begin{array}{l}\text { Abdelmotili } \\
\text { b et al } \\
(2018)\end{array}$ & $\begin{array}{l}\text { Lactobacillus plantarum DSM } \\
20174 ; \text { L. acidophilus DSM } \\
20079 ; \quad \text { Bifidobacterium } \\
\text { bifidum DSM 20082; } \\
\text { Kluyveromyces lactis CBS } \\
\text { 2359; Saccharomyces } \\
\text { cerevisiae ATCC } 64712 \\
\end{array}$ & $\begin{array}{l}\mathrm{M}_{1}(50 \mathrm{ng} \\
\left.\mathrm{mL}^{-1}\right) / \mathrm{PBS} \\
\text { e leite }\end{array}$ & $\begin{array}{l}\text { A maior redução foi utilizando } \\
\text { o efeito combinatório das BAL } \\
\text { tratadas termicamente na } \\
\text { concentração de } 5 \times 10^{9} \text { UFC } \\
\mathrm{mL}^{-1} \text {, conseguindo taxas de } \\
87,9 \text { e } 90,9 \% \text { em PBS e leite, } \\
\text { respectivamente. }\end{array}$ \\
\hline $\begin{array}{l}\text { Barukcic et } \\
\text { al (2018) }\end{array}$ & $\begin{array}{lr}\text { Bifidobacterium } & \text { animalis } \\
\text { subsp. lactis } & \text { BB-12, } \\
\text { Lactobacillus casei } & \text { LC-01; } \\
\text { cultura combinada } & \text { ABT-5 de }\end{array}$ & $\begin{array}{l}\mathrm{M}_{1}(50 \mathrm{ng} \\
\left.\mathrm{kg}^{-1}\right) / \text { Leite } \\
\text { fermentado }\end{array}$ & 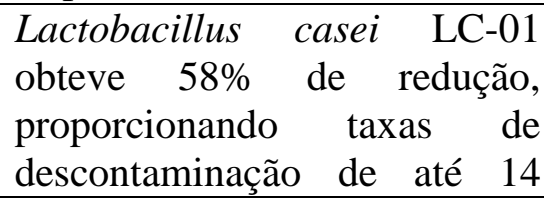 \\
\hline
\end{tabular}




\begin{tabular}{|c|c|c|c|}
\hline & $\begin{array}{l}\text { L. acidophilus La-2; BB-12 e } \\
\text { Streptococcus thermophilus; } \\
\text { culturas comerciais de iogurte } \\
\text { YC-380; mesófilos CHN-19; } \\
\text { kefir XPL-1 }\end{array}$ & & dias. \\
\hline $\begin{array}{l}\text { Delgado et } \\
\text { al (2018) }\end{array}$ & $\begin{array}{lr}\text { A proteína avaliada isolada ou } \\
\text { em combinação } & \text { com } \\
\text { Debaryomyces } & \text { hansenii } \\
\text { FHSCC } 253 \mathrm{H} & \text { e/ou } \\
\text { Pediococcus acidilactici fargo } \\
\text { 35; Aspergillus parasiticus } \\
\text { CECT 2682 }\end{array}$ & $\begin{array}{l}\mathrm{B}_{1} \text { e } \mathrm{G}_{1} / \\
\text { Extrato de } \\
\text { levedura, } \\
\text { extrato de } \\
\text { levedura } \\
\text { enriquecido } \\
\text { com cloreto } \\
\text { de cálcio e } \\
\text { queijo } \\
\text { fermentado a } \\
\text { seco }\end{array}$ & $\begin{array}{l}\text { O tratamento com a proteína e } \\
\text { Debaryomyces hansenii } \\
\text { FHSCC } 253 \mathrm{H} \text { inibiu o } \\
\text { crescimento do } A \text {. parasiticus } \\
\text { de } 5 \text { até } 15 \text { dias, com } \\
\text { concentrações de AFLAB } 1 \\
\text { menores que } 4 \text { ppb (LOD) e } \\
\text { AFLAG menores que } 1,5 \text { ppb } \\
\text { (LOD). }\end{array}$ \\
\hline $\begin{array}{l}\text { Ghanbari et } \\
\text { al (2018) }\end{array}$ & $\begin{array}{l}\text { Lactobacillus plantarum 1058; } \\
\text { L. delbrueckii subsp. lactis } \\
\text { 1057; Aspergillus parasiticus } \\
\text { ATCC } 15517\end{array}$ & $\begin{array}{l}\text { Expressão do } \\
\text { gene aflR / } \\
\text { Microdiluiçã } \\
\text { o em caldo }\end{array}$ & $\begin{array}{l}\text { A } \mathrm{AFLAG}_{2} \text { foi inibida a níveis } \\
\text { abaixo do limite de detecção e } \\
\text { as AFLAB } \mathrm{AFLAB}_{2} \text { e } \\
\mathrm{AFLAG}_{1} \text { foram menos } \\
\text { detectadas na exposição com } \\
\text { L. plantarum, obtendo } \\
\text { concentrações } 50600 ; 2200 ; \\
25600 \text { e } 78400 \text { ppb, } \\
\text { respectivamente; A análise de } \\
\text { PCR demonstrou redução na } \\
\text { expressão do gene aflR, em } \\
\text { ambas as BAL. }\end{array}$ \\
\hline $\begin{array}{l}\text { Kuharic et } \\
\text { al (2018) }\end{array}$ & $\begin{array}{l}\text { Lactobacillus plantarum SM1; } \\
\text { L. plantarum SMB; L. } \\
\text { plantarum MM; L. plantarum } \\
\mathrm{KM} \text {; L. paracasei } \mathrm{KM} \text {; L. } \\
\text { rhamnosus } \mathrm{KM} \text { L. plantarum } \\
\text { SMA; L. plantarum SS1; L. } \\
\text { helveticus S9; Lactococcus } \\
\text { lactis 5MS1 }\end{array}$ & $\begin{array}{l}\mathrm{M}_{1}(0,5 \mu \mathrm{g} \mathrm{L} \\
\left.{ }^{1}\right) / \text { Leite }\end{array}$ & $\begin{array}{l}\text { L. plantarum KM viável ou } \\
\text { tratado termicamente foi capaz } \\
\text { de ligar a } \mathrm{AFLAM}_{1} \text {, obtendo } \\
92,7 \text { e } 94,5 \% \text { de ligação, } \\
\text { respectivamente, em } 4 \text { h de } \\
\text { cultivo. }\end{array}$ \\
\hline $\begin{array}{l}\text { Marrez et al } \\
\text { (2018) }\end{array}$ & $\begin{array}{l}\text { Lactobacillus acidophilus CH- } \\
2 ; \text { Streptococcus thermophilus } \\
\text { CH-1; L. rhamnosus B-445; L. } \\
\text { plantarum EMCC-1039 }\end{array}$ & $\begin{array}{l}\mathrm{B}_{1}(50 \mathrm{ng} \\
\left.\mathrm{mL}^{-1}\right) / \text { Leite } \\
\text { integral } \mathrm{e} \\
\text { caldo Man, } \\
\text { Rogosa } \mathrm{e} \\
\text { Sharpe }\end{array}$ & $\begin{array}{l}\text { No caldo Man, Rogosa e } \\
\text { Sharpe as maiores reduções de } \\
\text { AFLAB }{ }_{1} \text { ocorreram com S. } \\
\text { thermophilus CH-1, seguido de } \\
\text { L. plantarum EMCC-1039, } \\
\text { com } 65,7 \text { e } 57,7 \% \text { de } \\
\text { descontaminação. L. plantarum } \\
\text { EMCC-1039, L. rhamnosus B- } \\
445 \text { e } S . \text { thermophilus CH-1 } \\
\text { propiciaram descontaminações } \\
\text { de } 85,2 ; 79,4 \text { e } 65,2 \% \text {, } \\
\text { respectivamente, no leite. }\end{array}$ \\
\hline $\begin{array}{l}\text { Sokoutifar } \\
\text { et al (2018) }\end{array}$ & $\begin{array}{lrr}\text { Lactobacillus } & \text { acidophilus } \\
\text { PTCC } 1643 ; \quad \text { L. } & \text { plantarum }\end{array}$ & $\begin{array}{l}\mathrm{M}_{1}(180 \mathrm{pg} \\
\left.\mathrm{mL}^{-1}\right) / \text { Leite }\end{array}$ & $\begin{array}{l}\text { L. plantarum PTCC } 1058 \\
\text { apresentou maior eficiência a }\end{array}$ \\
\hline
\end{tabular}




\begin{tabular}{|c|c|c|c|}
\hline & PTCC 1058 & $\begin{array}{l}\text { fermentado } \\
\text { industrial e } \\
\text { tradicional }\end{array}$ & $\begin{array}{l}37{ }^{\circ} \mathrm{C} \text { com } 100 \% \text { de redução } \\
\text { da micotoxina nos primeiros } \\
10 \text { dias para o leite fermentado } \\
\text { tradicional e industrial. }\end{array}$ \\
\hline $\begin{array}{l}\text { Sevim et al } \\
(2019)\end{array}$ & $\begin{array}{l}\text { Bifidobacterium } \\
\text { ATCC 35914; B. animalis } \\
\text { subsp. animalis ATCC 27672; } \\
\text { Lactobacillus } \quad \text { plantarum } \\
\text { ATCC 10697; culturas } \\
\text { iniciadoras de iogurte (L. } \\
\text { delbrueckii subsp. bulgaricus } \\
\text { RSKK 04087 e Streptococcu } \\
\text { thermophiles RSKK 01017) }\end{array}$ & $\begin{array}{l}\mathrm{M}_{1} \\
\left(100 \mathrm{ng} \mathrm{mL}^{-}\right. \\
\left.{ }^{1}\right) / \text { Iogurte e } \\
\text { PBS }\end{array}$ & $\begin{array}{l}\text { A ligação da micotoxina em } \\
\text { iogurte sem a suplementação } \\
\text { da inulina obteve os melhores } \\
\text { resultados com } B \text {. bifidum e } B \text {. } \\
\text { animalis subsp. animalis após } \\
\text { um dia de armazenamento com } \\
60,8 \% \text { de ligação. Após } 10 \\
\text { dias de armazenamento } L \text {. } \\
\text { plantarum e B. bifidum } \\
\text { atingiram 55,1\% de ligação. A } \\
\text { adição de inulina obteve o } \\
\text { máximo de ligação com } L \text {. } \\
\text { plantarum e B. bifidum, } 70,5 \% \\
\text { após um dia de } \\
\text { armazenamento. O ensaio com } \\
\text { PBS obteve resultados de } \\
\text { ligação inferiores ao } \\
\text { encontrado no iogurte. }\end{array}$ \\
\hline $\begin{array}{l}\text { Wochner et } \\
\text { al (2019) }\end{array}$ & Lactobacillus acidophilus La-5 & $\begin{array}{l}\mathrm{B}_{1}(3,25 \text { a } \\
\left.6,0 \mu \mathrm{g} \mathrm{L}^{-1}\right) \mathrm{e} \\
\mathrm{M}_{1}(1,0 \text { a } 2,0 \\
\left.\mu \mathrm{g} \quad \mathrm{L}^{-1}\right) \\
\text { Leite }\end{array}$ & $\begin{array}{l}\text { A maior redução de } \text { AFLAB }_{1} \\
\text { foi utilizando a BAL, } \beta \text { - } \\
\text { glucana e polidextrose } \\
\text { atingindo } 35,5 \% \text {, e a redução } \\
\text { de } \text { AFLAM }_{1} \text { foi de } 71,5 \% \text {. A } \\
\text { melhor condição experimental } \\
\text { foi } 6,5 \mu \mathrm{g} \mathrm{L}^{-1} \text { de } A F L A B_{1} \text { e } 2,0 \\
\mu \mathrm{g} \mathrm{L}^{-1} \text { de AFLAM } \mathrm{AM}_{1} \text { com tempo } \\
\text { de incubação de } 0 \mathrm{~h} \text { e adição } \\
\text { de probióticos e inulina } \\
(0,75 \%) \text {. }\end{array}$ \\
\hline $\begin{array}{l}\text { Gonçalves } \\
\text { et al (2020) }\end{array}$ & $\begin{array}{lr}\text { Lactobacillus } & \text { rhamnosus; } \\
\text { Lactococcus } & \text { lactis; } \\
\text { Saccharomyces cerevisiae }\end{array}$ & $\begin{array}{l}\mathrm{M}_{1}(0,5 \mu \mathrm{g} \\
\left.\mathrm{kg}^{-1}\right) / \text { Queijo } \\
\text { Minas frescal }\end{array}$ & $\begin{array}{l}\text { As BAL obtiveram } 94 \% \text { de } \\
\text { redução com } 10 \text { dias de } \\
\text { armazenamento. Avaliando } \\
\text { somente a levedura, atingiu-se } \\
100 \% \text { em } 20 \text { dias de } \\
\text { armazenamento. As BAL e a } \\
\text { levedura diminuiram } 100 \% \text { em } \\
10 \text { dias de armazenamento. }\end{array}$ \\
\hline
\end{tabular}

É possível observar no Quadro 2, que a aplicação de Lactobacillus plantarum, L. rhamnosus, L. bulgaricus e Bifidobacterium bifidum, viáveis ou tratados termicamente, em leite ou derivados lácteos, têm resultados promissores de descontaminação. Gonçalves et al (2018) atingiu níveis de 40 a 3670 ng L ${ }^{-1}$ de AFLAM $_{1}$ em leite, fazendo uso das condições experimentais desenvolvidas por Sarlak et al (2017), que obteve 98,8\% de descontaminação 
em leite fermentado com contaminação inicial de 0,5 ppb para AFLAM $_{1}$, utilizando concentração inicial de BAL em $7 \log \mathrm{UFC} \mathrm{mL} \mathrm{m}^{-1}$ e temperatura de $40{ }^{\circ} \mathrm{C}$ com pH final em 4,5 e Taheur et al (2017), por meio do cultivo por $24 \mathrm{~h}$ a $25^{\circ} \mathrm{C}$, fazendo uso de leite contaminado com $1 \mu \mathrm{g} \mathrm{mL}^{-1}$ de $\mathrm{AFLAB}_{1}$, atingiu $80 \%$ de redução, demonstrando as possibilidade de reduções dentro das concentrações nas diferentes legislações vigentes. Porém, a redução destes contaminantes dependerá dos micro-organismos que serão utilizados, das concentrações de BAL e de aflatoxina presente, tempo de contato entre bactéria e aflatoxina e, a estabilidade deste complexo.

\section{Considerações Finais}

O uso de BAL em leite e derivados contaminados com AFLAM1 e/ou AFLAB1 com o objetivo de reduzir e/ou degradar estes contaminantes é uma alternativa promissora, demonstrada pelos estudos apresentados nesta revisão. Entretanto ainda é necessário elucidar o mecanismo de ação entre os micro-organismos e as aflatoxinas, bem como avaliar a estabilidade deste complexo a fim de garantir que estes compostos não ofereçam risco à saúde humana.

\section{Referências}

ABBÈS, S.; SALAH-ABBÈS, J. B.; JEBALI, R.; YOUNES, R. B.; OUESLATI, R. Interaction of aflatoxin $B_{1}$ and fumonisin $B_{1}$ in mice causes immunotoxicity and oxidative stress: possible protective role using lactic acid bacteria. Journal of Immunotoxicology, v. 13, p. $1-9,2016$.

ABDELMOTILIB, N. M.; HAMAD, G. M.; ELDEREA, H. B.; SALEM, E. G.; SOHAIMY, S. A. E. Aflatoxin $M_{1}$ reduction in milk by a novel combination of probiotic bacterial and yeast strains. European Journal of Nutrition \& Food Safety, v. 8, p. 83 - 99, 2018.

AGÊNCIA NACIONAL DE VIGILÂNCIA SANITÁRIA- ANVISA. Resolução de Diretoria Colegiada (RDC) número 7 de 18 de Fevereiro de 2011. Limites máximos tolerados para micotoxinas em alimentos. Diário Oficial da União. Disponível em: http://portal.anvisa.gov.br/documents/10181/2968262/\%282\%29RDC_07_2011_COMP.pdf/4 2310948-a1c5-4213-a467-1da97b8f4cae. Acesso em: 30 julho 2020.

ALAHLAH, N.; MAADOUDI, M. E.; BOUCHRITI, N.; TRIQUI, R.; BOUGTAIB, H. Aflatoxin $\mathrm{M}_{1}$ in UHT and poder milk marketed in the northern área of Morocco. Food Control, v. 114, p. 1 - 5, 2020.

AWASTHI, V.; BAHMAN, B.; THAKUR, L. K.; SINGH, S. K.; DUA, A.; GANGULY, S. Contaminants in milk and impact of heating: na assessment study. Indian Journal of Public Health, v. 56, p. 95 - 99, 2012. 
BAHRAMI, R.; SHAHBAZI, Y.; NIKOUSEFAT, Z. Aflatoxin $\mathrm{M}_{1}$ in milk and traditional dairy products from west parto f Iran: occurrence and seasonal variation with emphasis on risk assessment of human exposure. Food Control, v. 62, p. 250 - 256, 2016.

BAKIRCI, I. A study on the occurrence of aflatoxin $\mathrm{M}_{1}$ in milk and milk products produced in Van province of Turkey. Food Control, v. 12, p. 47 - 51, 2001.

BARUKCIC, I.; BILANDZIC, N.; MARKOV, K.; JAKOPOVIC, K. L.; BOZANIC, R. Reduction in aflatoxin $\mathrm{M}_{1}$ concentration during production and storage of selected fermented milks. Intermational Journal of Dairy Technology, v. 71, p. 734 - 740, 2018.

BECKER-ALGERI, T. A.; CASTAGNARO, D.; BORTOLI, K.; SOUZA, C.; DRUNKLER, D. A.; BADIALE-FURLONG, E. Micotoxins in bovine milk and dairy products: a review. Journal of Food Science, v. 81, p. R544 - R552, 2016.

BECKER-ALGERI, T. A.; SOUZA, C.; BORTOLI, K.; CASTAGNARO, D.; SCAGLIONI, P. T.; DRUNKLER, D. A.; DORS, G.; VALDERRAMA, P.; BADIALE-FURLONG, E. Seasonal variation of milk quality: physicochemical, microbiological, and toxicological. Journal of Food Safety, v. e12796, 2020.

BENKERROUM, N. Chronic and acute toxicities of aflatoxinas: mechanisms of action. International Journal of Environmental Research and Public Health, v. 17, p. $1-28$, 2019.

BENNETT, J. W.; KLICH, M. Mycotoxins. Clinical Microbiology Reviews, v. 16, p. 497 $516,2003$.

BOVO, F.; CORASSIN, C. H.; ROSIM, R. E.; OLIVEIRA, C. A. F. Efficiency of lactic acid bacteria strains for decontamination of aflatoxin $\mathrm{M}_{1}$ in phosphate buffer saline solution and skimmed milk. Food and Bioprocess Technology, v. 6, p. 2230 - 2234, 2013.

BRASIL. Instrução Normativa (IN) número 76, de 26 de Novembro de 2018. Regulamento técnico de identidade e qualidade de leite cru refrigerado. Ministério da Agricultura, Pecuária e Abastecimento, 2018. Disponível em: http://sistemasweb.agricultura.gov.br/sislegis/action/detalhaAto.do?method=consultarLegislac aoFederal. Acesso em: 17 julho 2020.

BRASIL. Instrução Normativa (IN) número 77, de 26 de Novembro de 2018. Critérios e procedimentos para a produção, acondicionamento, conservação, transporte e recepção do leite cru em estabelecimentos registrados no serviço de inspeção oficial. Ministério da Agricultura, Pecuária e Abastecimento, 2018a. Disponível em: http://sistemasweb.agricultura.gov.br/sislegis/action/detalhaAto.do?method=consultarLegislac aoFederal. Acesso em: 17 julhon 2020.

BRASIL. Portaria número 7, de 09 de Novembro de 1988. Baixa os padrões mínimos de matéria-prima destinada à alimentação animal. Ministério da Agricultura, Pecuária e Abastecimento, $1988 . \quad$ Disponível em: http://sistemasweb.agricultura.gov.br/sislegis/action/detalhaAto.do?method=consultarLegislac aoFederal. Acesso em: 01 agosto 2020. 
CAMPAGNOLLO, F. B.; GANEV, K. C.; KHANEGHAH, A. M.; PORTELLA, J.; CRUZ, A. G.; GRANATO, D.; CORASSIN, C. H.; OLIVEIRA, C. A. F.; SANT'ANA, A. S. The occurrence and effect of unit operations for dairy products processing on the fate of aflatoxin $\mathrm{M}_{1}$ : a review. Food Control, v. 68, p. $310-329,2016$.

CHAVARRÍA， G.; GRANADOS-CHINCHILLA， F.; ALFARO-CASCANTE， M.; MOLINA, A. Detection of aflatoxin $\mathrm{M}_{1}$ in milk, cheese and sour cream samples from Costa Rica using enzyme-assisted extraction and HPLC. Food Additives \& Contaminants: Part B: Surveillance, v. 8, p. 128 - 135, 2015.

COMISSÃO DA UNIÃO EUROPEIA. Comissão da Regulamentação da União Europeia número 165/2010 de 26 Fevereiro 2010. Determinação de teores máximos para certos contaminantes em alimentos, no que diz respeito às aflatoxinas. Comissão da Regulamentação, 2010. Disponível em: https://eurlex.europa.eu/LexUriServ/LexUriServ.do?uri=OJ:L:2010:050:0008:0012:EN:PDF. Acesso em: 31 julho 2020.

CREPPY, E. E. Update of survey, regulation and toxic effects of mycotoxins in Europe. Toxicology Letters, v. 127, p. 19 - 28, 2002.

DADZIE, M. A.; OPPONG, A.; OFORI, K.; ELEBLU, J. S.; IFIE, E. B.; BLAY, E.; OBENG-BIO, E. Distribution of Aspergillus flavus and aflatoxin accumulation in stored maize grains across three agro-ecologies in Ghana. Food Control, v. 104, p. 91 - 98, 2019.

DALIÉ, D. K. D.; DESCHAMPS, A. M.; RICHARD-FORGET, F. Lactic acid bacteria Potential for controlo f mould growth and mycotoxins: a review. Food Control, v. 21, p. 370 $-380,2010$.

DAOU, R.; AFIF, C.; JOUBRANE, K.; KHABBAZ, L. R.; MAROUN, R.; ISMAIL, A.; KHOURY, A. E. Occurrence of aflatoxin $\mathrm{M}_{1}$ in raw, pasteurized, UHT cow's milk, and dairy products in Lebanon. Food Control, v. 111, p. 1 - 29, 2020.

DELGADO, J.; RODRÍGUEZ, A.; GARCÍA, A.; NÚÑEZ, F.; ASENSIO, M. A. Inhibitory effect of PgAFP and protective cultures on Aspergillus parasiticus growth and aflatoxins production on dry-fermented sausage and cheese. Microorganisms - Open Access Journal, v. 6 , p. $1-16,2018$.

DEVECI, O. Changes in the concentration of aflatoxin $\mathrm{M}_{1}$ during manufacture and storage of White pickled cheese. Food Control, v. 18, p. 1103 - 1107, 2007.

FABIAN, E.; MAJCHRZAK, D.; DIEMINGER, B.; MEYER, E.; ELMADFA, I. Influence of probiotic and conventional yoghurt on the status of vitamins $\mathrm{B}_{1}, \mathrm{~B}_{2}$ and $\mathrm{B}_{6}$ in Young healthy women. Annals of Nutrition \& Metabolism, v. 52, p. 29 - 36, 2008.

FAZELI, M. R.; HAJIMOHAMMADALI, M.; MOSHKANI, A.; SAMADI, N.; JAMALIFAR, H.; KHOSHAYAND, M. R.; VAGHARI, E.; POURAGAHI, S. Aflatoxin B binding capacity of autochthonous strains of lactic acid bactéria. Journal of Food Protection, v. 72, p. $189-192,2009$. 
FERNANDES, A. M.; CORRÊA, B.; ROSIM, R. E.; KOBASHIGAWA, E.; OLIVEIRA, C. A. F. Distribution and stability of aflatoxin $\mathrm{M}_{1}$ during processing and storage of Minas Frescal cheese. Food Control, v. 24, p. 104 - 108, 2012.

FOOD \& DRUG ADMINISTRATION - FDA. CPG Sec. 527.400 whole milk, lowfat milk, skim milk - aflatoxin $\mathrm{M}_{1}$. Office of Regulatory Affairs and Center for Food and Applied Nutrition, 2005. Disponível em: https://www.fda.gov/regulatory-information/search-fdaguidance-documents/cpg-sec-527400-whole-milk-lowfat-milk-skim-milk-aflatoxin-m1.

Acesso em: 28 julho 2020.

FOOD \& DRUG ADMINISTRATION - FDA. Sec. 683.100 Action Levels for Aflatoxins in Animal Food. Office of Regulatory Affairs and Center for Veterinary Medicine, 2019. Disponível em: https://www.fda.gov/media/121202/download\#: :text=In\%201969\%2C\%20FDA\%20set\%20 an,to\%20the\%20lowest\%20possible\%20level.. Acesso em: 30 julho 2020.

GHANBARI, R.; AGHAEE, E. M.; REZAIE, S.; KHANIKI, G. J.; ALIMOHAMMADI, M.; SOLEIMANI, M.; NOORBAKHSH, F. The inhibitory effect of lactic acid bacteria on aflatoxin production and expression of aflR gene in Aspergillus parasiticus. Journal of Food Safety, v. 38, p. $1-6,2018$.

GHAZVINI, R. D.; KOUHSARI, E.; ZIBAFAR, E.; HASHEMI, S. J.; AMINI, A.; NIKNEJAD, F. Antifungal activity and aflatoxin degradation of Bifidobacterium bifidum and Lactobacillus fermentum against toxigenic Aspergillus parasiticus. The Open Microbiology Journal, v. 10, p. 197 - 201, 2016.

GOMAA, E. Z.; ABDELALL, M. F.; EL-MAHDY, O. M. Detoxification of aflatoxin $\mathrm{B}_{1}$ by antifungal compounds from Lactobacillus brevis and Lactobacillus paracasei, isolated from dairy products. Probiotics and Antimicrobial Proteins, v. 10, p. 201 - 209, 2018.

GONÇALVES, L.; ROSA, A. D.; GONZALES, S. L.; FELTES, M. M. C.; BADIALEFURLONG, E.; DORS, G. C. Incidence of aflatoxin $\mathrm{M}_{1}$ in fresh milk from small farms. Food Science and Technology, v. 37, p. $11-15,2017$.

GONÇALVES, K. D. M.; SIBAJA, K. V. M.; FELTRIN, A. C. P.; REMEDI, R. D.; GARCIA, S. O.; GARDA-BUFFON, J. Occurrence of aflatoxinas $\mathrm{B}_{1}$ and $\mathrm{M}_{1}$ in milk powder and UHT consumed in the city of Assomada (Cape Verde Islands) and Southern Brazil. Food Control, v. 93, p. $260-264,2018$.

GONÇALVES, B. L.; MUAZ, K.; COPPA, C. F. S. C.; ROSIM, R. E.; KAMIMURA, E. S.; OLIVEIRA, C. A. F.; CORASSIN, C. H. Aflatoxin $\mathrm{M}_{1}$ adsorption by non-viable cells of lactic acid bacteria and Saccharomyces cerevisiae strains in Frescal cheese. Food Research International, v. 136, p. $1-5,2020$.

GOURAMA, H.; BULLERMAN, L. B. Inhibition of growth and aflatoxin production of Aspergillus flavus by Lactobaacillus species. Journal of Food Protection, v. 58, p. 1249 1256, 1995. 
GOVARIS, A.; ROUSSI, V.; KOIDIS, P. A.; BOTSOGLOU, N. A. Distribution and stability of aflatoxin $\mathrm{M}_{1}$ during production and storage of yoghurt. Food Additives \& Contaminants, v. 19, p. $1043-1050,2002$.

GUIMARÃES, A.; SANTIAGO, A.; TEIXEIRA, J. A.; VENÂNCIO, A.; ABRUNHOSA, L. Anti-aflatoxigenic effect of organic acids produced by Lactobacillus plantarum. International Journal of Food Microbiology, v. 264, p. 31 - 38, 2018.

HASKARD, C. A.; EL-NEZAMI, H. S.; KANKAANPAA, P. E.; SALMINEN, S.; AHOKAS, J. T. Surface binding of aflatoxin $\mathrm{B}_{1}$ by lactic acid bactéria. Applied and Environmental Microbiology, v. 67, p. 3086 - 3091, 2001.

HASSANIN, N. I. Stability of aflatoxin $M_{1}$ during manufacture and storage of yoghurt, yoghurt-cheese and acidified milk. Journal of the Science of Food and Agriculture, v. 65, p. $31-34,1994$.

IHA, M. H.; BARBOSA, C. B.; OKADA, I. A.; TRUCKSESS, M. W. Aflatoxin $\mathrm{M}_{1}$ in milk and distribution and stability of aflatoxin $\mathrm{M}_{1}$ during production and storage of yoghurt and cheese. Food Control, v. 29, p. 1 - 6, 2013.

IQBAL, S. Z.; ASI, M. R.; MALIK, N. The seasonal variation of aflatoxin $\mathrm{M}_{1}$ in milk and dairy products and assessment of dietary intake in Punjab, Pakistan. Food Control, v. 79, p. $292-296,2017$.

ISMAIL, A.; LEVIN, R. E.; RIAZ, M.; AKHTAR, S.; GONG, Y. Y.; OLIVEIRA, C. A. F. Effect of diferente microbial concentrations on binding of aflatoxin $\mathrm{M}_{1}$ and stability testing. Food Control, v. 73, p. 492 - 496, 2017.

JEBALI, R.; SALAH-ABBÈS, J. B.; ABBÈS, S.; HASSAN, A. M.; ABDEL-AZIEM, S. H.; EL-NEKEETY, A. A.; OUESLATI, R.; ABDEL-WAHHAB, M. A. Lactobacillus plantarum alleviate aflatoxins $\left(\mathrm{B}_{1}\right.$ and $\left.\mathrm{M}_{1}\right)$ induced disturbances in the intestinal genes expression and DNA fragmentation in mice. Toxicon, v. 146, p. 13 - 23, 2018.

KABAK, B.; VAR, I. Factors affecting the removal of aflatoxin $\mathrm{M}_{1}$ from food model by Lactobacillus and Bifidobacterium strains. Journal of Environmental Science and Health, Part B: Pesticides, Food Contaminants, and Agricultural Wastes, v.43, p. 617 - 624, 2008.

KAMYAR, S.; MOVASSAGHGHAZANI, M. Reduction of aflatoxin $\mathrm{M}_{1}$ in milk using kefir starter. Iranian Journal of Toxicology, v. 11, p. 27 - 31, 2017.

KLEIN, P. J.; BUCKNER, R.; KELLY, J.; COULOMBE, R. A. J. Biochemical basis for the extreme sensitivity of turkeys to aflatoxin $B_{1}$. Toxicology and Applied Pharmacology, v. 165 , p. $45-52,2000$.

KUHARIĆ, Ž.; JAKOPOVIĆ, Ž.; ČANAK, I.; FRECE, J.; BOŠNIR, J.; PAVLEK, Ž.; IVEŠIĆ, M.; MARKOV, K. Removing aflatoxin $\mathrm{M}_{1}$ from milk with native lactic acid bacteria, centrifugation, and filtration. Archives of Industrial Hygiene and Toxicology, v. 69, p. $334-339,2018$. 
LINDGREN, S. E.; DOBROGOSZ, W. J. Antagonistic actiivities of lactic acid bacteria in food and feed fermentations. FEMS Microbiology Reviews, v. 87, p. 149 - 164, 1990.

LÓPEZ, C.; RAMOS, L.; RAMADÁN, S.; BULACIO, L.; PEREZ, J. Distribution of aflatoxin $\mathrm{M}_{1}$ in cheese obtained from milk artificially contamined. International Journal of Food Microbiology, v. 64, p. $211-215,2001$.

MARREZ, D. A.; SHAHY, E. M.; EL-SAYED, H. S.; SULTAN, Y. Y. Detoxification of aflatoxin $B_{1}$ in milk using lactic acid bacteria. Journal of Biological Sciences, v. 18, p. 144 $151,2018$.

MOHAMMEDI-AMEUR, S.; DAHMANE, M.; BRERA, C.; KARDJADJ, M.; BEMMAHDI, M. H. Occurrence and seasonla variation of aflatoxin $\mathrm{M}_{1}$ in raw cow milk collected from diferent regions of Algeria. Veterinary World, v. 13, p. 433 - 439, 2020.

MOSS, M. O. Recent studies of mycotoxins. Journal of Applied Microbiology Symposium Supplement, v. 84, p. 62S-76S, 1998.

MURPHY, P. A.; HENDRICH, S.; LANDGREN, C.; BRYANT, C.M. Food mycotoxins: an update. Journal of Food Science, v. 71, p. R51 - R65, 2006.

NATEGHI, F.; NOORBAKHSH, F.; LOTFALI, E.; REZAIE, S. Investigation the effects of Lactobacillus acidophilus and Lactobacillus casei on aflR gene expression in Aspergillus parasiticus by real time- PCR. Iranian Journal of Public Health, v. 45, p. 781 - 786, 2016.

NDUTI, N.; MCMILLAN, A.; SENEY, S.; SUMARAH, M.; NJERU, P.; MWANIKI, M.; REID, G. Investigating probiotic yoghurt to reduce an aflatoxin $\mathrm{B}_{1}$ biomarker among school children in eastern Kenya: preliminar study. International Dairy Journal, v. 63, p. 124 129, 2016.

OBREMSKI, K.; ZIELONKA, L.; GAJECKA, M.; JAKIMIUK, E.; GAJECKI, M. Mycotoxins - dairy cattle breeding problem. A case report. Bulletin Veterinary Institute in Pulawy, v. 53, p. $221-224,2009$.

O'BRIEN, M.; O'KIELY, P.; FORRISTAL, P. D.; FULLER, H. T. Fungi isolated from contaminated baled grass silage on farms in the Irish Midlands. FEMS Microbiology Letters, v. 247, p. $131-135,2005$.

OMEIZA, G. K.; KABIR, J.; KWAGA, J. K. P.; KWANASHIE, C. N.; MWANZA, M.; NGOMA, L. A risk assessment study of the occurrence and distribution of aflatoxigenic Aspergillus flavus and aflatoxin $\mathrm{B}_{1}$ in dairy cattle feeds in a central northern state, Nigeria. Toxicology Reports, v. 5, p. $846-856,2018$.

ONILUDE, A. A.; FAGADE, O. E.; BELLO, M. M.; FADAHUNSI, I. F. Inhibition of aflatoxin-producing aspergilli by lactic acid bactéria isolates from indigenously fermented cereal gruels. African Journal of Biotechnology, v. 4, p. 1404 - 1408, 2005.

PARK, D. L. Effect of processing on aflatoxin. In: Mycotoxins and Food Safety, 1 ed. New York: Kluwer Academic, v. 504, p. 173 - 179, 2002. 
PEI, S. C.; ZHANG, Y. Y.; EREMIN, S. A.; LEE, W. J. Detection of aflatoxin $\mathrm{M}_{1}$ in milk products from China by ELISA using monoclonal antibodies. Food Control, v. 20, p. 1080 1085, 2009.

PIERIDES, M.; EL-NEZAMI, H.; PELTONEN, K.; SALMINEN, S.; AHOKAS, J. Ability of dairy strains of lactic acid bactéria to bind aflatoxin $\mathrm{M}_{1}$ in a food model. Journal of Food Protection, v. 63, p. 645 - 650, 2000.

PITT, J. I.; TANIWAKI, M. H.; COLE, M. B. Mycotoxin production in major crops as influenced by growing, harvesting, storage and processing, with emphasis on the achievement of Food Safety Objectives. Food Control, v. 32, p. 205 - 215, 2013.

PRANDINI, A.; TANSINI, G.; SIGOLO, S.; FILIPPI, L.; LAPORTA, M.; PIVA, G. On the occurrence of aflatoxin $\mathrm{M}_{1}$ in milk and dairy products. Food and Chemical Toxicology, v. 47, p. $984-991,2009$.

SAKIN, F.; TEKELI, I. O.; YIPEL, M.; KUREKCI, C. Occurrence and health risk assessment of aflatoxins and ochratoxin A in Sürk, a Turkish dairy food, as studied by HPLC. Food Control, v. 90, p. $317-323,2018$.

SALAH-ABBÈS, J. B.; ABBÈS, S.; JEBALI, R.; HAOUS, Z.; OUESLATI, R. Potential preventive role of lactic acid bacteria against aflatoxin $\mathrm{M}_{1}$ immunotoxicity and genotoxicity in mice. Journal of Immunotoxicology, v. 12, p. 1 - 8, 2015.

SANTOS, M. C.; SOUSA, R. B.; OLIVEIRA, S. E. M.; LIMA, K. S. C.; LIMA, A. L. S. Micotoxinas e seu potencial como agentes de guerra. Revista Virtual de Química, v. 6, p. $761-778,2014$.

SARLAK, Z.; ROUHI, M.; MOHAMMADI, R.; KHAKSAR, R.; MORTAZAVIAN, A. M.; SOHRABVANDI, S.; GARAVAND, F. Probiotic biological strategies to decontaminate aflatoxin $\mathrm{M}_{1}$ in a traditional Iranian fermented milk drink (Doogh). Food Control, v. 71, p. $152-159,2017$.

SARTORI, A. V.; MATTOS, J. S.; MORAES, M. H. P.; NÓBREGA, A. W. Determination of aflatoxins $\mathrm{M}_{1}, \mathrm{M}_{2}, \mathrm{~B}_{1}, \mathrm{~B}_{2}, \mathrm{G}_{1}$ and $\mathrm{G}_{2}$ and ochratoxin $\mathrm{A}$ in UHT and powdered milk by modified QuEChERS method and ultra-high-performance liquid chromatography tandem mass spectrometry. Food Analytical Methods, v. 8, p. 2321 - 2330, 2015.

SASSAHARA, M.; NETTO, D. P.; YANAKA, E. K. Aflatoxin occurrence in foodstuff supplied to dairy cattle and aflatoxin $\mathrm{M}_{1}$ in raw milk in the North of Paraná state. Food and Chemical Toxicology, v. 43, p. $981-984,2005$.

SCAGLIONI, P. T.; BECKER-ALGERI, T.; DRUNKLER, D.; BADIALE-FURLONG, E. Aflatoxin $B_{1}$ and $M_{1}$ in milk. Analytica Chimia Acta, v. 829, p. 68 - 74, 2014.

SEDAGHAT, H.; ESKANDARI, M. H.; MOOSAVI-NASAB, M.; SHEKARFOROUSH, S. S. Application of non-starter lactic acid bacteria as biopreservative agents to control fungal spoilage of fresh cheese. International Dairy Journal, v. 56, p. 87 - 91, 2016.

SEVIM, S.; TOPAL, G. G.; TENGILIMOGLU-METIN, M. M.; SANCAK, B.; KIZIL, M. 
Effects of inulin and lactic acid bacteria strains on aflatoxin $\mathrm{M}_{1}$ detoxification in yogurt. Food Control, v. 100, p. 235 - 239, 2019.

SIBAJA, K. V. M.; GONÇALVES, K. D. M.; GARCIA, S. O.; FELTRIN, A. C. P.; NOGUEIRA, W. V.; BADIALE-FURLONG, E.; GARDA-BUFFON, J. Aflatoxin $\mathrm{M}_{1}$ and $\mathrm{B}_{1}$ in Colombian milk powder and estimated risk exposure. Food Additives \& Contaminants: Part B, v. 12, p. $1-8,2019$.

SOKOUTIFAR, R.; RAZAVILAR, V.; ANVAR, A. A.; SHOEIBY, S. Degraded aflatoxin $\mathrm{M}_{1}$ in artificially contaminated fermented milk using Lactobacillus acidophilus and Lactobacillus plantarum affected by some bio-physical factors. Journal of Food Safety, v. 38 , p. $1-12,2018$.

SOUZA, G. N.; CARVALHO, A. C.; MENDONÇA, L. C. Qualidade do leite. In: Manual de bovinocultura de leite. Juiz de Fora: Embrapa Gado de Leite; Brasília: LK Editora, p. 545, 2010.

SWEENEY, M. J.; DOBSON, A. D. W. Mycotoxin production by Aspergillus, Fusarium and Penicillium species. Internatinal Journal of Food Microbiology, v. 43, p. 141 -158, 1998.

TADESSE, S.; BERHANU, T.; WOLDEGIORGIS, A. Z. Aflatoxin $\mathrm{M}_{1}$ in milk and milk products marketed by local and industrial producers in Bishoftu town of Ethiopia. Food Control, v. 118, p. 1 - 10, 2020.

TAHEUR, F. B.; FEDHILA, K.; CHAIEB, K.; KOUIDHI, B.; BAKHROUF, A.; ABRUNHOSA, L. Adsorption of aflatoxin $\mathrm{B}_{1}$, zearalenone and ochratoxin $\mathrm{A}$ by microorganisms isoltaed from kefir grains. International Journal of Food Microbiology, v. 251, p. $1-7,2017$.

TOMASEVIC, I.; PETROVIC, J.; JOVETIC, M.; RAICEVIC, S.; MILOJEVIC, M.; MIOCINOVIC, J. Two year survey on the occurrence and seasonal variation of aflatoxin $\mathrm{M}_{1}$ in milk and milk products in Serbia. Food Control, v. 56, p. 64 - 70, 2015.

WOCHNER, K. F.; MOREIRA, M. C. C.; KALLSCHNE, D. L.; COLLA, E.; DRUNKLER, D. Detoxification of aflatoxin $\mathrm{B}_{1}$ and $\mathrm{M}_{1}$ by Lactobacillus acidophilus and prebiotics in whole cow's milk. Journal of Food Safety, v. 39, p. 1 - 10, 2019.

WORLD HEALTH ORGANIZATION - WHO. Aflatoxins: aflatoxins pose a serious health risk to humans and livestock. Suíça, n. 18.1, p. $1-5,2018$. Disponível em: https://www.who.int/foodsafety/FSDigest_Aflatoxins_EN.pdf. Acesso em: 01 agosto 2020.

WU, Q.; JEZKOVA, A.; YUAN, Z.; PAVLIKOVA, L.; DOHNAL, V.; KUCA, K. Biological degradation of aflatoxinas. Drug Metabolism Reviews, v. 41, p. 1- 7, 2009.

XIONG, J.; XIONG, L.; ZHOU, H.; LIU, Y.; WU, L. Occurrebce of aflatoxin B 1 in dairy cow feedstuff and aflatoxin $\mathrm{M}_{1}$ in UHT and pasteurized milk in central China. Food Control, v. 92, p. $386-390,2018$. 
KRAUS, R. B; SANTOS, P. R; DORS, G. C; NASCENTE, P. S; LUND, R. G.

XIONG, J.; PENG, L.; ZHOU, H.; LIN, B.; YAN, P.; WU, W.; LIU, Y.; WU, L.; QIU, Y. Prevalence of aflatoxin $\mathrm{M}_{1}$ in raw milk and three types of liquid milk products in centralsouth China. Food Control, v. 108, p. 2 - 5, 2020. 


\title{
CAPÍTULO 52: COMPOSIÇÃO CENTESIMAL, ATIVIDADE ANTIOXIDANTE E ANTIMICROBIANA DE UMA PLANTA ALIMENTICIA NÃO CONVENCIONAL (PANC) DO GÊEERO Amaranthus
}

\author{
Karine Angélica Dalla Costa ${ }^{1}$; Mariane Ferenz ${ }^{2}$; Jean Carlos Budke ${ }^{3}$ Silvani Verruck $^{4}$; Sheila Mello da \\ Silveira ${ }^{5}$
}

\begin{abstract}
Resumo
Plantas alimentícias não convencionais são chamadas de "daninhas", "inços", "pragas", "invasoras" ou "espontâneas". Muitos estudos revelaram que essas plantas possuem teores de proteínas, vitaminas e outros nutrientes em quantidades mais elevadas que as plantas comumente utilizadas na alimentação. O objetivo deste estudo foi avaliar Amaranthus blitum L., popularmente conhecido como caruru, quanto à composição nutricional, propriedades antioxidantes e antimicrobianas. A espécie foi caracterizada quanto ao conteúdo de umidade, lipídios, proteínas, fibras e cinzas. Extratos aquosos e hidroalcoólicos de Amaranthus blitum L. foram obtidos para a realização dos testes de atividade antioxidante (radical ABTS) e antimicrobiana (difusão em ágar e microdiluição). A partir dos resultados, verificou-se ausência de atividade antimicrobiana frente às espécies de bactérias testadas e baixa a moderada atividade antioxidante. Amaranthus blitum L. apresentou 83,12 \% de umidade, 1,70\% de lipídios, 6,22 \% de proteína, $1,97 \%$ de fibras e 2,64 \% de cinzas, sendo estes valores superiores aos normalmente encontrados em hortaliças convencionais. Por este motivo, Amaranthus blitum L. surge como uma alternativa barata e de fácil acesso para melhorar a qualidade da dieta da população brasileira, visto que é uma espécie vegetal encontrada abundantemente na natureza e ainda é pouco explorada para este fim.
\end{abstract}

Palavras-Chave: Amaranthus blitum L., caruru, composição nutricional, alimento.

\begin{abstract}
Unconventional edible plants are called "weed", "plague" "invasive" or "spontaneous". Many studies showed that these plants have levels of protein, vitamins and other nutrients in higher quantities than in the plants commonly used as food. The objective of this study was to evaluate Amaranthus blitum L., popularly known as pigweed, in its nutritional composition, antioxidant and antimicrobial properties. The species was characterized by the moisture content, lipid, protein, fiber and ashes. Aqueous and hydroalcoholic extracts of Amaranthus blitum L. were obtained for the performance of antioxidant (ABTS radical) and antimicrobial (agar diffusion and microdilution) tests. The results showed the absence of antimicrobial activity from Amaranthus blitum L. extracts compared to the bacteria species tested and low antioxidant activity. Amaranthus blitum L. showed $83.12 \%$ moisture, $1.70 \%$ lipids, $6.22 \%$ protein, $1.97 \%$ fiber and $2.64 \%$ ash, these values being higher than those typically found in conventional vegetables. For this reason, Amaranthus blitum L. may be an alternative for human consumption, since it is a species found abundantly in nature and it is not explored by consumers.
\end{abstract}

Keywords: Amaranthus blitum L., pigweed, nutritional composition, food.

\footnotetext{
${ }^{1}$ Engenharia de alimentos, Universidade Regional Integrada do Alto Uruguai e das Missões karinedallacosta@hotmail.com

${ }^{2}$ Engenharia de alimentos, Instituto Federal Catarinense, mariane.ferenz@ @otmail.com

${ }^{3}$ Prof. Dr., Universidade Regional Integrada do Alto Uruguai e das Missões, jean@uricer.edu.br

${ }^{4}$ Prof ${ }^{a}$ Dra., Universidade Federal de Santa Catarina, silvani.verruck@ufsc.br

${ }^{5}$ Prof $^{a}$ Dra., Instituto Federal Catarinense, sheila.silveira@ifc.edu.br
} 


\section{Introdução}

A alimentação adequada é um direito social fundamental do ser humano, inerente à sua dignidade e indispensável, devendo o poder público garantir a segurança alimentar e nutricional da população (BRASIL, 2010; BRASIL, 2014). No mundo há cerca de 815 milhões de pessoas que estão passando fome, segundo relatório divulgado pela ONU (2018). No entanto a solução para esta insegurança alimentar não é apenas aumentar a produção de alimentos, mas também reduzir os impactos ambientais gerados. Uma alternativa para diminuir este número alarmante, poderia ser a valorização daquelas espécies vegetais que estão próximas das residências e propriedades, que a população pouco conhece e nem imagina que possam ser utilizadas como alimento (POLESI et al., 2017).

As plantas alimentícias não convencionais (PANCs) são as chamadas de matos, daninhas ou inços que medram entre as plantas cultivadas. Muitas das PANCs eram amplamente utilizadas, mas estão em desuso pela maior parte da população por diferentes fatores, tais como a competição no mercado com as hortaliças convencionais, mudanças de hábito de alimentação, baixa disponibilidade no mercado e não comercialização. Por isso, em determinadas regiões são consideradas não convencionais (FLECK et al., 2015; KINUPP, 2007).

Além da ampliação da oferta e variedade de itens alimentícios disponíveis à população, as PANCs ainda se inserem como potenciais de incremento nas dietas alimentares, complementando a ingestão de calorias, de micro e macro nutrientes (KINUPP, 2014). Rapport e Drausal (2001) estimam que existem 27 mil espécies com potencial alimentício no mundo. Kinupp (2007), em levantamento botânico na área metropolitana de Porto Alegre - RS identificou 311 espécies com potencial alimentício, dentre 1.500 espécies coletadas. Muitas das espécies de PANCs, quando comparadas com suas espécies aparentadas, incluem muito mais nutrientes, vitaminas, antioxidantes, compostos fenólicos, carotenóides, quantidades consideráveis de minerais como potássio, magnésio, manganês, vitamina $\mathrm{C}$ e próvitamina A, lipídeos, proteínas, fibras em altas quantidades, o que é enfatizado por diferentes autores (KINUPP, 2007; KINUPP e BARROS, 2008; OLIVEIRA et al., 2013; BIONDO et al., 2013; KINUPP e LORENZI, 2014; FLECK et al., 2015; POLESI, et al., 2017; FLECK, SANT'ANNA e BIONDO, 2017; ZEM et al., 2017).

Além disso, consumidores estão buscando cada vez mais por produtos de origem natural principalmente os provenientes de espécies vegetais, em função de alguns 
antioxidantes e antimicrobianos sintéticos serem alvos de questionamentos quanto à inocuidade, demostrando a possibilidade de desencadear alguma complicação à saúde do consumidor.

O presente estudo teve como intuito ampliar o conhecimento sobre uma PANC da região do oeste Catarinense, a fim obter informações que possam contribuir para a valorização da cultura local, aumento do consumo de PANC, bem como conservação dos recursos vegetais alimentícios. No mundo existem cerca de 60 espécies pertencentes ao gênero Amaranthus, família Amaranthaceae. São conhecidas popularmente por Caruru, Caruru-bravo, Bredo, Caruru-rasteiro, Caruru-roxo, Caruru-branco, Caruru-verde, entre outros (TEUTONICO e KNORR, 1985).

Dado o exposto, pesquisas direcionadas à caracterização nutricional e avaliação do potencial antioxidante e antimicrobiano de espécies da família Amaranthaceae podem vir a contribuir para a dieta alimentar bem como ampliar e diversificar a alimentação. $\mathrm{O}$ objetivo do presente trabalho foi avaliar uma planta alimentícia não convencional: Amaranthus blitum L. quanto à composição nutricional, e investigar a presença de propriedades antioxidantes e antimicrobianas em extratos preparados a partir desta espécie vegetal.

\section{Material e Métodos}

\section{Material vegetal}

A espécie vegetal Amaranthus blitum L., popularmente conhecida como Caruru, foi coletada na cidade de Concórdia - SC, Brasil (27²18'46" Sul, 51 $59^{\circ} 16^{\prime \prime}$ Oeste) em julho de 2015. A identificação botânica foi efetuada pelo Dr. J. C. Budke (URI, RS, Brasil). A exsicata das espécies vegetal foi depositada no Herbário Padre Balduíno Rambo (HPBR) do Departamento de Ciências Biológicas (URI) e identificadas pelo número de registro 11.912. 
Figura 1. Exsicata de Amaranthus blitum L.

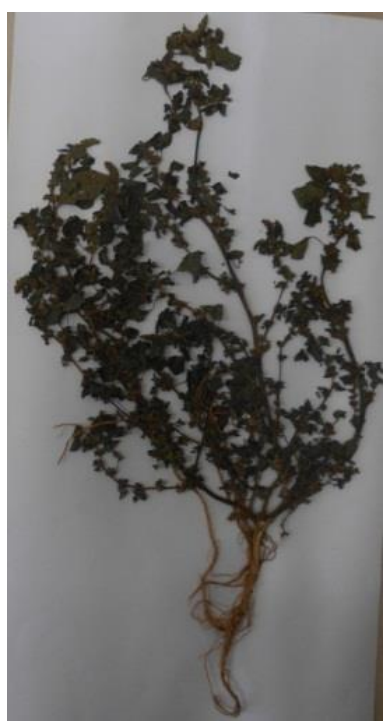

Fonte: Própria (2015).

As partes da planta (folha jovem, folha madura e caule) foram lavadas e submetidas à secagem em estufa (Solab SL - 102) com circulação de ar a $40{ }^{\circ} \mathrm{C}$ por $48 \mathrm{~h}$. Posteriormente, foram submetidas à trituração manual e por fim pesadas.

\section{Obtenção dos extratos}

\section{Obtenção do extrato aquoso}

A infusão da matéria seca foi realizada de acordo com Ferris e Zheng (1999), com adaptações. Misturou-se $20 \mathrm{~g}$ da planta seca com $200 \mathrm{~mL}$ de água destilada aquecida a $80{ }^{\circ} \mathrm{C}$, para obtenção do extrato bruto a $10 \%$. A mistura foi mantida em repouso por 10 min e posteriormente filtrada em papel filtro para obtenção do extrato límpido. Foram realizadas três repetições da preparação do extrato aquoso.

\section{Obtenção do extrato hidroalcoólico}

A obtenção do extrato hidroalcoólico foi realizada por maceração. Em erlenmeyers foram introduzidos 20 gramas de planta seca e adicionados $200 \mathrm{~mL}$ de solução de etanol:água 80:20 (v/v) como solvente. Os extratos foram mantidos em temperatura ambiente, ao abrigo da luz por $72 \mathrm{~h}$, e foram agitados a cada $24 \mathrm{~h}$. Foram realizadas três repetições da preparação do extrato hidroalcoólico.

Posteriormente os extratos foram filtrados e concentrados em evaporador rotativo (Biothec, modelo BT 351) acoplado a banho ultratermostático (Solab modelo SL 152) até a eliminação do solvente e obtenção do extrato bruto etanólico (adaptado de CAI, SUN e CORKE, 2003). 
COSTA, K. A. D; FERENZ, M; BUDKE, J. C; VERRUCK, S; SILVEIRA, S. M.

Todos os extratos foram armazenados a $4{ }^{\circ} \mathrm{C}$ em recipiente de vidro hermeticamente fechado e ao abrigo da luz.

\section{Determinação da composição centesimal}

A determinação da umidade foi realizada por secagem em estufa (Edutec, modelo EEQ9020D-2, Brasil) a $105^{\circ} \mathrm{C}$ até peso constante (IAL, 2005).

O teor de proteína foi determinado pelo método de Kjeldahl através da conversão de nitrogênio total em proteína de acordo com a metodologia preconizada pelo Instituto Adolfo Lutz (IAL, 2008). Baseou-se em três etapas: digestão, destilação e titulação. A digestão das amostras foi realizada em um digestor, a destilação em destilador (Kjeltec, modelo 1026) e a titulação foi realizada com solução padrão de ácido clorídrico $0,1 \mathrm{~mol} / \mathrm{L}$ até a viragem do indicador. Utilizou-se o fator de 6,25 para conversão em proteína bruta.

O conteúdo de lipídios foi determinado pela extração utilizando-se éter etílico como solvente, sob refluxo durante $8 \mathrm{~h}$ em aparelho Soxhlet (Nova ética) acoplado ao banho ultratermostático (Solab modelo SL 152) conforme o método estabelecido pelo Instituto Adolfo Lutz (IAL, 2005).

A determinação do resíduo mineral fixo (cinzas) foi realizado por incineração em mufla (Jung), a $600^{\circ} \mathrm{C}$ por $6 \mathrm{~h}$ (IAL, 2005).

O teor da fibra bruta foi realizado conforme o método Ba 6a-05 (AOAC, 2009). As digestões ácidas e alcalinas foram realizadas no determinador de fibra (Tecnal modelo TE - 149) acoplado ao banho ultratermostático (Solab, modelo SL 152).

\section{Avaliação da atividade antimicrobiana}

\section{Método de difusão em ágar}

A detecção de atividade antimicrobiana dos extratos sobre as bactérias testadas foi realizada conforme o método de difusão em disco com base no documento M2-A8 do CLSI (CLSI, 2009a), com adaptações conforme Silveira (2012). Primeiramente, realizouse a ativação das bactérias: estriou-se colônias para ágar sangue e incubou-se a $35^{\circ} \mathrm{C}$ por 12-18 h. Transferiu-se destas placas de 3 a 5 colônias isoladas para caldo triptose de soja (TSB), incubado a $35^{\circ} \mathrm{C}$ por 2 a $6 \mathrm{~h}$, a fim de obter culturas em fase de crescimento ativo.

O inóculo foi preparado a partir da cultura ativa de cada espécie bacteriana, diluída em solução salina $0,9 \%$ a uma concentração de aproximadamente $10^{8} \mathrm{UFC} \mathrm{mL}^{-1}$, comparável à solução padrão de McFarland 0,5, verificada espectrofotometricamente a $625 \mathrm{~nm}$. A suspensão foi então diluída a aproximadamente $10^{7} \mathrm{UFC} \mathrm{mL} \mathrm{m}^{-1}$, em solução salina, e esta solução foi utilizada para inocular placas de petri contendo ágar Mueller- 
COSTA, K. A. D; FERENZ, M; BUDKE, J. C; VERRUCK, S; SILVEIRA, S. M.

Hinton, utilizando-se swab estéril.

Foram testadas seis espécies de bactérias, sendo três espécies Gram-positivas e três Gram-negativas, respectivamente: Bacillus cereus ATCC 11778, Staphylococcus aureus ATCC 25923 e Listeria monocytogenes ATCC 19117; Escherichia coli ATCC 25922, Pseudomonas aeruginosa ATCC 27853 e Yersinia enterocolitica ATCC 9610.

Os extratos hidroalcoólicos foram diluídos a concentração de $100 \mathrm{mg} \mathrm{mL}^{-1} \mathrm{com}$ dimetilsulfóxido (DMSO), enquanto os extratos aquosos foram testados sem diluição. Discos de papel filtro estéreis (9 $\mathrm{mm}$ de diâmetro e $250 \mathrm{~g} \mathrm{~m}^{-2}$ ) foram impregnados com $25 \mu \mathrm{L}$ de extrato e depositados sobre as placas inoculadas, as quais foram incubadas por $24 \mathrm{~h}$ a $36{ }^{\circ} \mathrm{C}$. Discos comerciais de ampicilina $\left(10 \mu \mathrm{g}\right.$ disco $\left.^{-1}\right)$ e cloranfenicol $(30 \mu \mathrm{g}$ disco $^{-1}$ ) foram utilizados como controles positivos e discos impregnados com DMSO (25 $\mu \mathrm{L})$ como controle negativo.

O diâmetro da zona de inibição foi medido, em milímetros, e a inibição foi classificada como forte, moderada ou fraca conforme Carovic-Stanko et al. (2010). O ensaio foi realizado em triplicata e o valor apresentado como a média ( \pm desvio padrão). Concentração mínima inibitória (CMI)

Os extratos foram avaliados quanto à Concentração Mínima Inibitória (CMI) através do método de microdiluição com base no documento M7-A6 da CLSI (CLSI, 2009b) e com adaptações conforme Silveira (2012).

Os extratos aquosos foram testados em uma faixa de 100 a $0,75 \mathrm{mg} / \mathrm{mL}$ e os extratos hidroalcoólicos em uma faixa de 10 a $0,075 \mathrm{mg} / \mathrm{mL}$.

Foram mantidos controles de esterilidade (caldo Mueller-Hinton adicionado de DMSO e sem adição de inóculo) e controles de crescimento (caldo Mueller-Hinton adicionado de DMSO e inóculo). A incubação das placas foi realizada a $36{ }^{\circ} \mathrm{C}$ por $18-24$ h e o crescimento microbiano foi detectado visualmente e confirmado pela adição de solução aquosa de cloreto de trifeniltetrazólio (TTC) a $0,5 \%(\mathrm{~m} / \mathrm{v})$. As análises foram realizadas em triplicata e a CMI foi definida como a menor concentração de cada extrato que inibiu totalmente o crescimento microbiano.

\section{Atividade antioxidante}

A avaliação da atividade antioxidante foi realizada através do ensaio de capacidade de sequestro do radical 2,2'azinobis-3-etilbenzotiazolina-6-ácido sulfônico $\left(\mathrm{ABTS}^{\bullet+}\right)$ conforme Re et al. (1998) com algumas adaptações. Inicialmente, preparou a solução de $\mathrm{ABTS}^{\cdot+}$ através da reação do $\mathrm{ABTS}$ em solução aquosa a $7 \mathrm{mM} / \mathrm{L}$ e persulfato de potássio $\left(\mathrm{K}_{2} \mathrm{~S}_{2} \mathrm{O}_{8}\right)$ a 2,45 mM/L. Misturou-se quantidades iguais de ambas as soluções, 
agitou-se e então esta mistura foi armazenada por $16 \mathrm{~h}$ em temperatura ambiente em ausência da luz. Transcorrido o tempo, antes de ser usada, esta solução foi diluída com etanol até obter uma solução com leitura de absorbância de aproximadamente 0,700 a 734 nm. Os extratos foram diluídos até que ocorresse uma inibição entre 20-80\% em relação ao branco. Posteriormente, $3 \mathrm{~mL}$ da solução previamente preparada de $\mathrm{ABTS}^{\bullet+}$ foi misturada com $30 \mu \mathrm{L}$ da solução do extrato devidamente diluída, a mistura foi agitada e permaneceu em repouso por 6 minutos em ausência de luz e temperatura ambiente. Passado este tempo a absorbância foi imediatamente medida em espectrofotômetro (Biospectro modelo SP-220) a $734 \mathrm{~nm}$.

A análise foi realizada em triplicata para todas as amostras e o valor apresentado como a média ( \pm desvio padrão). Para a elaboração da curva padrão, usou-se o antioxidante sintético Trolox (Ácido 6-hidroxi-2,5,7,8-tetrametil-cromano-2-carboxílico) na faixa de concentração de 0,5-2,0 mM/L, em etanol. Os resultados foram expressos como mmol equivalente de Trolox por grama de extrato ( $\mu$ mol TEAC. $\mathrm{g}^{-1}$ extrato).

\section{Resultados e Discussão}

\section{Composição centesimal}

A Tabela 1 apresenta os resultados da caracterização nutricional da planta Amaranthus blitum L.

Tabela 1. Composição centesimal de Amaranthus blitum L.

\begin{tabular}{lc}
\hline Análises & Conteúdo $(\%)$ \\
\hline Umidade a $105^{\circ} \mathrm{C}$ & $83,12 \pm 2,23$ \\
Lipídeos & $1,70 \pm 1,020$ \\
Proteína bruta** & $6,22 \pm 0,26$ \\
Fibra bruta & $1,97 \pm 0,64$ \\
Cinzas & $2,64 \pm 0,07$
\end{tabular}

Resultados apresentados como média \pm desvio padrão, $n=3$.

$* * \mathrm{~N} \times 6,25$

Fonte: Própria (2015).

O conteúdo de fibras de $A$. blitum L. encontra-se inferior quando comparado a outras espécies do gênero Amaranthus. Estudos desenvolvidos por Connor et al. (1980) e Uso e Okorie (1983) apontaram teores de fibras entre 3,2-5,8\% para Amaranthus edulis e $8,1 \%$ para Amaranthus hybridus. Porém, A. blitum L. destacou-se frente a certas 
hortaliças, como agrião $(1,5 \%)$, serralha $(0,4 \%)$ e a folhosa mais consumida, a alface $(0,7 \%)$, apresentando teor de fibra superior (FURLANI, FURLANI e BATAGLIA, 1978). É interessante referir que a fibra dietética é importante, pois mantém o funcionamento normal do trato gastrointestinal. Ainda, sua presença nos alimentos induz à saciedade, no momento das refeições (FENNEMA, DAMODARAM e PARKIN, 2010).

Na Tabela 2 pode-se observar o conteúdo proteico de algumas espécies de Amaranthus e de algumas hortaliças convencionais. Desta forma, em relação ao conteúdo proteico de A. blitum L., nota-se que este se encontra inferior em comparação a outras plantas do mesmo gênero (A. edulis e A. hybridus), mas quando comparado com os teores de algumas hortaliças convencionais, como repolho, couve, alface, cenoura, brócolis e acelga a planta avaliada deste estudo destacou-se por apresentar teores superiores $(6,22 \%)$ de proteínas. De modo geral, os vegetais são considerados fontes proteicas pobres (MELO e FARIA, 2014).

Tabela 2. Conteúdo proteico de algumas espécies do gênero Amaranthus e de hortaliças convencionais.

\begin{tabular}{lcc}
\hline Espécie & Conteúdo $(\%)$ & Referência \\
\hline A. Edulis & $15,8-16,5$ & Amaya-Farfan, Marcílio e Spehar (2005) \\
A. hybridus & $14,0-17,2$ & Melo, Faria (2014) \\
Repolho & 1,58 & Melo, Faria (2014) \\
Couve & 1,38 & Melo, Faria (2014) \\
Alface & 0,89 & Melo, Faria (2014) \\
Cenoura & 0,73 & Saggin (2017) \\
Brócolis & 2,11 & Saggin (2017) \\
Brócolis & 2,02 & Maggiorini e Sassano (2013) \\
Acelga & 2,28 & Pereira et al. (2016) \\
\hline
\end{tabular}

Fonte: Própria (2015).

O conteúdo de lipídios e cinzas obtido para A. blitum L. foi de 1,70 e 2,64\%, respectivamente, teores estes inferiores aos obtidos para outras plantas do mesmo gênero.

Amaya-Farfan, Marcílio e Spehar (2005) obtiveram em seus estudos teor de lipídios entre 6,9 e 8,1\% para A. edulis, e entre 14,0 e 17,2 para o A. hybridus. Araújo, Menezes e Tomazini (2009), em seu estudo com plantas alimentícias convencionais, verificou teores de lipídios para agrião em torno de $0,60 \%$, indicando teor superior em $A$. blitum L. (1,70\%). 
Amaya-Farfan, Marcílio e Spehar (2005) também avaliaram teores de cinzas para A. edulis e A. hybridus, que apresentaram teores de 4,4 e 4,2\%, respectivamente. Comparando o conteúdo de cinzas com vegetais convencionais como o agrião $(1,04 \%)$, brócolis $(0,68 \%)$, cenoura $(0,82 \%)$, couve-flor $(1,02 \%)$, acelga $(0,52 \%)$ e couve $(1,61 \%)$ observou-se teor superior para A. blitum L. (2,64\%) (ARAÚJO, MENEZES e TOMAZINI, 2009; SAGGIN, 2017; PEREIRA et al., 2016). Esse conteúdo superior de cinzas em $A$. blitum L. em relação à planta convencional destaca-se, pois o conteúdo de cinzas é um indicativo do conteúdo de minerais, o que implica em seu valor nutricional. O teor de cinzas em alimentos refere-se ao resíduo inorgânico, ou resíduo mineral fixo (sódio, potássio, magnésio, cálcio, ferro, fósforo, cobre, cloreto, alumínio, zinco, manganês e outros compostos minerais) remanescente da queima da matéria orgânica em mufla a altas temperaturas (500-600 $\left.{ }^{\circ} \mathrm{C}\right)$ (ZAMBIAZI, 2010). Para estudos futuros sugere-se a determinação do perfil de minerais contidos nesta planta.

Diferenças quanto à composição centesimal entre as espécies do gênero Amaranthus podem ser explicadas pela variação do clima, do solo, estação do ano, características intrínsecas da própria espécie, diversidade genética, idade da planta no momento da colheita, entre outros (ASCHERI, CARVALHO e SPEHAR, 2004).

Avaliando o teor de umidade pode-se observar que as folhas e o caule da planta pesquisada contém teor elevado de umidade, o que é um indicador de vegetais frescos, assim como da sua elevada perecibilidade. Esse teor encontrado é semelhante ao obtido por outros autores em plantas comestíveis não convencionais. Oliveira (2013) encontrou para Pereskia aculeata (Ora-pro-nobis) e Xanthosoma sagittifolium (Taioba) valores de 86,99 e $82,96 \%$, respectivamente.

Sabe-se que vivemos num mundo onde existem muitos problemas tanto de desnutrição das populações menos favorecidas quanto de desperdícios das matériasprimas e alimentos de origem vegetal. Em virtude disso, avaliando os resultados obtidos, apresenta-se A. blitum L. como uma alternativa para dieta da população. Em comparação com certas hortaliças convencionais consumidas no dia-a-dia, A. blitum L. encontrou-se com teores nutricionais superiores, indicando potencialidade que ainda não é explorada por parte dos consumidores.

\section{Atividade antimicrobiana}

Não foi detectada atividade antimicrobiana através dos métodos difusão em disco e concentração mínima inibitória (CMI) de ambos os extratos testados de A. blitum L., 
frente as espécies bacterianas testadas. Na Tabela 3 podem ser observadas as zonas de inibição dos antibióticos sintéticos cloranfenicol e ampicilina, utilizados como controles positivos neste ensaio.

Tabela 3. Atividade antimicrobiana dos antibióticos sintéticos ampicilina e cloranfenicol detectado no ensaio de difusão em disco (mm).

\begin{tabular}{lcc}
\hline Bactérias Gram-positivas & Ampicilina & Cloranfenicol \\
Bacillus cereus ATCC 11778 & $14,5 \pm 0,6$ & $28 \pm 0,0$ \\
Staphylococcus aureus ATCC 25923 & $22 \pm 0,6$ & $28 \pm 0,0$ \\
Listeria monocytogenes ATCC 19117 & $28,5 \pm 0,6$ & $25,5 \pm 1,1$ \\
Bactérias Gram-negativas & & \\
Escherichia coli ATCC 25922 & $22 \pm 0,0$ & $22 \pm 1,0$ \\
Yersinia enterocolitica ATCC 9610 & $24,5 \pm 0,0$ & $33 \pm 0,6$ \\
Pseudomonas aeruginosa ATCC 27853 & $0,0 \pm 0,0$ & $0,0 \pm 0,0$
\end{tabular}

Resultados apresentados como a média \pm desvio padrão, $\mathrm{n}=3$. Graus de inibição: 10 -13,9 mm: fraca; 1418 mm: moderada; >18 mm: forte; nd: não detectado.

Fonte: Própria (2015).

Natalli e seus colaboradores (2011) reportaram atividade antimicrobiana de um extrato etanólico de A. viridis frente a bactérias patogênicas de interesse no setor alimentício. O experimento indicou atividade contra Escherichia coli, Staphylococcus aureus e Bacillus cereus, com CMIs iguais a 7,9, 62,5 e 31,2 $\mu \mathrm{g} / \mathrm{mL}$, respectivamente. Através da concentração mínima bactericida (CMB), os autores verificaram que aquele extrato apresentou atividade bactericida significativa em relação às três espécies testadas.

Nduche, Iwuoha e Igbokwe (2016) determinaram as propriedades antimicrobianas de extratos aquosos de A. spinosus, A. hybridus para quatro espécies bacterianas patogênicas: S. aureus, E. coli, Salmonella Typhimurium e Candida albicans. A concentração mínima inibitória (CMI) mostrou que os extratos possuem propriedades antimicrobianas em concentrações que variam de 12,50 a $200 \mathrm{mg} / \mathrm{ml}$. Contudo, todos os extratos em teste tiveram atividade menor que a dos antibióticos padrões.

Cruz (2010), em seu estudo, avaliou a atividade antimicrobiana através do método de difusão em disco de extratos hidroalcóolicos e aquoso de Amaranthus asplundii contra Streptococcus mutans, Klebsiella pneumoniae e o fungo Candida albicans. Os resultados apontaram baixa atividade através do método empregado. 


\section{Atividade antioxidante}

A atividade antioxidante dos extratos aquosos e hidroalcoólicos da planta $A$. blitum L. está apresentada na Tabela 4. Foram realizadas três repetições para cada amostra de extrato.

Tabela 4. Atividade antioxidante dos extratos aquosos e hidroalcoólicos de A. blitum L. avaliada pelo método ABTS.

\begin{tabular}{lc}
\hline Amostra & ABTS $^{\mathbf{a}}(\boldsymbol{\mu m o l ~ T E A C / g})^{\mathbf{b}}$ \\
\hline Aquoso 1 & $35,5 \pm 2,0$ \\
Aquoso 2 & $31,7 \pm 4,2$ \\
Aquoso 3 & $39,2 \pm 2,9$ \\
Hidroalcoólico 1 & $234,3 \pm 16,0$ \\
Hidroalcoólico 2 & $259,7 \pm 7,3$ \\
Hidroalcoólico 3 & $218,9 \pm 14,8$
\end{tabular}

Resultados apresentados como média \pm desvio padrão, $\mathrm{n}=3$.

aABTS: radical 2,2'-azinobis-(3-etilbenzotiazolina-6-ácido sulfônico); ' $\mu$ mol TEAC/g: capacidade antioxidante equivalente ao Trolox por grama de extrato.

Fonte: Própria (2015).

Analisando o resultado obtido nota-se que o extrato hidroalcoólico exerceu maior atividade que os extratos aquosos, indicando que a extração etanólica, em termos de compostos fenólicos foi muito mais eficiente. Os compostos fenólicos são considerados antioxidantes primários presentes nas espécies vegetais (SHYLAJA e PETER, 2004).

Esta diferença entre os extratos também pode estar envolvida com o modo de preparação dos mesmos, visto que o extrato hidroalcoólico foi submetido à maceração por $72 \mathrm{~h}$ e foi concentrado em rotavapor, enquanto o extrato aquoso foi obtido pelo método de infusão e não passou pela etapa de concentração, a fim de simular uma futura utilização em nível doméstico, através da preparação de um chá por infusão, prática rotineira de grande parte da população.

Vários estudos foram realizados acerca das atividades antioxidantes de espécies do gênero Amaranthus. Entretanto, diversos trabalhos utilizaram o método de captura dos radicais DPPH, tornando a comparação dos resultados com este estudo difícil. Outro fator que contribui para a dificuldade de comparação entre diferentes estudos são as modificações introduzidas nas metodologias, tais como os volumes adicionados das soluções de extrato e/ou de radical livre (SILVEIRA, 2012). 
Souza (2013) reportou elevada atividade antioxidante $(13439,45 \mu \mathrm{M}$ TEAC/g) para um extrato hidroalcoólico (etanol) obtido a partir das folhas de guabiroba, sendo quase cinco vezes maior que o menor valor obtido naquele estudo, exibido pelas folhas de acerola (3040,85 $\mu \mathrm{M}$ TEAC/g). Estes valores são muito superiores aos observados no presente estudo, podendo-se considerar como baixa a atividade antioxidante apresentada pelos extratos da espécie A. blitum L.

Estudos realizados por Simão e seus colaboradores (2012) demonstraram atividade antioxidante moderada para as folhas de marmelinho tanto para o extrato aquoso $\left(728,80 \mu \mathrm{mol} \mathrm{TEAC} \mathrm{g}{ }^{-1}\right)$ quanto para o etanólico $\left(731,06 \mu\right.$ mol TEAC $\left.\mathrm{g}^{-1}\right)$. Para as demais plantas pesquisadas no estudo (babosa, calunga e carqueja) as atividades antioxidantes foram relativamente baixas, na faixa de 1,74 a $33,78 \mu$ mol TEAC $\mathrm{g}^{-1}$.

Extratos hidroalcoólicos das folhas de Parapiptadenia rigida (angico vermelho), estudados por Silveira (2012) apresentaram relevante atividade antioxidante: $1965 \mu \mathrm{mol}$ TEAC $\mathrm{g}^{-1}$, sendo este teor muito superior aos extratos deste estudo. A espécie vegetal estudada por Silveira (2012) que obteve maior semelhança com A. blitum L. (faixa de 202,9 a 267,0 $\mu \mathrm{mol}$ TEAC $\left.\mathrm{g}^{-1}\right)$ foi a Persea americana Mill $\left(233 \mu \mathrm{mol}\right.$ TEAC $\left.\mathrm{g}^{-1}\right)$, popularmente conhecida como o abacate.

Bergamaschi (2010) avaliou a atividade antioxidante de resíduos de vegetais usualmente consumidos pela população. Película de amendoim, casca de maracujá, folha/talho de nabo, resíduo de alcachofra, casca de abóbora, folha/talo de cenoura, folha/talo de rabanete, talo de beterraba, talo de brócolis e couve foram estudados quanto à sua capacidade de sequestro do radical ABTS em extrato etanólico e aquoso. Os resultados indicaram maior atividade para a película de amendoim, apresentando teores de 990,79 $\mu$ mol TEAC g ${ }^{-1}$ de resíduo vegetal para extrato hidroalcoólico e 262,12 $\mu$ mol TEAC $\mathrm{g}^{-1}$ de resíduo vegetal para extrato aquoso. A menor capacidade foi detectada para o resíduo de alcachofra $\left(3,40 \mu \mathrm{mol}\right.$ TEAC $\mathrm{g}^{-1}$ de resíduo vegetal para extrato hidroalcoólico, 3,19 $\mu$ mol TEAC g-1 de resíduo vegetal extrato aquoso, respectivamente).

No estudo de Saggin (2017) a atividade antioxidante foi avaliada para três alimentos orgânicos (brócolis, cenoura e couve-flor) em extrato de metanol: acetona, apresentando 120,$12 ; 65,75$ e 48,26 $\mu$ mol TEAC g ${ }^{-1}$, respectivamente.

Clemes, Beirith e Zeni (2015) avaliaram a capacidade antioxidante de seis espécies da mata atlântica, dentre elas uma espécie da família Amaranthaceae: Alternanthera dentada, que apresentou insignificante atividade antioxidante para extrato aquoso $\left(0,05 \mu \mathrm{mol}\right.$ TEAC $\left.\mathrm{g}^{-1}\right)$ e etanólico $\left(1,02 \mu \mathrm{mol} \mathrm{TEAC} \mathrm{g}^{-1}\right)$. 


\section{Conclusões}

Os extratos de Amaranthus blitum L. testados não apresentaram atividade antimicrobiana frente as espécies testadas e a atividade antioxidante observada pode ser considerada como baixa. Contudo, a espécie vegetal Amaranthus blitum L. exibiu propriedades nutricionais interessantes, com teores superiores de proteína, fibras e cinzas em comparação a diversas hortaliças convencionais. Por este motivo, a espécie Amaranthus blitum L. pode ser uma alternativa barata e de fácil acesso para melhorar a qualidade da dieta da população brasileira, visto que atualmente é um recurso genético com usos potenciais inexplorados. Além disso, é importante considerar que os consumidores têm apreciado a disponibilização de alimentos naturais e saudáveis, e que possam ainda trazer algum benefício à saúde. Esta planta pode ser introduzida às refeições do consumidor como salada ou acompanhamento com outras hortaliças, entretanto faz-se necessário analisar futuramente sua aceitabilidade sob o ponto de vista sensorial.

\section{Referências}

AMAYA-FARFAN, J.; MARCÍLIO, R.; SPEHAR, C. R. Deveria o Brasil investir em novos grãos para a sua alimentação? A proposta do amaranto (Amaranthus sp.). Segurança alimentar e nutricional. Ensaios e Ciência: Ciências Biológicas, Agrárias e da Saúde, v. 12, n. 1, p. 47-56, 2005.

AOAC. Crude Fiber Analysis in Feeds by Filter Bag Technique Ba 6a-05. 2009.

ARAUUJO, E. M.; MENEZES, H. C.; TOMAZINI, J. M. Fibras solúveis e insolúveis de verduras, tubérculos e canela para uso em nutrição clínica. Ciência e Tecnologia de Alimentos, p. 401-406, 2009.

ASCHERI, J. L. R.; CARVALHO, C. W. P.; SPEHAR, C. R. A extrusão do amaranto no desenvolvimento de produtos: caracterização físico-química. EMBRAPA Agroindústria de Alimentos, 31 p. 2004.

BERGAMASCHI, K. B. Capacidade antioxidante e composição química de resíduos vegetais visando seu aproveitamento. Dissertação de mestrado. Universidade de São Paulo. Piracicaba, SP, 2010. 97 p.

BIONDO, E.; CEMIN, P.; SIMIONI, C.; KOLCHINSKI, E.; SANT'ANNA, V., ZAMBIASI, I. Caracterização citogenética e ecológica de populações de mamãozinho- 
COSTA, K. A. D; FERENZ, M; BUDKE, J. C; VERRUCK, S; SILVEIRA, S. M.

do-mato (Vasconcellea quercifolia A.St.Hill - Caricaceae) uma planta alimentícia nãoconvencional pouco explorada. Cadernos de Agroecologia, v. 8, n. 2, p. 1-4, 2013.

BRASIL. Ministério da Agricultura, Pecuária e Abastecimento, MAPA. Hortaliças não convencionais (tradicionais). Secretaria de Desenvolvimento Agropecuário e Cooperativismo. Brasília: MAPA/ACS, 52p. 2010.

BRASIL. Ministério da Agricultura, Pecuária e Abastecimento. Manual de Hortaliças Não-Convencionais. Brasília, DF: MAPA/ACS, 92p. 2010.

BRASIL. Ministério da Saúde. Guia alimentar para a população brasileira: promovendo a alimentação saudável. Brasília: Ministério da Saúde, 2014.

BURT, S. Essential oils: their antibacterial properties and potential applications in foods - a review. International Journal of Food Microbiology, v. 94, p. 223-253, 2004.

CAI, Y.; SUN, M.; CORKE, H. Antioxidant activity of betalains from plants of the Amaranthaceae. Journal of Agricultural and Food Chemistry, v. 51, p. 2288-2294, 2003.

CAROVIC-STANKO, K.; ORLIC, S. POLITEO, O.; STRIKIC, F.; KOLAK, I.; MILOS, M.; SATOVIC, Z. Composition and antibacterial activities of essential oils of seven Ocimum taxa. Food Chemistry, v. 119, p. 196-201, 2010.

CLEMES, S. M.; BEIRITH, A.; ZENI, A. L. B. Avaliação de polifenóis e capacidade antioxidante de seis espécies da Mata Atlântica. Scientia Plena. v. 11, n. 5, 2015.

CLSI (Clinical and Laboratory Standards Institute). Methods for dilution antimicrobial susceptibility tests for bacteria that grow aerobically; approved standard. 8.ed. 940 West Valley Road, Suite 1400, Wayne, Pennsylvania 19087-1898 USA, 2009b. (CLSI document M7-A6 [ISBN 1-56238-486-4]).

CLSI (Clinical and Laboratory Standards Institute). Performance standards for antimicrobial disk susceptibility tests: approved standard. 8.ed. 940 West Valley Road, Suite 1400, Wayne, Pennsylvania 19087-1898 USA, 2009a. (CLSI document M2A8 [ISBN 1-56238-485-6]).

CRUZ, C. D. G. Evaluación de la actividad antibacteriana y Antimicótica de los extractos de Myrciantes hallii (arrayán), Amaranthus asplundii (ataco), Peperomia 
peltigera (pataku Yuyo), especies reportadas en peguche - imbabura, Sobre Streptococcus mutans, Klebsiella pneumoniae, Candida albicans Causantes de enfermedades bucofaríngeas. Monografia (Engenharia em biotecnologia). Departamento de ciências, 2010. 167 p.

FENNEMA, O. R.; DAMODARAM, S.; PARKIN, K. L. Química de Alimentos de Fennema, 4 ed. Artmed, 2010, 400p.

FERRIS, H.; ZHENG, L. Plant Sources of Chinese Herbal Remedies: Effects on Pratylenchus vulnus and Meloidogyne javanica. Journal of Nematology, California, v. 31, n. 3, p. 241-263, 1999.

FLECK, M.; SANT'ANNA, V.; BIONDO, E. Centesimal and mineral analysis of native wild strawberries from southern of Brazil. In: 16th Euro-Global Summit on Food and Beverages, 2017, Amsterdã. Anais 16th Euro-Global Summit on Food and Beverages, v. 8. p. 101-101, 2017.

FLECK, M.; SILVA, M. R. S.; BIONDO, E.; KOLCHINSKI, E. M.; SANT’ANNA, V. Plantas alimentícias não convencionais ocorrentes no Vale do Taquari e suas principais utilizações. In: $5^{\circ}$ Simpósio de segurança alimentar e nutricional: alimentação e saúde, 2015, Bento Gonçalves. Anais. 2015. Disponível em: http://www.ufrgs.br/sbctarseventos/gerenciador/painel/trabalhosversaofinal/SAM273.pd f. Acesso em: 17 de junho 2018.

FURLANI, A.C.M.; FURLANI, P.R.; BATAGLIA, O.C. Composição mineral de diversas hortaliças. Bragantia, Campinas, v.37, p.33-44, 1978.

IAL (INSTITUTO ADOLFO LUTZ). Métodos físico-químicos para análise de alimentos. 4 ed. São Paulo: IAL, 2005. 1018 p.

IAL (INSTITUTO ADOLFO LUTZ). Métodos físico-químicos para análise de alimentos. 4 ed. São Paulo: IAL, 2008.

ICMSF - International Commission on Microbiological Specifications for Foods. Microorganisms in Foods, vol 5: Microbiological Specifications of Food Pathogens. Londres, Reino Unido: Kluwer Academic / Plenum Publishers. p. 20-180, 2003.

KINUPP, V. F. Riqueza de plantas alimentícias não-convencionais na região 
metropolitana de Porto Alegre. In: Plantas alimentícias não-convencionais da Região Metropolitana de Porto Alegre, RS. Tese - (Doutorado em Fitotecnia), Faculdade Agronomia, Universidade Federal do Rio Grande do Sul. Porto Alegre, 2007. 562 p.

KINUPP, V. F.; BARROS, I. B. I. de. Teores de proteína e minerais de espécies nativas, potenciais hortaliças e frutas. Ciência e Tecnologia de Alimentos. v. 28, n. 4, p. 846$857,2008$.

KINUPP, V.F.; LORENZI, H. Plantas Alimentícias Não-Convencionais (PANC) no Brasil: guia de identificação, aspectos nutricionais e receitas ilustradas. Nova Odessa: Ed. Plantarum, 768p. 2014.

MELO, C. M. T.; FARIA, J. V. Composition, phenolic compounds and antioxidant activity in conventional not edible part of six vegetables. Bioscience Journal, v. 30, p. 93-100, 2014.

NATAlli, V. D.; BARCElOS, R. M.; PINTO, A. P. A.; RESENDE, K. M.; BELINELO, V. J. Investigação fitoquímica e atividade antimicrobiana de Amaranthus viridis L. (AMARANTHACEAE). Enciclopédia Biosfera, Centro Científico Conhecer - Goiânia, v. 7, n. 12, 9 p. 2011.

NDUCHE, M.U.; IWUOHA, C. D.; IGBOKWE, A. U. Antibacterial Activity of Four Nigerian Medicinal Plants. Scholars Journal of Agriculture and Veterinary Sciences, v. 3, n. 3, p. 172-180, 2016.

OLIVEIRA, D. C. S.; WOBETO, C.; ZANUZO, M. R.; SEVERGNINI C. Composição mineral e teor de ácido ascórbico nas folhas de quatro espécies olerícolas nãoconvencionais. Horticultura Brasileira, v. 31, p. 472-475, 2013.

OLIVEIRA, S. R. de. Plantas Alimentícias não convencionais (PANCs) voltam a ganhar espaço na mesa dos brasileiros. Revista Letras da Terra, n. 36, p. 6-8, 2013.

ONU BR. Organização das nações unidas do Brasil. Disponível em: http://www.onu.org.br/index.php?s=fome $\& x=0 \& y=0$. Acesso em 6 de junho de 2018.

PEREIRA, E. M.; LEITE, D. D. F.; FIDELIS, V. R. L.; PORTO, R. M.; OLIVEIRA, M. I. V.; MAGAlHÃES, W. B. Caracterização físico-química de hortaliças tipo folha comercializadas no Brejo Paraibano. Agropecuária Técnica, v. 37, n. 1, p. 19-22, 2016. 
POLESI, R. G.; ROLIM, R.; ZANETTI, C.; SANT'ANNA, V.; BIONDO, E. Agrobiodiversidade e segurança alimentar no vale do taquari, RS: plantas alimentícias não convencionais e frutas nativas. Revista Cientifica Rural, v. 19, n. 2, 2017.

RAPOPORT, E. H.; DRAUSAL, B. S. Edible plants. In: S. LEVIN (Ed.). Encyclopedia of biodiversity. New York: Academic Press, p. 375-382, 2001.

RE, R.; PELLEGRINI, N.; PROTEGGENTE, N.; PANNALA, A.; YANG, M. EVANS, C. R. Antioxidant activity applying na improved ABTS radical cation decolorization assay. Free Radical Biology and Medicine, v. 26, p. 1231-1237, 1999.

SAGGIN, S. F. Avaliação físico-química de hortaliças orgânicas congeladas. Monografia (Nutrição). Universidade Regional do Noroeste do Estado do Rio Grande do Sul, RS, 2017. 26 p.

SILVEIRA, S. M. Avaliação da atividade antimicrobiana e antioxidante de extratos vegetais e óleos essenciais e aplicação do óleo essencial de louro (L. nobilis) como agente conservador natural em embutido cárneo frescal. Tese de doutorado. Universidade Federal de Santa Catarina. Florianópolis, SC, 2012. 215 p.

SIMÃO, A. A.; CORRÊA, A. D.; MARQUES, T. R.; RAMOS, V. O. ALVES, A.P. C. DUARTE, M. H. Atividade antioxidante de plantas medicinais. $\mathbf{5 2}^{\mathbf{0}}$ Congresso Brasileiro de Química. 2012.

SOUZA, W. de. Avaliação da atividade antioxidante e compostos fenólicos de extratos vegetais. Trabalho de conclusão de curso. Universidade Tecnológica Federal do Paraná, Campo Mourão, PR. 2013, p. 31.

TEUTONICO, R. A.; KNORR, D. Amaranth; composition, properties and applications of a rediscovered crop. Food Technology, v. 39, n. 4, p. 49-59, 1985.

ZAMBIAZI, R.C. Análise Físico Química de Alimentos. Pelotas: Editora Universitária, 202 p. 2010.

ZEM, L. M.; HELM, C. V.; ZUFFELLATO-RIBAS, K. C. Z.; KOEHLER, H. S. Centesimal and mineral anlysis of cupcakes base meal of leaves and stems of ora-pronobis (Pereskia aculeata). Revista Eletrônica Científica UERGS, v. 3, n. 2, p. 428-446, 2017.

Disponível

em: 
COSTA, K. A. D; FERENZ, M; BUDKE, J. C; VERRUCK, S; SILVEIRA, S. M.

https://ainfo.cnptia.embrapa.br/digital/bitstream/item/163084/1/2017-CrisH-RECCentesimal.pdf. Acesso em: 17 de junho de 2018. 


\title{
CAPÍTULO 53: DO RIO À MESA, O CONSUMO DE PESCADOS NA AMAZÔNIA: PERFIL DO CONSUMIDOR E CRITÉRIOS DE COMPRA EM BELÉM (PA)
}

\section{CHAPTER 53: FROM RIO TO TABLE, FISH CONSUMPTION IN THE AMAZON: CONSUMER PROFILE AND PURCHASE CRITERIA IN BELÉM (PA)}

\author{
Flavio Henrique Sousa Lobato $^{1}$; Matheus Yuri de Oliveira Rosa ${ }^{2}$
}

\begin{abstract}
Resumo
Diversas iniciativas têm promovido campanhas buscando aumentar o consumo de pescados no Brasil, dado os benefícios dos componentes nutricionais desse tipo alimento. Contudo, é imprescindível que, no momento da compra, vários aspectos sejam levados em consideração para garantir que os peixes estejam em condições apropriadas para o consumo. Diante disso, este trabalho teve como objetivo identificar o perfil e os critérios de compra e consumo de peixes por consumidores que frequentavam o Mercado Municipal do Distrito de Icoaraci, Belém (PA), a fim de investigar não apenas a regularidade de consumo, mas também os parâmetros de qualidade adotados no momento da aquisição dos pescados. Para tanto, foram realizadas pesquisas bibliográficas, documentais e de campo. A coleta de dados foi estabelecida a partir da aplicação de um questionário, com 25 perguntas semiestruturadas acerca de aspectos socioeconômicos e critérios como cor, sabor e textura dos pescados, bem como sobre a frequência e as formas de consumo, junto a 120 consumidores. Os resultados revelaram que até existe uma preocupação em adquirir e consumir alimentos com boa qualidade, mas a condição financeira, as formas de oferta e o baixo custo dos produtos inviabilizam a adoção de tais cuidados.
\end{abstract}

Palavras-Chave: Pescado, Perfil, Compra, Consumo, Mercado de Icoaraci.

\begin{abstract}
Several initiatives have promoted campaigns aimed at increasing fish consumption in Brazil, given the benefits of the nutritional components of this type of food. However, it is essential that, at the time of purchase, several aspects are taken into account to ensure that the fish are in conditions suitable for consumption. Therefore, this work aimed to identify the profile and the criteria for the purchase and consumption of fish by consumers who attended the Municipal Market in the District of Icoaraci, Belém (PA), to investigate not only the regularity of consumption, but also the quality parameters adopted in the purchase of the fish. To this end, bibliographic, documentary and field research were carried out. The data collection was established from the application of a questionnaire, with 25 semi-structured questions about socio-economic aspects and criteria such as color, flavor and texture of fish, as well as the frequency and forms of consumption, with 120 consumers. The results revealed that there is a concern to acquire and consume good quality food, but the financial condition, the forms of supply and the low cost of the products make the adoption of such care unfeasible.
\end{abstract}

Keywords: Fish, Profile, Purchase, Consumption, Icoaraci Market.

\footnotetext{
${ }^{1}$ Programa de Pós-Graduação em Desenvolvimento Sustentável do Trópico Úmido, Universidade Federal do Pará (NAEA/UFPA), flaviohslobato@ @mail.com;

${ }^{2}$ Acadêmico de Tecnologia de Alimentos. Universidade do Estado do Pará (UEPA), matheusyurid@ gmail.com.
} 


\section{Introdução}

Os pescados têm grande destaque nutricional em comparação aos demais alimentos de origem animal, pois possuem acentuadas quantidades de vitaminas lipossolúveis A e D, cálcio, fósforo, ferro, cobre, selênio e, no caso dos peixes de água salgada, iodo. Ademais, os peixes contêm alta proporção de ácidos graxos poli-insaturados de cadeia longa com cinco ou seis ligações duplas, o que beneficia tanto na saúde quanto na atividade antitrombótica humana (MATEUS et al., 2019; SOUSA; ALMEIDA, 2018). Destarte, auxilia na redução dos triacilgliceróis séricos e de alergias crônicas e atua na prevenção de aterosclerose e trombose (SILVA et al., 2017).

No mais, outros estudos (DURAN, et al., 2016; MACIEL et al., 2019; MATEUS et al., 2019; PINHEIRO et al., 2020) elencam como benefícios de um consumo regular de pescados: a minimização do risco de Acidente Vascular Cerebral (AVC), o combate à depressão e ao mal de Alzheimer, a redução de mortes por doenças cardíacas e a prevenção de certos tipos de câncer. Desse modo, nota-se que os peixes e seus derivados são importantes para melhoria da qualidade da alimentação, especialmente das crianças, tendo em vista que o ácido graxo ômega3, de acordo com diversos estudos (BARROS et al., 2019; CALDER, 2017; DURAN, et al., 2016; SUÁREZ et al. 2018), compreende um elemento basilar para otimizar o sistema nervoso de crianças e adolescentes, auxiliando no aprendizado e na coordenação mental, emergindo resultados positivos no que diz respeito ao crescimento corporal e ao intelecto na criança (LUZ et al., 2020; SILVA et al., 2017; SUÁREZ et al. 2018).

A Organização das Nações Unidas para Alimentação e Agricultura (FAO, 2016) recomenda a ingestão de pescados e derivados por pelo menos duas vezes por semana, em face de sua alta capacidade de manter, promover e/ou resgatar a saúde dos que consomem. O Brasil obteve média de consumo anual per capita de pescado em torno de $10 \mathrm{~kg} /$ per capita, em 2018, dado considerado baixo em relação à quantidade, recomendada pela FAO, para o consumo de 12 kg/per capita (MEDEIROS, 2019). Na particularidade amazônica, entretanto, não há grande preocupação com a ingestão contínua de pescados, tendo em vista que o Estado do Pará - por possuir uma abundância de peixes e uma forte valorização cultural desse alimento herdada dos povos indígenas - é um dos estados que mais consome pescados no Brasil, sendo um gênero alimentício marcante no cotidiano local (LOPES et al., 2020; LOPES; OLIVEIRA; RAMOS, 2016). Na pesquisa desenvolvida por Lopes, Oliveira e Ramos (2016), a Região Norte aparece em primeiro lugar no consumo de pescados no país, com $70 \%$ da amostra investigada. Por outro lado, a Região Sudeste - que concentra o maior quantitativo populacional - ocupou o último lugar, com somente $15,2 \%$. 
No contexto amazônico, as feiras livres e os mercados populares compreendem os espaços principais de comercialização de pescados e outros mais gêneros alimentícios, tendo uma acentuada importância econômica e cultural na região (LOBATO; RAVENA-CAÑETE, 2019). No entanto, esses espaços têm sido indicados por diversos estudos como propícios à contaminação de alimentos em face de suas precárias condições higiênico-sanitárias (FERREIRA, 2019; LOPES et al., 2020; ROSA et al., 2019; SANTOS et al., 2019). Dessa forma, “[...] os benefícios nutricionais dos pescados somente podem ser aproveitados quando os fatores segurança e qualidade forem garantidos [...]" (ROSA et al., 2019, p. 2). Afinal, não basta ter um consumo regular de pescados se estes não estiverem em boa qualidade e, por conseguinte, apropriados para o consumo.

O presente trabalho objetivou identificar o perfil e os critérios de compra e de consumo de pescados por consumidores que frequentavam o Mercado Municipal do Distrito de Icoaraci, Belém (PA), a fim de não somente compreender se eles têm consumido ou não esse alimento de maneira assídua, mas identificar quais os parâmetros ou os critérios mínimos de qualidade são adotados na hora de escolher os peixes e os locais de comercialização.

\section{Material e Métodos}

O estudo, com uma abordagem qualitativa e quantitativa, utilizou como técnicas de pesquisa levantamentos bibliográficos e documentais em bases e plataformas de conteúdo científico (PRODANOV; FREITAS, 2013). A pesquisa de campo ocorreu entre os dias 13 de novembro e 17 de dezembro de 2019, a partir de um questionário aplicado junto a 120 consumidores que à época frequentaram o Mercado Municipal do Distrito de Icoaraci, Belém (PA), e aceitaram participar da pesquisa, sendo uma amostra, portanto, por conveniência. Tal instrumento de coleta de dados foi composto por 25 perguntas semiestruturadas relacionadas aos aspectos socioeconômicos, às formas e aos critérios de aquisição, de consumo e de preparo de pescados. Convém pontuar que todos os sujeitos foram convidados a participar da pesquisa de forma espontânea e voluntária, por meio da assinatura do Termo de Consentimento Livre e Esclarecido (TCLE), a qual foi antecedida de uma conversa para explicar sobre a utilização dos dados e do TCLE, bem como a relevância da pesquisa.

Os dados obtidos foram tabulados e sistematizados em tabelas no Microsoft Office Excel 2013 e analisados pela técnica da Estatística Descritiva em diálogo com dados secundários obtidos em pesquisas documentais (BRASIL, 1997, 2012, 2016; FAO, 2016) e com as discussões teóricas acessadas pelas pesquisas bibliográficas (LEANDRO et al., 2018; LOPES; OLIVEIRA; RAMOS, 2016; ROSA et al., 2019; SANTOS et al., 2017; SILVA et al., 2017), a 
fim de identificar um perfil de compra e consumo de pescado entre os consumidores que constituíram a amostra do estudo.

\section{Resultados e Discussão}

A partir da aplicação dos questionários, constatou-se que dos 120 consumidores participantes da pesquisa, $70 \%(n=84)$ eram do sexo feminino e $30 \%(n=36)$ do sexo masculino. Com relação à faixa-etária, 13,33\% $(\mathrm{n}=16)$ dos participantes tinham entre 18 e 25 anos, 20\% ( $\mathrm{n}=24)$ de 26 a 35 anos, $35 \%(\mathrm{n}=42)$ tinham entre 36 e 45 anos, $28,33 \%(\mathrm{n}=34)$ de 46 a 55 anos e, por fim, 3,33\% ( $(n=4)$ tinham mais de 55 anos. Entre os consumidores, 7,5\% $(\mathrm{n}=9)$ moravam sozinhos(as), 27,5\% $(\mathrm{n}=33)$ moravam com 1 ou 2 pessoas, 40,83\% $(\mathrm{n}=49)$ com 3 ou 4 pessoas e 24,17\% $(n=29)$ residiam com 5 ou mais pessoas. No mais, acerca da renda familiar mensal, os resultados obtidos indicaram que 32,5\% $(\mathrm{n}=39)$ tinham renda per capita menor que 1 salário mínimo, 47,5\% ( $\mathrm{n}=57)$ entre 1 e 3 salários mínimos e 20\% (n=24) entre 4 e 6 salários mínimos, conforme dispõe os dados da Tabela 1. Tais dados são indicativos importantes do perfil socioeconômico do consumidor de pescados do Mercado Municipal de Icoaraci, tendo em vista que alguns percentuais como o das mulheres, o número de pessoas por residência e a renda mensal são marcadores da compra e do volume de consumo dos peixes.

Em estudo semelhante, Alho (2019, p. 35) - ao analisar o contexto de consumo de peixe no Mercado de Ferro do Ver-o-Peso, em Belém - revela que “[...] os fatores que influenciam o comportamento do consumidor, não estão relacionados somente a fatores intrínsecos ao peixe, mas também a fatores que correspondem ao perfil socioeconômico do consumidor". Alho (2019, p. 35) reitera ainda que as características socioeconômicas "[...] podem ser fatores limitantes e/ou facilitadores do consumo de peixe, tendo em vista que: as mulheres são quem normalmente fazem a compra do pescado; a idade pode influenciar, pois os mais velhos são normalmente quem conhecem as espécies de peixe". No entanto, além dos aspectos socioeconômicos, é importante ressaltar que a abundância de recursos e a influência cultural indígena possuem grande influência no consumo de peixes no Distrito de Icoaraci, tendo em vista que o mercado é um dos espaços principais para o abastecimento de famílias de baixa renda (ROSA et al., 2019), assim como ocorre no município de Sinop (MT), segundo Leandro et al. (2018). 
Tabela 1. Perfil sinótico de 120 consumidores do Mercado Municipal do Distrito de Icoaraci que participaram da pesquisa que subsidiou este trabalho

\begin{tabular}{|c|c|c|c|}
\hline \multicolumn{2}{|c|}{ Dados socioeconômicos } & \multirow{2}{*}{$\begin{array}{l}n \\
84\end{array}$} & \multirow{2}{*}{$\begin{array}{c}\% \% \\
70 \%\end{array}$} \\
\hline Sovo & Feminino & & \\
\hline sexo: & Masculino & 36 & $30 \%$ \\
\hline \multirow{5}{*}{ Faixa-etária: } & De 18 a 25 anos & 16 & $13,33 \%$ \\
\hline & De 26 a 35 anos & 24 & $20 \%$ \\
\hline & De 36 a 45 anos & 42 & $35 \%$ \\
\hline & De 46 a 55 anos & 34 & $28,33 \%$ \\
\hline & Mais de 55 anos & 4 & $3,33 \%$ \\
\hline \multirow{4}{*}{ Estado civil: } & Solteiro(a) & 41 & $34,17 \%$ \\
\hline & Casado(a) & 46 & $38,33 \%$ \\
\hline & Divorciado(a) & 23 & 19,17 \\
\hline & Viúvo(a) & 11 & 9,17 \\
\hline \multirow{4}{*}{ Renda per capita } & Menor que 1 salário mínimo & 39 & $32,5 \%$ \\
\hline & De 1 a 3 salários mínimos & 57 & $47,5 \%$ \\
\hline & De 4 a 6 salários mínimos & 24 & $20 \%$ \\
\hline & Mais de 6 salários mínimos & 0 & $0 \%$ \\
\hline \multirow{4}{*}{$\begin{array}{l}\text { Quantidade de moradores } \\
\text { na residência dos } \\
\text { consumidores: }\end{array}$} & Mora sozinho(a) & 9 & $7,5 \%$ \\
\hline & De 1 a 2 pessoas & 33 & $27,5 \%$ \\
\hline & De 3 a 4 pessoas & 49 & $40,83 \%$ \\
\hline & 5 ou mais pessoas & 29 & $24,17 \%$ \\
\hline
\end{tabular}

Fonte: Própria (2019).

Na busca por identificar o perfil de compra e consumo de pescados dos consumidores, por meio do instrumento de coleta de dados (questionário), perguntou-se qual o tipo de pescado mais consumido entre eles. Após a tabulação (Tabela 2), os resultados obtidos revelaram que $70 \%(\mathrm{n}=84)$ assinalaram que o peixe era, na época da pesquisa, o tipo de pescado mais consumido, seguido de $21,6 \%$ o camarão $(n=26), 4,15 \%$ as ostras $(n=5), 3,33 \%$ o caranguejo $(n=4)$ e $0,83 \%$ o mexilhão $(n=1)$. As espécies de peixe mais consumidas eram: Tambaqui com 44,16\%, seguido do Tucunaré (40,83\%), Mapará (1,6\%), Dourada (1,6\%), Tilápia $(0,83 \%)$, Curimatã $(0,83 \%)$ e outras espécies não identificadas, que somadas corresponderam $10 \%$.

O elevado percentual de consumo de peixe pelos consumidores entrevistados deve-se à disponibilidade acentuada de peixe na região, fato que influencia a comercialização e o consumo - dada a facilidade de encontrar esse alimento a custos mais baixos. Nesse sentido, cumpre destacar que, segundo o Anuário Peixe BR da Psicultura 2019, a Região Norte ocupa a segunda colocação da produção de pescados do Brasil (153.020 toneladas), sendo o Estado do Pará responsável por 23.720 toneladas, mostrando ser o líder das Regiões Norte e Nordeste na 
produção de Tilápia (MEDEIROS, 2019).

Tabela 2. Pescado mais consumido entre os 120 consumidores do Mercado Municipal do Distrito de Icoaraci participantes da pesquisa que subsidiou este trabalho

\begin{tabular}{lcc}
\hline \multicolumn{1}{c}{ Qual pescado de maior consumido } & $\mathbf{n}$ & $\mathbf{\%}$ \\
\hline Peixes & 84 & $70,00 \%$ \\
Ostras & 5 & $4,15 \%$ \\
Caranguejo & 4 & $3,33 \%$ \\
Camarão & 26 & $21,6 \%$ \\
Mexilhão & 1 & $0,83 \%$ \\
\hline Total & $\mathbf{1 2 0}$ & $\mathbf{1 0 0 \%}$ \\
\hline
\end{tabular}

Fonte: Própria (2019).

No tocante à forma de compra do pescado, 53,33\% $(\mathrm{n}=64)$ do total de consumidores $(\mathrm{n}=120)$ disse que compra normalmente congelado, 23,33\% $(\mathrm{n}=28)$ vivo, 21,67\% $(\mathrm{n}=26)$ resfriado, $20 \%(\mathrm{n}=24)$ in natura e 17,5\% $(\mathrm{n}=21)$ salgado (Tabela 3). Levando em consideração o contexto do Distrito de Icoaraci, a maior parte optava por adquirir o produto na forma congelado por ele ter frequentemente valores mais baixos e ser mais acessível que as demais formas. No caso específico dos pescados salgados, por normalmente terem passado por um processo de beneficiamento (salgamento e secagem), logo demandarem maior trabalho, são os com maiores valores. No mais, os vivos e os in natura são menos consumidos pela pouca disponibilidade nos locais de venda e por serem em geral mais caros, uma vez que possuem maior frescor.

Tabela 3. Forma de compra do pescado entre os 120 consumidores do Mercado Municipal do Distrito de Icoaraci participantes da pesquisa que subsidiou este trabalho

\begin{tabular}{lccc}
\hline Forma de compra do pescado & Sim & Não & Total \\
\hline Congelado & $53,33 \%$ & $46,67 \%$ & $100,0 \%$ \\
Resfriado & $21,67 \%$ & $78,33 \%$ & $100,0 \%$ \\
Vivo & $23,33 \%$ & $76,67 \%$ & $100,0 \%$ \\
In natura & $20 \%$ & $80 \%$ & $100,0 \%$ \\
Salgado & $17,5 \%$ & $82,5 \%$ & $100,0 \%$ \\
\hline
\end{tabular}

Fonte: Própria (2019).

Em face de o pescado ser um produto bastante perecível, deve-se atentar para os locais 
onde são comercializados e os fatores relevantes na hora da compra. Segundo os dados da Tabela 4, 40\% dos participantes da pesquisa optavam por comprar em peixarias, $34 \%$ em supermercado, 19\% em feiras livres e 7\% em outros locais. Em diálogo com estas informações, os dados da Tabela 5 mostram quais são os fatores relevantes na hora da compra do pescado, ao informar que: $68 \%$ dos consumidores indicaram que suas famílias buscam por um produto de qualidade, $9 \%$ optam por um bom atendimento, o preço $8 \%$, comodidade $0 \%$ e outros fatores 5\%. Em estudo semelhante realizado no Mercado de Ferro do Ver-o-Peso, em Belém (PA), notou-se que há uma diferenciação entre mulheres e homens quanto aos fatores de compra, enquanto as mulheres “[...] são as que mais se preocupam com a melhor qualidade dos pescados, demonstrando que o motivo mais relevante na hora da compra seria a "Higiene" $(23,00 \%)$. Os homens, por outro lado, afirmaram optar pelo "Menor preço" (12,00\%)" (ALHO, 2019, p. 29).

Tabela 4. Local que geralmente é realizada a compra dos pescados entre os 120 consumidores do Mercado Municipal do Distrito de Icoaraci participantes da pesquisa que subsidiou este trabalho

\begin{tabular}{lcc}
\hline Local de compra do pescado & n & \% \\
\hline Feira livre & 23 & $19,16 \%$ \\
Supermercado & 41 & $34,16 \%$ \\
Peixaria & 48 & $40 \%$ \\
Outros & 8 & $6,67 \%$ \\
\hline Total & $\mathbf{1 2 0}$ & $\mathbf{1 0 0 \%}$ \\
\hline
\end{tabular}

Fonte: Própria (2019).

Tabela 5. Fator relevante na hora da compra do pescado entre os 120 consumidores do Mercado Municipal do Distrito de Icoaraci participantes da pesquisa que subsidiou este trabalho

\begin{tabular}{lrr}
\hline Fator relevante na hora da compra & n & \% \\
\hline Atendimento & 15 & $12.5 \%$ \\
Qualidade & 81 & $67,5 \%$ \\
Comodidade & 0 & $0 \%$ \\
Preço & 14 & $11,66 \%$ \\
Outros & 10 & $8,33 \%$ \\
\hline Total & $\mathbf{1 2 0}$ & $\mathbf{1 0 0 , 0}$ \\
\hline
\end{tabular}

Fonte: Própria (2019).

Estas informações indicam uma preferência por peixarias, em razão da variedade das espécies comercializadas, e por supermercados em virtude da ideia preconcebida de que são 
espaços que apresentam melhores condições higiênico-sanitárias, dado que vai ao encontro do percentual de consumidores que têm como fator mais importante no momento da compra a qualidade dos pescados. Em estudo semelhante realizado no Mercado de Ferro do Ver-o-Peso, em Belém (PA), por Alho (2019), notou-se ainda uma diferenciação entre os gêneros durante a compra. Enquanto as mulheres "[...] são as que mais se preocupam com a melhor qualidade dos pescados, demonstrando que o motivo mais relevante na hora da compra seria a "Higiene" $(23,00 \%)$. Os homens, por outro lado, afirmaram optar pelo "Menor preço" (12,00\%)" (ALHO, 2019, p. 29). Essa constatação presente no trabalho de Alho (2019) pode ser relacionada aos dados desta pesquisa, uma vez que o atributo "qualidade" foi considerado o mais relevante no momento da compra por uma amostra que é formada em $70 \%$ por mulheres.

Contudo, existem outros fatores que precisam ser levados em consideração na hora da compra de produtos para consumo humano. Em se tratando do Mercado do Distrito de Icoaraci, estudos anteriores como o de Rosa et al. $(2019$, p. 6) revelaram "[...] que os consumidores deste local estão expostos ao risco de contaminação a partir da ingestão de alimentos adquiridos em seu interior, tendo em vista que os pescados são manipulados e armazenados sob péssimas condições”. A Portaria n 326, de 30 de julho de 1997 - que aprovou o Regulamento Técnico "Condições Higiênicos-Sanitárias e de Boas Práticas de Fabricação para Estabelecimentos Produtores/Industrializadores de Alimentos" -, no âmbito da Secretaria de Vigilância Sanitária do Ministério da Saúde, dispõe sobre uma série de requisitos gerais e essenciais de higiene e de boas práticas de fabricação para alimentos produzidos/fabricados para o consumo humano, objetivando à proteção da saúde da população (BRASIL, 1997).

A má conservação dos pescados comercializados em feiras e mercados públicos coloca em risco a saúde do consumidor, visto que o peixe é um alimento altamente perecível, tornandose um organismo profícuo na transmissão de microrganismos (SILVA JÚNIOR, 2014). Nesse sentido, no que se refere à qualidade do pescado consumido, indagou-se o seguinte: qual o atributo do pescado é considerado na hora da compra? Como resultado, obteve-se que 41,66\% $(\mathrm{n}=50)$ dos entrevistados apontaram que na hora da compra levavam em consideração a textura do pescado, 28,33\% $(\mathrm{n}=34)$ se atentavam para o aroma, $22,5 \%(\mathrm{n}=27)$ a cor e $7,5 \%(\mathrm{n}=9)$ a presença de hematomas, como mostra a Tabela 6. 
Tabela 6. Atributo considerado na hora da compra do pescado consumido entre os 120 consumidores do Mercado Municipal do Distrito de Icoaraci participantes da pesquisa que subsidiou este trabalho

\begin{tabular}{lrrr}
\hline Atributo do pescado é considerado na hora da compra & n & \% \\
\hline Cor & 27 & $22,5 \%$ \\
Presença de hematomas & 9 & $7,5 \%$ \\
Aroma & 34 & $28,33 \%$ \\
Textura & 50 & $41,66 \%$ \\
\hline Total & $\mathbf{1 2 0}$ & $\mathbf{1 0 0 \%}$ \\
\hline
\end{tabular}

Fonte: Própria (2019).

Em seguida, perguntou-se quais eram os critérios de frescor adotados antes e/ou na hora da compra desses pescados, os resultados mostram que: 48,33\% $(\mathrm{n}=58)$ dos entrevistados responderam a aparência dos olhos do peixe como fator de frescor, $34 \%(\mathrm{n}=28,33)$ se atentavam para a cor das guelras, 14,17\% $(\mathrm{n}=17)$ assinalaram a firmeza da carne, $9,17(\mathrm{n}=$ 11) a aderência das escamas, e $0 \%$ a presença do muco, conforme a Tabela 7 . Acerca destes dados, é primacial considerar as disposições da Agência Nacional de Vigilância Sanitária (BRASIL, 2016), uma vez que os peixes comprados frescos devem: ser livres de contaminantes físicos, químicos e biológicos; aparentar estar livres de manchas, furos ou cortes em sua superfície; as escamas devem estar firmes, consistentes e brilhosas; pele úmida; os olhos transparentes, brilhantes e salientes; a membrana que reveste a guelra precisa apresentar rigidez quanto à sua abertura; a face interna deve apresentar brilho característico, com os vasos sanguíneos cheios; as brânquias se apresentarem de cor avermelhada, úmidas e brilhantes, e com ausência de muco; odor característico e estar em bom estado de conservação sob uma grande camada de gelo. Com isso, deve-se atentar para essas características no momento da compra de um produto, pois elas são essenciais para evitar complicações à saúde. 
Tabela 7. Critério de frescor considerado antes da compra do pescado consumido entre os 120 consumidores do Mercado Municipal do Distrito de Icoaraci participantes da pesquisa que subsidiou este trabalho

\begin{tabular}{lrr}
\hline $\begin{array}{l}\text { Critério de frescor considerado antes da compra do } \\
\text { pescado }\end{array}$ & n & \% \\
\hline Aderência das escamas & 11 & $9,17 \%$ \\
Presença de muco & 0 & $0 \%$ \\
Cor das guelras & 34 & $28,33 \%$ \\
Aparência dos olhos & 58 & $48,33 \%$ \\
Firmeza da carne & 17 & $14,17 \%$ \\
\hline Total & $\mathbf{1 2 0}$ & $\mathbf{1 0 0 \%}$ \\
\hline
\end{tabular}

Fonte: Própria (2019).

Quanto à motivação do consumo de peixe, os dados mostraram que 50,83\% (n=61) dos consumidores entrevistados consumiam o peixe por conta de ser um alimento mais saudável, $39,16 \%(\mathrm{n}=47)$ pela facilidade de preparo, 35,83\% $(\mathrm{n}=43)$ por gostarem do sabor/textura, $8,33 \%(\mathrm{n}=10)$ pelo valor calórico, $5,83 \%(\mathrm{n}=7)$ pela marca do produto, $0,83 \%(\mathrm{n}=1)$ pela disponibilidade no mercado e $12,5 \%(n=15)$ por outras motivações, consoante a Tabela 8 . Para além da questão cultural de consumo na região, compreende-se a partir dos resultados que a população, ainda que informalmente, reconhece a importância nutricional desse alimento. Segundo Lopes et al. (2020), o pescado é caracterizado por elevada digestibilidade, pelo alto valor biológico, bem como pelo elevado teor de ácidos graxos poli-insaturados, sendo um alimento mais saudável do ponto de vista nutritivo. A partir de pesquisas amplamente divulgadas, importa assinalar que o consumo de pescado é fundamental para o desenvolvimento do sistema nervoso das crianças, visto que contribui com o processo de aprendizagem e as atividades física e mental (RAMALHO, 2019). 
Tabela 8. Motivação do consumo de peixe entre os 120 consumidores do Mercado Municipal do Distrito de Icoaraci participantes da pesquisa que subsidiou este trabalho

\begin{tabular}{lccc}
\hline Motivação do consumo de peixe & Sim & Não & Total \\
\hline Benefícios à saúde & $50,83 \%$ & $49,17 \%$ & $100,0 \%$ \\
Facilidade de preparo & $39,16 \%$ & $60,84 \%$ & $100,0 \%$ \\
Sabor / Textura & $35,83 \%$ & $64,17 \%$ & $100,0 \%$ \\
Valor calórico & $8,33 \%$ & $91,67 \%$ & $100,0 \%$ \\
Marca do produto & $5,83 \%$ & $94,17 \%$ & $100,0 \%$ \\
Disponibilidade & $0,83 \%$ & $99,17 \%$ & $100,0 \%$ \\
Outros & $12,5 \%$ & $87,5 \%$ & $100,0 \%$ \\
\hline
\end{tabular}

Fonte: Própria (2019).

Cascudo (1983) lista alguns ingredientes e preparos do bioma local que são a base da culinária paraense, entre eles se destacam: peixes de água doce (Aracu, Acari, Jaraqui, Mapará, Pirarucu, Tucunaré, Tambaqui); peixes de água salgada (Cação, Camurim, Corvina, Gurijuba, Piramutaba). De acordo com Lobato, Aires e Ravena-Cañete (2018, p. 264), essas características tornaram a gastronomia de Belém como “[...] uma das mais originais do Brasil, com ingredientes vindos de quase todos os cantos do mundo. Mas, certamente foi o uso dos recursos naturais locais que desenhou o destaque para a culinária paraense".

Sabendo-se que os consumidores residem no Distrito de Icoaraci, localizado às margens da Baía do Guajará, Estado do Pará, indagou-se qual a frequência em que consomem peixe e a preferência do modo de cocção (preparo). Como mostram os resultados (Tabela 9), 65\% (n = 78) dos participantes apontaram que consomem pescados pelo menos uma vez por semana. Quanto à forma, 43,33\% $(\mathrm{n}=52)$ preferem consumir o peixe assado, prosseguindo, 35,83\% (n $=43)$ assinalaram que preferem o peixe frito e 20,83\% $(n=25)$ peixe cozido (Tabela 10). Tal preferência por assado e frito deve certamente estar associada à tradição cultural indígena (ALHO, 2019). 
Tabela 9. Frequência do consumo de peixe entre os 120 consumidores do Mercado Municipal do Distrito de Icoaraci participantes da pesquisa que subsidiou este trabalho

\begin{tabular}{lrr}
\hline Frequência do consumo de peixe & $\mathbf{n}$ & $\mathbf{\%}$ \\
\hline Uma vez por semana & 78 & $65 \%$ \\
Duas vezes por semana & 25 & $20,83 \%$ \\
Três vezes por semana & 12 & $10 \%$ \\
Quatro vezes por semana & 4 & $3,33 \%$ \\
Todos os dias & 1 & $0,83 \%$
\end{tabular}

Total

120

$100 \%$

Fonte: Própria (2019).

Tabela 10. Preferência do modo de cocção do peixe consumido entre os 120 consumidores do Mercado Municipal do Distrito de Icoaraci participantes da pesquisa que subsidiou este trabalho

\begin{tabular}{|c|c|c|}
\hline Modo de preparo preferido & $\mathbf{n}$ & $\%$ \\
\hline Cozida & 25 & $20,83 \%$ \\
\hline Frito & 43 & $35,83 \%$ \\
\hline Assada & 52 & $43,33 \%$ \\
\hline In natura & 0 & $0 \%$ \\
\hline Total & 120 & $100 \%$ \\
\hline
\end{tabular}

Fonte: Própria (2019).

No que tange aos locais de consumo dos pescados pelos consumidores e por suas famílias, os dados (Tabela 11) revelaram que 79,16\% ( $\mathrm{n}=95)$ dos entrevistados consomem em suas residências, $13,33 \%(\mathrm{n}=16)$ em praias e apenas 4,16\% $(\mathrm{n}=5)$ em restaurantes. Sobre estes dados, salienta-se que culturalmente o paraense pouco frequenta restaurantes, preferindo o consumo do alimento caseiro. Afinal, ingerir alimentos na residência implica saborear um prato produzido por mães e avós, as quais têm certos cuidados nos preparos atrelados a uma carga emocional e cultural, que são importantes para promoção da saúde. Em estudo semelhante realizado por Santos et al. (2017), que buscou analisar o perfil do consumo de peixes com a população de Maceió, constatou-se que $92 \%$ dos entrevistados têm o hábito de consumir em casa, uma vez que os custos são menores que consumir em outros locais. 
Tabela 11. Local de maior consumo de pescado entre os 120 consumidores do Mercado Municipal do Distrito de Icoaraci participantes da pesquisa que subsidiou este trabalho

\begin{tabular}{lcc}
\hline Local de maior consumo do pescado & n & \% \\
\hline Residência & 95 & $79,16 \%$ \\
Restaurante & 5 & $4,16 \%$ \\
Praia & 16 & $13,33 \%$ \\
Outros & 4 & $3,33 \%$ \\
\hline Total & $\mathbf{1 2 0}$ & $\mathbf{1 0 0 \%}$ \\
\hline
\end{tabular}

Fonte: Própria (2019).

\section{Conclusões}

Conclui-se que no Distrito de Icoaraci, em Belém (PA), o perfil do consumidor é o seguinte: o pescado mais consumido é o peixe, sendo as peixarias e os supermercados os principais locais de aquisição e as residências os de consumo. Normalmente, os peixes são comprados congelados, uma vez na semana e a maior motivação para compra e consumo é o benefício à saúde. No entanto, compreendeu-se que, embora os consumidores constituintes da amostra e suas famílias se preocupem com os aspectos da qualidade higiênico-sanitária elementares nos momentos de compra, preparo e consumo de peixes, evidenciou-se que a vulnerabilidade social somada às formas de oferta e ao custo baixo inviabilizam, por vezes, tais cuidados e precauções. Afinal, com um número de pessoas por família representativo, buscar por pescados com preços mais acessíveis implica adquirir maiores quantidades desse alimento.

\section{Referências}

ALHO, T. V. L. Perfil do consumidor e fatores relevantes na compra de peixe no mercado de ferro do Ver-o-Peso, Belém (PA). 2019. 40 f. Trabalho de Conclusão de Curso (Graduação em Engenharia de Pesca) - Universidade Federal Rural da Amazônia, Belém, 2019.

BARROS, F. A. L. et al. Body morphometric measurements, yield and centesimal composition of king weakfishfillet. Biota Amazônia, Macapá, v. 9, n. 4, p. 16-19, 2019.

BRASIL. Ministério da Pesca e Aqüicultura. Pescado na alimentação escolar. Brasília: MPA, 2012.

BRASIL. Ministério da Saúde. Agência Nacional de Vigilância Sanitária (ANVISA). Escolha bem o seu pescado. Dicas para você levar um pescado fresquinho para casa. (Cartilha). Brasília: ANVISA, 2016.

BRASIL. Portaria n. 326 de 30 de julho de 1997. Dispõe sobre o Regulamento Técnico Sobre as Condições Higiênico-sanitárias e de Boas Práticas de Fabricação para Estabelecimentos Produtores/Industrializadores de Alimentos. Diário Oficial da União - DOU da República 
Federativa do Brasil. Ministério da Saúde. Brasília, DF: 30 jul. 1997. Disponível em: https://bvsms.saude.gov.br/bvs/saudelegis/svs1/1997/prt0326_30_07_1997.html. Acesso em: 16 jan. 2020.

CASCUDO, L. C. História da Alimentação no Brasil. 2. ed. São Paulo: Editora da USP, 1983.

CALDER, P. C. Omega-3 Fatty Acids and Inflammatory Processes: From Molecules to Man. Biochemical Society Transactions, United Kingdom, v. 45, n. 5, p. 1105-1115, 2017.

DURAN, N. D. et al. Availability and consumption of fish as convenience food - correlation between market value and nutritional parameters. Food Science and Technology, Campinas, v. 37, n. 1, p. 65-69, 2016.

FAO. Food and Agriculture Organization of the United Nation. The state of world fisheries and aquaculture. Roma: FAO, 2016.

FERREIRA, V. C. Estudo da comercialização e condições de armazenamento do pescado em duas feiras da cidade de Parintins/AM. 2019. $43 \mathrm{f}$. Trabalho de Conclusão de Curso (Graduação em Ciências Biológicas) - Centro de Estudos Superiores de Parintins, Universidade do Estado do Amazonas, Parintins, 2019.

LEANDRO, S. V. et al. Perfil de consumo e do consumidor de peixe no município de Sinop, Mato Grosso. Revista Agroecossistemas, Belém, v. 10, n. 1, p. 73-98, 2018.

LOBATO, F. H. S.; RAVENA-CAÑETE, V. "O açaí nosso de cada dia”: formas de consumo de frequentadores de uma feira amazônica (Pará, Brasil). Ciências Sociais UNISINOS, São Leopoldo, v. 55, n. 3, p. 397-410, 2019.

LOBATO, F. H. S.; AIRES, J. C. A.; RAVENA-CANETE, V. Belém, cidade criativa da gastronomia: uma Amazônia de sabores e de experiências turísticas. In: LAVANDOSKI, J.; BRAMBILA, A.; VANZELLA, E. (Org.). Alimentação e Turismo: criatividade, experiência e patrimônio cultural. 1ed.João Pessoa: Editora do CCTA, 2018, v. 2, p. 255-284.

LOPES, I. G.; OLIVEIRA, R. G. D.; RAMOS, F. M. Perfil do consumo de peixes pela população brasileira. Biota Amazônia, Macapá, v. 6, n. 2, p. 62-65, 2016.

LOPES, L. R. et al. Dimensões associadas ao consumo de pescado na Região Metropolitana de Belém - PA. Revista Contribuciones a las Ciencias Sociales, Texcoco, p. 1-19, junho, 2020.

LUZ, L. J. B. et al. Desenvolvimento de preparações para a alimentação escolar. Segurança Alimentar e Nutricional, Campinas, v. 27, p. 1-11. e020011, 2020.

MACIEL, E. S. et al. Avaliação do consumo de pescado durante campanha de incentivo em comunidade universitária. Revista de Ciência em Extensão, São Paulo, v.15, n. 1, p. 93-100, 2019.

MARTINS, F. J. Gastronomia do Pará: o sabor do Brasil. Belém: Abresi, 2014.

MATEUS, M. P. et al. Alimentação mediterrânica no linfedema. 1. ed. Faro: Universidade do Algarve, 2019. 
MEDEIROS, F. Anuário PeixeBR da piscicultura 2019. São Paulo: Associação Brasileira da Psicultura, 2019.

PINHEIRO, B. C. M. et al. Análise centesimal e de descrição do teor de aminoácidos presente nos sarnambis (protothaca antiqua) coletados na ilha de Algodoal-PA. Brazilian Journal of Development, Curitiba, v. 6, n. 4, p. 21677-21686, 2020.

PRODANOV, C. C.; FREITAS, E. C. Metodologia do trabalho científico: métodos e técnicas da pesquisa e do trabalho acadêmico. 2. ed. Novo Hamburgo: Universidade FEEVALE, 2013.

RAMAlHO, R. M. M. Controlo oficial de contaminantes no pescado. 2019. f. 99. Dissertação (Mestrado em Tecnologia e Segurança Alimentar) - Universidade Nova de Lisboa, Lisboa, 2019.

ROSA, M. Y. O. et al. O risco sanitário na comercialização de alimentos em um mercado público da Amazônia: um estudo de caso em Belém (PA). Scientia Plena, Aracaju, v. 15, n. 10, p. 1-7, 2019.

RUXTON, C. H. S. The benefits of fish consumption. Nutritivos on Bulletin, Somerville v. 36, n. 1, p. 6-19, 2011.

SANTOS, E. L. et al. Perfil do consumo de peixes na cidade de Maceió, Alagoas. Revista Científica de Produção Animal, Paraíba, v. 18, n. 1, p. 45-54, 2017.

SANTOS, E. J. R. et al. Qualidade higiênico-sanitária de tambaqui (Colossoma macropomum) comercializado na cidade de São Luís - MA. Ciência Animal Brasileira, Goiânia, v. 20, p. 1$12,2019$.

SILVA JÚNIOR, E. A. Manual de controle higiênico-sanitário em serviços de alimentação. 6. ed. atual. São Paulo: Varela, 2014.

SILVA, R. R. M. D. et al. Pescado na alimentação escolar: caracterização nutricional. Segurança Alimentar e Nutrição, Campinas, v. 24, n. 2, p. 169-179, 2017.

SOUSA, A. B. B. D.; ALMEIDA, N. M. D. Ácidos graxos em pescado: composição, influência da dieta e benefícios à saúde humana. CIENTEC-Revista de Ciência, Tecnologia e Humanidades do IFPE, Recife, v. 10, n. 1, p. 105-120, 2018.

SUÁREZ, H. et al. Importância de ácidos graxos poliinsaturados presentes em peixes de cultivo e de ambiente natural para a nutrição humana. Boletim do Instituto de Pesca, São Paulo, v. 28, n. 1, p. 101-110, 2018. 


\title{
CAPÍTULO 54: PERFIL POPULACIONAL E CONHECIMENTO ACERCA DA FOME OCULTA E BIOFORTIFICAÇÃO DE ALIMENTOS
}

\section{CHAPTER 54: POPULATION PROFILE AND KNOWLEDGE ABOUT HIDDLE HUNGER AND FOOD BIOFORTIFICATION}

Maria Juliana Simplício de Souza ${ }^{1}$; Carina Raissa Rocha Oliveira da Cunha ${ }^{2}$; Amanda Priscila da Silva ${ }^{3}$; Raquel Maria da Silva ${ }^{4}$; Álvaro Carlos Gonçalves Neto ${ }^{5}$

\begin{abstract}
Resumo
A fome oculta é uma situação de risco a saúde humana que ocorre no mundo todo, principalmente em regiões e países menos desenvolvidos. A população mais pobre é a que mais vem sendo afetada pela fome oculta, isto porque essa população se alimenta com maior frequência de alimentos com alta densidade energética, ricos em açúcares e gorduras, mas de baixo valor nutritivo. Nesse cenário, observa-se a importância da biofortificação de alimentos para uma melhor alimentação. Apesar de ser um assunto alarmante e de grande importância, esses assuntos são ainda pouco abordados e divulgados pela mídia. Por isso, tendo em vista que a fome oculta ocorre devido à deficiências nutricionais, a mesma pode provocar doenças, aumentar risco de infecções e diminuir a qualidade de vida. Este artigo teve como objetivo realizar a investigação do perfil da população, avaliar o entendimento/conhecimento da mesma sobre a fome oculta e a biofortificação de alimentos e relacionarmos essas questões. Para isso foi desenvolvido questionário no Google Forms - serviço gratuito utilizado para criação de formulários online - contendo um total de 14 perguntas com questionamentos sobre $\mathrm{o}$ conhecimento da população acerca do tema abordado e perguntas de cunho pessoal. $\mathrm{O}$ questionário foi disponibilizado através de link remoto, sendo aplicado entre os dias 14 a 25 de julho de 2020. No total, foram obtidas 121 respostas onde os gráficos foram tabulados, agrupados e apresentados em gráficos/tabelas confeccionadas no excel. A maior parte dos pesquisados $(60,3 \%)$ foram do sexo feminino, com idade entre 18 e 25 anos e nível superior incompleto. A maior parte da população avaliada não possuía conhecimento algum sobre a biofortificação de alimentos $(72,7 \%)$ e a fome oculta $(83,5 \%)$, alegando ainda nunca terem ouvido estes termos. Apesar das diversas formas de comunicação e acesso à informação disponíveis atualmente como a internet, considerada segundo meio de comunicação mais utilizada, ainda é possível ver o quão é difícil o acesso à informação sobre a biofortificação e fome oculta pela população.
\end{abstract}

Palavras-Chave: Alimentos, nutrição, pesquisa exploratória. ${ }^{1}$

11 Graduanda do curso de Agronomia, integrante do Programa de Educação Tutorial-PET Agronomia, Universidade Federal Rural de Pernambuco - UFRPE. E-mail: julianasimplicio92@gmail.com

2 Graduanda do curso de Agronomia, integrante do Programa de Educação Tutorial-PET Agronomia, Universidade Federal Rural de Pernambuco - UFRPE. E-mail: carinaraissa1998@ hotmail.com

${ }^{3}$ Graduanda do curso de Agronomia, integrante do Programa de Educação Tutorial-PET Agronomia, Universidade Federal Rural de Pernambuco - UFRPE. E-mail: a.prisciila@ hotmail.com

${ }^{4}$ Mestranda do Programa de Pós-Graduação em Produção Agrícola (PPGPA), bolsista da Fundação de Amparo à Ciência e Tecnologia do Estado de Pernambuco (FACEPE); Universidade Federal do Agreste de Pernambuco- UFAPE. E-mail: raquel.maria18@hotmail.com

5 Doutor em Agronomia (Fitotecnia), Universidade Federal de Lavras - UFLA. E-mail: alvarocgneto@gmail.com 


\begin{abstract}
Hidden hunger is a situation of risk to human health that occurs worldwide, especially in less developed regions and countries. The poorest population is the one that has been most affected by hidden hunger, this because this population eats more frequently of foods with high energy density, rich in sugars and fats, but of low nutritional value. In this scenario, the importance of food biofortification for better nutrition is observed. Despite being an alarming and very important issue, these issues are still rarely addressed and disseminated by the media. Therefore, in view of the fact that hidden hunger occurs due to nutritional deficiencies, it can cause diseases, increase the risk of infections and decrease the quality of life. This article aimed to investigate the profile of the population, evaluate their understanding / knowledge about hidden hunger and the biofortification of food and relate these issues. For this purpose, a questionnaire was developed on Google Forms - a free service used to create online forms - containing a total of 14 questions with questions about the knowledge of the population about the topic addressed and questions of a personal nature. The questionnaire was made available via remote link, being applied between July 14th to 25th, 2020. In total, 121 responses were obtained where the graphs were tabulated, grouped and presented in graphs / tables made in excel. Most of the respondents $(60.3 \%)$ were female, aged between 18 and 25 years old and with incomplete higher education. Most of the evaluated population had no knowledge about food biofortification $(72.7 \%)$ and hidden hunger $(83.5 \%)$, claiming they had never heard of these terms. Despite the various forms of communication and access to information currently available, such as the internet, considered the second most used means of communication, it is still possible to see how difficult it is to access information about biofortification and hidden hunger by the population.
\end{abstract}

Keywords: Food, nutrition, exploratory research.

\title{
Introdução
}

A fome oculta é algo que acomete pessoas do mundo inteiro, independente de classe social. Trata-se de uma deficiência nutricional geralmente causada por alimentação incompleta e inadequada, de alto teor calórico e baixo teor de nutrientes. Essa questão torna-se mais complexa em regiões mais pobres, menos desenvolvidas, com agravante para crianças em pré-escola, gestantes, lactantes e idosos. O fator mais alarmante se dá pelo fato desse distúrbio alimentar ser silencioso, ou seja, imperceptível no organismo inicialmente (SIQUEIRA et al, 2020).

Vilas Boas (2016) afirma que a fome oculta acontece quando indivíduos possuem dietas inadequadas, no que tange o aporta a nutrientes, o que acaba acarretando em problemas de saúde e diminuição na qualidade de vida, o que gera para essas pessoas diversas enfermidades associadas a essa sub alimentação.

As principais vitaminas e minerais que se apresentam de forma insatisfatória na alimentação são: pró vitamina A, ferro e zinco, que geralmente ocorrem de forma combinada, principalmente no que se diz respeito ao ferro e zinco (BESSA, 2019). Algumas doenças causadas pela falta dessas vitaminas e sais minerais são: 
aumento do risco de infecções e cegueira noturna (pró vitamina A), podendo chegar à cegueira parcial ou total, anemia e atraso do desenvolvimento fetal (ferro), diarreia crônica e redução da imunidade (zinco), entre outros.

Os dados acerca da fome oculta são alarmantes, ela é responsável por debilitar mais de 2 milhões de pessoas em todo o mundo. $48 \%$ das crianças no mundo com menos de cinco anosde idade apresentam anemia (deficiência de ferro) e 30\% possuem deficiência em vitamina A. No Brasil, os números também são altos, 55\% das crianças com menos de cinco anos de idade apresentam deficiência de ferro e $13 \%$ de vitamina $\mathrm{A}$ (BioFORT, 2020).

Diante dessa problemática, surge a biofortificação de alimentos. Os estudos sobre o tema em questão tiveram início nos Estados Unidos em 1990, com Howarth Bouis, economista do Instituto Internacional de Pesquisa em Políticas Alimentares (IFPRI). Bouis começou a questionar se as próprias plantas não poderiam fazer o trabalho de combater a fome oculta e 10 anos depois ele fundava o programa HarvestPlus, um programa internacional que visa dar impulso e coordenar ações de biofortificação de alimentos no mundo (SILVA, 2018).

No Brasil, a biofortificação de alimentos é conduzida pela rede BioFORT, coordenada pela Embrapa. A rede reúne uma gama de mais de 150 pesquisadores e mais de 14 estados brasileiros, sempre priorizando regiões com baixos Índices de Desenvolvimento Humano (IDH), tornando o país destaque no mundo no que se diz respeito a biofortificação, pois é o único que trabalha com oito culturas simultaneamente, são elas: arroz, feijão, feijão-caupi e trigo (maiores teores de ferro e zinco); mandioca, milho, abóbora e batata-doce (maiores teores de vitamina A). Esses alimentos foram escolhidos tendo como critério principal a dieta comum dessas comunidades, ou seja, alimentos que já faziam parte de sua alimentação, dessa forma esses indivíduos não seriam obrigados a mudar o seu cardápio usual e não teriam ressalvas em receber esses alimentos (SILVA, 2018).

Os dados acerca da fome oculta são alarmantes, ela é responsável por debilitar mais de 2 milhões de pessoas em todo o mundo. $48 \%$ das crianças no mundo com menos de cinco anosde idade apresentam anemia (deficiência de ferro) e 30\% possuem deficiência em vitamina A. No Brasil, os números também são altos, endo $55 \%$ das crianças com menos de cinco anos de idade apresentando deficiências de ferro e $13 \%$ com deficiência de vitamina A (BioFORT, 2020). 
Tendo em vista o impacto desse problema na vida de várias pessoas ao redor do globo, o processo de biofortificação configura um esforço para a melhora do estado nutricional e promoção de alimentação saudável, diversificada em nutrientes, como a fortificação e a suplementação. Ela se configura como um complemento para reforçar outras alternativas de alimentação rica e saudável, como a fortificação e a suplementação. Além disso, a disseminação de conhecimentos técnico-científicos, experiências de produtores com o cultivo de alimentos biofortificados e divulgação para o público em geral faz com que a população aumente sua atenção sobre o consumo de alimentos e aspectos relacionados a nutrição, bem como anos que são levados em pesquisas e nas etapas para obtenção dos alimentos biofortificados sejam prestigiados e deem um bom resultado (BioFORT, 2020).

Sendo assim, este artigo teve como objetivo investigar o perfil, avaliar o entendimento/conhecimento de parte da população sobre a fome oculta e a biofortificação de alimentos e relacionar essas questões.

\section{Material e métodos}

O caminho metodológico utilizado neste trabalho foi um estudo descritivo de natureza quantitativa, sendo uma pesquisa de caráter exploratório. Como ferramenta para coleta de dados foi aplicado um questionário contendo 14 (catorze) perguntas, de forma remota. A plataforma eletrônica online utilizada para criação do questionário foi o Google Forms, o mesmo quantificou os dados e gerou os gráficos . Após a criação, foi gerado um link de acesso ao questionário. Este link foi divulgado e compartilhado em aplicativos de conversa em grupo, individual e redes sociais.

O início do compartilhamento se deu no dia 14 de julho de 2020 e foi encerrado em 25 de julho 2020. Foi utilizado o método de estatística descritiva para inferência dos resultados, visto que a mesma realiza uma descrição e sistematização dos dados amostrais, podendo ser expressa em tabelas e figuras gráficas.

\section{Resultados e Discussão}

Do público entrevistado, as mulheres representaram 60,3\%, como mostra a Figura 1. Em seguida, tivemos o sexo masculino com $38 \%$ das respostas e outros com $1,7 \%$. Atualmente, segundo Instituto Brasileiro de Geografia e Estatística (IBGE, 2019), o Brasil possui cerca 211,9 milhões de habitantes, sendo 51,8\% da população composta por mulheres e $48,2 \%$ da população representada por homens. 
Com a inserção cada vez maior da mulher no mercado de trabalho, o consumo de lanches e alimentos ultraprocessados pode ser uma tendência pela falta de tempo e praticidade, deixando de lado alimentos que exigem mais tempo de cozimento e provavelmente mais saudáveis. Os diferenciais de morbimortalidade constatados entre homens e mulheres resultam, em grande parte, de diferenças do estilo de vida e dos comportamentos relacionados à saúde. Pesquisas nacionais que utilizam marcadores de consumo alimentar saudável e não saudável apontam que comparados às mulheres, os homens apresentam prevalências mais elevadas de ingestão de sal, de refrigerantes e de carnes com excesso de gordura, bem como menor ingestão de frutas e hortaliças (ASSUMPÇÃO et al., 2017).

Figura 1. Sexo da população avaliada.

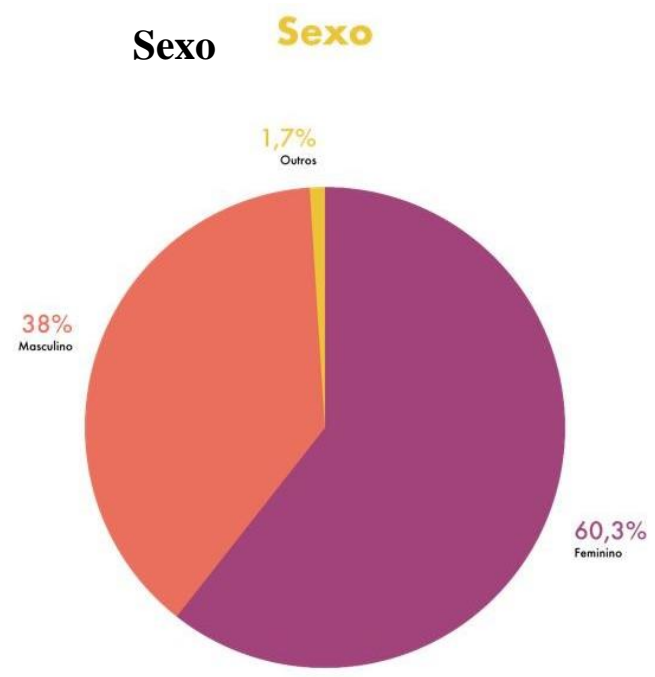

Fonte: Própria (2020).

Quanto a faixa etária dos entrevistados, 38\% eram pessoas com idade de 18-25 anos, a idade de 26-35 anos com 29,8\% das respostas, a idade de $36-45$ anos com $12,4 \%$, a idade de pessoas com mais de 45 anos com 10,7\% e menores de 18 anos representando 9,1\% (Figura 2). Segundo Delmondes (2016) a qualidade da alimentação tende a melhorar com o aumento da idade e da escolaridade. Entretanto, é sabido que pessoas mais velhas tendem a usar menos tecnologias do que os jovens entre 18-25 anos, o que explica a ampla adesão de respostas na presente pesquisa. 
Figura 2. Faixa etária da população entrevistada

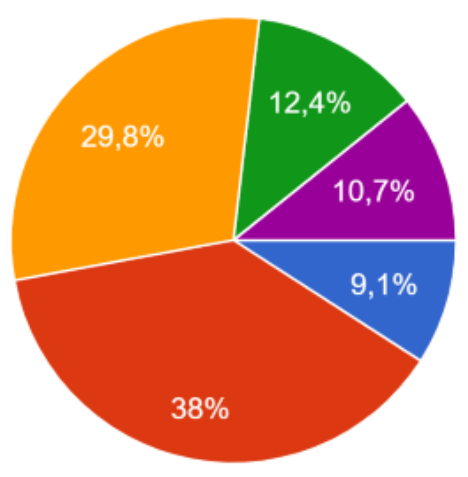

Menor que 18 anos
$18-25$ anos
$26-35$ anos
$36-45$ anos
Maior que 45 anos

Fonte: Própria (2020).

Tratando-se da escolaridade do público atingido, 36,4\% possui ensino superior incompleto, $27,3 \%$, possuindo ensino superior completo, $16,5 \%$ com ensino médio completo, 6,6\% com ensino médio incompleto, 6,6\% possuem ensino fundamental incompleto, $4,13 \%$ possuem fundamental completo e por fim $2,47 \%$ responderam outros (Figura 3). Uma pesquisa afirmou que pessoas mais escolarizadas ingerem mais grãos integrais, frutas, vegetais, leite e derivados, e também mais gordura saturada do que aquelas que tinham até sete anos de estudo, evidenciando que quanto maior a escolaridade, maior a preocupação com a alimentação (DELMONDES, 2016).

Figura 3. Nível de escolaridade da população avaliada.

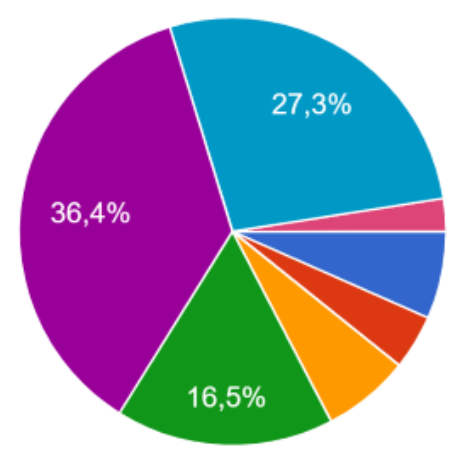

Ensino fundamental incompleto

- Ensino fundamental completo

Ensino médio incompleto

Ensino médio completo

- Ensino superior incompleto

Ensino superior completo

Outro

Fonte: Própria (2020).

Do universo investigado, 76,9\% residem em área urbana e 23,1\% afirmaram residir na zona rural (Figura 4). Mais da metade da população mundial vive em áreas urbanas, no Brasil chega a 80\%. E, é sabido que o Brasil é um país de dimensões continentais, com variações regionais significativas e um patrimônio culinário 
expresso em hábitos e receitas tradicionais. Porém, os processos de urbanização e industrialização desiguais parecem afetar de forma diferenciada os grupos populacionais e, provavelmente, as macrorregiões do país. De tal modo que, avaliar as diferenças no consumo alimentar dos brasileiros que vivem em áreas urbanas e rurais é importante, sobretudo pelo país apresentar contínuo e sistemático esforço para garantir o Direito Humano a Alimentação Adequada e Saudável e a soberania alimentar mediante a valorização e respeito à cultura alimentar.

Segundo tal trabalho, há diferenças no consumo alimentar, segundo marcadores de alimentação saudável e não saudável, entre adultos residentes nas áreas urbanas e rurais do Brasil, e macrorregiões. Brasileiros residentes nas áreas rurais têm maior chance de manter um padrão alimentar tradicional, com o consumo de alimentos minimamente processados, especialmente feijão; e menor consumo de alimentos ultraprocessados; apesar do menor consumo de frutas e hortaliças, e de peixes. (COSTA et al., 2020). Mas sabemos que a energia elétrica, bem como o acesso à Internet ainda são escassos na zona rural, o que dificulta a sua participação em pesquisas remotas.

Figura 4. Área de residência dos avaliados

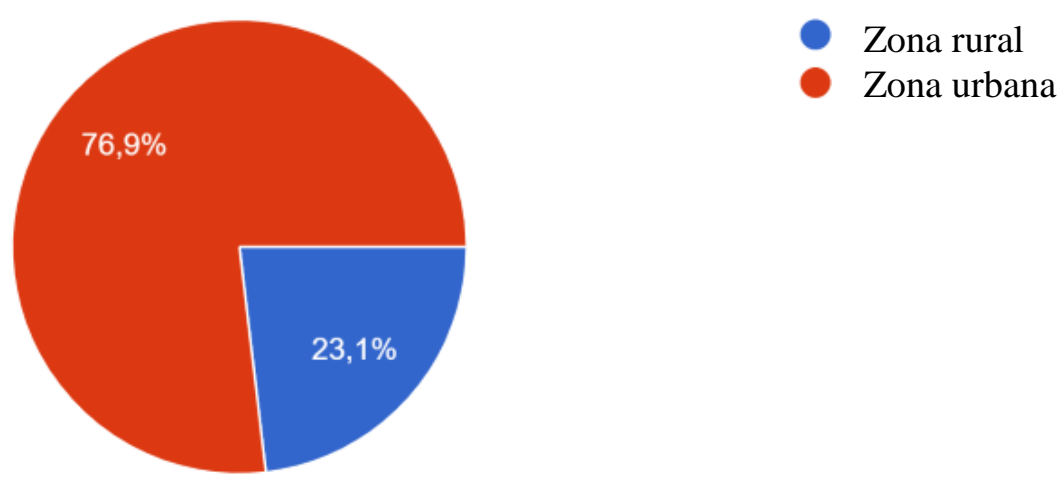

Fonte: Própria (2020).

83,5\% negaram já terem ouvido falar sobre a fome oculta, já 16,5\% afirmaram já terem ouvido (Figura 5).A professora do Instituto de Nutrição da Universidade Federal do Rio de Janeiro (UFRJ), Andréa Ramalho afirma que o combate à fome oculta tem apresentado resultados tímidos diante da grandeza do problema, que atinge até mesmo regiões consideradas fora do eixo tradicional da miséria no Brasil. O custo de não intervir adequadamente para superar as carências específicas é muito maior do que o custo de programas de intervenção. Mesmo assim não é raro que os setores envolvidos na busca de uma solução - universidades, governos, indústrias, mídia e população - falem 
SOUZA, M. J. S; CUNHA, C. R. R. O; SILVA, A, P; SILVA, R. M; GONÇALVES NETO, Á. C.

linguagens diferentes. Além disso, afirma que precisamos de interfaces entre esses setores para permitir que o conhecimento científico se traduza em ações e programas de intervenção nutricional de alcance social (ÉPOCA, 2015).

Figura 5. Conhecimento da população sobre a fome oculta.

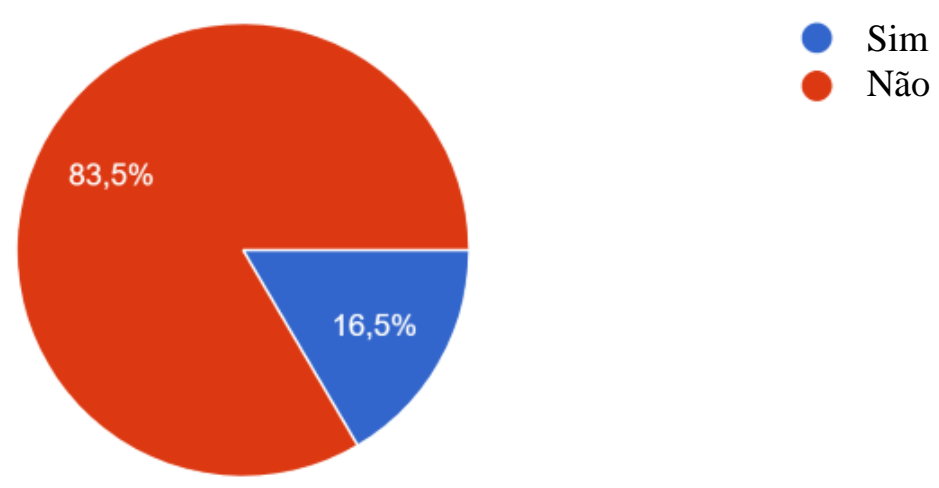

Fonte: Própria (2020).

Quando questionados se já tiveram conhecimento sobre algum caso de fome oculta, 86,8\% alegaram não conhecerem algum caso. Já 13,2\% alegam conhecer (Figura 6). A insegurança alimentar e nutricional no Brasil tem duas faces: uma associada à negação do direito ao acesso à alimentação necessária à vida; outra resultante da alimentação inadequada ou não saudável. Pessoas com excesso de peso ou obesidade são pessoas expostas ao consumo inadequado de alimentos. Na alimentação dos mais pobres, alimentos com alta densidade energética - açúcares, refrigerantes e alimentos com alto teor de gordura - vêm substituindo alimentos tradicionais mais saudáveis (PINHEIRO, CARVALHO, 2010).

Por não apresentar sinais clínicos de carência, que são característicos das manifestações finais do quadro de ausência de vitaminas e minerais, a fome oculta se instala de forma imperceptível e silenciosa. Porém, mesmo que não evolua para os estágios terminais da deficiência, já causa prejuízos à saúde, podendo comprometer várias etapas do processo metabólico, com alterações no sistema imunológico, nas defesas antioxidantes e no desenvolvimento físico e mental. A deficiência é fator predisponente/agravante de diversas doenças crônicas, como doenças cardiovasculares, hipertensão arterial, diabetes mellitus, dislipidemia, obesidade, alguns tipos de câncer e osteoporose, entre outras (ÉPOCA, 2015) 
Figura 6. Conhecimento de algum caso de fome oculta.

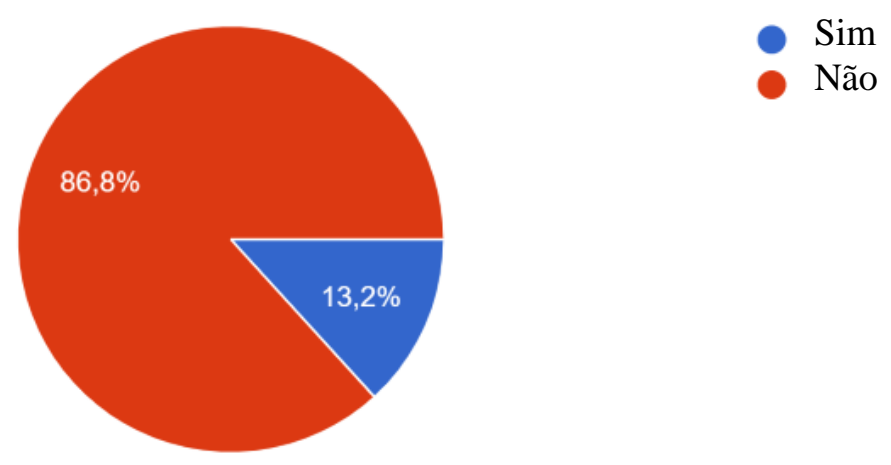

Fonte: Própria (2020).

$66,9 \%$ dos entrevistados afirmaram que não ouviram falar sobre a biofortificação de alimentos e 33,1\% afirmam que já tinham ouvido falar (Figura 7). Desde os anos 1940, Josué de Castro ampliara o reconhecimento das distintas formas e expressões da fome, e denunciava a monocultura como uma causa estrutural da alimentação e da fome oculta. No entanto, muitas instituições e iniciativas insistem em soluções que não interferem sobre as causas do problema, quando sim apenas sobre os desfechos (GOMES et al., 2016).

Figura 7. Já ter ouvido falar e conhecimento da população sobre biofortificação de alimentos

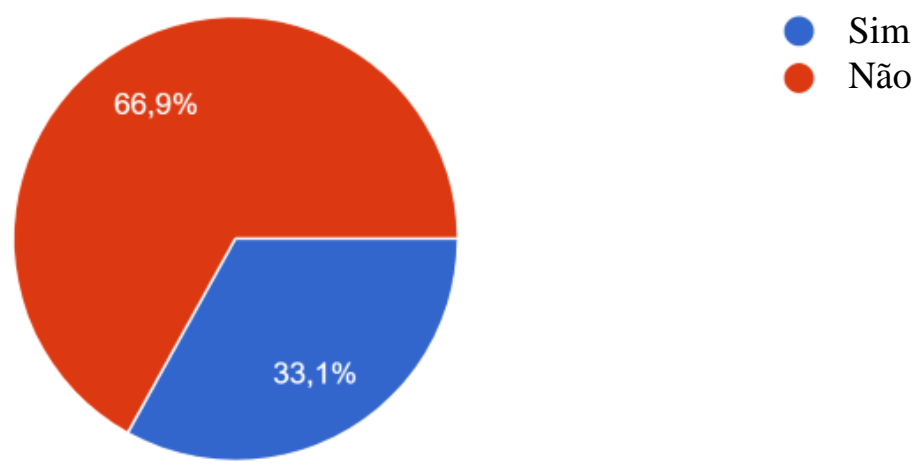

Fonte: Própria (2020).

Questionando sobre se as pessoas sabiam o que é a biofortificação de alimentos, a resposta majoritária foi afirmando que não sabiam o que é, 72,7\%. Em seguida, tivemos $27,3 \%$ das respostas afirmando que sabiam (Figura 8). 
Figura 8. Conhecimento da população sobre biofortificação de alimentos

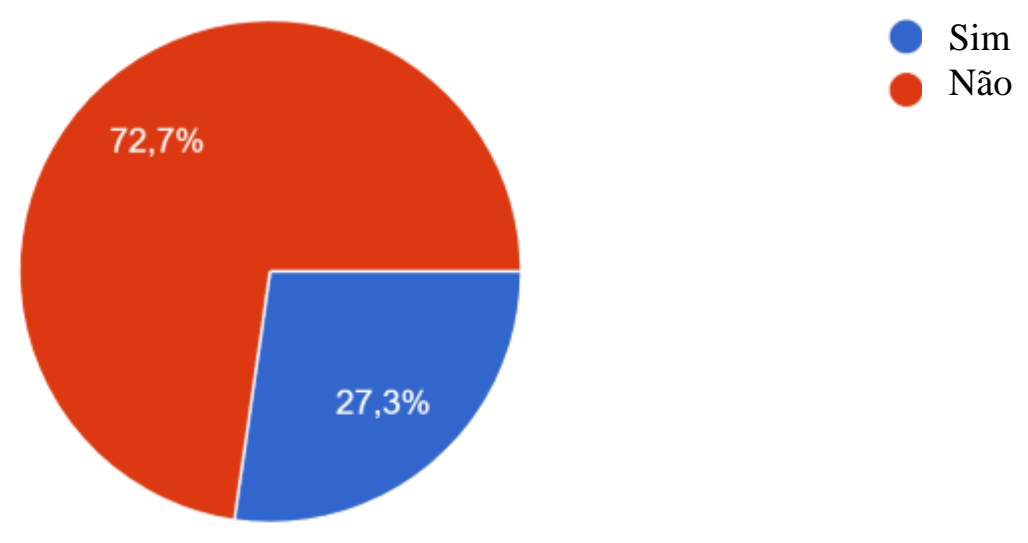

Fonte: Própria (2020).

Das pessoas que afirmaram que sabiam o que é a biofortificação de alimentos, a resposta majoritária foi afirmando que souberam através da Internet 57,8\%. Em seguida, tivemos $20 \%$ das respostas afirmando que conheceram através de amigos, $6,7 \%$ jornais como dados principais (Figura 9). A internet é o segundo meio de comunicação usado mais frequentemente pelos brasileiros, atrás da televisão e à frente do rádio, segundo a primeira edição da Pesquisa Brasileira de Mídia 2014 - Hábitos de Consumo de Mídia pela População Brasileira (G1, 2014).

Figura 9. Métodos pelo qual a população tomou conhecimento da biofortificação de alimentos.
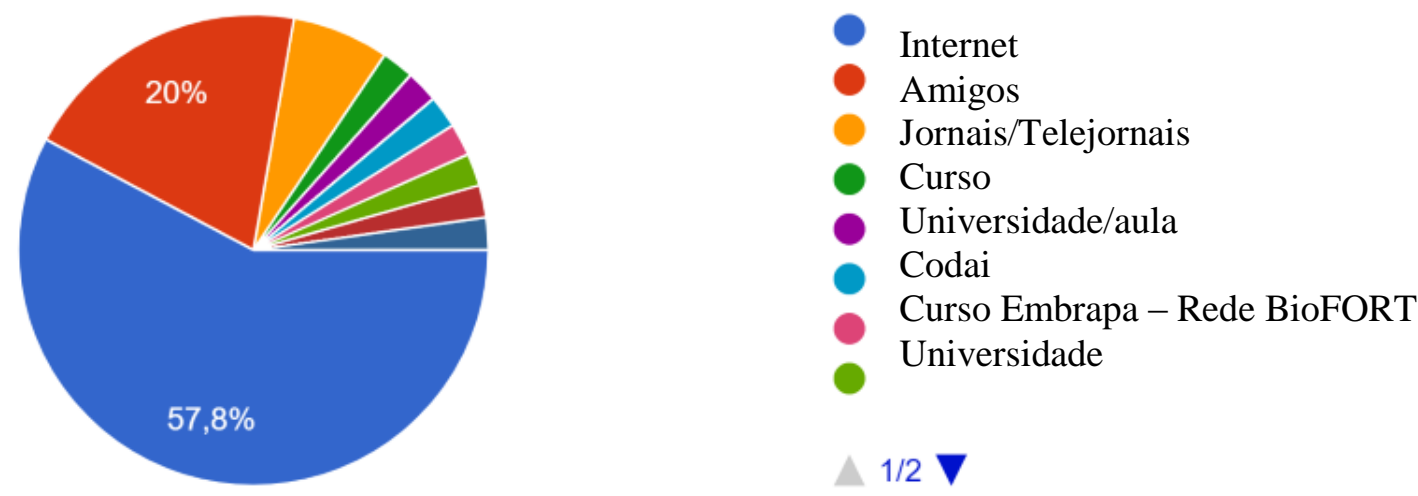

Fonte: Própria (2020).

Quando perguntados sobre qual o sexo tinha mais interesse por esse assunto, $73,3 \%$ afirmaram que eram as mulheres e $26,7 \%$ afirmaram que eram os homens (Figura $10)$. 
SOUZA, M. J. S; CUNHA, C. R. R. O; SILVA, A, P; SILVA, R. M; GONÇALVES NETO, Á. C.

Figura 10. Interessados pela biofortificação de alimentos.
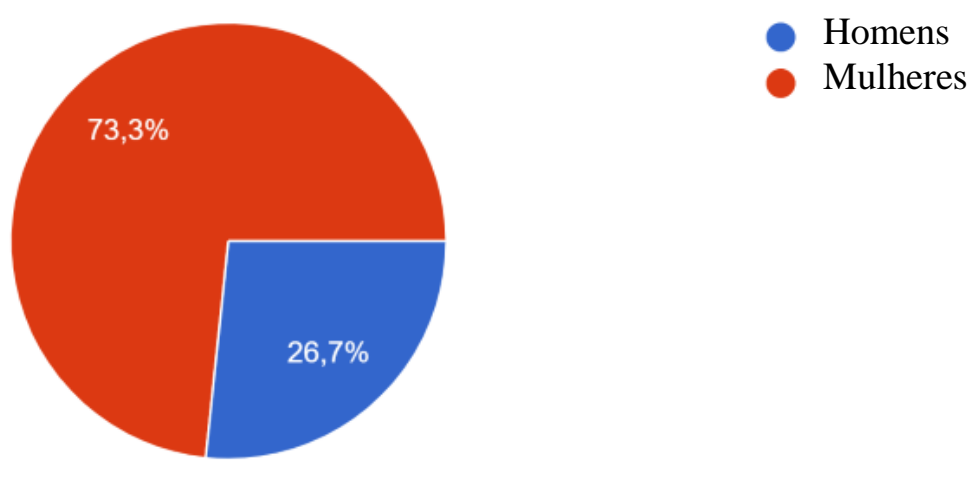

Fonte: Própria (2020).

E quando perguntados sobre o conhecimento de quais alimentos eram biofortificados, $77,7 \%$ negaram saber e $22,3 \%$ afirmaram saber (Figura 11).

Figura 11. Conhecimento da população sobre as plantas alimentícias biofortificadas atualmente.

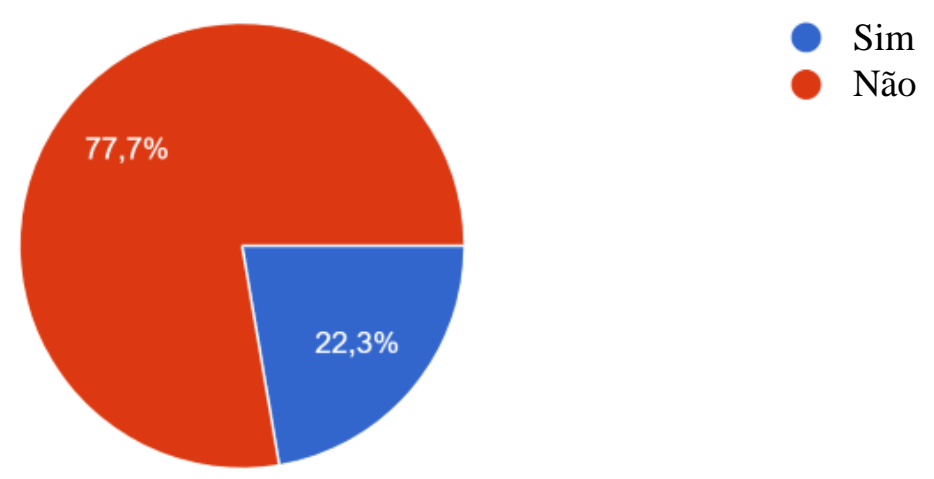

Fonte: Própria (2020).

Ao observar se as pessoas já consumiram

alimentos biofortificados, $82,6 \%$ afirmaram não saber, $14 \%$ afirmaram que já consumiram e 3,3\% disseram que não consumiram (Figura 12). 
Figura 12. Conhecimento da população acerca de seu próprio consumo de alimentos biofortificados.

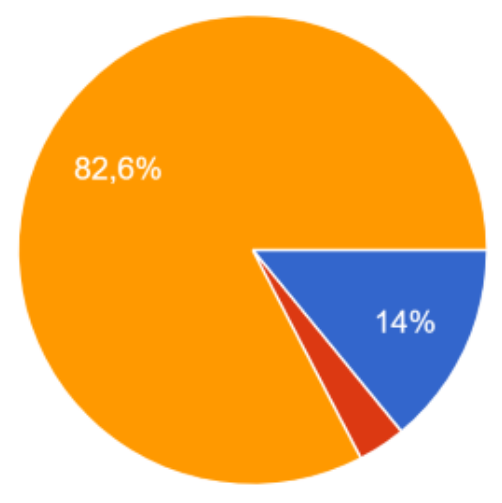
Sim
- Não
Não sei

Fonte: Própria (2020).

$\mathrm{Na}$ pesquisa, $82,6 \%$ afirmaram que não sabiam onde obter alimentos biofortificados, enquanto 17,4\% afirmaram que sabiam onde encontrar (Figura 13).

Figura 13. Conhecimento da população acerca de locais de obtenção de alimentos biofortificados.

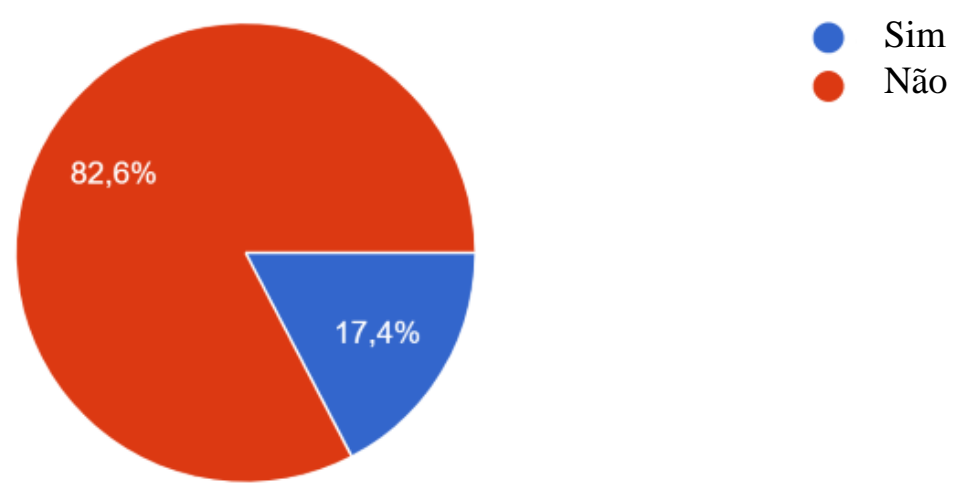

Fonte: Própria (2020).

Quando questionados acerca de quantas plantas alimentícias estavam sendo biofortificadas no Brasil, 20,7\% responderam que 10 culturas estavam sendo biofortificadas, $14 \%$ responderam que apenas 5 culturas, 11,6\% responderam que nenhuma cultura estava sendo biofortificada no país e 46,7\% responderam outros. Apenas $5,8 \%$ dos avaliados responderam o valor correto, 8 culturas. 
SOUZA, M. J. S; CUNHA, C. R. R. O; SILVA, A, P; SILVA, R. M; GONÇALVES NETO, Á. C.

Sobre o consumo de vitaminas e suplementos alimentares, 60,3\% afirmaram não consumir e 39,7\% afirmaram que consumiam (Figura 14).

Figura 14. Consumo pela população, de suplementos e vitaminas alimentares.

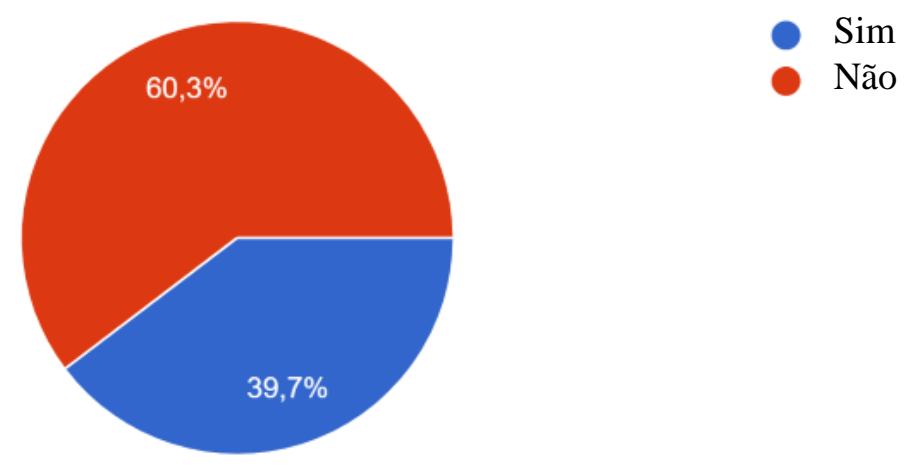

Fonte: Própria (2020).

Outra questão é o fato que a compra destes produtos não significa estar levando alimentos biofortificados para a mesa dos brasileiros; isto, porque o problema vem desde o início da cadeia produtiva, onde as sementes biofortificadas chegam sem nenhum controle às mãos dos agricultores familiares, estes, responsáveis pela maior parte da produção dos alimentos, como a mandioca e batata doce.

\section{Conclusões}

A pesquisa mostrou que grande parte da população ainda não tem conhecimento sobre o que se trata a fome oculta e a biofortificação de alimentos, muito embora esses assuntos venham sendo trabalhados no Brasil desde meados dos anos 2000. As pessoas que menos possuem conhecimento sobre o tema abordado são mulheres com idade entre 18 e 25 anos, com grau de escolaridade de ensino superior incompleto e residentes de área urbana.

Por mais que o Brasil esteja na posição de país destaque na produção de alimentos biofortificados, o mesmo não se destaca no fornecimento de informações sobre este assunto, deixando a população, em sua maior parte, sem conhecimento sobre este tipo de alimento.

\section{Referências}

ASSUMPÇÃO, D et al. Diferenças entre homens e mulheres na qualidade da dieta: estudo de base populacional em Campinas. Ciências e Saúde Coletiva. 22.2. fev. 2017. 
SOUZA, M. J. S; CUNHA, C. R. R. O; SILVA, A, P; SILVA, R. M; GONÇALVES NETO, Á. C.

Disponível em: <https://www.scielosp.org/article/csc/2017.v22n2/347-358/>. Acesso em 28 de jul. de 2020.

BESSA, F. Pesquisa da Embrapa busca aumentar teor de zinco de arroz no Maranhão. 2019. Disponível em: <https://www.grupocultivar.com.br/noticias/pesquisada-embrapa-busca-aumentar-teor-de-zinco-de-arroz-no-maranhao>. Acesso em: 27 julho 2020.

BIOFORT. Perguntas Frequentes. Disponível em: <https://biofort.com.br/perguntasfrequentes/>. Acesso em: 25 jul. 2020.

COSTA, D.V.P et al. Diferenças no consumo alimentar nas áreas urbanas e rurais do brasil: Pesquisa nacional de saúde. Ciência \& Saúde Coletiva. Disponível em: < http://www.cienciaesaudecoletiva.com.br/artigos/diferencas-no-consumo-alimentar-nasareas-urbanas-e-rurais-do-brasil-pesquisa-nacional-de-saude/17486> Acesso em 29 de julho de 2020.

\section{DELMONDES, C. Qualidade da dieta aumenta com idade e escolaridade, aponta pesquisa da FCM. 2016. Disponível em: <https://www.fcm.unicamp.br/fcm/noticias/2016/qualidade-da-dieta-aumenta-com- idade-e-escolaridade-aponta-pesquisa-da-fcm>. Acesso em 28 de julho de 2020.}

ÉPOCA. Fome oculta: um problema real. Redação prêmio Jovem Cientista. 15 de abril de 2015. Disponível em: <https://epoca.globo.com/vida/noticia/2015/04/fome-ocultaum-problema-real.html>. Acesso em: 28 de julho de 2020.

G1. Segundo meio de comunicação mais usado é internet, aponta pesquisa: $26 \%$ usam internet diariamente, e $65 \%$ veem TV todos os dias, indica Ibope. Governo encomendou pesquisa que revela hábitos de consumo de mídia, 2014. Disponível em: <http://g1.globo.com/economia/midia-e-marketing/noticia/2014/03/segundo-meio-decomunicacao-mais-usado-e-internet-aponta-pesquisa.html> Acesso em: 31 jul. 2020.

GOMES, F.S et al. Biofortificação: As controvérsias e as ameaças à soberania e segurança alimentar e nutricional. Disponível em: <https://br.boell.org/sites/default/files/biofortificacao_as-controversias-e-as-ameacas-asoberania-e-seguranca-alimentar-e-nutricional.pdf>. Acesso em 28 de jul de 2020.

BRASIL, Instituto brasileiro de geografia e estatística - IBGE, 2019. Disponível em <https://biblioteca.ibge.gov.br/visualizacao/livros/liv101707_informativo.pdf>. Acesso em: 30 de julho de 2020 .

PINHEIRO, A.R.O; CARVALHO, M.F.C.C. Transformando o problema da fome em questão alimentar e nutricional: uma crônica desigualdade social. Ciência \& Saúde Coletiva.15. 1.2010 .2 Jan. Disponível em: <https://www.scielo.br/scielo.php?script=sci_arttext\&pid=S1413 $81232010000100018 \& \operatorname{lng}=e n \& n r m=i s o>$. Acesso em: 27 de julho de 2020.

SILVA, C.S.M; ARAÚJO, C.R.M. Introdução à Biofortificação. Módulo II: Afinal, o que é biofortificação? 28 de julho de 2018. Disponível em: <https://ava.sede.embrapa.br/course/view.php?id=66>. Acesso em 29 de julho de 2020. 
SIQUEIRA, K.B et al. Custo benefício dos nutrientes dos alimentos consumidos no Brasil. Ciência \& Saúde Coletiva, 25 (3): 1129-1135, 2020. Disponível em: $<$ https://www.scielosp.org/article/csc/2020.v25n3/1129-1135/>. Acesso em 28 de julho de 2020.

VILAS BOAS, L. G. Fome oculta e seus liames como a economia, a política e a sociedade. GeoGraphos. Alicante, Grupo Interdisciplinario de Estudios Críticos y de América Latina de la Universidad de Alicante, v. 7, n. 90, p. 207-232, sept. 2016. Disponível em: < https://rua.ua.es/dspace/bitstream/10045/57425/1/Lucas_Guedes.pdf>. Acesso em: 14 maio 2018. 